\title{
جامعَة الأزهنح
}

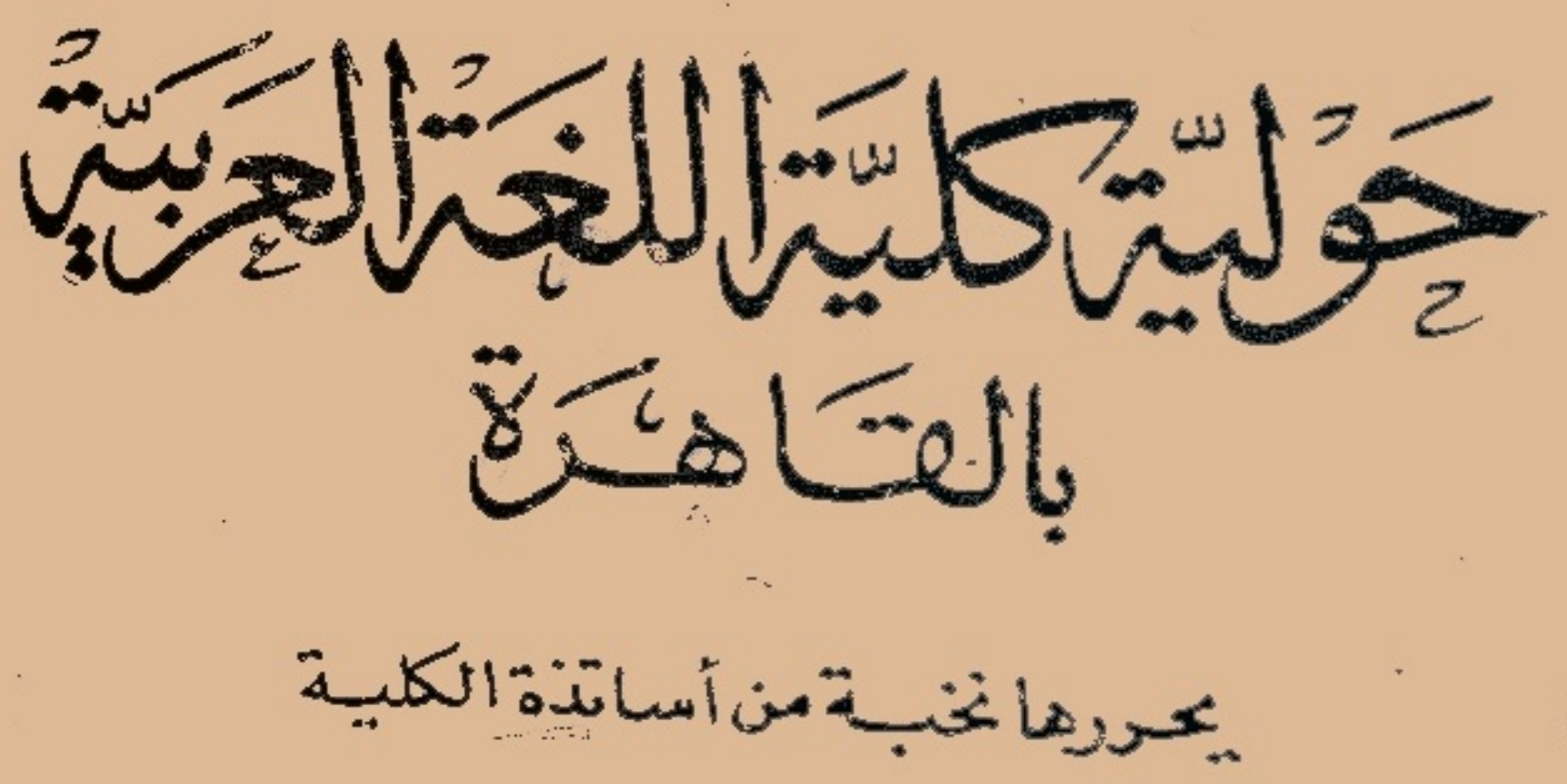

العدد Ir

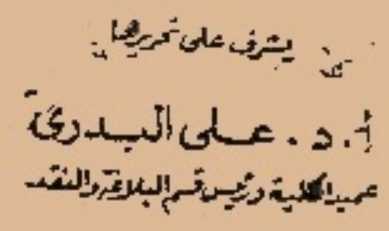

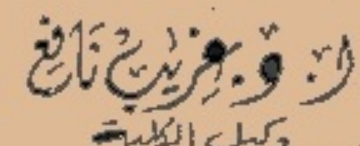




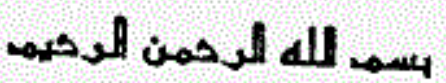

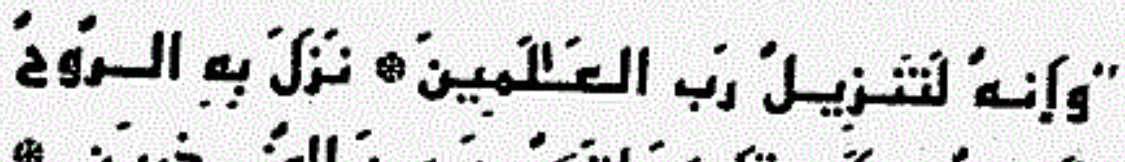

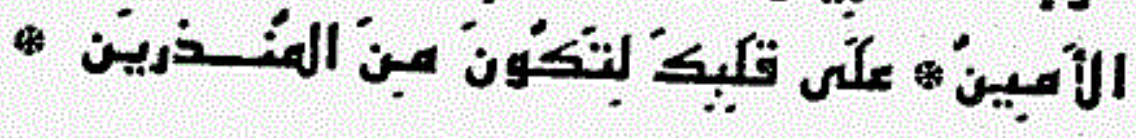

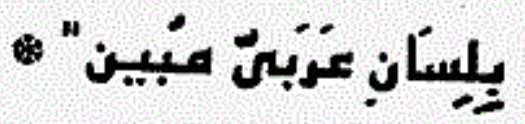

صدت الله العنيم

سورن الشعرا.

190 - I9r 


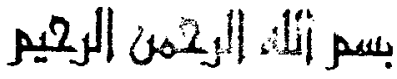

الحمد الله رب العالمين حمد الشاركرين، والصلاة والسلام على رئل

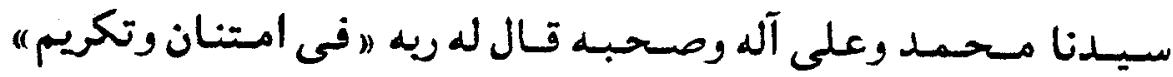
وعلمك مالم تكن تعلم وكان فضل الله عليك بمظيماً، .

g-بـــ

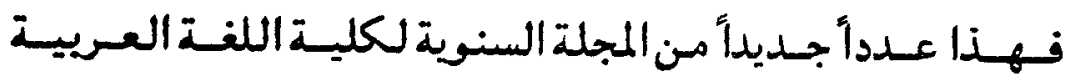

بدمنهور، نضم مجموعة من البحوث المتخصصة، فى علوم العربية،

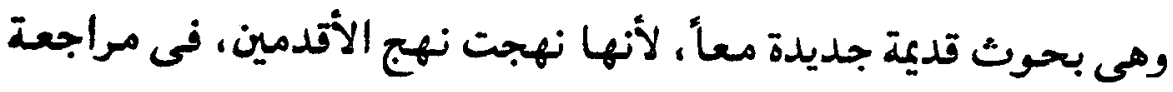

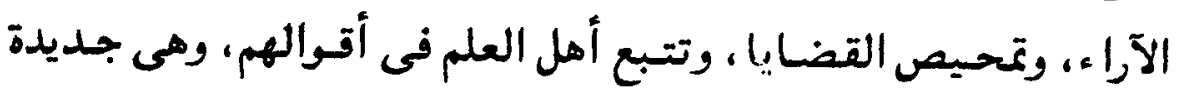

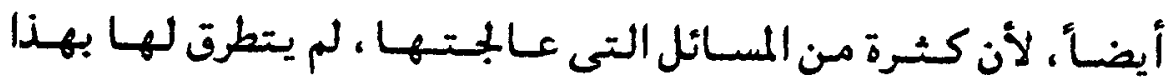

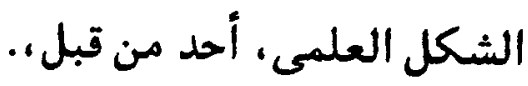

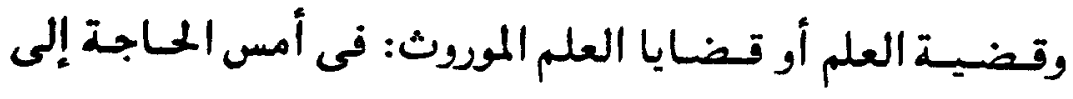

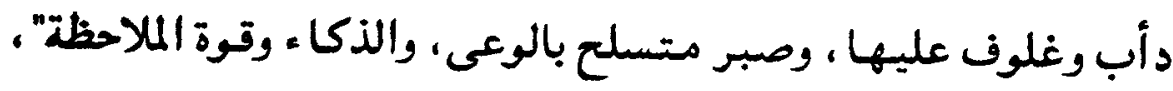

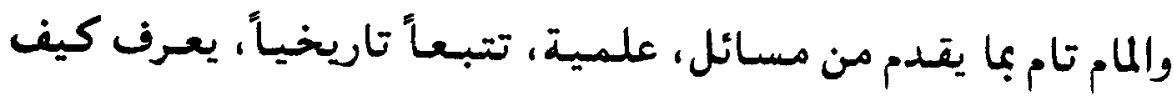

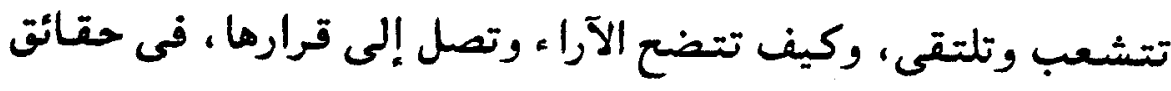

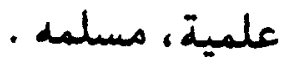

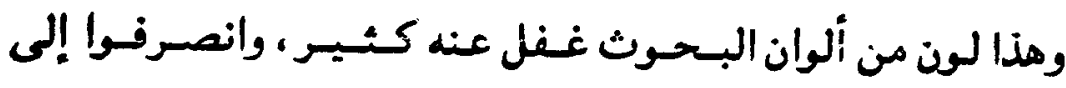

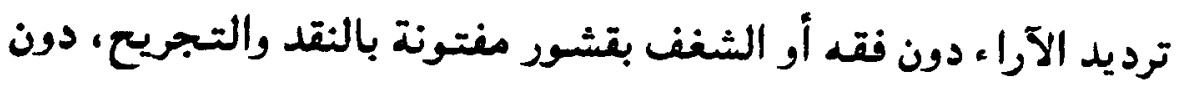
أن تقدم جديداً.

وهناك لون من البحوث تدخل فى نطاق التطبيق اللغوى ، وهى

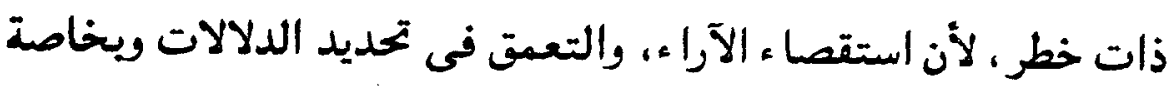

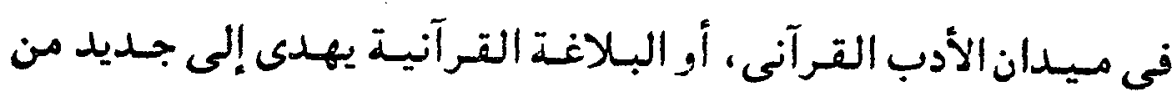

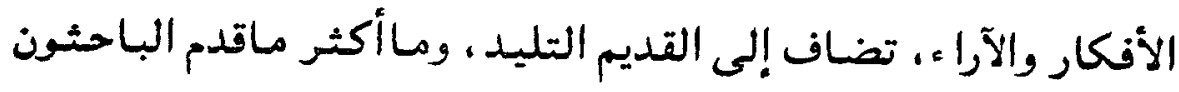


فى دلالات الصيخ والألفاظ والتعابيـ ، والظواهر اللغوية، والبلاغية

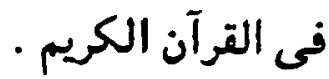

ومـايزال كــــاب الله تعـالى بكراً فى انتظار لون من البـاحــن

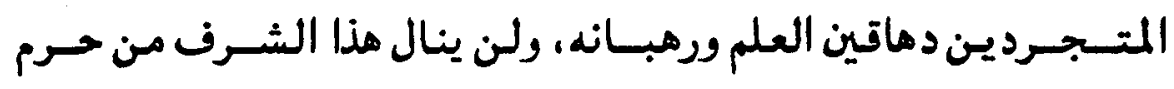
العمق، والذكاء والإدراك وعاش أفكاراً سطحية تضر أكثر معا تنفع.

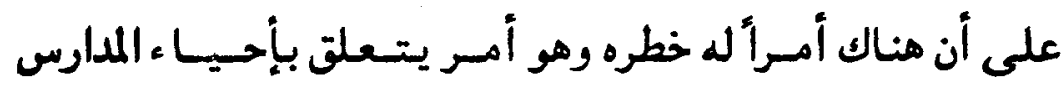
العلمية تحليلية أو تاريخية وصفية .

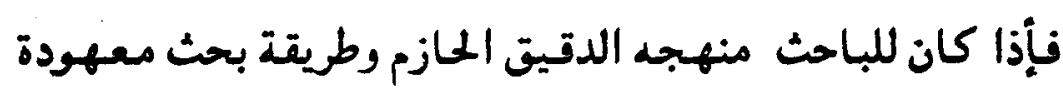

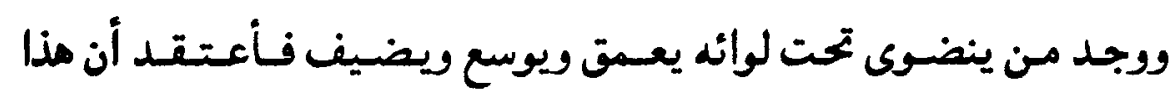

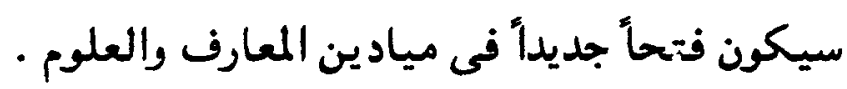

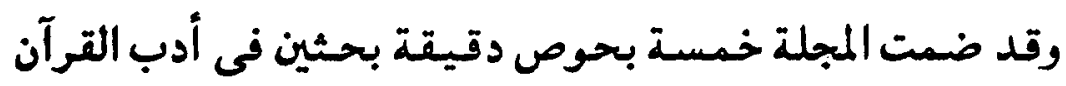

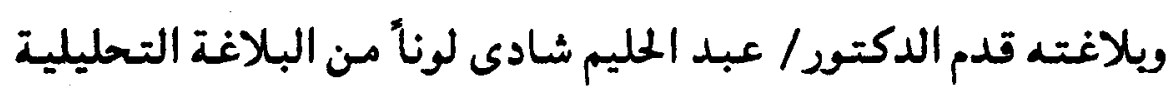

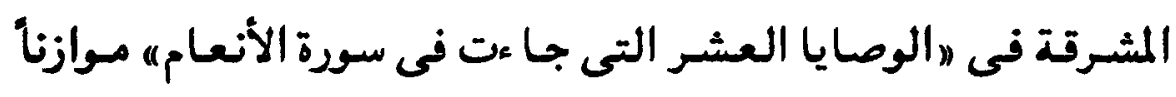

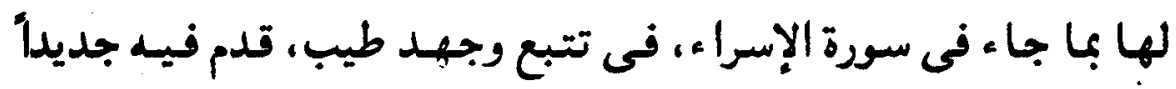

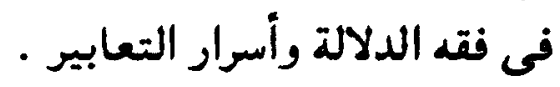

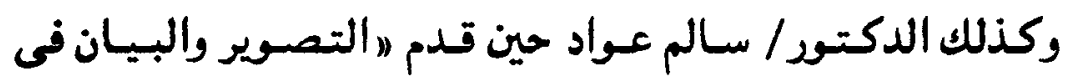

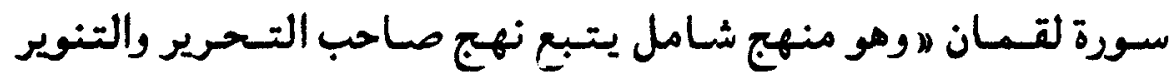

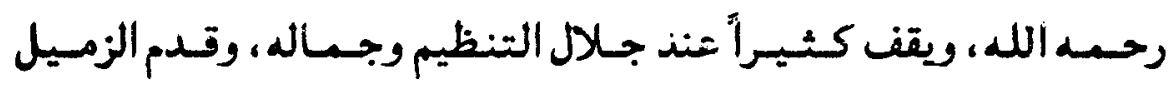

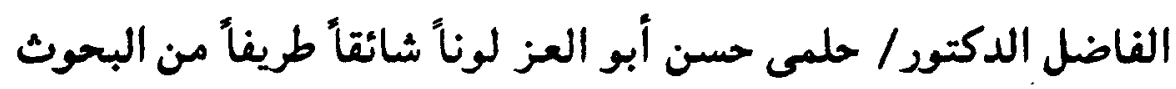

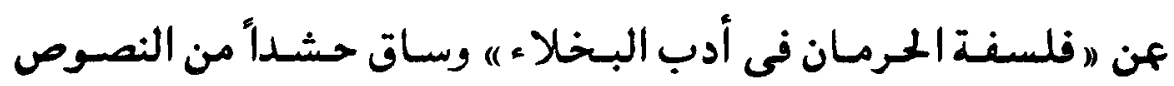

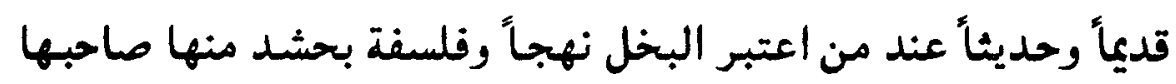

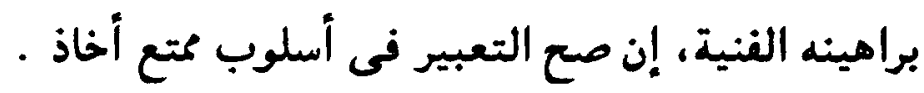




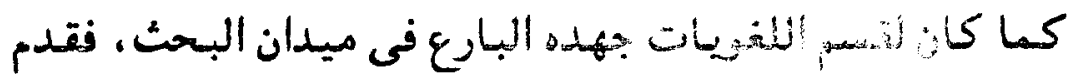

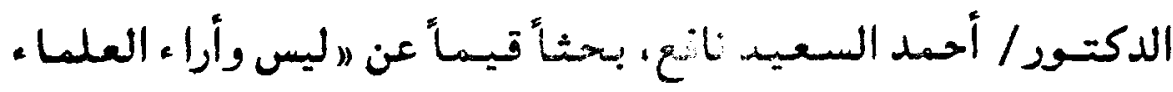

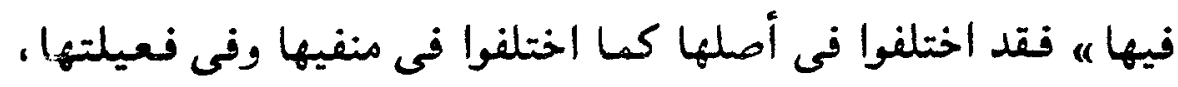
وفى تقديم خبرها عليها ، وفي كونها عاطفة واستثنائين ه ه .

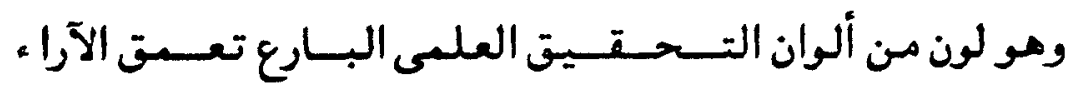
ويحققها ويربحه بالدليل مايراه جديراً بالترجيح.

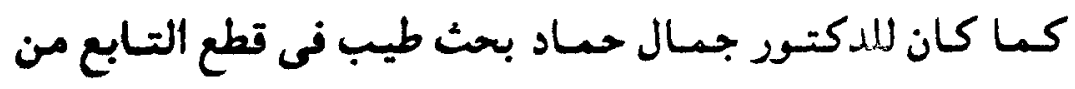

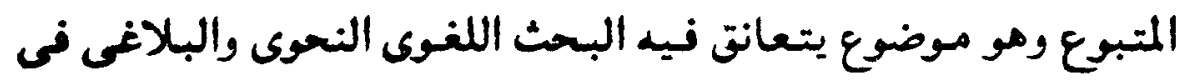

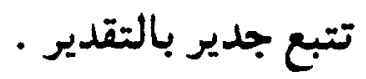

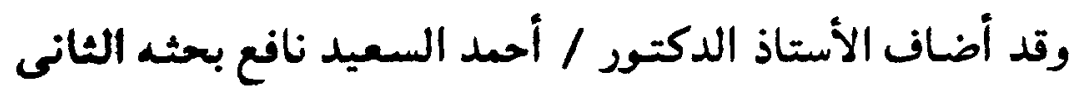

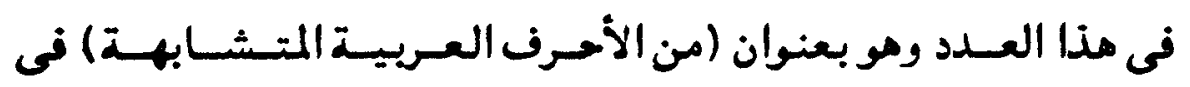

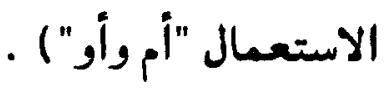
ويعد تلك الافتتاحية المبسطة للأستاذ الدكتور/ عميد الكلية

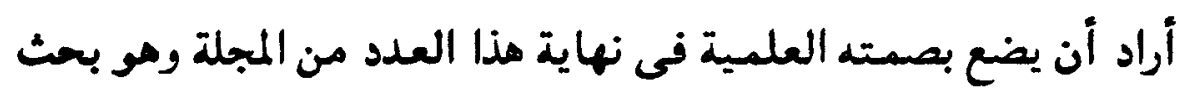

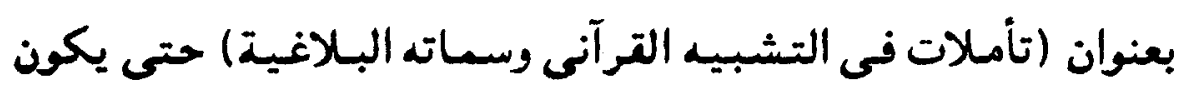

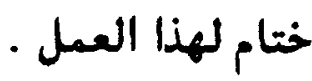
هذه كلمة موجزة تتقدم هذه البحوث نسأل الله أن ينفع بها وأن

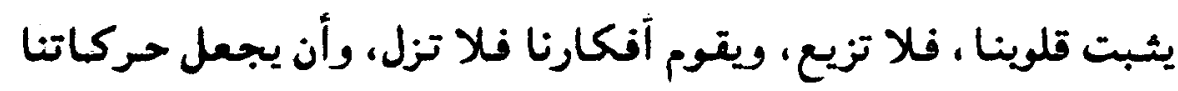

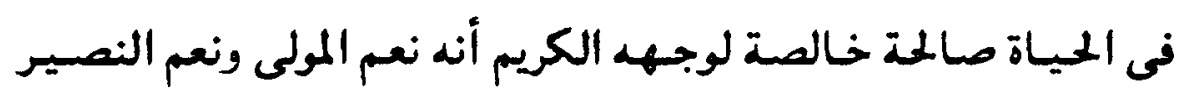

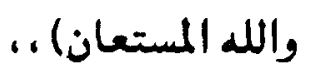
عميد الكلية

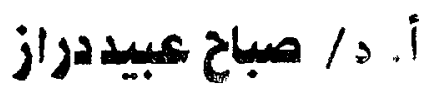


النهru

zano

الموزوكات

rq

1०9

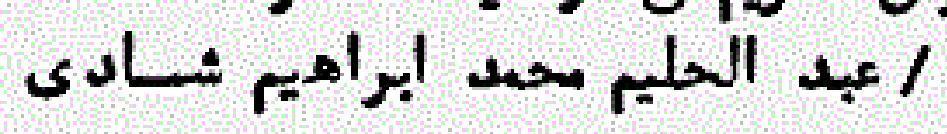

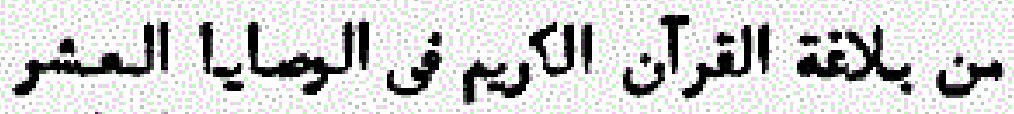
r

فلسفة الحرمان في أدب البخلا: دكنمر / حلى حسن أبو العز

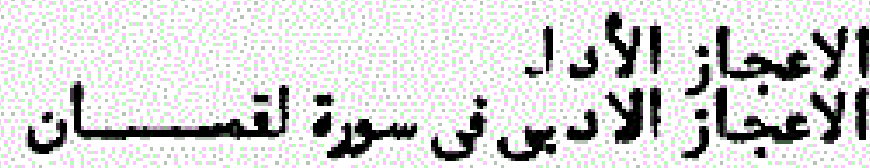
دكثر ; سالم عواد السيد حثبين

(ليس) في العرية بين النعلية والحرنية

YrI

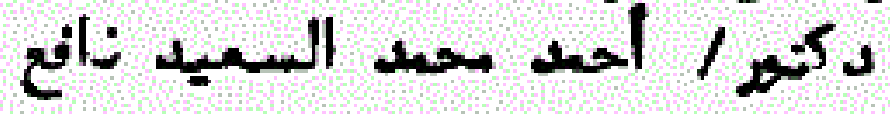

rir

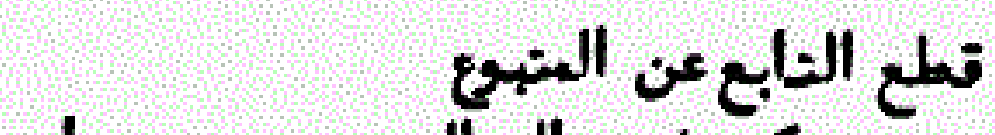
دكنم/ جبال الدين محس حماد

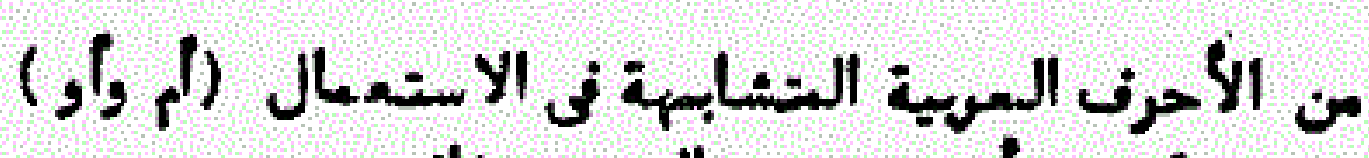

ris

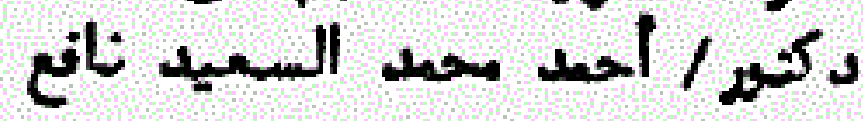

roy

تأملات في التبيه القرآنى وسباثه البلاغية دكته/ الباح عبيد دراز 


\section{هن بلاغية القرآن الكريم

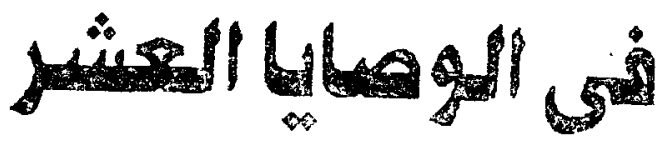

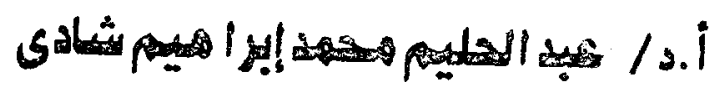

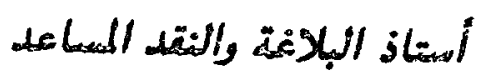

$$
\begin{aligned}
& \text { بكلية اللغة العيية } \\
& \text { بإيتاي البارود }
\end{aligned}
$$



بسم إلله الرحمن الرحير

الوصية في اللفية مين هأوصى الرجل ووصاه: عهل إليه (بكذا)

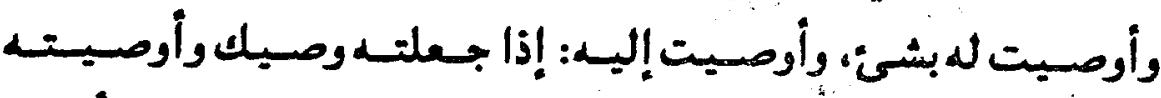

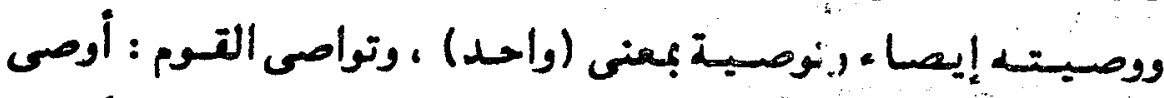

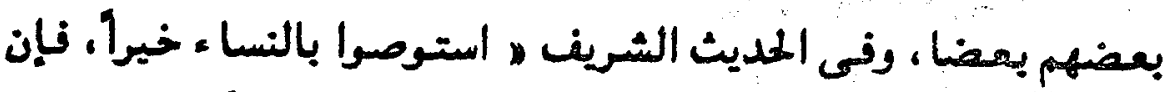

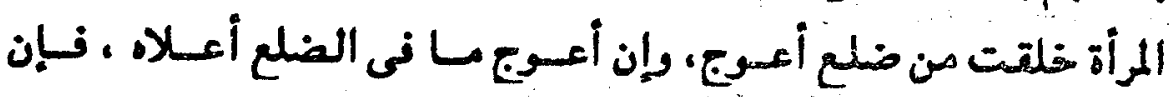

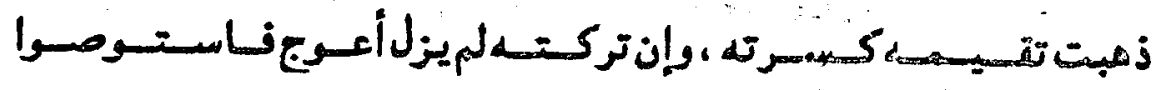

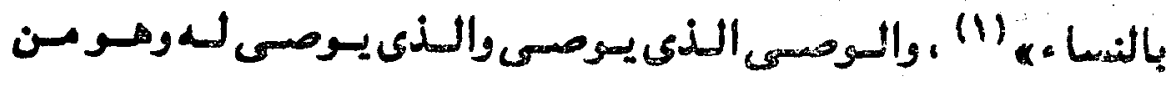

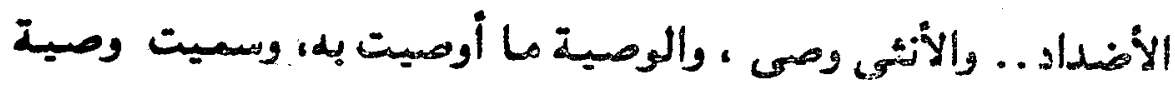

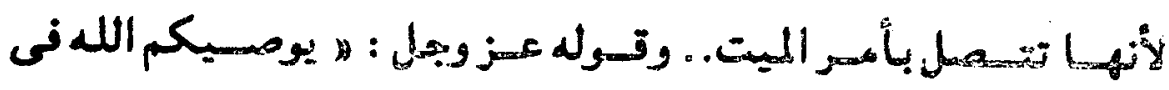

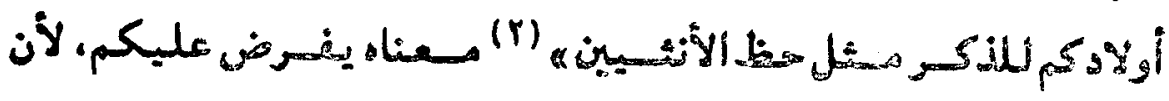

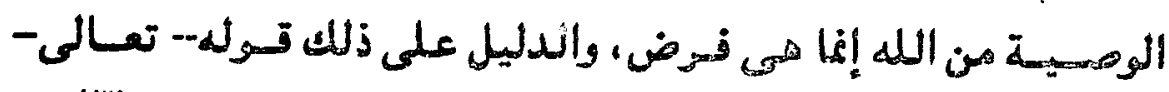

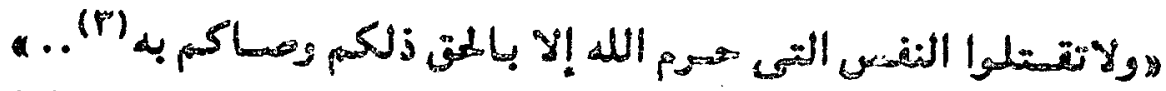

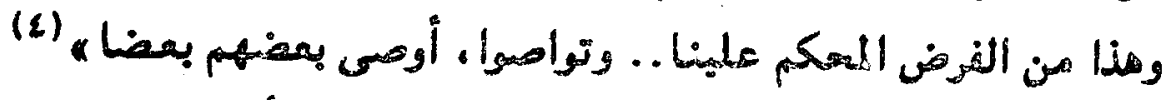
وإذا تيلا: أوصيته بولده همناه : استعطنته عليه ، وأصيته بالصلاة:

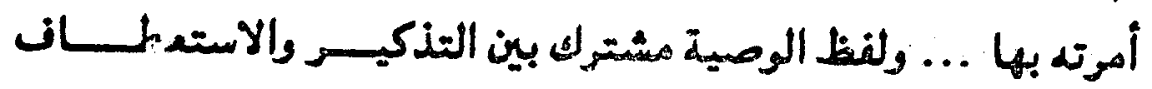

رواه أبو هريرة - رضه الله عنه - (رياض الصالحين ص . عا للإمام المحدث بعييي بن شرف النورى ـ تعليق وشرع مصطنى معمد علارة.

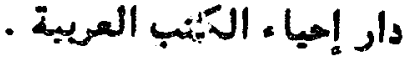

$$
\begin{aligned}
& \text { الآية ال سيعرة النيسا. }
\end{aligned}
$$

من الآية 101 الأنعام من الواليطاءيا موضوع الدراسية.

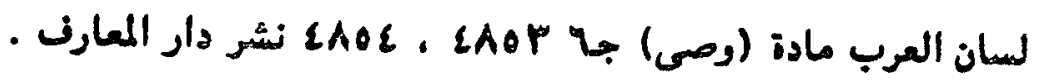




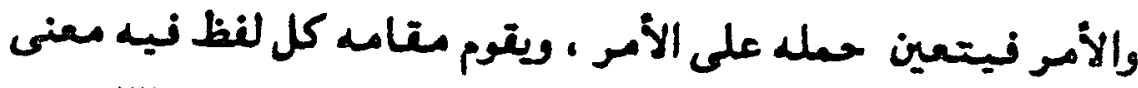

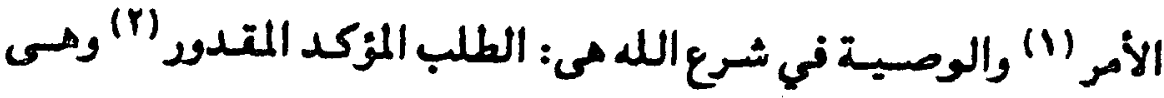

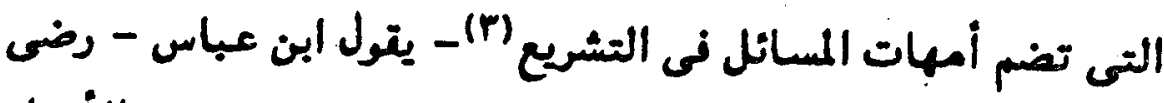

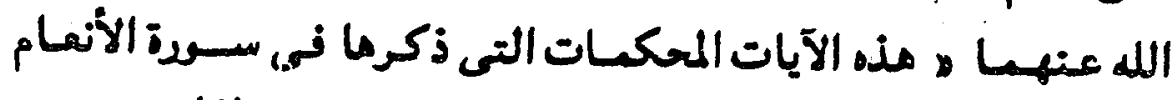

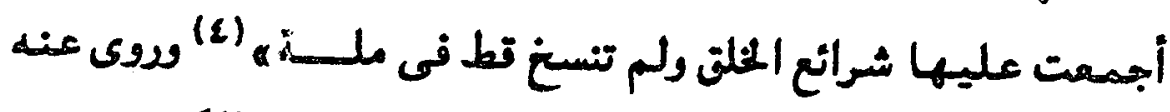

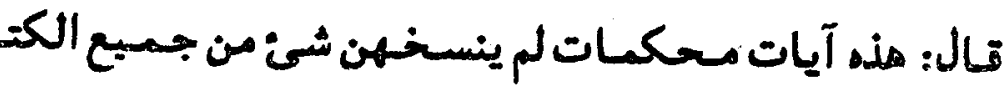

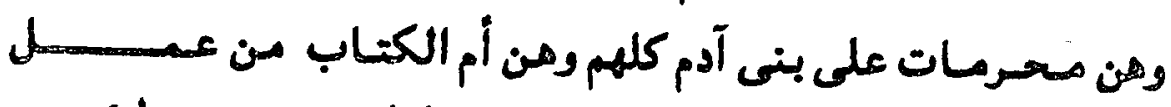

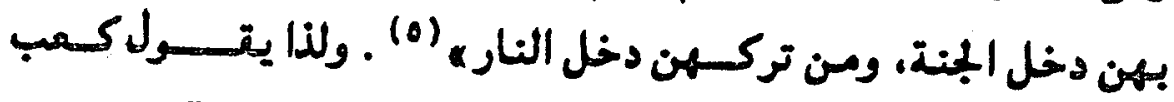

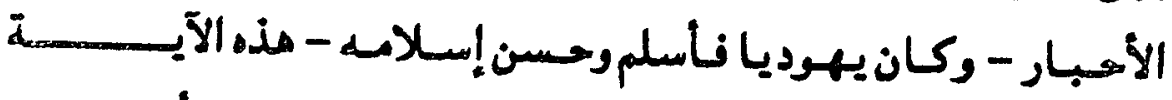

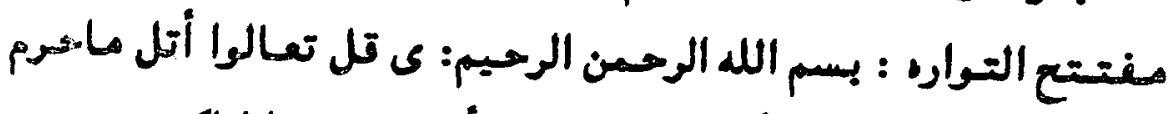

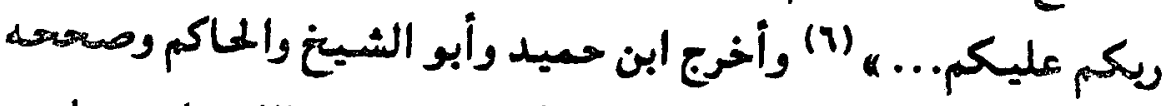

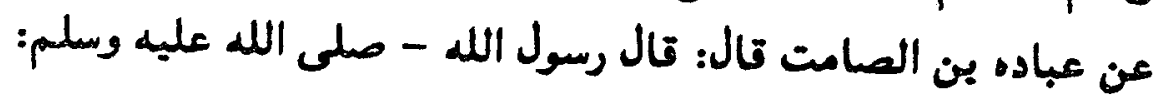

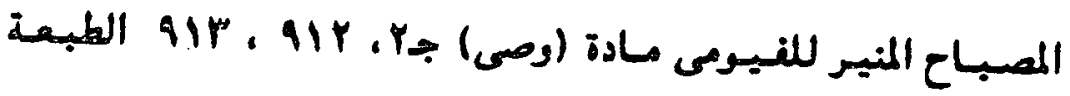

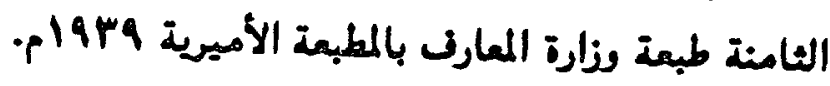

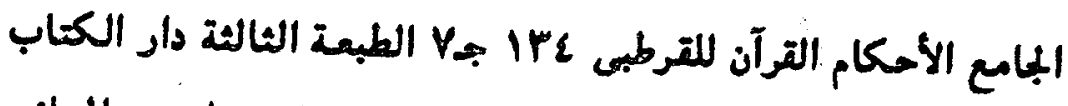

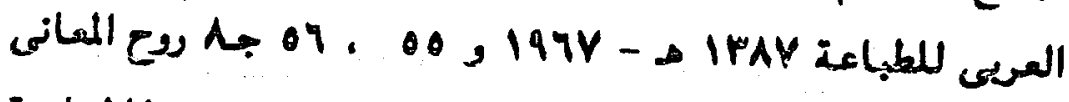

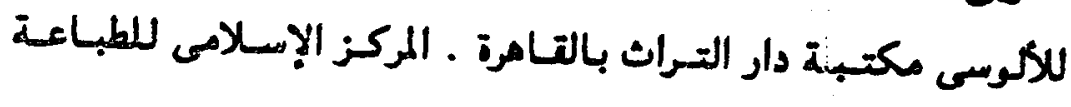

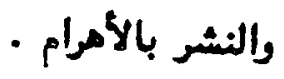

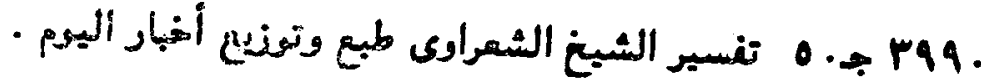
1 البامع ... اللقرطبس. - به (0) r 


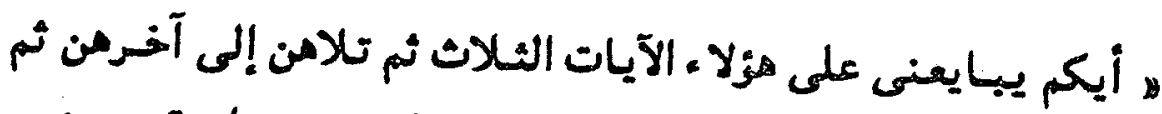

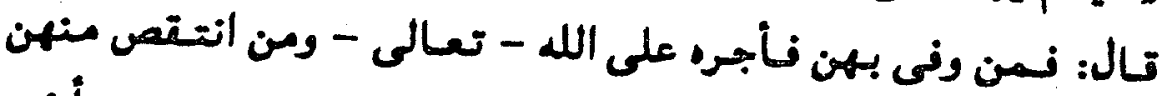

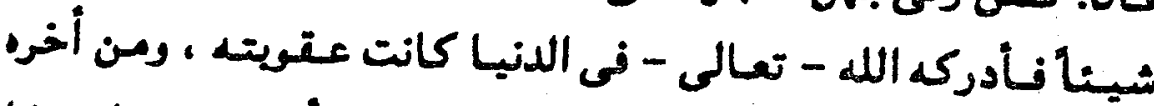

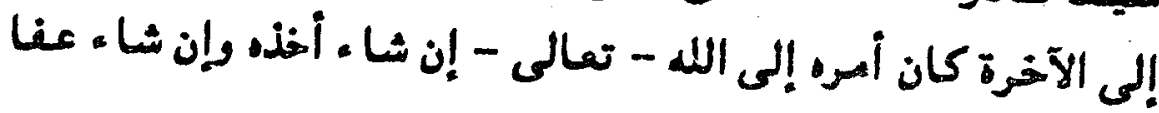

عنه (1)

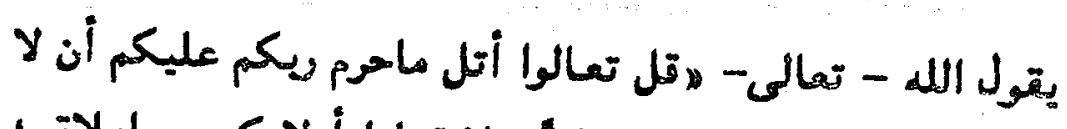

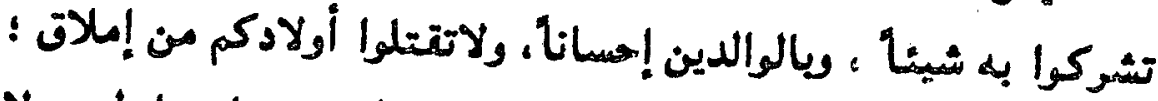

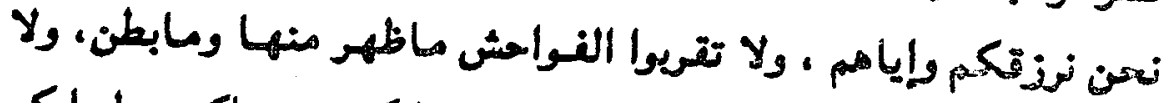

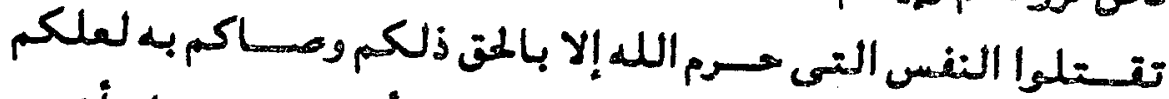

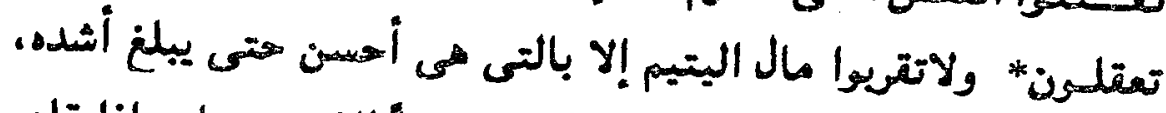

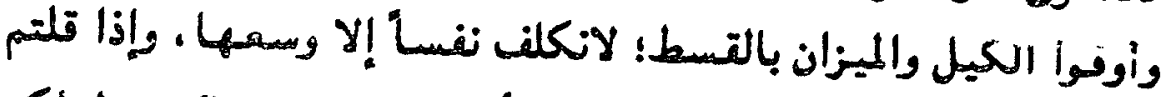

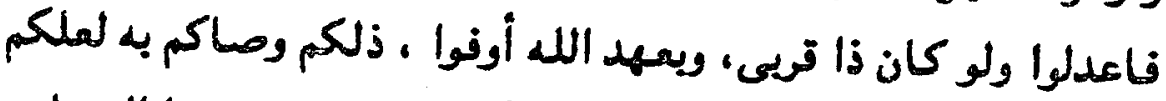

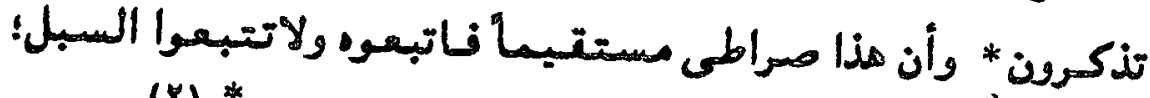

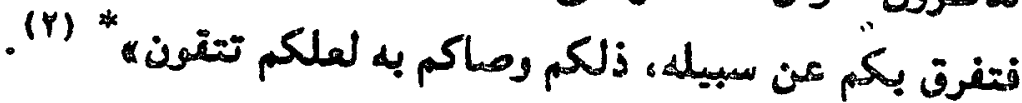

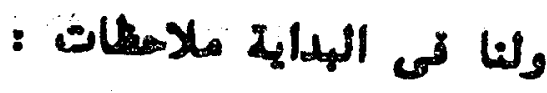

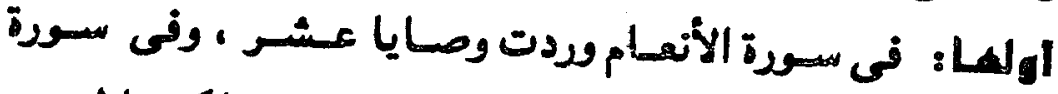

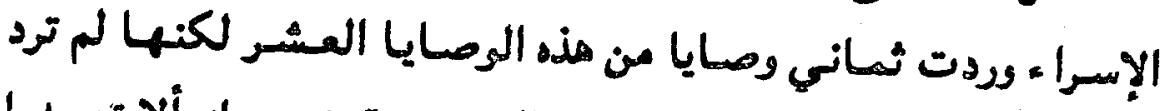

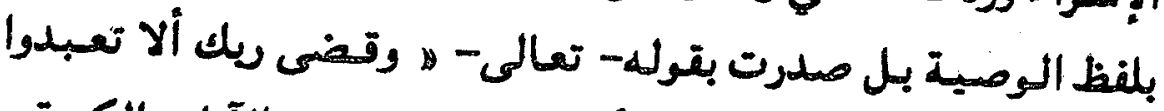

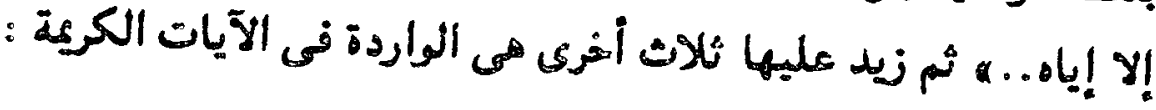

(1) (I) الألوسى : المرجع والصنحة

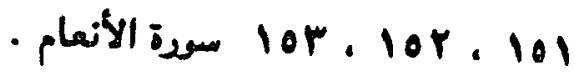




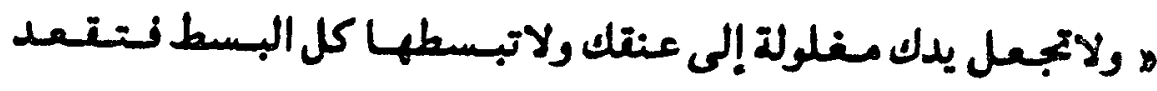

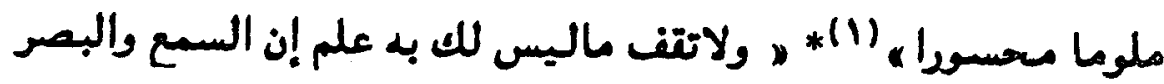

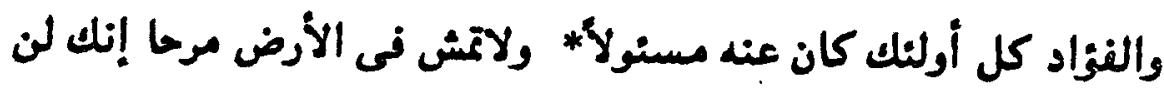

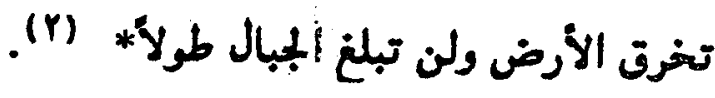

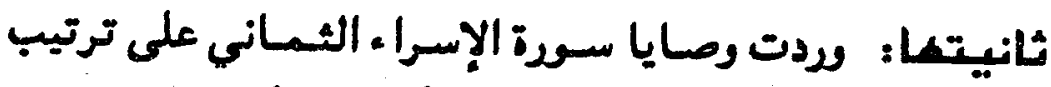

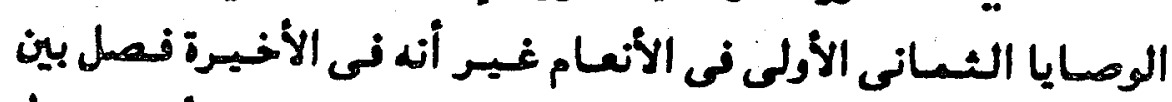

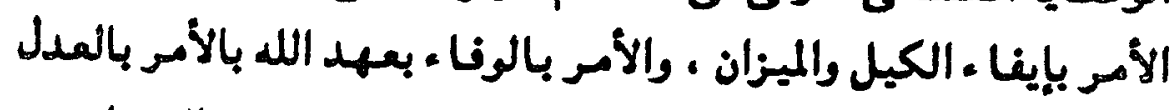

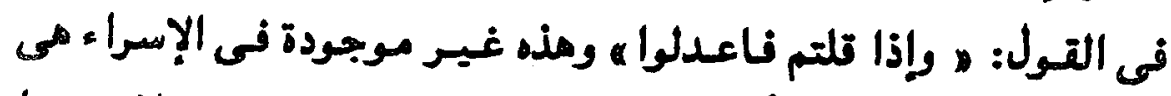

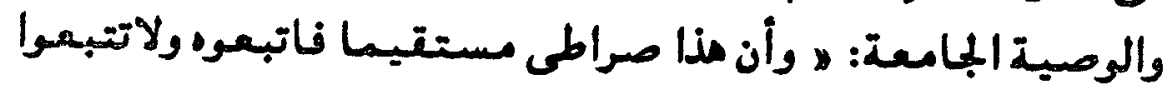
اليبيل....

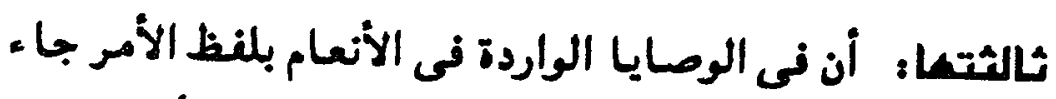

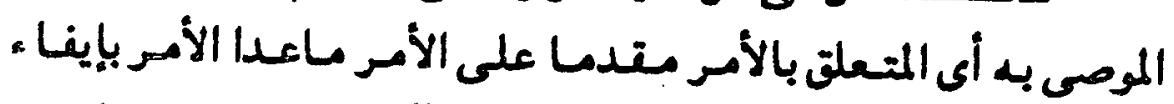

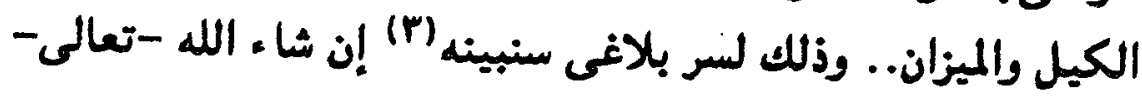

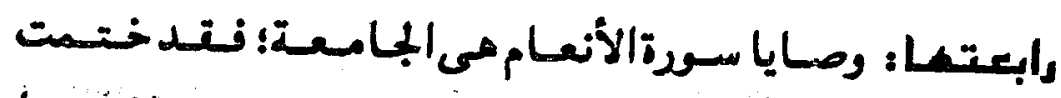

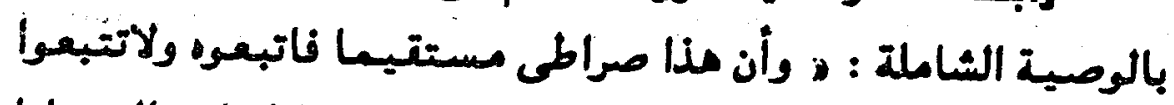

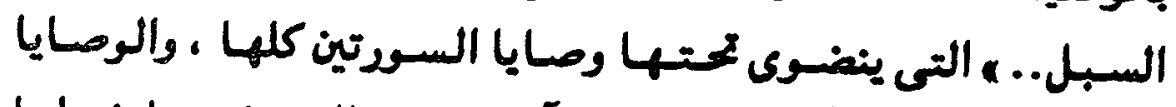

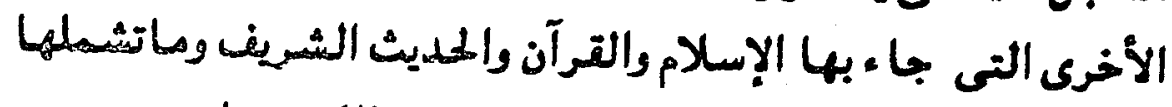
مصادر التشريع الأخرى ما بدخل تيجت مافرضه الله ، وماهرهمان.

$$
\begin{aligned}
& \text { 19 سورة الإسراء . }
\end{aligned}
$$

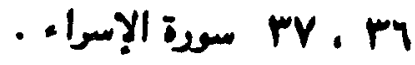

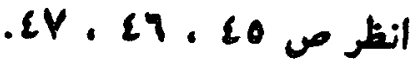


ذا هعتها: ما أثيسر البلاغى فى مجى بعض الوصايا بصيغة

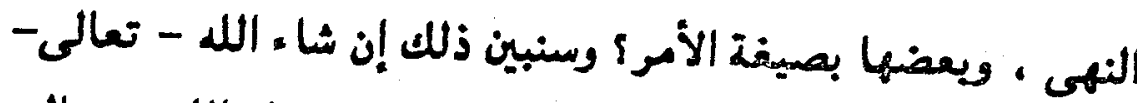

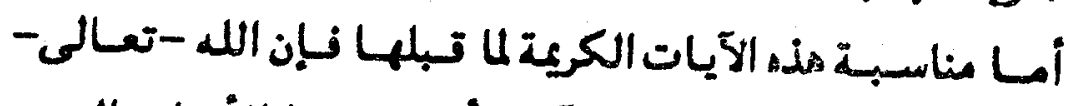

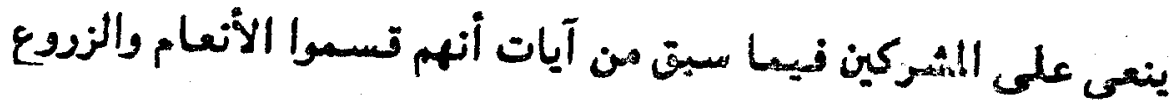

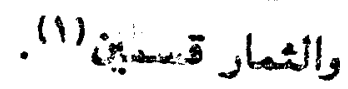

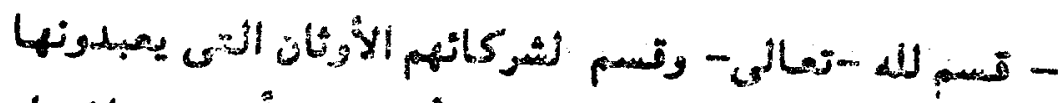

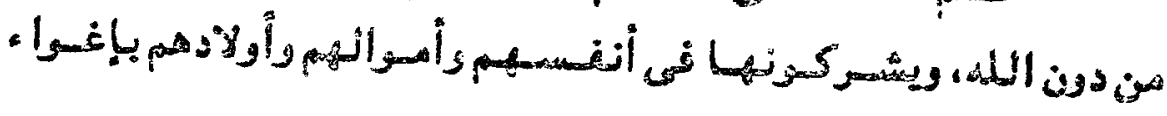

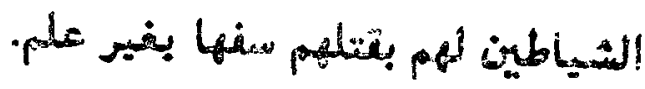

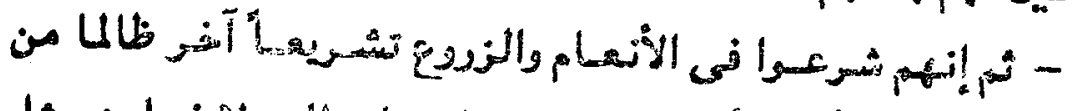

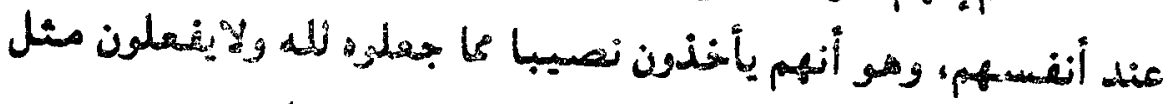
ذلله نيما يجعلوند لئركائهم بل يبقونه على ما هايو عليه.

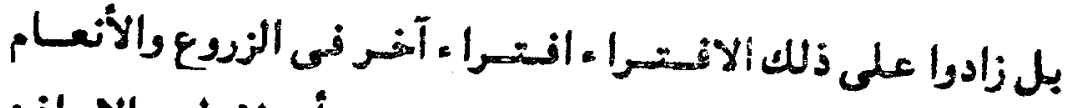

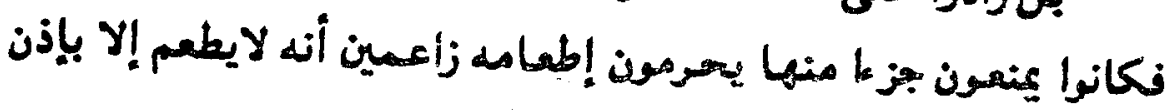

الله.

بل كـانوا يحرمسون زكوب بعض الأنعام ولاييكسبونها فى الحهج

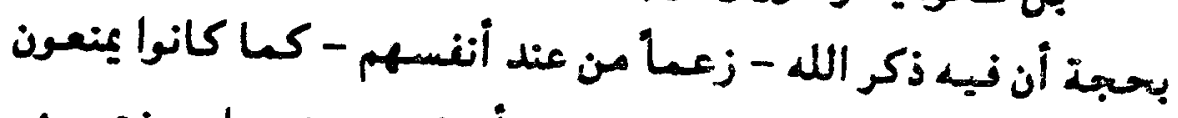

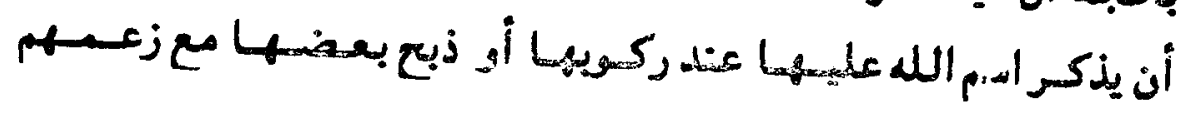

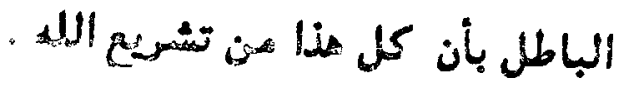

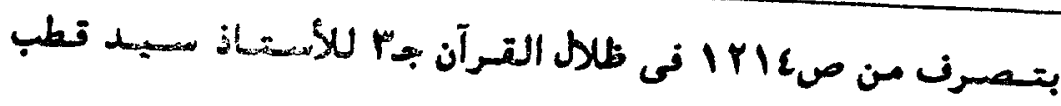

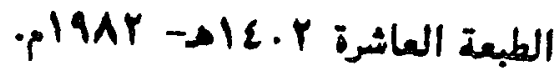


بل كانوا يشرعون تشريطا آخر عجببا ؛ إذ كانوا يخصون ما

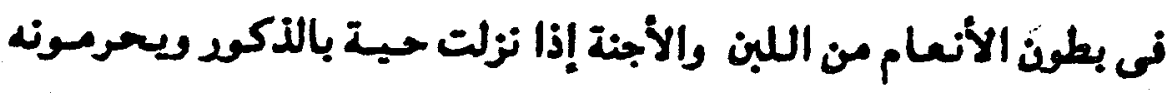

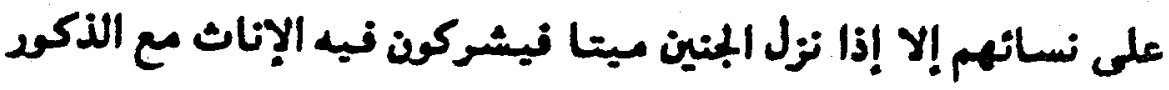

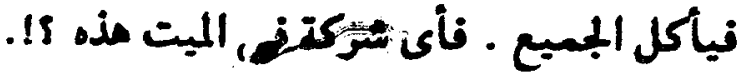

يقول الله - تعالى - فى ذلك كله رادأ عليهم وناعيا عليهم

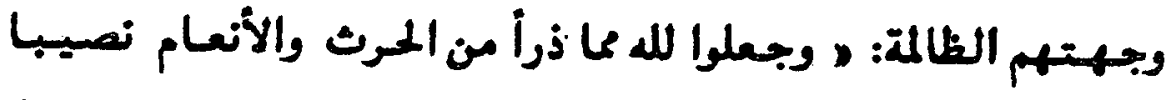

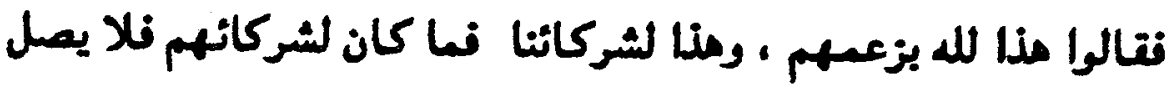

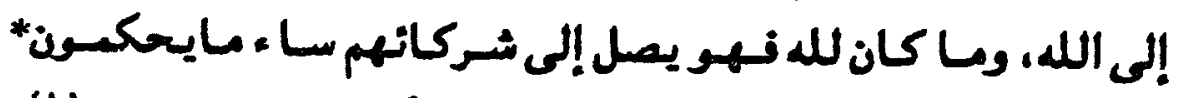

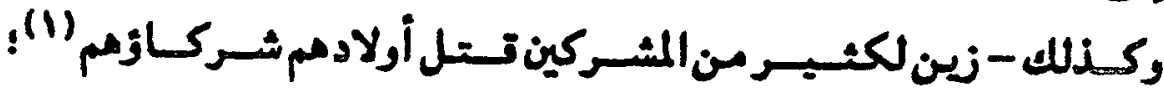

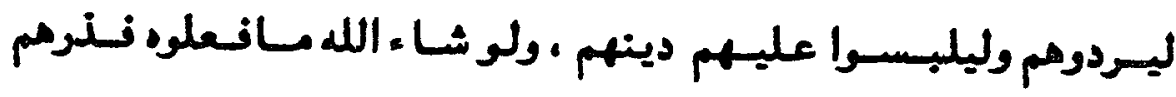

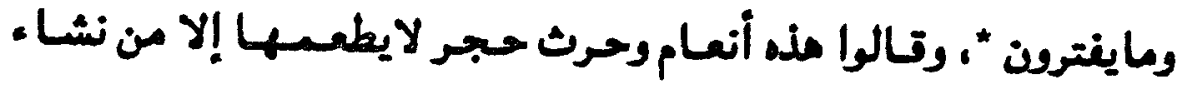
يزعمهم وأنعام حرمت ظهودها وأنعام لايذكرون اسم الله عليها افتراء

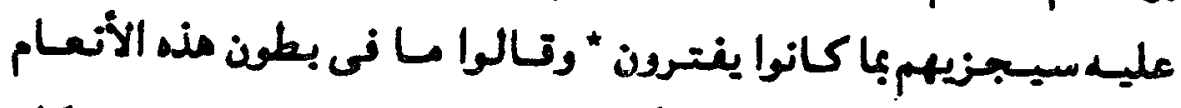

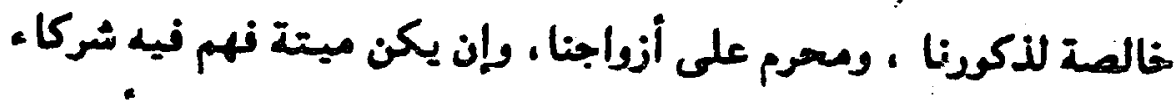

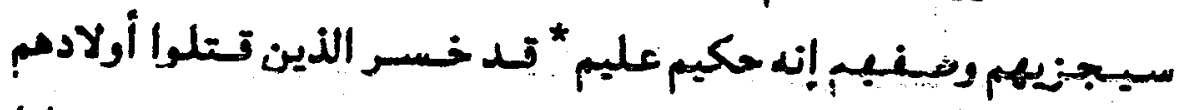

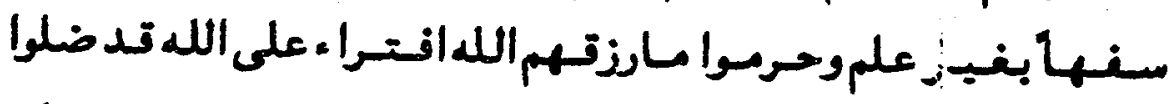

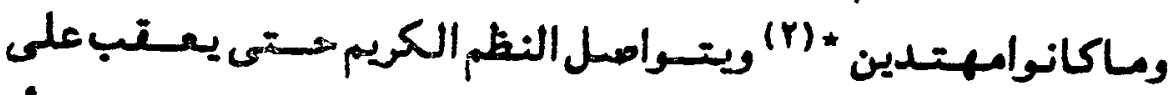

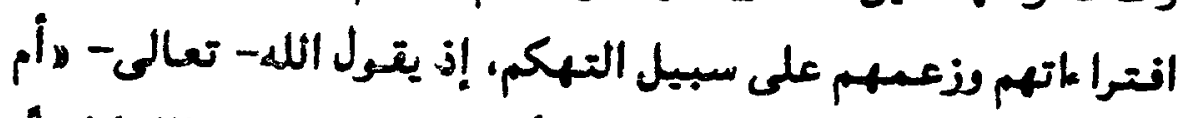

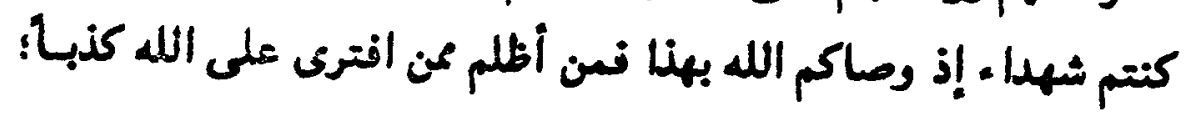

, شركازمم ، فاعل و داتله منعول به متدم.

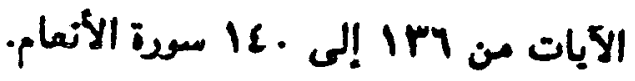




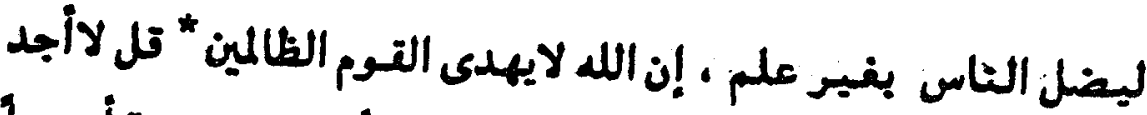

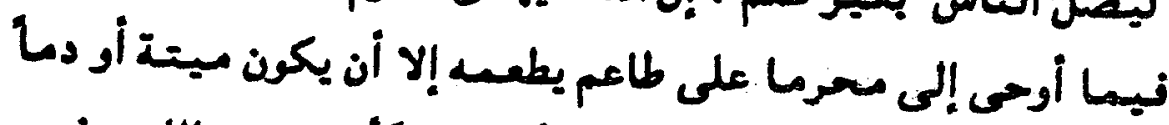

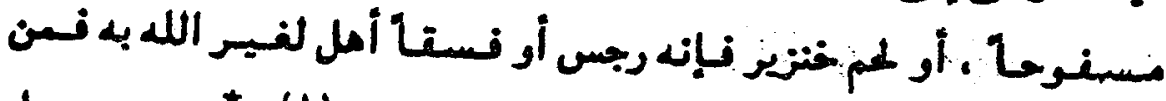

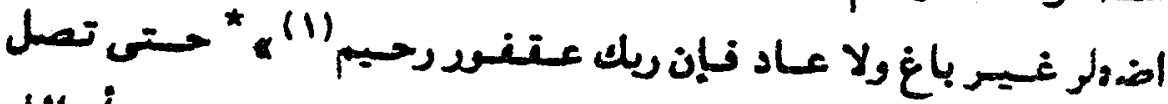

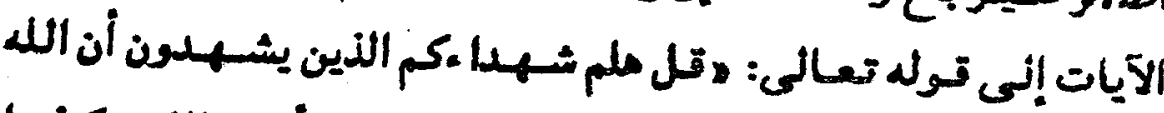

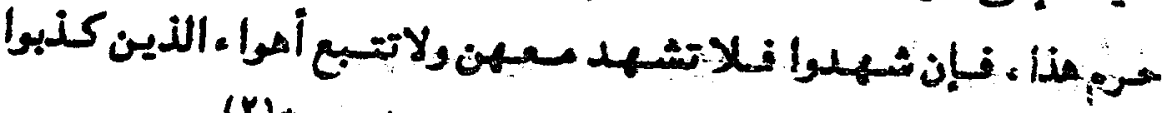

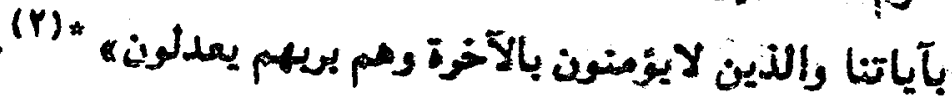

وفى النهـاية ينزل الله - تعـالى - على رسـوله - صلى الله

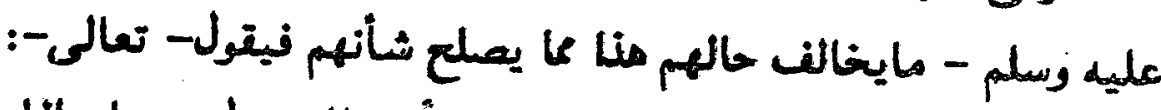

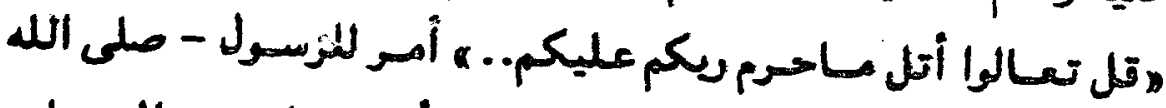

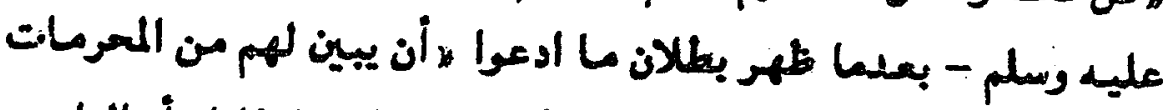

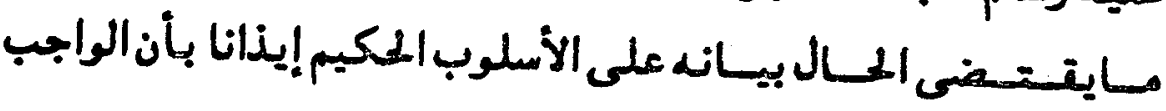

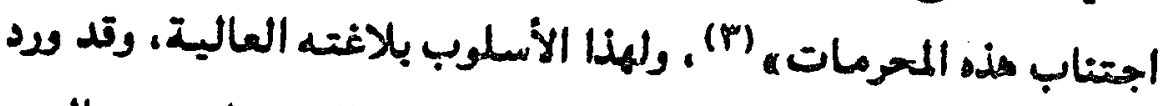

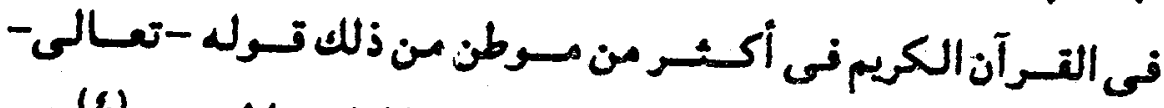

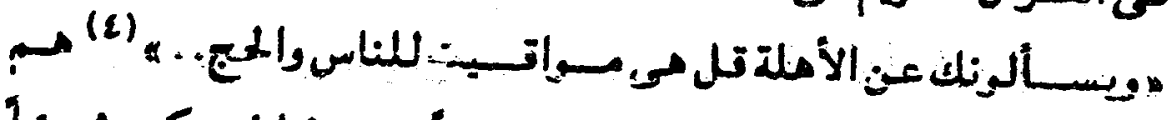

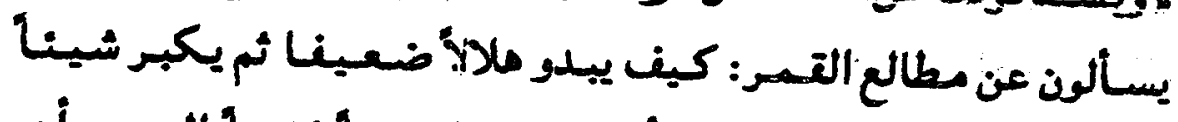

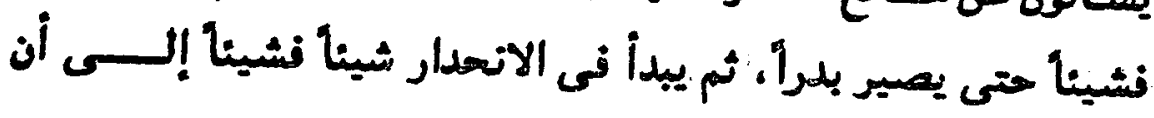

- IEO ، IEE (I)

. 0 سورة الأنعام.

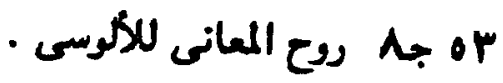

ال 149 
يصـير هلالأ مـرة أخرىى ثم مسحاقاً، لكن الرسول - صلى الله عليـ

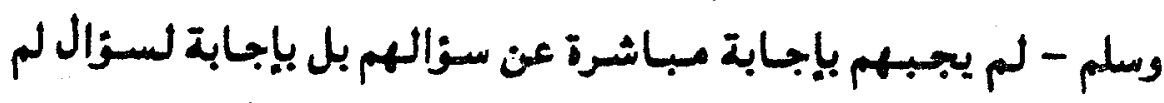

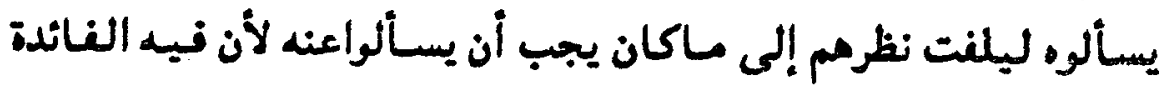

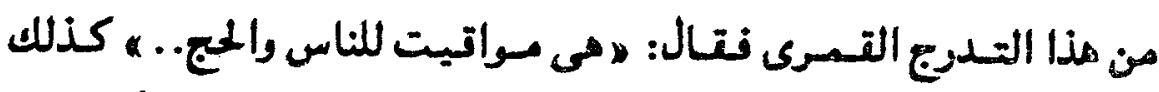

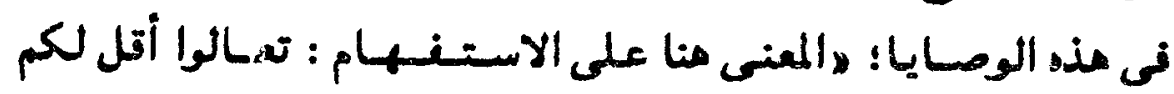

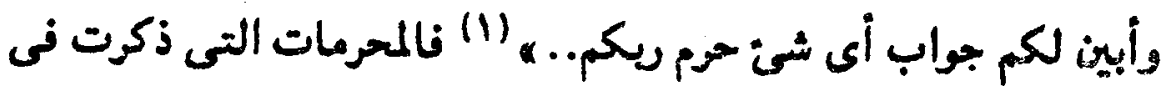

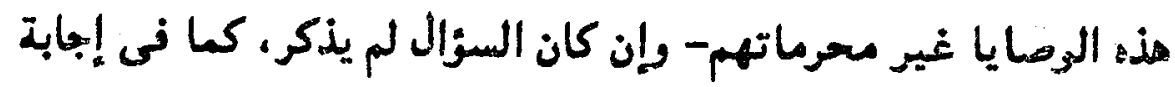

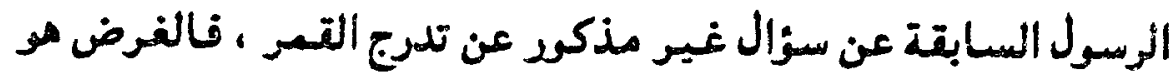

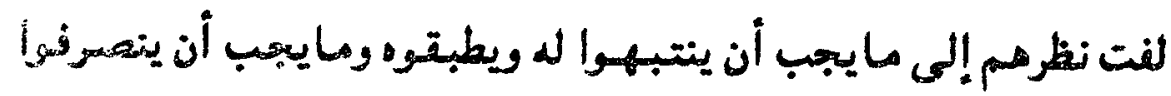

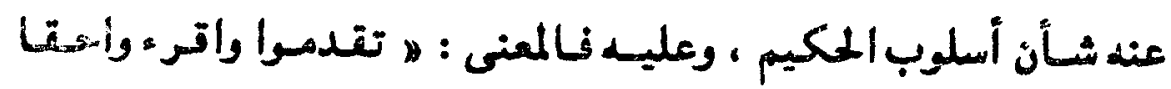

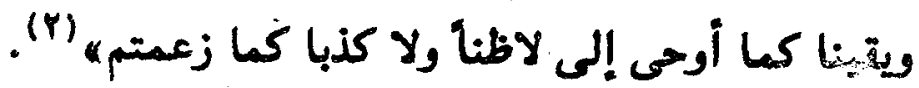

ومن يدقق النظر فى هذه الوصـايا يجـدها من الآيات البـامسعـ

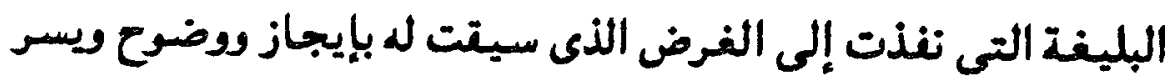

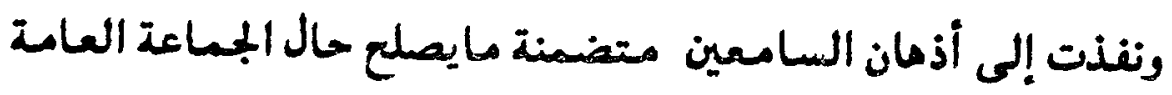

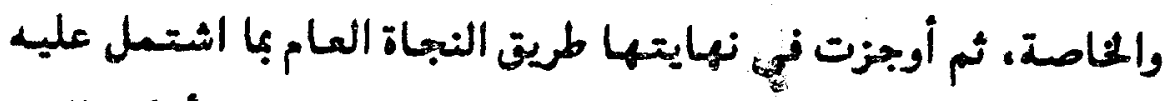

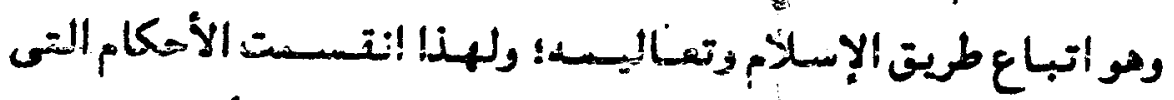

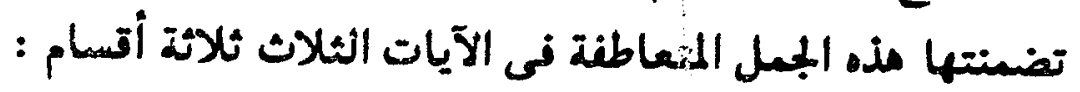

$$
\text { - (1) }
$$

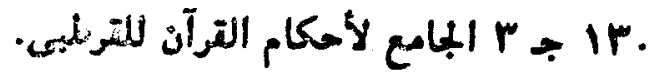


التسمر الأول "(1): أحكام بها إصلاع الحسالة الاجتماعية بين الناس.

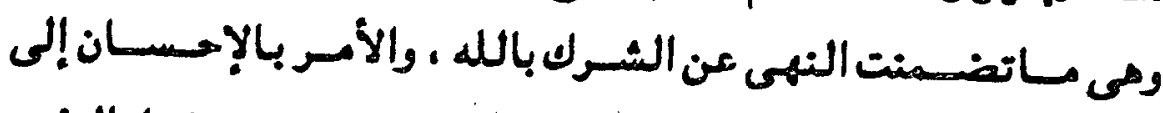

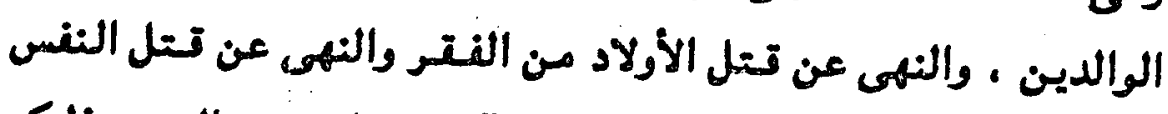

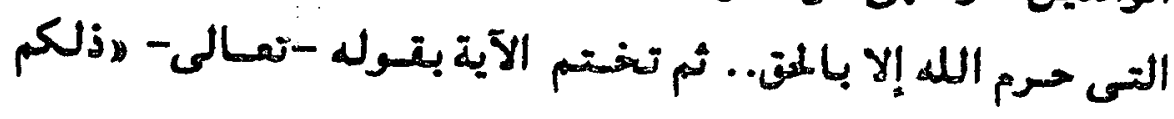

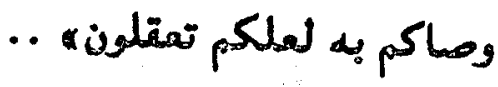

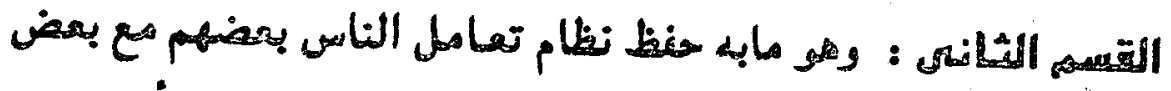

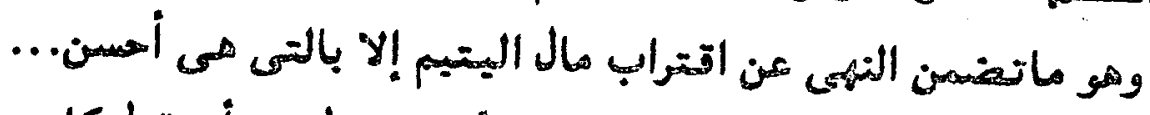

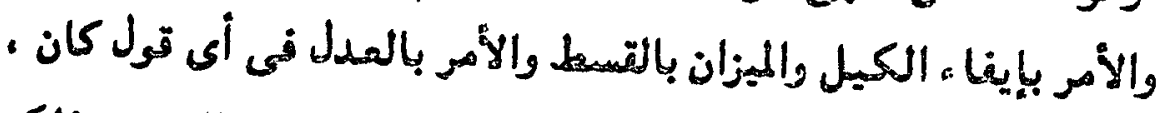

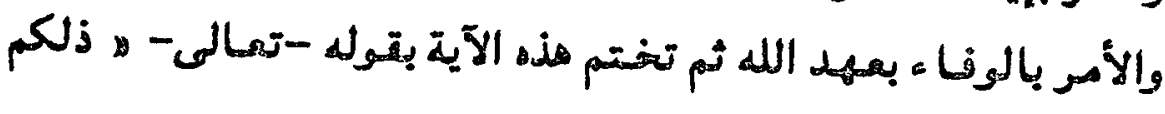

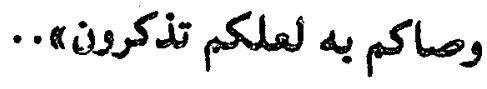

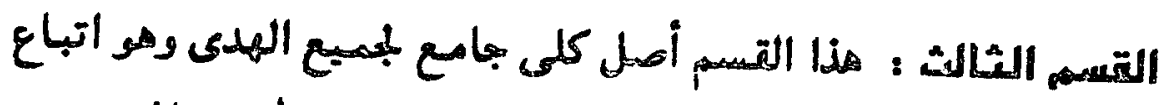

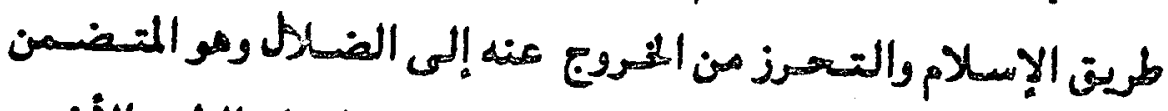

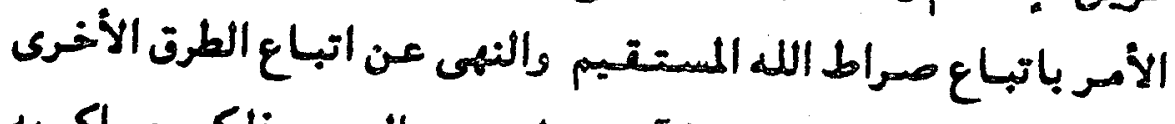

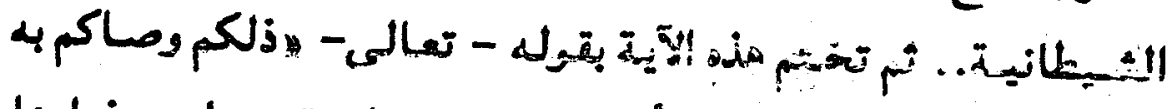

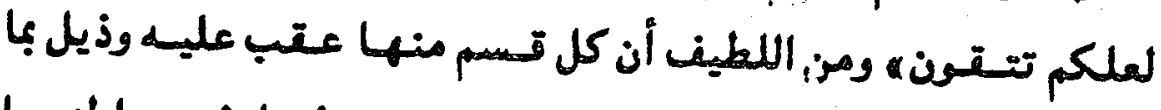
يلامهد وسنفعل الهير البلاغى في كل تعتبب وتذييل في مواطنهيا

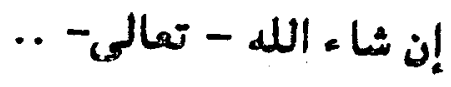

ينظر - أيضا - 102 بم تفسير التعرير والتنوير للطاهر بن عاشهد

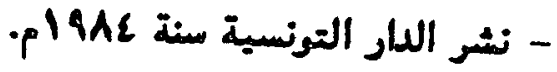


״ تل تعالوا أتل ما حرم ربكم عليكم: ألا تشركرا به شيئا...

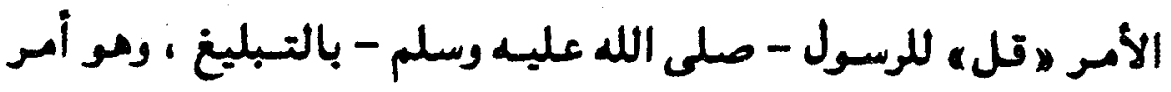

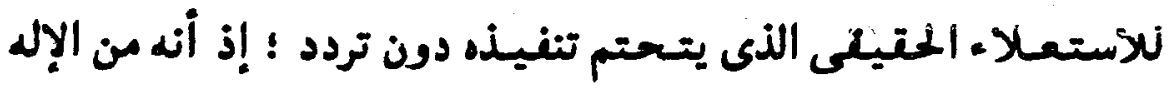

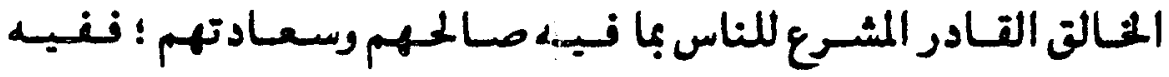

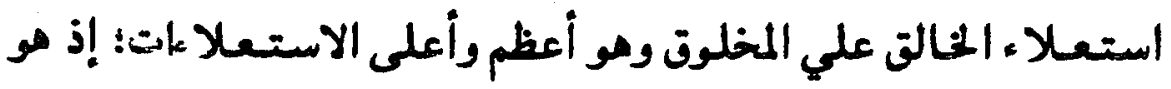

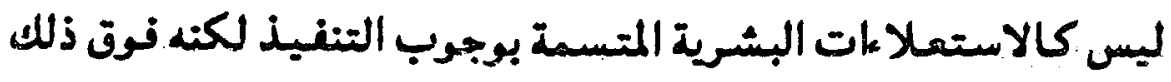

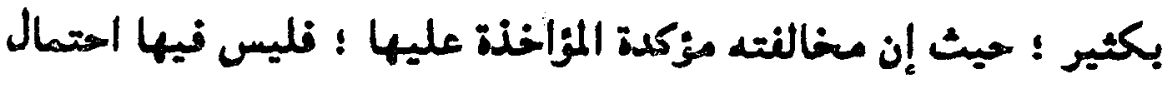

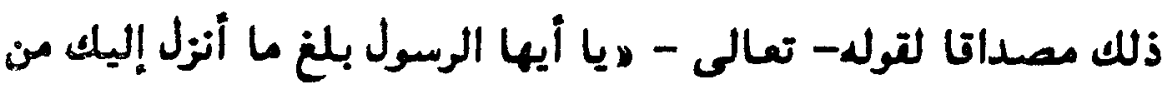

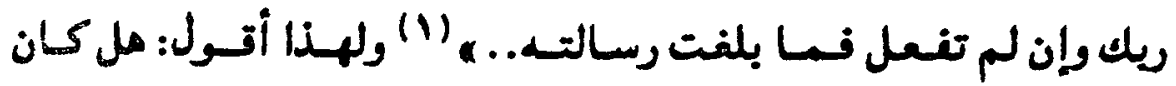
يتسنى التعبير بصيغة أخرى غير قوله: «تل تعالوا أقل ... «ـ.

التصورات البشرية العاجزة - تتصور التعبيرات الآتية :

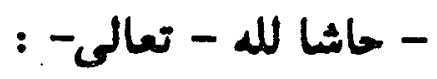

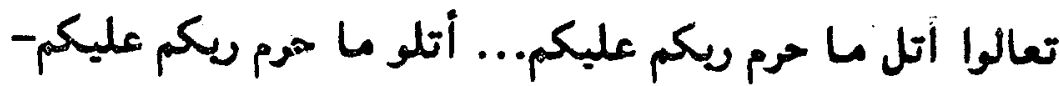
إنا أتلو ما حرم ريكم عليكم - إنا حرم ديكم عليكم- قد حرم ربكم

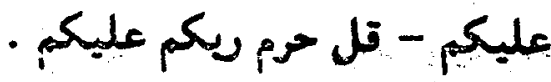

ويلاحظ أن التعبيرات الحمسة الأولى خلت من الأمر لقاله هوأن

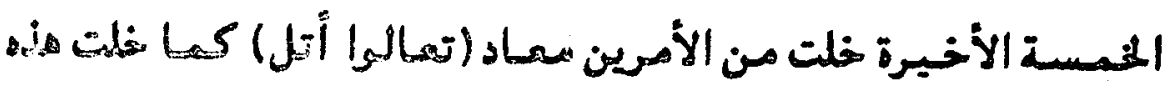

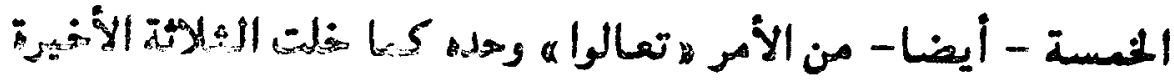

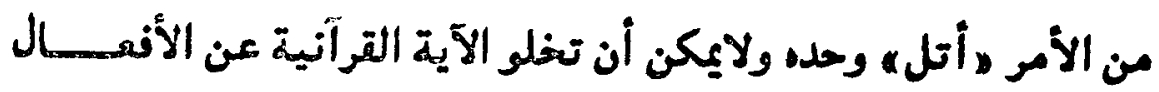


الثلائة معا ؛ أما عن الأمر هقله فإن من يدقق النظر أكثر يجد أن هذا

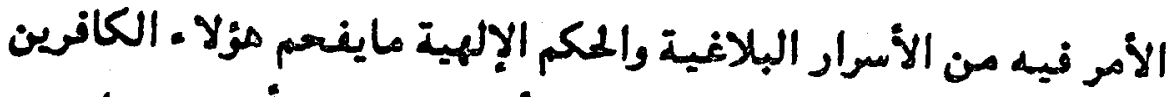

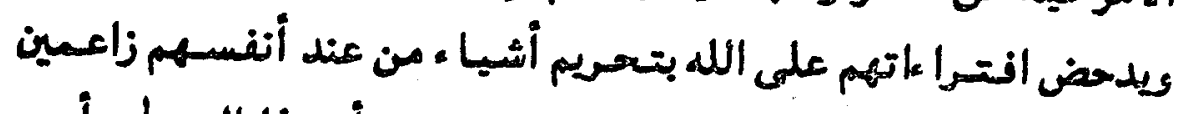

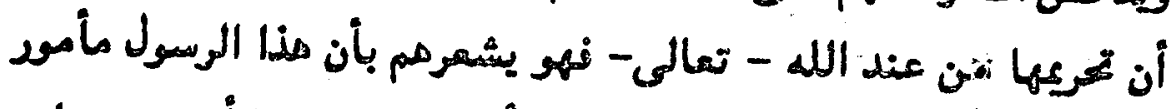

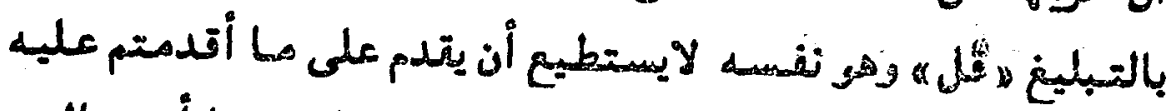

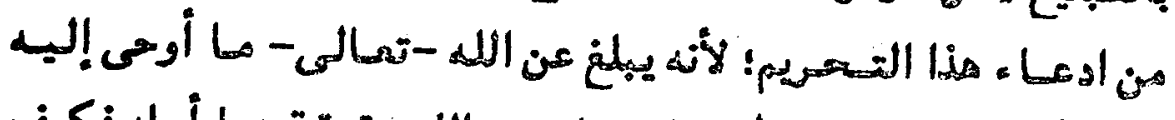

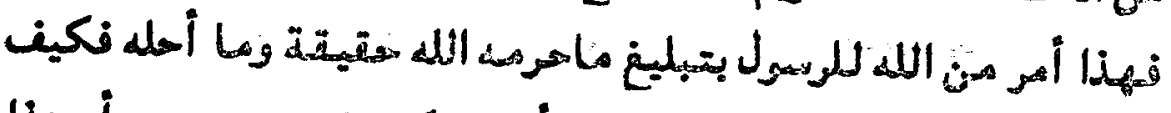

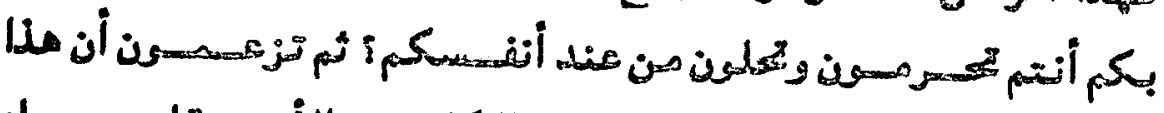

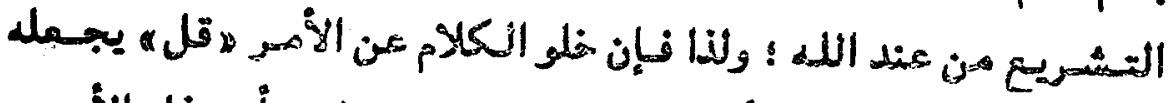

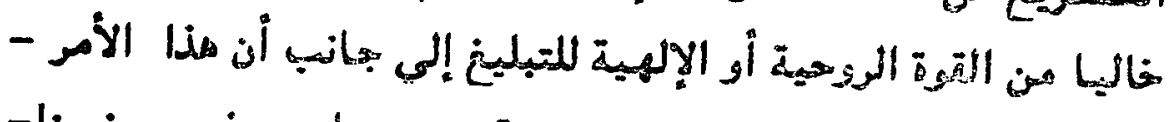

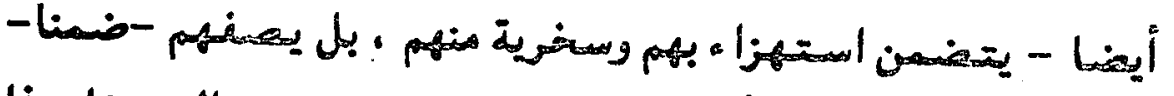

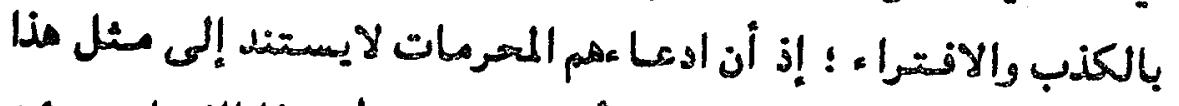

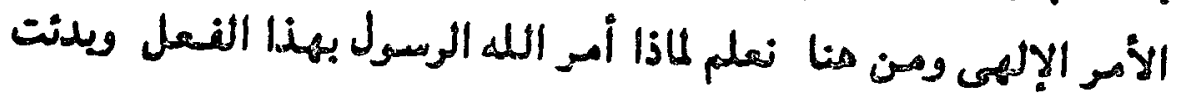

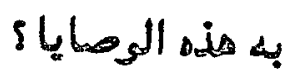

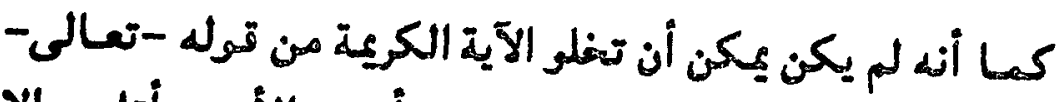

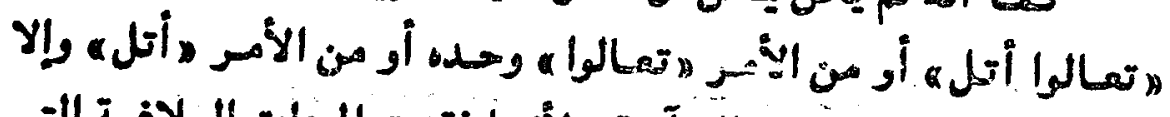

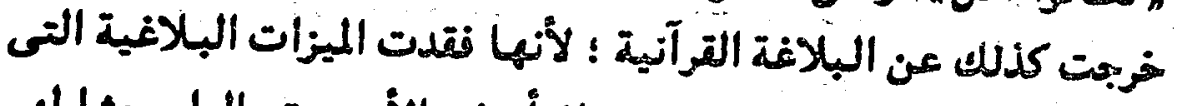

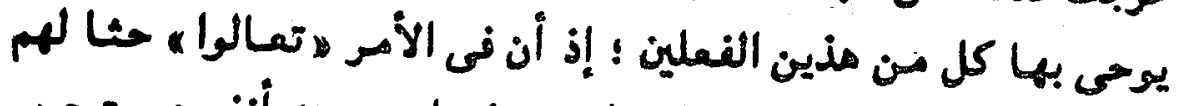

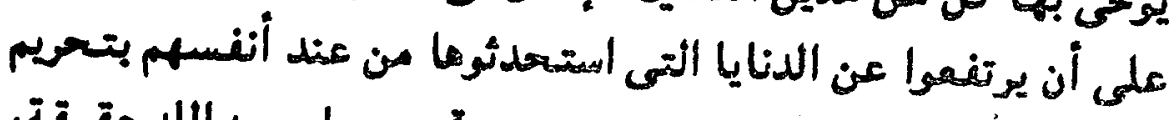

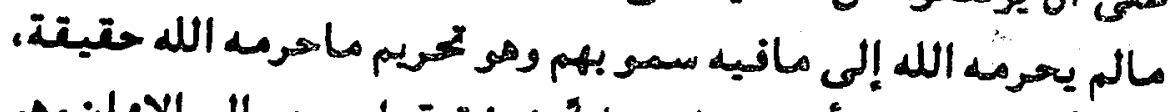

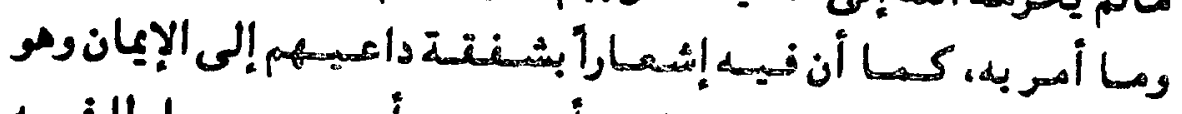

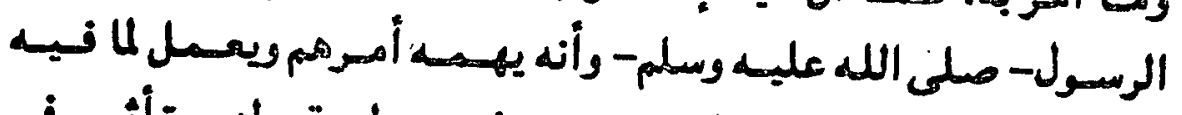

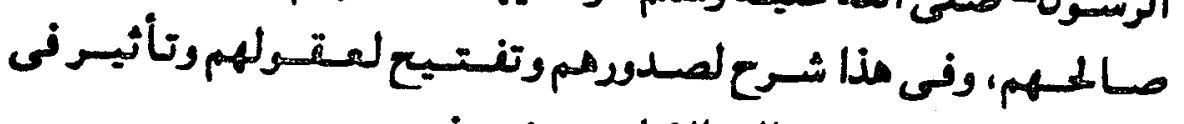

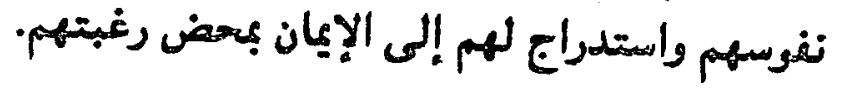




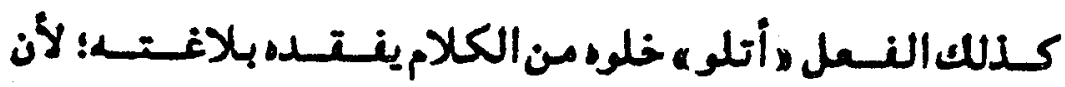

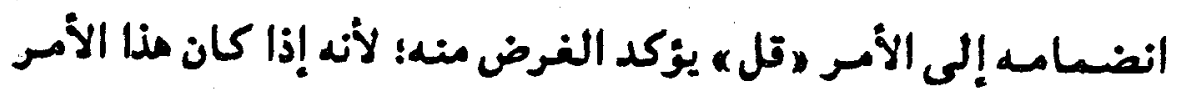

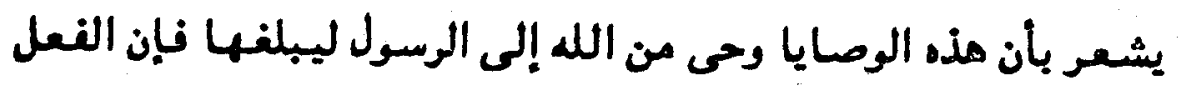

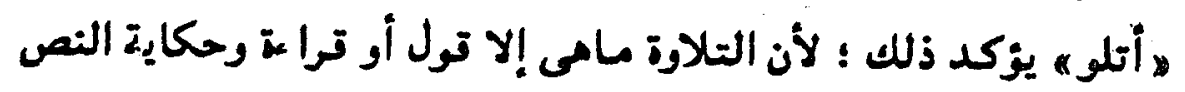

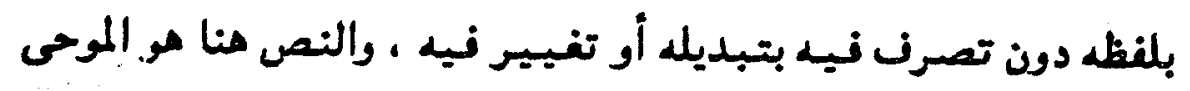

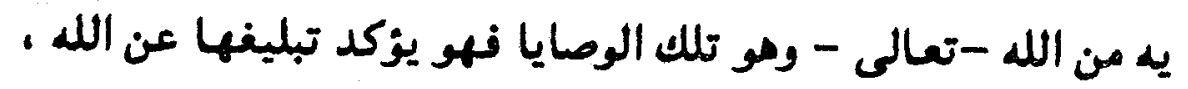

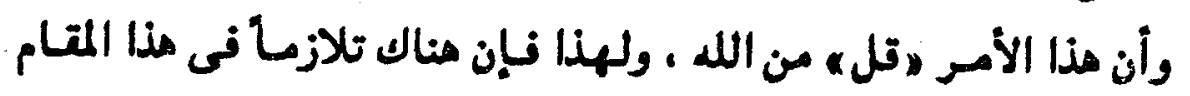

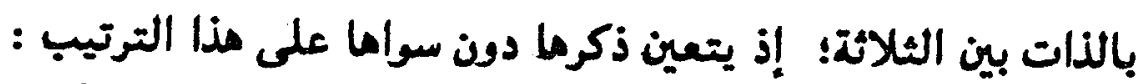

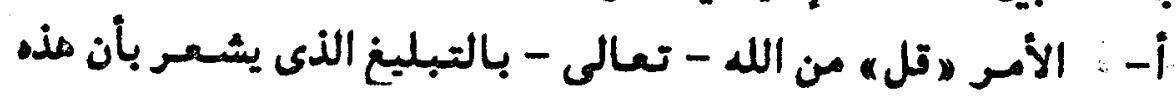

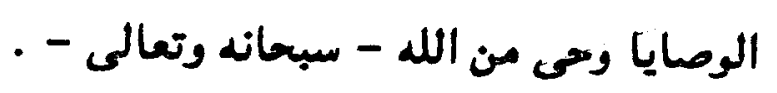

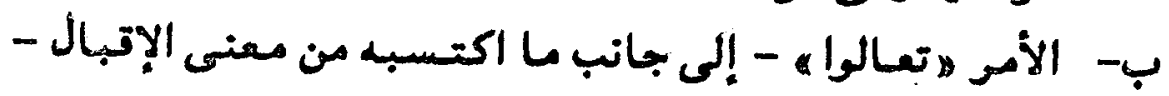

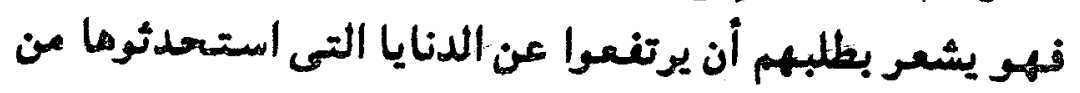

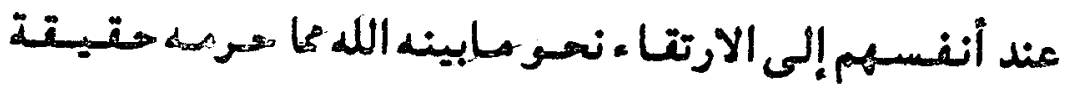

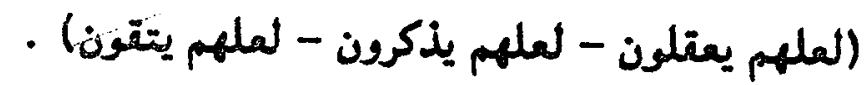

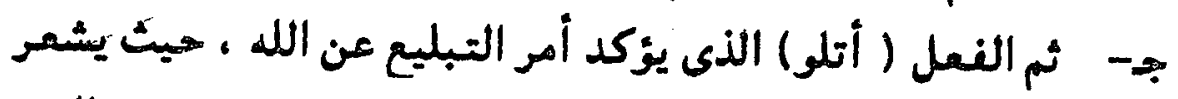

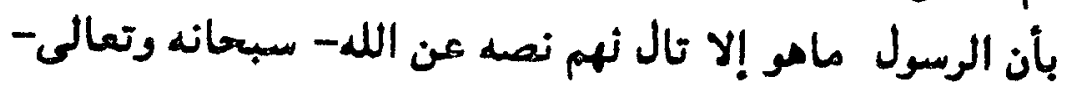

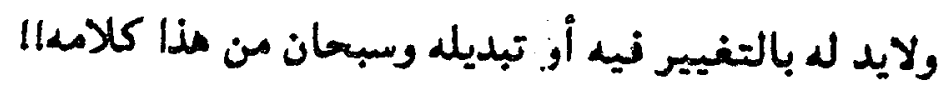

هذا .. والأمر ( تعالوا!) معناه الحقيقى الأصلى الاعتلاء إلى إلى

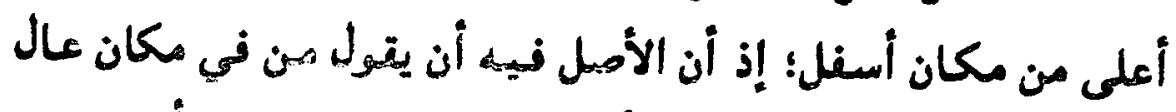

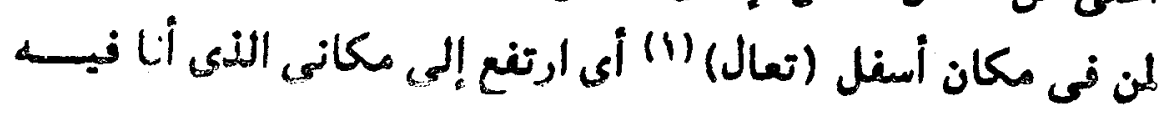

IrV

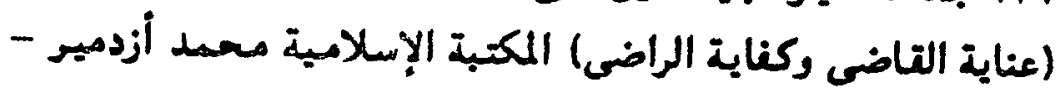




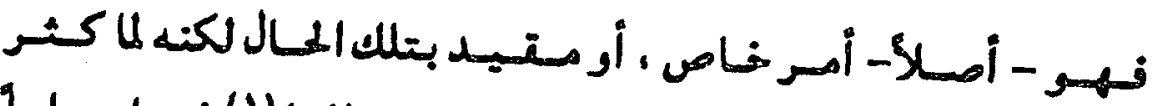

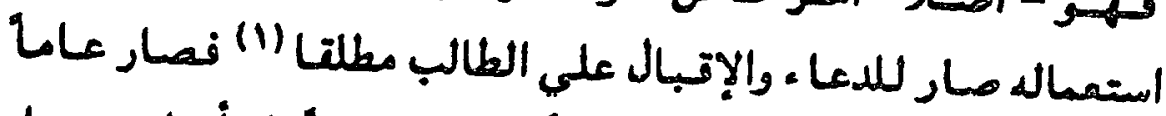

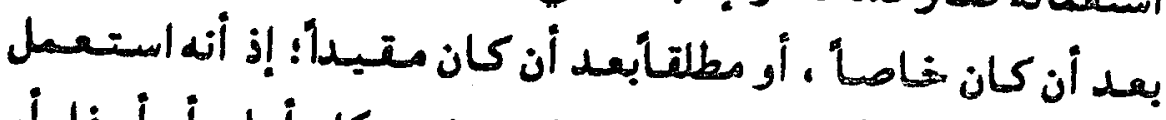

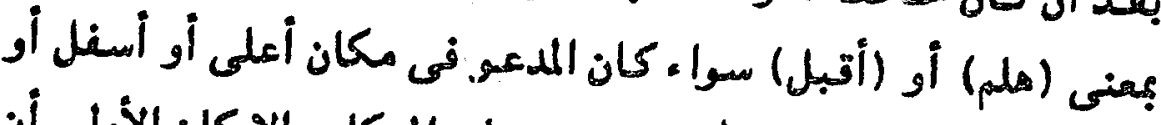

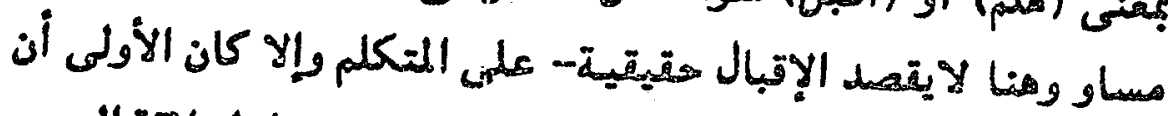

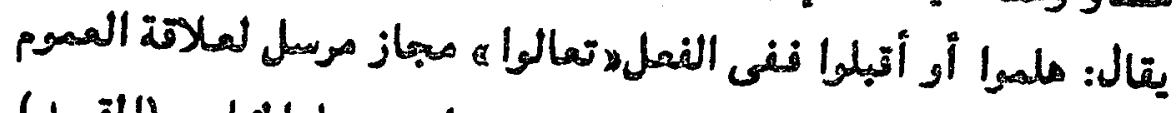

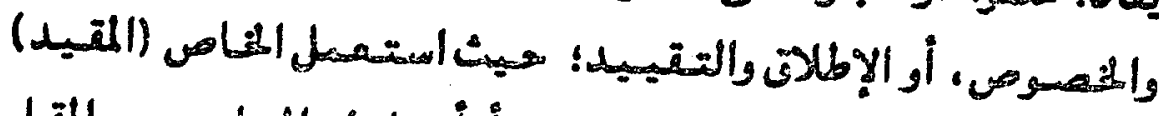

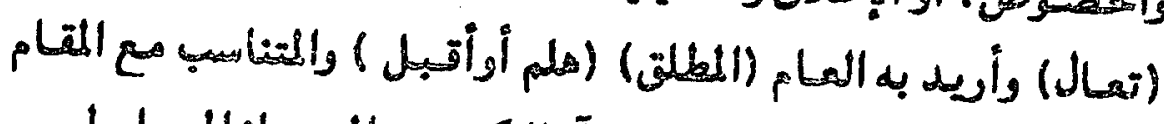

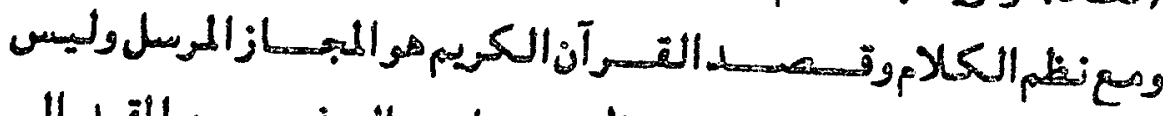

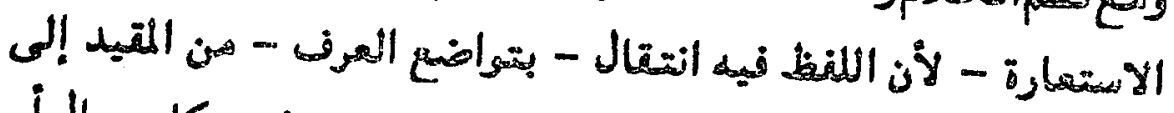

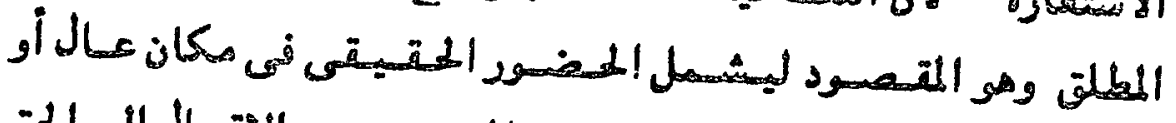

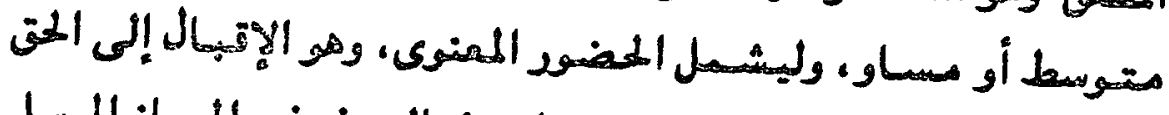

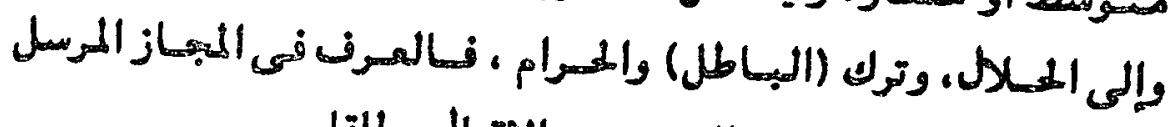
أعان على ذلك؛ هيث إن الفرض هو الإقبال هطلقا.

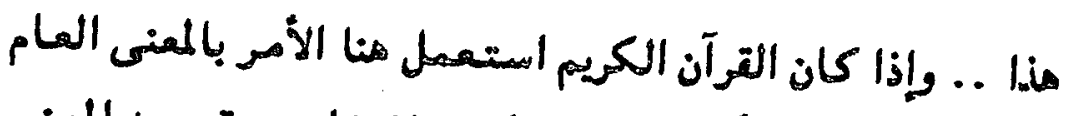

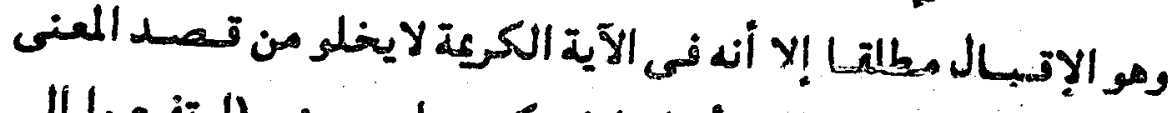

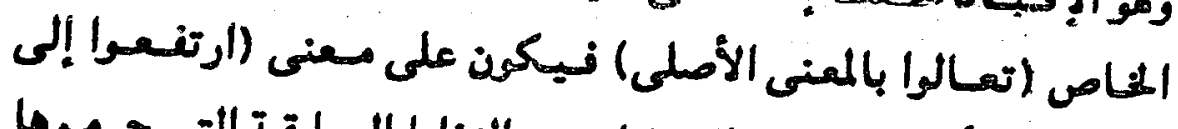

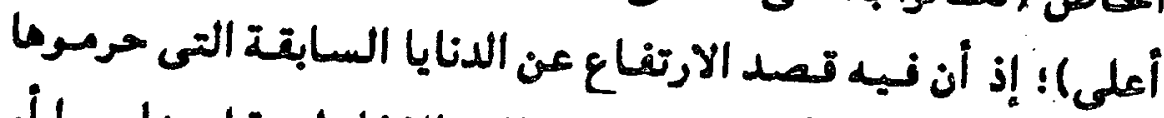

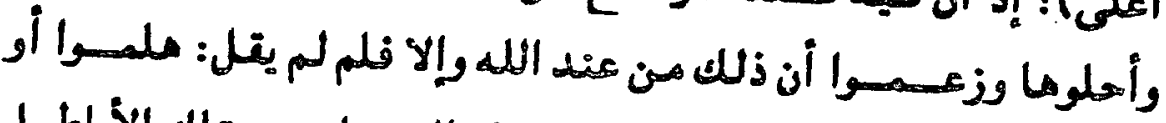

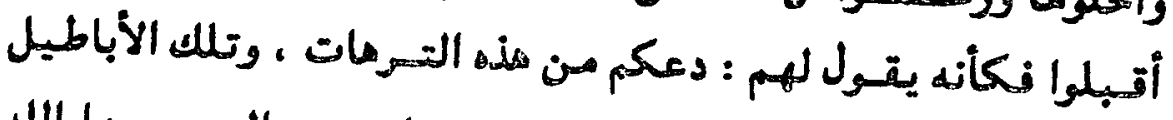

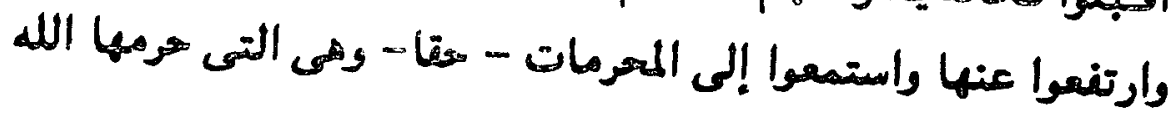




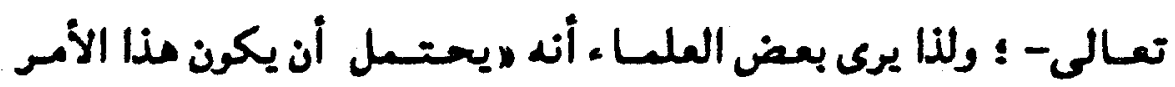

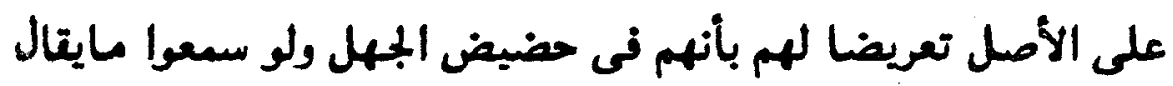

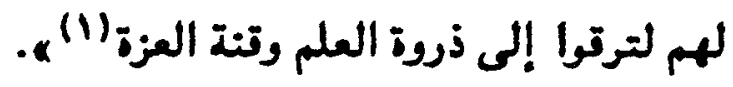

\section{" ماحرم ربكم عليكم " :}

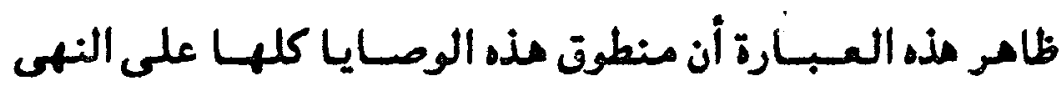

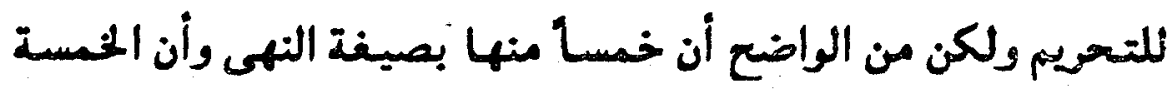

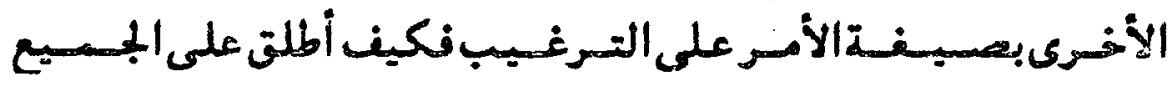

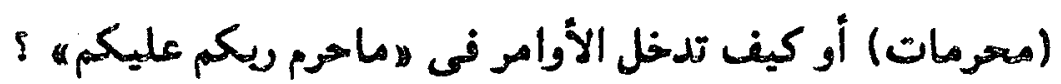

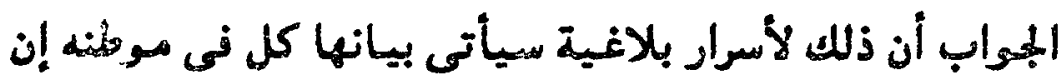

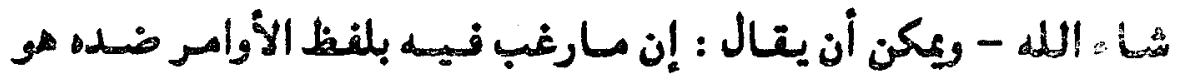

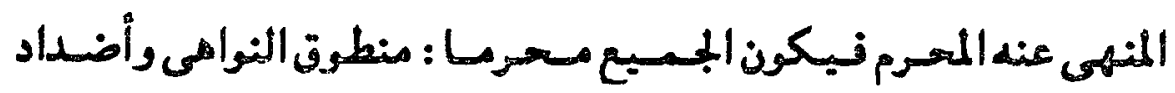

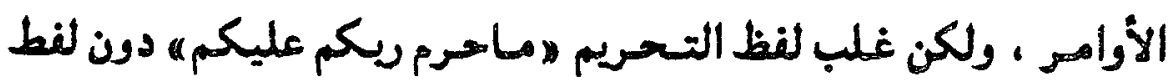

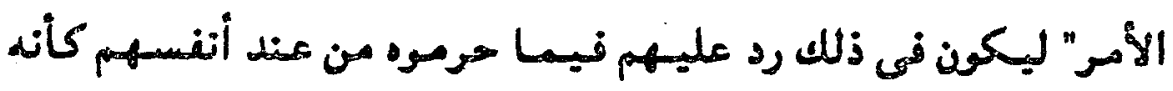

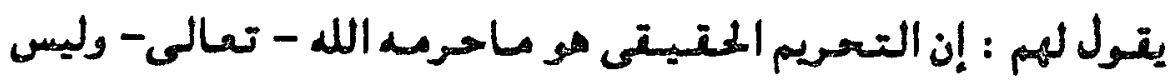

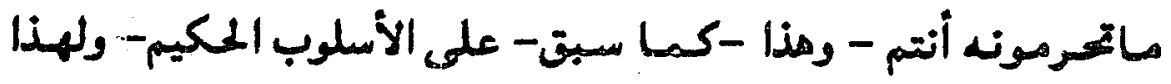

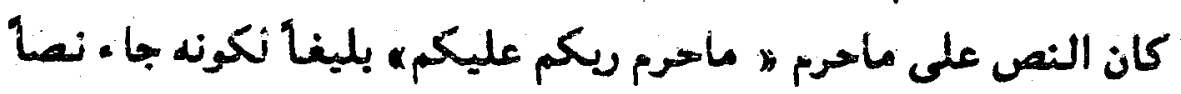

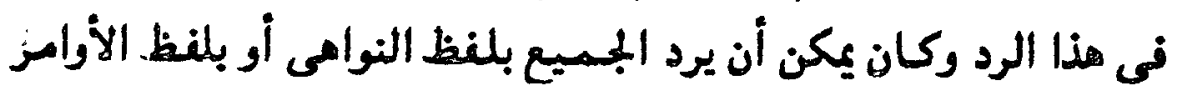

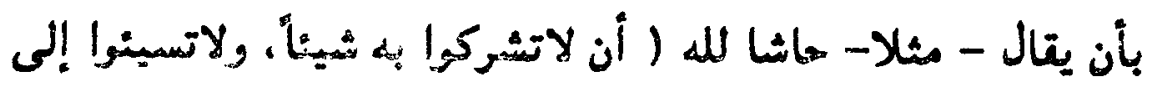

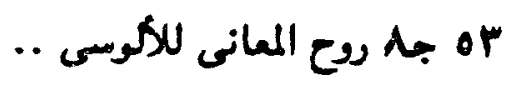

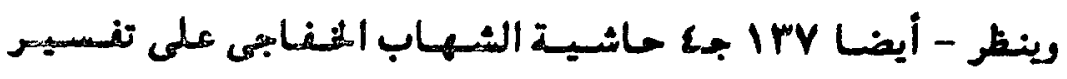

$$
\text { البيضاوى ولكن بلنظ (يتول) بالبناء للمعلدم.. }
$$




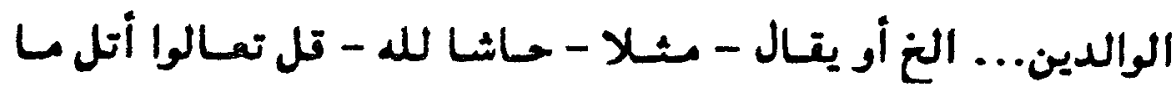

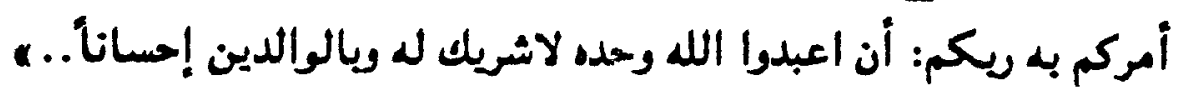

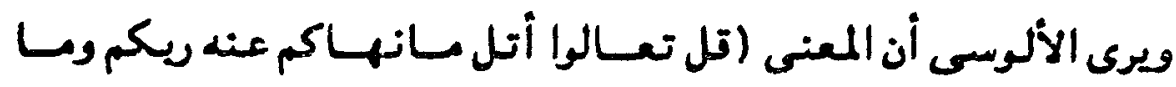

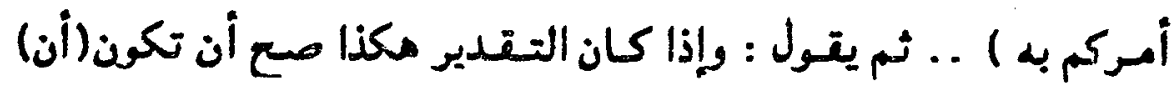

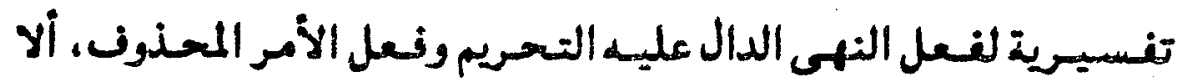

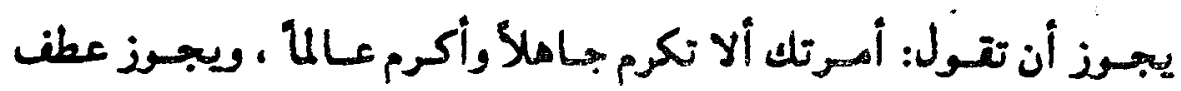
الأمر على التهى كقول امرئ القيس :

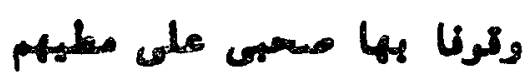

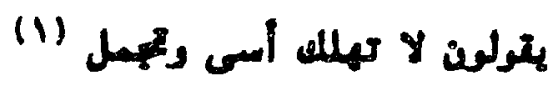

أولول: رإذا كان تقدير الكلام : ( تل تمالوا أتل مانهاكم عنه

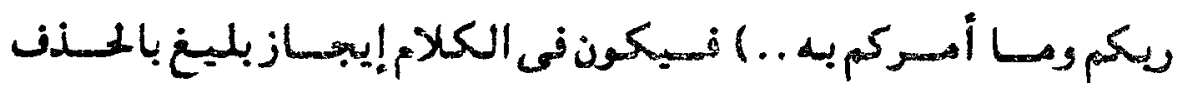

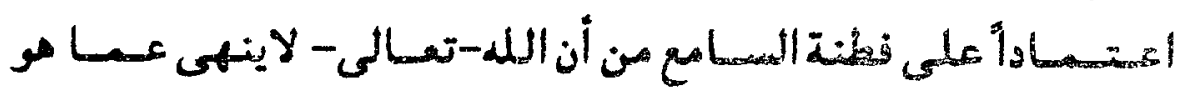

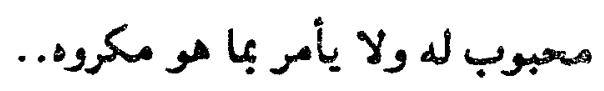

مذا ويرى بعض العلما ـ أن هاعليكمه أسم نعل أمر بمعنى الزموا

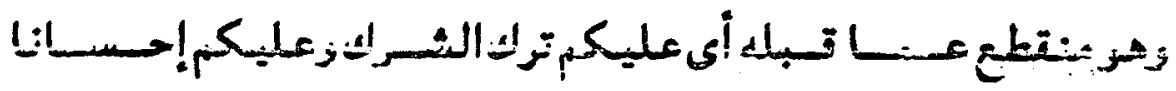

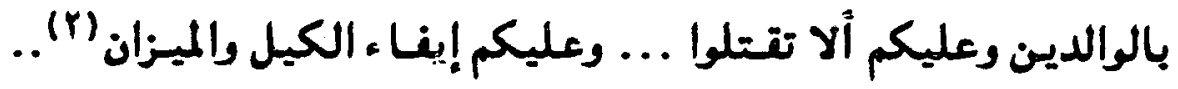

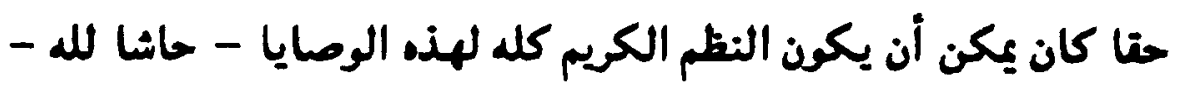

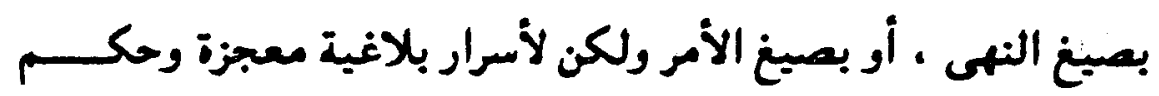

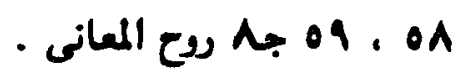

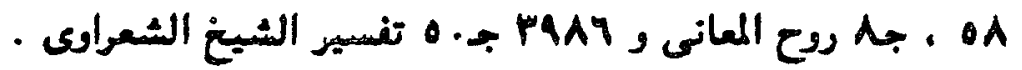




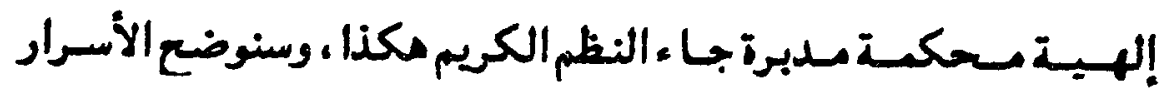
البلاغية - كا تلت - بتدر طاقد البشر فى ذلك كل في في موطنه بإذنه

تعالى - مالهية

" أن لإتشركوا به شيتاً،

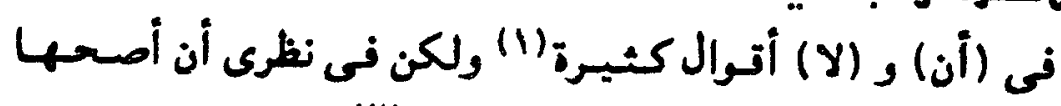

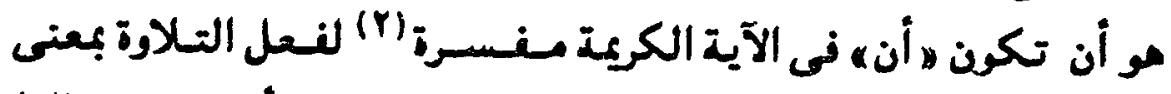

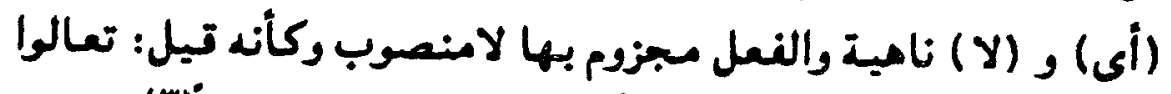

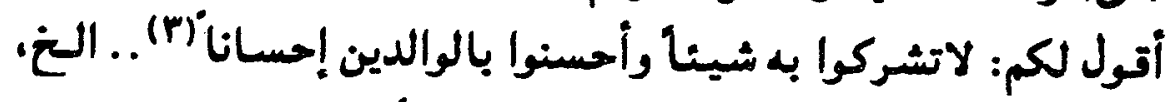

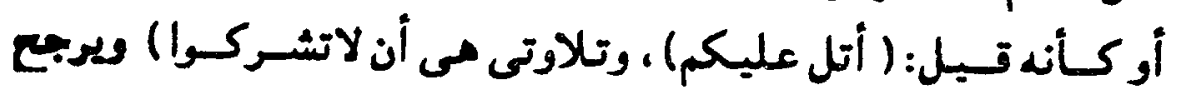

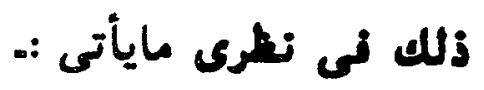

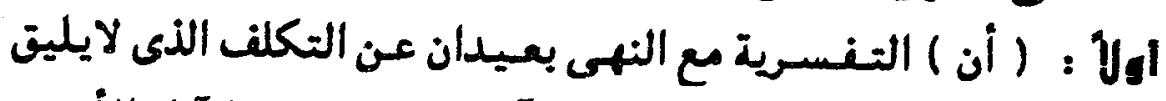

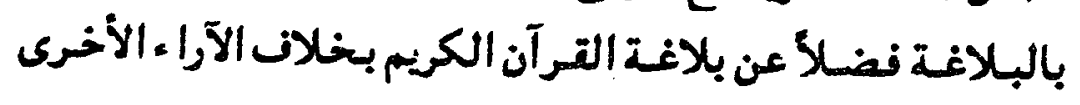

$$
\text { فإن تكلفا فيها واضحاً. }
$$

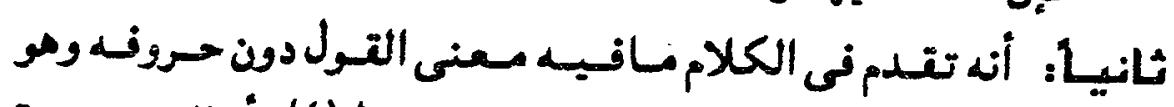

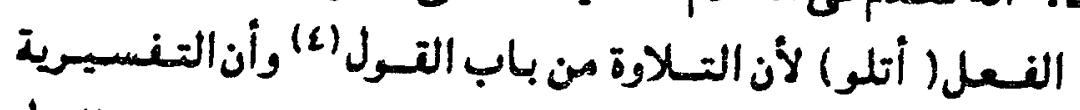

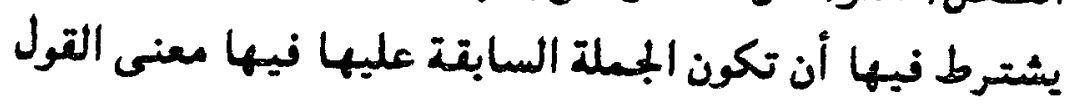

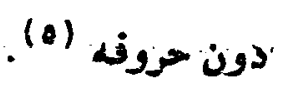

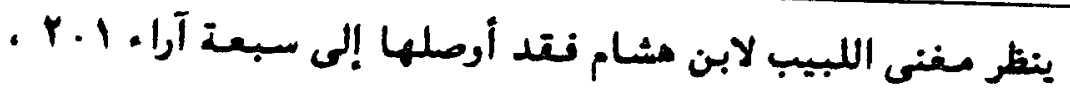

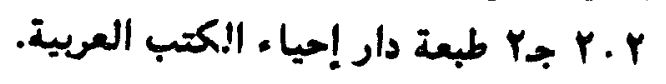

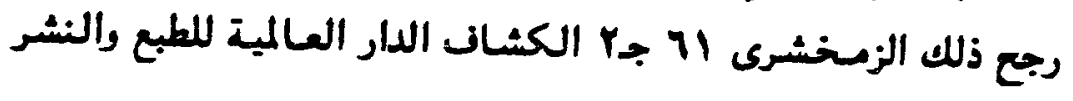
والتوزيع.

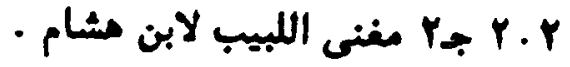

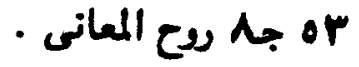

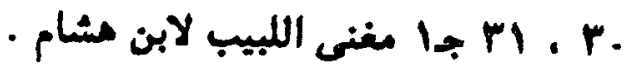


ثالثا: أن المقام متام ردود على محرمات لم يحرمها الله - تعالى- وتهري

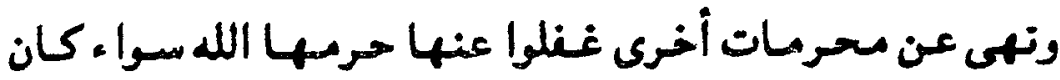

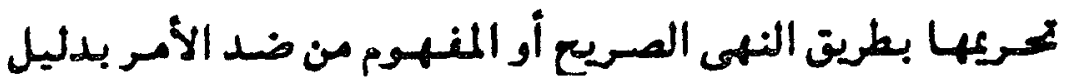

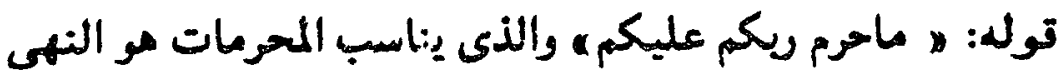

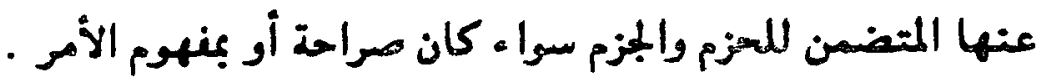

رابعاً: يحتمل - كما يقول الألوسى - أن يكون فى الكلام محذوف

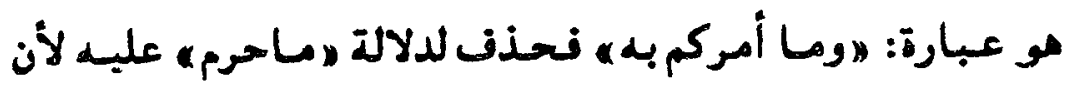

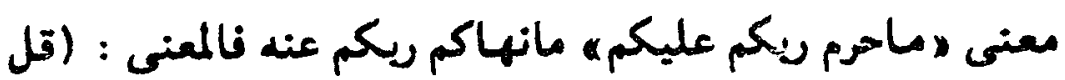

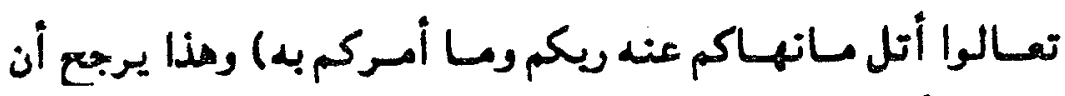
تكون (أن) مغسرة و (لا) نامية جازمة.

خاهساً: أن فى قسوله -تعـالى - رقل تعـالوا أتل مـاحسرم ريكم

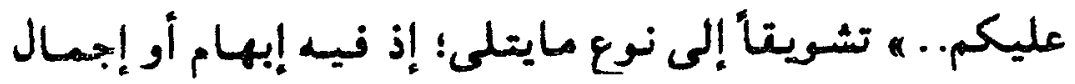

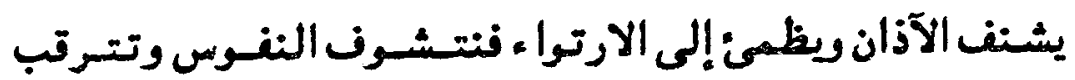

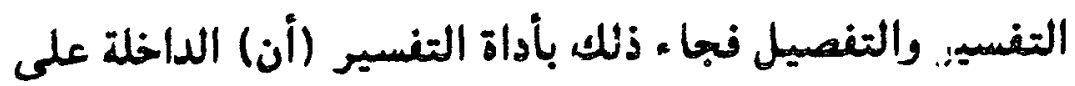

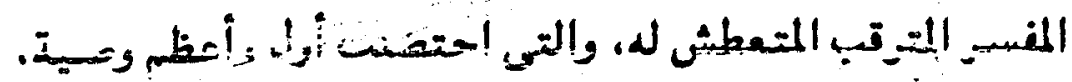
وأول المنسرات أو المحرمات ومو الشرك بالله رأن أن لاتشركوا بـ أله شيئاً. . والمن

سادساً : قد ترد شبهة على أن (أن) مصدرية و (لا) نافية منادها:

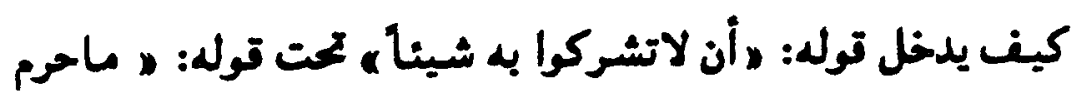

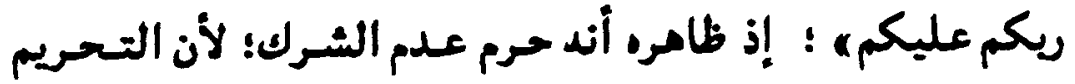

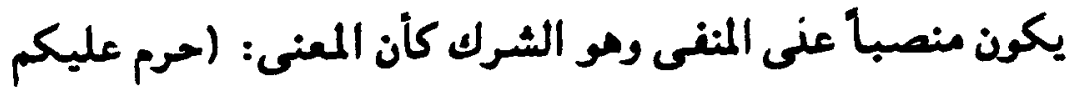




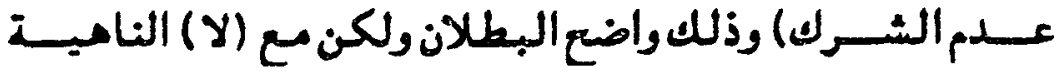

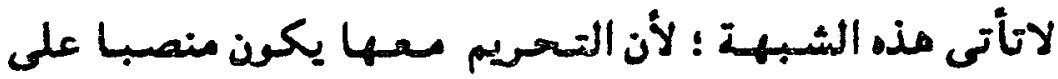
المنهى عنه وهو الثـرك نالمعنى معـه: (حرم عليكم المنهى عند

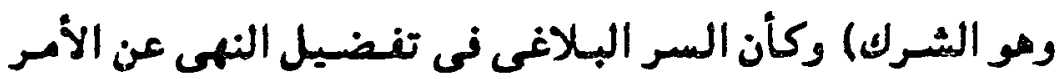

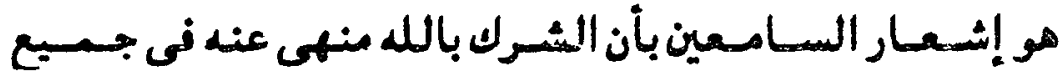

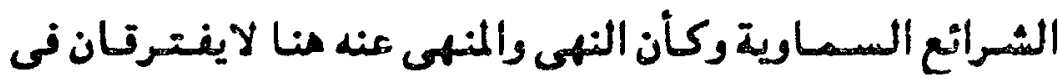
الأذهان، وينطبق مذا على جميع المنهيات عنها ، وعلى أضداد

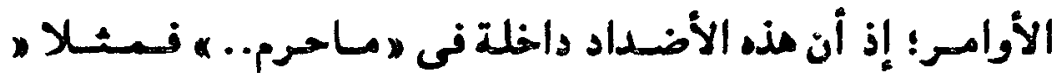
ولاتفتلوا أولادكم من إملاق.. ؛ المنهى عنه مو تـلهم فالمحرم

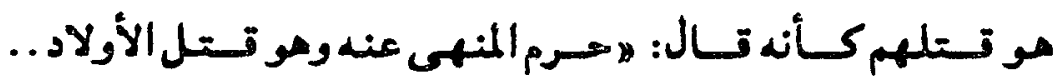

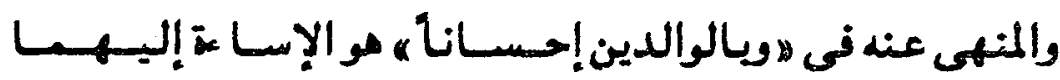

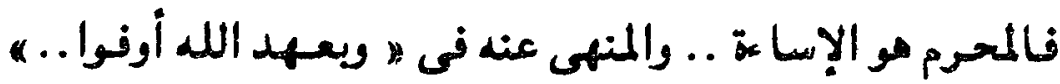
هو تقض عهد الله فالمحرم هو نقض عبهده - تعالى - كأنه قال:

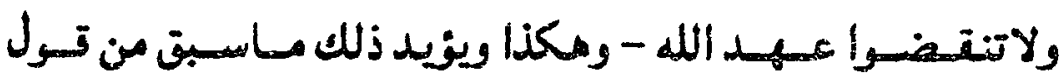

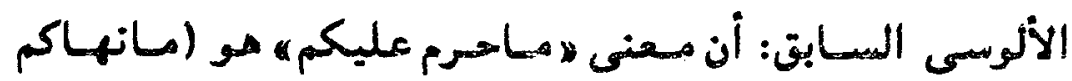

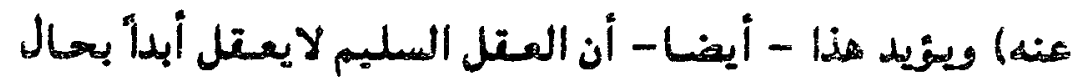
هن الأمهوال - أن يكون المراد يحريم النفى (تمحيم عدم الشيرك )

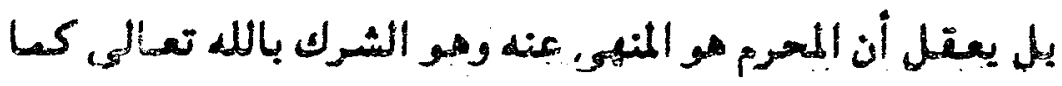

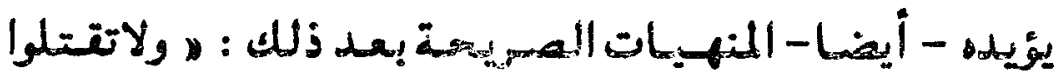

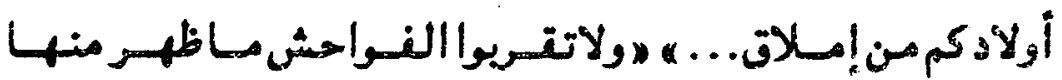

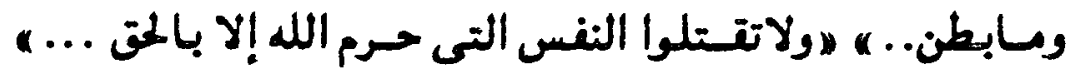

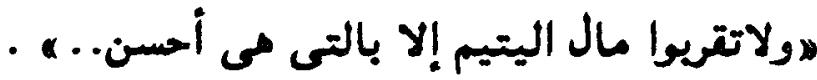




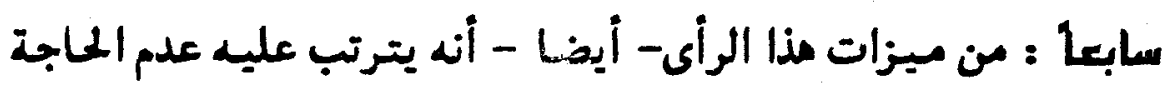

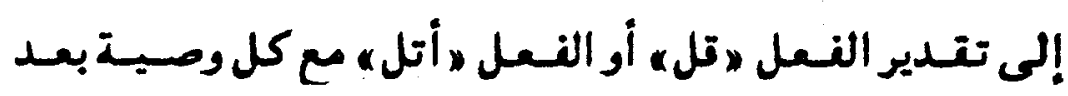

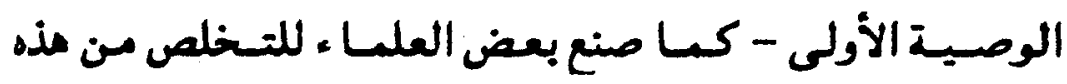

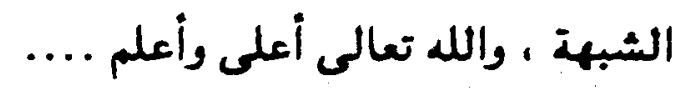

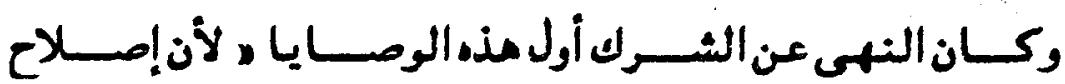

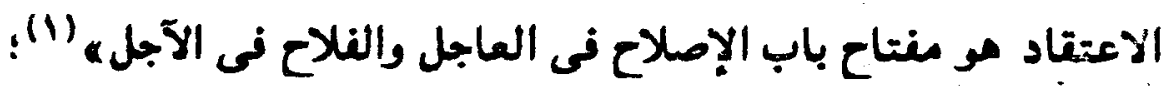

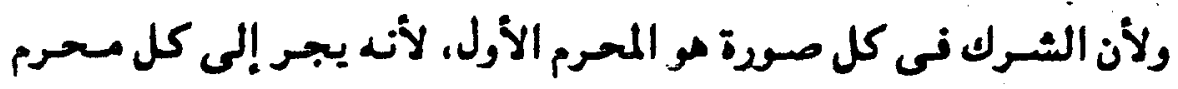

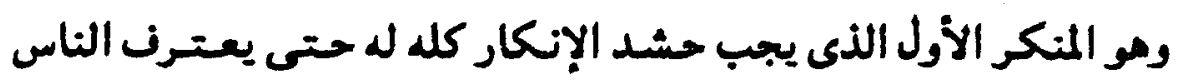

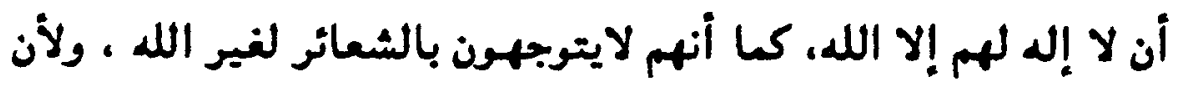

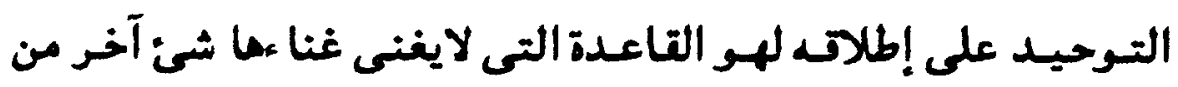

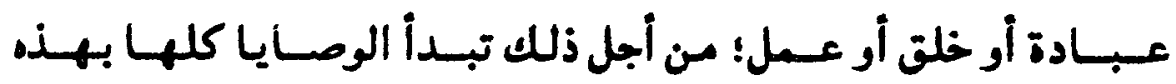

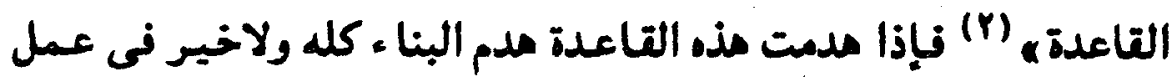

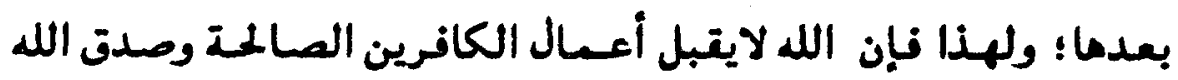

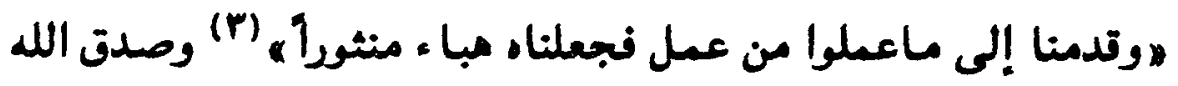

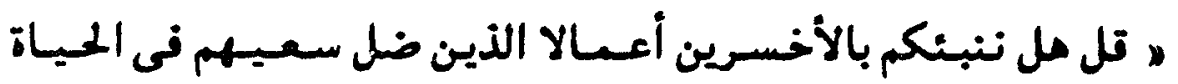

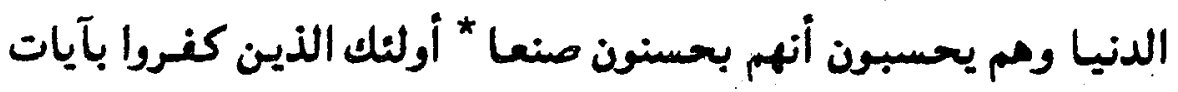

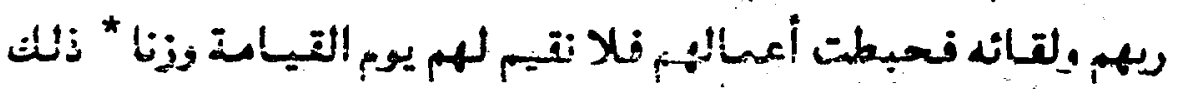

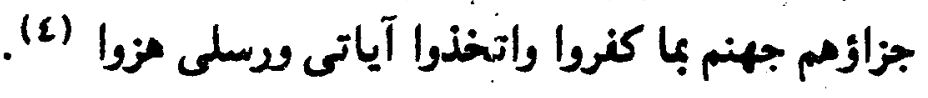

101 جـ التحرير والتنوير ..

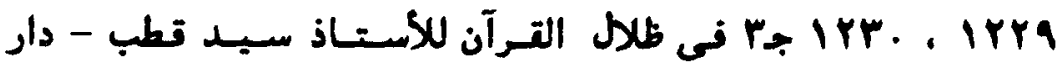

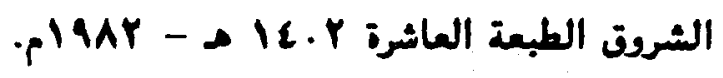




\section{-YA-}

وجـاء ـ النهى عن الشـرك باللنظ الصــيح : , لاتشـركـوا، دون

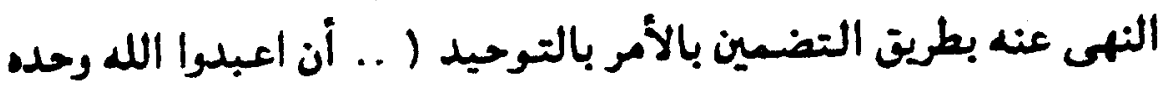

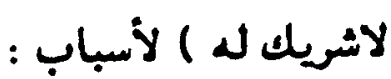

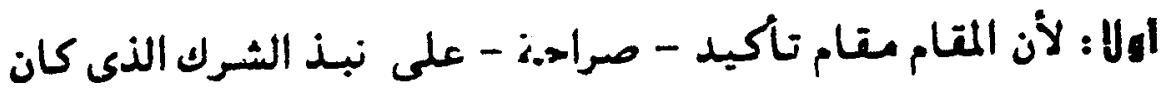
سائدا . ثانيا: لإرساء عقيدة التوحيد وإشاعتها فهو من باب التخلية تبل التحلية . ألاء ثالثاً: أن النهى عن الشرك صراحة يتضسن الأمر بتوحيده .

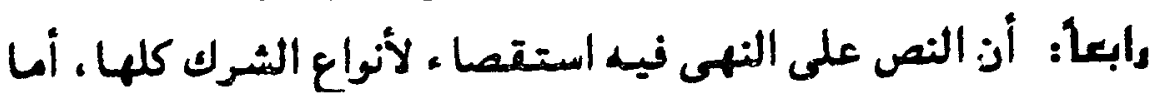

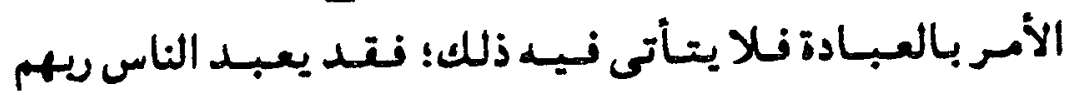

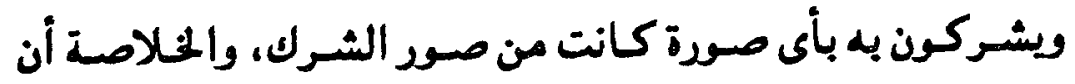

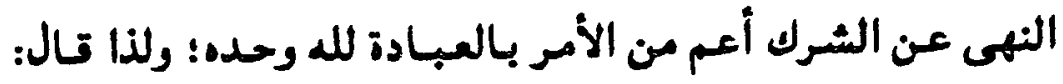

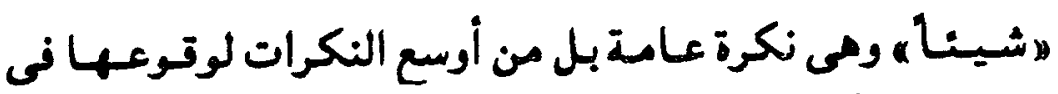

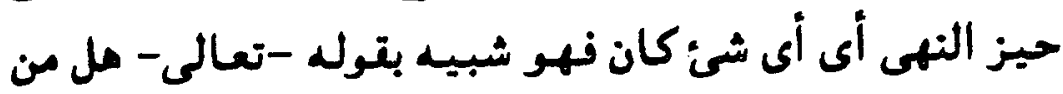

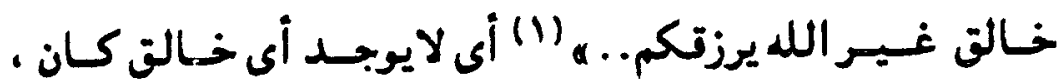

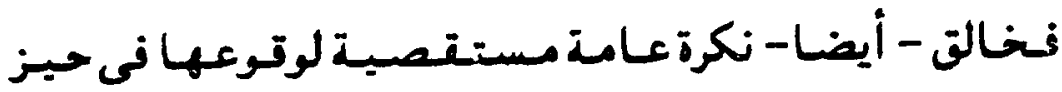

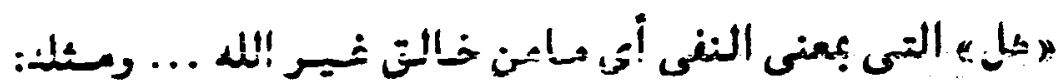

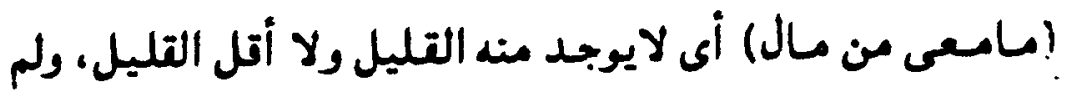

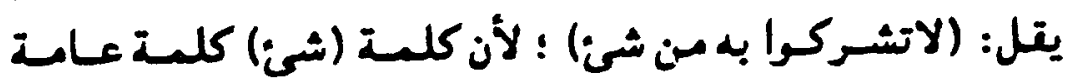

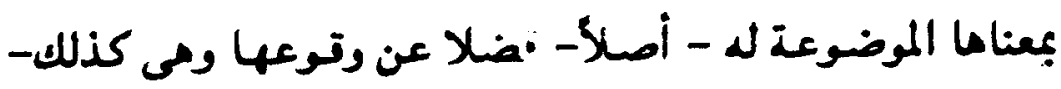

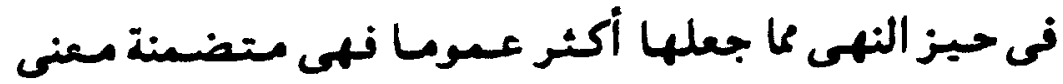
"من شئه ولنا نليست فى عاجة إلى من التى تؤكد عمومها، 
وتد تجين من معها صريحة بعد النفى لإنادة زيادة العموم -أيضا-

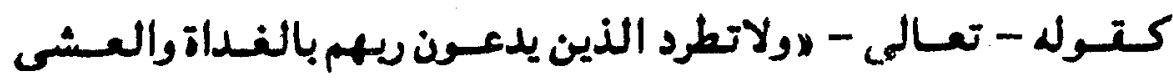

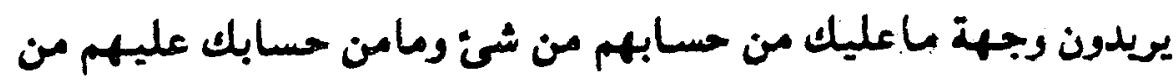

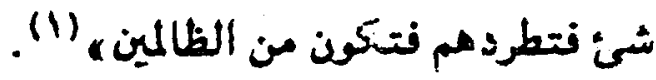

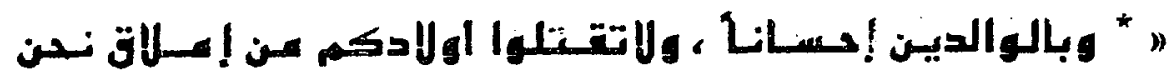
نهزتكم وإياهم، ولاتتعبوا الغواحشر عاظهر هنها و هابطنه. بين يدى هذه الومايا الثلاث :

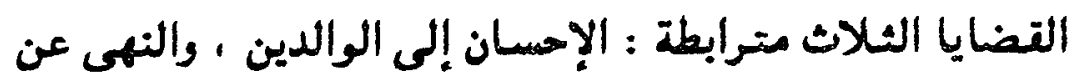

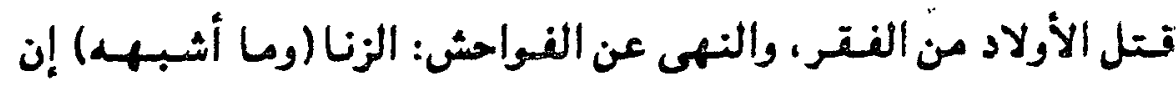

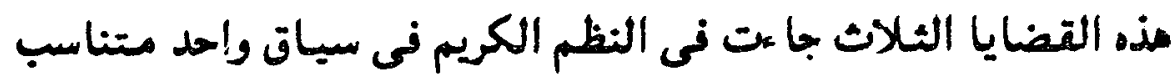

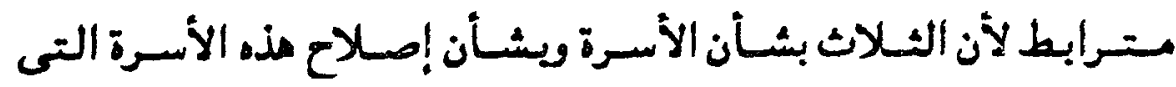

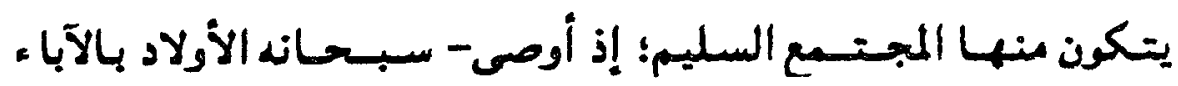

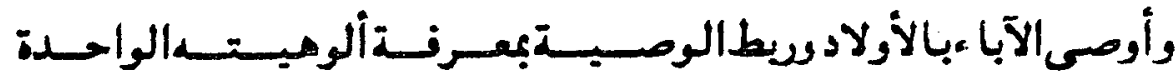

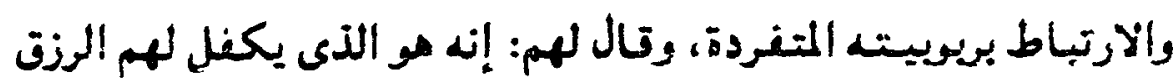

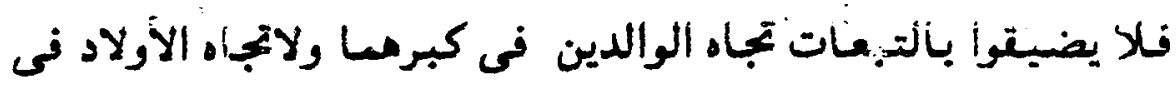

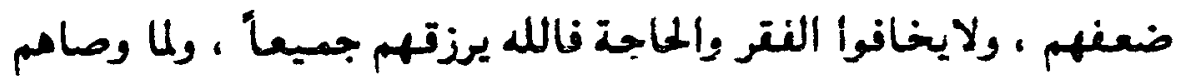

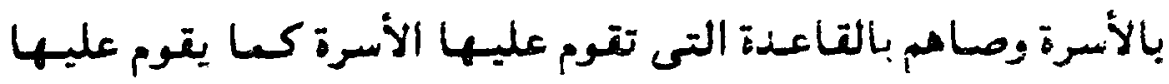

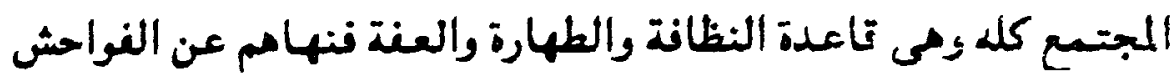

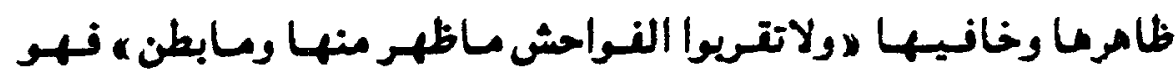

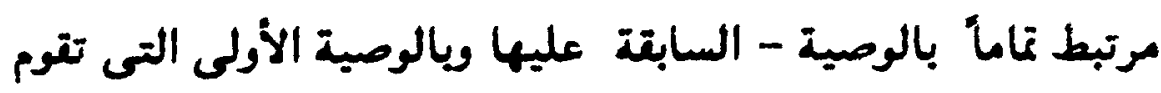


عليها الوصايا- وكان مذا النهى فى ملا المجال ضروريا؛ لأنه لايككن

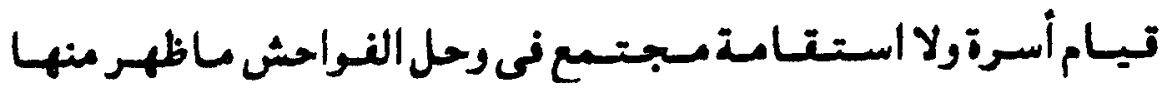

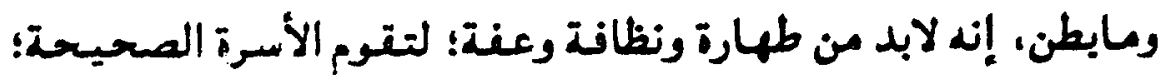

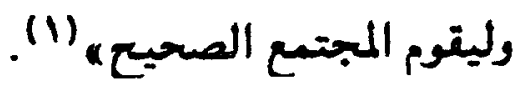

$$
\text { " وبالوالديـ إحسانا... " }
$$

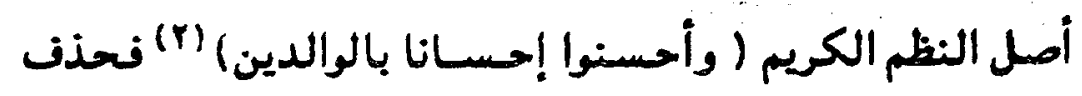

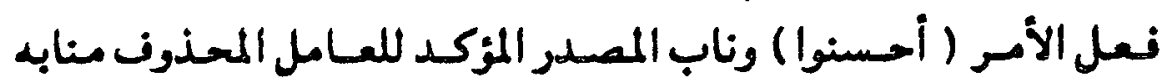

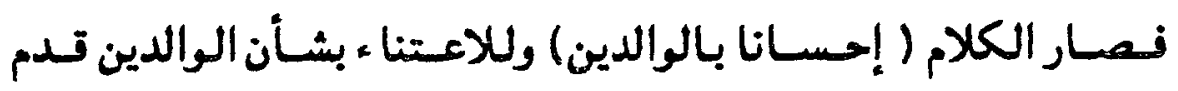

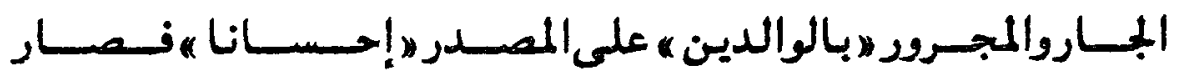

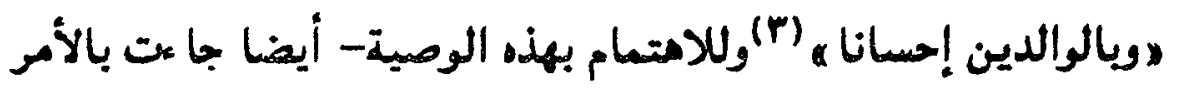

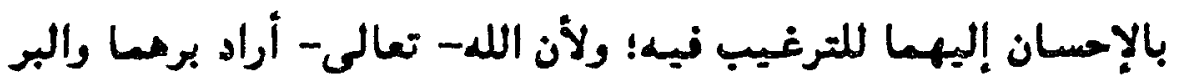

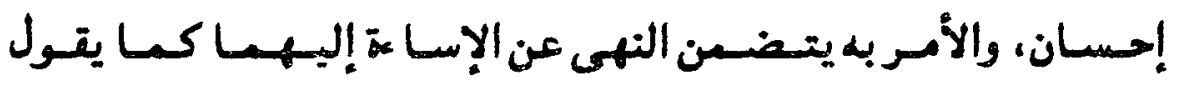
المتنبى:

إذا المجود لم يهذت خلاصا من الأذى

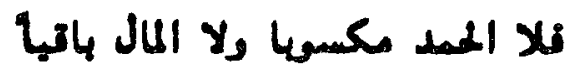

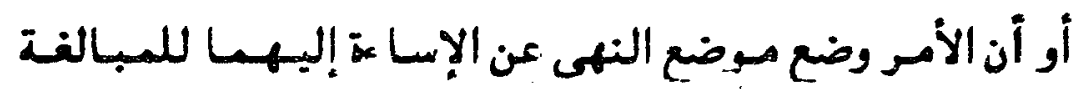

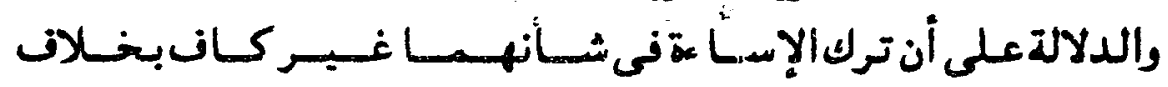

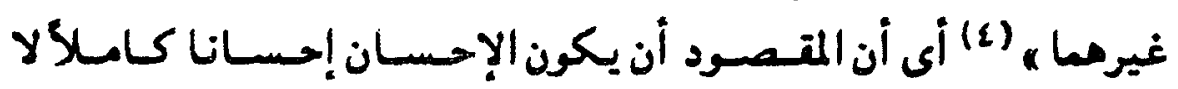

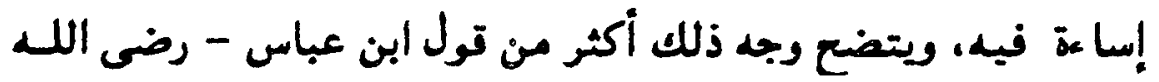

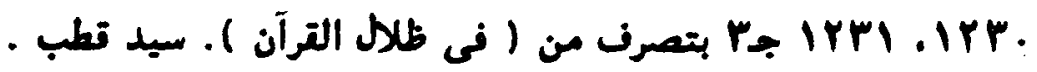

ا Irr

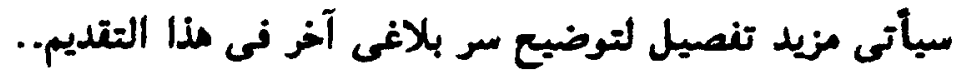

IPA ا جع تنسير البيضاوى. 


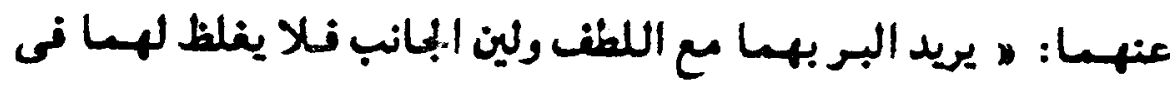

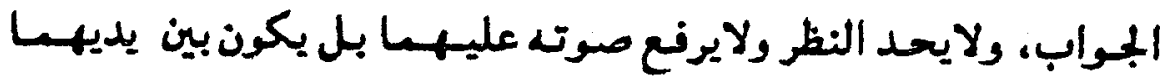

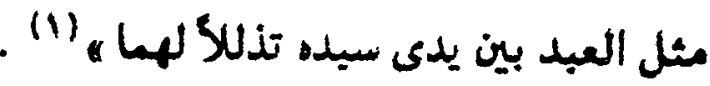

ومنا ملامسن لطينة وهى: أن الوصية بالوالدين فى الترآن جاءت

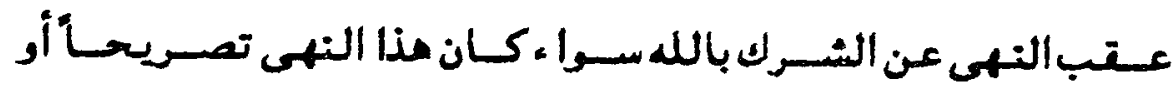

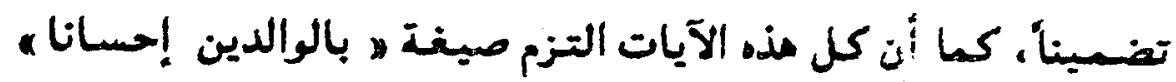

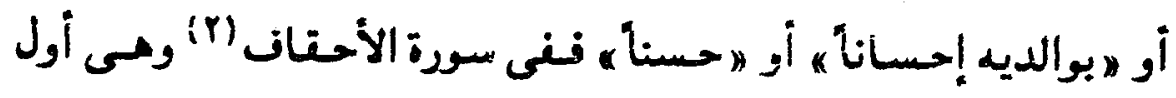

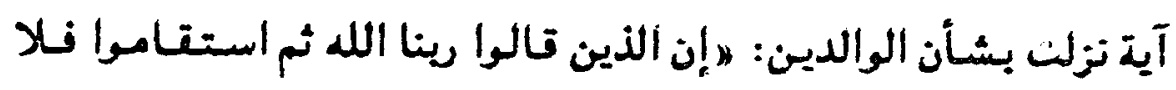

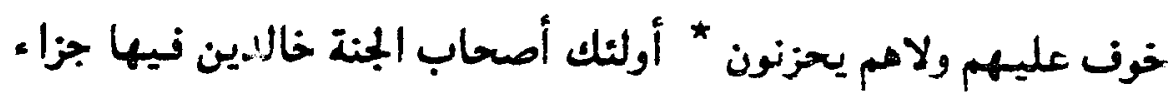

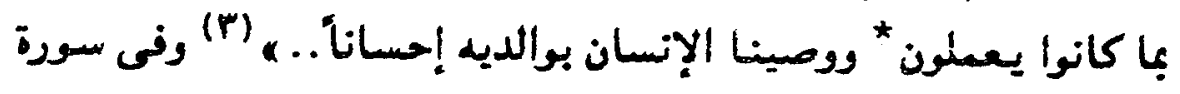

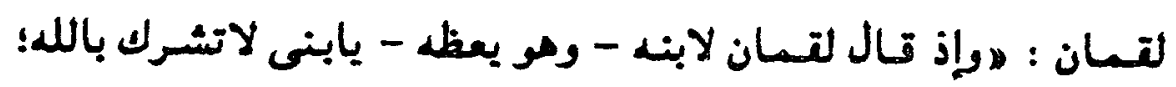

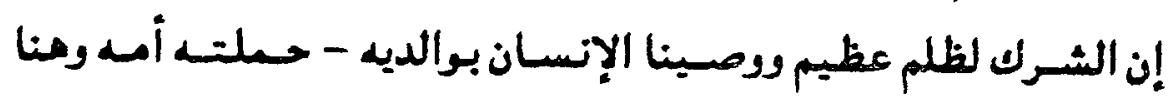

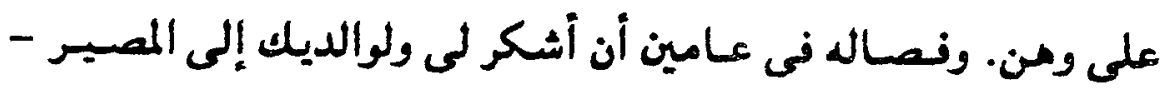

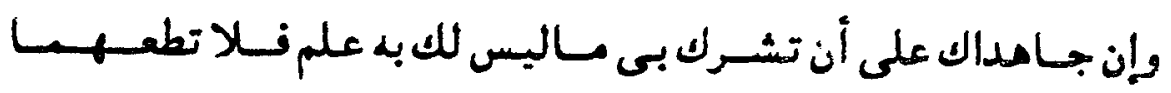

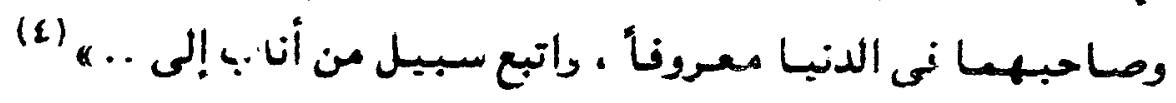

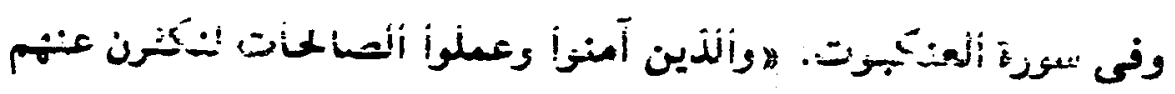

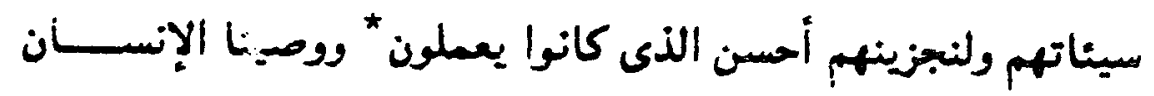

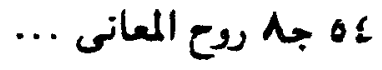

$$
\begin{aligned}
& \text { رتبت هذ، الآيات حسب توتيب النزول. }
\end{aligned}
$$

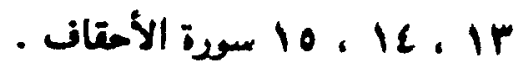

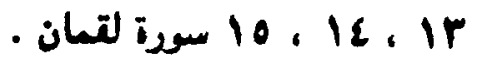


بوالديه حسناً.. " "(1) وفى سورة الإسراء : "( وتضى ريك أن لاتعبدوا

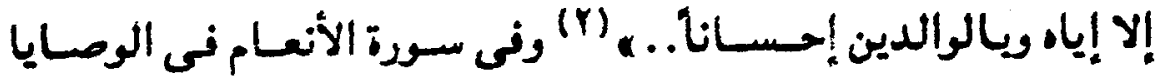

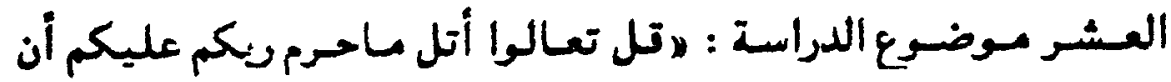

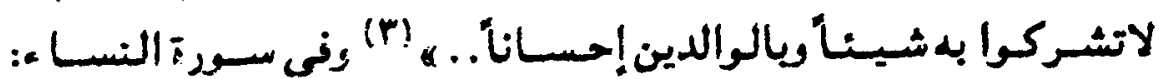

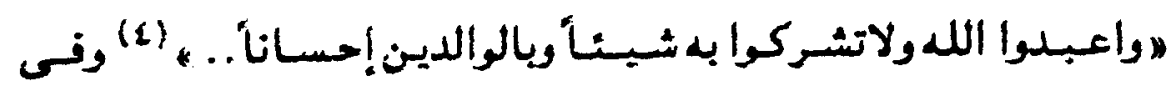

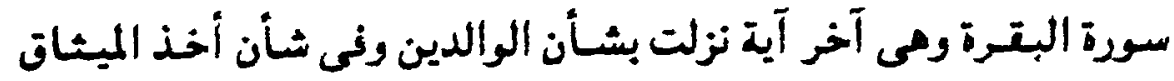

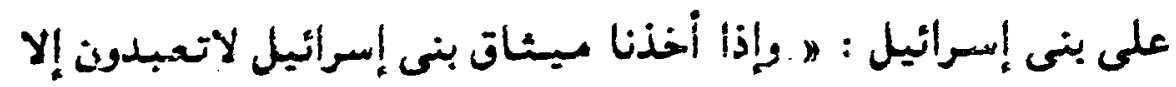

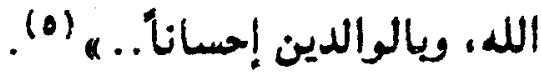

ما السر البلاغى فى سذا النظم :أولا : فى الوصية بالوالدين

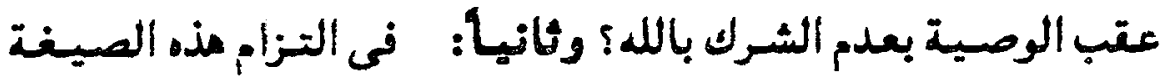

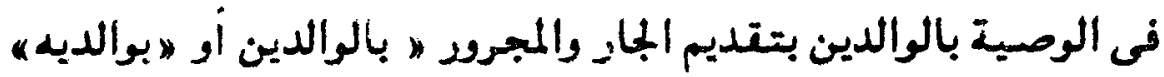

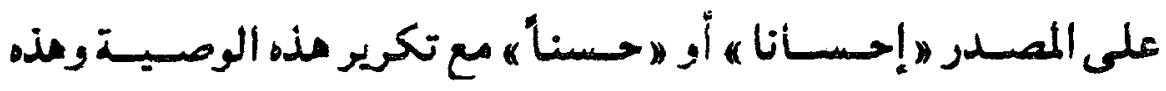
الصيغ على المعت

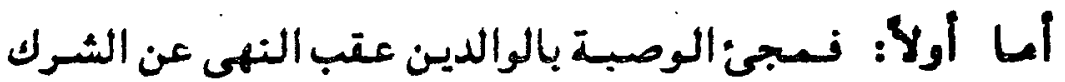

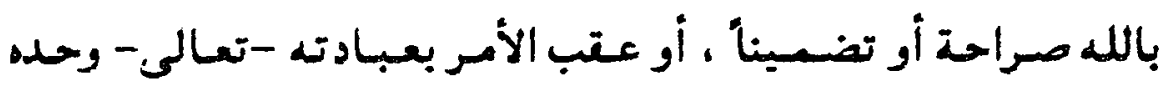

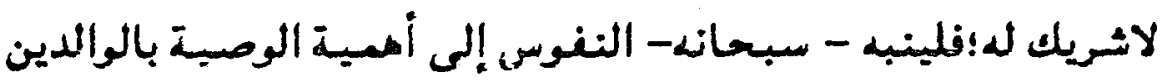

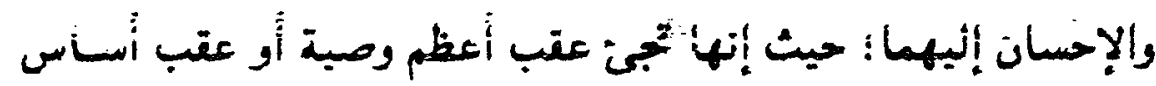

$$
\begin{aligned}
& \text { V ، } 1 \text { سورة العنكبوت . } \\
& \text { rrr } \\
& 101
\end{aligned}
$$

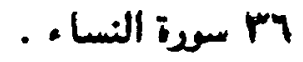

$$
\begin{aligned}
& \text { A مسوة البترة. }
\end{aligned}
$$


الوصايا ألا وهى (عدم الشـك بالله) الذى مو العـود النترى للإيان

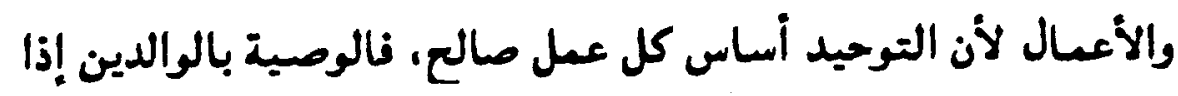

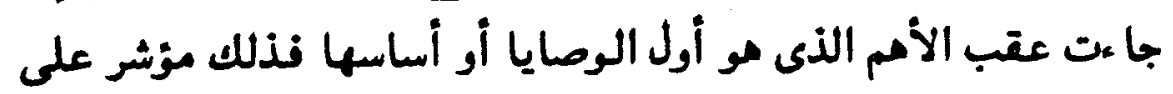

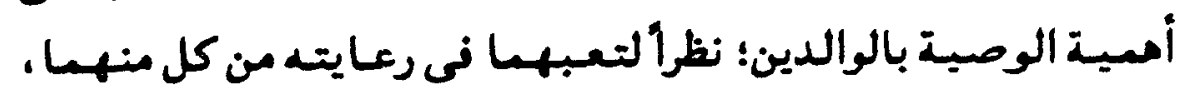

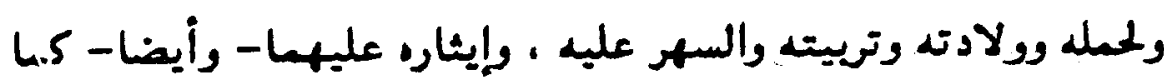

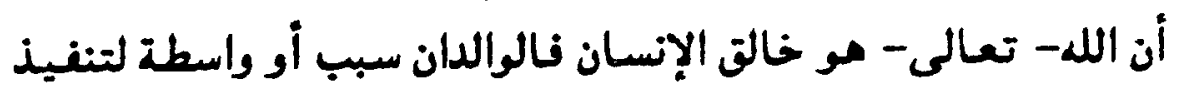

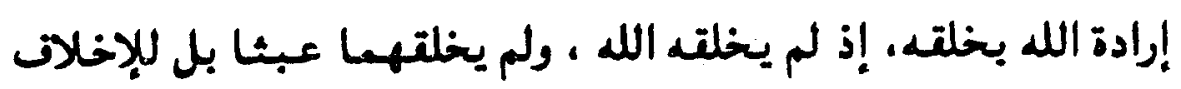

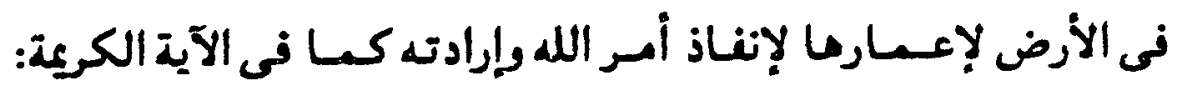

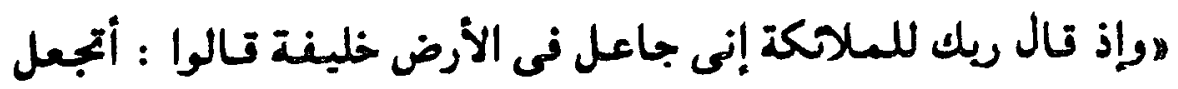

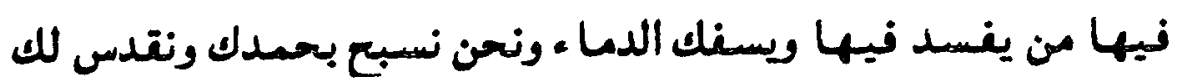

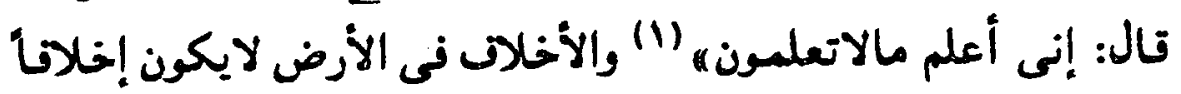

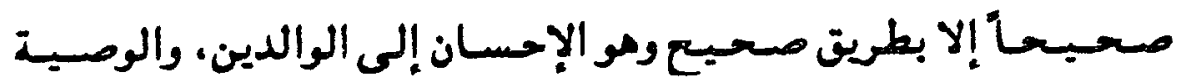

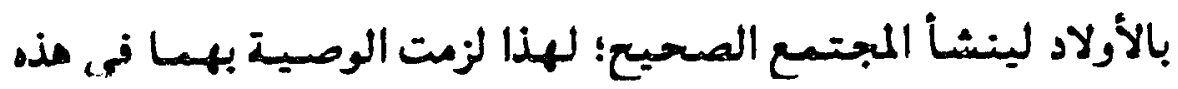

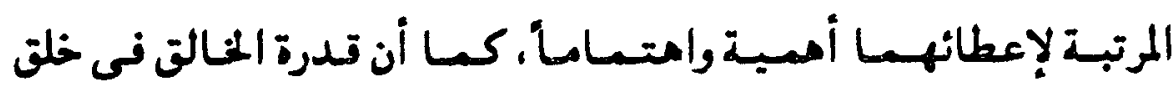

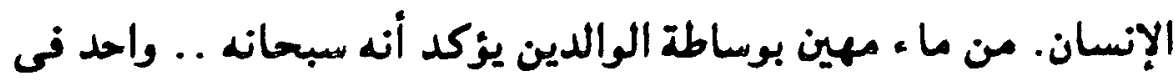

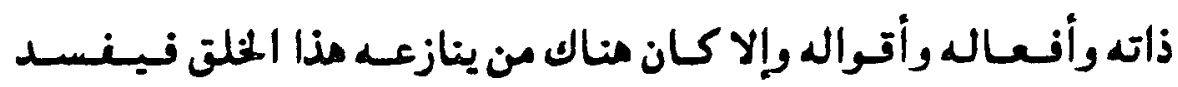

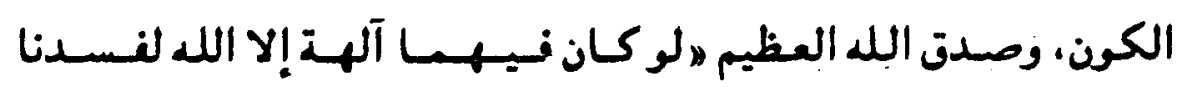

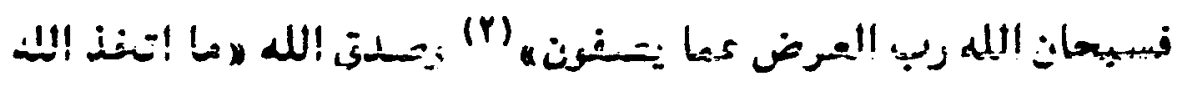

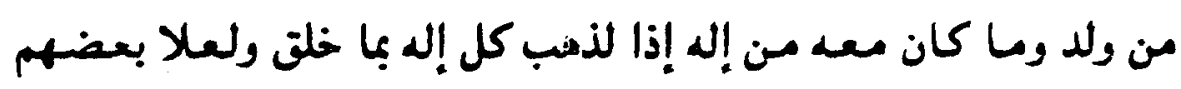

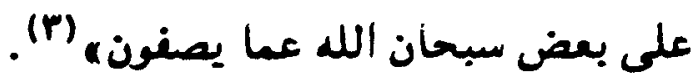

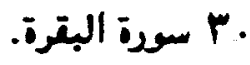

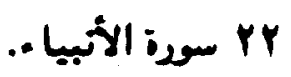


أما ثانيا: فيحتمل أن يكون السر البلاغى أو الحكمة الالهية التى

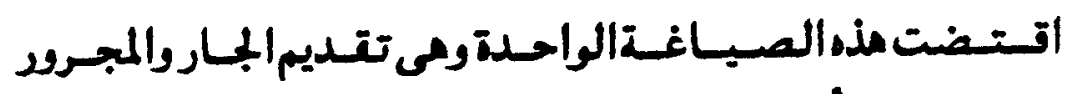

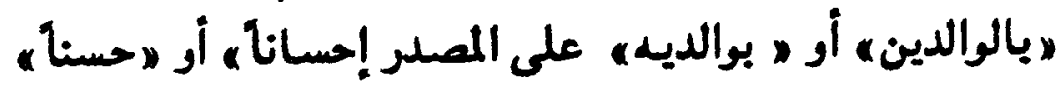

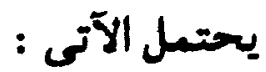

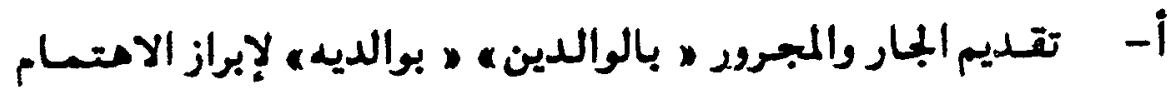

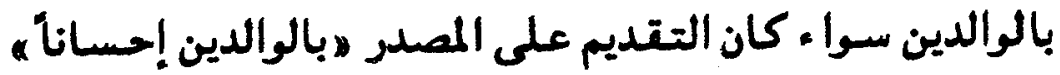

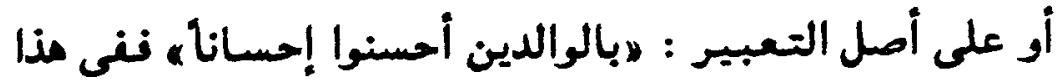

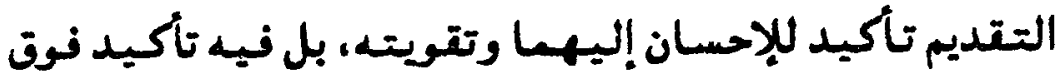

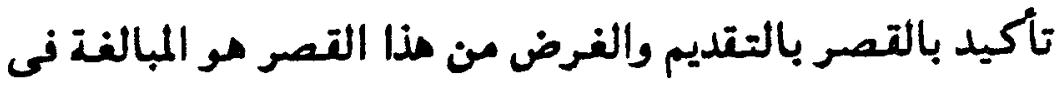

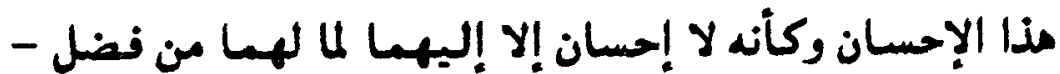

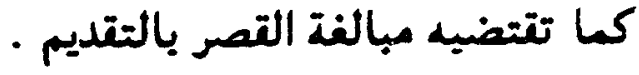

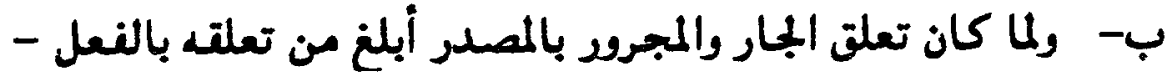

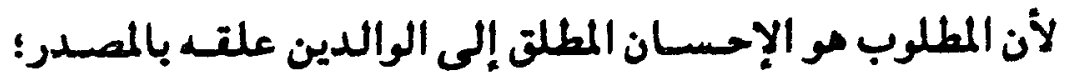

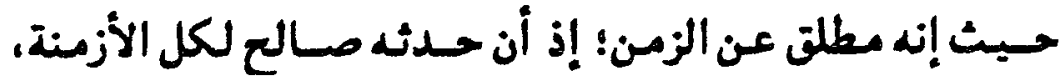

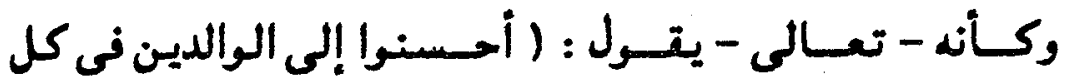

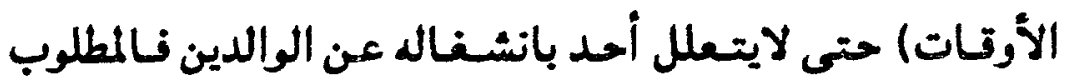

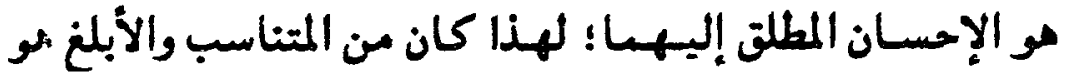

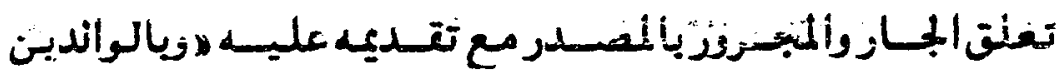
إحسانا، ولاغرو - بعد هذا البيان - إذا ذكر بهذه الصيغنة عيلع تكراره.

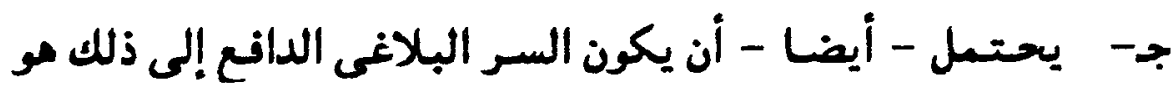

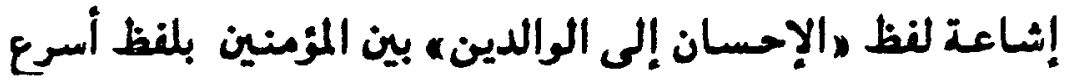

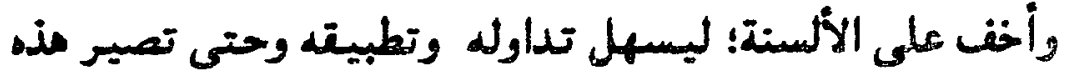




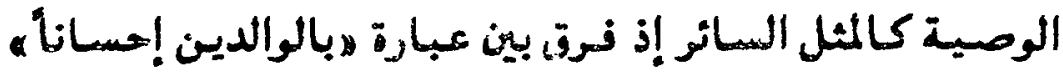

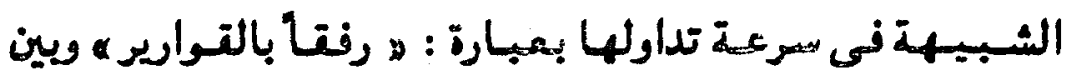

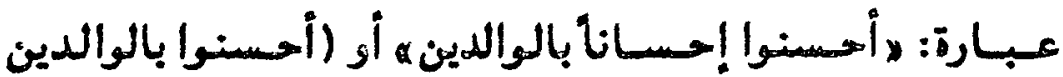
إحسانا ) (

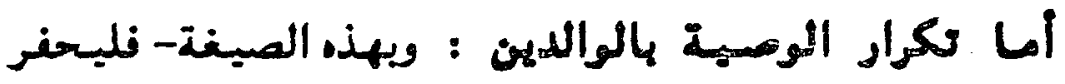

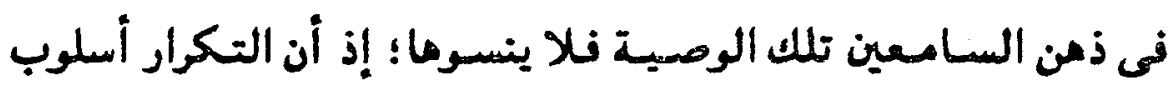

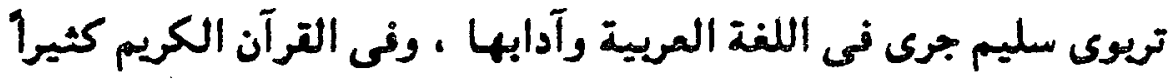

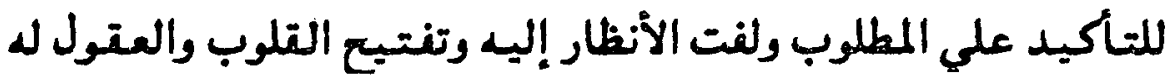

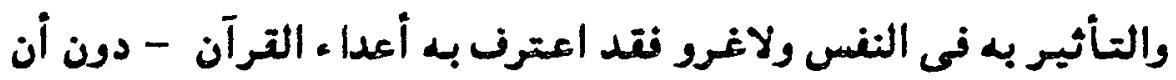

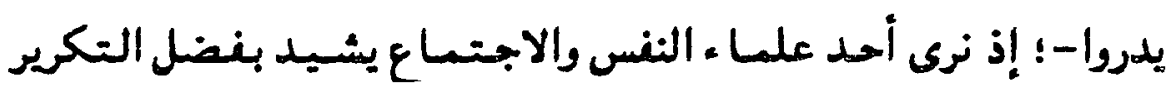

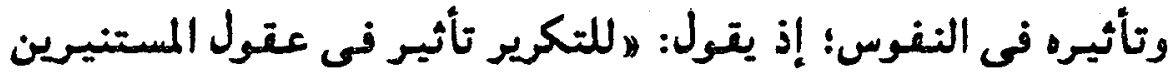

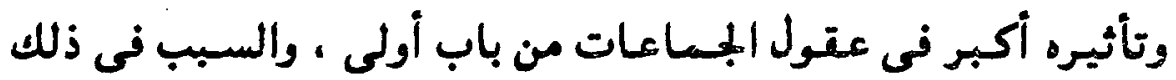

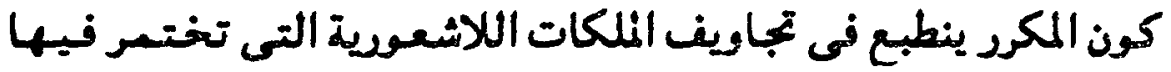

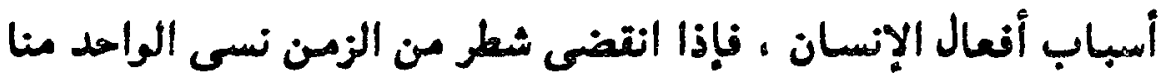

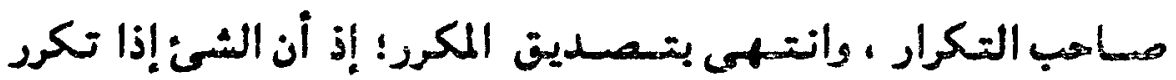

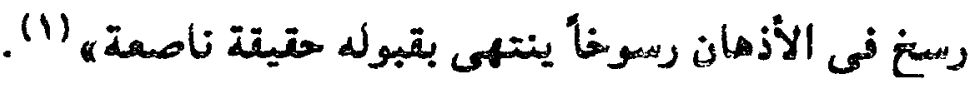

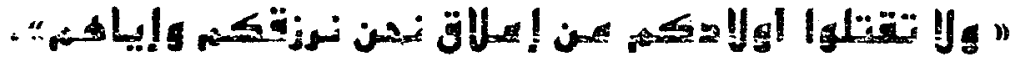

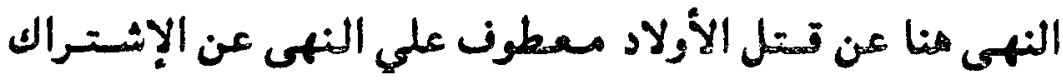

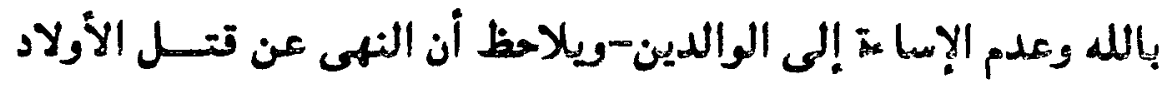

Ira 
من إملاق جى به عتب الأمر بالإحسان إلى الوالدين ، ولم يؤخر مذا

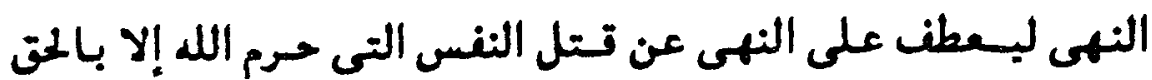

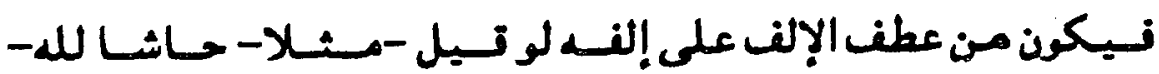

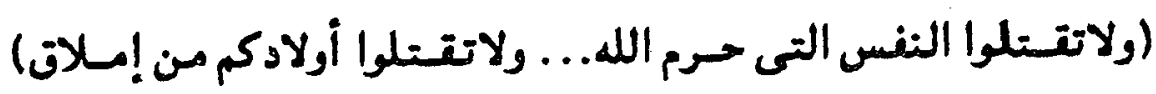

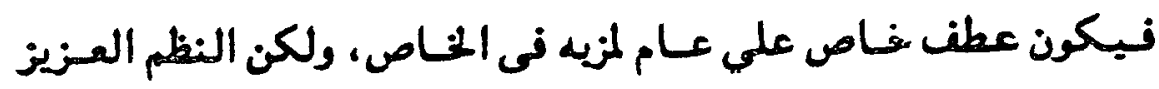

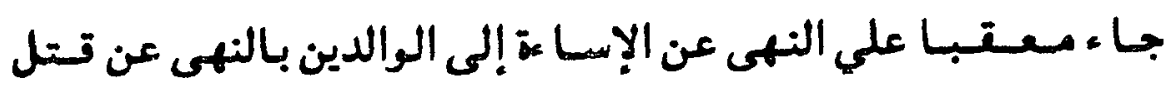

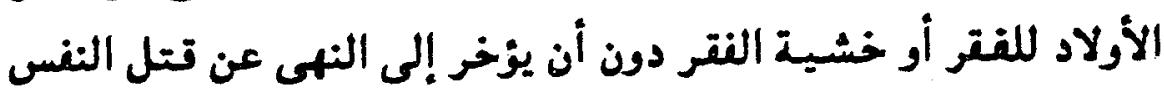

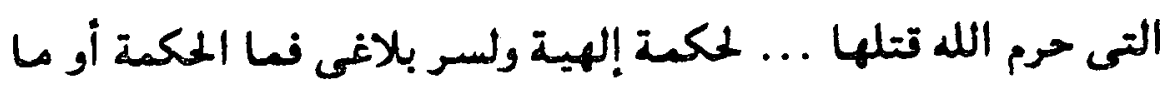

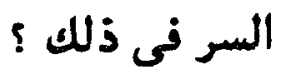

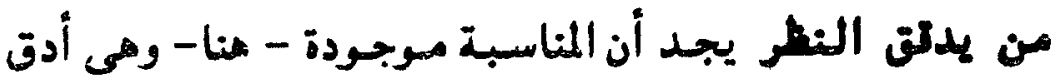

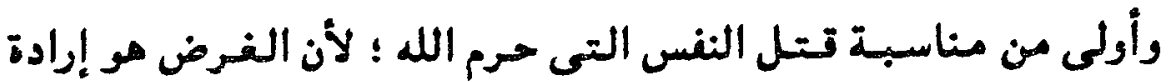

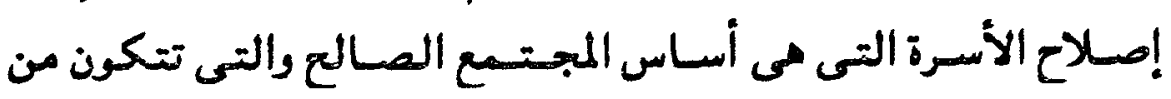

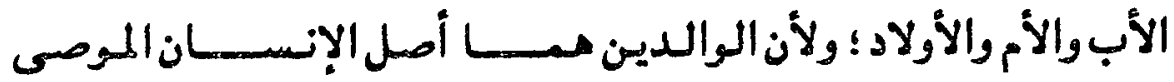

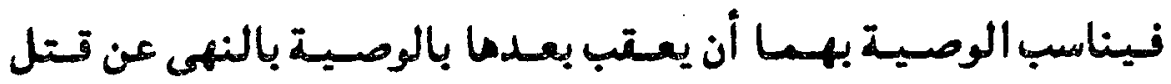

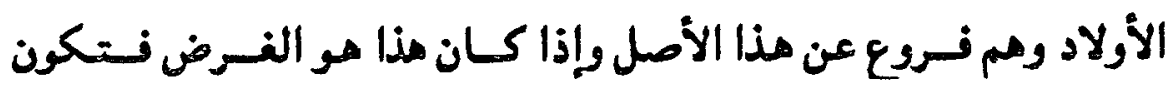

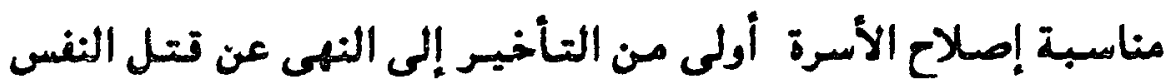

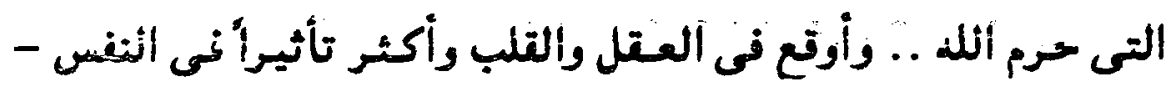

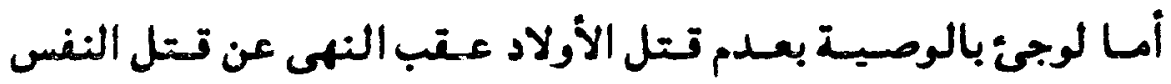

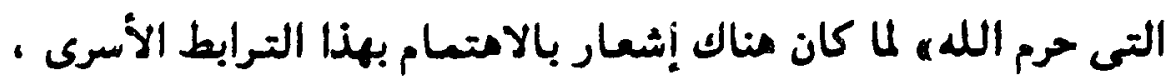

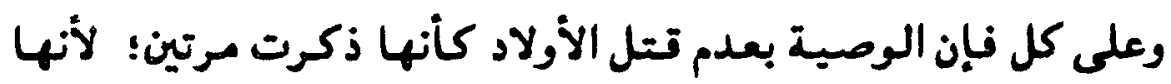

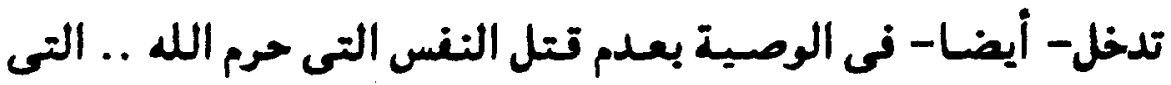

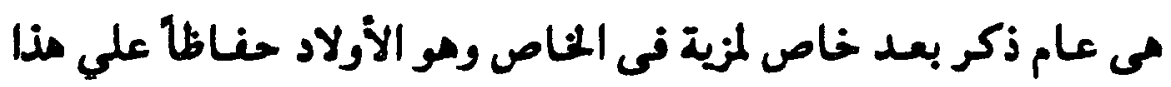

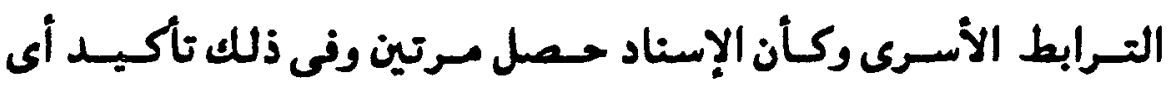




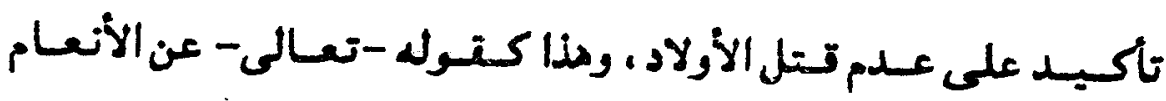

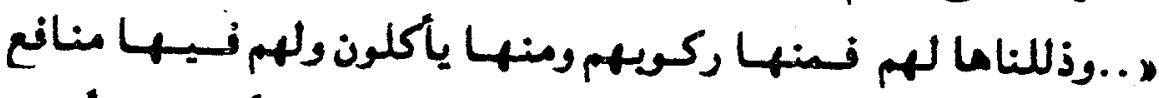

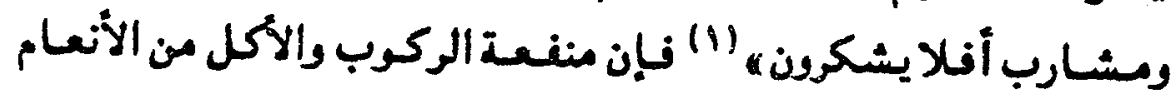

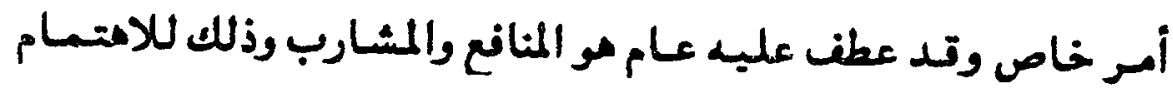
بالحناص ؛ لأنه أبرز المنافع وأكثرما للإتسان .

أنـا لماذا جاء النهى عن تَتل الأولاد بلفظ النهى الصريح دون

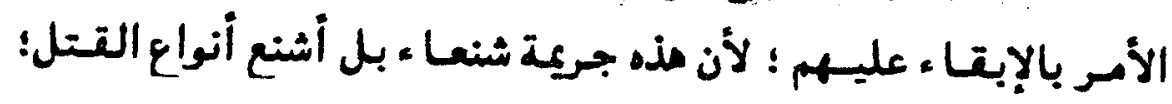

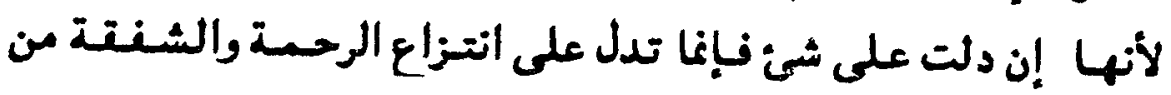

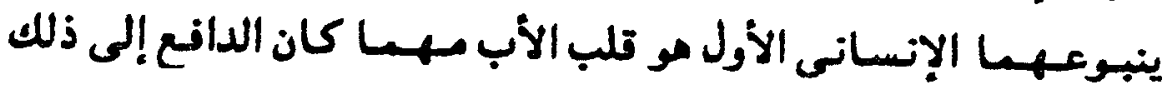

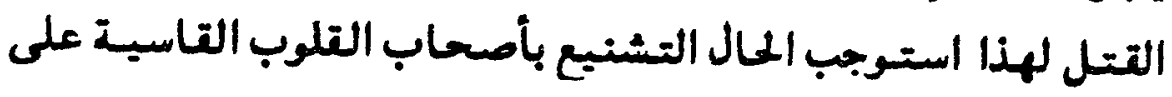

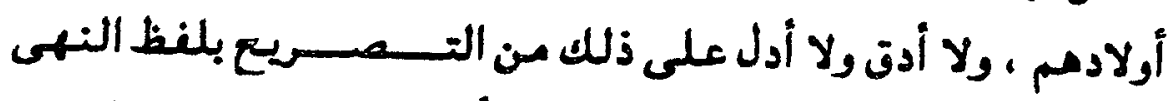

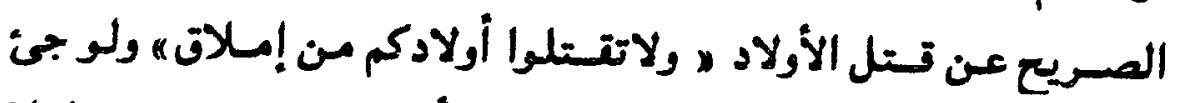

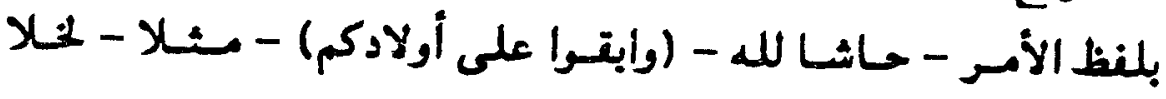

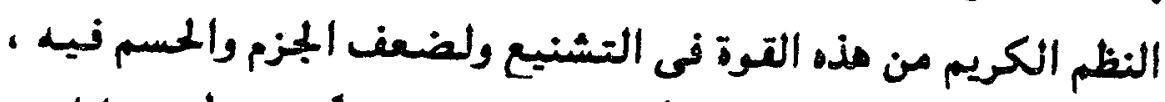

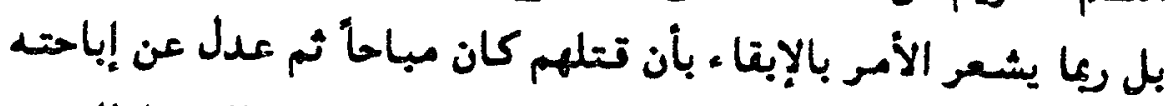

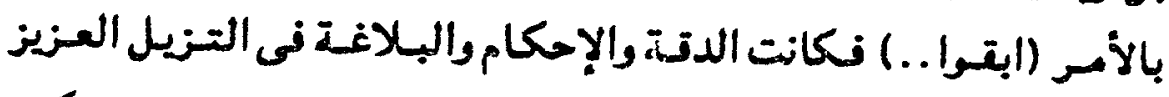

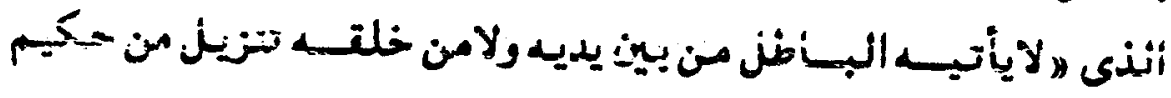

حميد، (r)

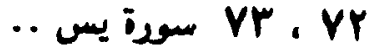




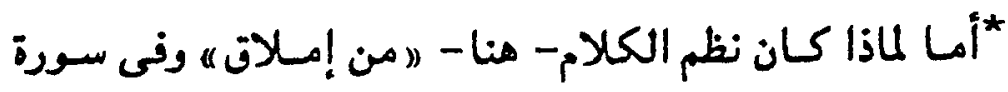

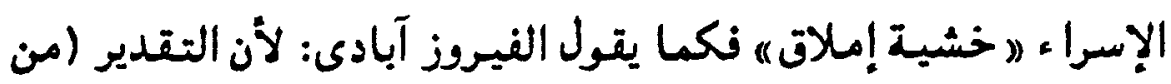

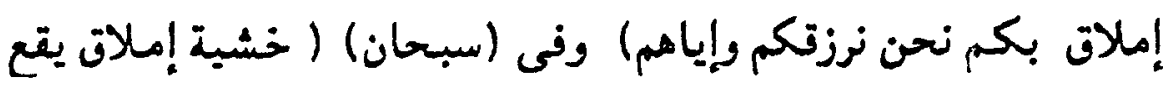

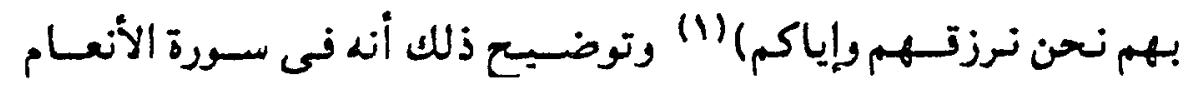

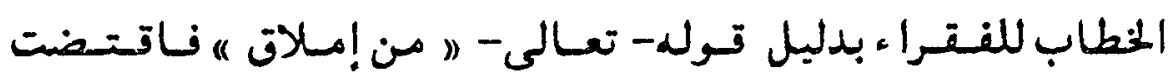

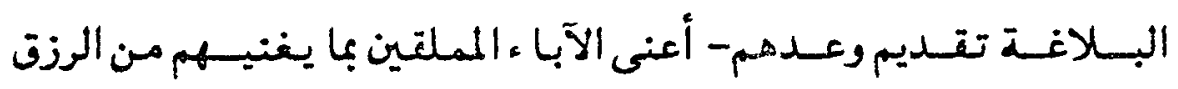

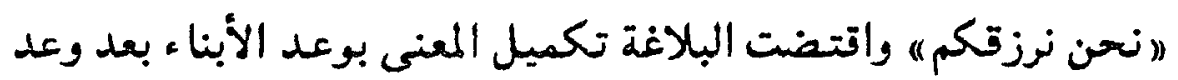
الآباء " وإياهم ه وفى سورة بنى إسرائيل (الإسراء) الخطلاب للأغنياء

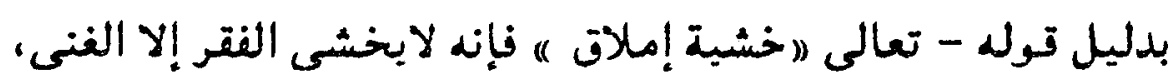

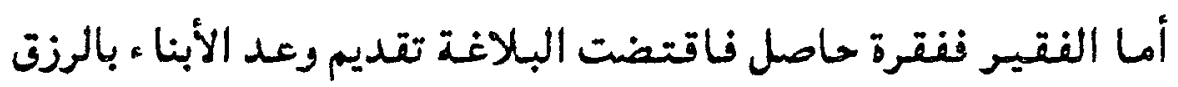

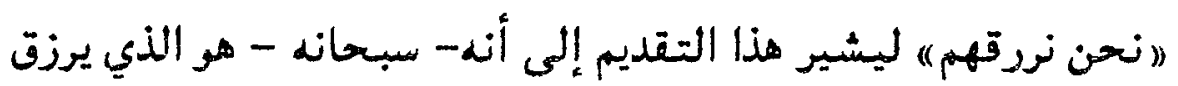

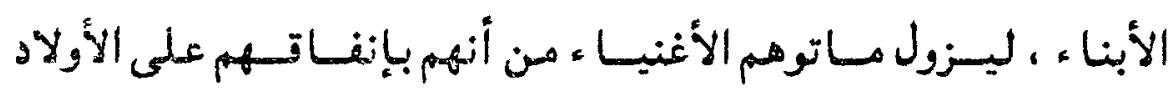

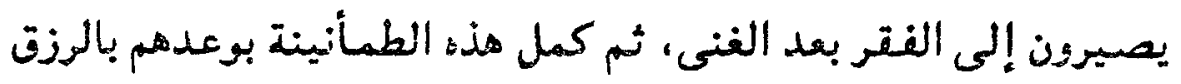

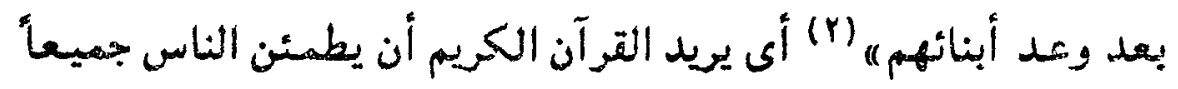

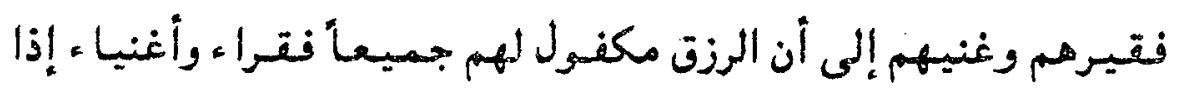

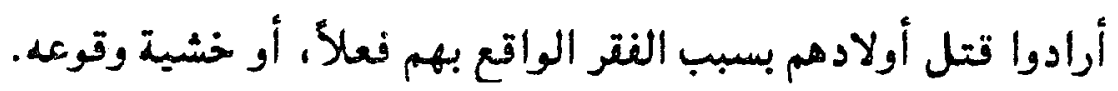

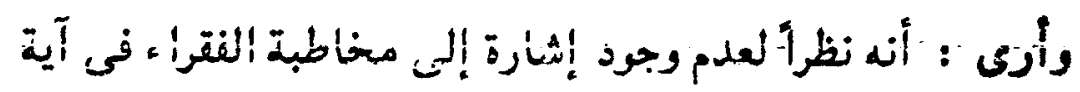
الأنعام، أو الأغنيا ؛ فى آية الإسراء -أرى أن القرآن آنسأ الكريم -هنا-

999 | 14 بصاتر ذوى التمييز - المجلد الأوله : مدية منبر الإسلام ربي. A I E.

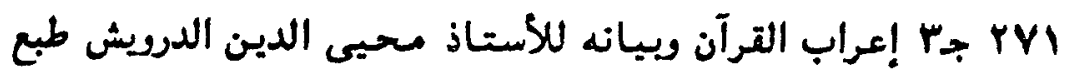

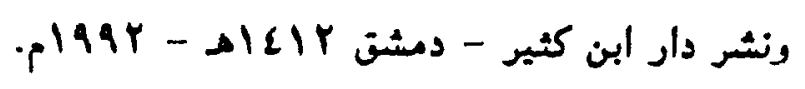


فى الأنعام يريد أن يشدد النكبر عنيهم فى موطن الرد عليهم ذيما

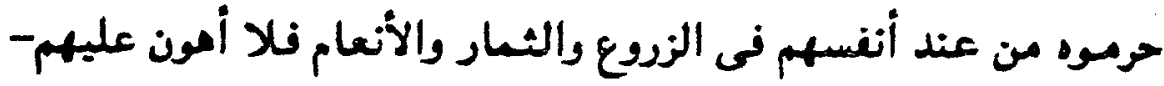

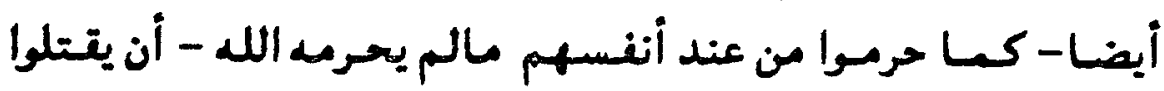

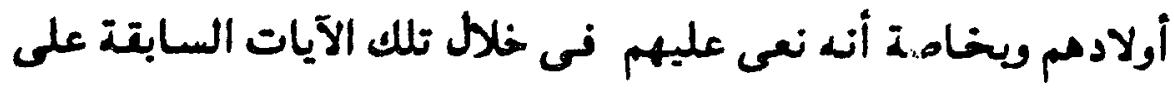

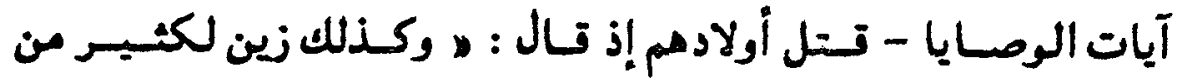

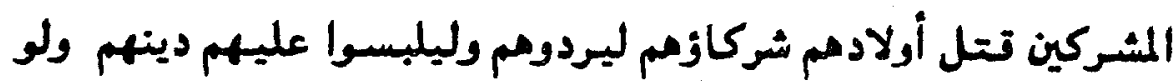

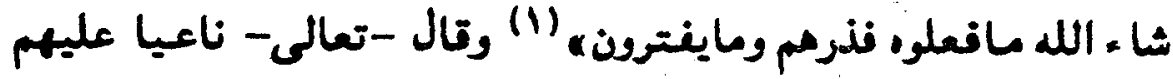

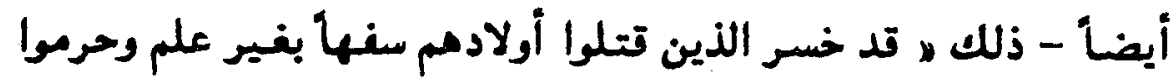

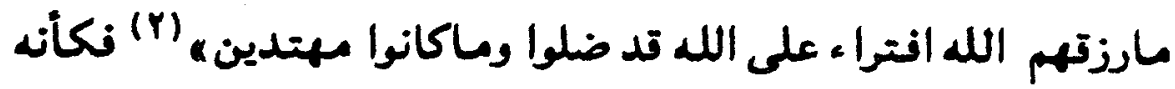

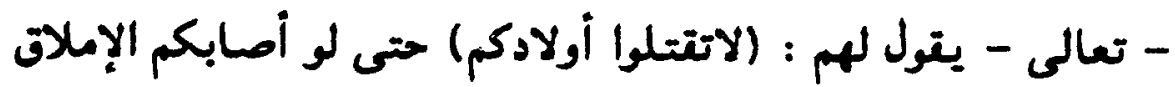

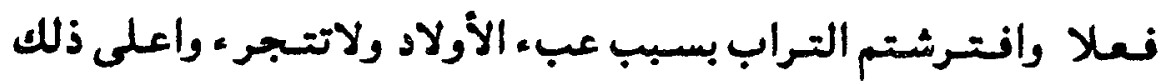

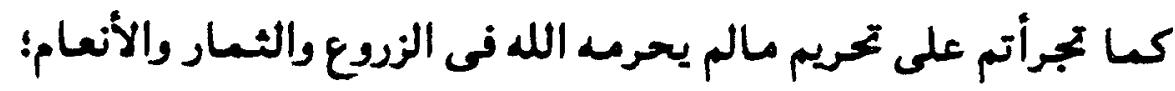

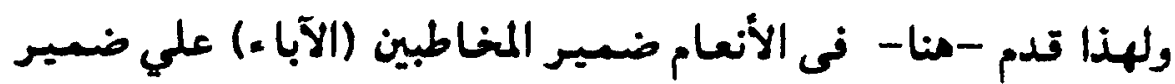

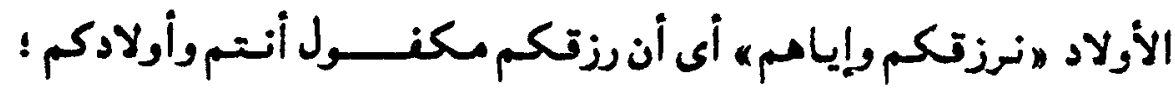

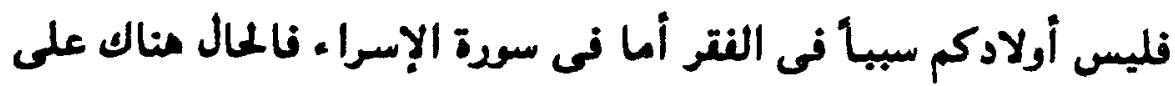

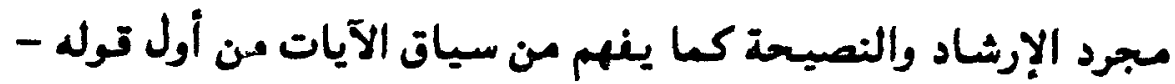

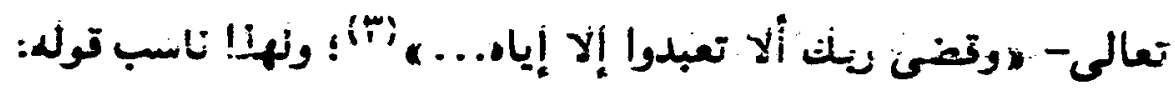

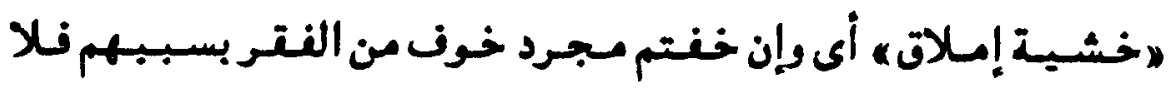

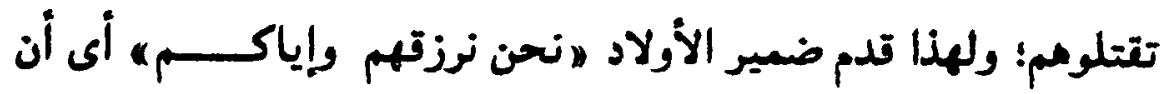

- lrr

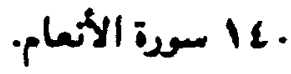


رزتهم مكغهول من الله- تعالى - نلا تخشـوا نترا تعزونه إليهم -

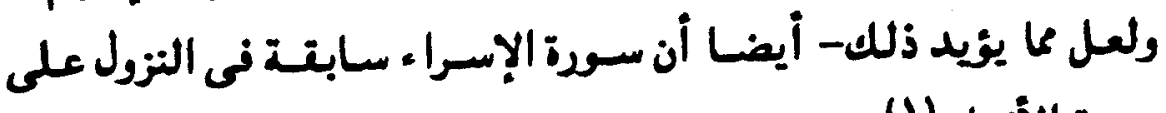

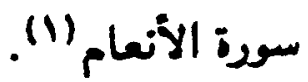

فريا لم يرتدعوا عن تتل الأولاد خشيتة من النتر على الرغم من

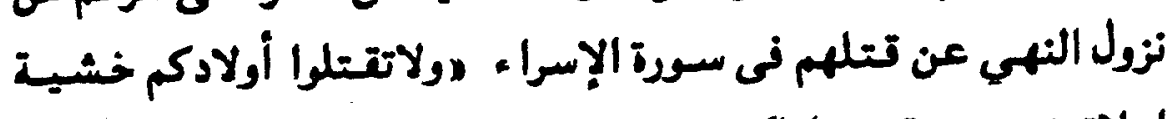

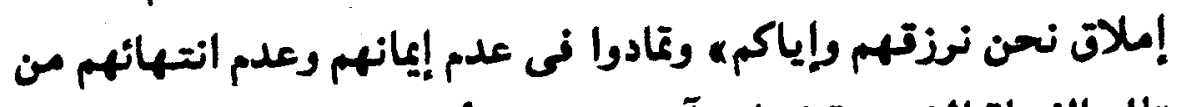

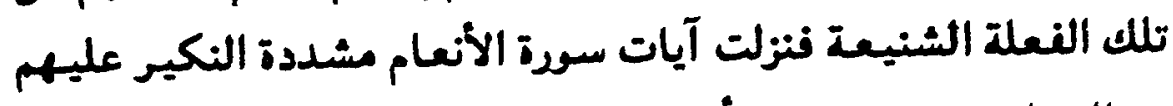

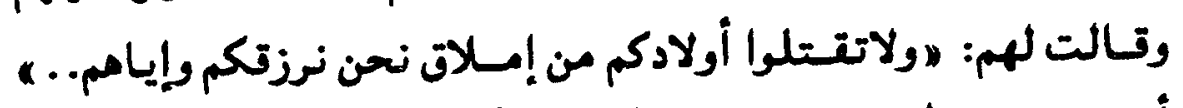

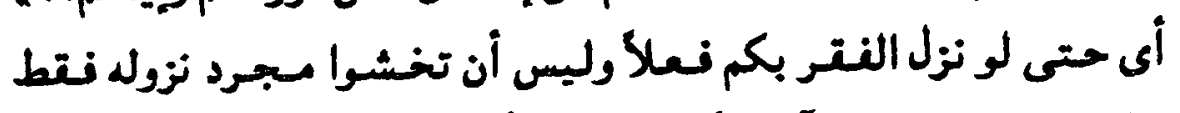

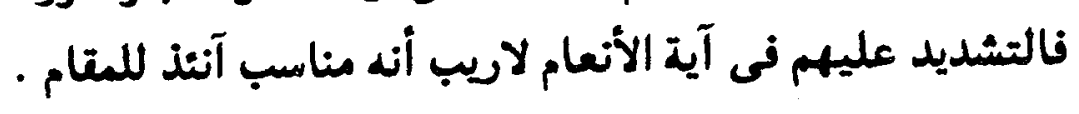

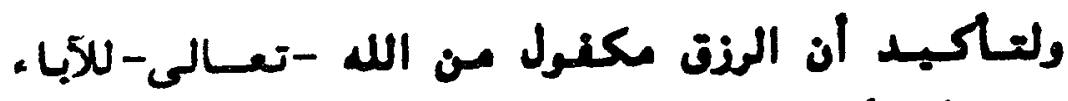

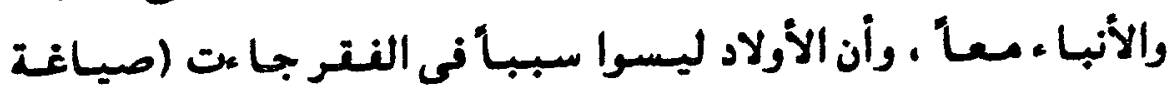

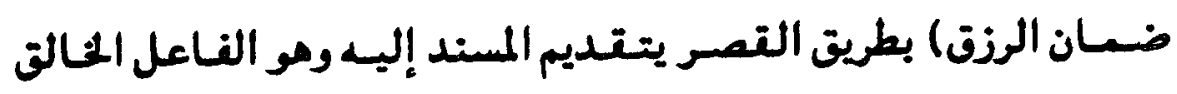

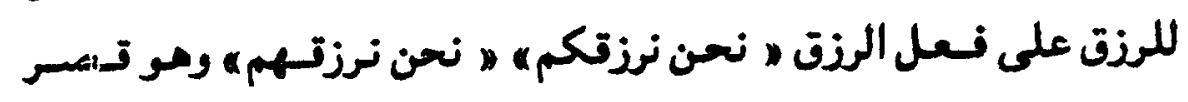

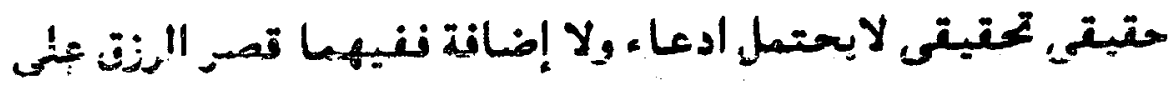

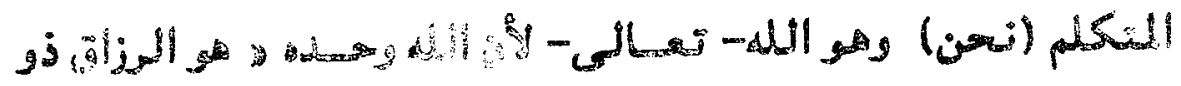

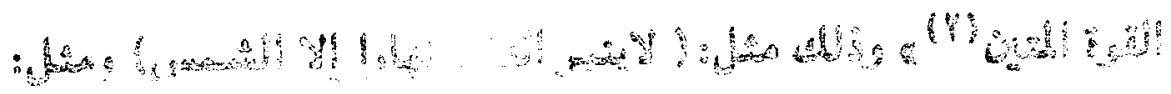
ans 45

ss 


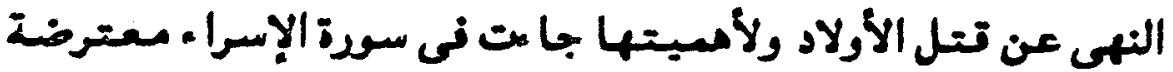

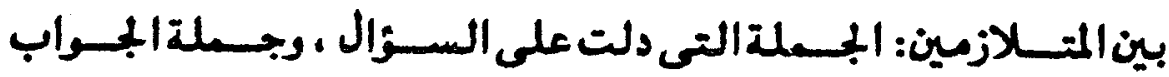

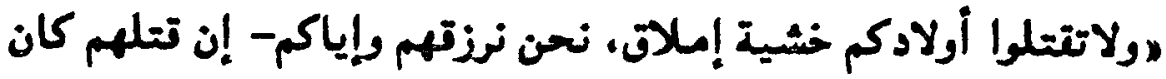

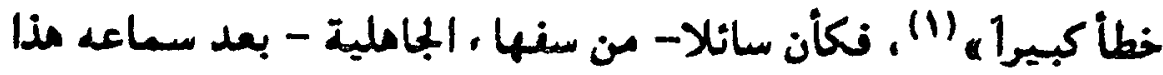

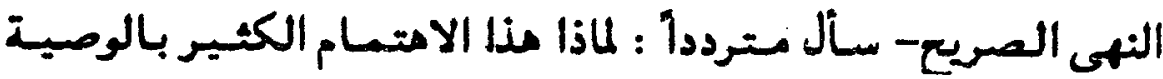

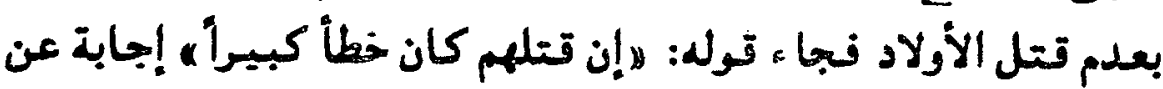

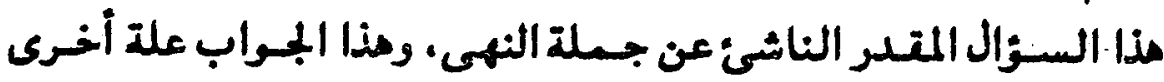

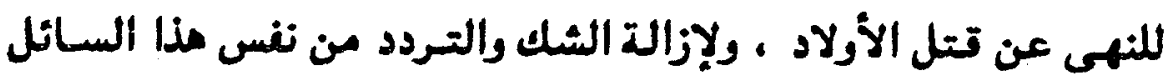

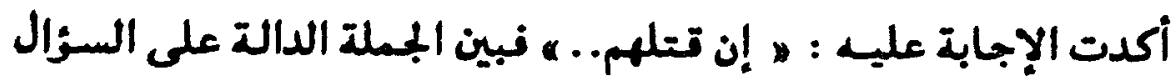

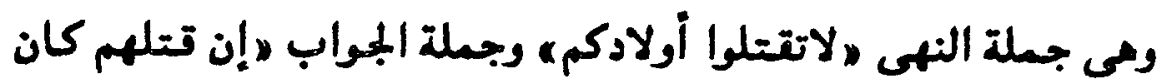

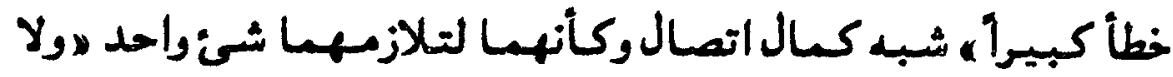
تتتلوا أولادكم .... إن تتلهم كان خطأ كبيرأه ...

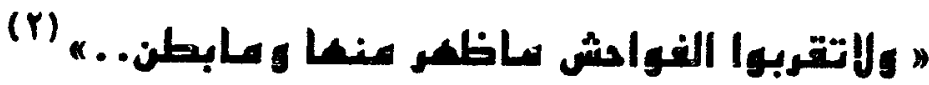

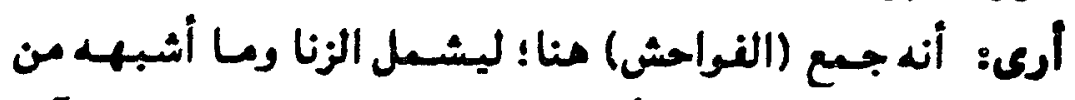

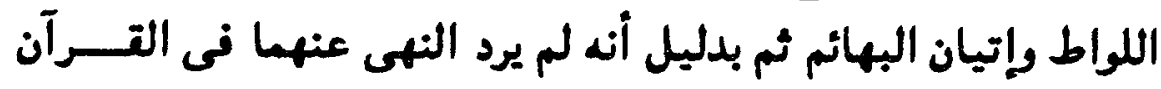

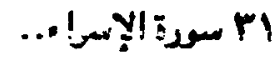

(النواحش ) من المنسرين من نسرها بالآثام الكبيرة كالزنا والسرتة والتَل

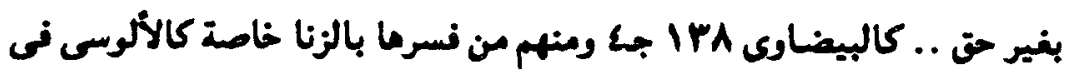

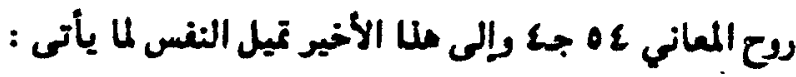

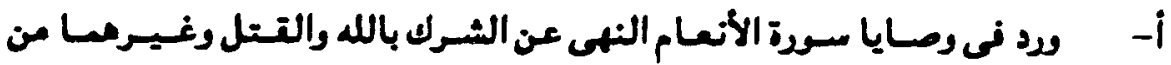

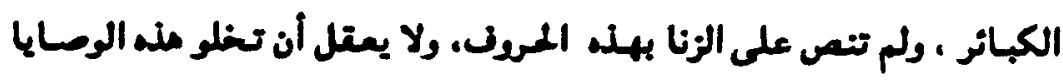

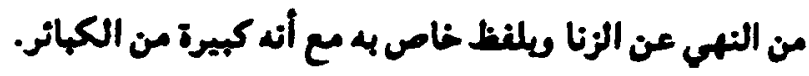

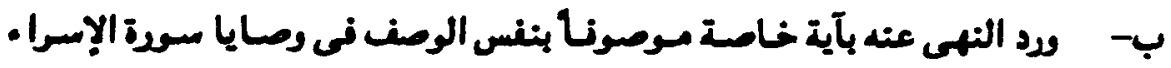

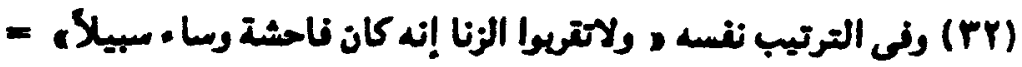


الكريم إلا فى الأول ولكن فى عرض تصنة توم لوط- عليه السلام -

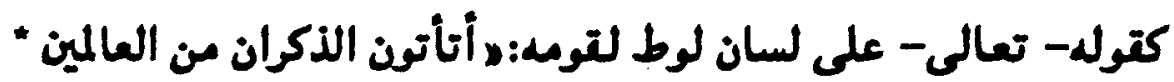

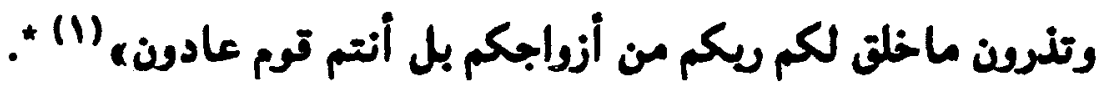

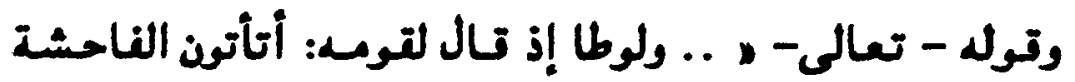

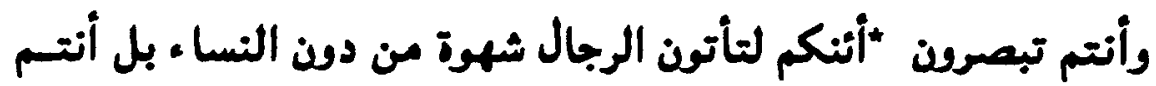

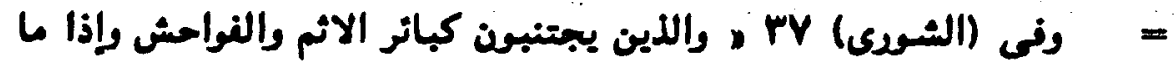

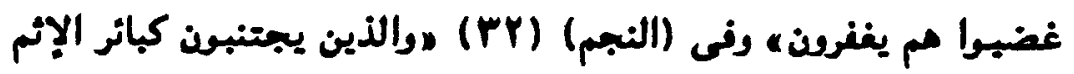

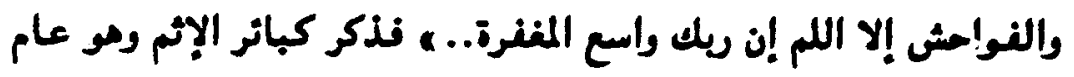

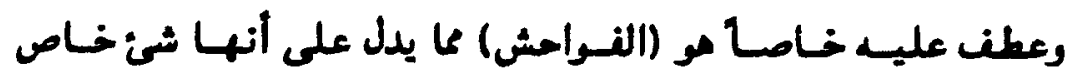
استوجب انغراده بذكره بعد دخوله فى العام ( كبائر الإثم) .

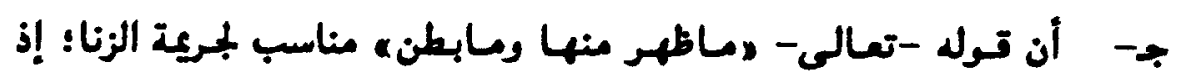

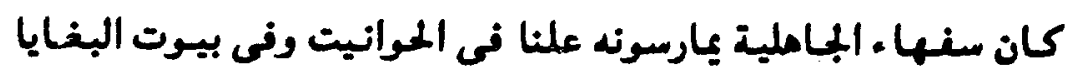
وكانوا يعتتدون أن المحرم منه ماكان علنا..

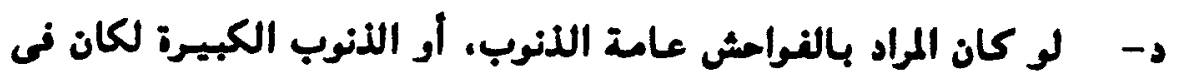

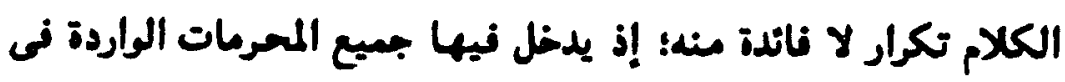

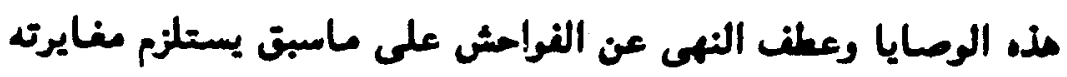

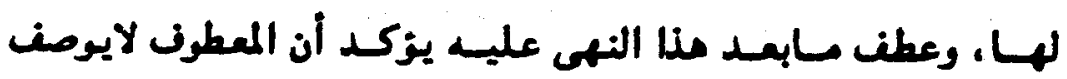

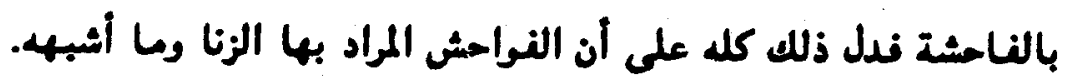
والله أعلم ولعل ملا مو ماجعل الأستاذ سيدقطب يقول فى تغسيرها:

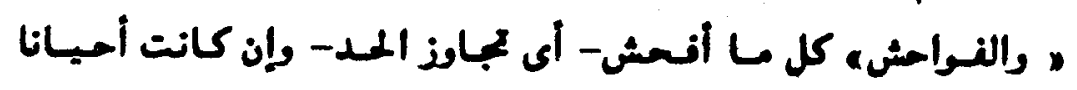

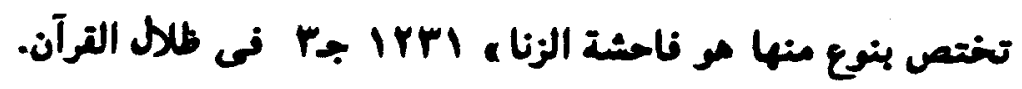

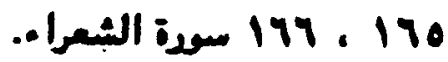


توم تجهلون، "(1) وقولد -تعالى- ״ إنكم لتأتون الفاحشة ماسبتكم بها من أحد من العالمينه هونه

والنهى عن النهب من الفرامش : أبلغ من النهى عن

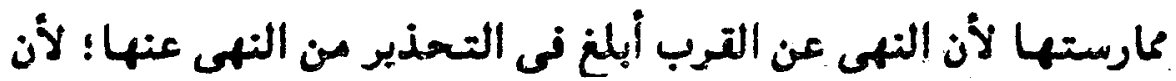

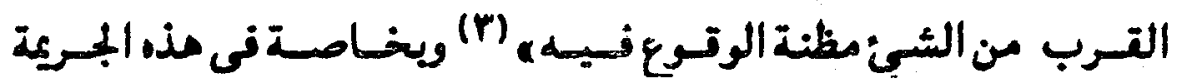
الشنعا ـ (الزنا وأشبهـ) ؛ لأن القرب من أسبابها يغرعى بالوتوع فيها فيها

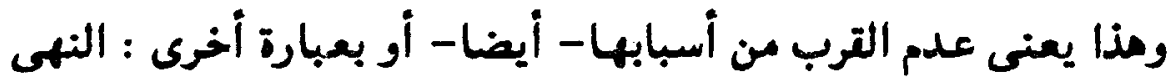

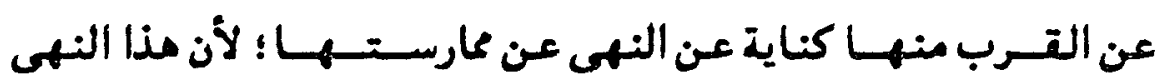

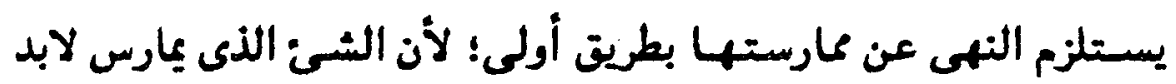

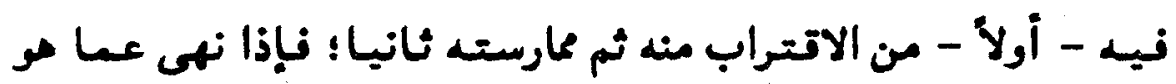

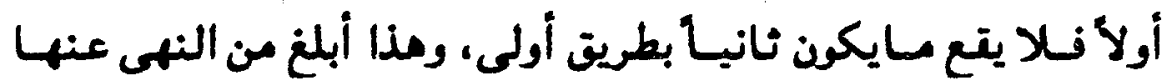

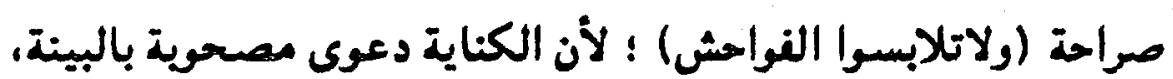

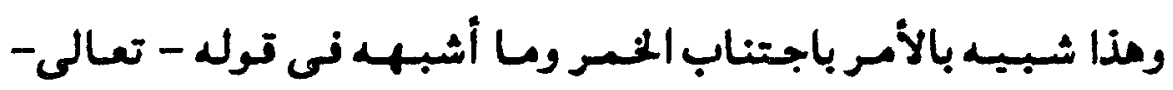

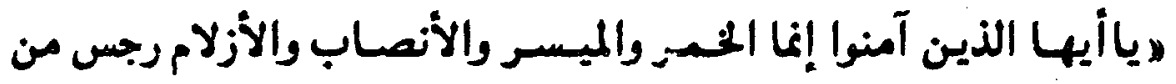

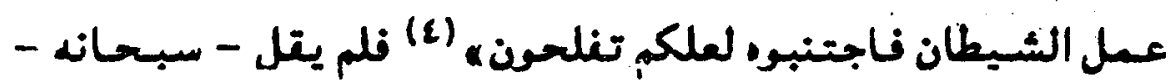

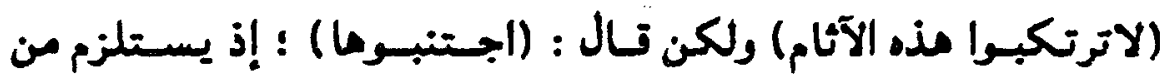

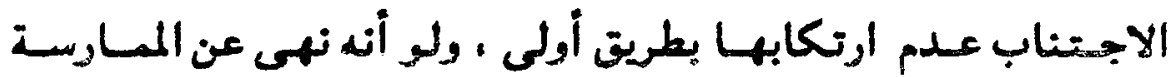

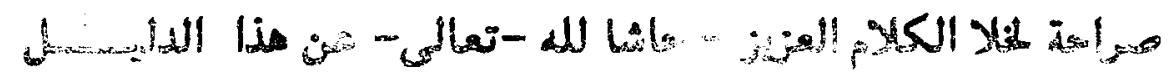

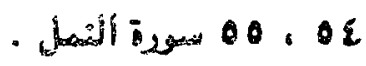

$$
\begin{aligned}
& \text { س سورة العنكبوت } \\
& 109 \text { جـ التحرير والتنوير . }
\end{aligned}
$$


الأولوى، وريا يفهم منه أن الترب منها لايؤدى إلبــا ؛ ولهـذا كـان

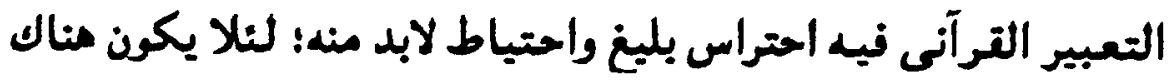

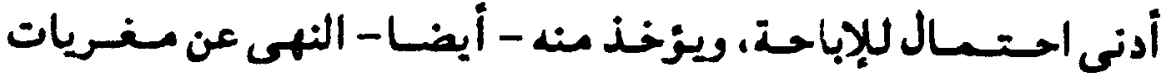

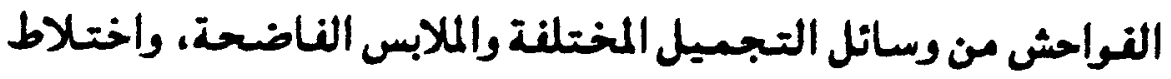

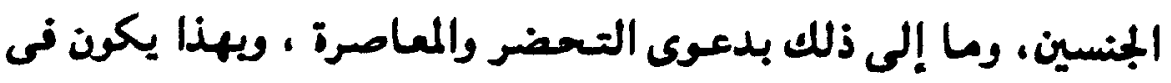

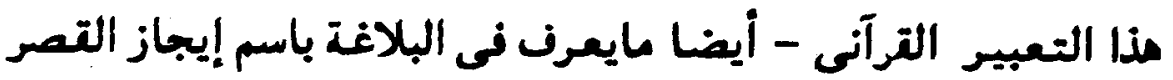

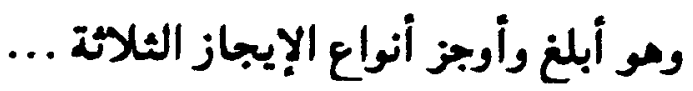

" عا ظلهر عنها و عابطن" :

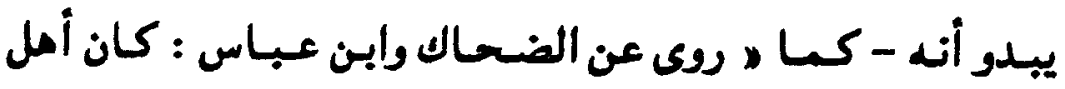
الجاملية يرون الزنا سرا حلالا ويستتبحونه فى العلاتية فحرم الله الزنا

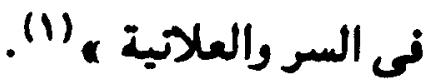

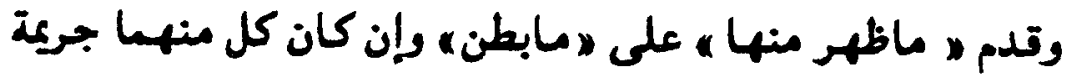

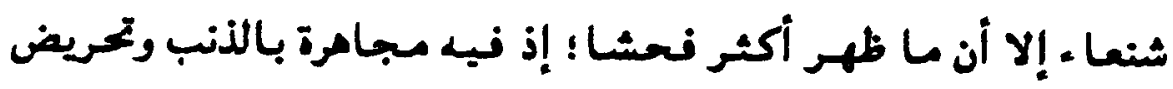
وتشجيع عليه ، إلى جانب التجرد من الحباء ، ، فلزم تقديم لذلك.

" ولا تتتلوا النغس التى حرم اللا إل بالحتة " :

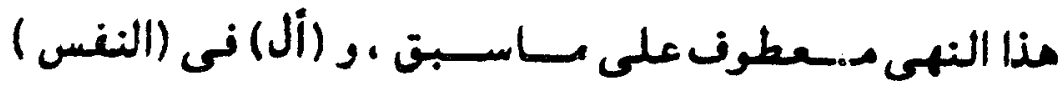

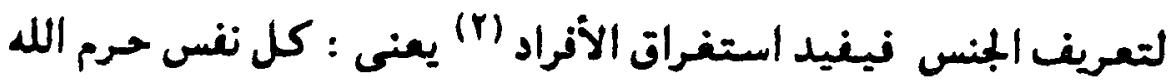

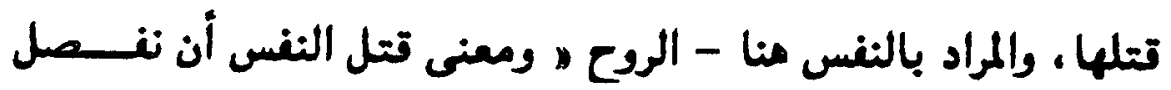




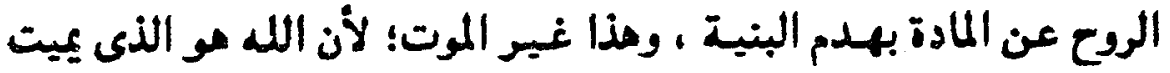

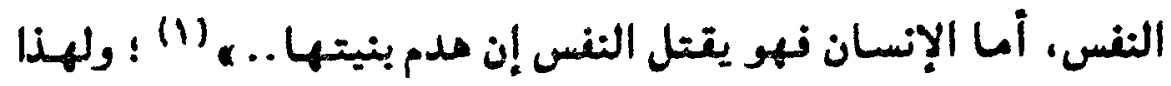
فإن المعنى فى النهى عن تتل النفس النهى عن تتل الجسد المتعلقة به وليس قتلها مى، وعليه ففى "الننس، مجاز مرسل علاقته الحالية ؛

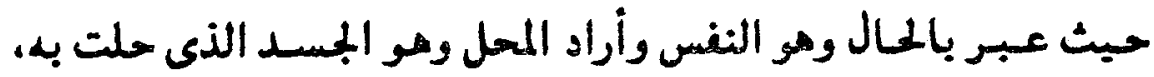

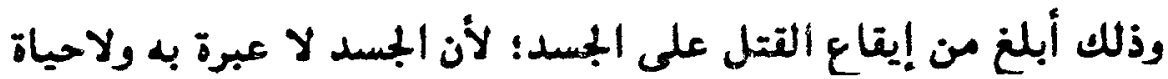

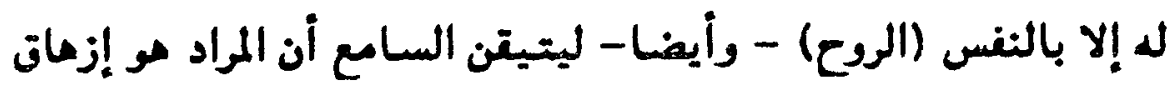

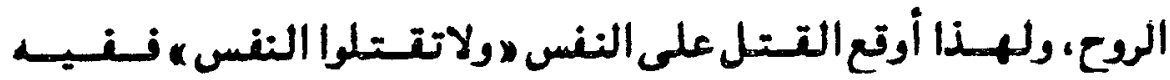

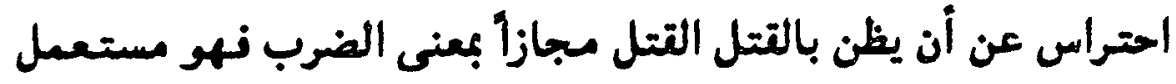
عريية: إذ يقال : قتلت فلانا نقتلنى.

أَا وصف هذه النفس ״بالتى حرم الله هـ فهو لتاكيد التحريم

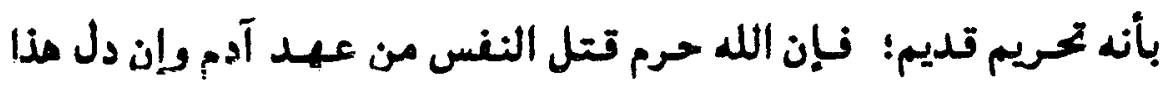

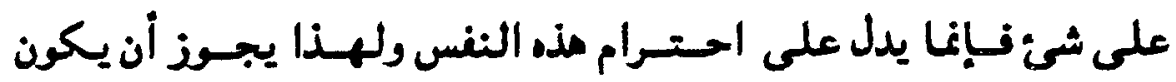

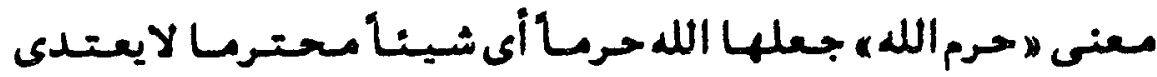

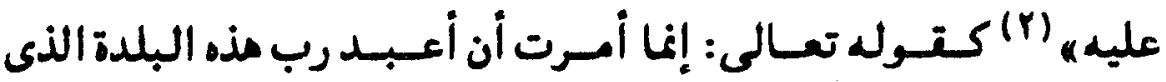

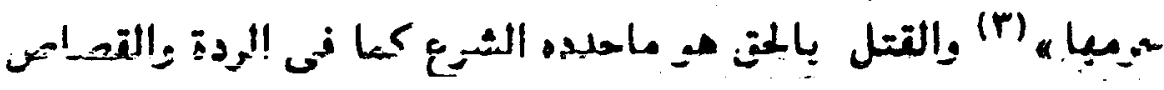
وقطع الطريق......

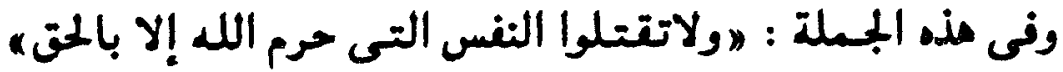

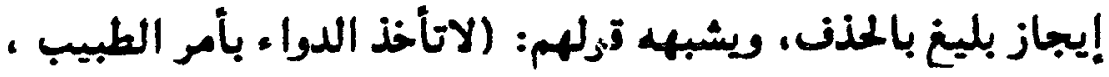

MAA4 MAA

| 14| به التعرير والتنوير - 
أصله : لا تأخذ الدواء إلا دواء مباحا بأمر الطبيسب نـالمستئنى مند

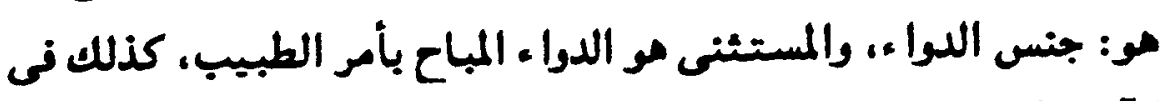

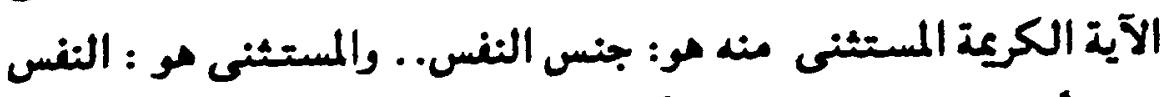

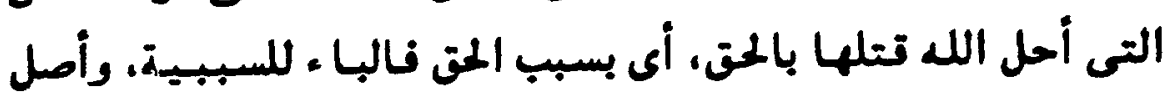
الكلام : ولاتتــلوا النفس التى حرم الله تـتلهـا إلا نفســا أحل الله قتلها بالمحق، ونى ذلك - كسا قلت- إيجاز بليخ بالحذف دلت عليه قرينة السيات ومذا المذن للبعد عن الملل والركاكة بسبب التكرار غير المبول كما مو واضح.

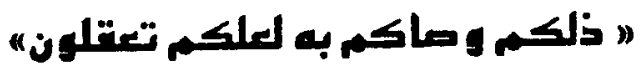
اسم الإشارة لمجموع ماتقدم ذكره من الوصايا ، ولذا جاء منودا

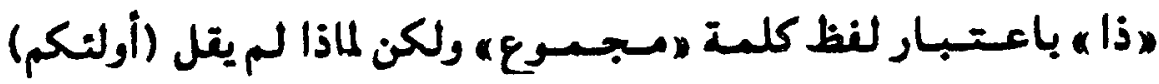

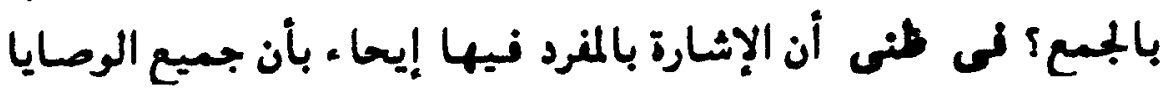
مى كالشئ الواحل يجب تنفيذها جـيـعا كأنها وصسية واحدة ، نلا يهتم ببعضها ويهمل بعضها الآخر ، لأن الإيمان بها ويتطبيقها شئ

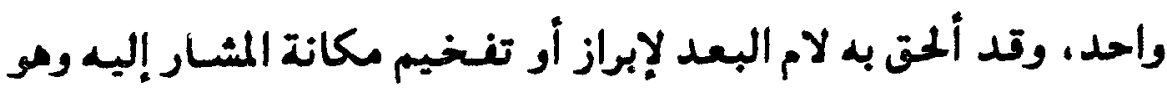

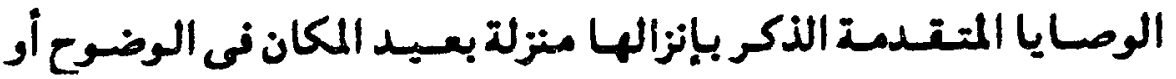

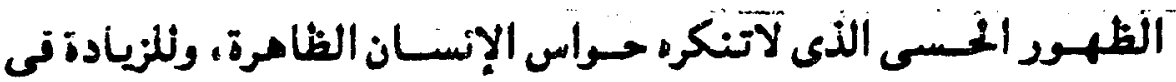

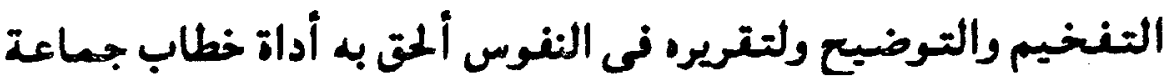
الذكور ״ كمه غير مراد بها مخاطبون معينون ، بل موجد إلى كل من

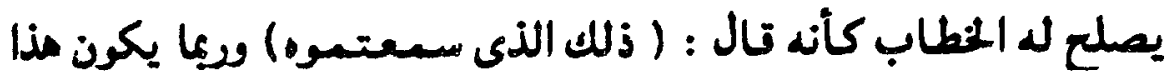
للإشعار بأن مذه الوصايا عامة ومطالب بها جميع الناس. و ،لعل، للتوقع وليست للرجاء؛ إذ لايتأتى الرجاء من الله -

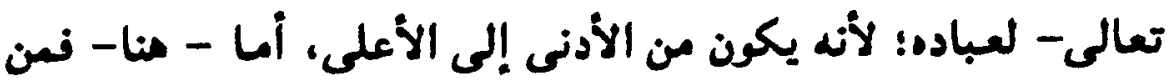




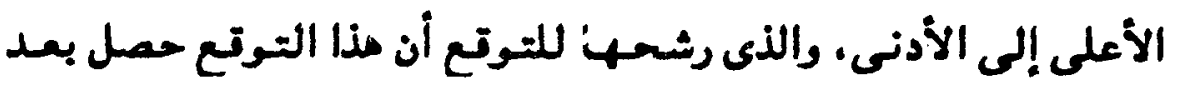

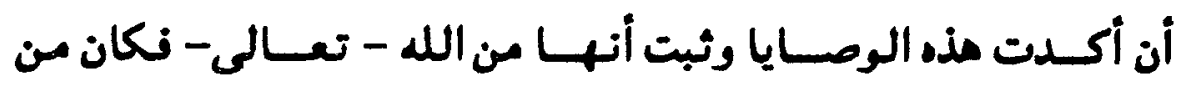

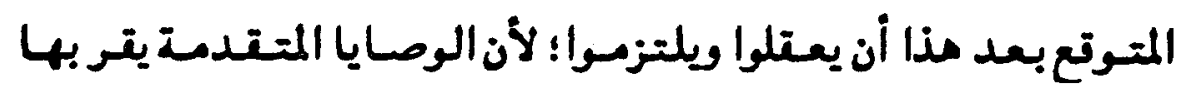

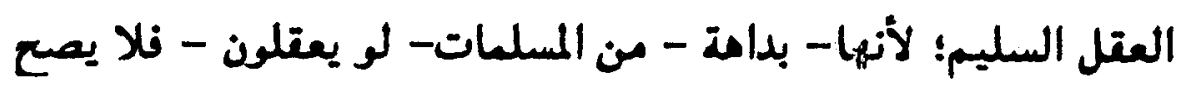

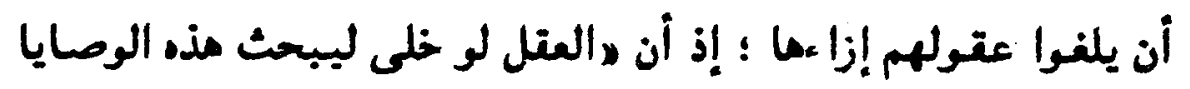

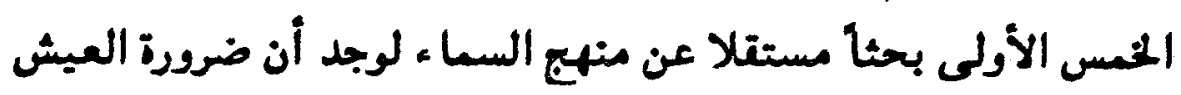

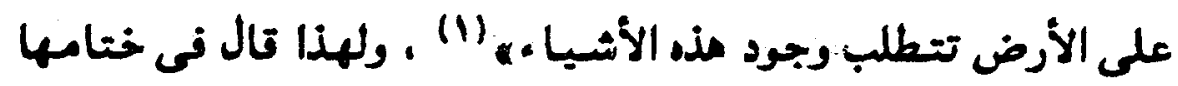

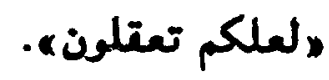

أما تكرير عبارة , ذلكم وصاكم بهه فى آيات الوصايا „ذلكم

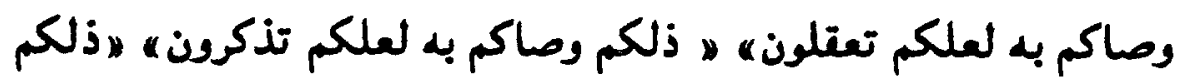

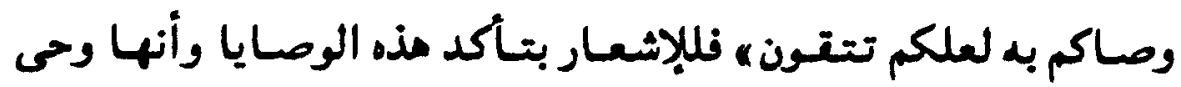

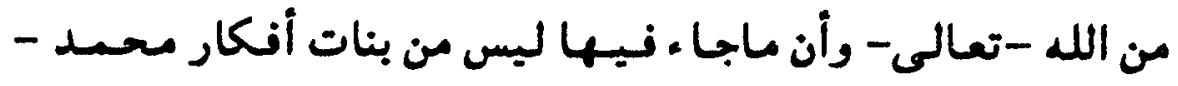

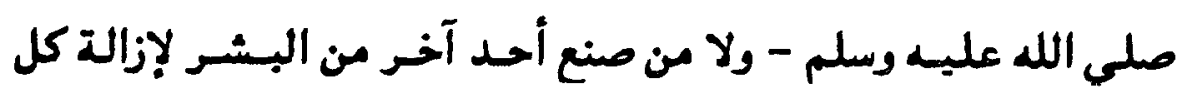

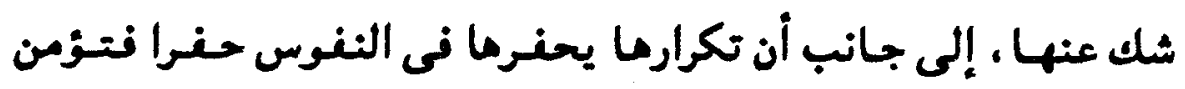

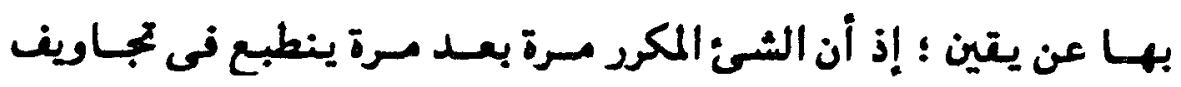

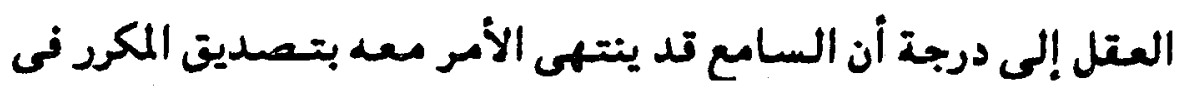

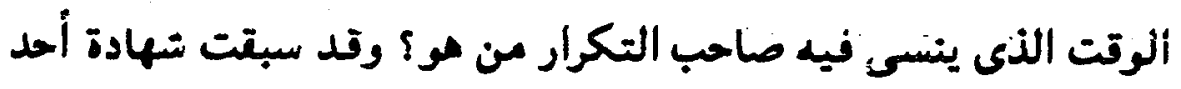

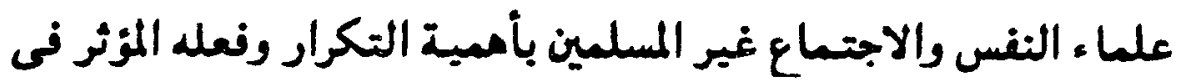

النغس (r)

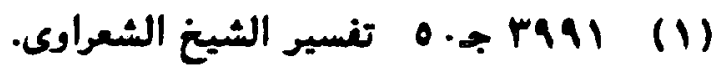
(r) 


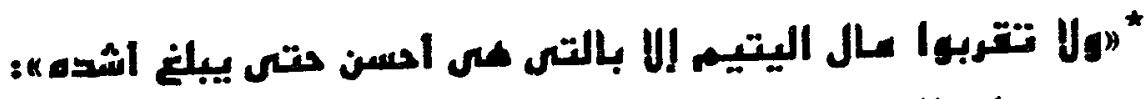

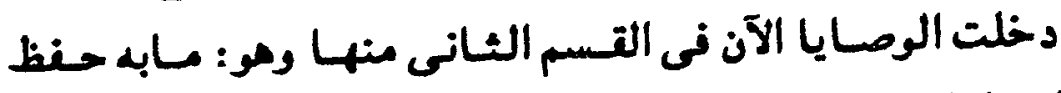

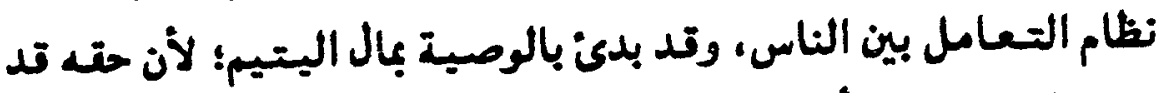

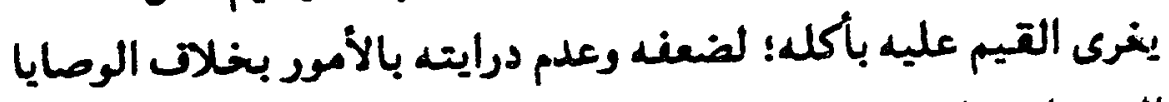

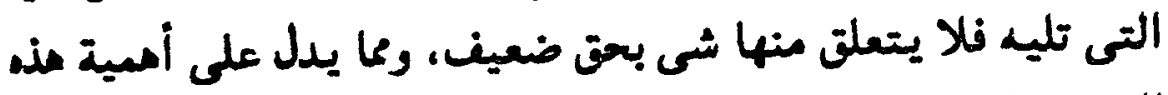

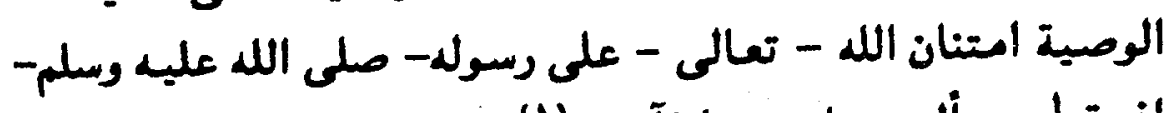

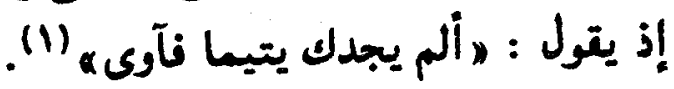

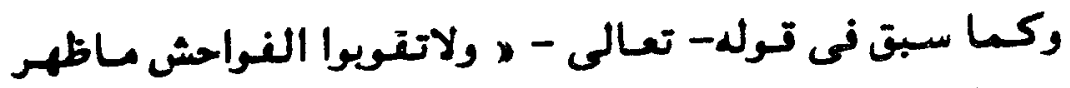

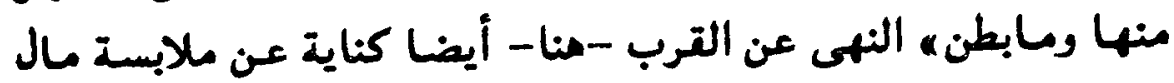

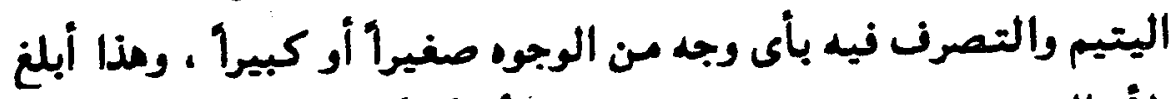

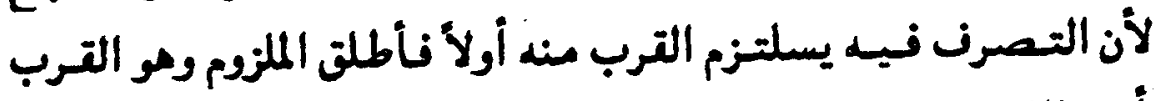

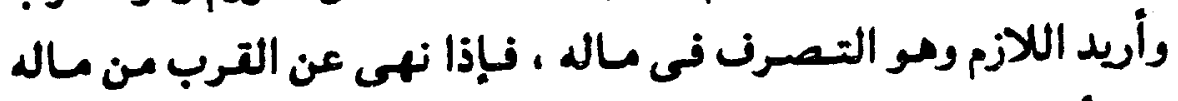

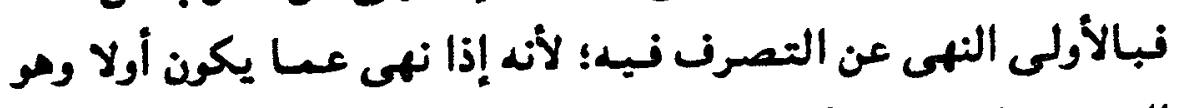

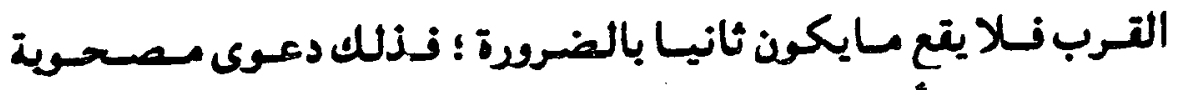

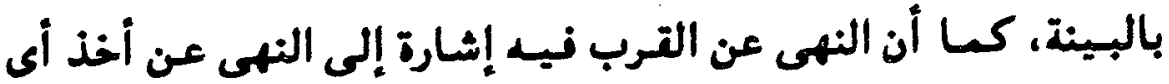

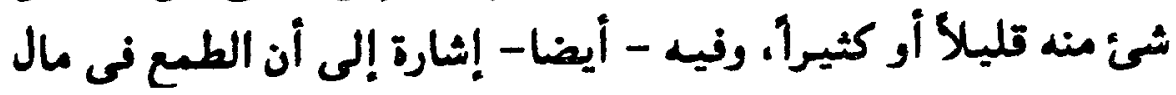

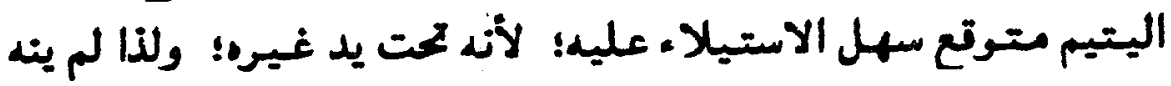

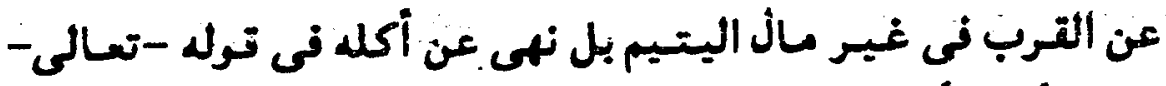

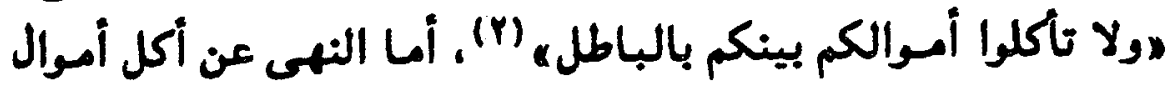

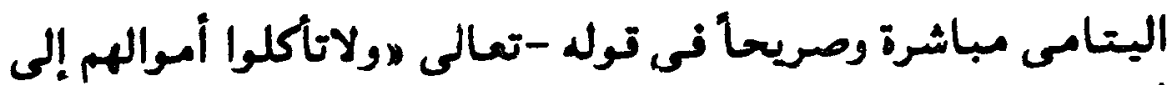

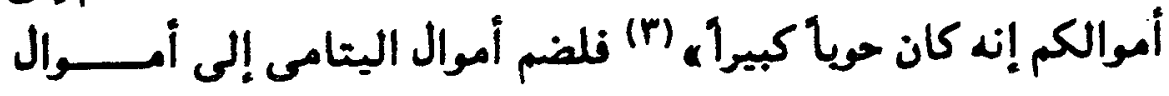

$$
\begin{aligned}
& \text { ل مسرة الضحى .. } \\
& \text { IAA سيدة البترة. } \\
& \text { Y بورة النساء. }
\end{aligned}
$$




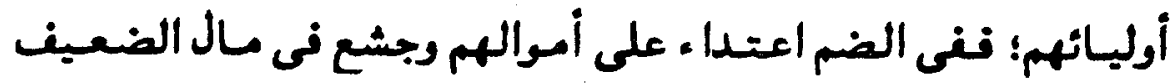

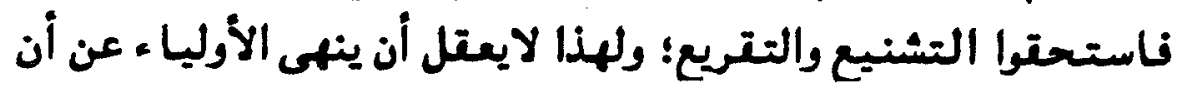

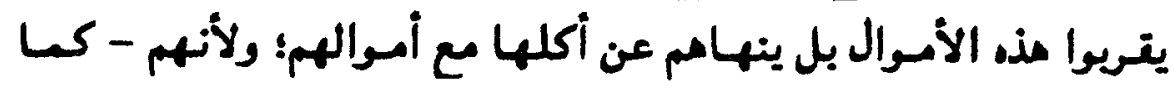

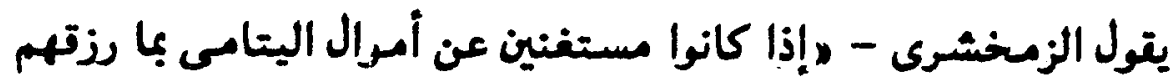

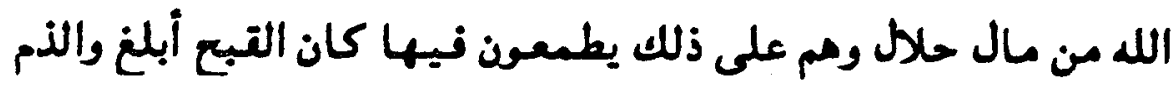

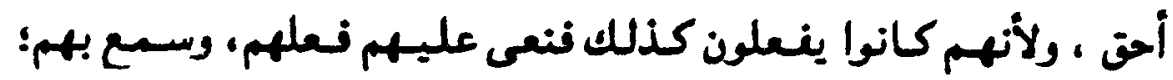
ليكون أزجر لهم..." (I).

" ل بالتى هى احسن "

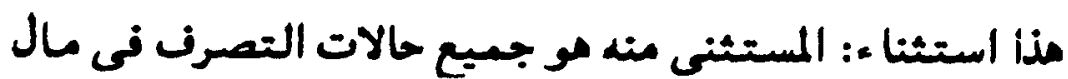

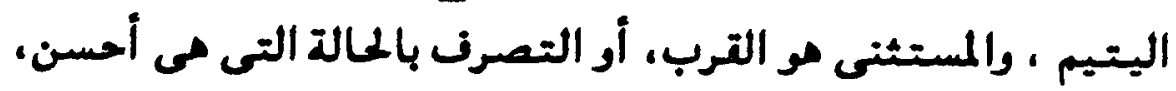

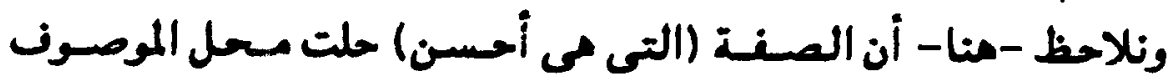

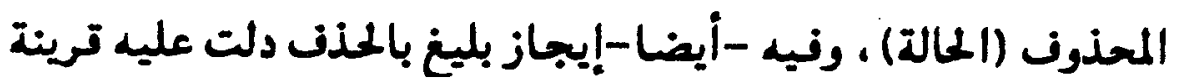

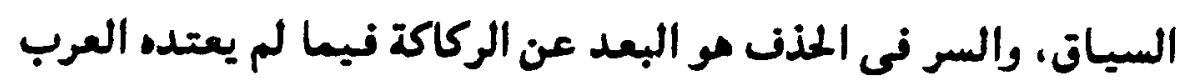

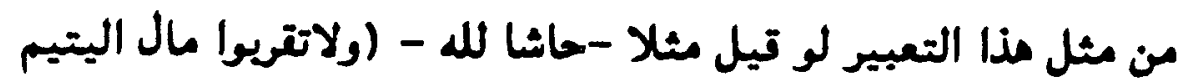

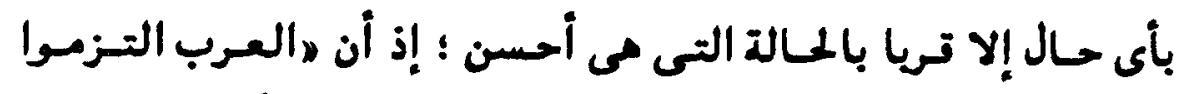

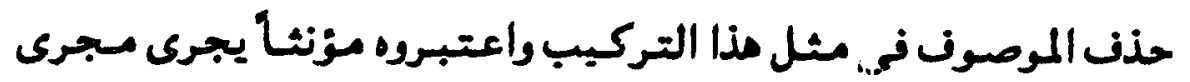

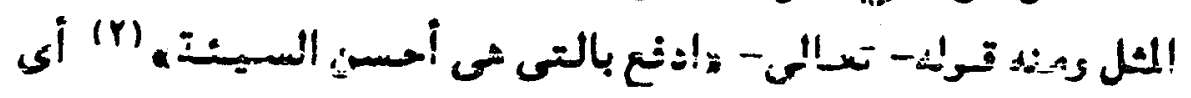

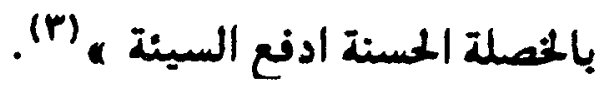

$$
\begin{aligned}
& \text {. ra Pا الكثاف } \\
& \text { re }
\end{aligned}
$$

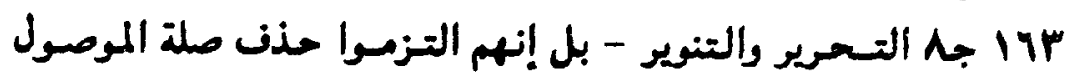

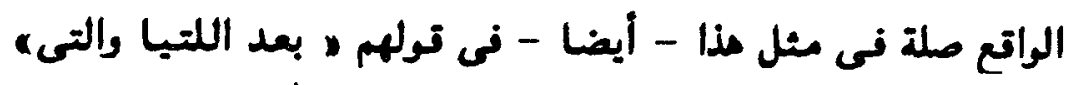

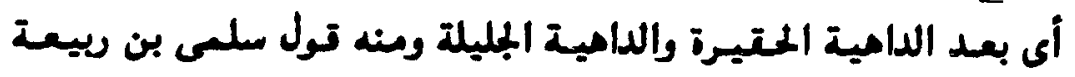
$=$ 
و رأحسنه - منا- أنعل ليس على بايه من المفاضلة بل لمجرد

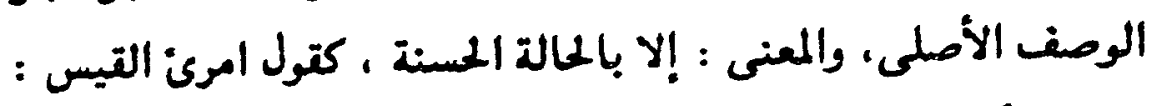

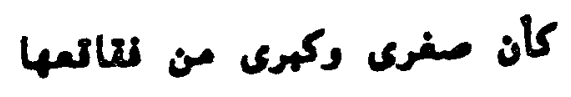

مسهاء در علم ارض من الدهب

نلا يقصد امرؤ القيس المغاضلة بين الكبير من النتاقيع أو بين

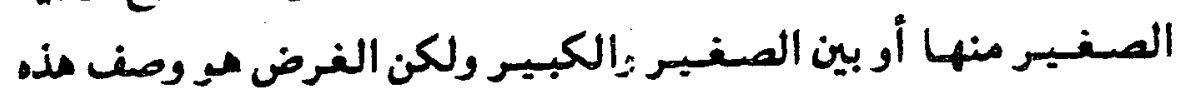

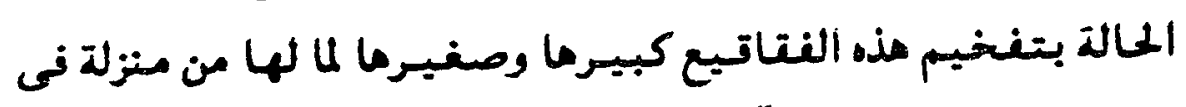

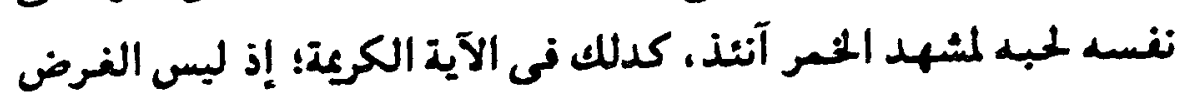

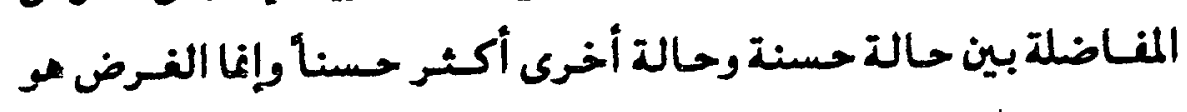

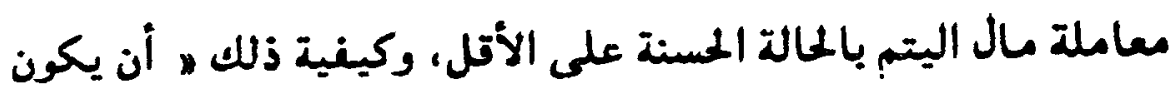

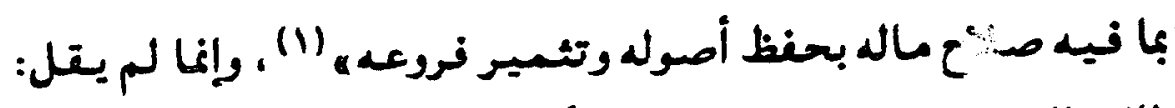

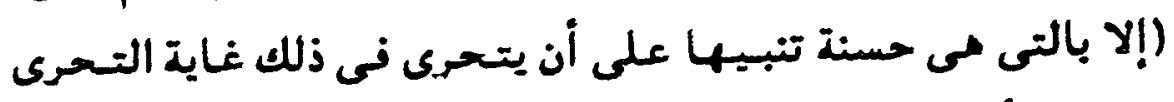

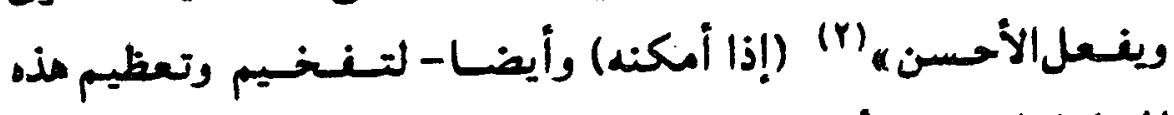

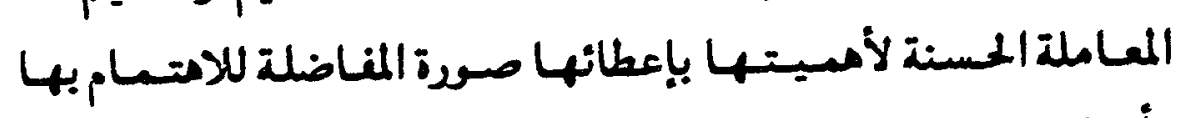

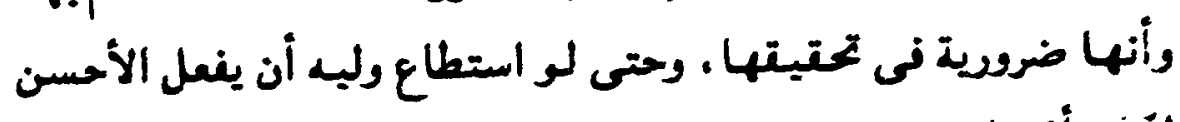

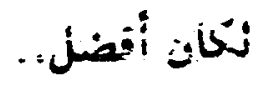

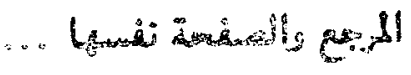

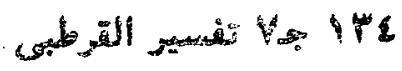

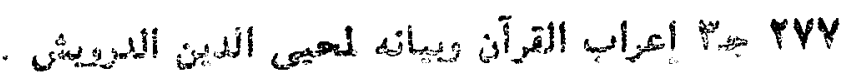


* (حتى يبلغ اشده ) :

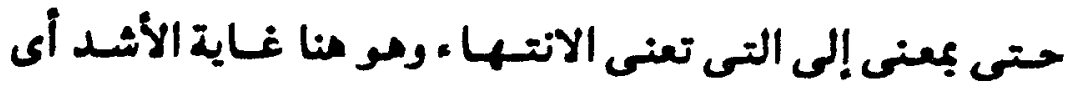

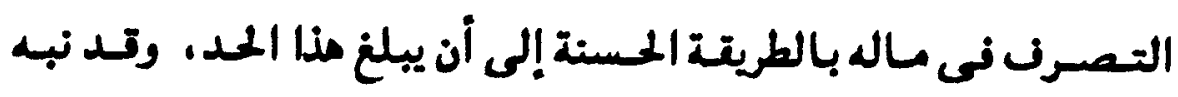

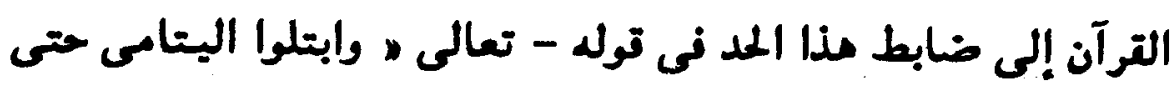

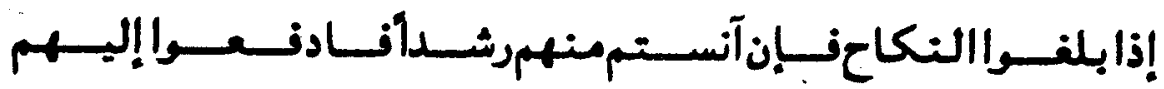

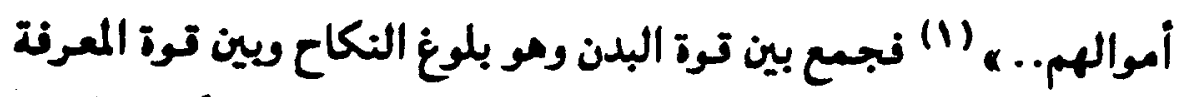

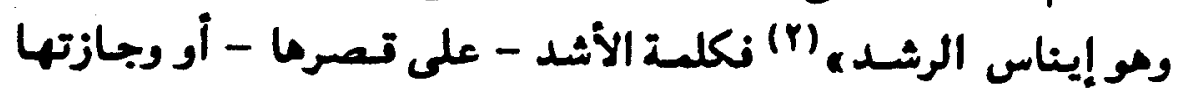

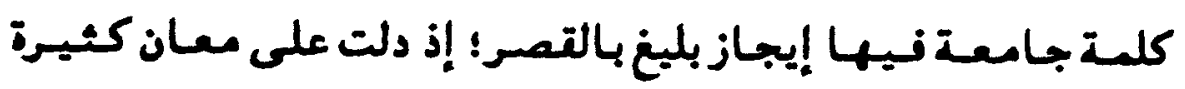

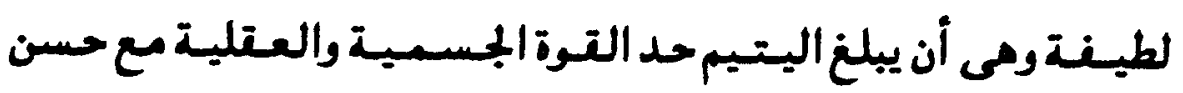

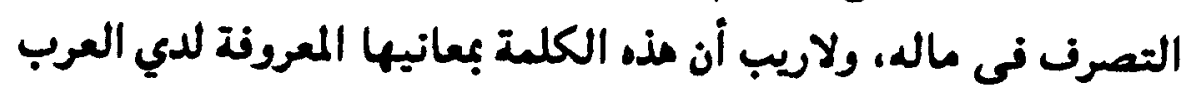
أسرع إلى ذمن الساسع من مذا التفصيل - والبلاغة الإيجاز.

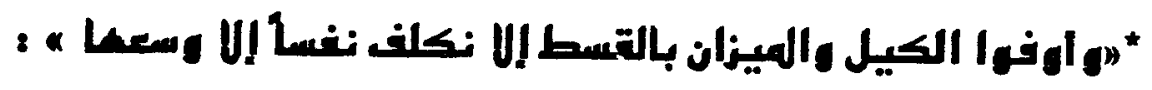
ومنا- أيضا- جاءت الوصية بالأمر للترغيب فى مذا الإيغا ..

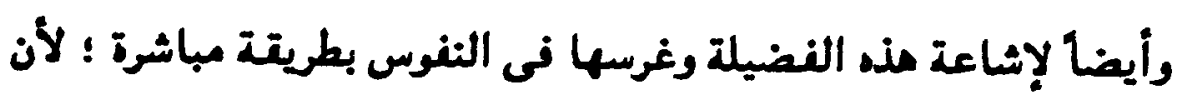

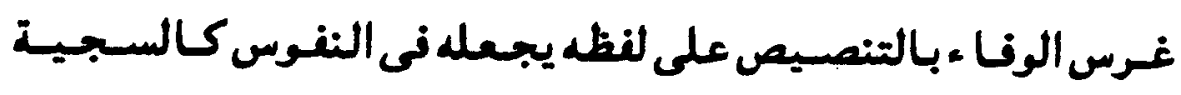

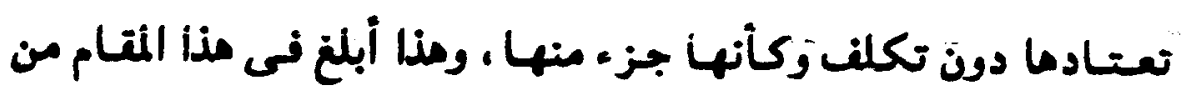

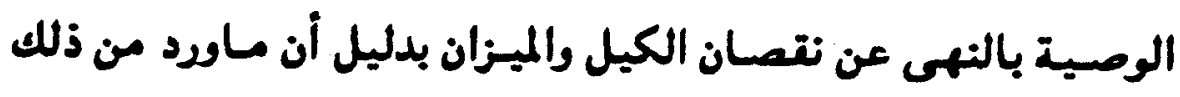
فى الترآن جاء بصيغة الأمر ومو فى خمسة مواضع جميعها مصحوية 


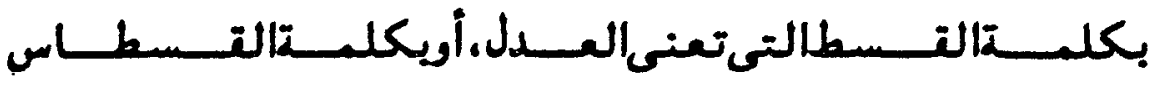
المستقيم (1)

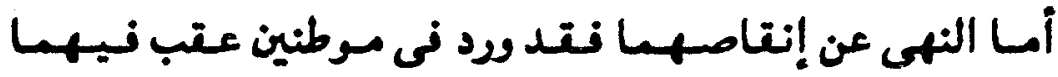

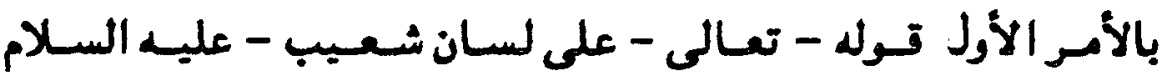

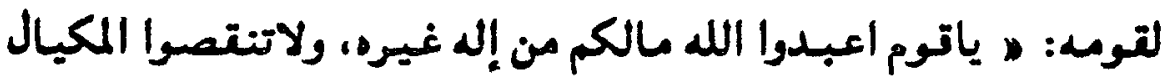

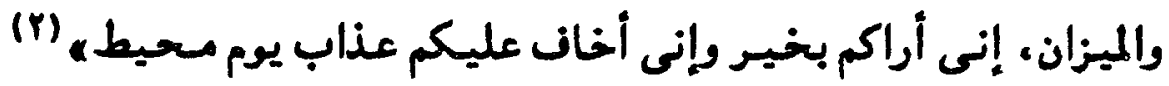

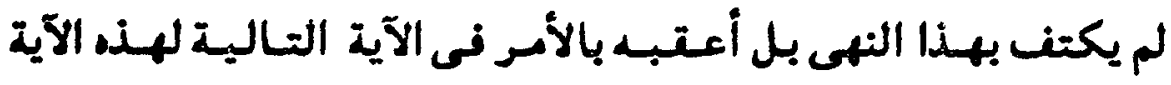

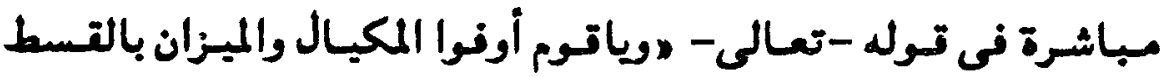

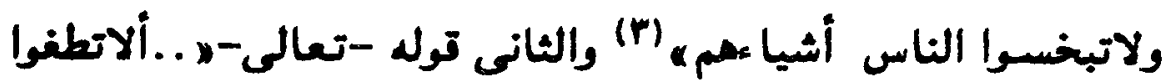

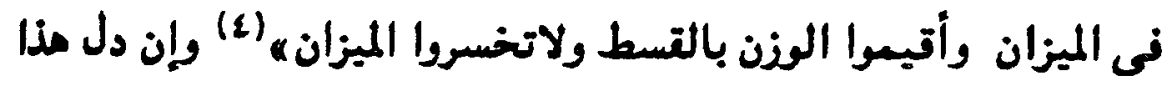

$$
\text { مذه الآيات هى : }
$$

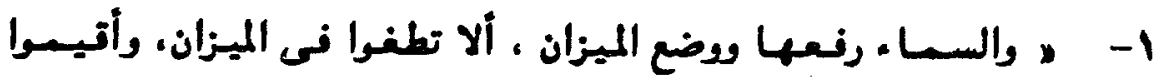

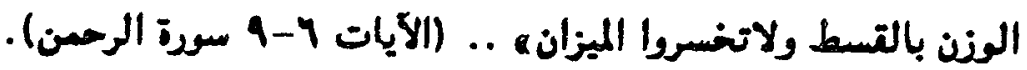

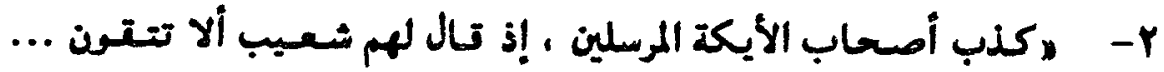

أونوا الكيل ولاتكونوا من المغسرين وزنوا بالتسطاس المستقيمه .

$$
\text { ( الشعراء - IAF - IVY) }
$$

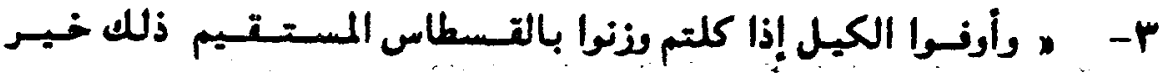

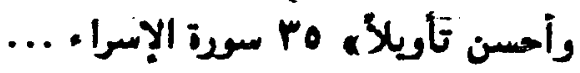

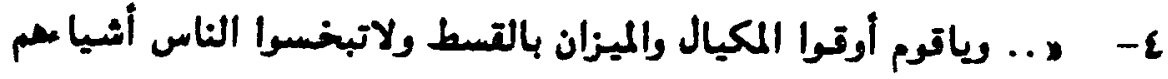

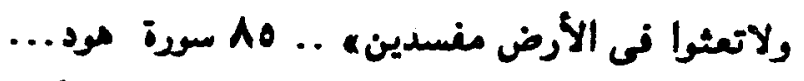

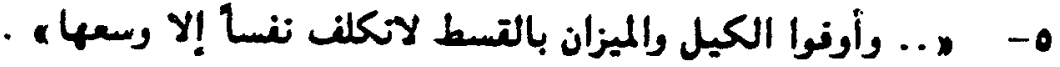

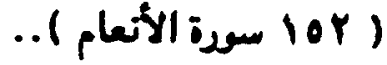

A 1 ، 10

•

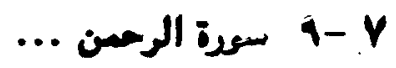




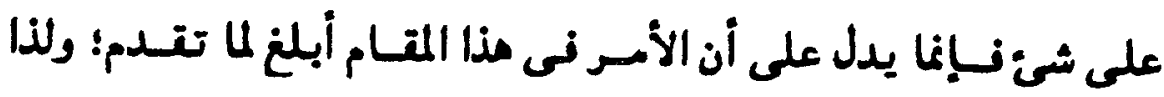

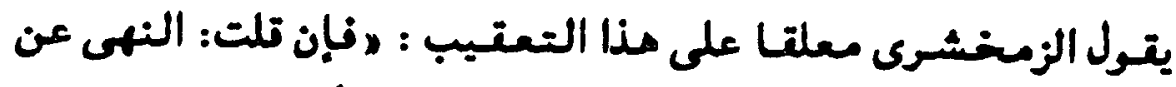

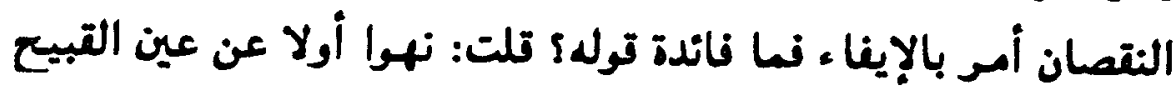

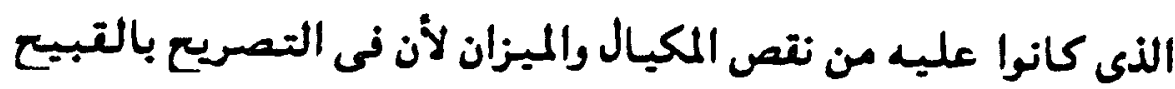

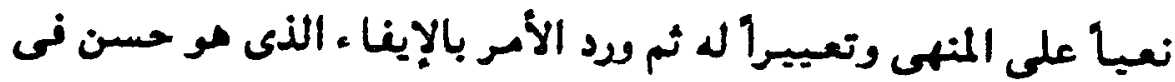

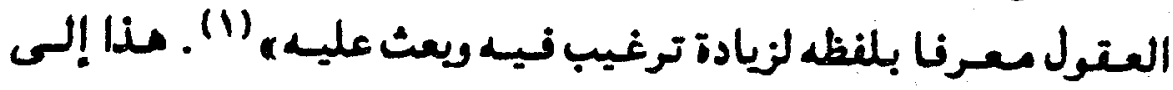

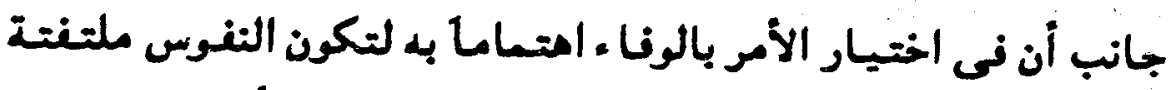

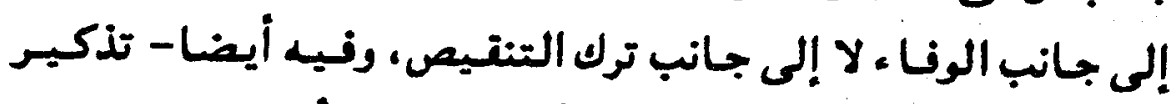

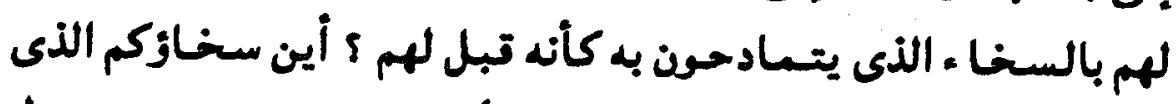

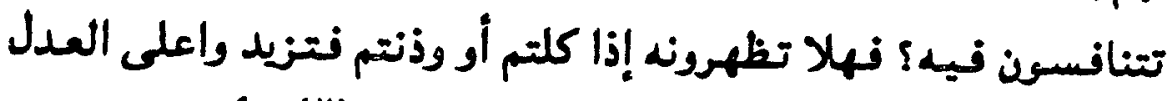

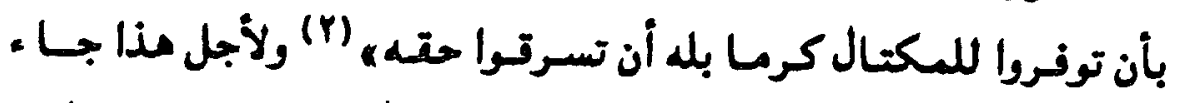

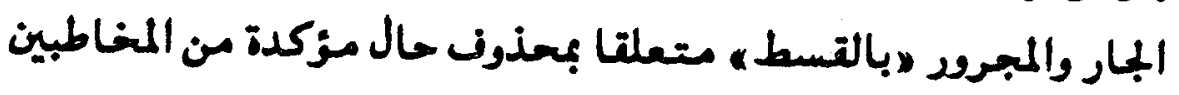

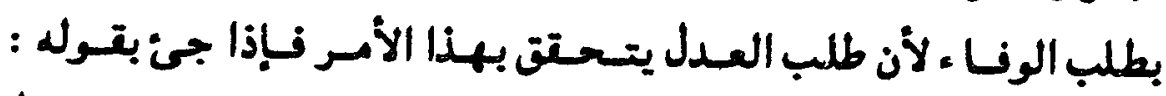

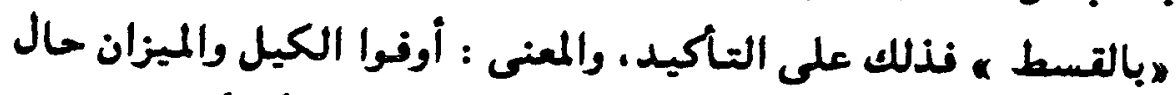

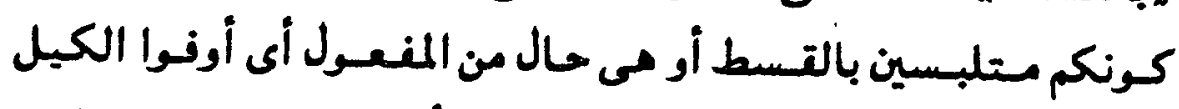

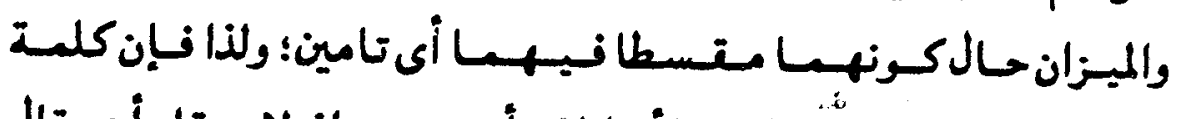

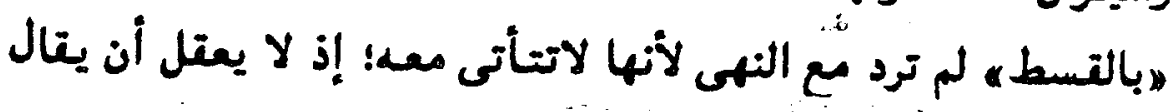

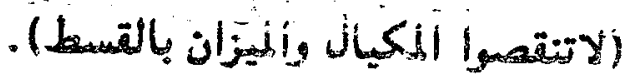

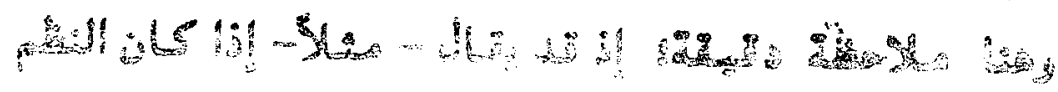


الوفا ء كأن يقال - ميلا- حاشا لله - (بالتسط أوفوا...) حتى يكون

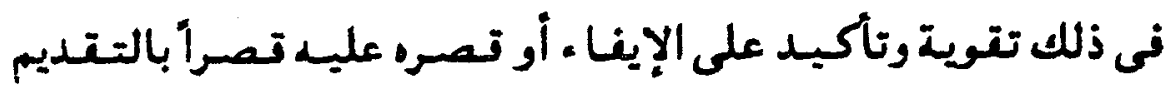

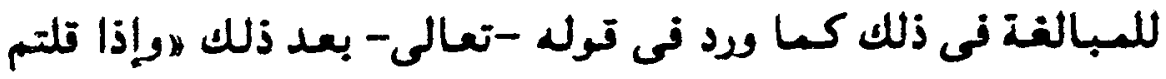

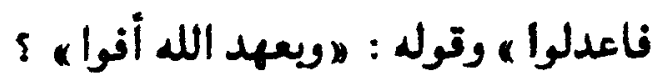

الجبهواب عن ذلك : أنه لو تـدم هبالتـسطه، على عـامله لأشعـر

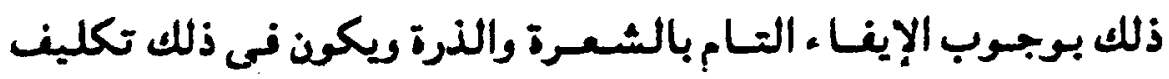

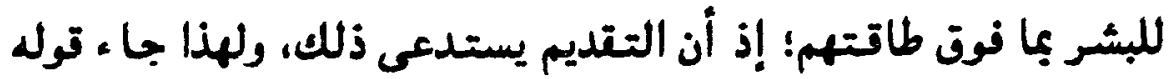

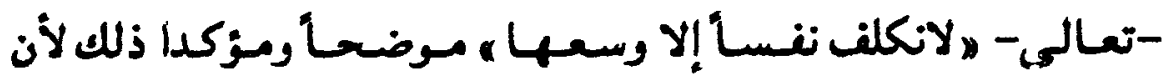

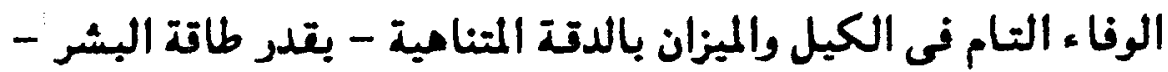

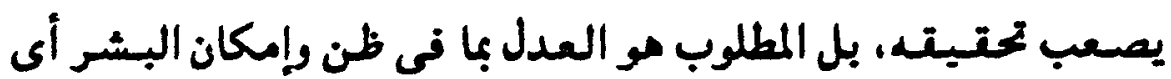

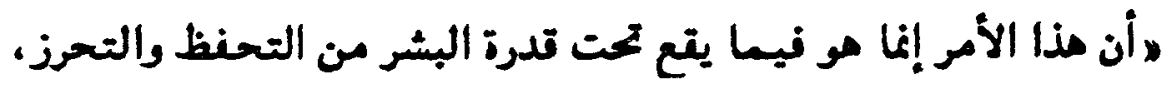

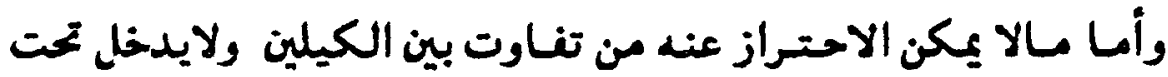

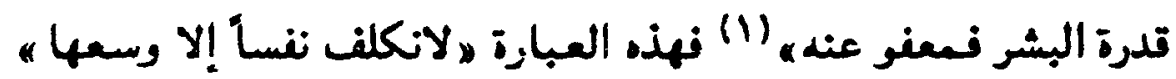

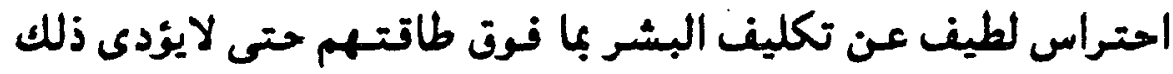

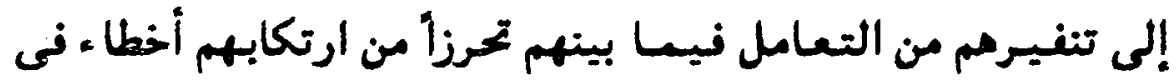

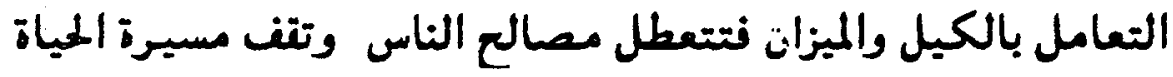

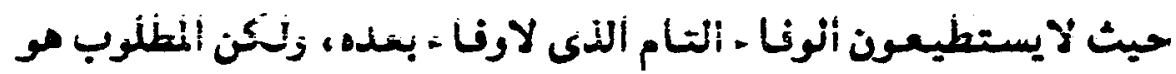

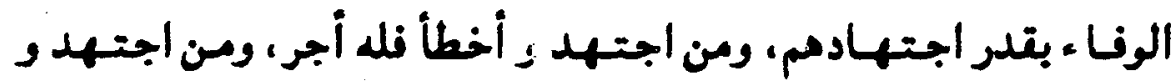

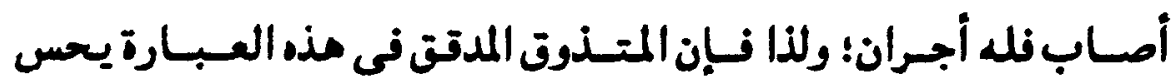

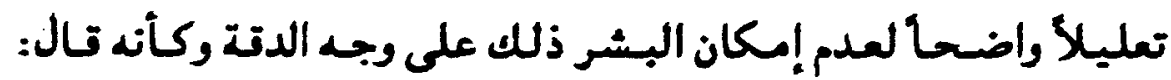

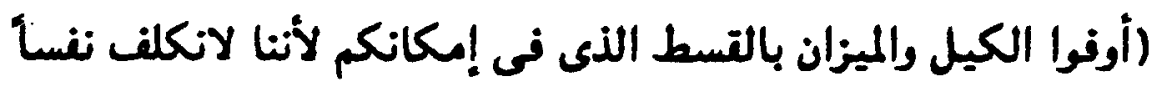




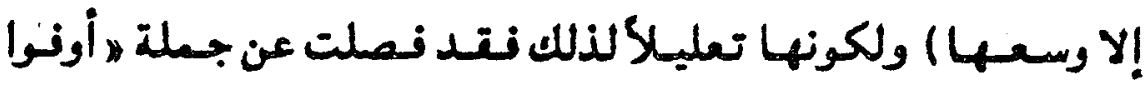

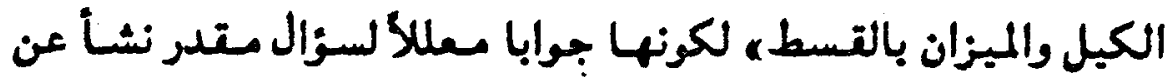

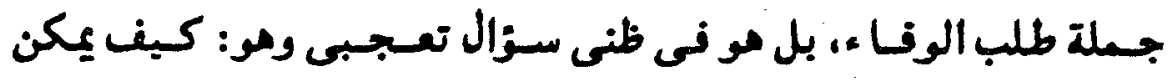

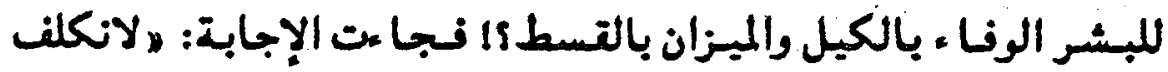

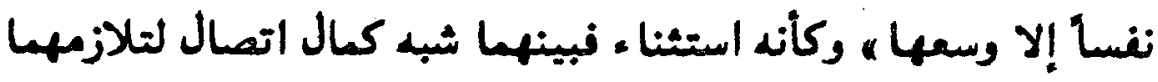

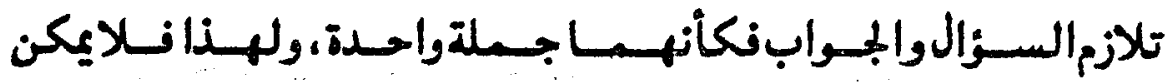
تعاطنهيما لإشعار العطف بالتغاير بينهما ؛ وريما يؤكد رخصة الإيغا -

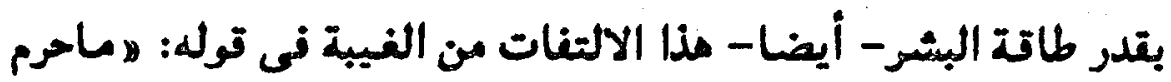

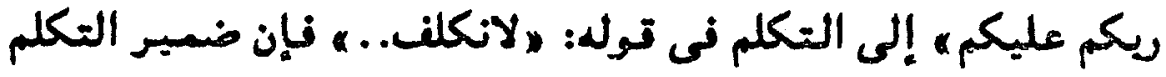

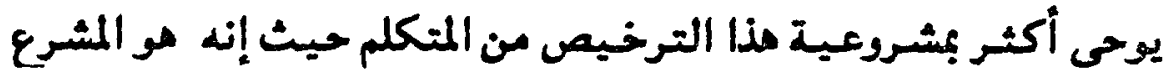

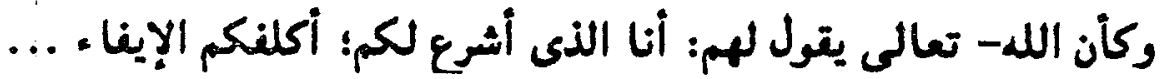
بقدر طاقتكم رحة بكم فلا تخشوا التعامل فيما بينكم.

* أما تلدم العمول: على عـاملد فى تسوله تهـالى: „إذا

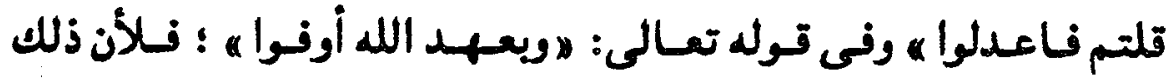

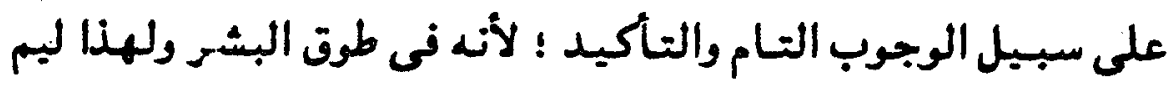

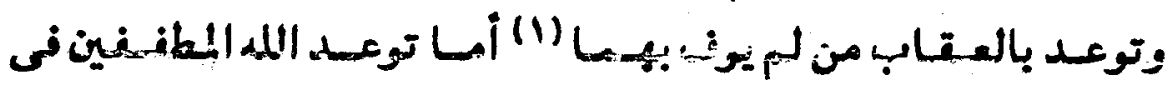
الكيل والميزان؛ نلأتهم تعـدوا أن يأخذوا أكثر من حتهم إذا اشتخروا

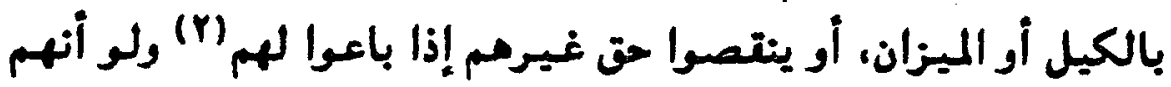

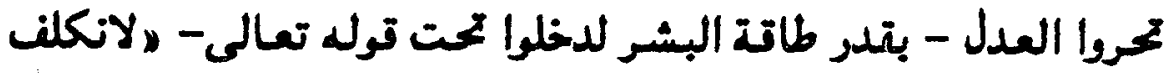

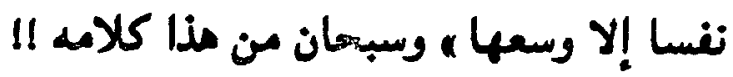

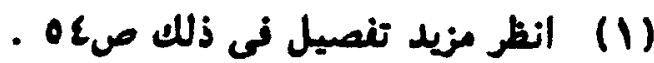
(Y) يستونوف *، وإذاكالومم أو وزنوم يخسرون... ، (1-"اسودة المطننين) 
" وإذا تلتمر ناعلوا ، وله كان ذا تربيى " يرى بعضـم أن لاالتعليق بأداة الشرط فى قوله : هإذا تلتم فـاعـلوا ه إشـارة إلى أن المره فـ سعـة من السكوت إذا خشى تـول

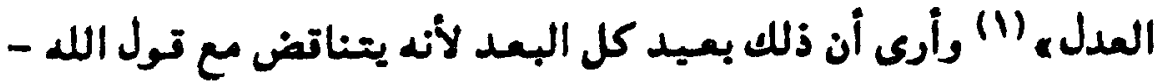

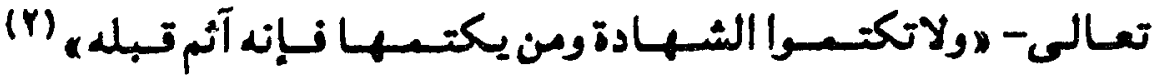

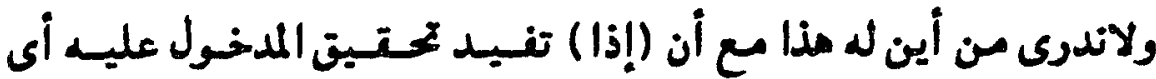
وتوعه بالتطع أَ بعبارة البلاغيين : ( الأصل فى إذا أن يكون الشـرط فيـا متطوعا بوقوعـ كسا تتول : إذا زالت الشسس آتيك) نقطعا ستزول الشمس، ولذا يقول البلاغيون: (وغلب لنظ اللاضى مع (إذا)

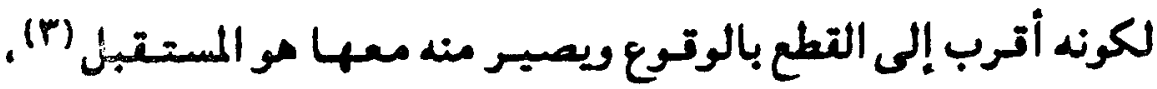
وفى قوله - تعالى: „وإذا تلتم نساعدلوا ، التول بالعدل وابب وواتع

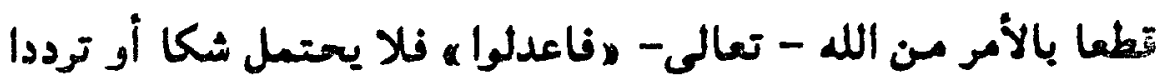

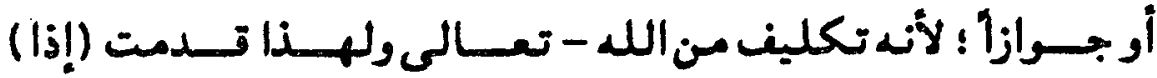
ومدخولها على عاملها الأمر لاعدلوا ه ولزا با عت الآية الكريمة منددة

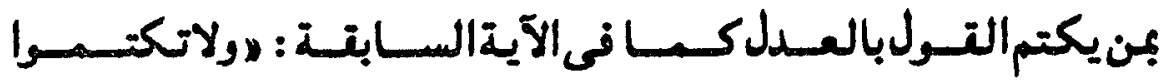
الشـهادة.... م ويتـول تعالى : ، يا أيها الذين آمنرا كونوا تـوامين

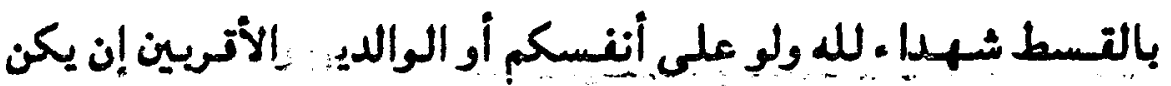
غنيا أو نقيرا نالله أولى بها نلا تتبعوا الهوى أن تعدلوا وإن تلورا:

(I) سمدة البترة. رابع حاثية الدسوقى هr بـr شروح التلخيص ويغية الإيضاع للثينغ

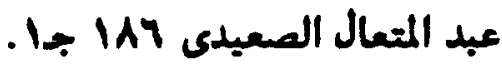


أو تعرضوا نإن الله كان با تعملون خببراه (1) ويتول تعالى: يا أبها

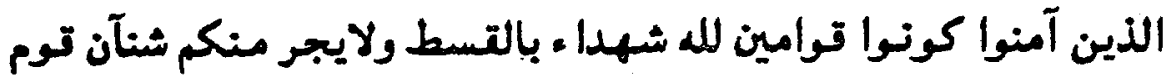

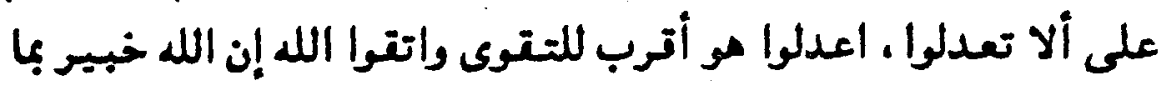

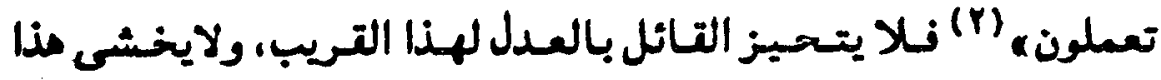

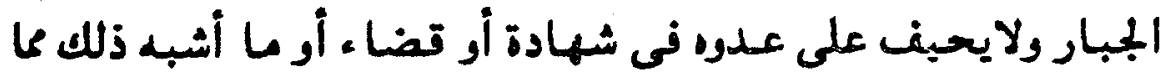
يدخل تحت القول بالعدل.

فلهما كـان التكاليف بالقـول بالعـدل \& -هكذا - فـرضـاً من الله-

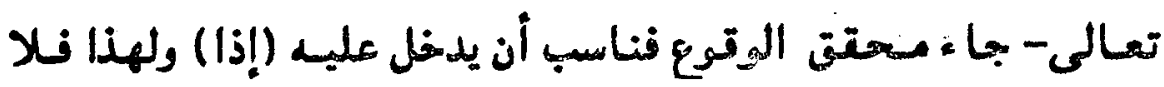

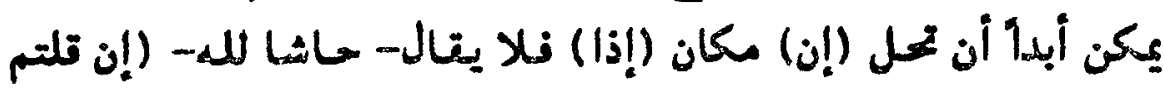

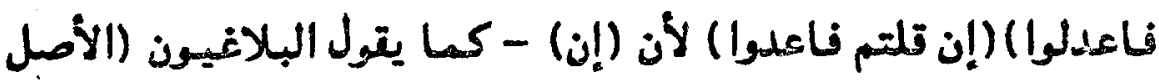

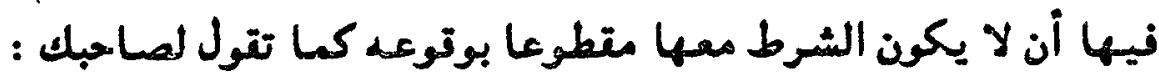

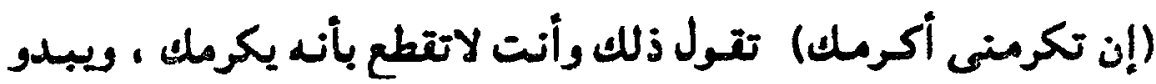

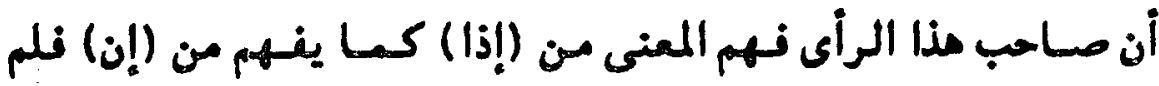

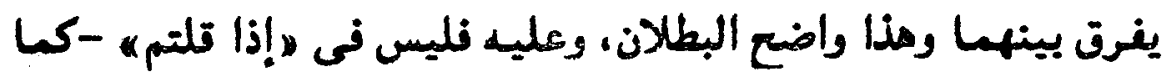

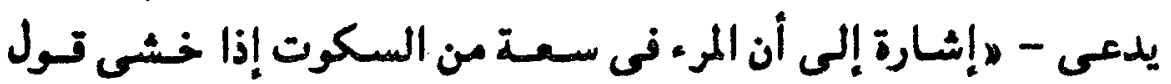

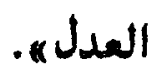

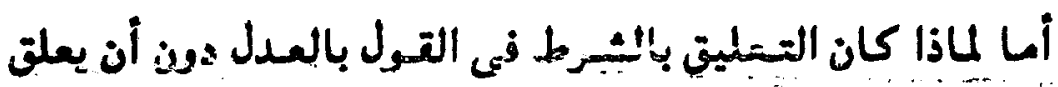

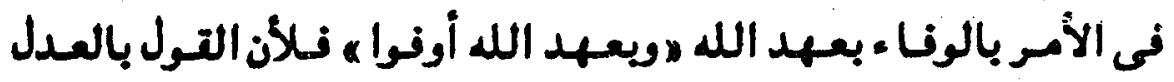

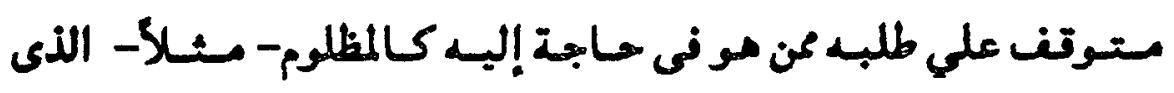

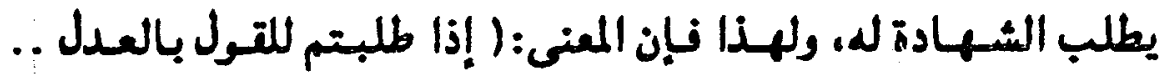

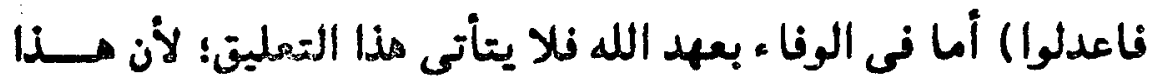

(I) (1) ( 1 ( 1 (r) 
الوفا ـ متضى فيه وانتهى إيجابه من الله -تعالى- على عباده؛ فلا

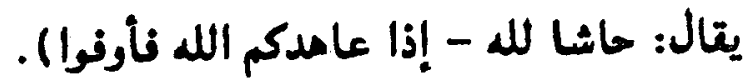

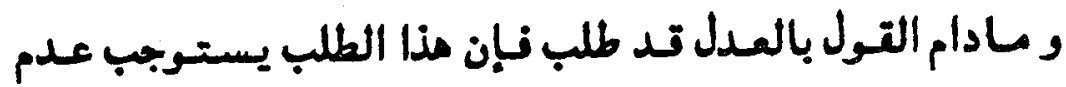

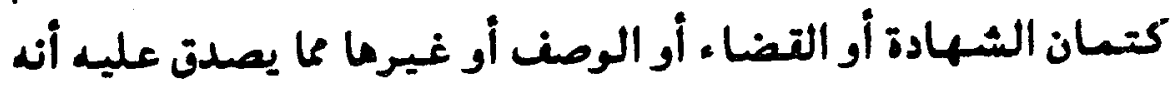

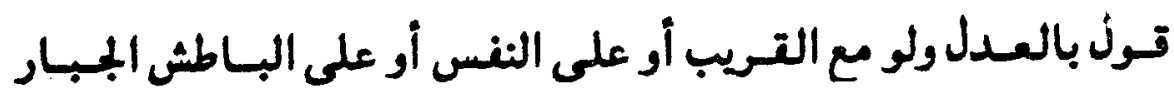
الذى يخشاه ومع العدو مصداتا للآيات الكريمة السابتة.

وإذا كان المعنى على طلب القول بالعدل نكان الأصل أن يعلق

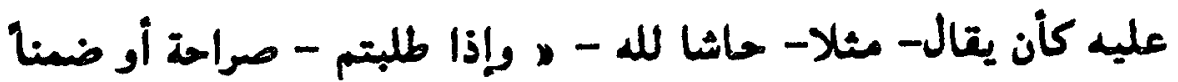

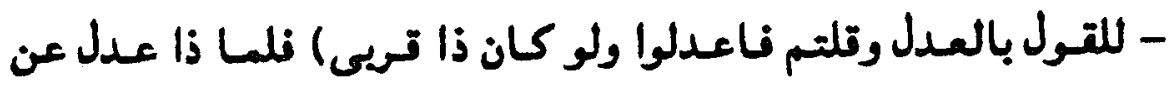

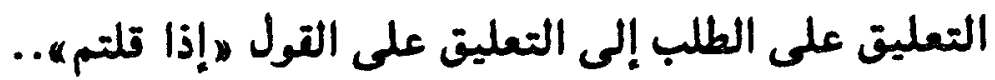

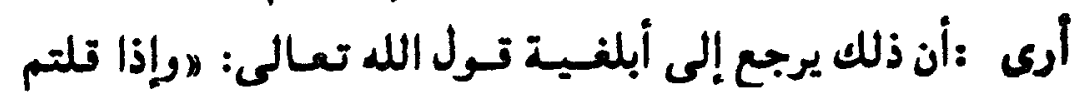
فاعدوا... ه عن " وإذا طلبتم للتول بالعدل فاعدلواله وأرى أن أبلغئَة ذلك ترجع إلى ثلائة أسرار بلاغية:

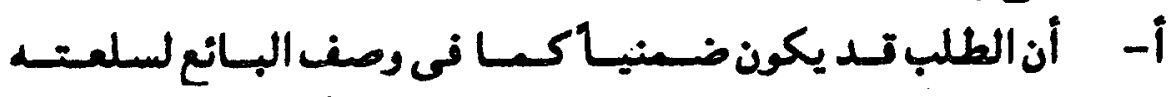

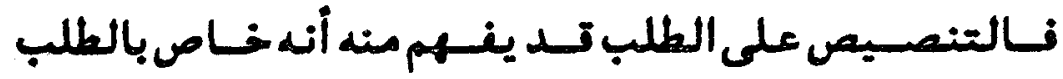

الصريح.

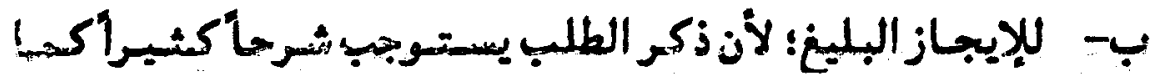
سبق لـ (1).

جـ- النــاذ مبـاشـرة إلى المطلوب ومو التـول الجـامع: ه إذا تلتمه؛؛

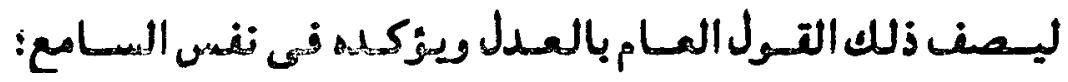
ليرسخ ويستخر فيها؛ ولهذا سلط الشرط عليه.

مثل: (وإذاطلبتم للقول بالعدل - صراعة أو ضسنا وتلتم فاعدلوا). 


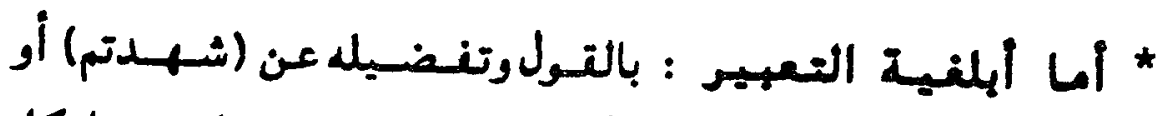

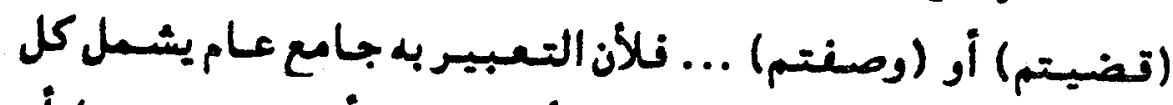

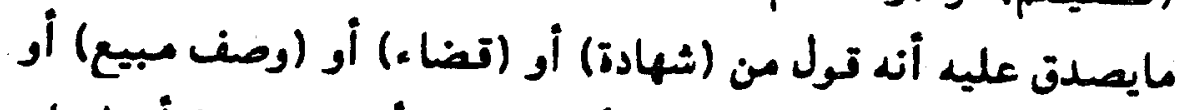

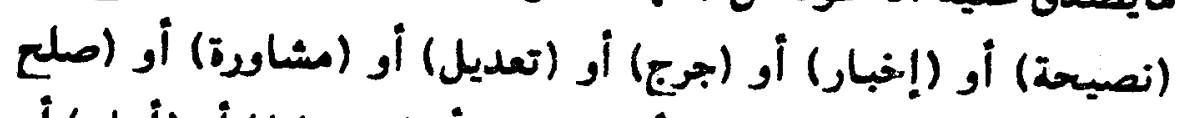

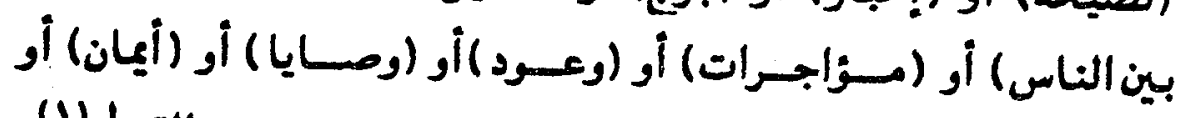

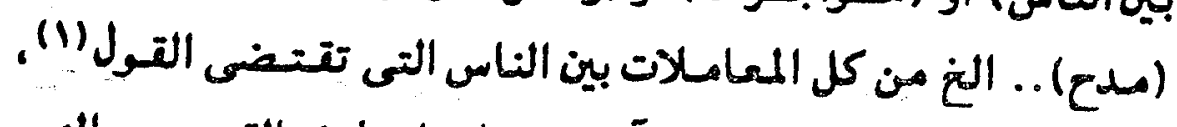

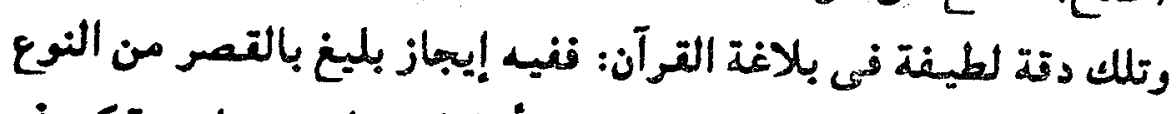

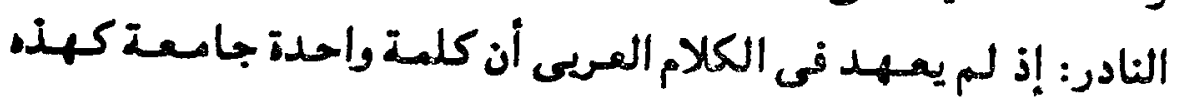

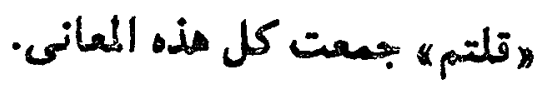

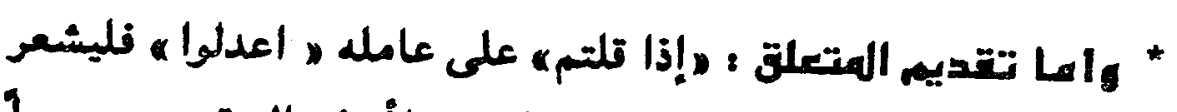

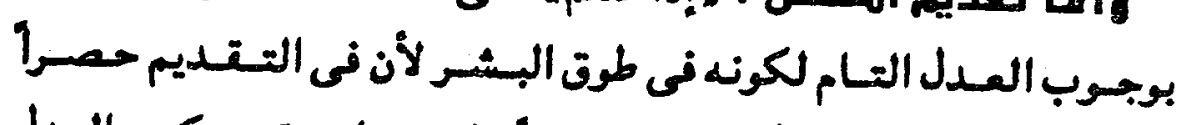

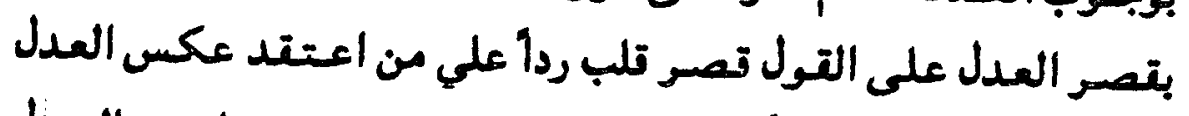

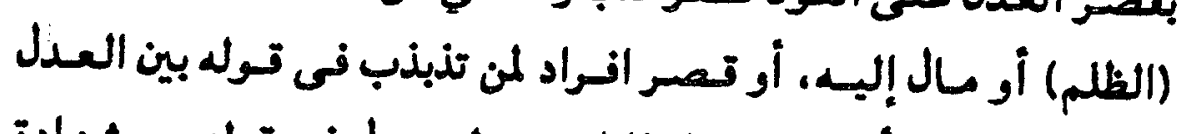

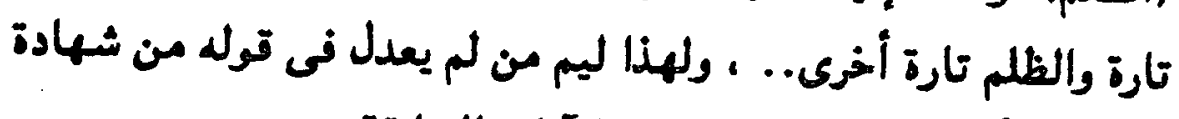
أو تضاء أو مدح ... الخ كما فى الآيات السابتة.

\section{" ماعا توله : "ه وله كان ذا تربهى" :}

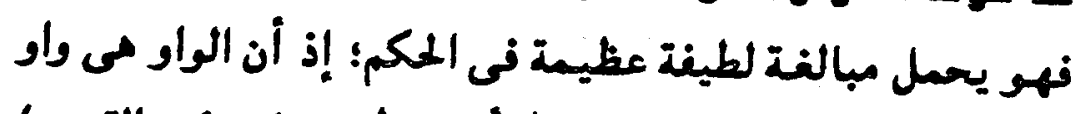

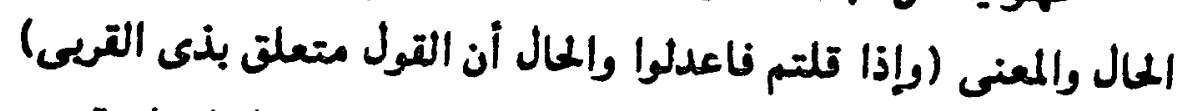

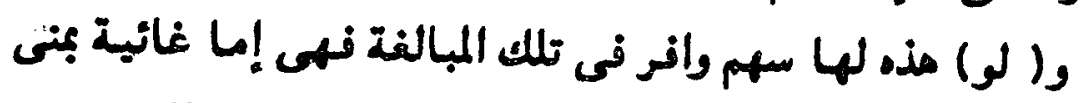

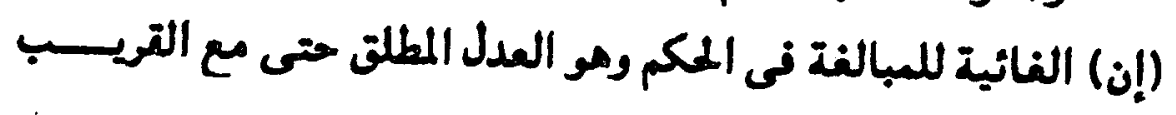


فلا يجامل أو يصانع التائل قريبه لأنه تول لوجه الله - تعالى

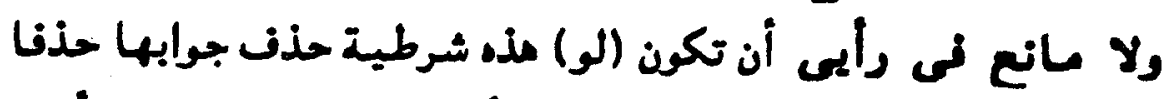

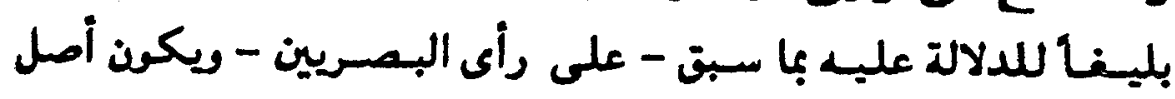

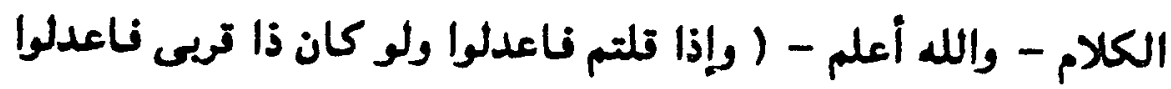

وادن أن أن جعلها شرطية ابلغ لسببين

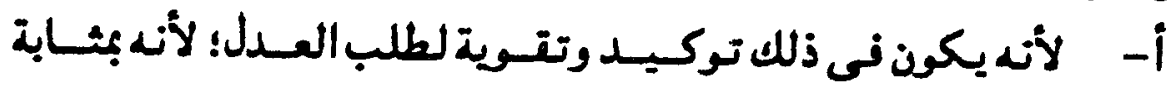

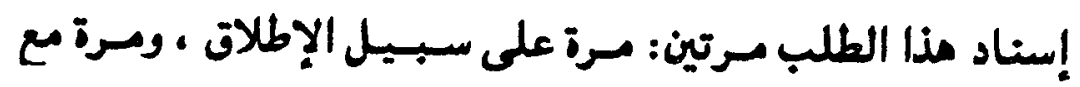

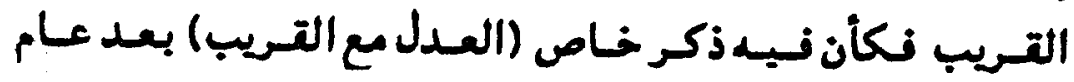

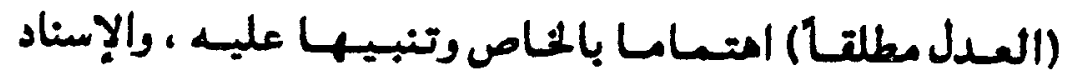

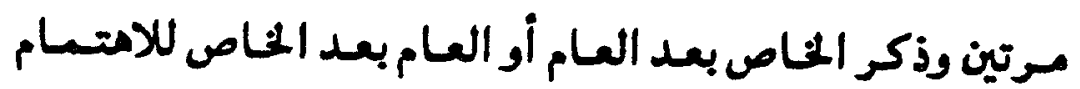

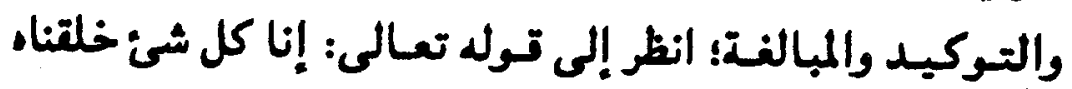

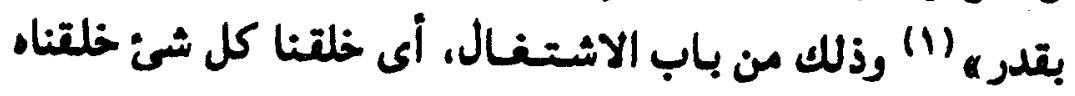

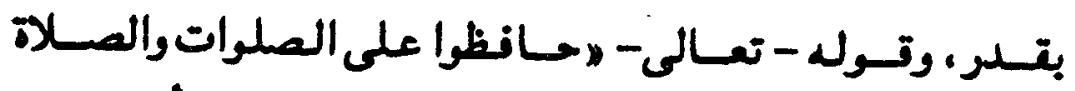

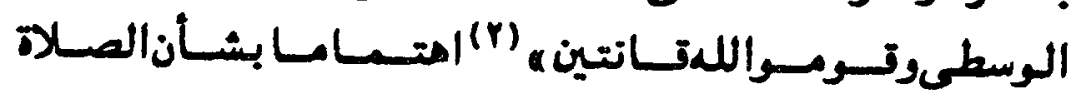

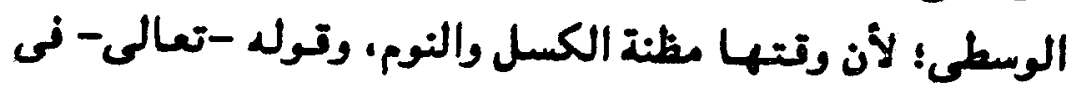

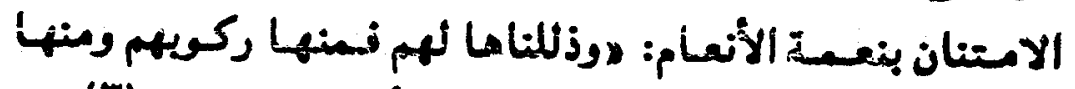

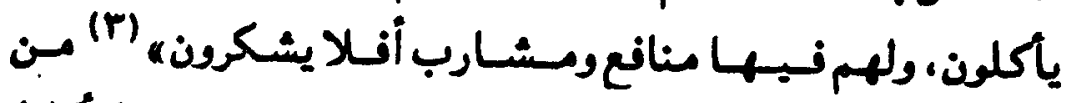
عطف العام (المنافع والمثارب) على الحهاص (الركوب والأكلي)

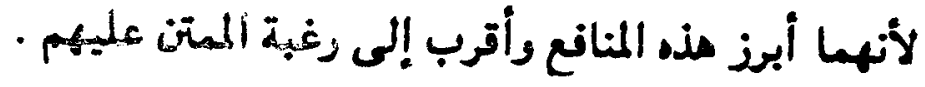

- 19 
ب- أن هذا التـــدير لهـا المعنى فيـه إتناع للسـامع بالعـدل المطلق

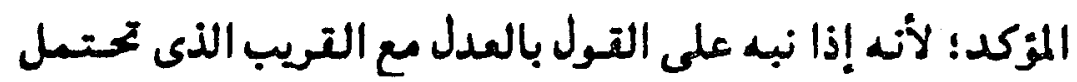

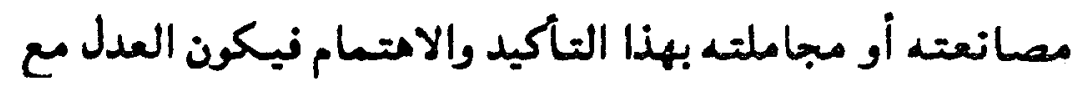

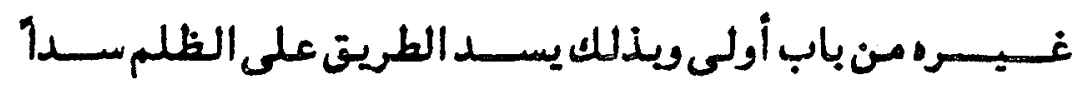
مسكما..

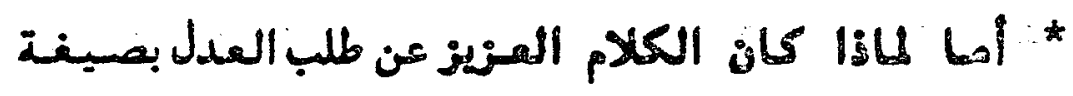

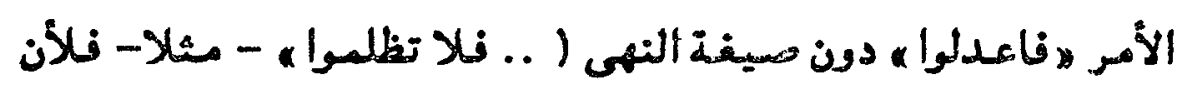

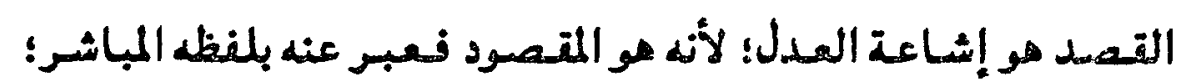

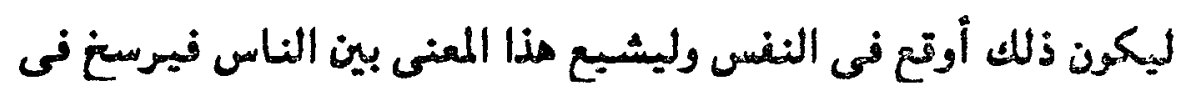

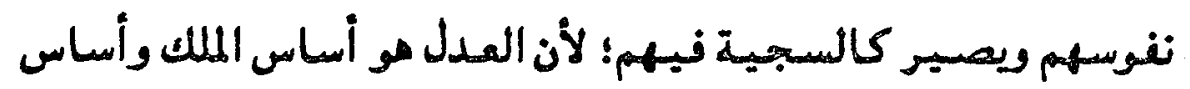

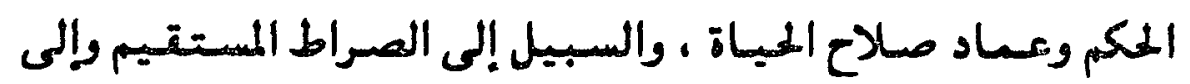

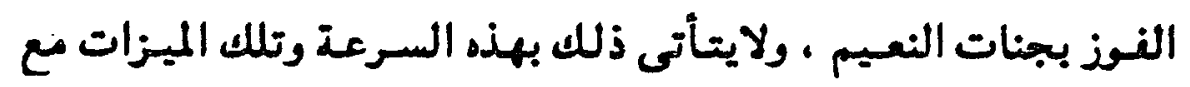

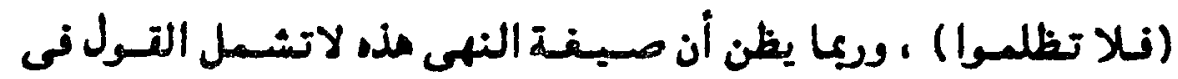
وصف مبيعه- مثلا- نصيفة الأمر أجمع وأمنع.

" " وبعهد الله أونهوال " وعهد الله المأمور بألوناء به ، هو كل عهاه المهد فيه معنى الانتساب

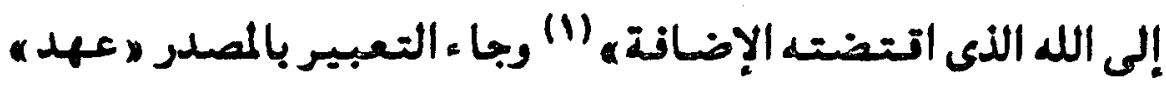

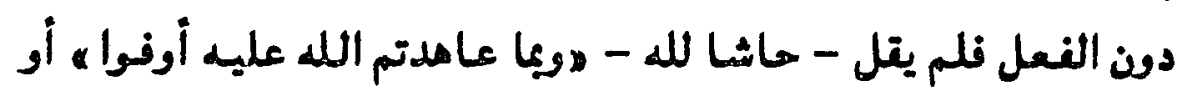

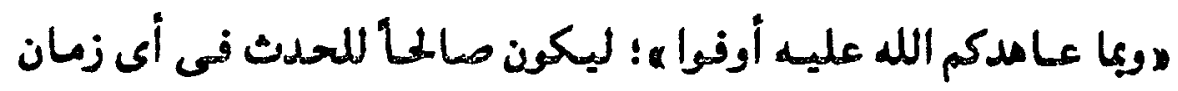

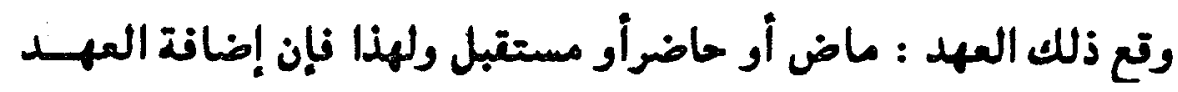


إلى الله -تعالى - لأونى مناسبة ليكون العهد شاملاك لما عاهدمم الله

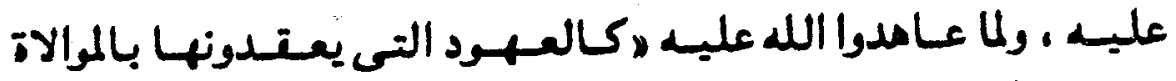

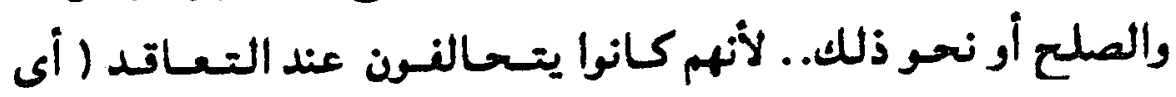

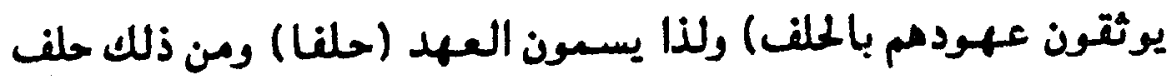

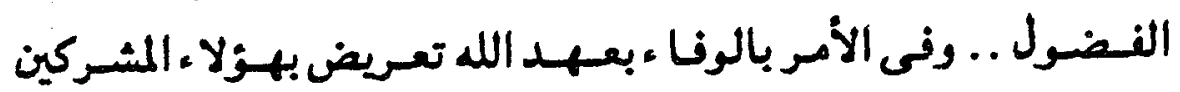

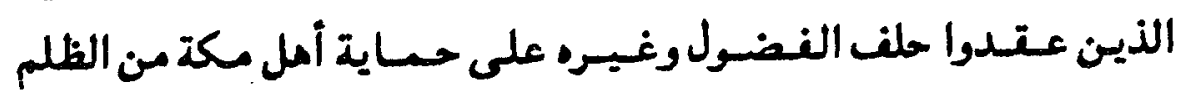

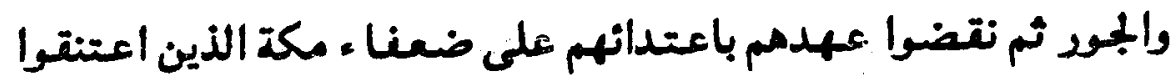

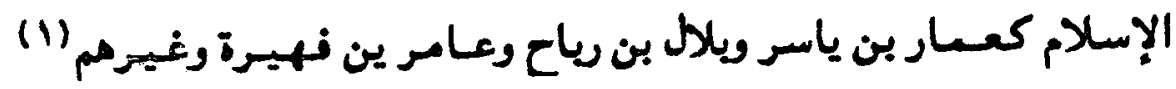

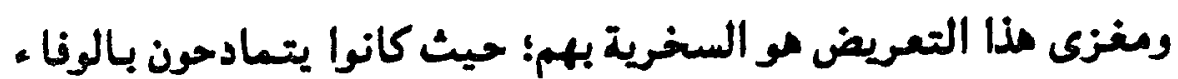

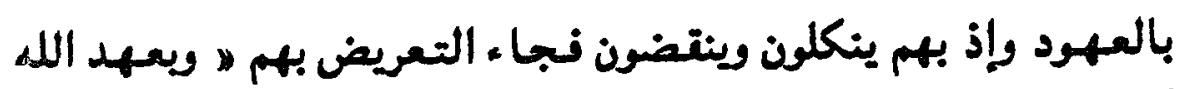
أوفوا ه.

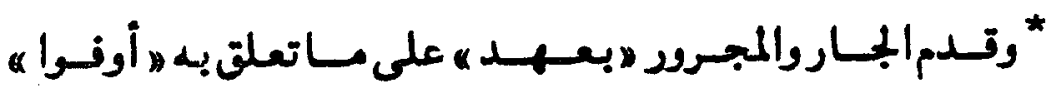

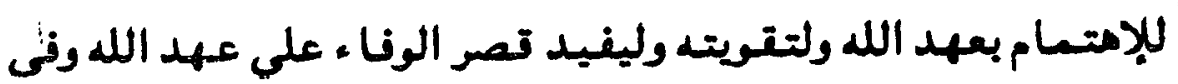

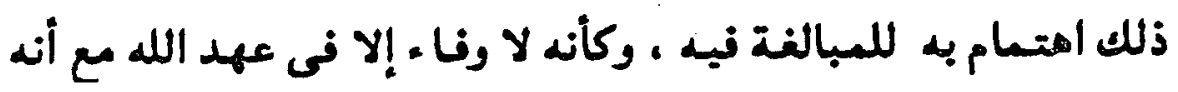

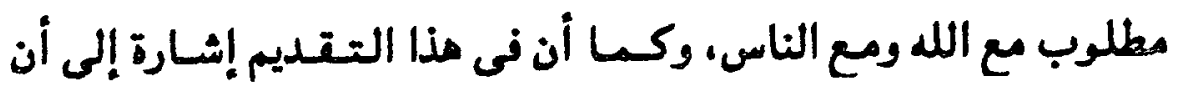

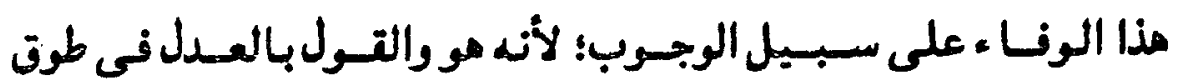

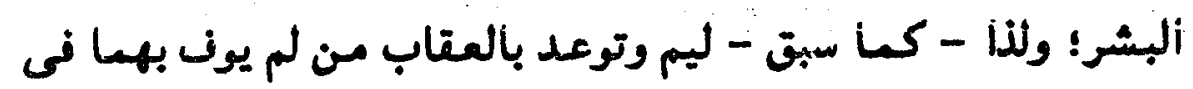

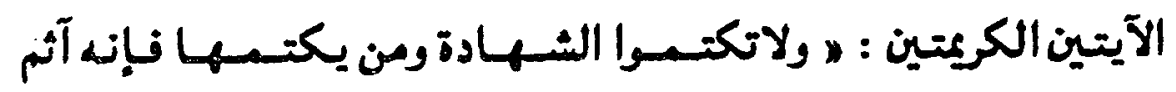

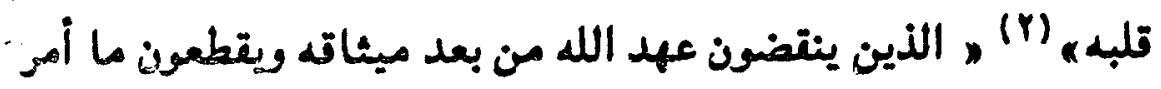


الله به أن يوصل ويفســدون نى الأرض أولئك لهم اللعنة ولهم سـو. (1) الدار (1)

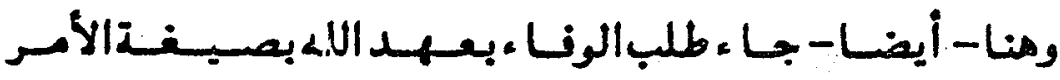

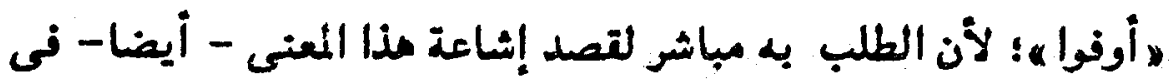

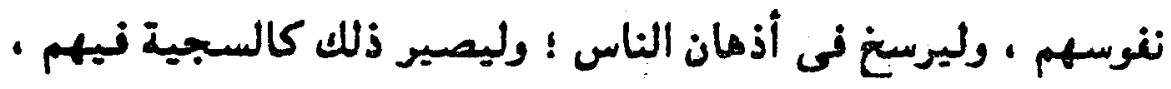

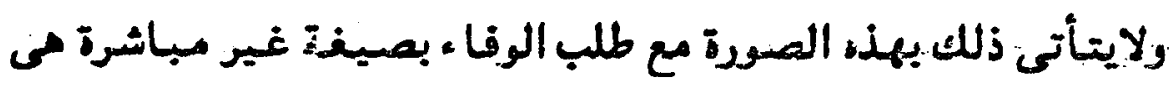

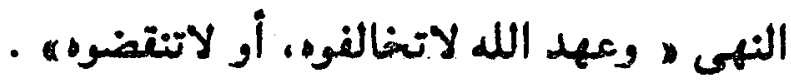

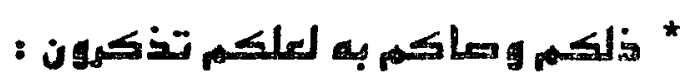

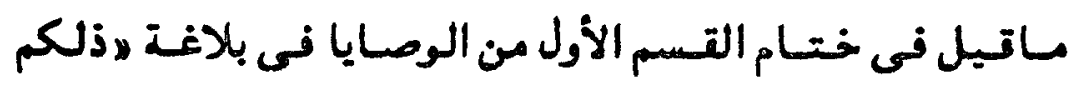

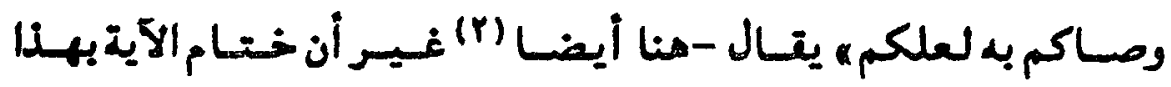
التوقع: „لعلكم تذكرونه فلأن مذه الوصايا الأربعة كانوا يفعلونها

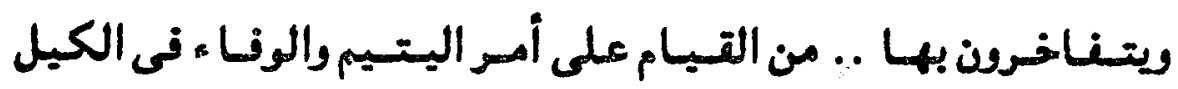

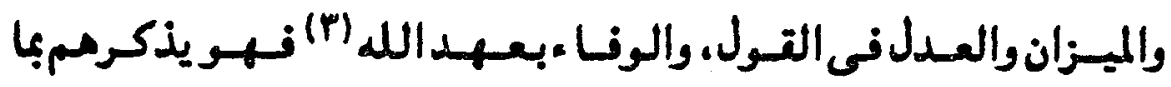

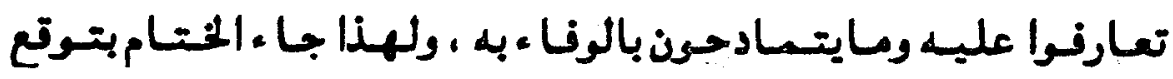

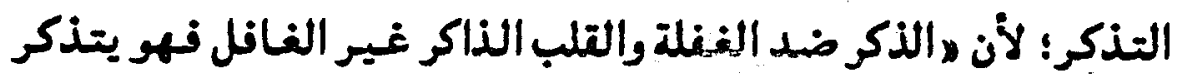

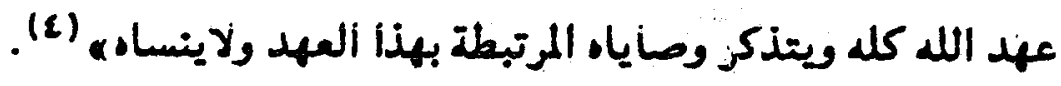

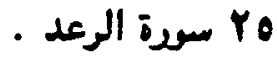

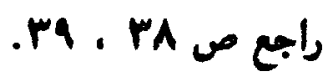

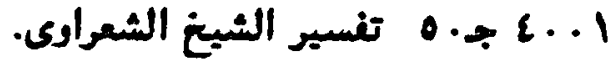

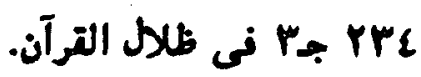




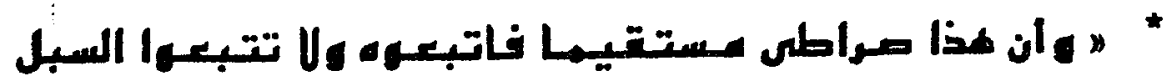

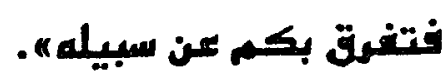

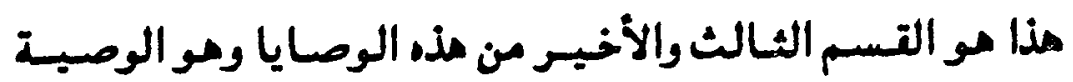

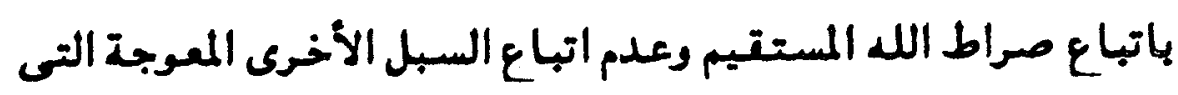

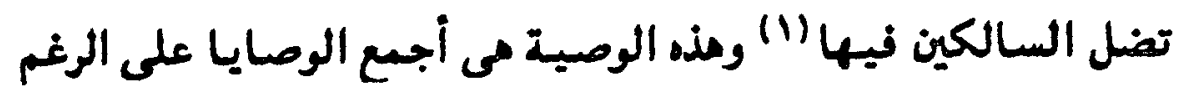

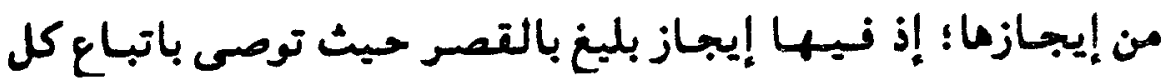

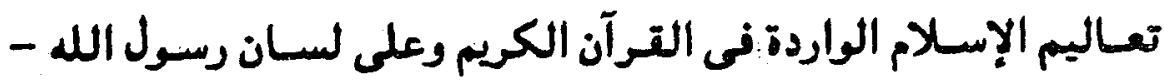

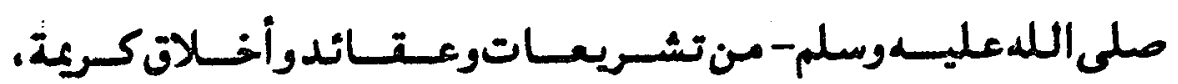
وتوجيهات اجتماعية.. كسا تشمل-أيضا- الوصايا السابقة وكأنها

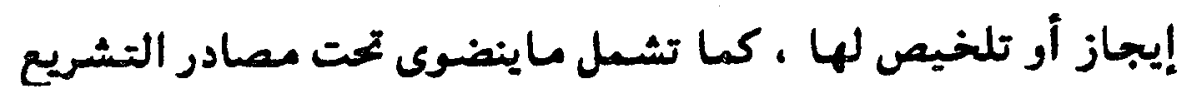

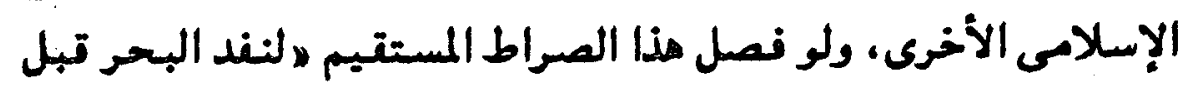
أن تنفذ كلمات ريى ... .

ولى (أن) ثلاث كـراءات : كل منهـا لايخلو عن بلاغـة عالية .

أخرج أحمد وجماعة عن ابن مسعود- رضى الله عند- تال: خط لنا

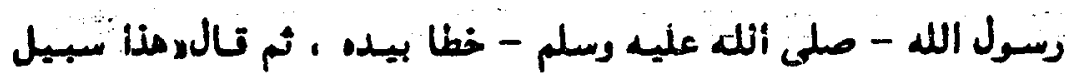

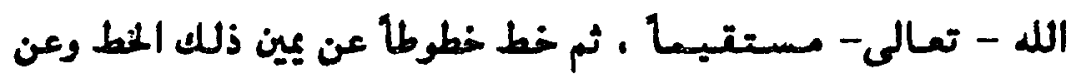

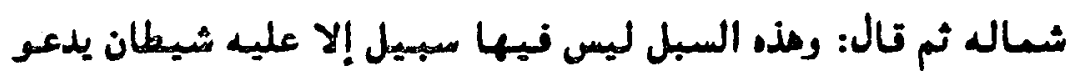

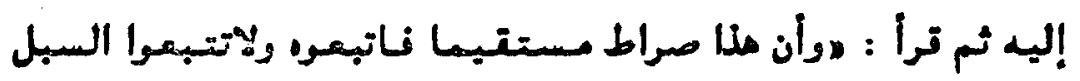

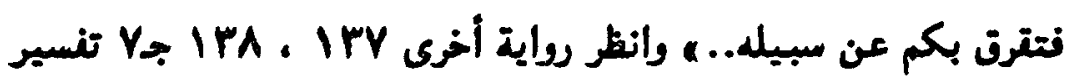

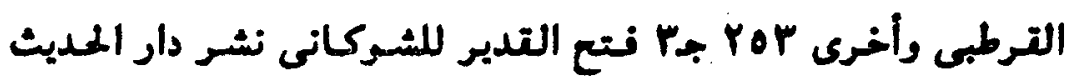


العرا هi الأولى : هى ما كانت بالهمزة المنتوحة وتشديد النون

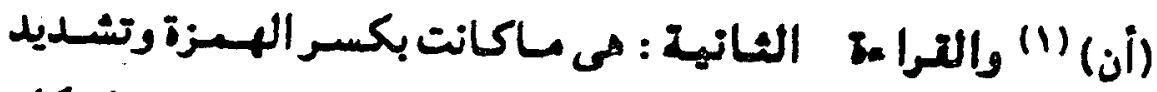

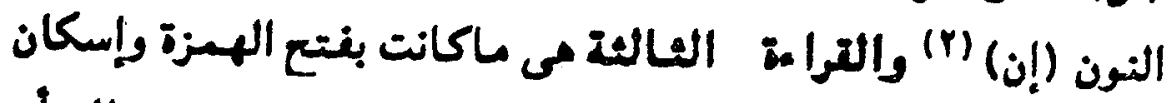

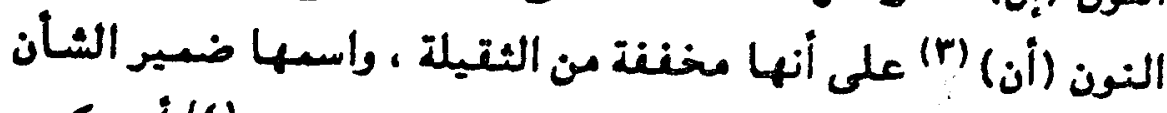

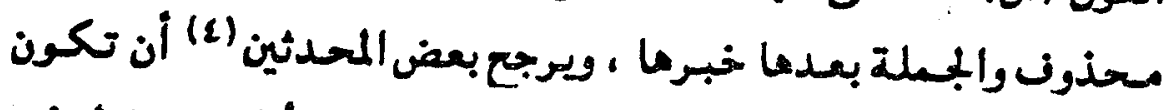

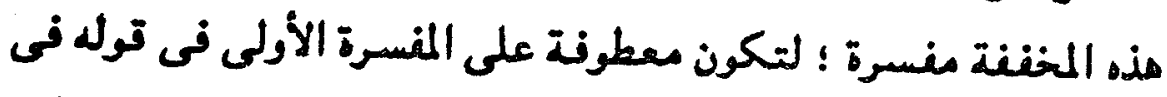

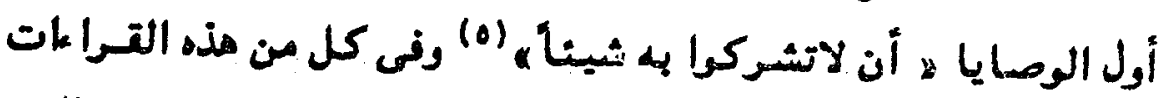

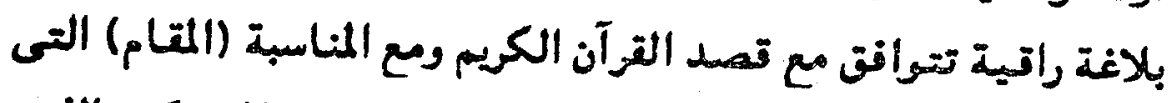

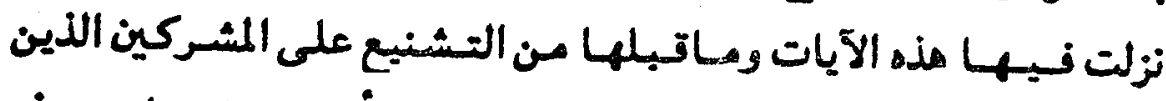

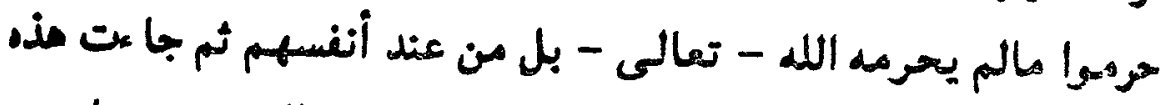

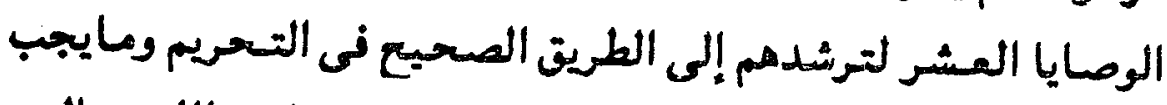

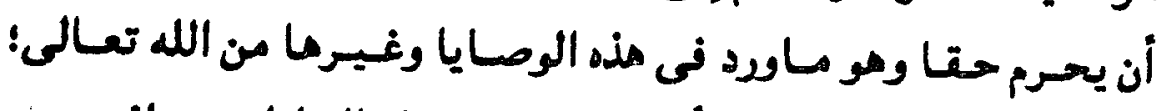

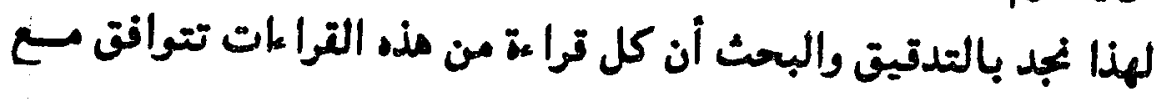

$$
\begin{aligned}
& \text { هم قرا هi نافع وابن كثير وابن عمرو وعاصم وأبو جمغر . }
\end{aligned}
$$

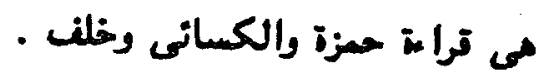

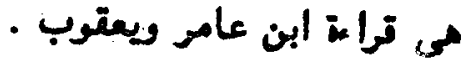

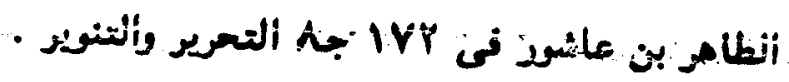

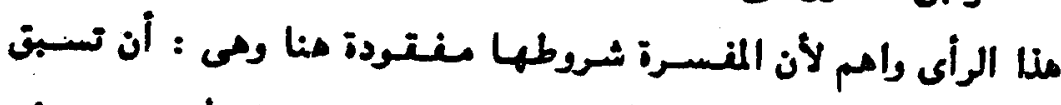

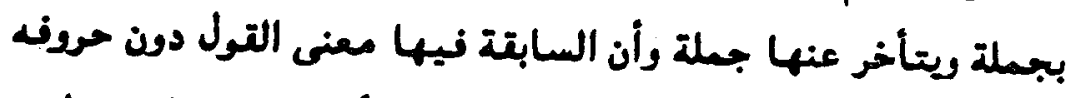

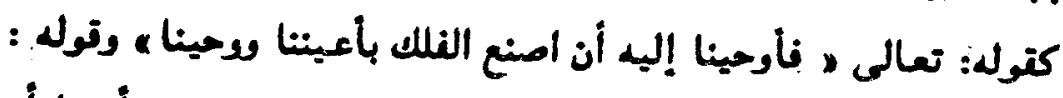

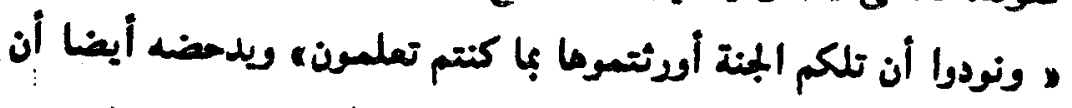

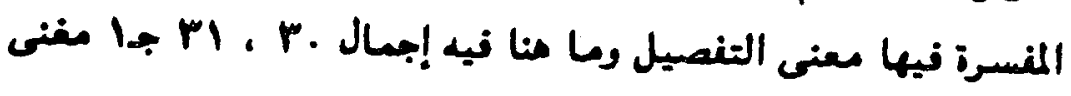


هذه المناسبة ، وعلى كل نإبـا أن تكون الواو نى قـوله - تعـالى-"

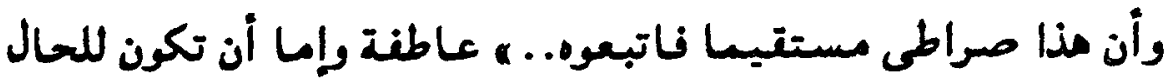

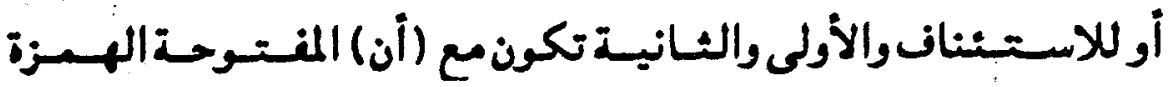

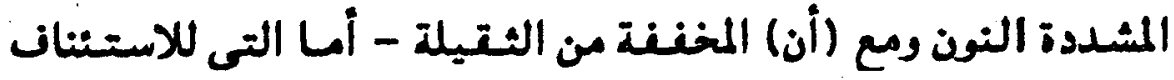

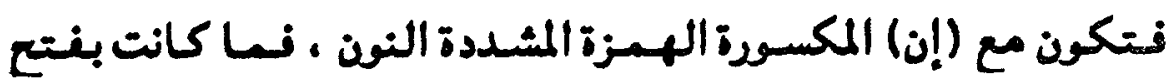

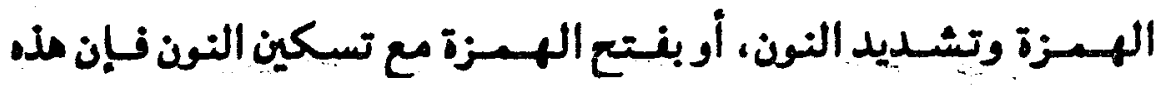

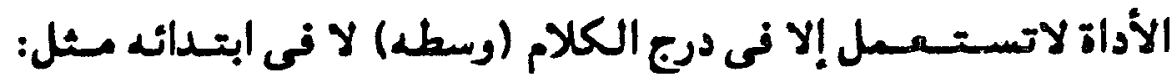

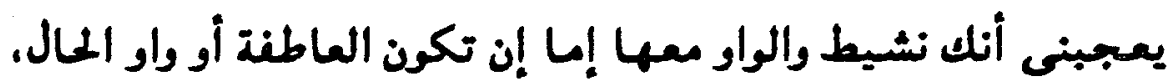
وإذا كان الألوسى قد أنكر أن تكون عاطفة، إذ قال: راقوله -سبحانه

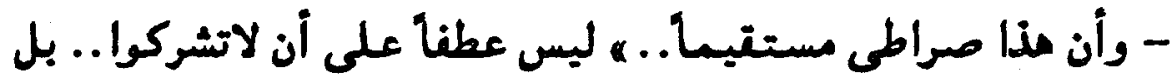

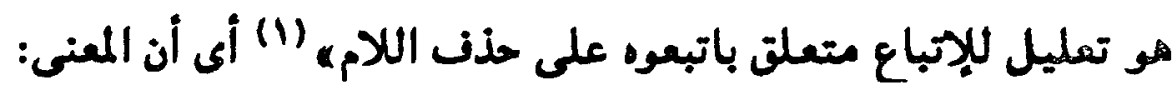

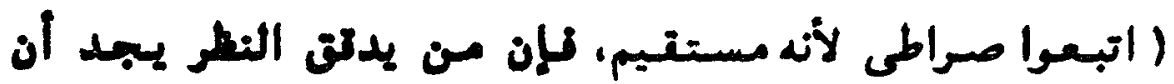

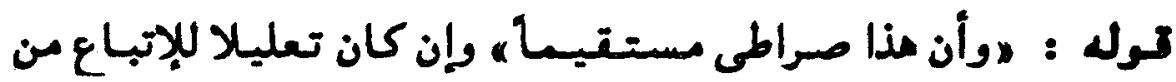

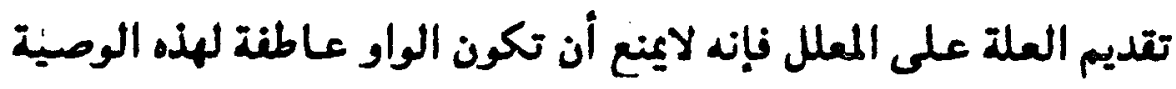

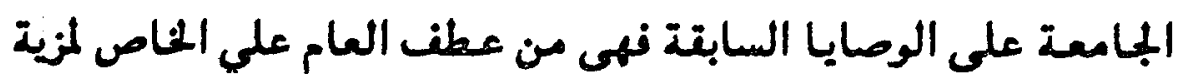

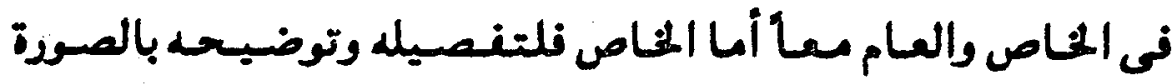

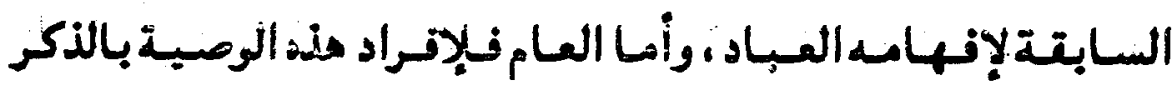
لكونها بامعة شاملة كل تعاليم الإسلام ولذا فلو لم يذكر من وصايايا

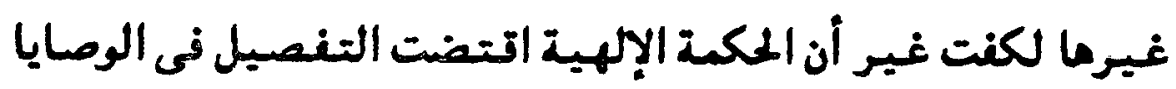

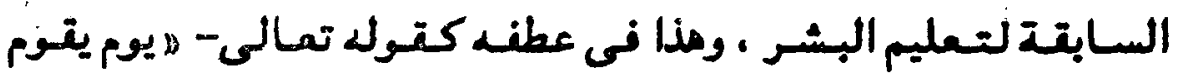

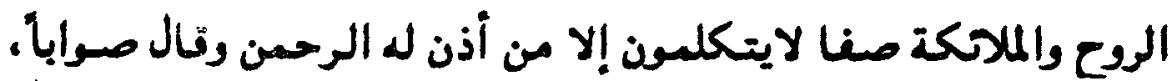
نتد عطف عاما وهو الملاككة على خاص ومو الروح (جبريل) لمزية فيد. 
وما يلفت النظر هنا - تتـدم التعلبل على المعلل فلإن تـوله ه وأن مذا

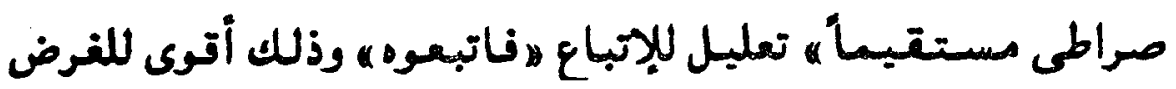

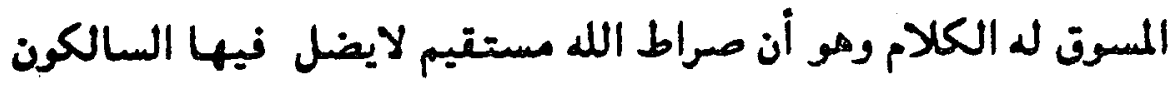

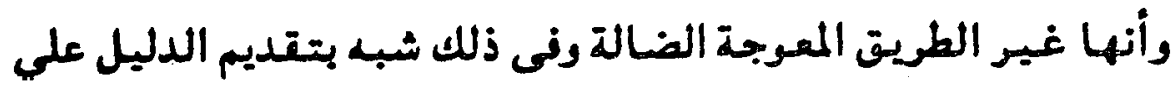

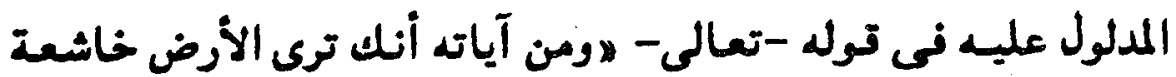

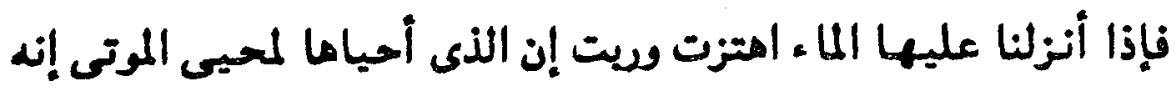

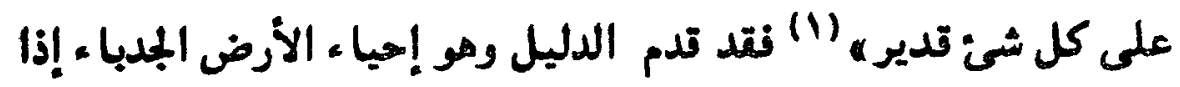

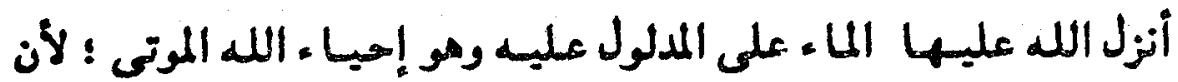

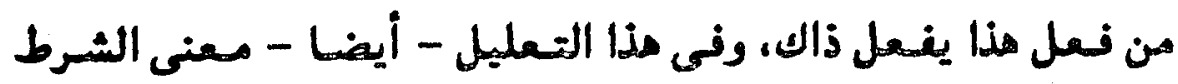

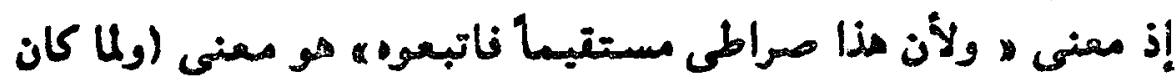

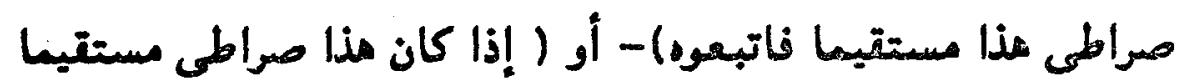

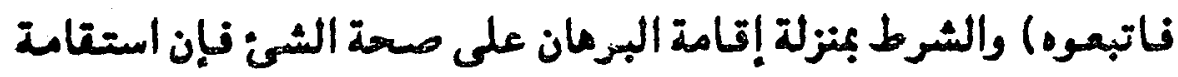

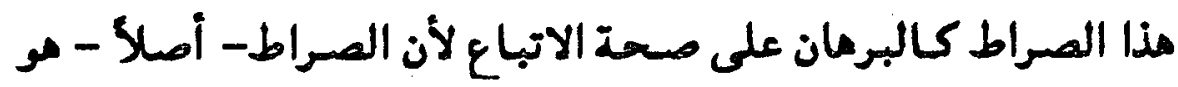

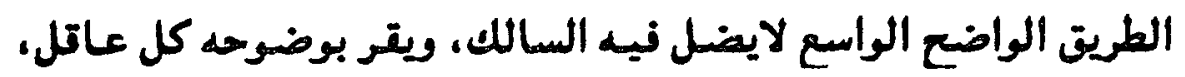

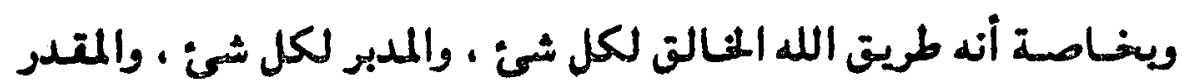

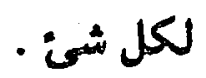

وعلى أن الواو للحهال مع (أن) بالنتـع والتشـديد؛ فتـد جـاءت

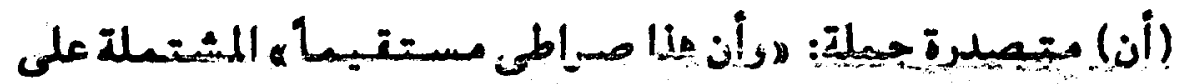

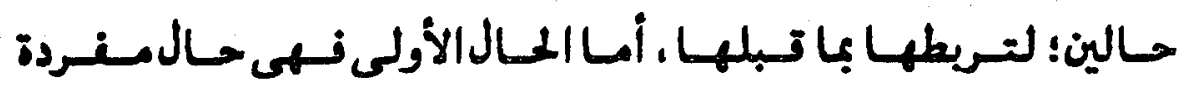

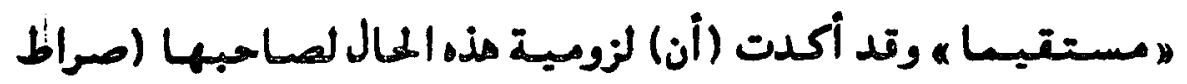

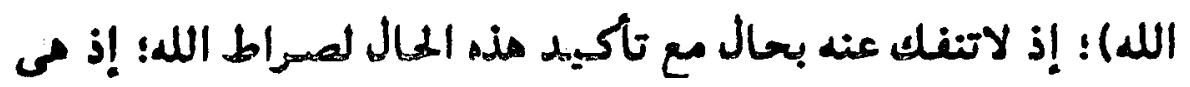

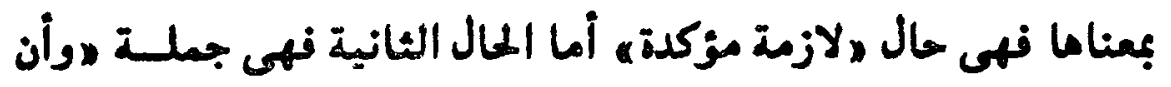


هذا صساطى ؛ فإن المعنى (نصلت لكم مذه الوصايا والحسال أن مذا

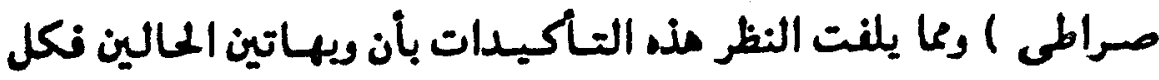

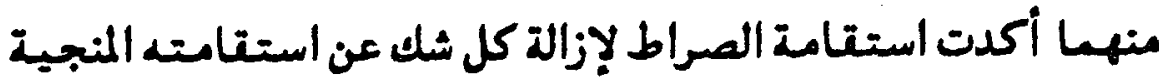
من الهلاك .

وأما ما كانت بنتح الهــزة وإسكان النون (أن) ومى المنـنفنة من الثقيلة واسـها ضمير الثـأن محذوف فالبلاغنة مع مذه ومع واو

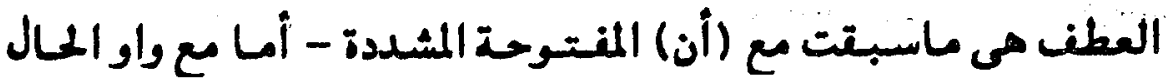

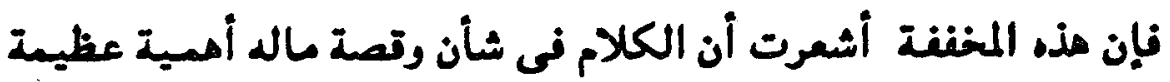

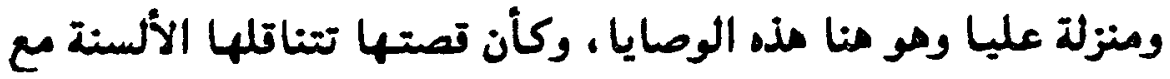

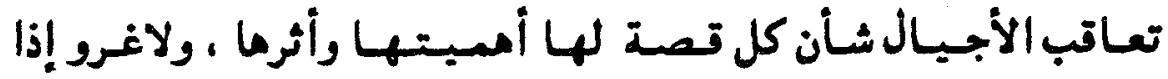

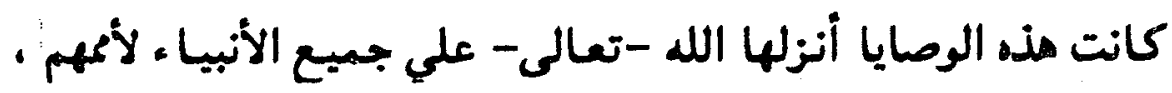

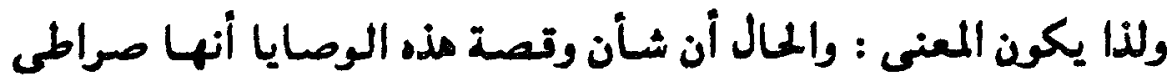

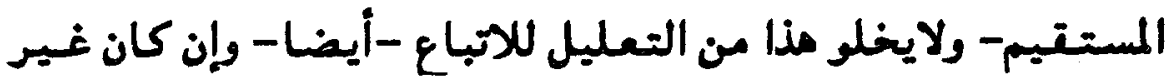

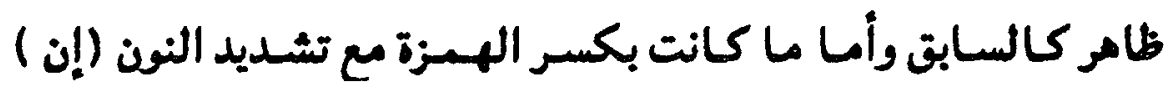

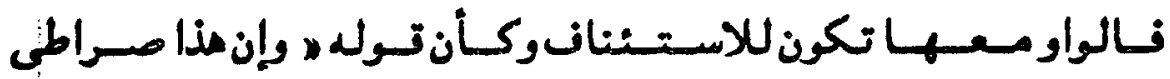

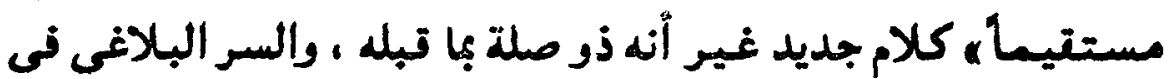

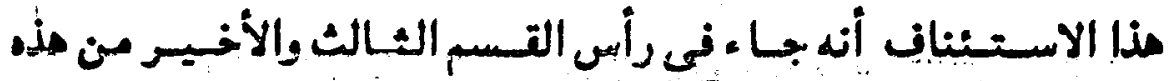

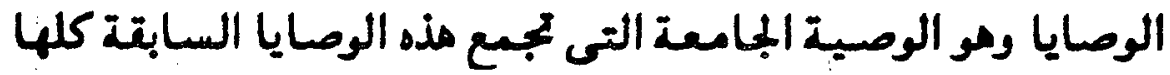

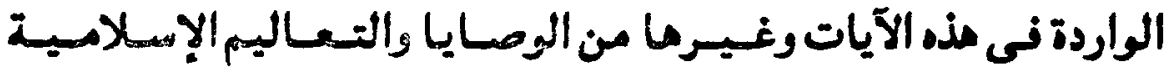

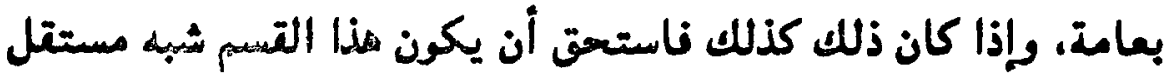

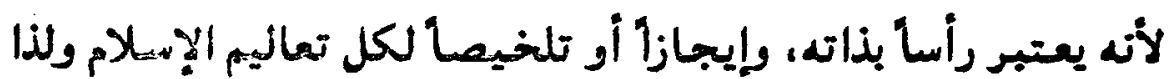

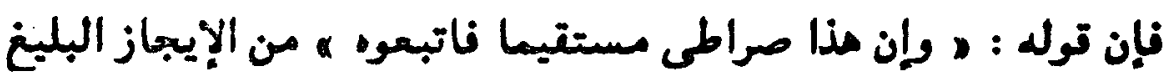

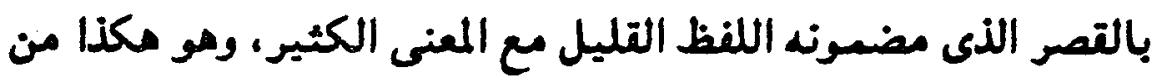




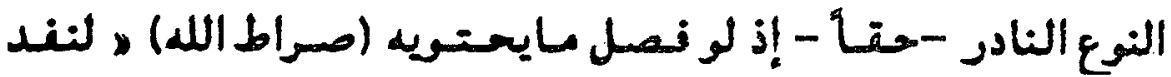

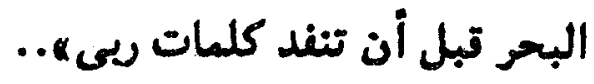

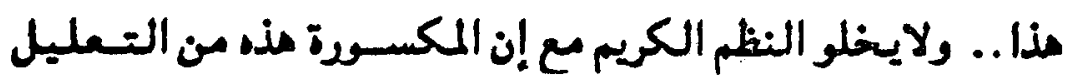

لإلباع ضمناً.

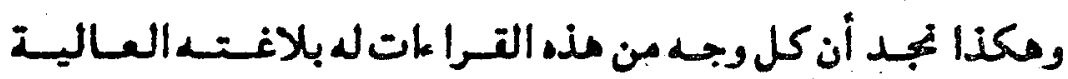

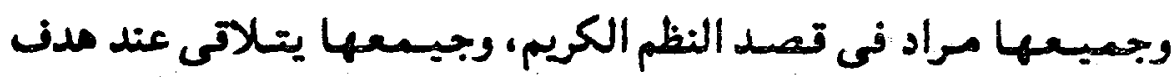
واهد مو الحث علي اتباع هذه الوصايا دون سراها من من السبل.

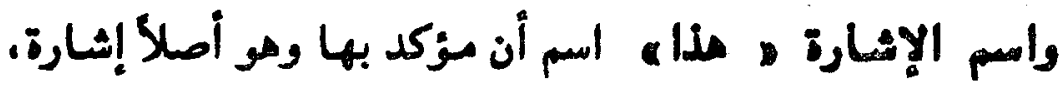

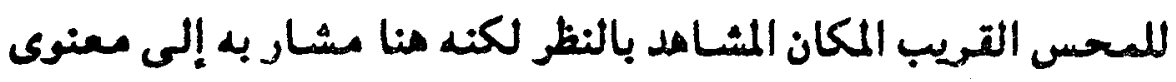

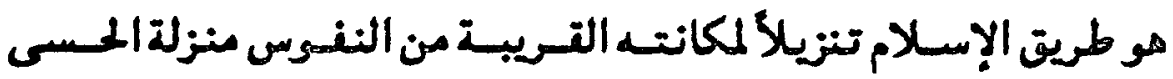

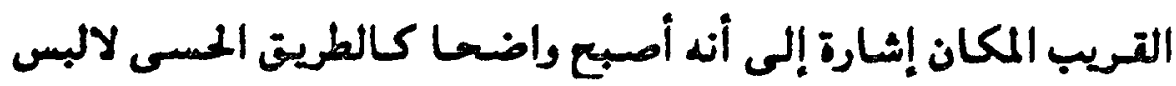

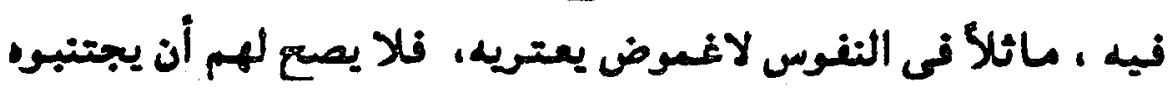

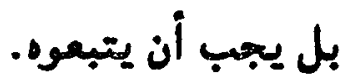

و ״ السراله، - أصلا - مو الطريق الحتيقى الواضع الواسع

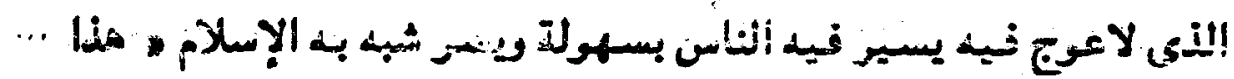

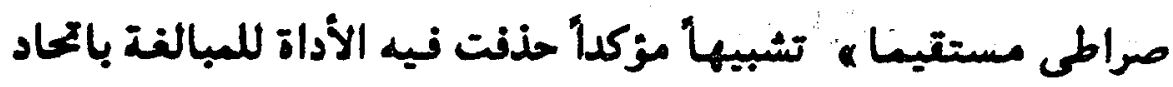

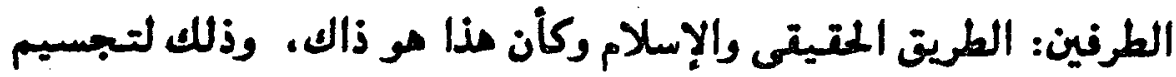

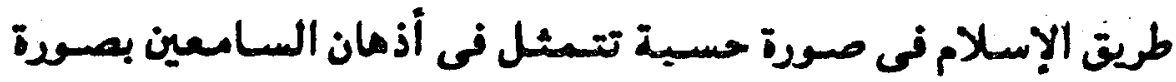

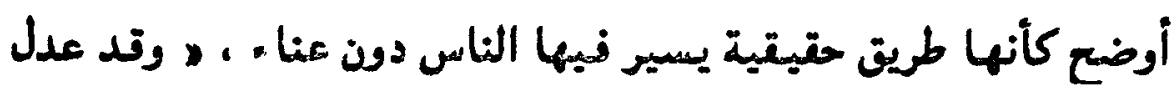

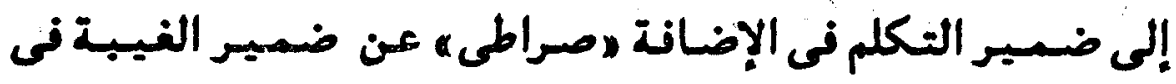

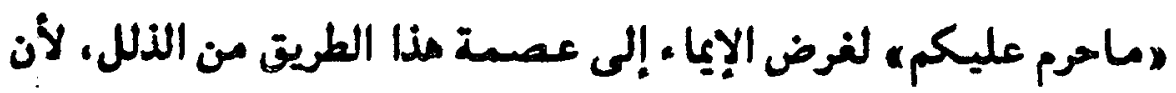




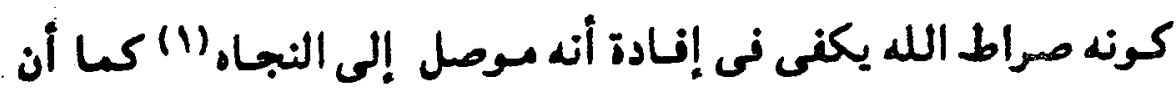

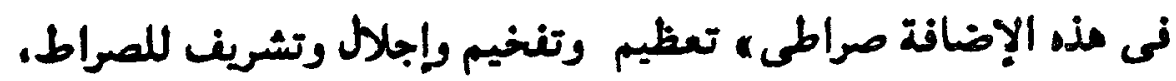

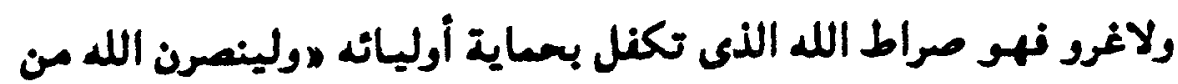

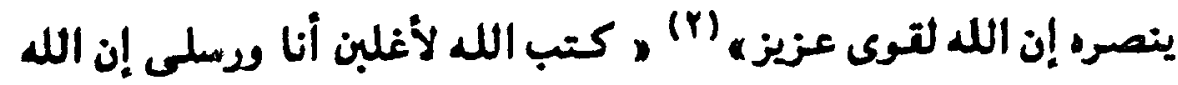

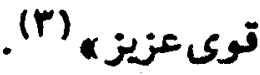

ومن البلاغة الترآنية اللطينة أن يجئ وجه الثبه لا مستقيماً.

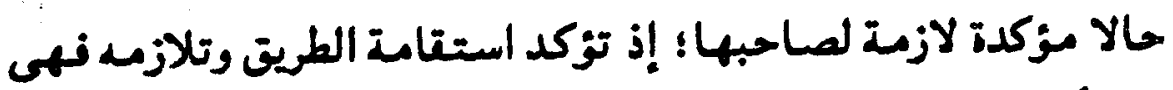

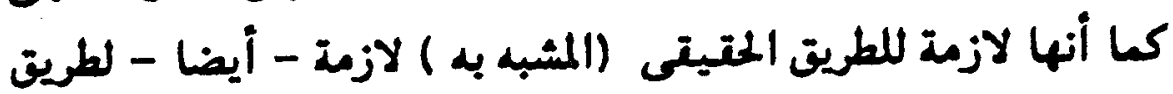

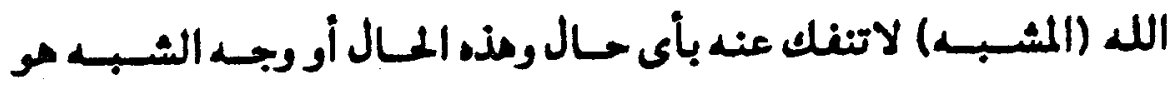

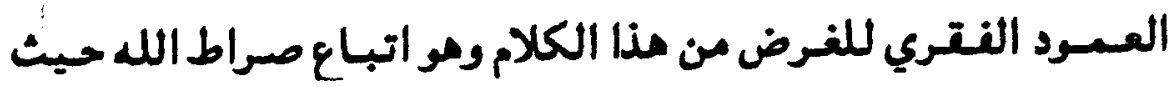

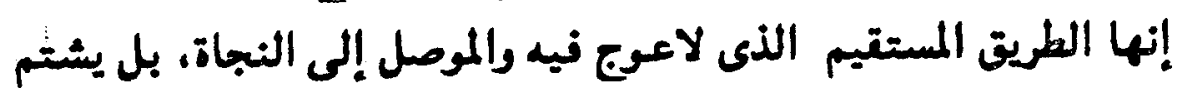

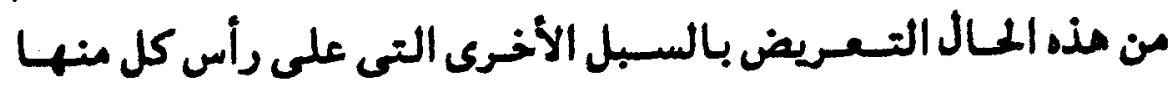

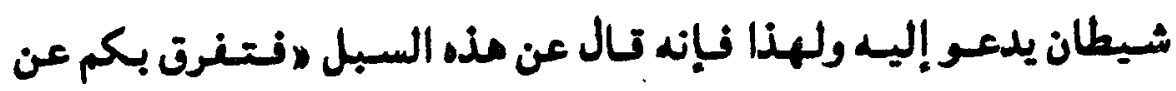
سبيله ه.

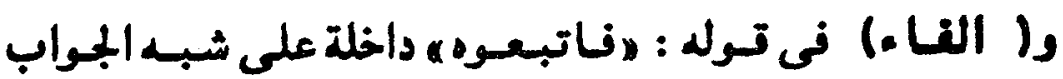

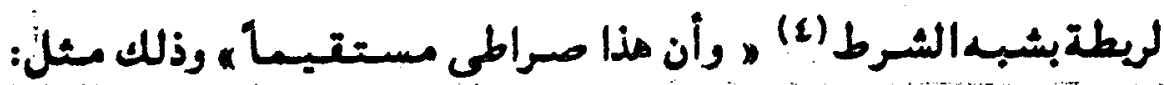

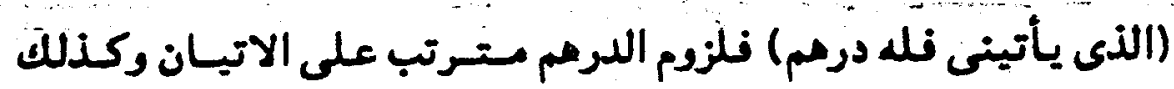

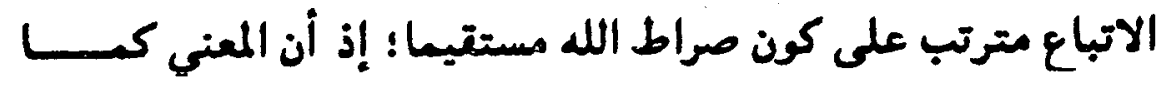

$$
\begin{aligned}
& \text { IVY } \\
& \text {. } \\
& \text { II سوة المجادلة. } \\
& \text { يراجع || || جال مغنى الليب لابن مشام. }
\end{aligned}
$$




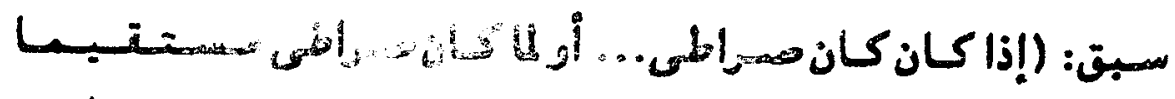

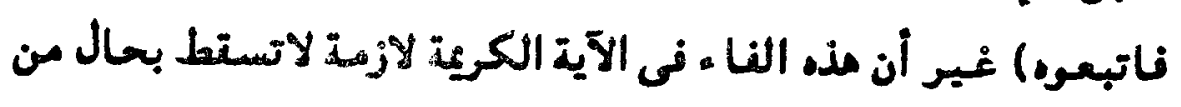

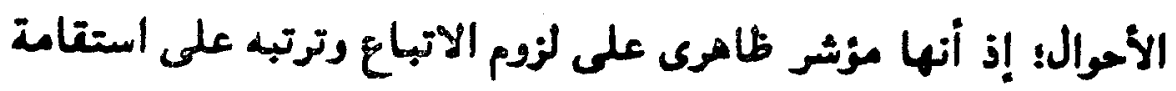
صراط الله بخلاف مذا المثال فإنها فيد يجهذ إثباتها أو إستاطها؛

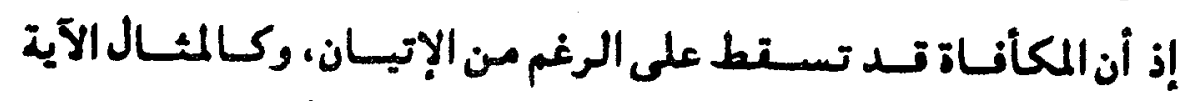

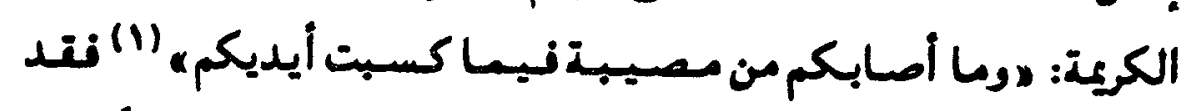

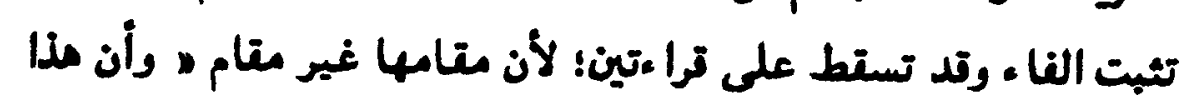

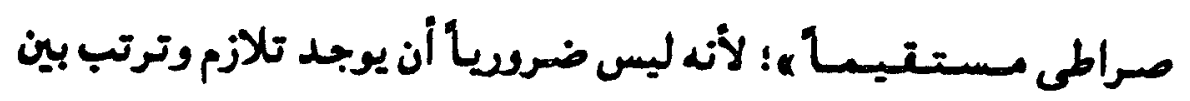

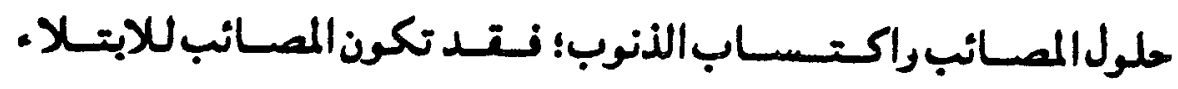

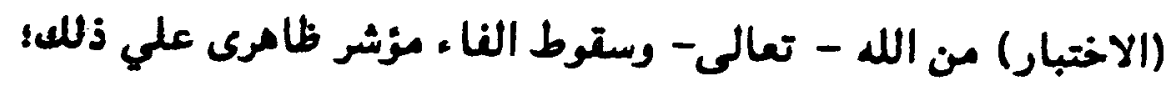

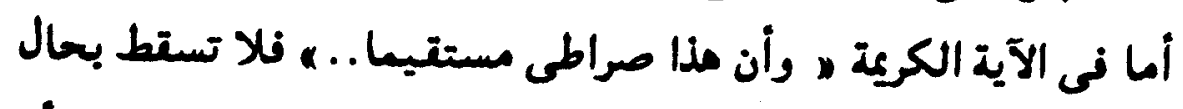

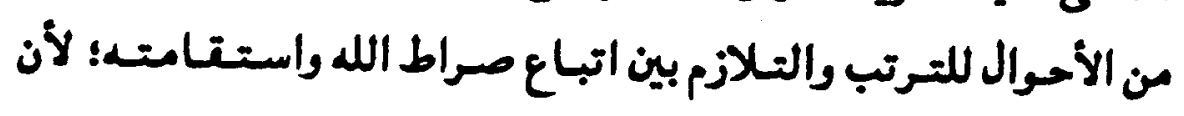
اتباعه واجب وجوبا عينيا...

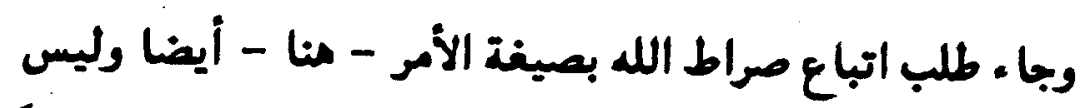

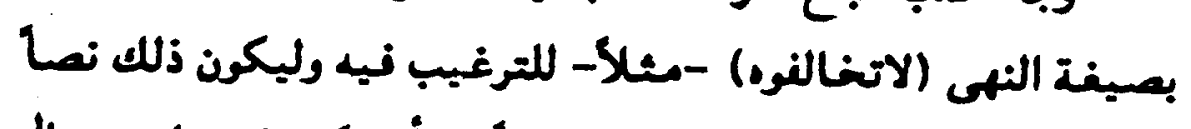

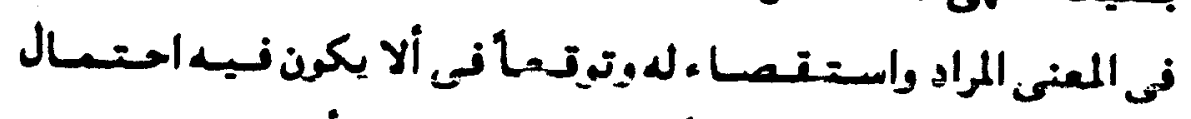

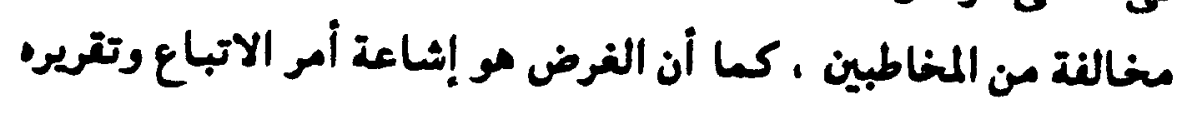

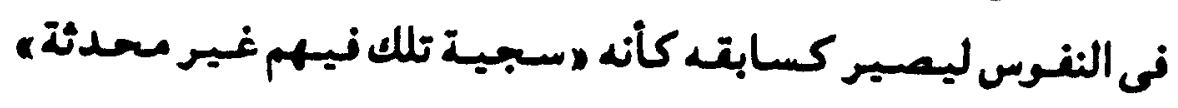
نذكره بنصه لذلل. 
ه ولا تتبعما السبل نتغرت بكم عمن سبيله : • السيل، جع سبيل ومو يرادف الصراط، ألا ترى إلى توله-

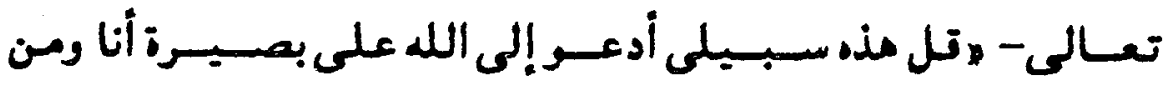

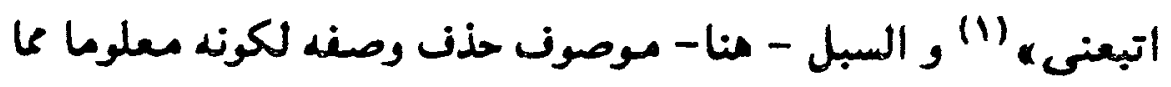

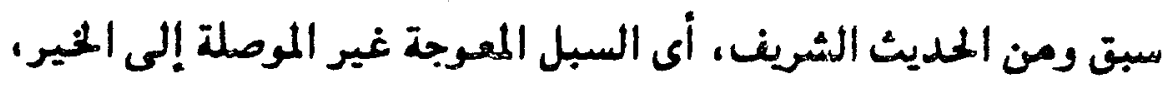

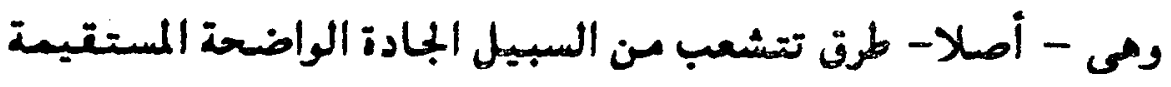

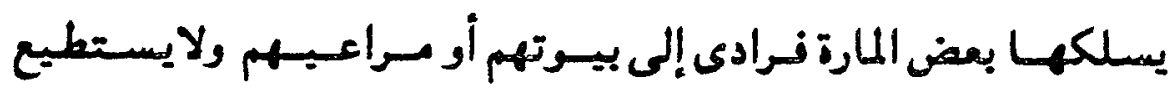

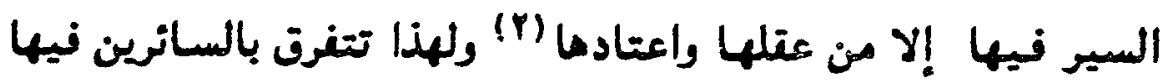

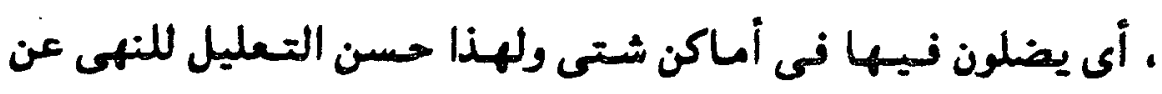
سلوكها بقوله -تعالى- " نتغرق بكم عن سبيله ه.

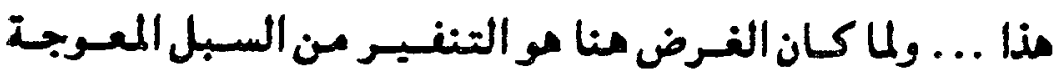

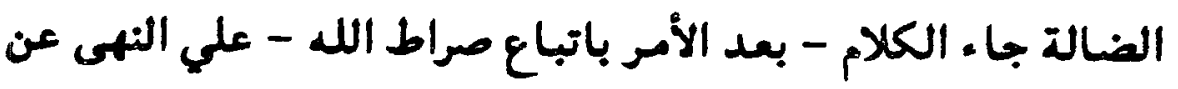

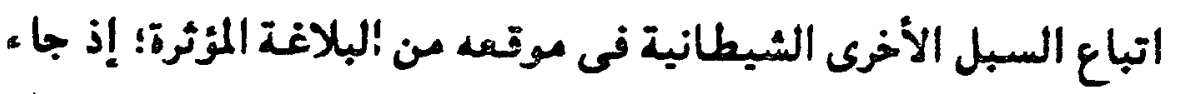

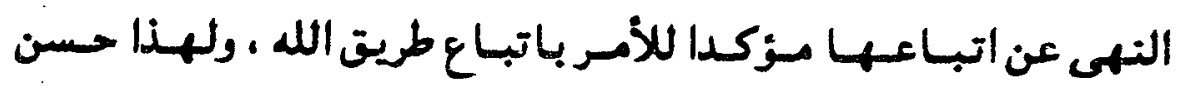

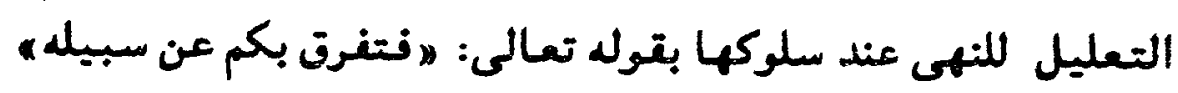
نالفاء للتعليل .

وأرى أنه لا مانع من أن تكون عـاطنة للترتيب والتعتبيب

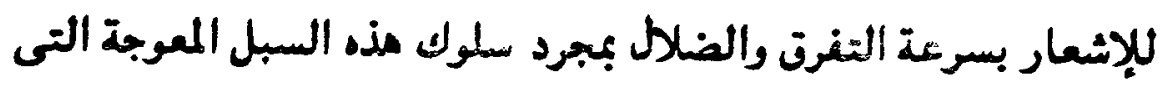


تدعو إليها الشياطين كسا فى المديث الشريف - كسا أن المعنى على

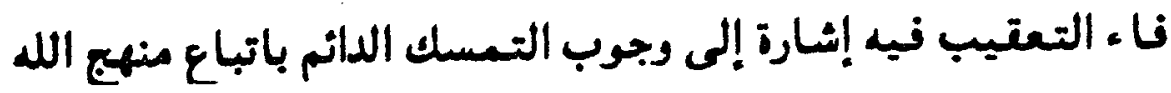

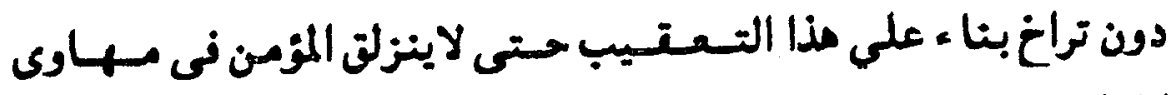
المتطينة.

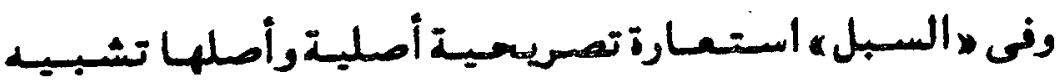

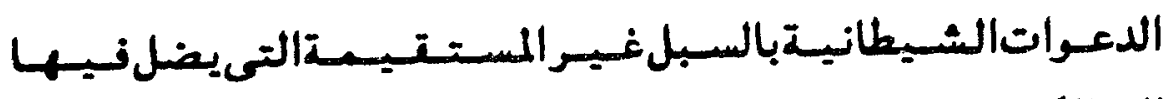

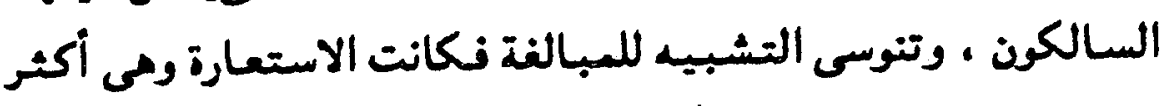

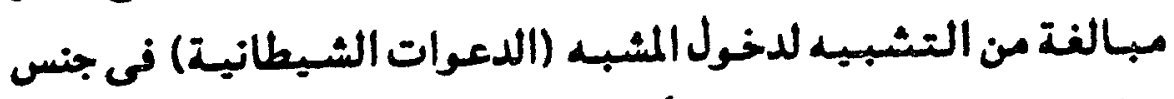

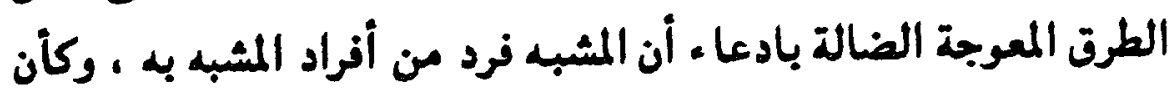

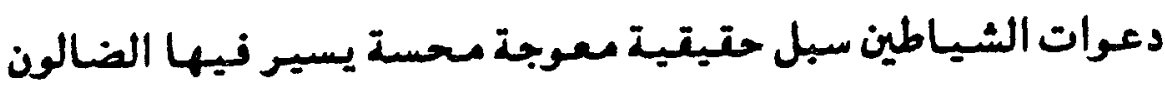

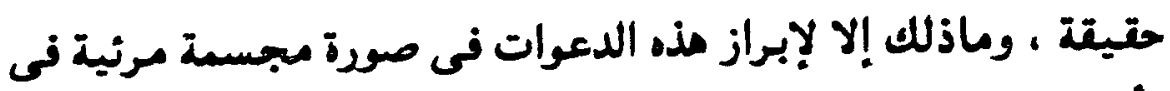

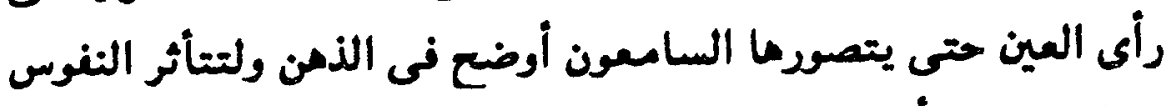
بهذا التصوير أكثر نيجتنبوا مذه السبل.

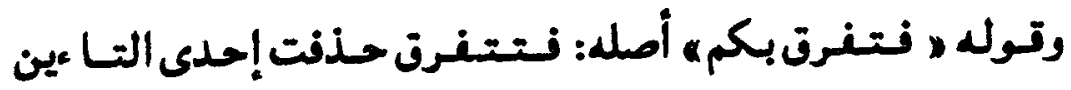

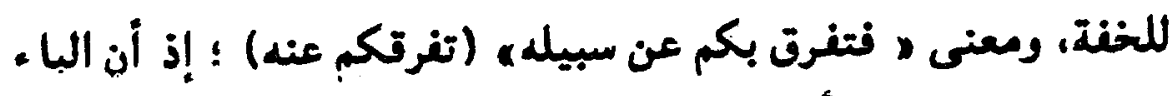

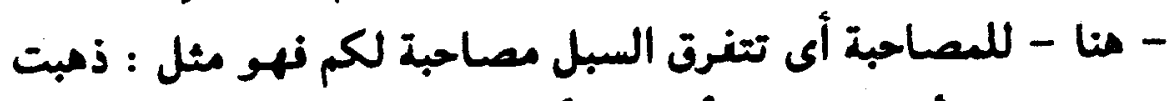

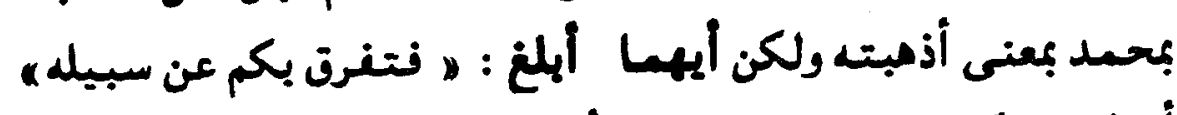

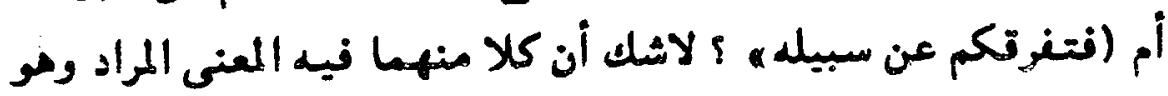

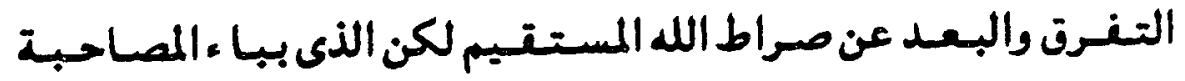

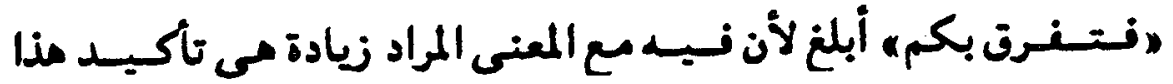

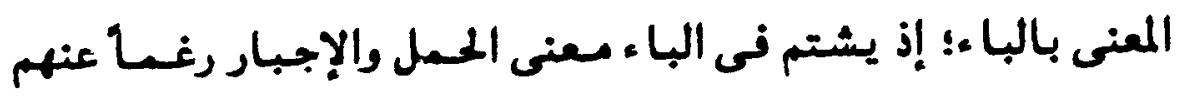

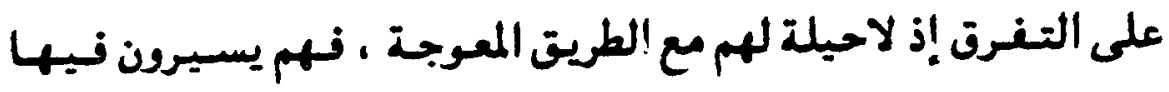


حيثـاس سـارت وينتهون حيث انتهت فتكون الهلكة ويظهر ذلك أكثر

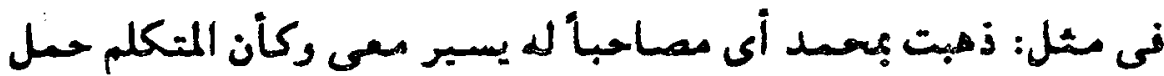

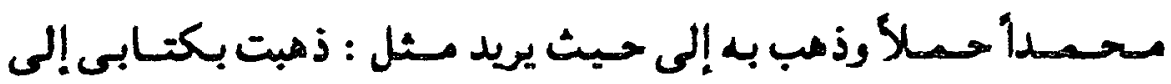

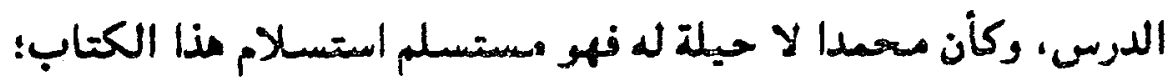

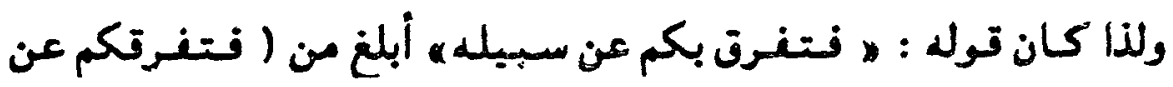
سبيله) .

وفى " سبيله ه التفات من المتكلم فى لصراطى ه إلى الغيبة؛

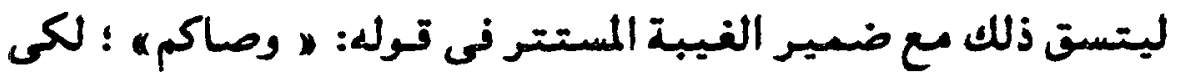

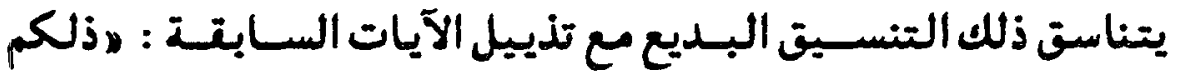

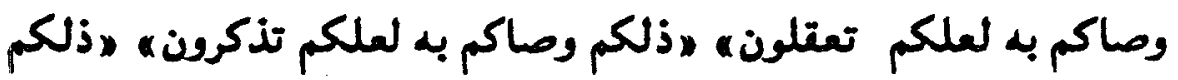

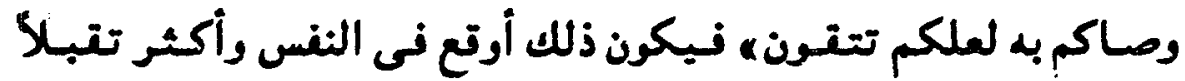
للمعانى.

والإشـارة فى "ذلكمه مى - على الصـحسيح - للــــار إليـ

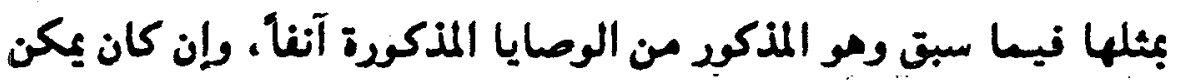

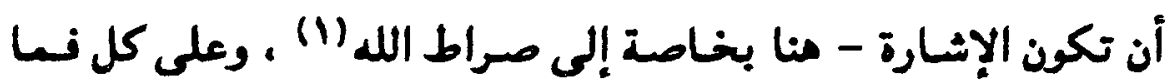

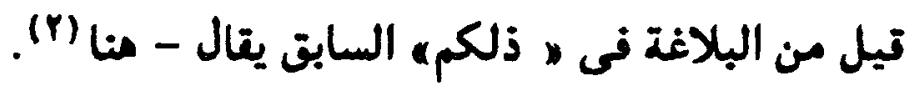

يرى البيضاوى فى تنسيره أن الإشارة لاتباع صراط الله 9سا جـا. يراجع ص A+\$. 
و" لعله شنا - كيا في السابق للتوتع - أيضا - - حيث يتوتع

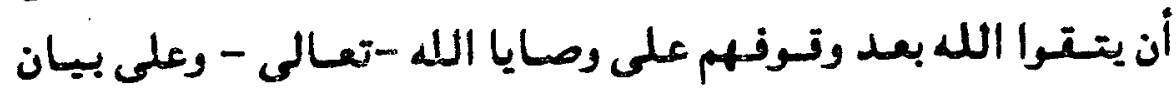

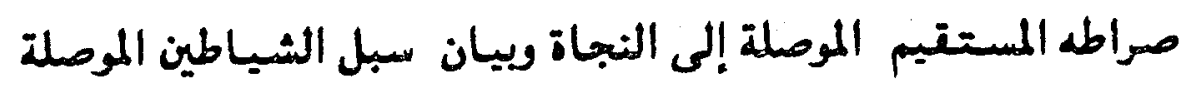

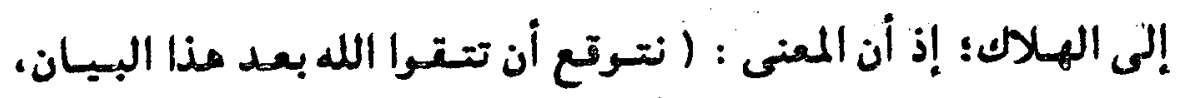

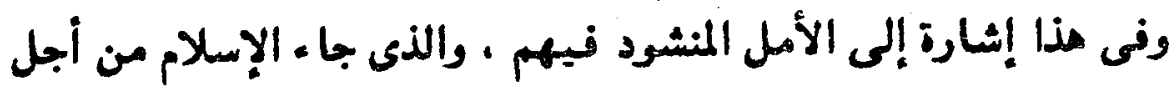

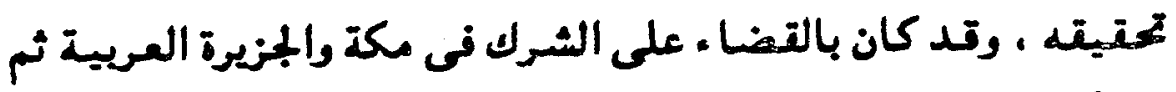

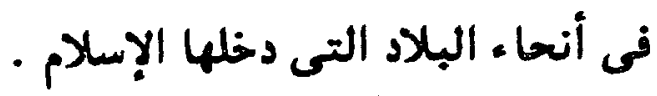


1- إعـراب القـرآن ويـيانه للأســـاذ / محسيس الدين الدرويش طبع

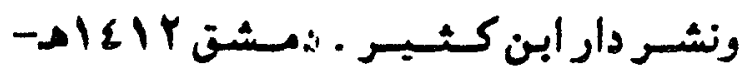

$$
\text { p } 1494
$$

Y- بصائر ذوى التمييز فى لطائف الكتاب العزيز الجلد الأول مدية

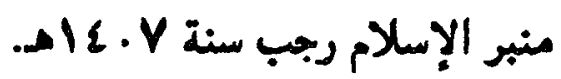

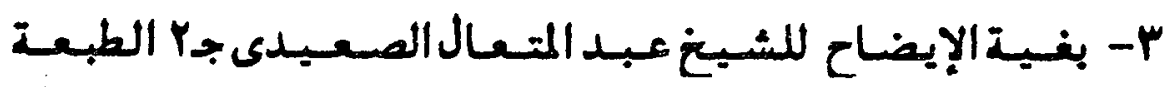

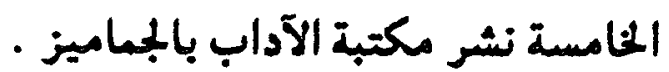

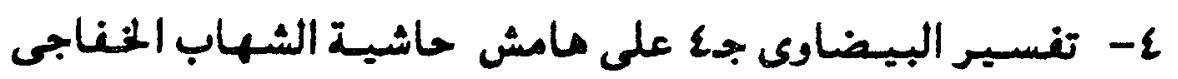

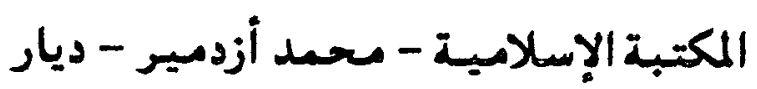

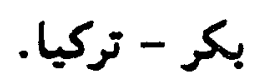

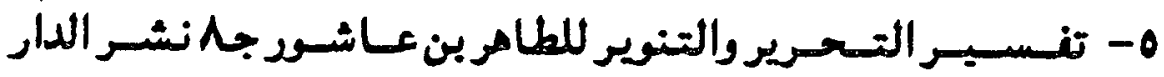

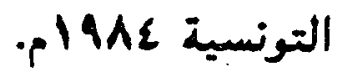

7- تغسير الشيخ الشعراوى ج. • طبع وتوزيع أخبار اليوم •

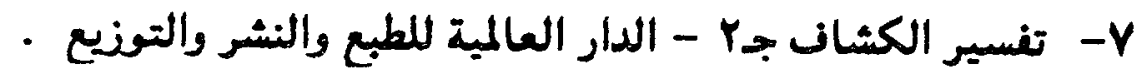

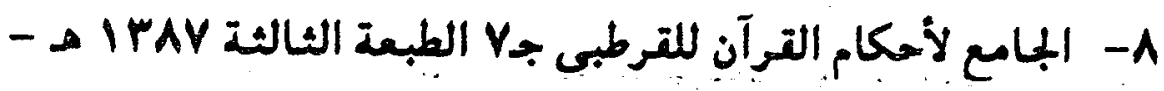

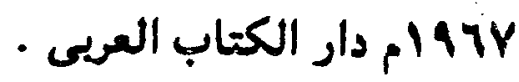
1- - حاشية الدسوقى - شروح التلخيص جب الطبعة الأولى .

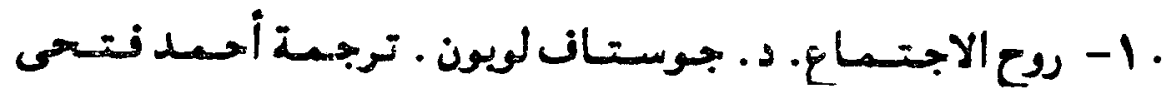
زغلول - المطبعة الرحمانية.

11 - روح المعانى للألوسى جـ مكتبة دار التراث بالتامرة . المركز

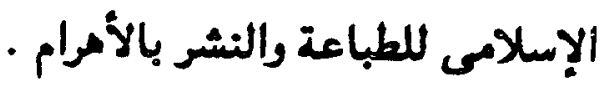


$-40$

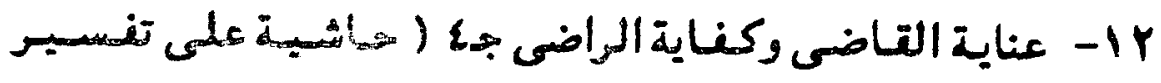

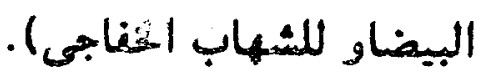

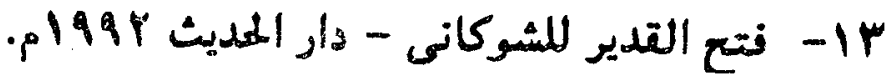

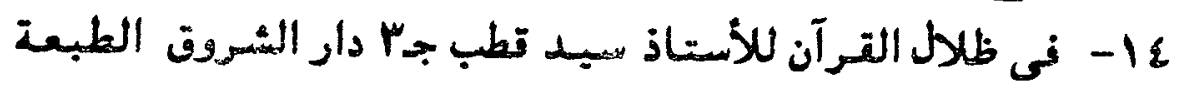

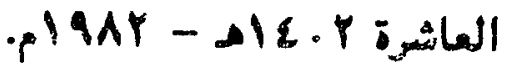

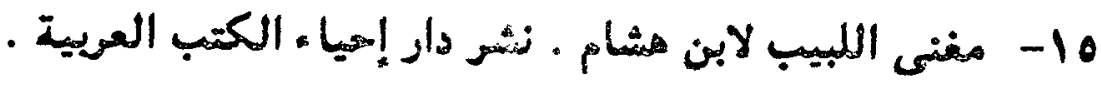

هعابم أستعنت بها ذفى البعث :

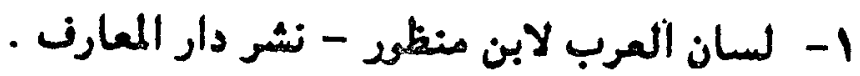

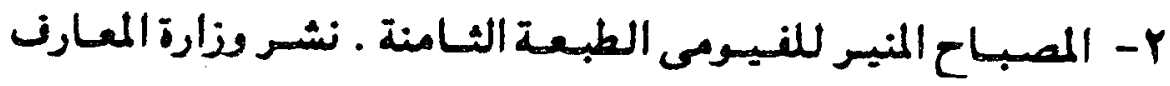
o 1949

r- العبجم المنهرس لألفاظ القرآن الكريم للأستاذ / محمد فؤاد عبد الماد

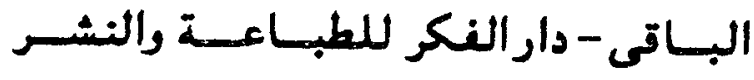

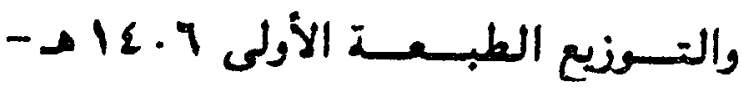

.8197 
فلسفئة الحرمان.

في أدب البخلاء

دكتور

حلمى هسن أبو العز

أستاذ مساعد، ورئيس قسم الأدب والنتد

فى كلية اللغة العرية بإيتاي، البارود

$$
1990-01217
$$




$$
\ldots, \cdots
$$




\section{أضواء، وظلال}

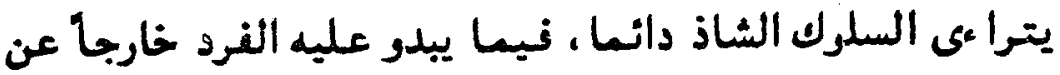

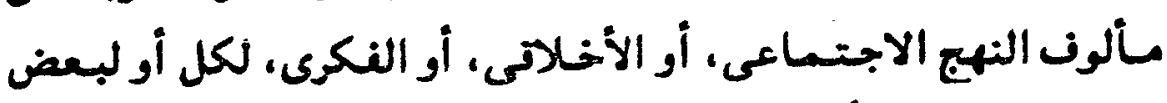

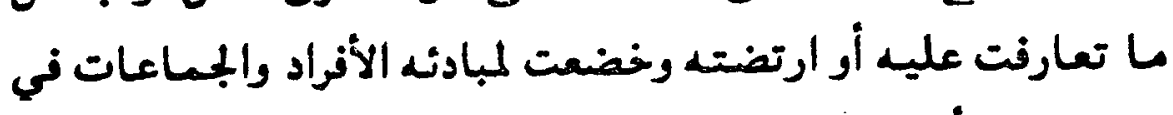

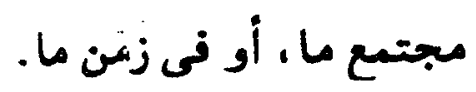

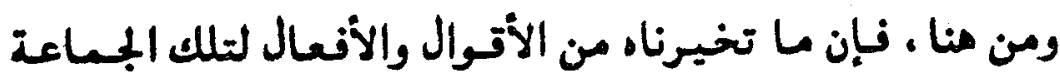

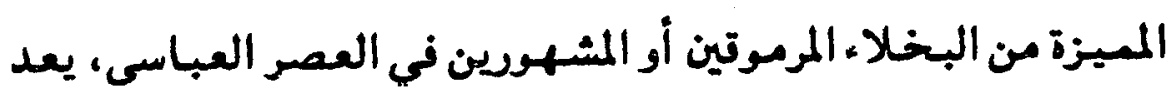
ترجعة صادقة وتجبيداً حياً لذلك السلوك غير المير الحميد.

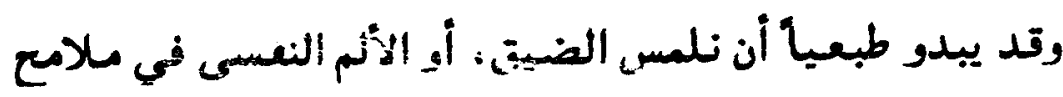

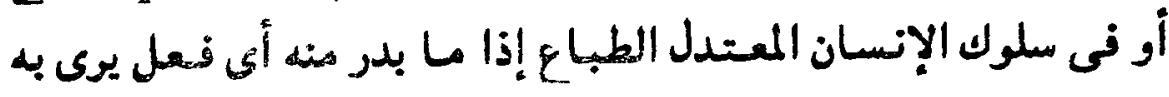

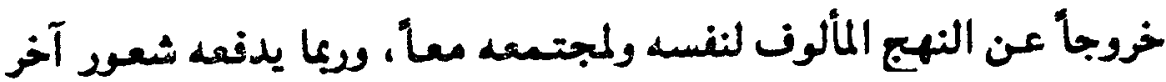

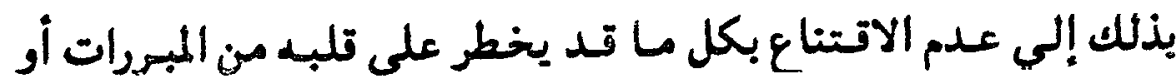

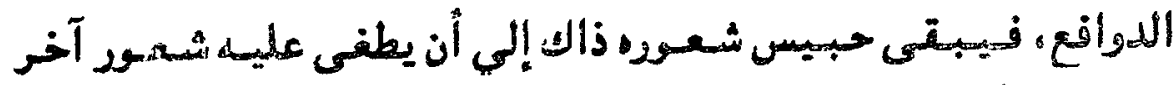

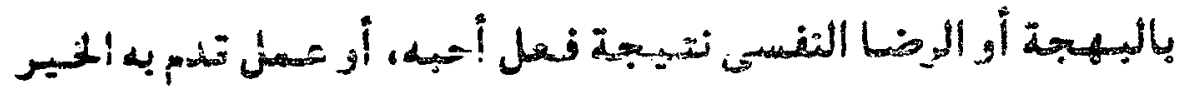
لسواه.

بينما نجد كل ما يصدر من سلوك أو يبدو من تصرنات لأفراد

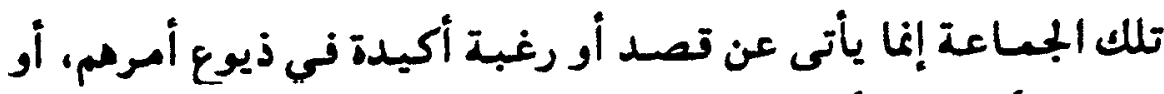

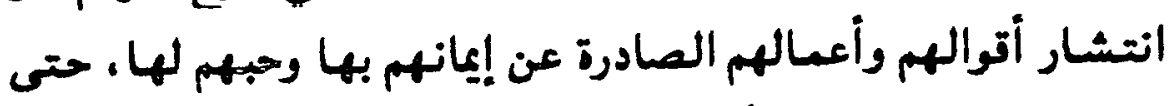

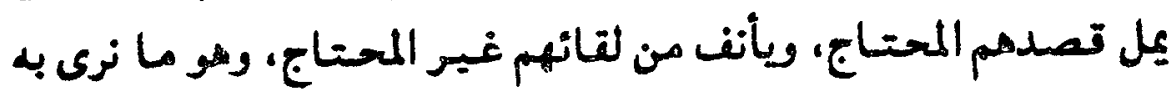




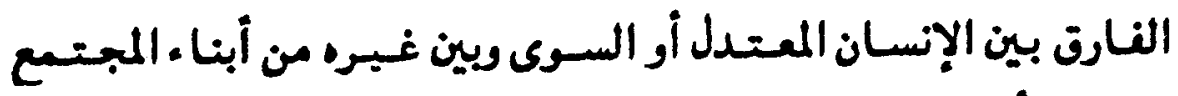

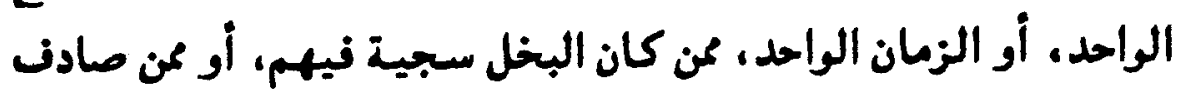

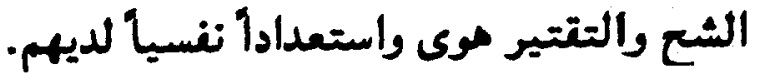

ودون شك فلبان مذه الآفـة الاجتـــاعـية الخطيرة تـد تسللت بين

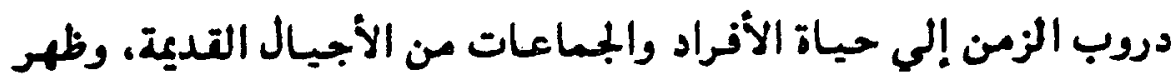

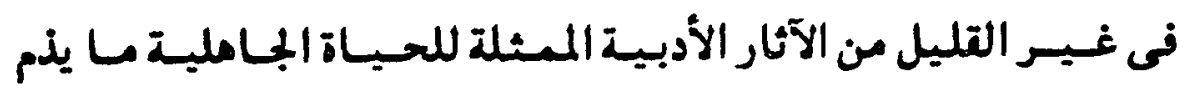

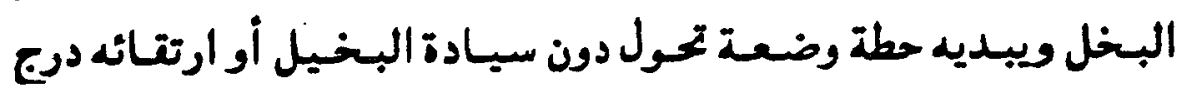
العلا مع الآخرين.

ولعل ذئك ما نلمسه ني تصريح "الأعلم الهذلىه إذ يقول: (I)

وإن سعاده الأموام كاعلم

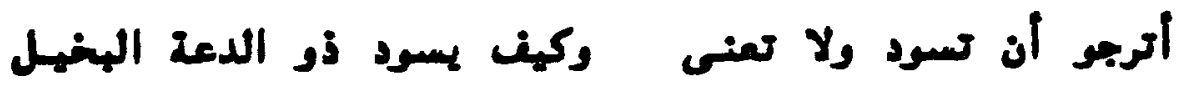

كلا كان يتسامى بالجود فاعلوه، بل ويحتالون من أجل الحظوة

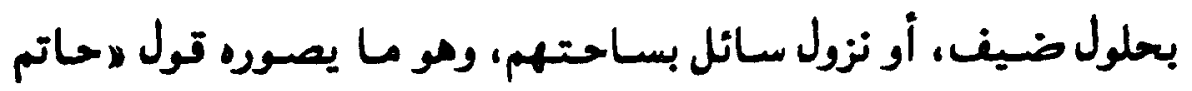
الطائى م لغلامه في إحدى ليالى الشتاء العاصفة (r) : برول

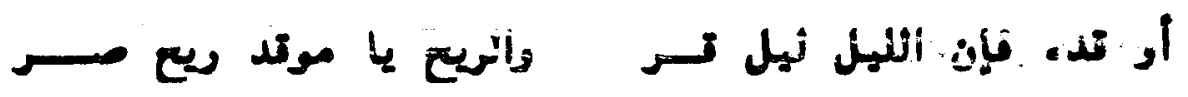

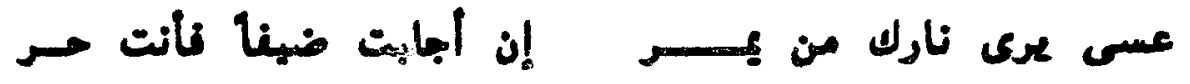

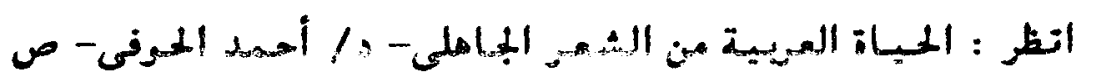

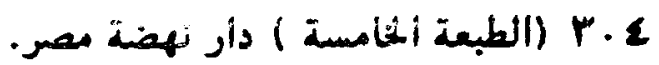

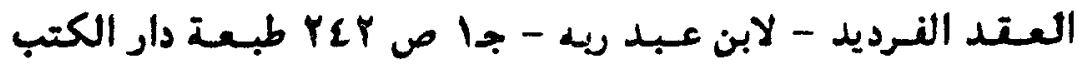
العلدية / بيروت. - العرديد الانين 


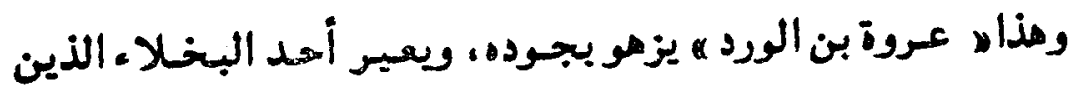

(1) : عابوا عليه نحافة جسده، فيقول

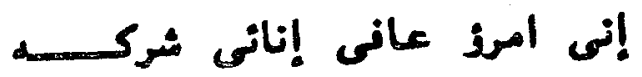

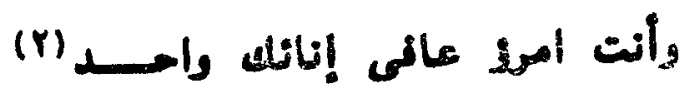

أهز| منى أن سمنت، وأن تسرى إن

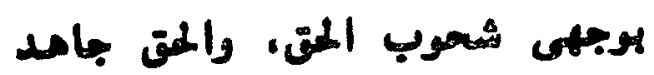

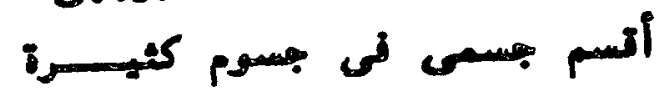

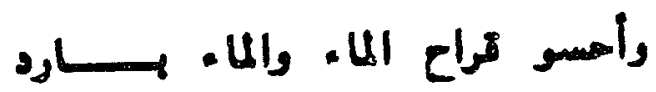

وحتي الصعاليك المخضرمين، وبدنامم يستحلون مال البخلاء.،

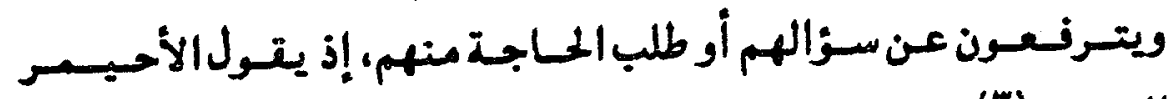
السعدى (I)

رانى لامتحفى من اللـــ أن أرى

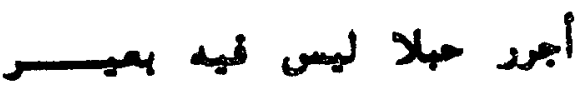

وان أمال المهبس اللئسـم بعيــره

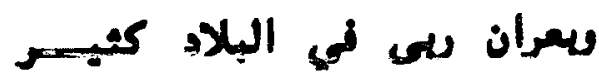

كا يروى عن لا عثان المياطله قوله : لا ما سرقت جارأ وإن كان

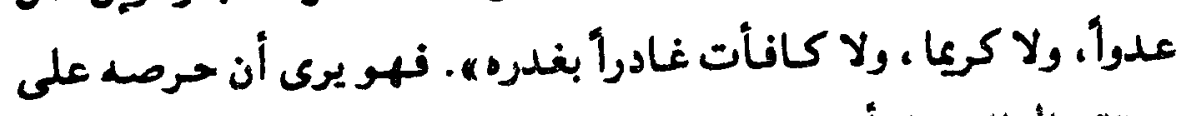
سرتة مال البخيل أحد جوانب رالنضل م في سرقاته.

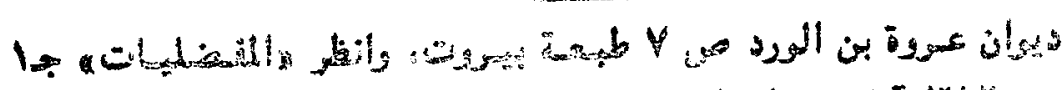

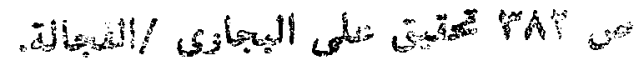

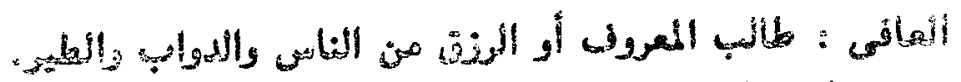

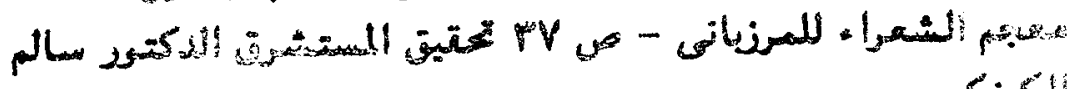




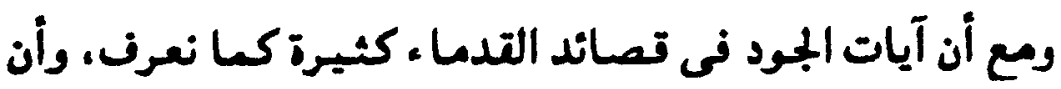

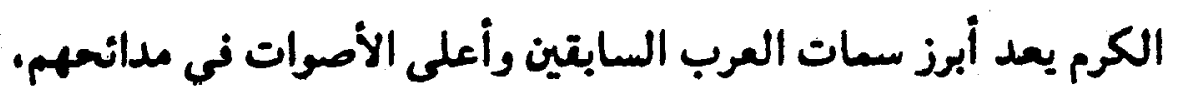

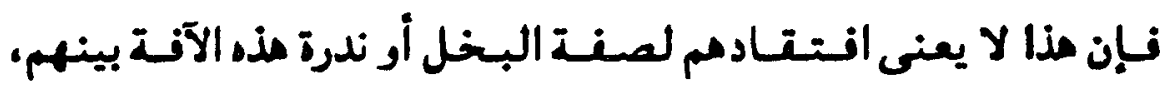

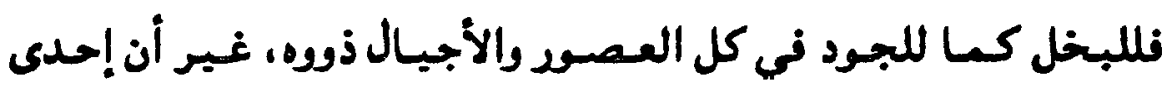

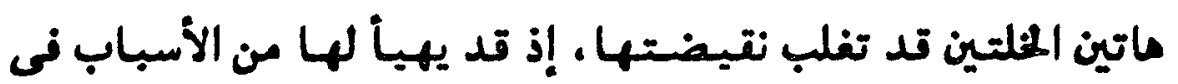

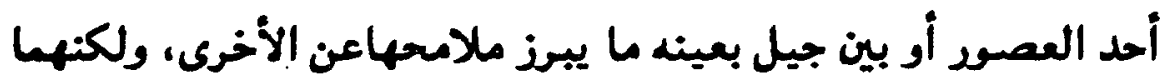
فى كل الأحوال متلازمان، بل وياقيان بيقاء الناس والحياة.

فكم ذمت أفراد بل وقبائل فى العصر الجاهلى الذى ساد فبد

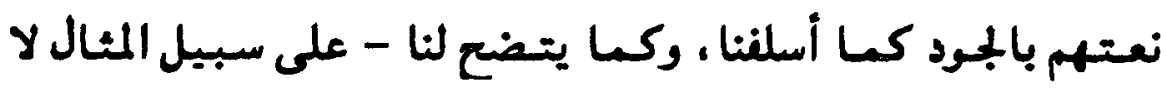

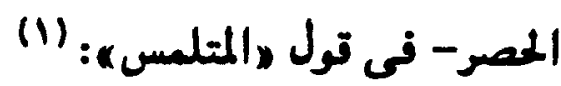

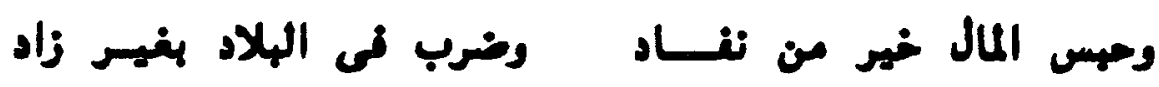

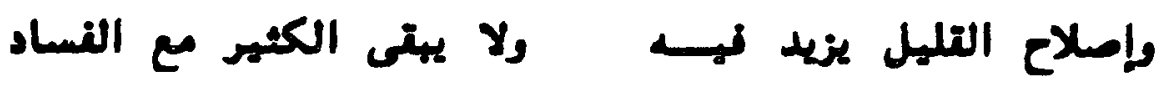
وفي تول الحطيئة هاجيا الزيرتان بن بدر وقبيلته ومنضلا بنى

أنغ الناقة : (r)

ألم أله باركم فتركتعنى لكلبى في دهاركم عــراء

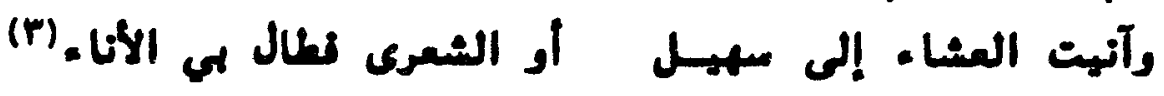

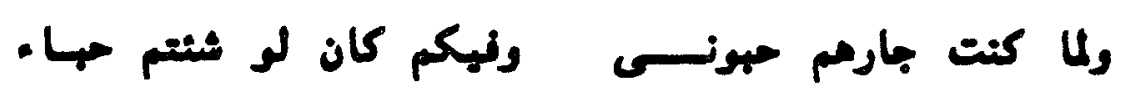

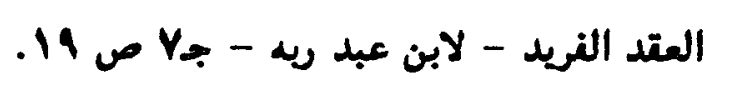

(r)

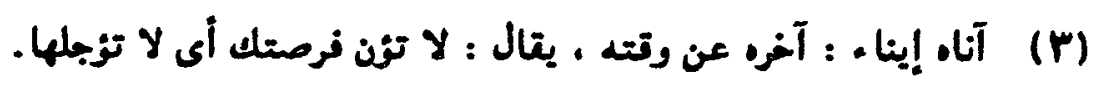


$-\Lambda 0-$

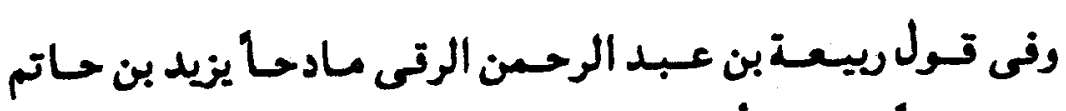

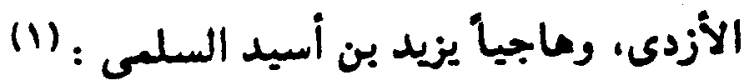

ليتان ما بينة اليزيدين فم النــى

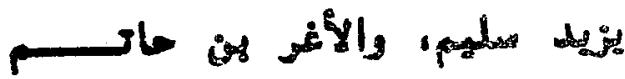

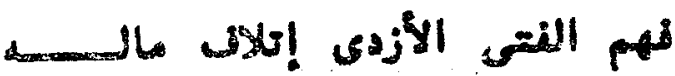

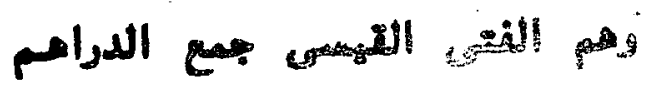

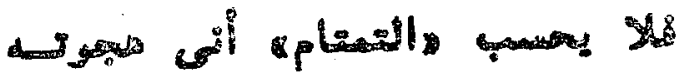

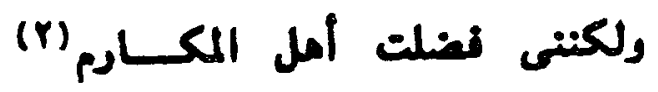

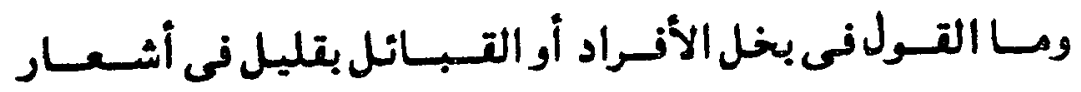

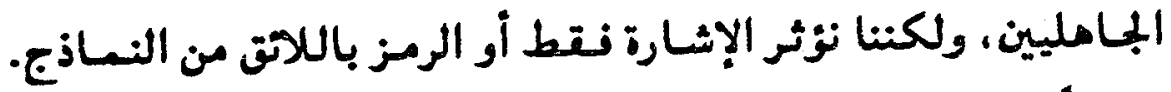

تثبيتا لقولنا في كل مقام على حدة.

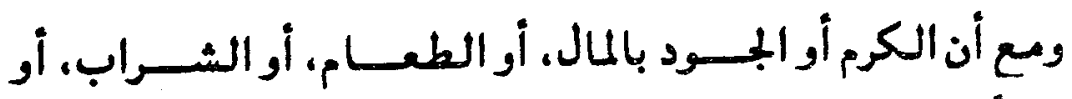

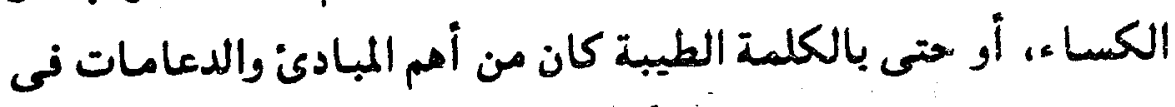

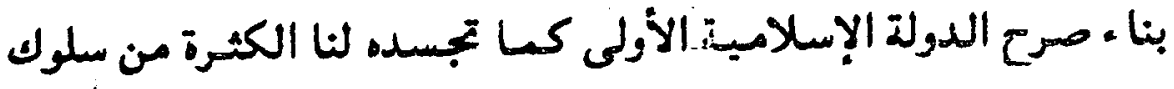

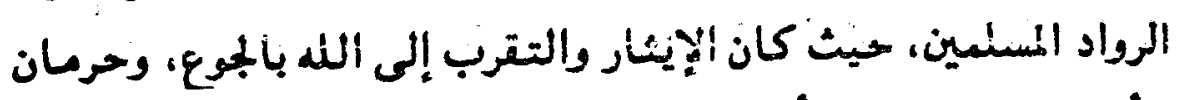

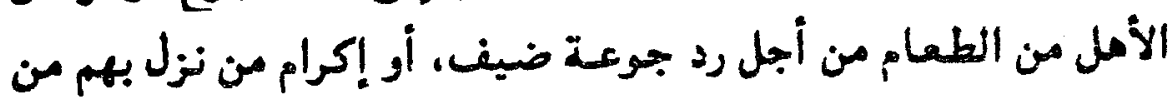

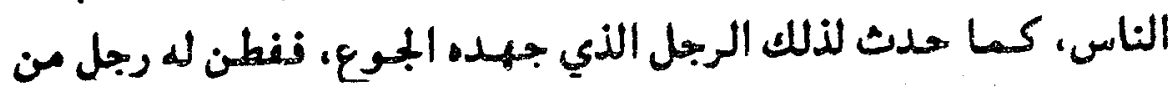

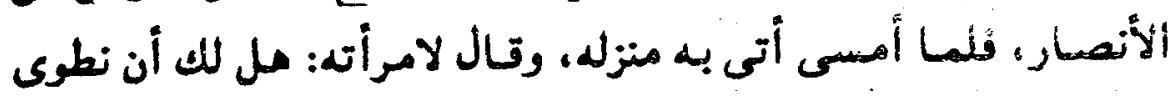

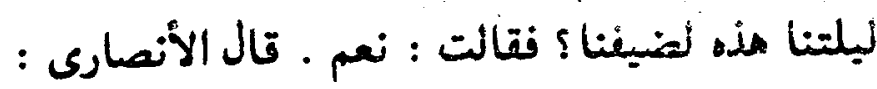

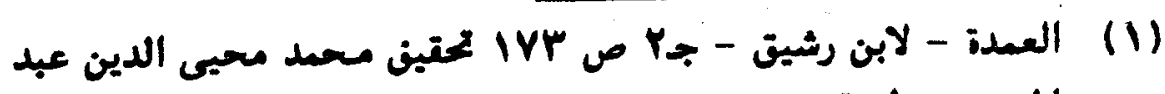

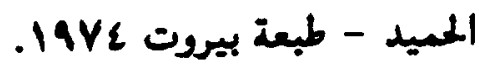

التمتام : كثير التمتسة أي أنه بعجل فى كلامه ولا يبيند.

(r) 
إذا تدمت الطعام فادنى إلي السراج كأنك تصلحينه فأطفئيه.

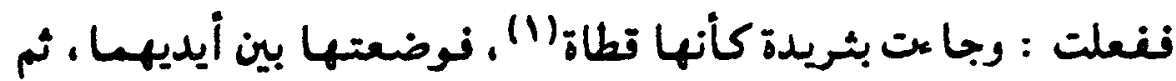

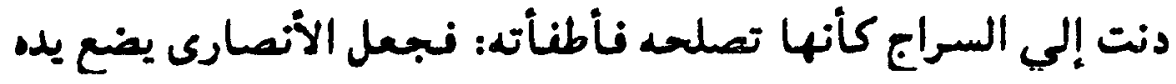
في القصعة ثم يرنعها خالية. فأطلع على ذلك رسول الله صلى الله علبه وسلم، فلسا أصبح

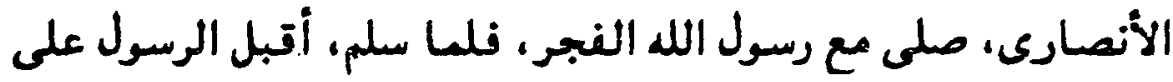

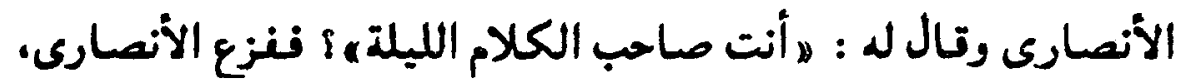

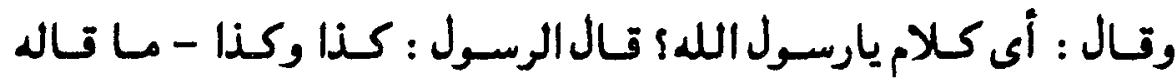

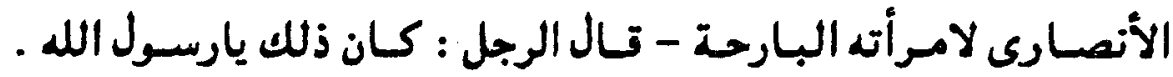

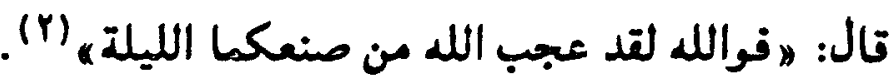

وكعا حدث فى تنازل الأنصار للسهاجرين بكل الحب والرضى عن أقرب وأحب الأشياء إلي أنفسهم، أملا في التقرب الأبار بعطائهم هذا إلي الله ورسوله.

وكسا نجده أيضا فى دعوته عليـه السلام إلى بذل الماله وحئة

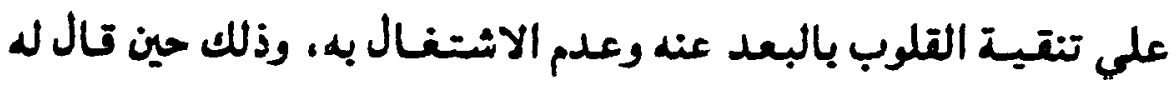

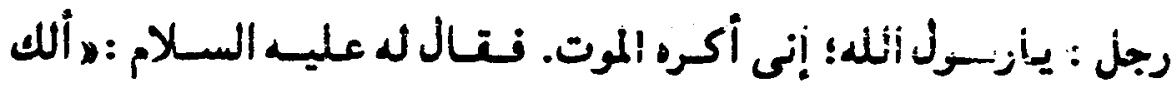

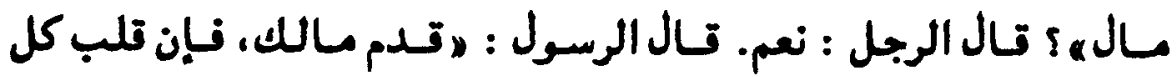

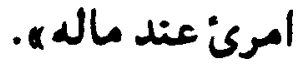

التطاة : واحدة التطا، وهو نوع من اليعام يؤثر الحياة فى الصعراء.

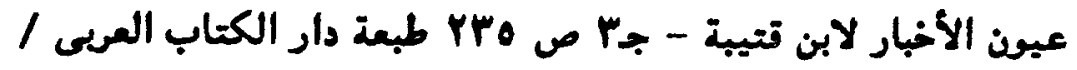


وحين قال الحسبن والحسين رضم الله عنهما لعبد الله بن جعفو:

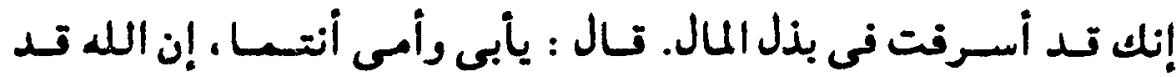
عودنى أن يتفضل على، وعودته أن أتغضل علي عباده، فأخان أن أن أن النهل أقطع العادة فيتطع عنى.

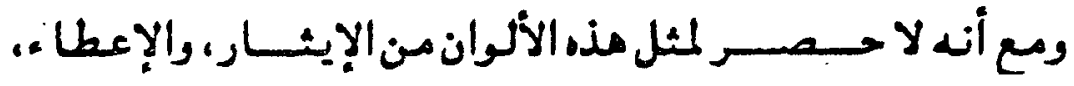

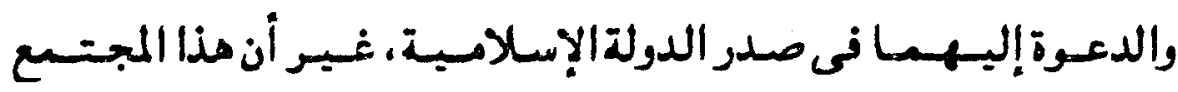
الإسلامى نغسه لم يسلم من آفة البخل والتتتير بين أفراده. ولعل عذا ما يتمثل لنا - ني أبسط صسره- فى أقوال وأعسال

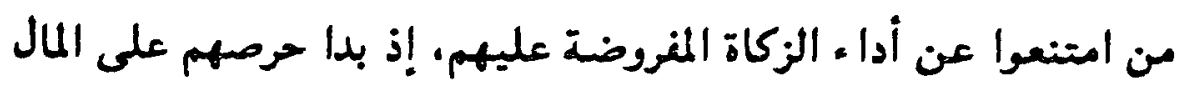

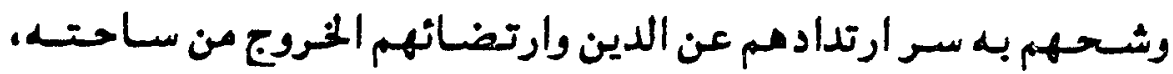
حتى أصبسحوا يدافعسون عنه بأرواحهم، ويستهينون بالموت فى سبيل

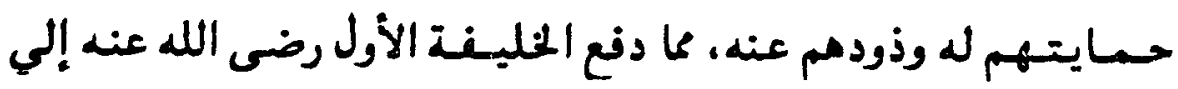
مواصلة حريهم وعدم العنو عنهم، انصياعاً لمبادى التشئريع السامية،

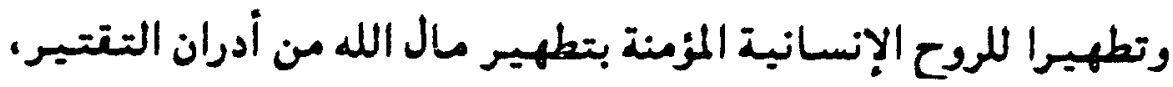
وشوائب الضعف الإيانى، بإخراج حت النقراء منه.

وها تكاد تنصهر تللة البمبوع البشرية إثر ألنتويات الإسلامية على أديم الدولة الجديلدة، حتى تتراءى الحيباة الاجتماعيـة في صور شتى من العادات والتعاليد والسلوكيات لم يكن للعرب عهد بها من قبل.

ولقد كان مذا أو قريبا منه شان الدولة الإسلامية أيضا في عصر

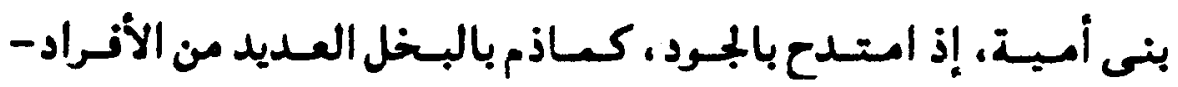
الحلفا ء والأمراء والولاة: وذوى السعة من المال- ويذا الشئ نغسه فى

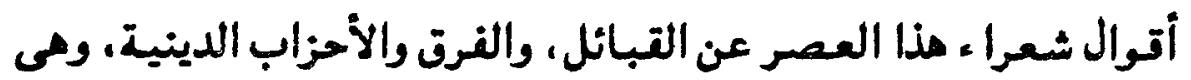


$-\wedge \Lambda-$

كثرة يحول ضيق المقام منا عن تناولها، أو حتى إجسالة لمنرداتها.

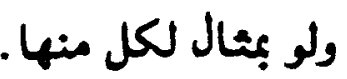

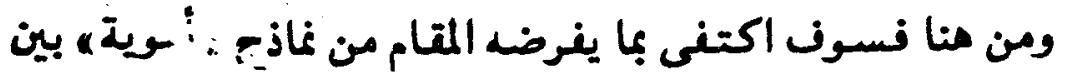

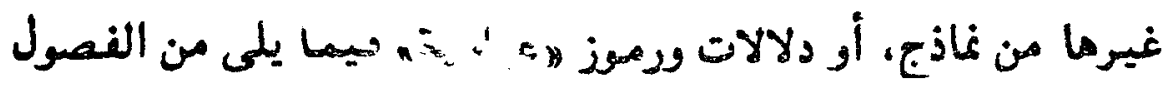

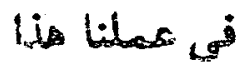

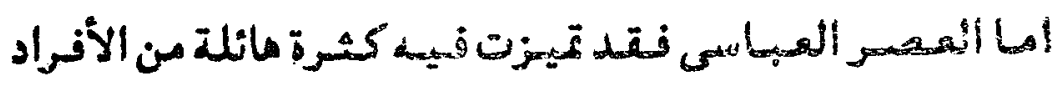

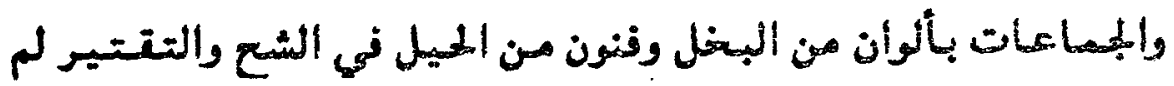

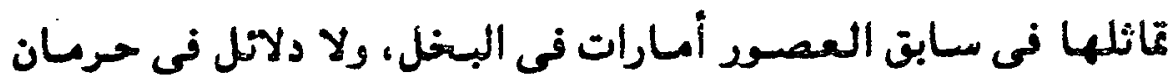
أنغسهم بله المحتاجين منهم.

ومن أبرزهم تلك الجماعة التي تخيرناها نماذج لعصرهم هذا، إذ بهري

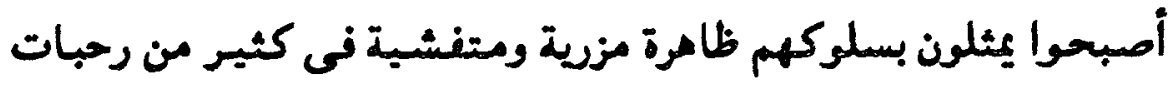

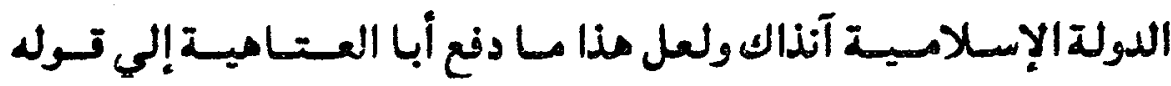

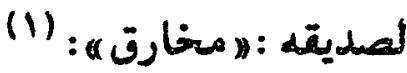

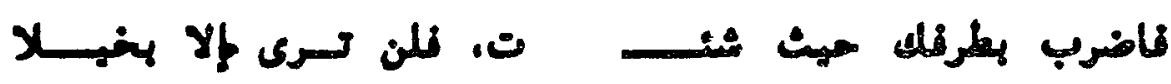

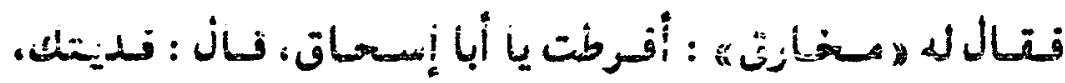

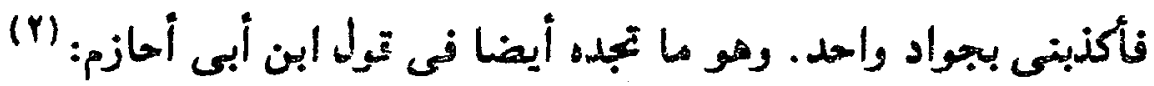

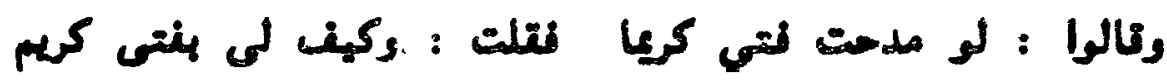

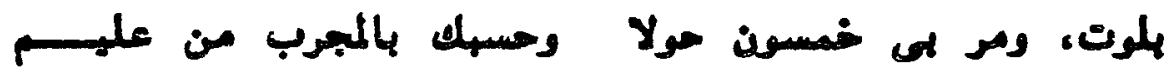

(1) ديوان أبى العتاهية ص rarr- تقديم كرمه البستاتى - دار صادر /

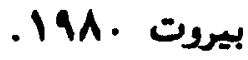
(r) 
$-19-$

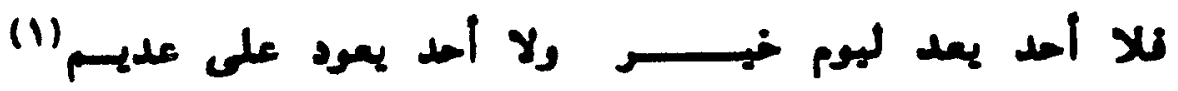
(r) : ويذكر ابن عبد ريد لأحد معاصريه قوله

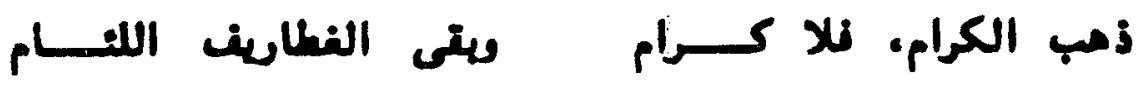

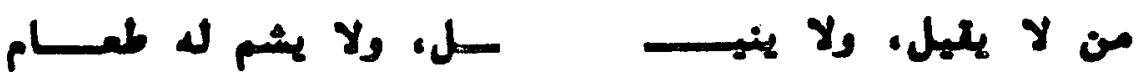

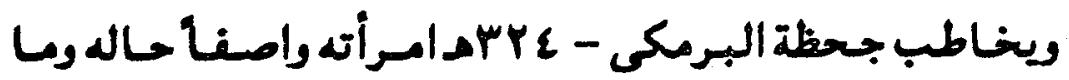
أضحى عليه من البؤس وضيت العيش نتيسجة سوء التتدير له ممن ظل

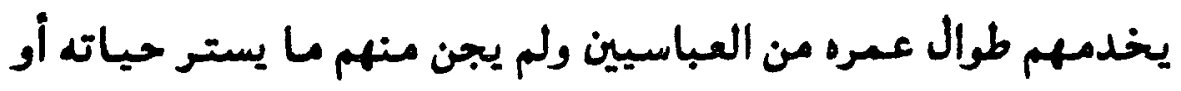

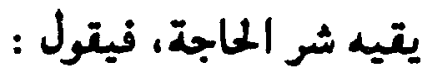

كبعت إذ رأنى נـــوت مكســد من المعهر، عتهر الشهر، منسرد

كلت : لا تعبه منى، ومن زمسن

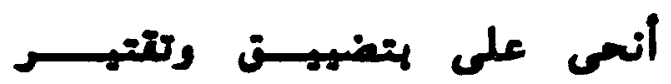

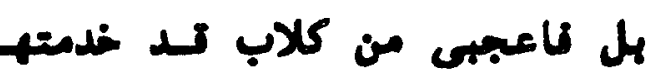

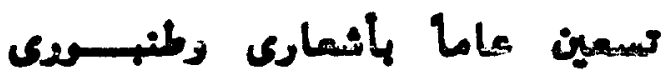

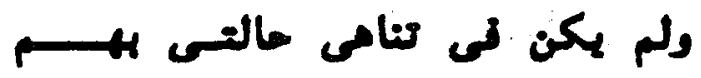
حر بعود على مالسـى بتغري

ومي كها نري ألوان أو صور من واتع الحياة تَثل ظاهرة التفشى

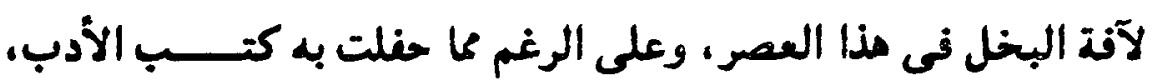

(Y) (I) (1) (Y) 


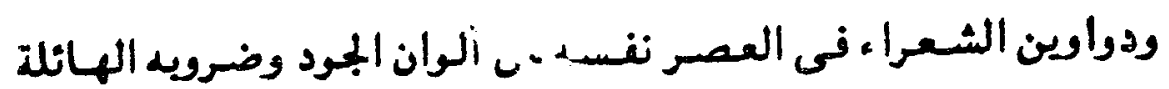
آنذاك.

وعلي كلل، فلا أخفى أننى كنت أشـعر بالنشـرة كلها أتيحت

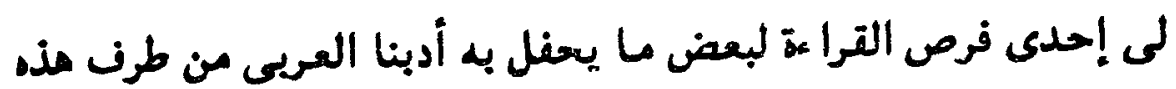

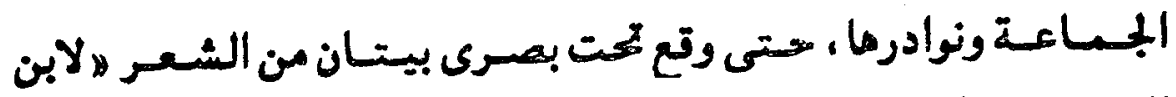

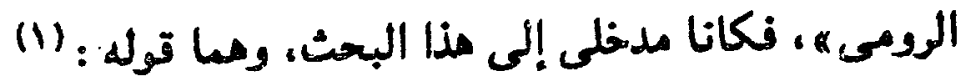

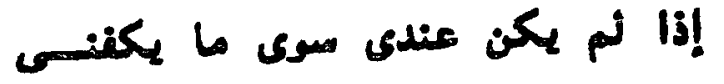

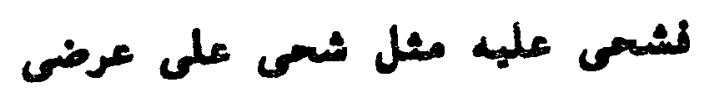

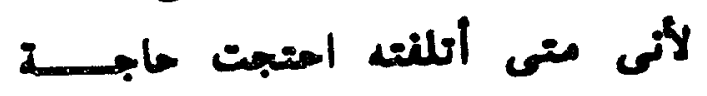
تزيل مصون العرض فى طلب الترض

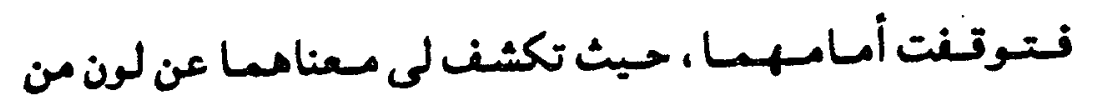

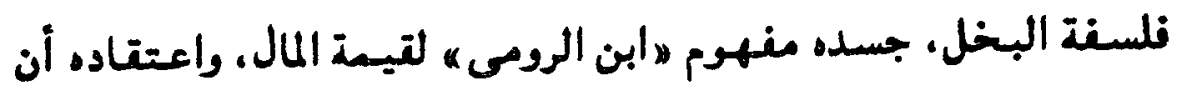
في الشح به شحا بالعرض، وحصنا منيعا لحمايته.

ودون شك فقد كان لإشراقة مذه الحاطرة فمى ذهنى أثرما في غو

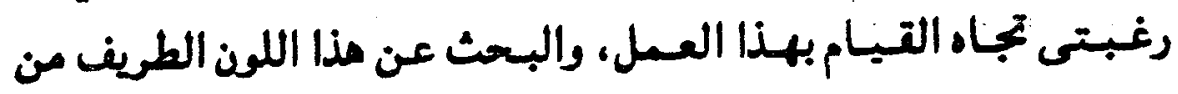

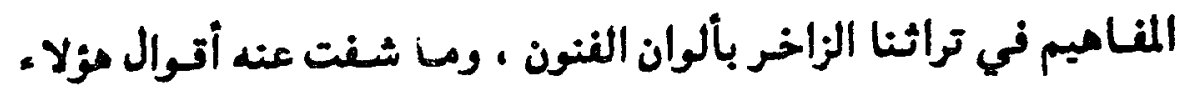

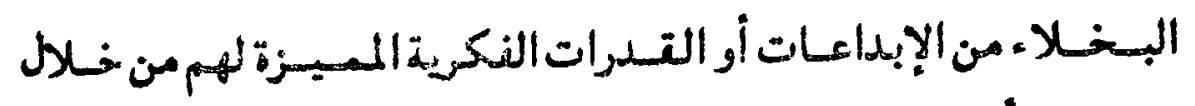

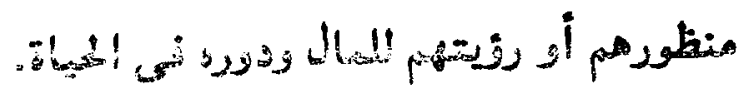

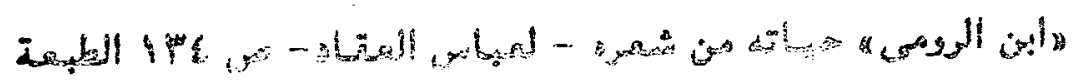


وفي إطار محدود بالتركيز والإيجاز حرصت على إجلاء الهدف

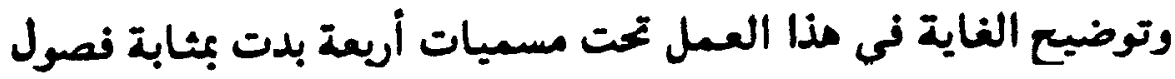
أو بحوث ملاتمة للمتام.

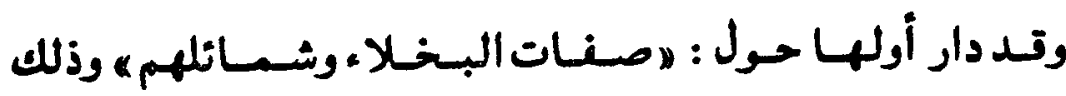
للتعزيف بهم، والكثف عن ملامحهم من خلال أتوالهم.

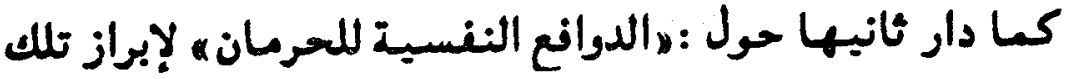

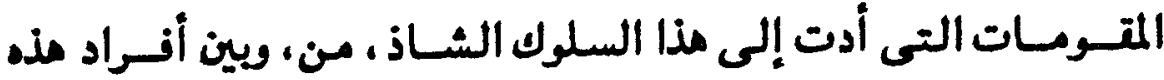
الجماعة.

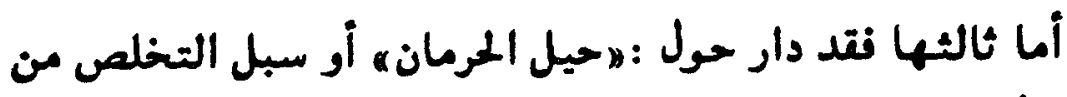

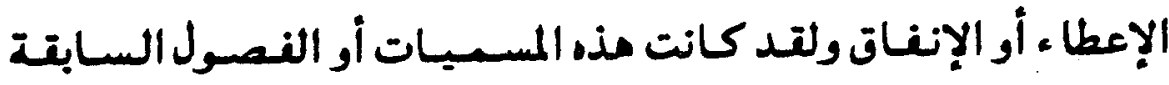

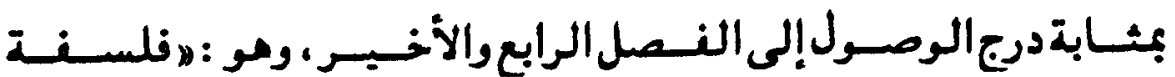

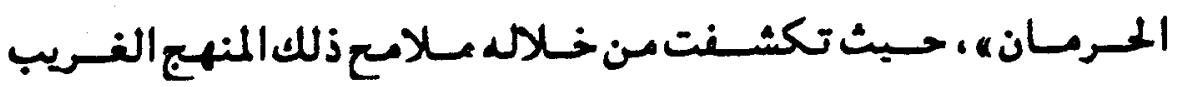
والسلوك غير المألون لمن دار حولهم عملنا مذا.

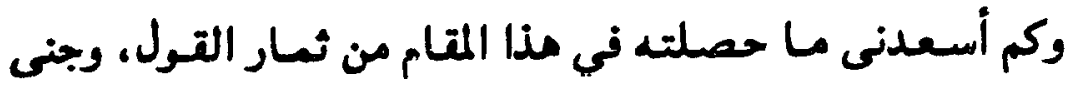

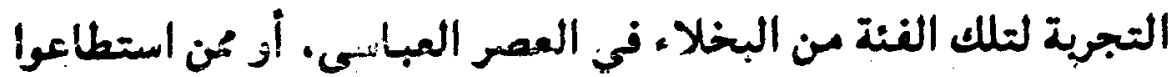

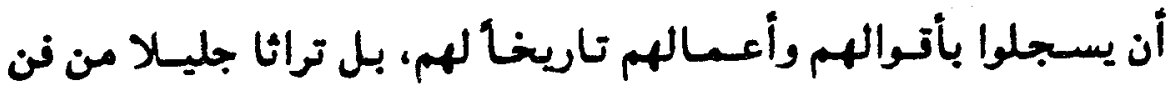

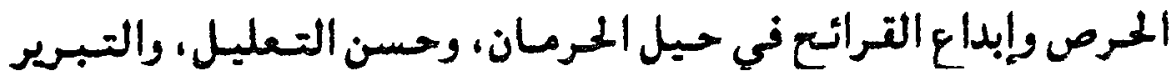

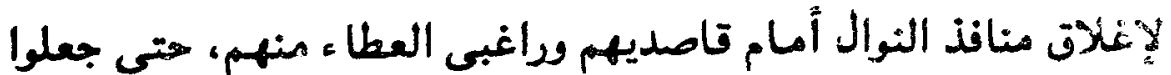

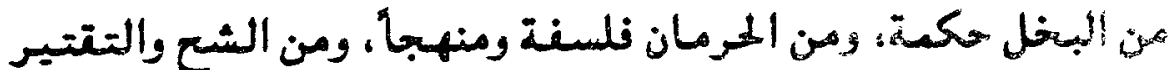

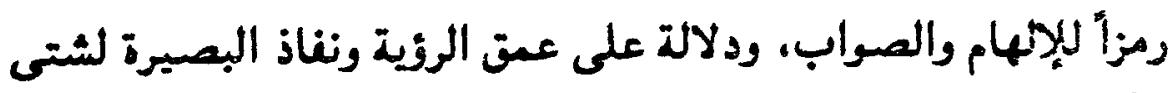

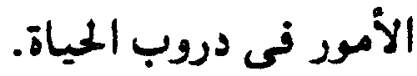


ومكذا وجــدت ننسـسى أمسام لوذ فنى طريف ونادر فى أدبنـا

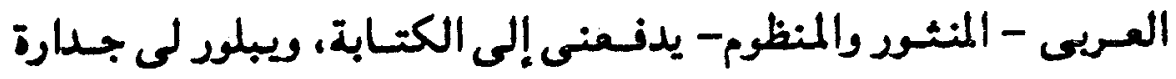

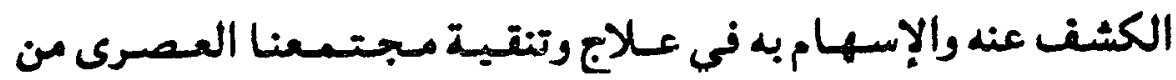

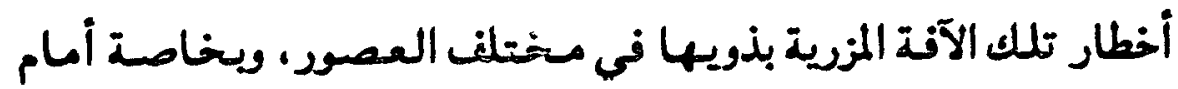

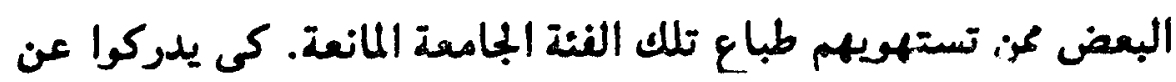

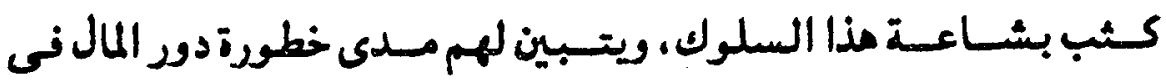

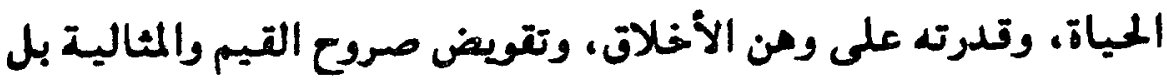

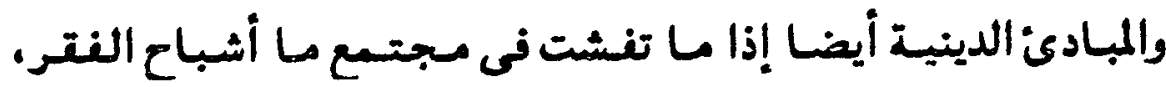

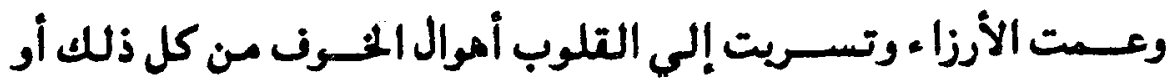
بعضه فى قادم الأيام. 


\section{شيمائل ، ومفات}

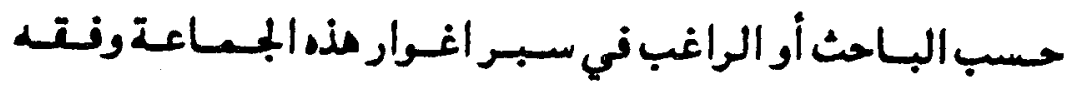
سلوكها ، أن يعن النظر فى أتوالهم ومحتلف معاملاتهم مع الآخرين، فغى ذلك ما يكشف بوضوح عن ملامسهرم، وما يميزمم بغيـر التليل

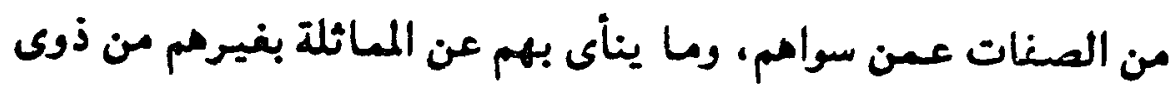
النطر الإنسانية المعتدلة.

ولعل من أبرز صغات هذه الجماعة أو أخص شمائلهم ما تراءى

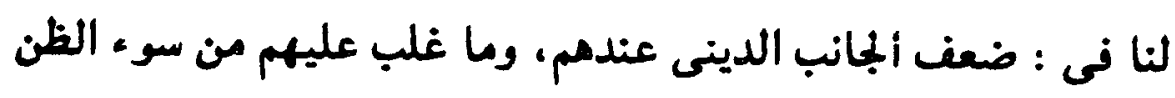

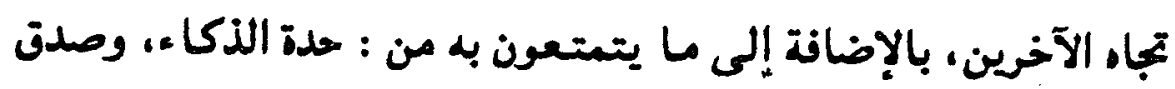

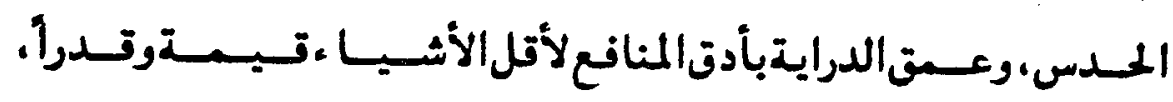

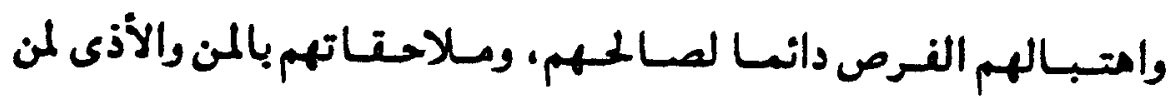
هاتفلت ، علي كره منهم الإحسان إليه. ومع أن مغردات مذه الصفات التى أجملناها ليست تصرا على الاحسان إلها

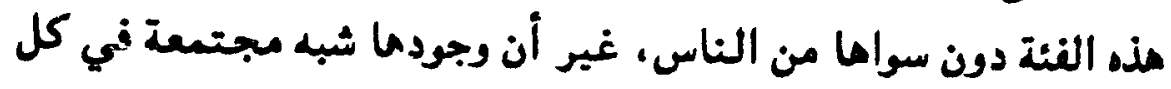

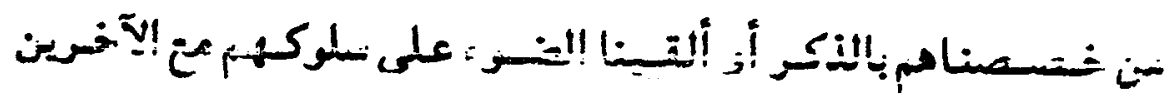
تكاد تبديهم متغردين بها

وونا ، بالتزامنا الإيجاز فى هذا العمل، فقد أغنلت أو تعمدت

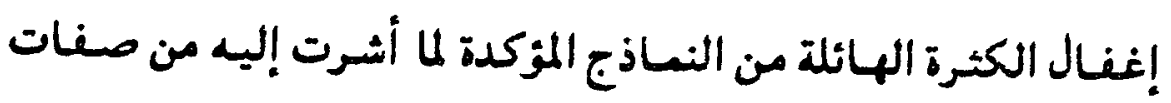

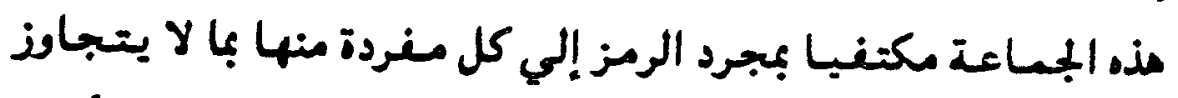
الاثنين أو الثلائة من الأحداث أوالسلوكيات الموثقدة فى كتب الأدب. 
حيث لا تدعو الحاجة إلى أكثر من ذلل، كسا لا تسهم الكثرة منها

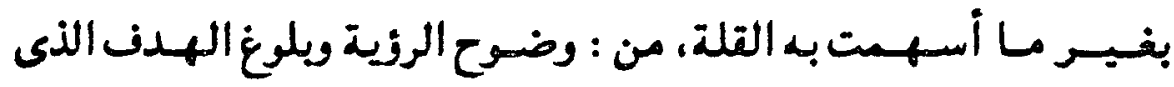
نتشده في عملنا هذا.

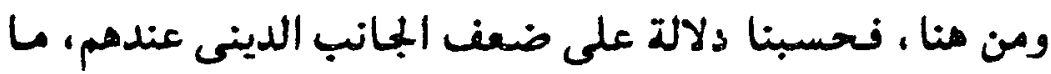

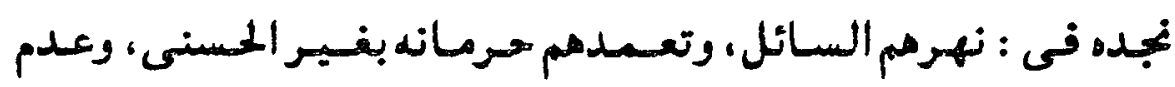

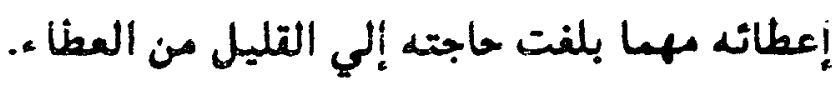

فمبا يذكره الجاحظ (1) أن ابن لاجـذام الشسبى" (r) .كسان يلح

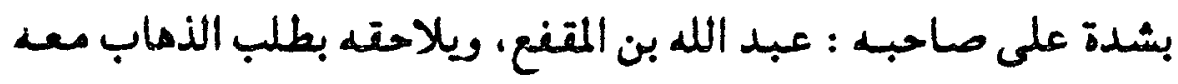

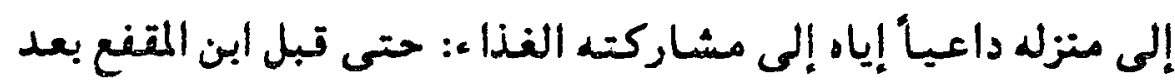

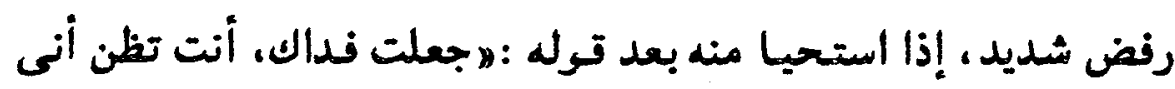

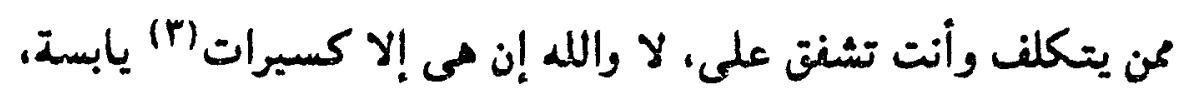
وملع، وما ، الحبب.

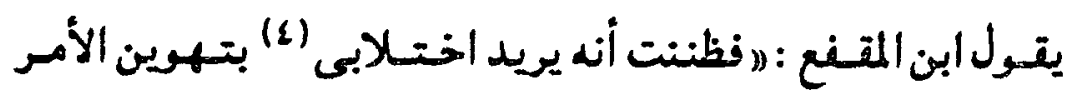

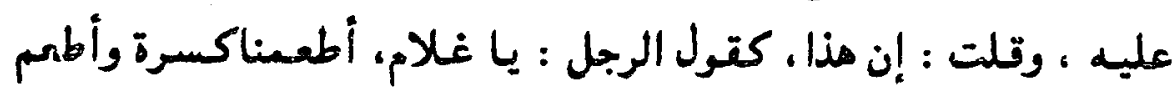

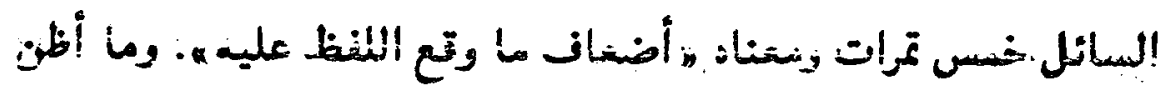

انظر هالبخلاءهـ- للجاهظ - ص 191 ومابعدما، طبعة دار الهلال/

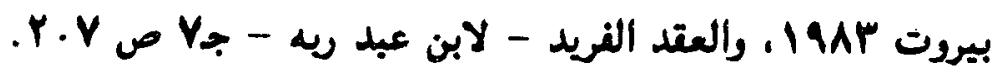

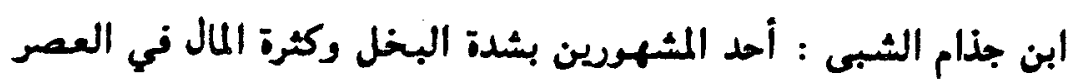
العباس الأول. كسيرات : فضلات.

اختلابس : يريد الاحتيال على : فيلات. 


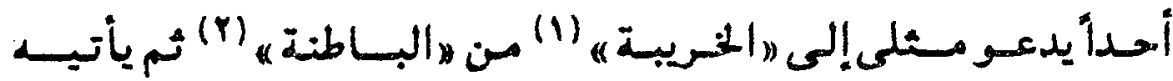

$$
\text { بكسيرات وملع كسا يقول. }
$$

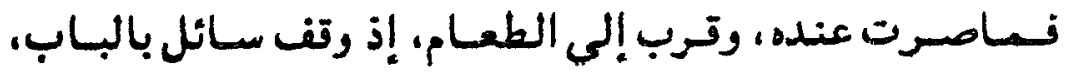

نقال : أطععونا ماتأكلون أطعمكم الله من طعام الجنة.

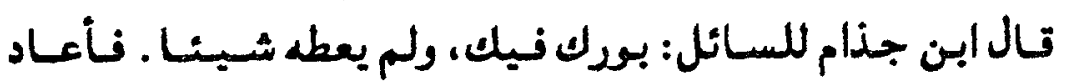

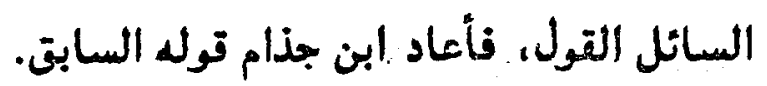

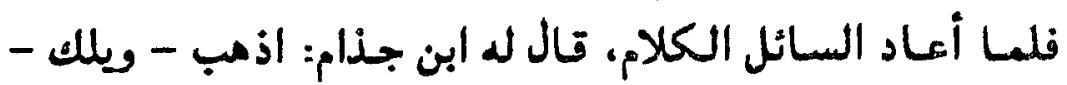

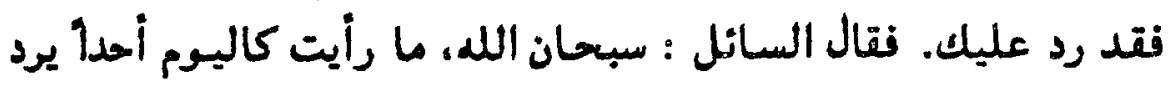

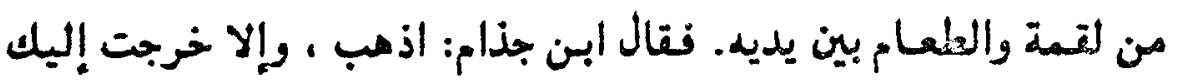

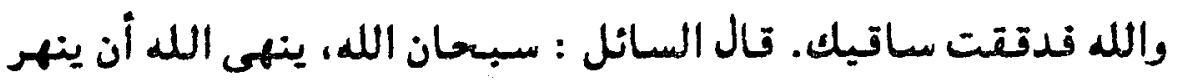

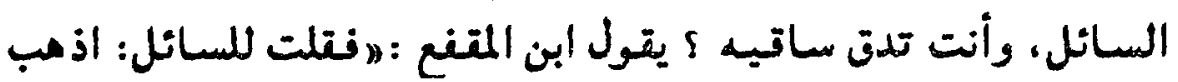

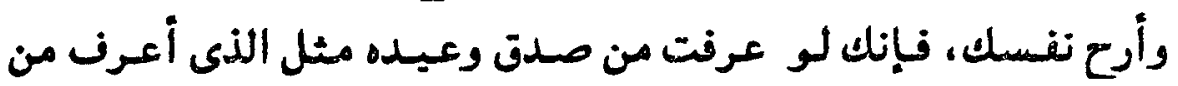

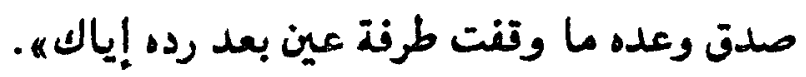

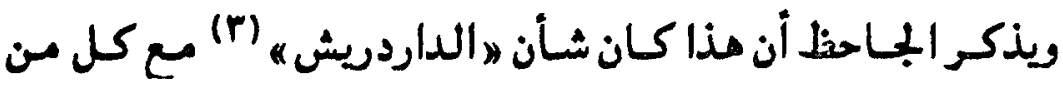

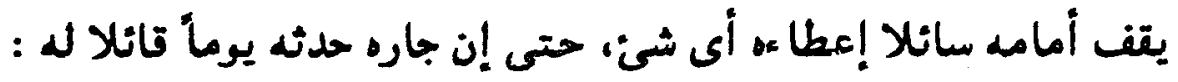

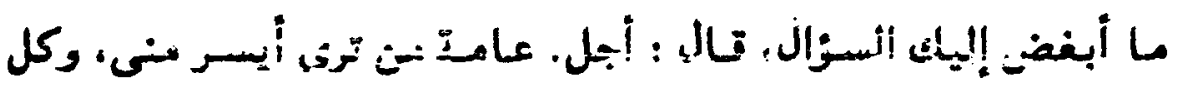

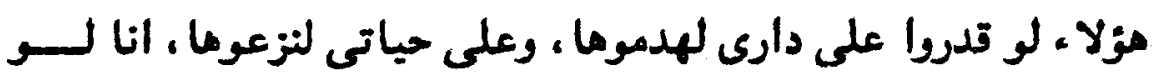

(1) الحريبة : موضع بالبصرة كما يقول ياتوت في لامعجم البلدانه مادة

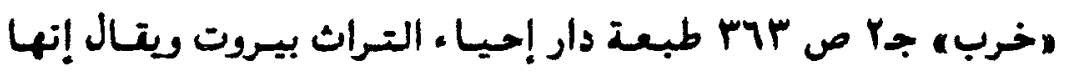

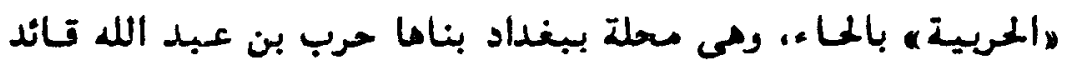
الثنلينة المنصور.

الباطنة : مجتسع من الأسوات والبيوت بين البصرة والكونة.

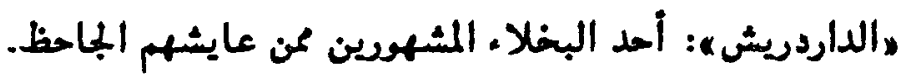


طاوعتهم كللا سألونى كنت قد صرت مثلهم منذ زمان، فكيف تظن

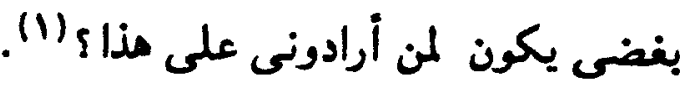

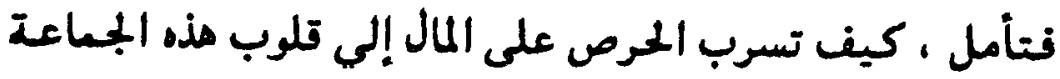

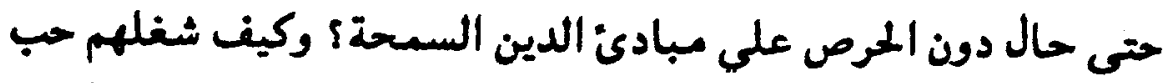

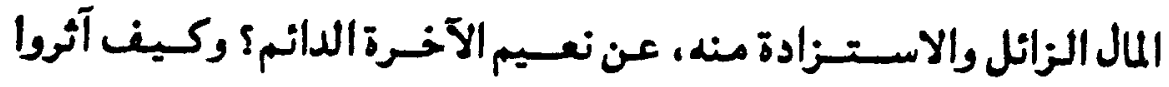

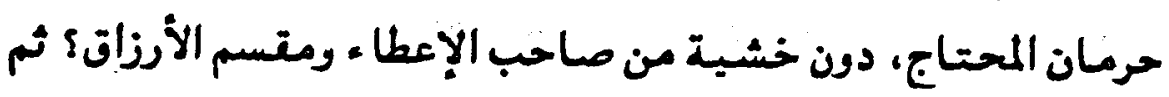

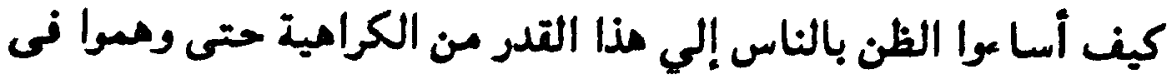

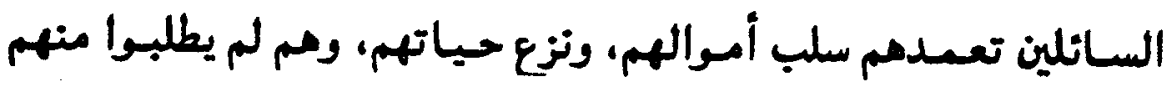
غير ما يسدون به رمتهم ، أو يسترون به عوراتهم ؟

ثم ألاترى معى أنهم قد أسا هوا الظن بالله تبل أن يسينوا الظن الظه

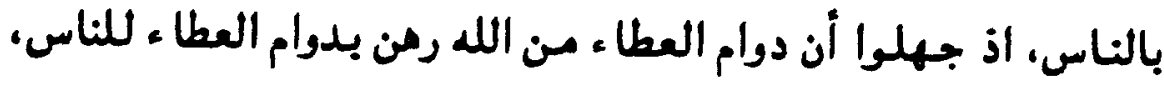

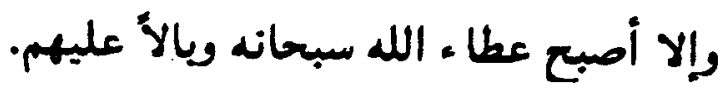
ومن هنا فإننا نظن ظنا أن فلسنتهم فى الحرمان، أو التهاء التهاسهم

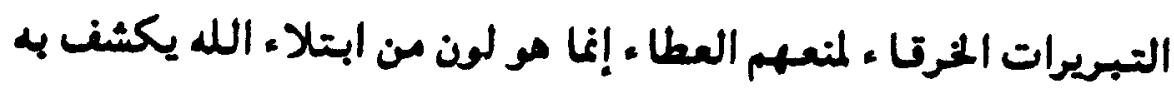

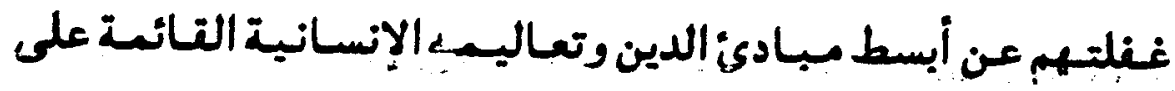
التعاون والبر، وقضا ء حوائج المحتاجين.

ولعل من أعجب الأقوال فى هذا المقام، ما يحدثنا به محمد بن

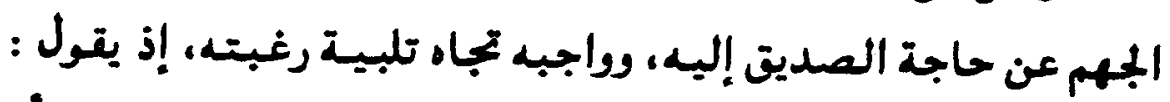

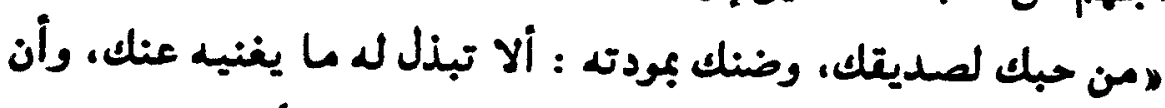

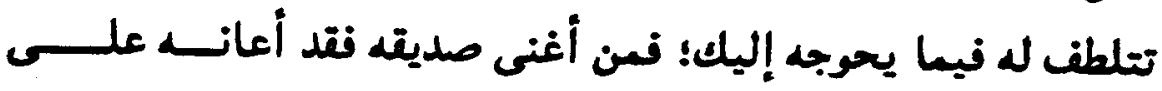




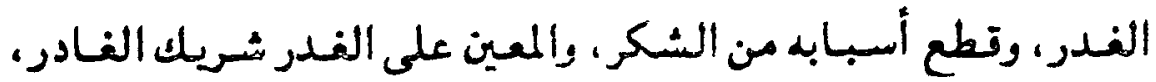
كا إن مزين الفجور شريك الفاجو ه "(1).

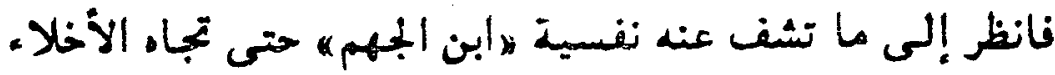

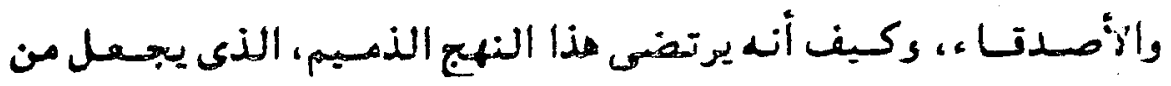

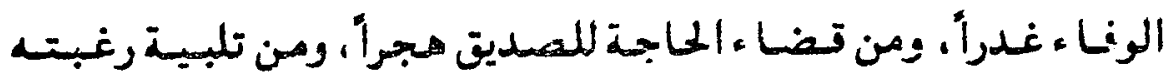
والإبقا ، على مودته فجوراً وأثما.

إن هذا اللون من الفلسفة أو الحكمة من الحرمان تبدو في نظرنا

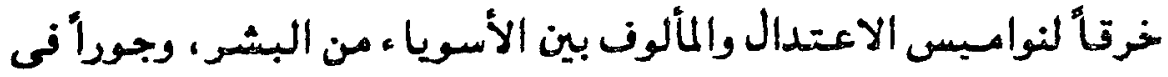

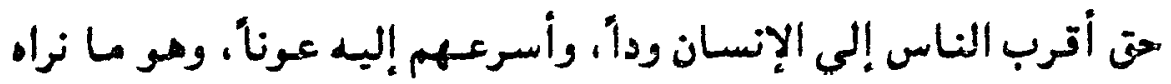

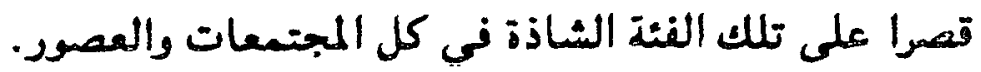

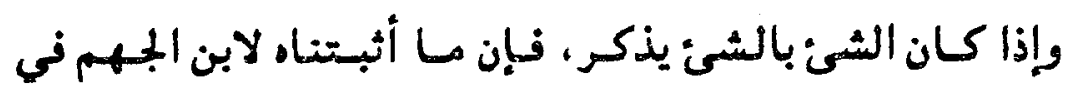

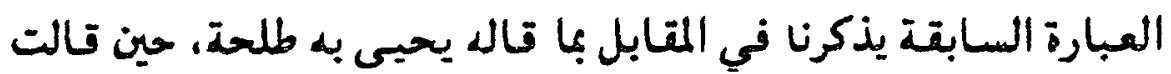

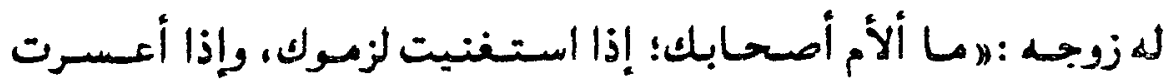

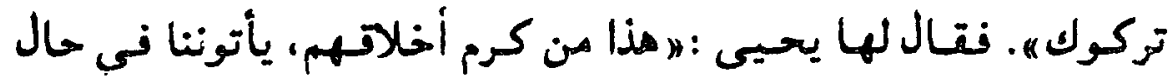

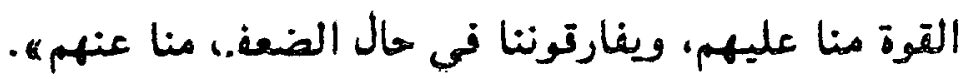

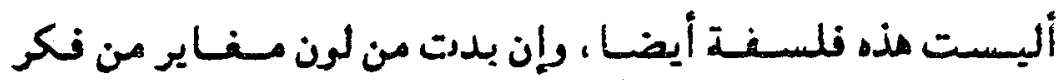

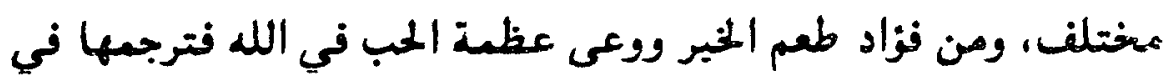

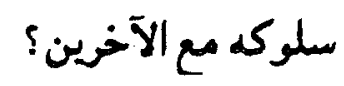

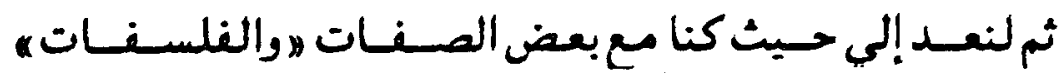

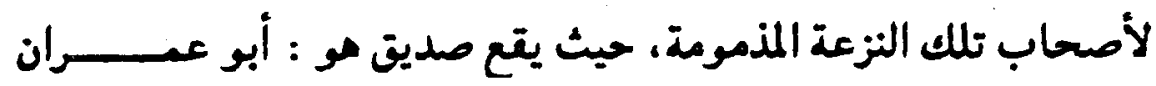


(موسى) (1) تحت طائلة التشهير والملاحقة بالمن والأذى من صديقه :

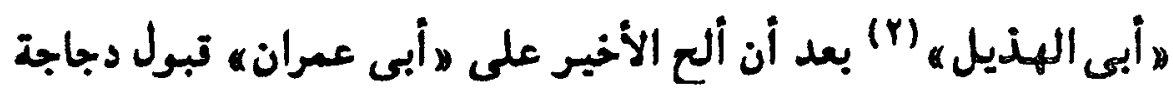
مثله على سبيل الهدية. وكانت مذه الدجاجة - كما يقول شاهد العيان : هالجاحظه|-

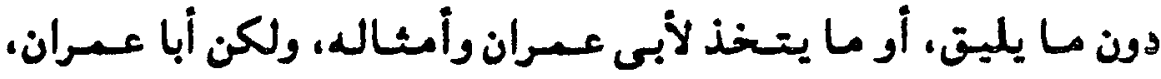

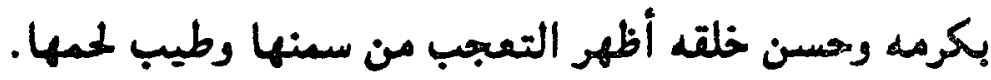

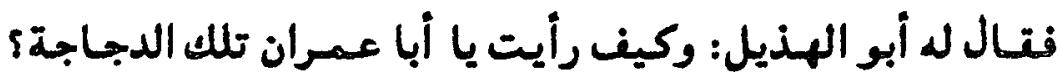
قال أبو عمران ـ مجاملا إياه - كانت عجبا من العجب. وكبئ

فيـقـول أبو الهذيل: وتدرى مـا جنسـهـا؟ وتدرى مـاسنها ؟ فـإن

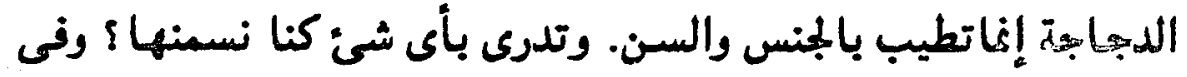
أى هكان كنا نعلفهاء.

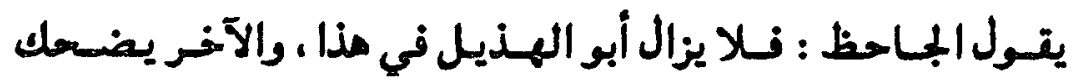

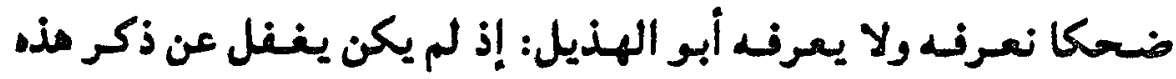

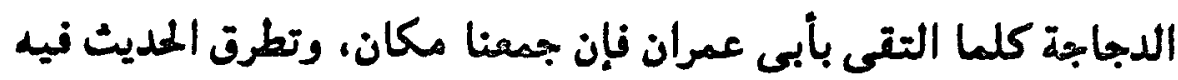

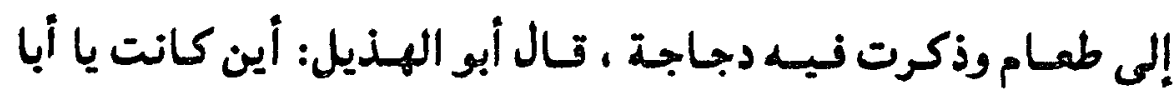

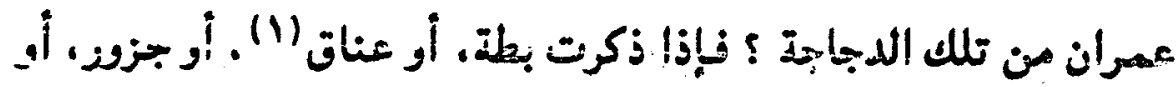
بقرة في مجلس آخر يجمعه بموسى، فإنه يقول له : فأين تكون كــــلـل

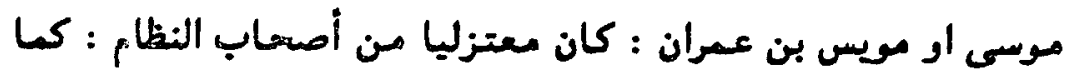
كان واسع العلم في الكلام والفتيا.

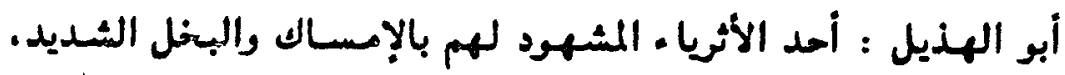
وكان له مع الباحظ مواتف عدة. العناق : الأنهى من أولاد المعز والغنم فى حين الولادة إلى تمأم الحول. 


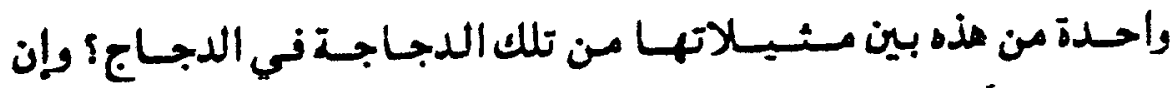

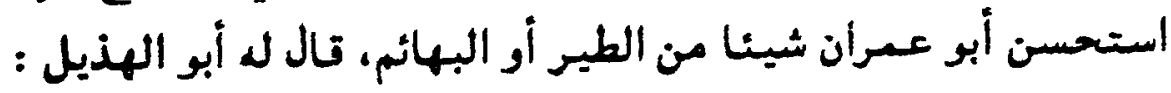

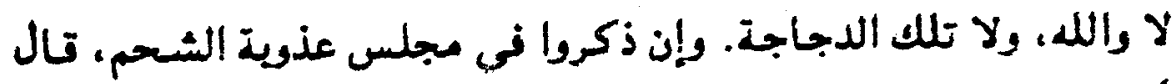

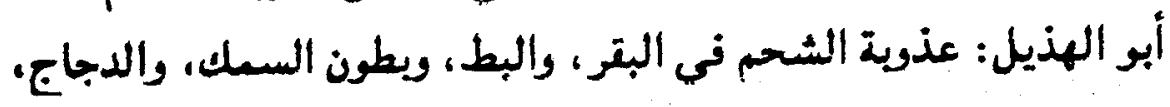
ولاسيما ذلل الجنس من الدجاج.

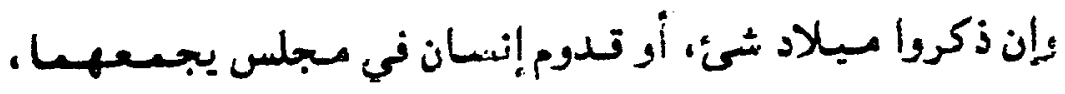

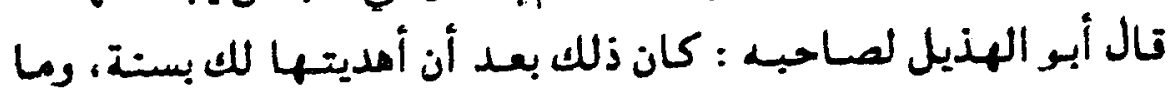

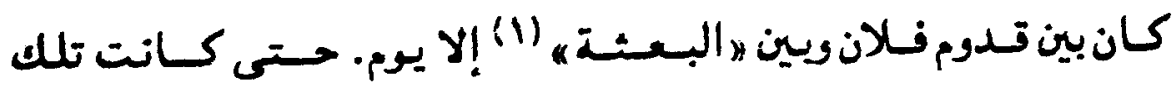

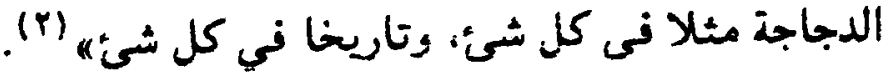

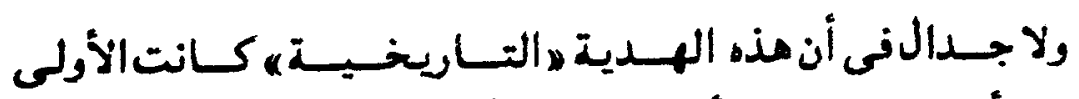

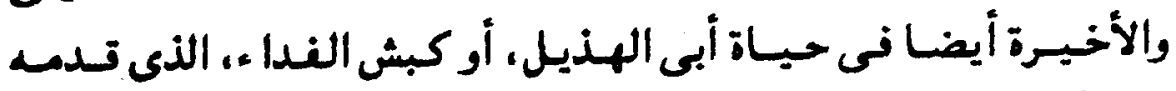

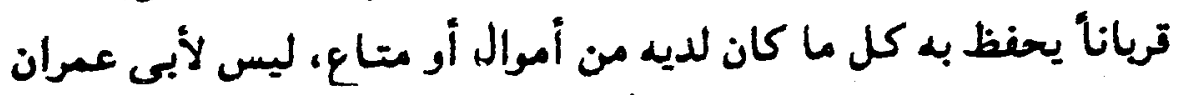

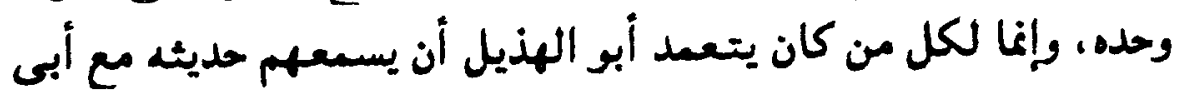

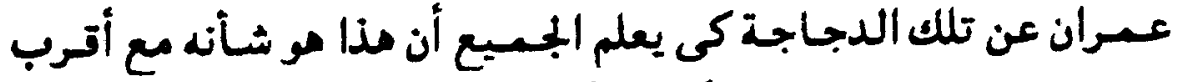

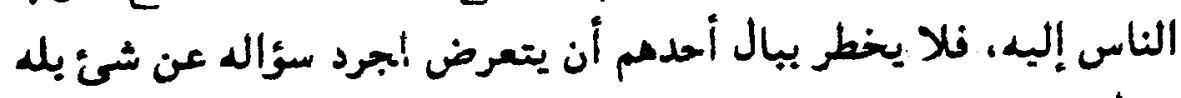
:

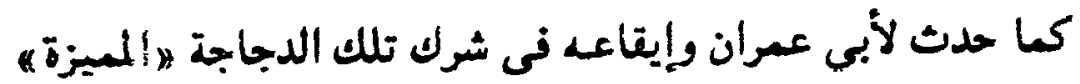
عن بنى جلدتها في ذنك. الزمان. ثم مل ترى معى أن هذا اللوذ القبيح من إلمن والأذى في أتوال

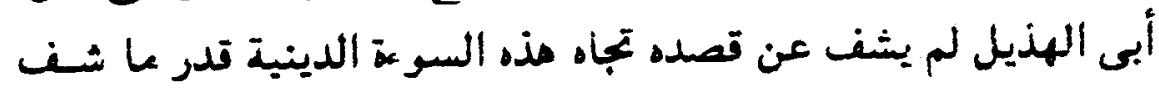

البعثة : يقصد بها اليوم الذى، بعث بها إليه.

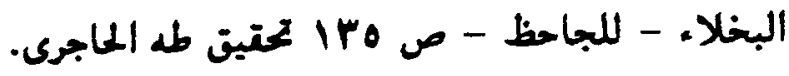




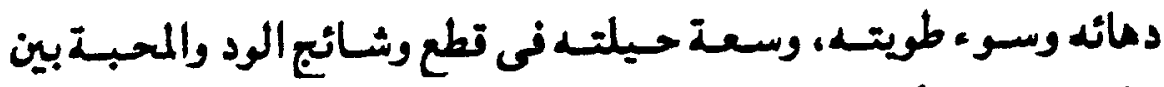

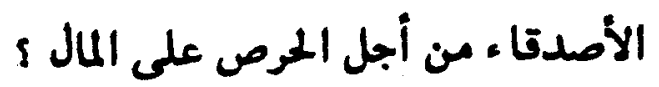

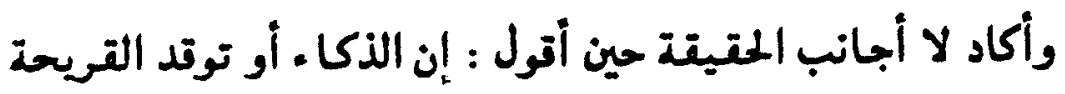

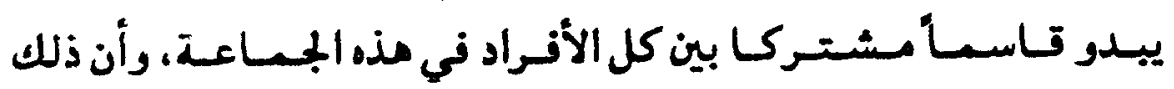

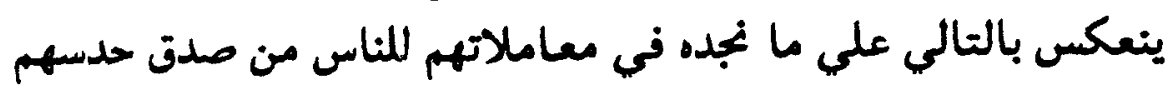
وقوة فراستهم.

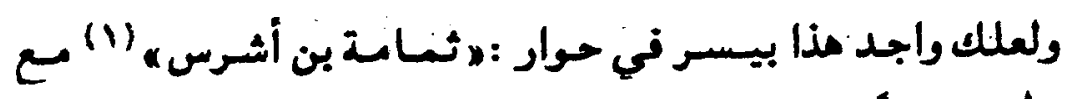
سائل قال له يوماً : إن لى إليك حلى حاجة ؟

فيبادره ثمامة بقوله : وأنا لى إليك حاجة ؟

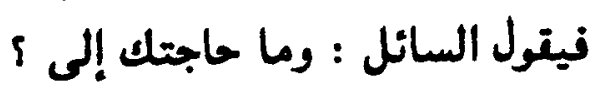

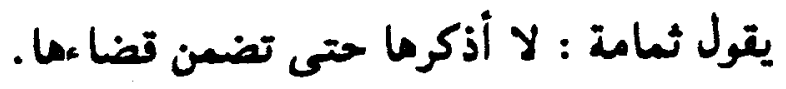

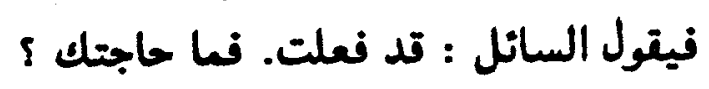
يتول ثمامة : إن حاجتى إليك ألا تسألني حاجة.

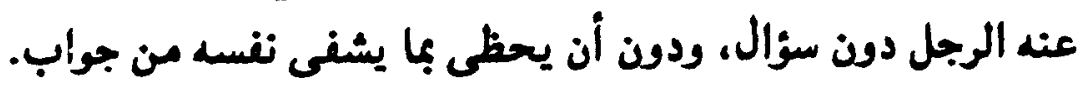

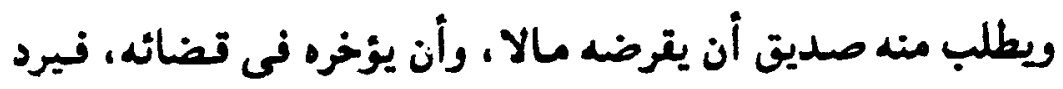

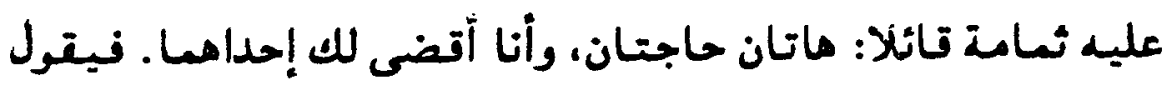

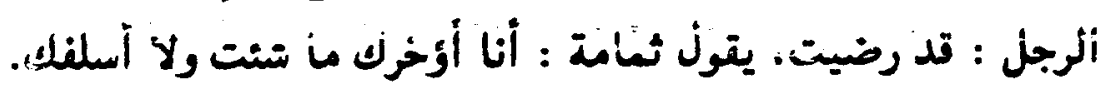

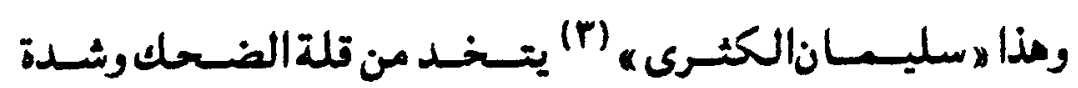
القطوب أو العبوس فى وجه كل من يلقاعم وسيلة ينأى بها عن سـورّال ثمامة بن أشرس : أحد زعماء المعتزلة، وقد أوذى فى أيام الرثيد.

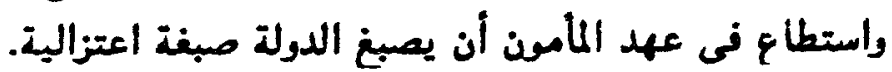

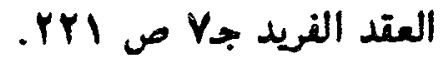
الكثرى : كان من أشد الناس بحلا فى اليصر العباسى. 


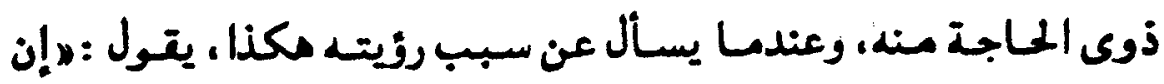

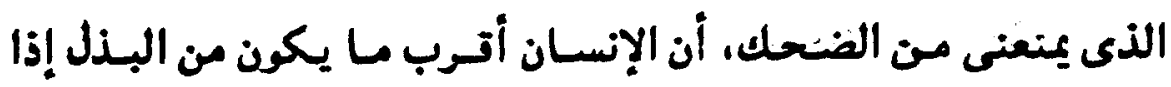

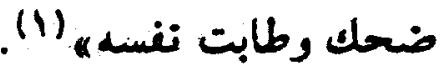

نكل من لا ثمامة هو والكثرىه يبدوان وكأنما قد أعدأ لكل سؤال

جوابد ولكل موتف ما يلانسه ويتفق معه من قول.

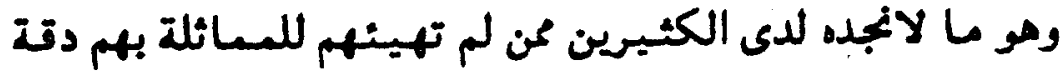
النظر إلى المال. وعمق المعرفة بنغعه.

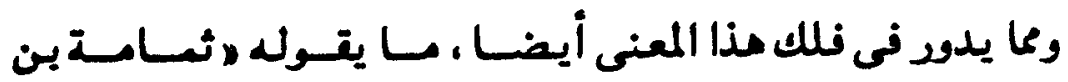

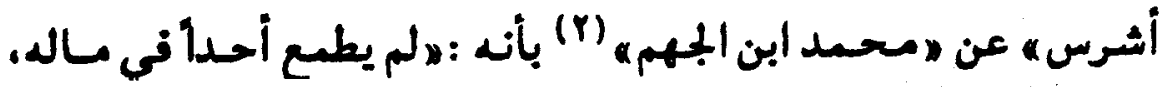

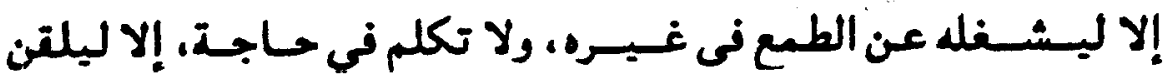

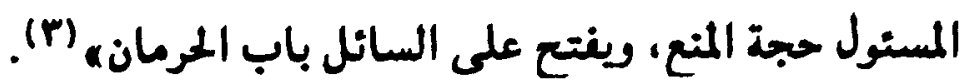

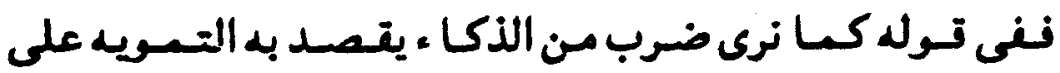

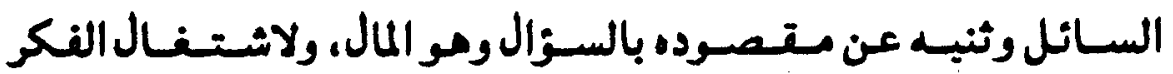

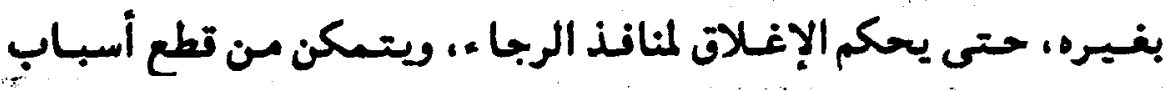
أنوصول إنيه.

البخلاء - اللجاحظ - ص البعا 17 طبعة دار الهلال - بيروت تقديم د/ عباس عبد الستار.

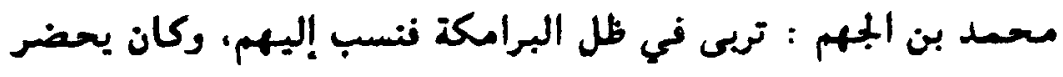

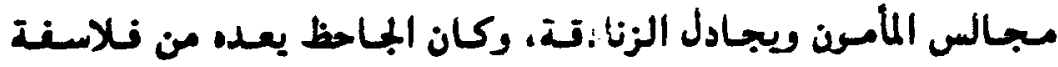

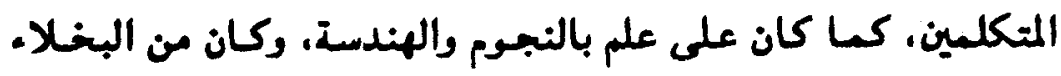
المشهورين. 


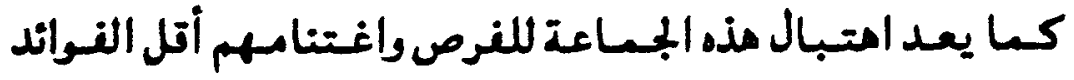

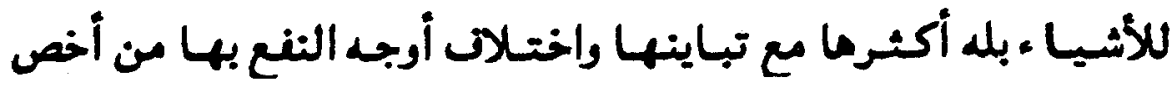
ميزاتهم وأكثرها شيوعاً في معاملاتهم ولتا ياتهم بالآخرين.

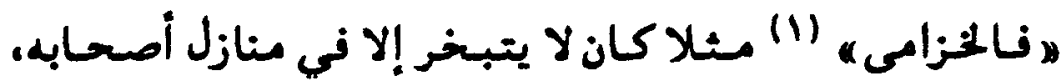

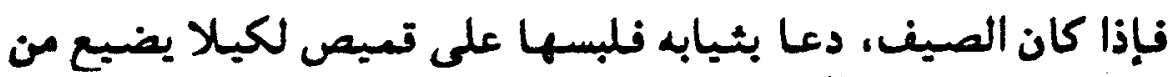

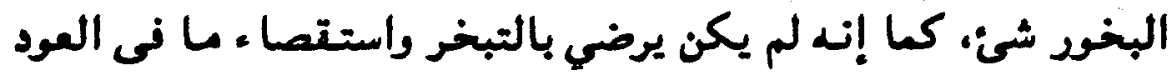

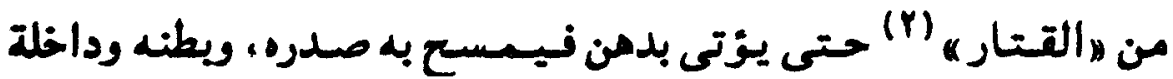

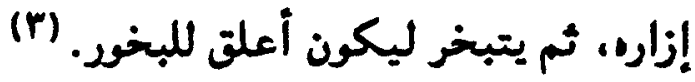

ويالطبع لم يكن حرص ״العزامى، على اغتنام ما يعلق بـالهواء

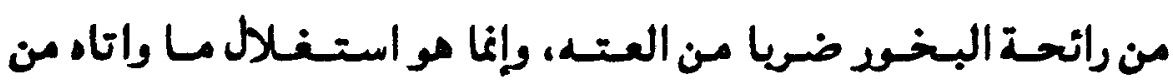

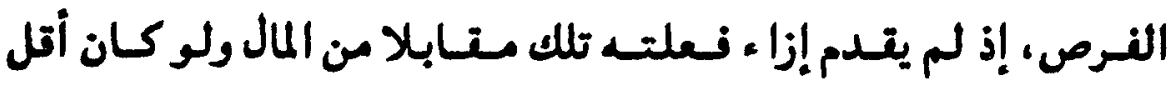

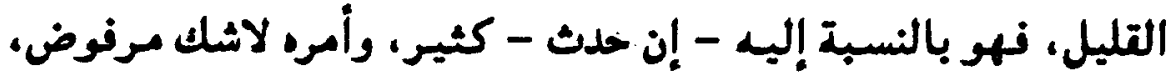

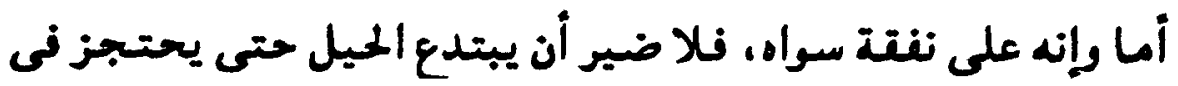
طيات ثيابه غير التليل من ذلك لالدخان المعطره.

وفلسفة هالعزامىه في حرمان نفسه من شراء البخود والتمتع به

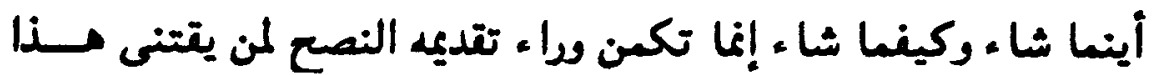

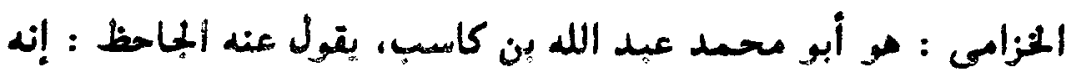

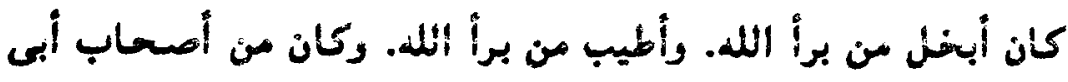

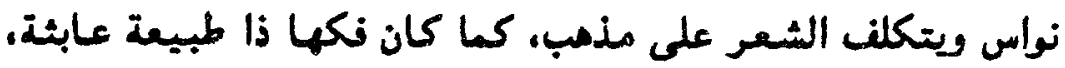
وكان كاتبا لئويس بنئ عمران. التتار : الدخان.

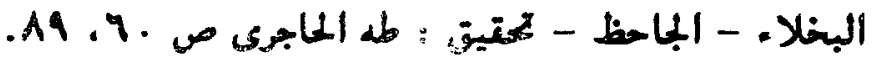


البخور، أو لمث عنده شئ منه بالحناظ عليه، لعله واجد بذلله بغسيتهـ

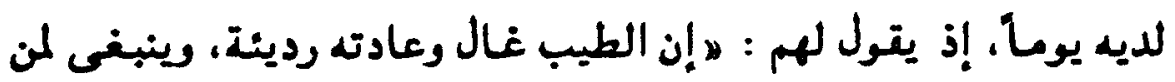

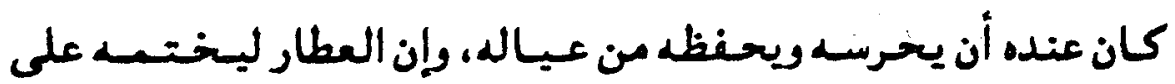

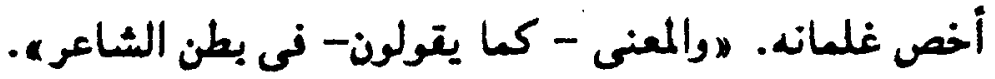

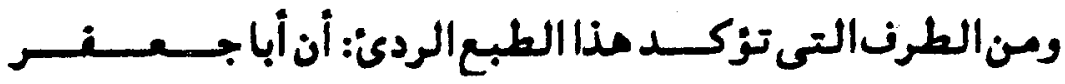

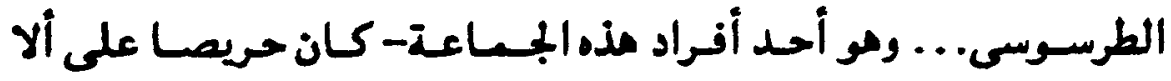

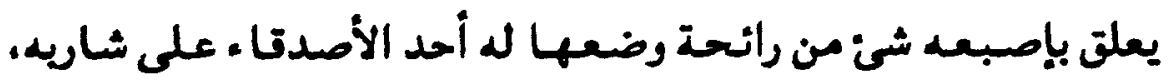

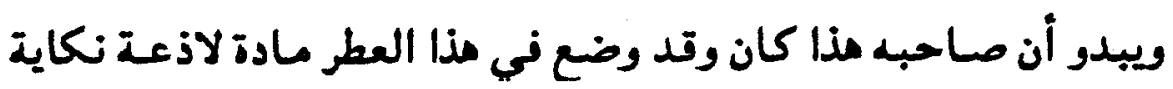

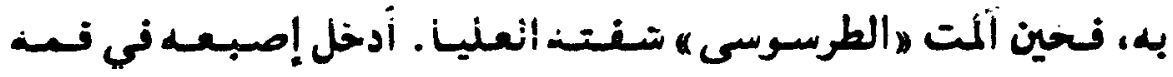

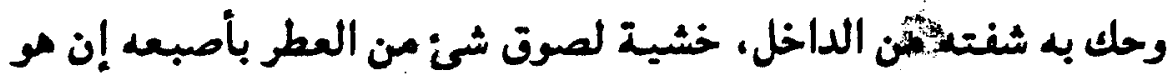
حك بد شاريه مباشرةه (1).

ويقول الجاحظ :إن "عبد الرحمن الثودى م (r) كان يرتضع لبن

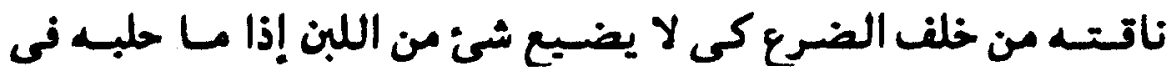
(i)

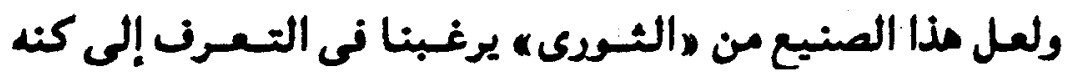

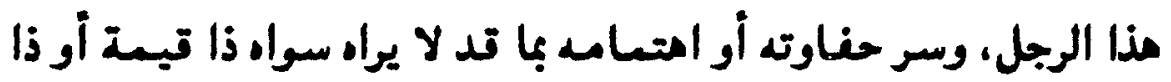

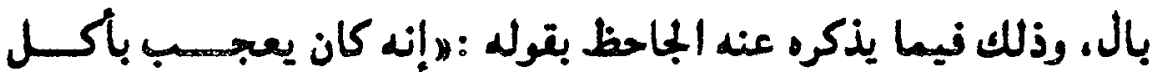

المصدر السابق ص هA.

الثـوى : أحد سراة البصرة، وكان يصطنع التجارة، كسا كان شـديد

العارضة، عضب اللسان. 
الرأس، ويلذ له أن يصنها ويجسد منافعها، ومن لطيف توله عنها :

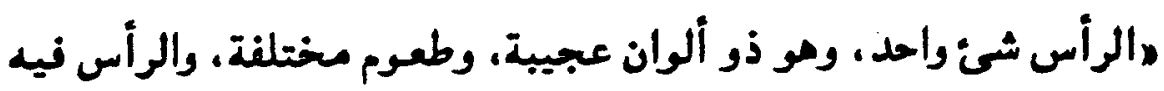

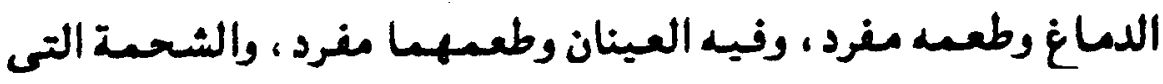

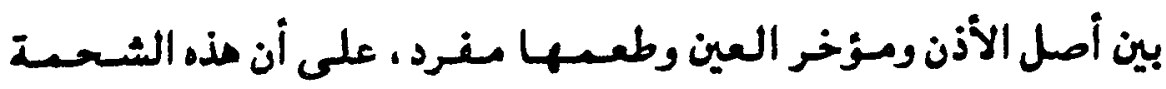

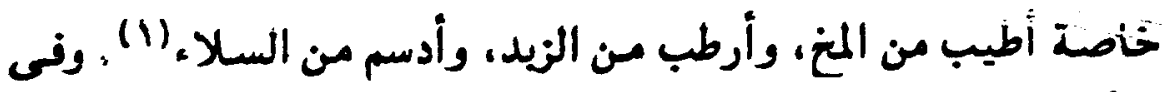

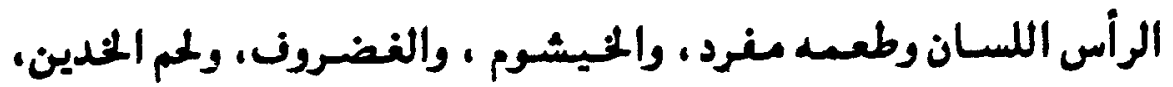

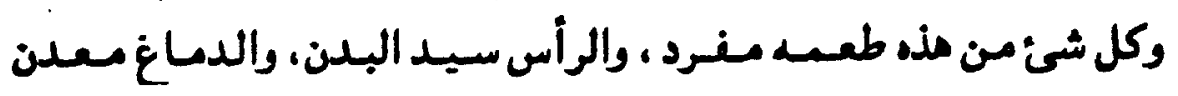
العقل، وخاصة الحواس، ويه توام البدن، وفيه يتول الشاعر : إذا نزعوا رأس وفى الرأس أكثرى وغودو عند الملتخى ثم سائرى

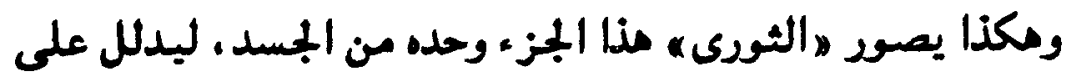

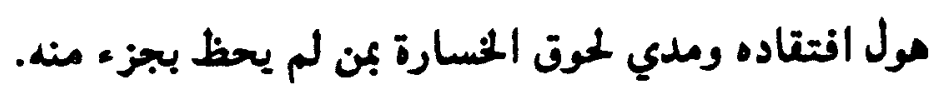

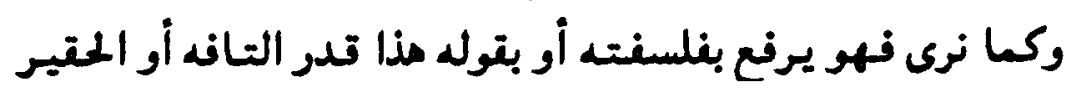

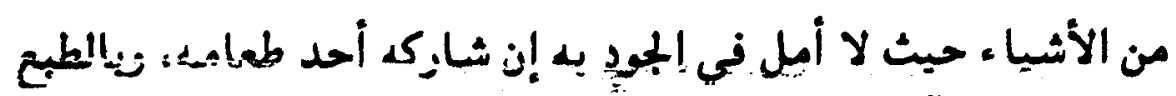

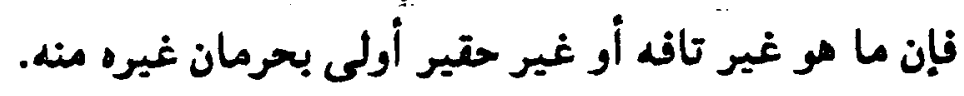

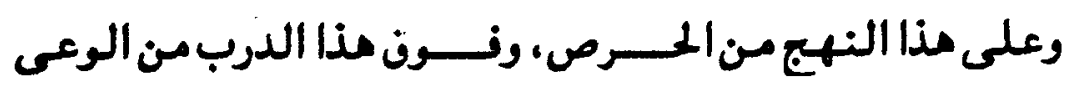

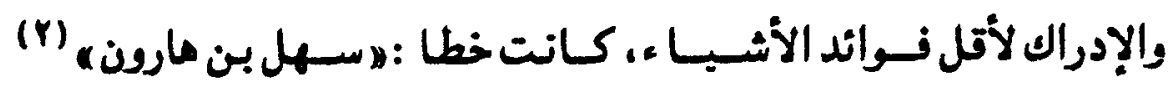

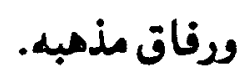

السلاء : السمن ونحو، ما دام خالصا، وجسعد: أسلثة.

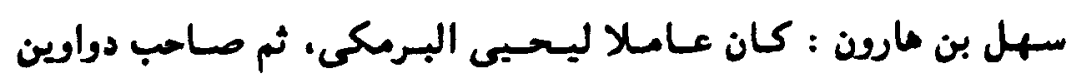
مارون الرشيد بعد ذلل. 
فما يذكره صاحب العقد الفريد :ه أن دعبل المززاعى - الشاعر

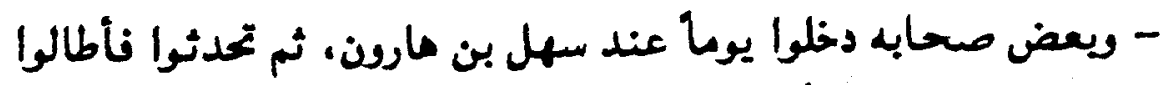

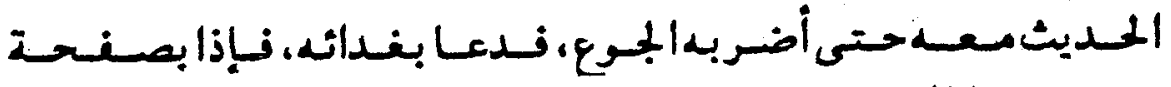

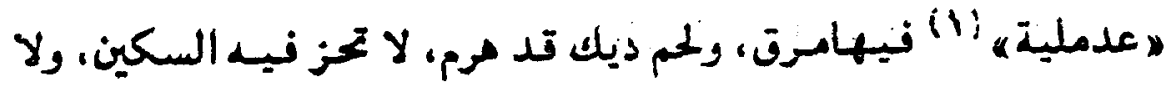

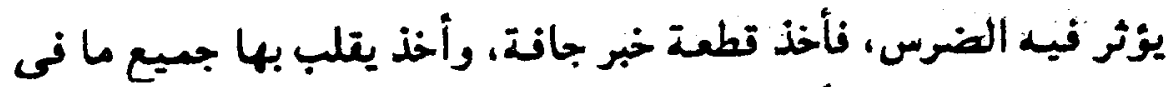

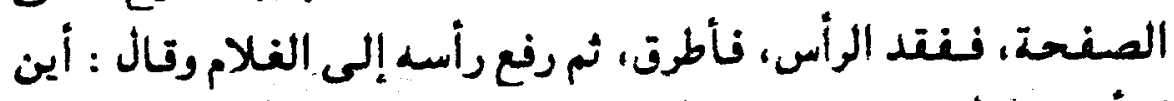

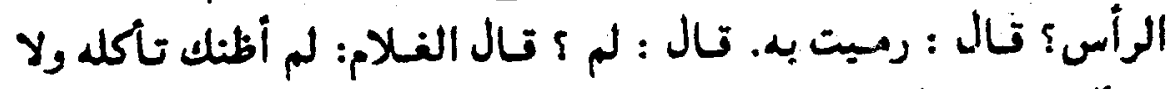

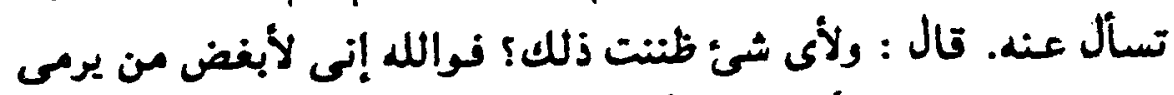

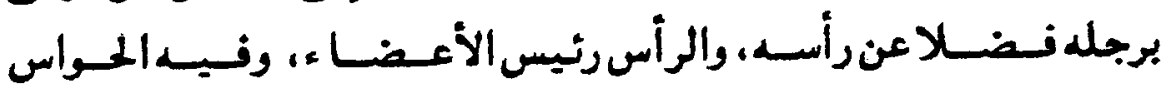

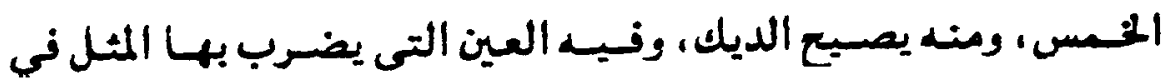

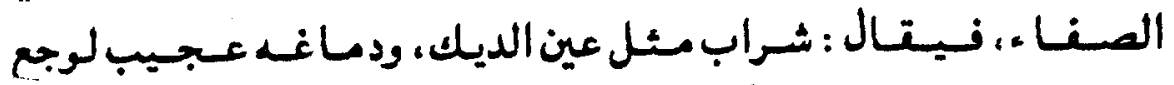

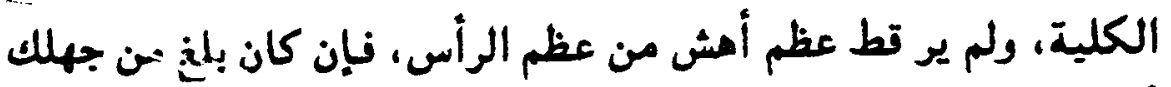

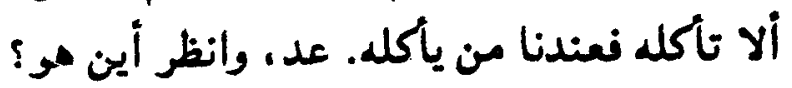

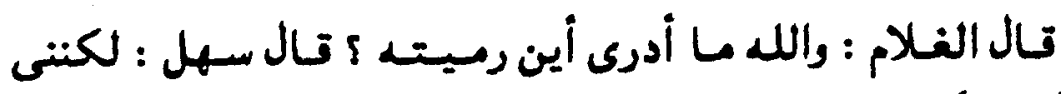

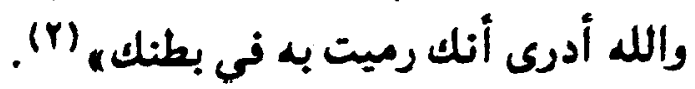

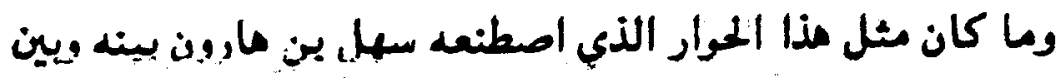

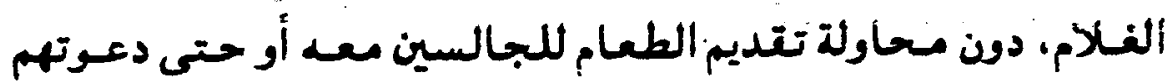

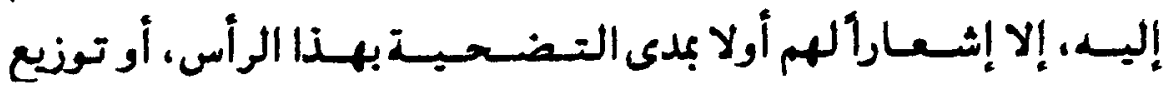

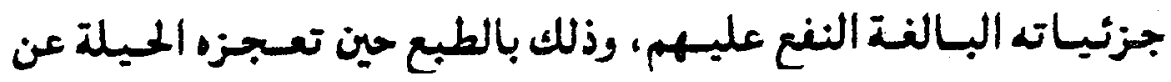

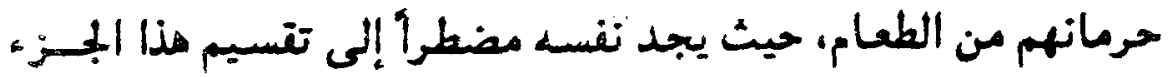

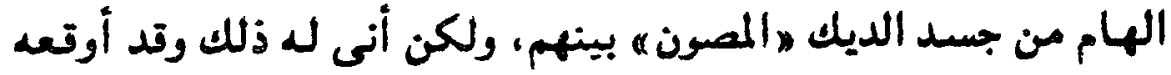
الغلام فيما لم يكن يتوقعه أويرجوه ؟

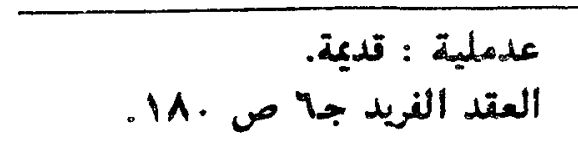




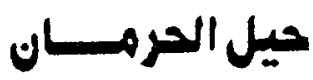

تباينت ألوان الحربمان واختـلفت مظاهره، وحيله بين أفراد تللك

المبــاعة تبعاً لمدي العزون وعدم الرغبة في لتـا ـ السائلين أو إبـابة

طلب المحتاجين.

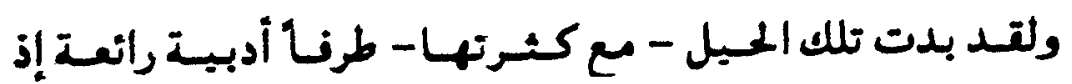

إحتوت على سلوكيات تلاتم طباع ذويها ودون أدنى اتفات أو ملا عمة

لطباع المقتدلين وسلوكهم.

نهذا "أحسد الحاركى )(1)" يرد على أحد البالسين معد. بعد أن

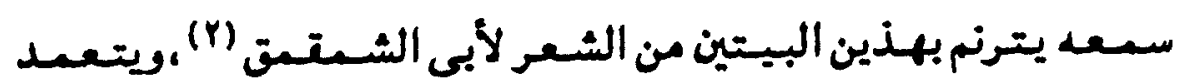

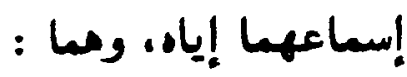

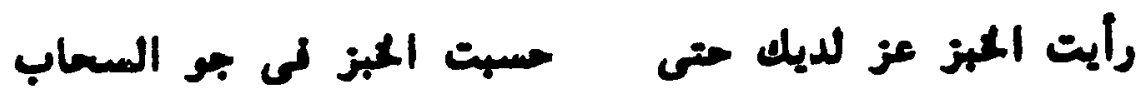

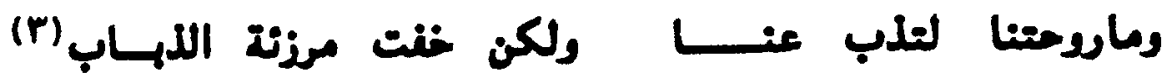

فـــــــول له ابن الحــاركى : ولم زب عنهم لعنه الله ؟ والله مــا

أعلم إلا أند شهى إليهم الطعام،ونظف لهم القصاع، وفرغهم له: ألا

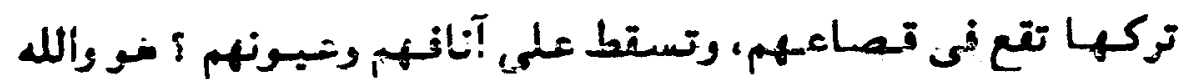

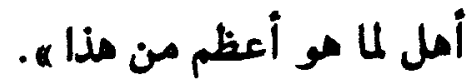

أحسد الملاركى : أحد بخلاء العصر العباسى الأول، وكان تاجرأ، كسا كان كثير الاوعاء بما لا يملك.

أبو الشستمق : شاعر عباسى واسمه : مروان بن محسد، وقد أنشد ملين البيتين في حت جعغر بن أبى زمير. روحتنا : جلبت لنا الهواء. 


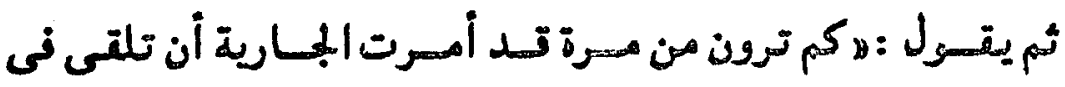

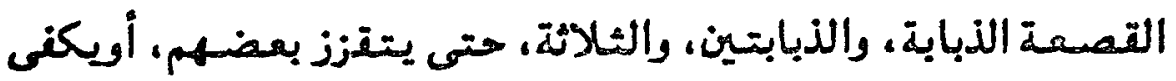

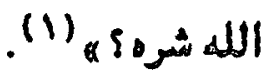

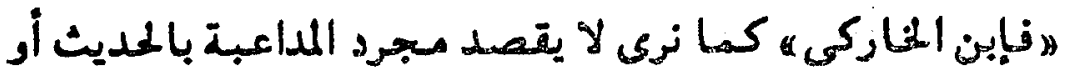

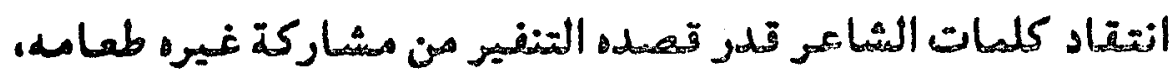

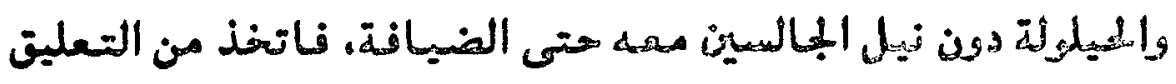

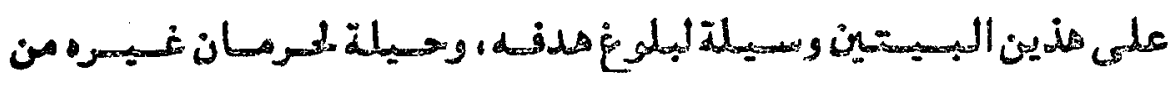

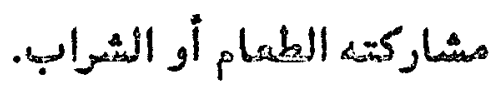

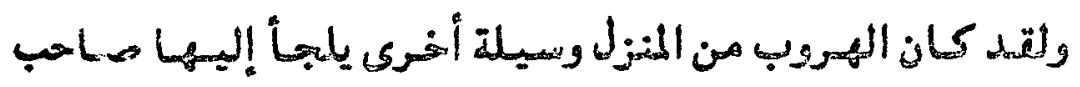

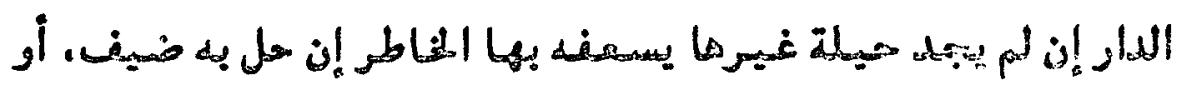

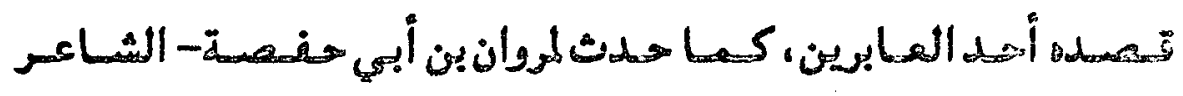

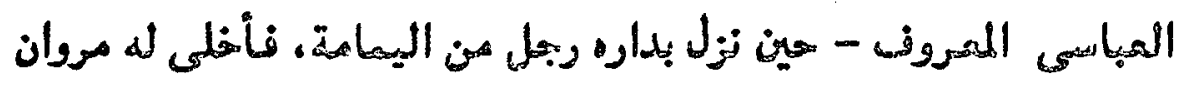

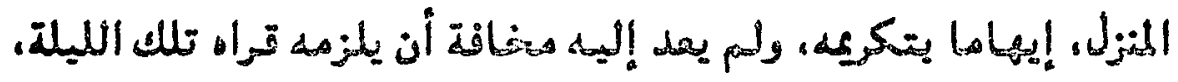

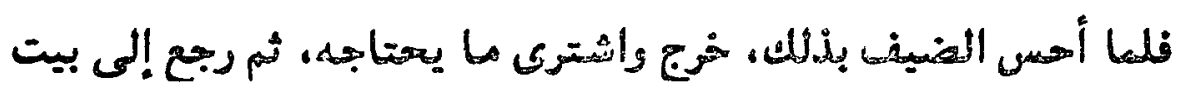

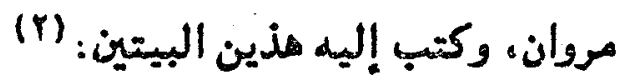

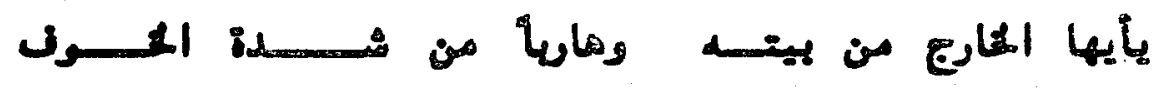

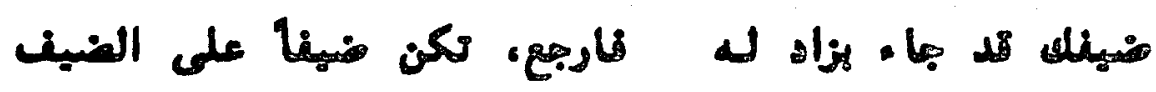

فمروان لم يبال عند تركه المنزل بما يككن أن يقال فى هقه، أو ما

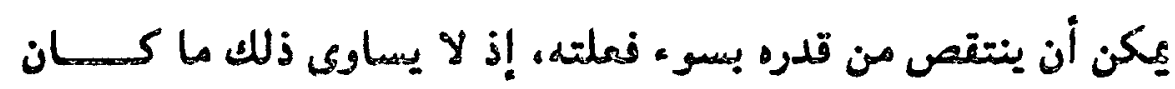

البخلا. - للجاهظ - ص 171 البهار الهلال بيروت 1910. 
يقدره من انتقاص ماله، والحروج عن منهج الملماية له من لا يحسنون تدره، ويباغتون أصحابه بضيافتهم.

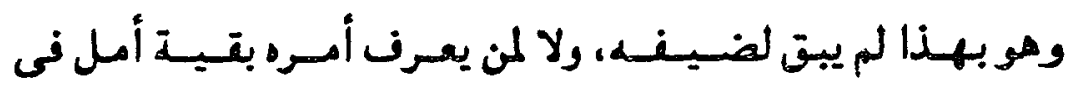

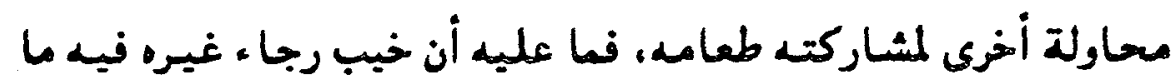

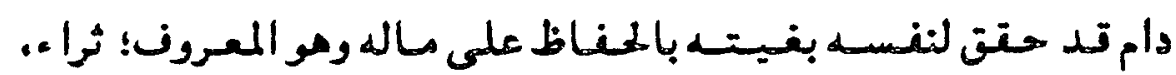
ومنزلة أديية فى عمره.

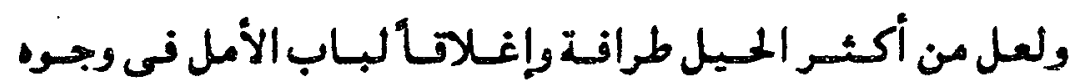

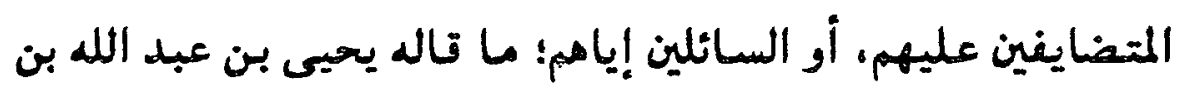

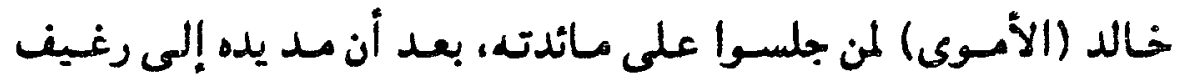

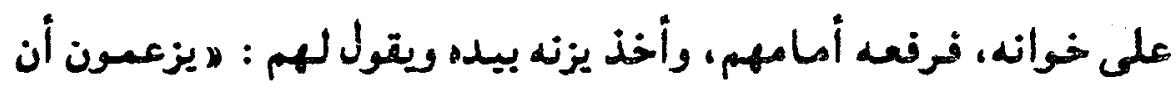

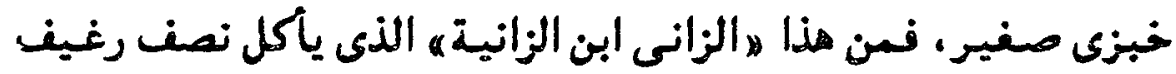
منده|"حيزي (1)

فهو كما نرى لم يتـورع عن بلوغ هدفه ببذا هة تعبيره والوصول

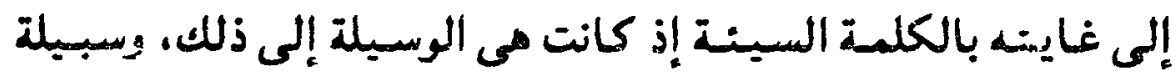

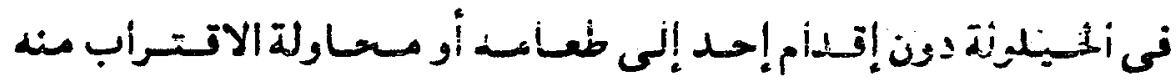

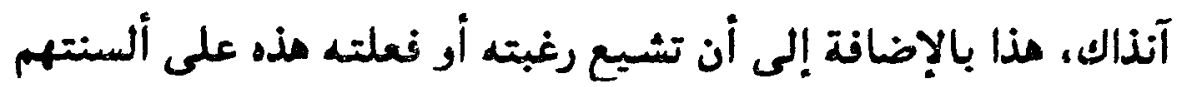
فلا يترب أحد بعدما طعامه إن لم يكن منزله.

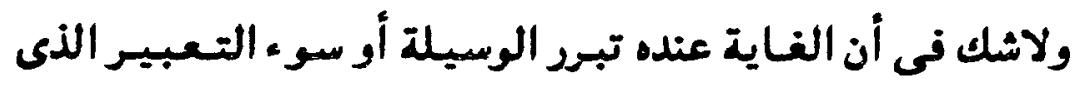

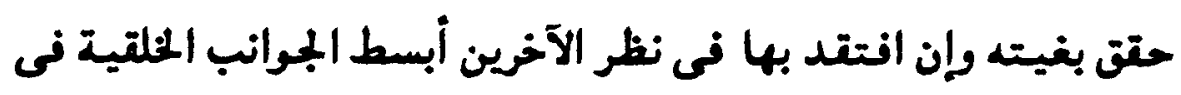
الإنسان. 
كس نجد „ثمامة بن أشرس، لا يتورع أيضا أن يشهر بمن تدم

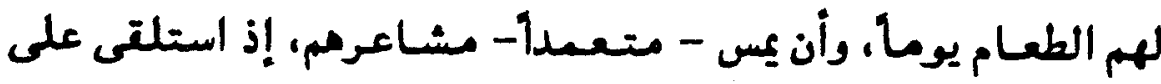

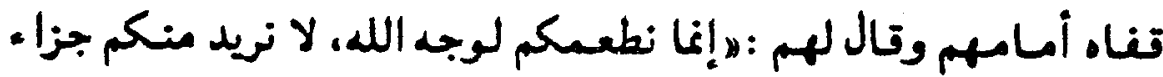

$$
\text { ولا شكور' (1) }
$$

فهو لا يرجو بإطعامهم وجه الله كا تنطق الآية الكيمة، وإلا ما

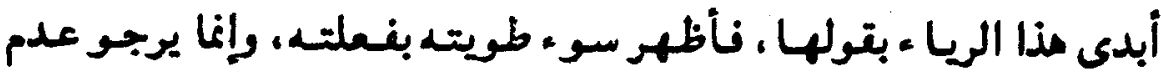

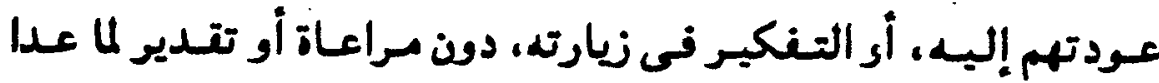
زلك.

ركان الشاعر : هاحيد الأرقطه (Y) يتخذ من سلاطنة لسانه في الهجاء سلاحاً يحول به دون عودة من نزل عليه ضيناً، حتى ليقال :

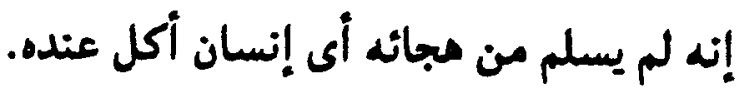

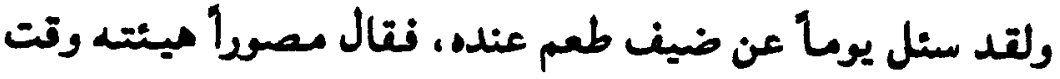
تناول طعامه :

ما بين .للعت الأرلى إذا انمسدرت صين أخرى كليها. كده أكفود (r) فهو يرصد لقيماته، ويتابع انحدارما فى حلقه، ويتدر الزمن بين

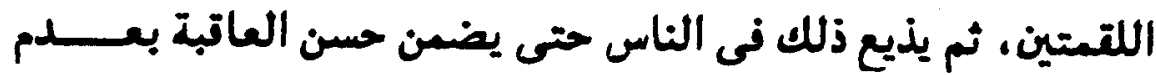

المصلو ننسه ص IV9.

حسبـد الأرتط: أحد شعبراء العصر العباسى، وكان يلتب بهـباء

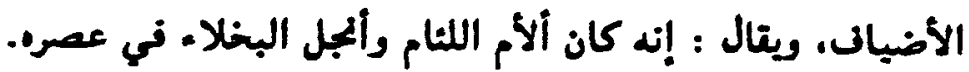


تســده أو حلول أحسد داره، ويذلل يأمن على ماله، وزاده من أمســال زائره هذا.

ويتال إن ضيفا آخرنزل بداره وطعم أيضا عنده، نقال فيه :

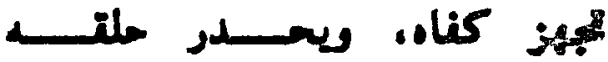

إلى النعد ما ضمت علب الأنامل

أهانا، ومساواه سمهان واتسـل

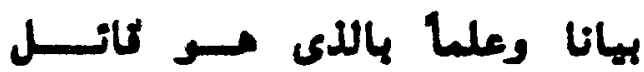

كسازال عند اللقم حتى كأنــ

من العي لمان أن تكلــــم باتـــل

فمع طرانة توله تبدو دقة وصفه، كعاتحس صدق تعبيره ونقل

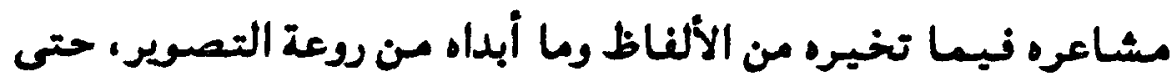

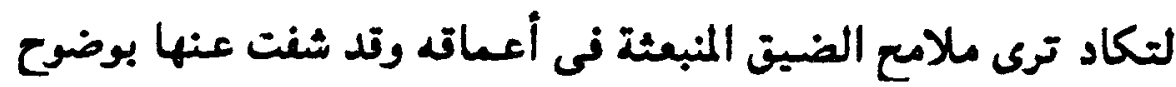

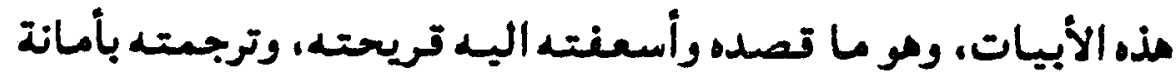
ملكته ومومبته الشعرية محقتة هدفه بإبعاد تاصديه.

وأظن ظنا أن زورة هذا الضيف كانت آخر زورات الضيفان له :

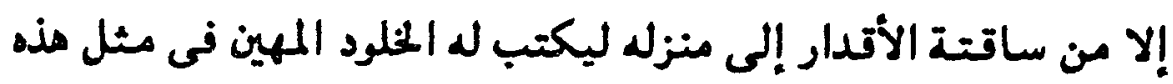

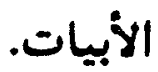

ومذا، أبو الأسود الدؤلى، يقول أيضا واصنا أهد ضيفانه وقت

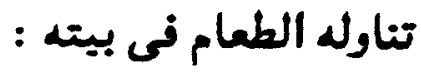

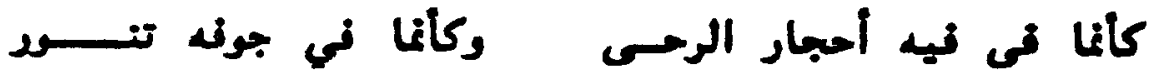


ويخسيل إلى أن مسصدر غضب الثـعـرا +ممن يتـصدون منازلهم

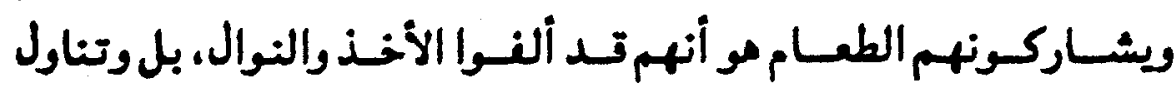

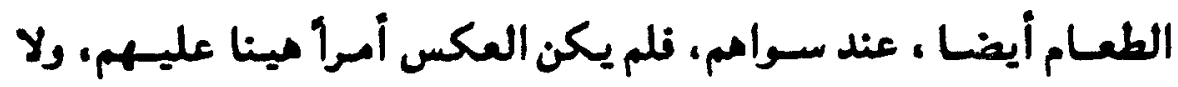

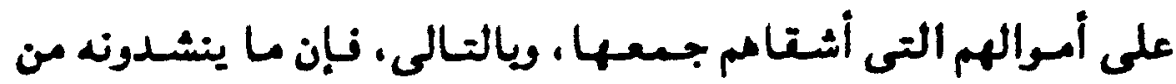

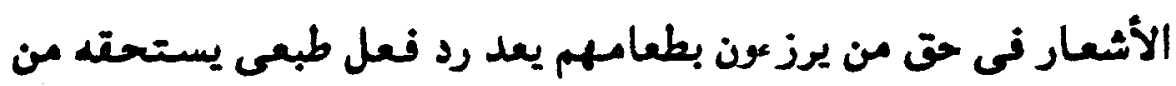

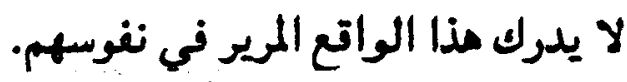

وكان لا مسحد بن أبى المؤمل ه يعلى صوته بالتنويه والتشنيع

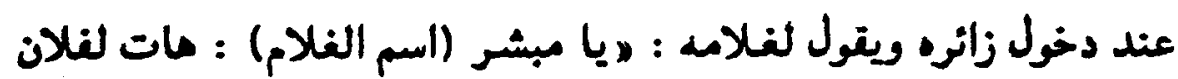

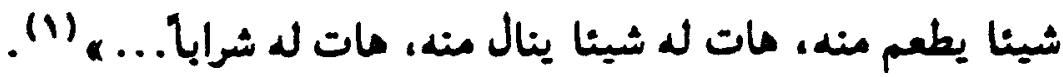

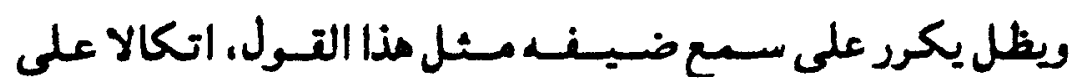

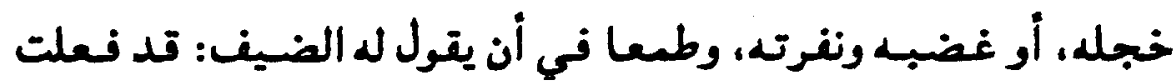
(أكلت أو شريت) فيبرأ من الذم، ويسلم يحيلته مذه زاده، وماله.

أما ل امسد بن الإهمه ، نكان من حيله في إبعاد الطامعين عن

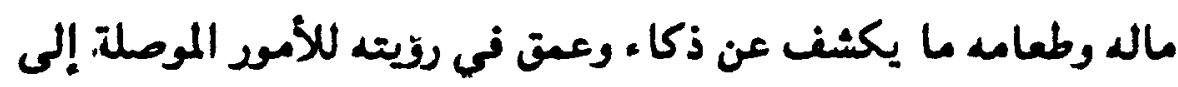

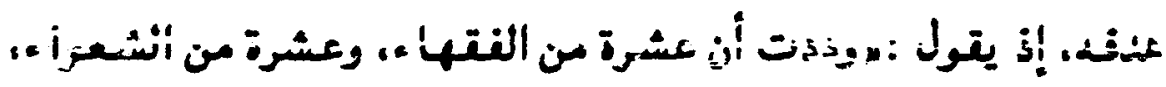

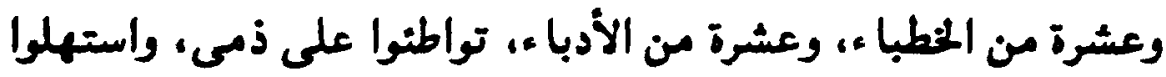

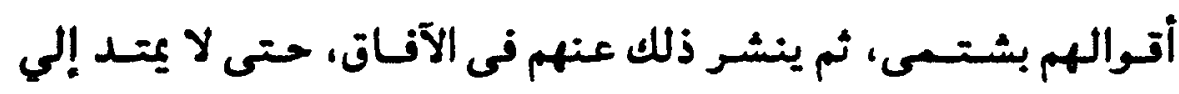

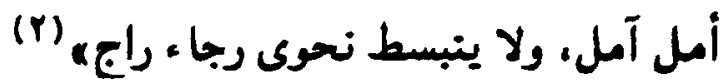

البغلاء : للجاحظ - تحقيق طه الحاجرى ص 19. 


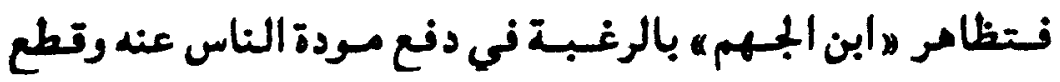

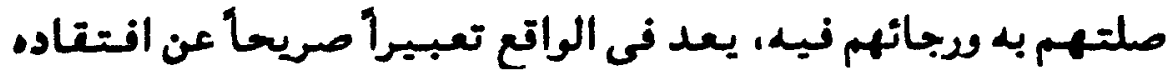
بالفعل عودة التريب والبعيد.

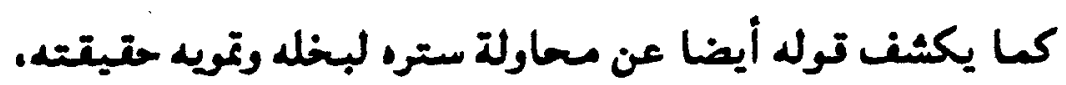

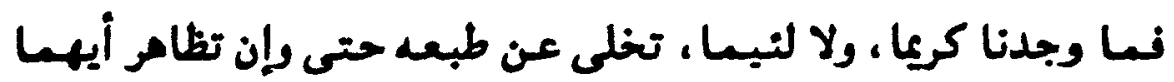

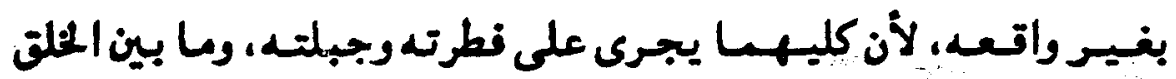
والتخلق لا يخفى على بصير.

ومن المحيل الطريفـة أيضـا والتى اتخــها مؤلاء البخلاء وسيلة

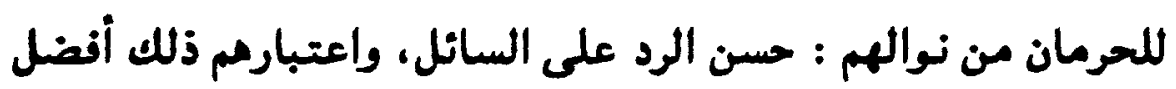
من العطا \&، حيث يغنى القول فى نظر أصحاب مذه الحيلة عن الفعل. فبحنظون المال، وينالون الرضا من السائل.

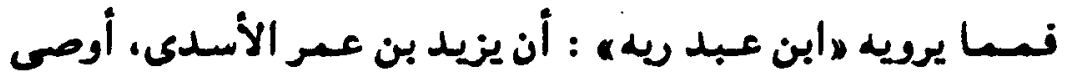

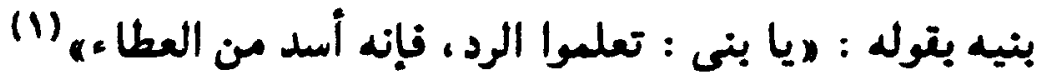

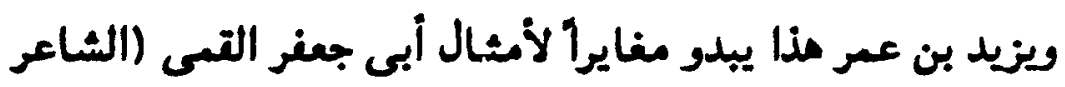

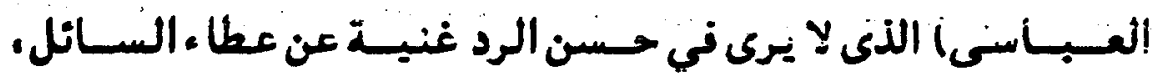
(r) نيقول: با جماد اللسان من غعر جود

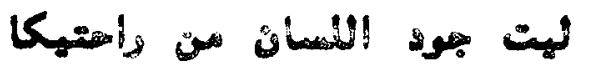

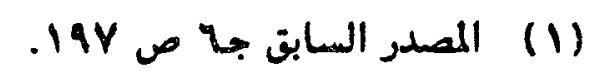

يتيمة الدهر - لأبى منصور الثعالبى - جئ ص (Y) 
إذ يتسنى لمن هذا شأنه ألا يخنس بخله وراء لساند، وألا يستر

عطا مه بمن رده، فيقصر نواله على توله، وهو في نظره مأ أمر غير حمبد.

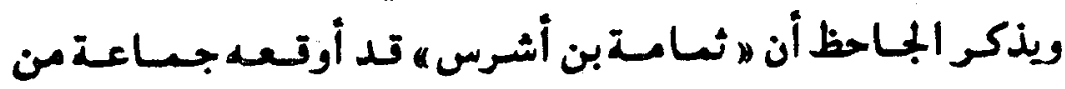

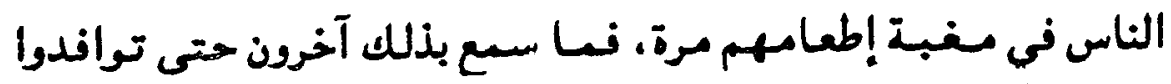

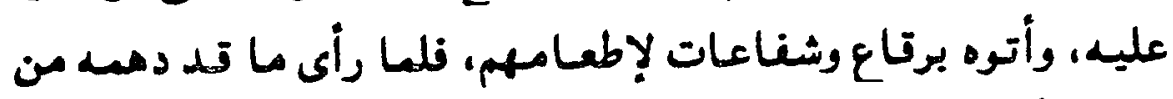

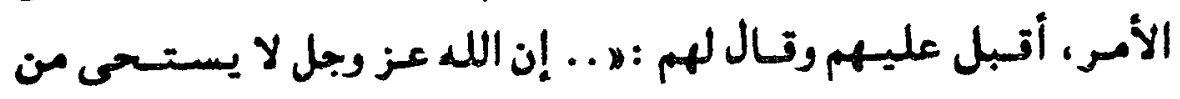

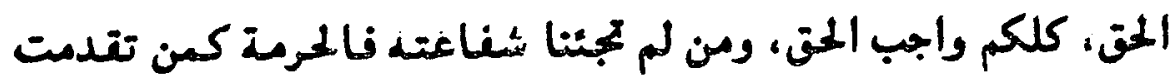

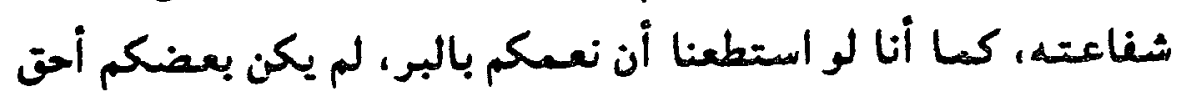
بذلك من بعض، ذكذلك أنتم إذا أعجزنا ، أو أو بدالنا.

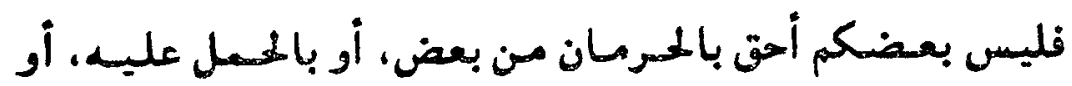

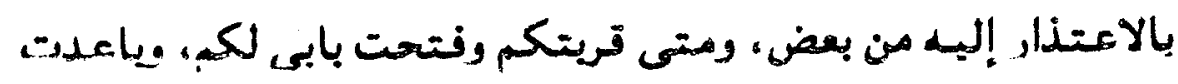

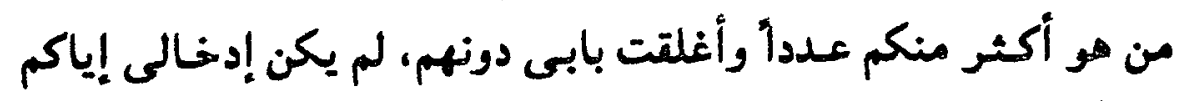

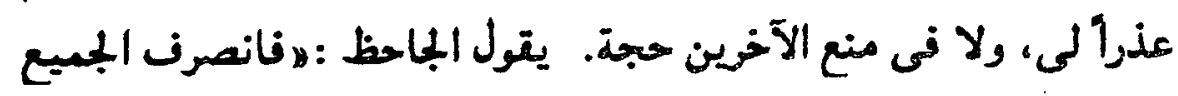
(1) ولم يعودوالهن

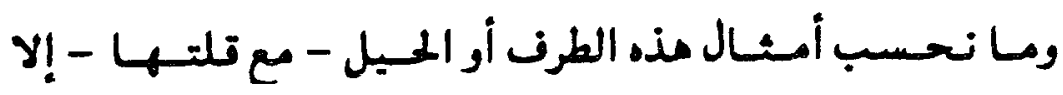
مجسدة فى جملتها مشاعر استيا ـ أصحابها ، ومبدية بوضوح نفرتهم

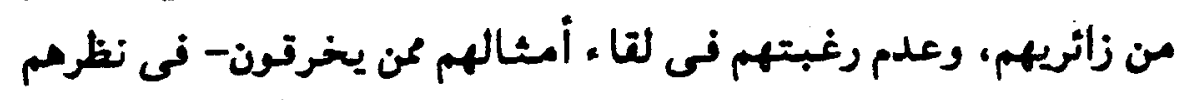

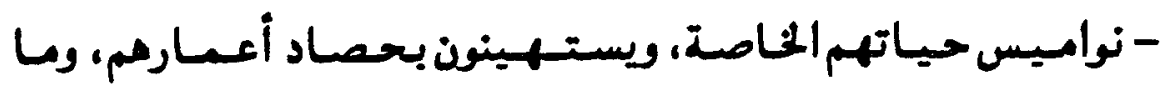

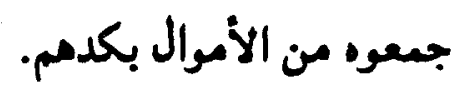

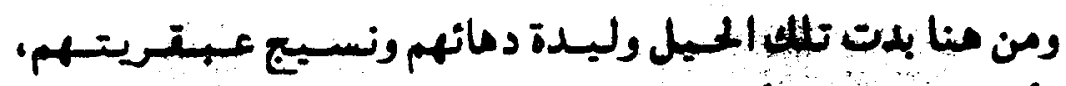
وسياج أمن يحنطون به أعز ما لديهم في المياة ومو المال.

البخلاء - للجاحظ - يحتيق طه الحاجرى ص 199. 
وكان طبيعبا أن تكثر حيل البخلاء بكثرة المرتادين لبيوتهم

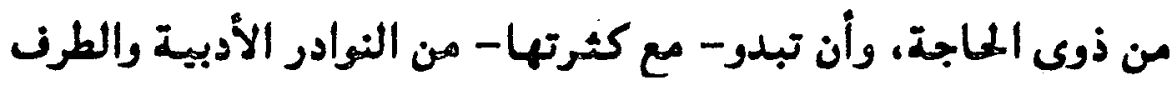

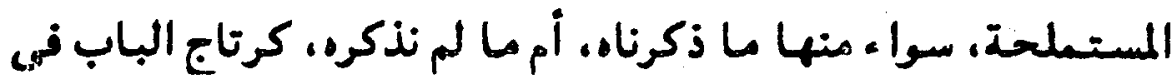

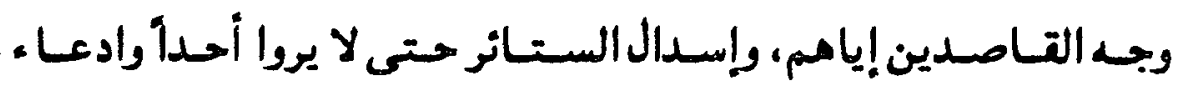

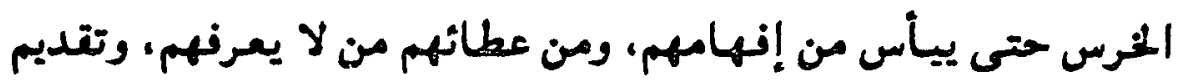

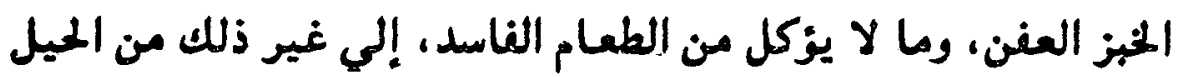
الموائل دون بلوغ القاصدين إياهم شيئا ما يأملون.

ولكنا آثرنا ذكر القلبل التزاما بنهجنا في هذا العسل، وأيضا

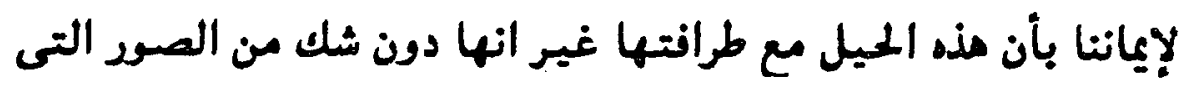

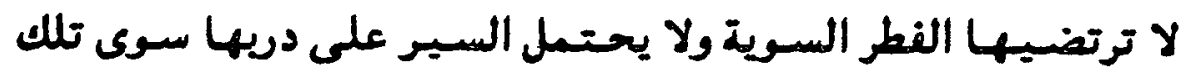

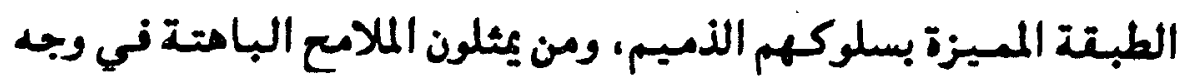

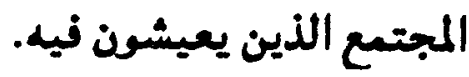




\section{الدوافع النفسية للحمرمان.}

إن ما تبلوره سلوكيات تلك الجماعة ججاه غيرمم من المحتاجين فى صودة حرمانهم أو مد العون لهم حتى بنضلة ما لديات لديهم من الأموال

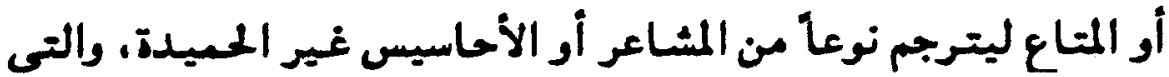

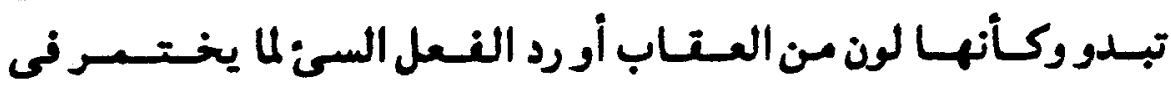

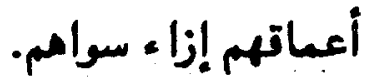

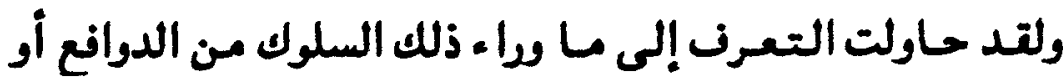

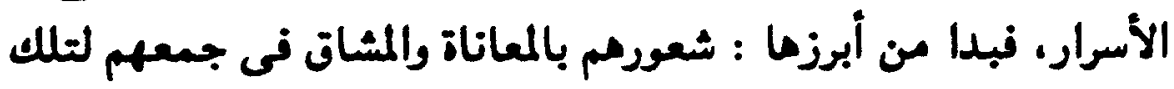

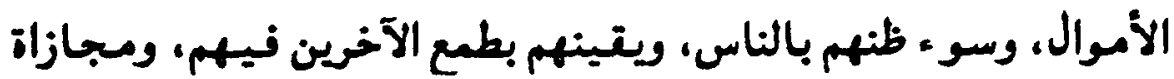

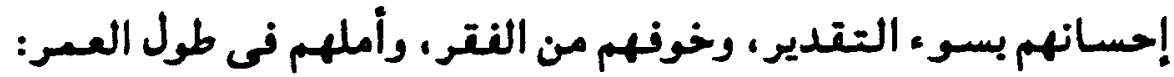
إلى غير ذلك ما سنتاوله في مقامنا مذا.

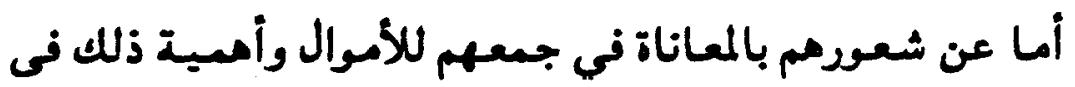

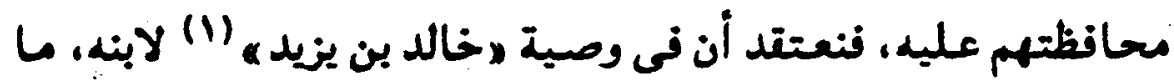

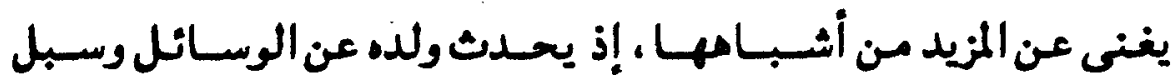

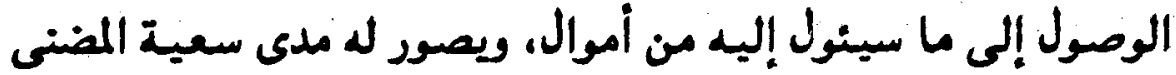

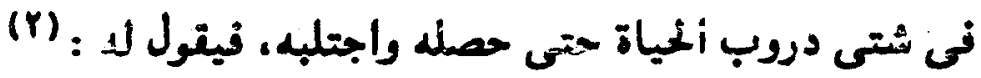

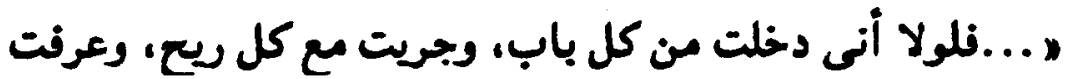

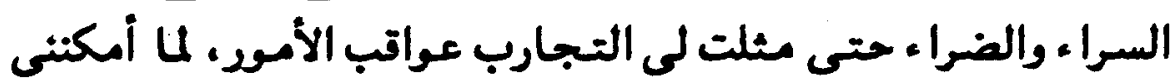

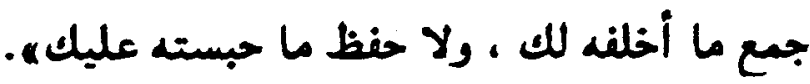

خالد بن يزيد مو : خالويد المكدى مولى المهالبة. وكان قد بلغ في اليل

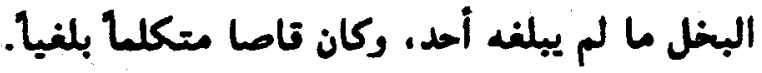

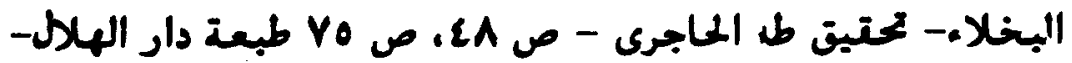


سل عنى صسعاليك الجسبل ، ورؤوس الأككراد ، ومسردة الأعسراب. والفتاك، واللصوص: كيف بطش بساعة البطش ، وكيف حيلتى ساغة

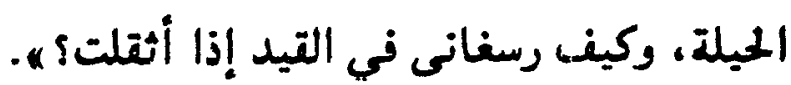

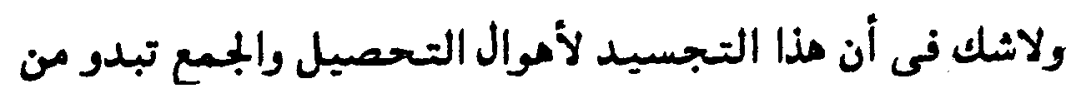

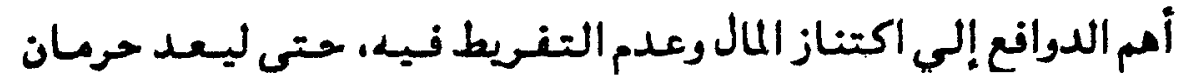

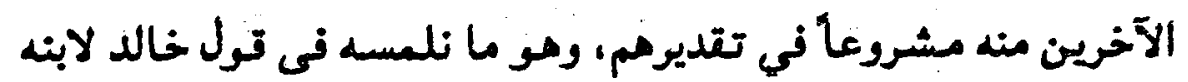

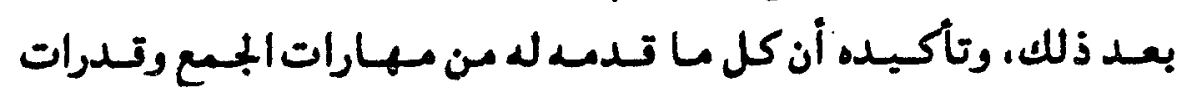

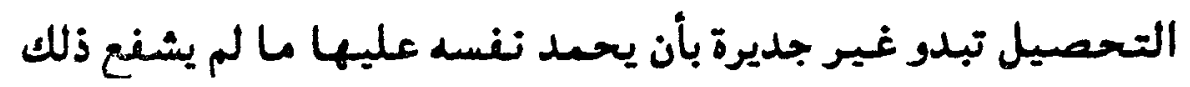

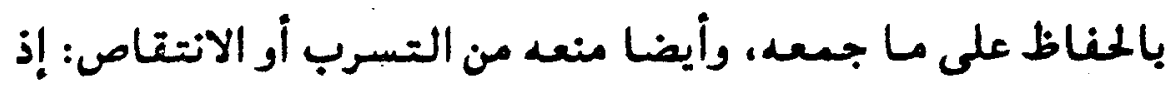

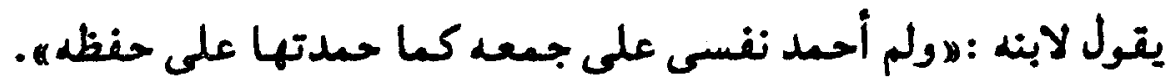

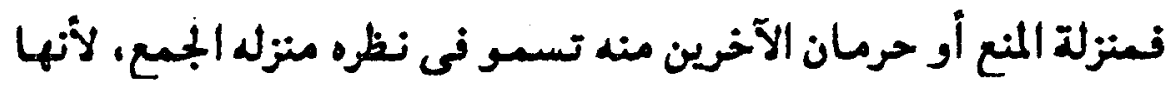
النتيجة المرضية لكل مقدمات المعاناة والتحصيل السابتة.

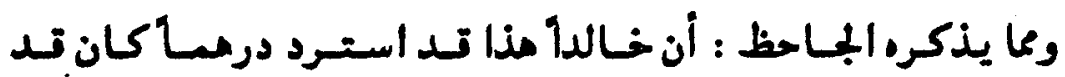

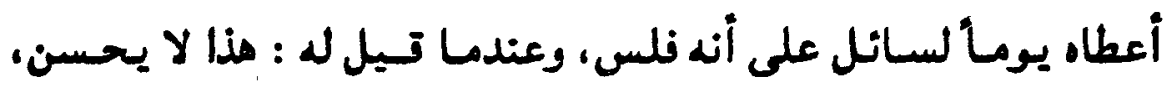

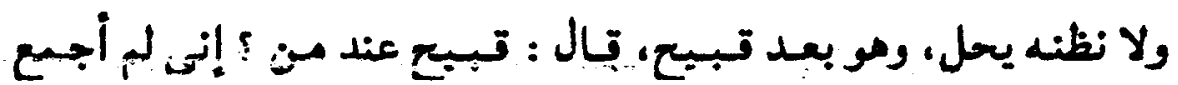

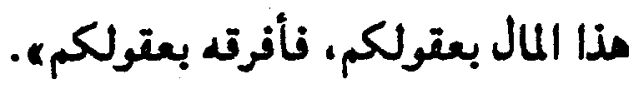

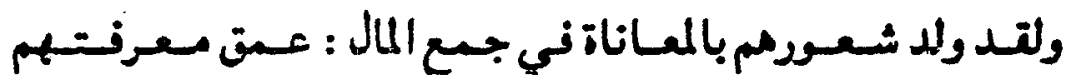

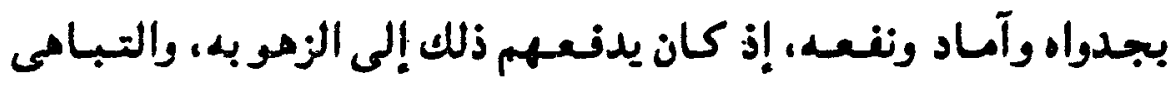

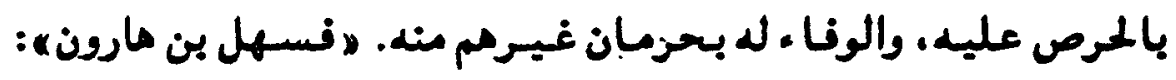

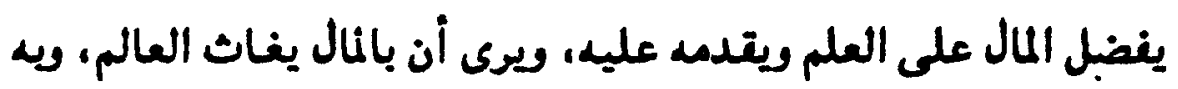

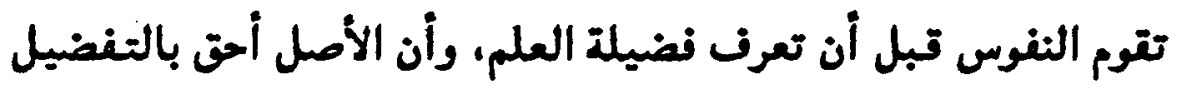
من الفرع. - منوم اليعوس 


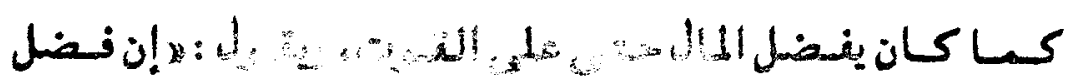

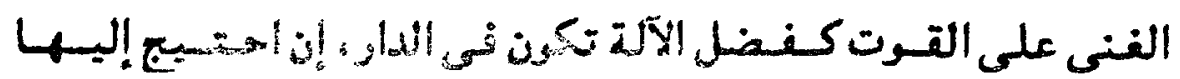

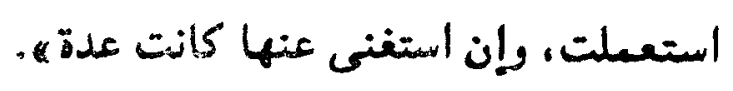

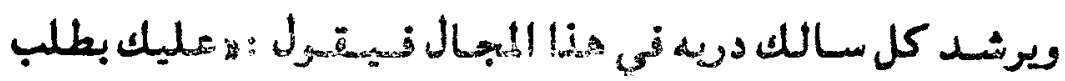

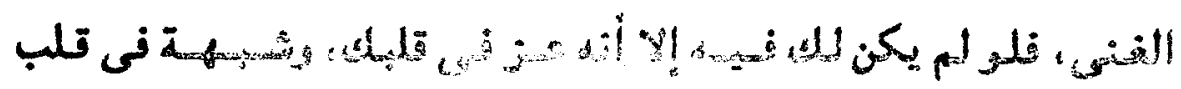

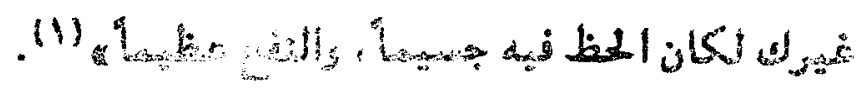

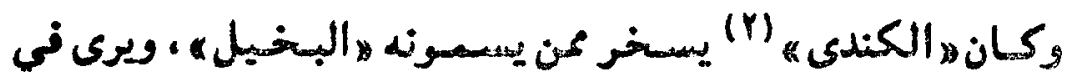

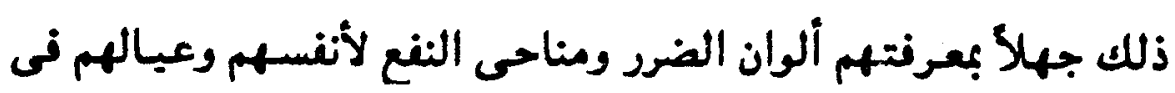

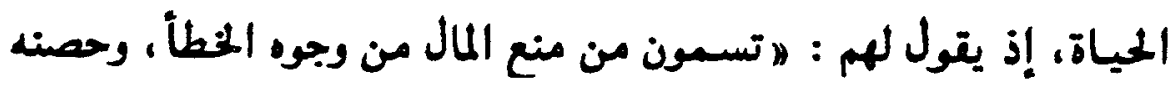

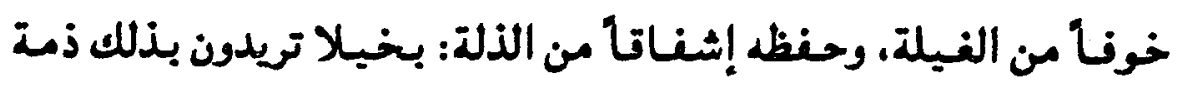

وشينه؟.

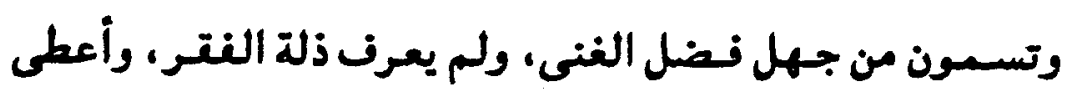

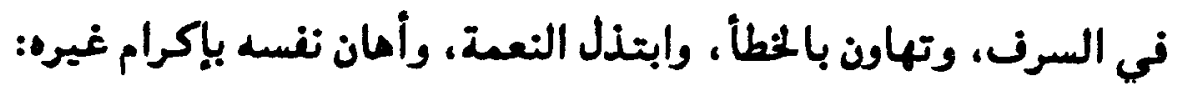

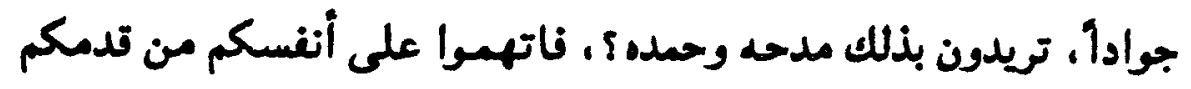

على نفسه، فهو أجدر أن يخطى علي غيره، (r)"

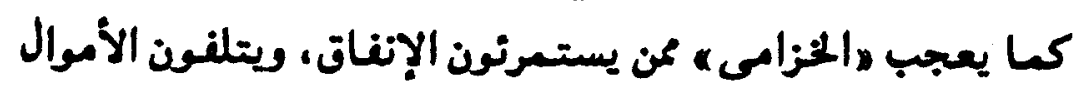

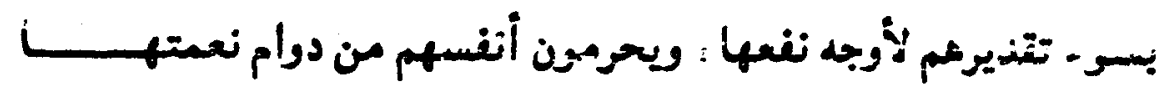

$$
\text { البخلاء - يحتيق الحاجرى - ص ع اومابعدها. }
$$

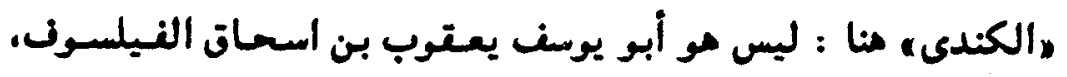

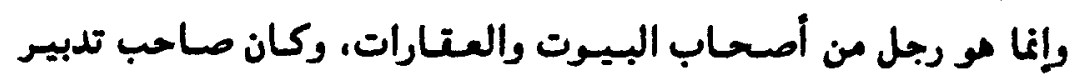

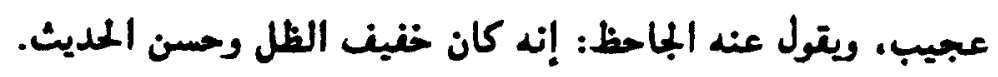
المصدر السابق ص • لومابعدما. 
والتستع بحيازتها ، نبسسى المنفت مغسداً، والمسكلك مصلحاً، ويرى

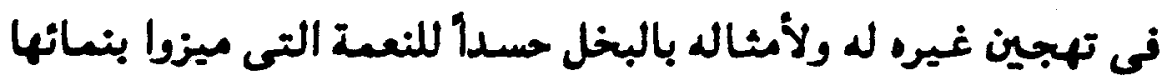
وحايتها من الانتغاص. وطبعى أيضا : أن يتولد من حبهم للسال وحرصهم عليه: سوء

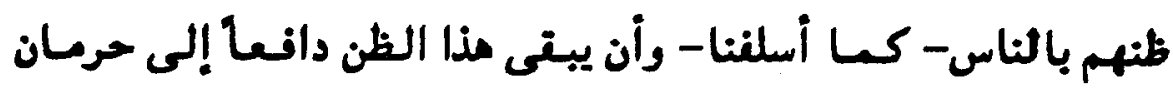
الآخرين ، وفنض تضائهم لسواعم ما مم بأمس الحاجة إليه.

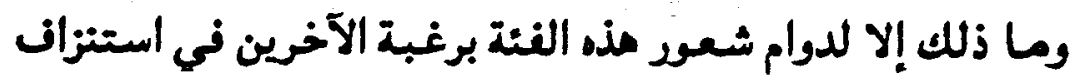

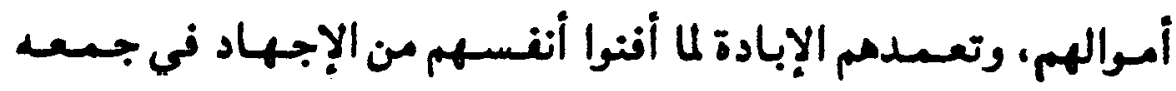
والمفاظ عليه.

فخالد بن يزيد، حين أوصى ابنه بحنظ ما سيئول إليه من مال.

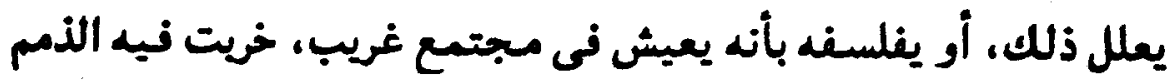

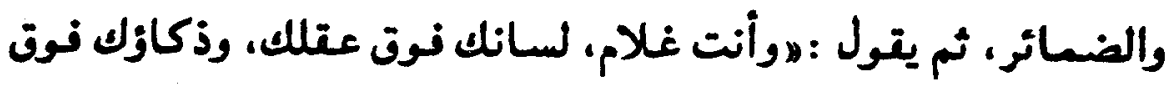

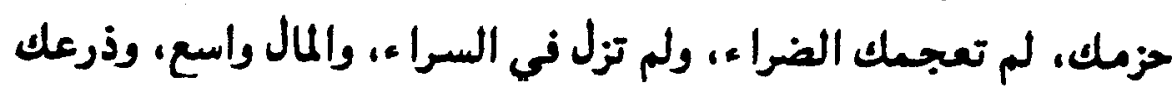
ضين، وليس شئ آخوف عليك عندى من حسن الظن بالناس.

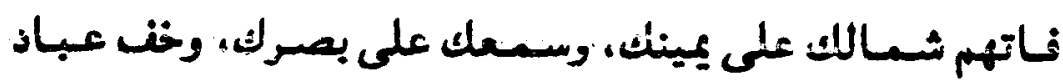

الله على حسب ما ترجو الله ه (1).

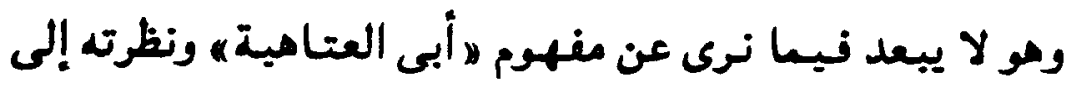

الناس. إذ يقول : (r)

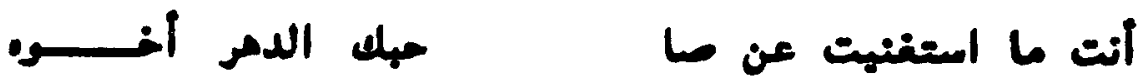

$$
\text { البخلاء - تحتيق الحاجرى - ص • م. }
$$

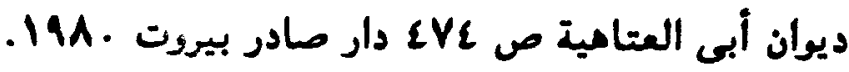


ماعد مول كـــ

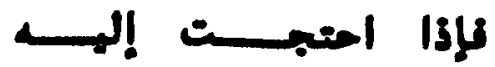

(1) : كسا يتول

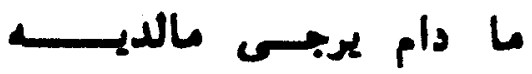

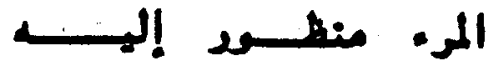

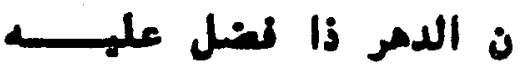

من كنت تهف أن كهـ

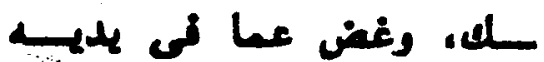

Lat

ويرد „الأصمعى - وكان مشهـورأ بالبخل والإمسـاك - يوما

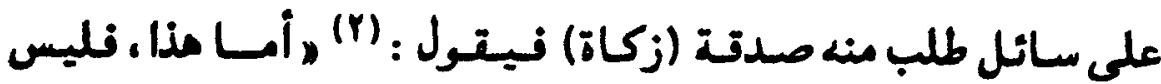
يسعـة إلا بيت المال، ولو ومبت لل درمبا واحداً لفتحت على مـالى باباً لا تسده البجبال، والرمال، ولو استطعت أن أجعل دونه ردما كردم وليك يأجوع ومأجوع لنعلت.

كــا يتــول : هإن الناس فـاغـرة أفـوامهم نحسو من عنده درامم، فليس يمتعهم من النهس إلا اليسأس، وإن طسعـا: لم تبق راغبـة، ولا

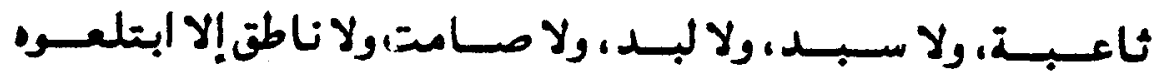
والتهبوهن (r)

ويبلغ سـو الطن بسهل بن مارون أن يختم - فى بيته - علي

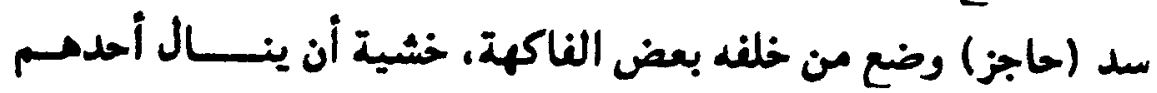

$$
\begin{aligned}
& \text { المصدر نفسه ص .27. }
\end{aligned}
$$

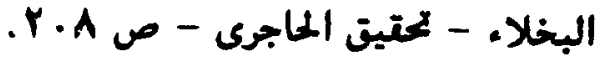

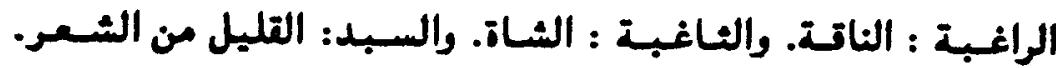

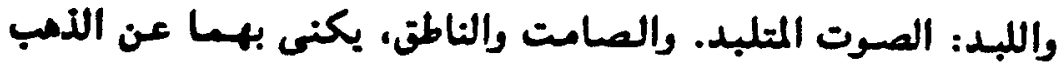

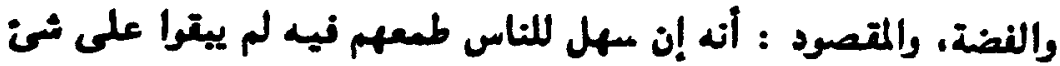

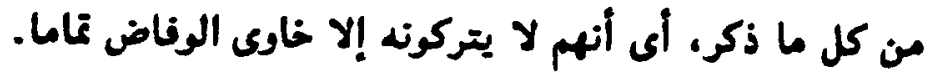


شينا ، ونجده فى رده على من عاب فعلته هذه يقول : ها ... وعبتهونى

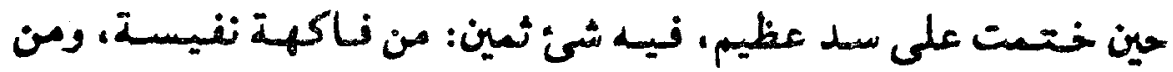

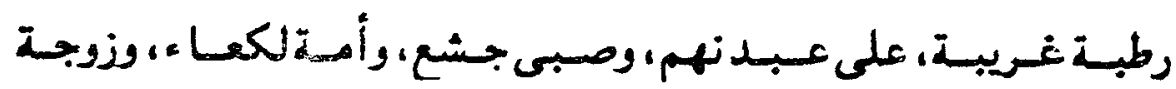

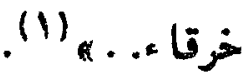

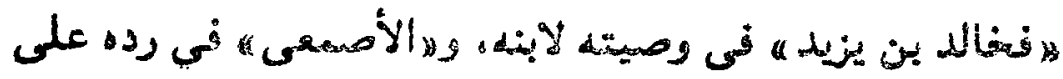

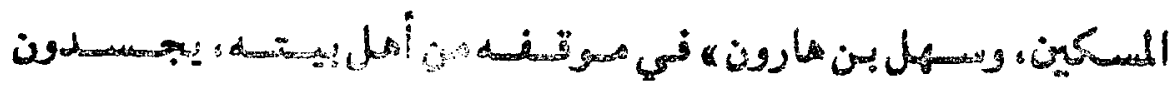

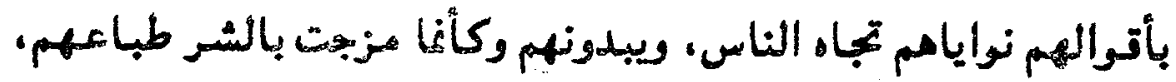

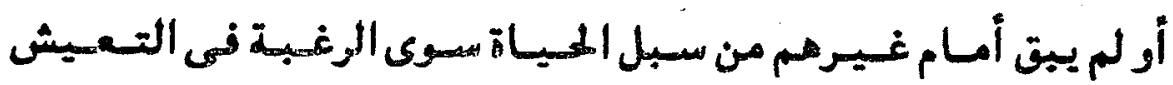
بأموالهم، أو اغتصاب ما اشعامم جمعه مند.

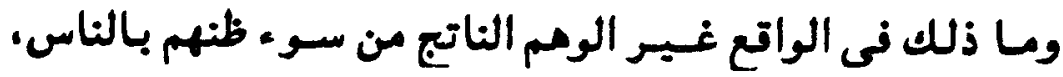

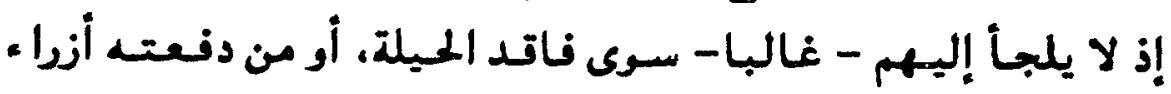

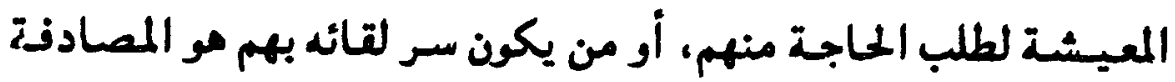

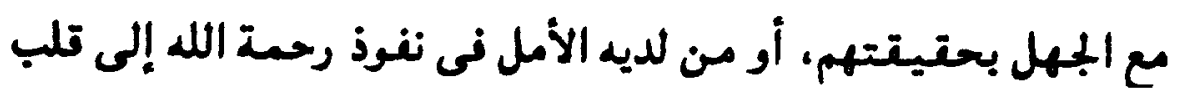

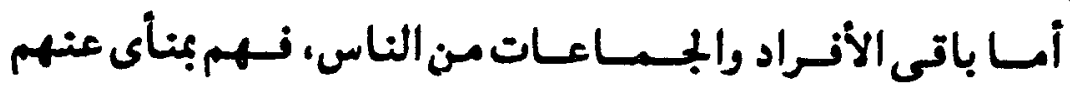
لمعرفتهم بحقيتتهم، ويقينهم أن فاقد الرحمة لا يرحم.

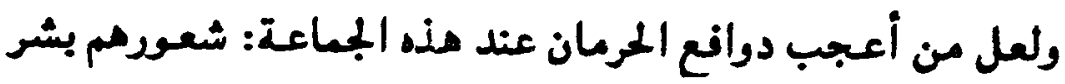

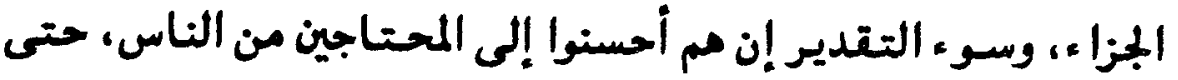

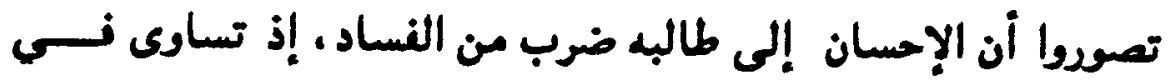

$$
\text { البخلا. - - حتيق الحاجرى - ص Ir ومابعدها. }
$$


$-|r|-$

نظرمم: الإعطا) ، والحــرمـان، حـيث لا يعسود عليـهم من الأمـرين مـا

يسرمبم.

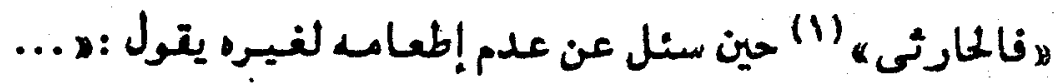

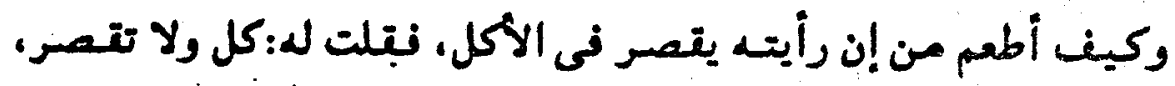

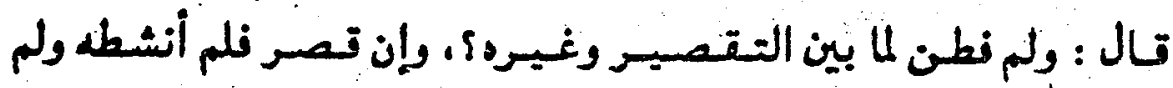

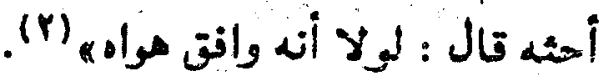

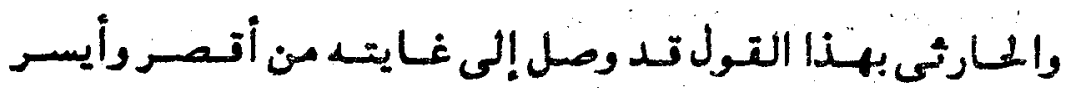

طريق، إذ وجذ فه بيخلد أو عدم إكرام من تصده : تخلصاً من الشعود

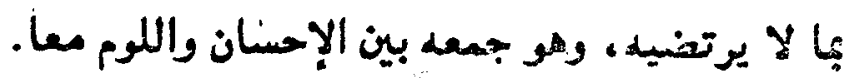

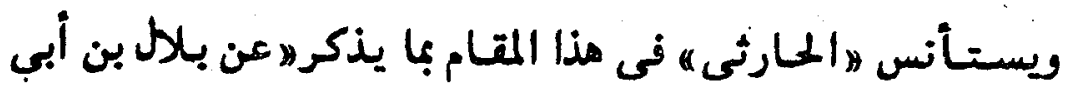

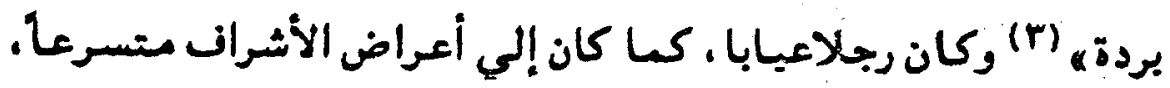

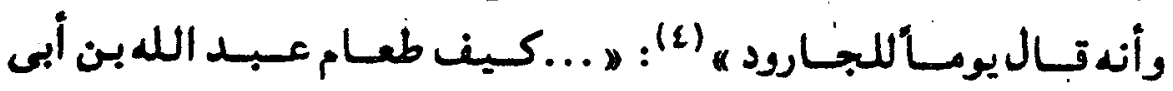

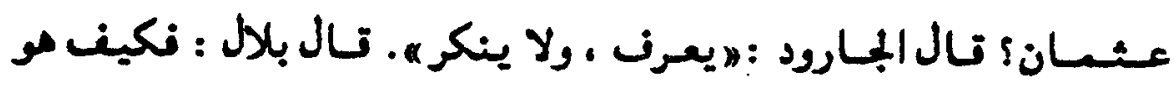

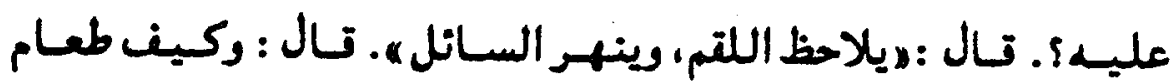

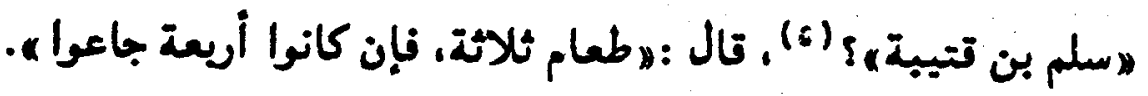

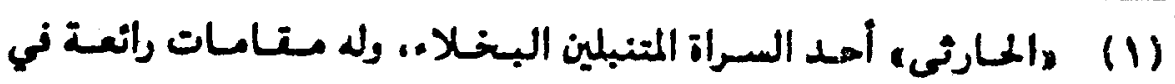

تصوير البنل. واحتجاجات البخلاء من أمثاله.

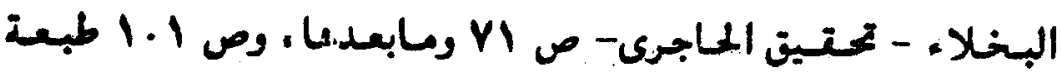

بيروت .191.

(r) بلال بن أبى بردة : مو ابن موسى الأثعرى، وعسل تاضيا. وواليا

على البصرة.

الجارود : مو ابن أبى سبرك، وكان شاعرا متشبعا حسن المديث.

(c)

(0) ملم بن تتية : كان أحد ولاة البصرة فى العصر العباسى الأول. 
تال بلال : نكيف طعام "المنجاب بن أبس عيبنةه (1) قال الجارود :

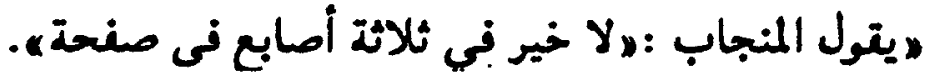

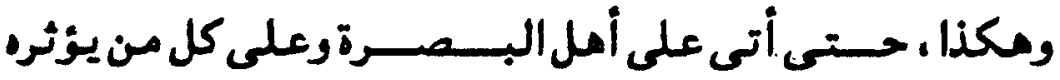
بالدعوة، ويالآنسة. والحاصة، ويحكسه فى مالد. نلم ينج منه إلا من

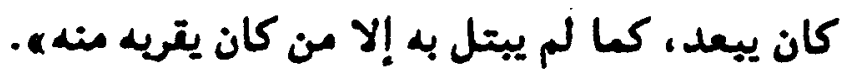

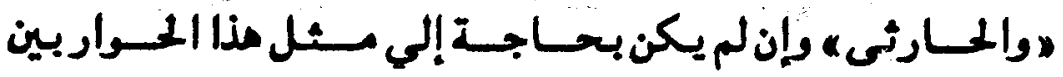

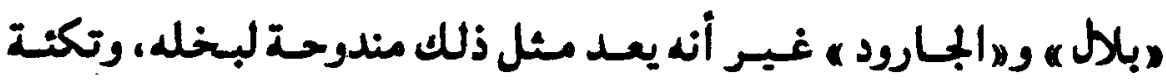
للحرمان ومنع الإعطا ـ.

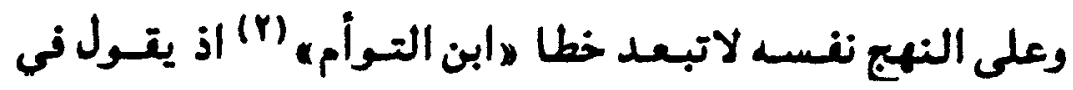

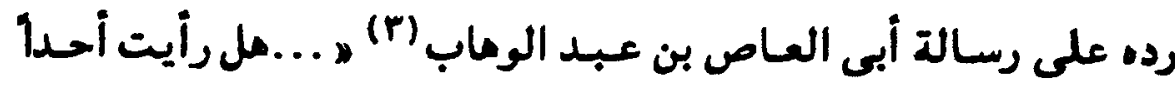

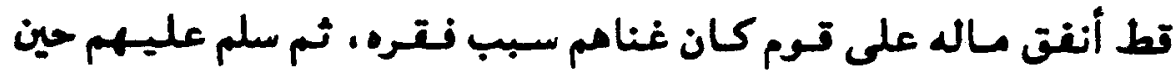

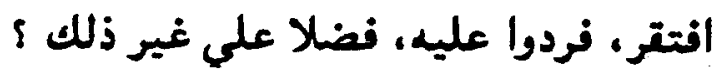

أو لست قد رأيتهم بين محمق له ومحتجب عند؛ وين من يقول:

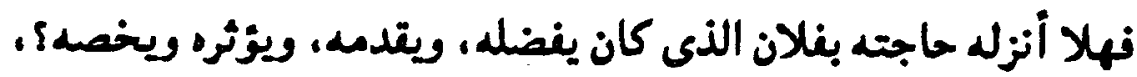

المبجاب بن أبى عيبنة: أحد السراة البغلاء فى البصرة في عهد | الباحظ. ابن التوأم, الرقاش : كان من العنلاء ذوى الرأى والنلسنة، كا كان

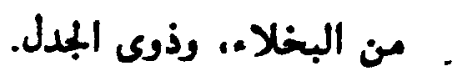

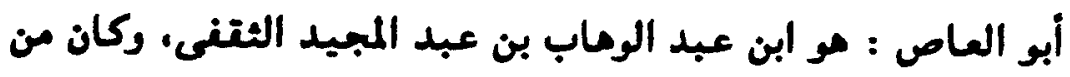

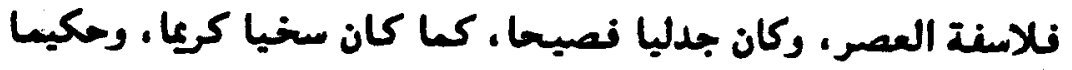




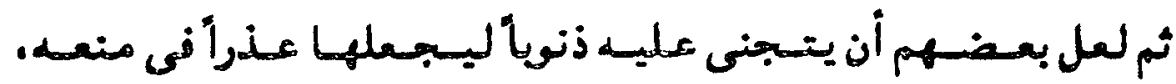
وسبيلا إلى حرمانه ه "

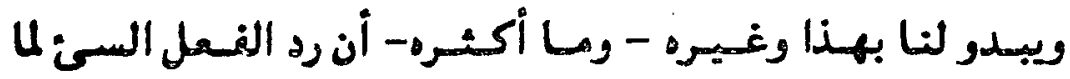

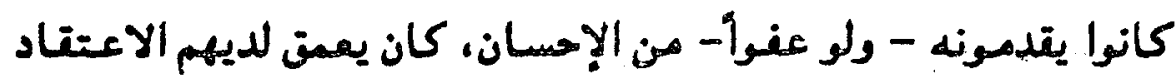

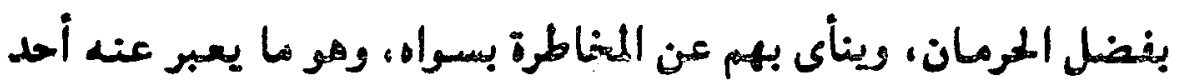
(Y) : شعرائهم بقوله

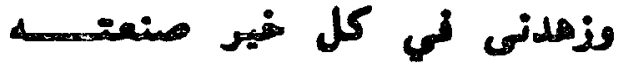

إلى الفاس، ما مركت من ملا الثكر

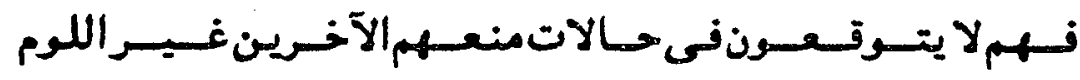

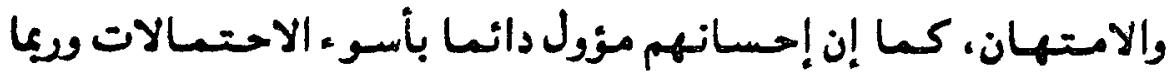

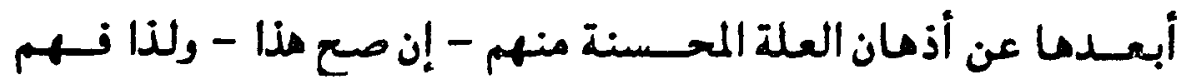
يفضلون المرمان عن مقابله، إذ لاشك في أن اللوم مع المحرمان أكثر نفعاً لهم من اللوم مع الإعطا ـ.

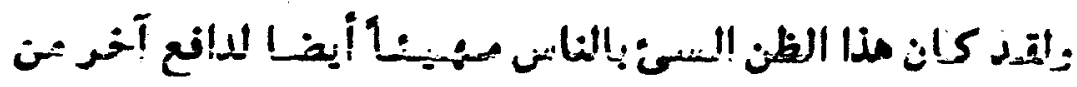
دوافع الحرمان ومو الشعور بطمع الناس فيهم، بل إنهم اعتبروا ذلك

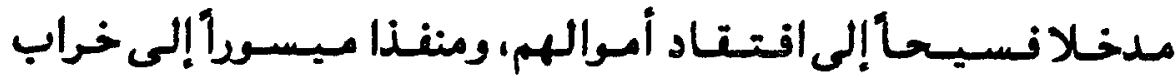
دورمم.

ولعل مذا ما جعل "المززامى يشعر بالمرم حين أقرض صديته

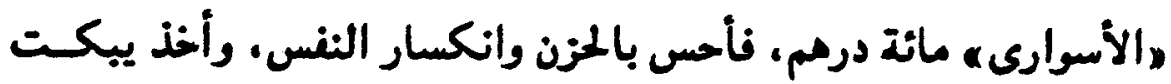

$$
\begin{aligned}
& \text { البخلا. - تحقيق الحاجرى - ص IVY. } \\
& \text { العتد النريد جr ص rYr. }
\end{aligned}
$$


نغسه، ويهون من أمره على غبره بهذه النعلة أو المدعة التى وقع فى إلى

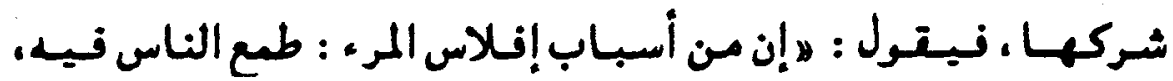

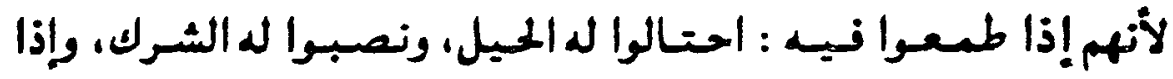

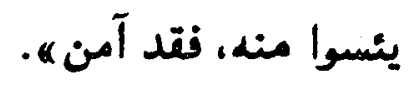

ويبلغ به الأسى من نعلته مذه، أو من إقراضه صديقه مذا المبلغ

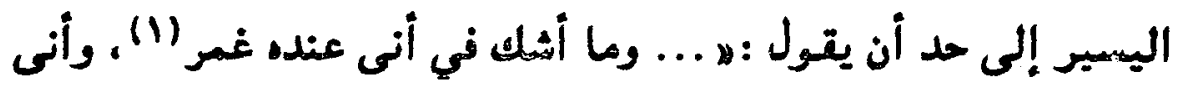

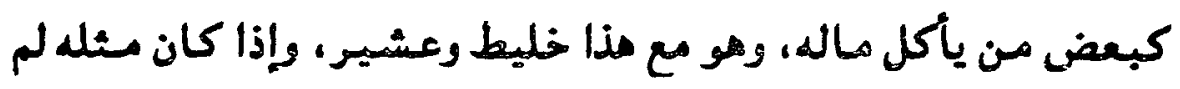

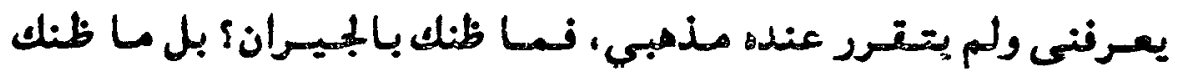

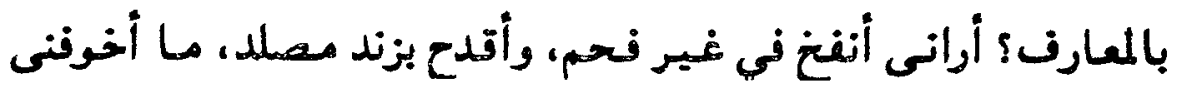

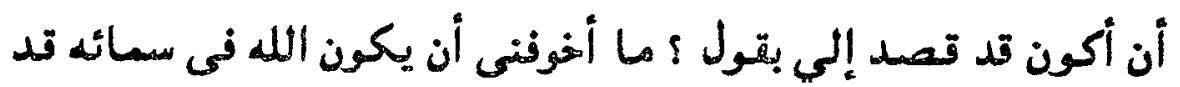
إلي أن ينقرنى" .

ولعل ذلل راجع إلي أن هالمزامى ه لا يرى مبررأ لاستهانته با

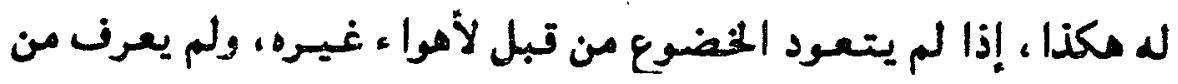

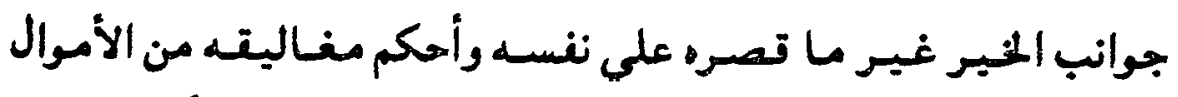
على الآخرين، ولذا تجده يخشى العاقبة، ولا يتـوقع العفو أو الإحسان من الله إنبه بالإبتاء على ما لديه من مال.

كسا يصور لنا „ابن التوأمه مدى خشيته من طعع الناس نيه

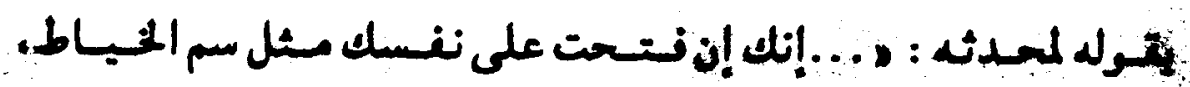

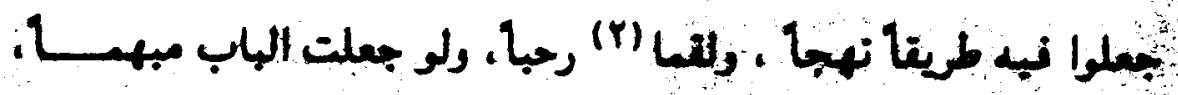

(1) (1) الغمر (بنتح الغاء) : غير المجرب للأمور. (Y) اللتم : الطريق الواضع الفاءع : (r) 
والتفل مصمتاً، لتسودوا عليك من فوقلك.. ، (") فإن لم تستعمل

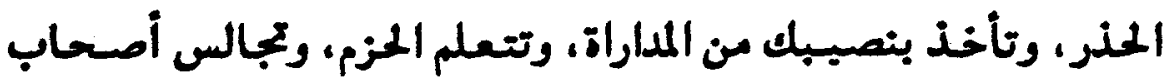

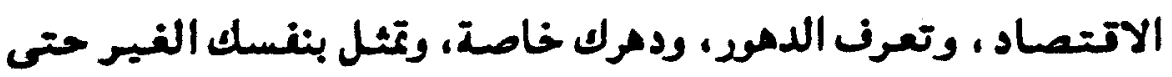

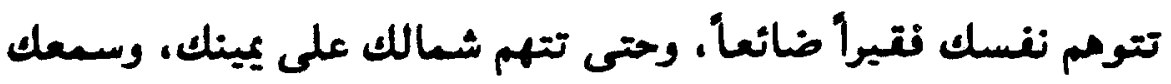

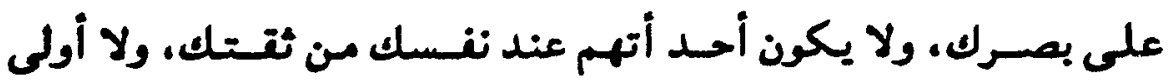

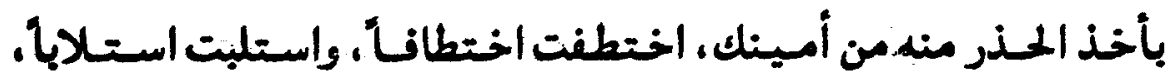
وذويؤا مالك وتحينوه، وألزموه السل ولم يداروه ه. (r)

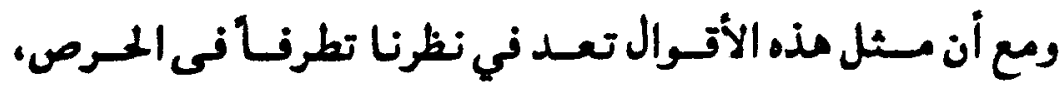

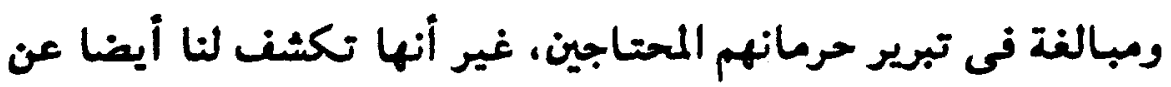
مدى رغبتهم في الإمساك وأصالة حيلتهم فى الشح.

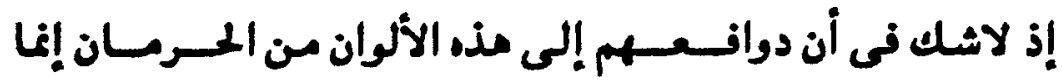
تتسلل من أعماقهم إلي سلوكياتهم، وتنطوى عليها نغوسهم طوال

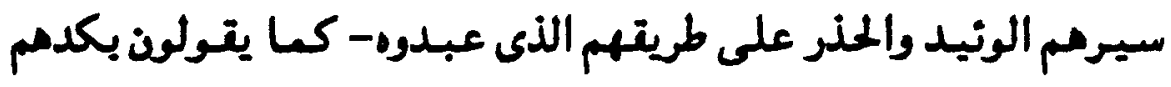
وشقائهم- ونهجهم غير المألوف لسوامم.

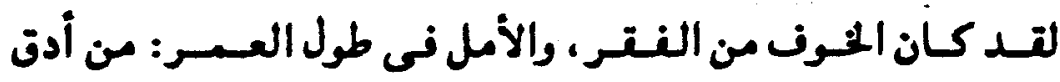

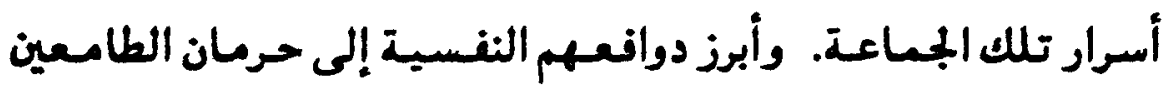

ألبخلاء - تحقيق الحاجرى - ص AVA

المصر ننسه ص 191. 


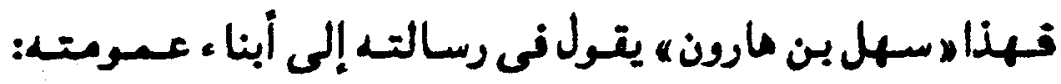

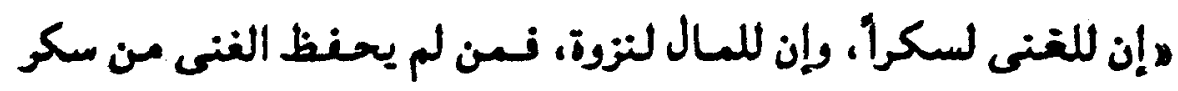

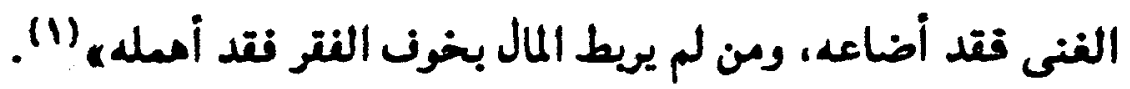

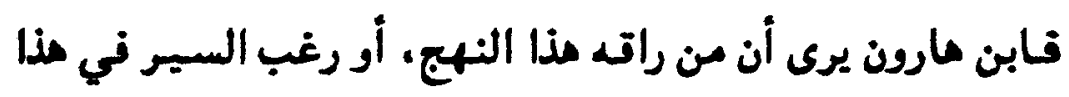

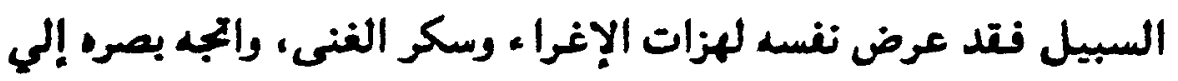

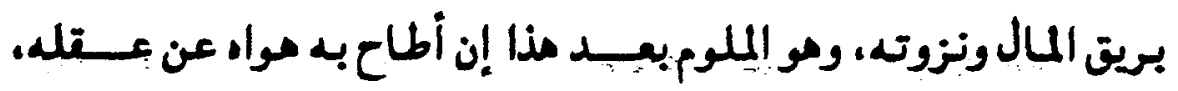

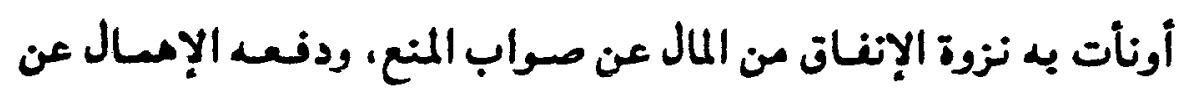

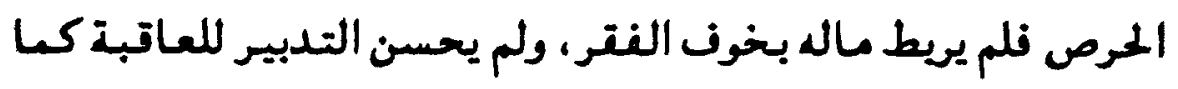

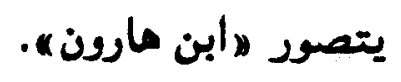

وأعتتد أيضا أنه يدفع - بهذا النهج- إلي الحذر في كل المطال،

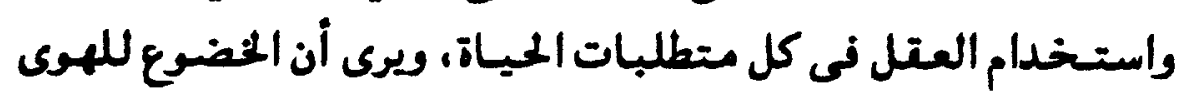
سبيل الضياع، وأن الإنغاق منحدر الفتر ومهبط الهوان الهيان.

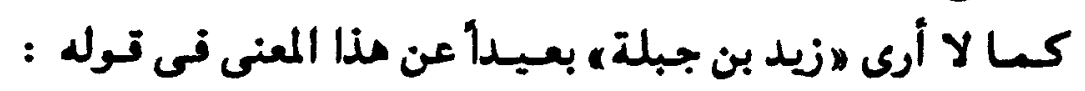
״ليس أحد أفقر من غنى أمن الفقره.

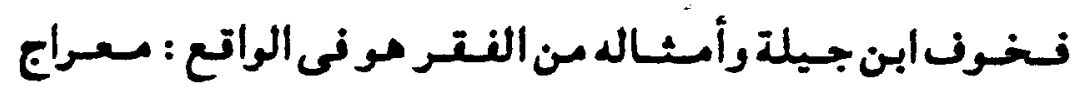

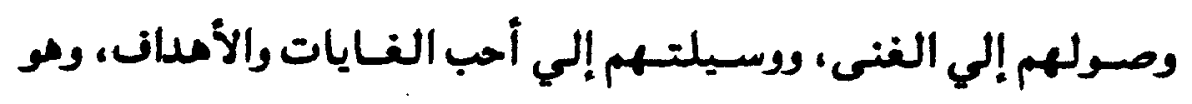
الحفاظ عليه من الضياع.

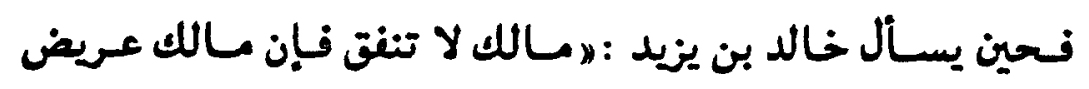
يقول لهم : پالدهر أعرض منه ه. 
وعندمـا يقـال له : „كأنـل تؤمل أن تعـيش الدمر كله ؛ يقـول :

لا ، ولكنى أخاف ألا أموت في أوله (1).

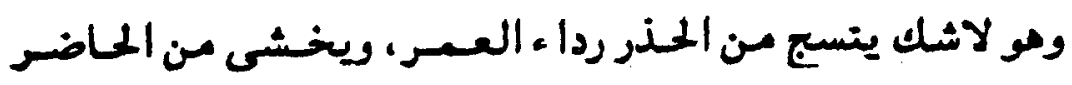

فجأته ومن المستقبل نقمته وغدر الأمل به.

ولقــد أوضح هذا أيضــا : لاســـل بن مارونه في رسـالتـــ إلى

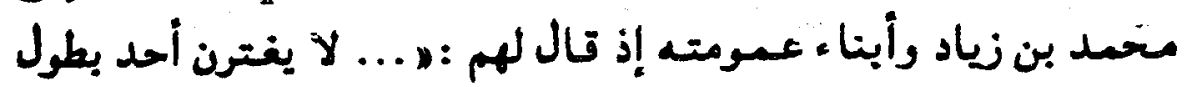

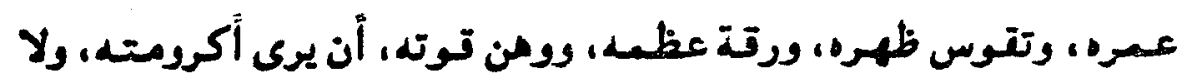

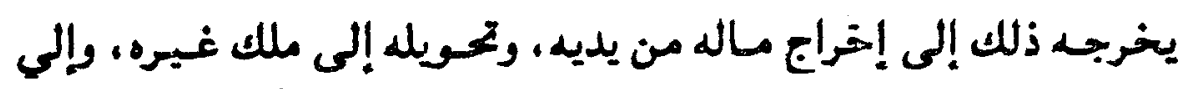

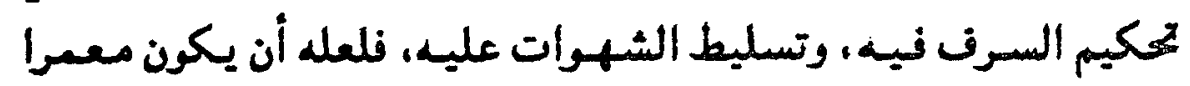

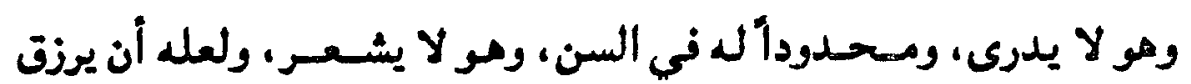

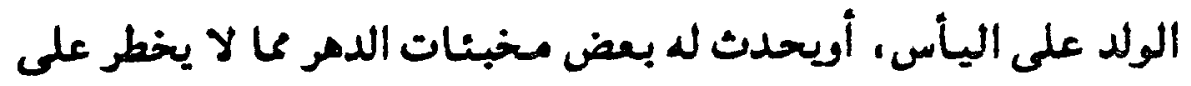

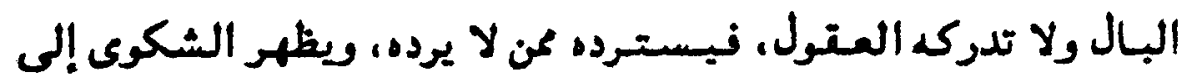

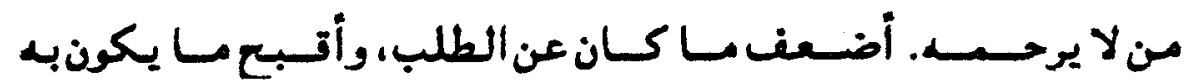

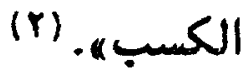

فإلى هذا القدر بتحسب سهل بن مارون لطول العمر، ويقدر لا

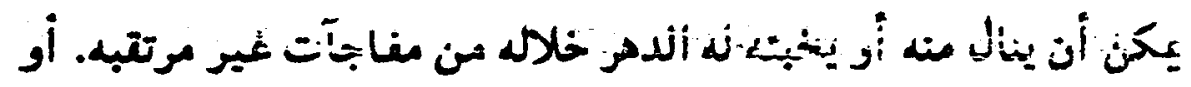

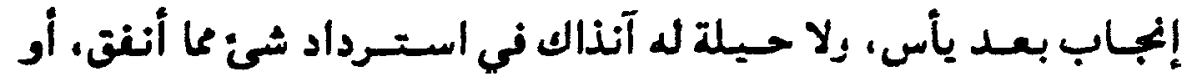

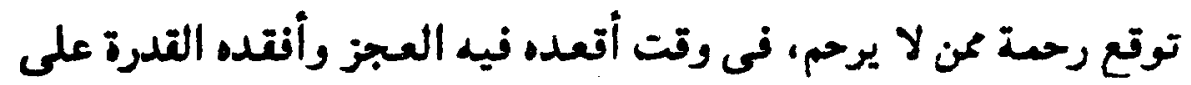

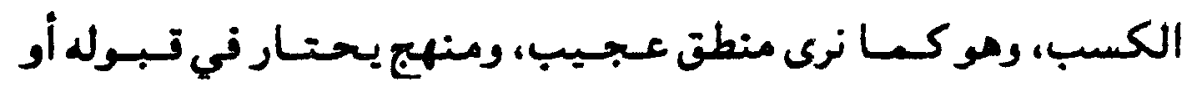
رفضد أولوا الألباب.

$$
\begin{aligned}
& \text { العتد الفريد جـ ص IIV }
\end{aligned}
$$

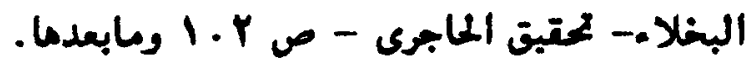




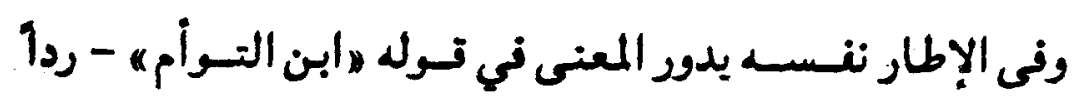

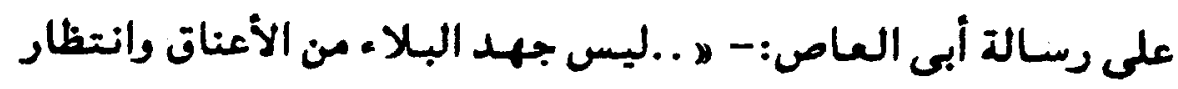

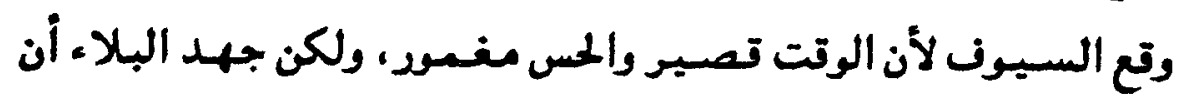

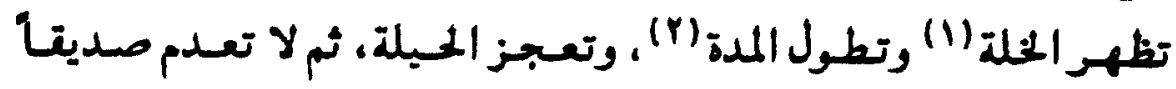

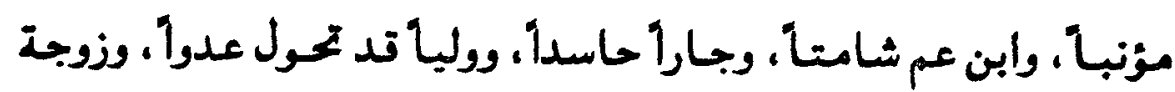

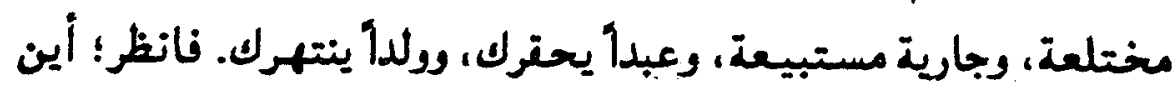

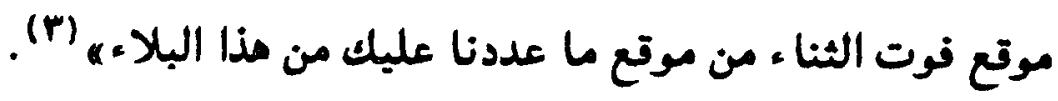

نتـأمل كيف صسور الحيـاة والأحيا ، من حسوله بعد أن حسال المال

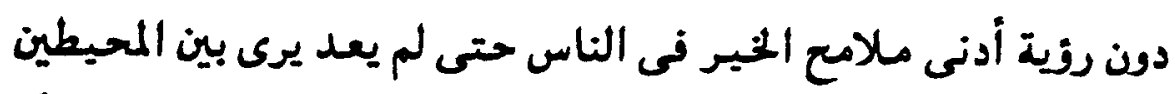

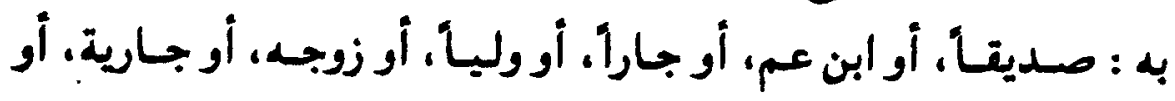
عبدأ، أو ولدأ، إلا ومو متريص به، ومظهر له اله ما لا يرتضيه من التول

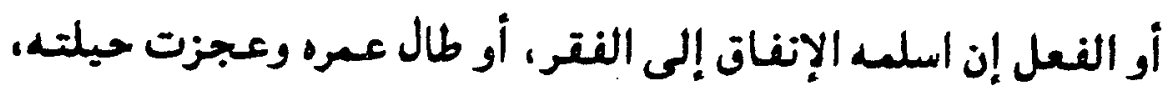

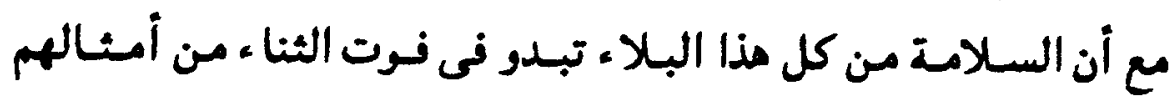

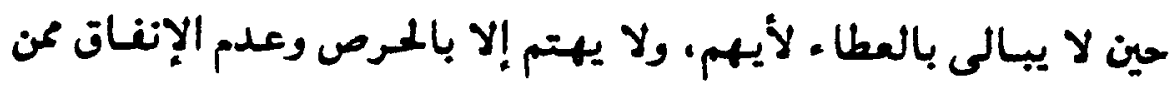
يعز عليه فراقه ويفتديه ينغسه ومو المال؛.

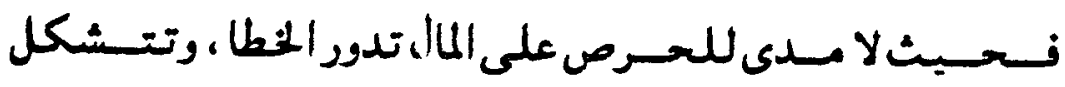

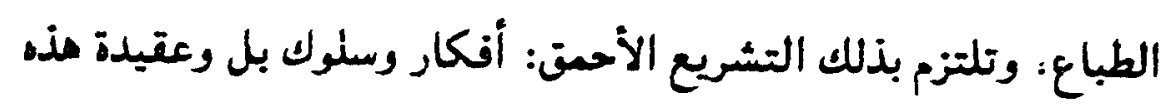

الملة : الحاجة.

المدة : العمر.

المصدر السابق ص IVV. 


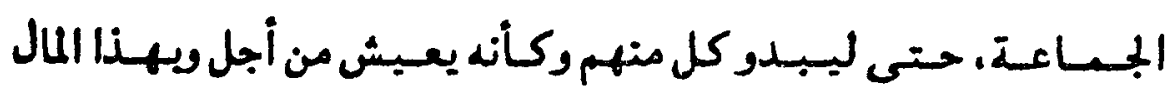

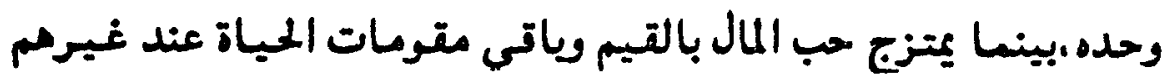
من الناس.

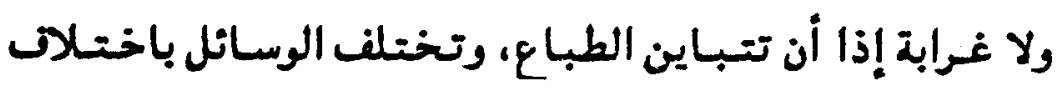

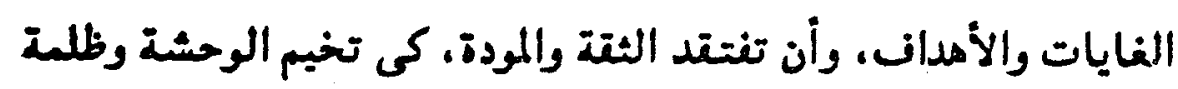
الهدف بين تلل الجماعة ويين سواها من أسوياء البشر. 
نام

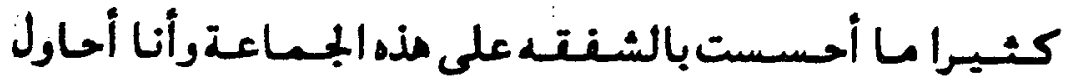

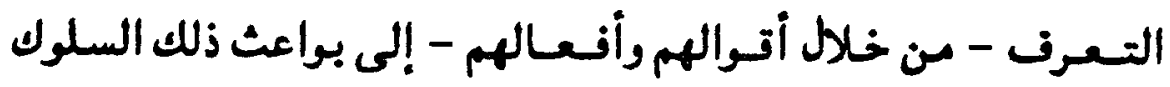

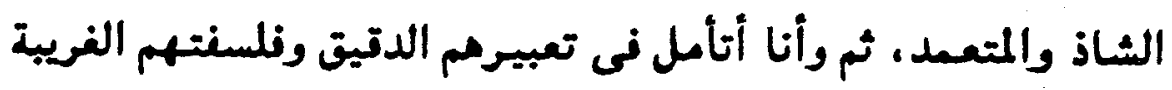

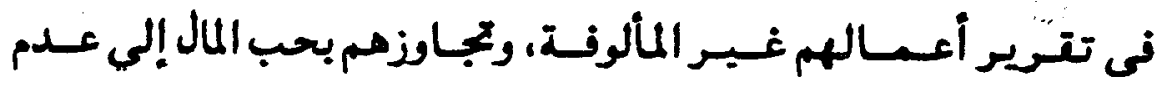

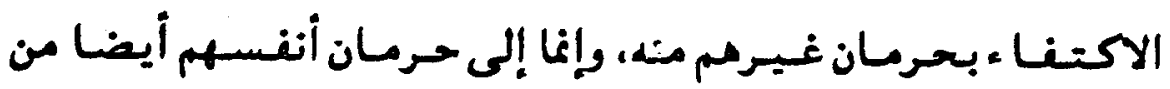

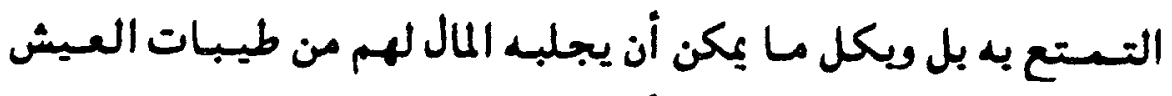

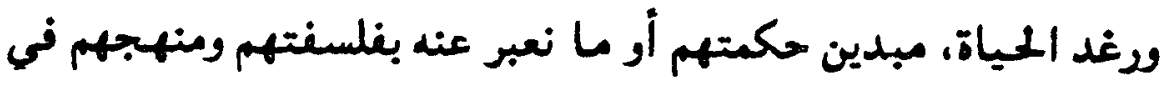
كلتا الحالتين.

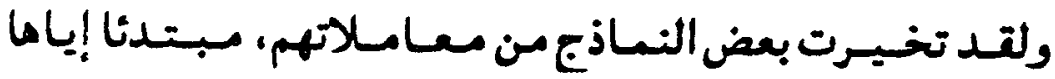
ببعض الأحداث أو التجارب التي دفعتهم إلي الإنصاح عن فلسفتهم

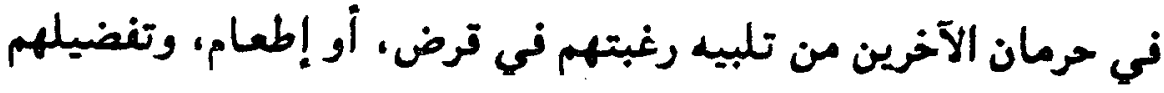

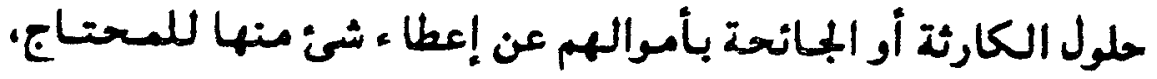

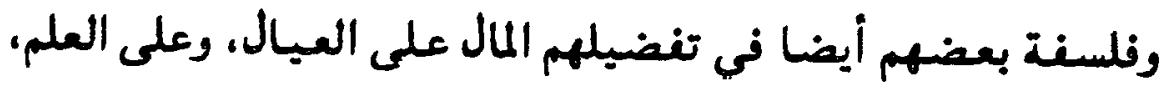

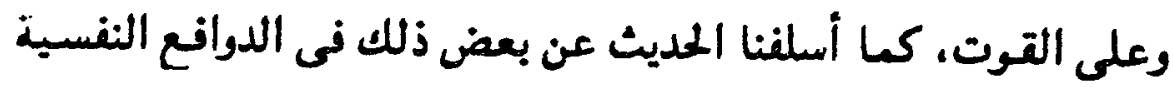
للحرمان.

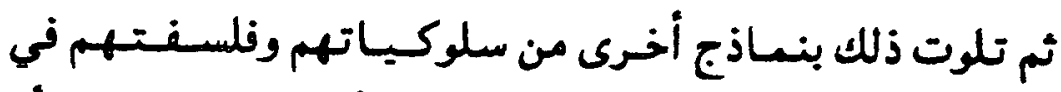

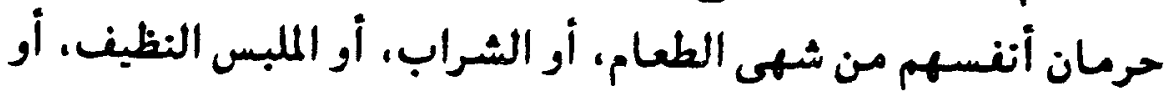

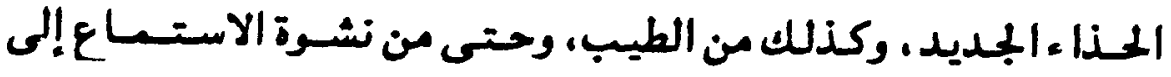

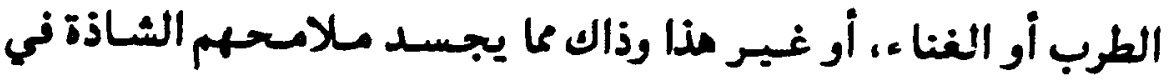




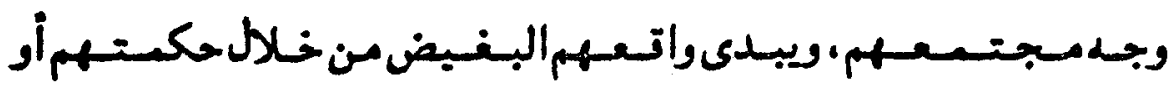

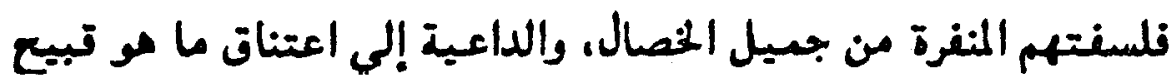
ومذموم من السلوك أو المعاملات.

نلسفه الهوهان للآنرين :

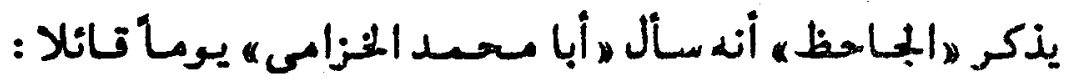

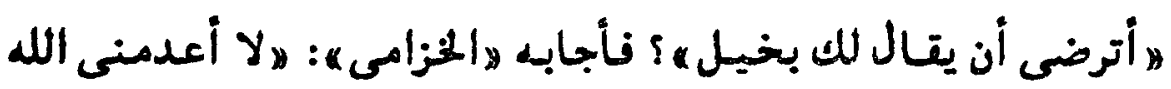

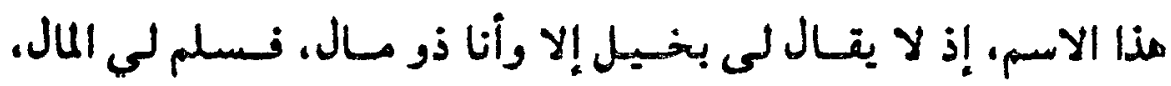
وسندى بأى اسم شئته ه. وحين يرد عليه رالجلاحظه بقوله : لاولا يقال لل سخى إلا وأنت

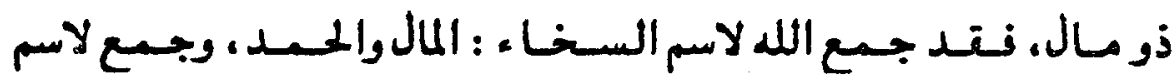

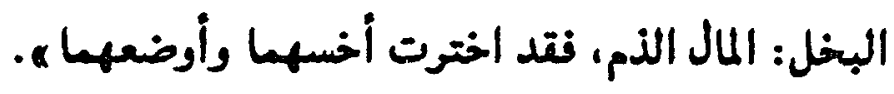

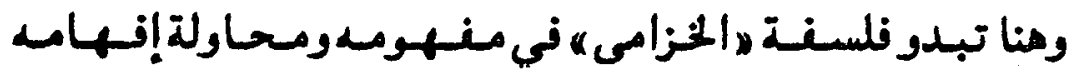

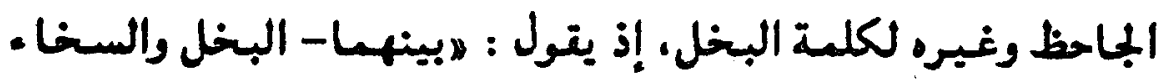

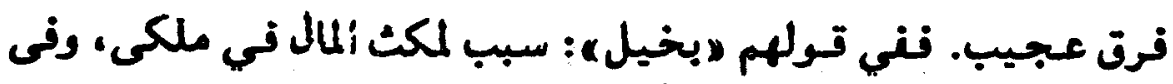

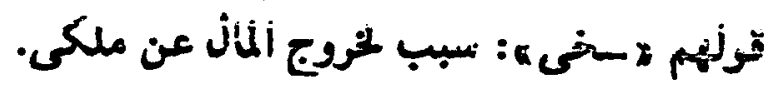

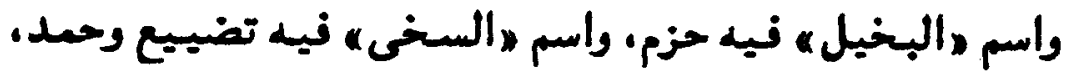

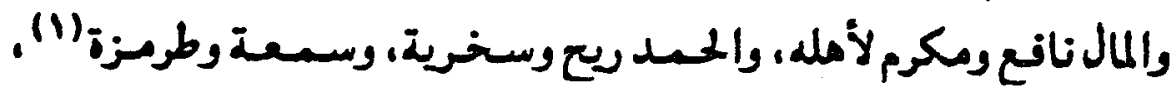

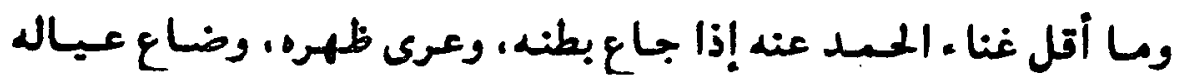

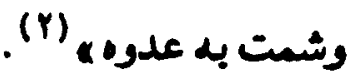

طرمزة : مناخرة وصلف.

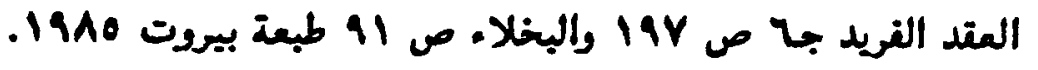


وأعتقد أن في بدئنا بهذا الحوار ما يظهر لنا مدى الحرص حتى

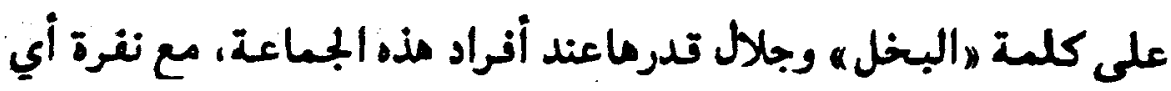

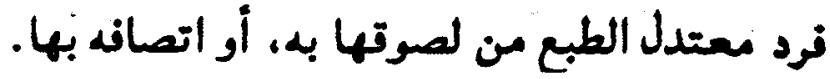

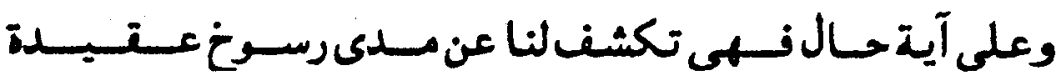

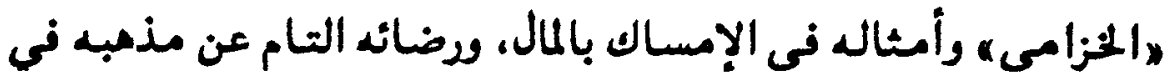

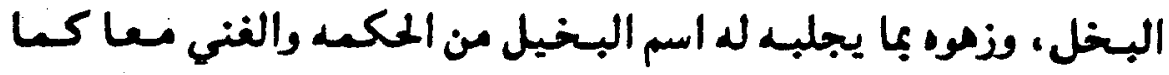
يتصور.

ثم لنســـــع إلى صسوت ها ســل بـن هارونه ومو يرد علي من

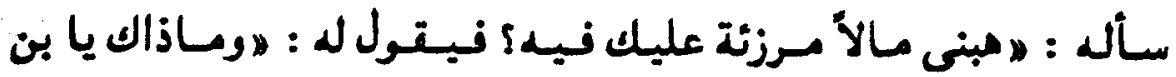
أخىى" فيقول السائل : درماً واحداً.

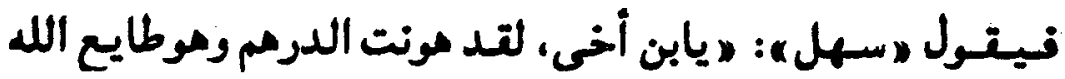

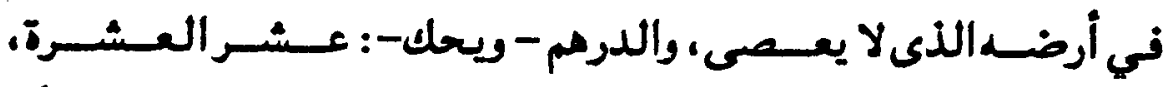

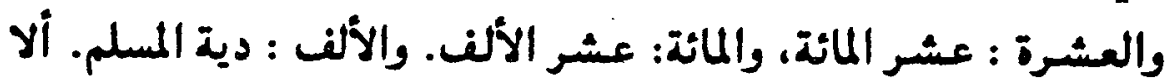

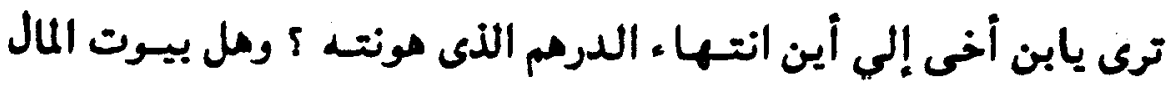

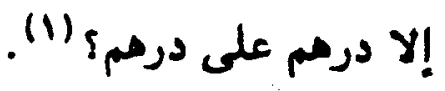

نسهل بن مارون كسا نرى يعكس على السائل منهومه، ويبدى

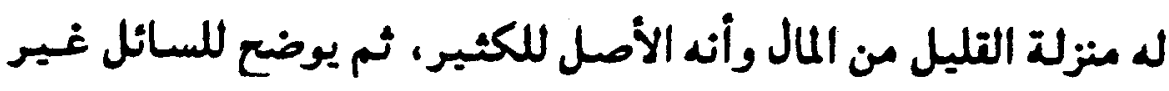

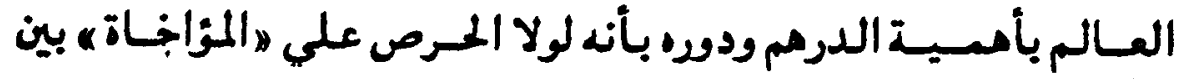

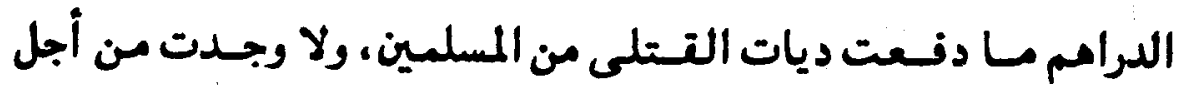

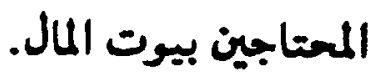


ومو بهذا لا يكتفى بإبعاده عنه، وحرمانه من العطا ه نحسب،

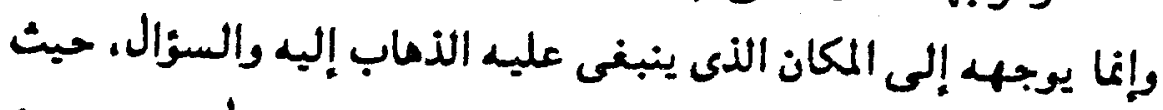

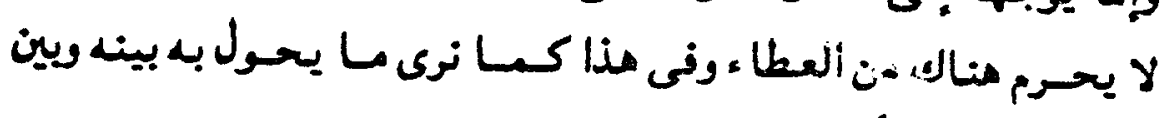

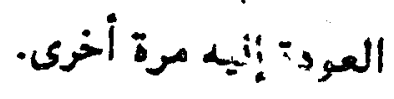

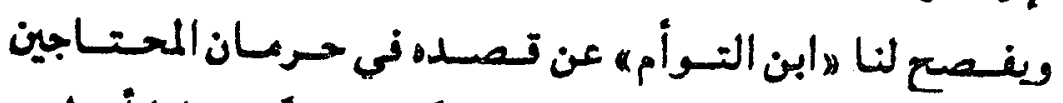

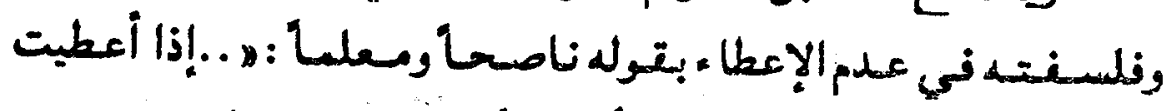

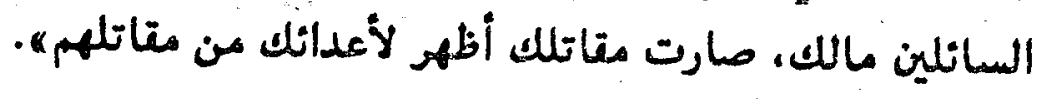

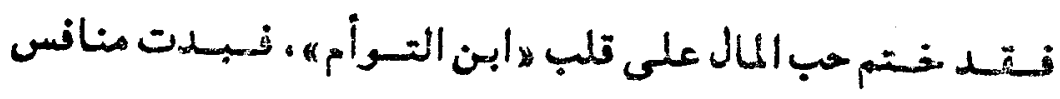

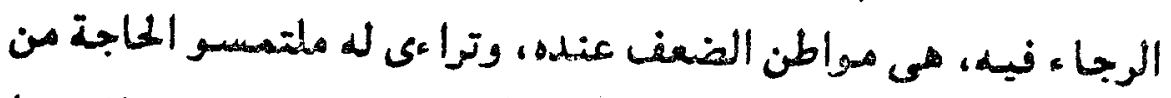

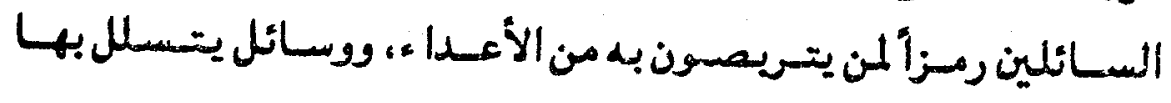
الكارهون إلى مقاتله بقصدهم إياه وطلبهم منه.

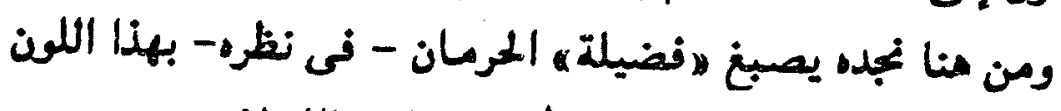

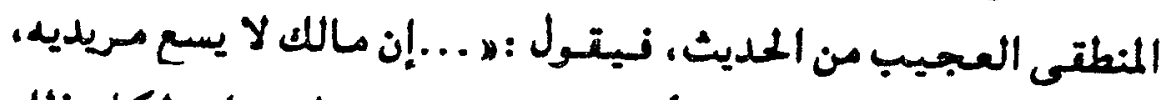

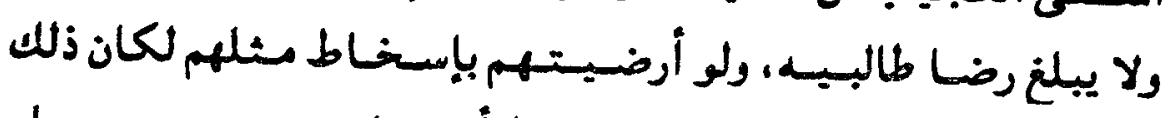

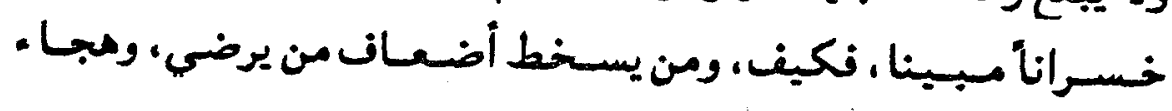

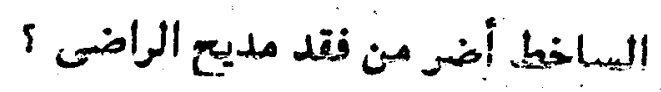

كما يدلل علي فسـاد طوية المعطى من السايلين وتخليه عـن

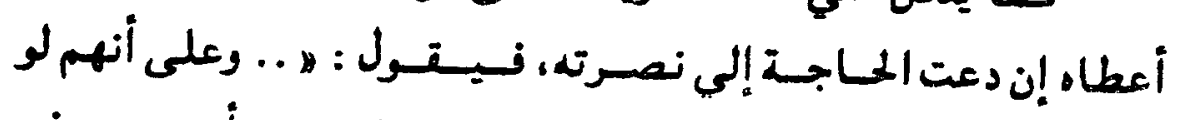

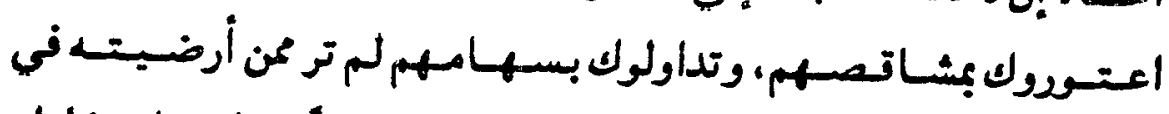

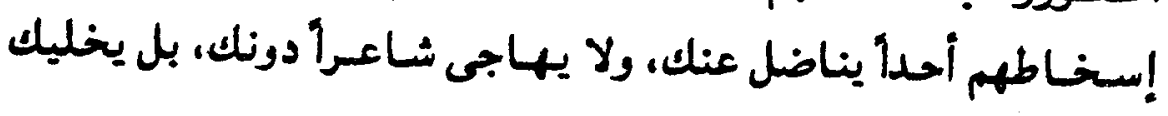
غرضاً لسهامهم ورديئة لنبالهم. 


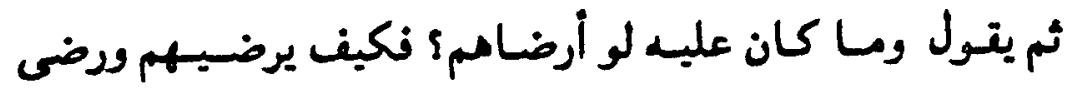

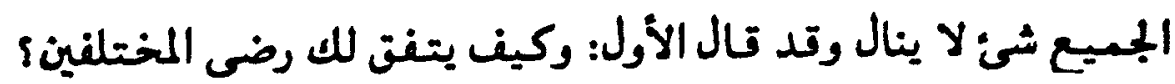

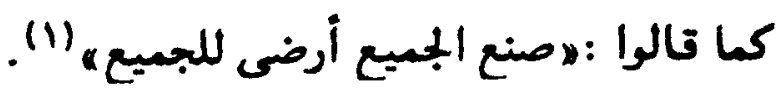

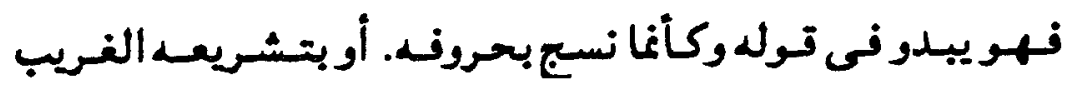

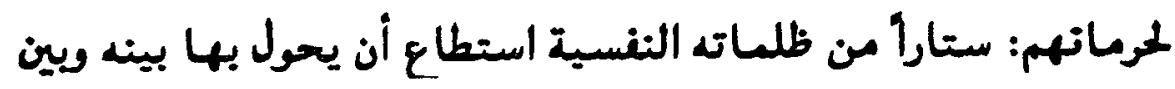

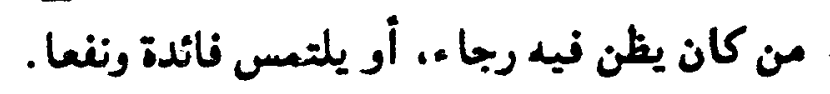

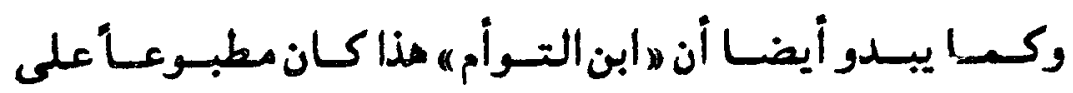

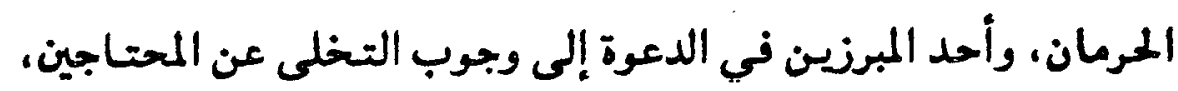

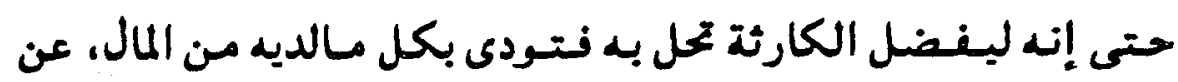

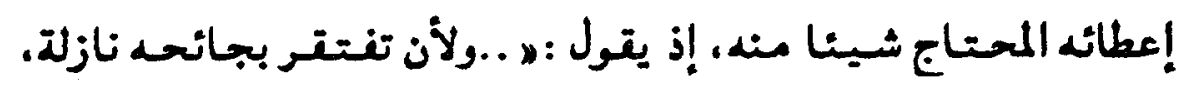
خير لل من أن تفتقر بجناية مكتسبة ه.

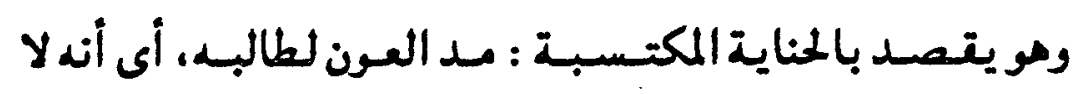
يبالى بالمزيد من حرمان نفسه، مادام ذلك مؤديا إلى حرمان غيره.

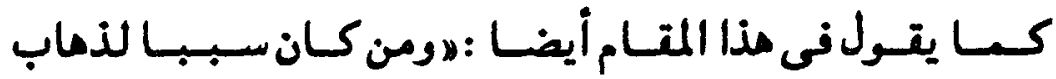

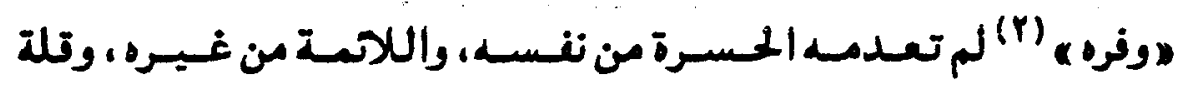

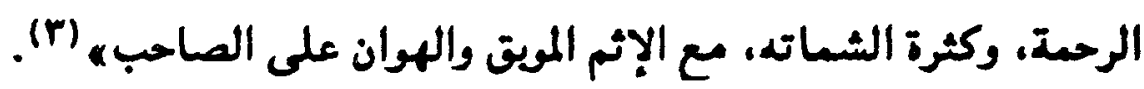

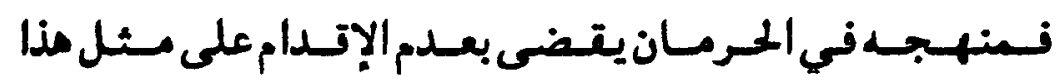
الصنيع (\&)، إيانا بسوء العاقبة حيث الشعور بالحسرة من النفــس،

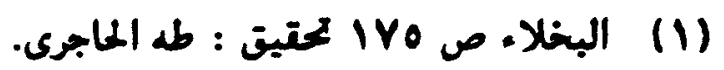
وفره : يتصد مالد.

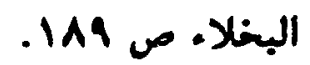


والتصدى للوم الغير ، وكثرة شعاتتهم به، وتوقعه البعد عن رحمة الله لارتكابه مذا الإثم الكبير وهو : قضاء الحاجة لمن قصده.

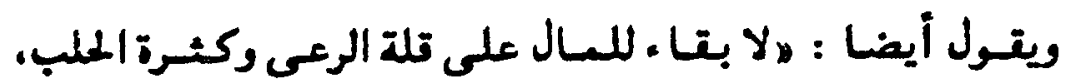
نكس فى أمرك، وتقدم في حفظ مالل، فإن من حفظ مالد فقد حفظ

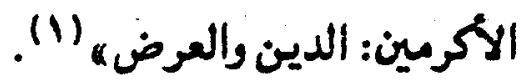

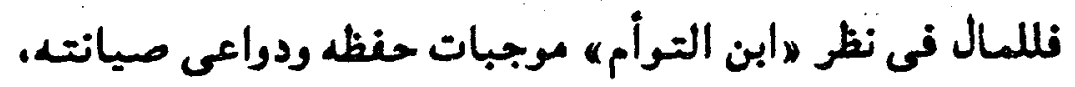

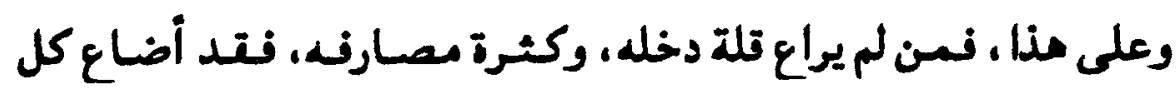

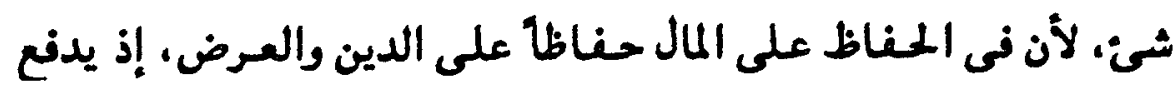
به عنهما الفتن، ويقيها من ذل العيش، ونكد الفتر، ودواعى الحلاجة فى المياة.

ويبـدو أن ابن الرومى قـد راتـه مذا المنهـ فـصـاغـه في البـيـتين التاليهن، معلنا بهما : أن شحس بالمال وحمايتد له - بعدم الإنغات، وحرمان المحتاجين منه - يعد وجا ـ لعرضه، وصيانة من غوائل الزمن وعوادى الحاجة إليه، وذلل إذ يقول : (r) :

أذا لم عكن عندى سوى ما بكننى نشعى عليه مثل شعى على عرضى

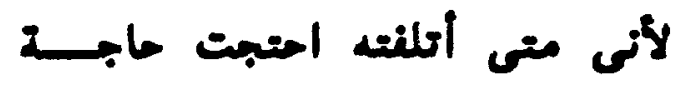
تزيل معرن المرض لم ملب الترض

$$
\text { المصدر السابق } 191 .
$$

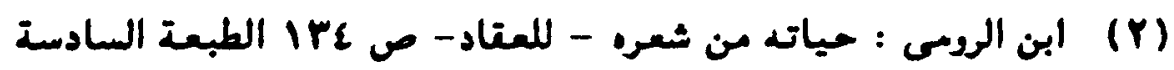




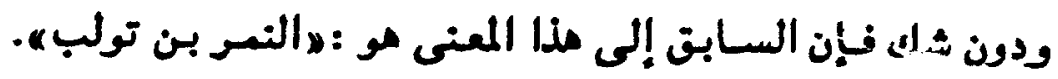

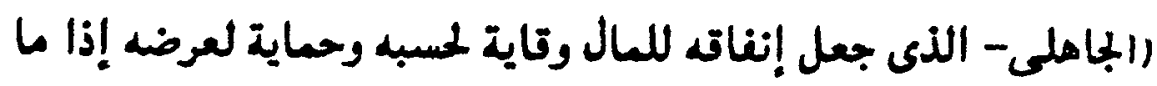

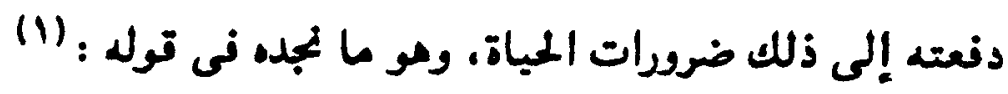

أقى هسب 4 ويعز عرضسى على إذا المغيطة أدركتنى

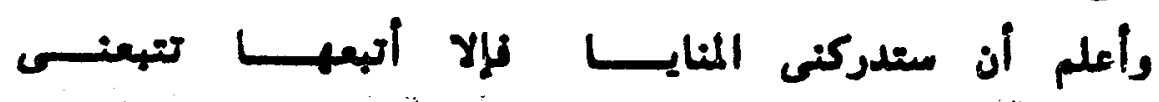
وإن جعل هابن التوأمه حمايته للفال وشحه به من أجل حسايته

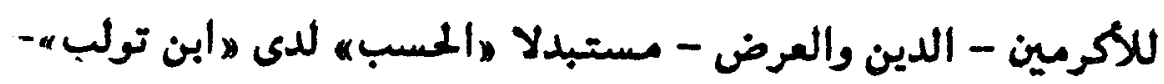

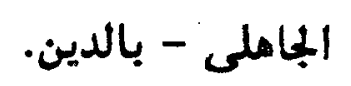

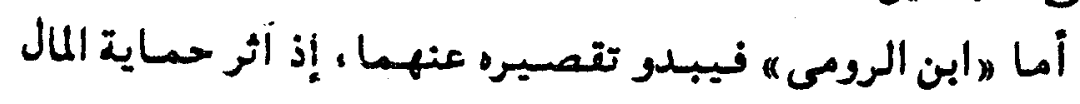

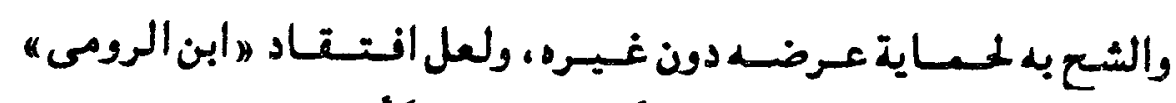
للحسب جعله لا يبالى به، كسا أنه يعلم يقيناً أن للدين ريا يحميه.

هذا مع اتفاق الثلاثة في ادعائهم بأن حعاية المال والحرص عليد من أجل حماية العرض وعزته، والله أعلم بالنوايا. وكان سهل بن مارون - فوق ما ذكرناه من هيامه بالمال وحرمان

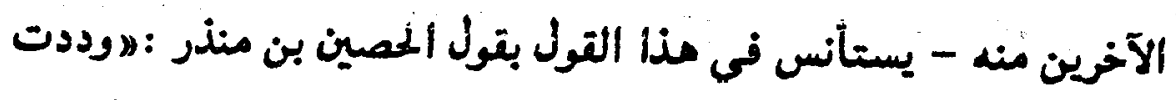

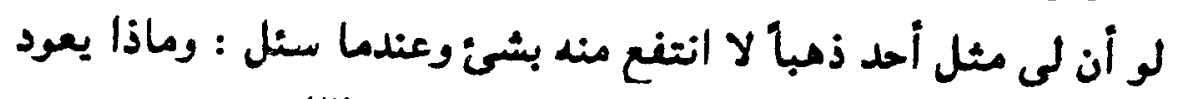

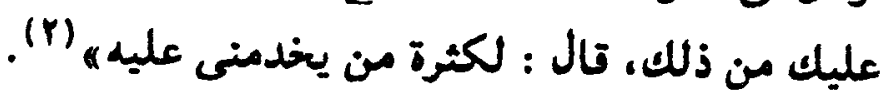

طبتات نعول الشعراء - لابن سلام - ص الآ| لمحقيق محمود شاكر مطبعة المدنى بالتاهرة. البخلا. - كحتيق الحاجرى - ص 10 المانه 
كا سبقت الإشارة إلي تنضيل سهل للمال على العلم، وعلى

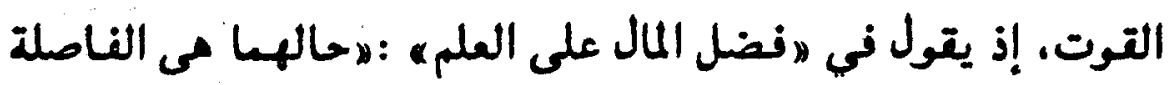

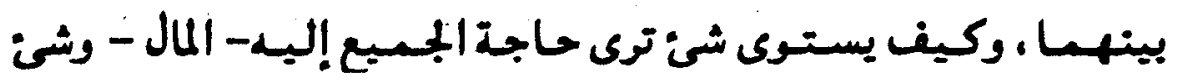

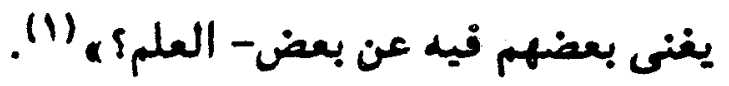

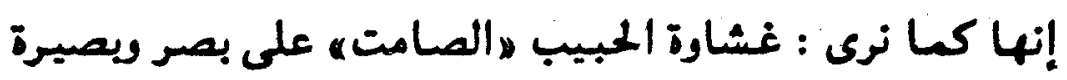
المحب هالناطقىه.

نلسفة الهرعان اللنغس : ربا لا يجد المزء ما يدمشه من سلوك مذه الجماعة وحرصها على

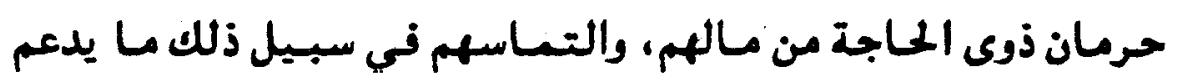

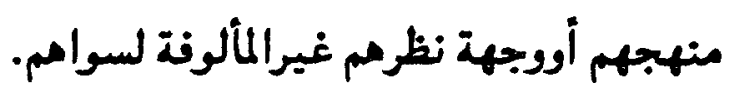

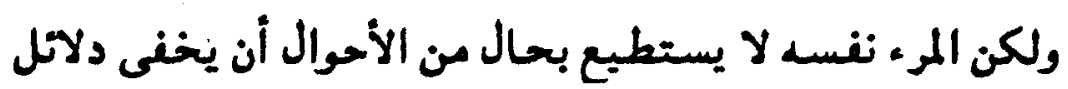
دمشته وعجبه من ذلل السلوك الذى يجسد شدة حرصهم علم حرمان

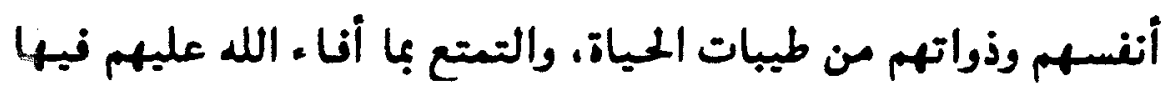

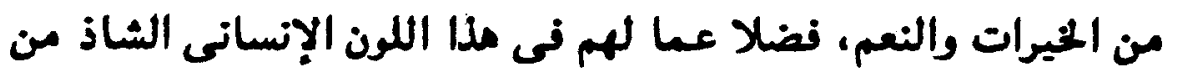

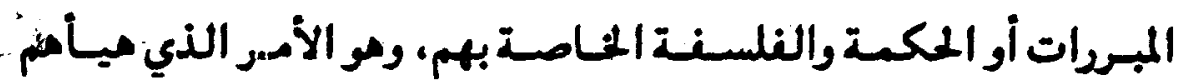
لحياتهم تيلك ، أز ميأ تلك إلميان لهم آنذاك.

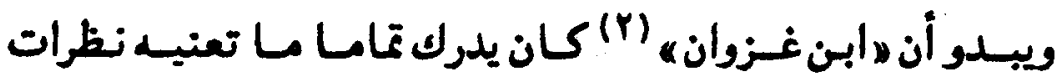

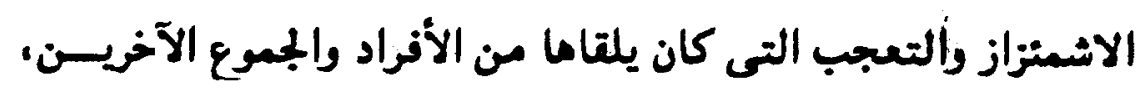

$$
\text { المصدر السابق ص Ir أi ومابعدها. }
$$

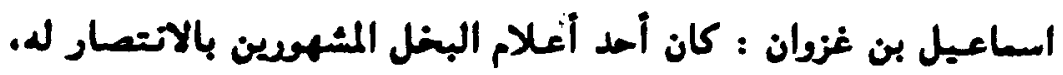

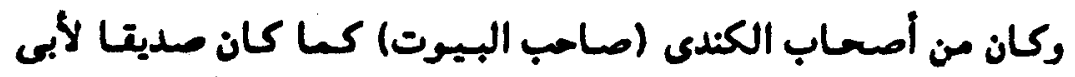
سعيد الثورى، ويابن أبى شيخ كاتب إعب جعفر بن يحيى البرمكى. 


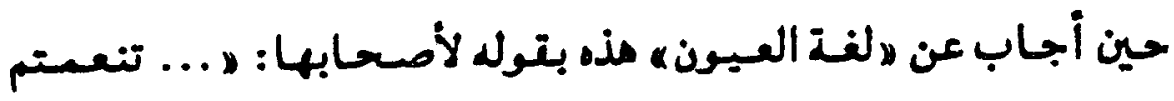

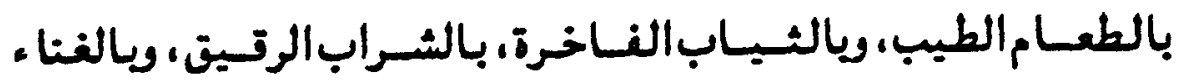

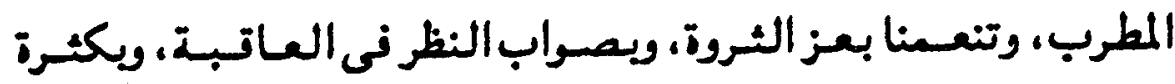

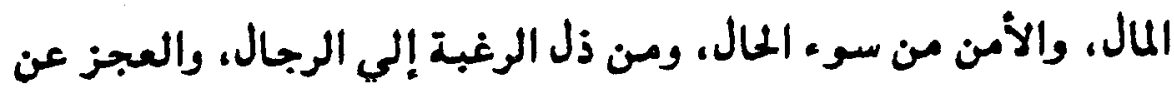

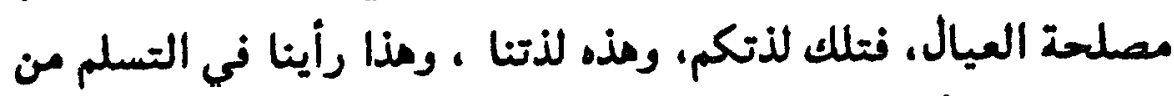

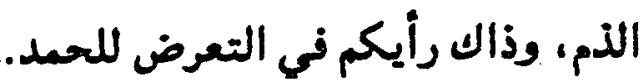

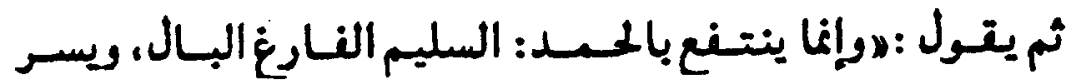
باللذات الصادق الحس، فأما النتير: فيا أغناه عن الحمد الحد وأفتره إلي ما به يبجد طعم الحمد.

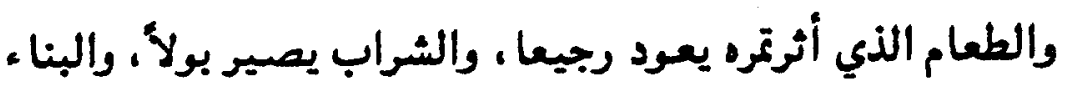

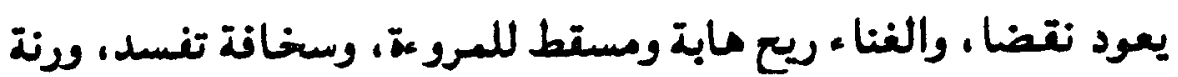
تسير. فلذتكم فيسا حوى لكم النتر ونتص المروءة، ولذتنا فيما حوى

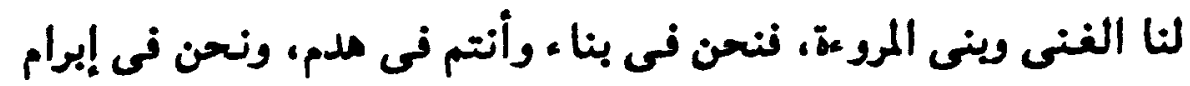

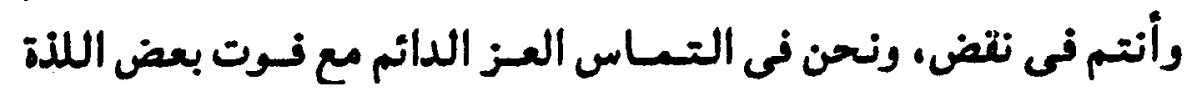

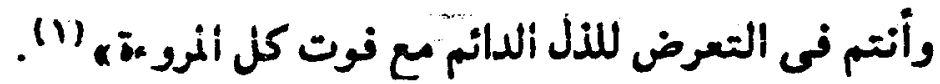

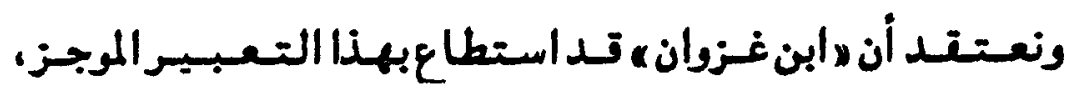

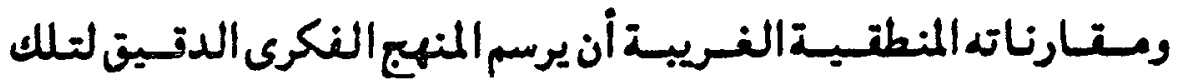

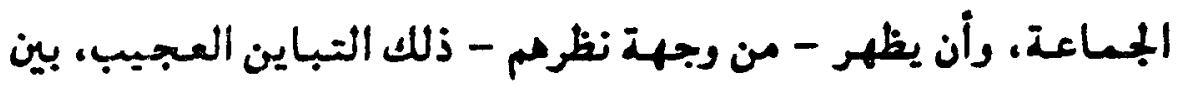
مغهوم السعادة والنعيم لأفراد الجماعتين.

$$
\text { البخلاء - ص . الحتيق الحاجزى. }
$$




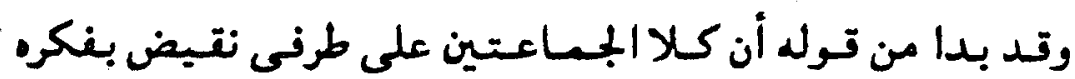
أمام متومات الحياه.

وأن ما يحسبه غير البخيل شذوذأ فى المعاملات والسلوك يؤمن

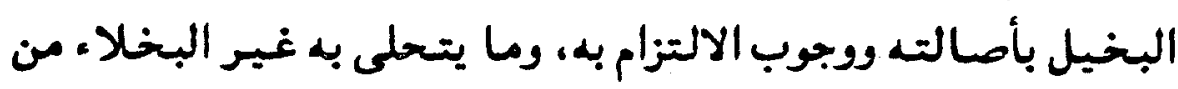

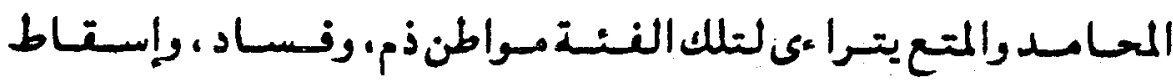

للمرو عة.

وما نشك في أن (ابن غزوان هان مجانب للصسواب فى هذا الحكم المتطرن الذى تضى به على غير المتتنعين بمعاملات وسلوك أمثاله.

فليس الجمسيع على درجة واحدة من الثـراء، أو الإسران المؤدى

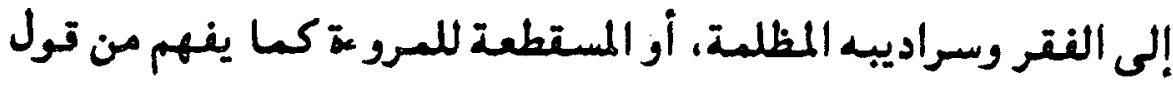

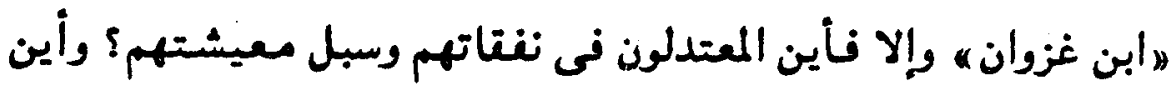

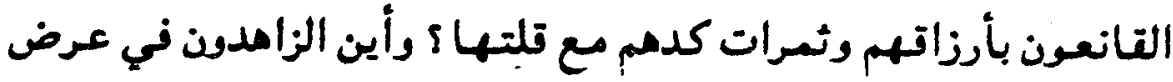

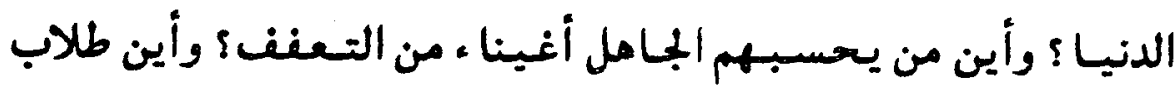

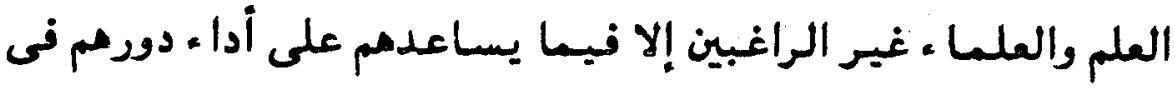

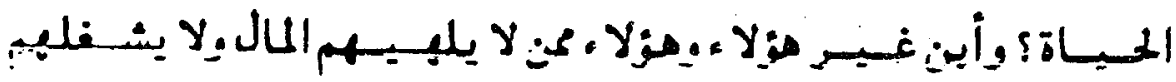

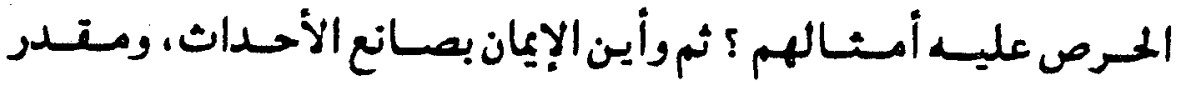
الأرزاق ومن بيده وحده متاليد الأمور ؟

إن الشعود بالسعادة أو باللذة لا يكمن في حرمان النفس من

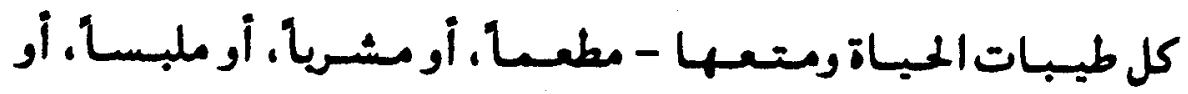

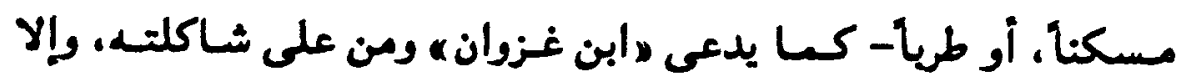

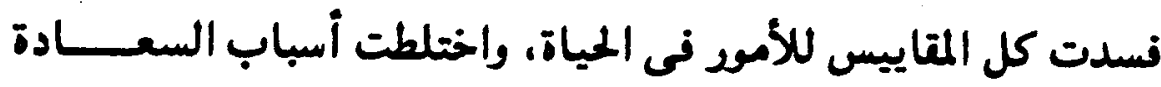




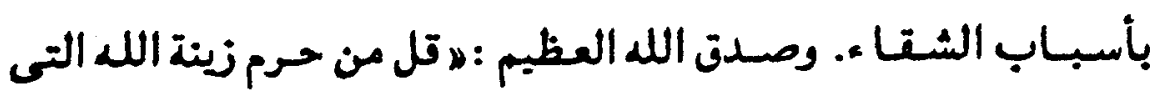

أخرج لعباده والطيبات من الرزقي، (1).

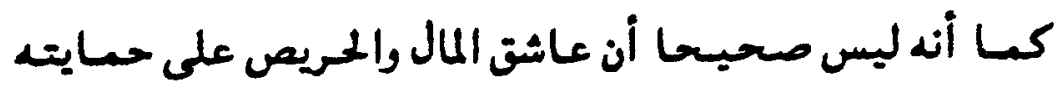

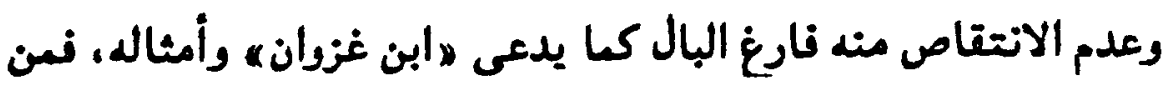

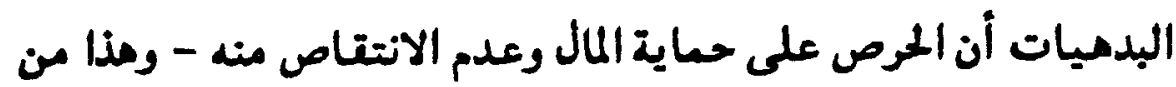

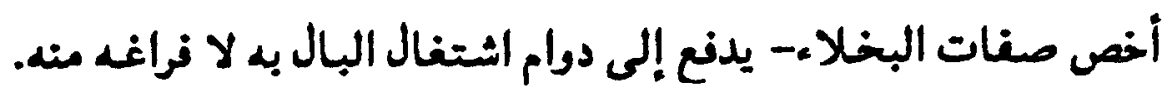

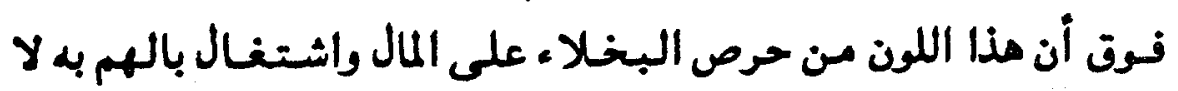

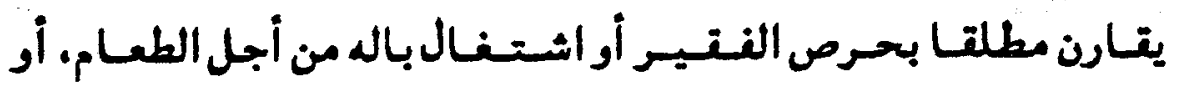

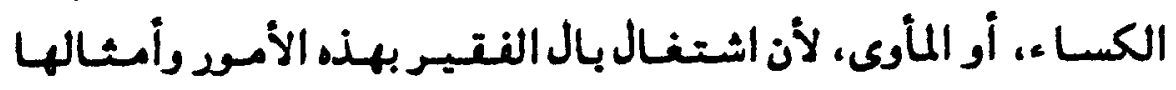

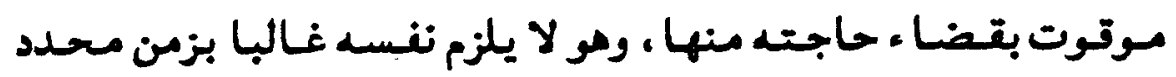

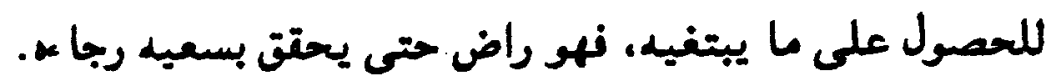

أما البـخيل فــرصه على المال دائم، واشتـغـال باله بزيادته.. والتفنت في حرمان غيره، أو كيفية التقتير على نفسه وعلى أولاده لا لاله يقف عند قدر، ولا يحد بزمان.

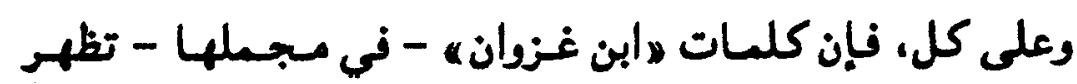

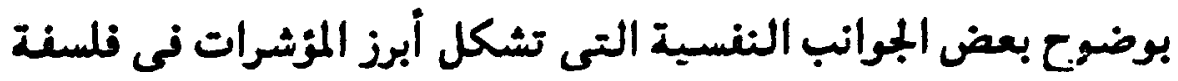

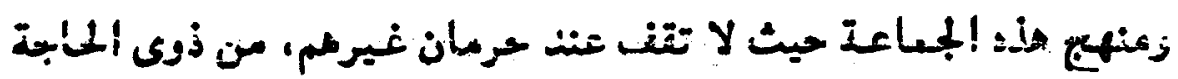

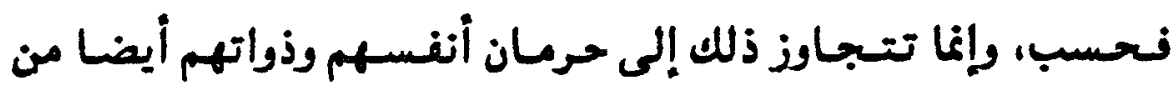

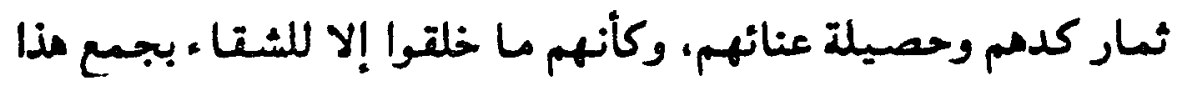

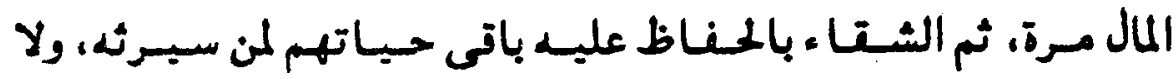

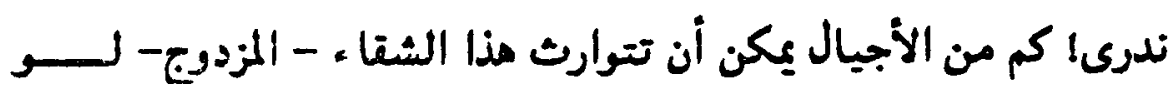




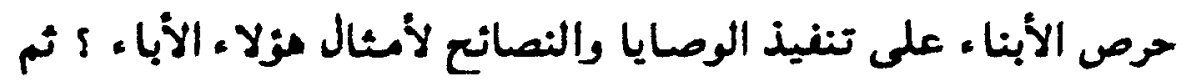

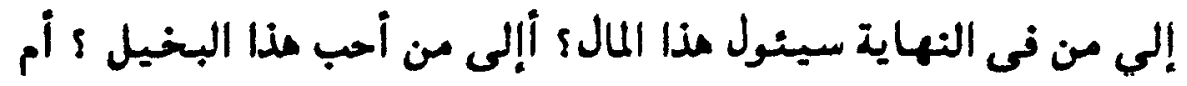

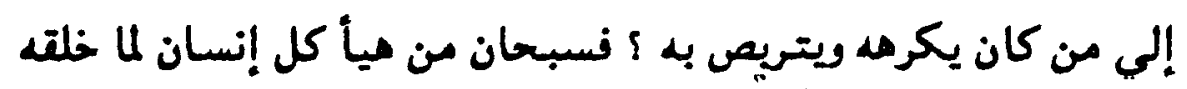
له. له.

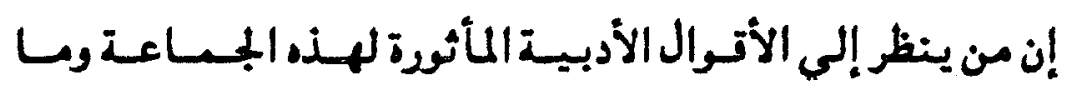

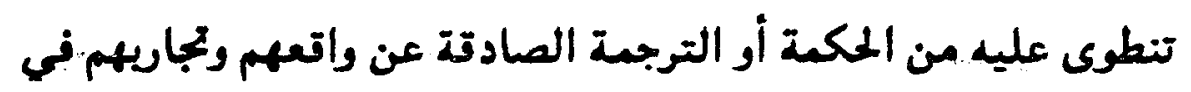

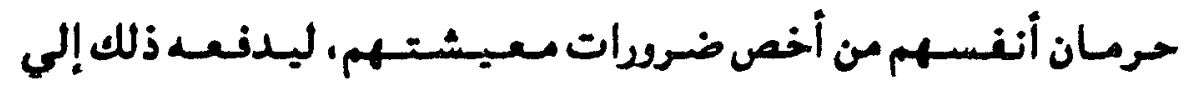
الدمشة والعجب حتما.

فهذا : لاعبد الرحمن الثورى " مع كثرة ماله، وقدرته على التستع

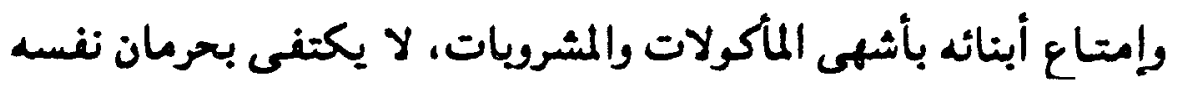

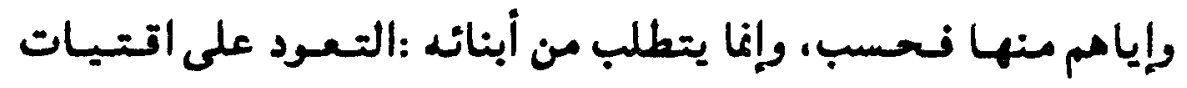

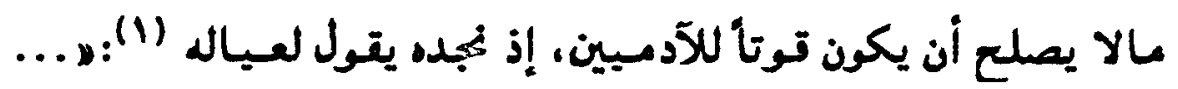

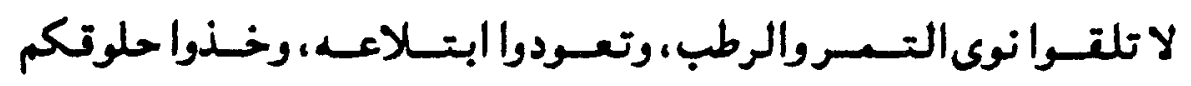

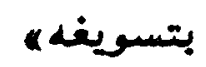

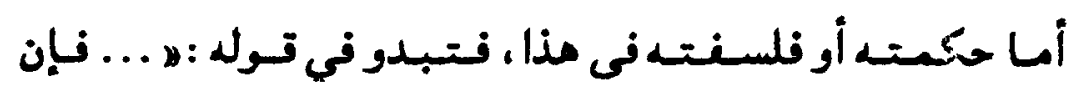

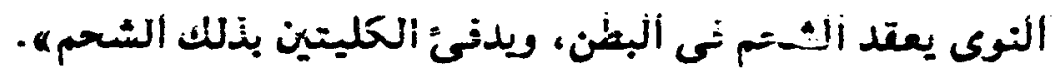

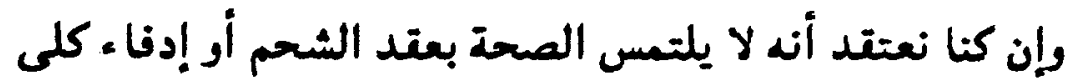

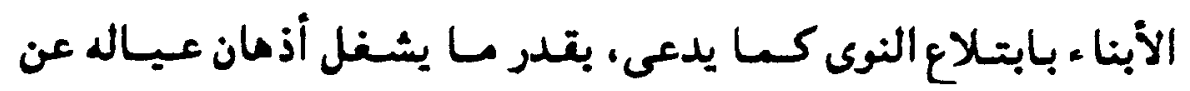

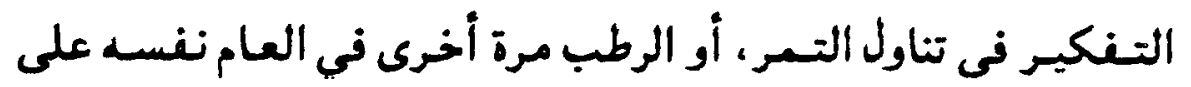
الأتل.

البخلا. - تحقيق الحاجرى - ص r.1 ومابعدما. وص اع| طبعة

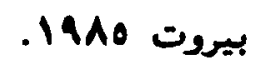




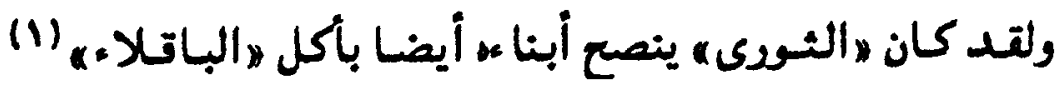

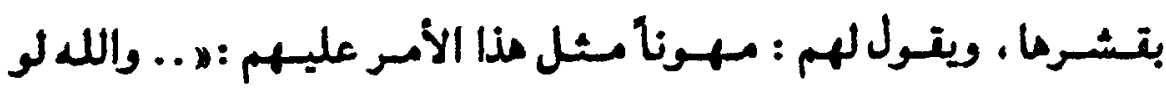

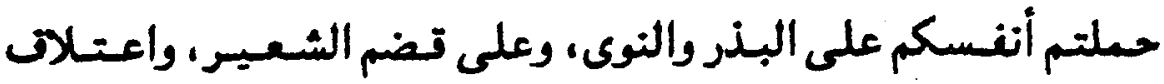

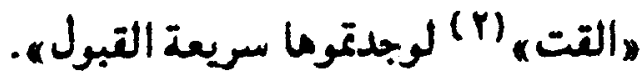

أما عن الحبز، ومو ما يعد في نظره أشههى وأغنى المأكولات،

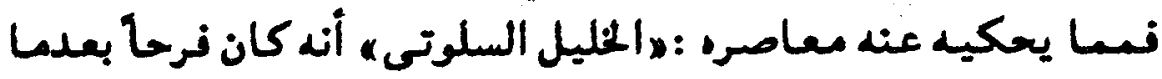

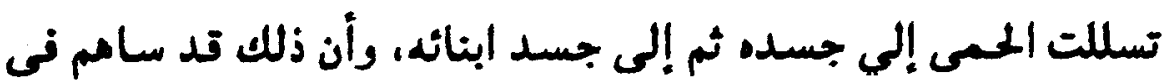

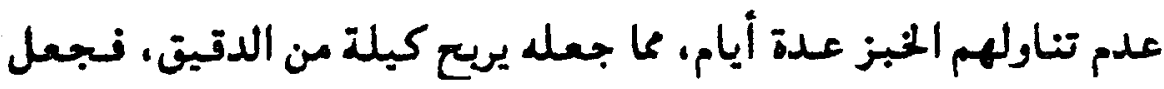

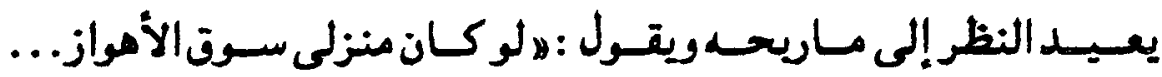
لرجوت أن أستفضل كل سنة مائة دينار ه .

وما نرى فيمن يسعده المرض له ولأبنائد رباء ادخار ثمن الحبز،

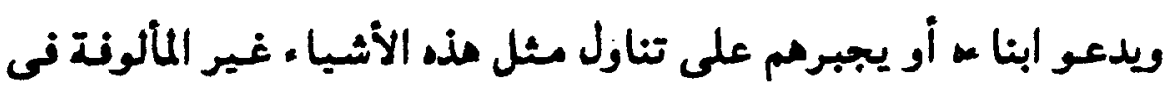

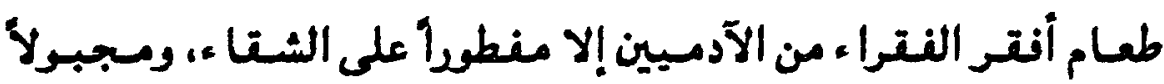

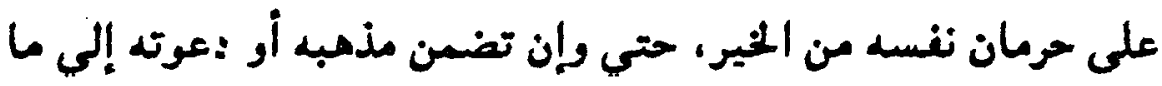

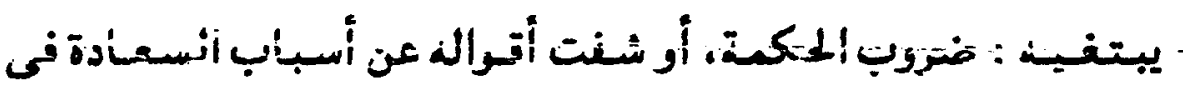

الحياة.

ولنتـأمل فى بعض نصاتح " الكندى ه وعو يقول لعبـاله داعيلا

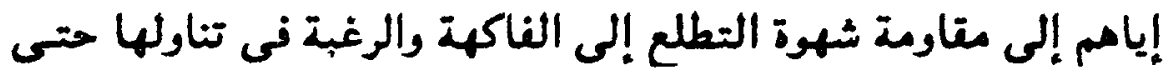

الباتلاء : نبات عشبى من النصيلة القرنية. التت : كلا عشبى بعض يندع وبعضه ينبت بريا والمتول. 
تنتضى أيامها : (1)، ل. ... اصببروا عن الرطب عند ابتـدائه وأوائله. وعن باكورات الناكهةه.

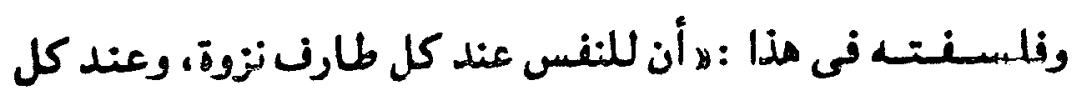

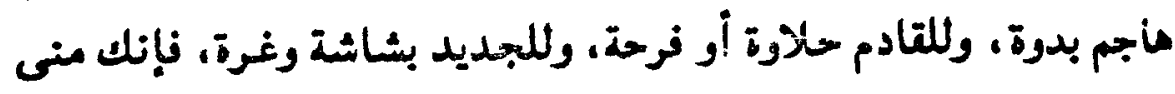

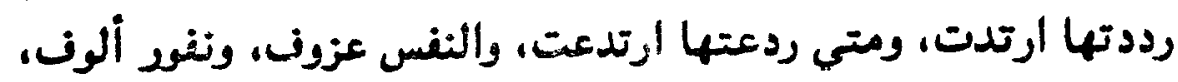

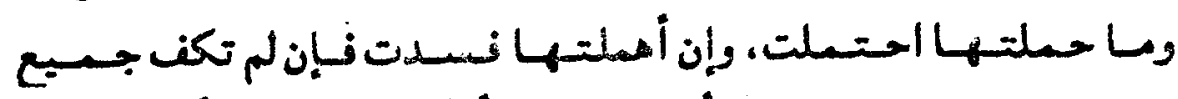

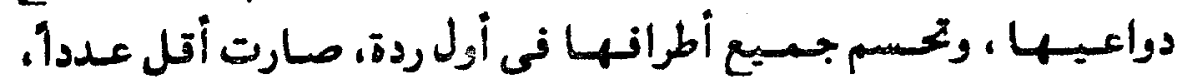

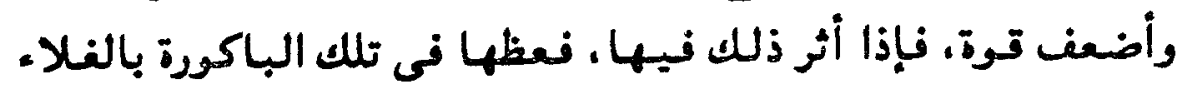

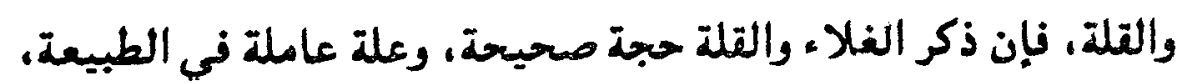

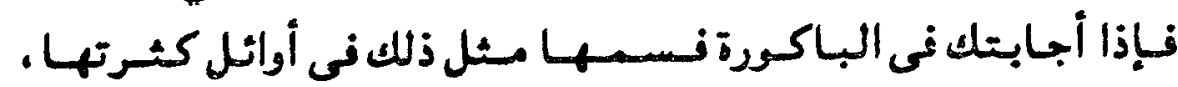

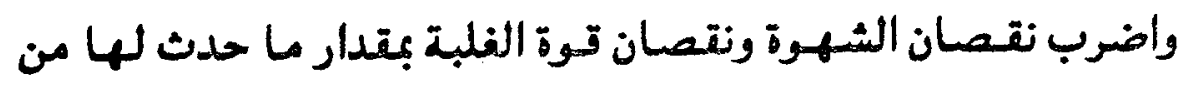

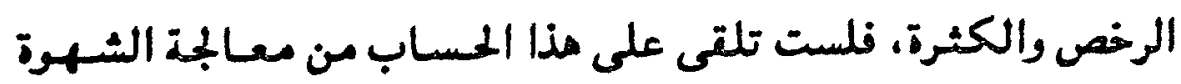

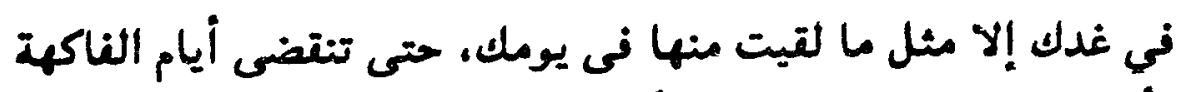

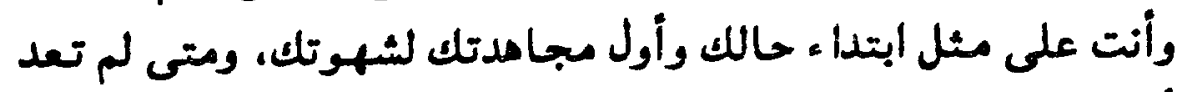

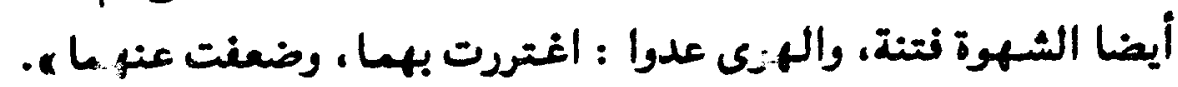

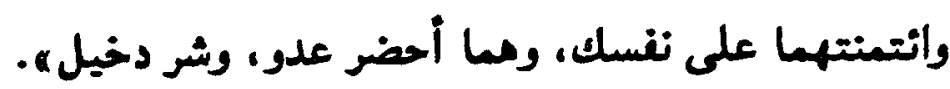

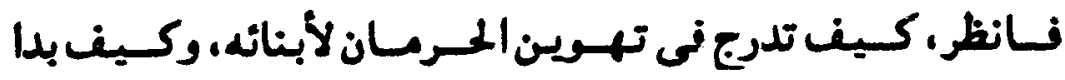

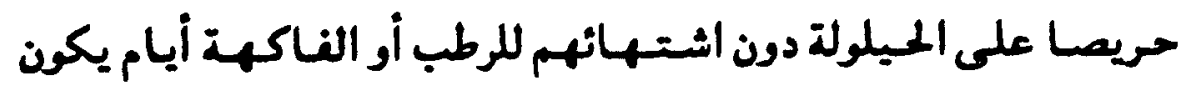

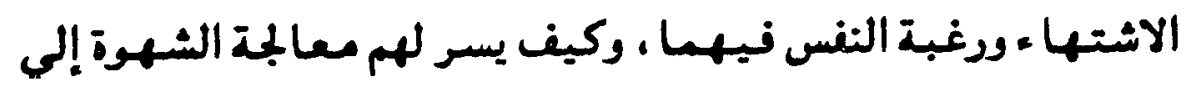

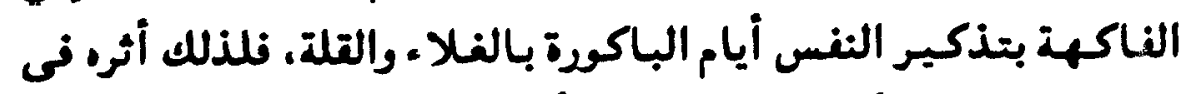

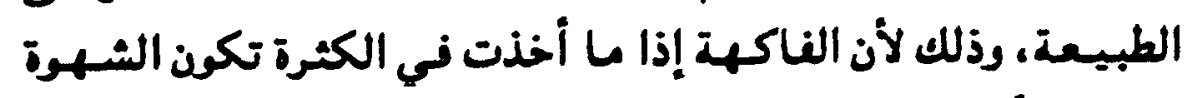
إليها تد أخذت فى النقصان.

انظر أقوال الكندى ص rه ومابعدها من البخلاء - تحتيق الحاجرى. 
ومكذا تبقى المجامدة حتى تنقضى أيام الناكهة ومم على مثل

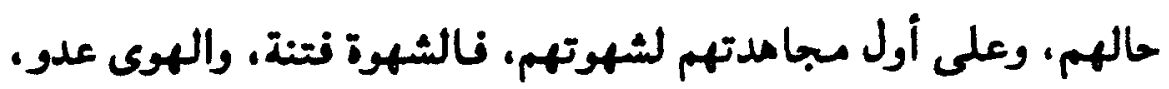
كا يقول.

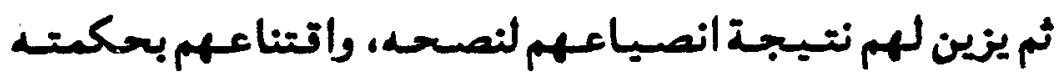

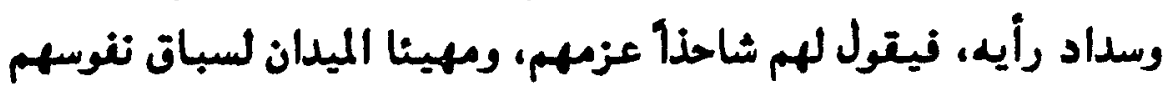

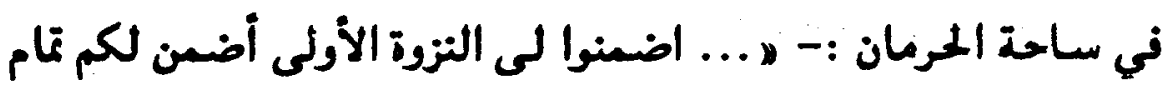

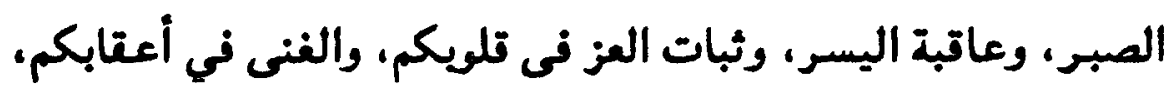
ودوام تعظيم الناس لكمه.

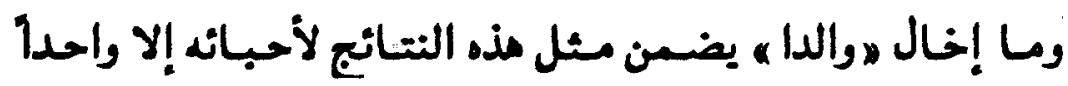

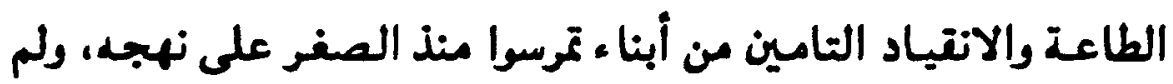

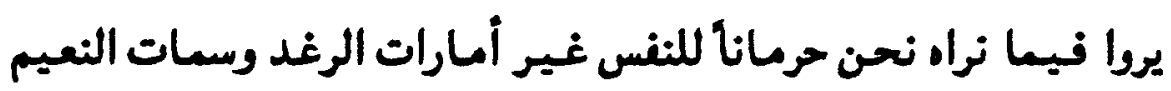

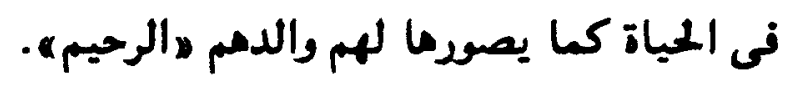

ثم لنتـتل إلى لون جديد من المرمـان وفلسـنته مع أحسد الرواد

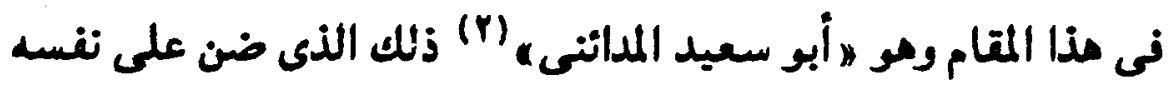

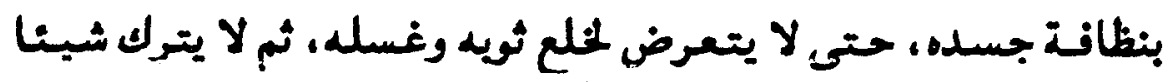

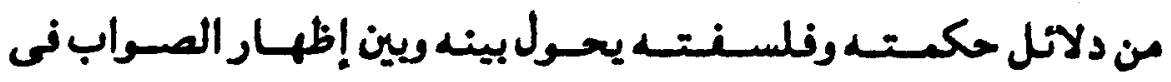

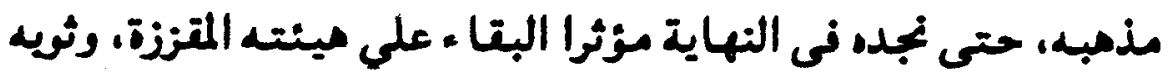

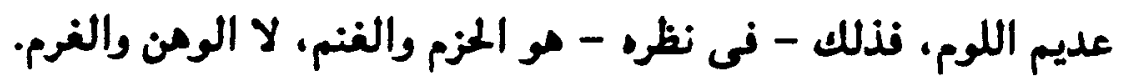

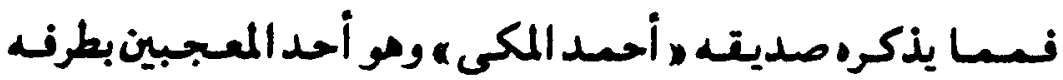

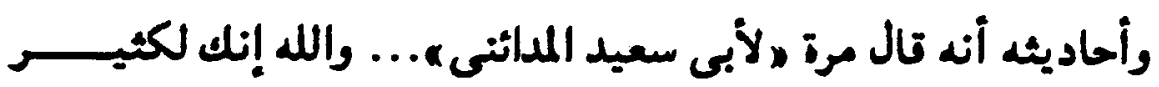

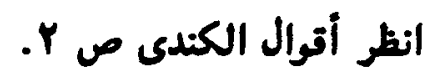

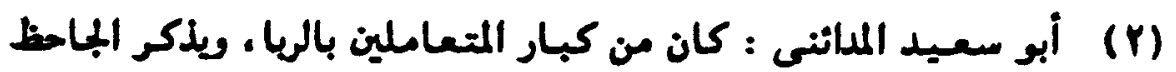
أند كانت له حلقة يجلس فيها ميل مع علانه. 


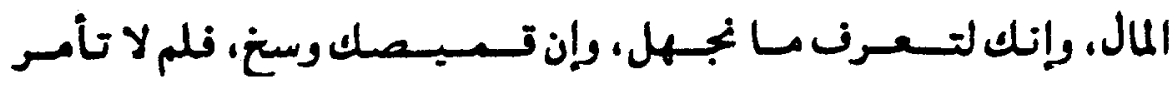
بغسله هـ.

تال أبو سعبد : ه .. فلو كنت تلبل المال وأجهل ما تعرف، كيف

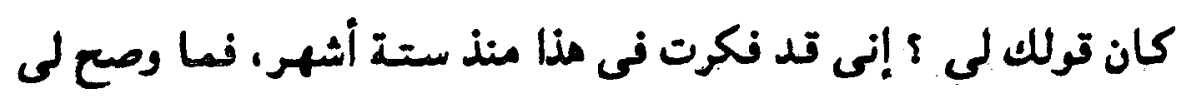
بعد وجه الأمر فيد.

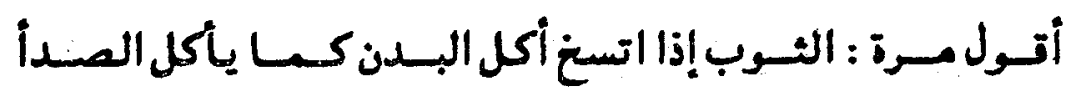

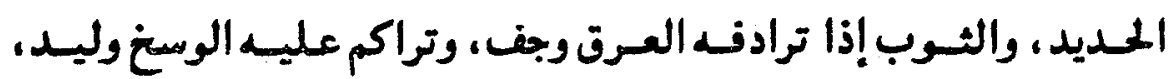

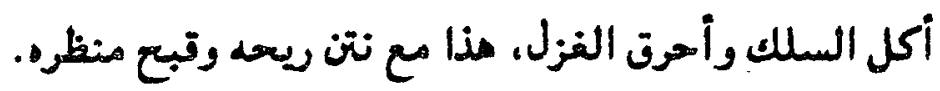

ويعد، فبإنى آتى أبواب الغرماء، وغلمان غرماتسى جبابرة، فما

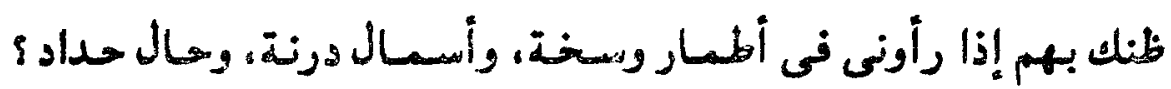

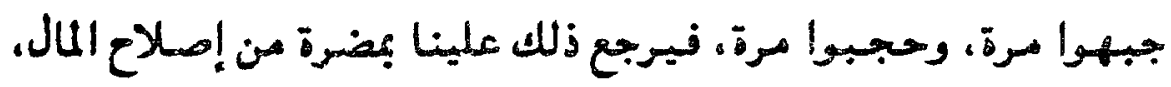

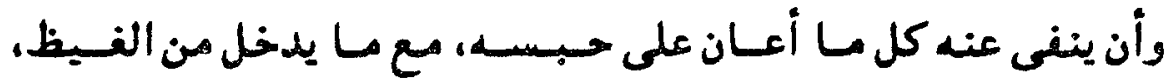
ويلقى من كان كذلك من المكروه.

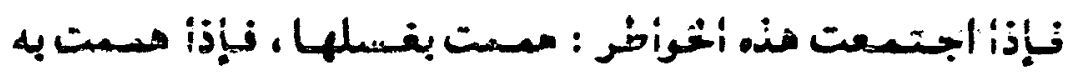

عارضنى معارض يومنى أنه أتانى من الحزم ومن قبل العتل نقال :

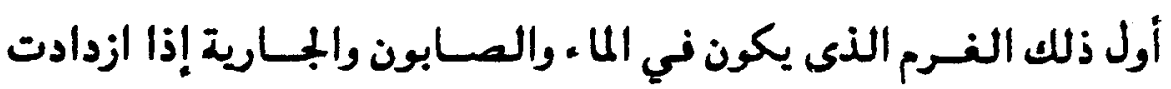

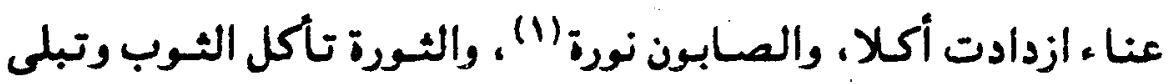

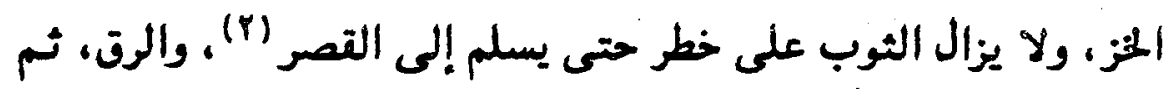

النورة : أخلاط من أملاح الكالسيوم وغيره. التصر : إزالة اللفن من أليات النسيج أو تهنفيفه. 


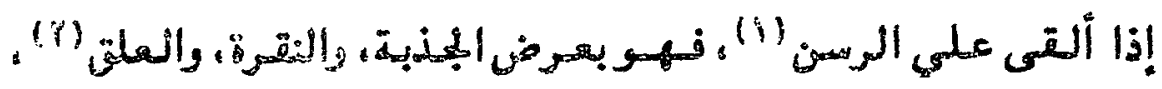
ولابد من الجلوس يومئذ في البيت.

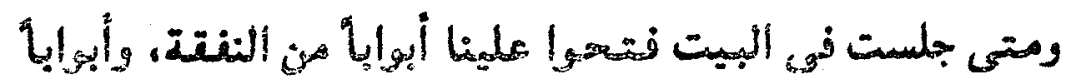

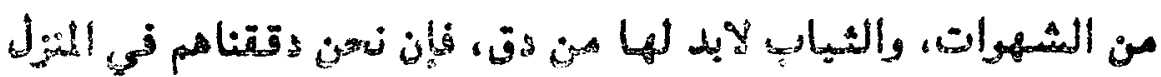

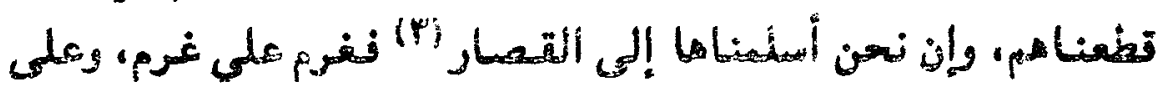

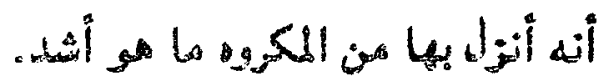

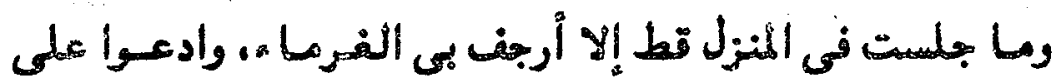

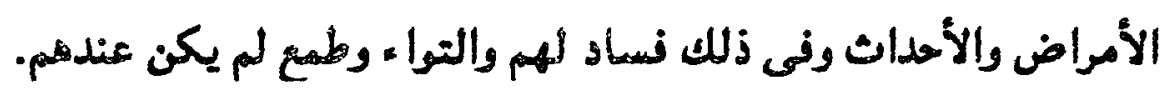

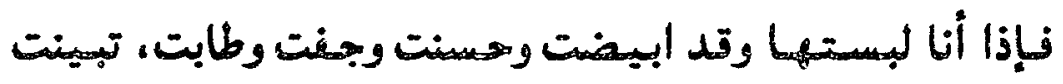

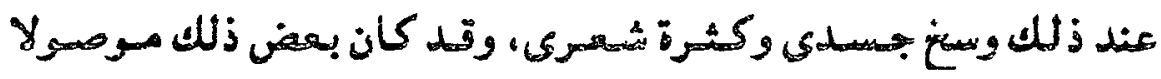

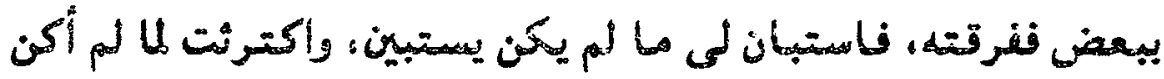

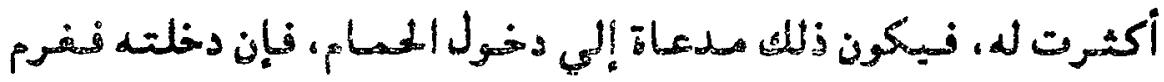

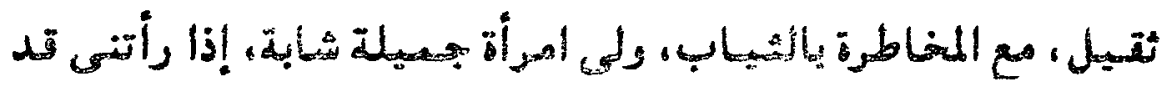

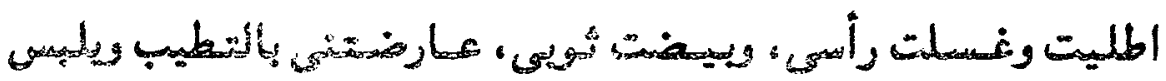

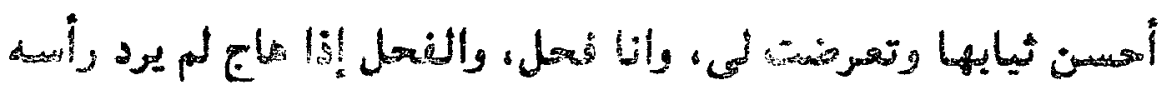

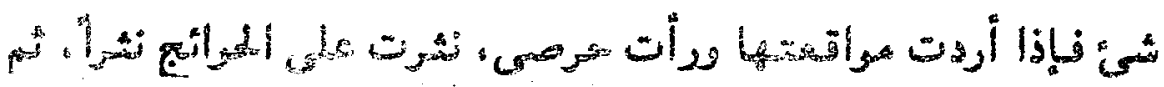

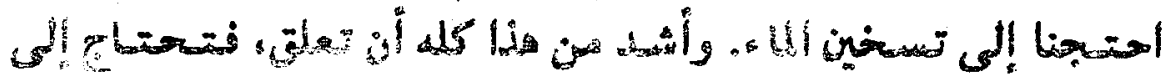

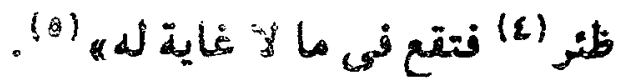

(1)

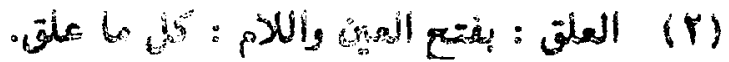
(r) التصار : المييض لإلثياب.

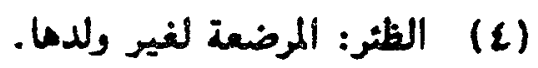

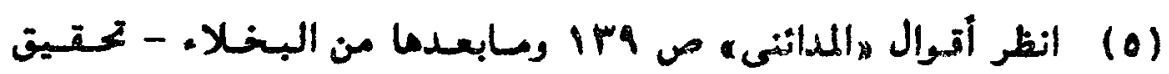


وحسبك أيها القارئ الكريم أن تعيد النظر إلى كلماته الأولى

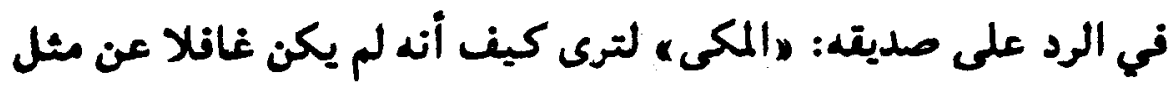

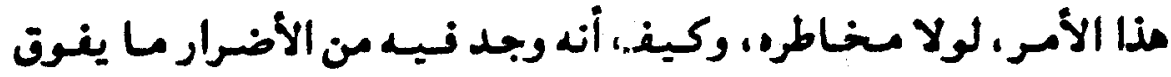

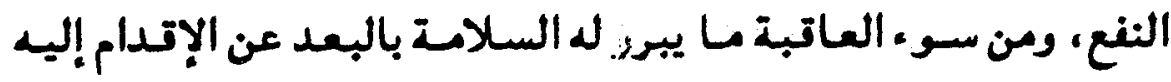

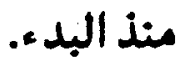

فأثر حرمان نفسه من نظافة جسده، وثويه، مقتنعا بصواب رأيد

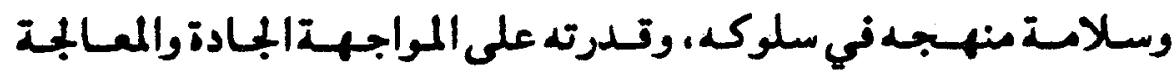
العكيعة لما يخالف طبعه، دون مبالآ بطباع الآخرين.

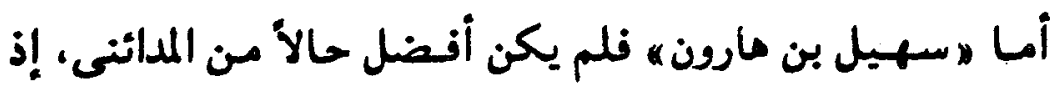

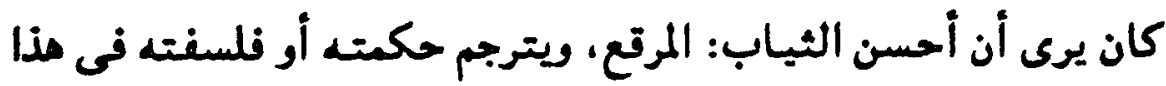

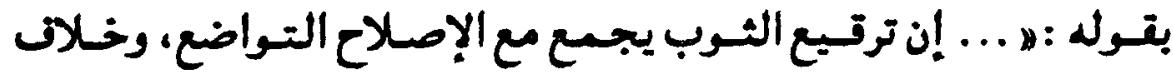
ذلل يجمع مع الإسراف التكبر، "(1).

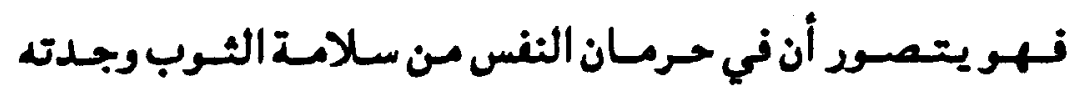
تواضعا وفى نظافته والتنعم به إسرافا وتكبراً.

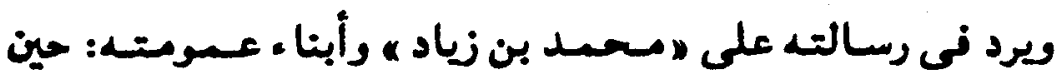

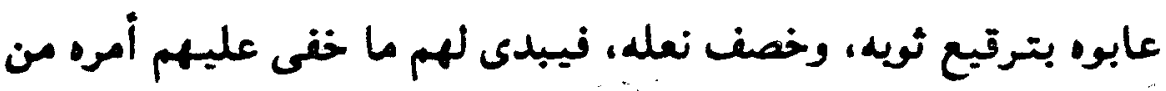

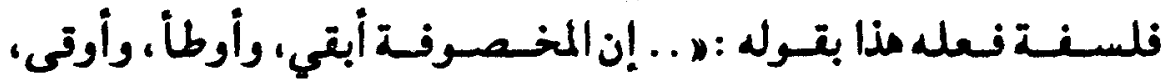

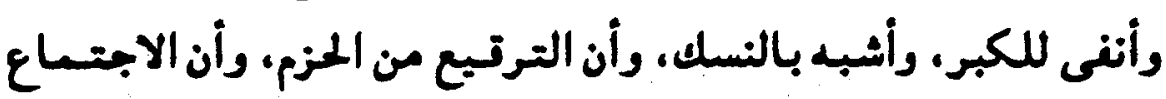

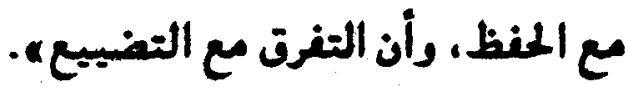




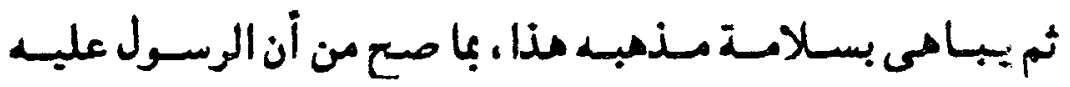

الصلاة والسلام، كان يخصف نعله، ويرتع ثويه، وأن عمر بن الخطاب:

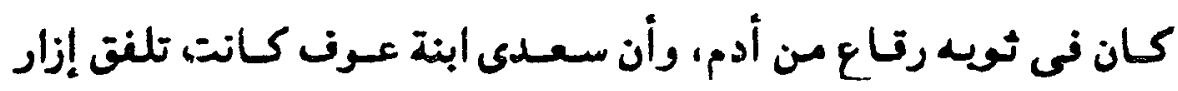

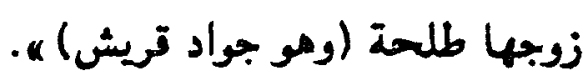

ولا يفوتنا أن نشير فى مذا المقام إلي أن الرسول عليه السلام الهام

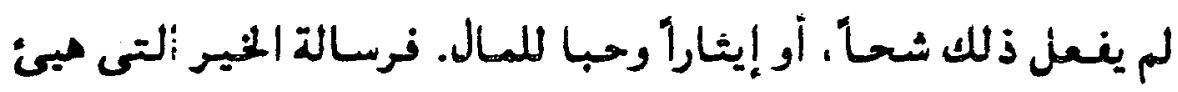

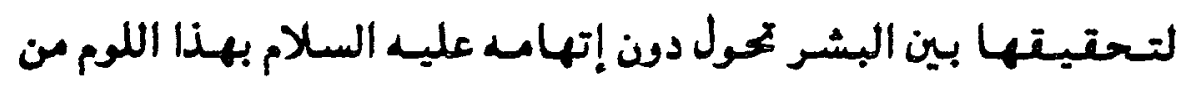
الحرص أو التفرغ لمثل مذه الأمود الهينة، وإنا نعل ذلك الك عليه السلام الهام

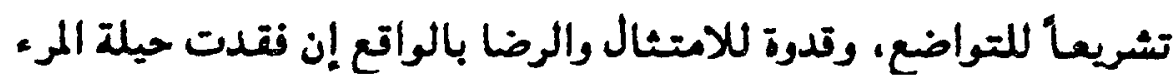
لامتلاك شئ آخر، أو تعذر الحصّول على سواه.

وعلى دريه عليه السلام كانت خطا وحياة عمر بن الحططاب من بعده، إذ كان يؤثر الانقياد والامتثال لا التشريع كقائده الموحى إليه

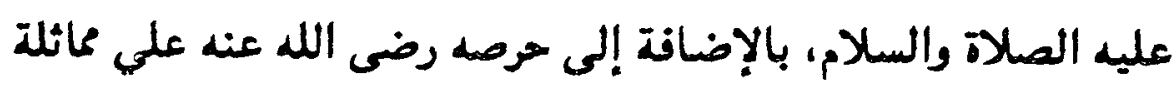
باقى الرعية دون زيادة على أدناهم.

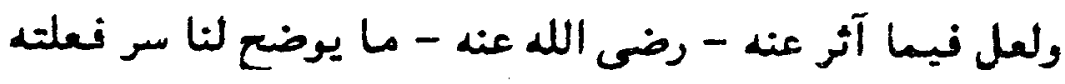

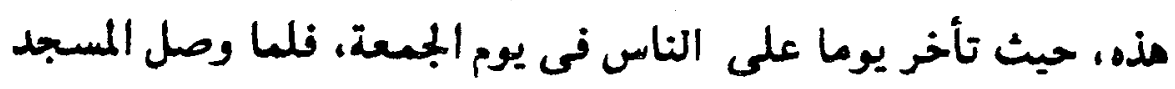

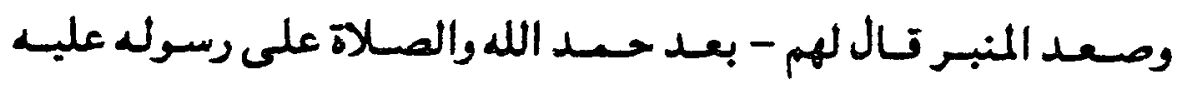

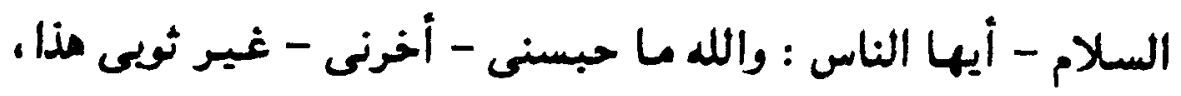
فتد انتظرته حتى جف بعد غسله، وليس لى ثوب غيره، (1)".

انظر : (1)

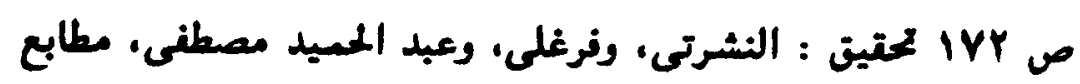
الأهرام 1992. 


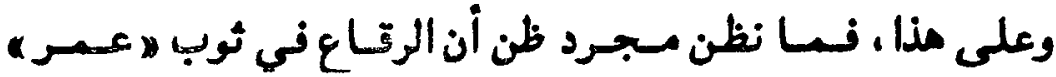

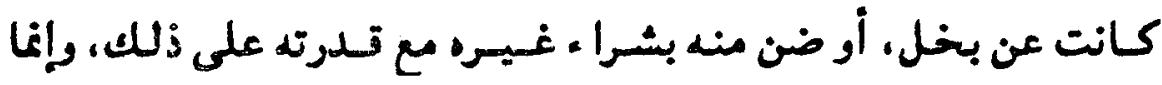

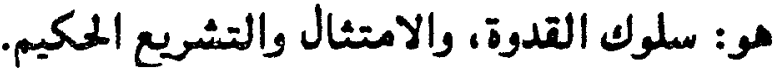

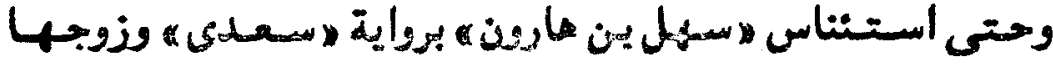

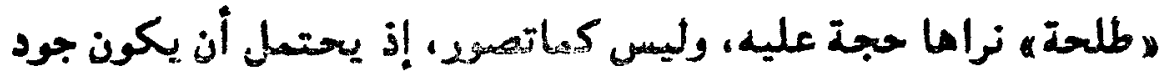

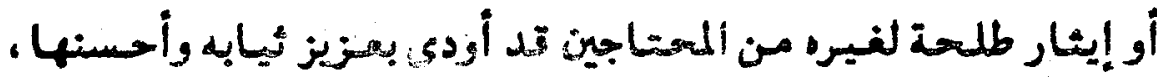

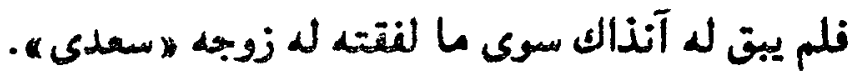

ونوق هذا ، نلا يستطيع ه سـل بن مارون ه أن يزعم أن ما شنع

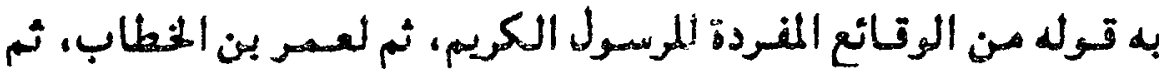

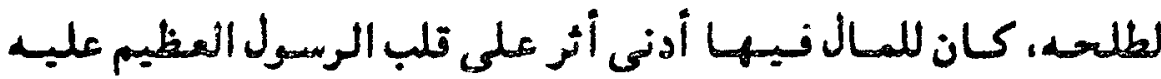

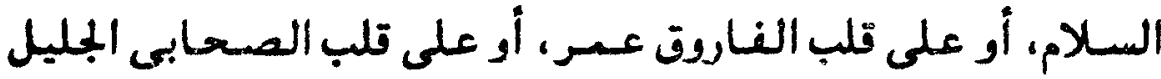

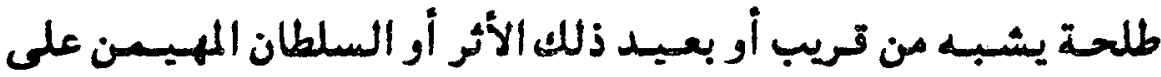
تلب هـهل بن مارونه حتى بدا للهال عبداً، يحدد من أجله سلوكه. ورقع خطاه ، ومذهبه فى الحياه. ولتد كان خصف النعال التديمة وحرمان النغس من شواء ـ النعال. أو الأحذية الجديدة، أو المشى فيها : من أبرز مميزات تلك الجماعة.

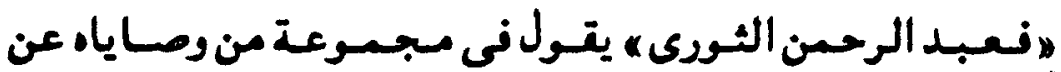

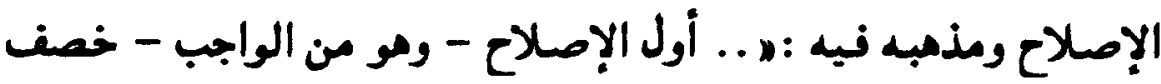

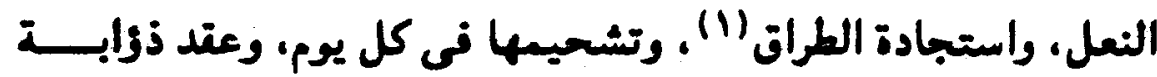

الطراق (بالطاء المشدودة المكسورة) : الطبتة أو الطبتات من البلد تطبق على مثلها. كل طبتة : طراق. 
الشرال (1)": من زى النساك، لكيلا يطأ عليـ إنسـان فيقطعه، ومن

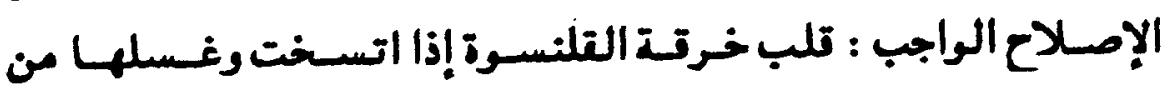
اتساخها بعد التلبه.

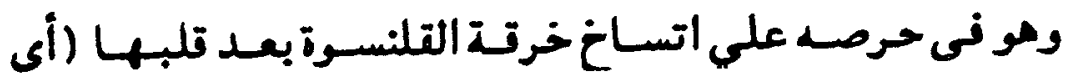

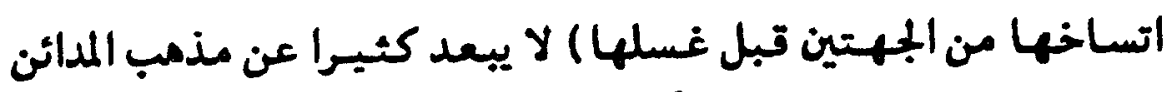

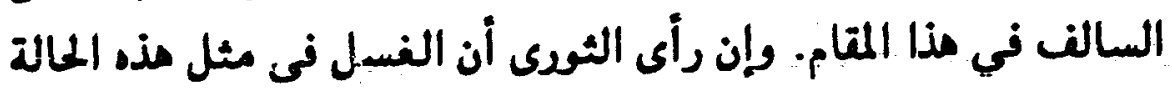
من الإصلاح الواجب كما يقول.

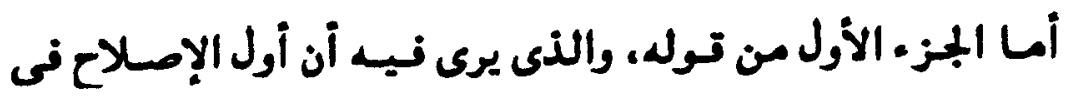

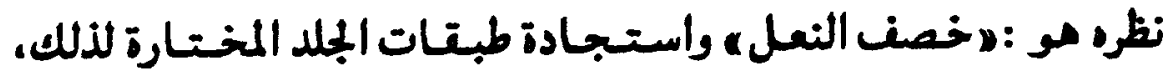

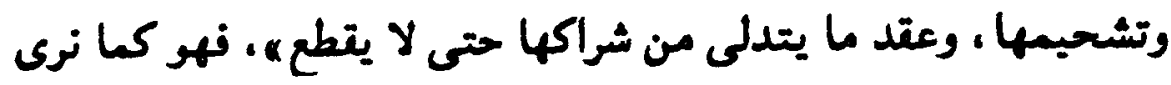

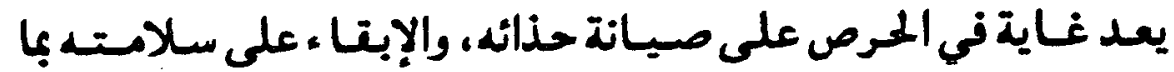
استمده من واتعه وخبرته في حياتد.

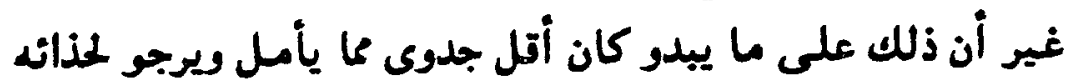

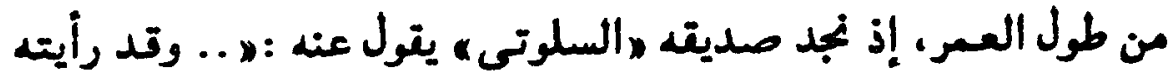

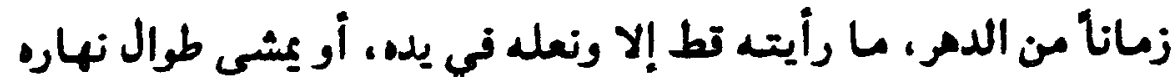

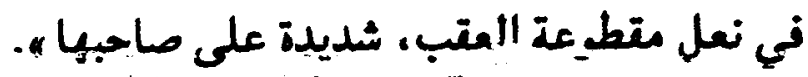

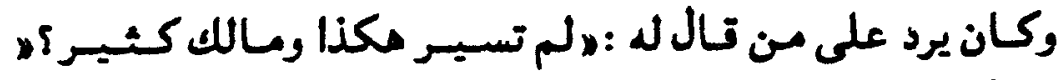

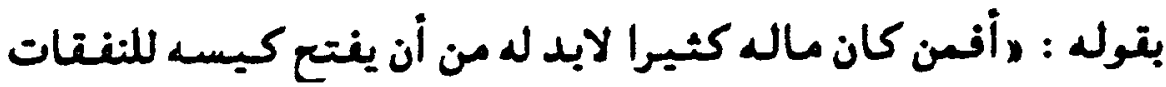

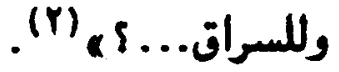

الشرال (بالشين المثددة المكسورة): سير النعل الذى يكون على ظهر

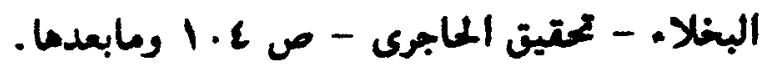




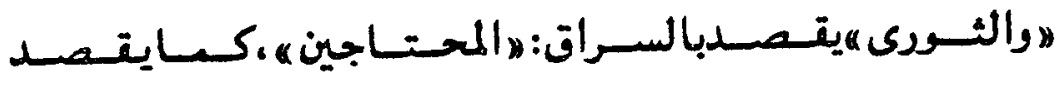

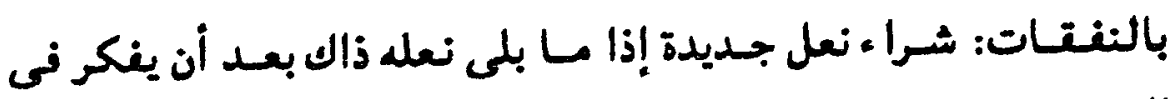

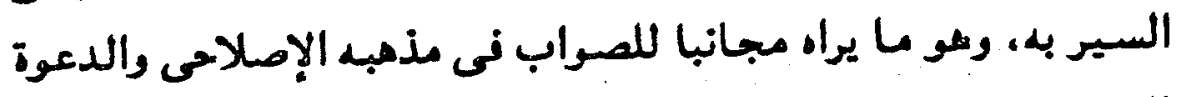

إليه.

ومعا يذكره ير أبو اسحاتي : إبرامبم بن سيار (النظام) عن جاره

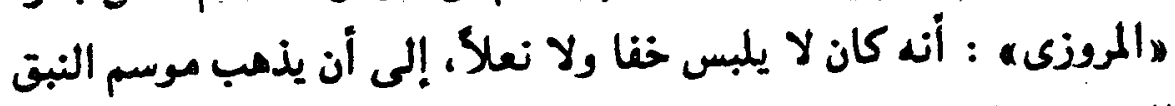

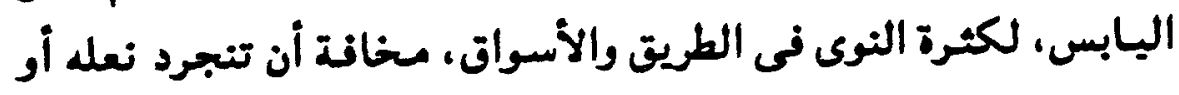

تنقب.

كسا لا يغيب عن أذهاننا ما ذكرناه من قبل عن " أبى محسـد

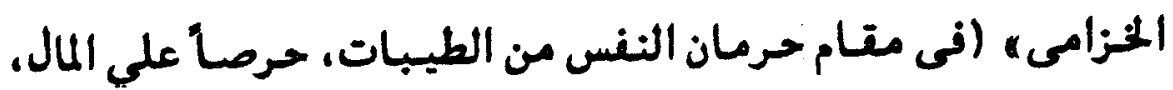

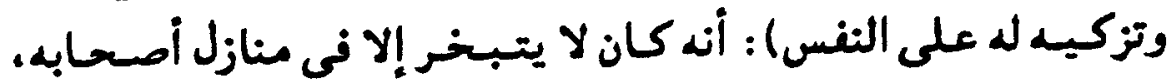

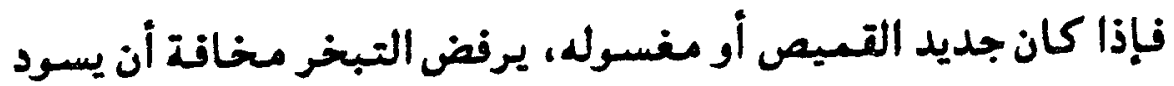

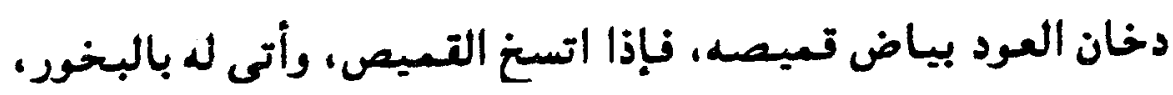

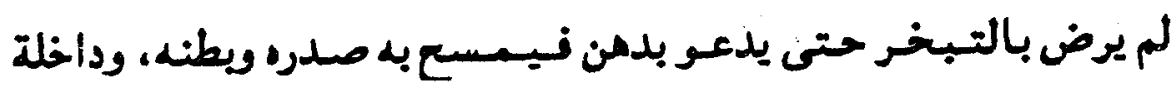

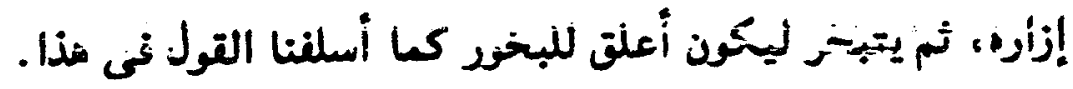

فـما أتى له من الآخرين يقبله ويحسن استغـلاله، وإستـتصـاء

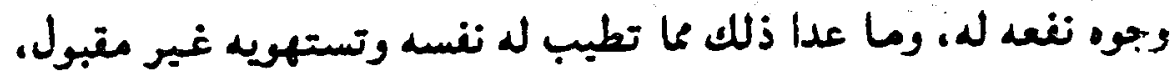

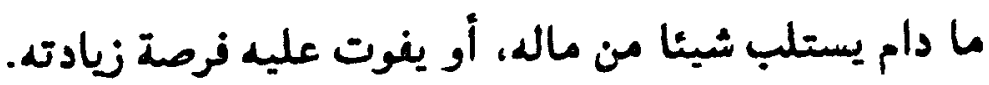

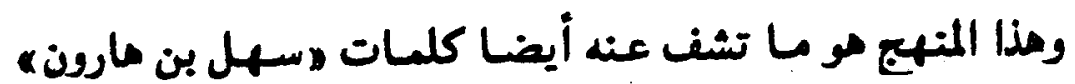

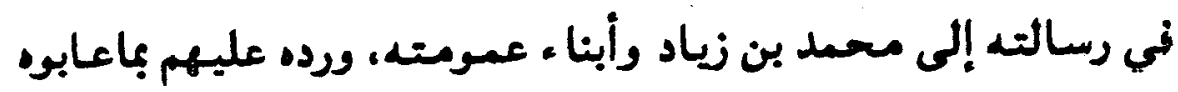

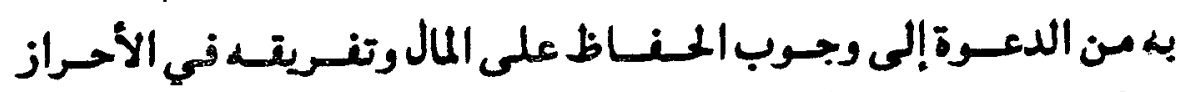

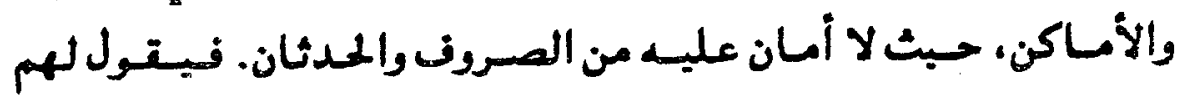




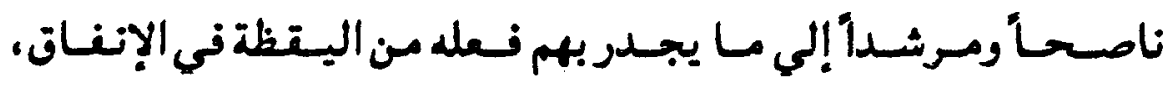

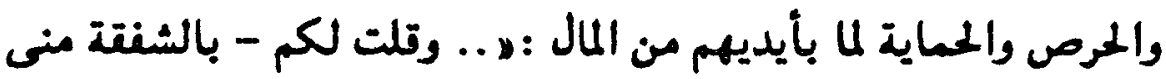

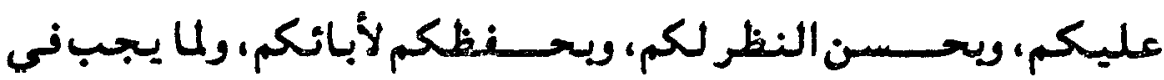

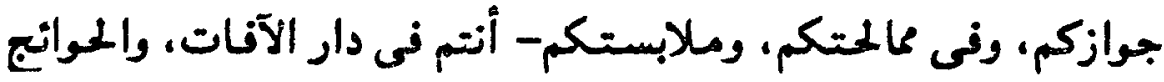

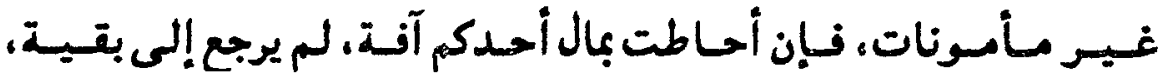

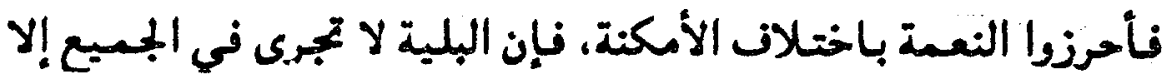

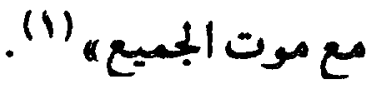

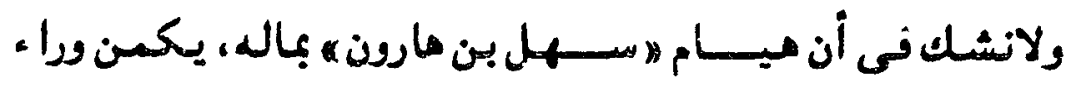
وعوته في مذهبه إلى اكتنازه، والتحفظ عليه بتغريق أماكنه، فئقاؤه

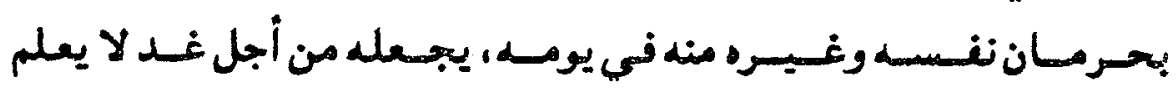
جوائحه، ومبالغاته فى الحُرص عليه، بتعلده مواطن حمايته، تجسيدها نطنته وإعداده لما قد يرمى به من أحداث الدهر.

وكسا يبدو، فإن منهجه في سلامة المال من النتصان يعد صدى

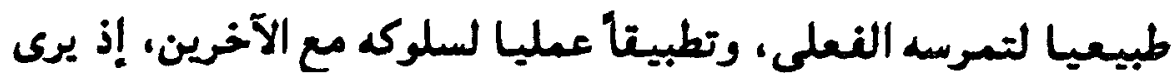

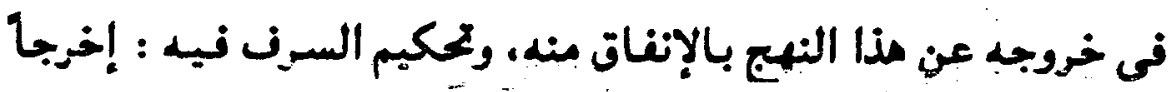

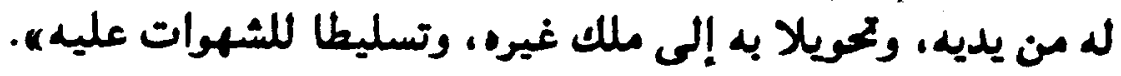

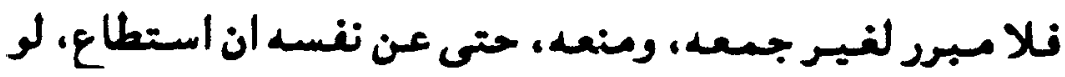

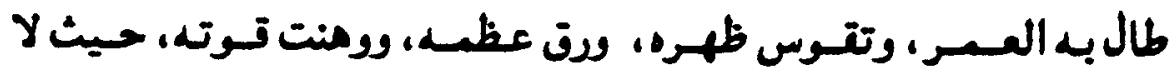

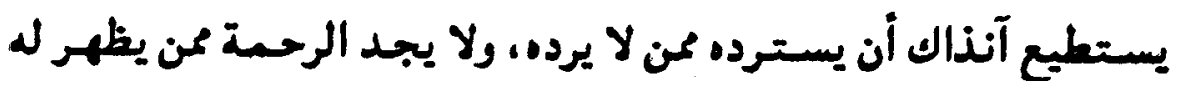

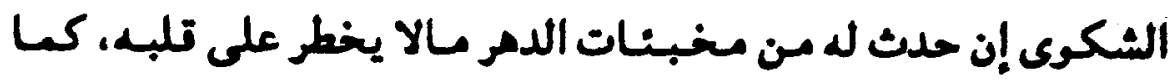
يغهم من قوله. 


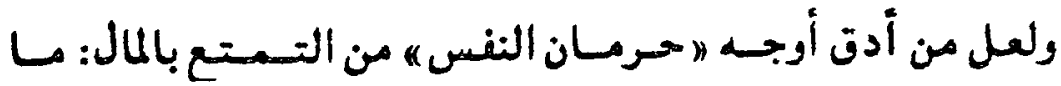

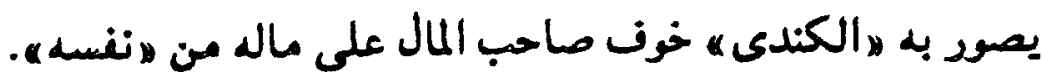

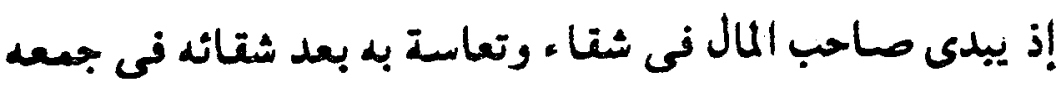

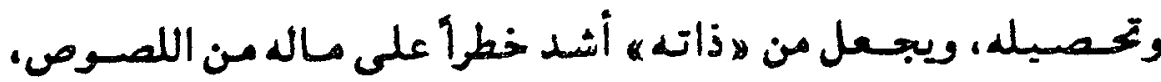

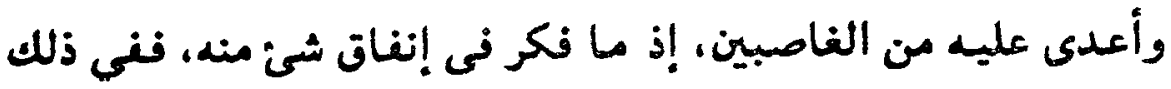

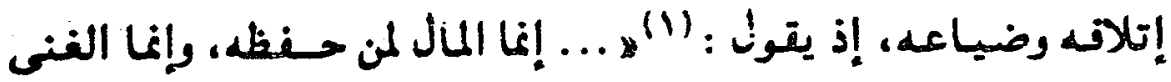

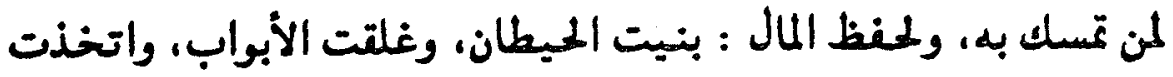

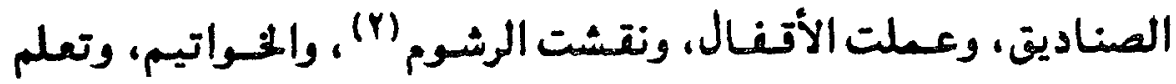

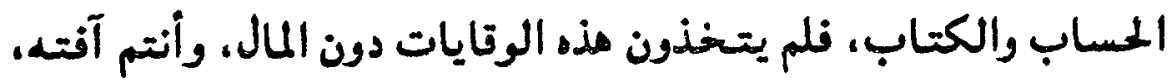
وأنتم سوسه وقادحه.

ثم يكشف عن مدى خطورة الإنسان نفسه أو صاحب المال علي

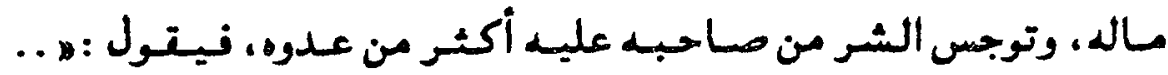

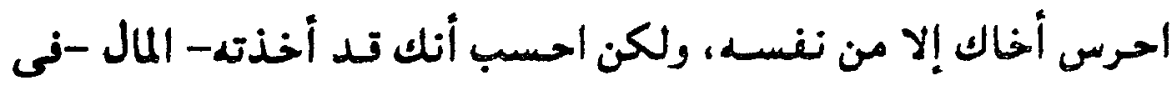

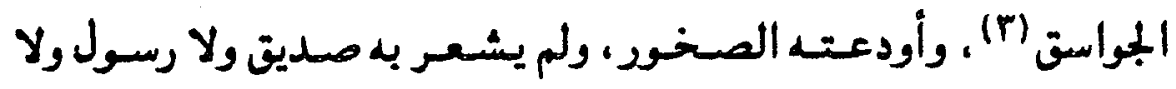

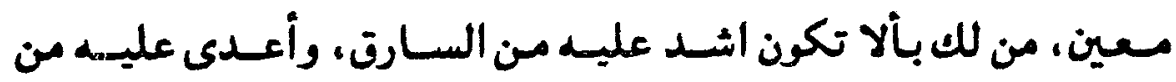

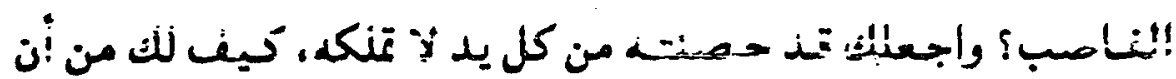

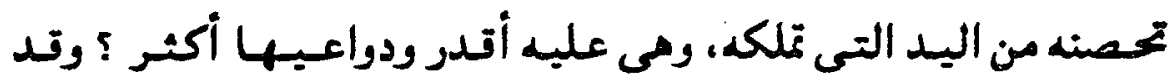

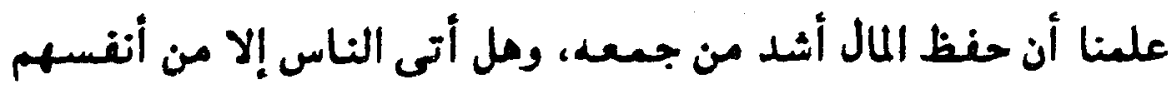

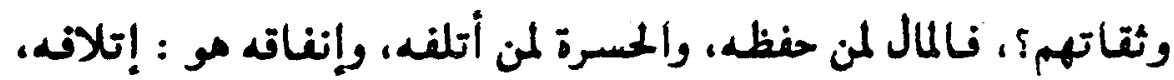

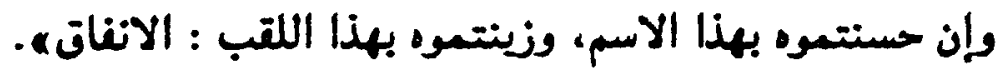

المدر السابق ص 11.

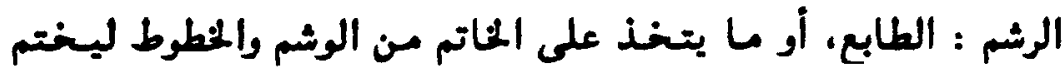

$$
\text { البهاسق : الملى المبوب وغيرها. }
$$




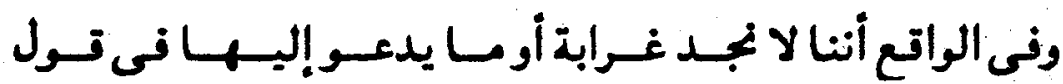

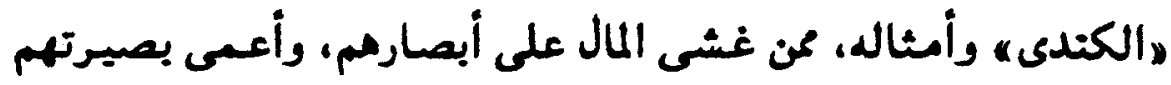

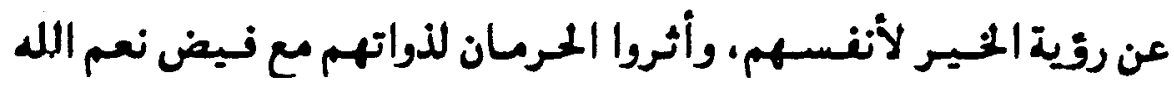

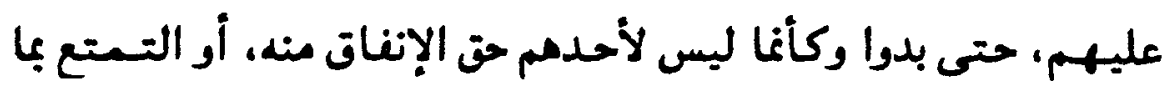

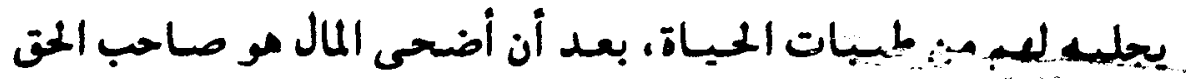

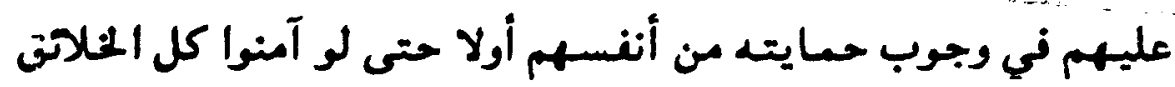
عليه، حيث لا يؤتى الناس إلا من أنفسهم وثقاتهم كها يقولون.

ومكذا نجد أن حب اللال، وفلسفة الحرص عليه والحرمان منه -

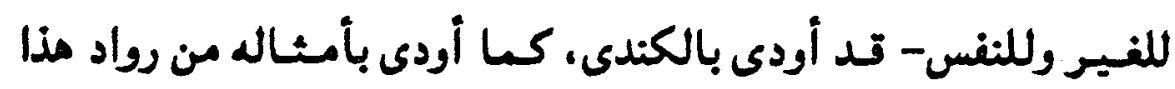

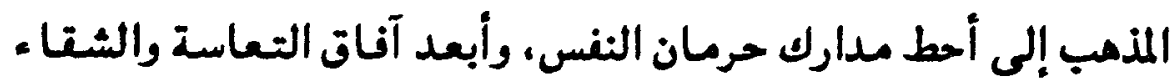

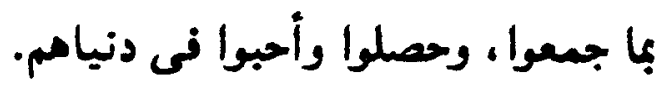

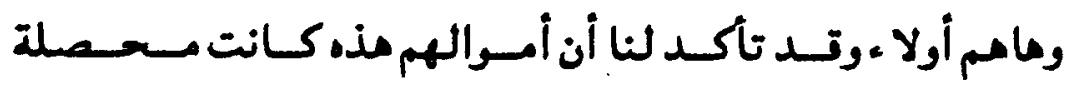

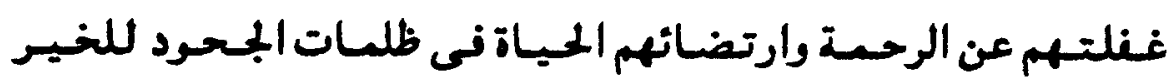
والحرمان لأنفسهم وللآخرين.

لقد أغنلهم منهجهم المشوه عن منهج الحيباة السوى الذى دبره

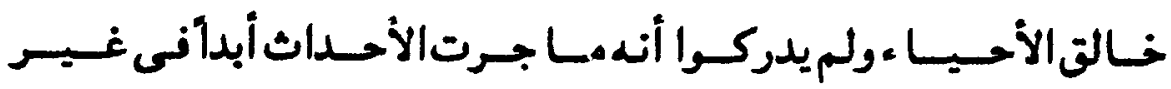

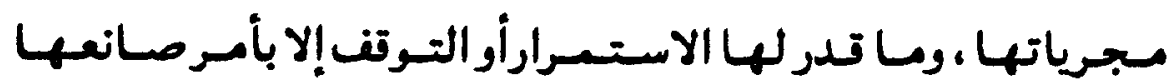
سبحانه. ومن منا ، فسا نطن الغاية من فلسفتـهم في البجمع، والحرمان،

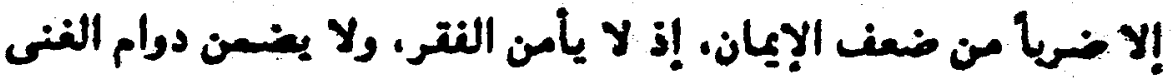
إلا من رقت عقيدته أو تصدعت دعامات دينه. 


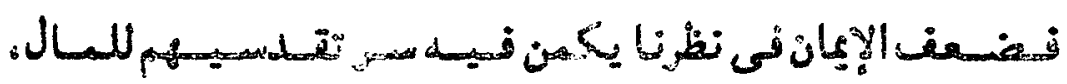

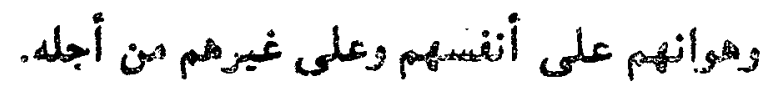

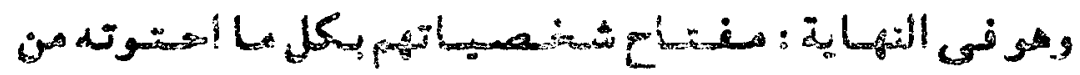

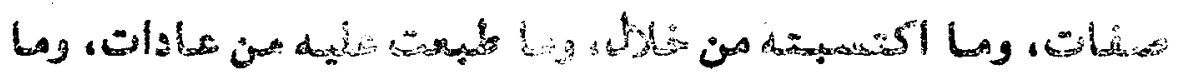

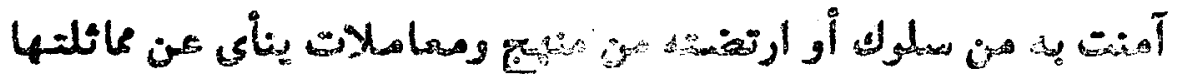

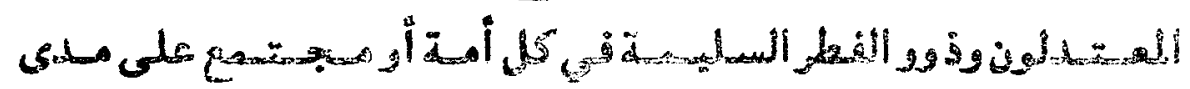
الزمان.

$$
\begin{aligned}
& 395^{29}
\end{aligned}
$$

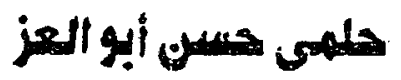




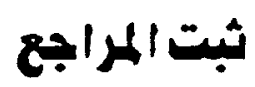

* القرآن الكريم. (الك.

1- ابن الرومى - حـيـاته من شعـره - لعـبـاس العـــاد- الطبعسة

\section{السادسة.}

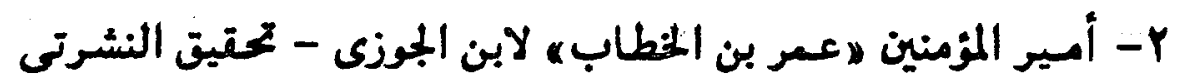

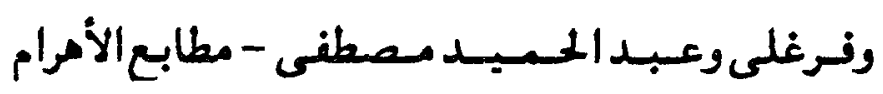

.1992

r- البخلاء - لأبي عمرو الجاحظ - تجقيق طه الحاجرى - بدون.

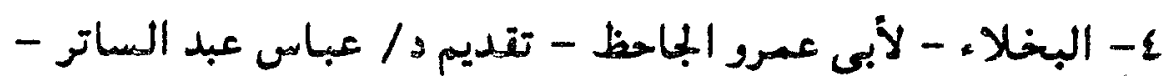

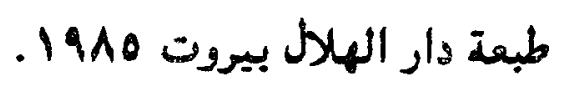

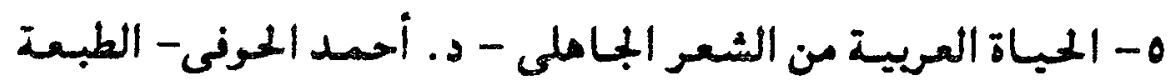

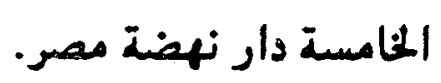

1- ديوان أبى العتامية - دار صادر بيروت .191.

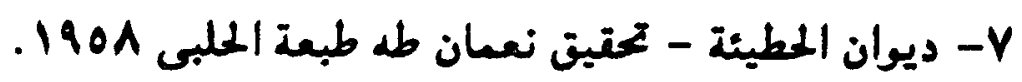

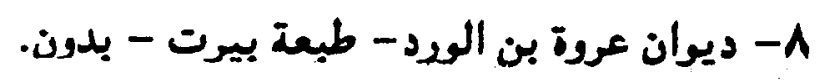

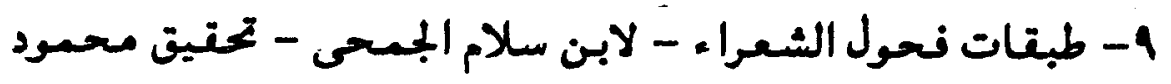

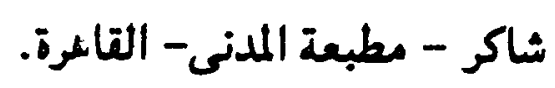

. 1 - العقد الغريد- لابن عبل. ريه - دار الكتب العلمية - بيروت.

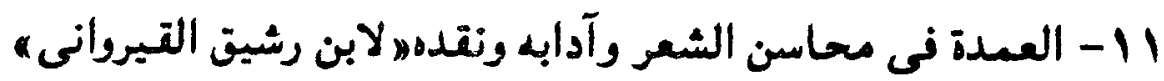

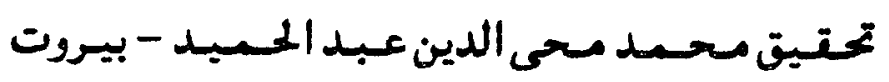

$.19 v \varepsilon$

r ا - عيون الأخبار- لابن قتيبة- دار الكتاب العيبى- بيروت. 


$$
-108-
$$

با - معجم البلدان - لياقوت الحمبى - دار إحياء التواث العريى بيروت.

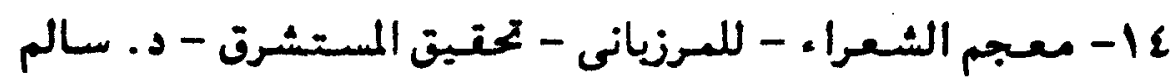
الكرتكوى.

ه- المفضليات - شرح التبريزى - تحتيت على البجاوى - الفحالة $.14 \mathrm{VY}$

17 - يتيمة الدمر- لأبى منصسد الثعالبى - تحقيق د/ إيليا حاوى

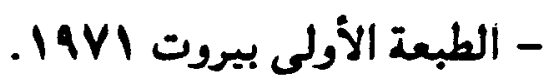

 
جاهعة الأزهر

كلية اللغة العربية

إيتاى الهاروى

الإعجاز الأبلى

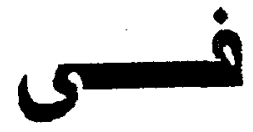

سورة لقمستسان

!

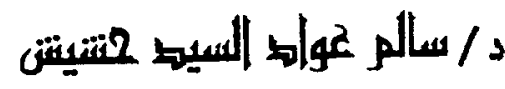

قسم الأوب والنتد.

p1990- 21217 

بسم إلله الزئمن ألزحيز

الحســـد لله رب العـالمين والصـلاذ والسـلام على أشـرن الرسلين

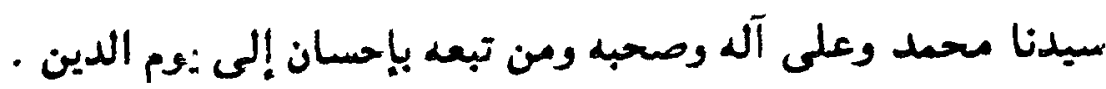

وبعـ

فإن الله سبــحساند وتعالى أنزل الترآن الكريم على رسـول الله

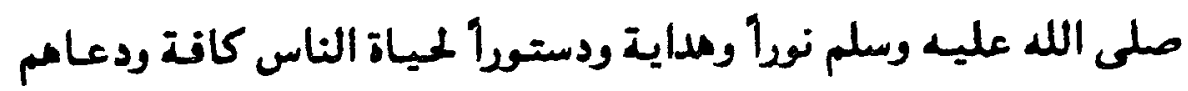

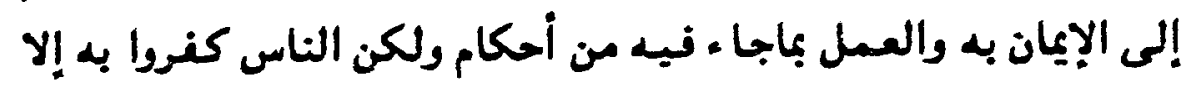

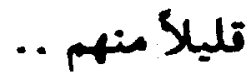

وقال الكافرون مذا سحر منترى وقالوا أساطير الأولين اكتتبها

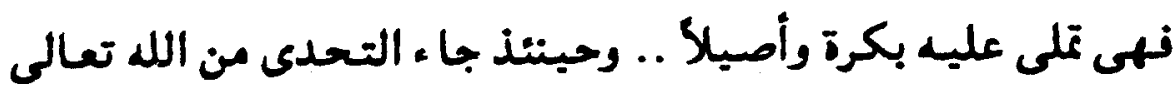

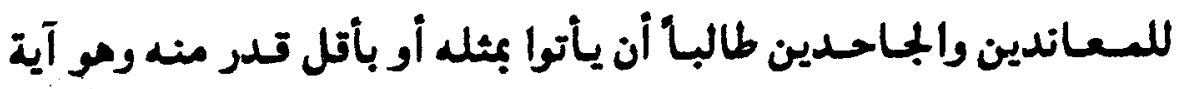
فلم يستطيعوا إلى ذلك سبيلا ..

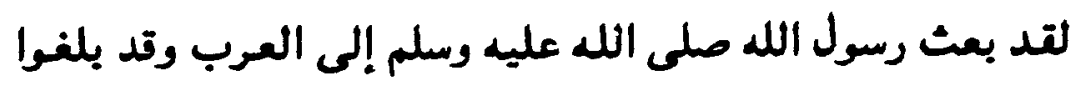

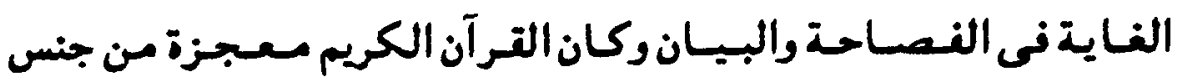

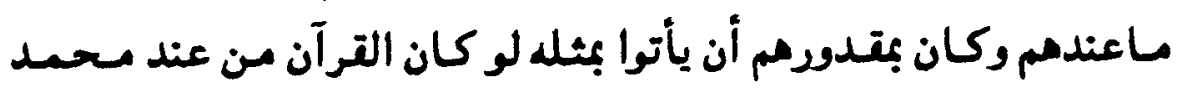

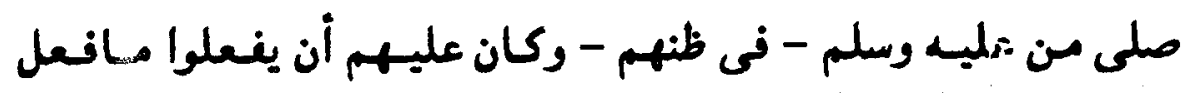

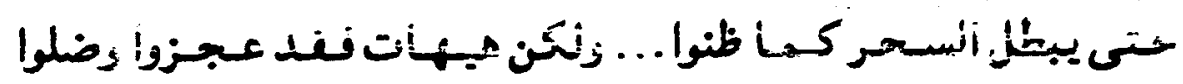
وتاموا وفشلت محاولات الكثيرين منهم فى الإتيان بمثله وحينتئذ لم

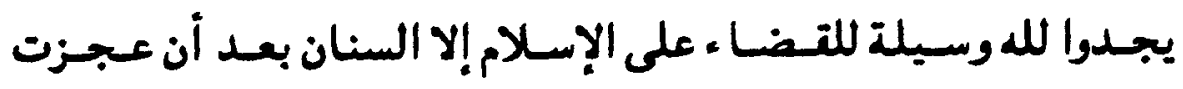

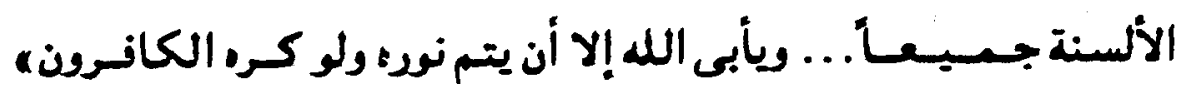

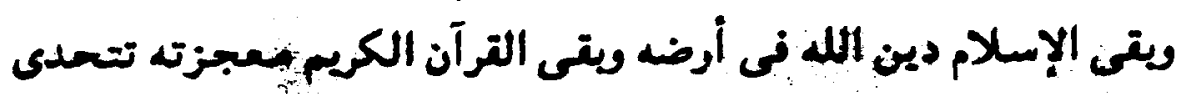

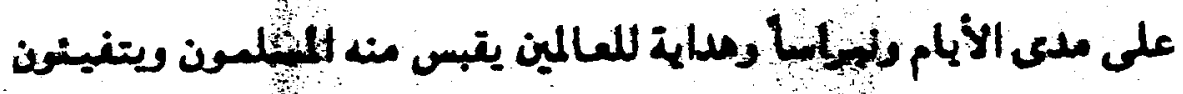


$-17 r-$

ظلاله وينعمون با فيسه من خبر الهداية ونور اليتينين وإعجاز البيـان

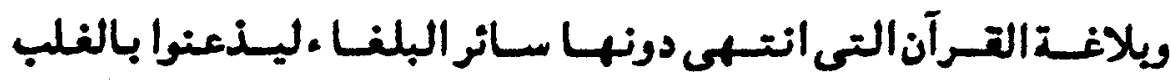

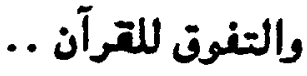

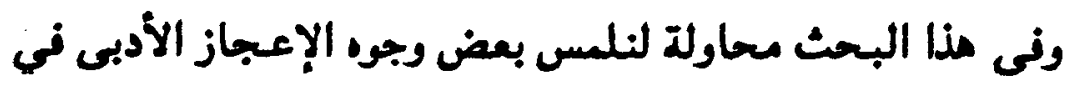

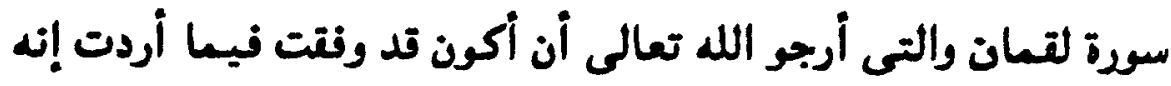

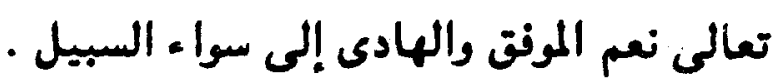

د. سالم عواد السيد حشيش

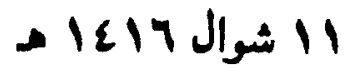

1 مارس 1997 


\section{Pيل}

سورة لتعان مكية إلا ثلاث آيات منها مى قوله نعالى : دولو

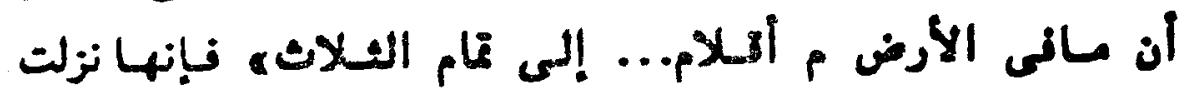
بالمدينة .

وذلك أنه صلى الله عليه وبسلم لها أتم هجرته إلى المدينة المنورة

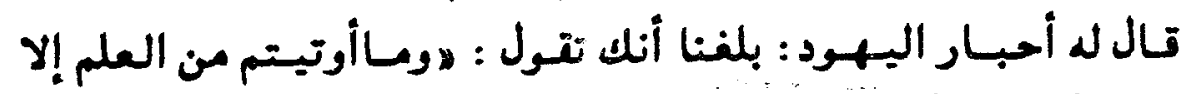

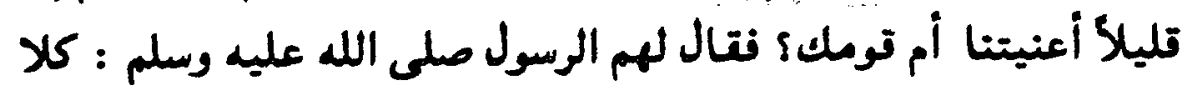

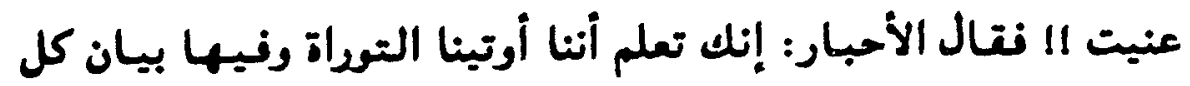

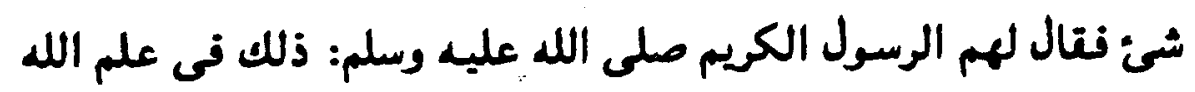
تعالى قليل ... نأنزل الله الآيات.. (1)

السورة مغتتـعة بالبسـلة - والبسملة تسم من الله تعالم أنسـس

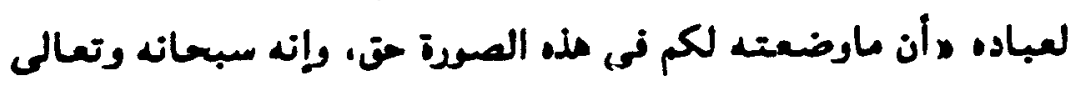

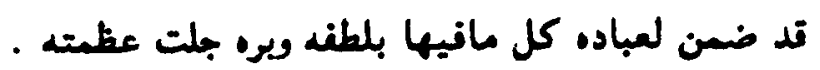

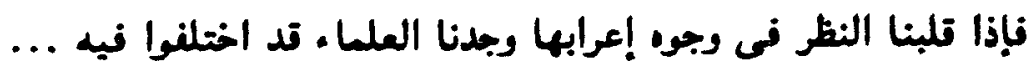

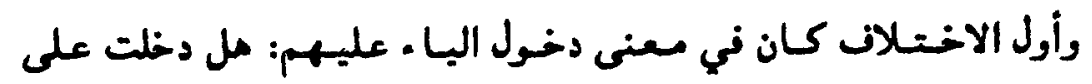

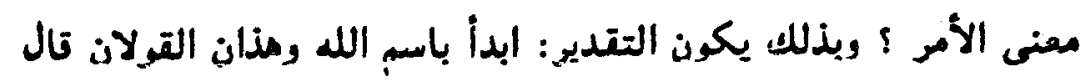

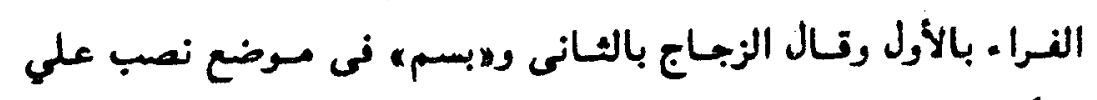

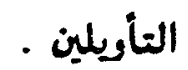

وتيل المعنى: إبتداتى: بسم الله، وربسم الله، في موضع نصب على التأويلين .. وقيل المعن:

وتيل: المبر مسذون.... أى ابتدائى مستتر أر ثابت بسم الله، فإذا

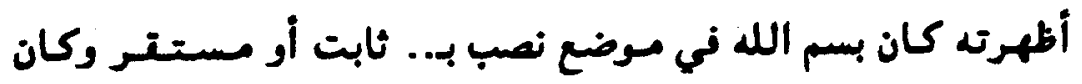
بمنزلة تولك : ل ازيد في الداره . 
وسبب نزول السورة أن تريشـا سـألت عن تصنة لتسان مع ابنه

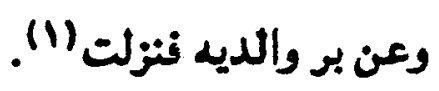

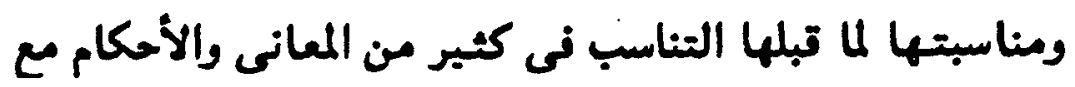

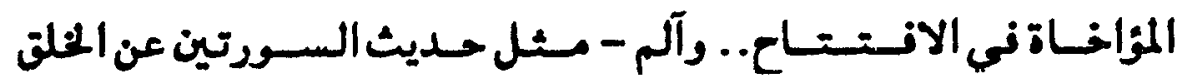

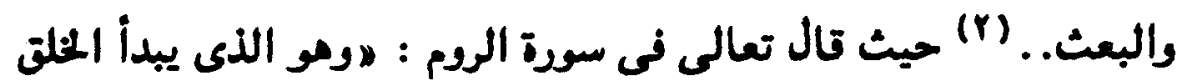

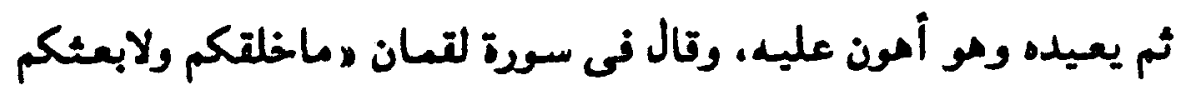

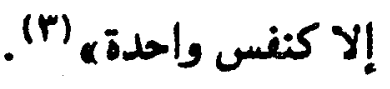

$$
\text { والبسملة تعددت الآراء فبها مل مى آية أمرال ؟ }
$$

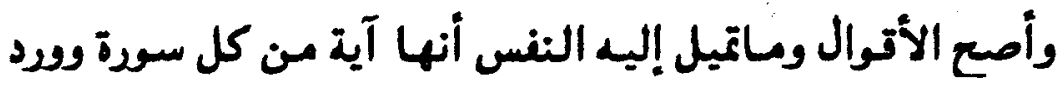

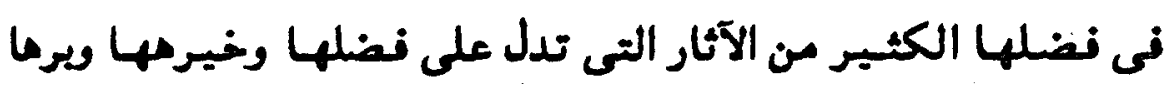

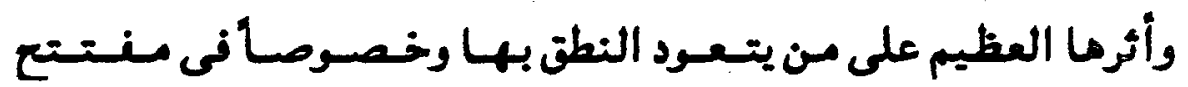

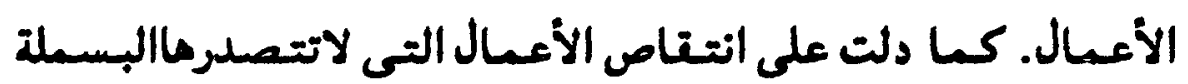
من ناحية الحير والبر فيها (ع).

قوله تعالي ״ آلمه قد ورد في تغسيرها أقوال متعددة منها :

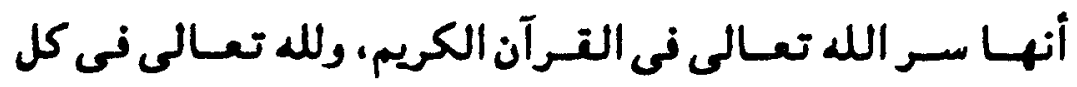

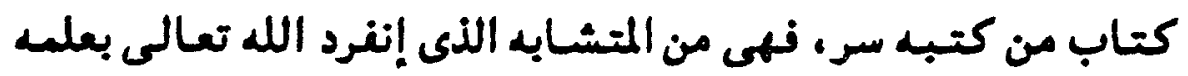

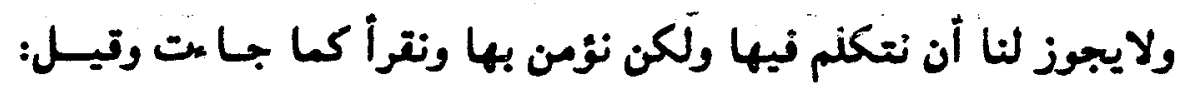

روح المعانى في تفسير الترآن العظيم والسبع المثانى الألوسى حـاه

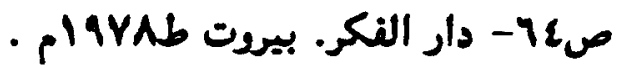

$$
\begin{aligned}
& \text { السابق ص10 . } \\
& \text { السابق صها } \\
& \text { تغسير الترطبى حـ ص . }
\end{aligned}
$$




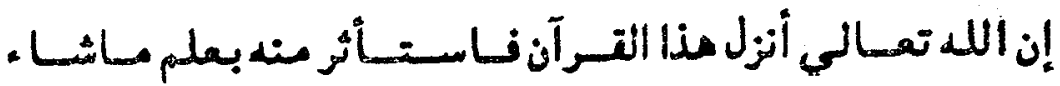

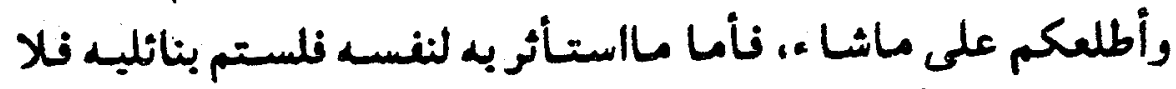

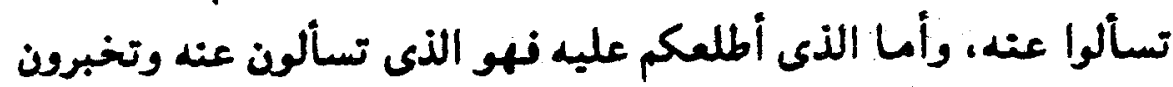
ومابكل انترآن تعلمون ولابكل ماتعلمون تعملون .

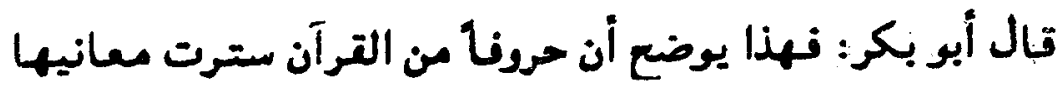

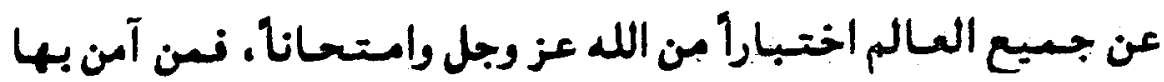

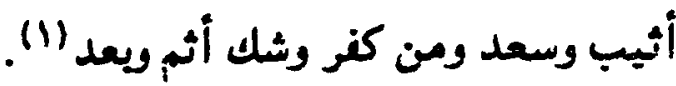

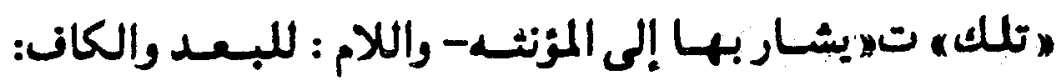

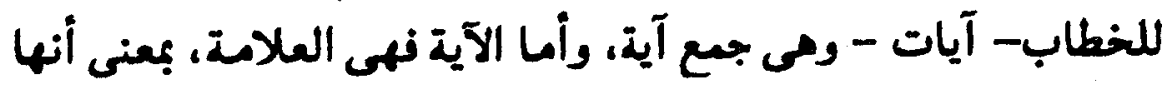

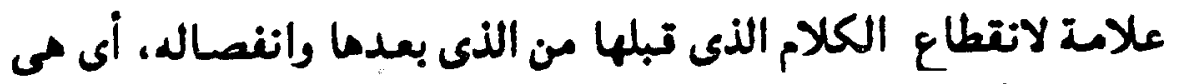

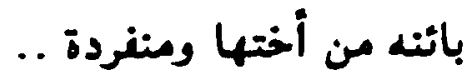

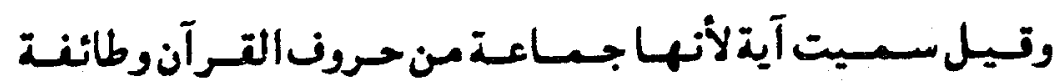

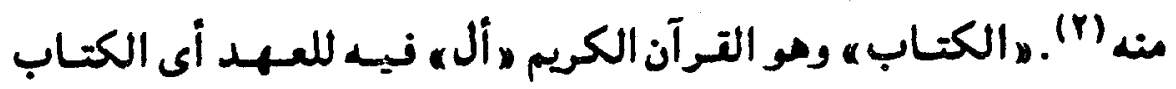

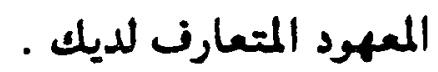
والحكيم "أى ذى المكية - المحكم الذى لاخلل فيه ولاتناتض.

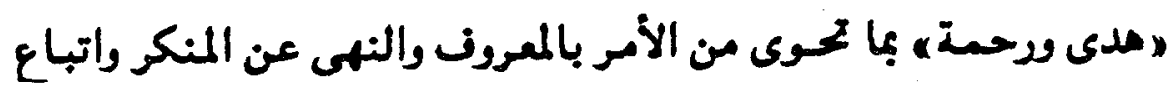

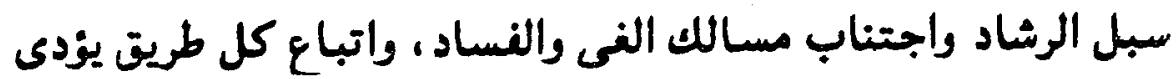
:

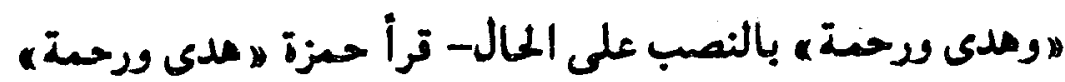

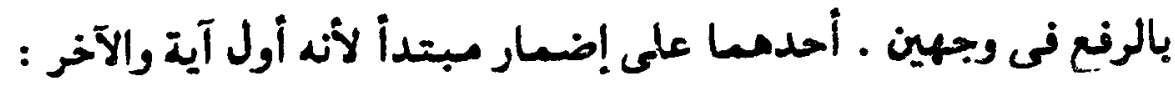

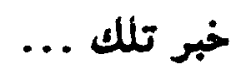

$$
\begin{aligned}
& \text { الترطيى حاصl r r } \\
& \text { السابق حا سبه . }
\end{aligned}
$$


والمحسنين - مغردما ، محسن ه ومن صنات المحسن أنه يعبد

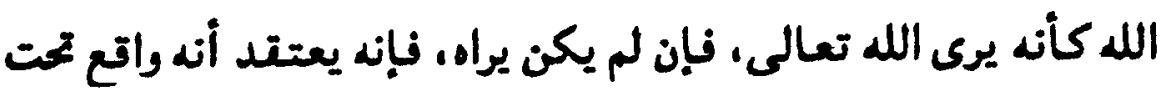

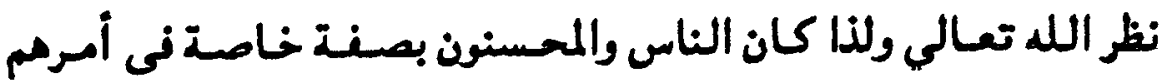

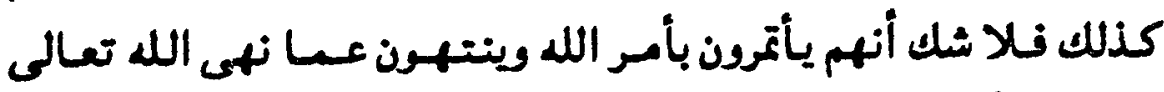

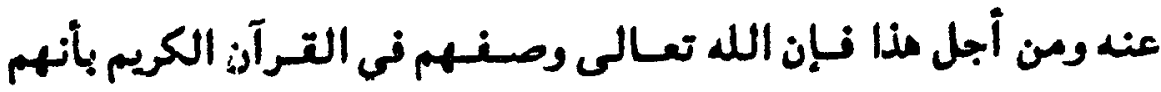

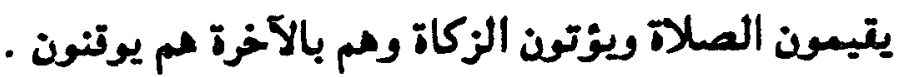

ولاشك فى أن من يكون عمله على مذه الصسوة وعتبدته كذلك

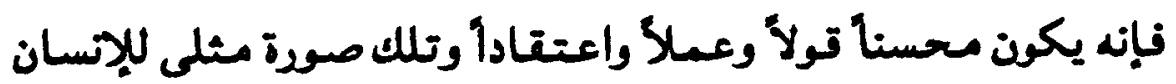

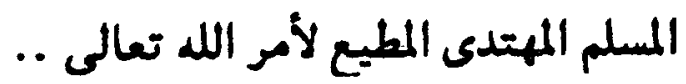

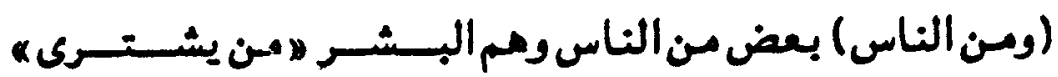
الاشتراء مو مبادلة مال بعابل من نتول أو عتار أو منفعة كأنه تبل:

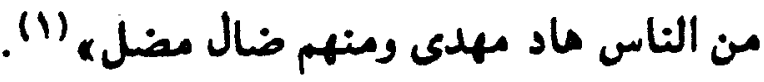

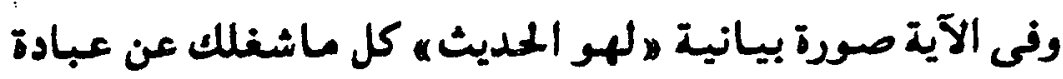

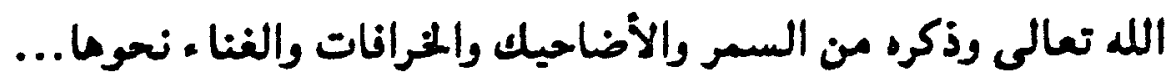

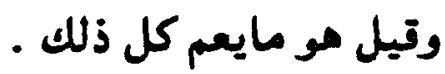

ونزلت مذه الآية فى النضــــ بن المـرث، وذللك أنه اشـــــى قـينة

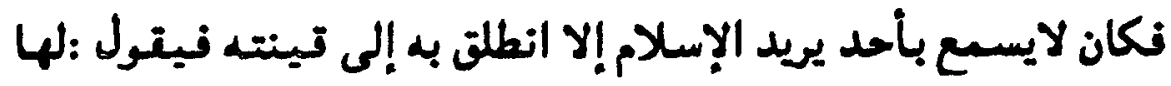

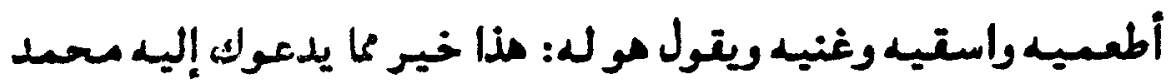

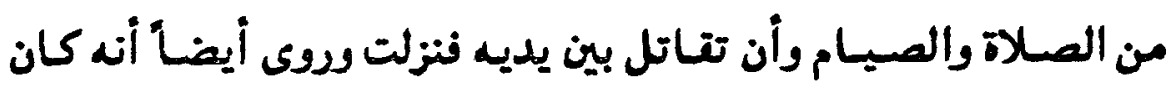

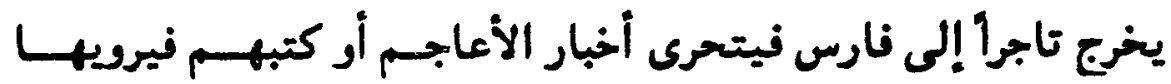




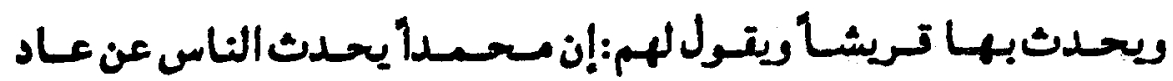

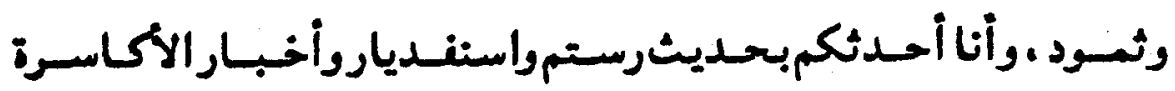
فيستملحون حديثه ويتركون استماع القرآن الكريم ...

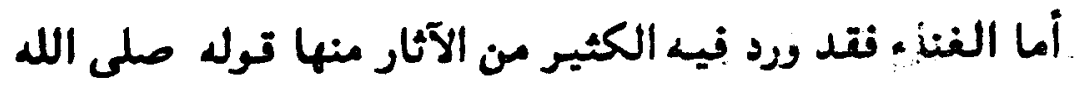

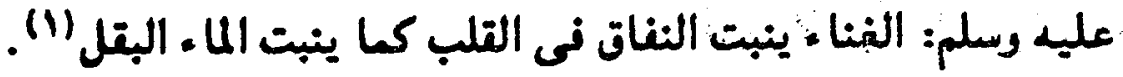
وروى عن رسول الله صلى الله عليه وسلم أنه تال: مارنع أحد

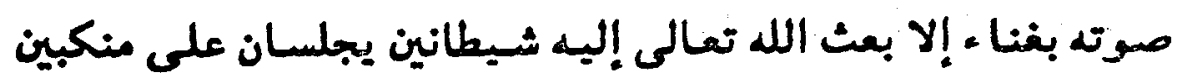

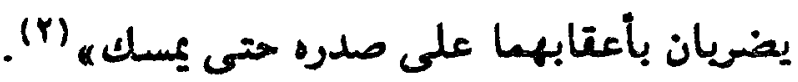

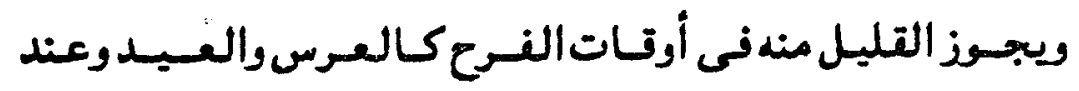

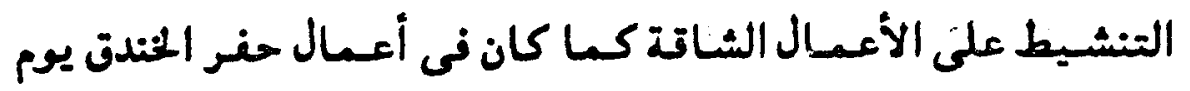
غزوة الأحزاب وحدو ألمجشه (r).

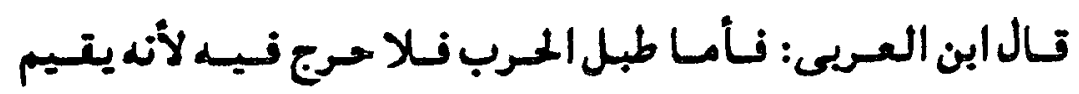
النفوس ويرمب العدو والدف مباح ..

تال التشـــرى: ضرب بين يدى النبى صلى الله عليه وسلم يوم

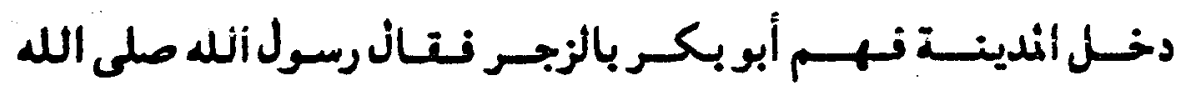

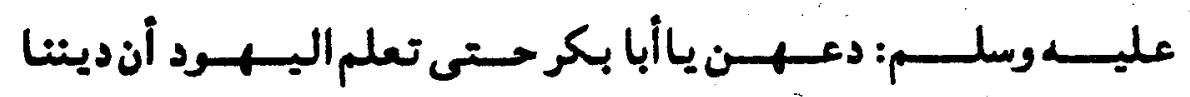

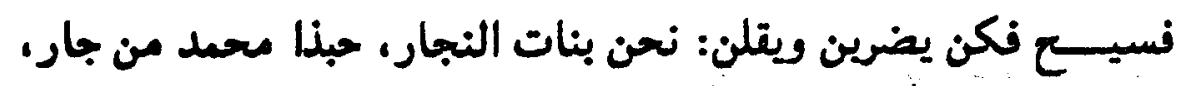

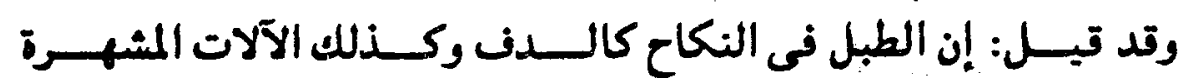

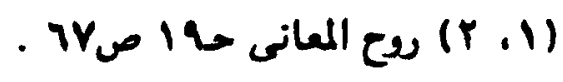

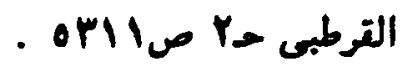




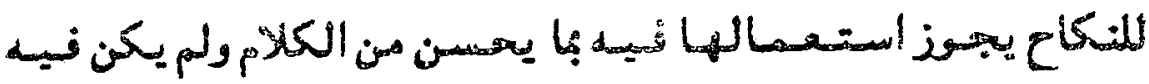

$$
\text { رفث ") }
$$

ويكن التول استنبـاطاً من قول الرسول صلى الله عليـ وسلم:

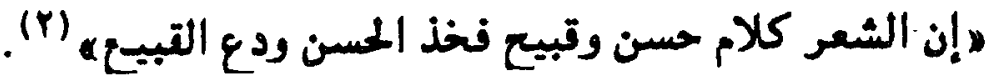

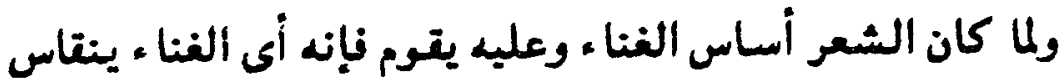

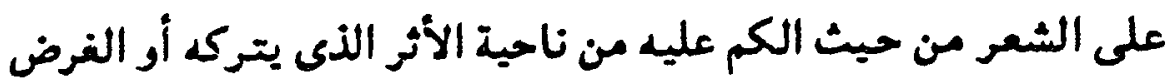
الذى يراد من وراته .

وعلى مذا نإذا كان الغنا ـ خالياً من الرفث ولايدعو إلي إذكاء .

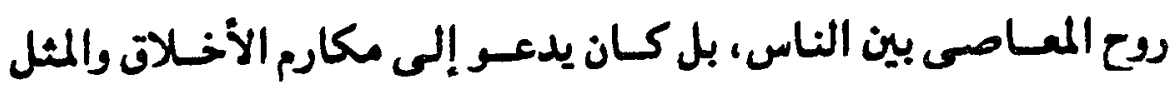
ويث الحماس والحمية فى النغرس فلا شئ فيه ..

مسـداتـأ لتـول النبى صلى الله عليه وسلم ها إنما الشعـر كلام مؤلف فـا وافق المق منه فهو حسن، ومالم يوافق الحقى منه فلا خير فيها).

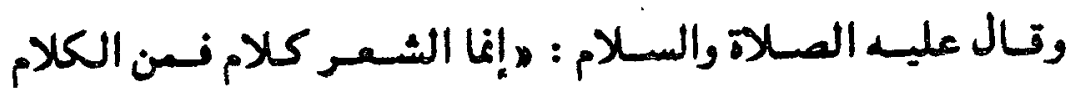

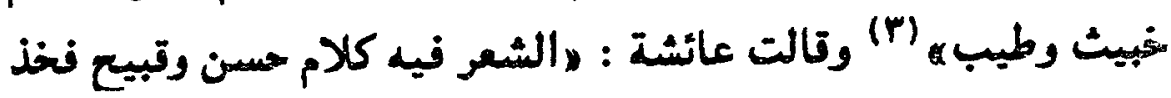

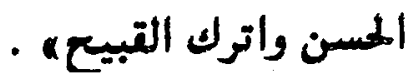

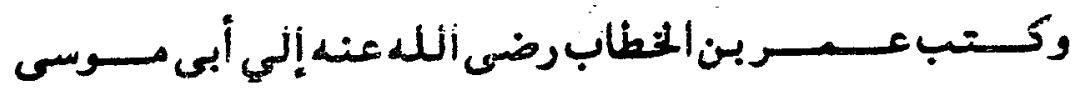

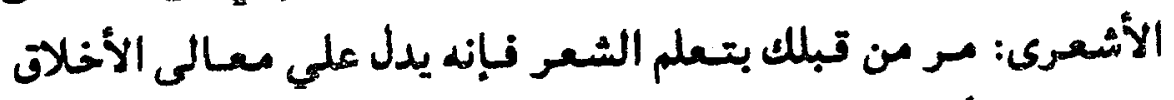

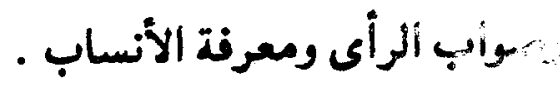

السابق والصغعة .

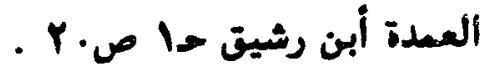

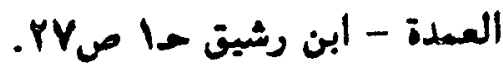




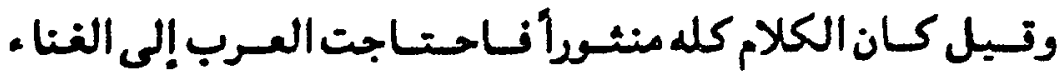

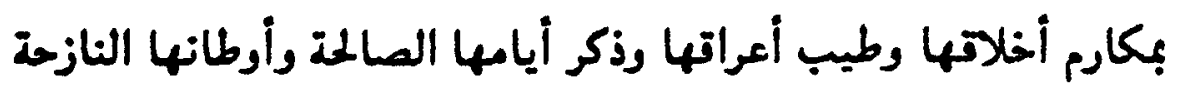

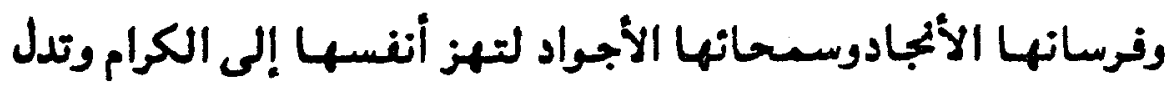

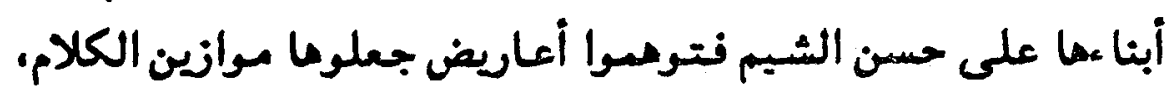

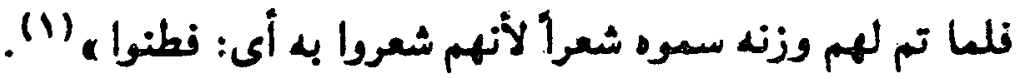

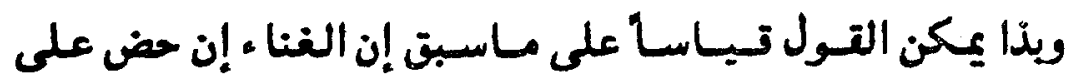

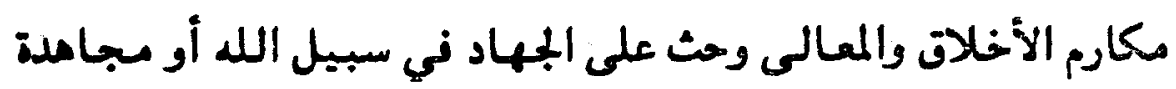

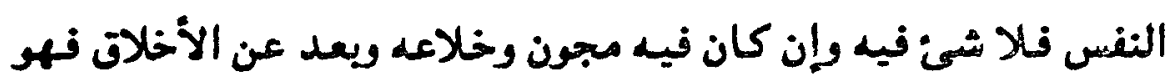

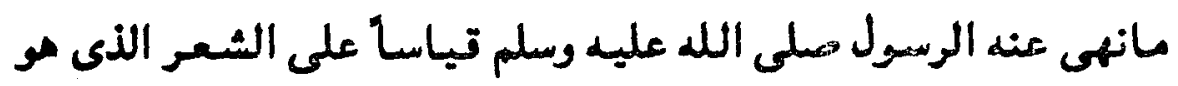
أساسه وعليه ينقاس ..

ويزكد ذلل فيما أرى قول الله تعالى لا ليضل عن سبيل الله.

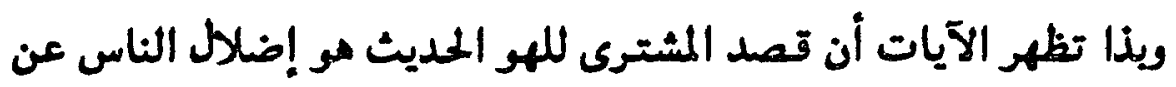

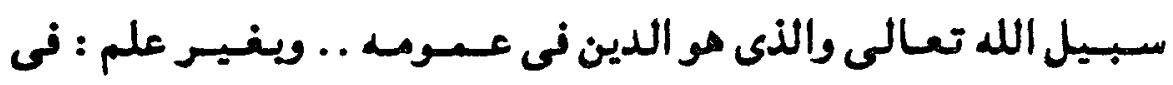

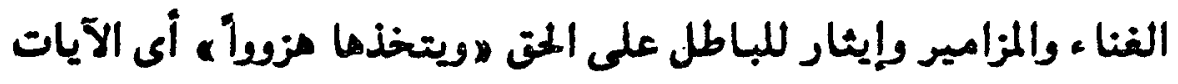

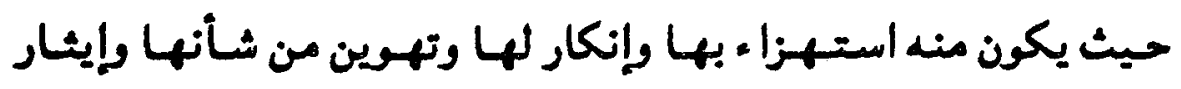

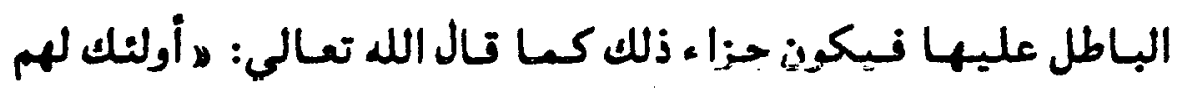
- عذاب مهنينه

حيث يصليهـم الله العـاب بفاسد أعمالهم فيكون ذلل إمانة

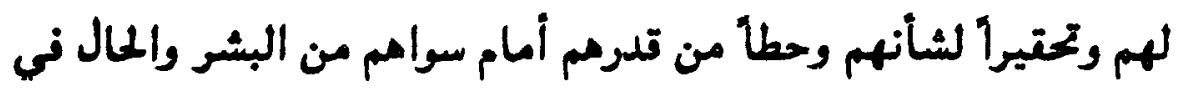
الإنسان أن يكرم فى الدنيا والآخرة . 
ويؤكد ماسبق من تبـاس الغنا ، بالشعر وييـان الهدف من كل

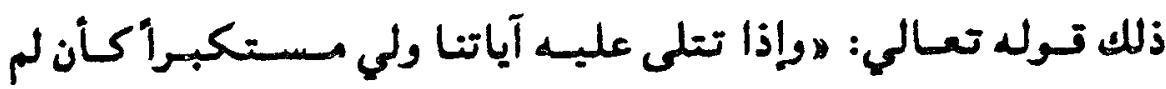
يسعبا كأن فى أذنبه وقرأ فبشره بعذاب أليمه .

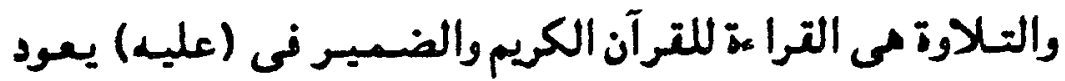

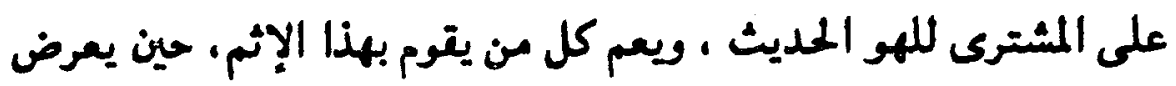

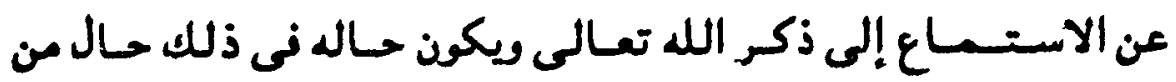
أصيب بالصم ولاجزاء له عند الله تعالى إلا العذاب الأليم ومو جزاء

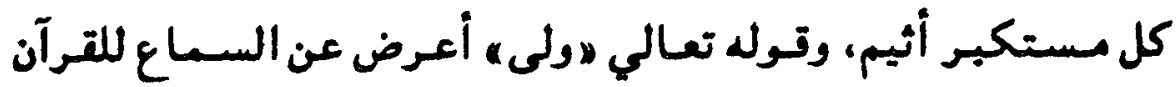

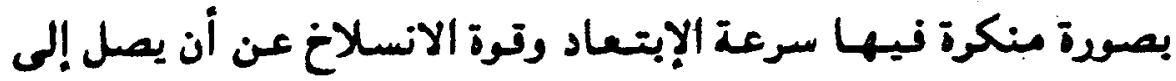
أذنه صوت الترآن الكريم •

والترآن يدل على تلل المعانى من خلال الألناظ الموحية المؤدية للمعنى فى قوة واتتدار ومى يذلك مساوقة للمعنى لأنها من عند الله

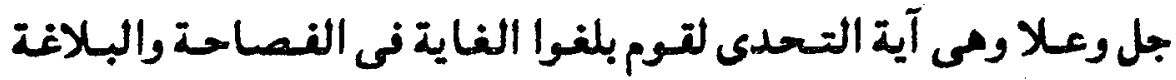

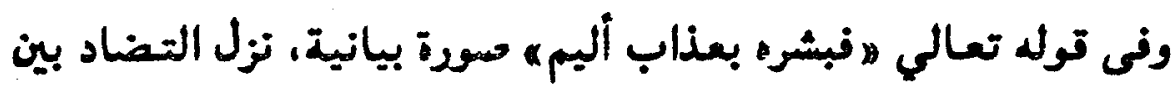

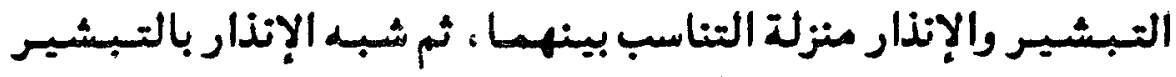

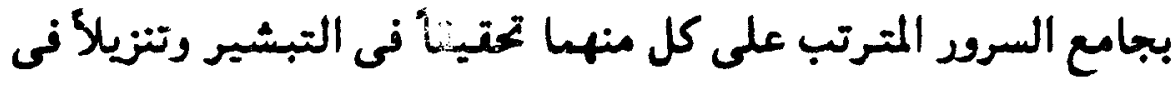

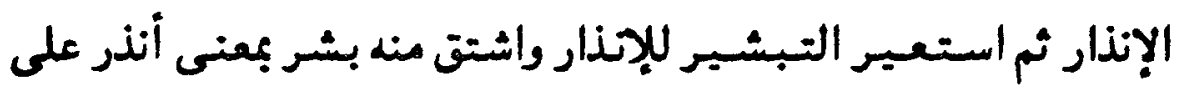

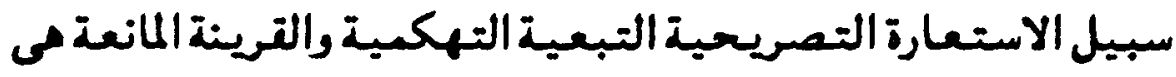
عذاب ومو مجرور بالبا ء ومتعلق بالنعل الذى وتعت فيه الاستعارة،

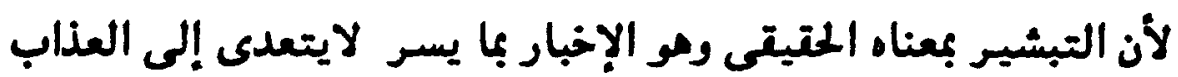


فـدل ذلل على أن المراد بالنـعل بشــر: مسعنى ينـاسب العــاب ومو

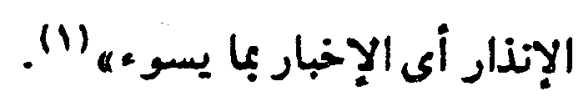

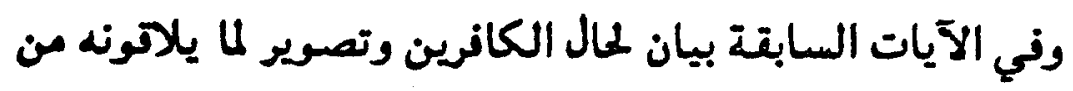

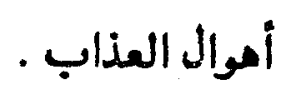

$$
-r-
$$

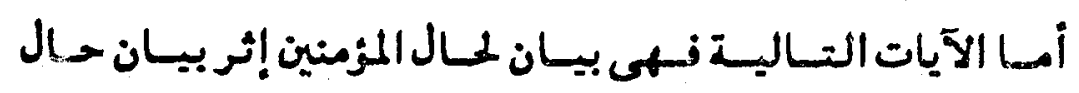

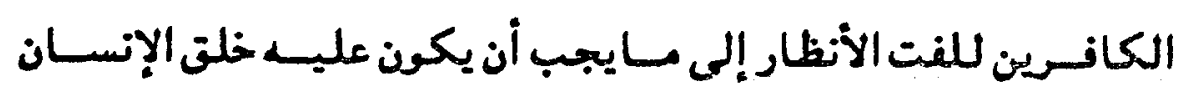

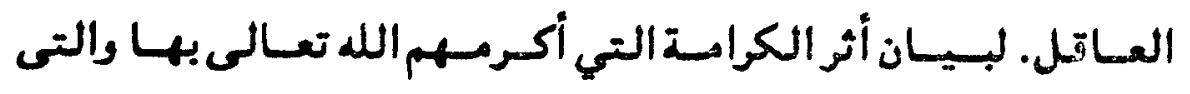

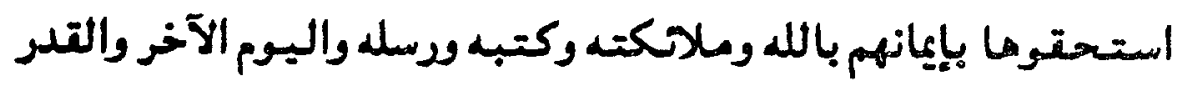

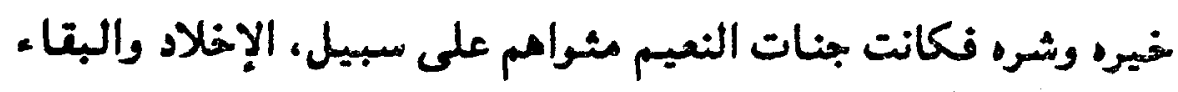

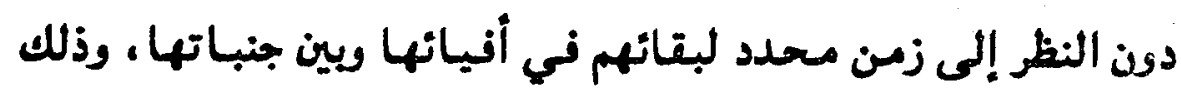

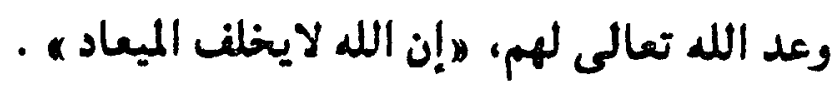

\section{ويقول القائل ، ويضدما تتميز الأشياءه، .}

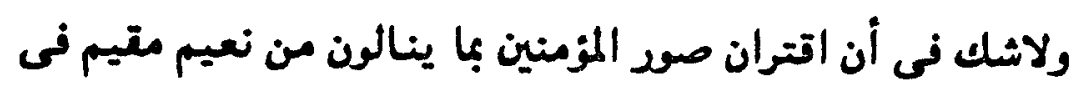

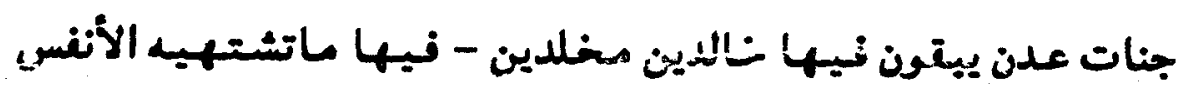

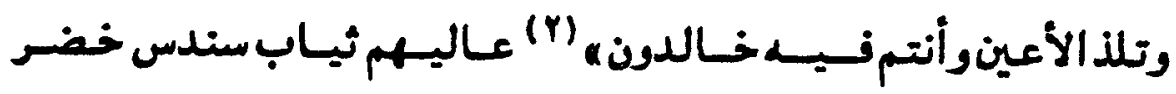
وإستبرق وحلوا أساور من فضة وسقامم ربهم شراباً طهورا إن مذا كان

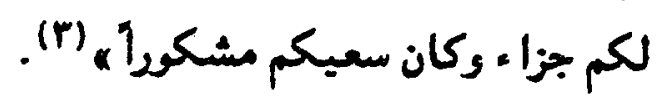

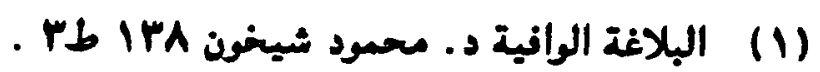

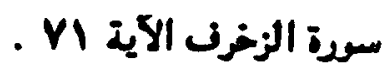

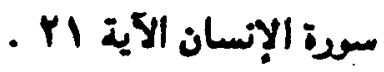


ومذه الصسورة الملى يتابلها ويناظرما تصوير الترآن الكريم لما ينالد الكافرون من عذاب أليم متيم وذلك لكى تزداد الصود إيضاحا

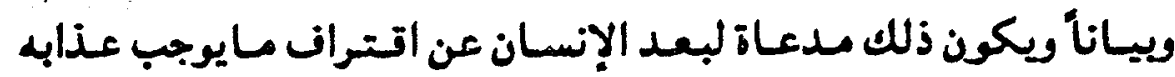

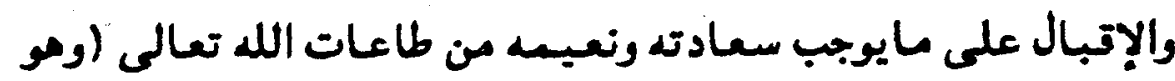

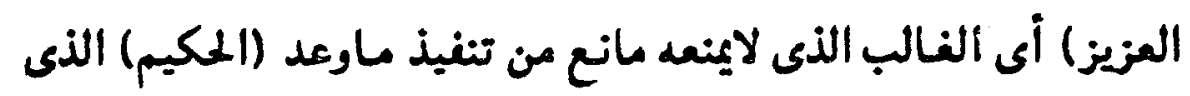
تأتى أنعالد كلها من منطلق المكسة . .

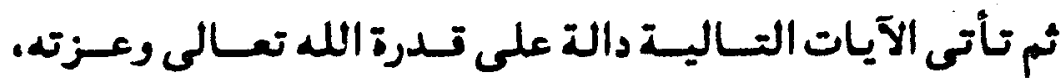

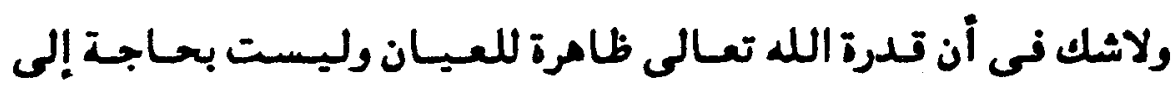

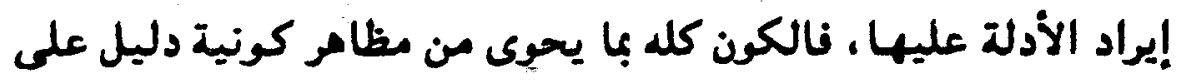

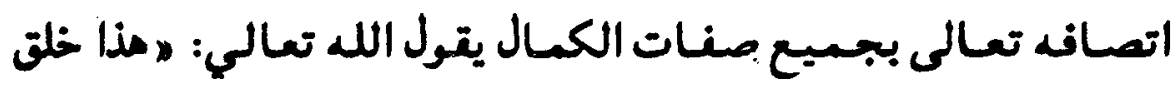

الله نأرونى ماذا خلق الذين من دونه يج (1).

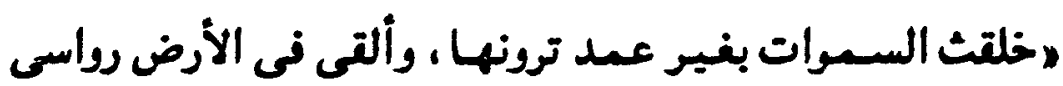

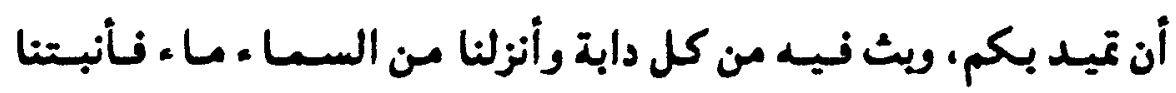
فيها من كل زوع كريمه (r)

ومى مظامر ليست فى حاجة إلي إيضاح وتنسير لأنها ظاهرة للعيان لايجحدها إلا من عمى قلبه وصد عن سبيل الله ..

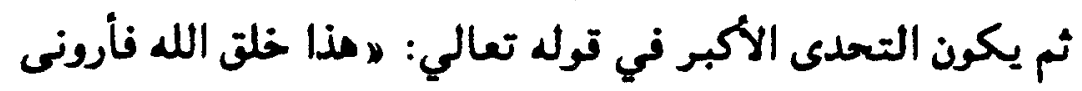

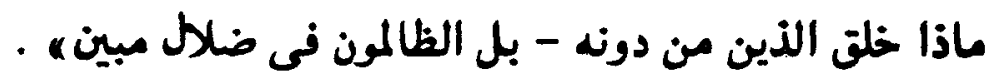




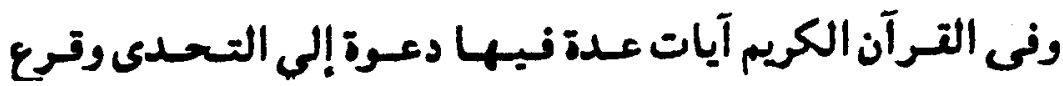

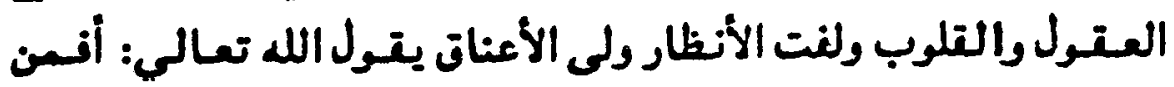

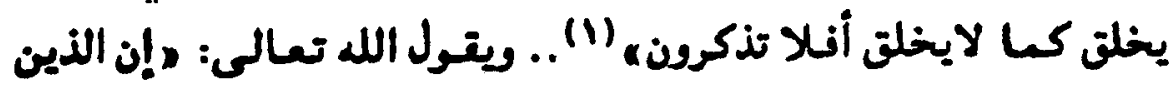
تدعون من دون الله لن يخلتوا ذبابا ولو اجتسعوا له....

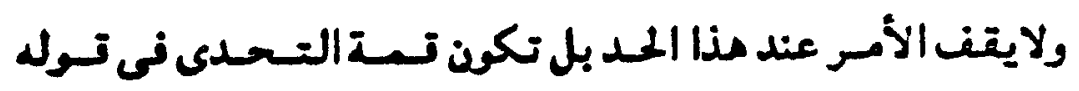

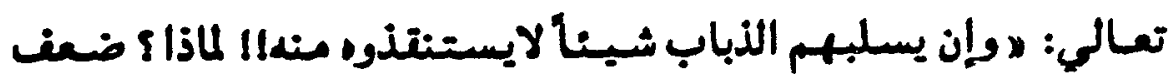

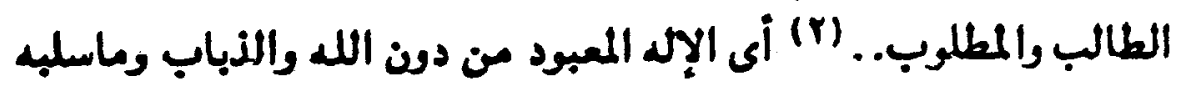
منه .

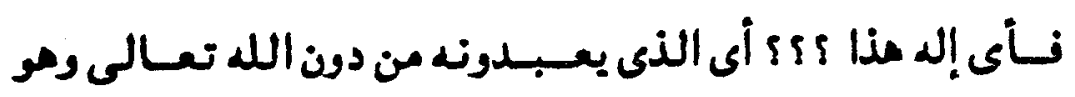

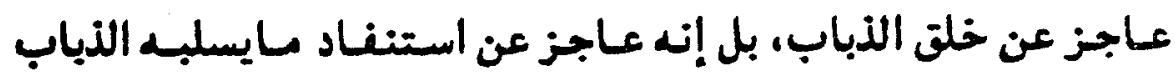
مند!| وفى هذا التسعبـيسر أيضـالفت للألظظار ولى للأعناق كى تغني

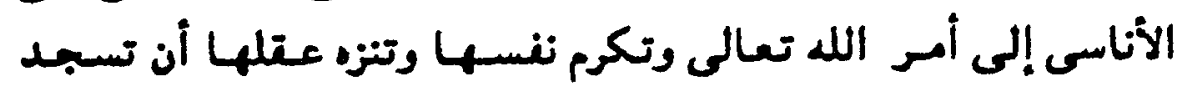

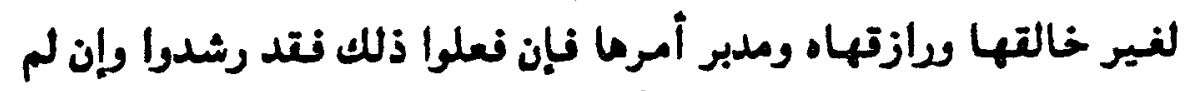

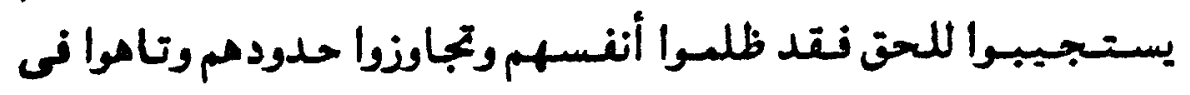

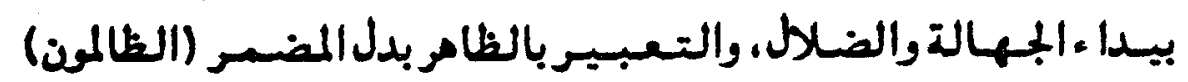

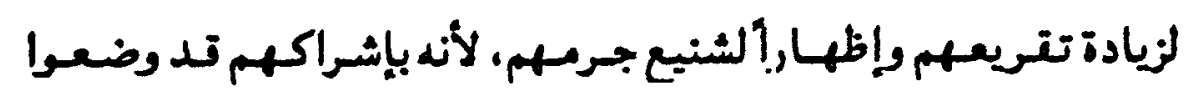

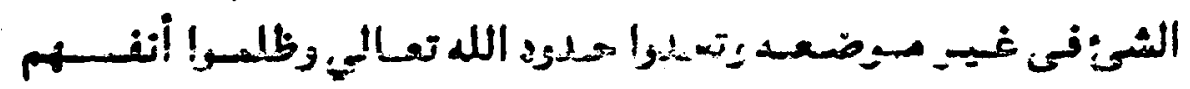
بتعريضها للعذاب المالد ... $-1-$

(ولقد آتينا لتمان المكعة) كلام مستأنف مسوق لبيان بطلان

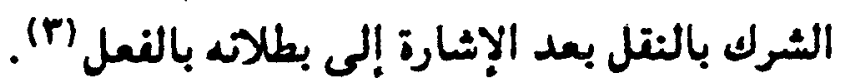

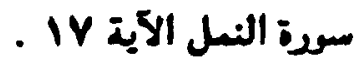

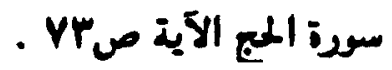

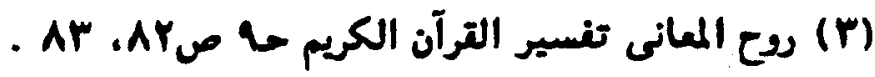


(ولتمان) إسم أعجسى لاعيى مشتق من اللتم واختلف الناس

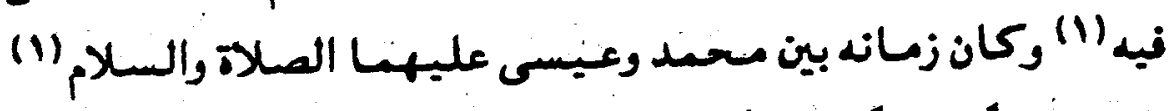

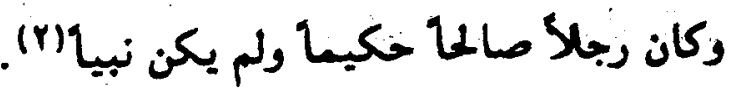

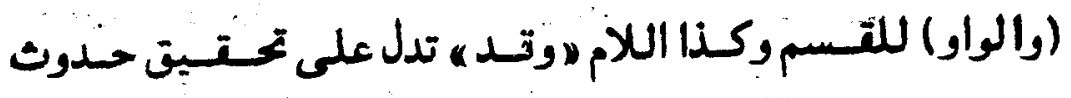

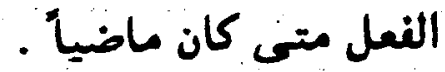

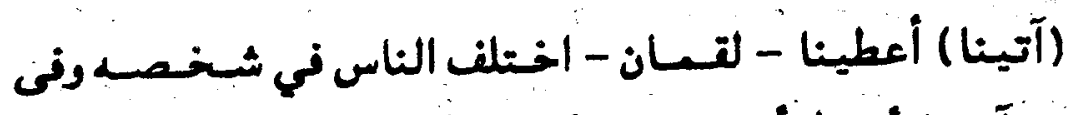

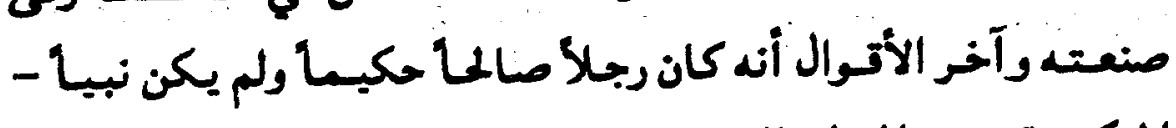

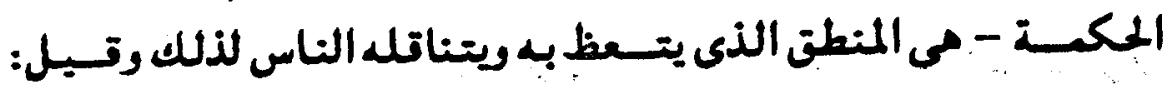

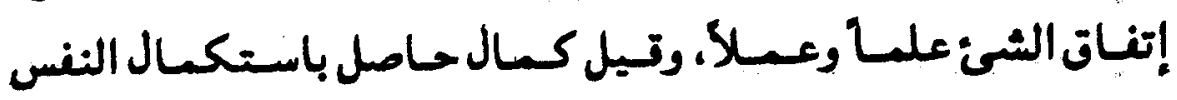

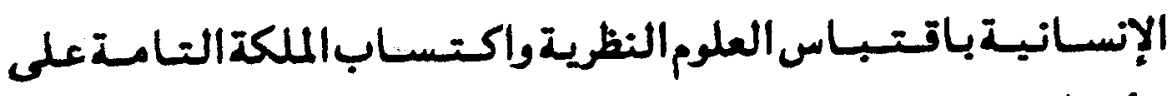

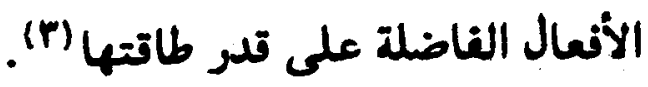

(أن اشكر لله) أى اجغل شكرك لله تعالى من منطلق الملكسة

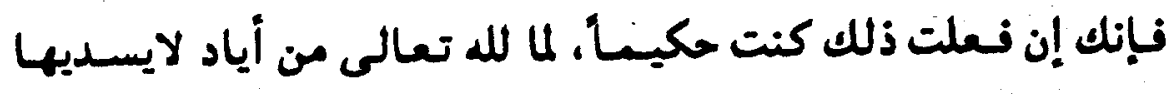
سـواه جل وعلا نهـو حتـيق بالشكر جدير بالحمد والثنا ـ ولاينفع الله

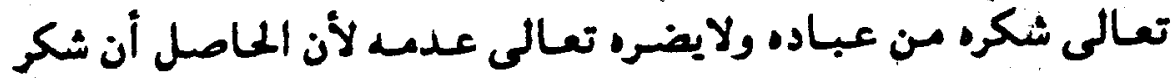

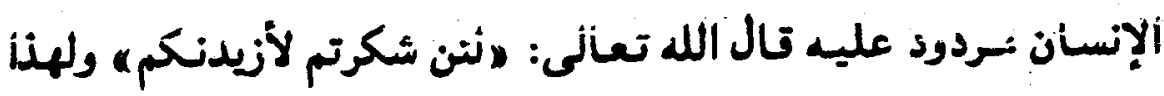

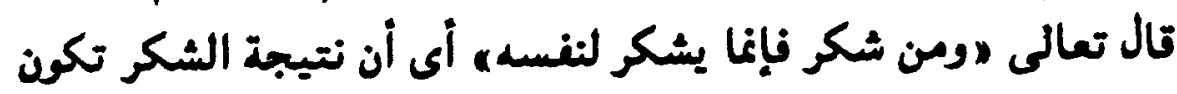

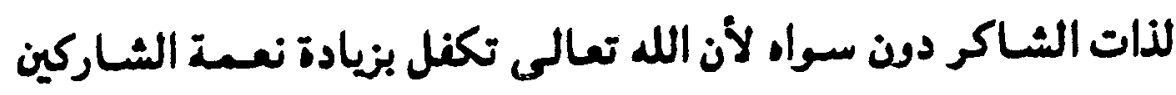

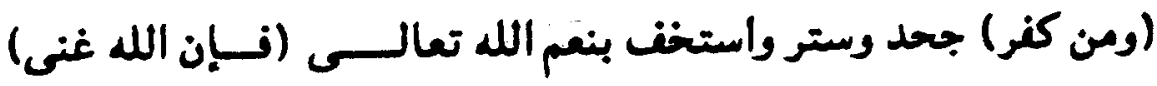

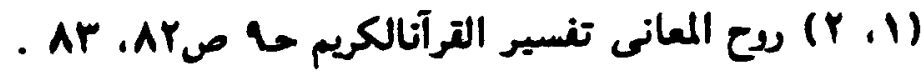
المبم الوجيز . 


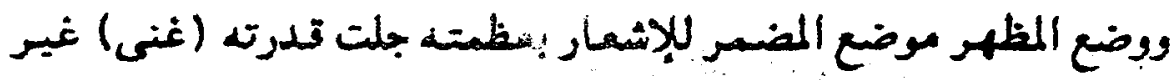

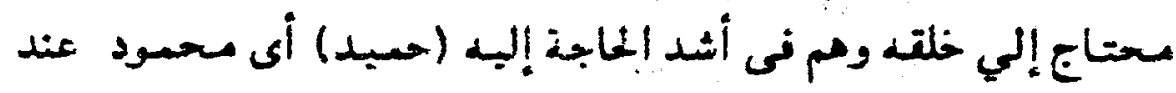

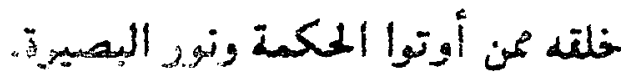

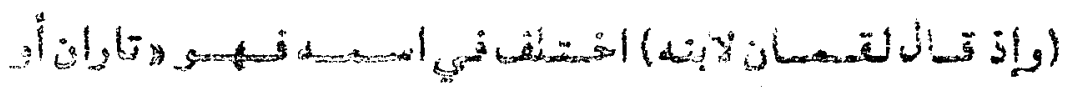

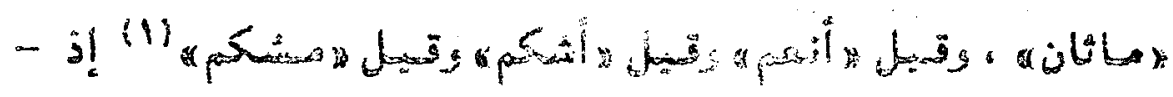
(r) معهول - J

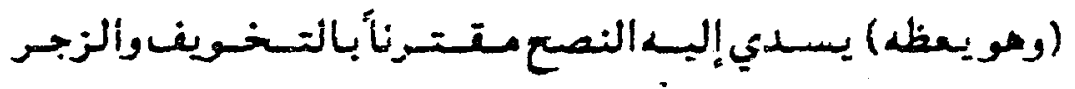

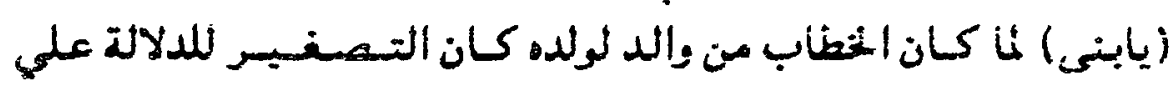

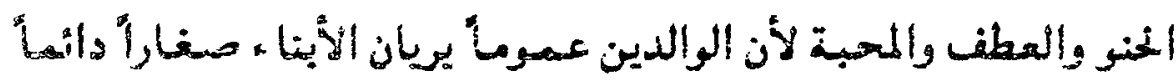
وإن كبروا

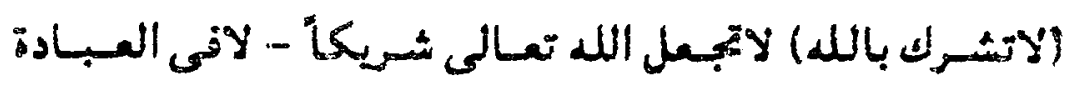

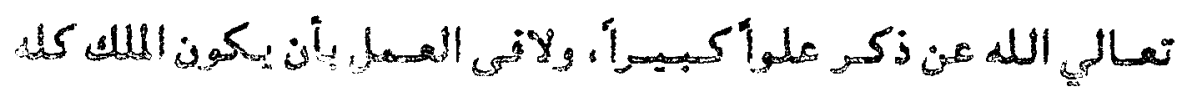

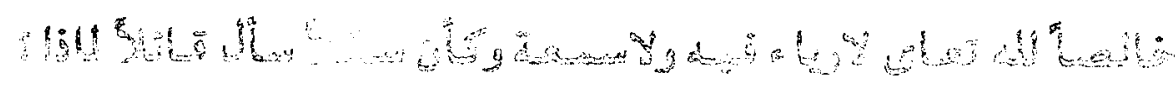

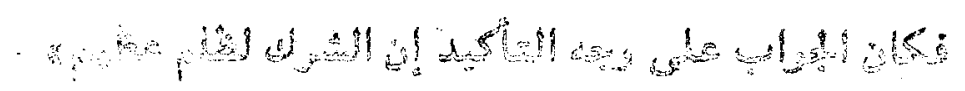

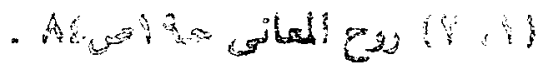

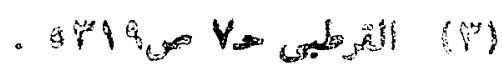




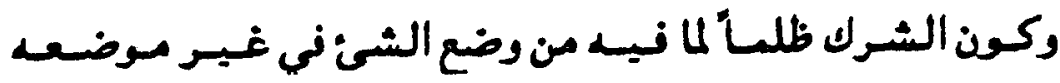

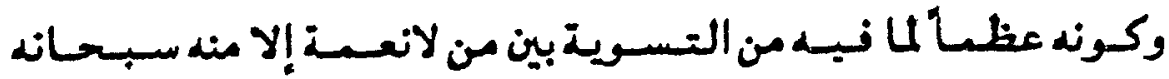

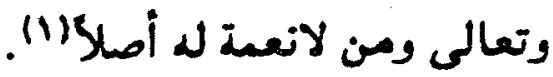

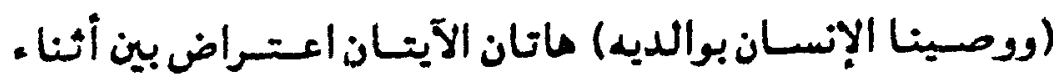

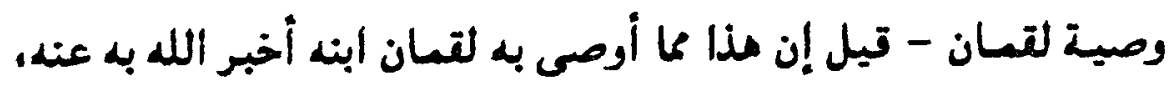

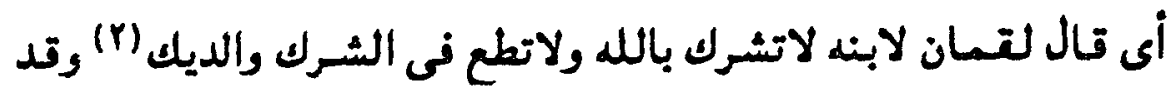

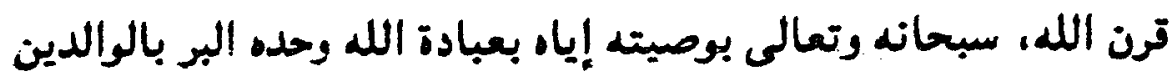

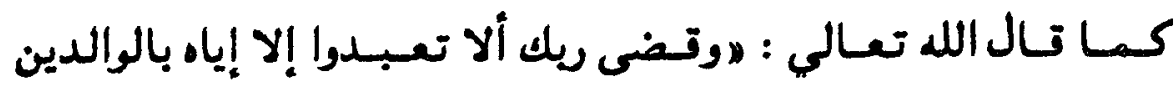

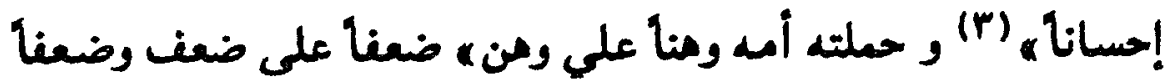
حال من أمه، أو الضمير فى حملته .

"ونصاله أى فطامه وانتطا ع رضاعته (فى عامين) أى مدة

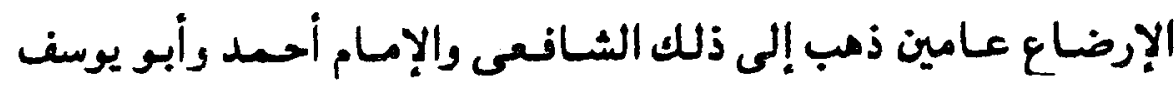

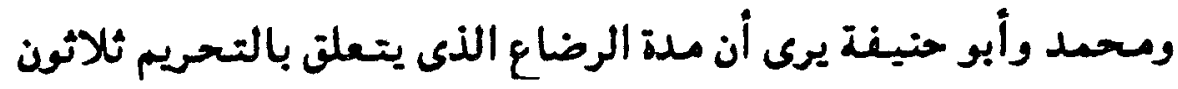
شهر| (2) رأن اشكر لى ولولديلك، قلنا له أن اشكر لى ولوالديك تــبل:

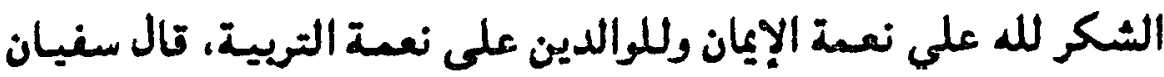

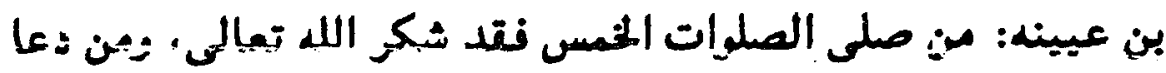

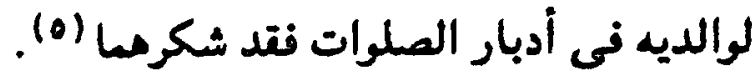

$$
\begin{aligned}
& \text { روع المعانه حعا صه صم . } \\
& \text { الترطبى حYصrr }
\end{aligned}
$$

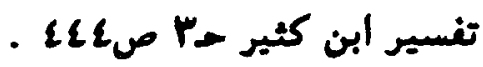

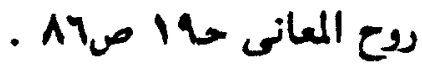

الترطبى حلاصrrrorro 


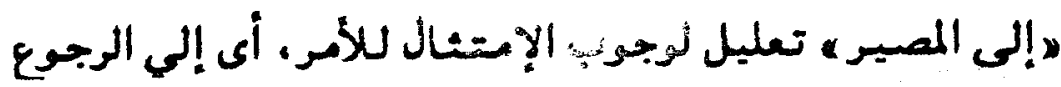

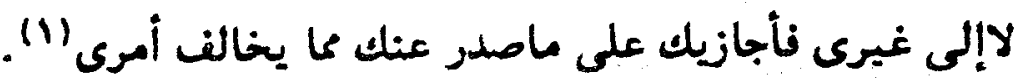

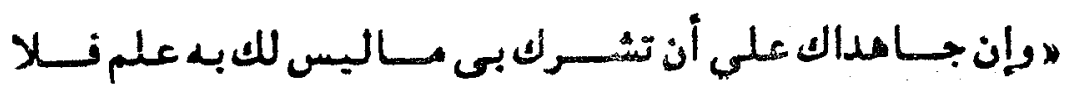

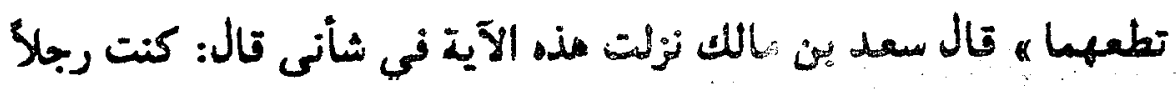

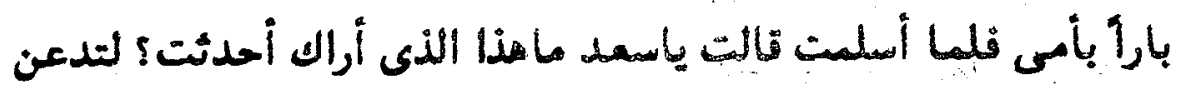

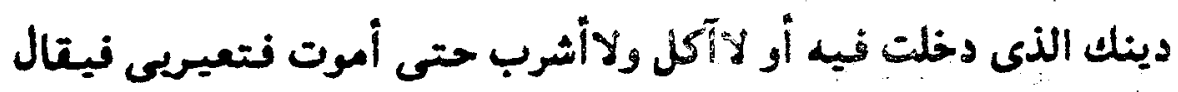

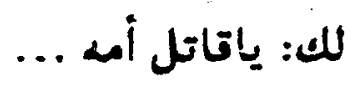

نقلت لاتفعلى ياأمه فإنى لاأدع دينى مذا الثن نسكثت يوما

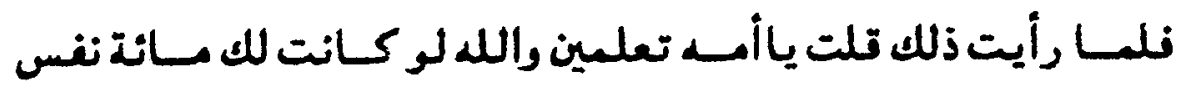

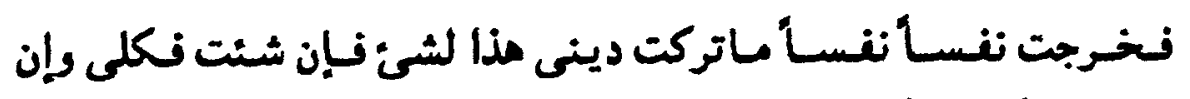

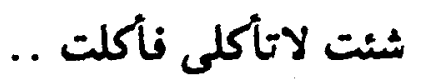
ثم كان أمره تعالى له بحسن مصات ماحبة الوالدين رغم متاسـاة

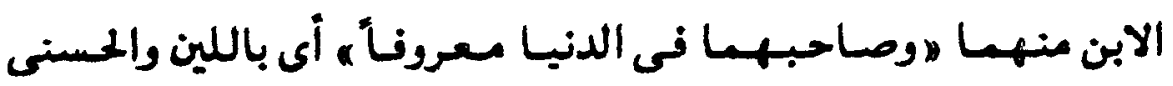

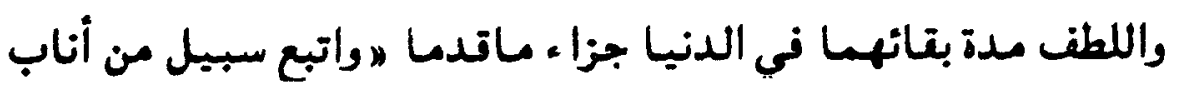
إلى" اللط. أم.ـ من الله تعـالي باتبـاع الطريق الأمــل ومو طريق الهـدى

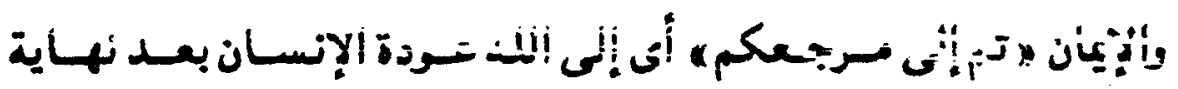

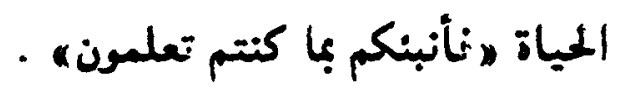
يتولون „ لمالهذا الكتاب لايغادر صغيرة ولاكبيرة إلا أحصاها

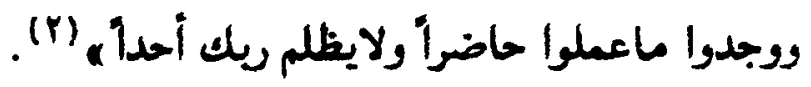

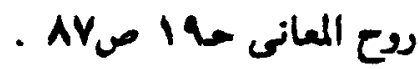




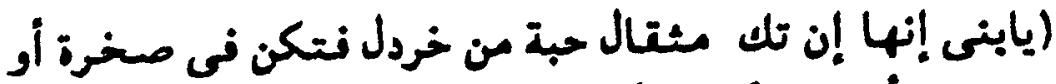

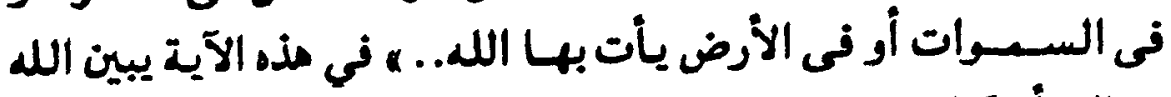

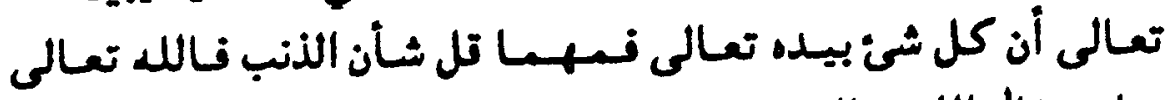

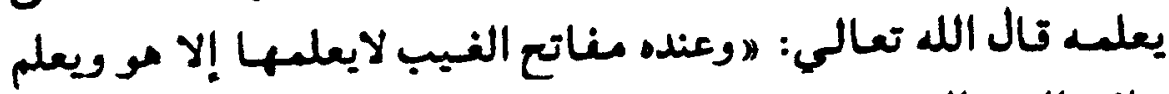

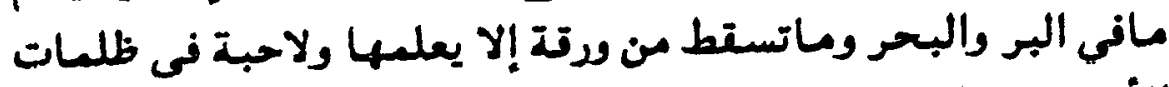

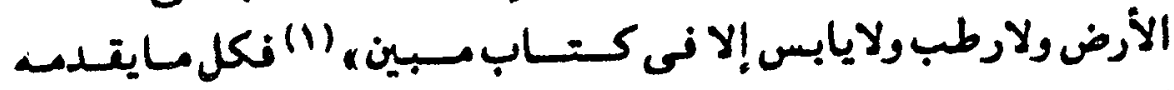

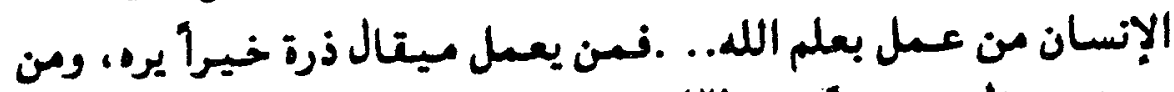
يعل مثقال ذرة شرا يره، (Y)

ولذا قـال الله تعـالي: „إن الله لطيف خـبـيـر ، أى لطيف العلم

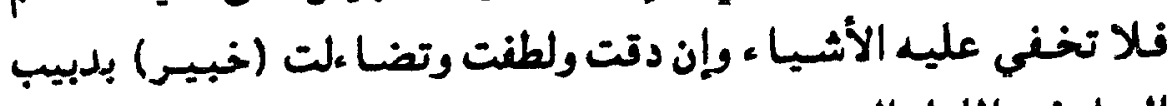

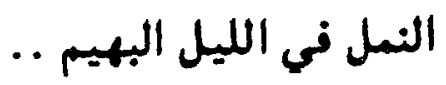

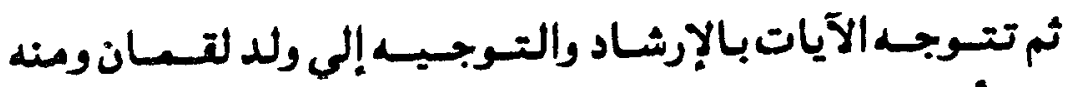

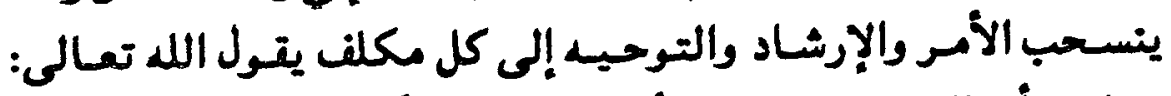

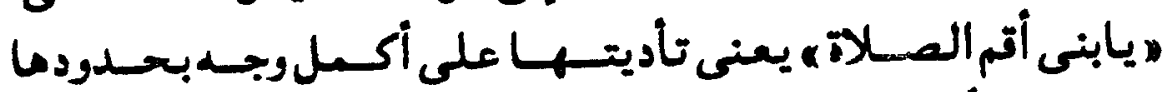

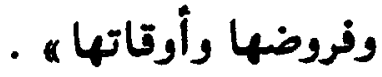

والصلاة عماد الدين من أقامها نقد أقام الدين ومن هدمها فتد

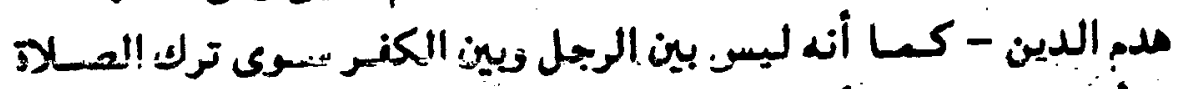

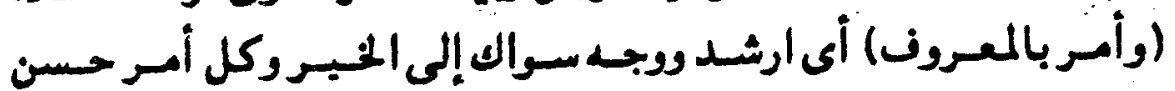

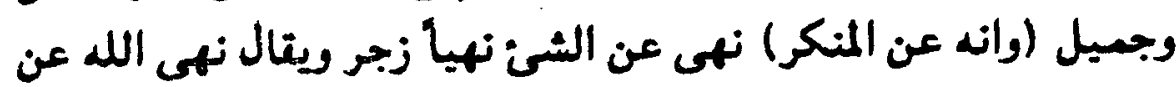

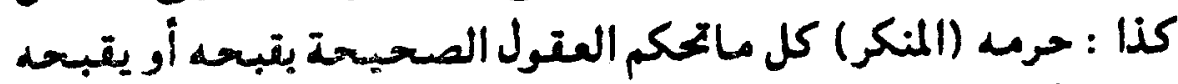

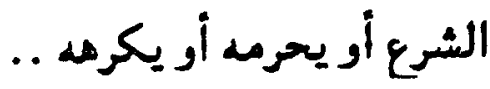


(واصبر علي هاأصابلك) أهر، بألصبر والتحمل والجلد لمايصيب

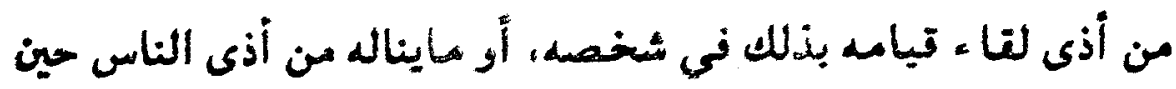

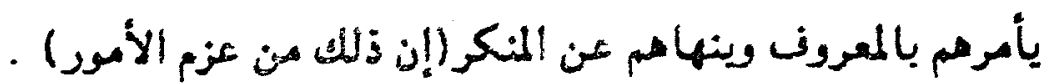

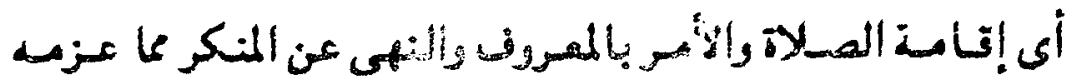

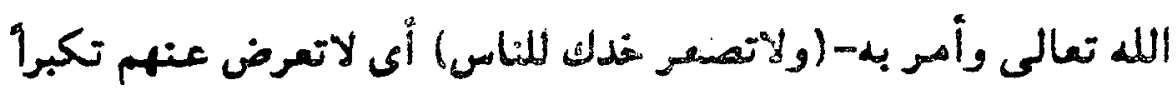

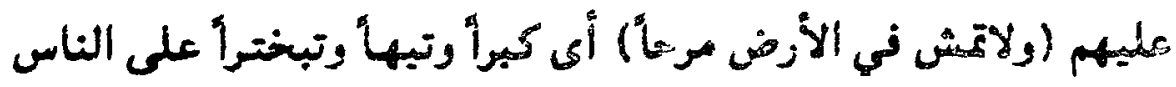

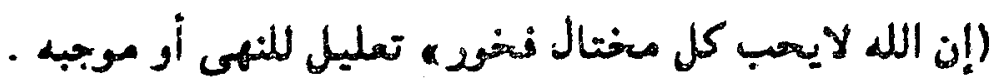

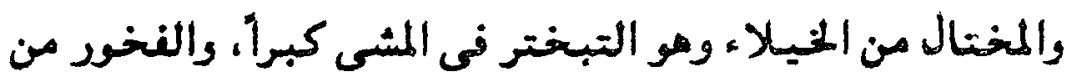

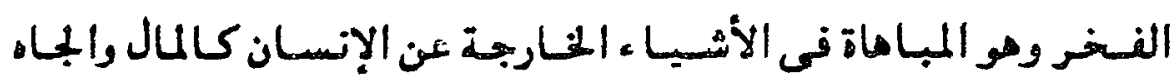
ويخلات ذلك .

(واقصـل في مشيك ه أى توسط في سيرك، بين الإسراع والبط.

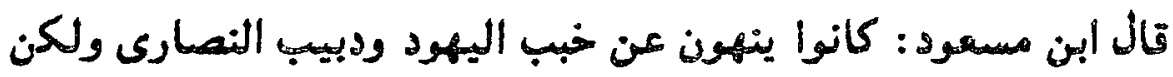

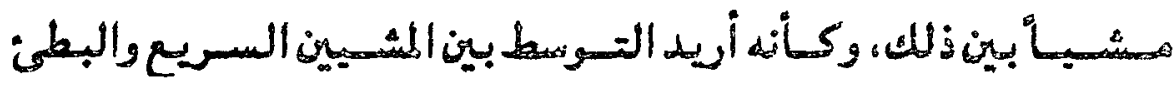

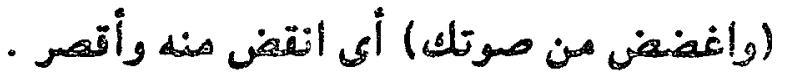

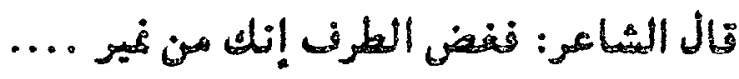

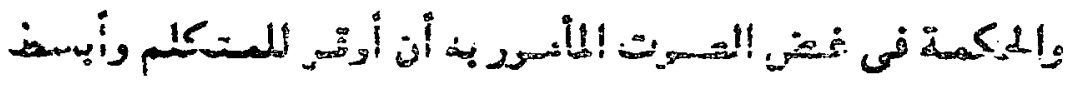

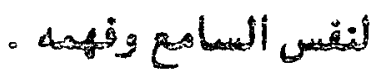

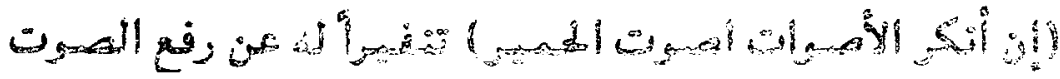

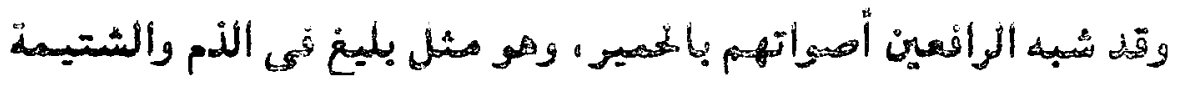

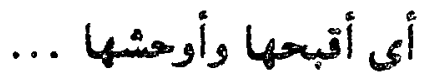
روى أن النبى صلى الله عليه وسلم أنه قال: " إذاذا سععتم تهيت

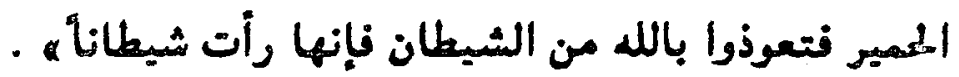




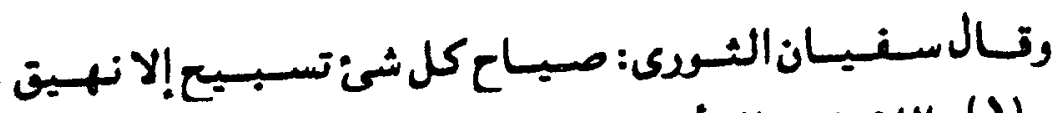

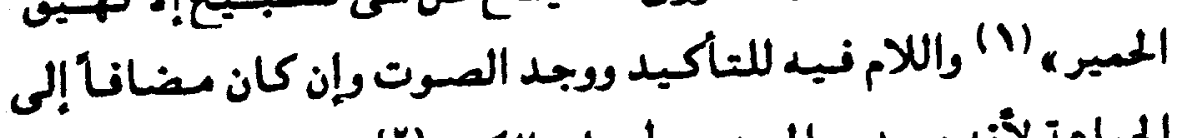

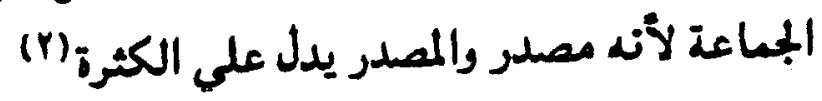

ثم إنتستلت الآيات إلى التسحدث عن النعم التى أسبـغهـا الله

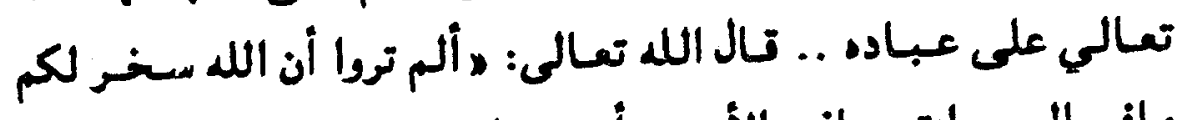

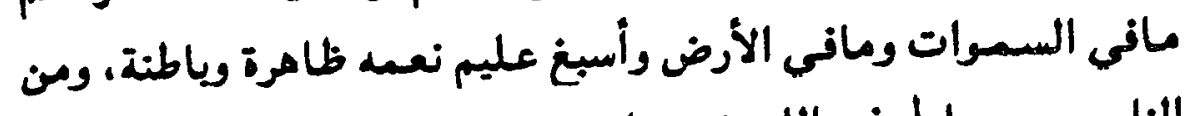

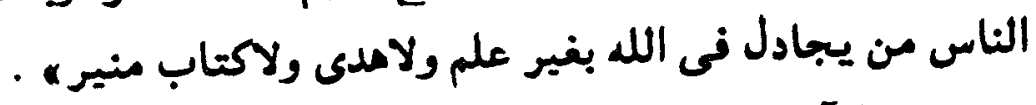

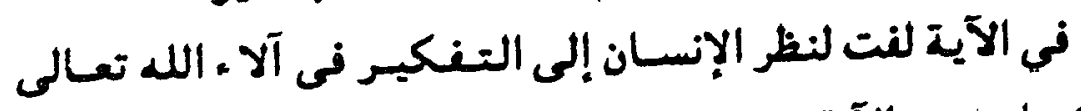

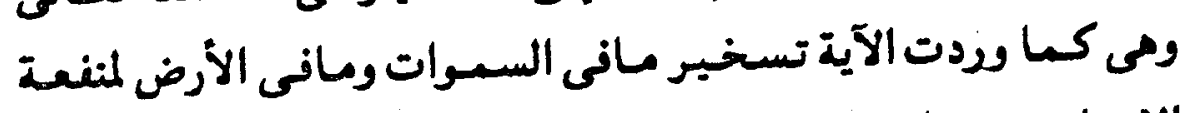

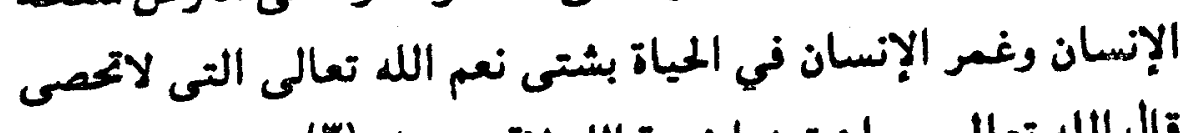

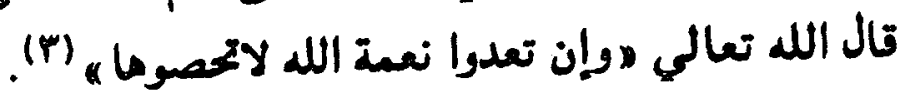

فواجب ذى العتل أن ينظر حوله بعتل منتوع ونظر سديد ليرى

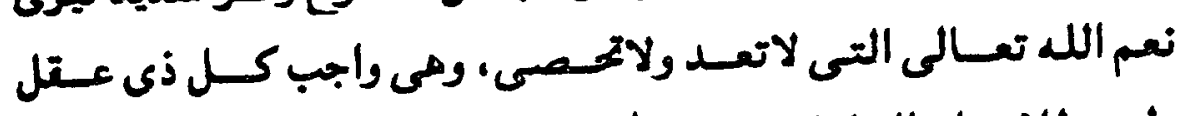

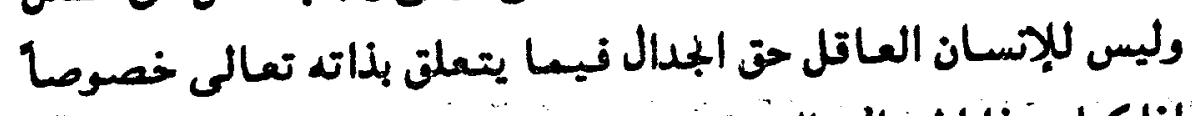

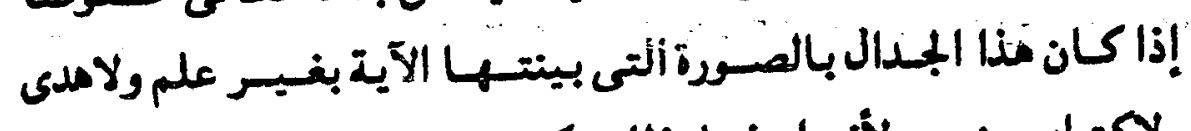

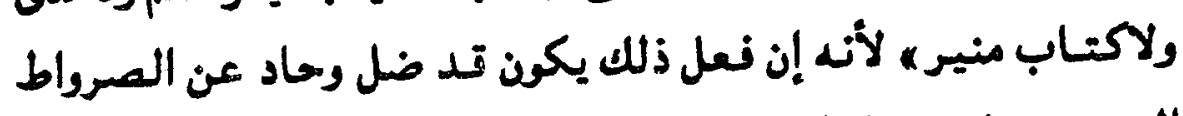

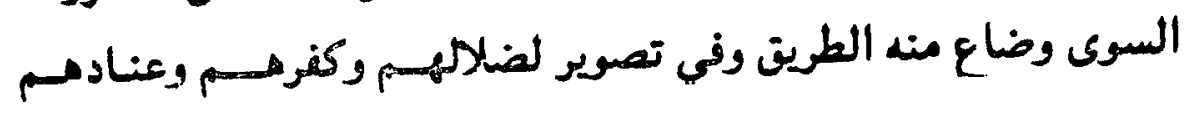

الترطبى حY صarra orra.

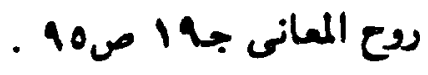

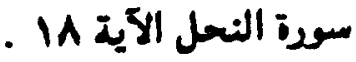




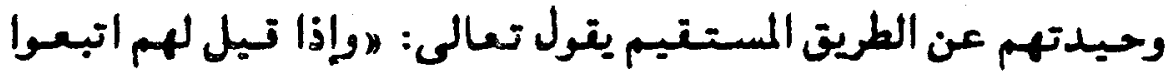

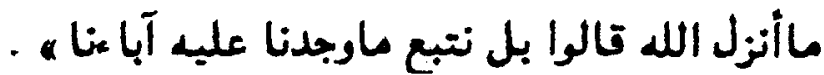

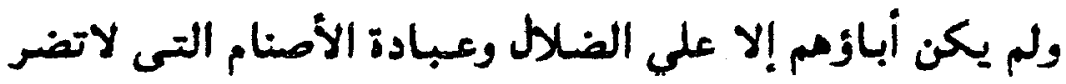

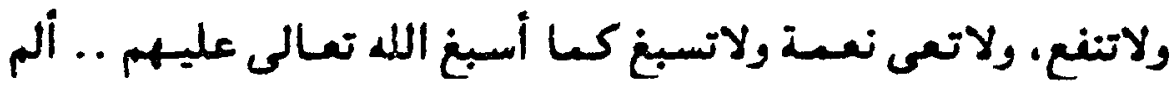

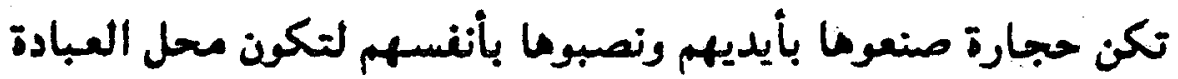

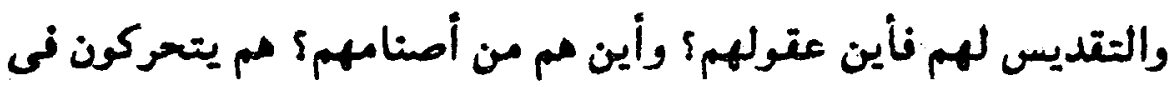

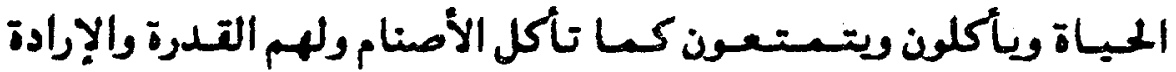

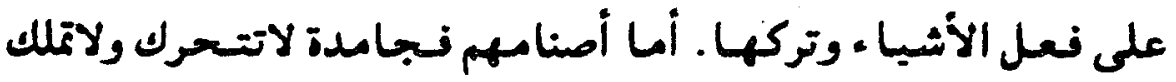

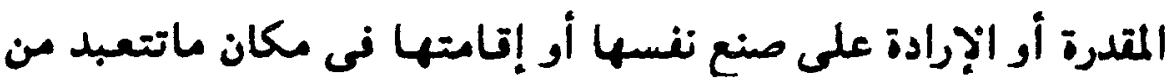

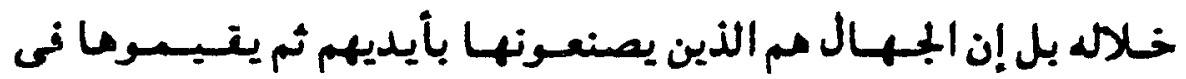

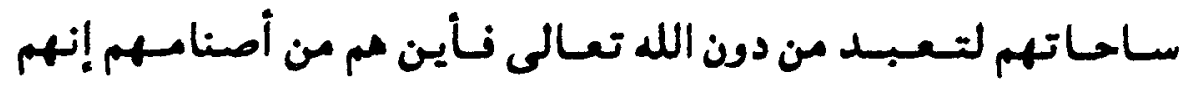

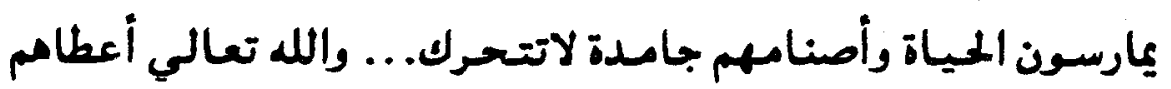

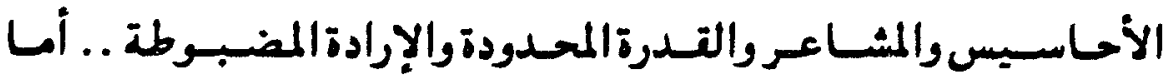

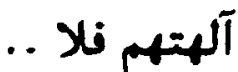
تـال الله تعـالى: "ا إن الذين تدعسون من دون الله لن يخلقــوا

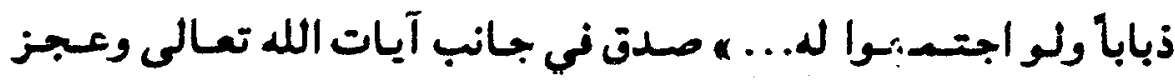

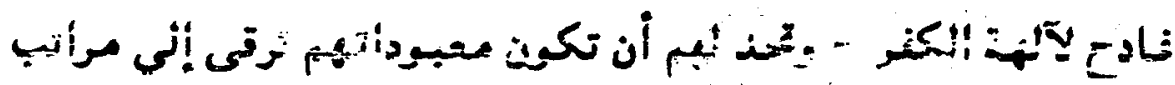

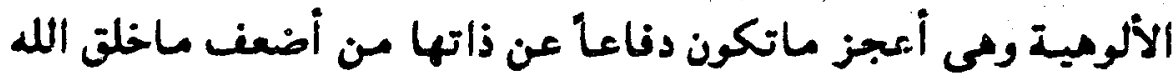

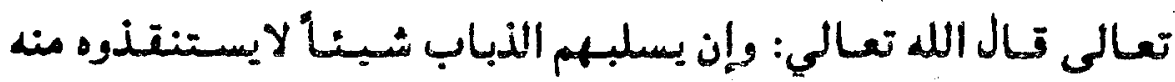

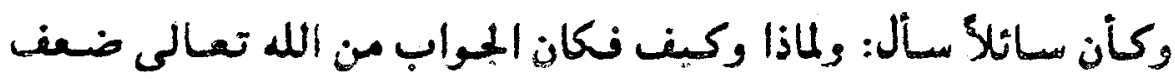
الطالب والمطلوب ..!! فأين التميبز والعقل من قبل مؤلاء ؟ 
ولا لم يكن لديهم منه شئ أو كان ذلله منهم صادرأ عن عناد

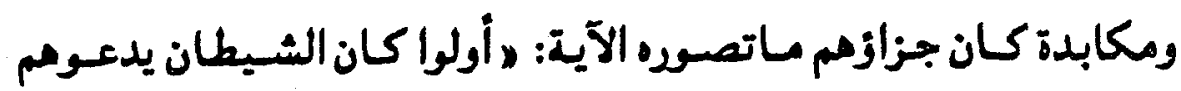

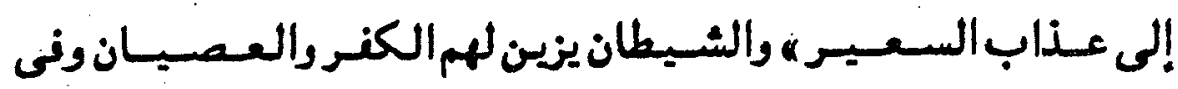

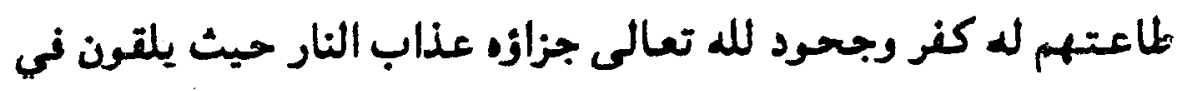

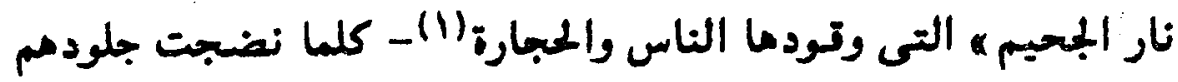

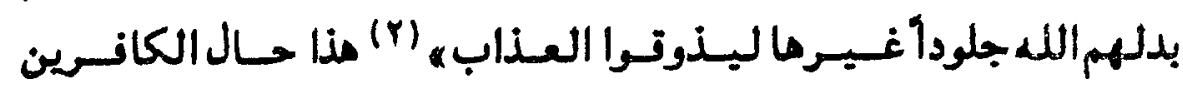
صويتهم الآيات فأبدعت في تصويرهم .

وفى الآيات السابقة تصوير لمن باع نفسه للشيطان نكان جزازو.

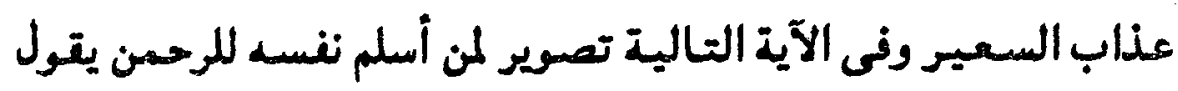

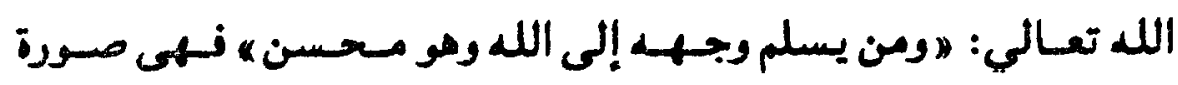

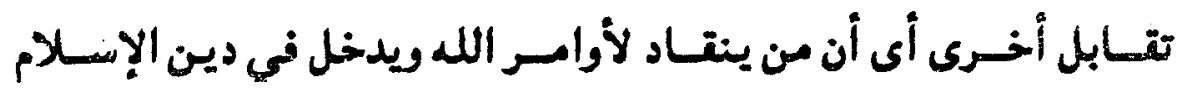

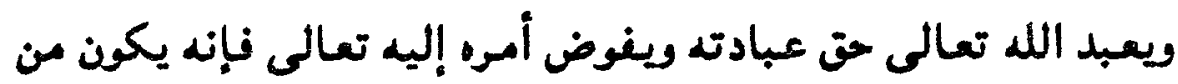

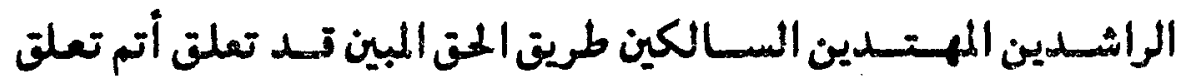

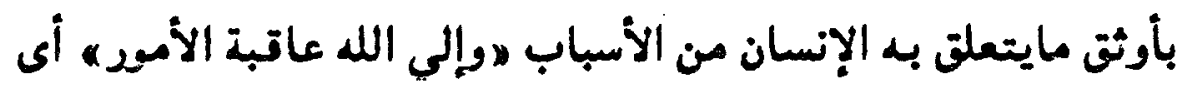

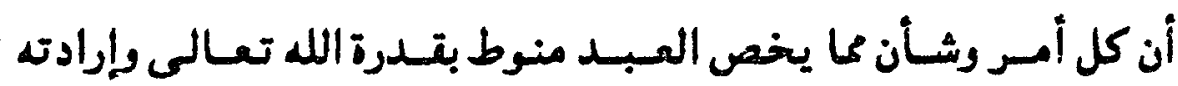

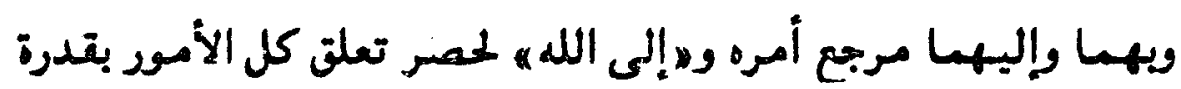

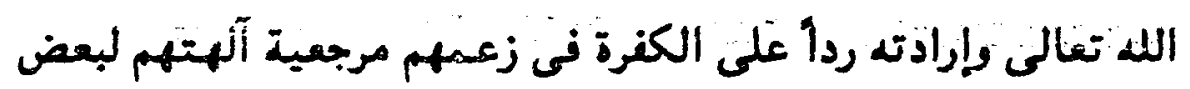
الأمور "(r)

سورة التحريم الآية 1 .

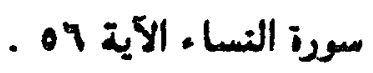

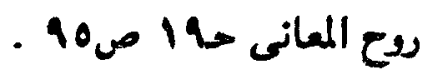


ولما بينت الآيات حسال مـ يسلمسون وبــومهم إلى الله تعـالي

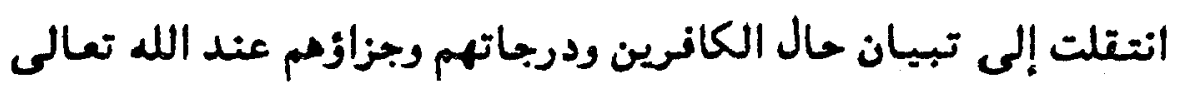

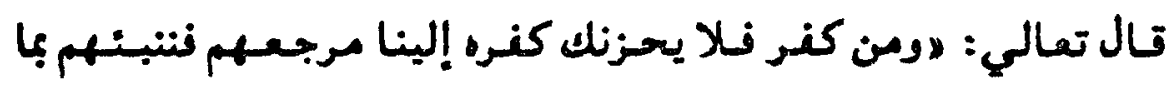

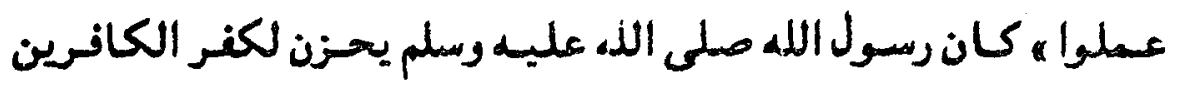

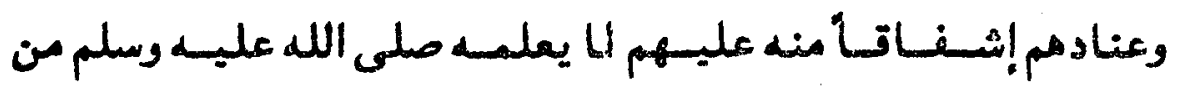
العذاب الذي أعده الله تعالى للاكافرين فبين الله تعالى له صلى الله

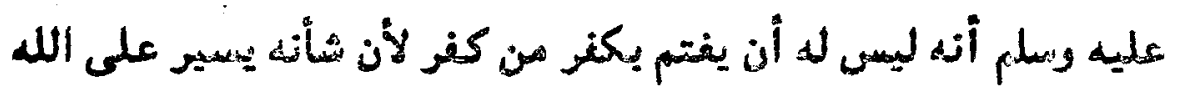

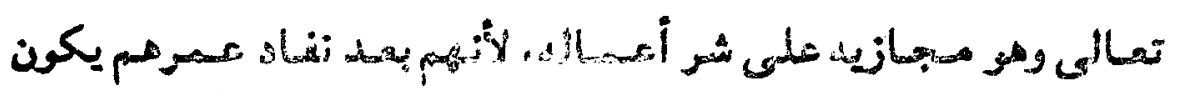

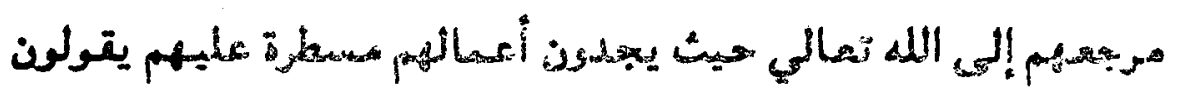

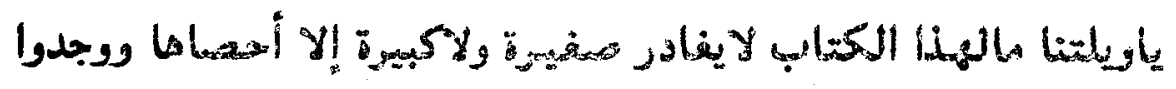

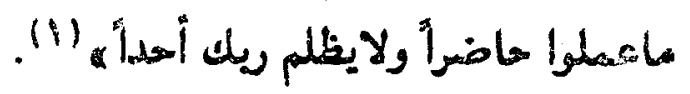

وتأكيداً لملم الله تعالي بهم ومسجازاته لهم قـال الله تعالى:

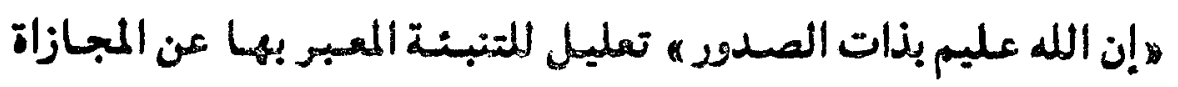

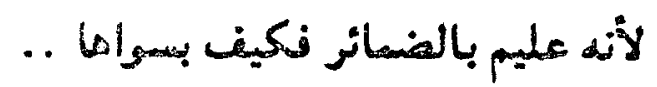

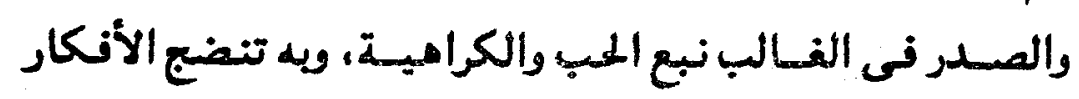

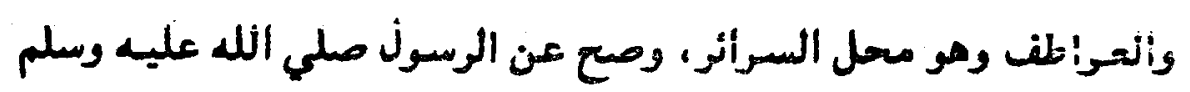

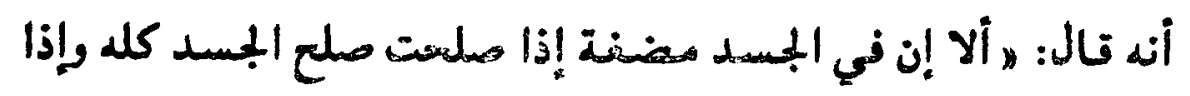

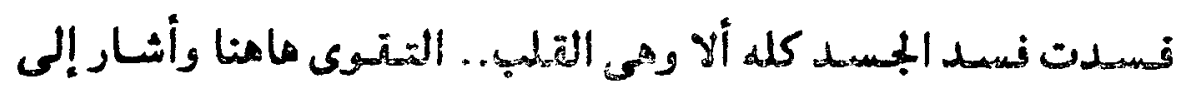




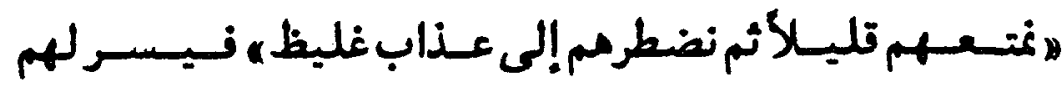

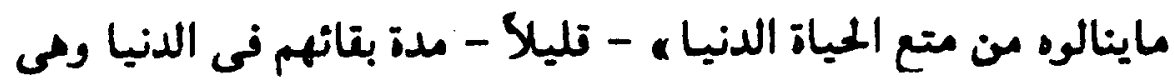

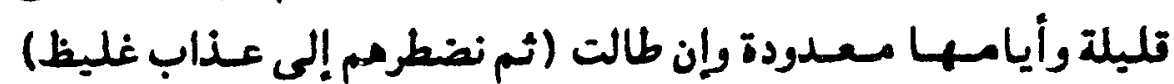

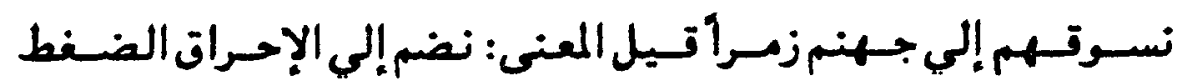

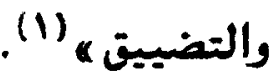

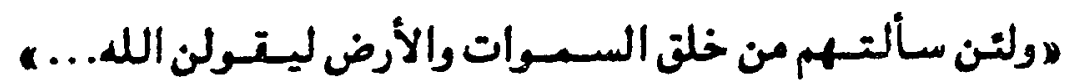

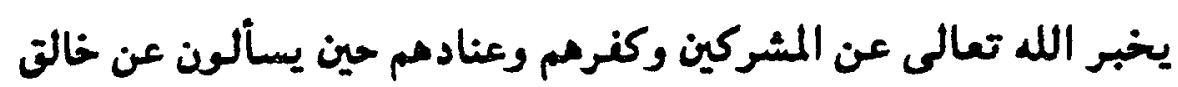

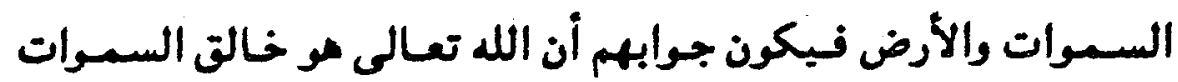

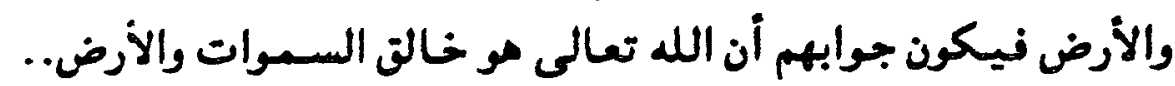

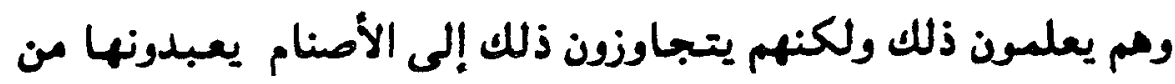
دون الله ...

(تل الحمد لله) والحمد مو الثنا ـ والشكر للخالق بجل وعلا على

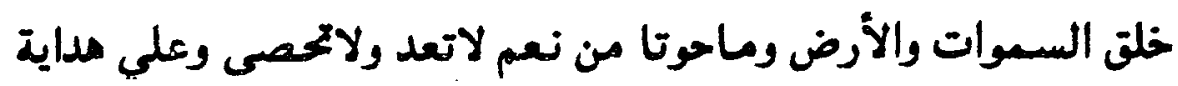

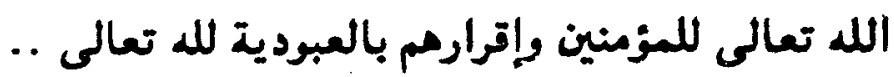

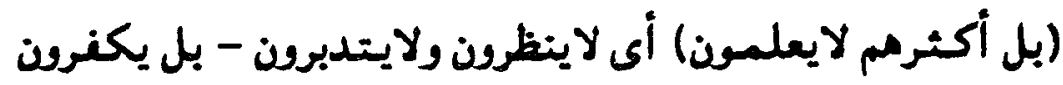

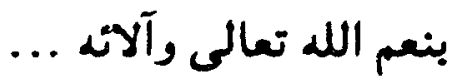
ثم يكون لفت الأنظار إلي أمسيــة إتـرار العـبـودية لله تعـالي

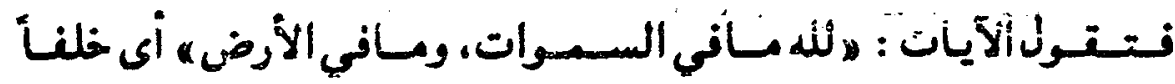

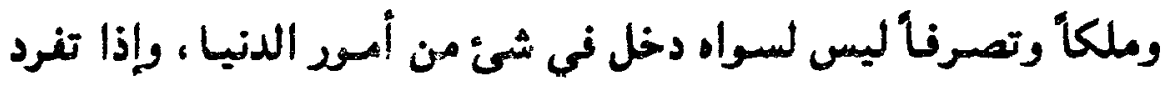

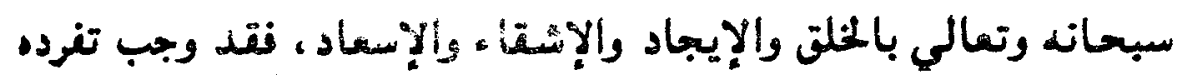

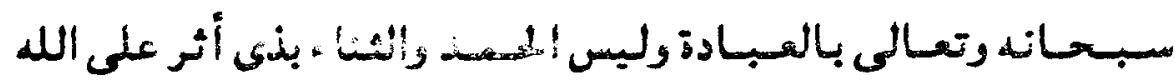
تعالى... 


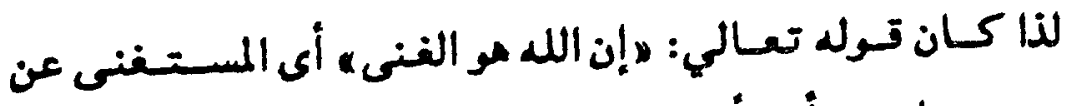

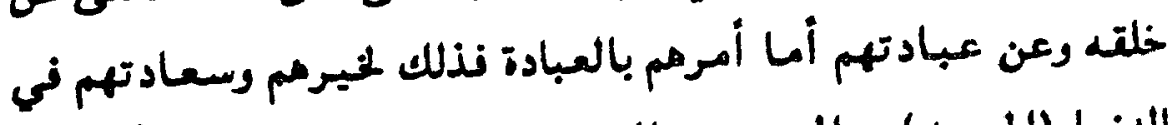

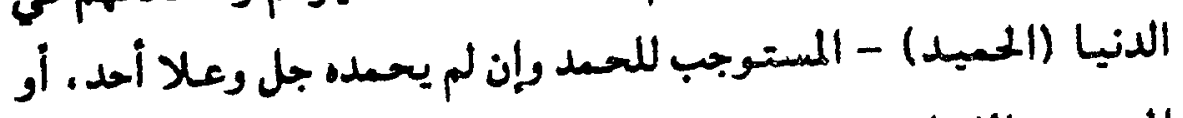

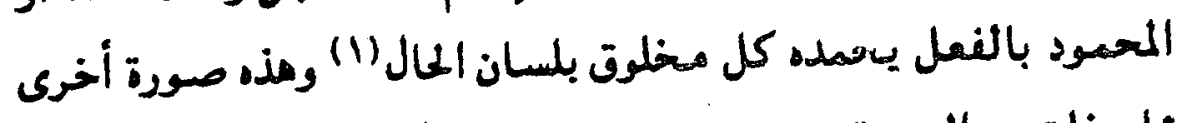
كا حغلت به السورت من صود قوية موحية يقول الله تعالى:

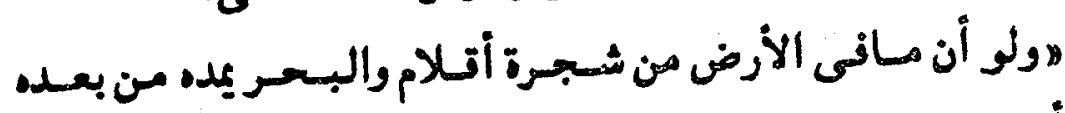

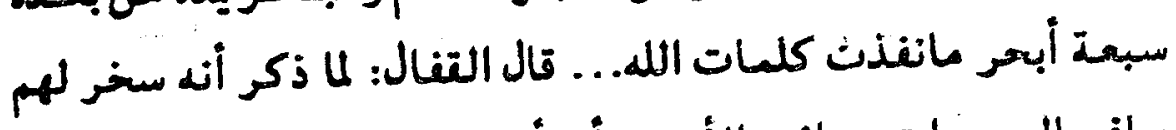

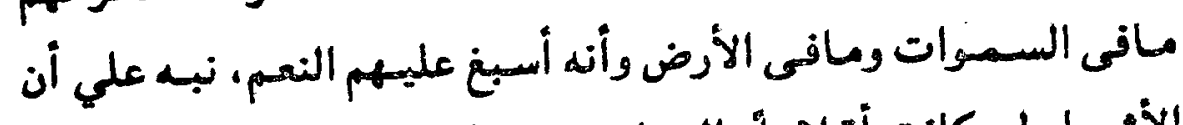

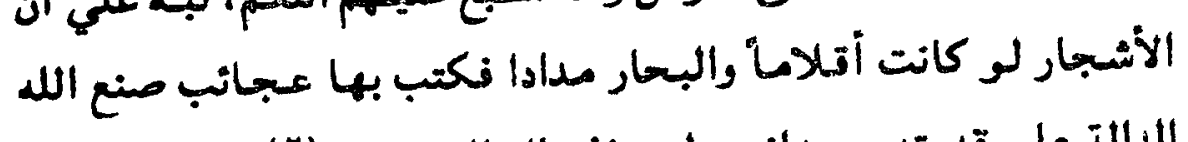
الدالة على قدرته ووحدانبته لم تنفذ تلله العجائب، (r).

تسال ابن عسبـاس : إن سـبب نزول مذه الآية : إن اليسهـود تـالت

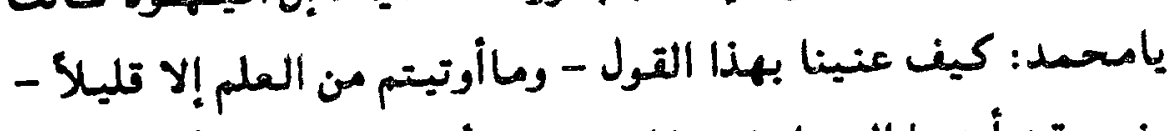

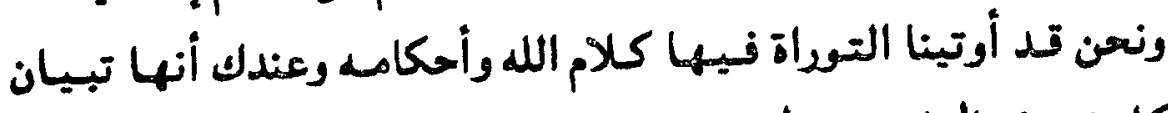

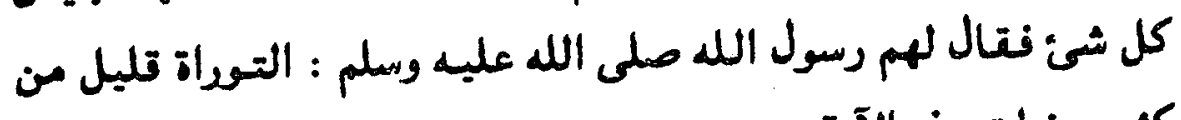

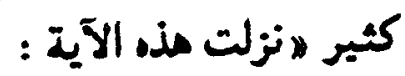

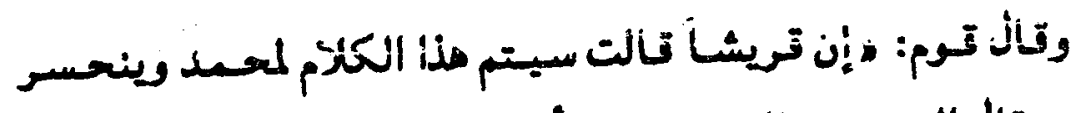

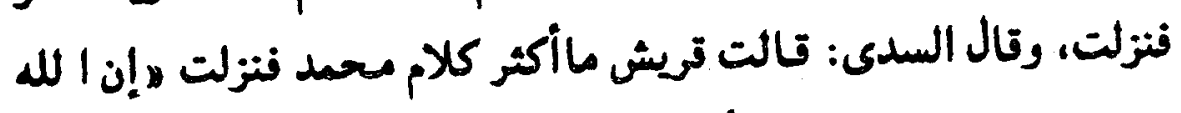

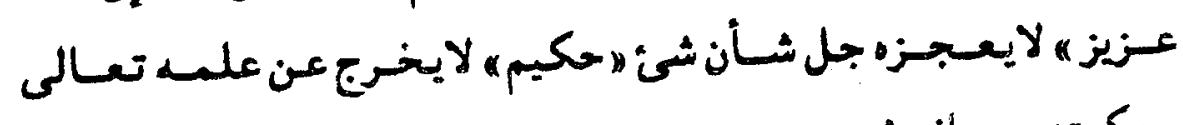
وحكمته سبحانه شئ .

السابق والصنهة . 
والبملة تعليل لعـدم نغـاذ كلعاته تبارك وتعالى .. وإذا كان من آيات الله تعالي وتدرته أن كلامسه سبحانه لاينفد، بيد أن أن تلدرته

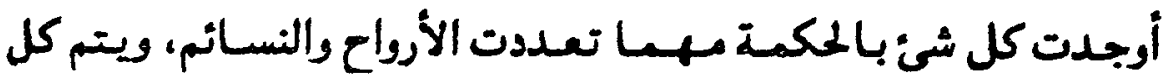

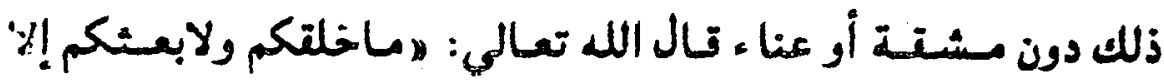
كنغس واحسة، هنأمره جل وعلا بين الكان والنون - إنا أمره إذا أُراه شيناً أن يقول له كن فيكونه (1)

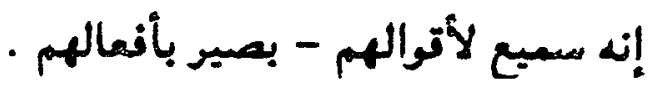

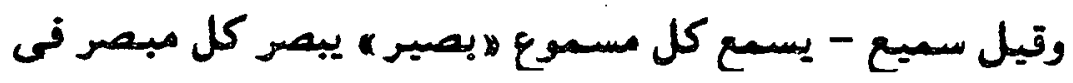

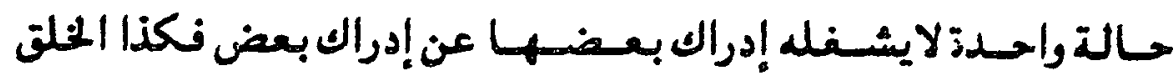

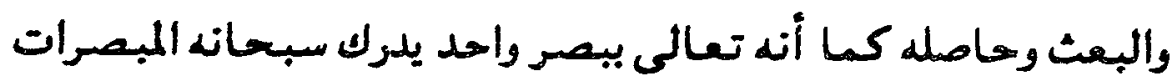

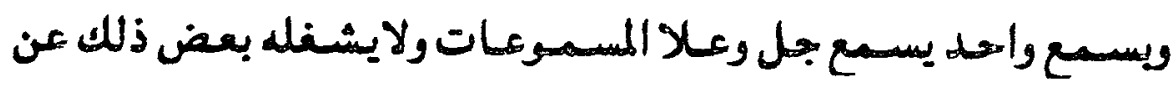

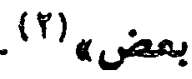

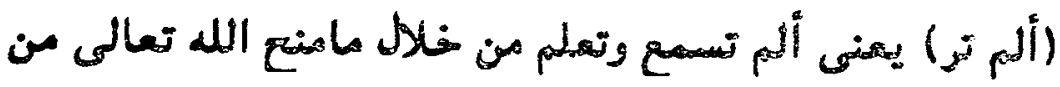

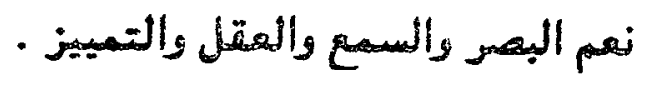

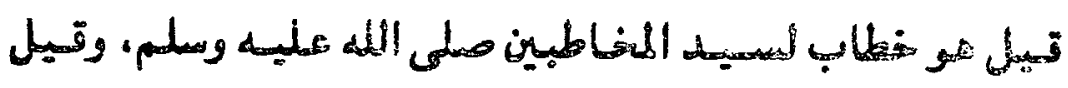

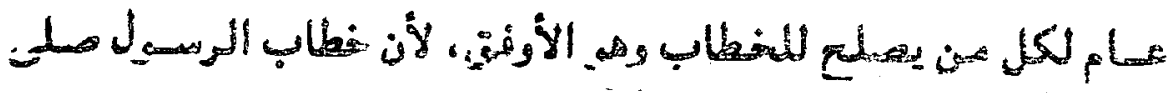

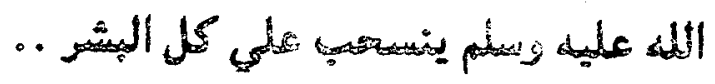

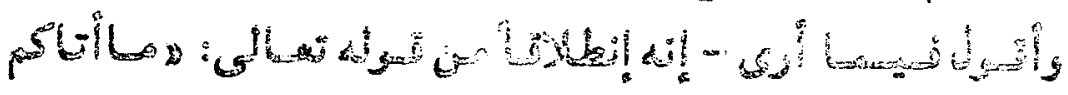

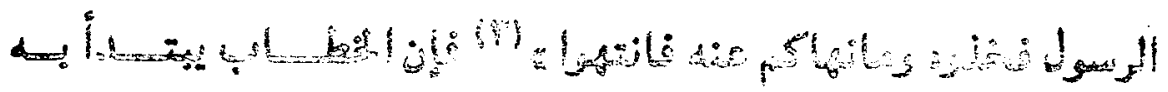

$$
\begin{aligned}
& \text { سمدة يس الעية AP }
\end{aligned}
$$

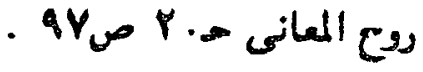

$$
\begin{aligned}
& \text { سورة المشر الآية V . }
\end{aligned}
$$


رسـول اللد صلى الله عليـه وسلم - ثم ينسسحب على كل من بصلح

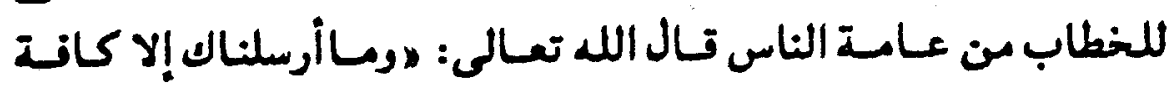

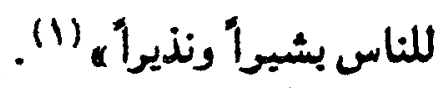

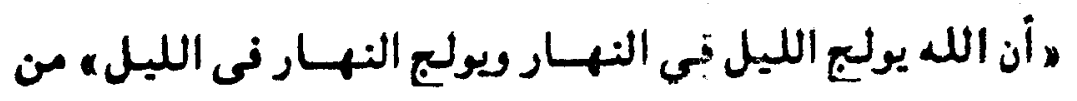

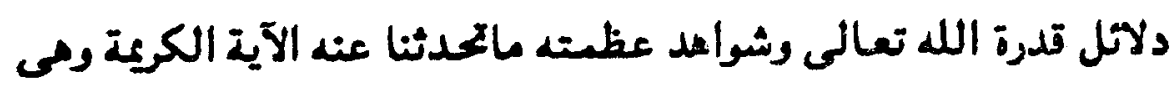

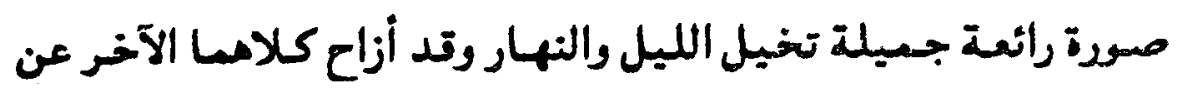

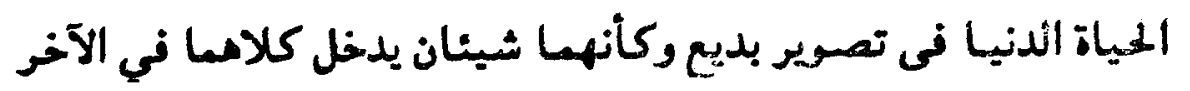

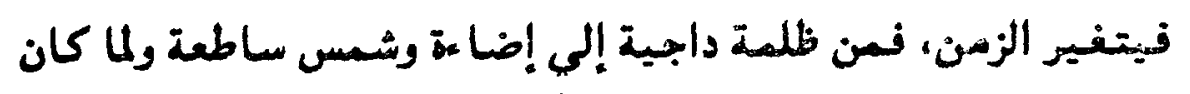

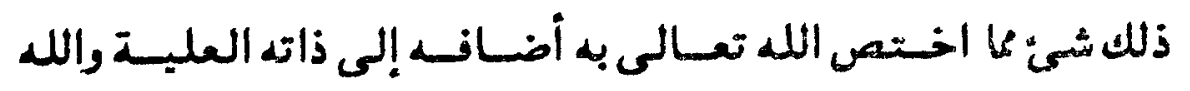

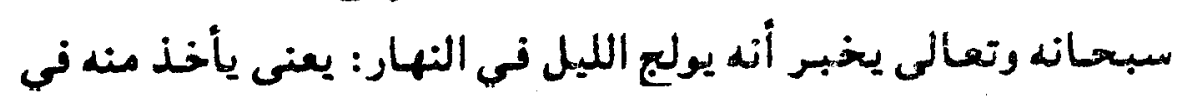
النهار فيطول النهار ويقصر الليل.

ومذا يكون زمن الصـيف ثم يكون زمن الصــيف هـيث يطول

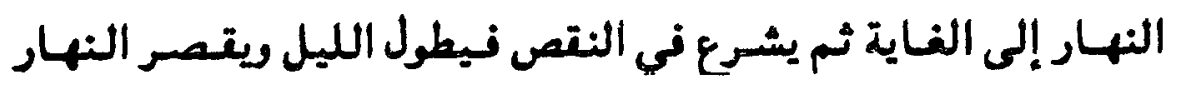

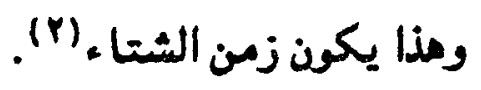
وتيل أى يدخل كل واحد منهـا فى الآخر ويضينه سبحانه إلبه فيتفازت بذلك حاله زيادة ونقصدان.

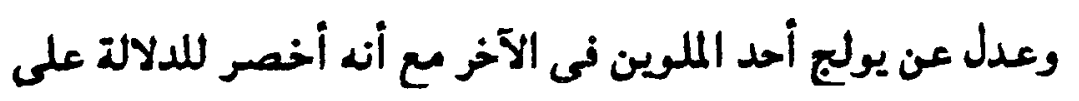
استتلال كل منها في الدلالة على كسال القدرة .

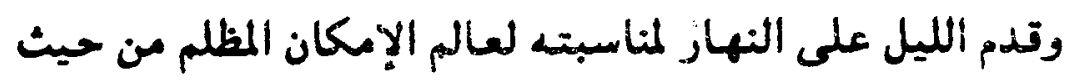
!... 
تال تعالى: עمو الذى جعل الشمس ضيا ـ والقـر نورأ وتدره

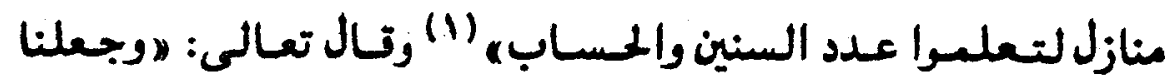

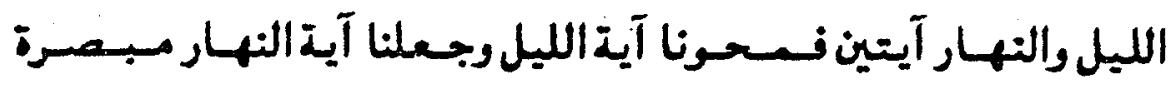

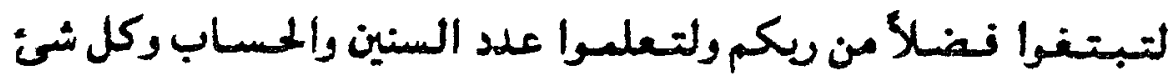

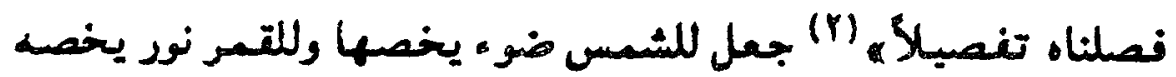

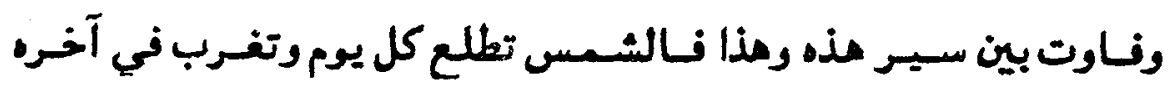

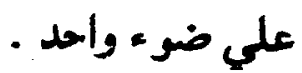

ولكن تنتقل فى مطالعها ومغاربها صبنا وشتاء يطول بسبب

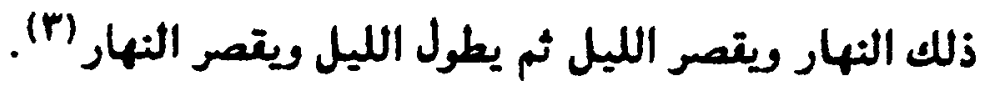

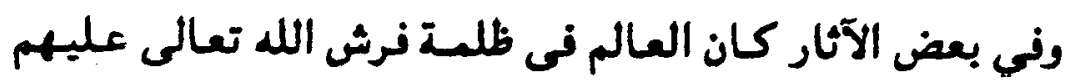

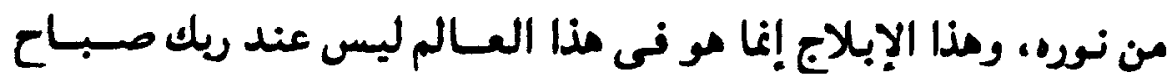

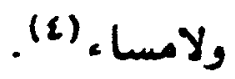

(وسخر الشسس والتـر ) مع تقديم الليز الذى فيه سلطان التعر

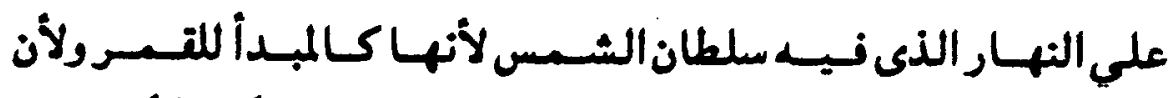

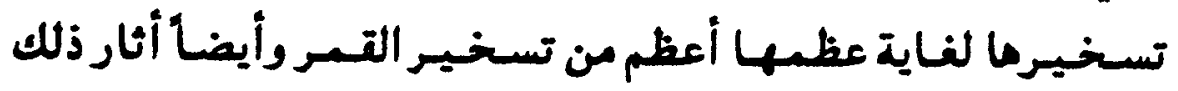
التسخير أعظم من أثار تسخيره(ه)

$$
\begin{aligned}
& \text { سورة يونس الاية ه . }
\end{aligned}
$$

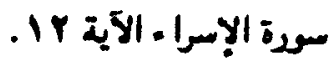

$$
\begin{aligned}
& \text { ابن كثير حك صنr orr }
\end{aligned}
$$

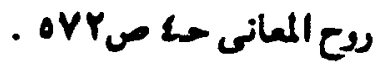

$$
\begin{aligned}
& \text { السابق والصفسة . }
\end{aligned}
$$


وتسخير الشمس والتمر : قيل إلى غاية محدودة وتيل إلى يوم

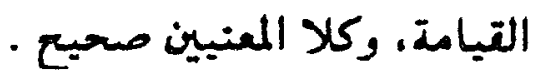
والشسمس والقهر آيتان من آيات الله تعالم أنحم :بها إبراهيم

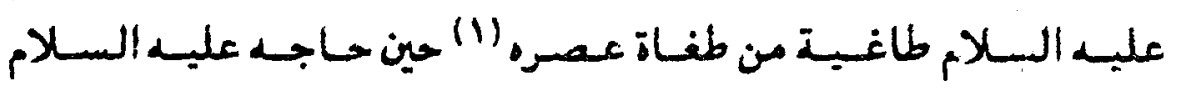

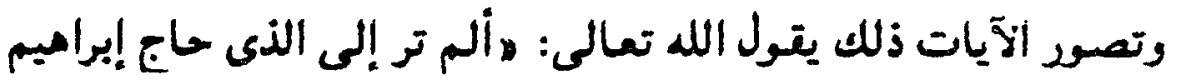

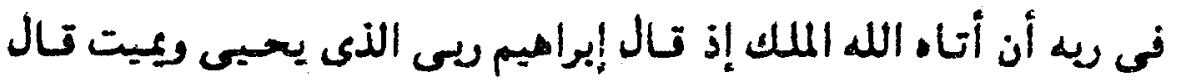

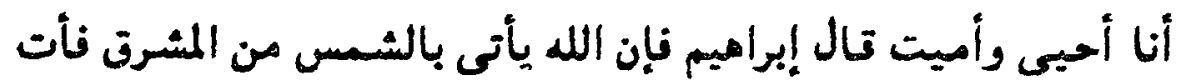

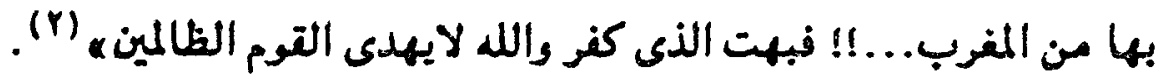

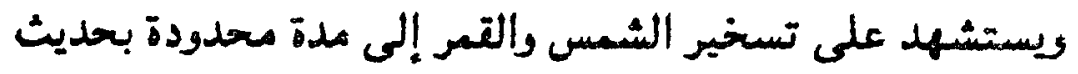

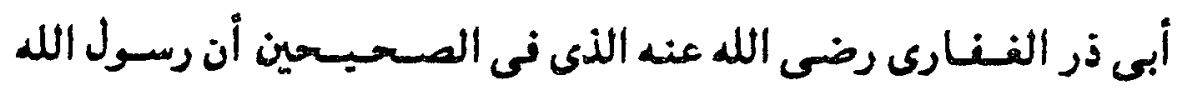

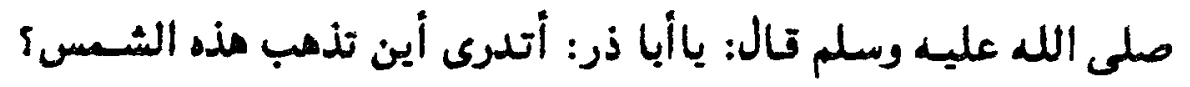

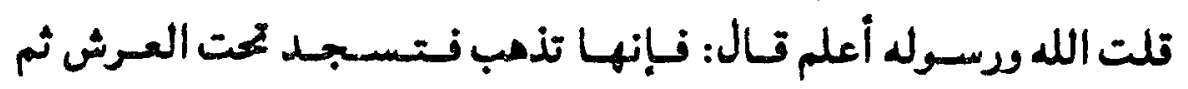

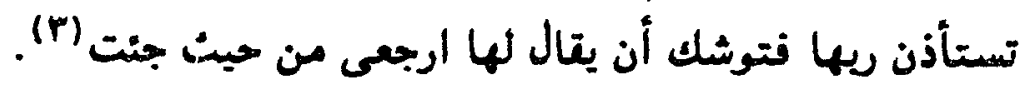

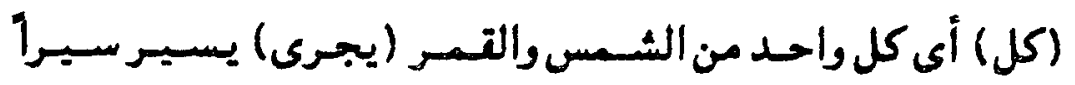

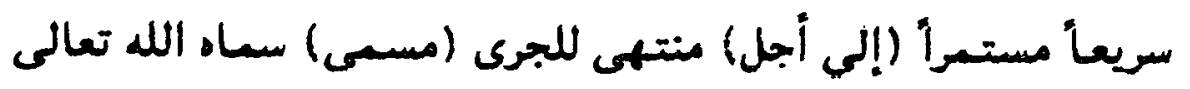

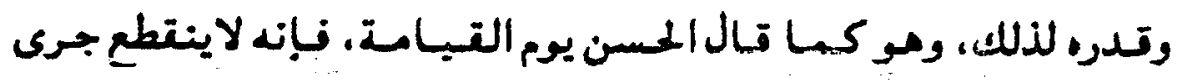

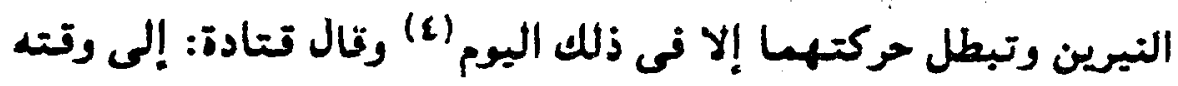
نى طلوعه وأقوله لايعدوه ولايقصر عنه (0)

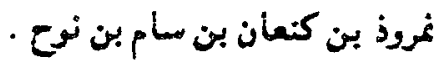

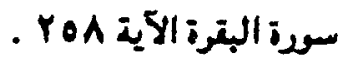

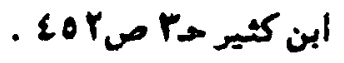

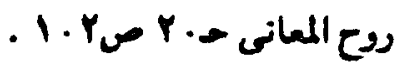

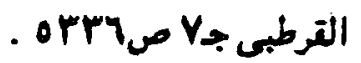


(وأن الله بما تعسلون خبيـر) أى أن من تحر على مذه الأثـيـياء

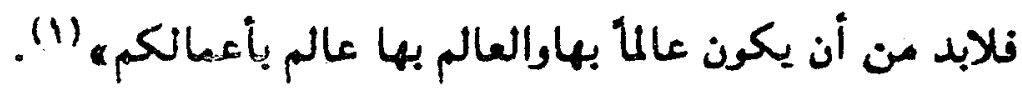

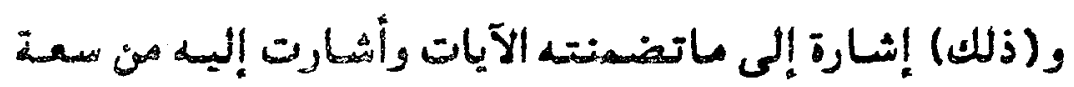

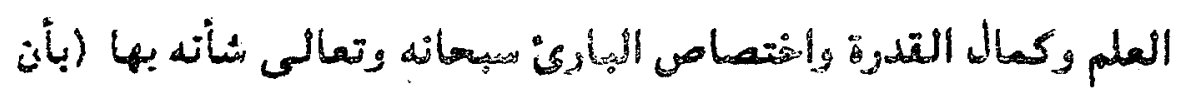

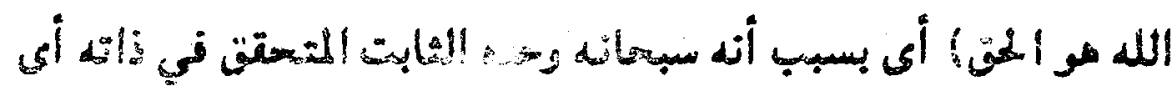

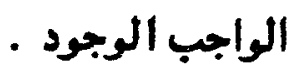

(وأن مـايدعـنون من دونه) من آلهـة يعـبـدونهـا من دون الله -

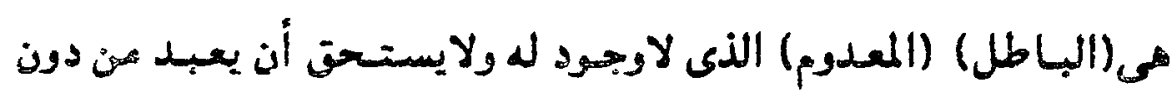

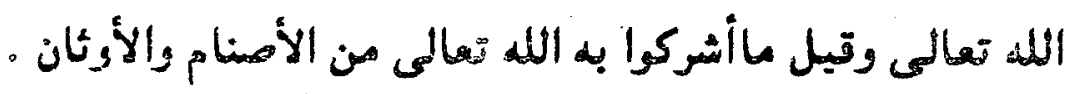

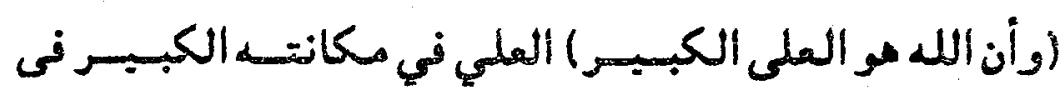

(i) wivilu

as

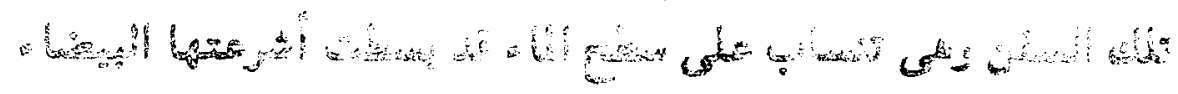
40 on

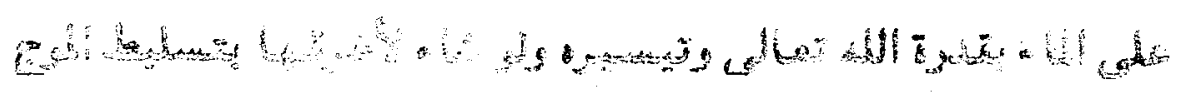
4

of

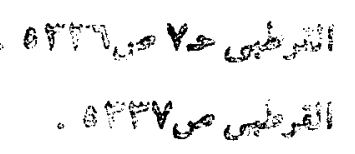


والتـــــرآن الكريم في آيـاته يلنت نظر المؤمنـين إلي آيـات الله تعالي والاته فى الكون ليدفعه ذلك إلي التدبر والتفكر والإقرار لله

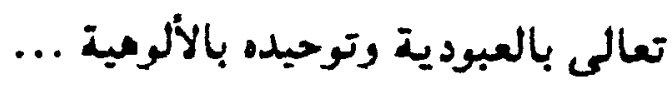

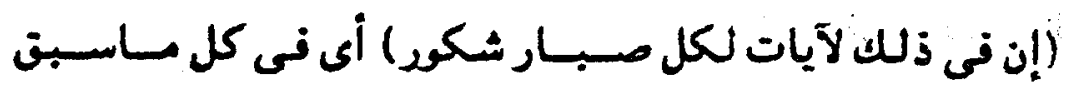
الحديث عنه من دلاتل تدرة الله تعالى ووحداتيته .

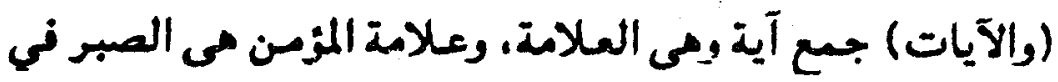

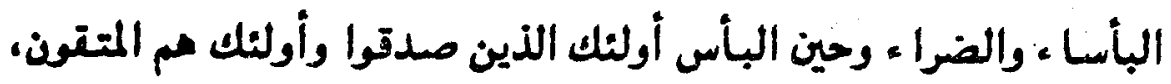

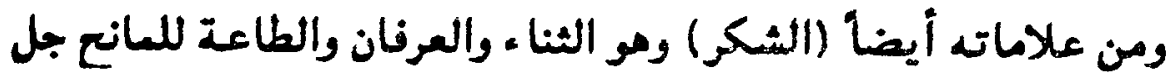
وعلا .. والصسبـر نصف الإيمان والشكر نصف الإيمان ، واليـتين الإيمان

$$
-7-
$$

ثم تنتـل الآيات إلى إبراز صسورة أخـرى للفلك حين يعلو الموج

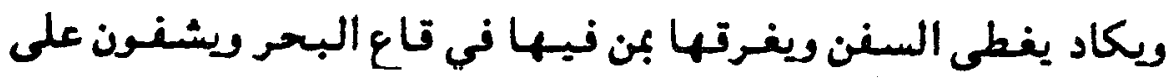

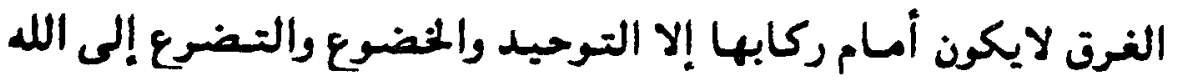

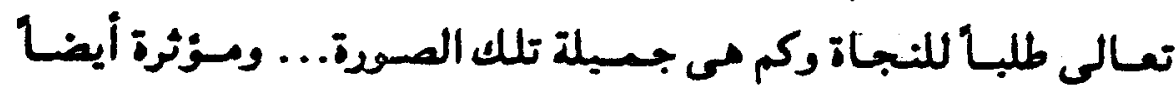

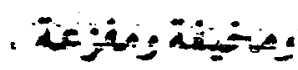

سفينة على صفحة الماء تتهلل أسارير ركابها نرحاً وابتهاجا

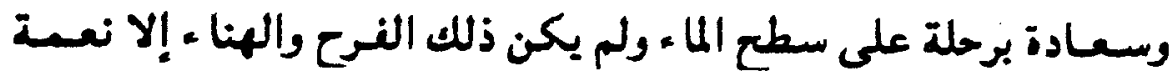

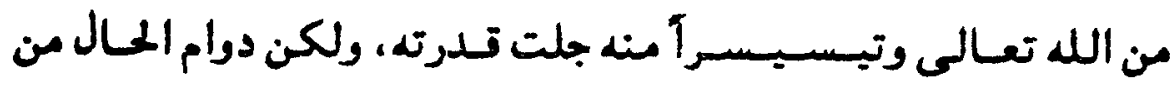

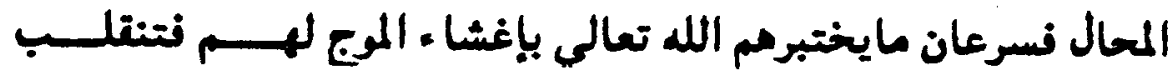


صورة الغرح والسـعـادة إلى فنزع واضطراب ولايكون أمسام مؤلاء ـإلا

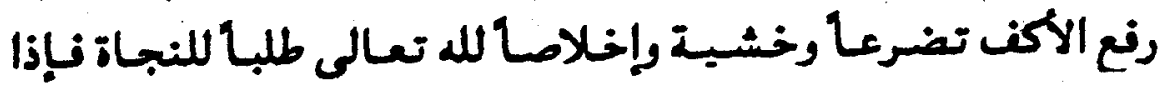

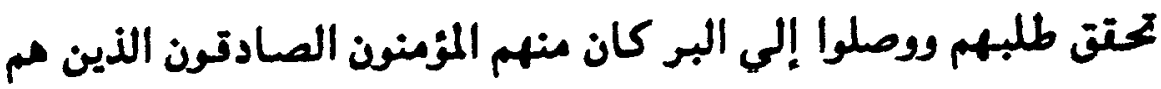
على ذكر داتم للد تعالى، ومنهم الكافرون بنعم الله تعالى . . .

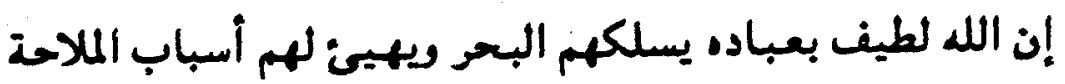

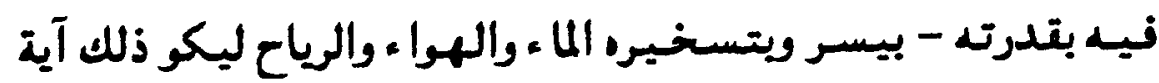

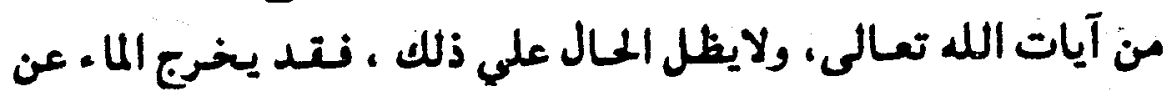

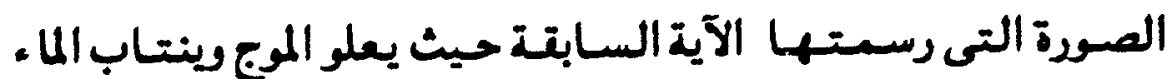

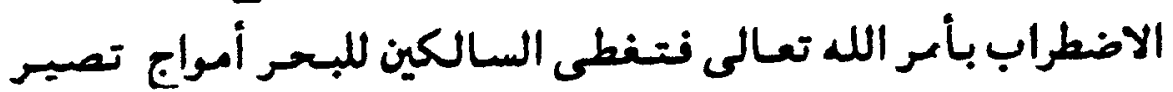

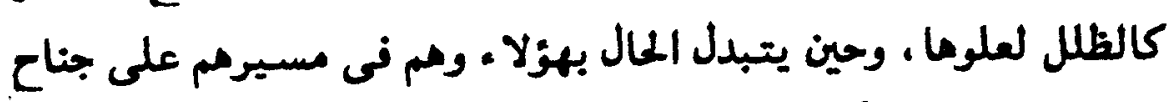

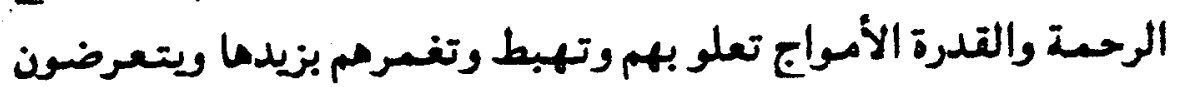

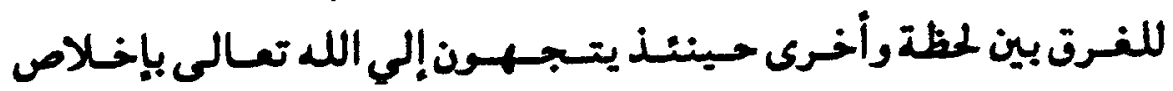

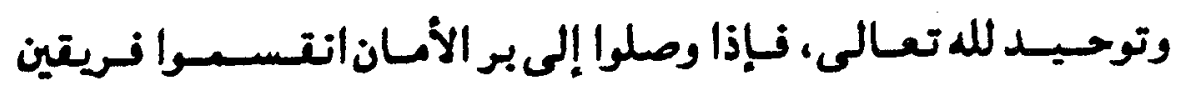

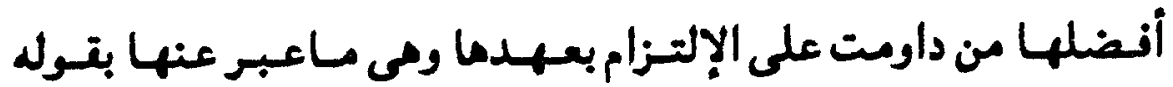
تعالى: "فمنهم متتصد - أى سالك التصد - أى الطريت المستقيم لايعدل عنه إلى غيره . تعنه معتص

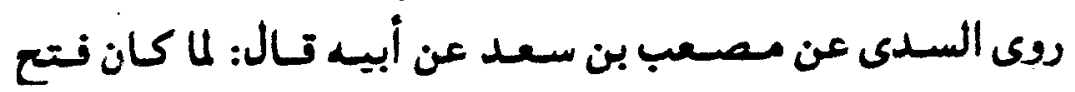

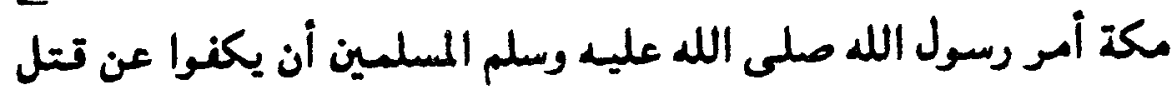

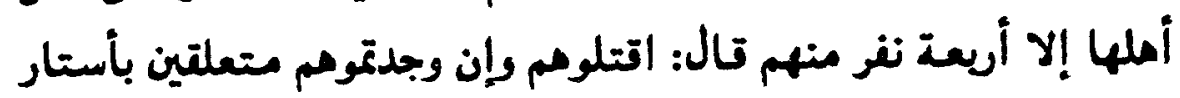

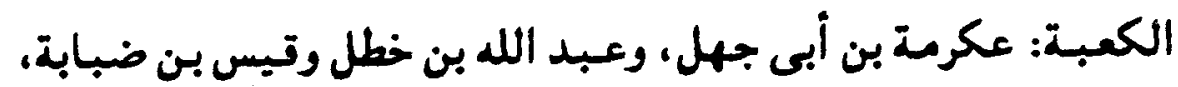
وعبد الله بن أبى سرح . .

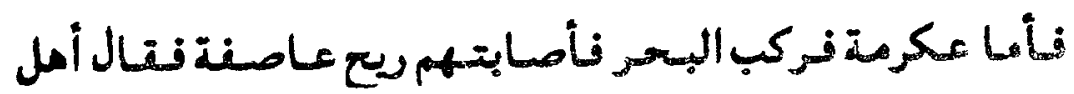

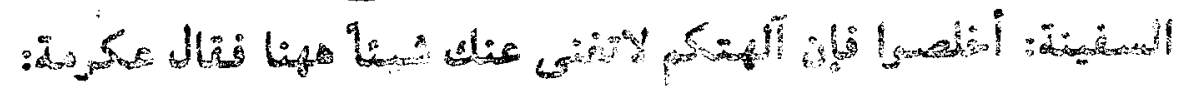




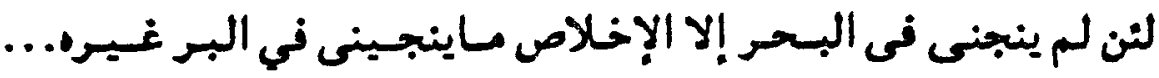

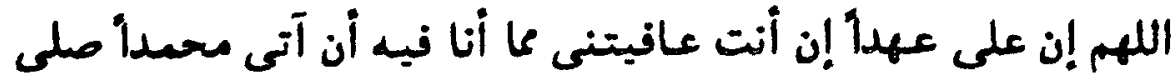

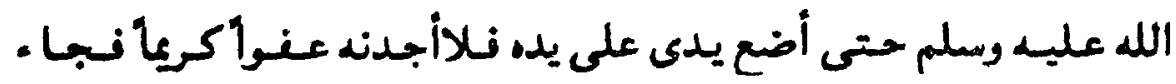

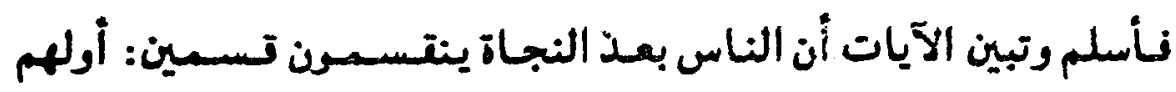

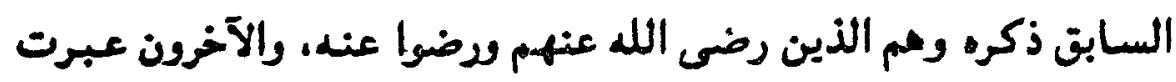

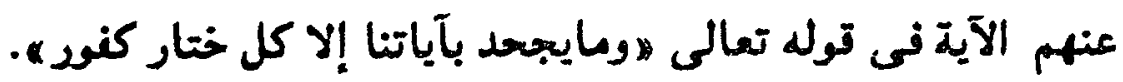

والجمسحسود الإنكار مع العلم، أى أنهم عـالمون بتـدرتنا وإرادتنا

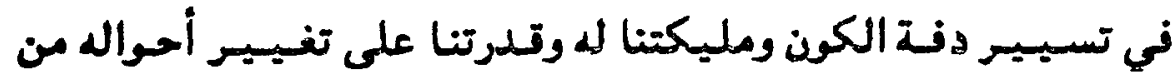

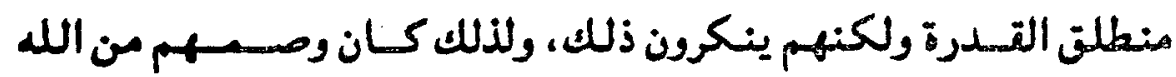

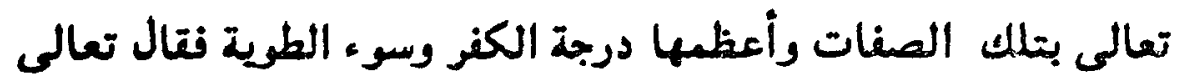
في حقهم :

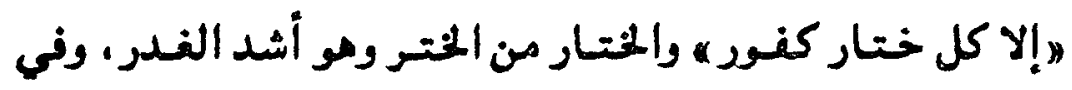

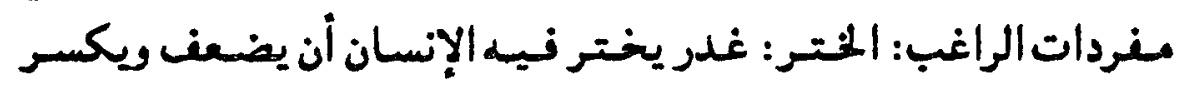
لاجتهاده فيه .

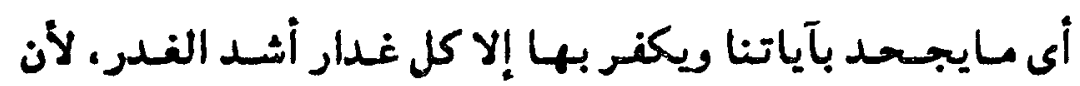
كغره نقض للعهد النطرى، وتيل لأنه نقض لماعامد الله تعاليه عليه

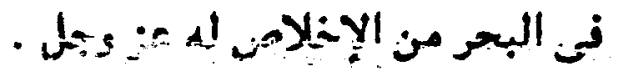

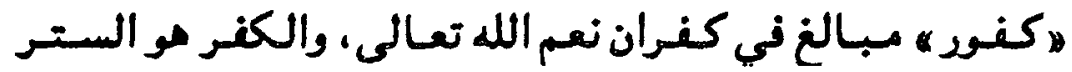

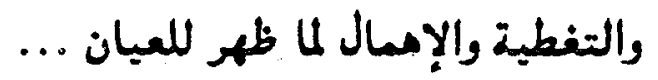

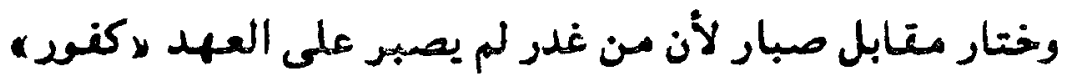

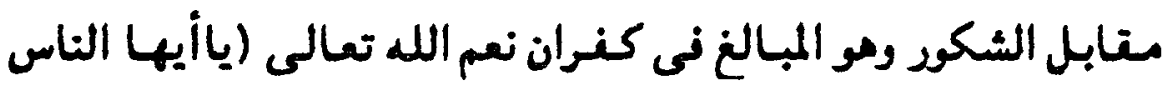

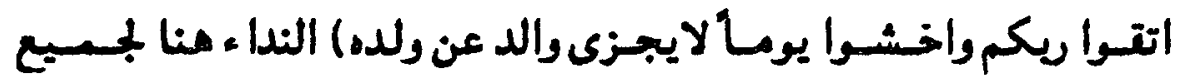

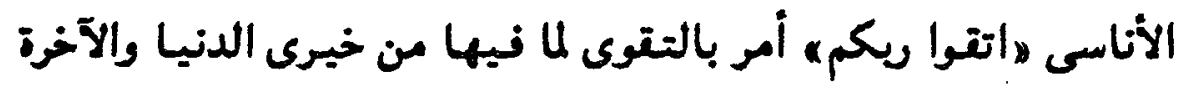




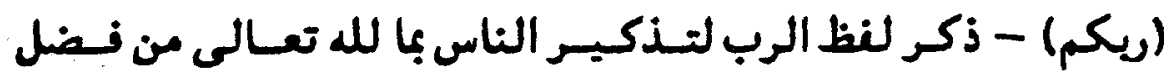

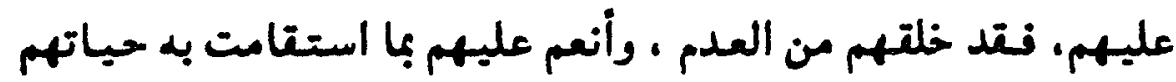
وأعظمها الرحمة التى وسعتهم ومذا جانب التبشير فى الآية .... أنا جانب الإنذار والتخويف فيتمئل فى تولد تعالى "ا واخشوا

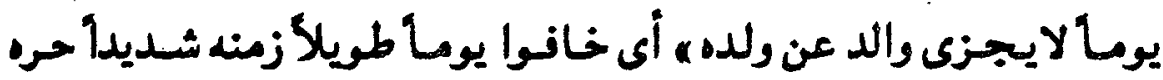

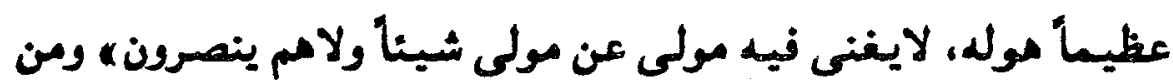

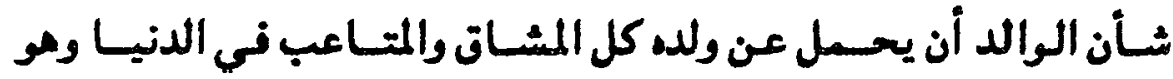

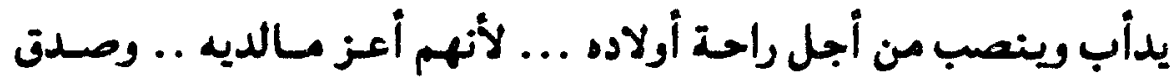

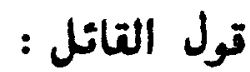

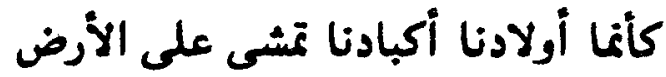

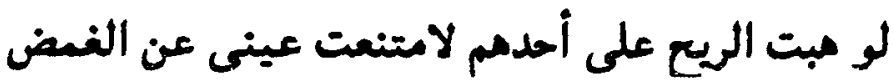

هذا فى الدنيـا أمـا فى الآخرة فـلا ... إنه يوم ها تذهل فـيـه كل

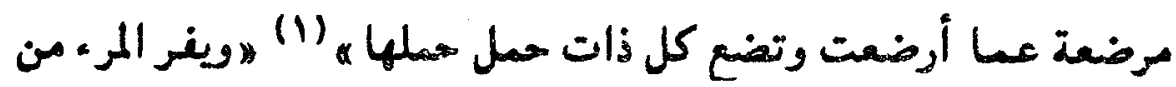

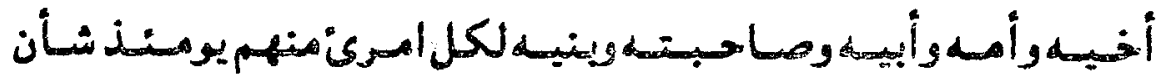

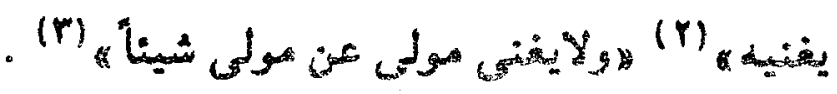

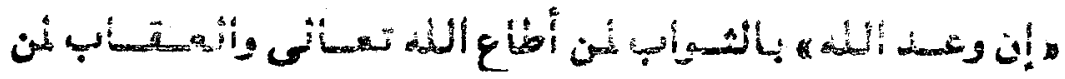

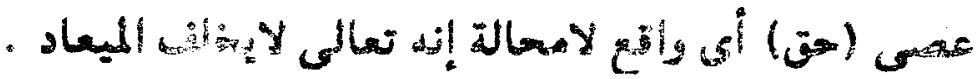

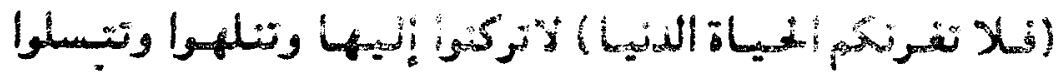

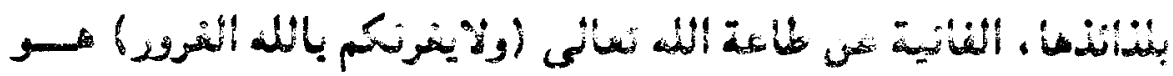


الشيطان بأن يزين لكم المعاصى ويدفعكم بذلك التزيين والتهوين على

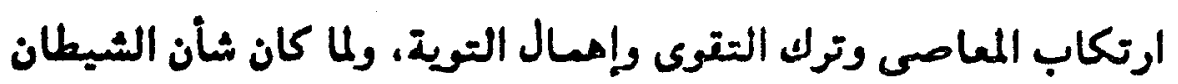

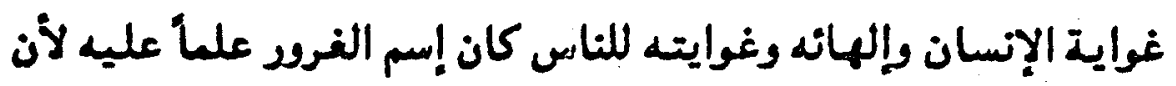

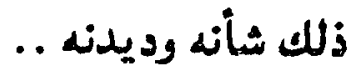

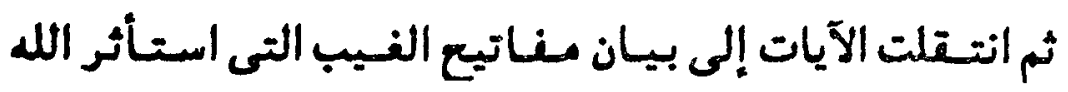

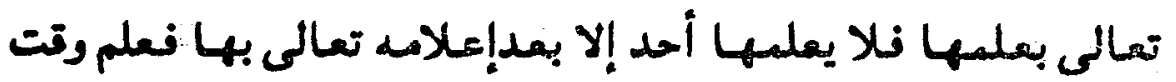

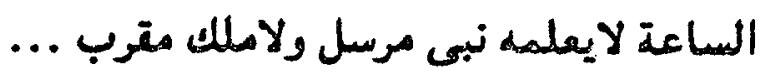

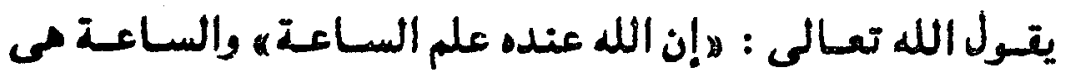

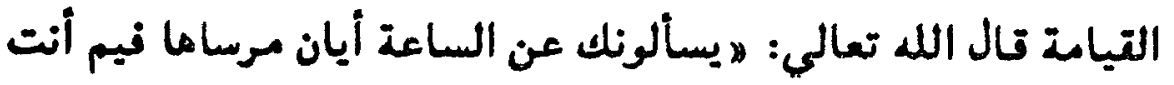

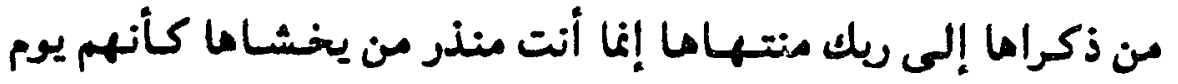

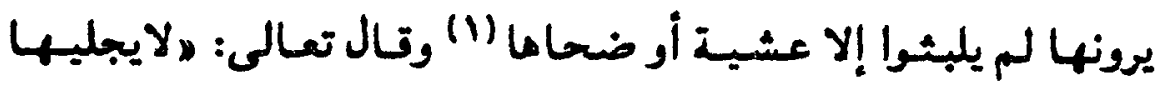

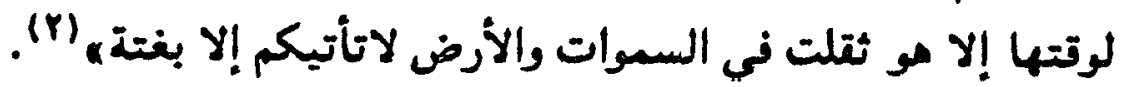

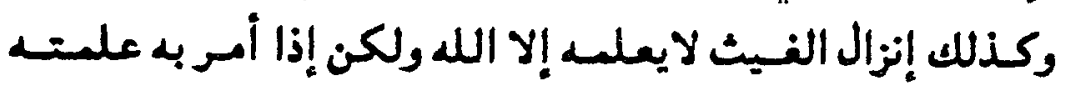
الملاككة الموكلون بلدلك، ومن شاء الله من خلته .

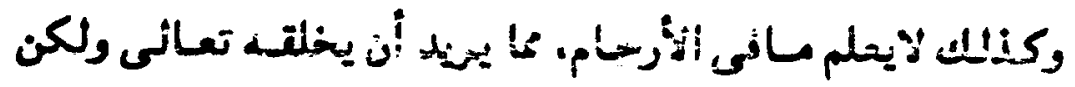

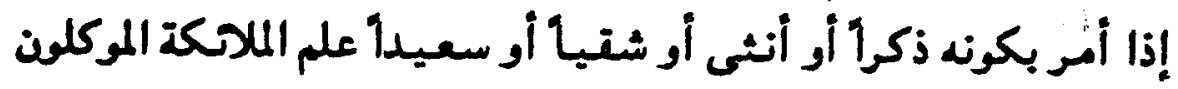
ومن شاء الله من خلقه .

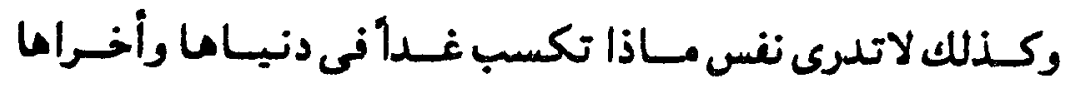

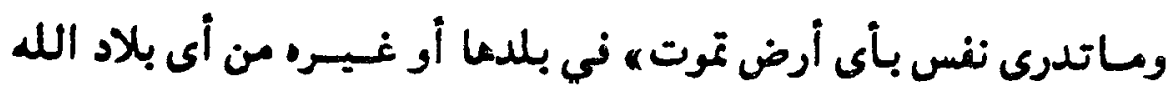

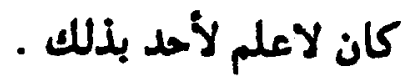


روى عن رســول الله صلى الله عليـــ وسلم أنه تــال: خــــس لايعلدهن إلا الله عز وجل الآية .

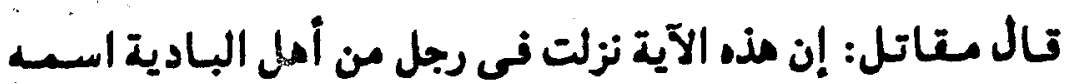

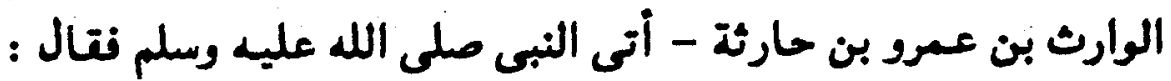

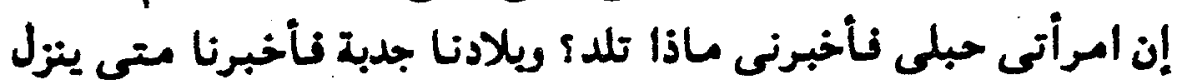

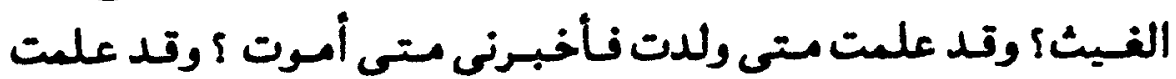

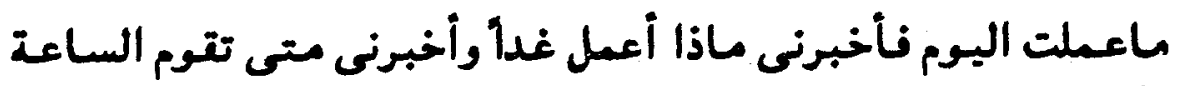
فأنزل الله تعالى مذه الآية ...

״ارينزل الغيث ه أى المطر ولايقدر علي ذلك سواه جل وعلا تال

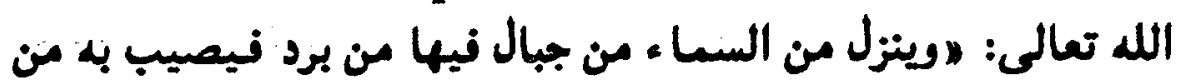

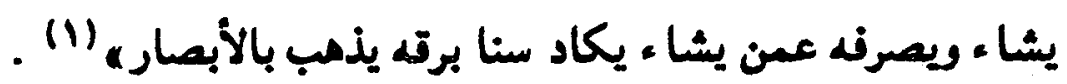

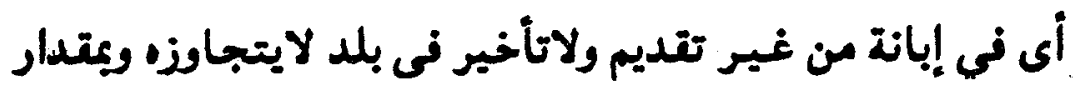

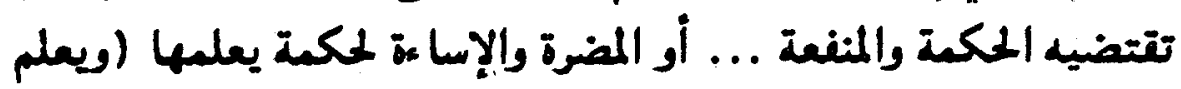

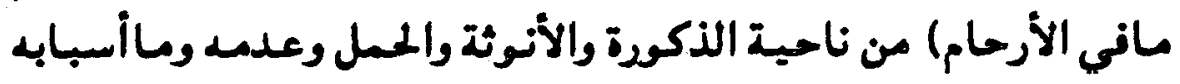
ورقت خروجه إلى الحياة الدنيا وسعادته فيها وشقاوته ومدة بقائه فى الحى

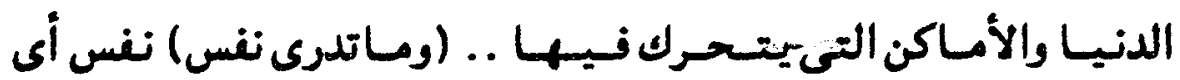

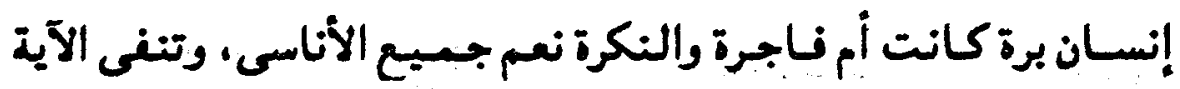

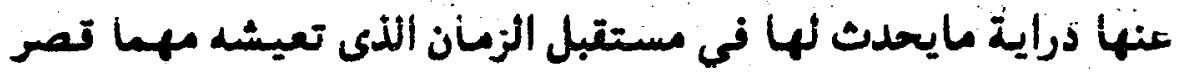

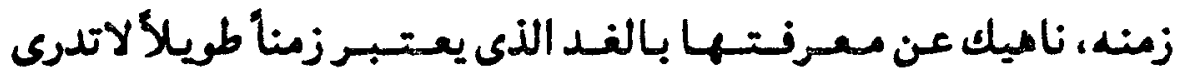

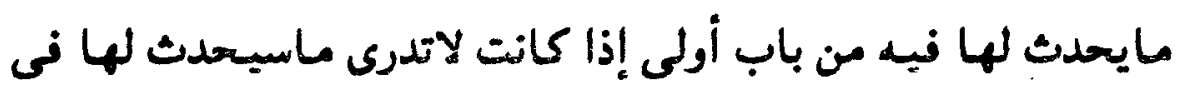

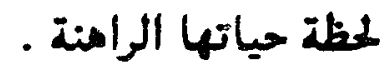

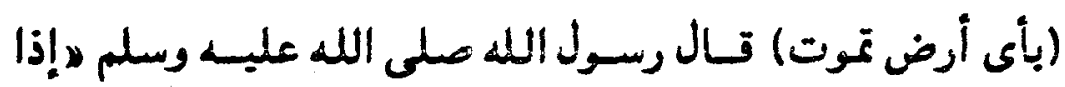

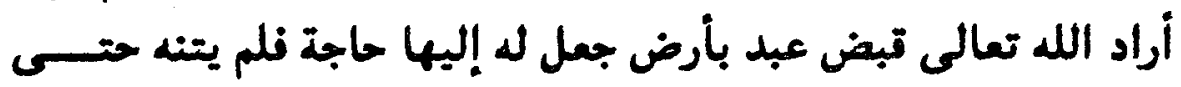




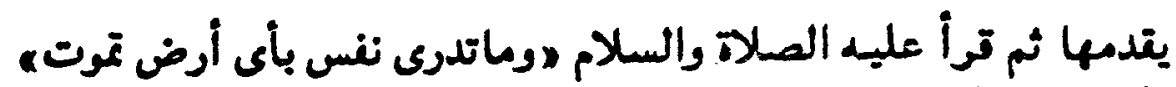

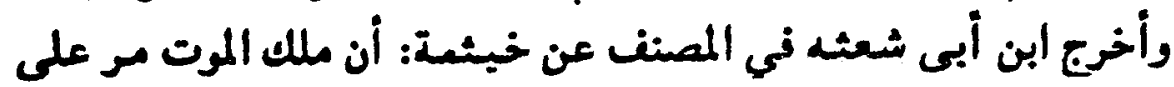

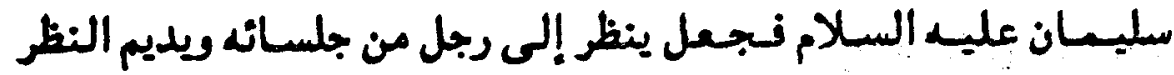

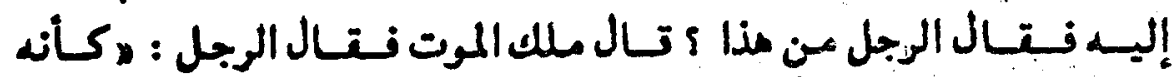

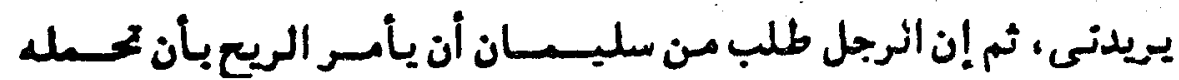

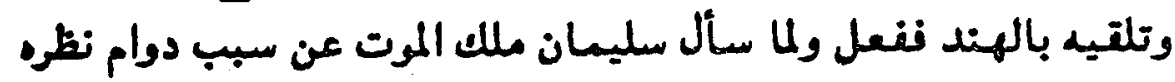

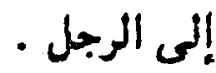

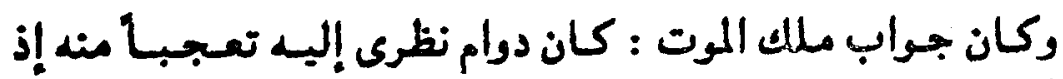

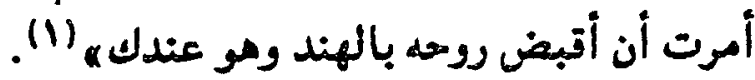

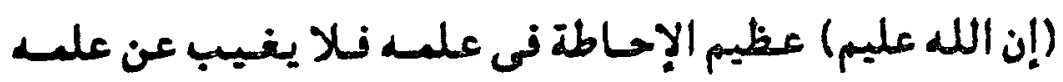

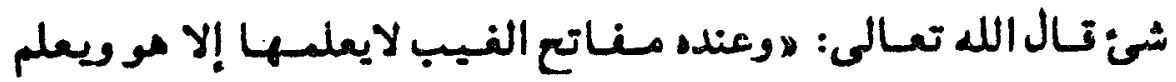

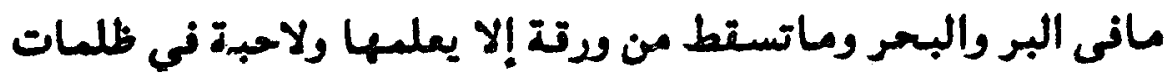

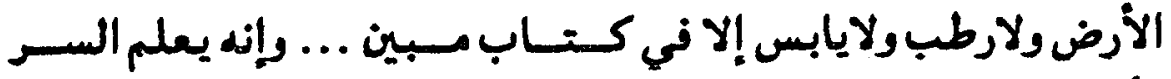

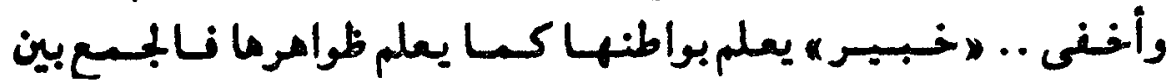

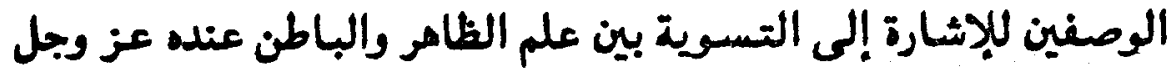

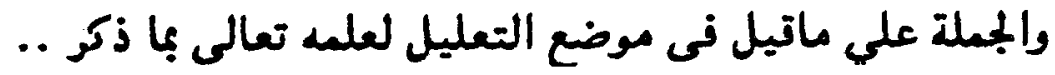

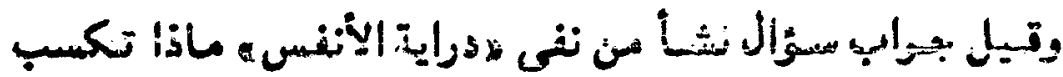

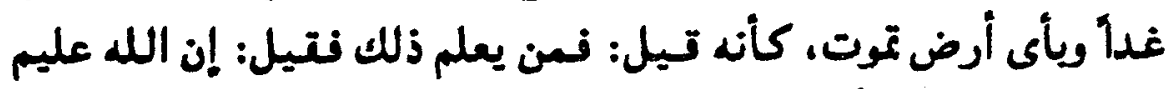

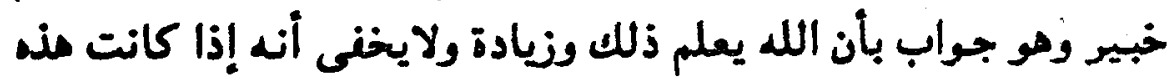

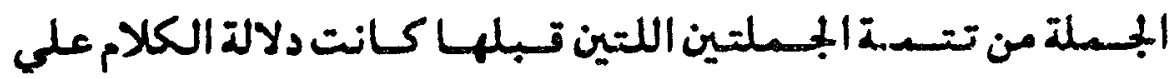

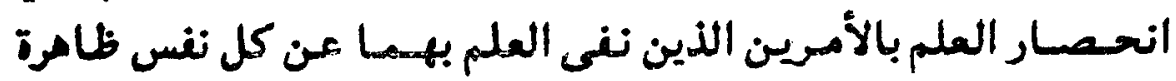

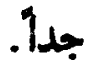

نتامل ذاك والله يتولى مداك

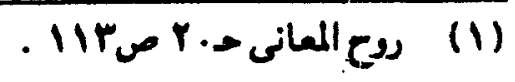




\section{الدراسة الصنية}

- ابتدأ الله تعالى السورة بسر من أسراره مى قولد تعالى: (آلم)

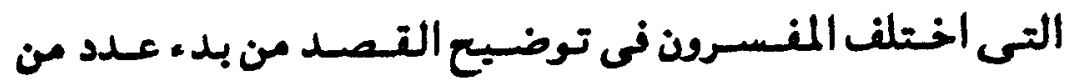

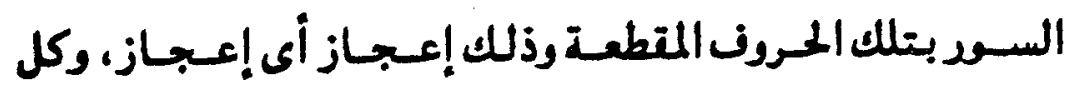

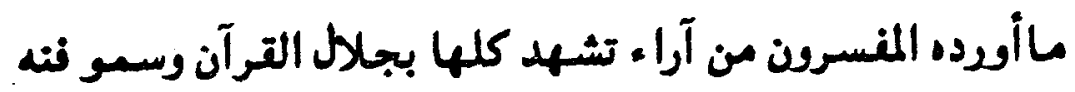

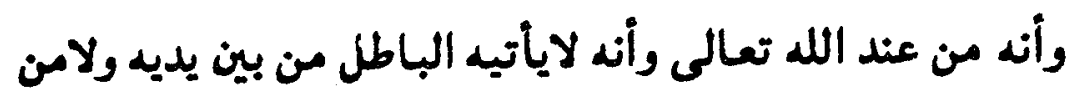
خلفه تنزيل من حكيم حميد .

- رد فى النص ألفاظ قوية محكسة تدل على المعانى فى قوة -

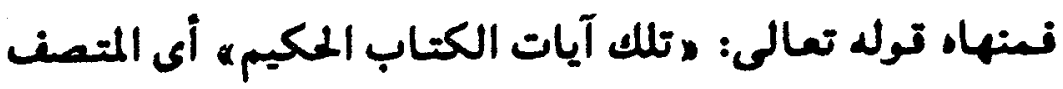

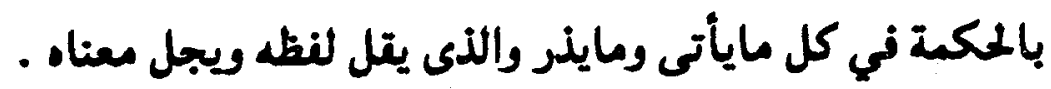

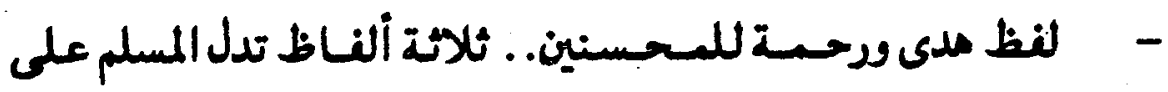
الحتير فى الدنيا والآخرة - فبين دفتى الكتـاب الكريم الهداية

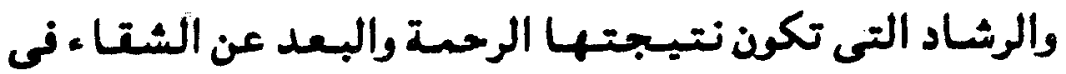

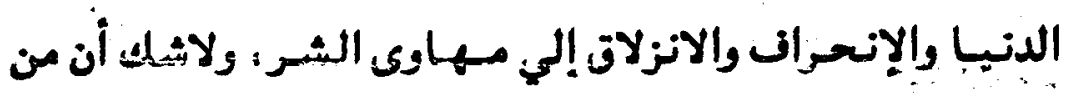

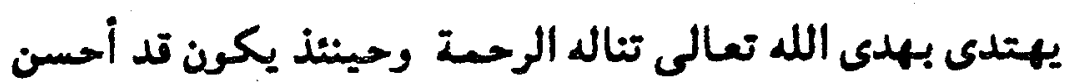

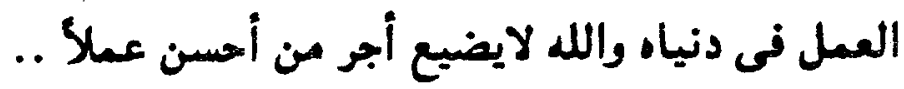

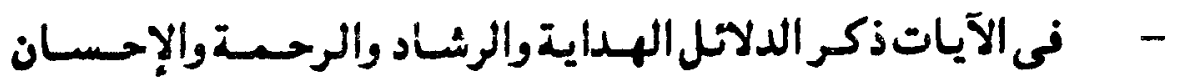

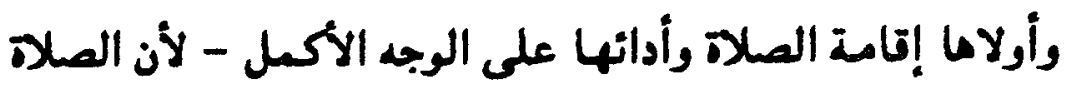

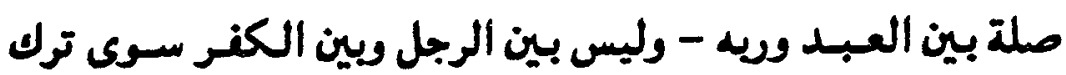

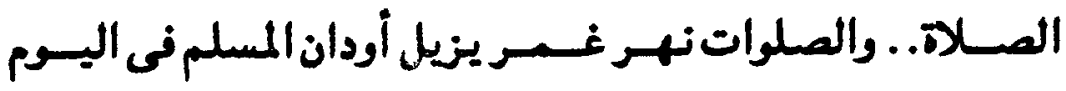




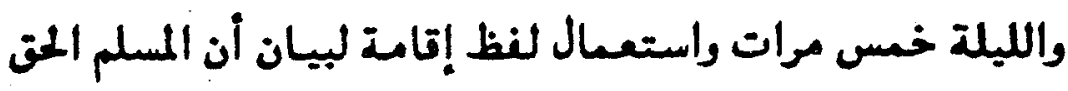

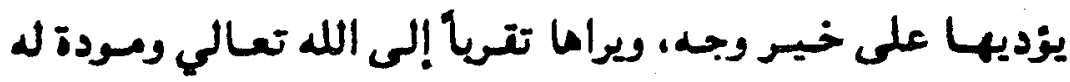

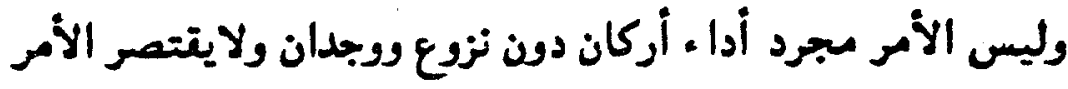

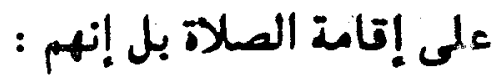

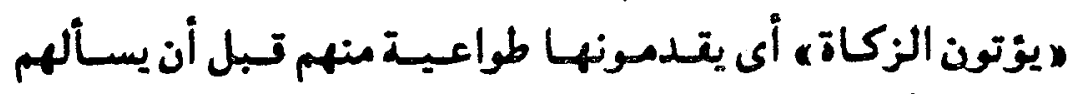

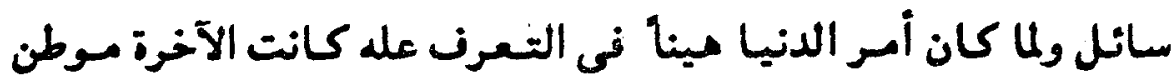

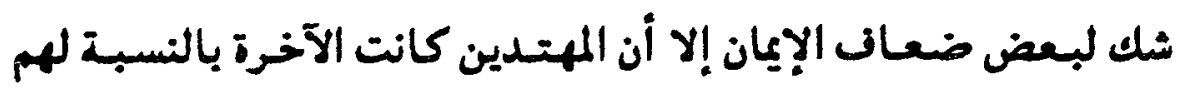
يقيناً، فلا يخامر الشك تلوبهم وعتولهم جبامها ـ

وعبر بالمضارع للدلالة علي دوام اليقين واستمراره فى عتولهم

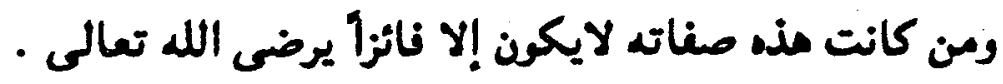

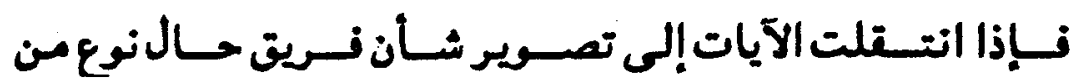

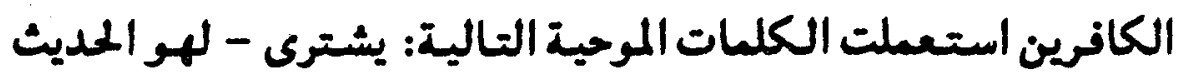
ليضل عن سبيل الله بغير علم ويتخذها مزواً .

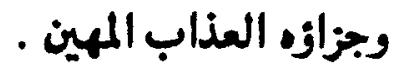

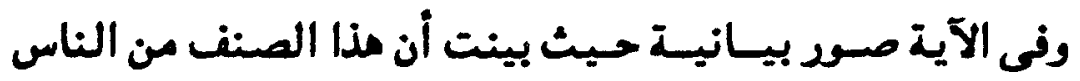

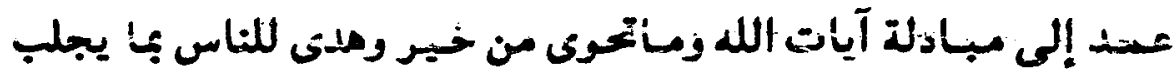

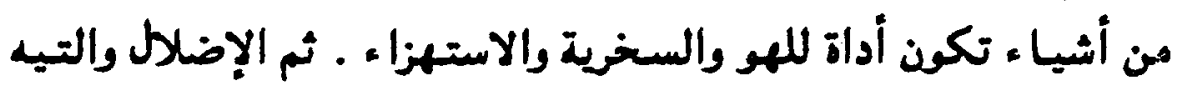

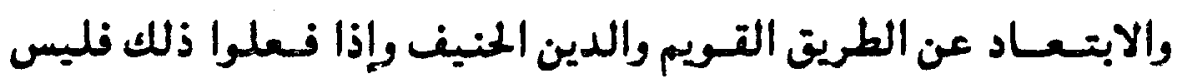

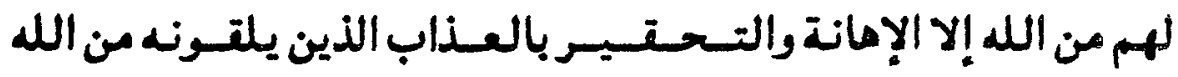
تعالى.

فإذا صورت الآيات حال مؤلاء المستكبرين عن الانتياد للحتق

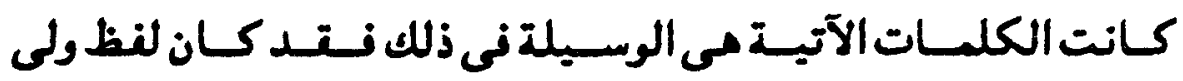

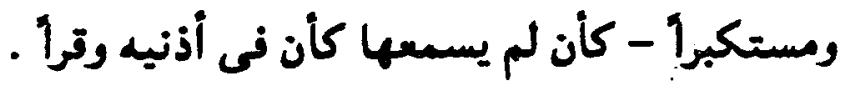


ومى تصسو الطفـات لاتؤثر فـيـــم آيات الله تعـالى حين تتلى

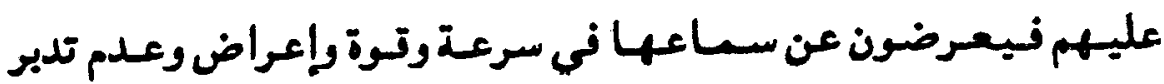

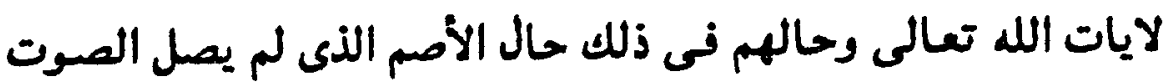

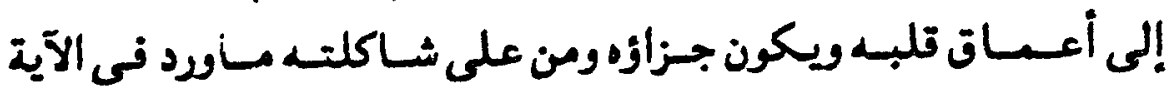

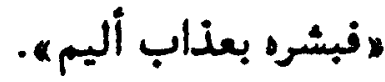

ومنا صودة بيانية فالبشارن لاتكون إلا بالمير ولكن الآية فيها

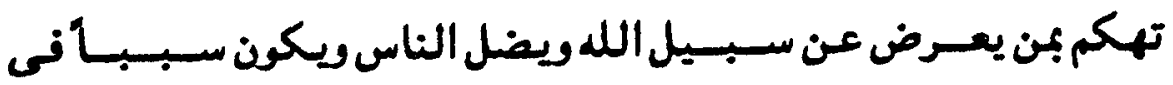

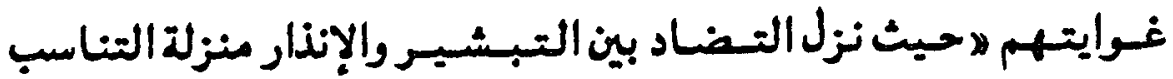
بينهـا تحتيقا فى التبشير وتنزيلاً فى الإنذار، ثم استعير التبشيبر

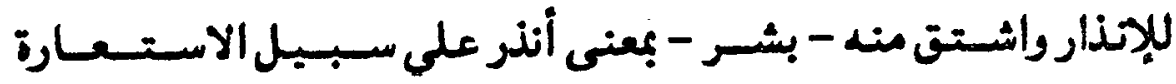

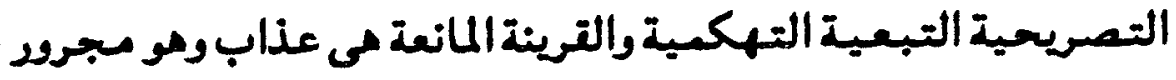
بالياء ومتعلق بالنعل الذى وتعت فيه الاستعارة لأن التبشبير بمعناه

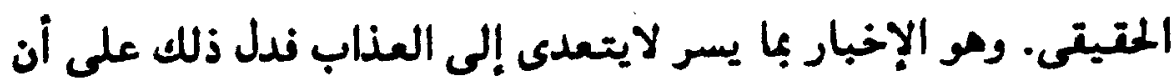

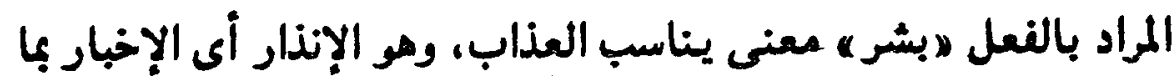
يسوء (1)

فإذا انتقلت الآيات لتصوير حال المؤمنين الصالمين بأعمالهم

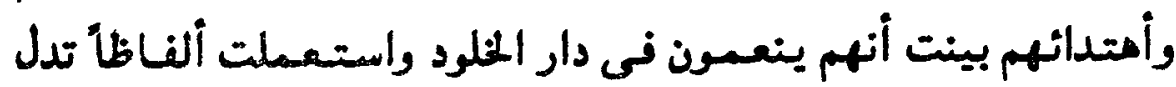

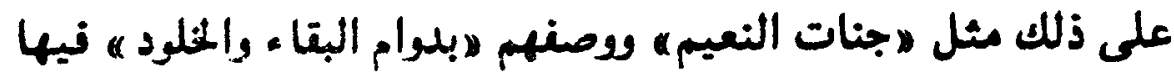

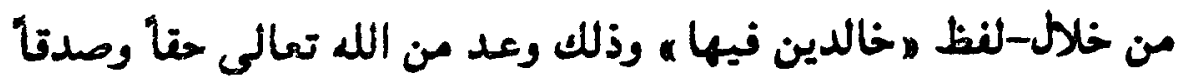

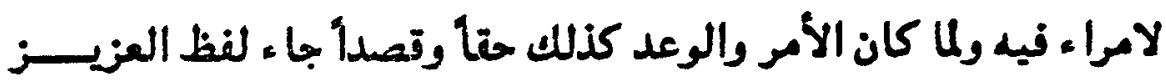


المكيم ليسبين أن عذا الحسبـر حق لأنه من عند من لايغلب والذى تأتى

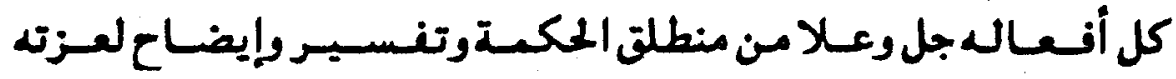

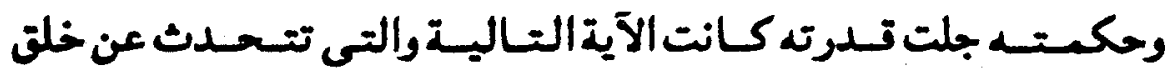

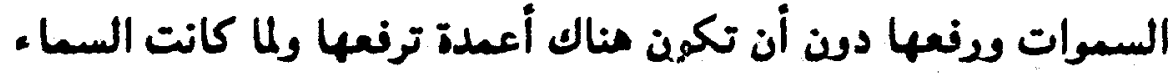

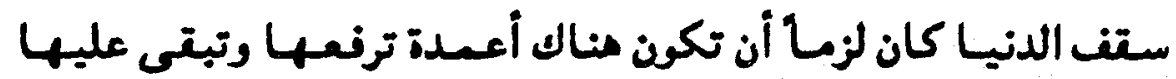
منصوية ولكن تدرته تعالى رنعت السموات بغير عمد ترونها وتلك

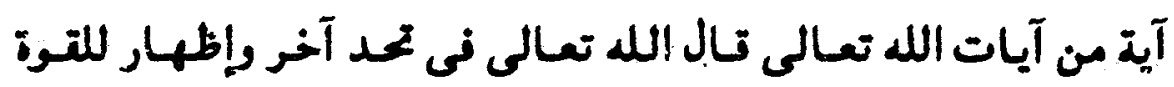

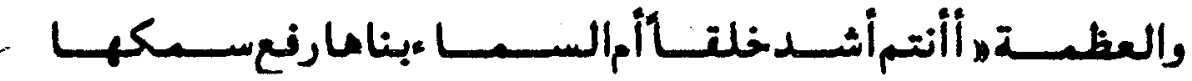
(1) فسراما....

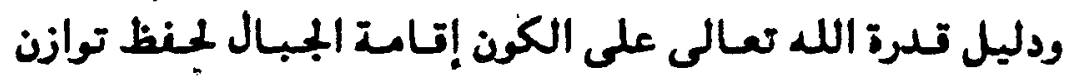

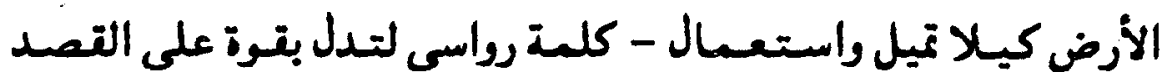

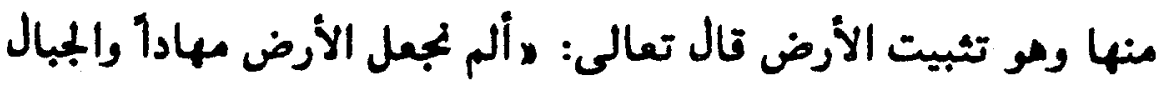

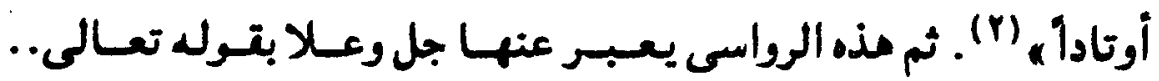

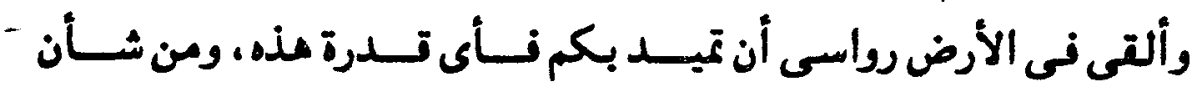

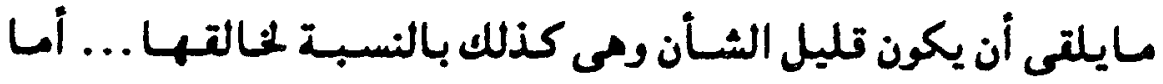

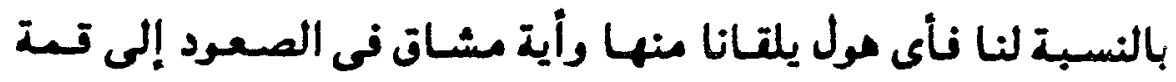
.

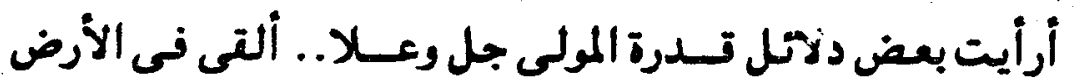

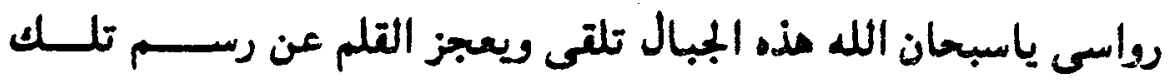

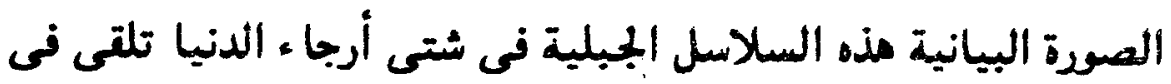

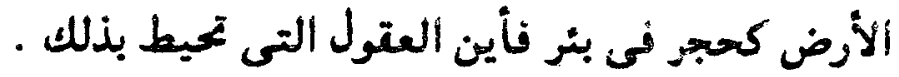




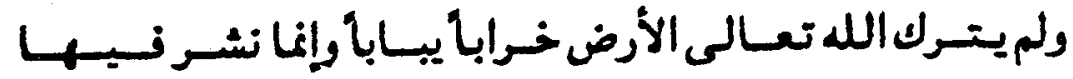

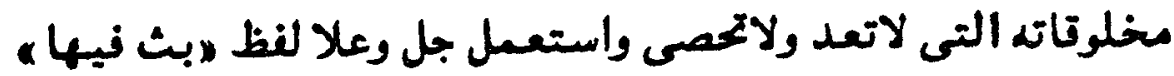

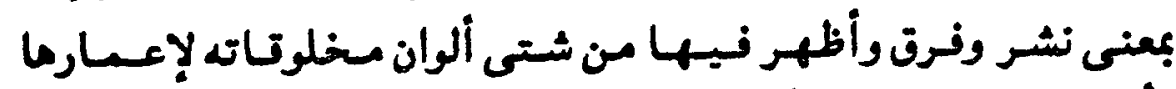

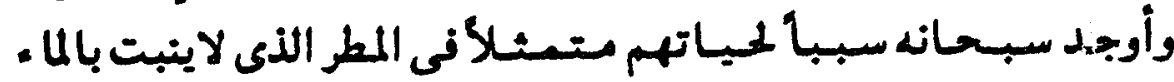

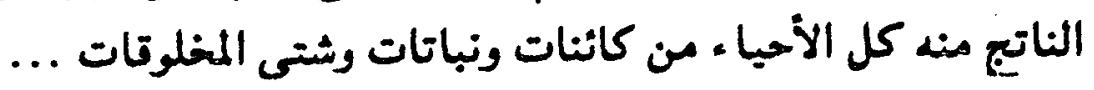

وإذا كان الله تعالى قد خلق ويخلق كل مذه الظواهر فى الحياة

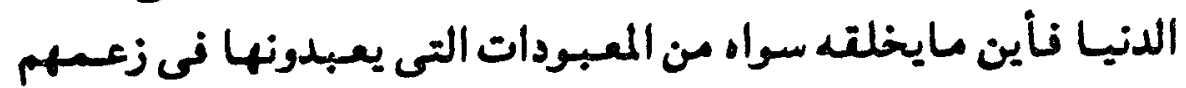

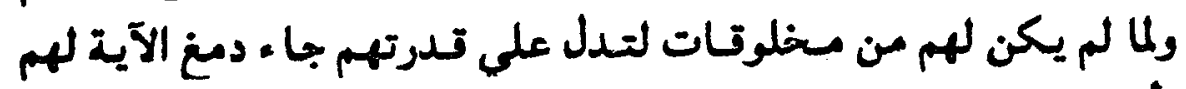

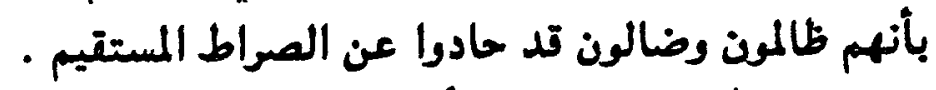

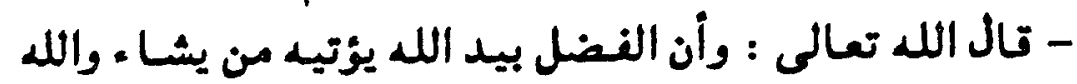

ذو النضل العظيم (1)

وفى الآية التى تلى ماسبق الحسديث عند من سورة لتهان تعبر

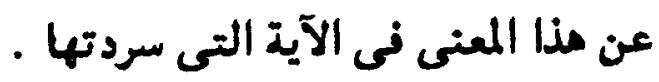

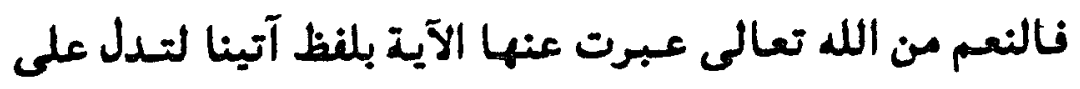

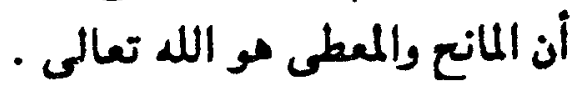

أما المعطى - نهو الحمكمة - وهي العلم والتنقه ونتاجها شكي

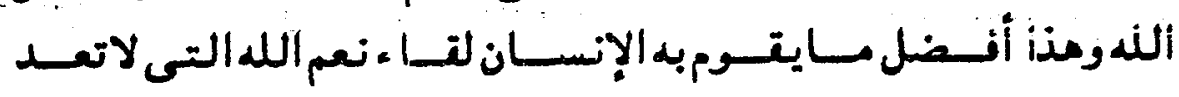

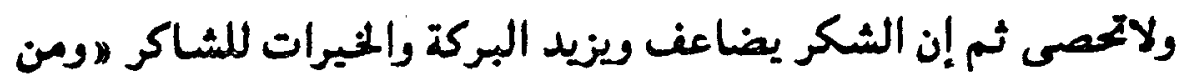

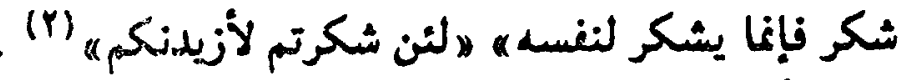

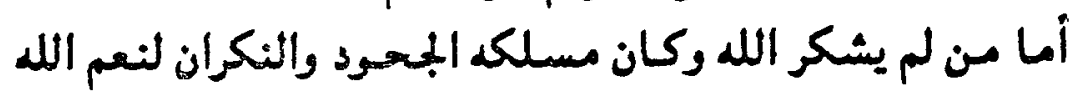

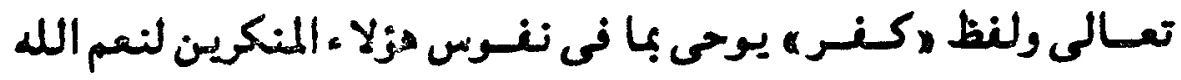

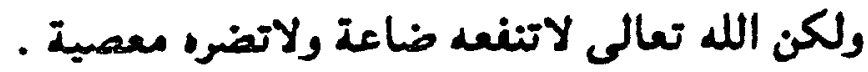




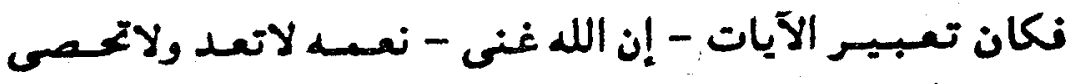

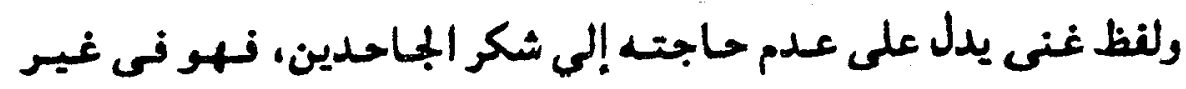

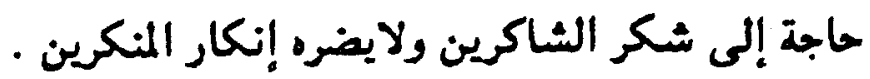

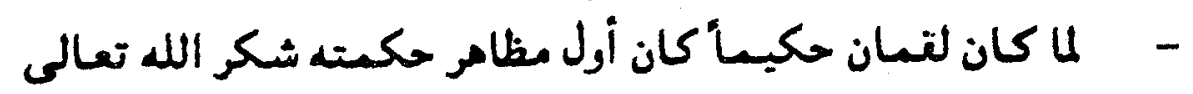
علي النعم. وكان من مظاهر حكمته توجيه انديه النصح لابنه بأمور

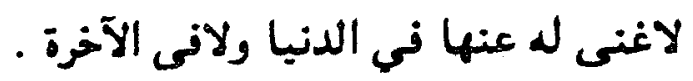

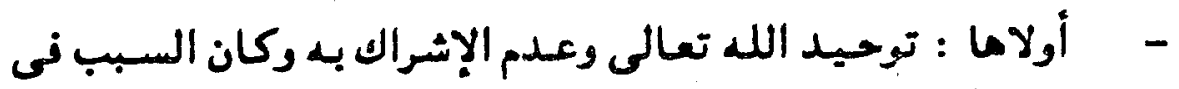

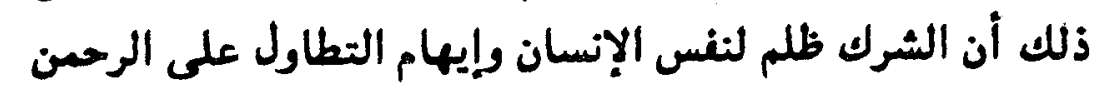

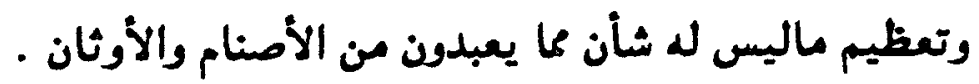

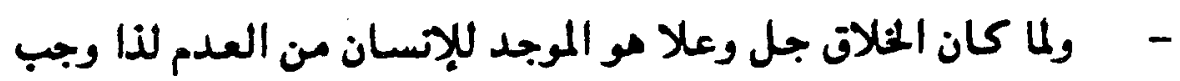

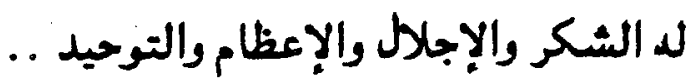

أما بالنسبة للوالدين فهبـا السبب في الوجود الذى مو دليل

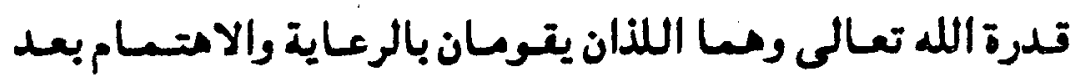

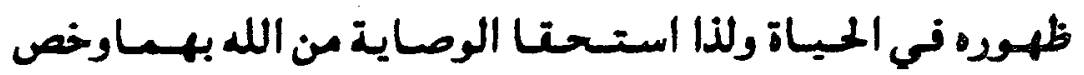

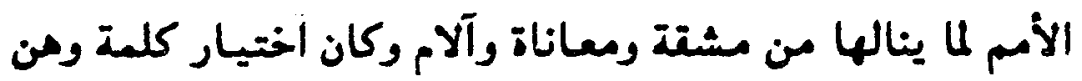

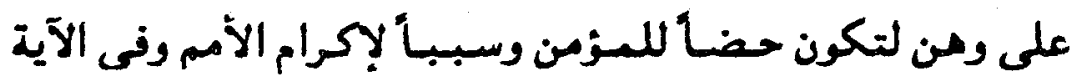

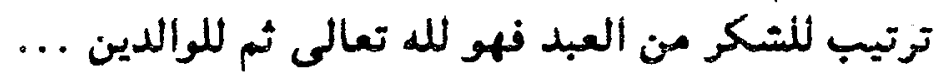

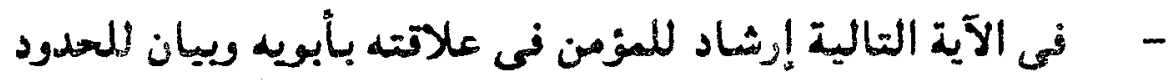

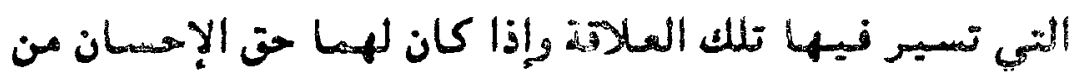

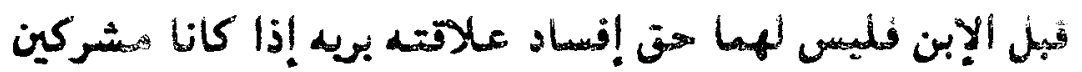

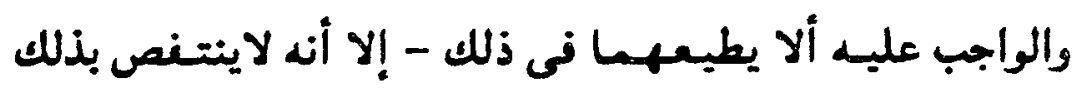

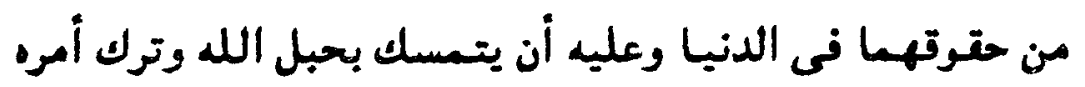

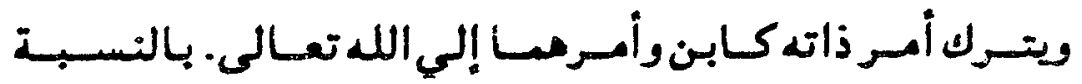




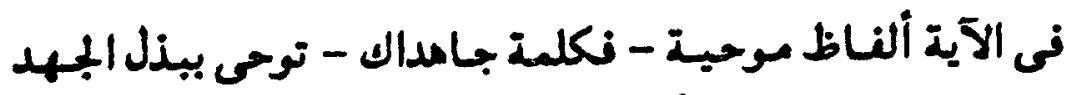

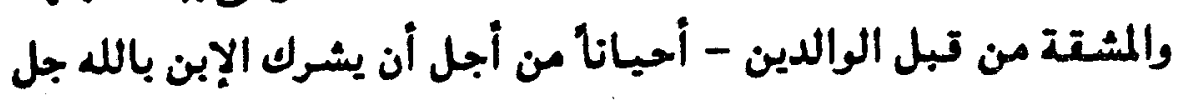

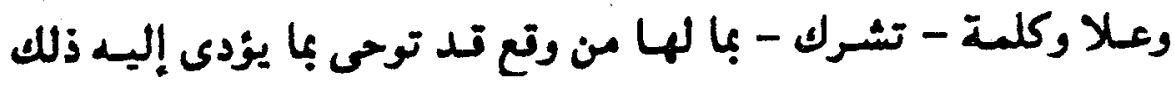

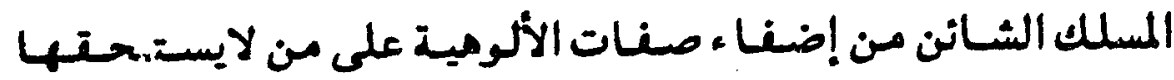

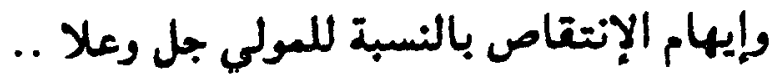

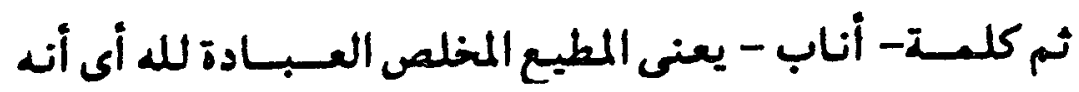

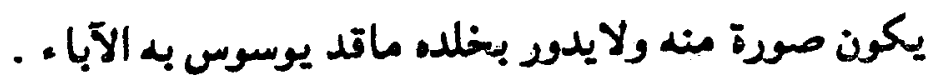

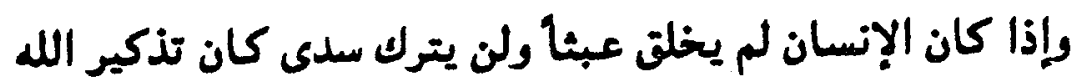

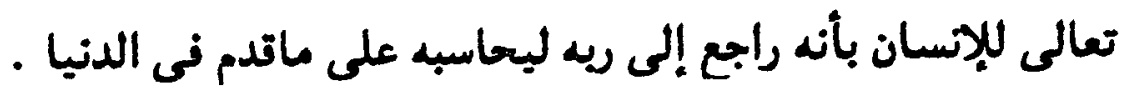

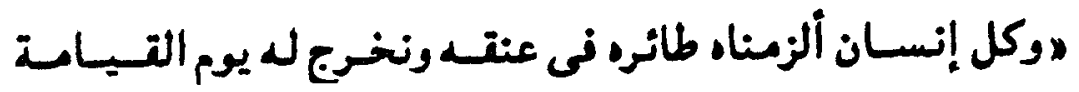

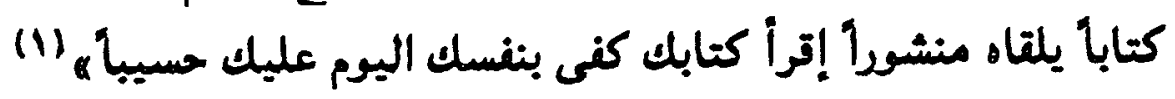

- الآية التالية تأكيد لعلم الله تعالى بما يأتيه الإنسان ومايذره

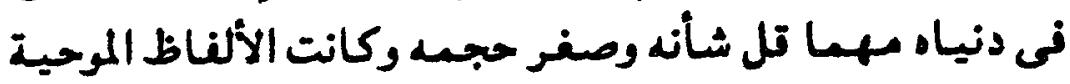

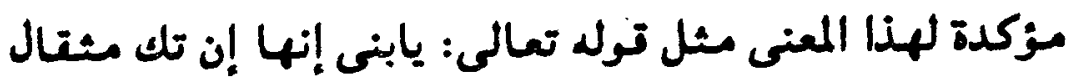

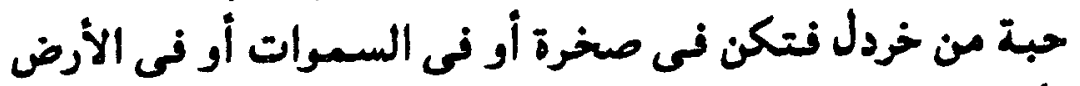

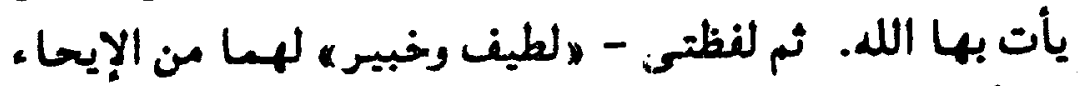

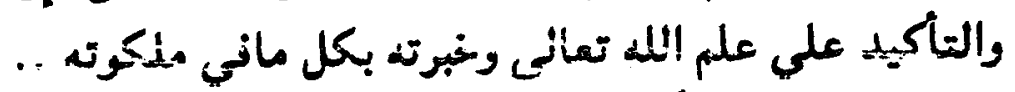

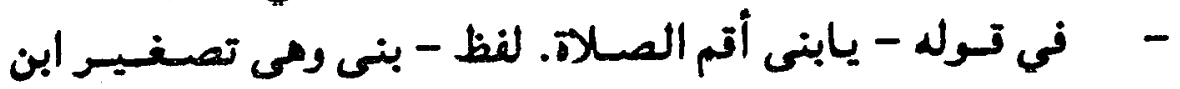

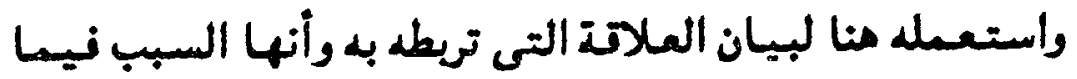

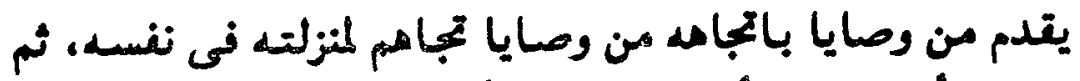

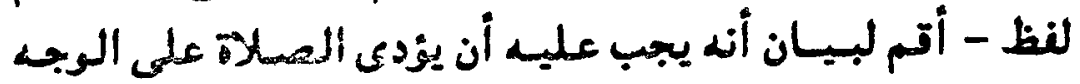

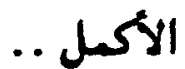




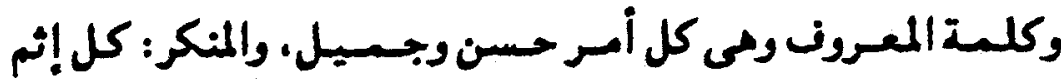

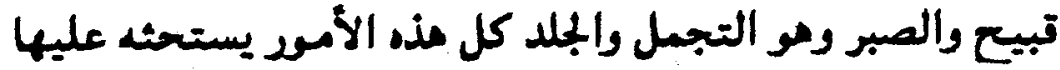

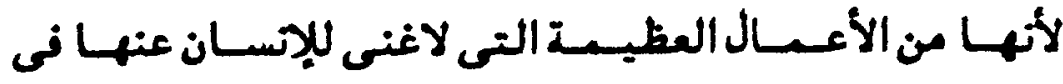

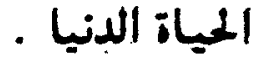

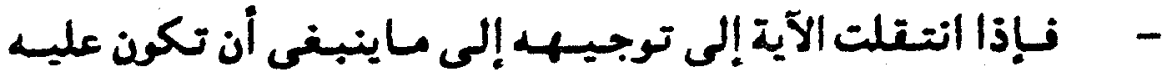

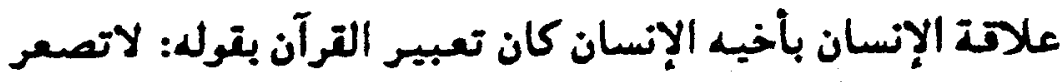

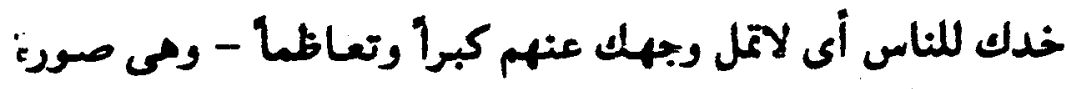
بيانية قال ابن جرير :

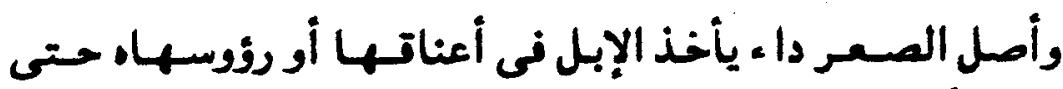

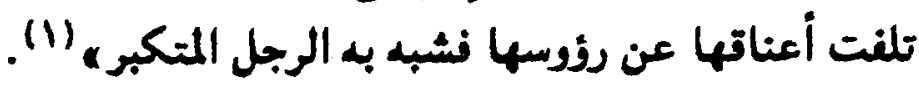
تال أبو طالب في شعره :

وكنا تدياً لانتــر ظلامـــــ إذا ماثنوا صعر الرؤوس نتيسها

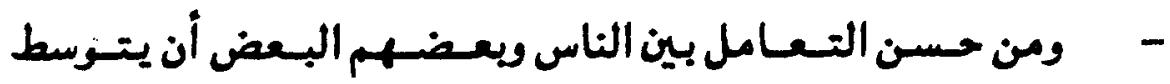

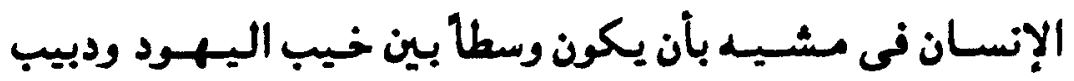

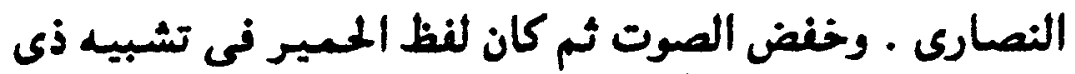

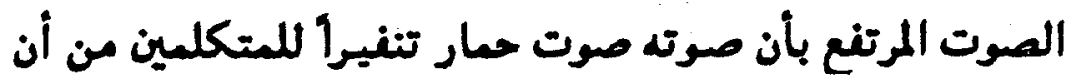

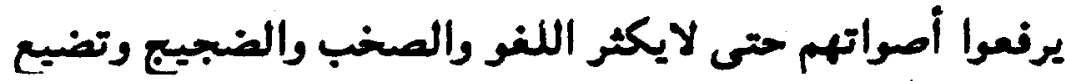

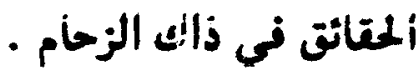

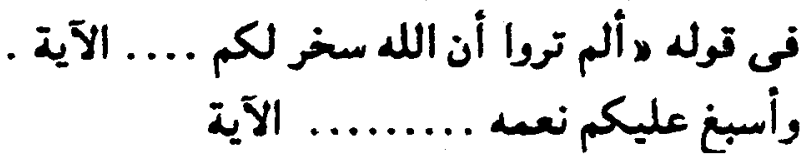
تدل على عظيم نعم الله تعالى على الإنسان فكل شئ شئ ميسي

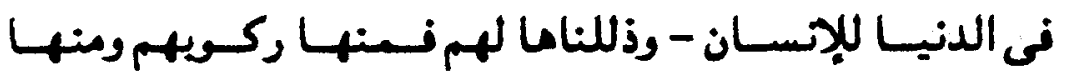

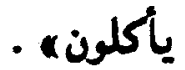


ونعم الله تعالى قد غطت الكون كله بما فيه ومى صورة بيانية

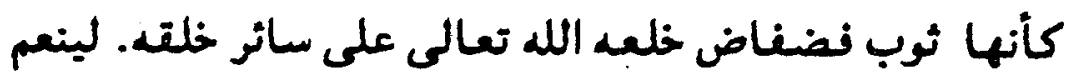

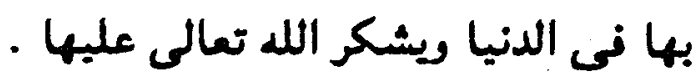

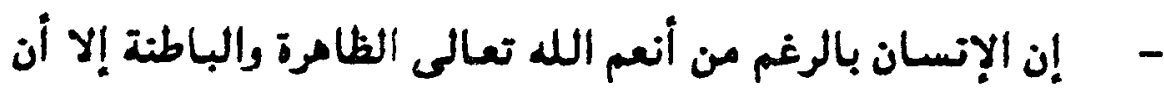

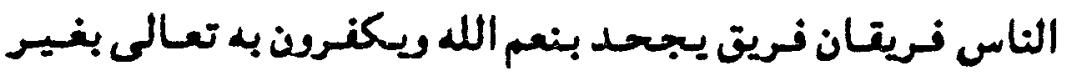

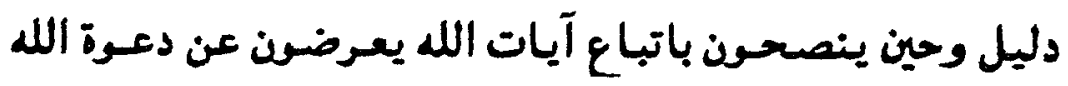

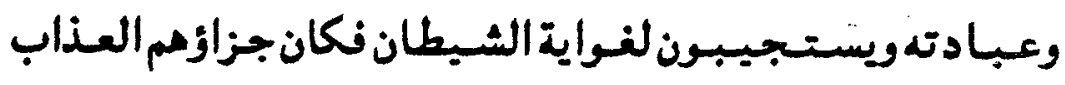
الأليم وعبادت

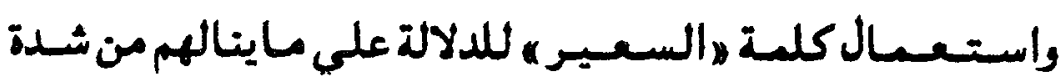
العذاب نهو ليس عذابا نتط وإنما تسعر بهم نار بهنم ويشتيد أوارما .

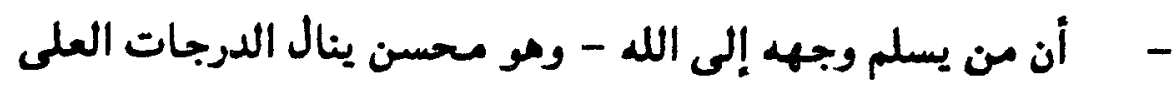

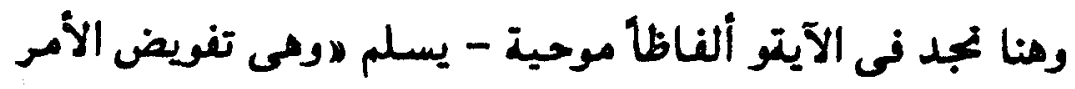

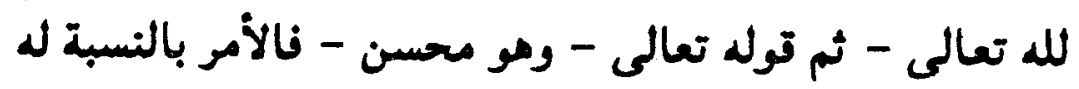

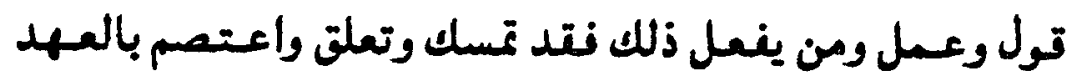

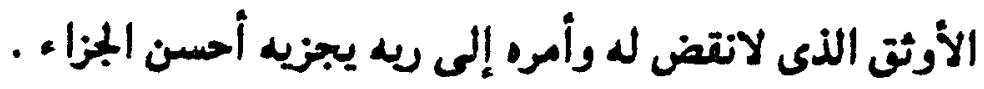

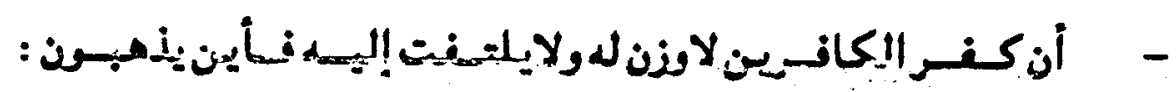
وسيعلم الذين ظلموا أى منقلب ينقلبون ولن يستطيعوا الإنكار

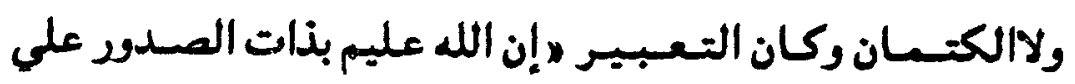

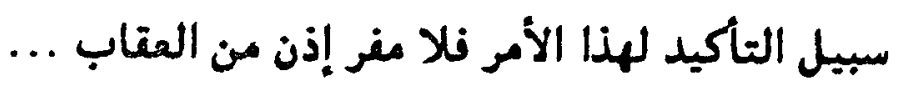

- فى الآية لفت لأنظارمم إلى شأن الدنيا وكين أن متاعها تليل

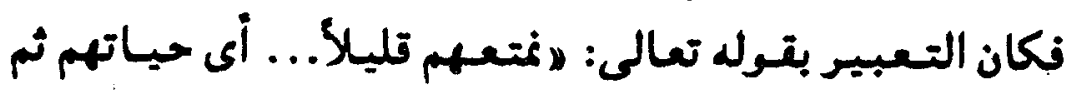

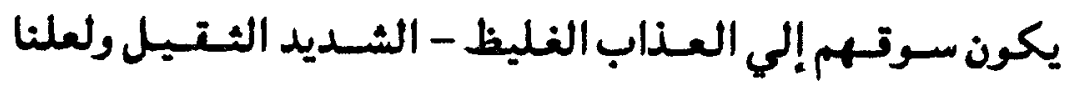




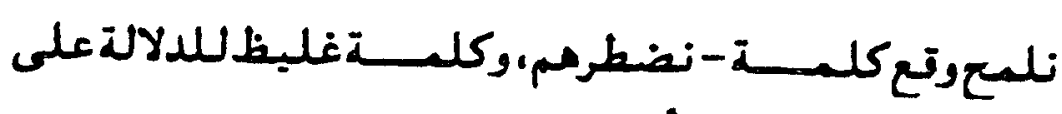

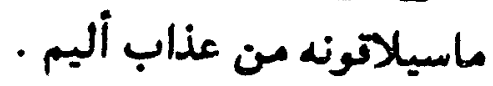

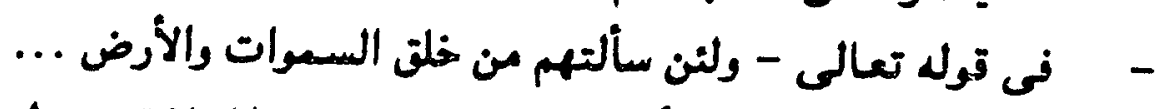

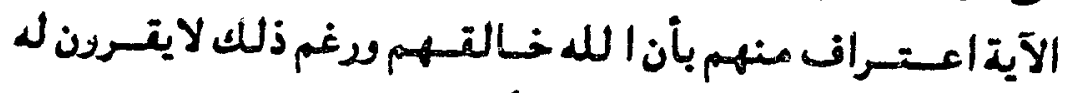

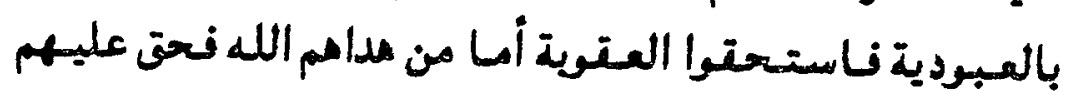
الحمد والثكر على ماوفتهم الله تعالى .

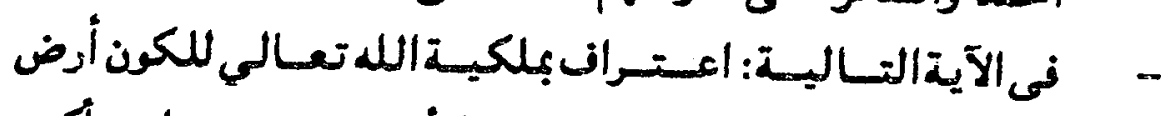

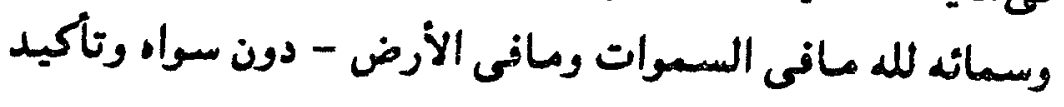

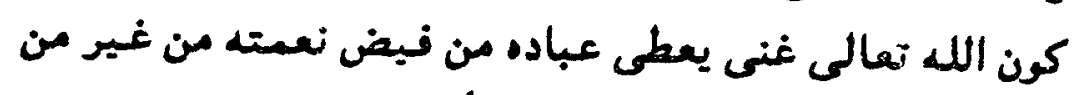

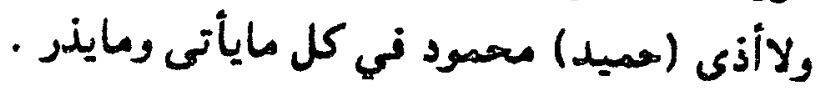

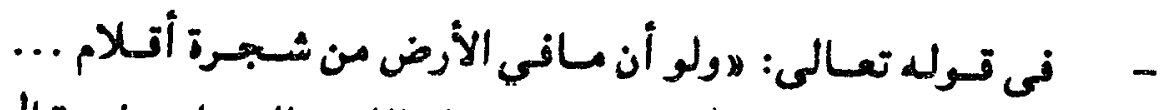

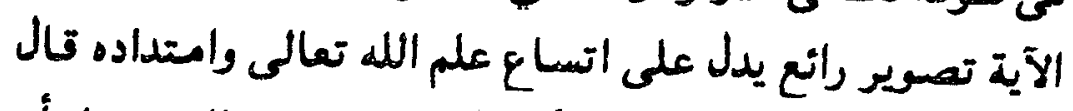

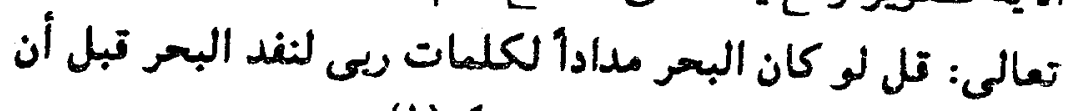

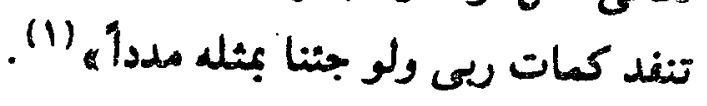

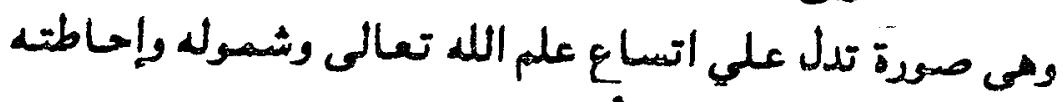
بكل ماكان ومايكون إلى أزي تقوم اليساعة .

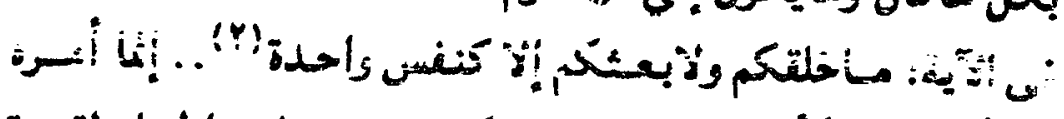

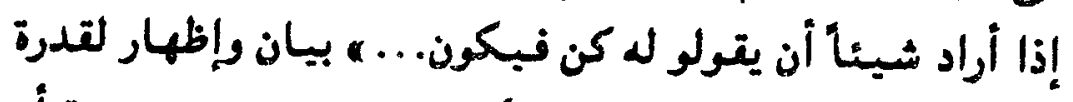

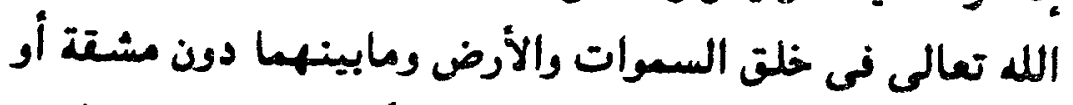

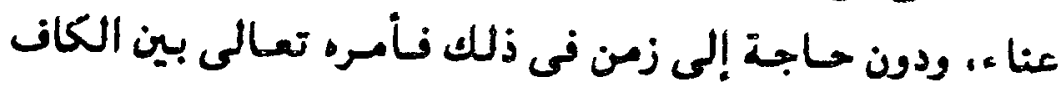

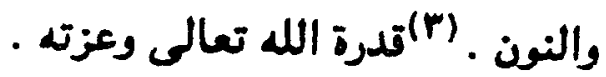




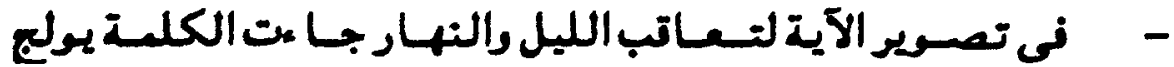

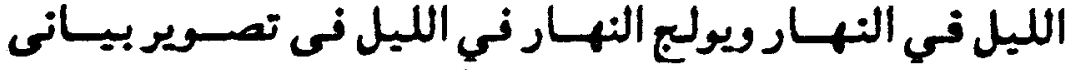

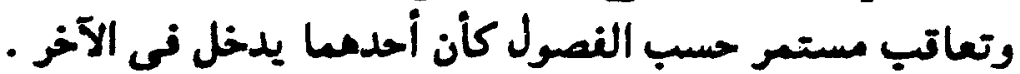

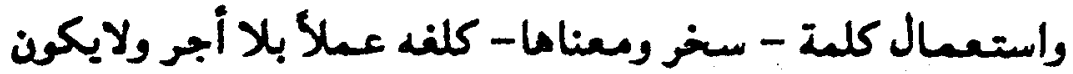

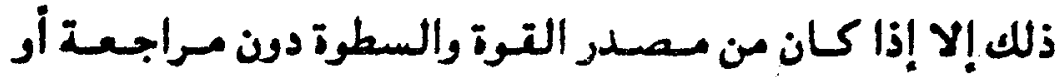

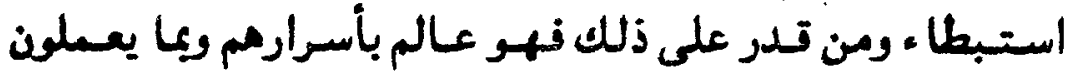

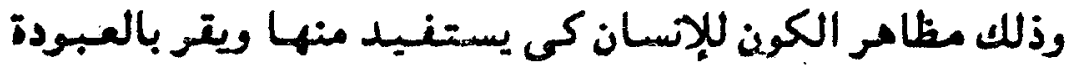

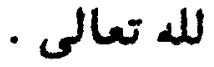

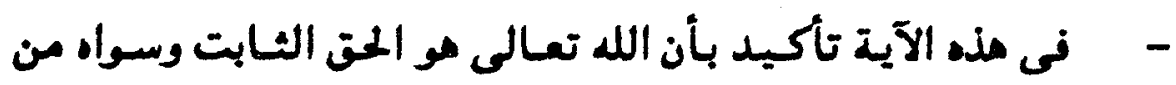

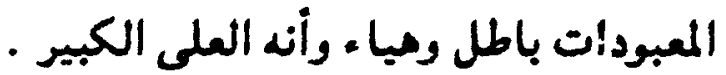

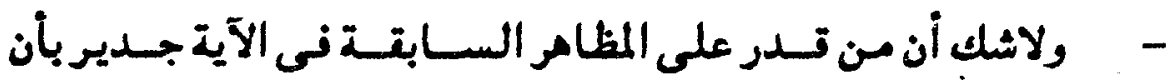

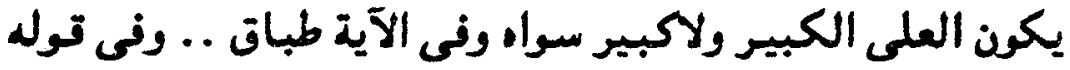

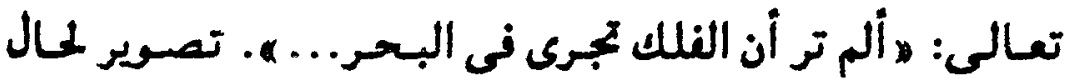

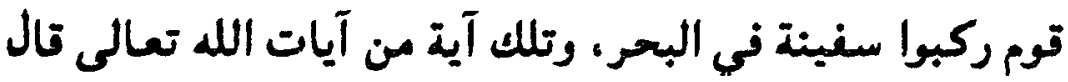

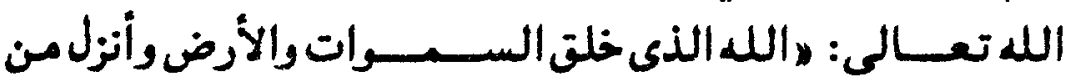

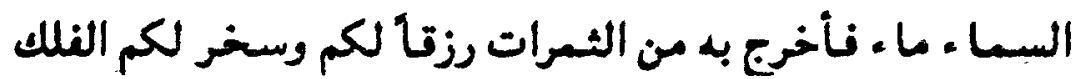
لتجرى في البحر بأمره وسخر لكم الأنهاري.

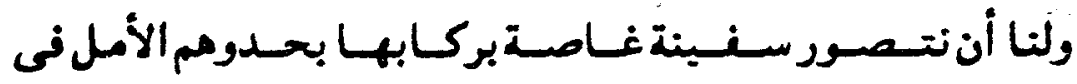

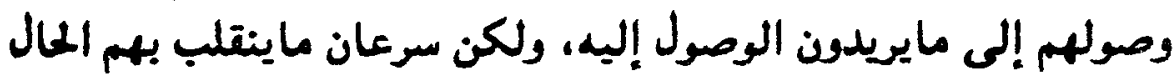

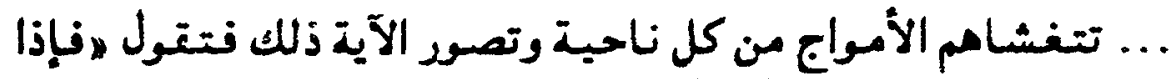

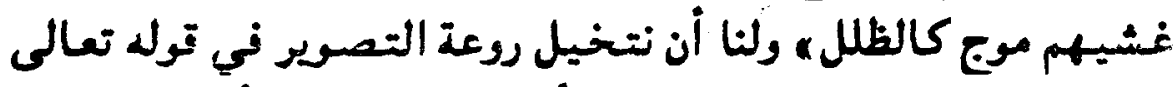

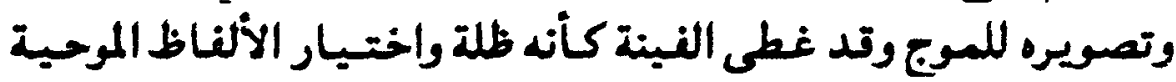
مثل لنظة - غشيهم - كالظلل . وكأن الله تعالى أراد ابتلاءمم فى سفرمم فأمر الماء ـ أن يضطرب

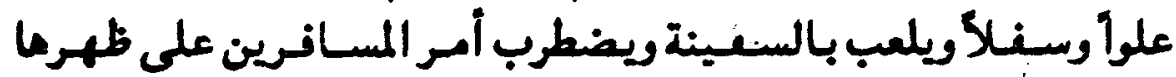


ويشرفون على الموت ولايكون أمامهـ إلا التفرع والليعاء ـ وإخلاص

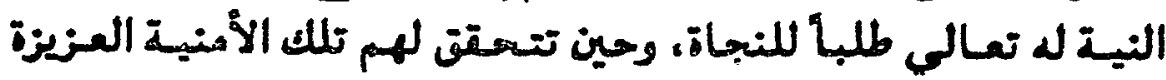

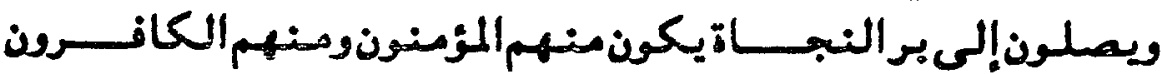

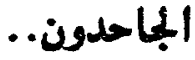

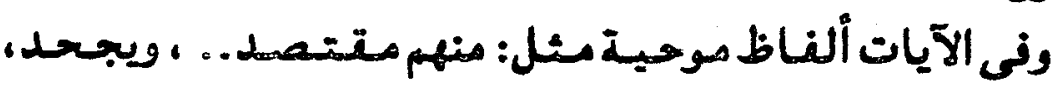

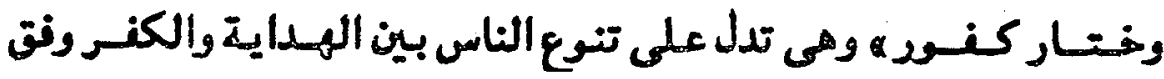
اختيار الإنسان لنفسه وهلاية الله تعالى له.

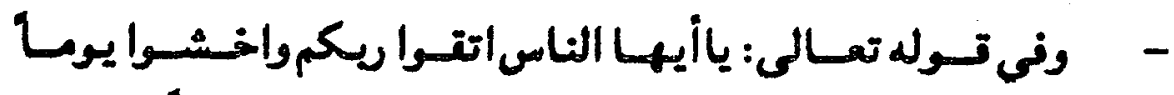

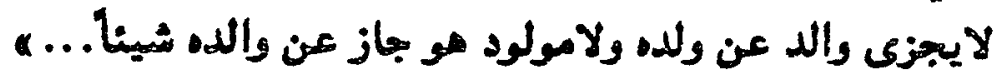

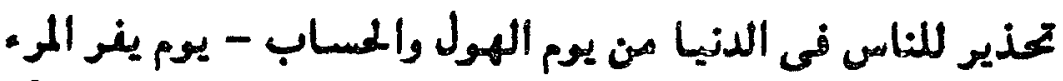

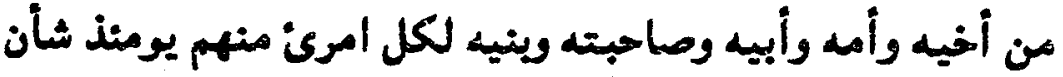

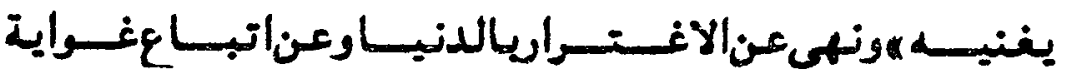
الشيطان.... ه.

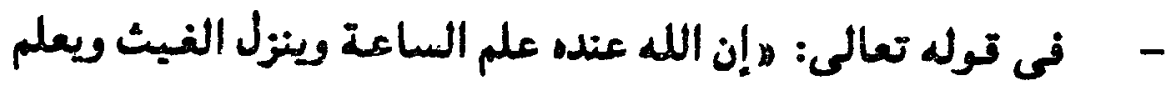

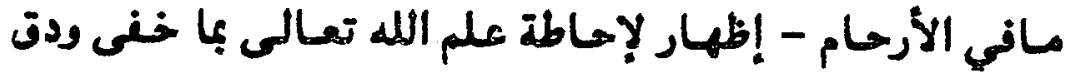

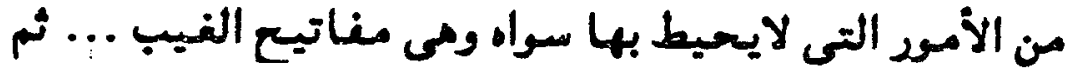

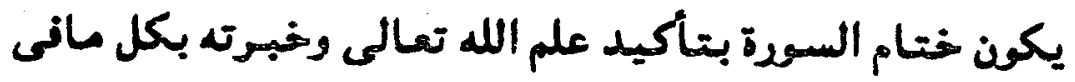
الكون من مخلوقات .

وماذال إلا لأن الكون وماحوى من كائنات مى من صنعة ومو

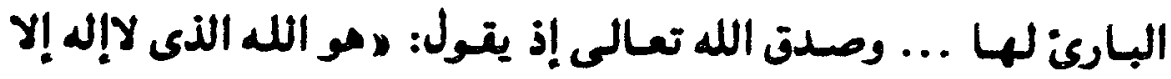

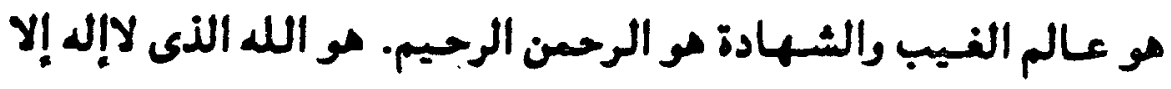

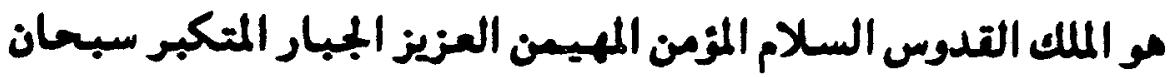

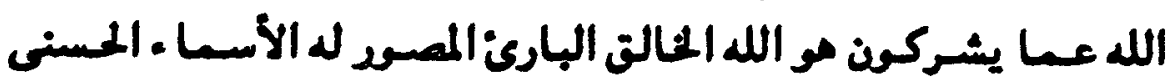

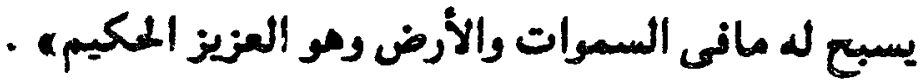




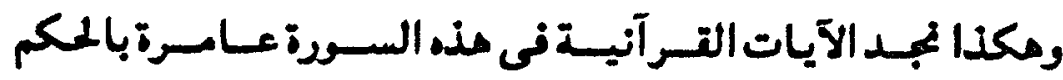
والعظات والعبر والتوجيهات .

هى فيض ثر ونود ساطع تتلألأ فى جوانبه أنوار الهداية ويحس

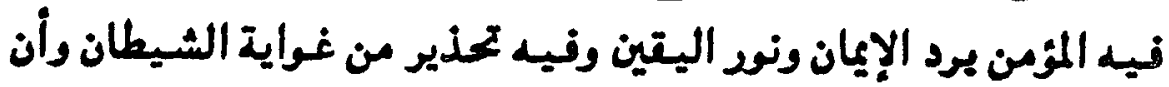

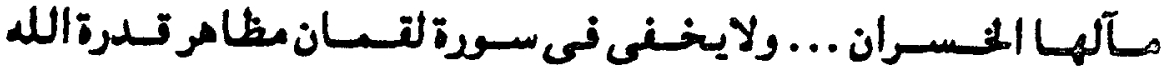

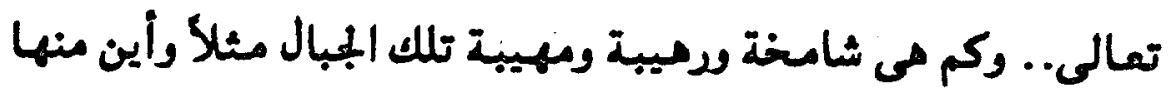

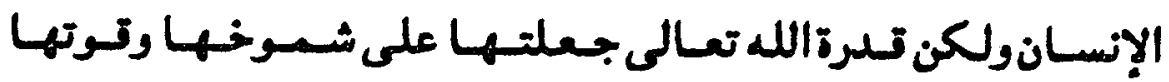
وجبروتها وتنوع أشكالها وارتناعها وكثرتها ... شيناً يلقى ..

ولكنها بالنسبة إلى تدرة القادر جل وعلا كائن .. ألقى في

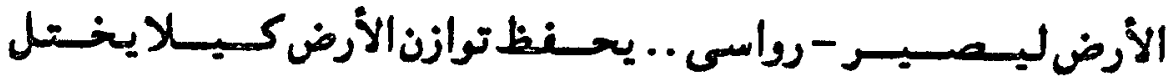
توازنها .. وتهتز بمن عليها .

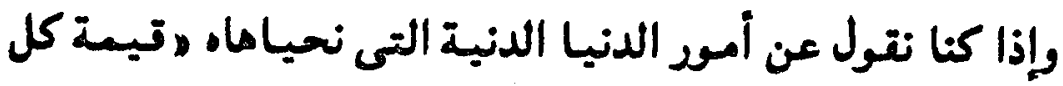

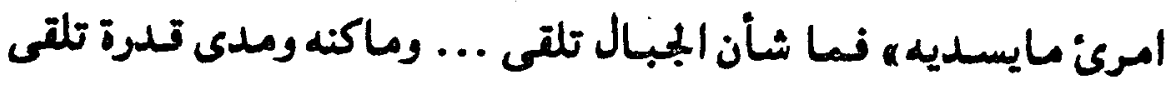

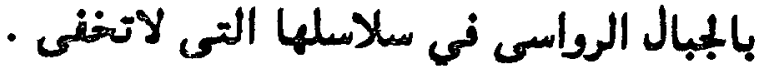

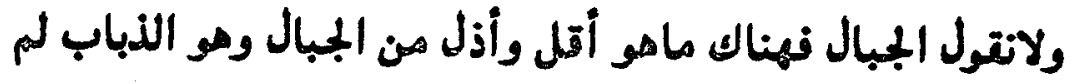

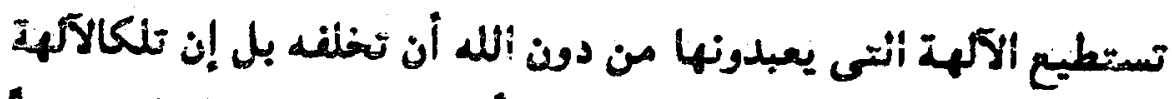

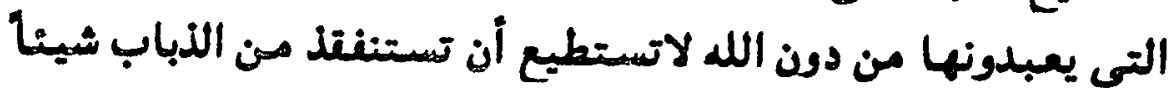

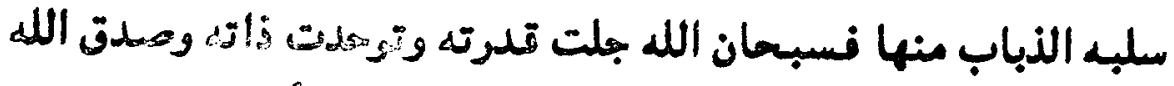

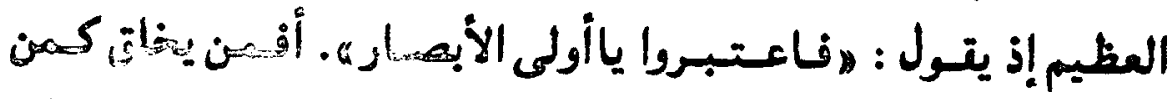

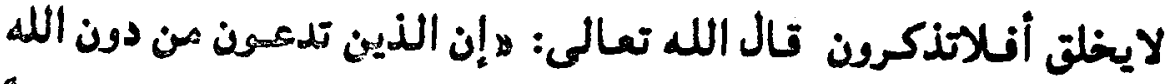

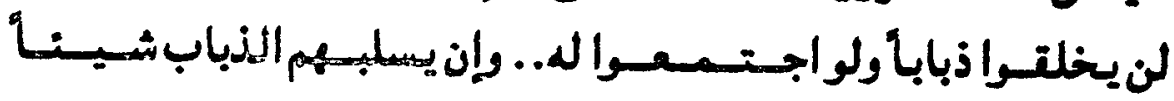

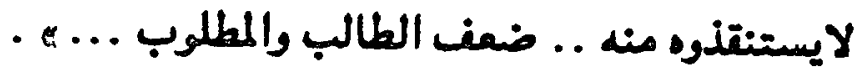

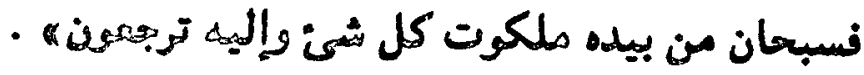




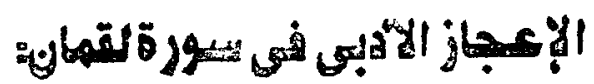

فهى سهرة لتمان إعجاز ادبه هما يععر الله تعالم هعرفته لنا كيشتمل على مايلى :

$$
1 \text { - إعباز فس الأسلوب كبلاغنة فى الأداء : }
$$

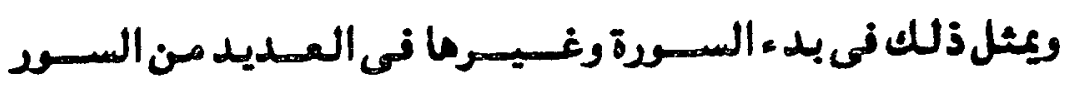

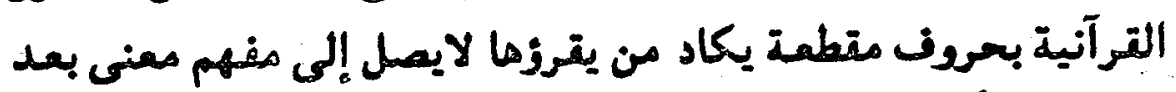

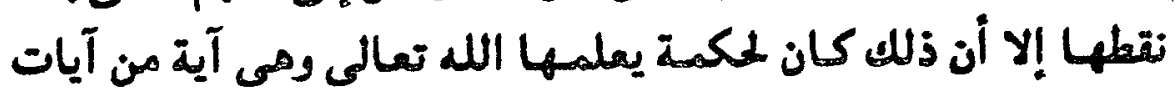

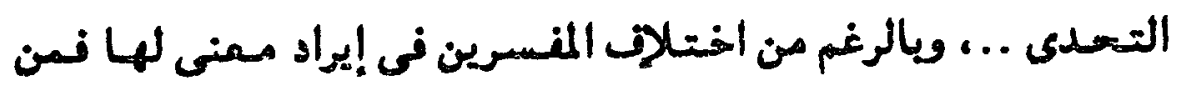

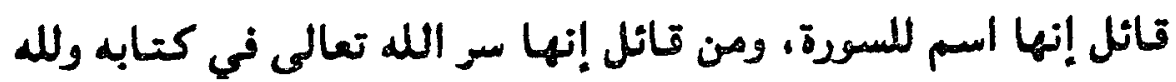

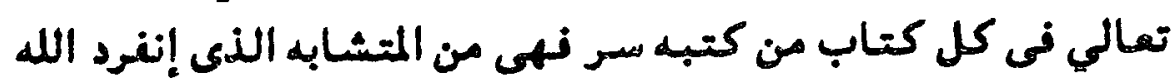

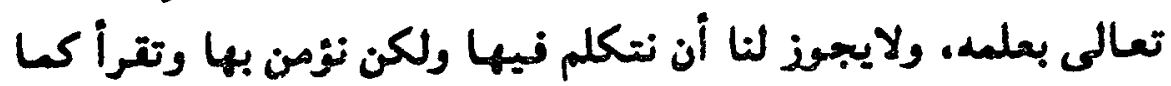
جايت . تعالع.

وتيل إن الله تعالى أنزل مذا الترآن فاستأثر منه بعلم ماشاء

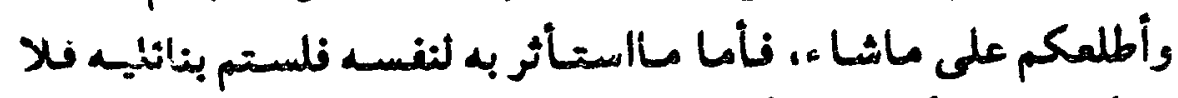

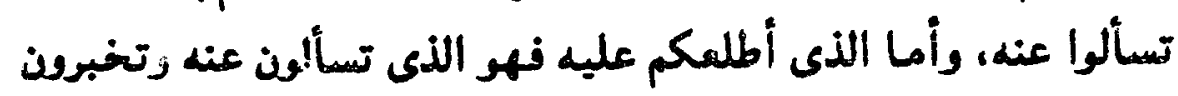

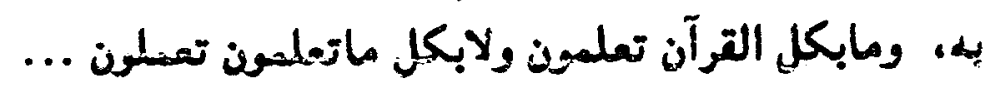
ومن الإعجاز فى الأسلوب والبلاغنة فى الأداء أيضاً كان تلمان تنزيل

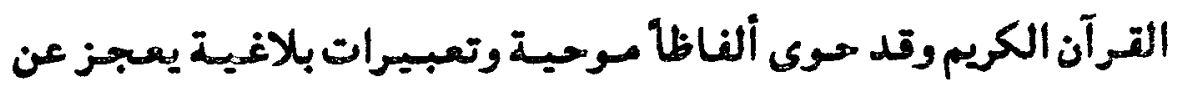

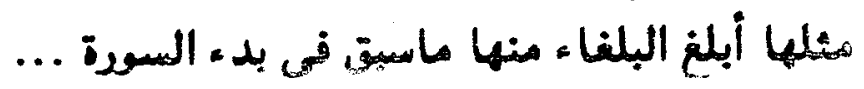

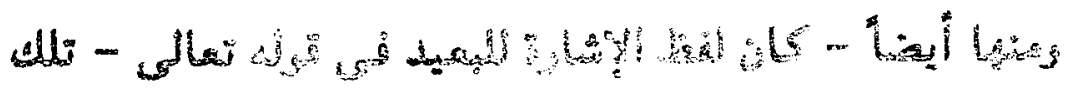

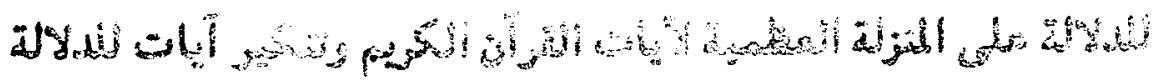

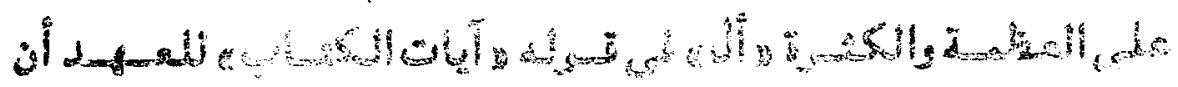




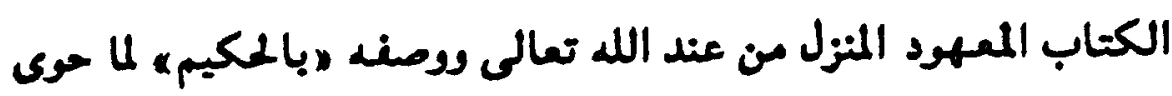

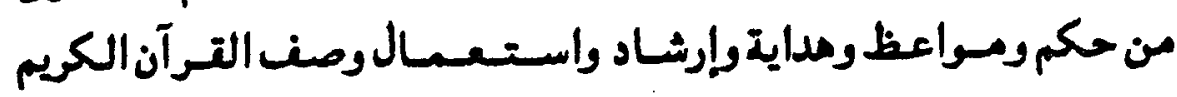

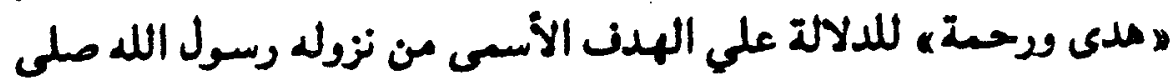

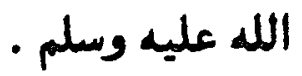

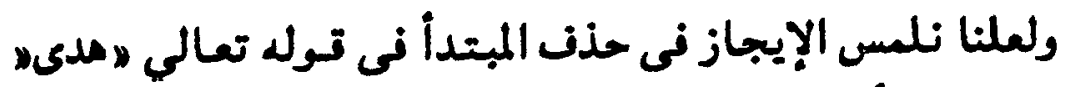

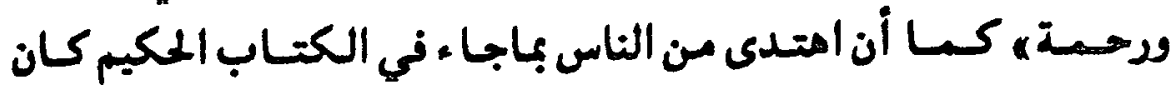

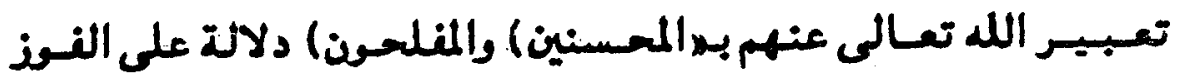

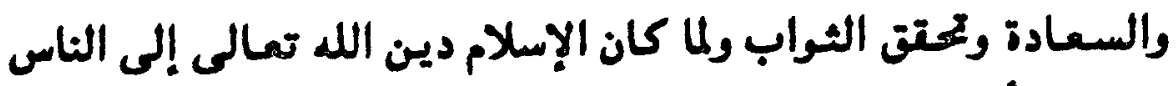

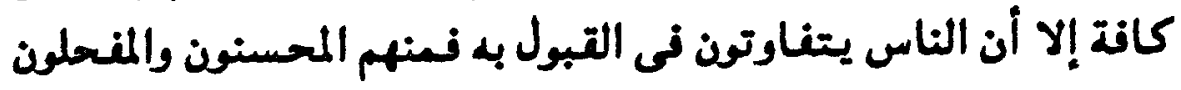
الذين وردت صناته فى الآيات السابقة .

كسا أن منهم من مو يعكس ذلله ومو يغضل الباطل على الحتق

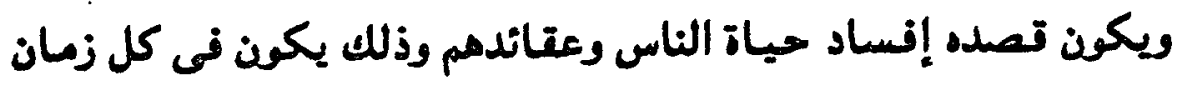

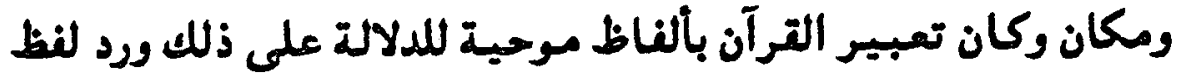
الاشتراء . ومان ونان ولهو المديث - ليضل - وسبيل الله - بغير علم ومزوا ويكون

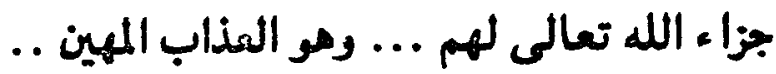

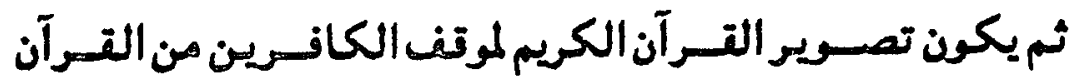

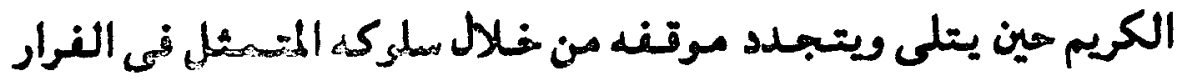

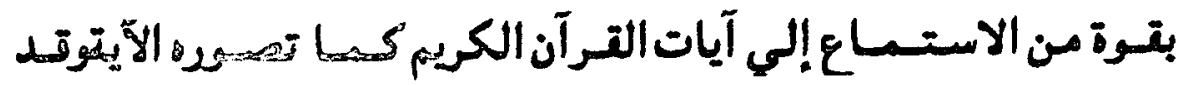

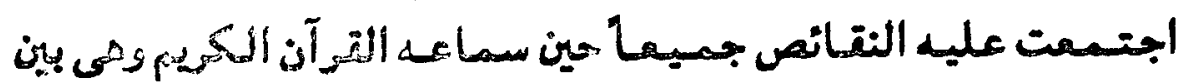

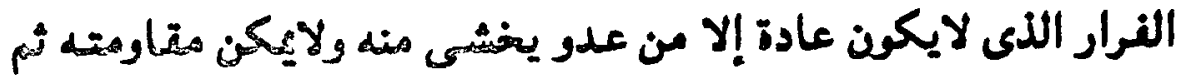

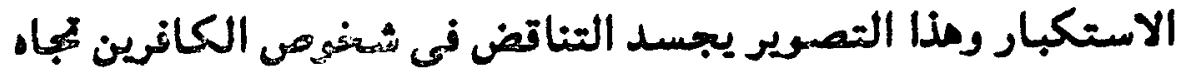

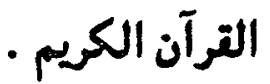


ثم تتابع الآيات تصوير حال بعض الكافرين حيث يكونون في

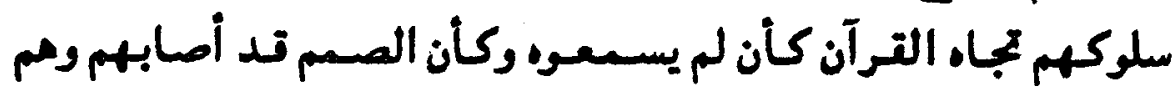

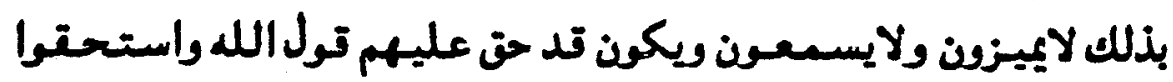

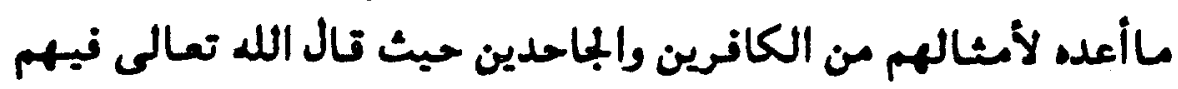

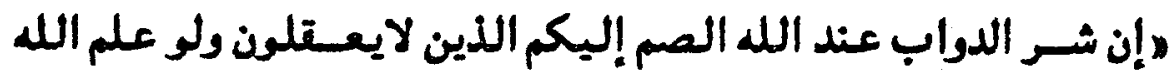

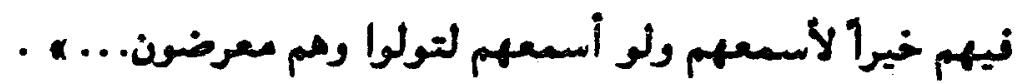

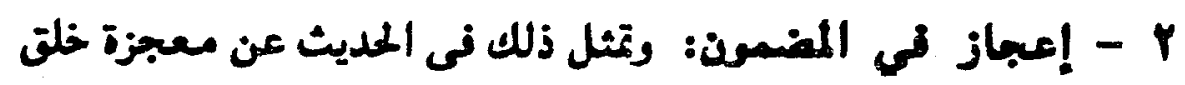

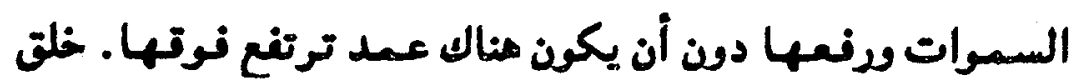

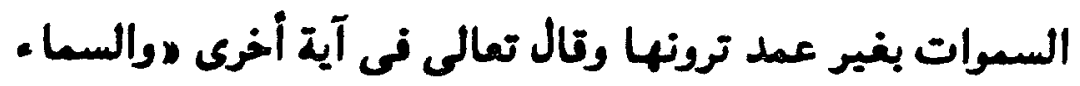

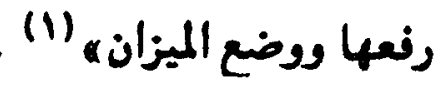

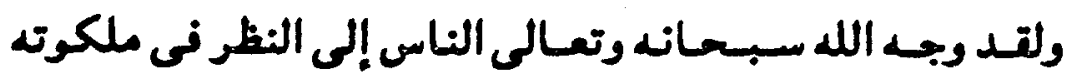

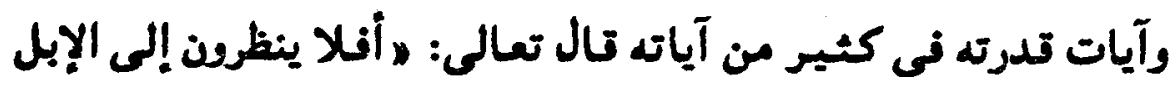

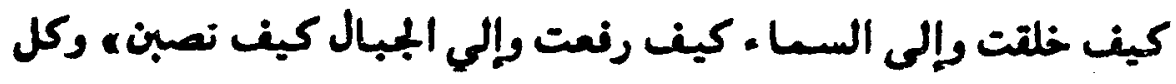

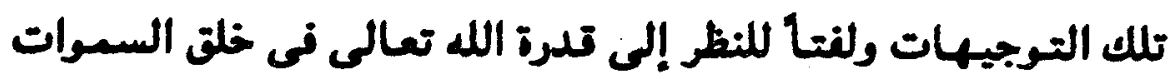

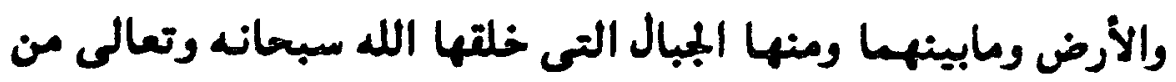

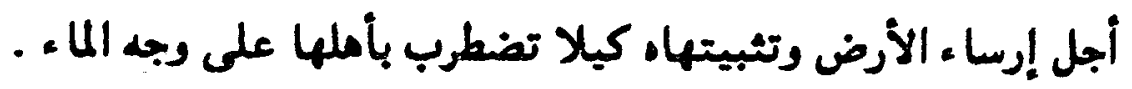

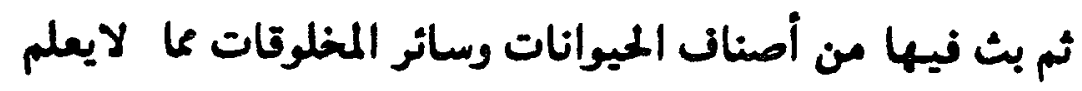

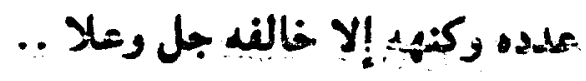

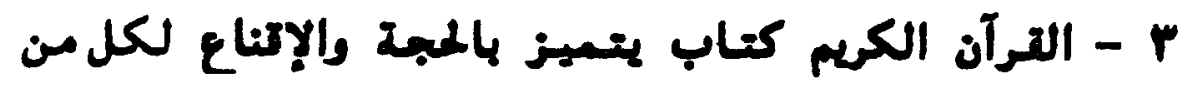

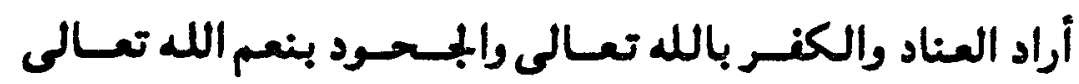
بالرغم من الآيات الظاهرة والدلاتل الينة على قدرة الله تعالى والى وإرادته . 
وقد جايت آيات سودة لتعان الكافرين با يغعمهم ويلحق المزىى

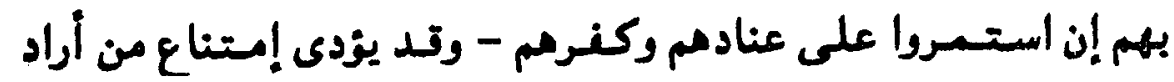

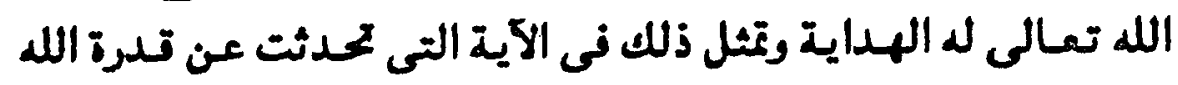

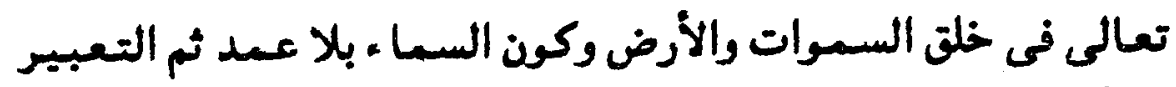

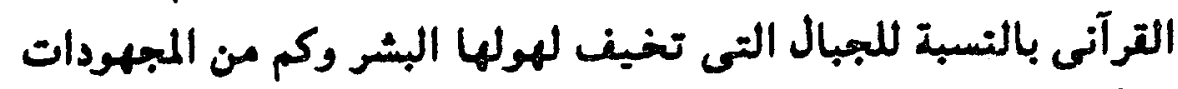

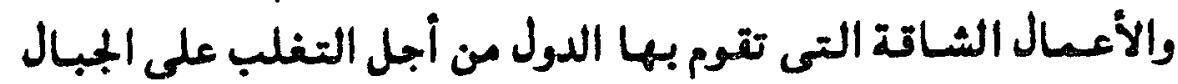
وتذليلها والاستفادة منها . إلا أنها بالنسبة للنالق جل وعلا كالِ كان تعبير القرآن الكريم قوله

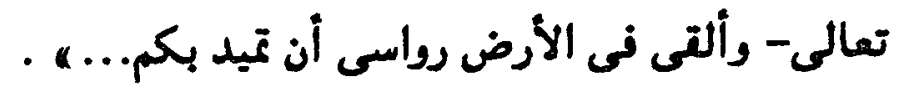

وإذا كانت الدول والهيئات تتحمل الشات من أجل التفلب على

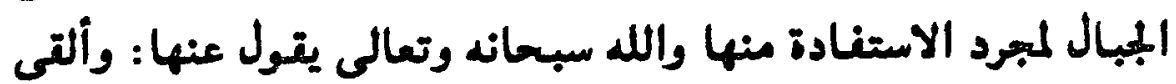

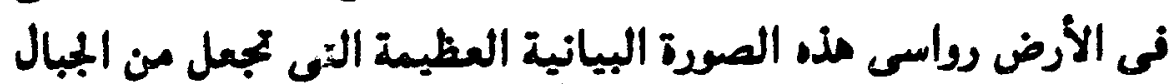

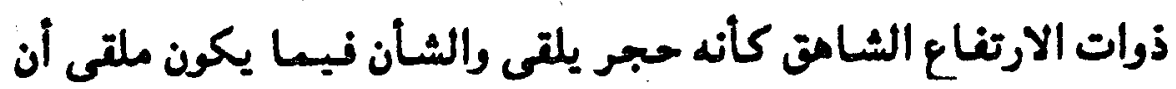

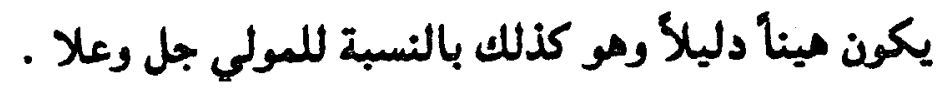

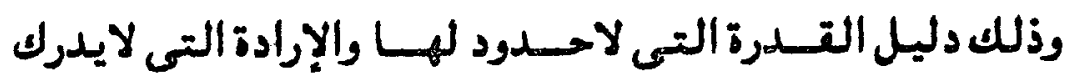

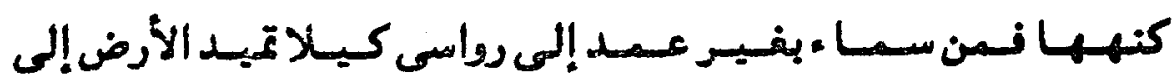

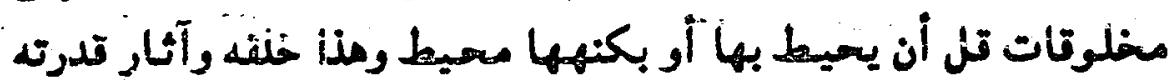

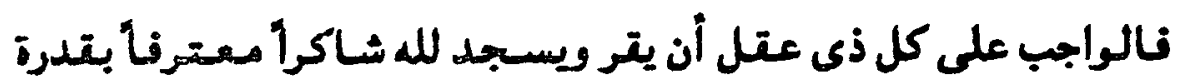

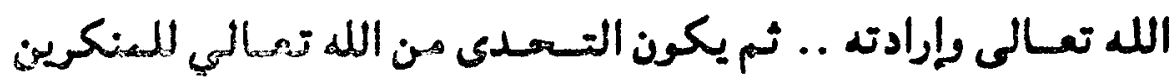

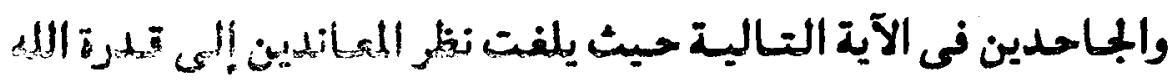

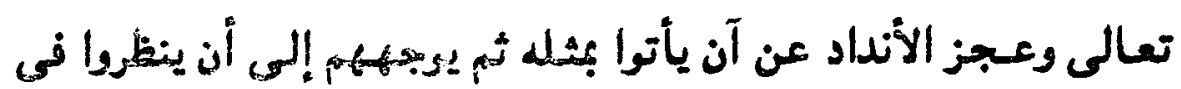

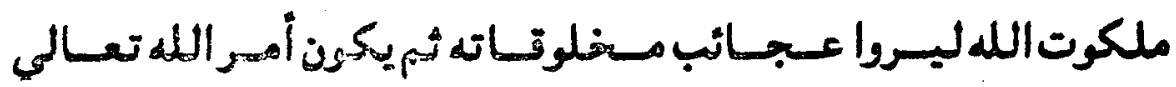

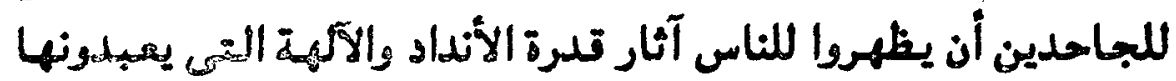
من دون الله إن كان صادقين . 
وذلل أُملوب عظيم فى المحاجـة والبيان تمثل فى إظلهار آيات

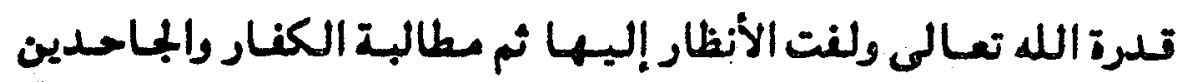

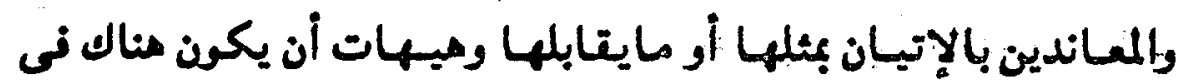

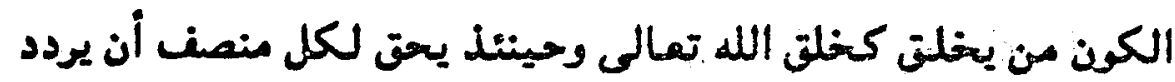

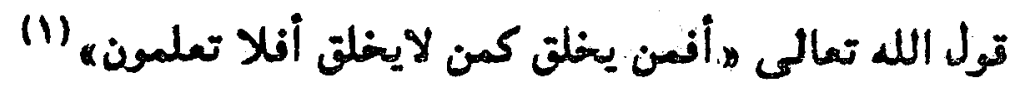

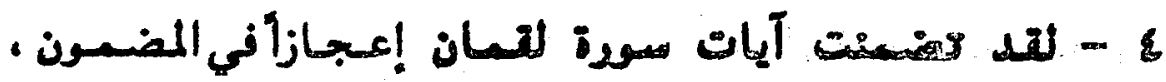

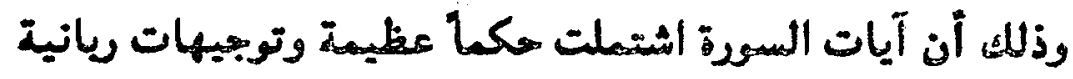

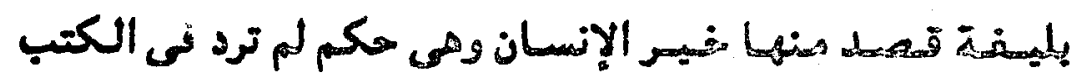

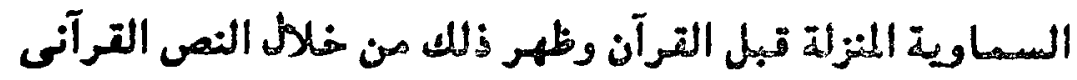

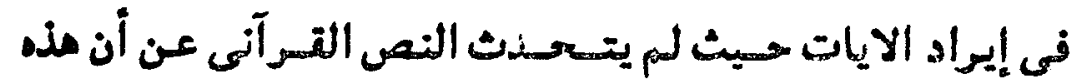

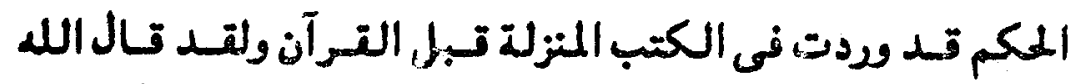

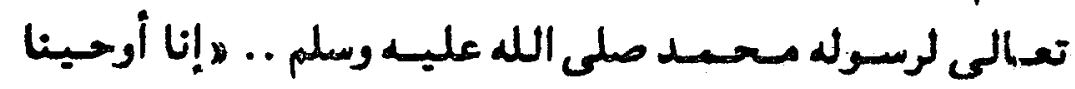

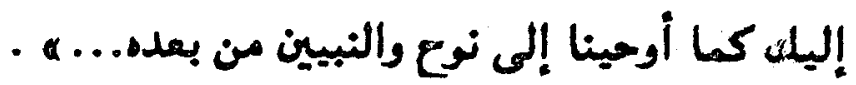

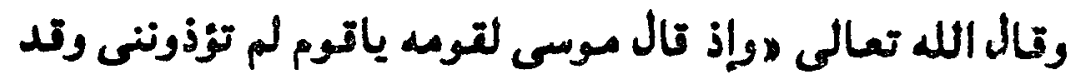

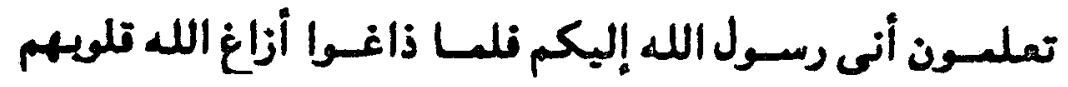

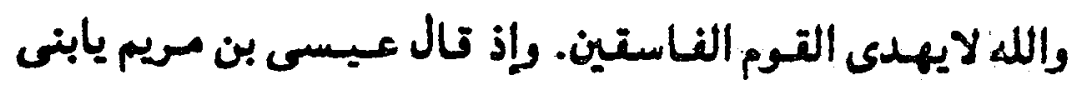

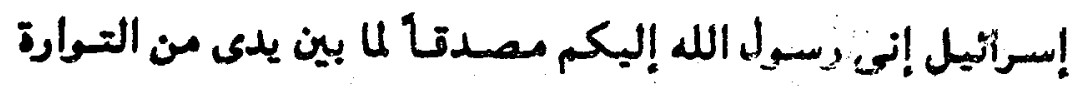

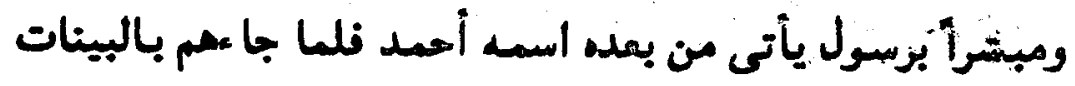

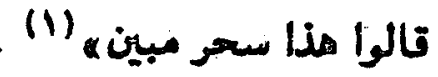

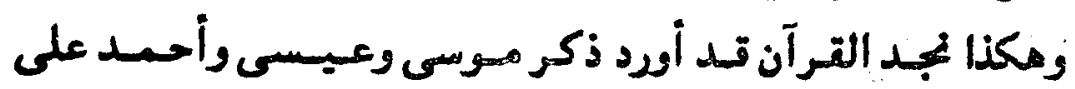

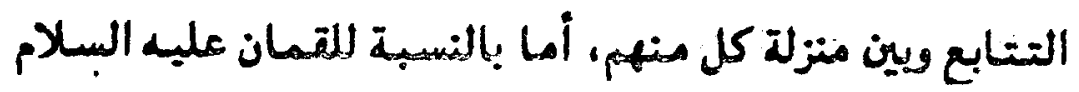

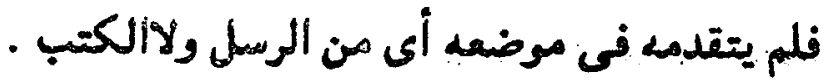




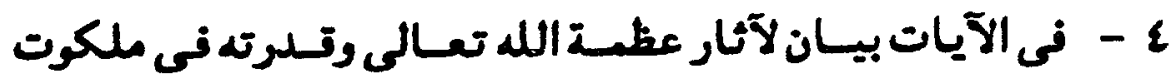

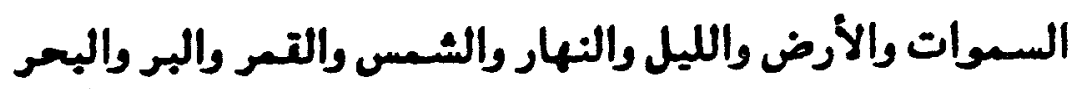

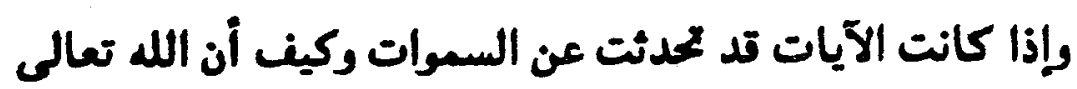

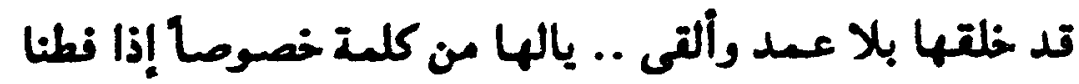

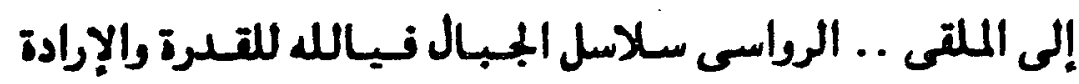

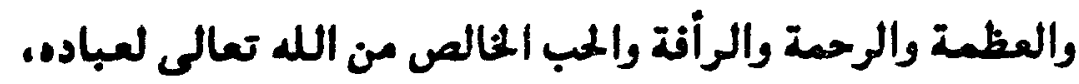

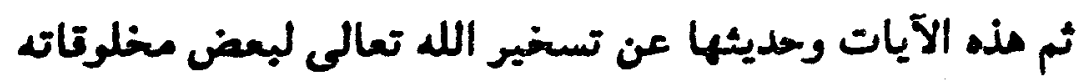

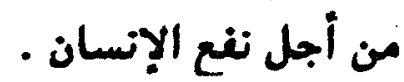

فتد سخر الله تعـالى الأرض وذللها للإتسان.. مو الذى جعل

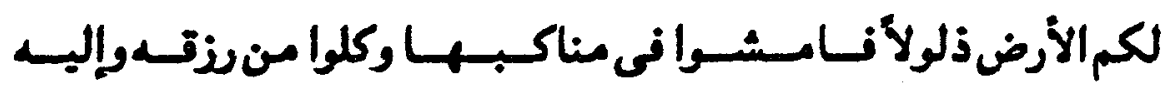
النشور " (1) وكذلك كان من مطامر قدرة الله تعالى وعظمته تسخير

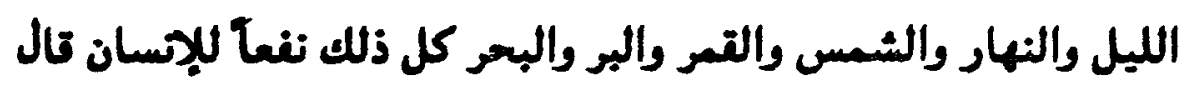

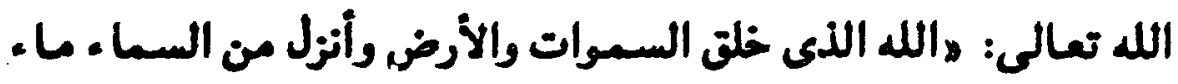

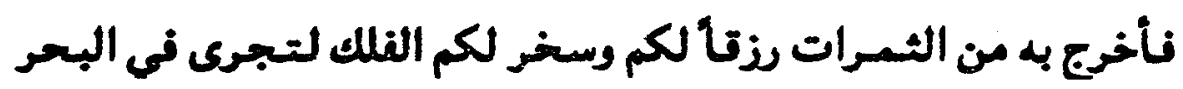

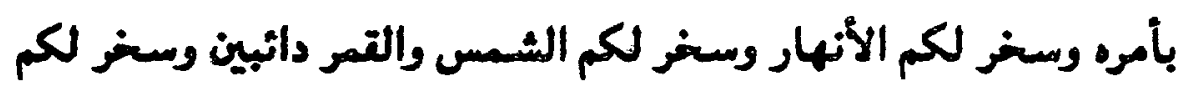

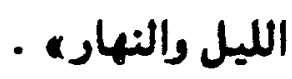

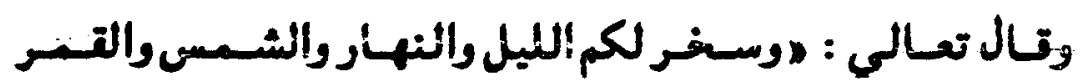

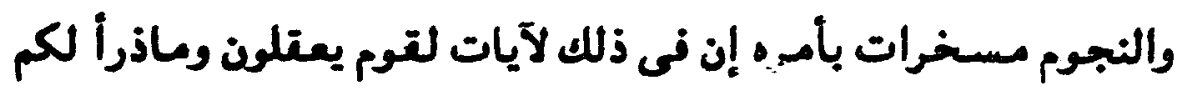

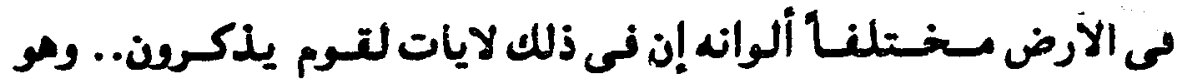

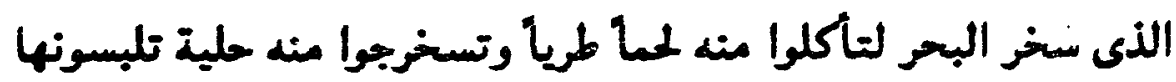
وترى الفلك مواخر فيه ولتبتغرا من فضلد ولعلكم تشكرون: 


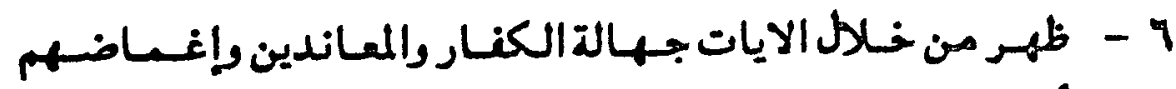

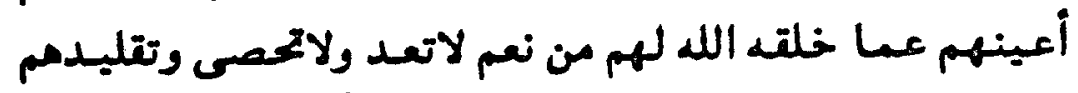

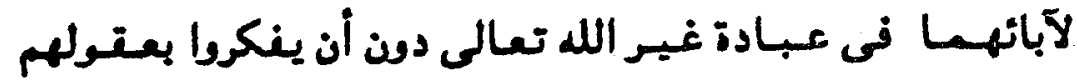

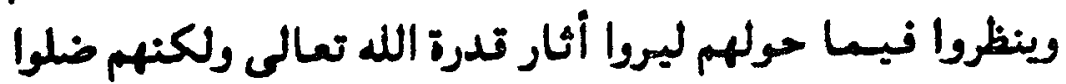

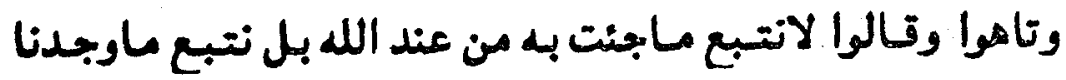

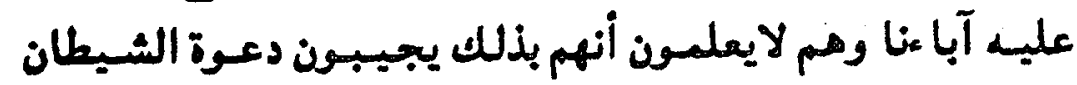

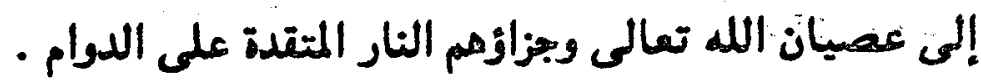

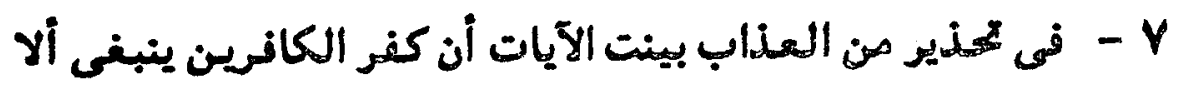

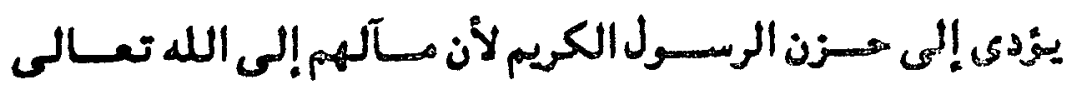

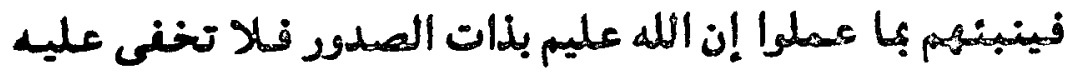

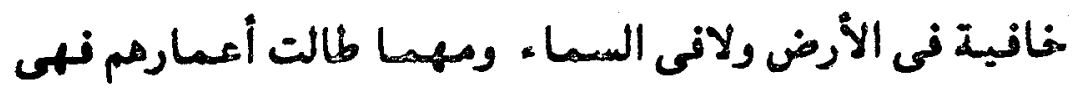

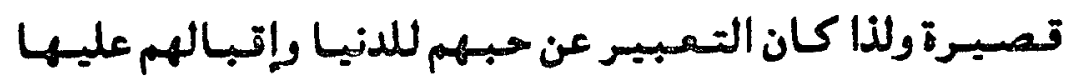

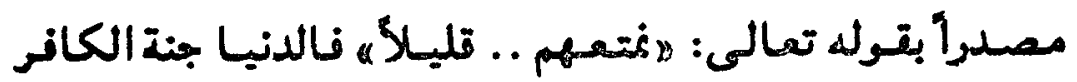

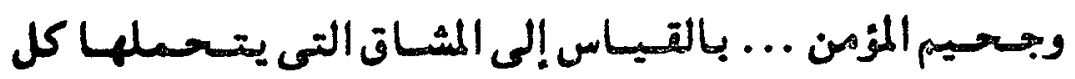
منهـا فيها وصبر علي أذاها وغواية الشيطلان وطاعة الرحمن.

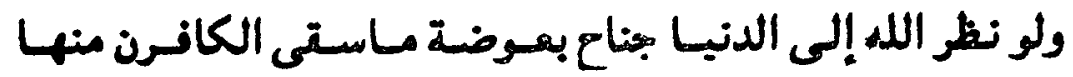

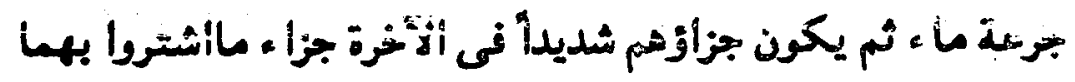
متع المياة النانية .

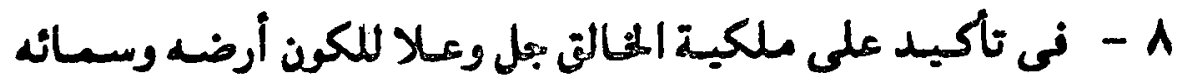

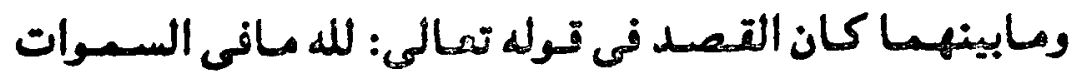

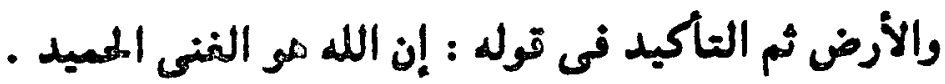

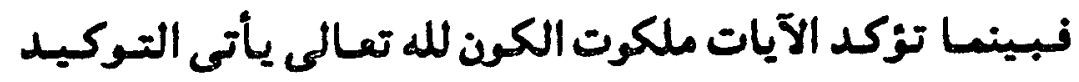

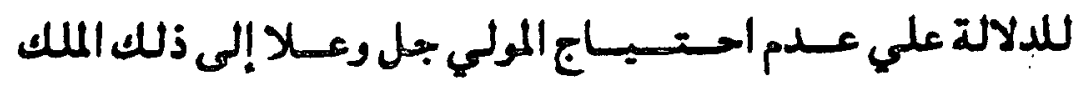


والملكوت ومذا مو الفارق بين ملكية الله تعالى للكون وملكية

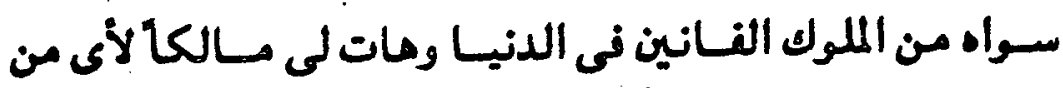

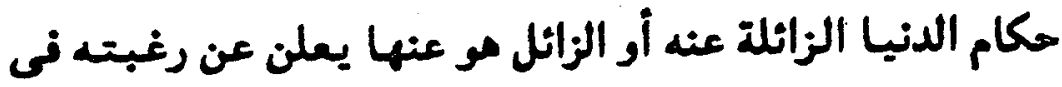

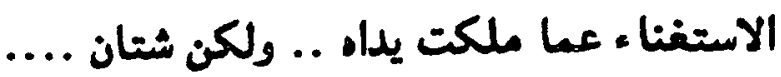

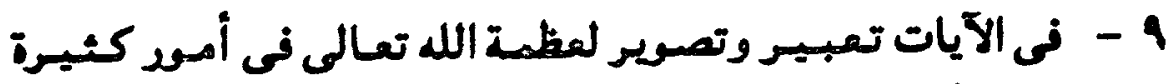

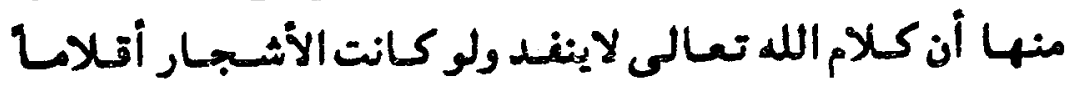

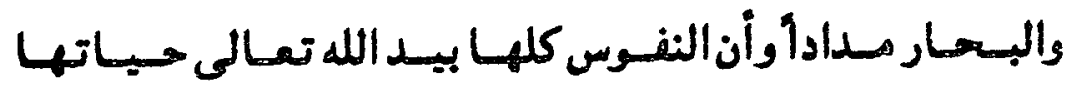

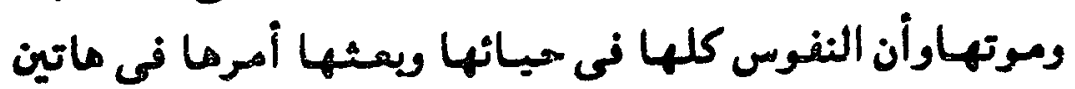
اللحطتين كأنها نفس واحدة الفوس كليا في

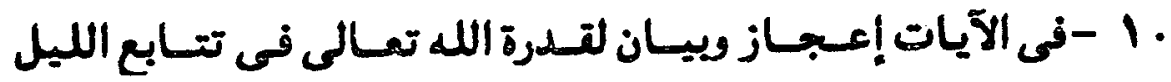

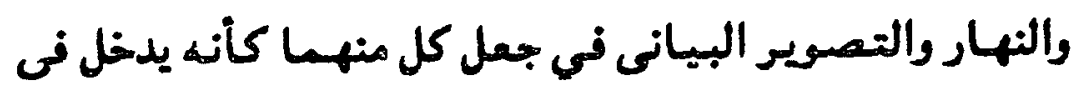
الآخر

11 - تصوير حياة الناس ومم آمنوذ فإذا أصابهم المططر فروا إلى الله

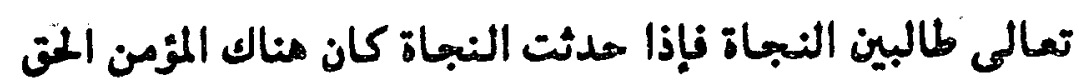
والمعاند الجاحد .

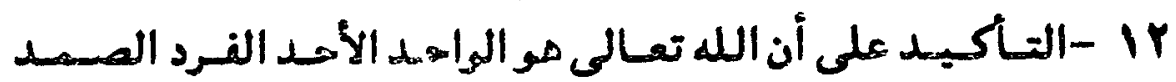

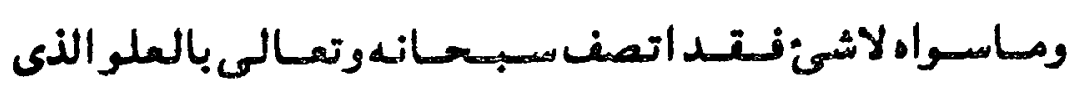

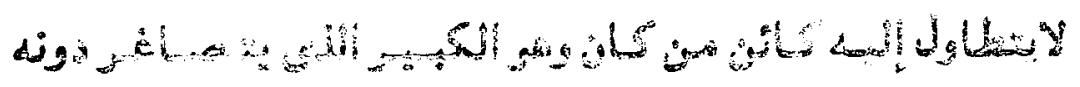
. as ast

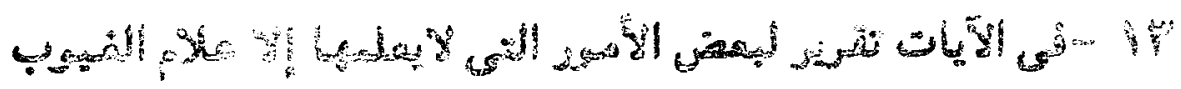

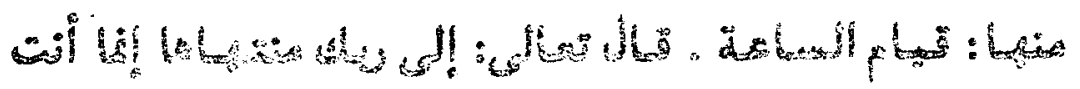




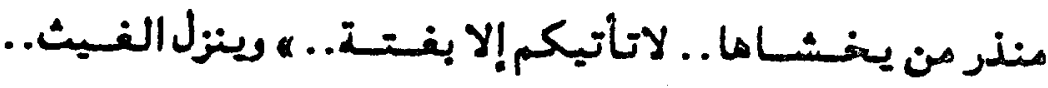

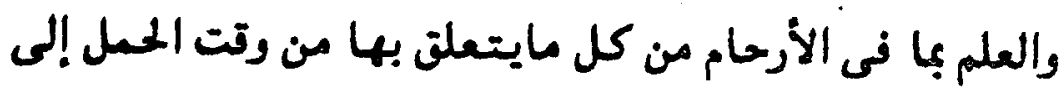

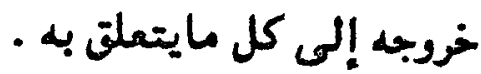

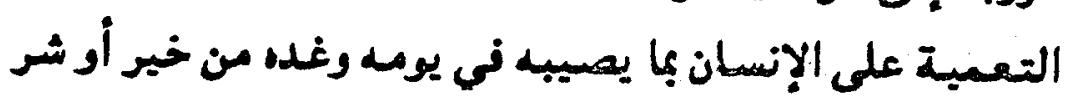

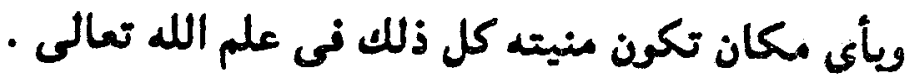

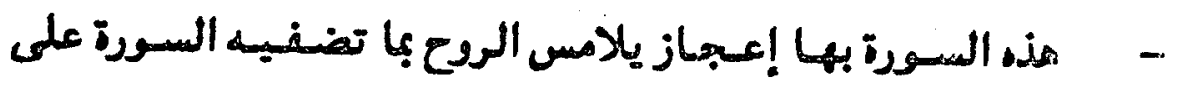

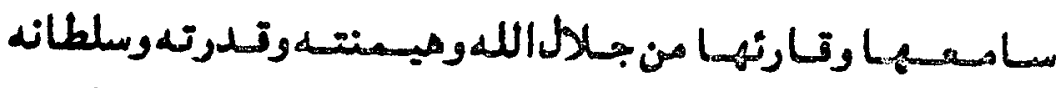

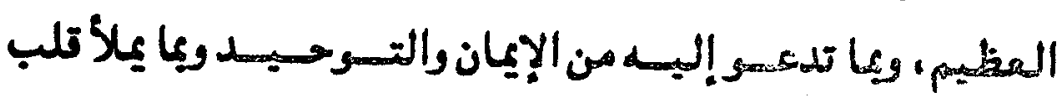

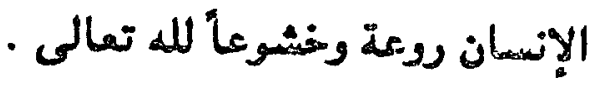

والله أسال أن يونتنا ويهدينا سواء السبيل ،

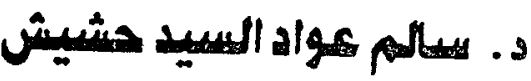




\section{$8 \rightarrow \operatorname{lig} g$ gal}

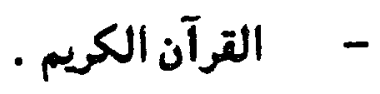

- - العـدة فى محساسن الشعر وآدابه - ابن رشيق القيسروانى دار

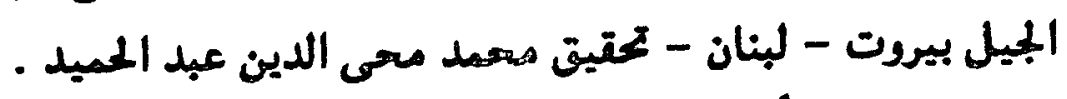

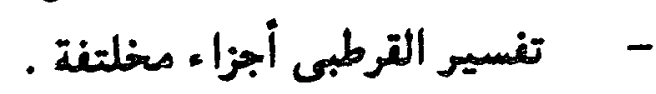

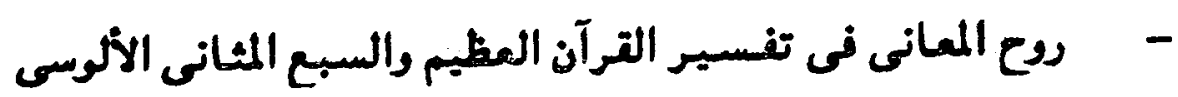

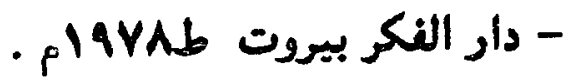

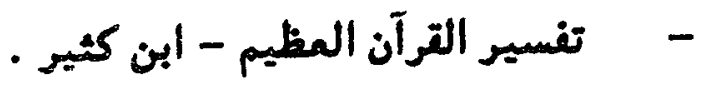

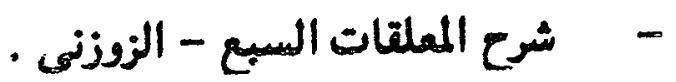

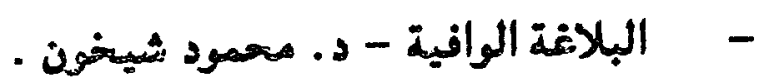

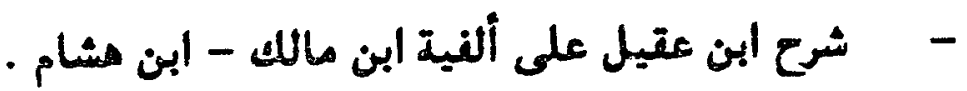

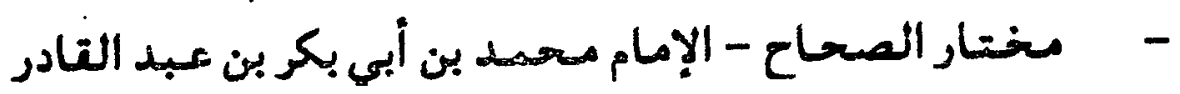
-

- 
(ليس) فى العربية بيسن

الفعلية والحرفية

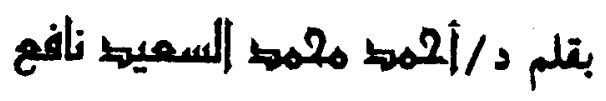


$\ldots \ldots+\ldots \ldots \ldots \ldots+\ldots$

1
$-\quad 1$ 


\section{بعم الله إلرحمن إلرحيير}

الحمد لله والصلام والسلام علي أشرث من نطق بالضـاد سيدنا

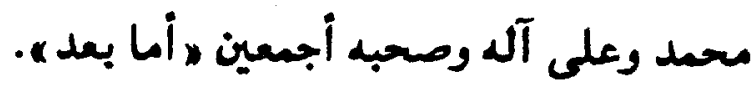

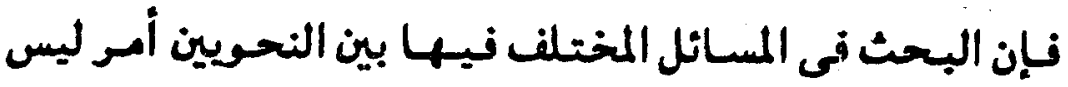

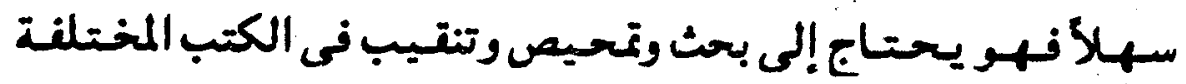

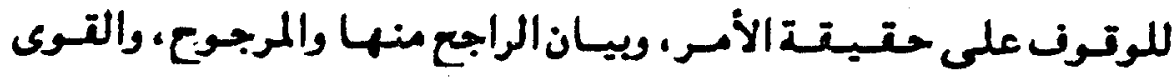

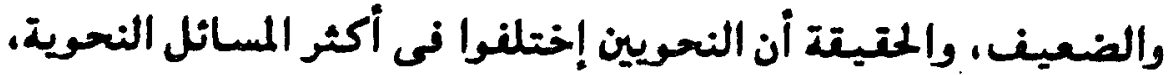

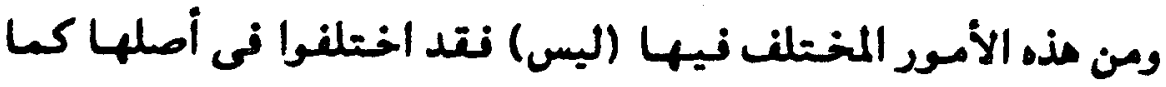

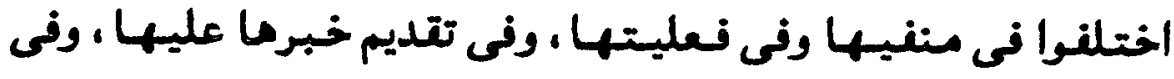

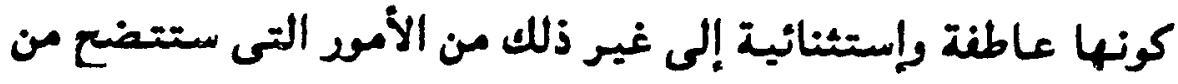
خلال مذا البحث فنقول ويالله التوفيق :

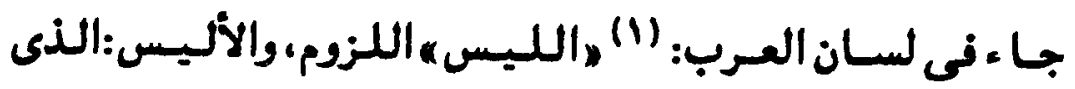

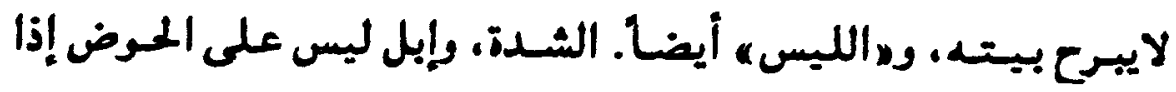
تامت عليه لم تبرحه، .

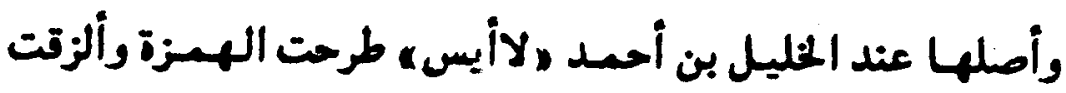

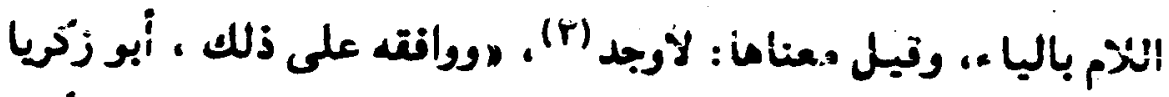

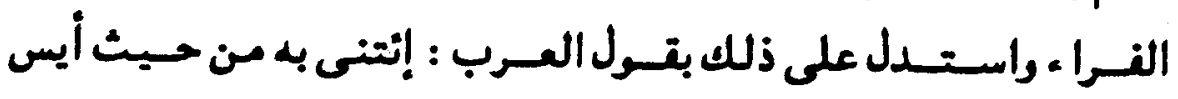
وليس، أى من حيث مو ولاموه .

(1) اللسان فى مادة (ليس) السابق

مغنى اللبب لابن مشام PrV وانظراللسان (مادة ليس). 


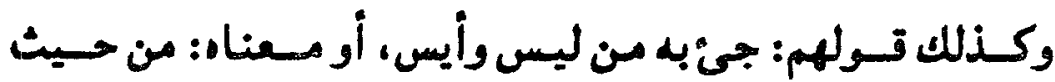

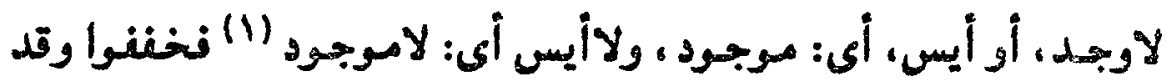

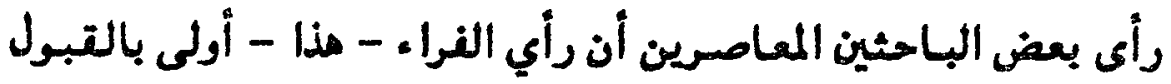

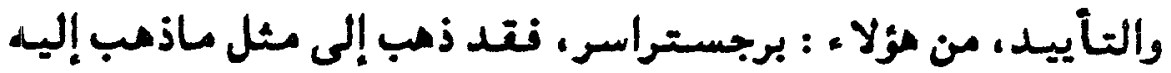

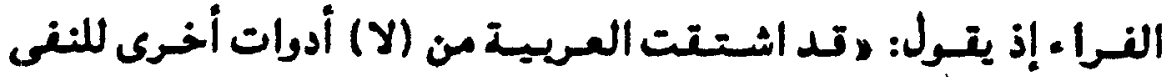
لاتوجد فى اللغات السامبة إلا (ليس) فيتابلها في الآرامية (Lait)

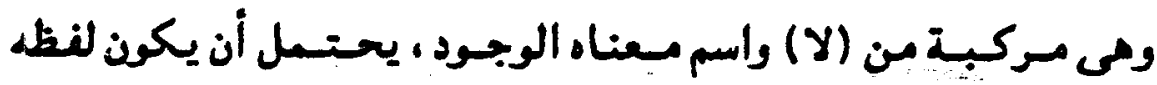

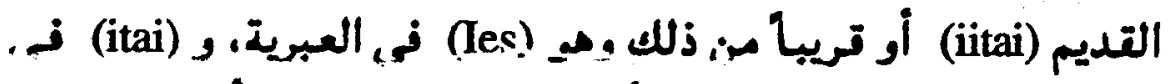

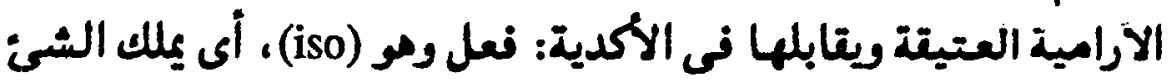

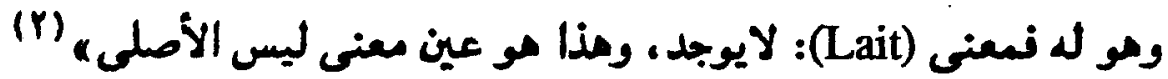

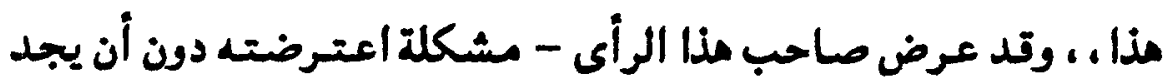

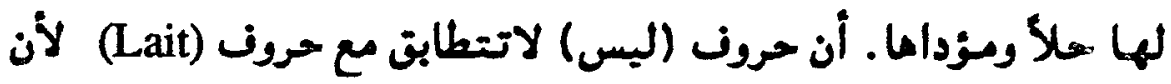

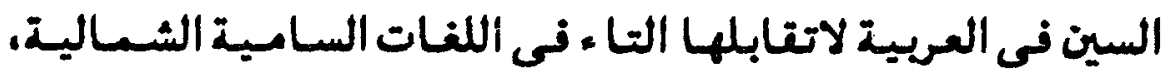

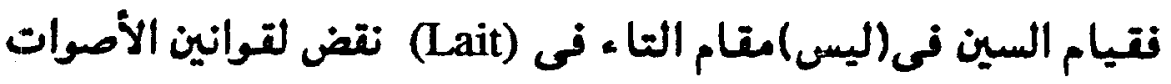

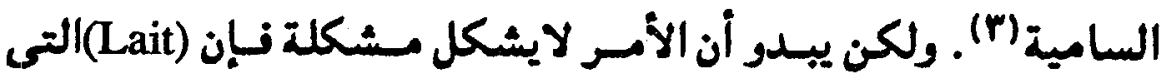
تحدث عنها على أنها تقابل (ليس) العريبة. لها من الأدوات العريية

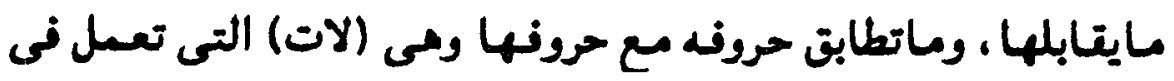

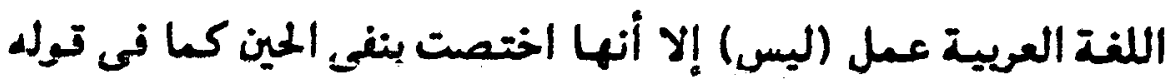

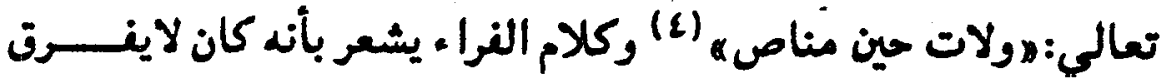

تاج العروس reL/L مادة (ليس) -

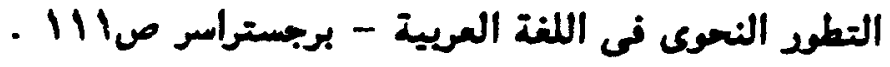

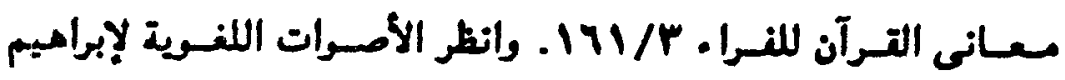


بينها وبين (ليس) من حيث دلالة كل منهـا على نني الوجود. فإنه

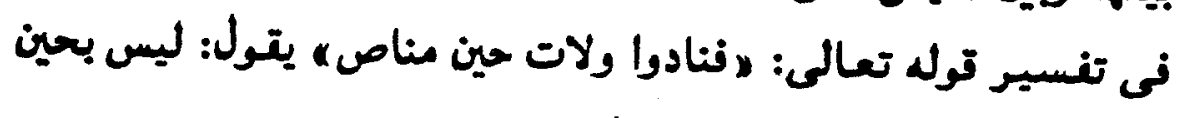

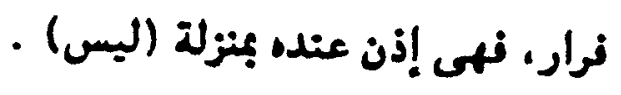

ولعل الغراء كان يرى أن التا ، نيها أصلبة، ولبست للتأنيث،

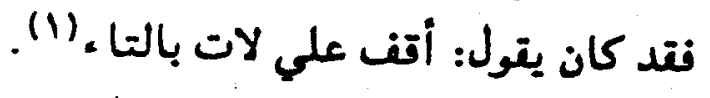

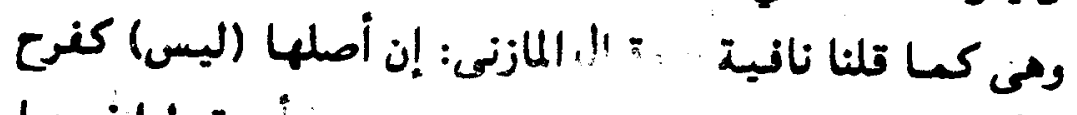

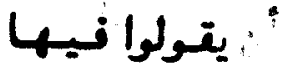
ولكنها أسكنت، ولم ينا:

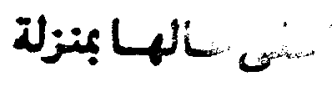

وقـال ابن سيـده: ، ليس كلعة نفي، ومى فعل ماض، وأصلها

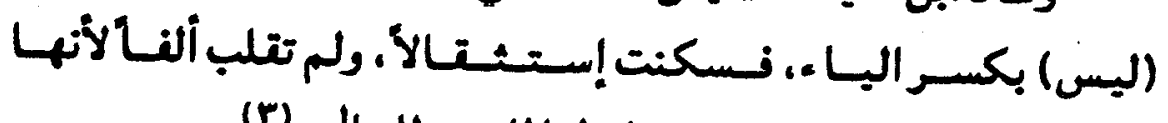

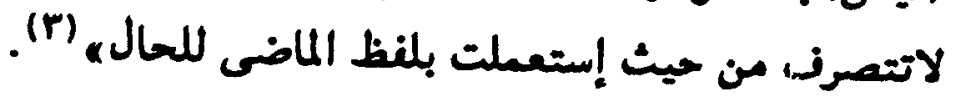

وهو - فـبــا أظن - تـاس (ليس) على نعم نـإن من اللفـات

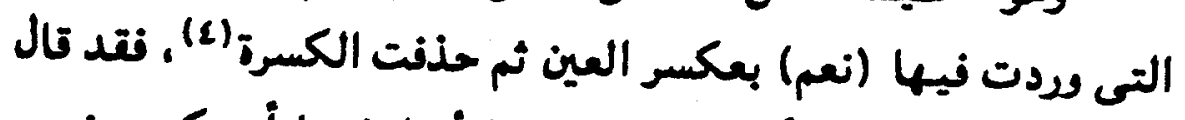

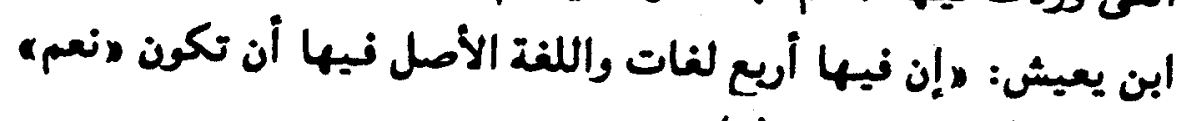
على وزن (حمد) وعلمه" (0).

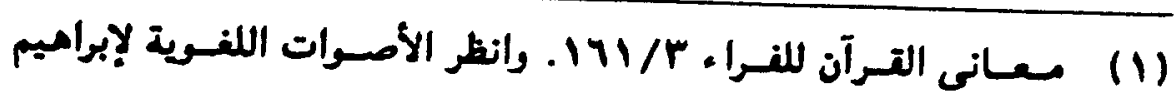

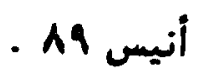

rOA/ المنصف لاين بنى على شرع التصريف للمازنى (r)

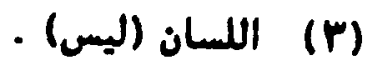

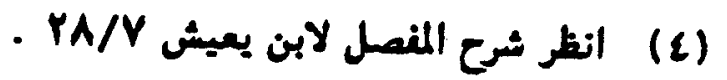

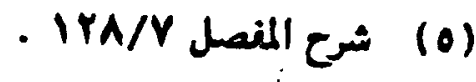


وعلى مذا - ابن هشام - نتد تـال: همى فعل لايتصرف وزنه

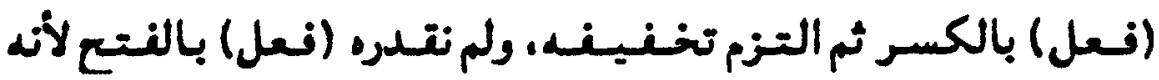

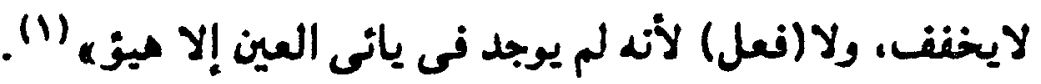

:

(ليس) كلفة جامدة غير مشتتة، وشبهبا أبو علي النارسى بد(ليت) إذ يتولك لاولايكون (ليس) مشتأ لمابهة الحرون، كما أن

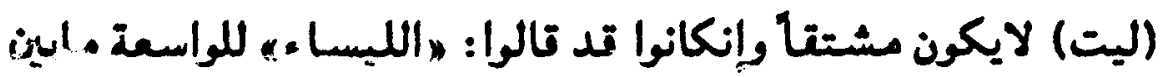

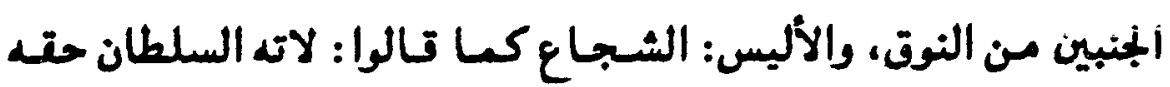

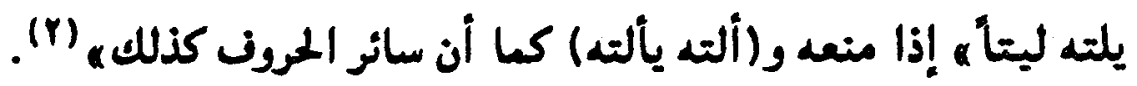

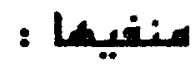

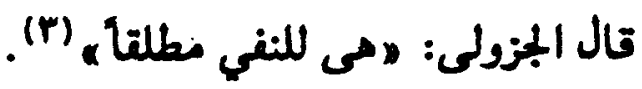

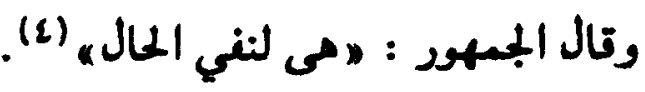

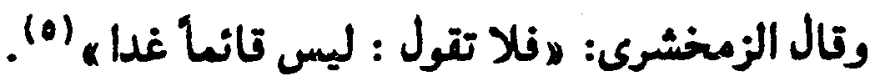

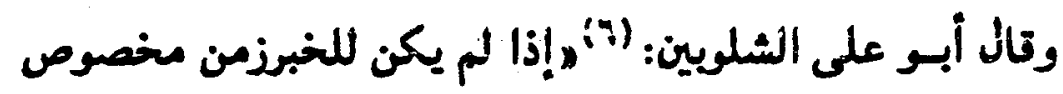

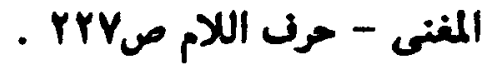

- raI المسائل الحلبيات

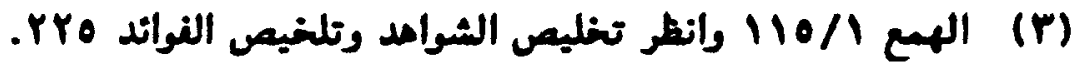

- (ع) (2)

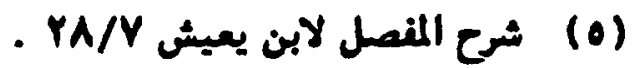

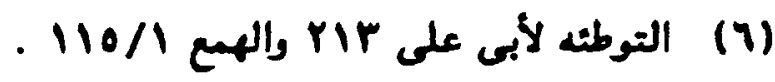




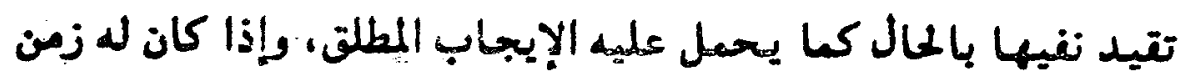

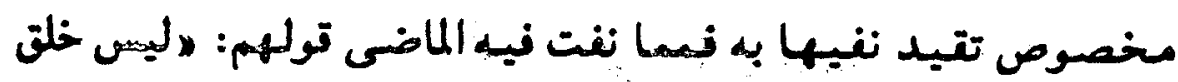

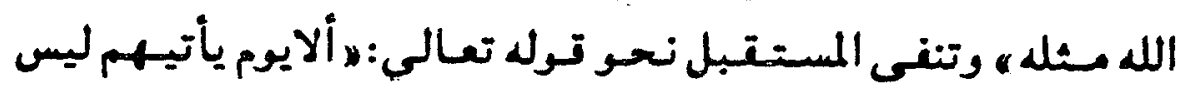

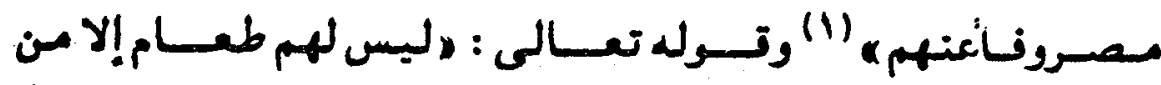

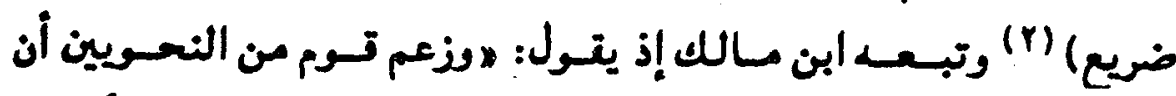

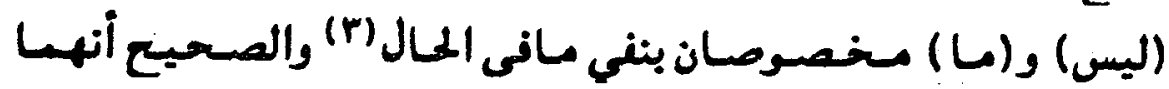

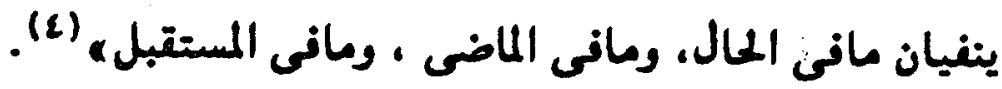

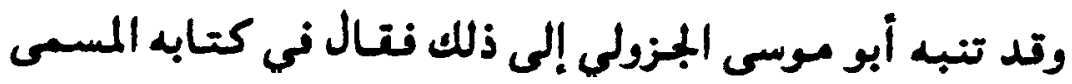

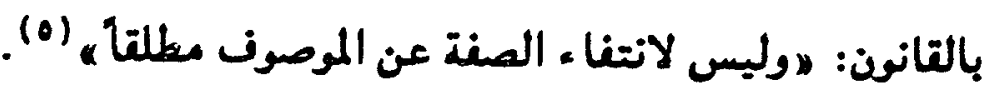

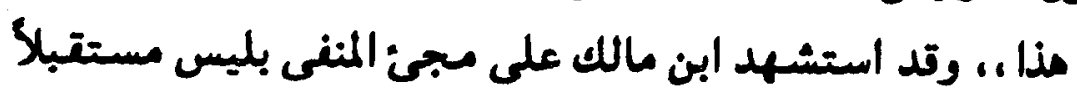
ولبس بكمن الدمر مادام علهل (7)

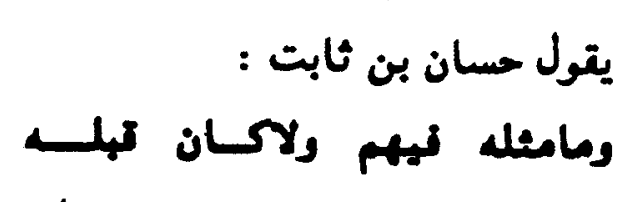


ومثلد تول الآخر:

إنى على العهد لست أنعتهـ

ماأنضر فى رأس نعلة سعف (I)

إنتلانه النحويين نيما بين النعلية الحرنية واللاسمية ؛

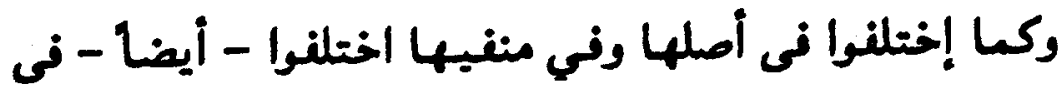

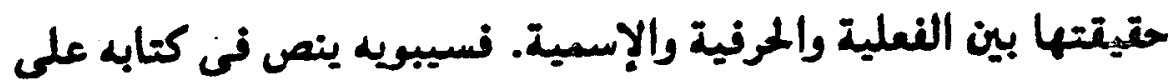

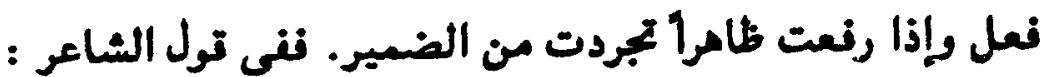

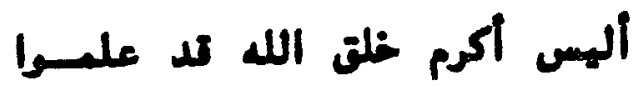

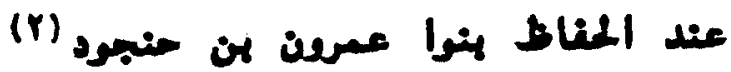

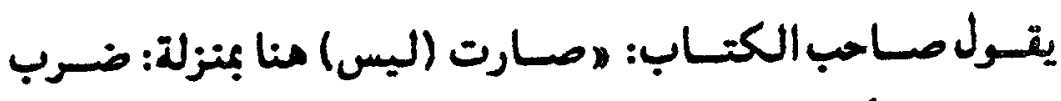

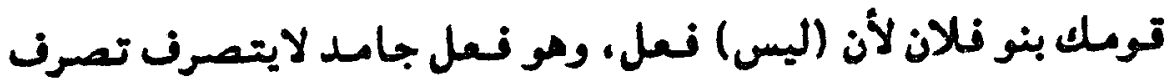

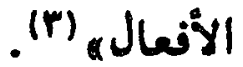

ويقول - فى موطن آخر - : : وليس فعل وهى للنفى (ع)".

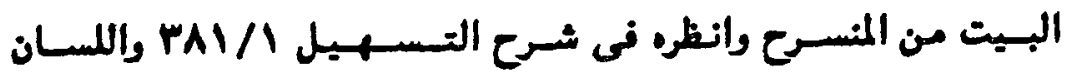

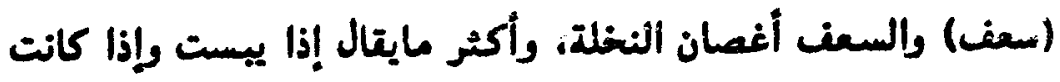

رطبه فهى الشطبة واحدتها سعنه .

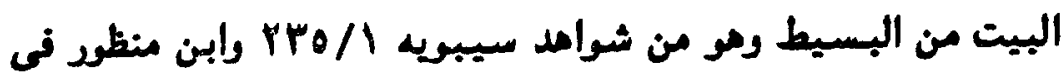

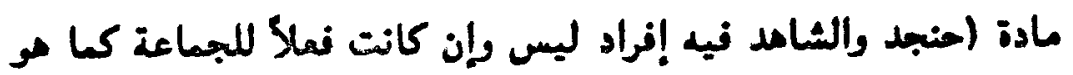

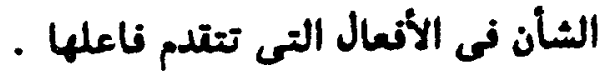

سييويه

سييويد rrT/L 


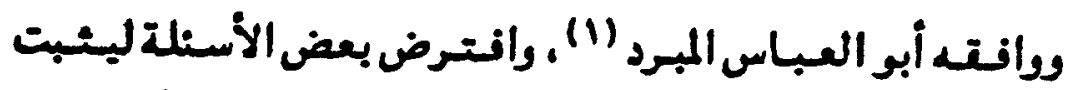

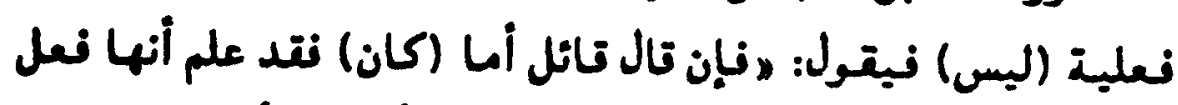

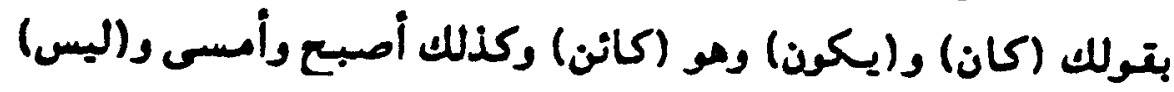

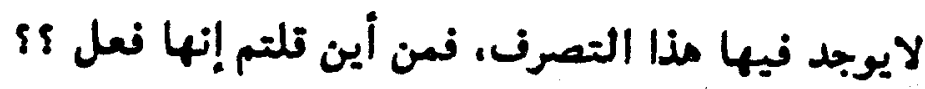

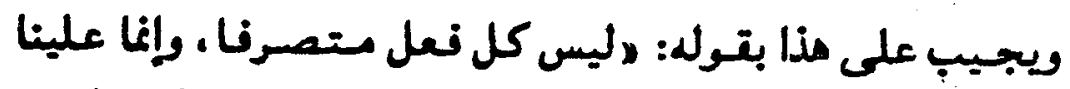

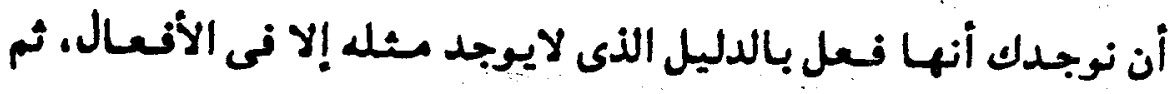

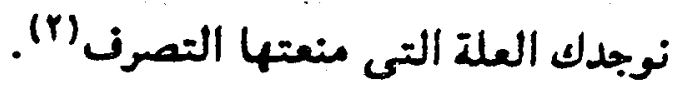

أنسا الدليل على أنها فعل فوقوع الضمبير الذى لايكون إلا في

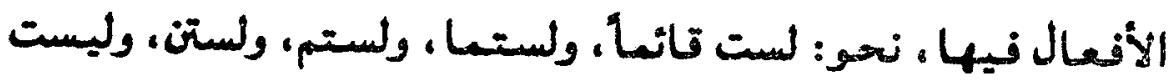
أمة الله ذامية، كقولهم: ضهيوا، وضريا، وضريتم، وضريتن .

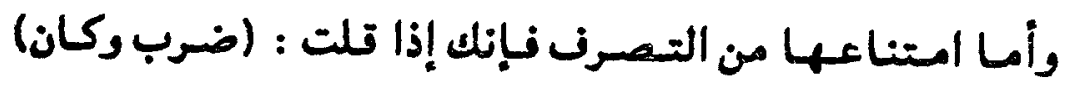

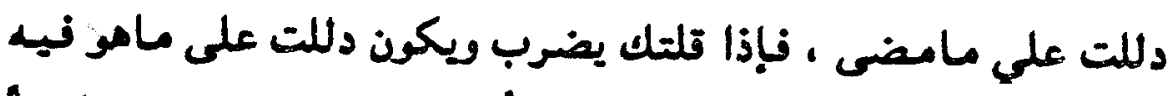

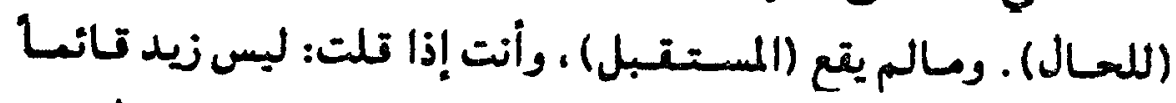

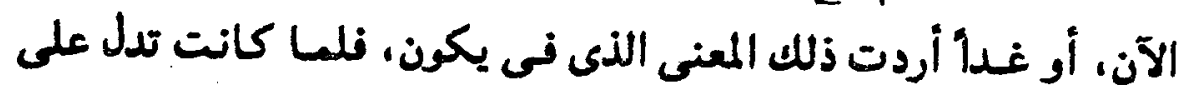

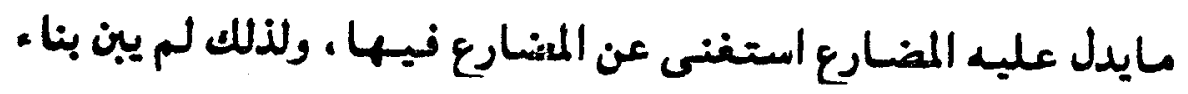

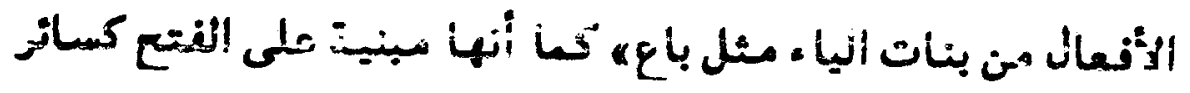

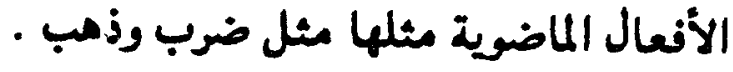

ودليل من تال بنعليتها أيضا - أنها تغسر النعل المحذوف

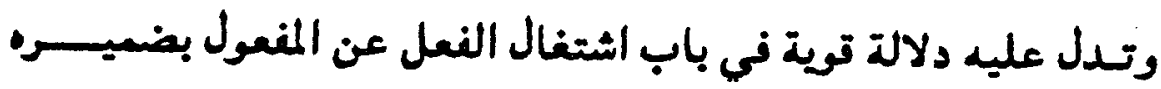


نكعا.تتول: زيدأ ضريت أباه فالمعنى أمنت زيدأ ضريت أباه، فكذلك ألك

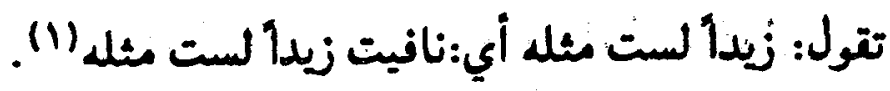

رأى أهى على الأرسى :

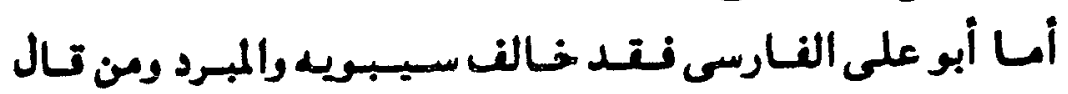

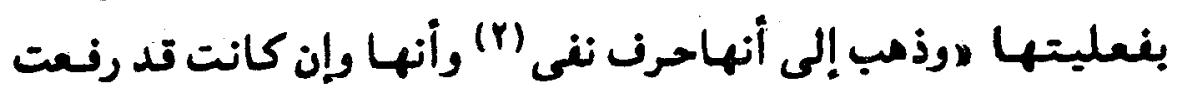

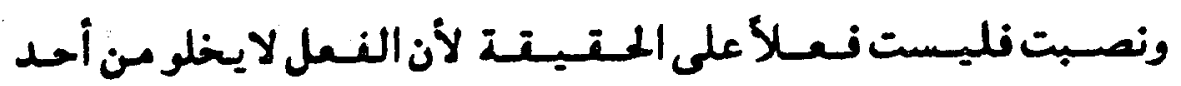
أمريسـن: ونهين فلئ الأول: أن يكون: أن دالأ على المدث وأحد الأزمنة الهلائة .

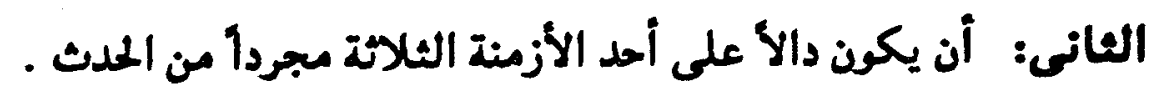

فإذا لم يخل النعل من أحد مذين التسسين، ولم تكن (ليس)

واحدة منهما ثبت أنها ليست بنعل، وإن كان فيها بعض الفعل الشبه مند.

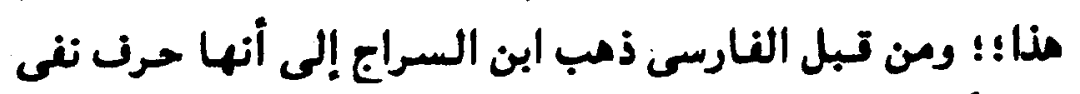

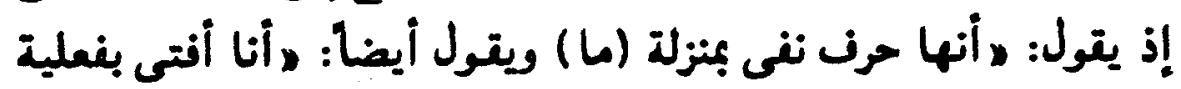

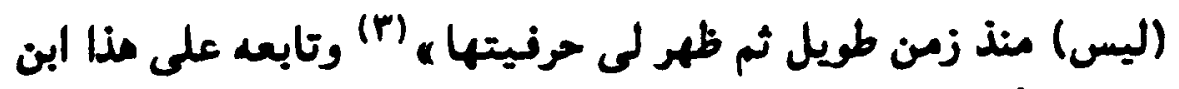

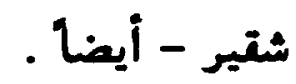

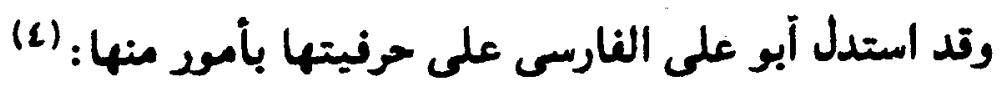

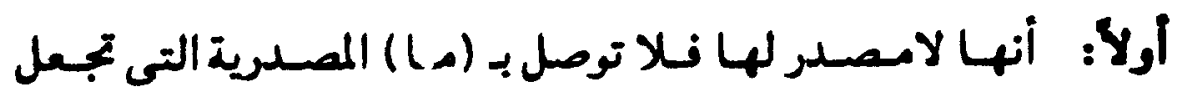
ماتدخل عليه فى تأويل المصدر، فلا يستتبم أن تقول:ماأحسن

(1)

المالبيات 19

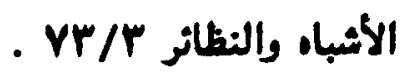

المليات Mla 
-rMI-

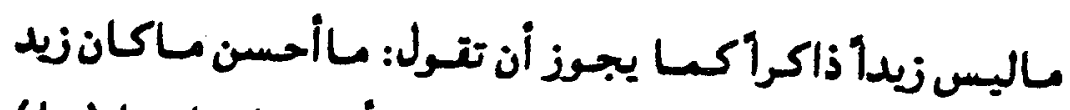

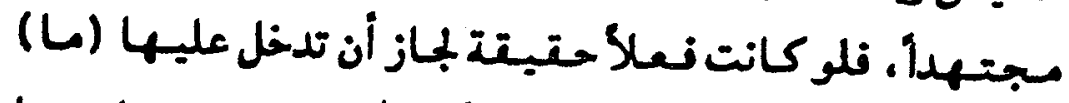

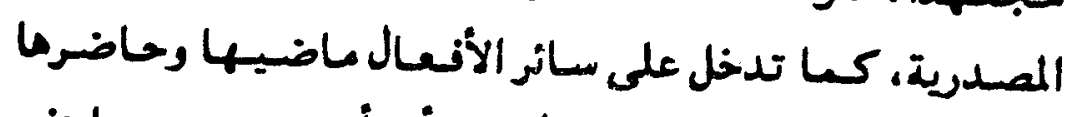

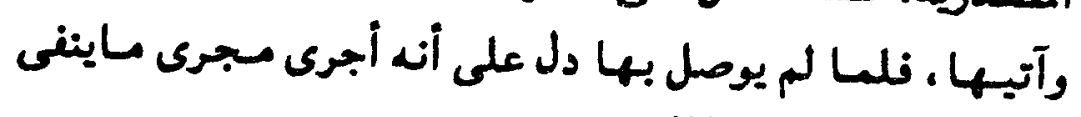

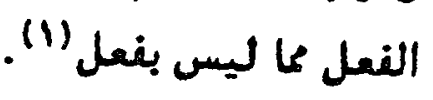

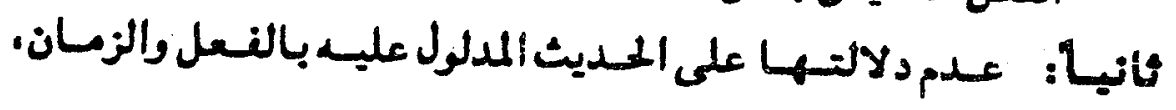

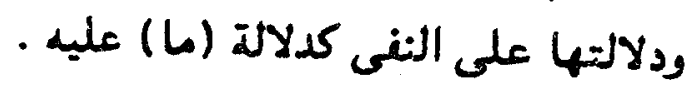

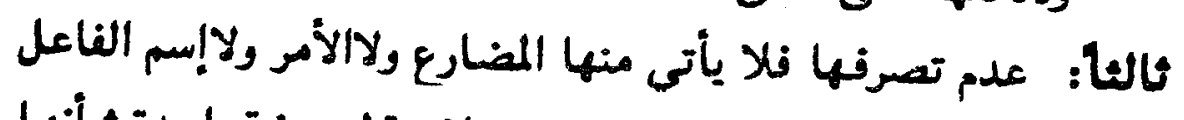

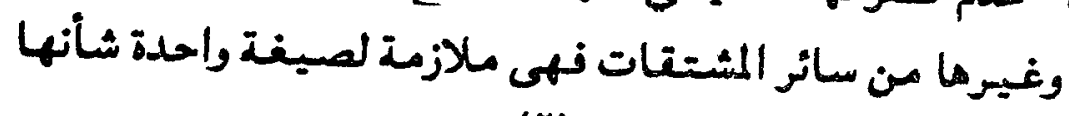

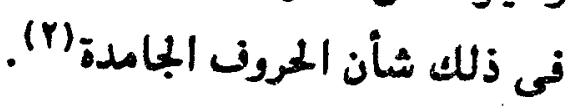

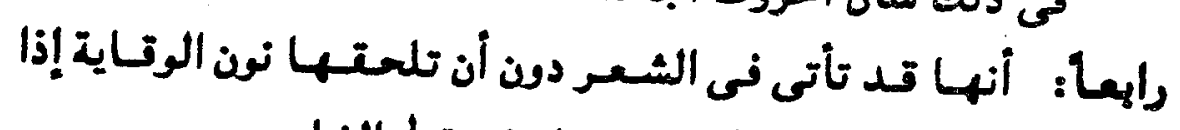

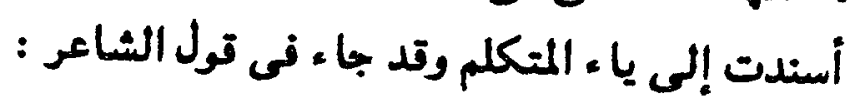

عددت كومى كعديد الطيـسـ

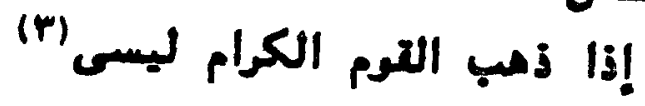

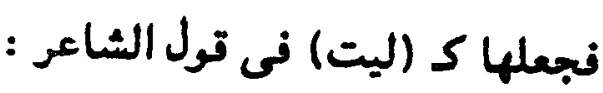

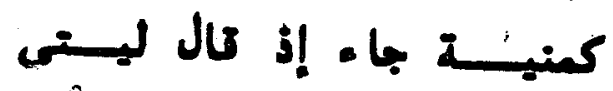

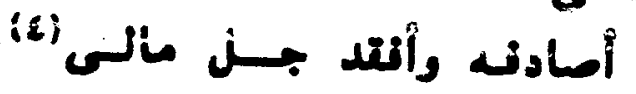

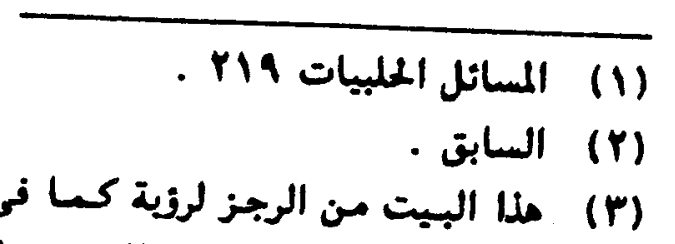

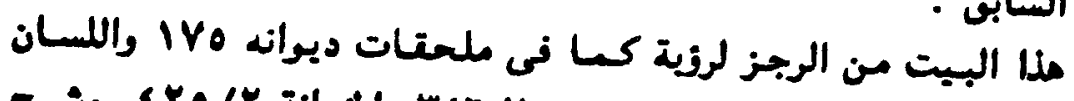

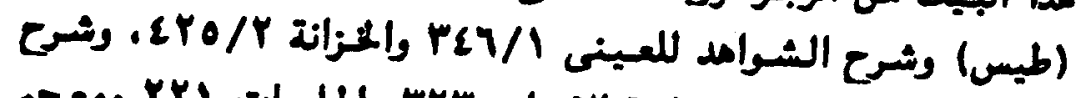

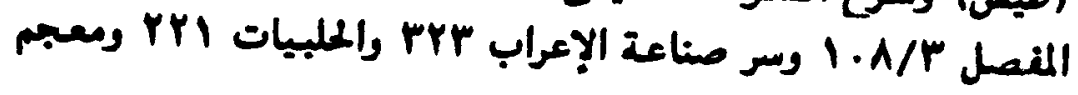

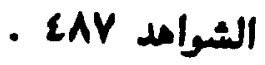

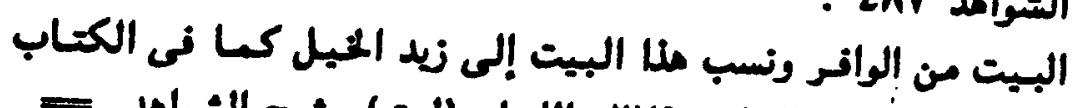

(z)

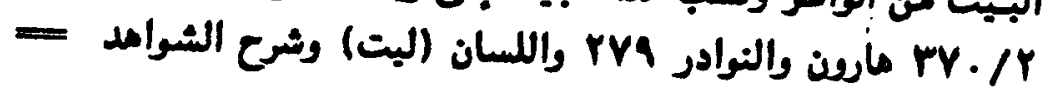


يقول النارس: رفحذفهم له من (ليس) كحذفهم له من (ليت)

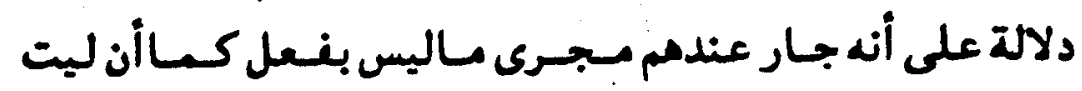
كذلكي، (1)".

غامسا: عدم محاثلتها لـ (كان) وأخواتها نليس فيها مافى(كان)

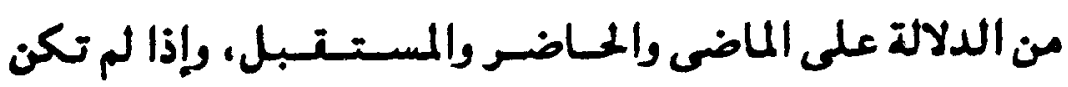

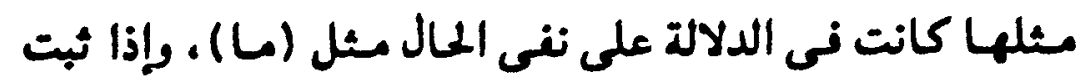

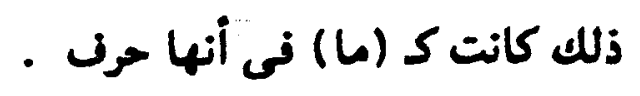

\section{ولم ذكرت مع كان أو أو}

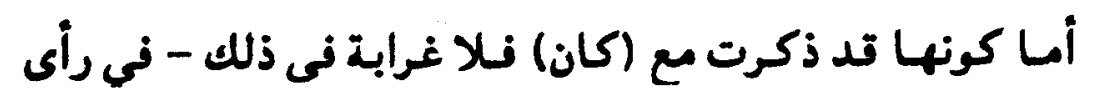

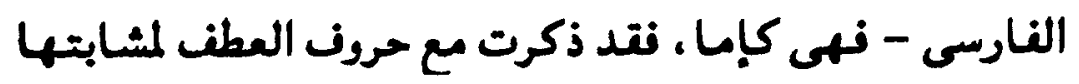
(أو) فى بعض المعانى (r)

ولاغرابة - عنده - في كونها تعل عمل المعانى (كان) فبعض المروف

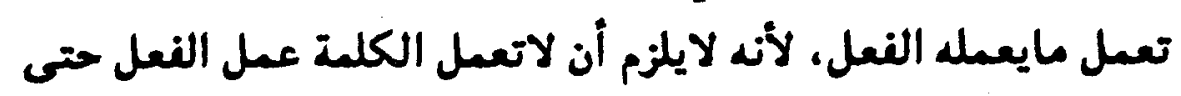

$=$

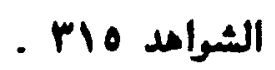

الملبيات rrr

لم يعد النـارسى (إمـا) من حروف العطن وذلل لأمسرين : الأول:

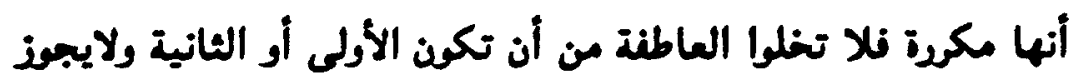

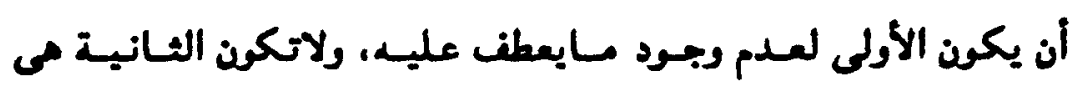
العاطنة لدخول واو العطف عليها وحرى العطف لايدخل على مثلد.

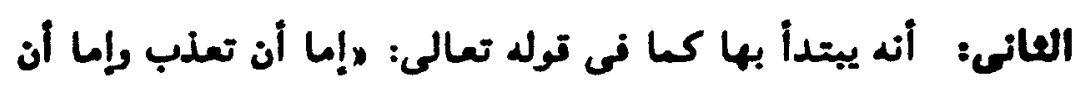

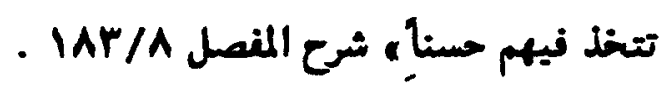




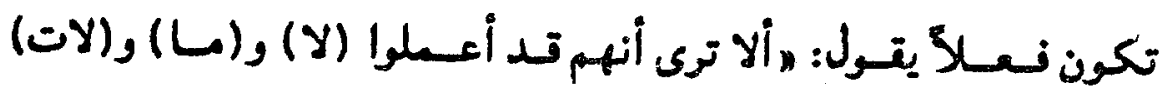

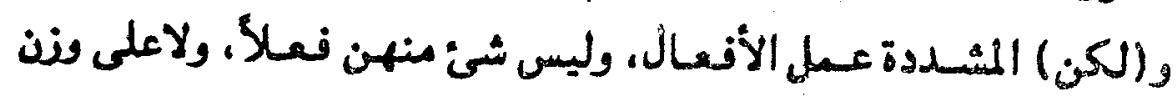

(1) a a

مذا ؛ ؛ وقد جعلها شبيهة بالنعل من غيبر جهة ويحسب كثرة

المشابهة بالنعل حسن إعمالها عمل النعل ، ومن أوجه المشابهة :

أولا: أنها على وزن من أوزان الفعل المضغ، ومثال من أمثلته

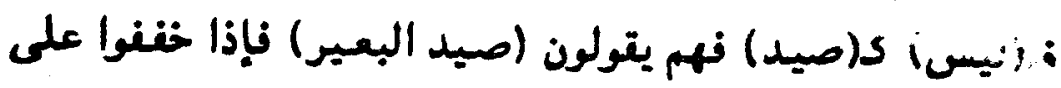

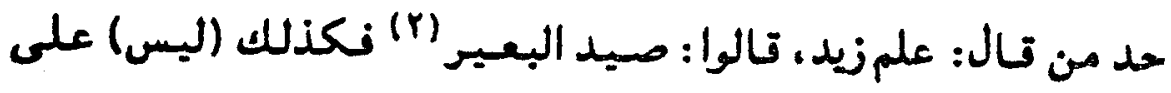
وزنه وإذا كان الثانى لم يتحرك فى ليس) كنا تحرك فى (صيد) فهذا

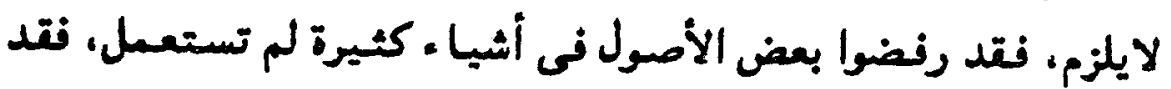

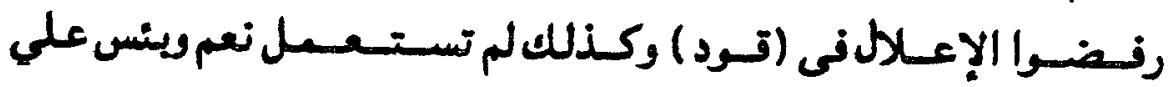

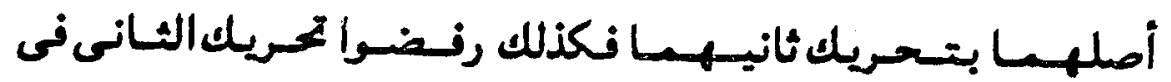
(ر) (ليس)

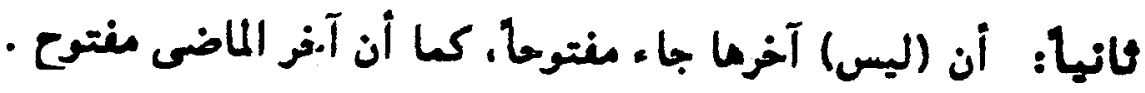

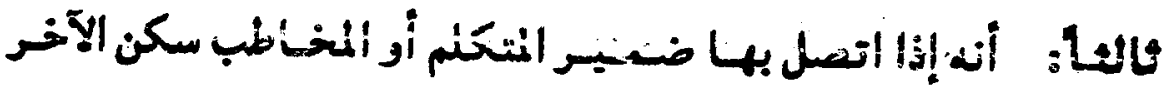
منها كا يعدث فى الفعل اللاضى -

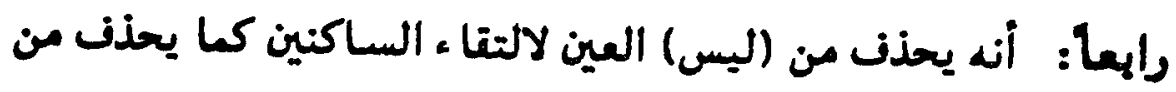
بعغ الأنعال كهبت وخفت وغير ذلك .

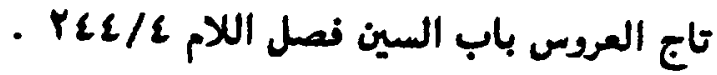

الملبيات 
فإذا كانت مذه الأوجه موجودة بين (لبس) وبين النعل كان ذلل

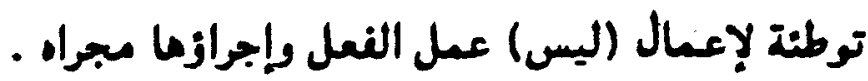

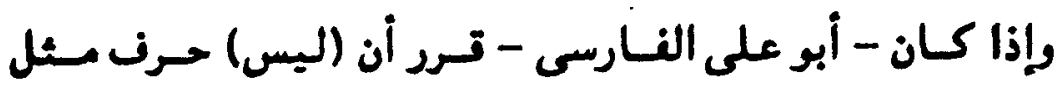

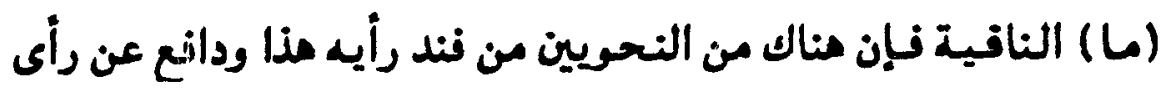

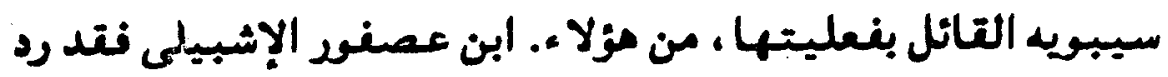

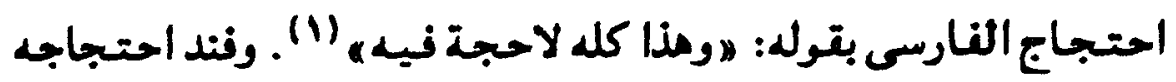
بقوله : 1 - أما كونها لاتتصرن، نكثير من الأفعال لاتتصرن مثل نعم ويتس. وعسى فشـأنها فى عدم التصرن كشئأن مذه الأنعال.

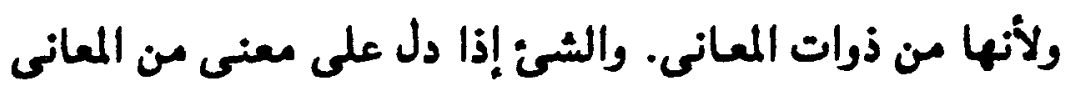

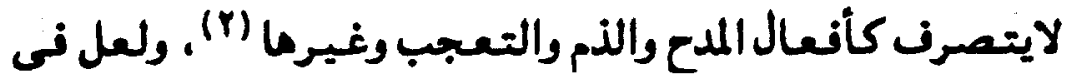

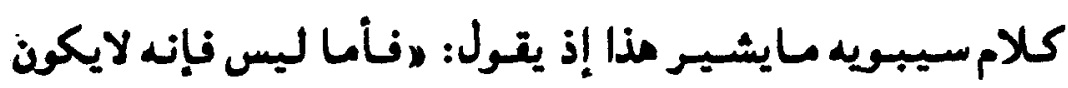

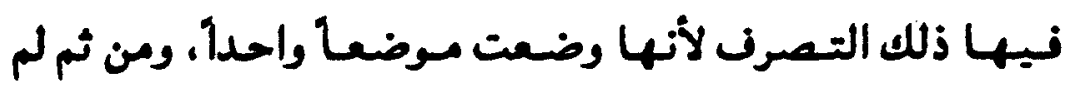
تصرف تصرن النعل الآخره (r)"

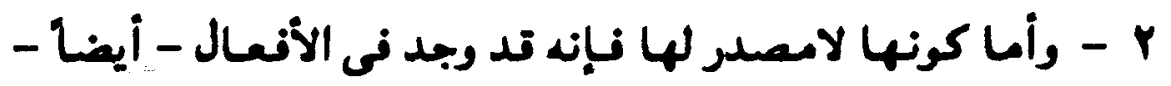

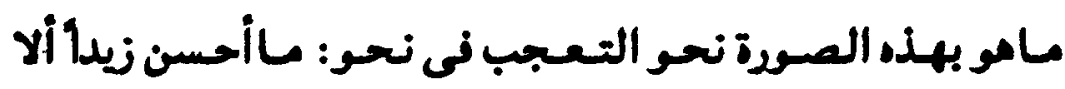

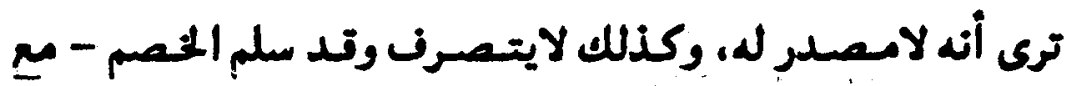

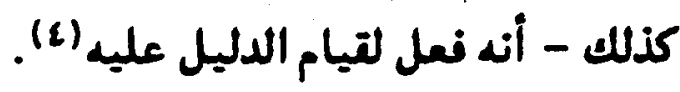

شرح جمل الزباجى لابن عصنود rYA/

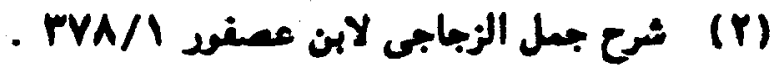

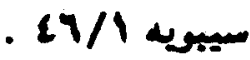




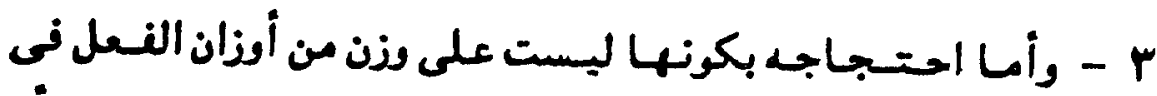

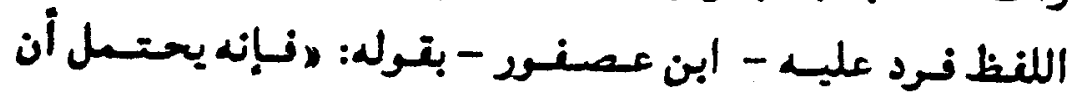

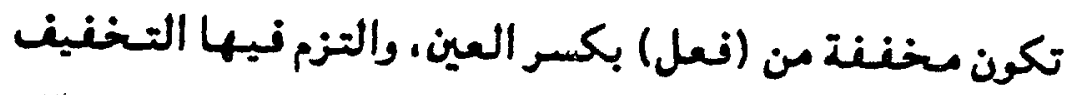

لثقل الكسرة على الياء." (1). ثم بعد ذلل نتول :

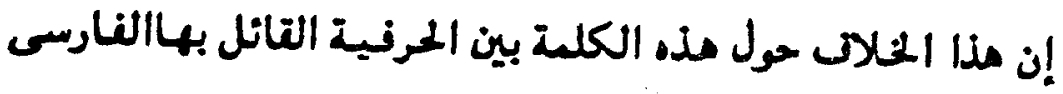

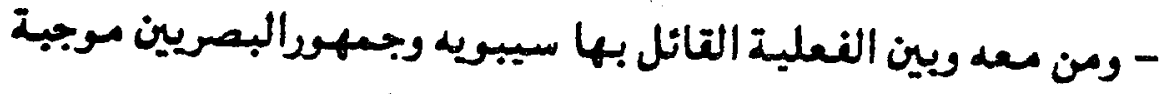

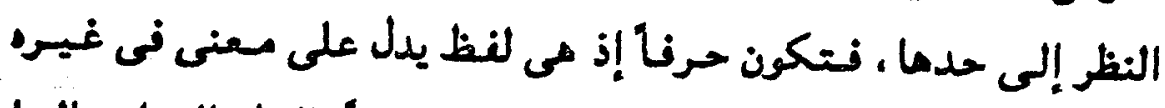

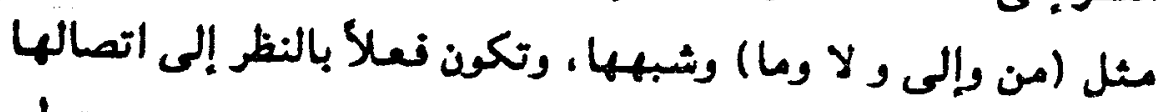

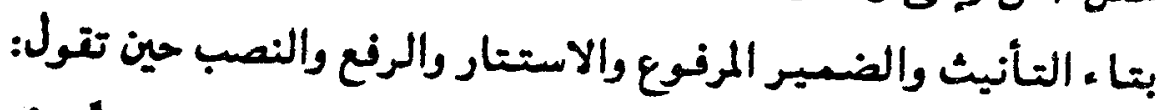

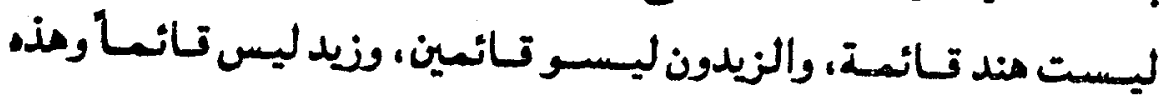
خواص الأفعال لاالحرون .

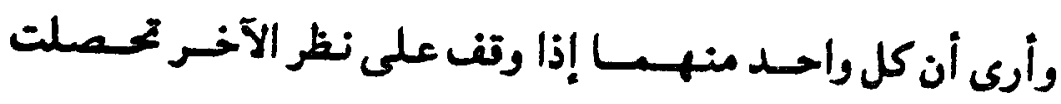

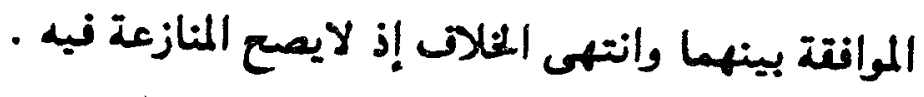

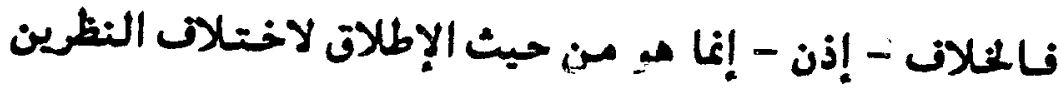

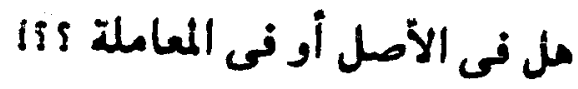

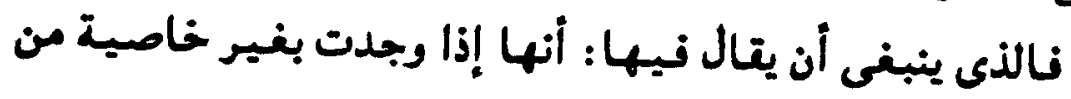

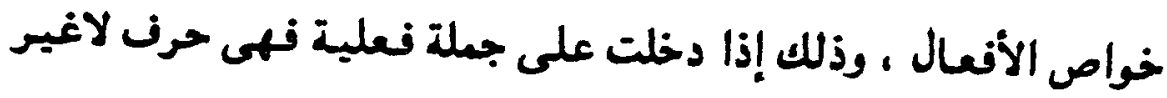

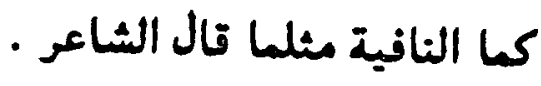


تهلى كائب خمنرا لبس بعaمها

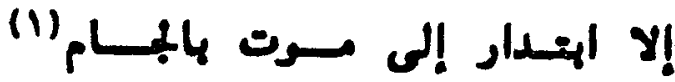

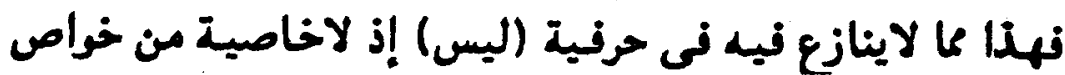

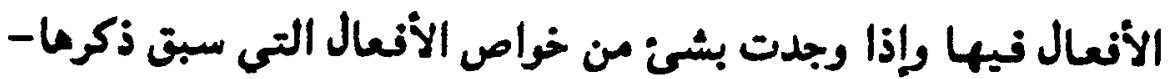

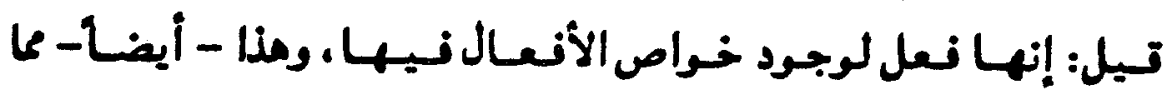

لاينزاع نيه .

ولكن. مل يمكن جعل (ليس) - فى البيت السابق - فعلكا

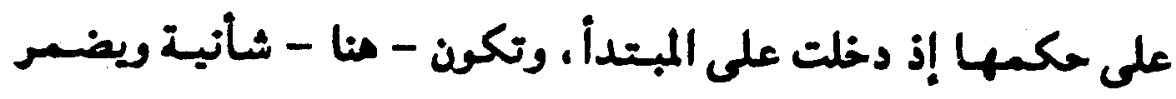

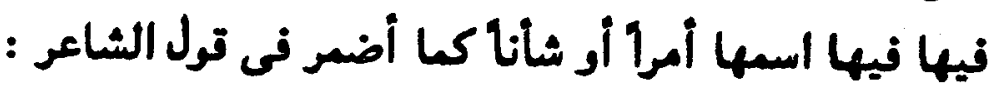

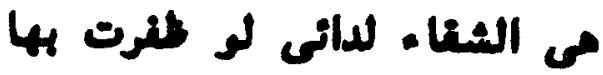

ولهس منها شناء الداء مهدول

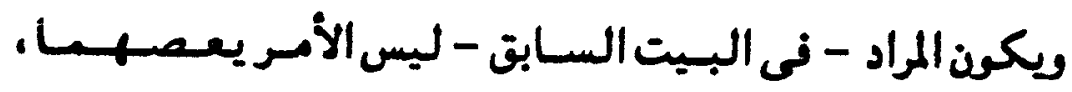

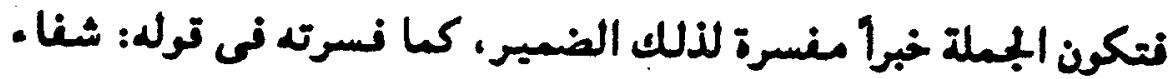

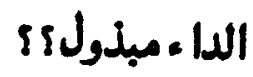

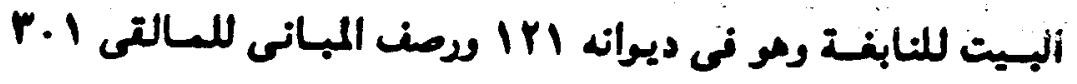

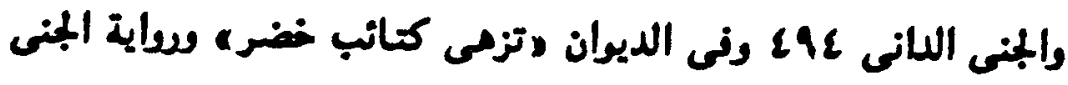

الدانى دإلى موت بأسيانه الفي وفي الديران

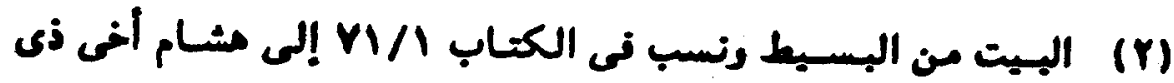

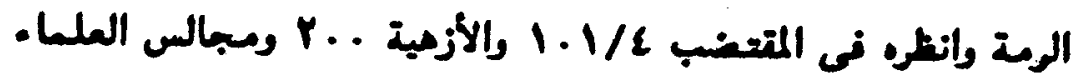

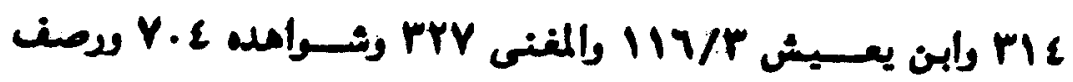

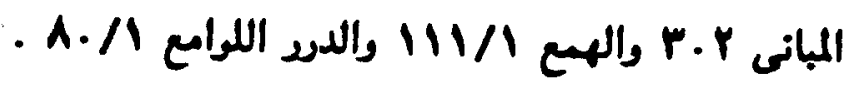




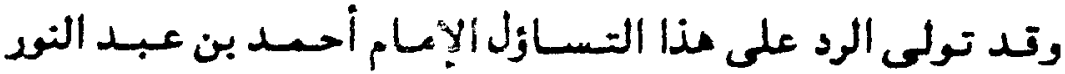

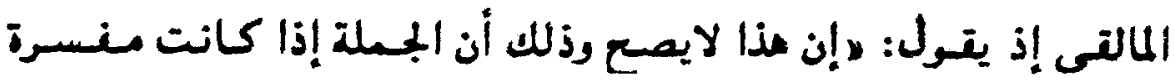

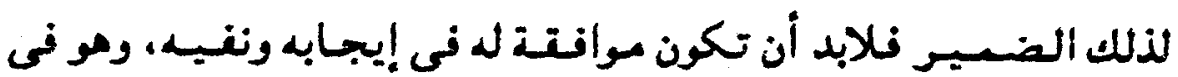

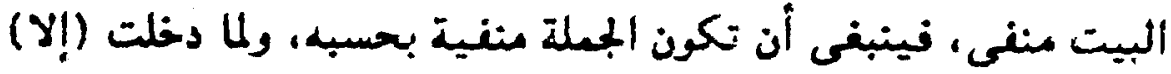
فى الجمسلة المفسرة كانت تناقض الفسيسر لأته لايتـال: يتوم إلا زيلد

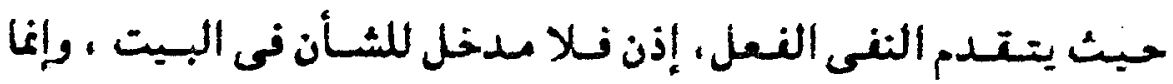

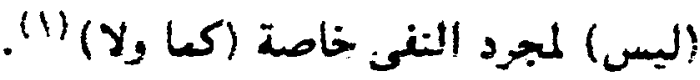

أما سيبويه فقد تال بالإضسار فى (ليس) كس يضسر فى (إن)

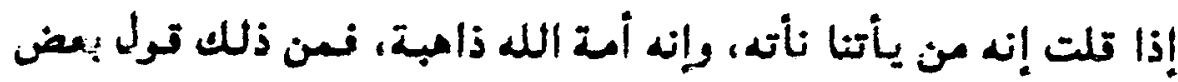

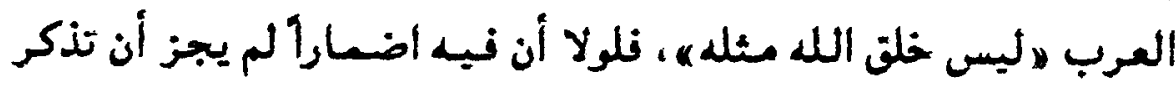

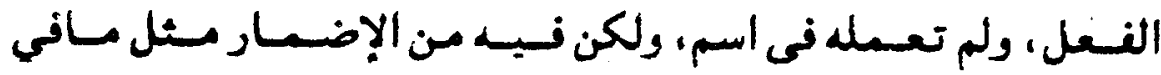
(إند) (r) وقد استشهد سيبويه علي مذا بتول الثهاعر:

رلهس كل النوى بلأى المساكسين لأصسعرا والنوى عالى معرسمسم 
يقول سيبويه : رفلو كان (كل) على (ليس) ولاإضسار فيه لم

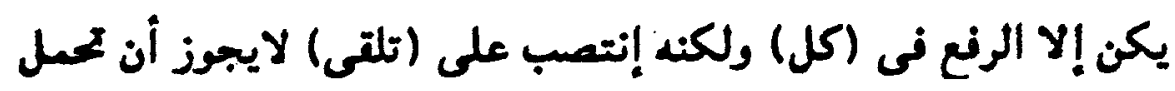

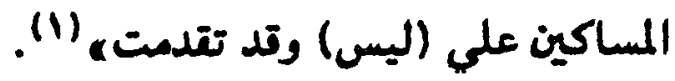

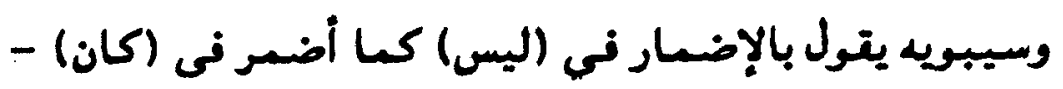

$$
\text { أيضا - فى قول الشاعر : }
$$

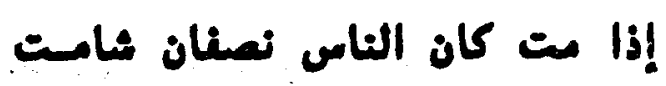

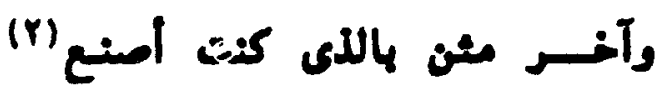

إذ يتول: هولولا أن الشاعر أضمر فى (كان) لقال: نصفين كأند

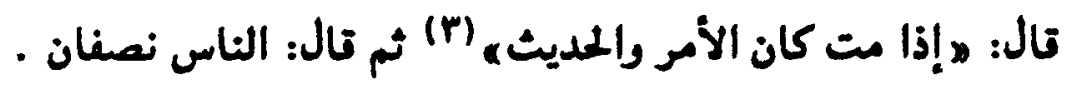

حمل (ليس) على عا :

بعض العرب أمل (ليس) حملكا لها على (ما) ) ويرى سيبويد

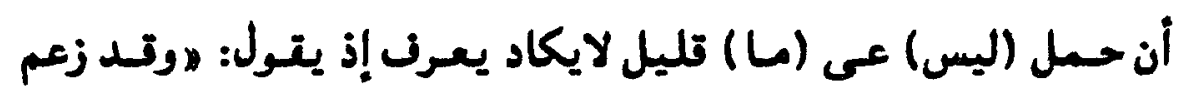

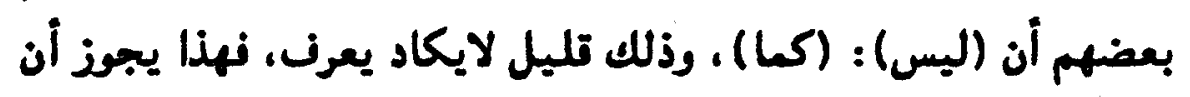

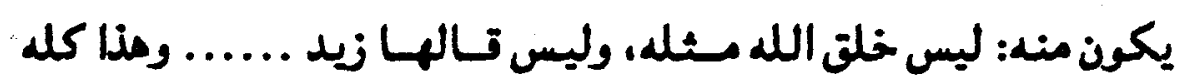

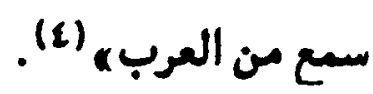

•

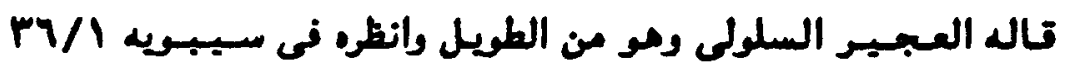

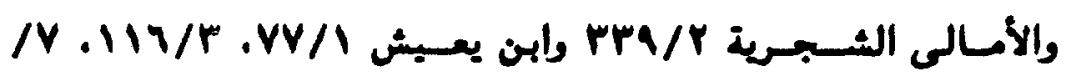

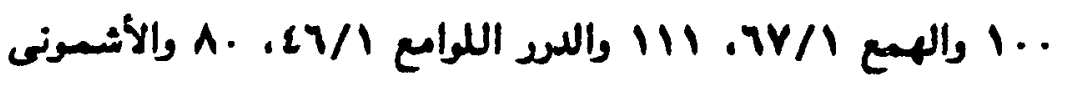
. Ira/ 
وكونه تليلاً إلا أنه ورد عن ألعرب، ونظير ذلل إذا انتفض ننى

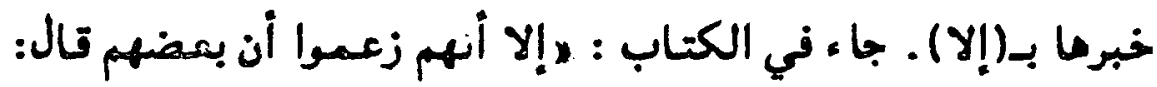

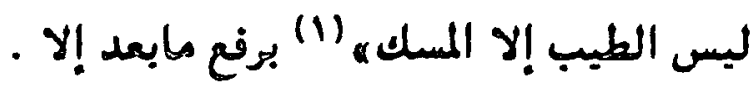

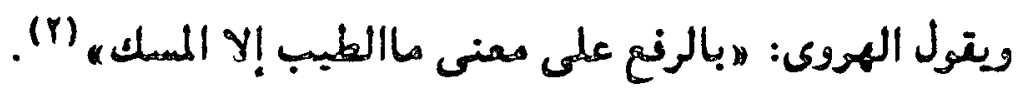

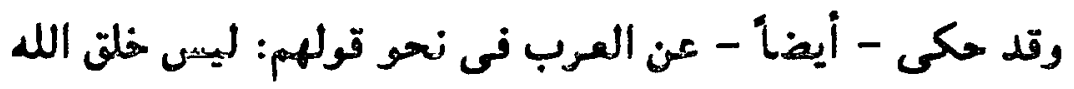

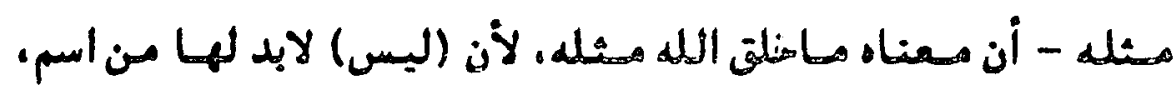

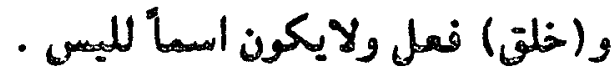

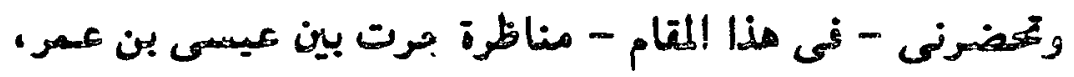

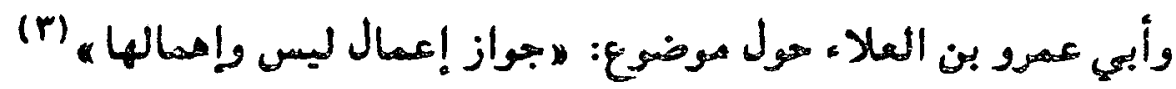

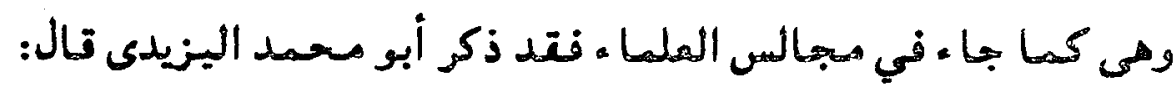

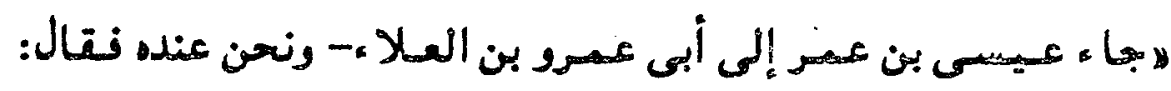

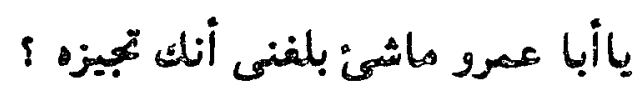

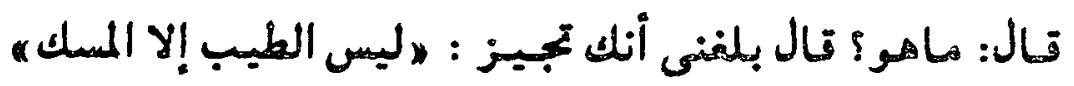

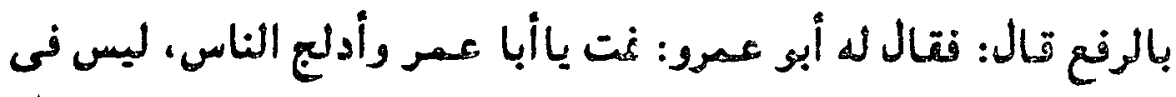

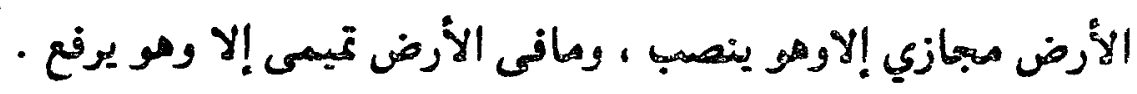

. $\mid 6 V / 1$ |

الأزهية 190.

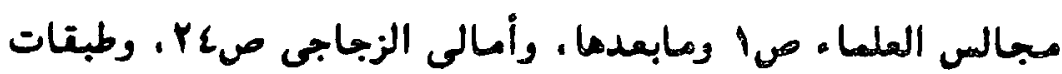

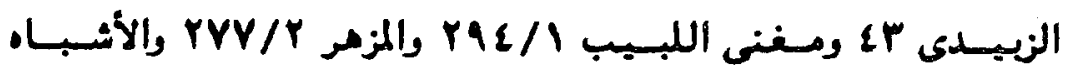

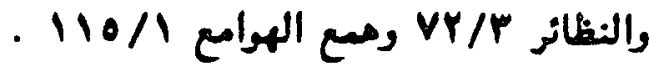


تال اليزيدى: ثم تال لى أبو عمرو: تعال أنت يايعبى، وتعالى

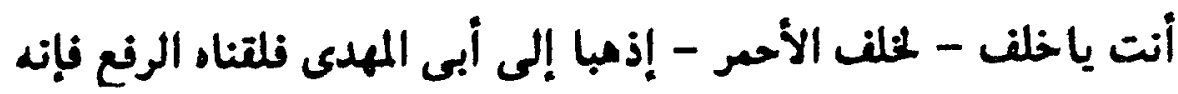

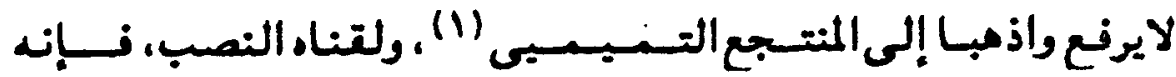

قال: فـدمبت أناوخلف وأتينا أبا المهدى فإذا مو يصلى، وكان

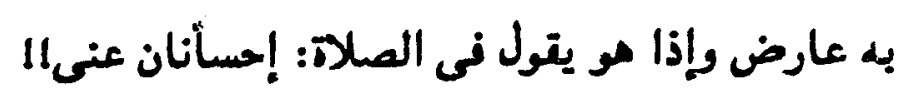

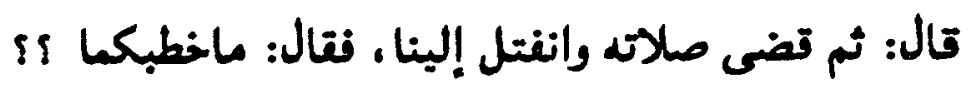

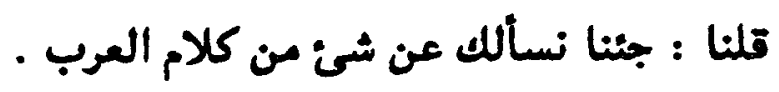

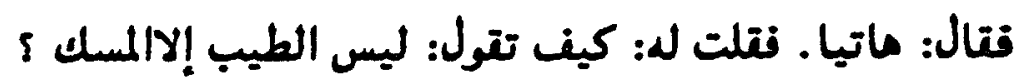

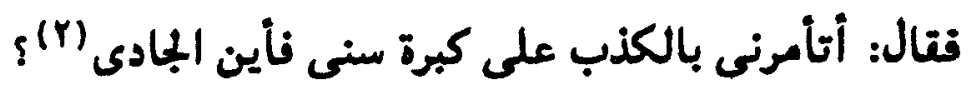

قـال اليزيدى : نتال له خلف: ليس الشـراب إلا العسل، تـال:

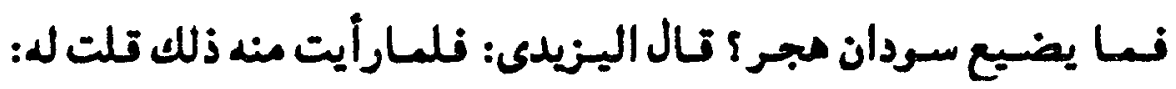

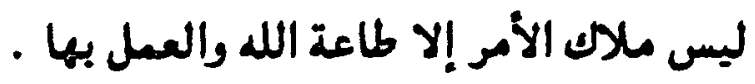

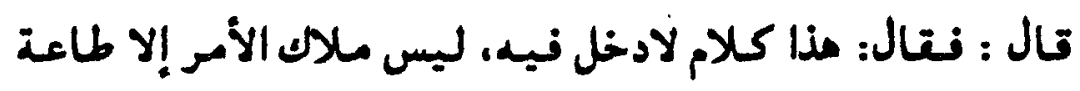
الله والعمل بـ ـ فنصب .

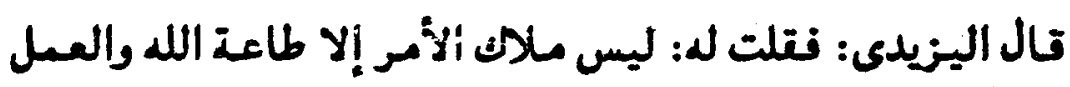
بها ورنعت . نتال: لا، ليس مذا من لحنى ولامن لحن قومى . 
هبعد: فهذه مناظرة جرت بين إمامين من أنتة العرية المتدمين

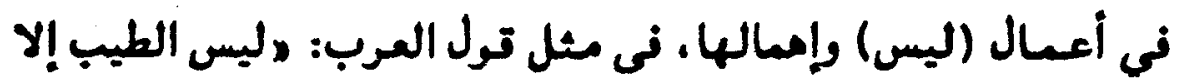

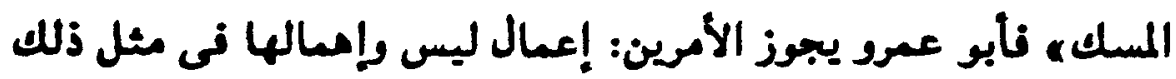

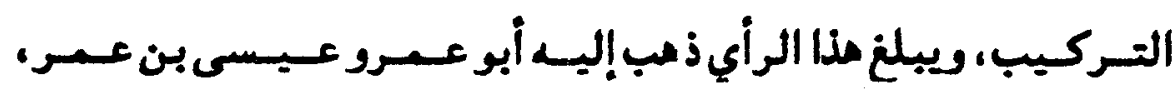

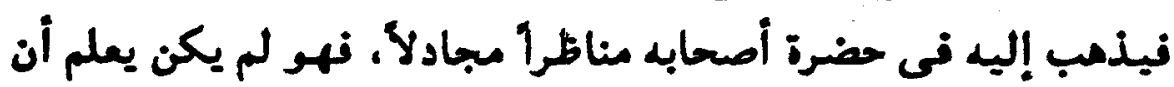

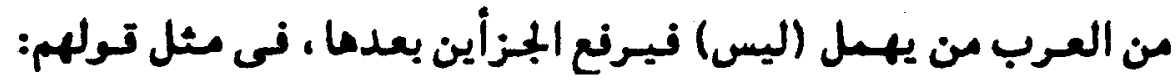

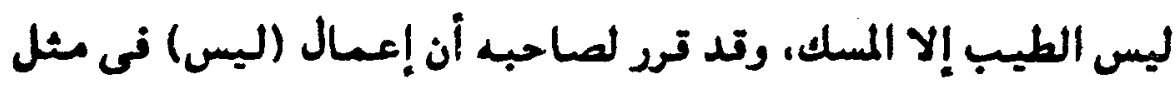
ذلك التركيب ونصب خبرما مو لغة الحجازيين جمبعهم وأن إمالها

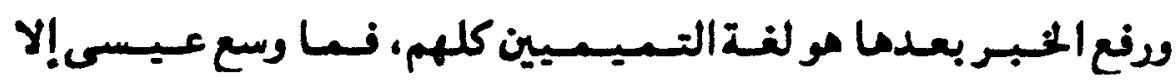

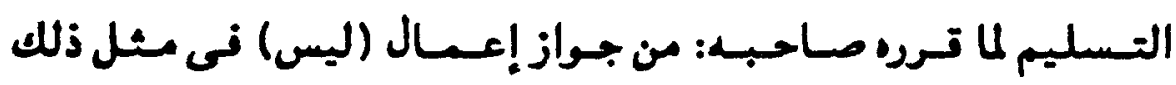
التعبير كا مو لفة الحجازيين وجواز إمالها ومور لغة التعيعيين .

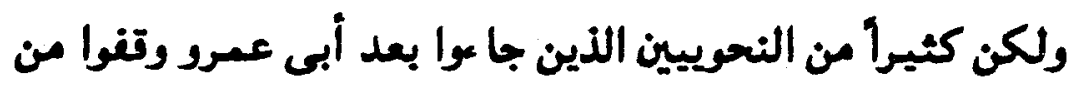
هذه القاعدة المتينة فى إمال (ليس) موتنا غريباً ، فرنضوا الإمسال

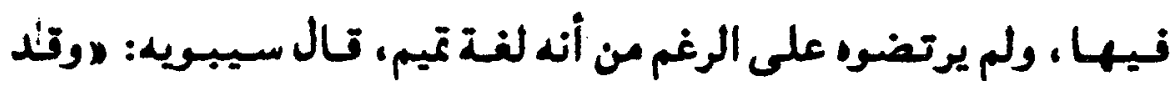

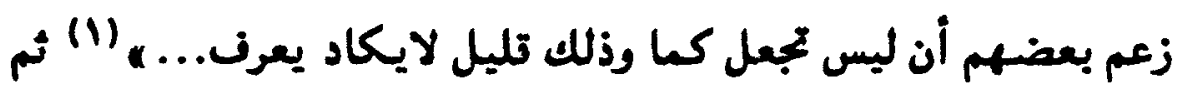

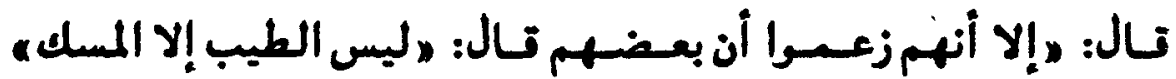

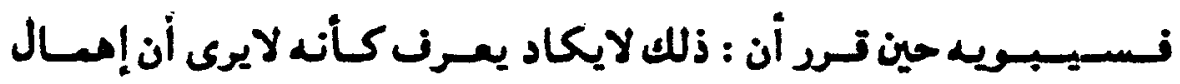

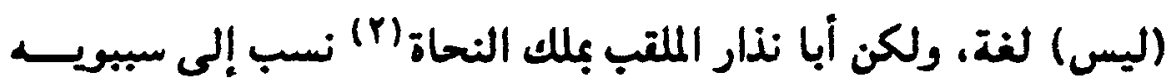

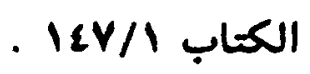

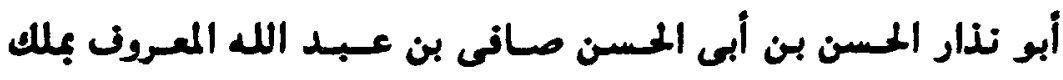

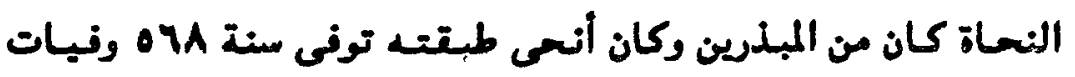


مالم أجده. قال فيما حكى عنه السيوطى: لروى سيبويد فى كتابد

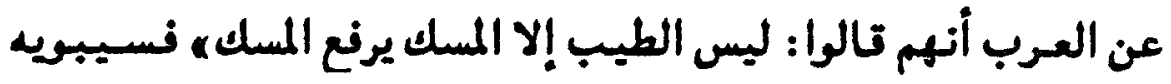

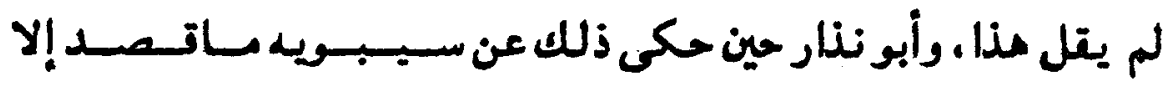

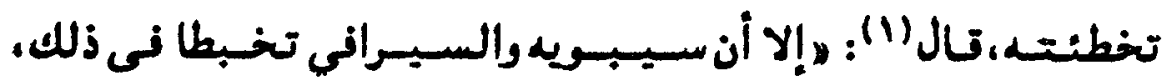
وماأتيا بطائل، لأن الصواب عنده رفع المسك ليس لغة، ومو يعترض

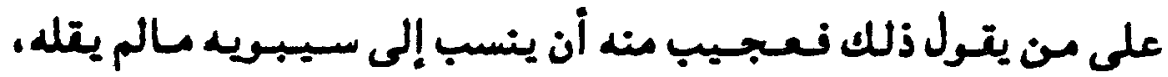

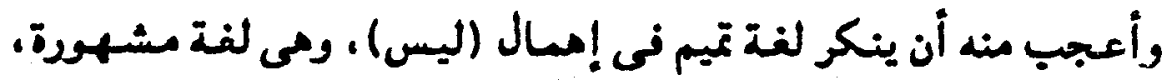

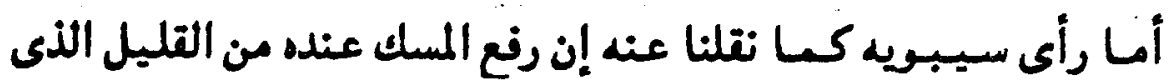

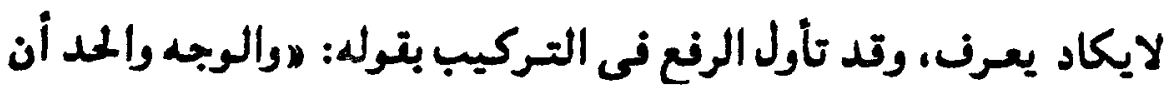

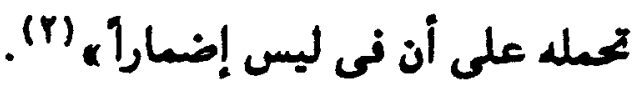

ثم جا ـ كثير من النحات وسلكوا مسلل سيبويه، وتأولوا الرنع فى المسك من تولهم : ليس الطيب إلا المسك بتأويلات كثيرة :

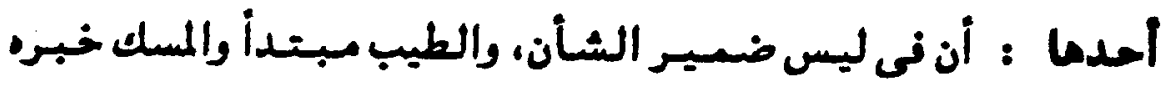

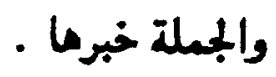

ثانيها أن الطيب إسمها وأن خبرها محذوف، أى فى الوجود وأن

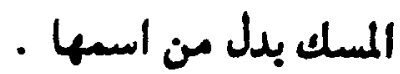

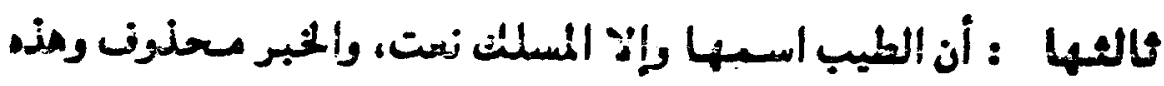

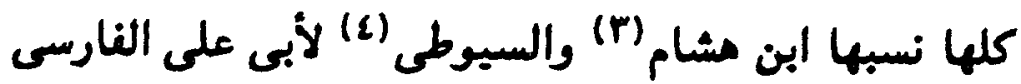

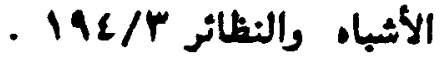

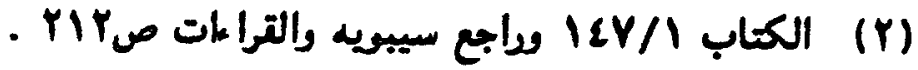

$$
\text { مغنى الليب }
$$




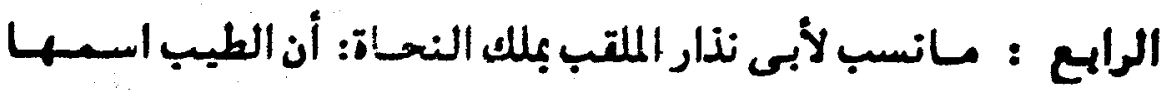

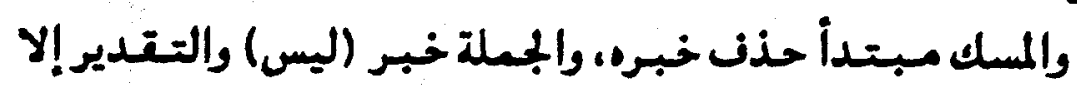

المسك أفخره." (1).

ومكذا التمس أولثل النحاة للتركيب تخريجات شتى، وماخلت

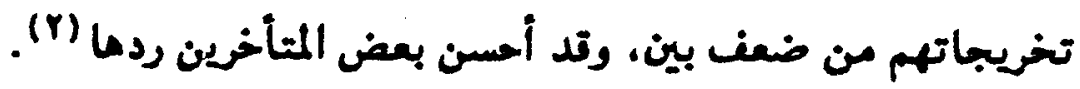

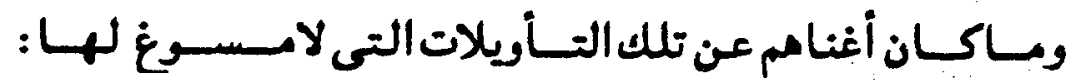

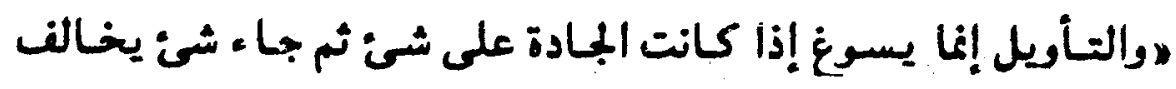

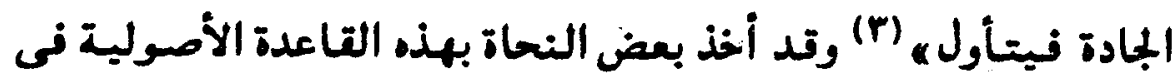

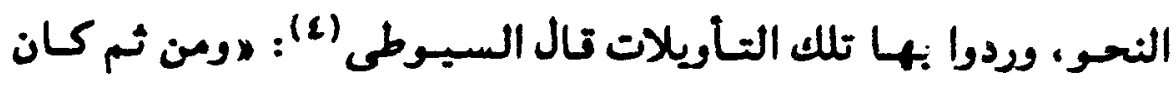

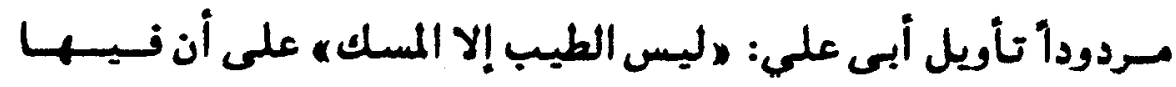

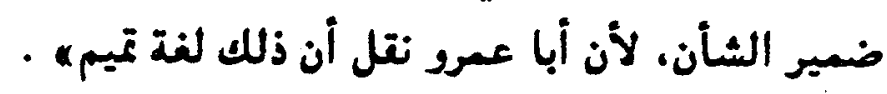

ومن قبل تـال اين مشـام (0) : ووماتتـدم من نقل أبو عسمرو أن

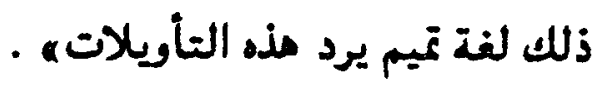

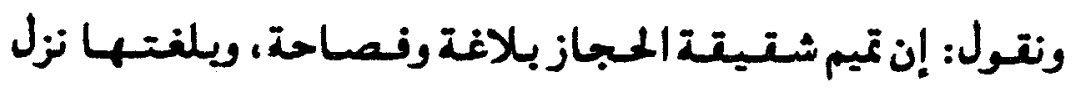

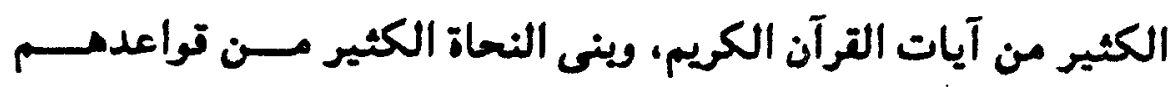

الأثباه والنظائر / 19ع ـ

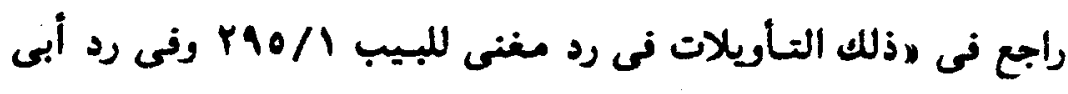

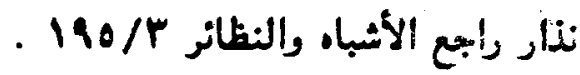

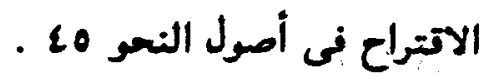

المصدر السابق .

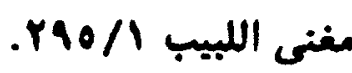


-Y\&L-

النحوية والتصريغية على لغتة تميم وتد ثبت عنها أنها لاتعمل

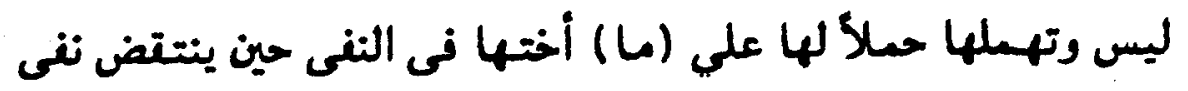

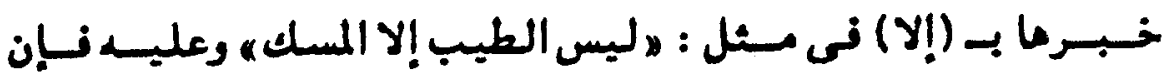

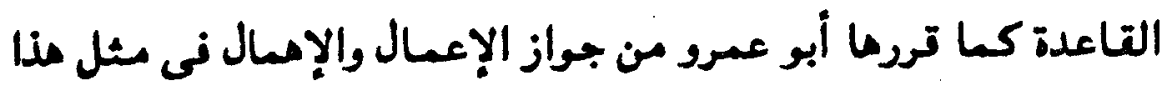
التركيب كلاما تياس وعلى الجادة . 
الإستثناء بـليس) :

يستشنى بد(ليس) كسا يستـنى بـ(إلا) وينصب المستثنى بها

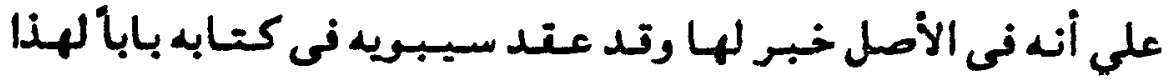

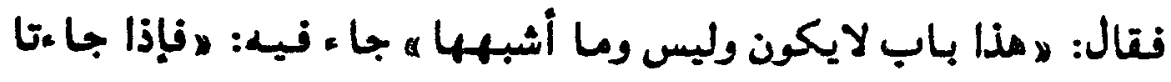

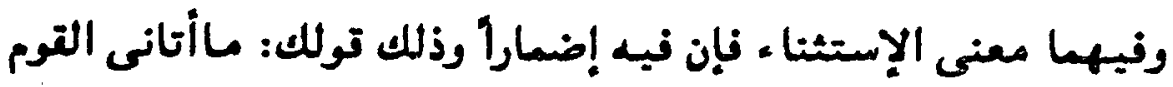

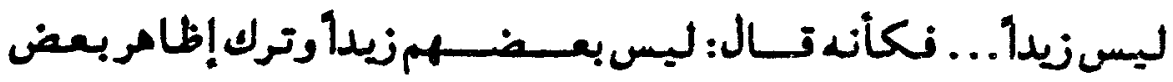

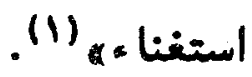

فسيبويد يقرر أن اسمها مضمر وأن مابعدما منصوب ، ويوضع

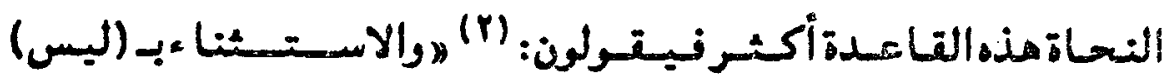

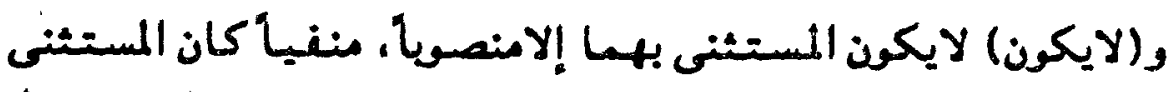

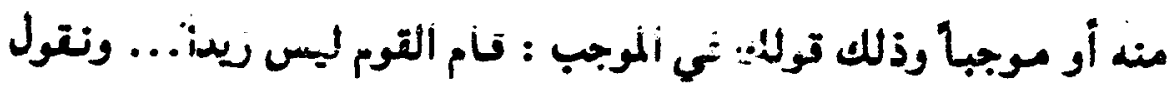

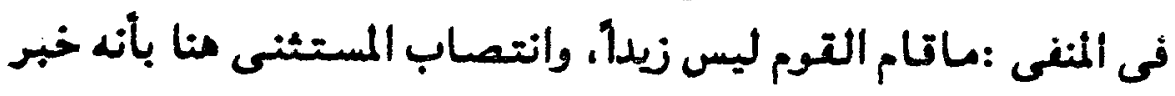

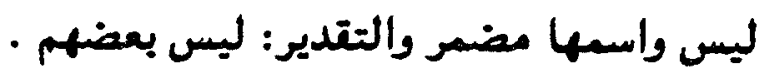

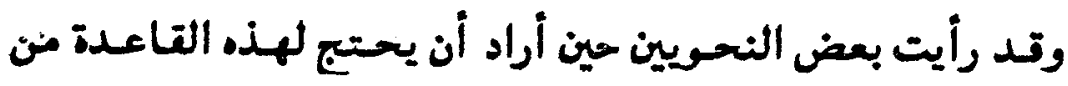

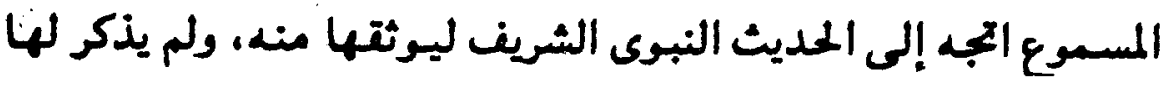

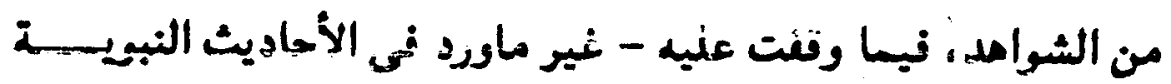

الكتاب reV/r

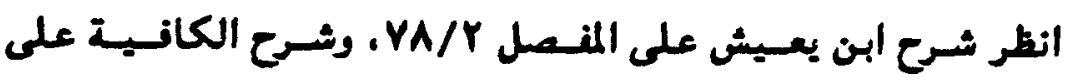

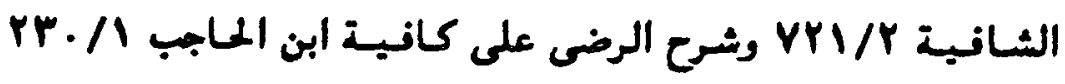

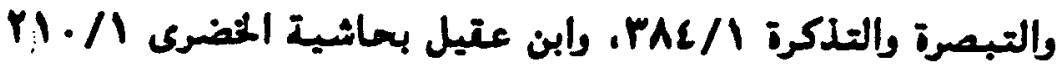

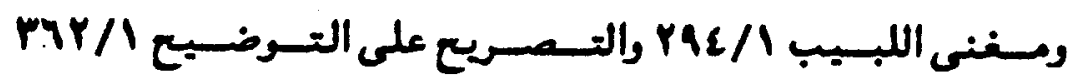

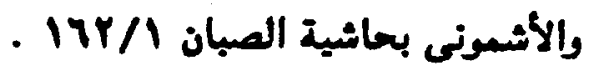


كأنهم تأثروا با جا ـ عنها فى حوار سيبيويه وشيخـه حماد حين تال

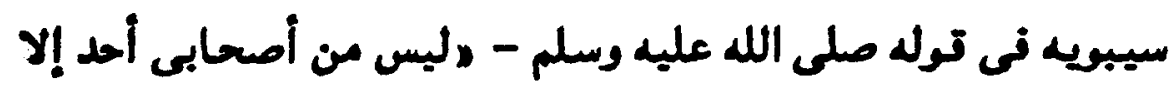
من لو شئت لأخذت عليه ليس أبا الدرداءه. (1).

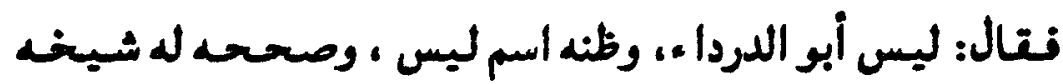

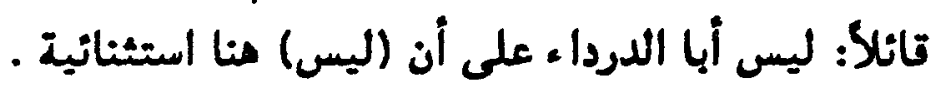

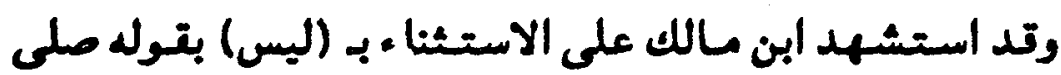

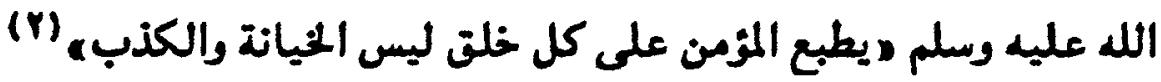
أى ليس بعض خلقه الميانة والكذب .

وتال ابن مشام فى التوضيح (r) هوالمستينى بليس ... واجب

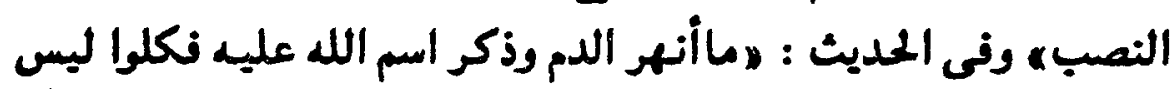

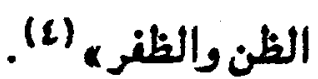

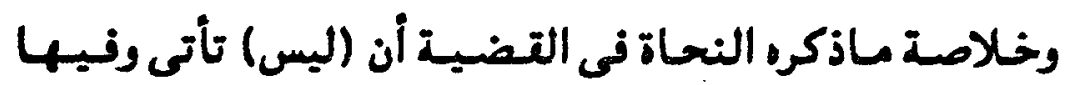

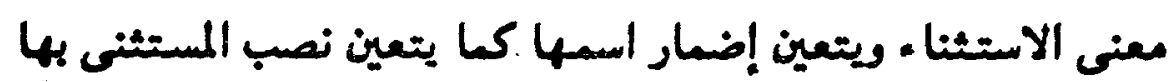

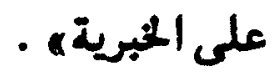
وتال النارسى : هوالبغداديوذ أو طائنة منهم، تد أجازورا شأ نحكرا: قام القوم ليس زيداً ، (0) .

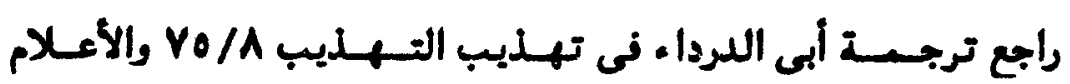
اللزركلى 11/0 . 11/

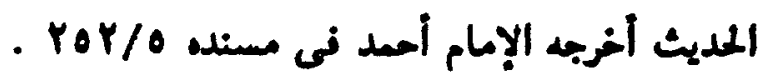

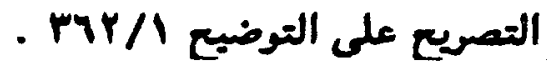

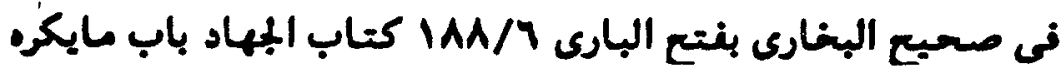

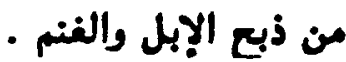




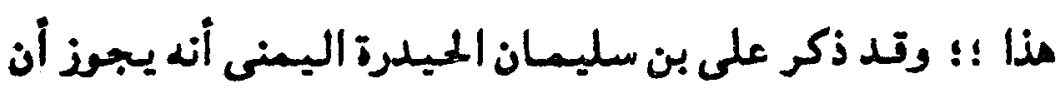

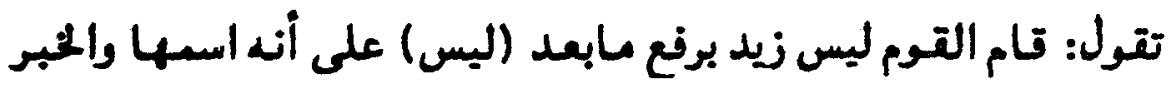
محذون (1) وهذا الرأى ضعين للأمود الآتبة :

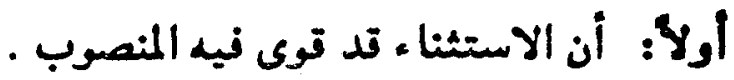

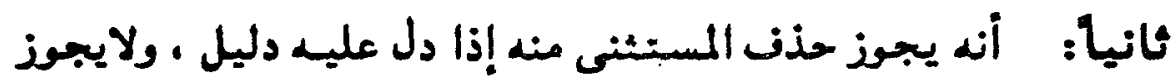

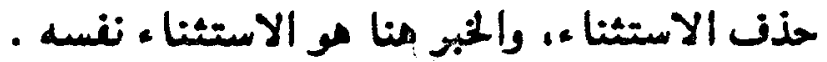

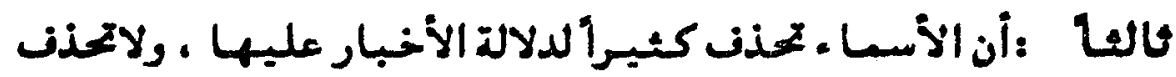

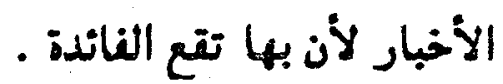

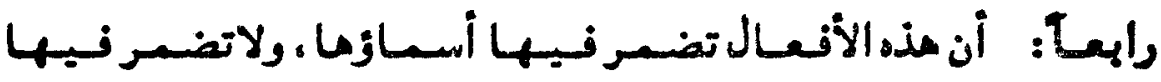
أخبارها أنا

مل قديند إلى ضمير المغاطب المتصل يقول الزيبدى (r): : هولك أن تتول: بائنى التوم ليسلك ه إلا أن

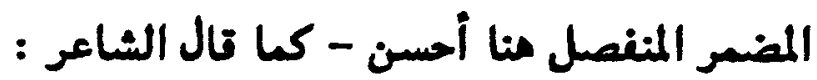

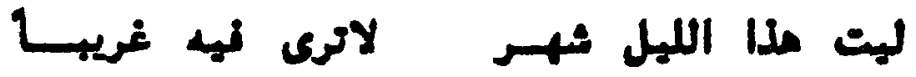

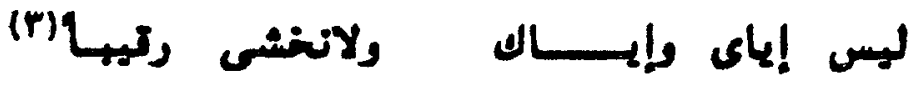

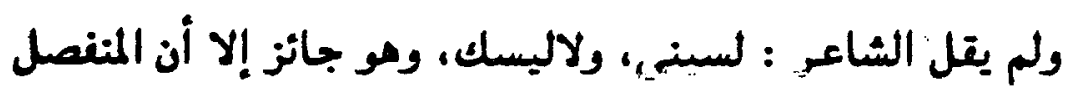

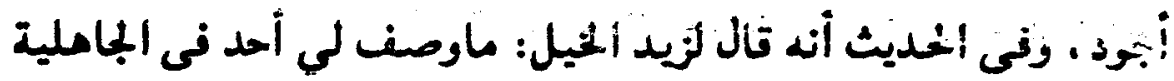

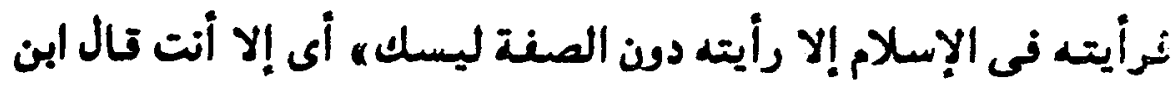

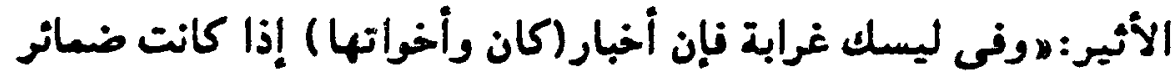

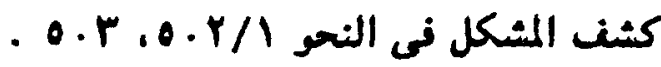

تاج العروس فrع/\&

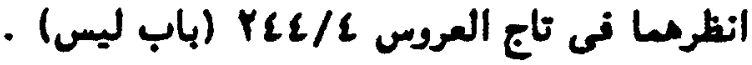


فإنا يستعمل فيبها كيبرا" المنغصل دون المتصل تتول: رليس إياى

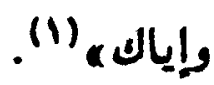

\section{مل بوصف 84}

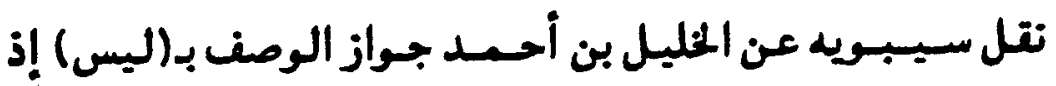

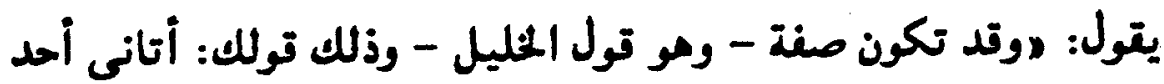

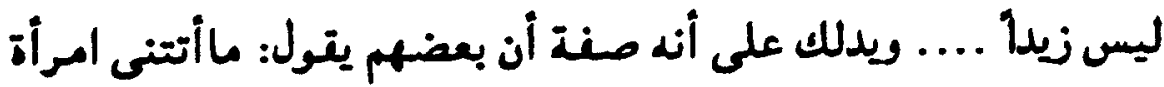

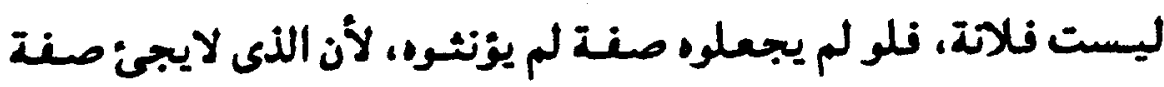

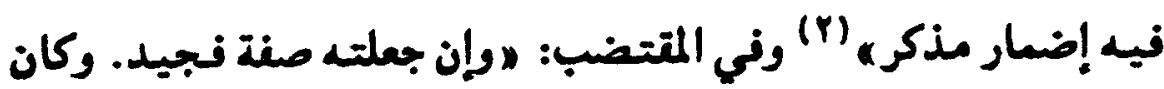
الجرمى يختاره ومو قولل: „أتانى القوم ليسوا اخوتكه، (r)".

وتد نتل أبو على الغارسى كلام سيبويه السابق نقال: "اوزعم

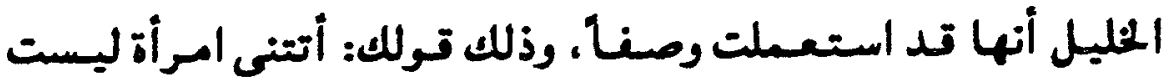

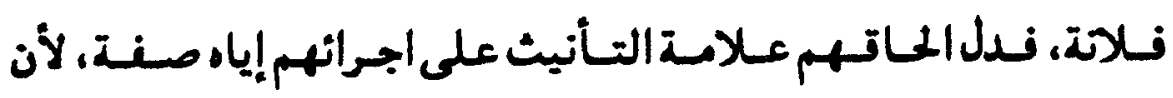
استعطالها فى الاستثنا ، لايككون النعل فيه إلا على التذكير ، لتقدير

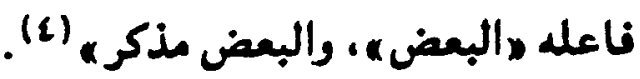

المصدر السابق .

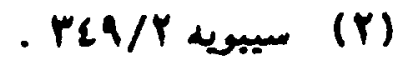

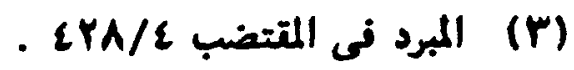

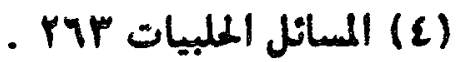


: مل

زمب الفراء إلى جهواز استعــالها عاطنة، وتد نتل ذلل عنه

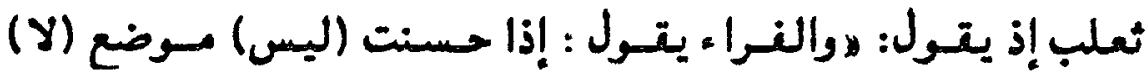
(1) باز

وممن نتل أنهـا تكون حسرفـا عـاطنـا - عند الكوفـيـين - ابن

بابثـاذ والنهـاس وابن مـالك، وحكاء ابن عـصنسود والنـارسى عن

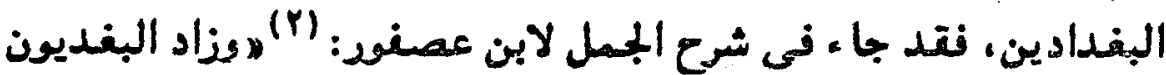

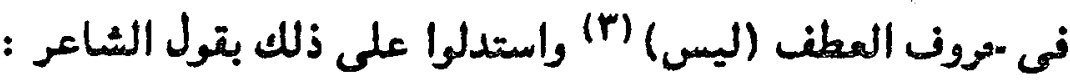

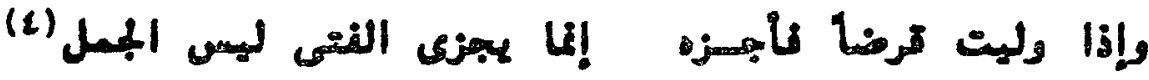

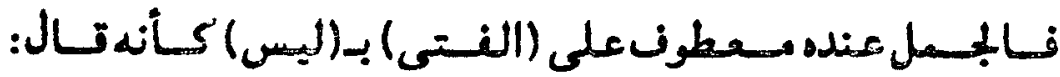

(1) (1)

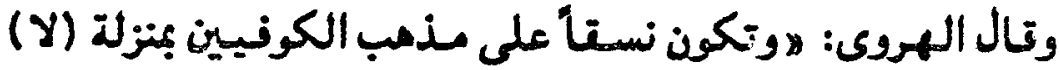

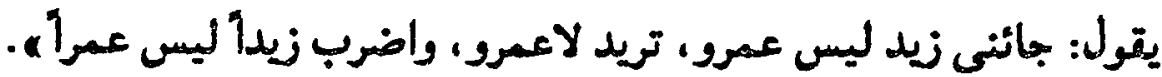

وجاء فى كتاب الحلبيات للفارسى : "وقالوا - (البغداديون)-

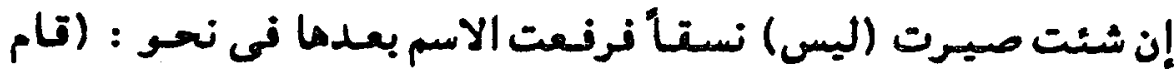

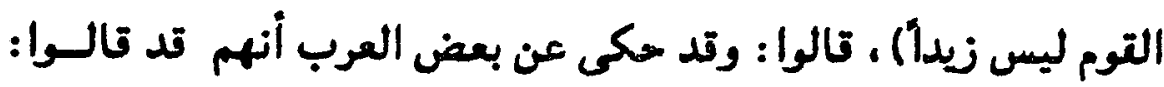

$$
\begin{aligned}
& \text { مجالس ثعلب I\&/Y. } \\
& \text { - Yrol } \\
& \text { المليات rir } \\
& \text { التبصرة } 194 \text { ـ }
\end{aligned}
$$

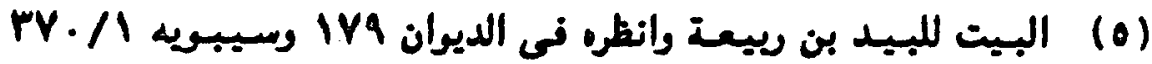

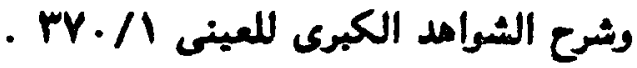


ذال ليس واهد ولااثنان فرفعه ه "(") ولعل من أدلة المجيزين لذلك تول الشناعر :

أهن المفر والإلد الطلسب والأهرم المغلوب لهيس الفالب) ونتول: إن ماحكاه - أبو على النارسى - عن بعض العرب من

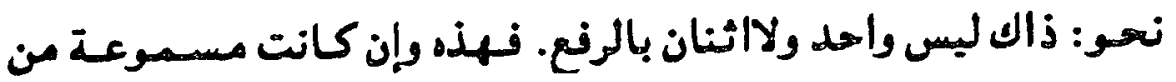

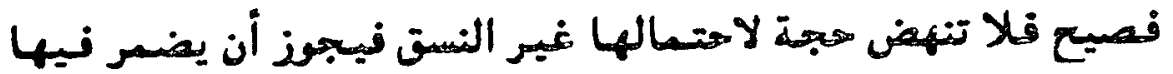

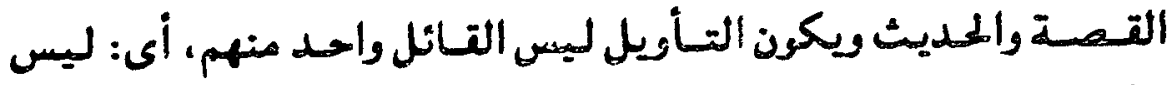

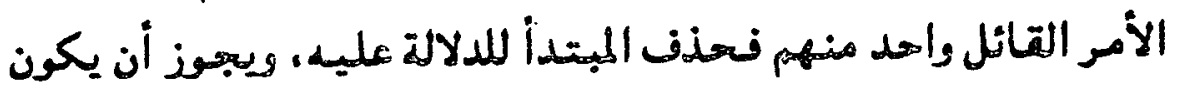

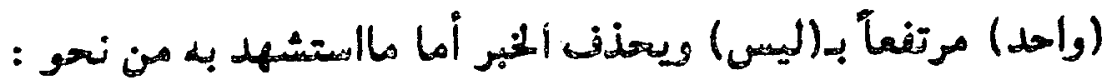

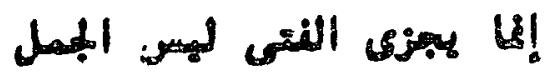

فرواية سيبويه : إنا يجزي الفتهى غير الجململ(").

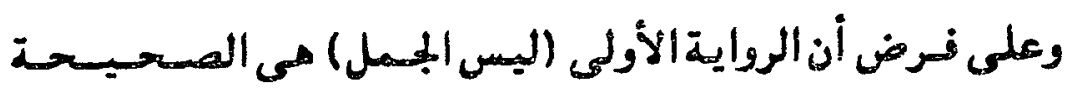

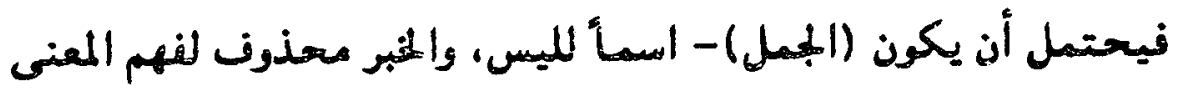

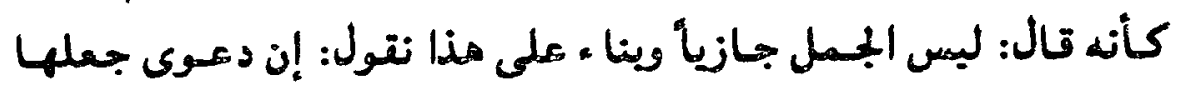

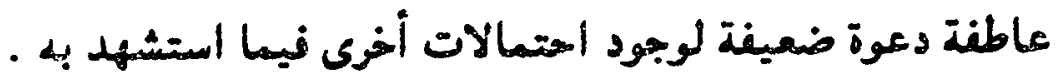

$$
\text { الحلبيات r M r . }
$$

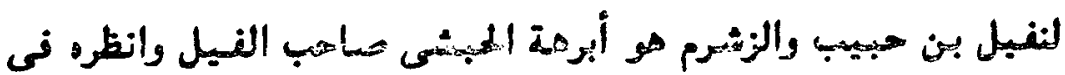

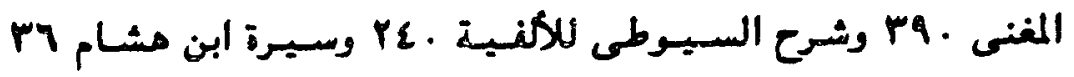

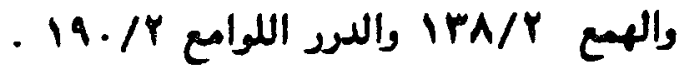


وقد انترض - الفارسى - بعض التساولات نتال: (1) بإن قال

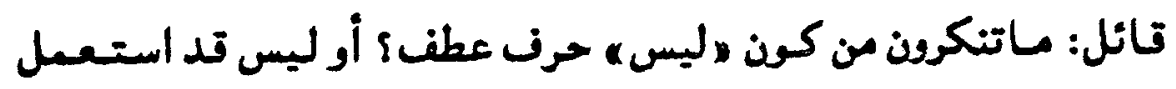

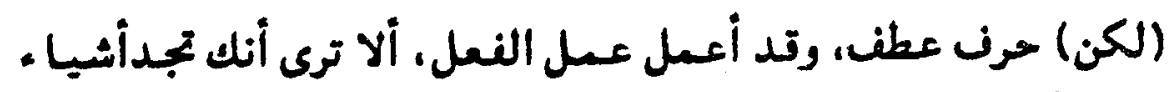

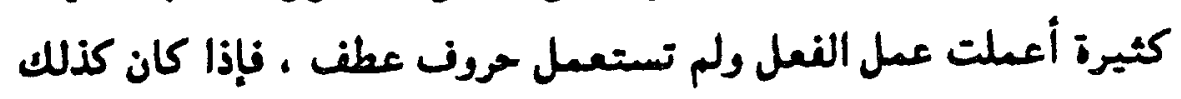

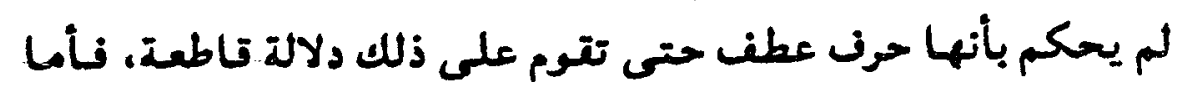

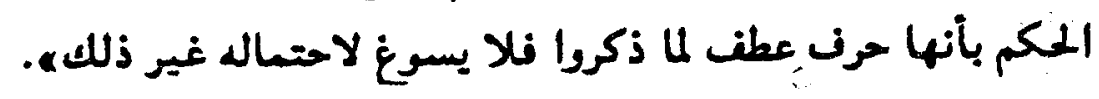

دخول همزة الإستغهام عليها : هذا؛؛ وإذا دخلت عليها ممزة الاستغنهام للتحرير كقوله تعالى:

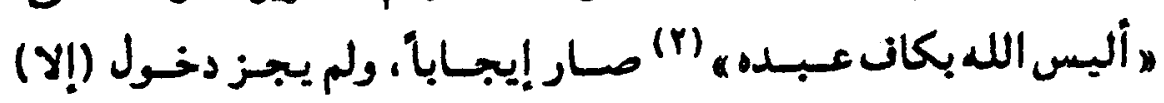

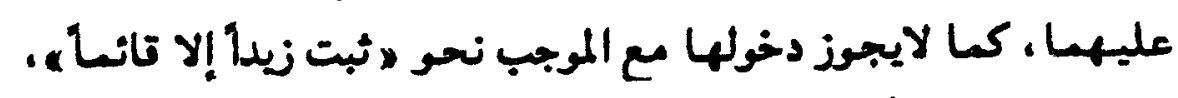

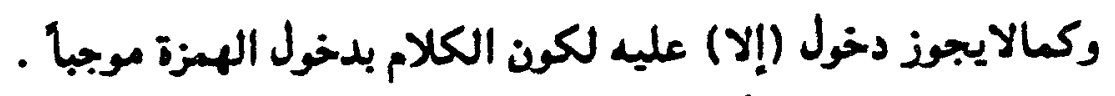

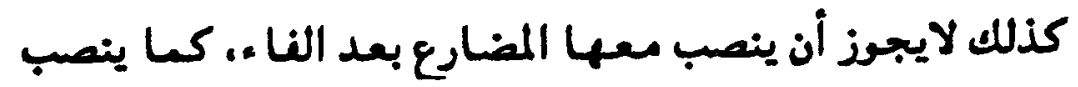

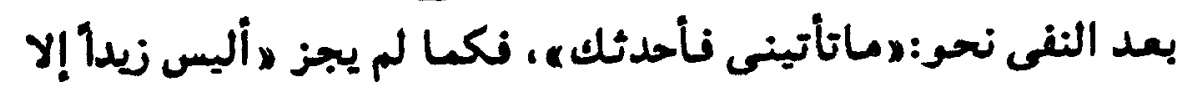

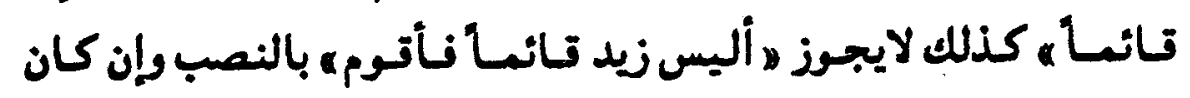

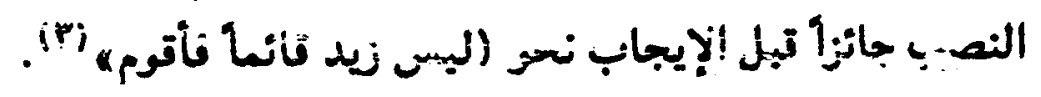

دخول الباء ني خبرها :

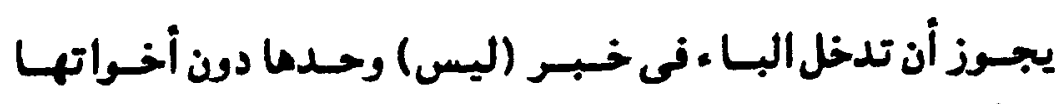

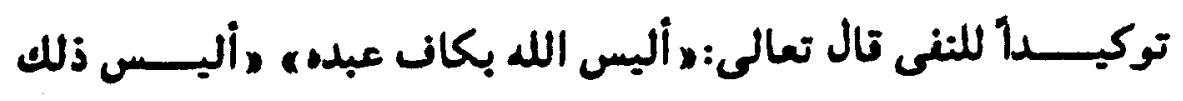

$$
\text { آلية لبه من الزمر . }
$$




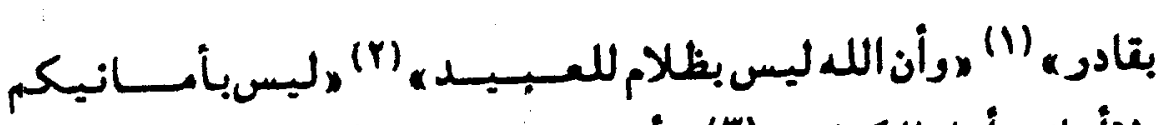

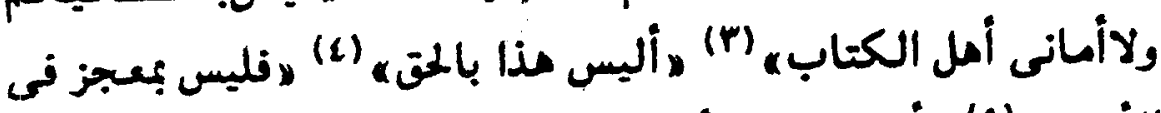

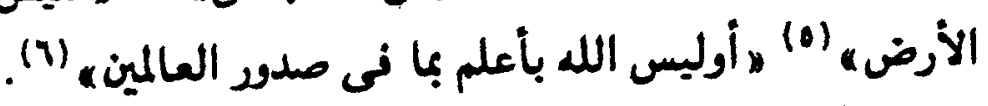
ومنه قول الشاعر :

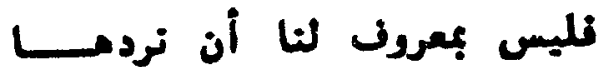

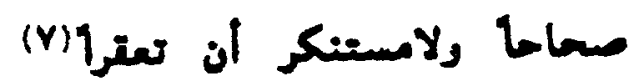

أى: نليس بمعروف لنا ردها. فردما اسم ليسم، و(بعروف) خير.

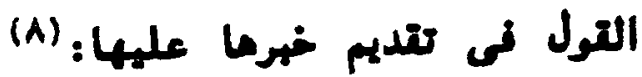

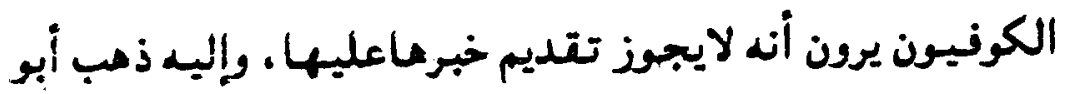

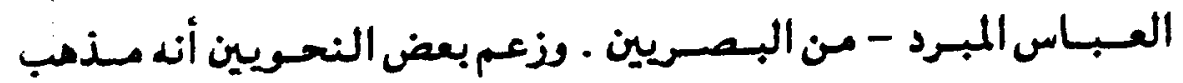

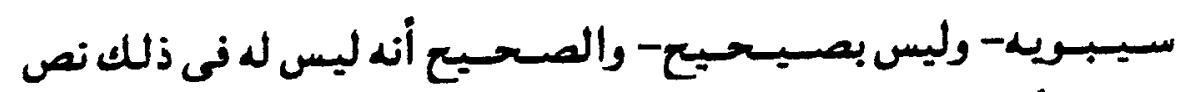

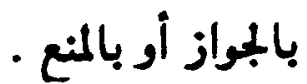

$$
\begin{aligned}
& \text { آية .ع من التيامة . }
\end{aligned}
$$

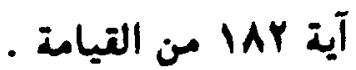

$$
\begin{aligned}
& \text { آية rr r من النساء . . }
\end{aligned}
$$

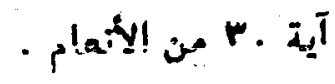

$$
\begin{aligned}
& \text { آية rr من الأحقان . }
\end{aligned}
$$

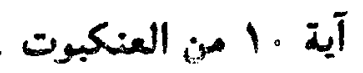

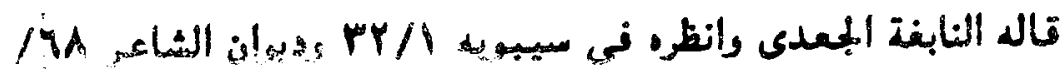

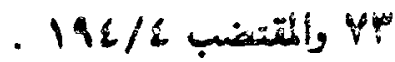

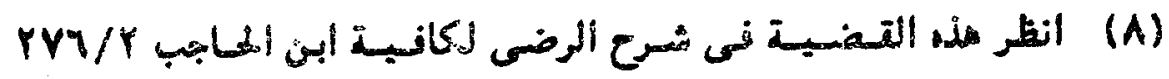

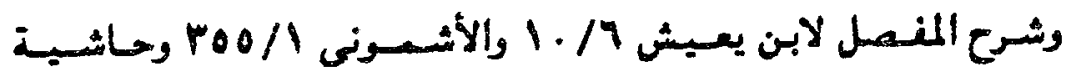

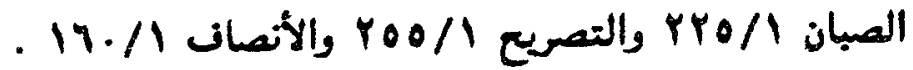


والبصريون قالوا: بجواز تقديم خبر (ليس) علبها ، كسا يجوز

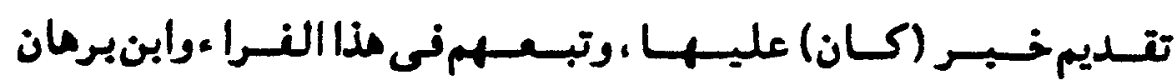

والزمخشرى والشلويين ، وابن عصفور:

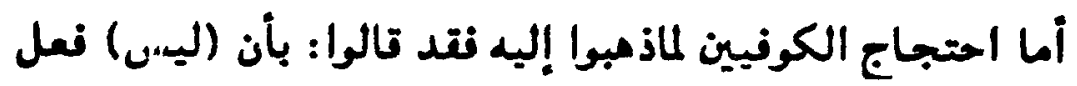

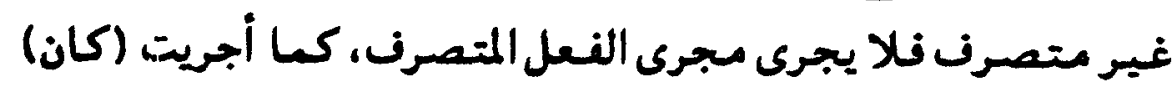
مجراه لأنها متصرفنة فنقول كان - يكون - كن - كائن - ولايكون ذلك فى (ليس) .

وإذا كان كذلك فوجب ألايجرى مجرى ماكان متصرنا ولايجوز

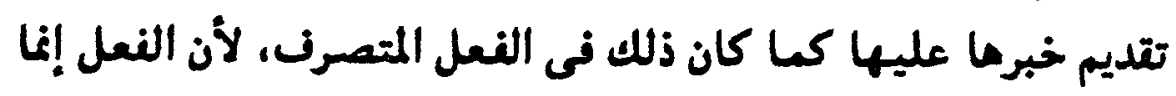

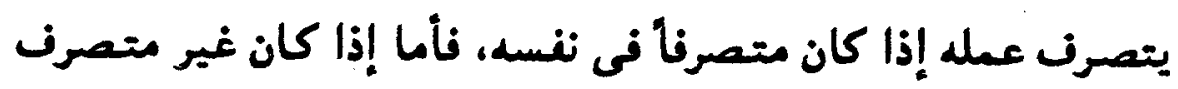
فى نفسه فبنبغى ألا يتصرف عمله . أما البصريون فتد قالوا بالجواز قياسا على تقديم خبر (كان)

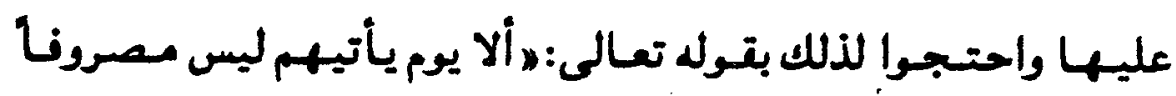

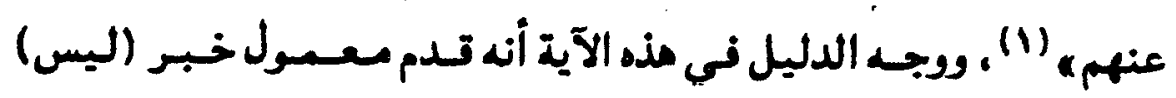

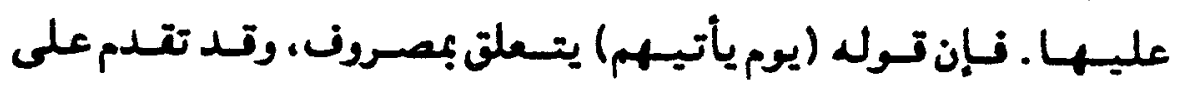

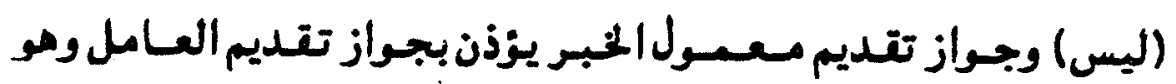
(الحبر) على (ليس) لآن المعمول، لايتع إلا حيث يقع العامل -

والصحيح من مذين الرأيين مو رأى الكوفيين وقد ردوا اهتججاج

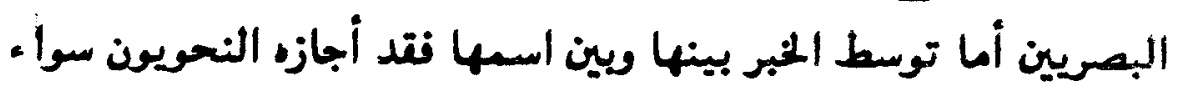

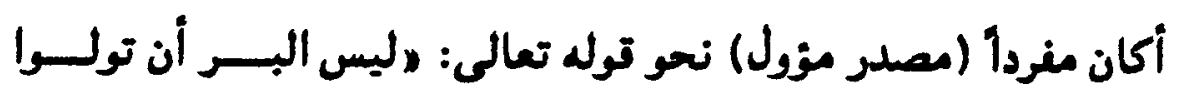




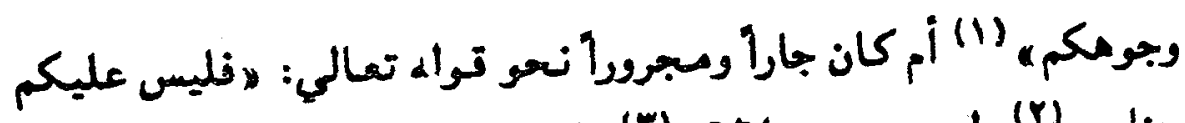

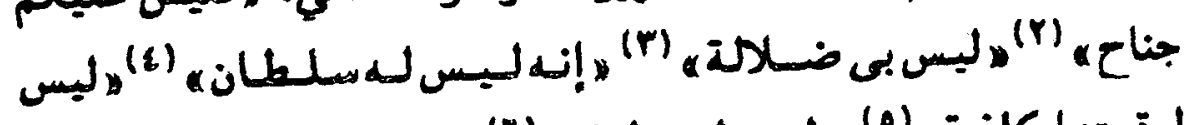

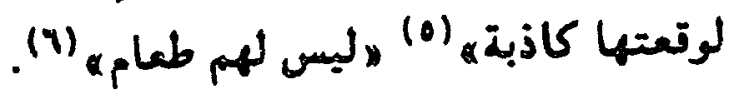

\section{خهرما في الترآن الكيكيم :}

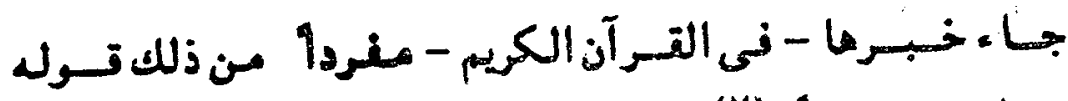

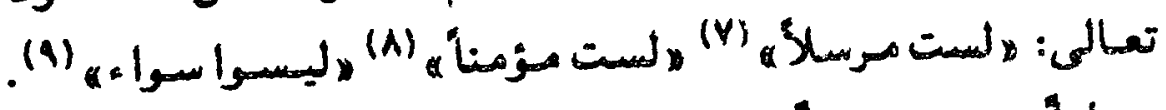

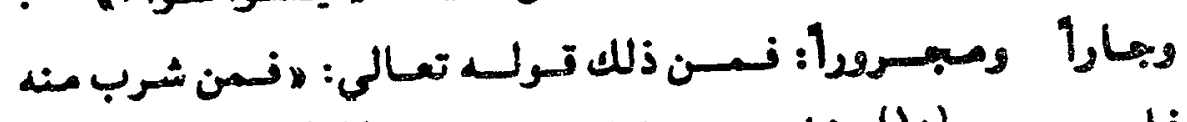

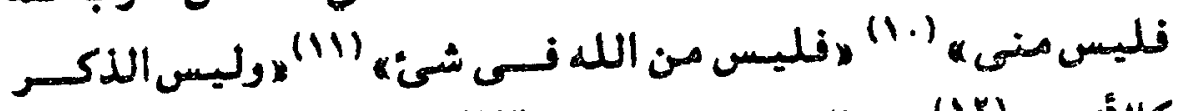

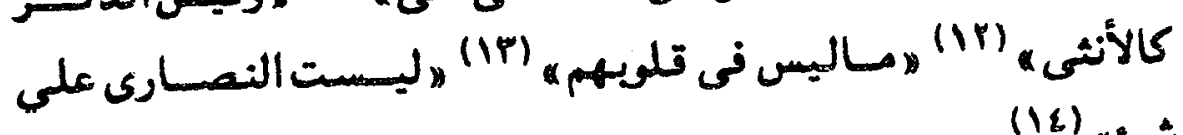
شى: (18)

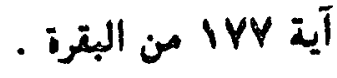

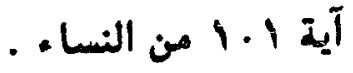

$$
\begin{aligned}
& \text { آية ال7 من الأعراف ـ }
\end{aligned}
$$

(0) آية Y من الواقعة .

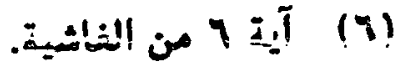

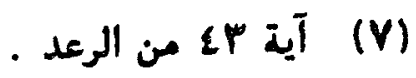

(A)

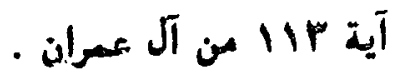

(1)

(II)

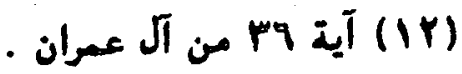

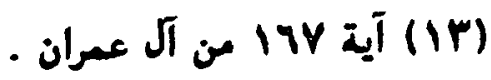

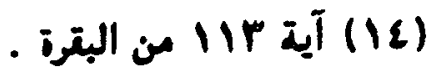




\section{tomg}

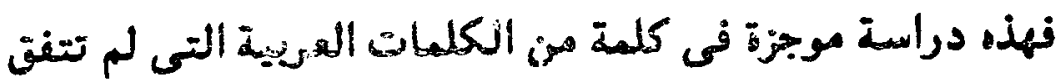

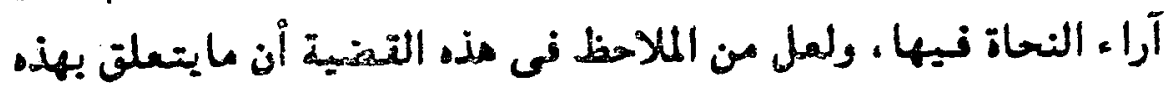

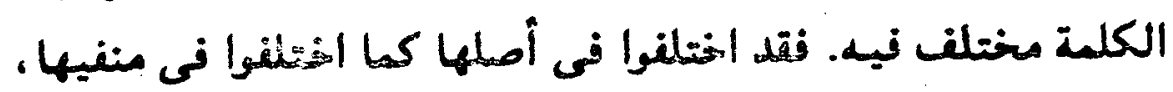

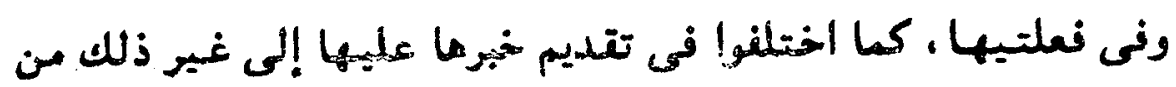

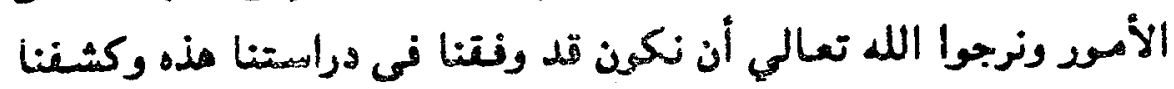

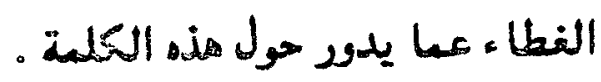

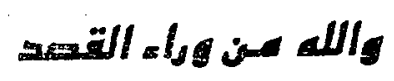

/ أحمد ميمهد السعيد نافه

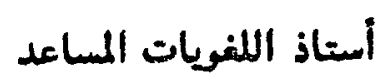
المنصورة فى 1990/9/40 فى كلية اللغة العربية بإيتاى البارود 
- YoY-

8) Iflg glingl

1 - أخبار النحويين البصريين: لأبيى سعيد الحسن بن عبد الله السيرافى،

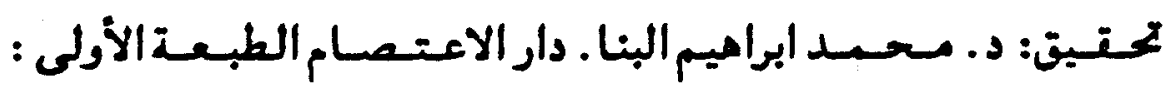

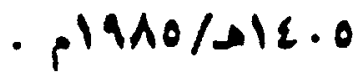

r - ارتشان الضرب من لسان العرب: لزيس حيان الأندلسى، يحقيق: د. د.

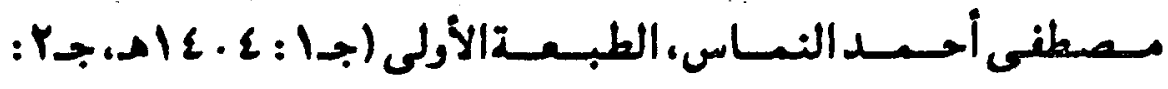

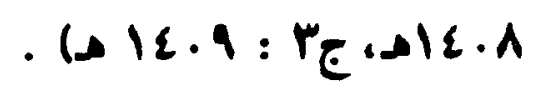

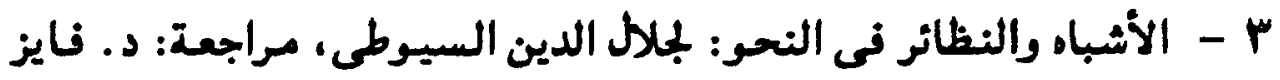

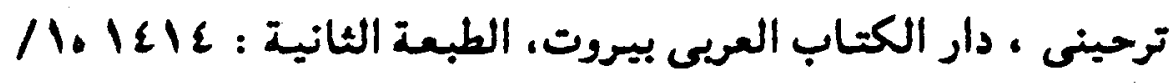

.

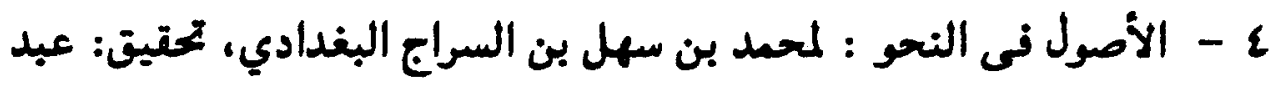

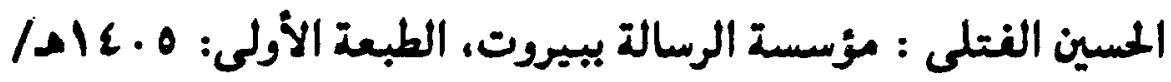

199r

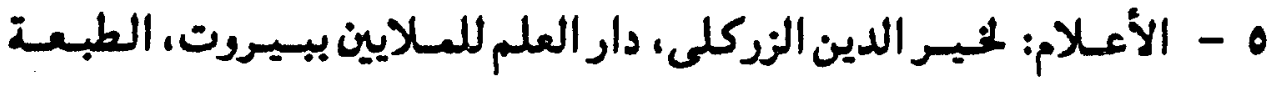

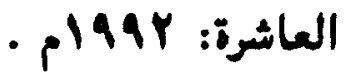

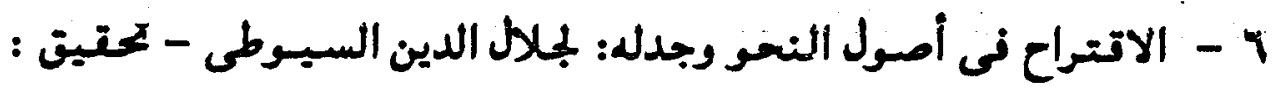

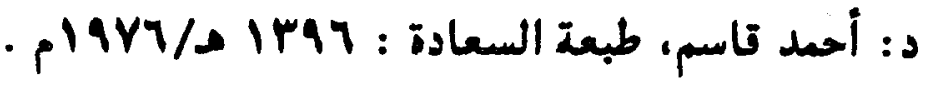

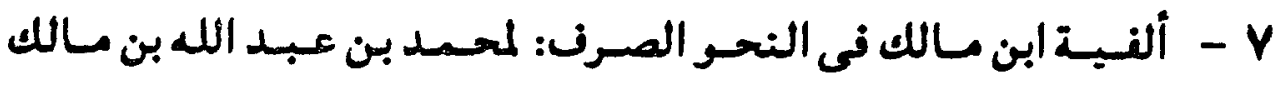

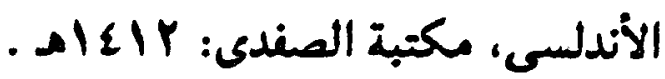

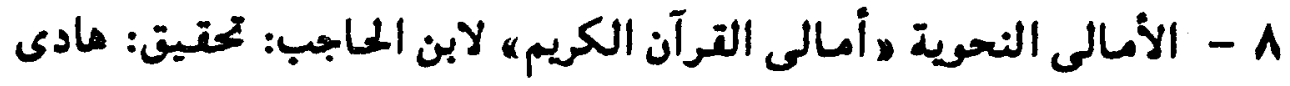

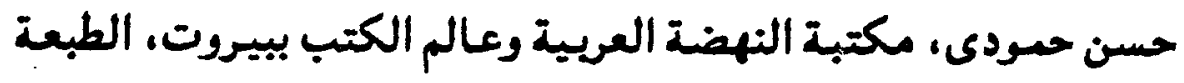

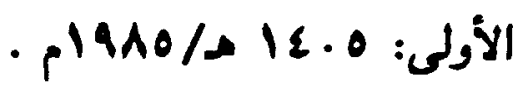




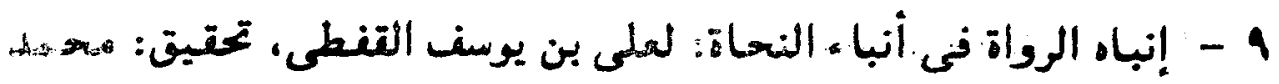

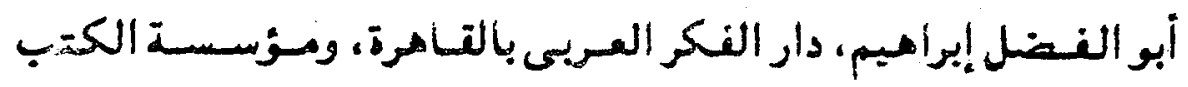

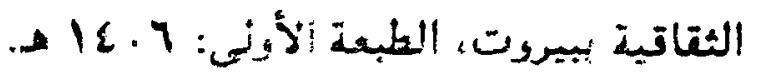

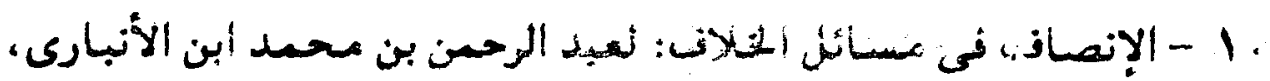

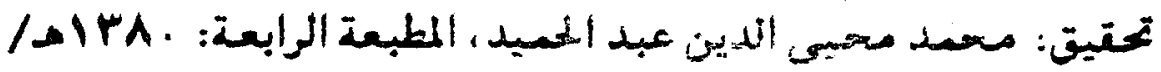
· 11 - أوضع اللدالك إلى ألفية ابن مالك: لابن عشام الأنصارى. تحتيق :

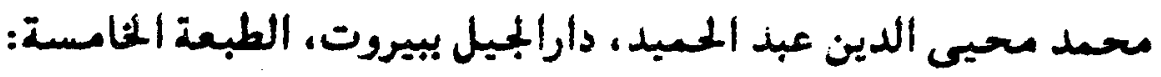

$$
\text { - plava/sirq }
$$

r البسيط فى شرح جسل الزجاجى: لابن أبى الربيع عبيد الله القرشى

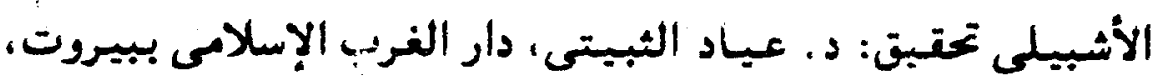

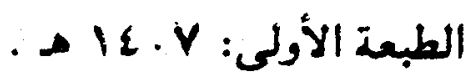

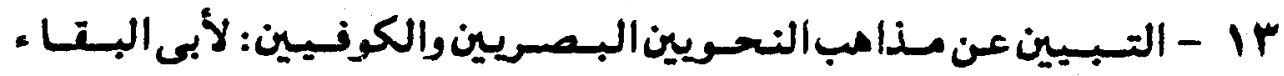

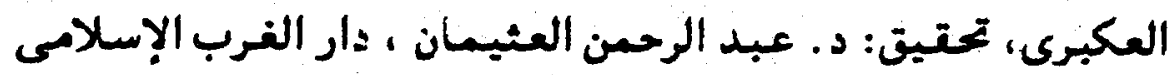

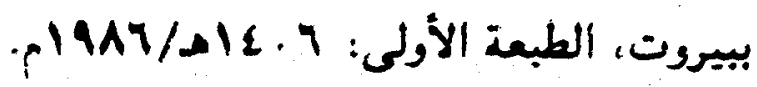

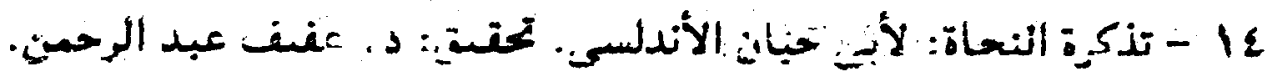

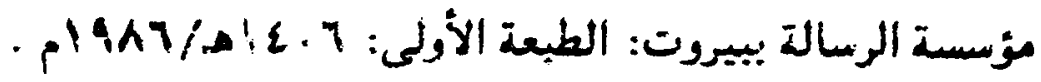

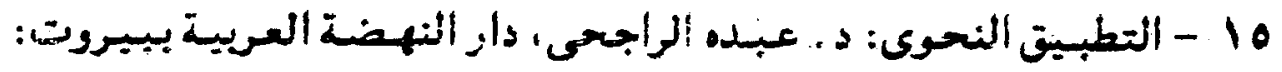

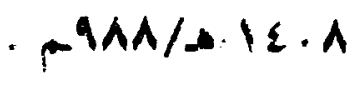

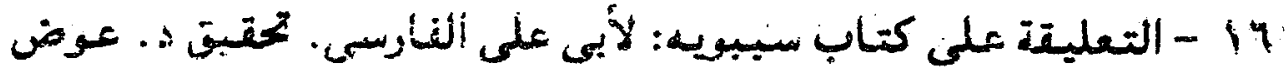

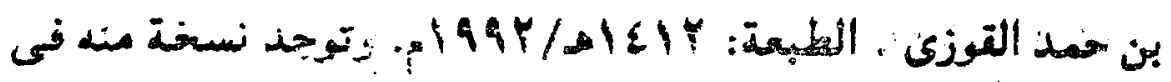
هكتبة ألملك فها هله 
IV - تفسير البحر المحيط، لأبى حيان الأندلسى. طبعة السعادة، وطبعة

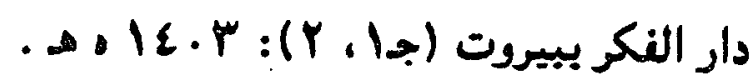

11 - تغسير الكشاف : لمحمود بن عمر الزمششرى، دار الكتاب العريى ببيروت .

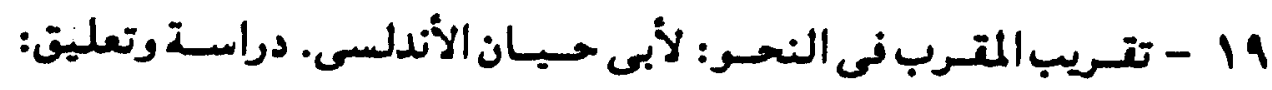

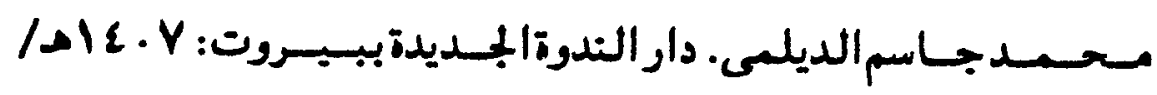

- par

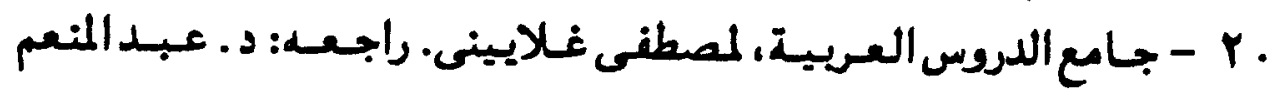

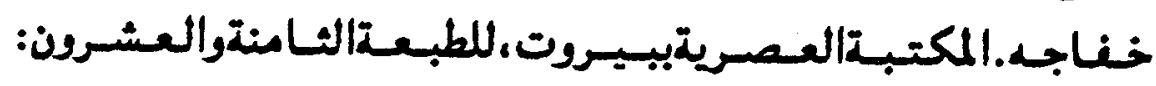
. $1994 / A \mid \varepsilon / \varepsilon$ ا Y - الجدول فى إعراب القرآن: لمحمود صافى، دار الرشيد ومؤسسة الإيان

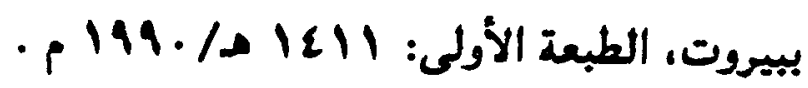

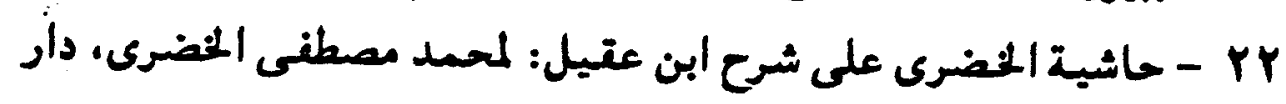

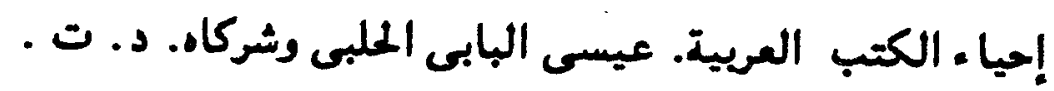

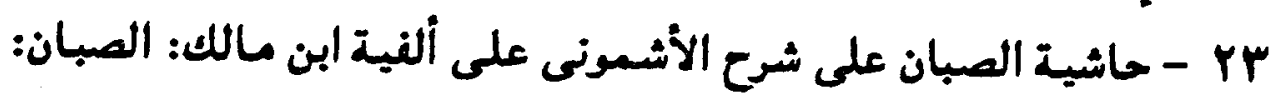

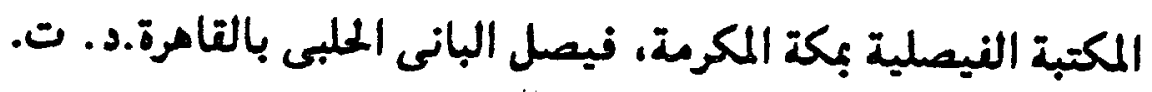

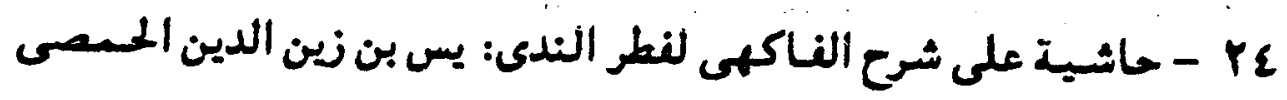

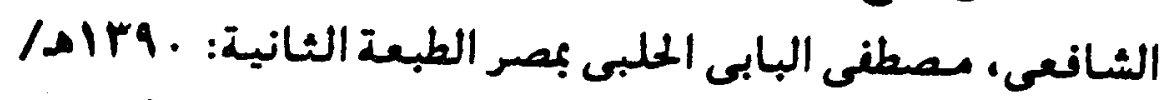

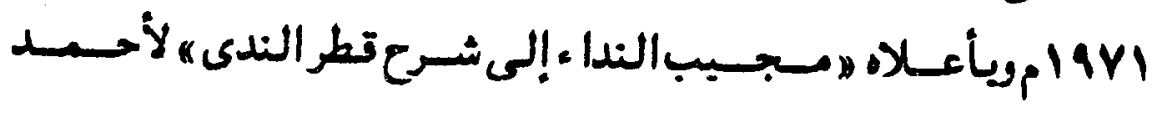
- الفاكهى

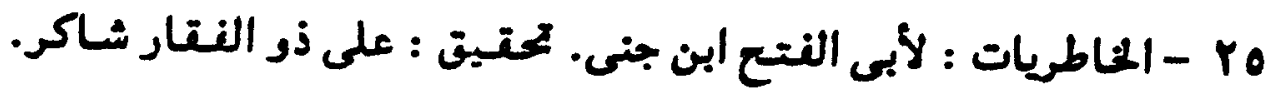

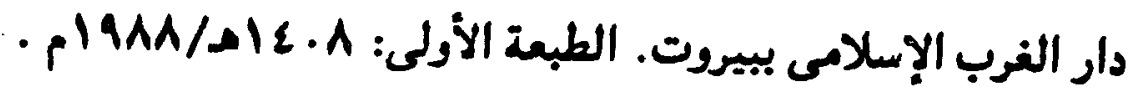


YY - الخصائص: لأبى النتح ابن جنى. تحقيق: د. ـ محمد على النجار. دار

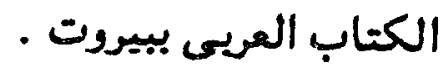

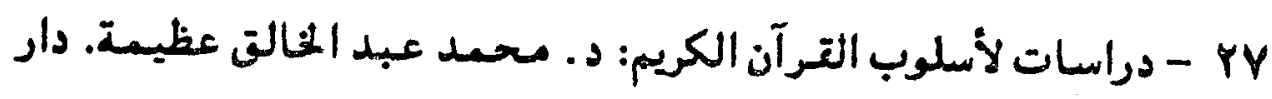

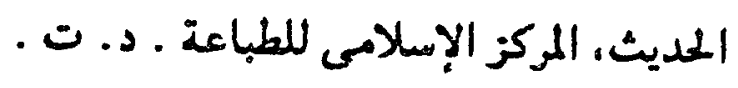

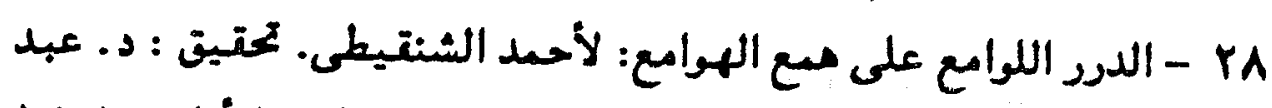

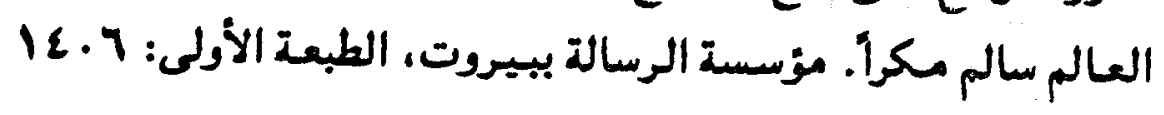

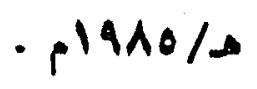

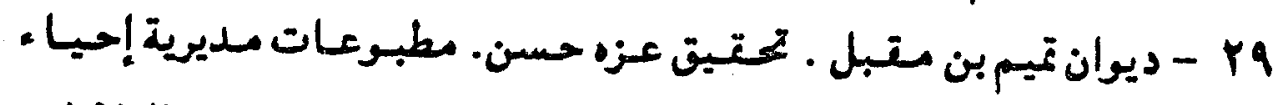

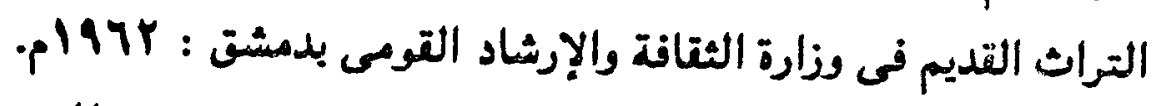

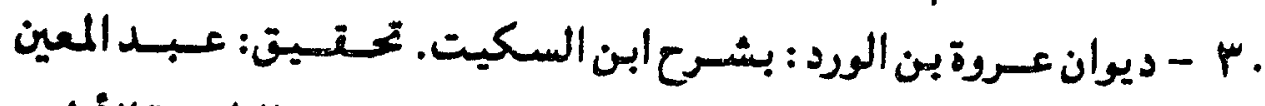

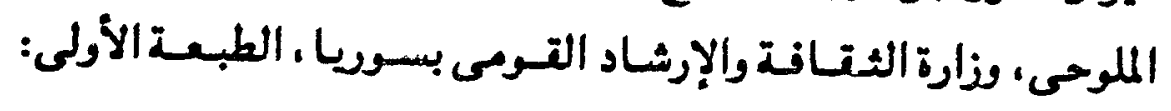

$$
\text { • - 1974 }
$$

اس - ديوان الغرزدق:لهام بن غالب (الغرزدت) ، دار صادر بيبروت.د.ت.

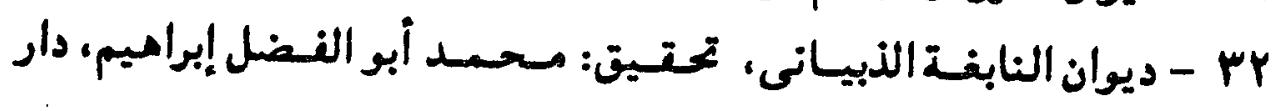

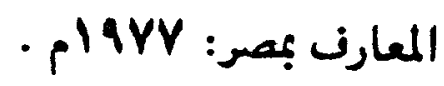

rr - رصف المبانى فهى شرح حروف المعانى: لأحمد بن عبد النود المالقى:

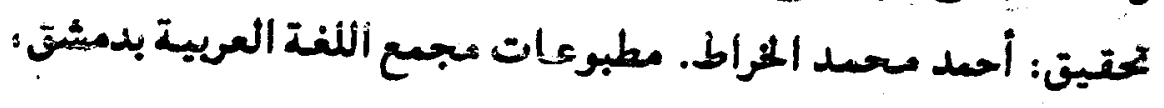

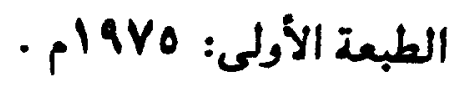
ع - شرح الأشسونى على ألنية ابن مالل (منهج المسالك إلى ألنية ابن

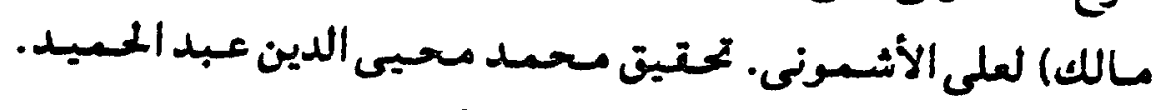

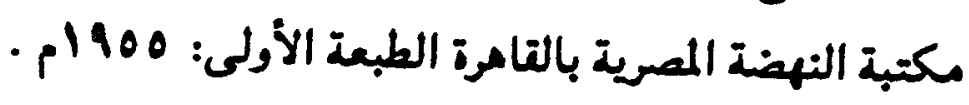

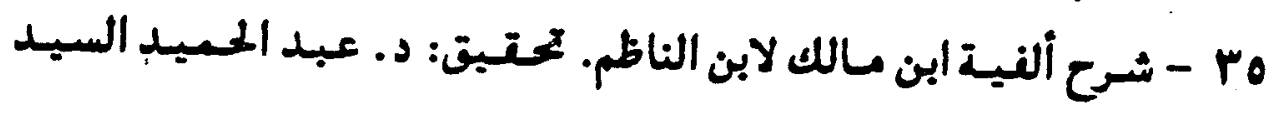

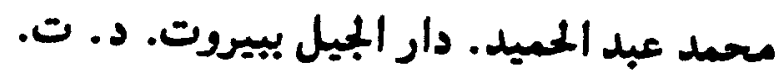




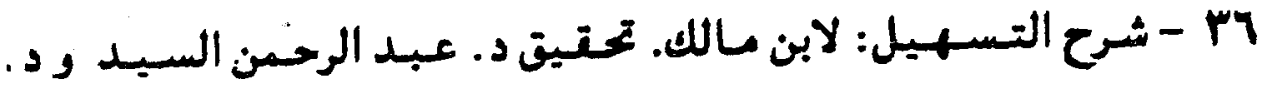

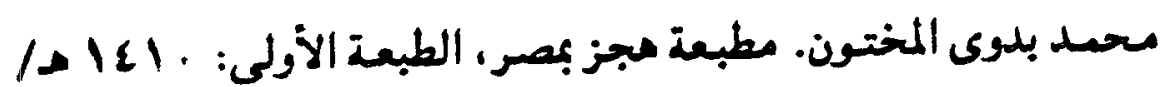
- 199 .

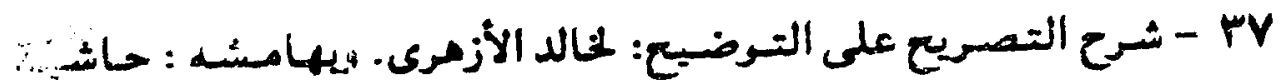
الشيخ يس ألعليسى إلممصى. دار الفكر . د. ت .

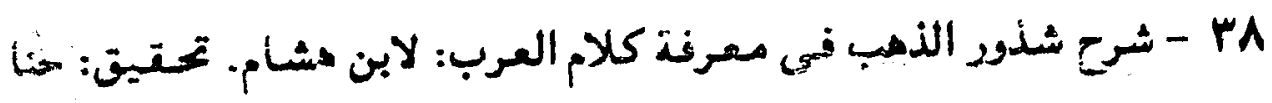

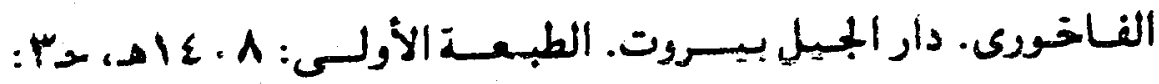
( (1)

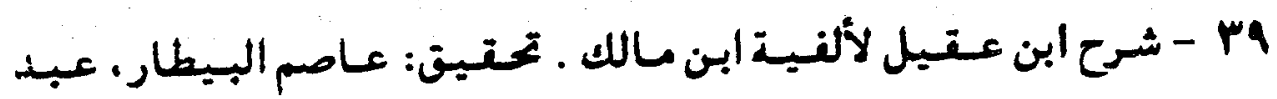

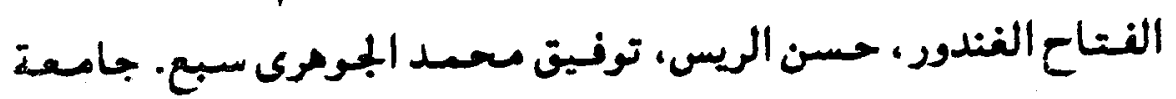

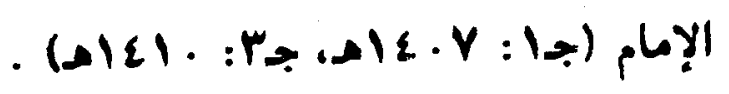

•ع - شرح قطر الندى وبل الصدى: لابن مشام الأنصارى. تحقيق : محسد محيى الدين عبد إلمبيد. مكتبة الرياض المديثة بالرياض . د. ت . . .

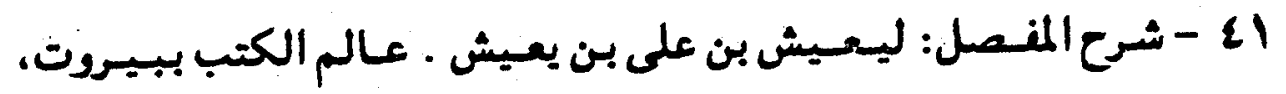

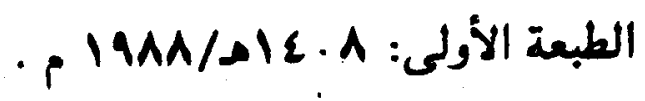

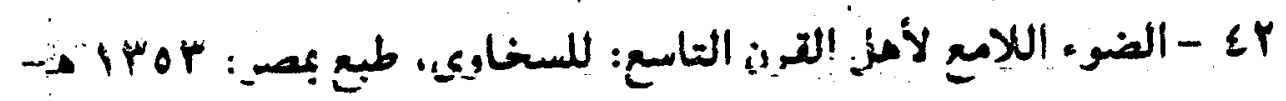

\section{. (ج) (ج) (1700}

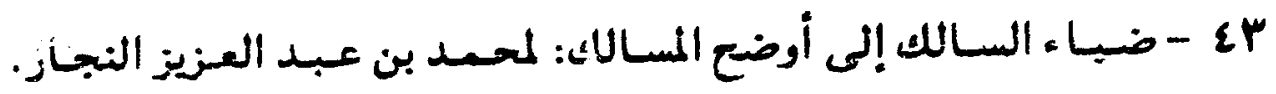

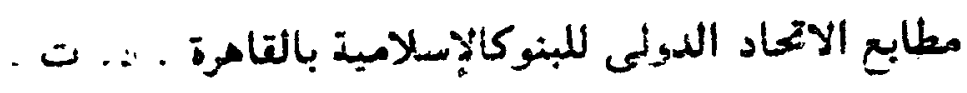

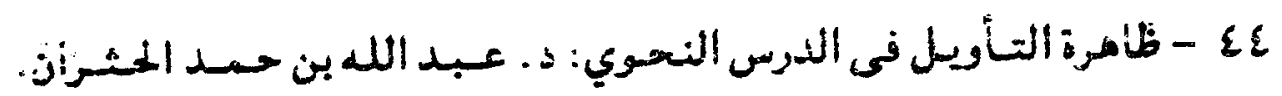

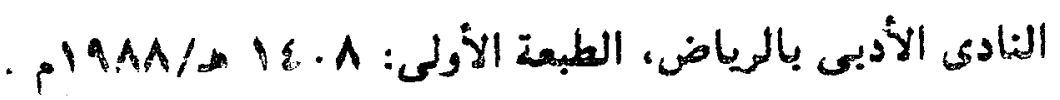

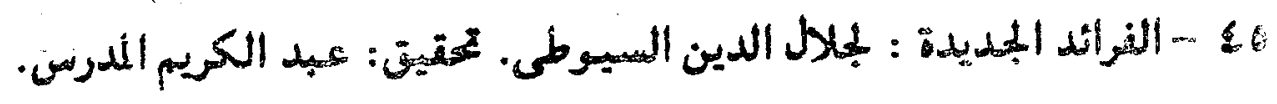

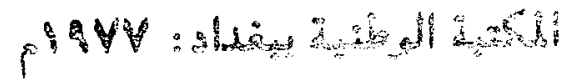


$-r M 1-$

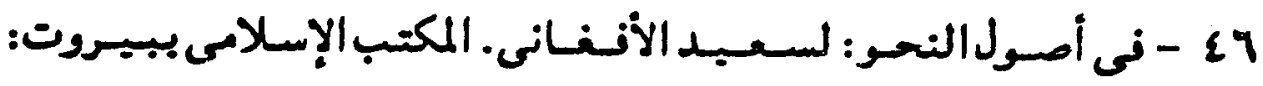

. IAAV/AlE.V

\&V

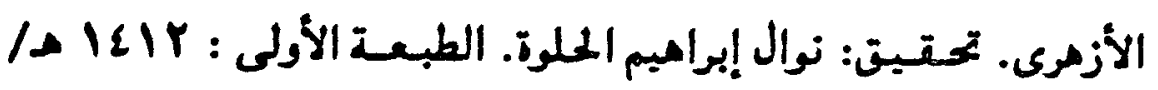

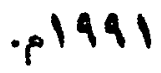

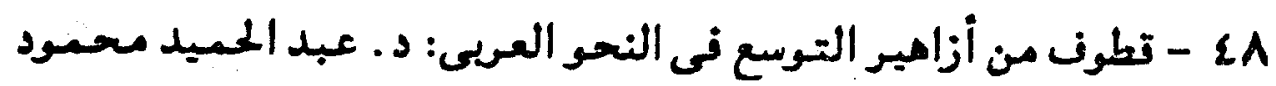

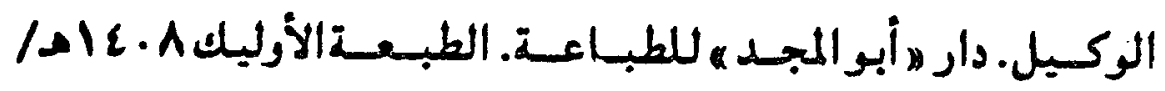

. 1919

9ع - الكتاب: لسيبويه. تحقيق: عبد السلام محمد هارون. مكتبة الحائجى

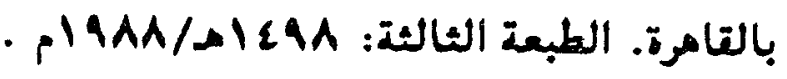

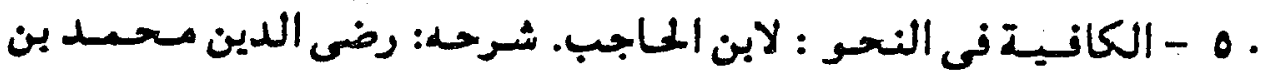

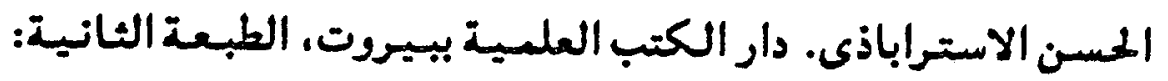

- مان

1 - 1 - لباب الإعراب : محمد بن محمد بن أحمد الإسفرايينى. تحتيق: بهاء

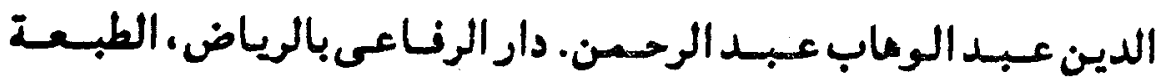

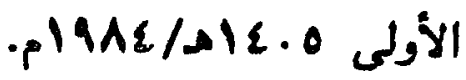

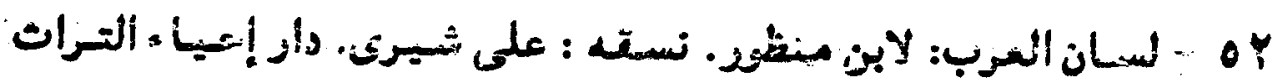

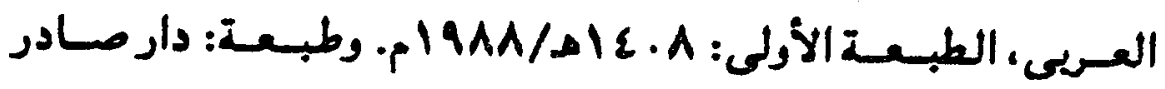

بييروت .

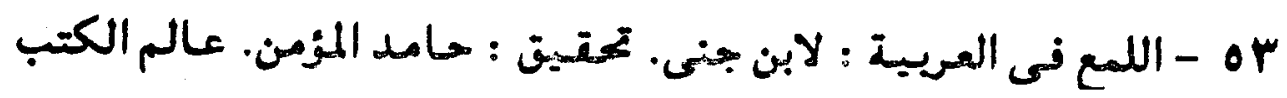

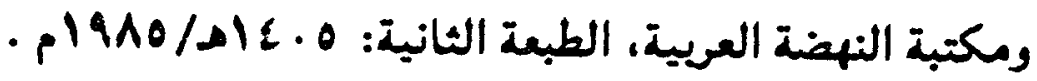

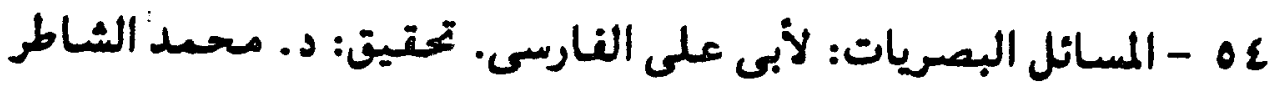

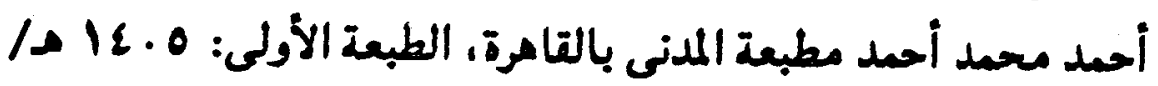

.$p 1910$ 
;

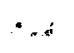


من قضايا الثحو

مطع التابع عن المثتبوع

دراسة نظرية وتطبيقية على القرآن الكريم

والشعر العربى

بحث علمى

تاليف

دكتور

جمال الاين محتَّد حَّمَاد

المدرس بعسم اللغويات

في كلية اللغة :"عريبة بإيتاى البارود

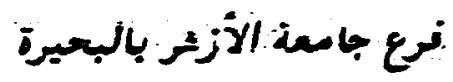

$$
p^{1990-81817}
$$





\section{بلبر الله الرحمن الرحيم}

\section{إلمتدمبس}

أسلوب التسابع المتطوع من الأسالبب التى تحتـاج إلى مزيد من

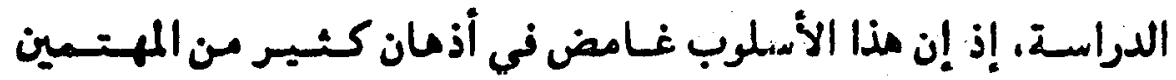

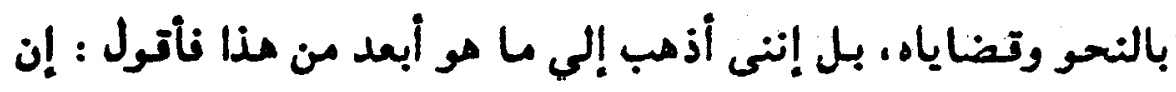

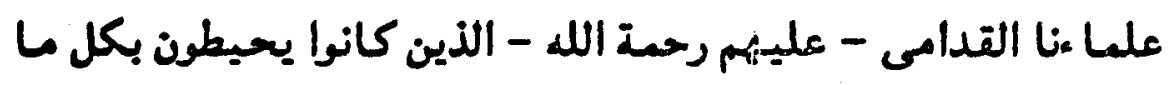

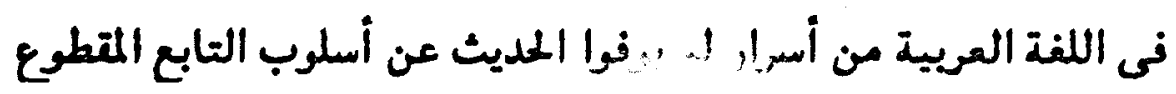

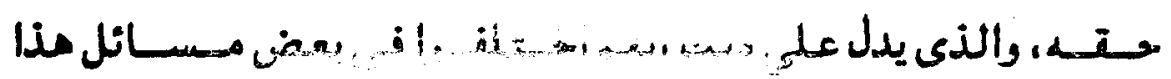

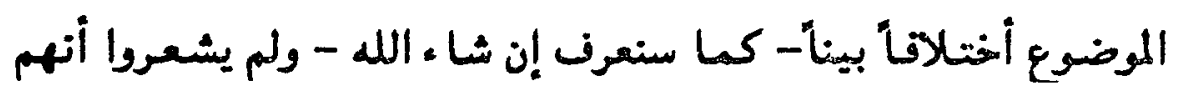

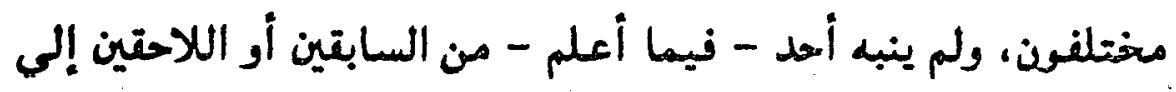
هذا الملاق.

ولعلى ما يؤيد زعمى أن هذا الأسلوب مازال غامضاً ومسحتاجاً

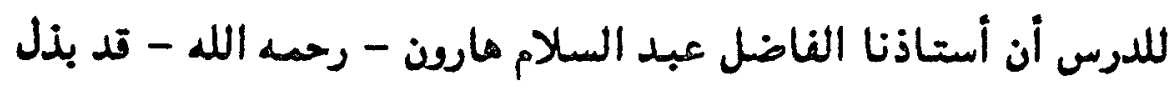

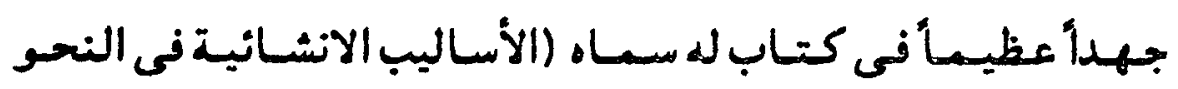

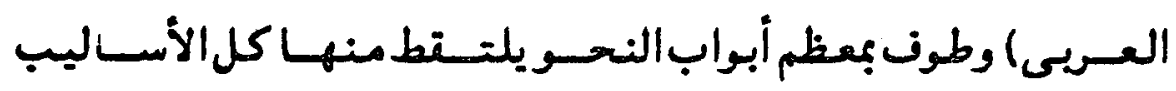

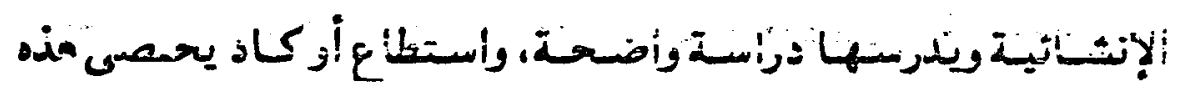

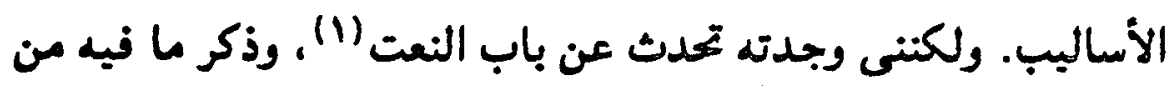

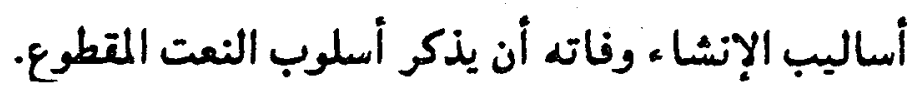

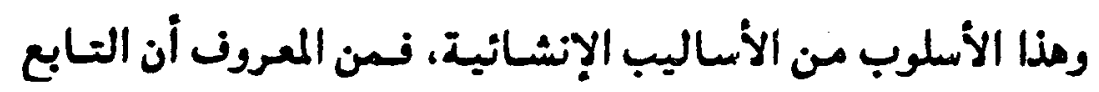

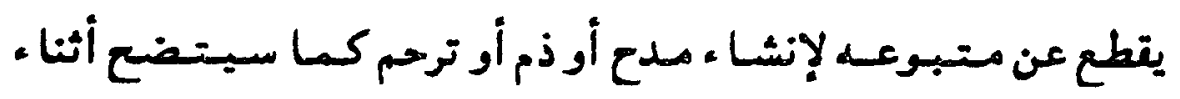
الدراسة.

انظر الأساليب الإنشائية ص 1 ا 1 ط الثانية. نشر مكتبة الماليجى 
نعوتف أستاذنا - ومو المعروف بالدتة والصبر فى البحث- من

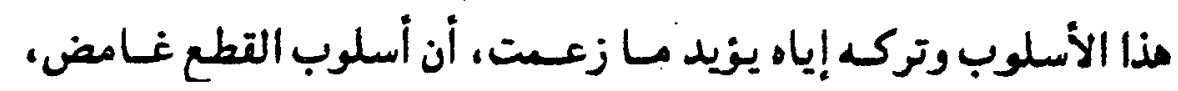
ومازال في حاجة إلي البحث والدرس.

وقد ذكر أبو حيان فى البحر "(1) عن الزمخشرى أن بعض الناس

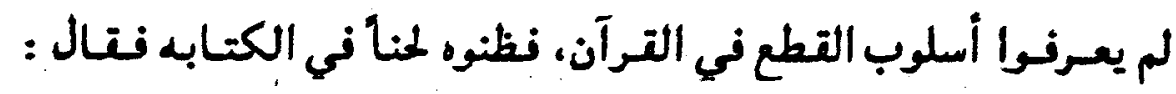

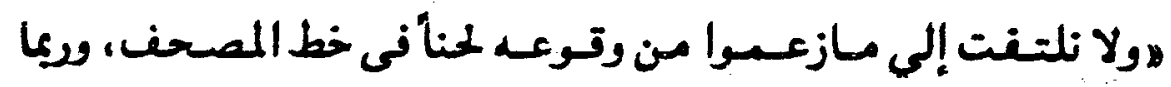

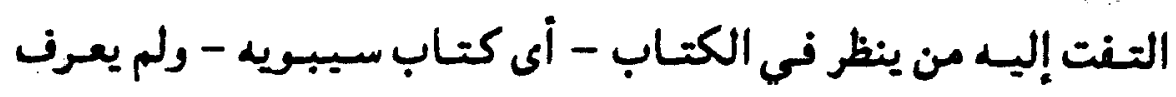

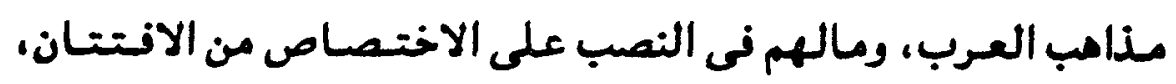

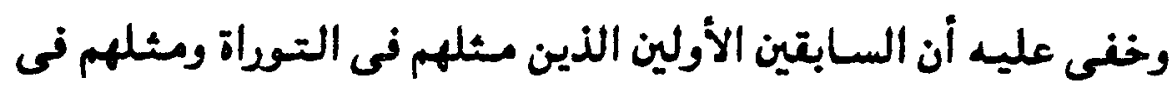

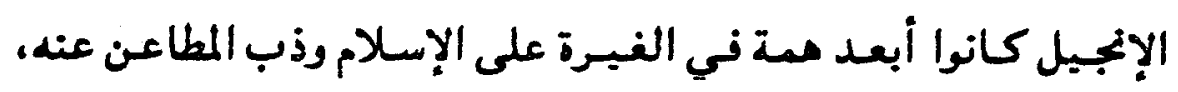

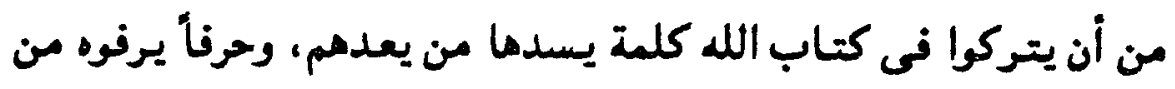

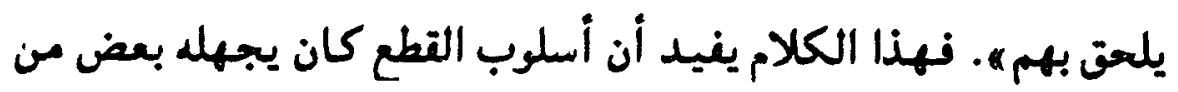

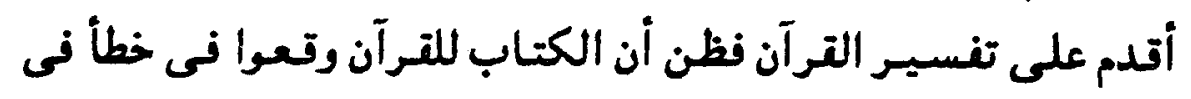

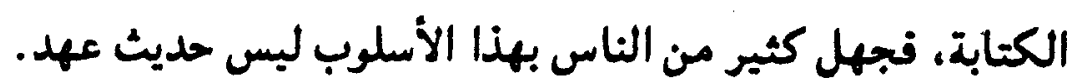

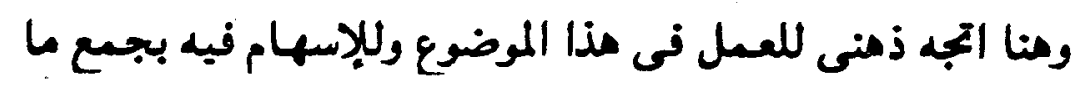
استطعت، وما من به ريى على من أقوال السابقين ومناقشتهيا.

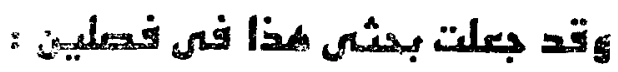

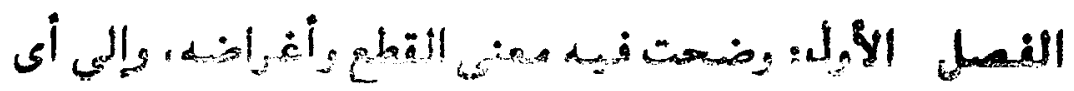

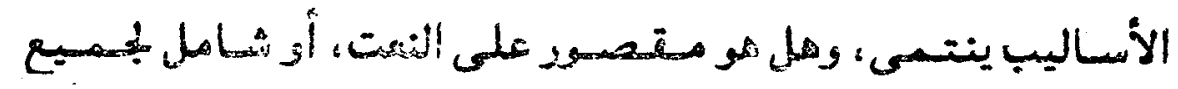

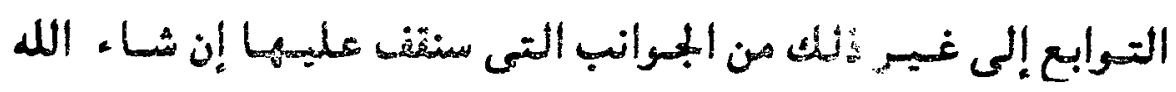
تعالى. 
وأما النصل الدانى : فقد تمت فيه بدراسة تطبيقية على

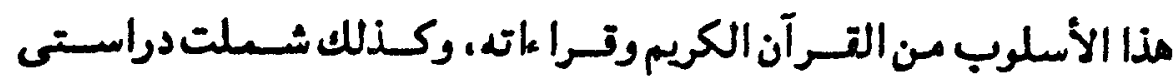

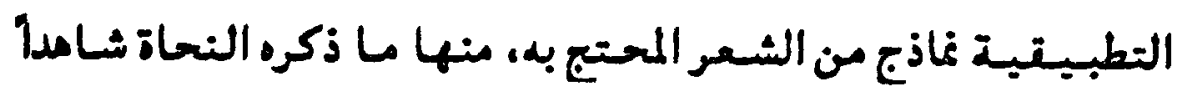

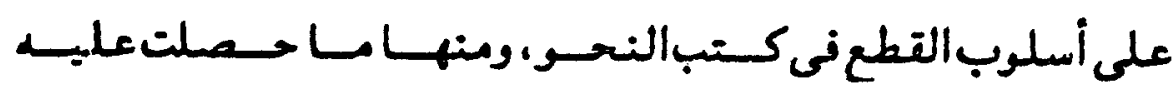
باجتهادى.

والله أسأل أن تكون مذه الدراسة خالصة لوجهه الكريم إنه نعم

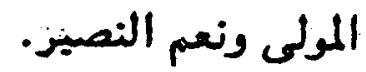

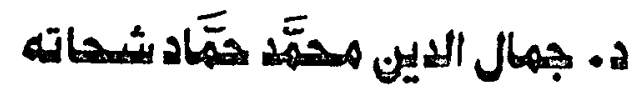

المبرس بتسم اللفويات - بكلية اللغة العريية

فرع جامعة الأزمر بالبحيرة 
|لفولئ |

القמط:

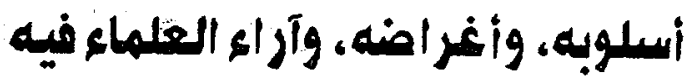

هتيقة التطك :

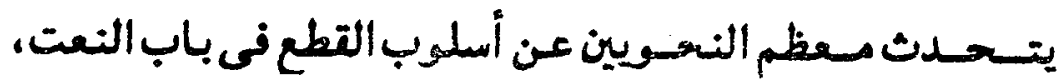
وكسأن القطع لا بحسـد ني تابع من التــوابع إلا النعت. مامو ذا ابن

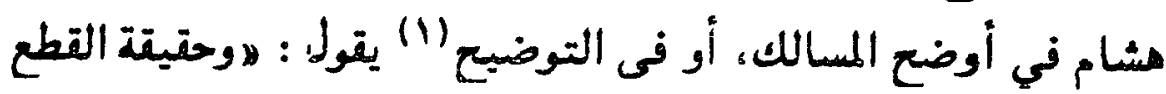

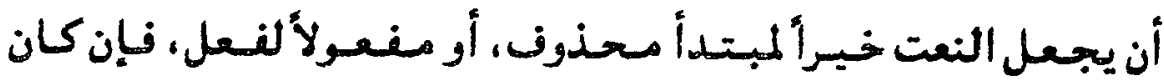

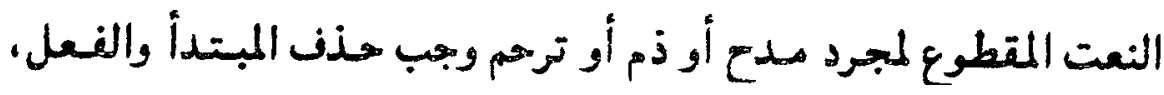
وأن كان لغير ذلك جاز زكرهم.

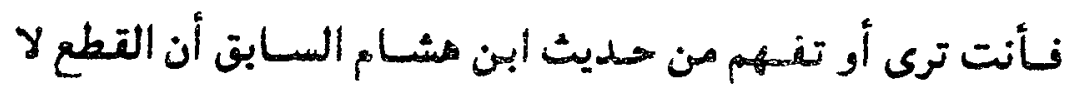
يكون إلا في النعت. أقولى : لعل ابن هثـام وكثيرا من النحاة جعلوا

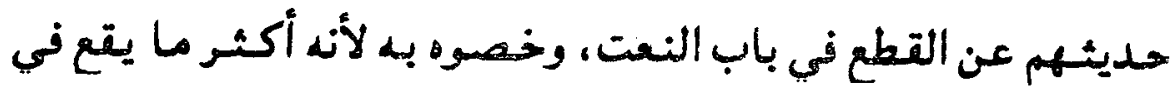

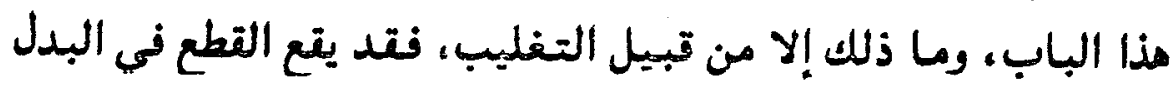

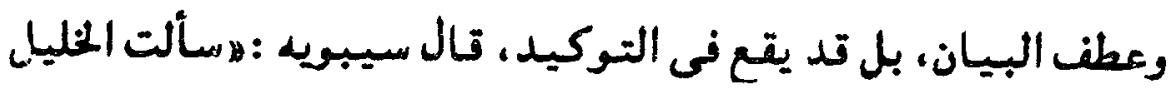

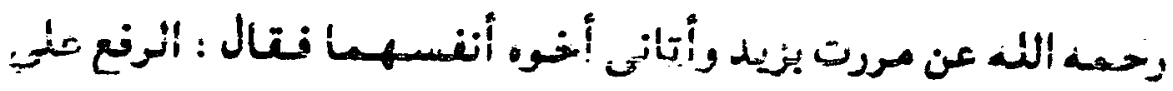

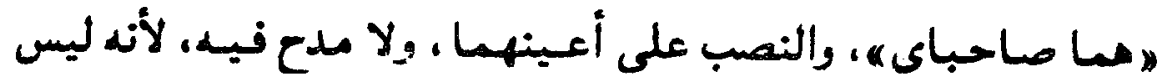
(r) عا عد"

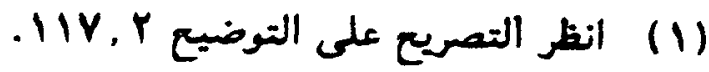

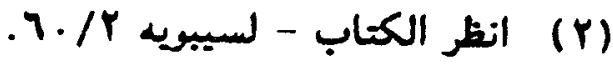


فظاهر هذا القول جواز القطع فى التوكيد مع أن معظم النحويين

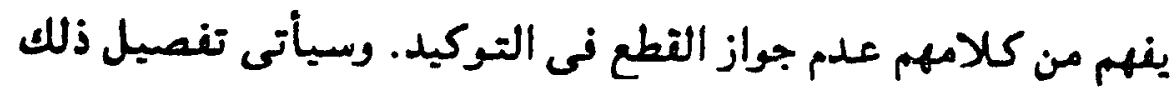
إن شاء الله تعالى.

الهواضع التى بيجب نيها التطع :

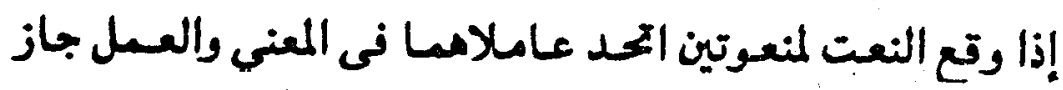

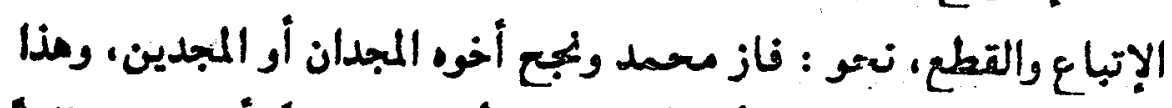

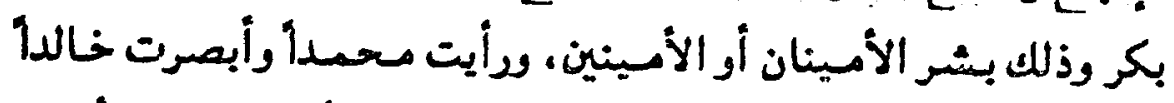

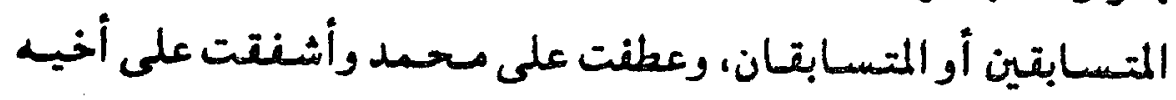

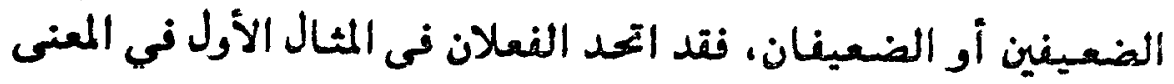

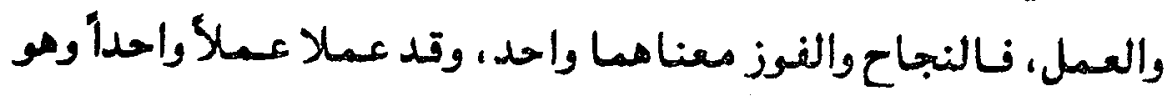

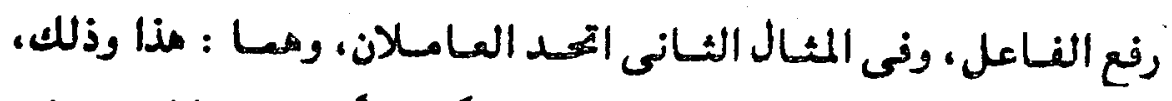

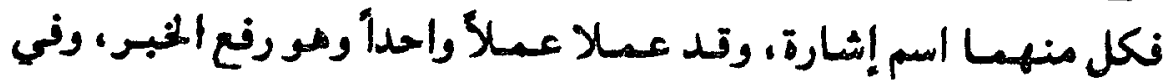

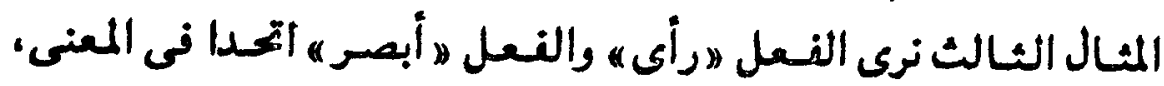
فالرؤية والإبصار معنامها واهد واتحدا في العمل، وهو نصب المنعول.

وفى المثال الرابيح نرى أن الحرف هعلى ه عمل الجر أولاً فى كلهة

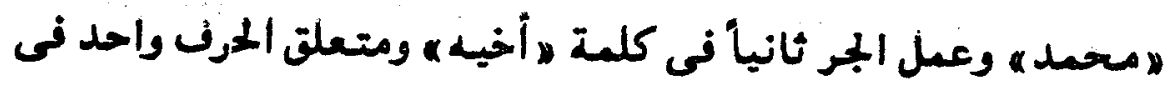

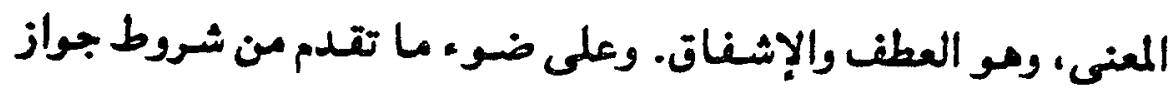

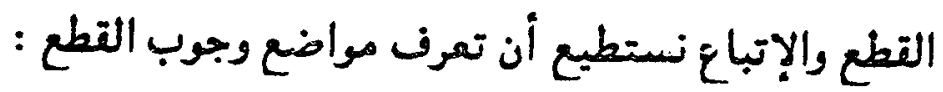

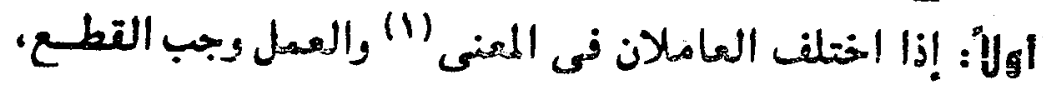
نلا يشترط الإتحاد في اللفظ، انظر ماشية الصبان بهامش الأشمونى 


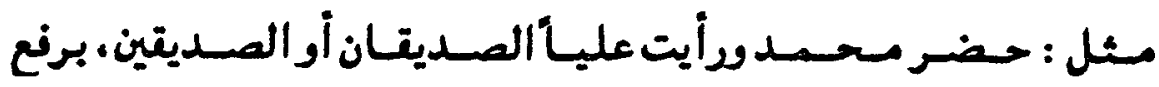
الصديقين خبر| لمبتدأ محذوف أو النصب بغعل محذوف، كسا عرننا .

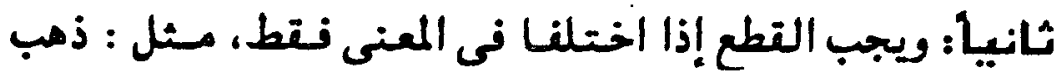

$$
\text { زيد وأتى عمرو الكرينين أو الكريكان. }
$$

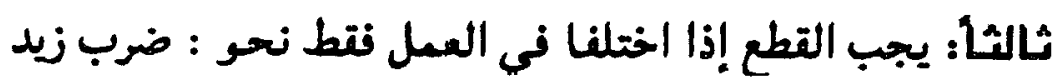
وضريت عمرأ المجرمين أو المجرمان، على التطع.

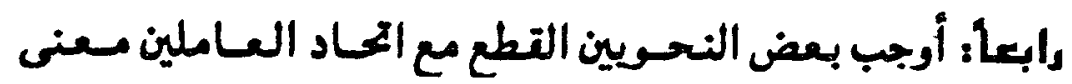

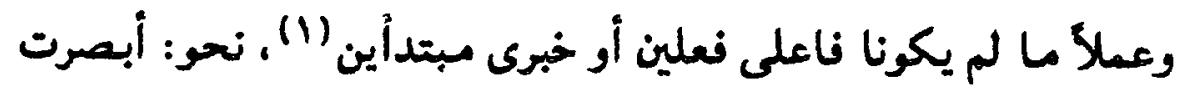

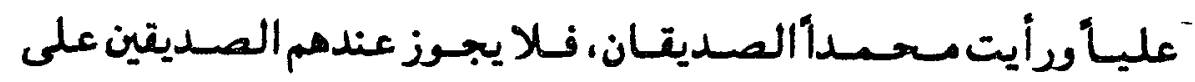

ناهسأ: يجب القطع للا انجبر من جهين كالحرف والإضافة نحو:

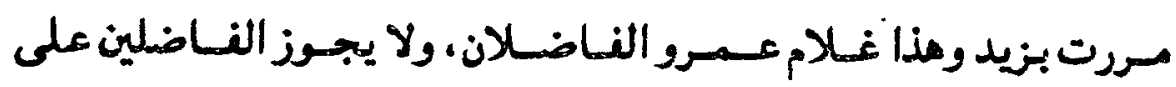

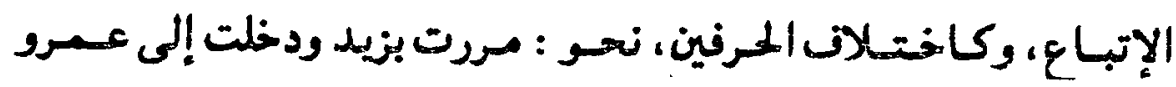
الكريان، ولا يجوز "الكريكن ه على الإتباع، وكاختحلاف مهنى اللمرنين

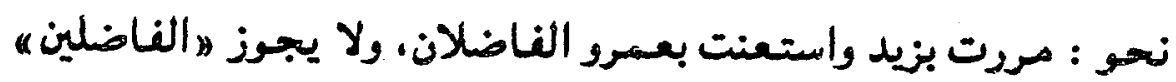

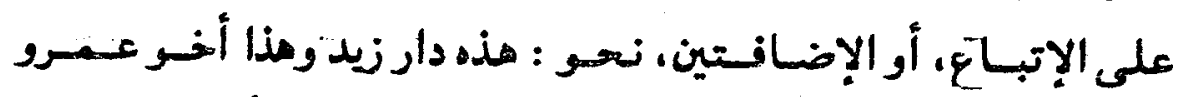

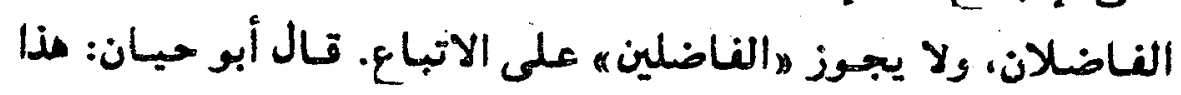
(r) مقتضه مذهب سيبويه.

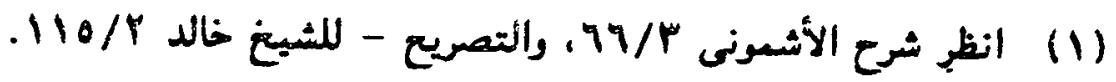
نتلك عن شع الهواسع - للسبوطى 119/r بتصرن، وانظر حاشيت

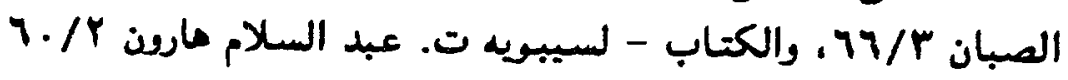

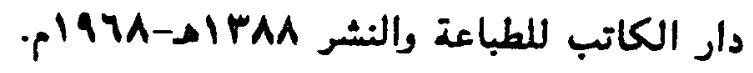


سا دساً: أوجب بعـضهـم القطع عند اختـلان الكنعـوتين تعريفاً

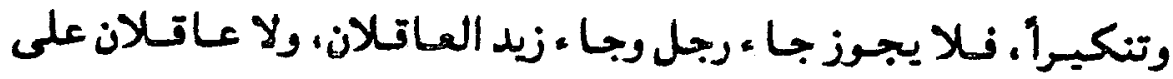

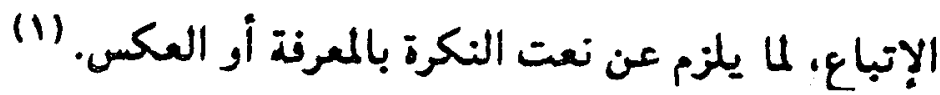

وتال المحقق الرخبى :" يمتنع تخالف النعت مع المنعوت تعريناً

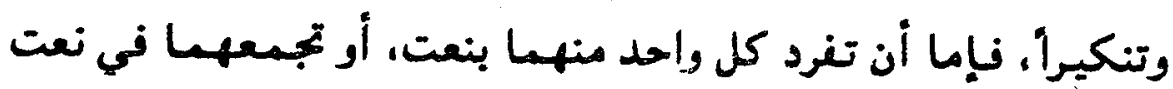

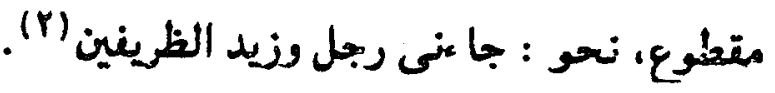

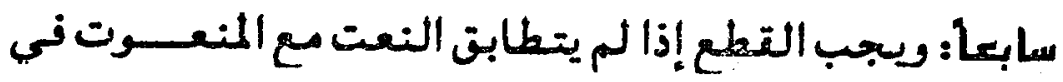

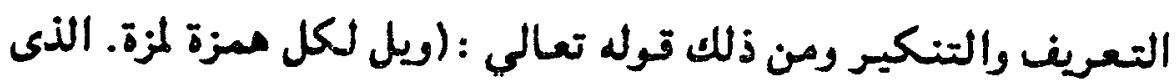

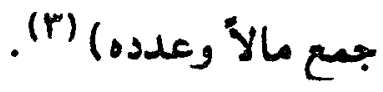

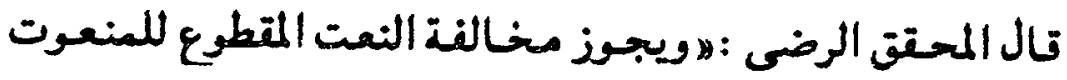

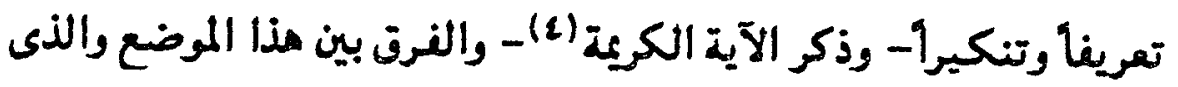

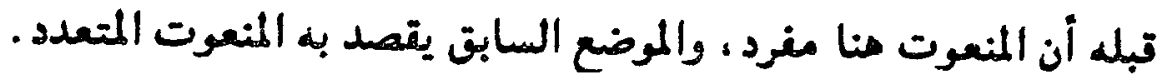

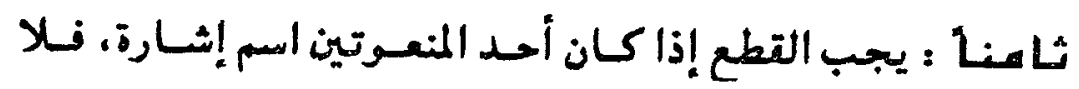

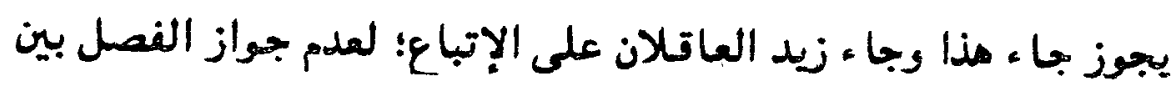

المبهم ونعته.

نقلأ عن عاشية الصبان على الأشسونى ب/11 بتصرن، والبمل ص

.17

(r) النظر شرح الكافية - للرضى (r)

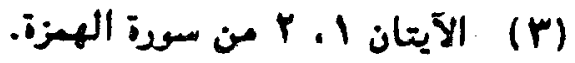

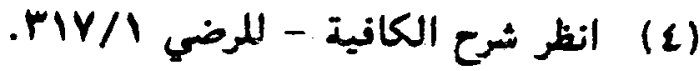

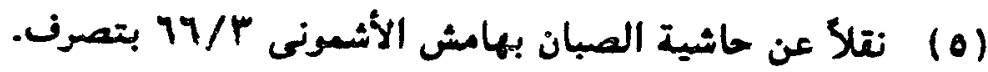


تاسعا: منع الشاطبى الإتباع إذا كان أحد المنعوتين في جملة

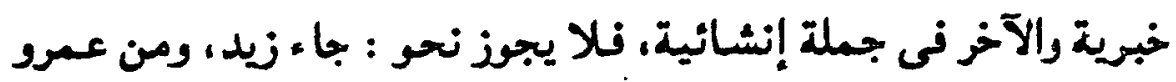
العاقلان على الإتباع.

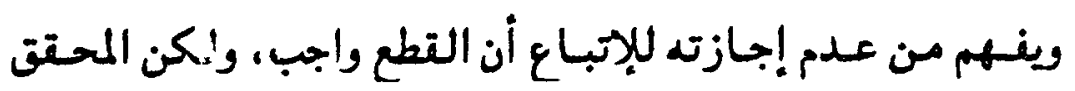

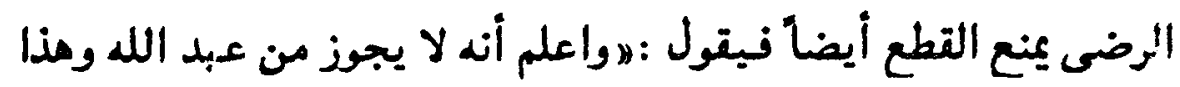

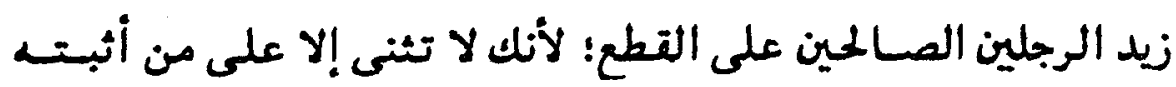

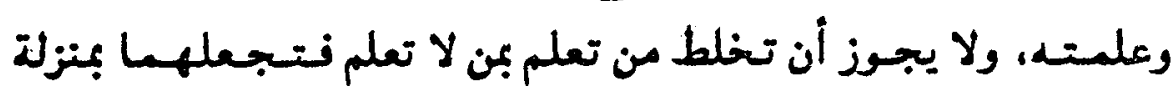

(1) والهدة وعلدid)

الهواضع التى يهنع نيها القطع :

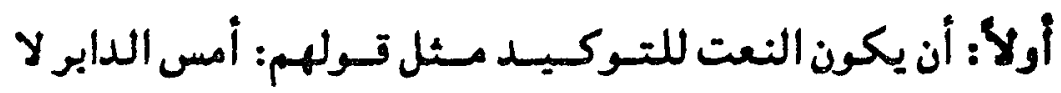

قال المحقق الرضى : لالأنه يكون تطعاً عما مو متصل به معنى؛ ودأ لأن الموصوف فى مثل ذلك نص فى معنى الصفة دال عليه ولهذا لم

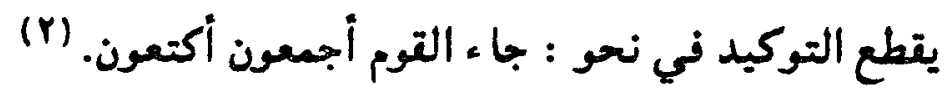

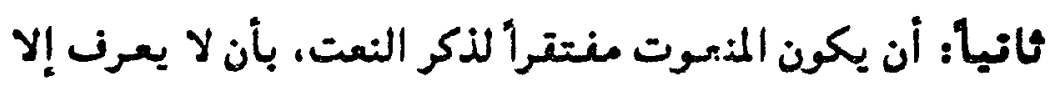

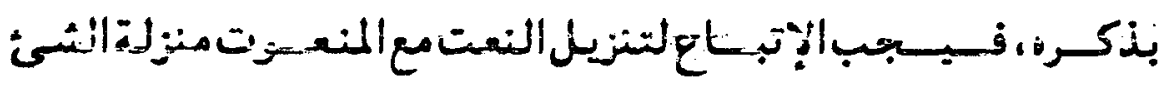

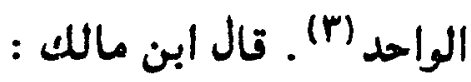

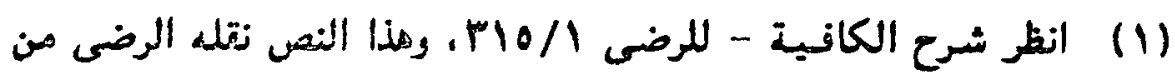

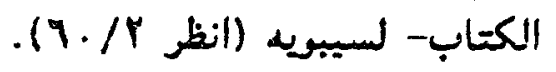

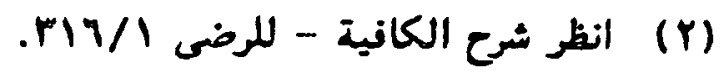

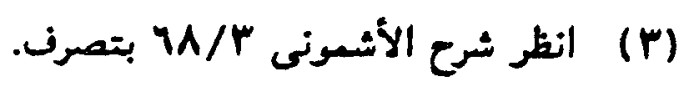




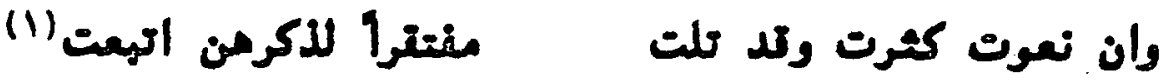

ثالهاً: إذا كـان المنعسوت نكرة امستنع النعت الأول عن التطع؛

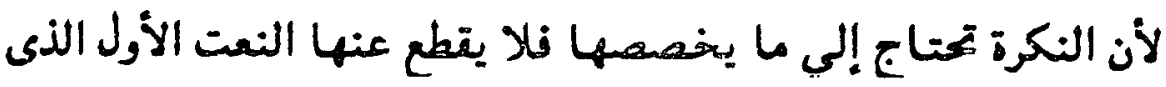

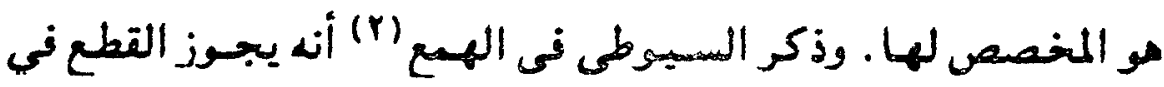

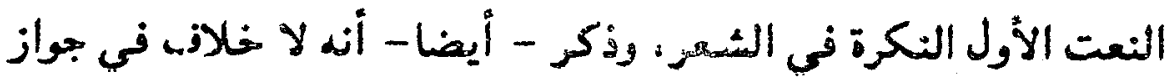

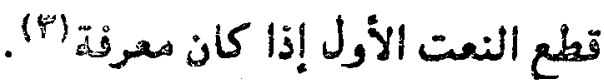

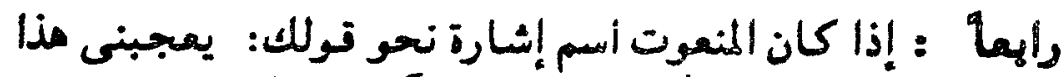

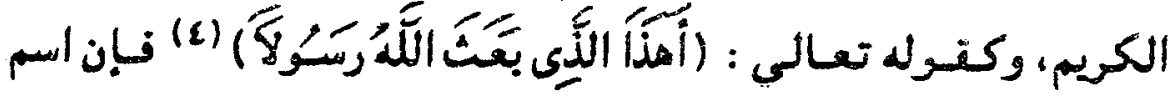

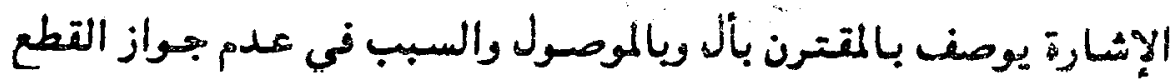

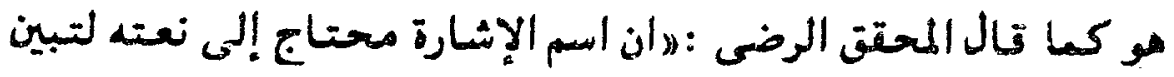

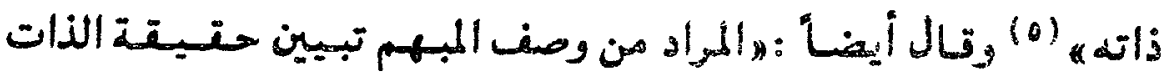

المشار إليها" (7)

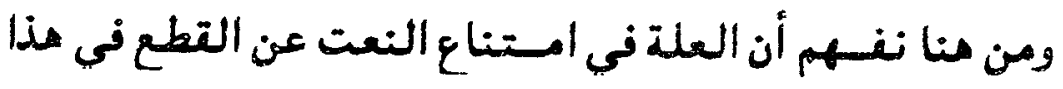

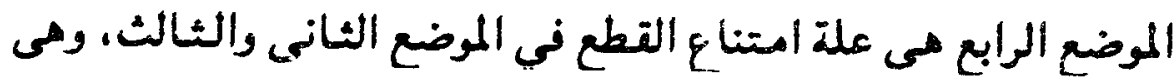
احتياج المنعوت لنعته.

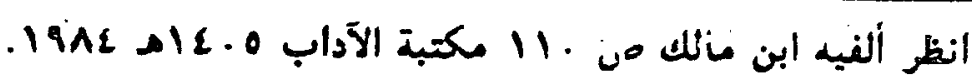

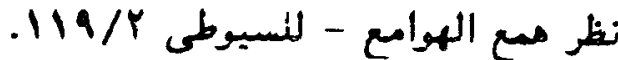

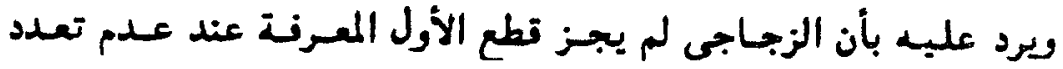

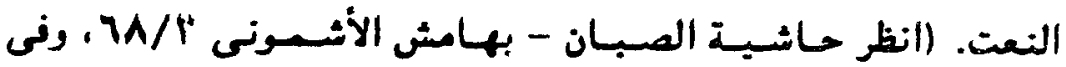

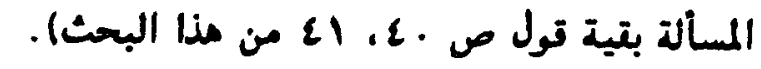
من الآية الع من سورة الفرقان.

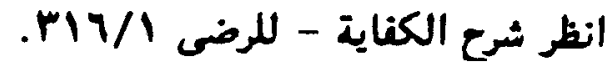

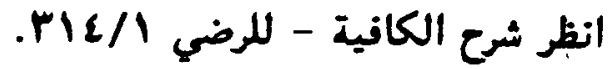


عامساً: يمتنع التطع عند الزجـاجى عند عـدم تعـدد النعـوت نيوجب الإتباع فى نحو : "جاء محمد الكريم) (") ويرد عليه بالآية

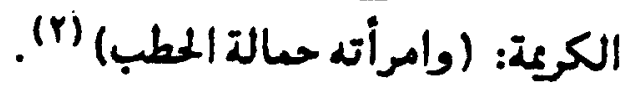

\section{جواز التطع والإتباع :}

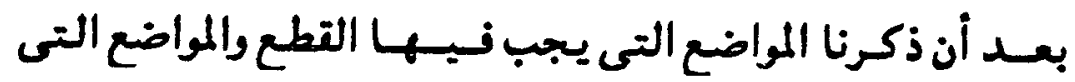

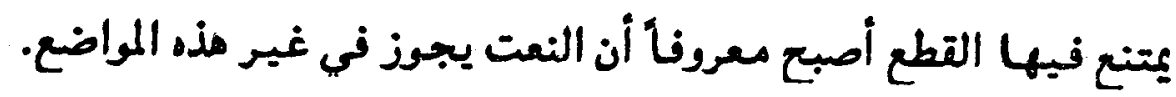

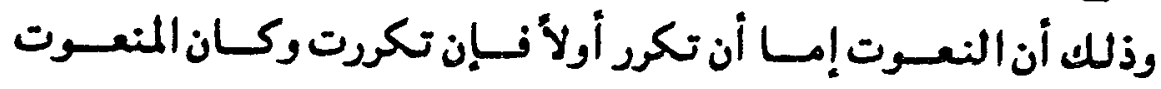

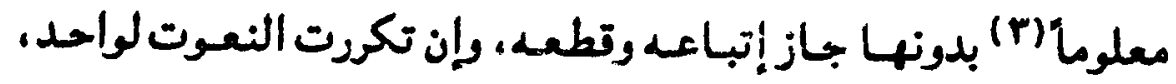

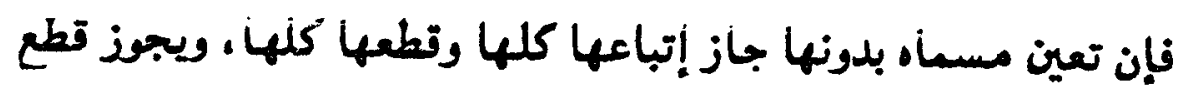

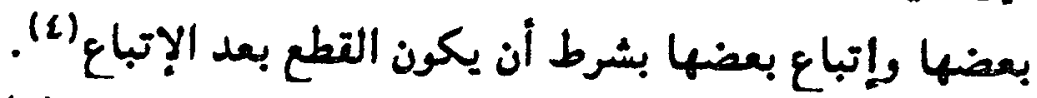
هذا موجز لحالات التطع والإتباع والملاف فيها كثير (0).

\section{العلة في اشتراط تتحم الإتباع :}

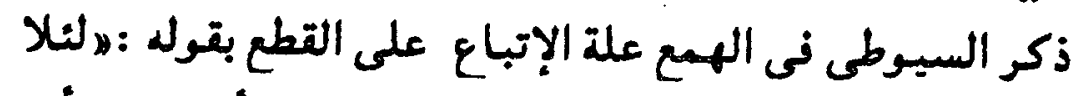

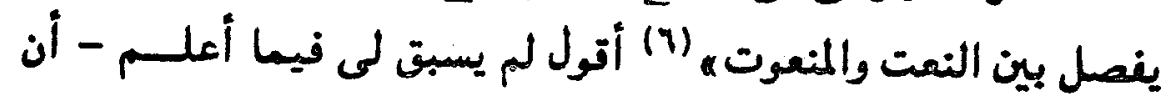

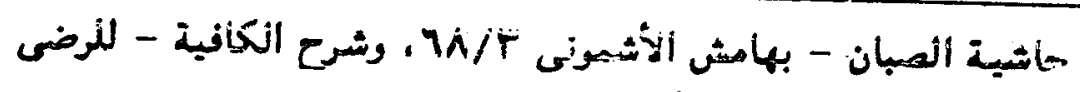

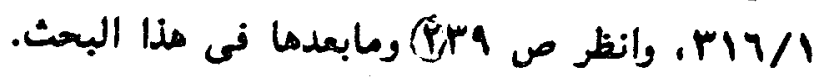
الآية ع من سورة المسد.

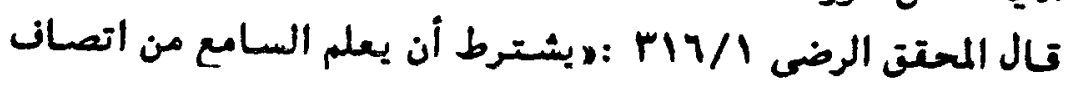

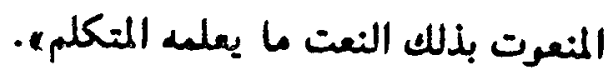

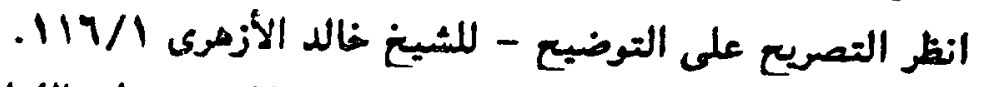

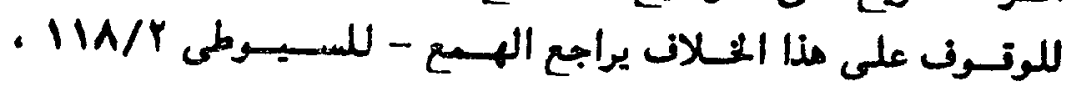

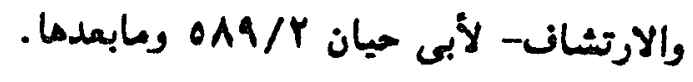

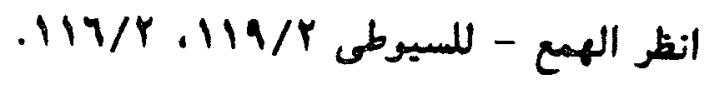




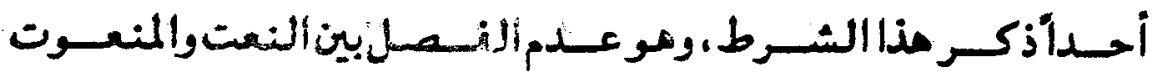

مطلll (1)

وقال المحقى الرضى : الإتاتباع بعذ القطع تبيحع (r) وسكت عن

$$
\text { زكر سبب القبح. }
$$

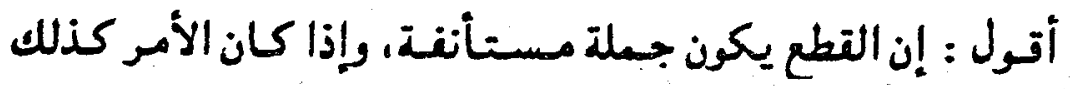

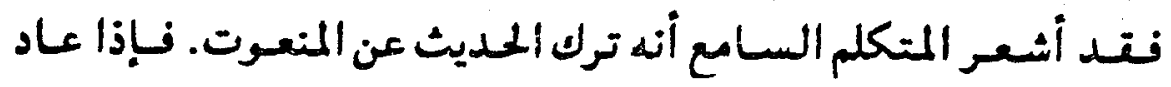
المتكلم ليصف المنعوت شق على السامع الفهم وغمض النهل معنى الكلام.

وقد أوضح صاحب التصريح مذا المعنى بقـوله : والإتباع بعد

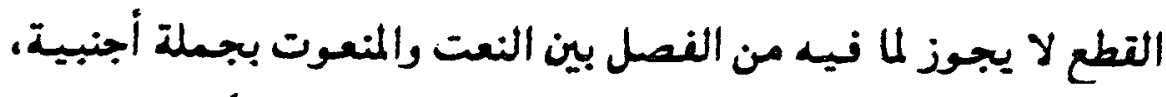

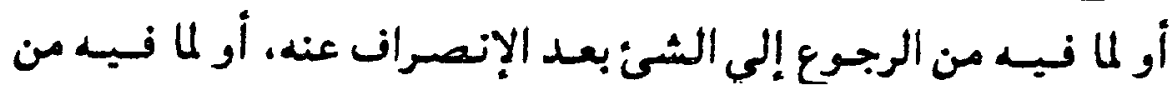

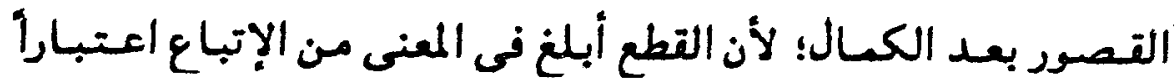

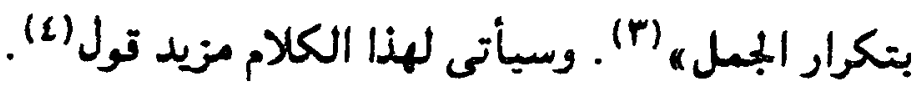

العا هل فى النعت الهتطوع :

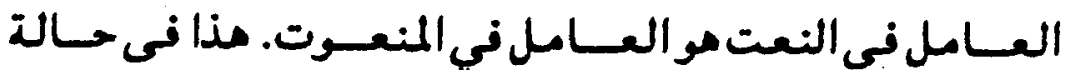

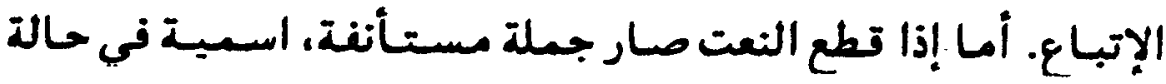

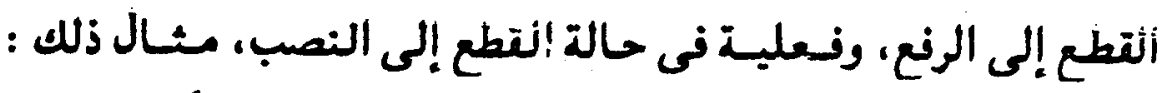

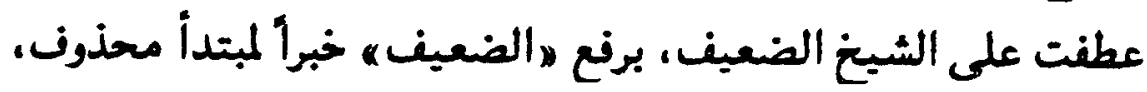

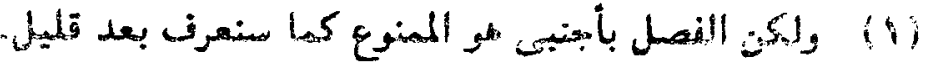

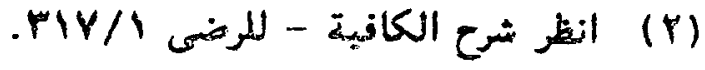

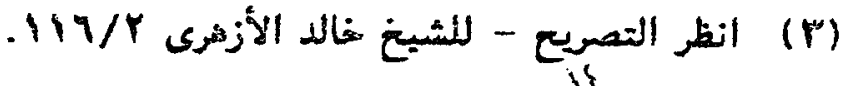

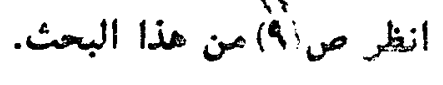


أى : عو الضعيف، أو بنصسب هالضعيفه منعولاً به بغعل مناسب

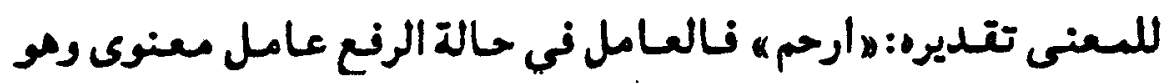

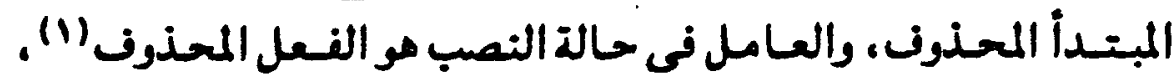

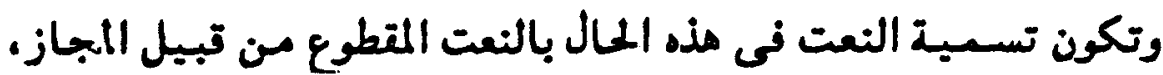

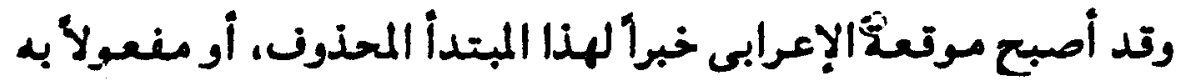
ناصبه مو الفعل المحذون، وتكون الجملة استئنافية على أصح الأقوال أو حالية.

هكم حذف العا هل نه النعت المتطوع والعلة فى ذلك :

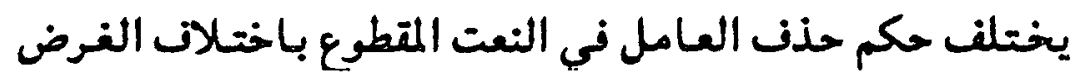

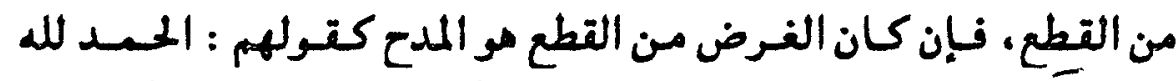

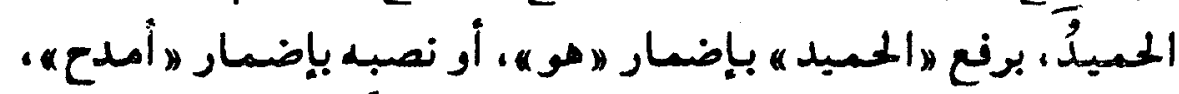

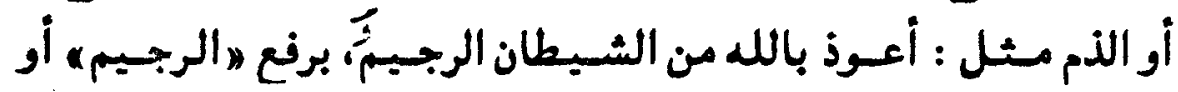

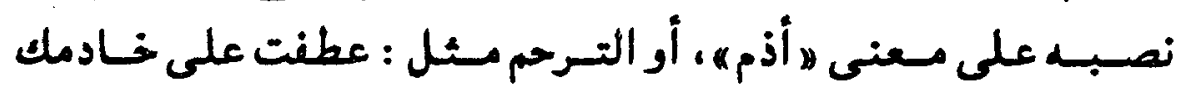

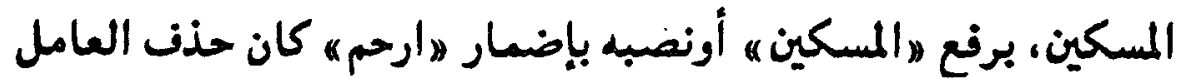

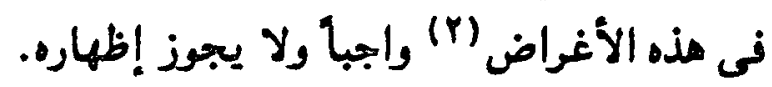

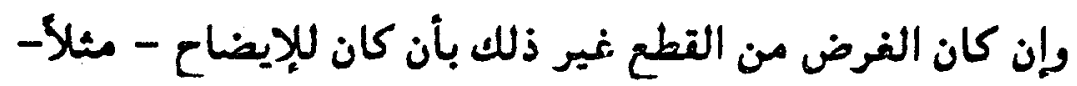

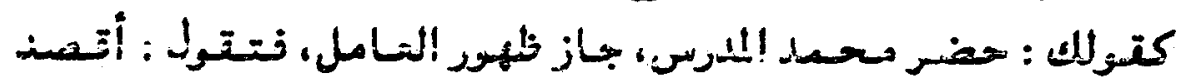
المدرسَ بالنصب، أو هو المدرش بالرفع.

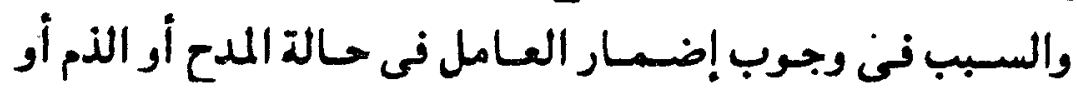

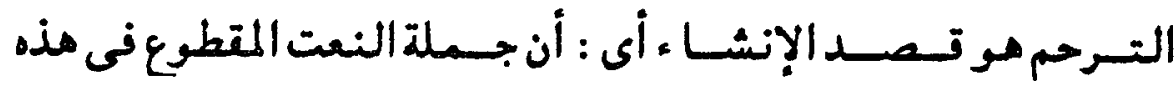

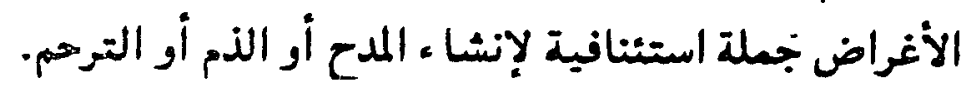

(1) (1) انظر ص آ من مذا البحث.

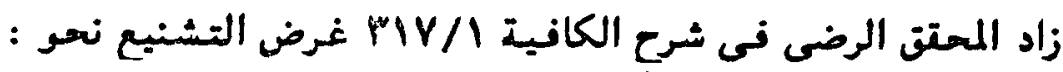

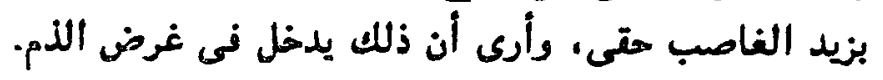




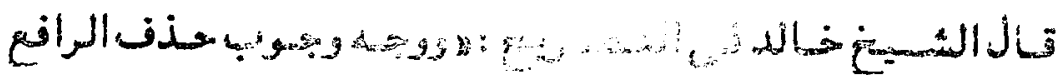

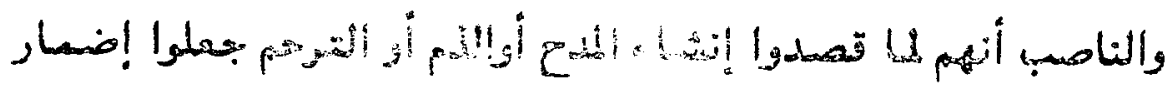

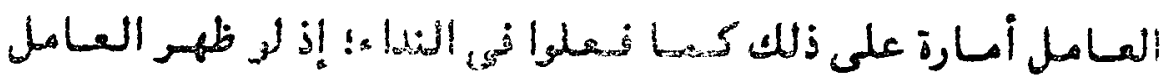

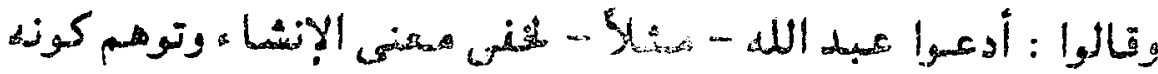

(i) مثبراً

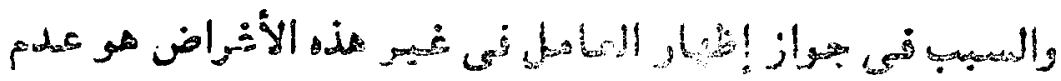

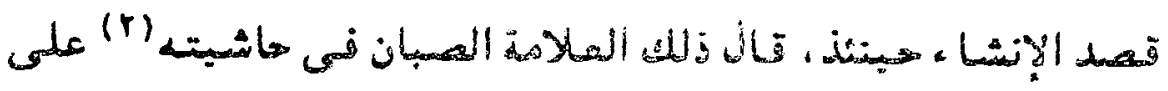

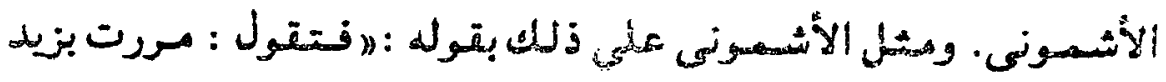

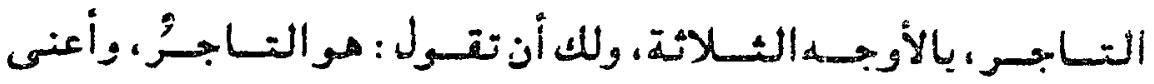

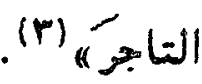

والذى يبدو لى أزن العلاهـة المحقق الرضي لم يجز التطع إذا كان

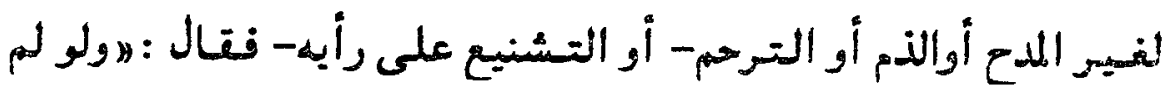

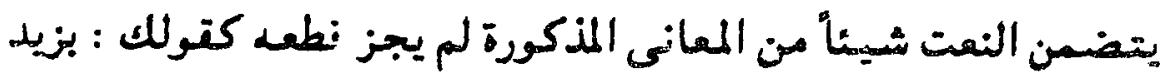

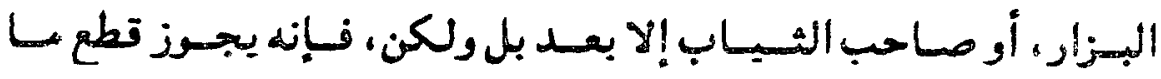

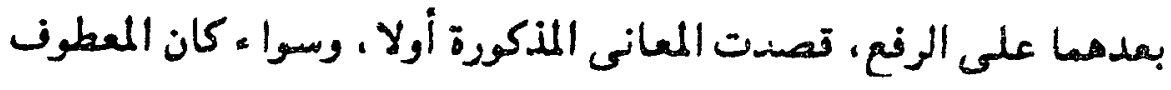

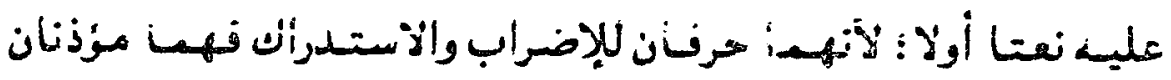

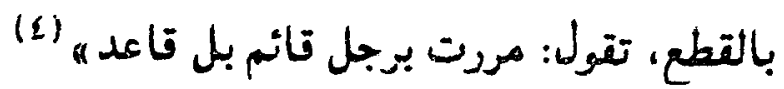

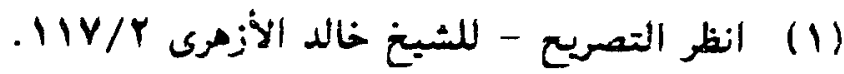
V) حاشية الصبان بهامش الأشمونى V./r) ( ) المرجع السابق. (L)

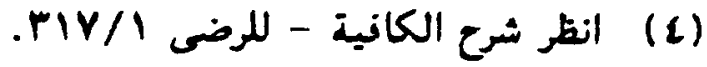


ويذهب أحد الباحثين (1) المحدثين إلي أن النعت المتطوع كلبـة

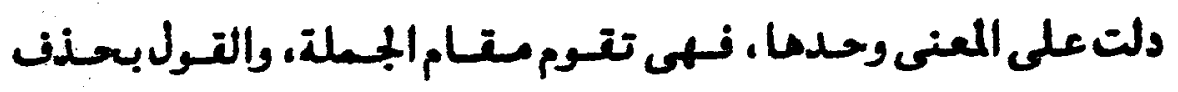

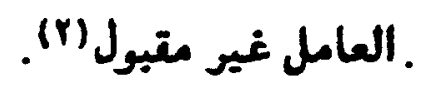

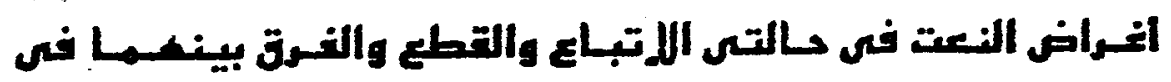
كاتا الحالتين : تحدث النحويون عن أغبراض النعت فى حالة الإتباع، وفهبهنا

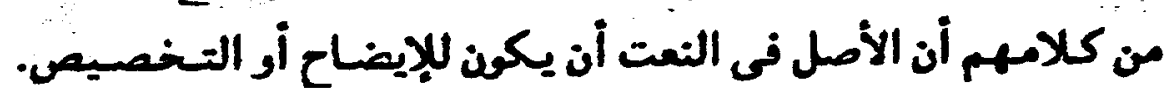

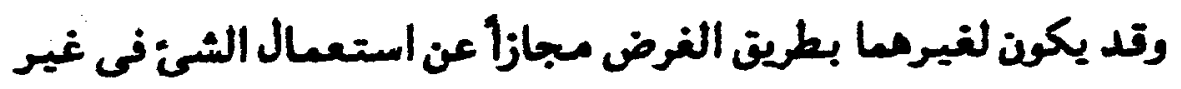

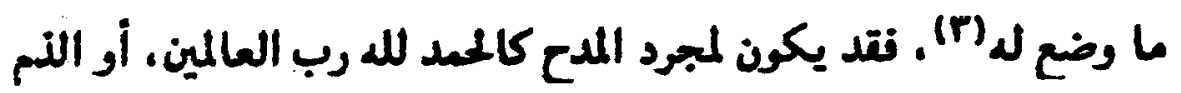

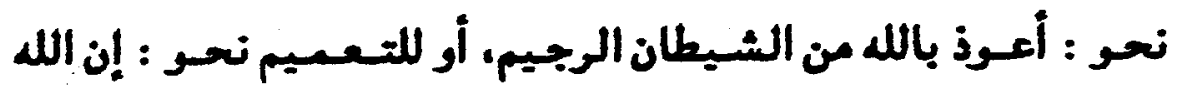

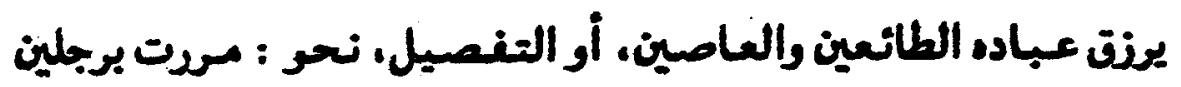

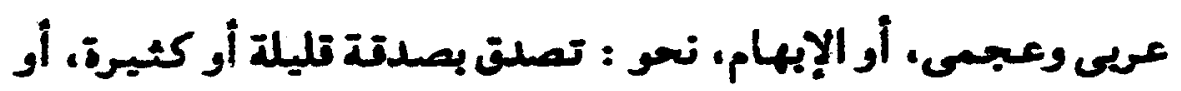

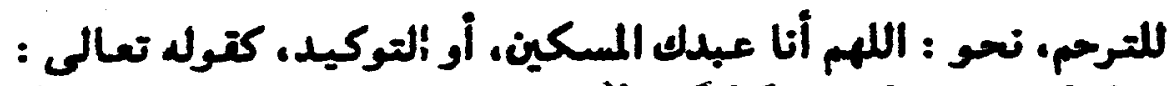

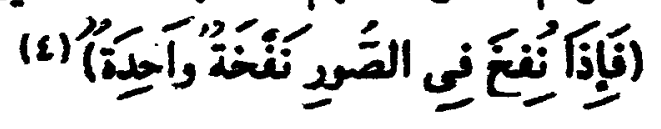

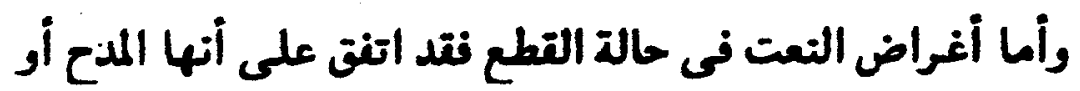

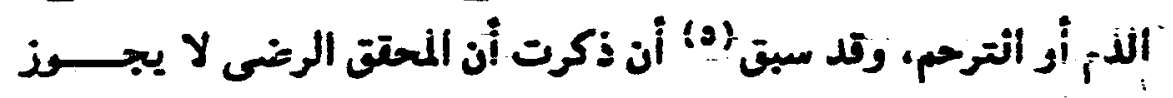

$$
\text { مو الدكتود كمال بشر. }
$$

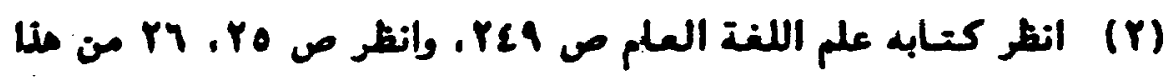

$$
\text { البعث. البطر كيابل }
$$

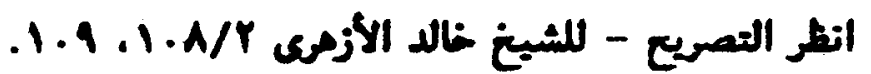

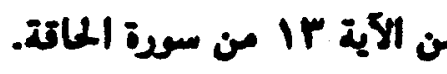

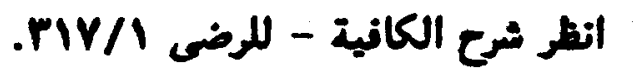




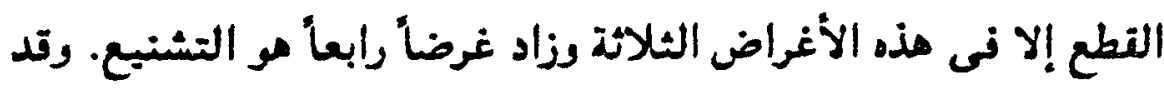

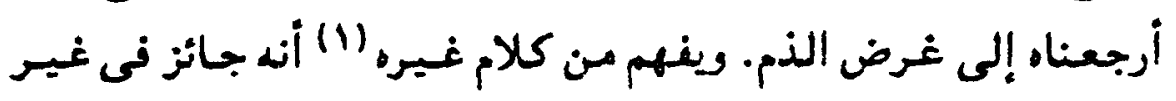
مذه الأغراض. - معناه

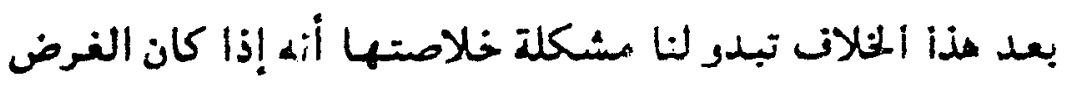

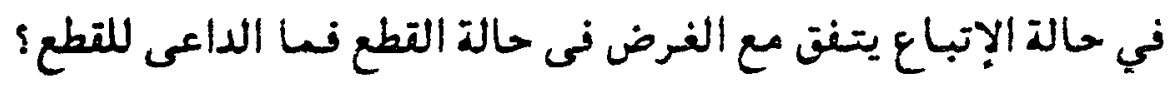

وما الفائدة منه ؟

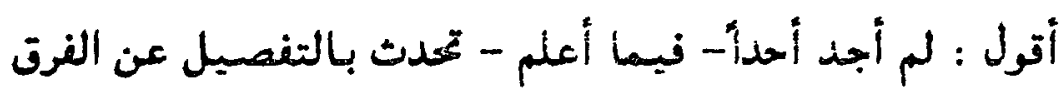

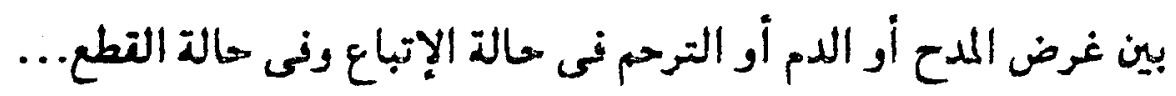

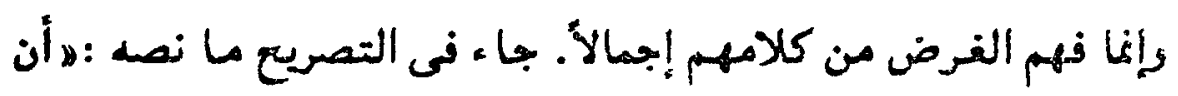

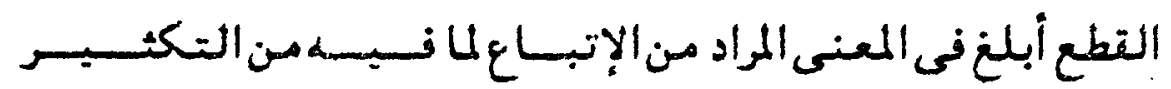

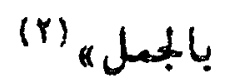

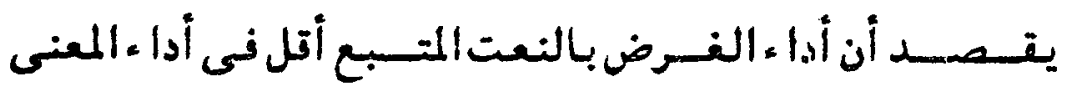

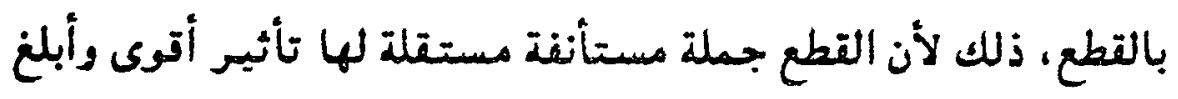
فى نفس السامع من أدائه بالنعت في حالة الإتباع.

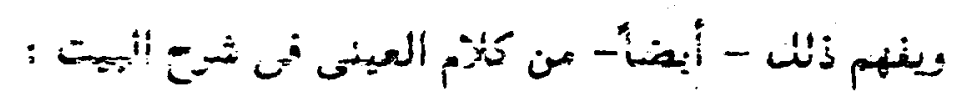

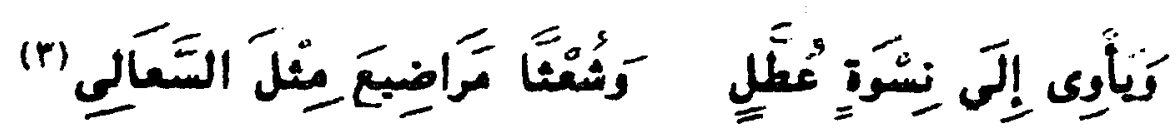

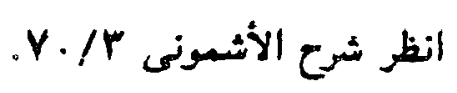

(r)

(T)

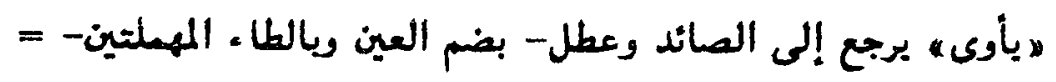




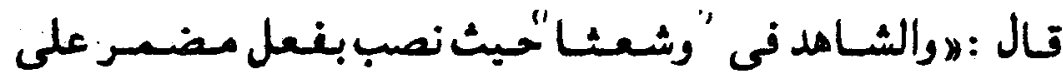

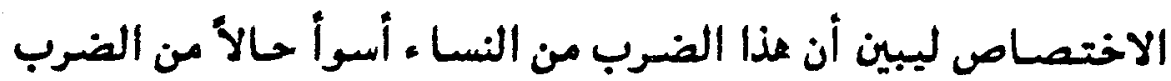
الأول الذى مو العطل منهنه" (1).

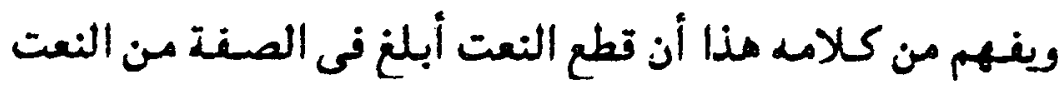

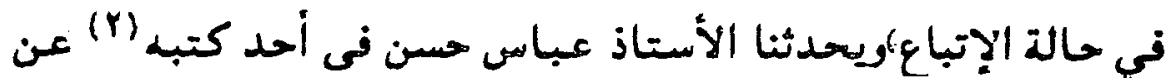

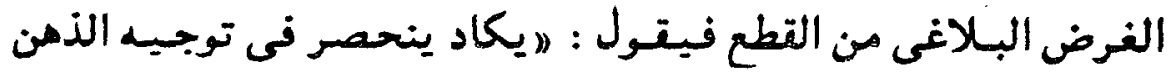

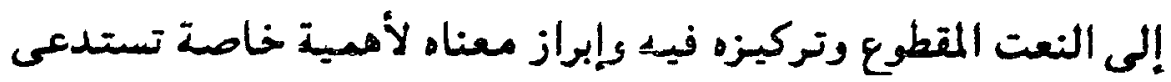

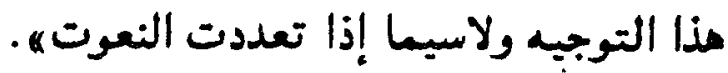

ويقـول أبو حيان : "(قال النارسى إذا ذكرت الصغات الكثيرة فى معرض المدح والذم فالأحسن أن تخالف بإعرابها ولا تجبعل كلها

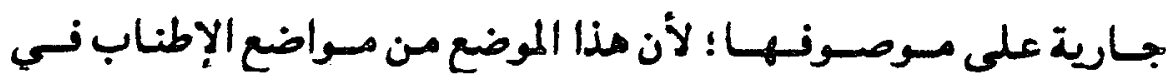

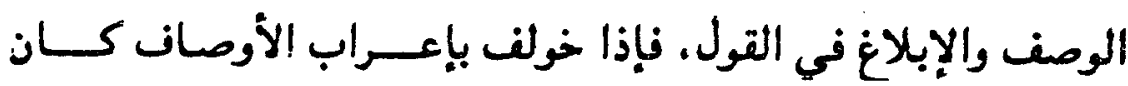

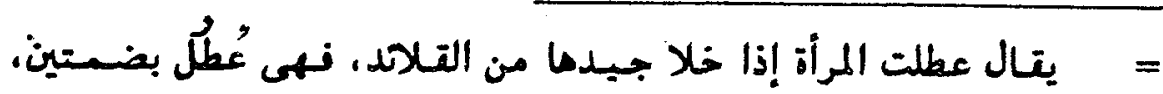

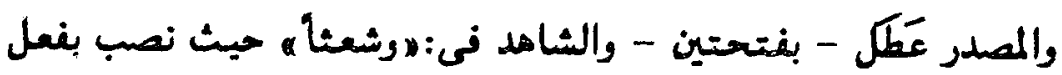

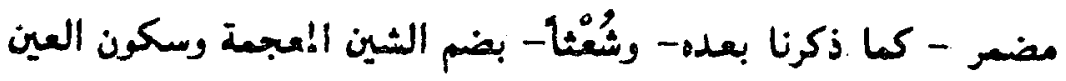

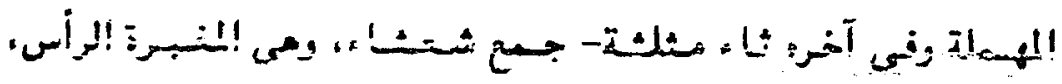

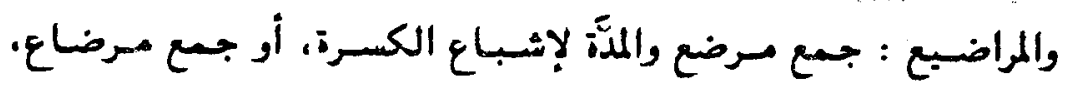

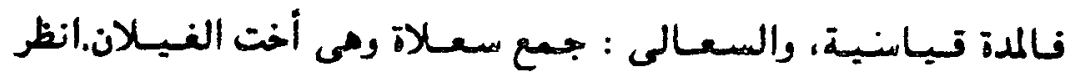

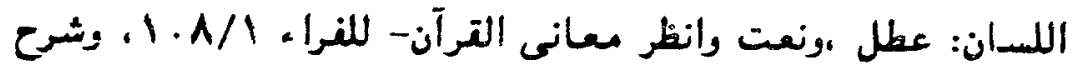

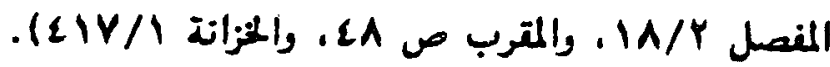

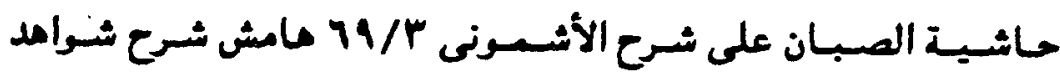
العينى. (الع.

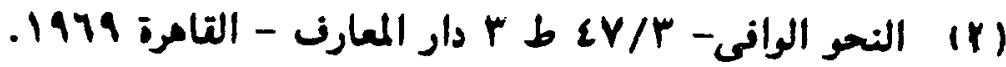




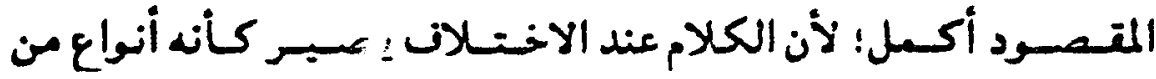

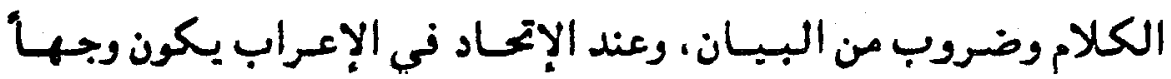

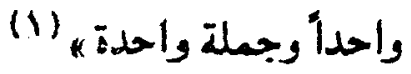

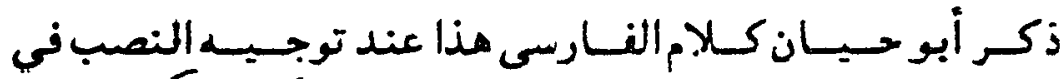

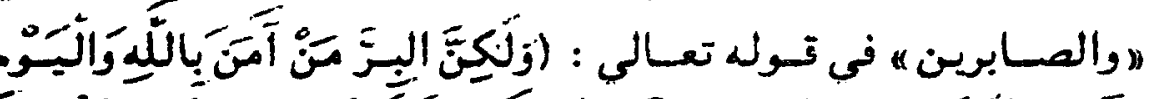

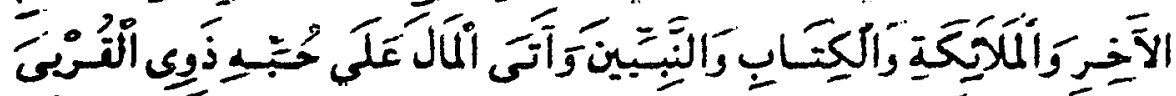

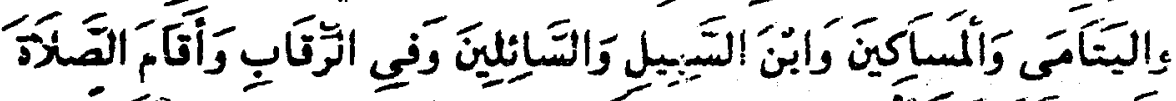

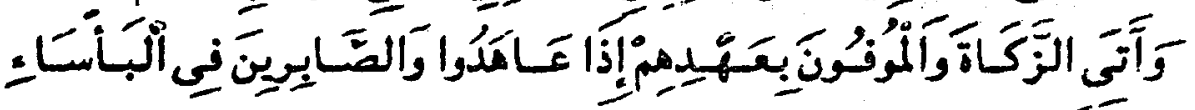

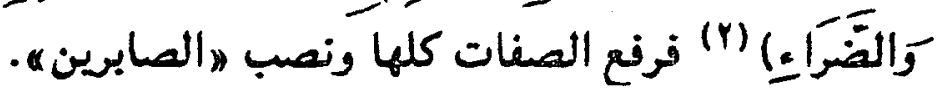

جملة النعت الهتطوع :

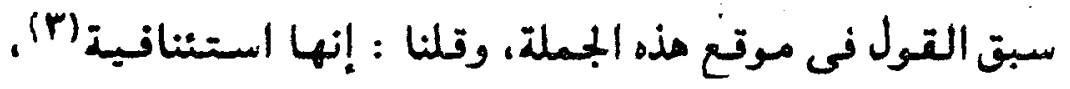

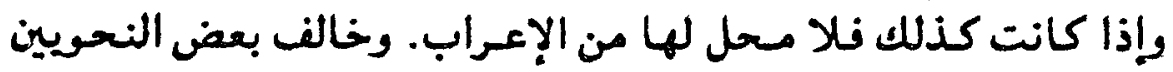

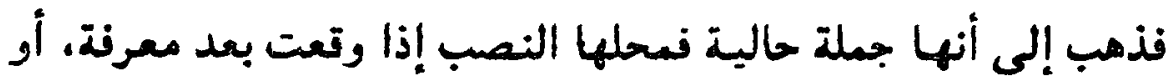

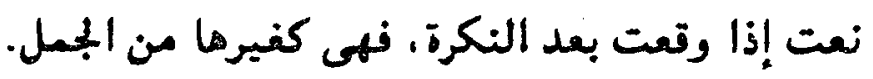

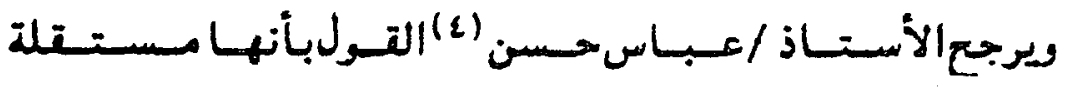

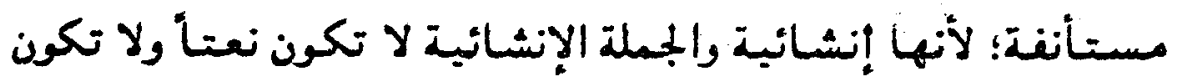

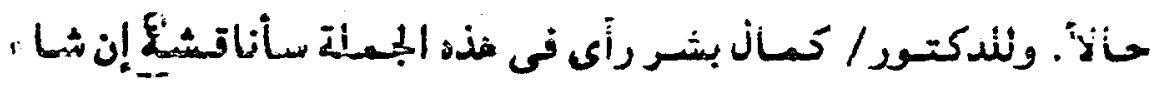
الله (0)

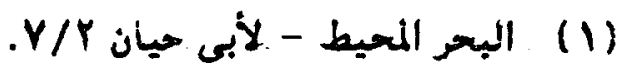

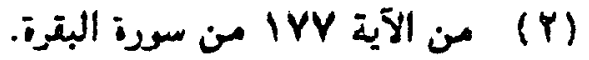

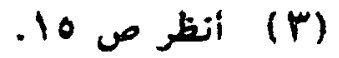

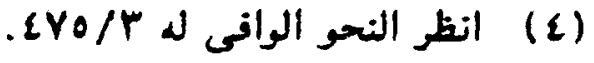

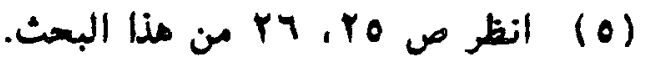


الواو التس تسبق النعت الهتطوع :

ذهب المحستق الرضى إلى أن ســبت النعت المتطوع بهــــه الواو

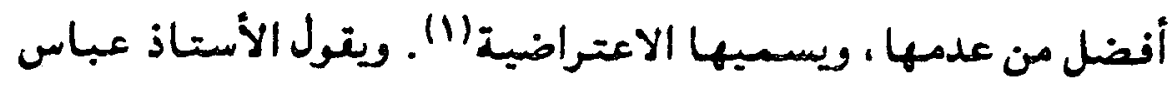
حسن : إنها زائدة للاعتراض تبل النعت المقطوع سواء ء أكان متطوعاً

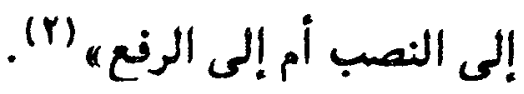

وذهب أبو الحسسن المزنس واسـمه على بن النسل نى كتـاب له

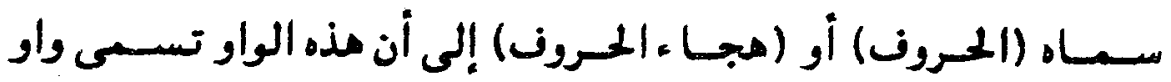

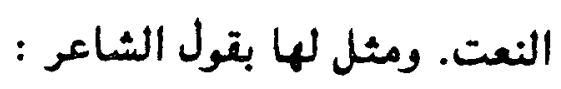

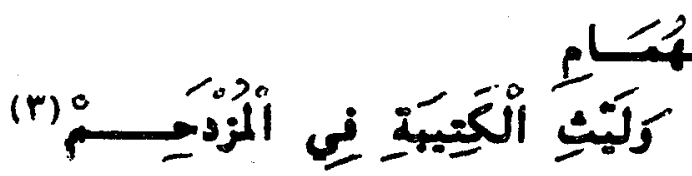
وقـال : " إن هذه الواو دليل النعت، ومـتَّل لهـا أيضـا بآيات،

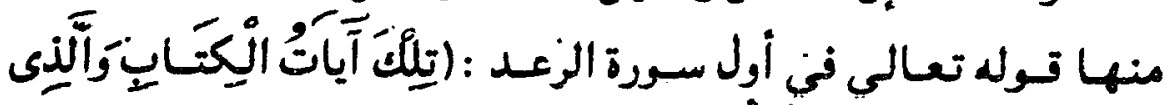

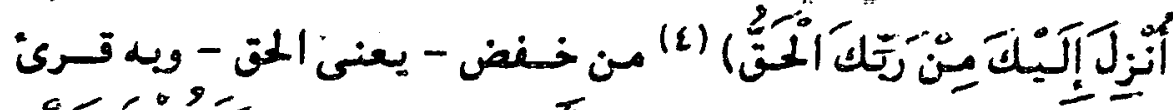

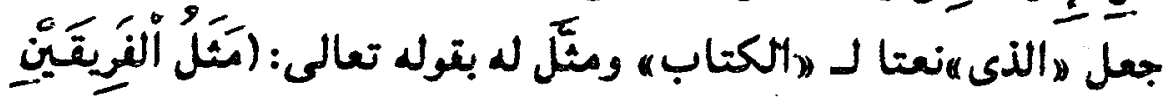

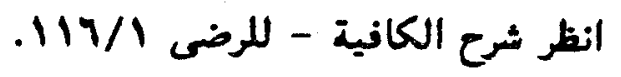

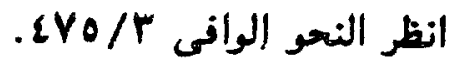

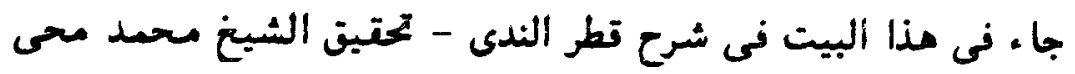

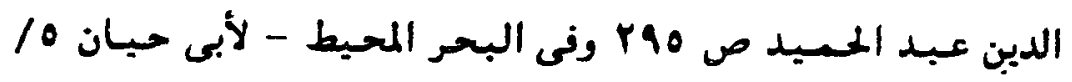

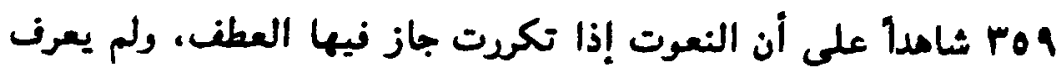

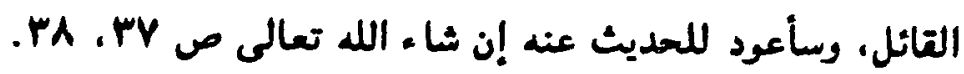

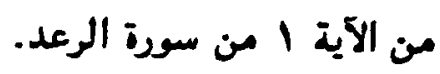




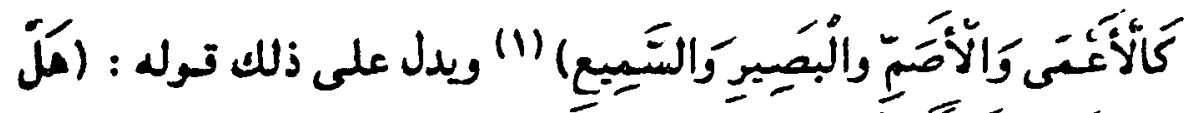

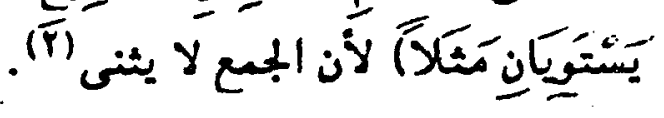

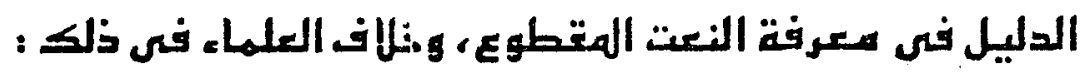

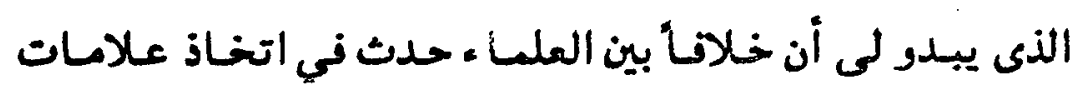
الإعراب دليلاً مفرقاً بين النعت المقطوع والنعت المتبع.

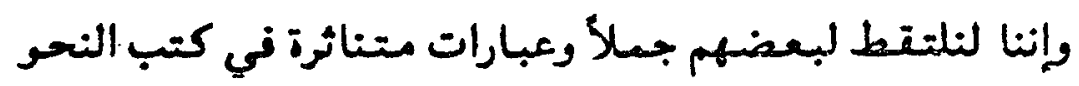

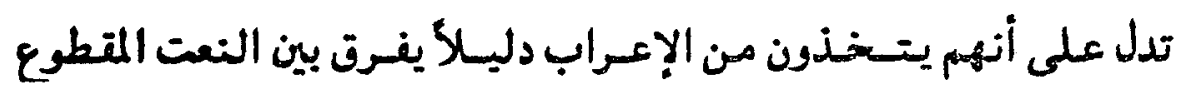

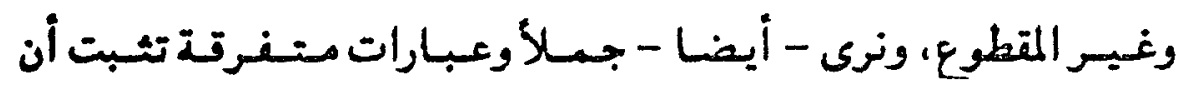

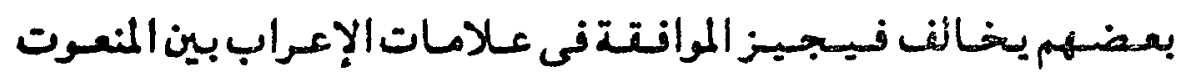

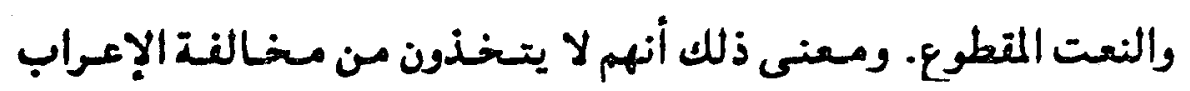

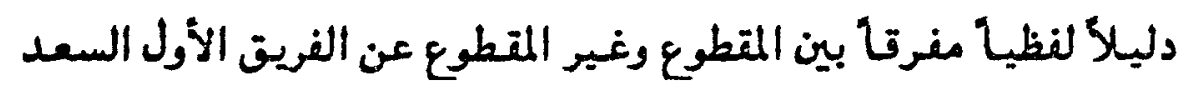

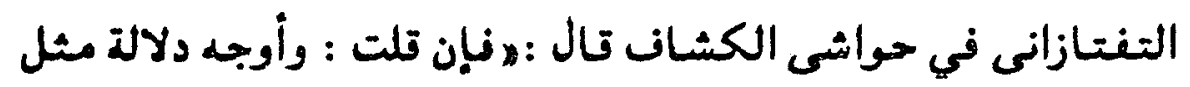

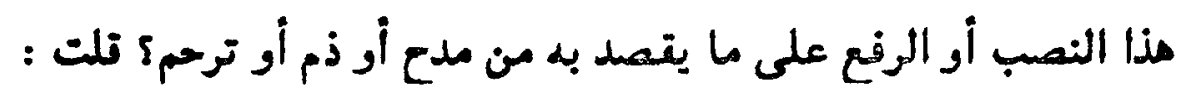

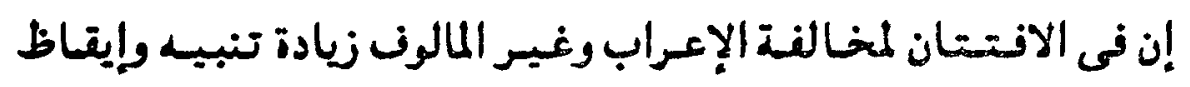

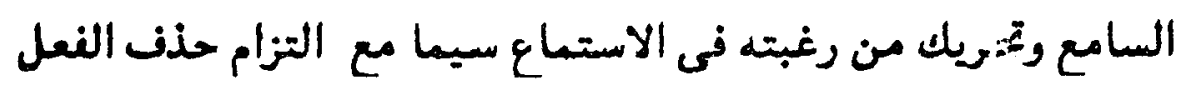

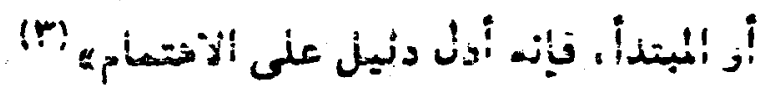

$$
\text { من الآية ع إب من سورة هود. }
$$

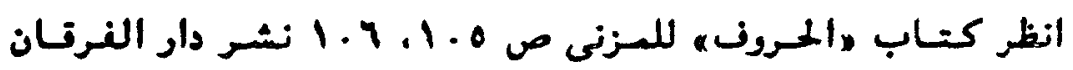

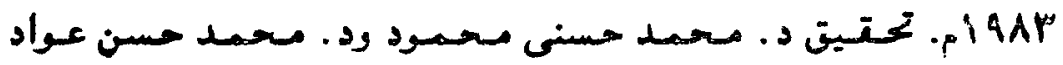

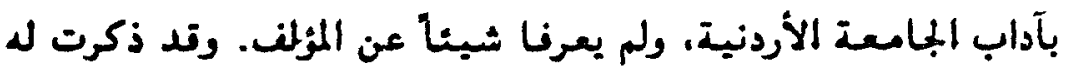

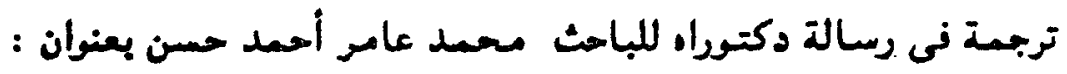

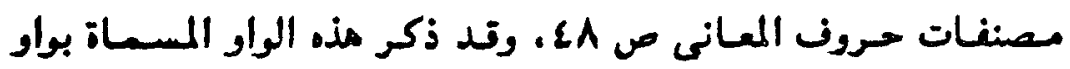

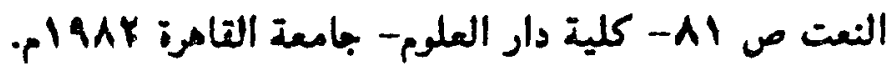

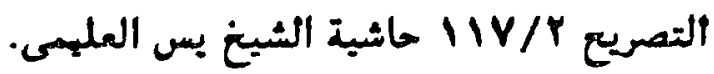


ومنهم السيبوطى في شرحه المسمى بالبهجة أو النهجة المرضية

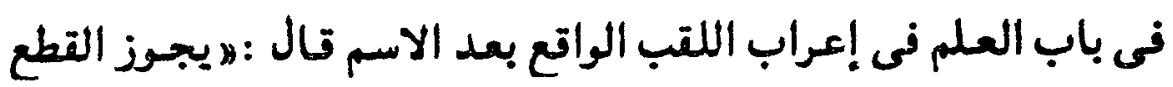

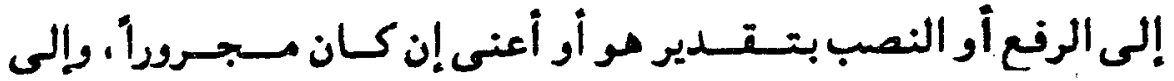

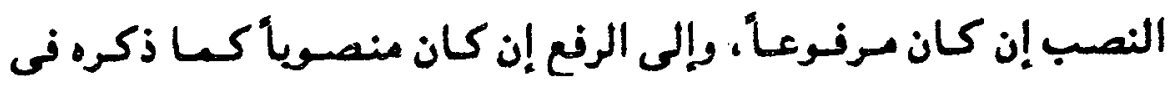
(1) التسهيل (1)

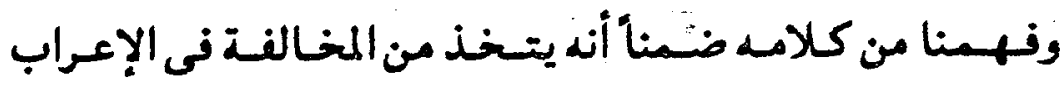

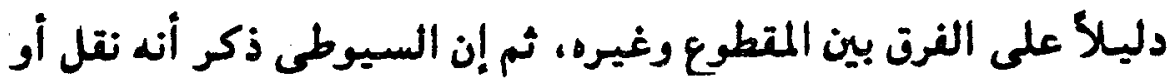

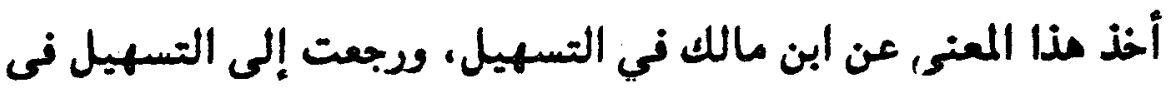

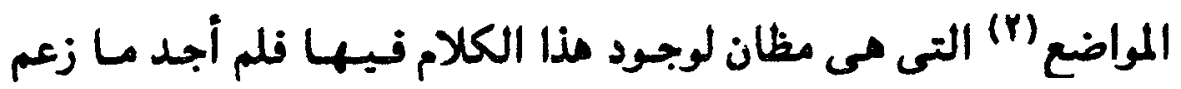

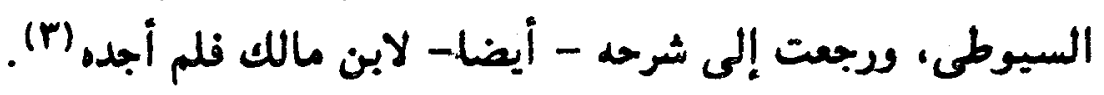

ويبدو أن ابن هشام من الفريق الذى لا يعتد باختلات الإعراب عند التطع دليلأ عليه. ' . قال فى التوضيح بعد أن ذكر قول الحرنق :

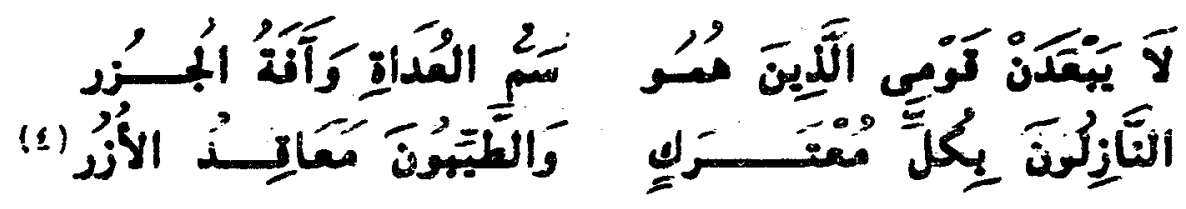
كتاب البهجة ألمرضية فى شرح الألفية - للسيوطى - الطبعة الأرلى.

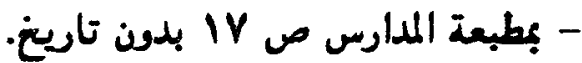

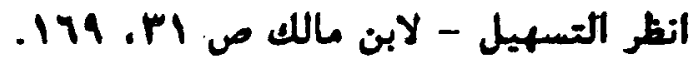

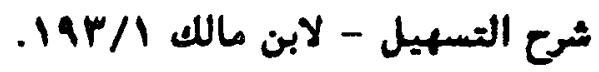

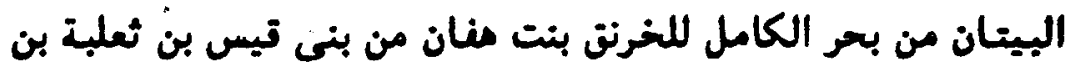

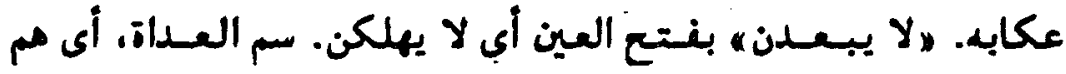

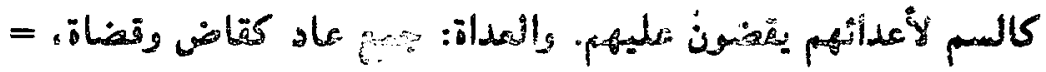




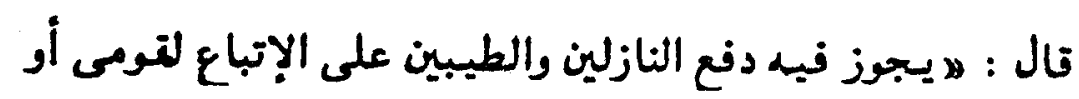

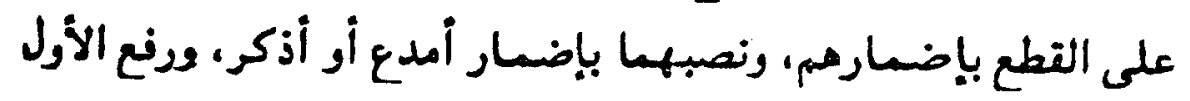

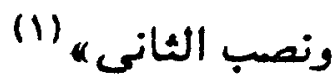

نقبوله بجواز الرنع على الإتباع وجوازه على القطع ينهم منه أند النه

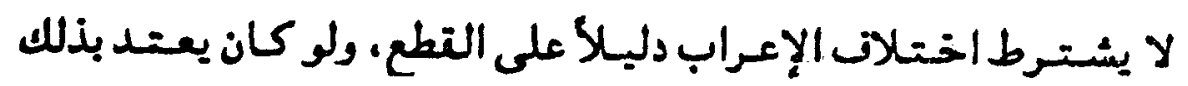

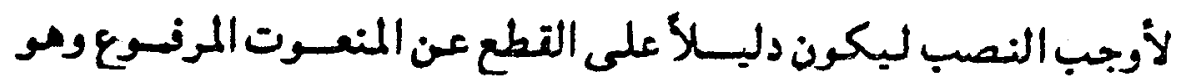

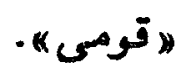

ونقل الأشـــونى ذلله عن ابن مشـام في شرحس على الألغيسة.

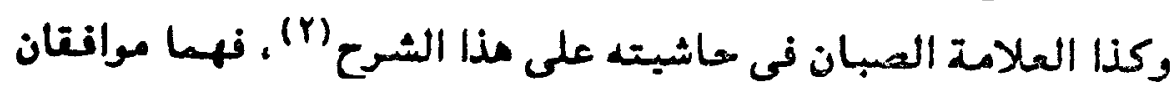
لابن هشام فى ذلك.

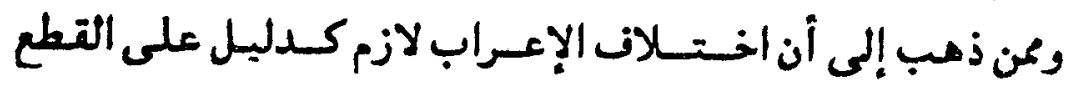

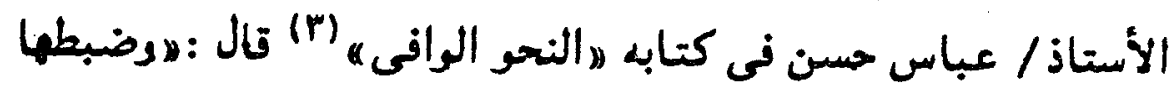

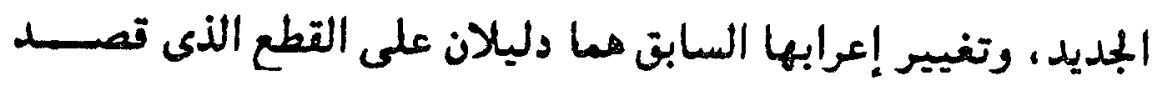

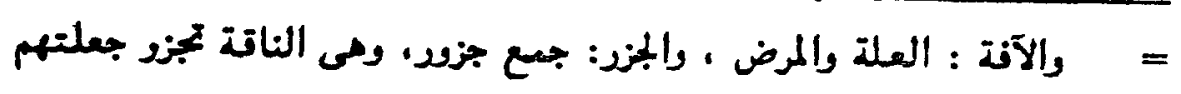

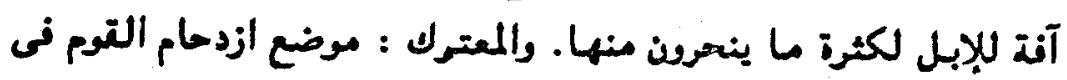

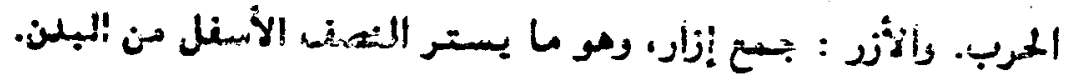

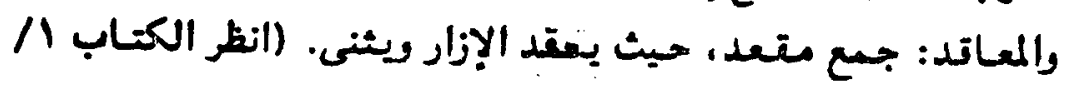

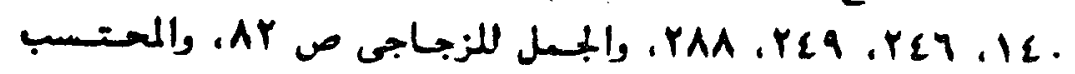

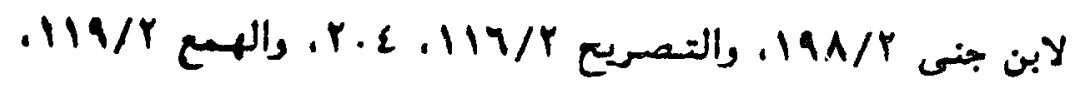

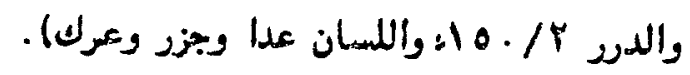

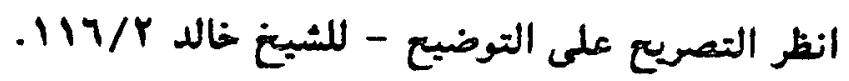

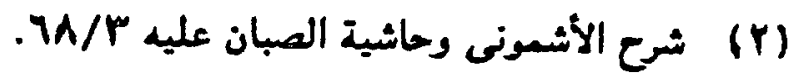
(r) 


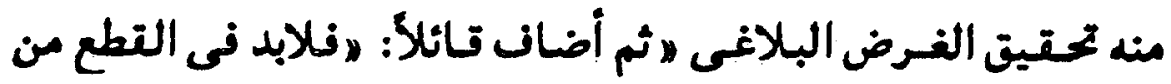

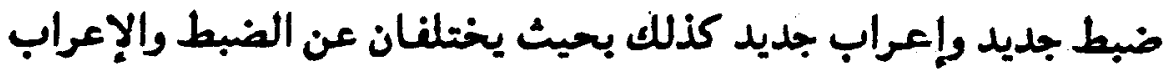

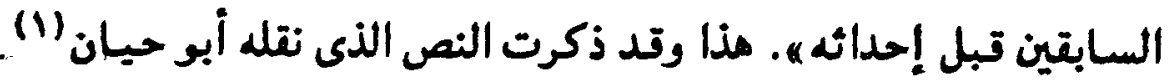

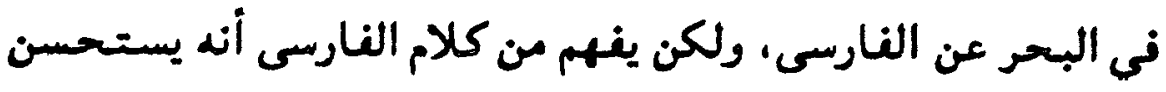

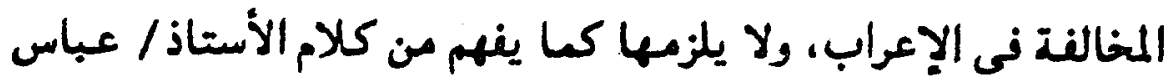

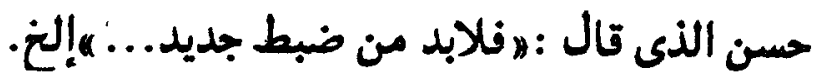

$$
\text { رايس ني هذا الخلانه : }
$$

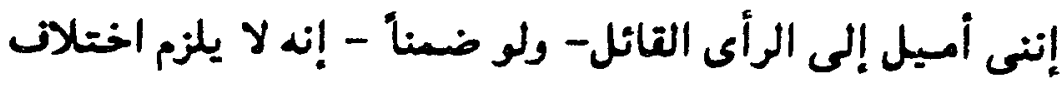

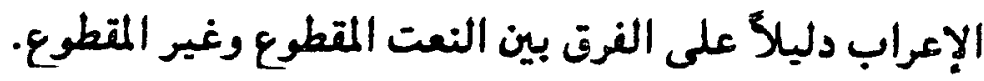

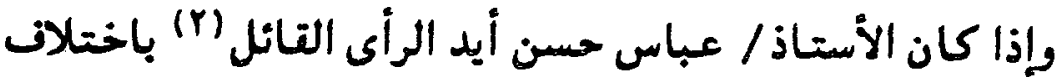

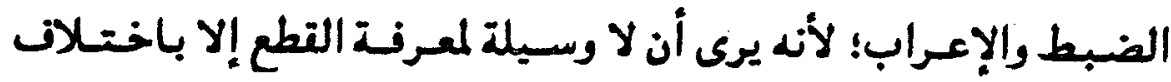

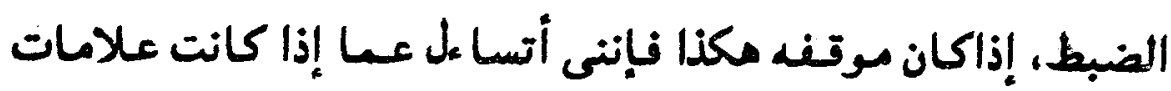
الإعراب مقدرة كسا فى الاسم المقصور والمضات لياء المتكلم مئل : جا ءت ليلى النضلى، كيف يعرن الفرق هنا بين النعت المقطوع وغير

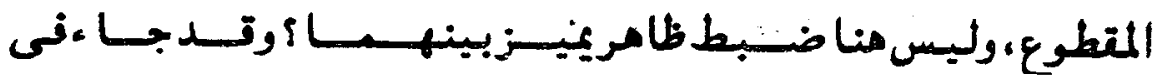

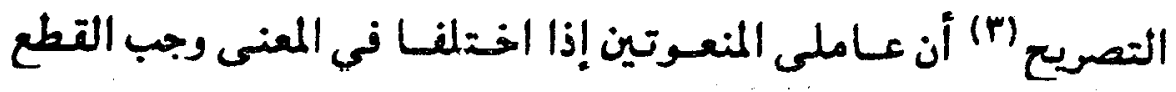

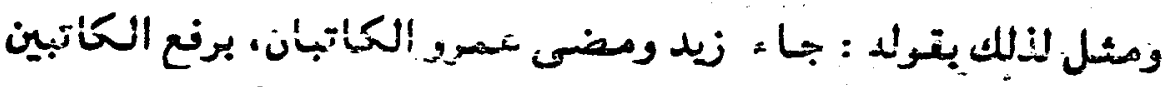

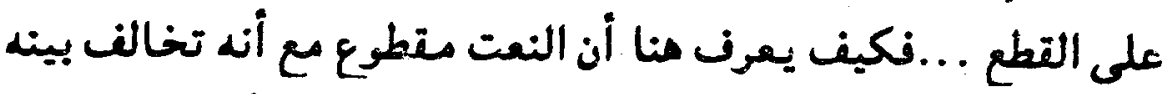

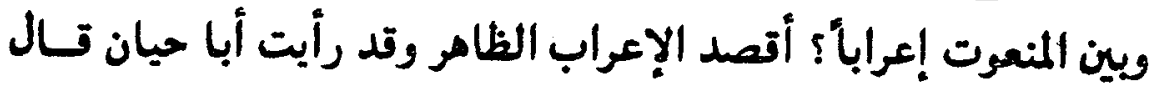

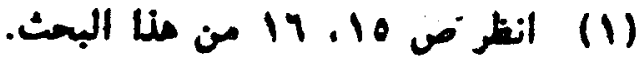

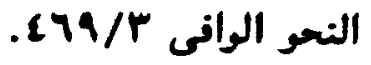

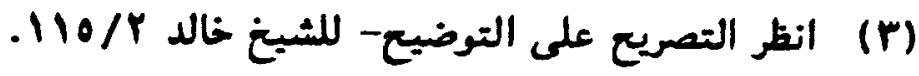




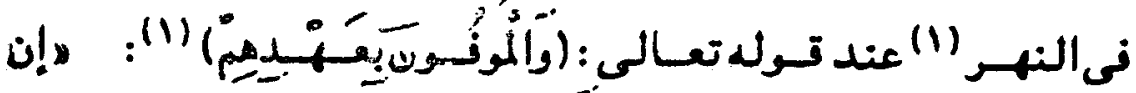

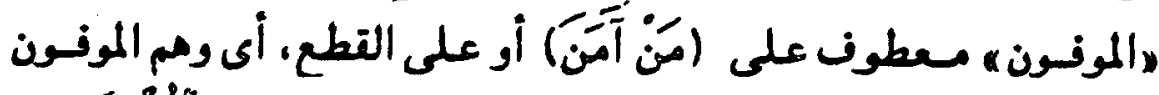

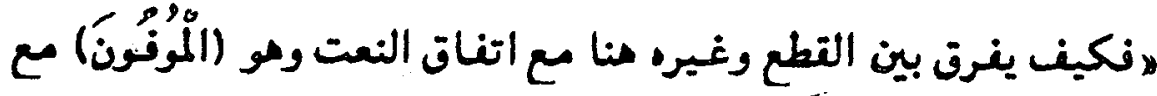

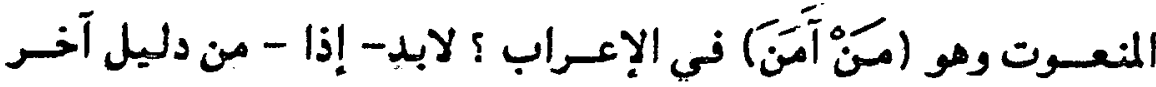

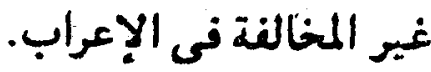

أقول : لقد امتـديت إلى دليل آخر أعرضه الآن عسى أن ينال

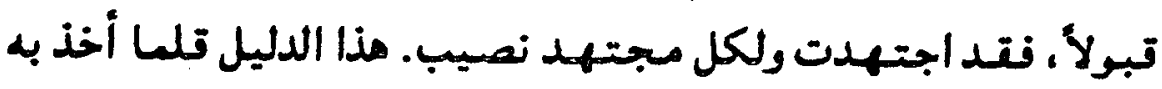

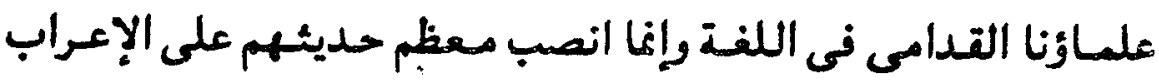

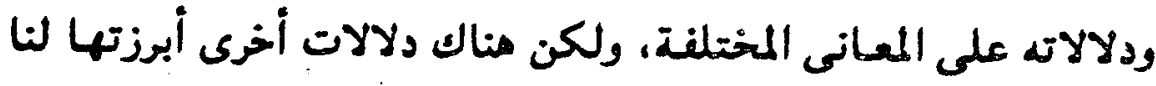

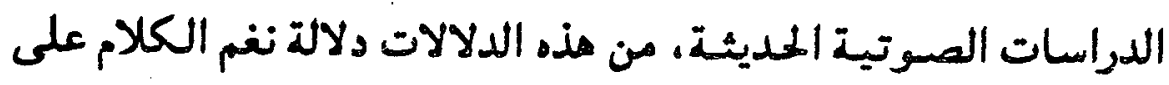

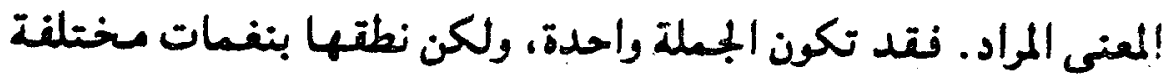

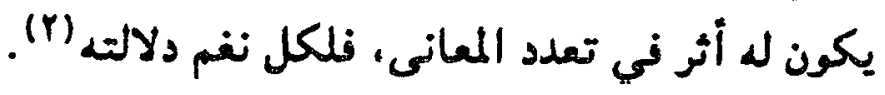

فـارتفاع الصسوت مرة وانخفاضه مسرة، وتطويله مرة وتقصيسه

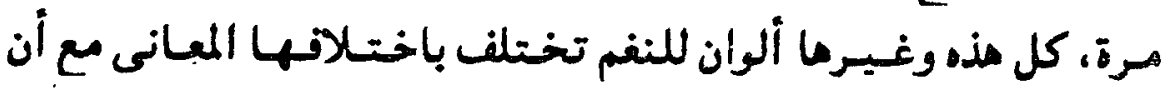

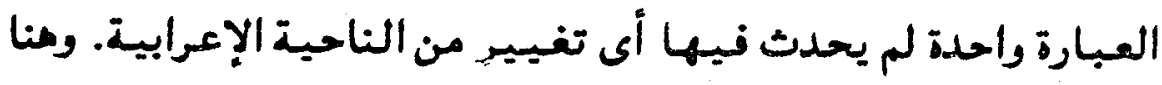

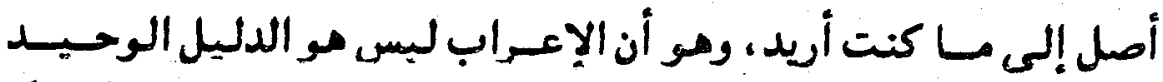

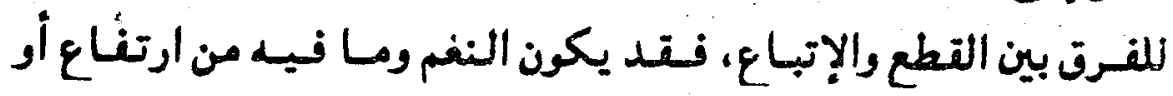

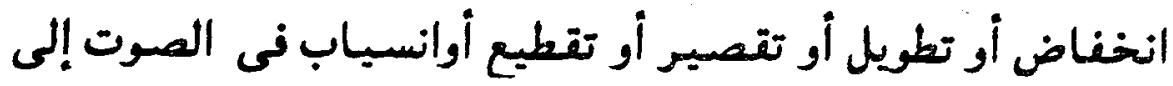

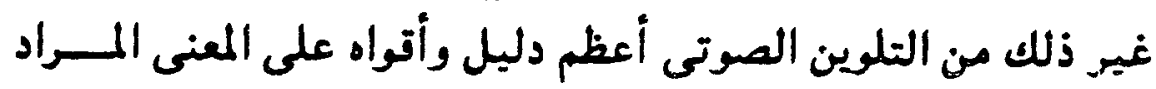

$$
\begin{aligned}
& \text { النير المادبهامش البحر المعيط - لأبع حيان Y V/P. } \\
& \text { من الآية IVY من سورة البقرة. }
\end{aligned}
$$

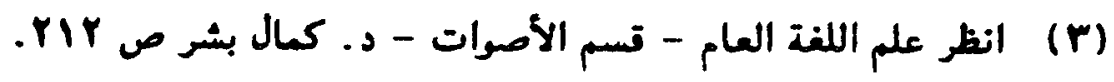




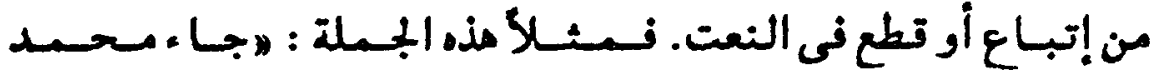
الكريم" إذا كنت تريد الإتباع كانت نفمة الصوت مستوية ني الجملة

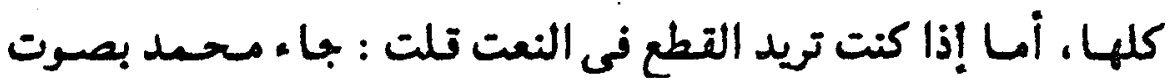

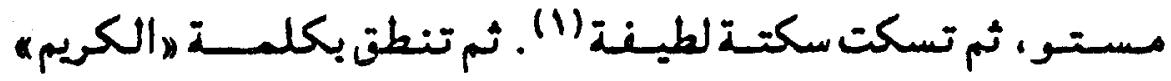
بصوت يختلف عن نطقل بجملة لا جاء محسد ه تد يكون نطقل بكلهة

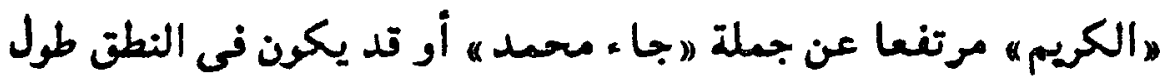

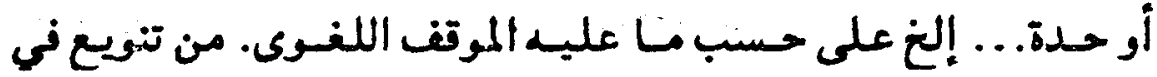

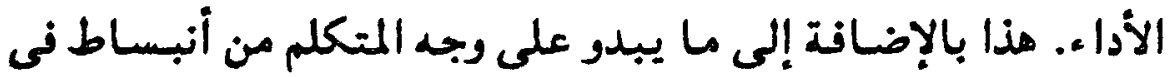

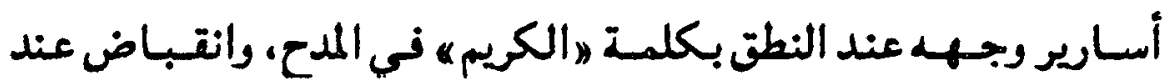
النطت بكلمة رالبخيل ه في الذم.

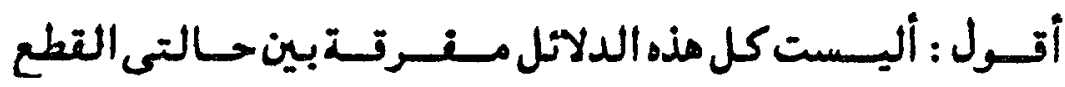

تشبه السكتة التى حِدث عنها القراء وعلعاء الضبط ونبهِهوا إليها

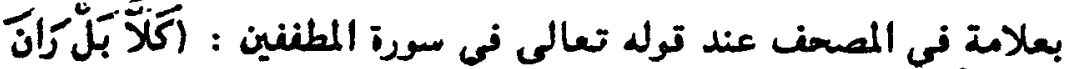

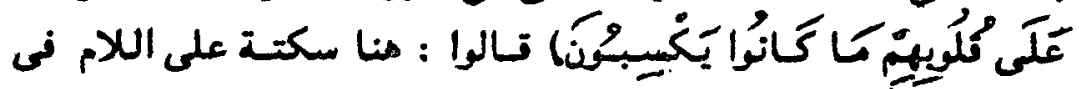

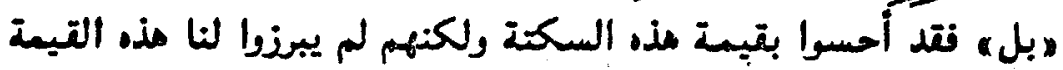
وأمهيتها نى الأواء. أتول : إن الغرض من الوتوف هو تلكن التارئ من النطق باللام ولولا

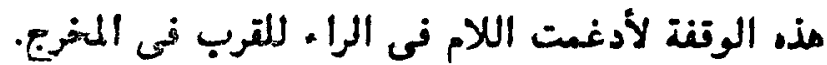

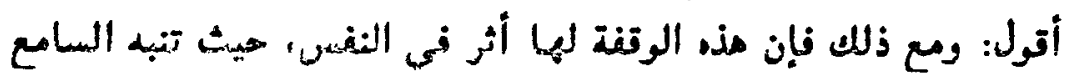

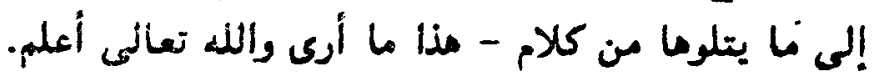

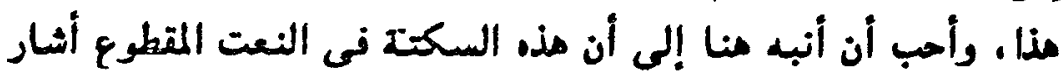

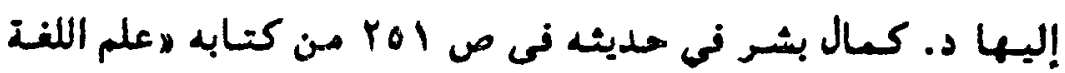




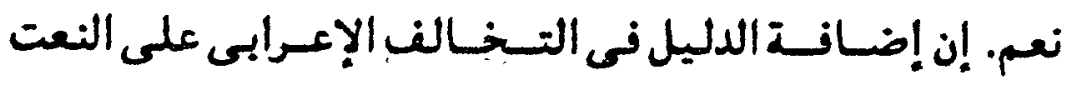

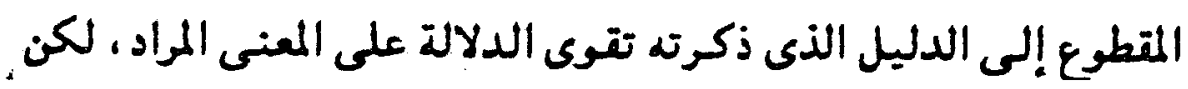

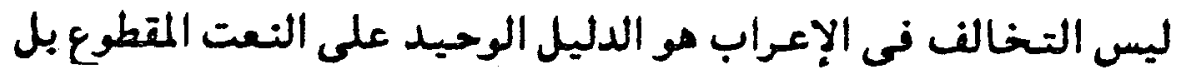

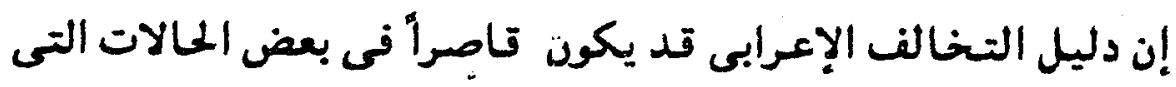

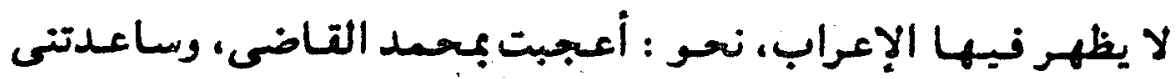

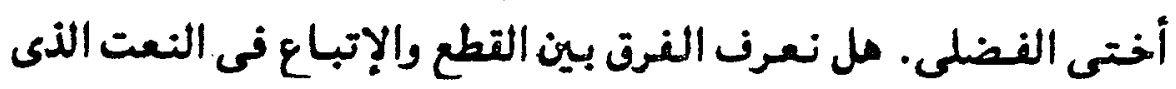

مو القاضى والفضلى فى الجملتين السابتتين ؟

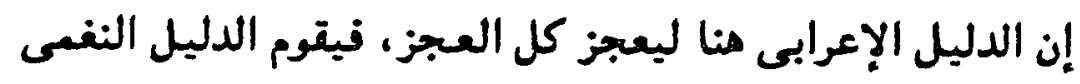
بالتفرتة بين ألقطع والإتباع خير قيام.

هناتشة راى الدكتور بشر فه النعت المتطوع :

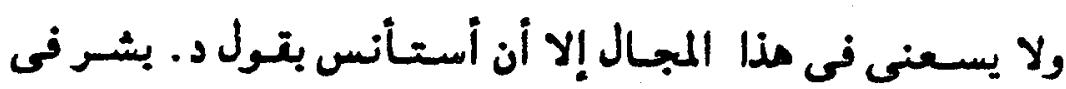

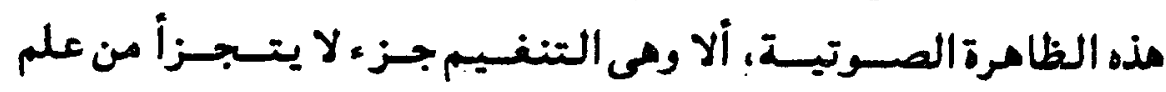

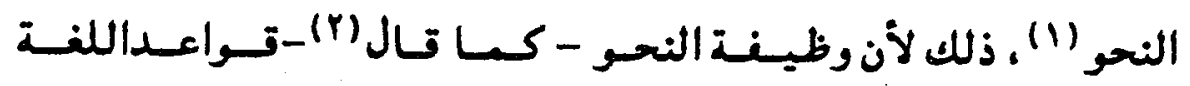

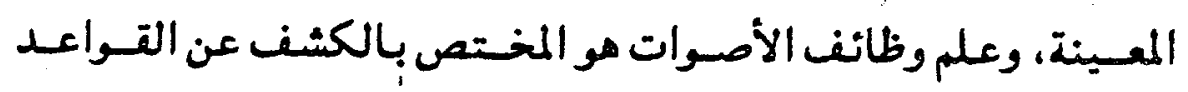

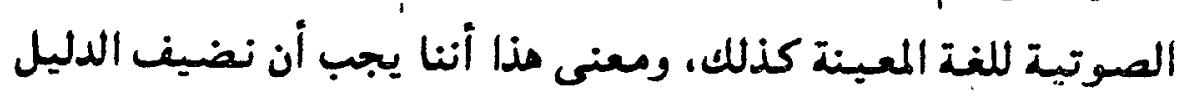

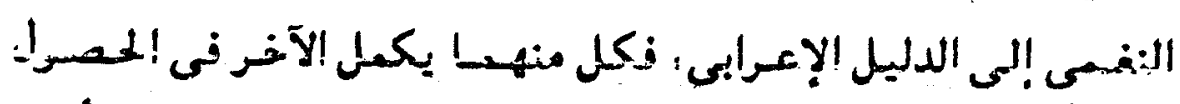

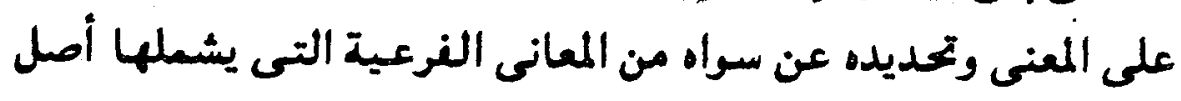
واحد.

وتحدث - بعد ذلك - عن النعت المقطوع فنالف النحويين في

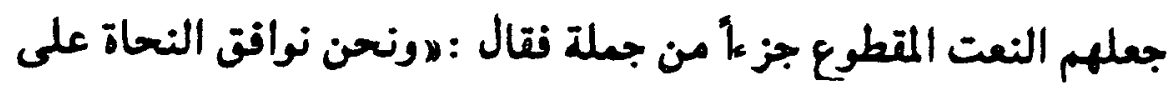

انظر علم اللغة العام ص ع ب ط الثانية - دار المعارت - بصر.

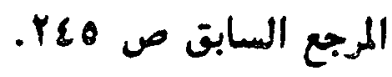




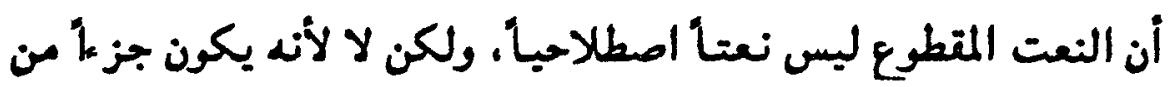

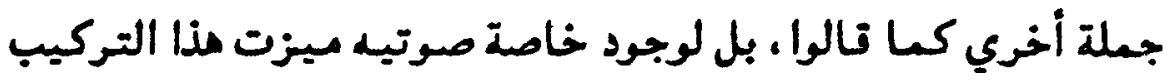

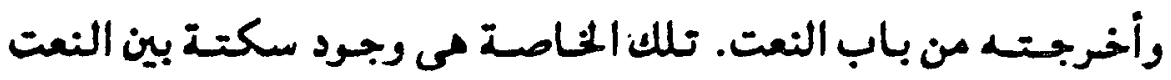

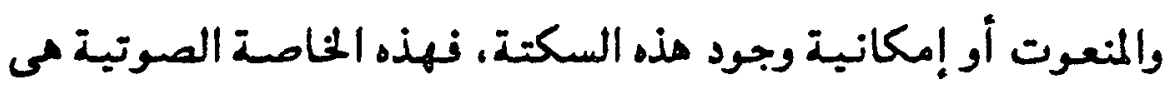

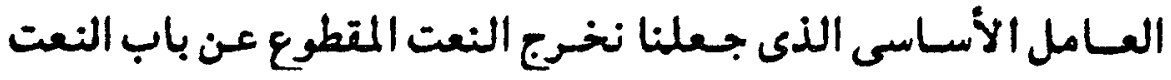

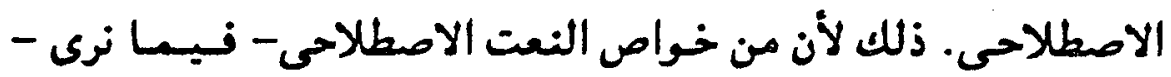

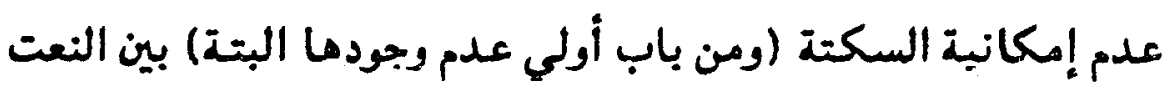
والمنعوته ه

أقـول : إذا كان حسيث (أ) عبـاس حسن تـد دار حسول الدليل

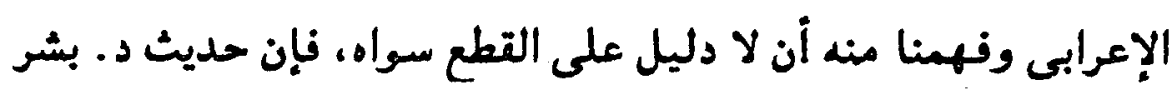

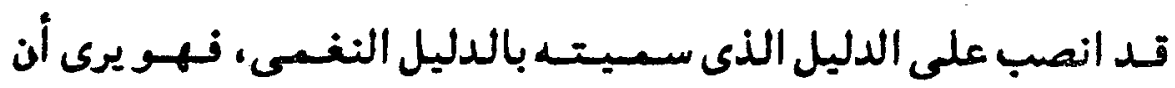
التنغيم مو النرق الأساسى بين النعت المقطوع والمتبع.

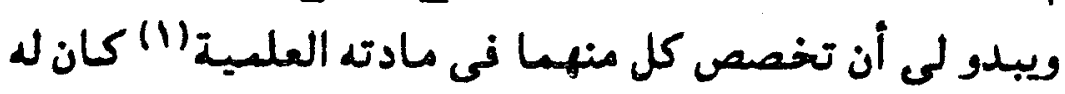

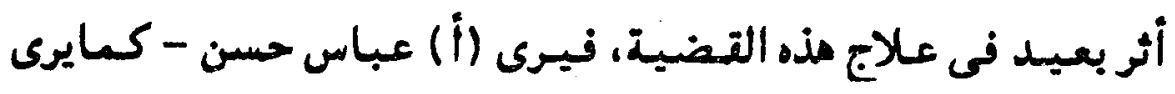

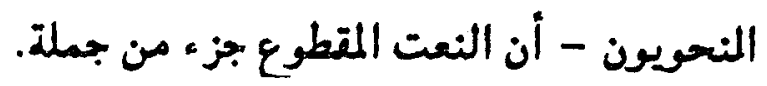

ويرثى د. بــــر أن النعت المقطوع - وحسده - يتم بـ المننى ولا

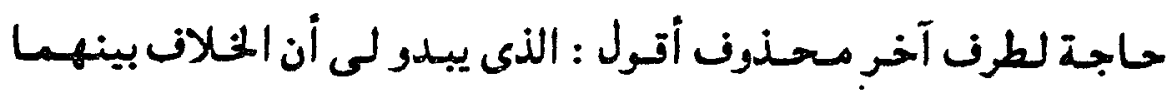

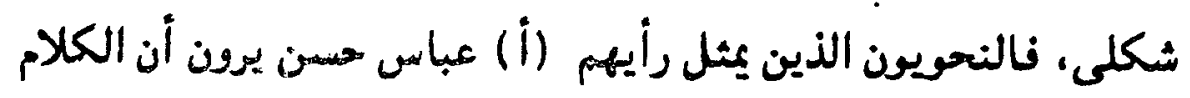

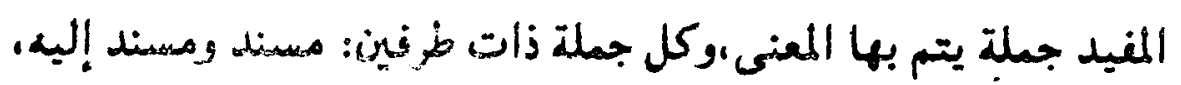

تخصص الأستاذ عباس حسن فى علم النحو وتخصصر 2. كمال بشر

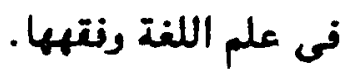




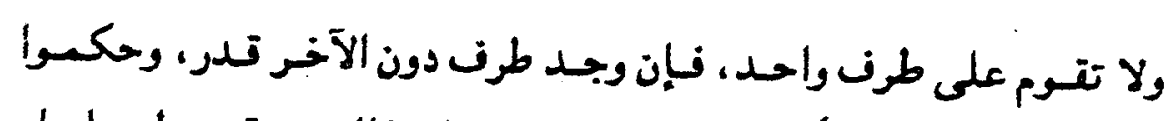

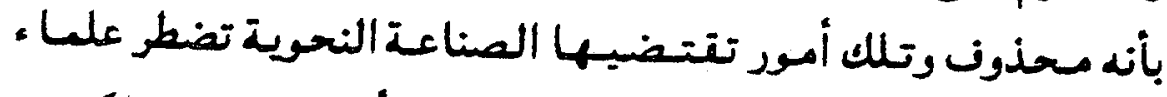

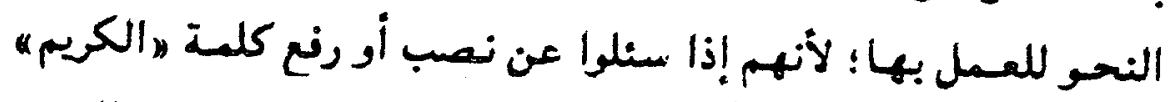

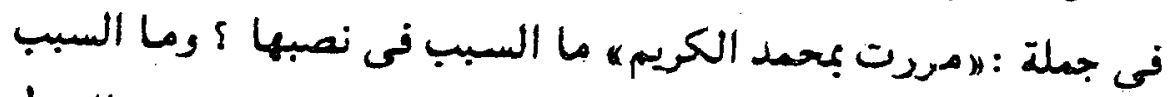

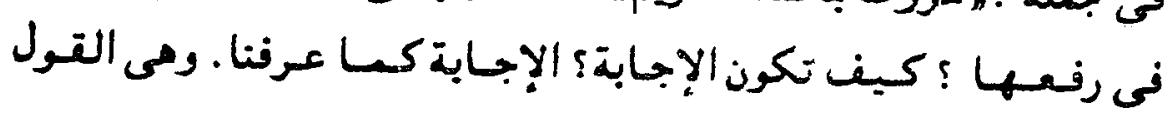

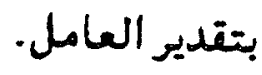

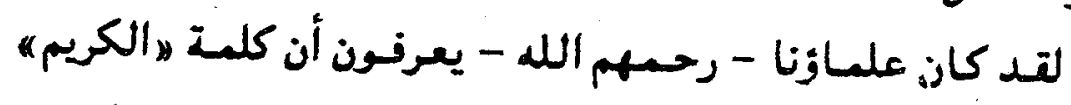

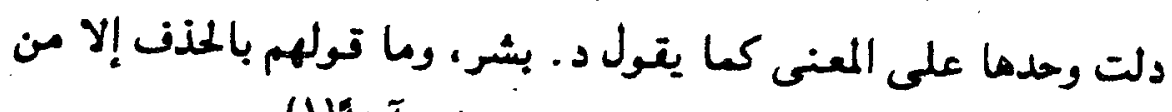

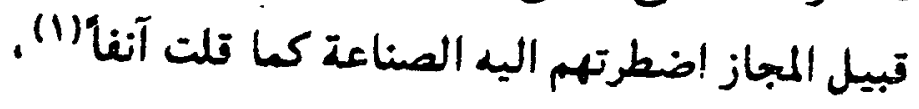

وإليك أحد علمائنا التـدامى، ذلك الرجل الذي عاش في القرن

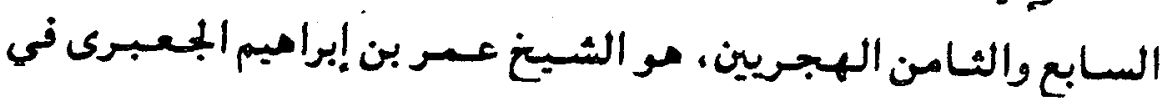
منظومة له في التذكير والتأنيث يقول :

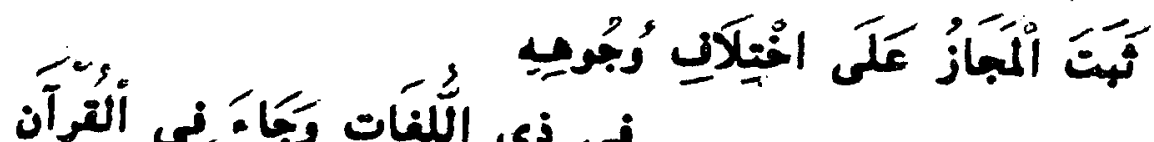

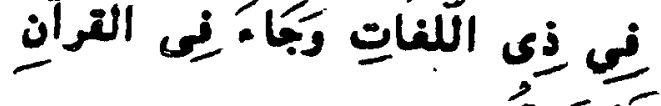

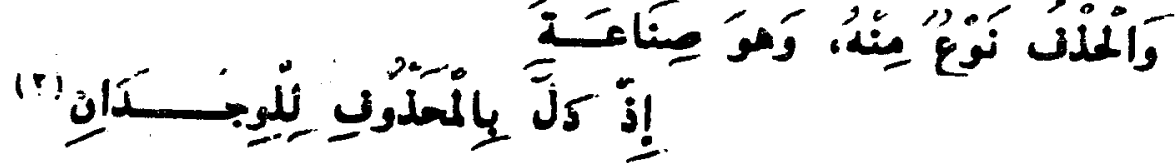

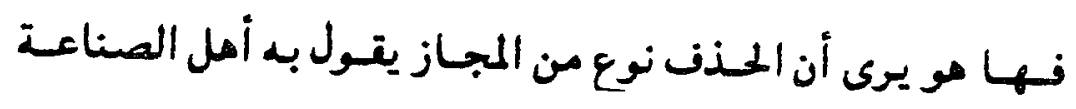
والمتحدثون بالمغة يفهمونها دون التنبيه لهذا الحذف.

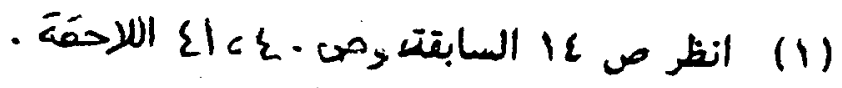

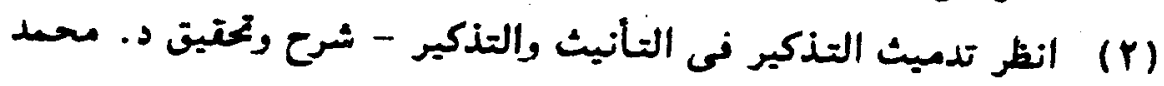

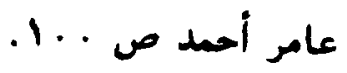




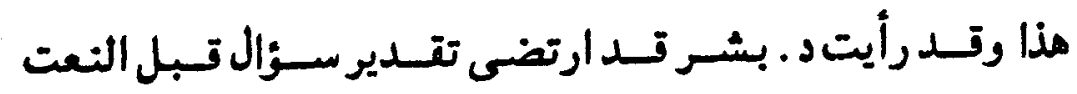

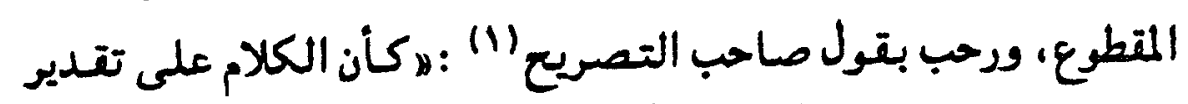

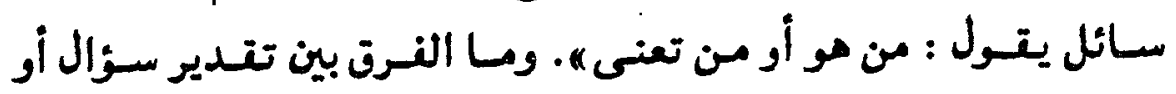

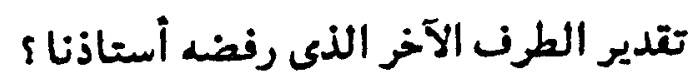

\section{جواز القطع والاتتباع فى رائ ح. بشر :}

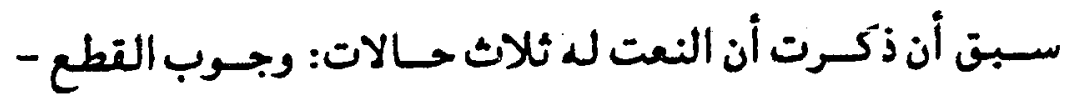

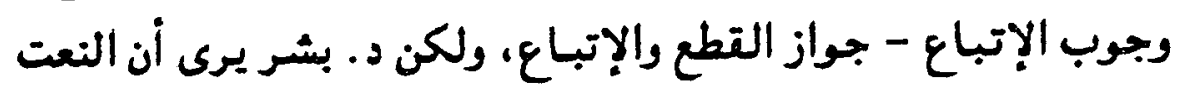

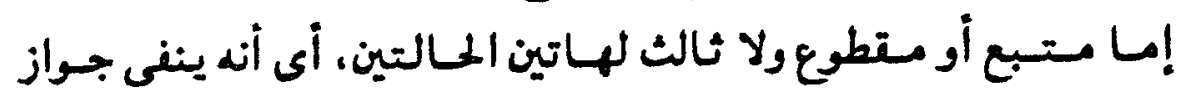

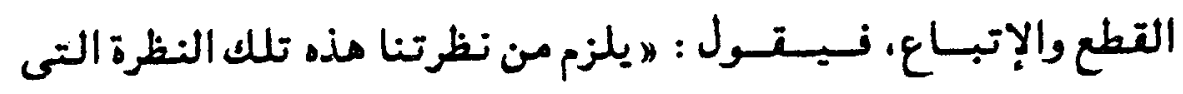

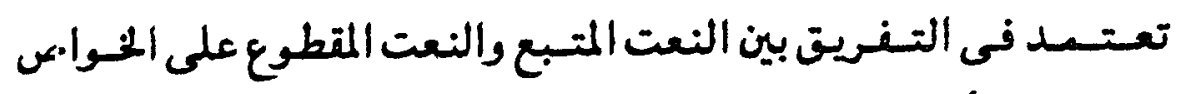

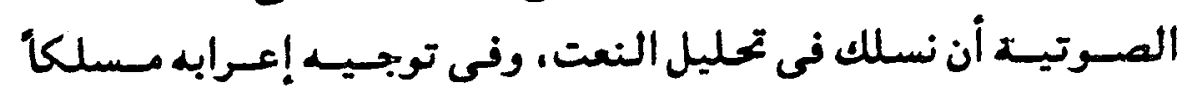

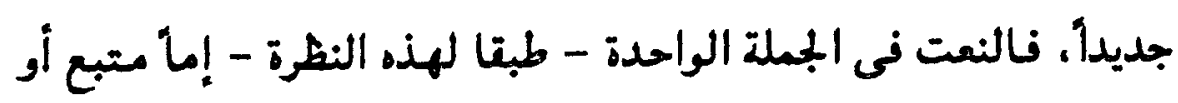

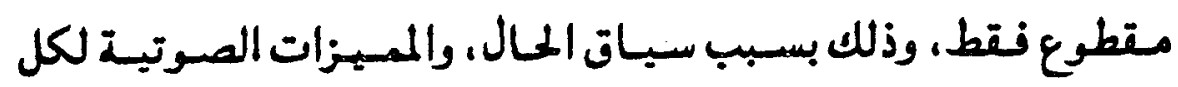

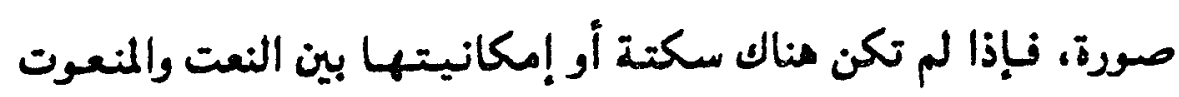

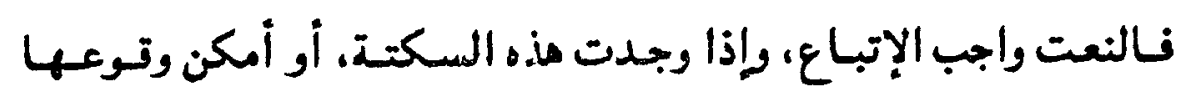
نالنغت وأجب القطع " (r)

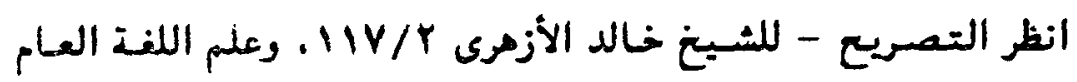

$$
\text { ص r }
$$

انظر علم اللغة العام ص rop ror. ror 
ويقول مؤكدا رأيه : لاوتهجنا فى مذه التضيسة مبنى على أساس الواقع اللغوى (لا الافتراض العتلى) الذى يعتمد عليه الدرس اللغوى

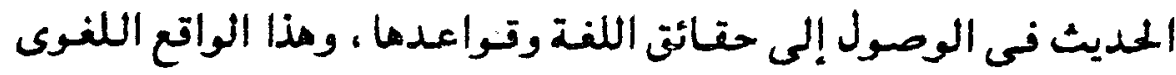

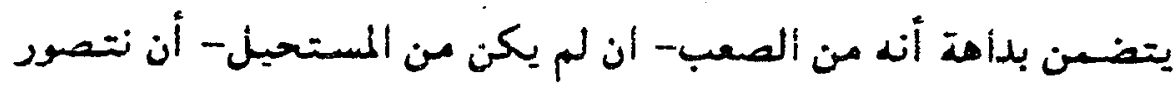
الموتف اللغـوى الواحد بقتهفى نجملة نيهل نهت قابل للإتباع والقطع فى يقت واحد ، نالمتكلم ينطق الجملة بصورة واحدة في موقعها المعين، فإذا ما نطقت علي وجد آخر تضمن ذلك بالضرورة وجود موتف آخر. فى هذه الحالة تصبح جملة جديدة تحتاج إلى نظر مستتل " (I)

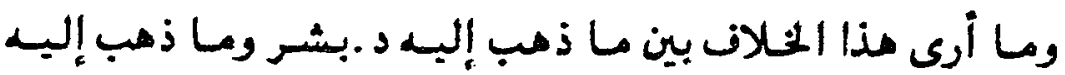
النحويون إلا ظاهرأ، فهو على حت فيسـا زأى، والنحويون - أيضا -

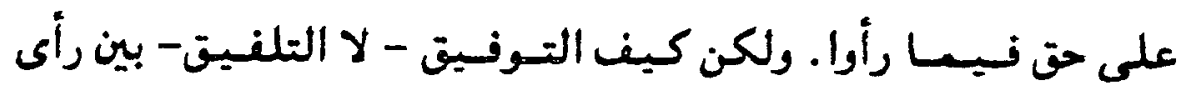
ينفى ورأى يثبت، نالنحويون يثبتون حالة الجواز، زود ـ بشر ينفيها.

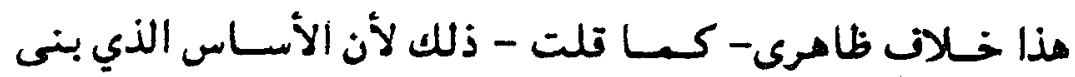

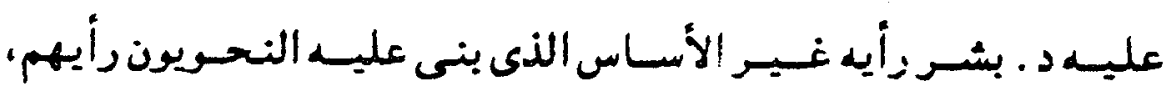

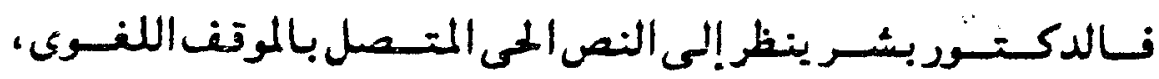

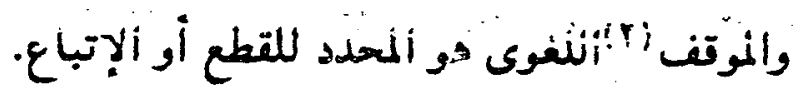

$$
\text { الكرجع السابق. }
$$

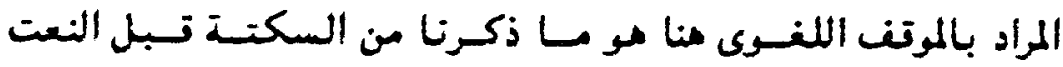

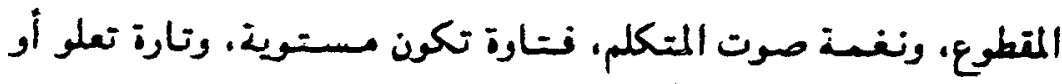
تنـخـفض إلى غـيـر ذلك من التلوين الصسوتى الذى تخــلف المعـانى 
وأمـا التحسويون فنظروا إلى النص منفـصلا عـن الموتف اللغـوى.

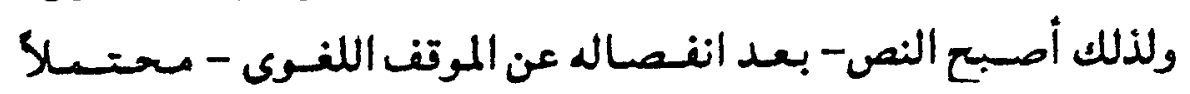

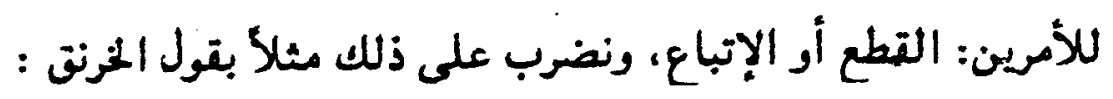

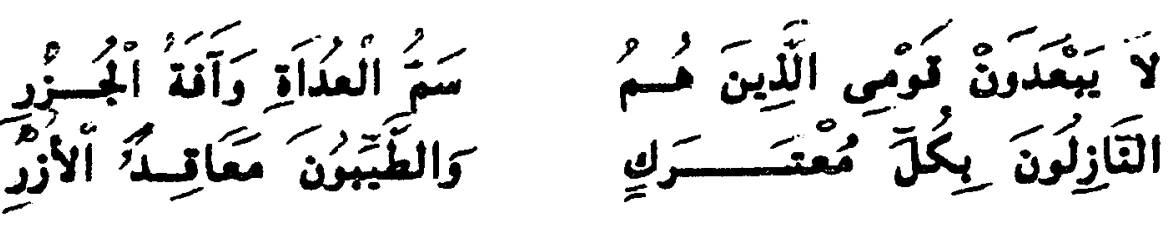

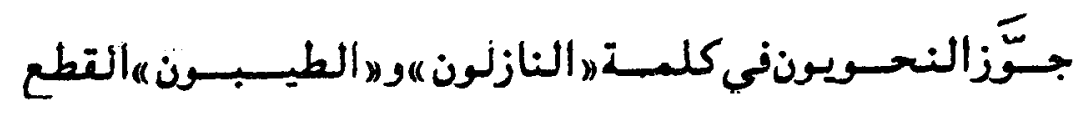

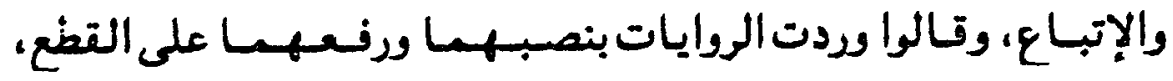

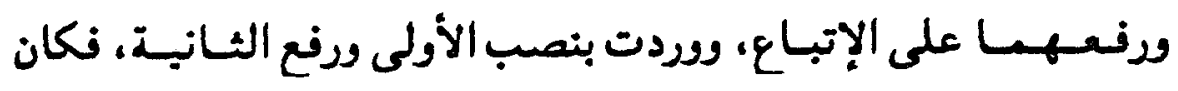
حكهـما مبنيا على النظرة إلى النص وحده، ولم يلتفتـوأ إلى الأداء

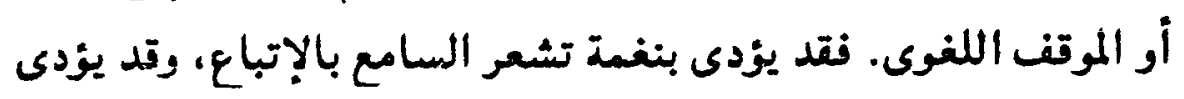

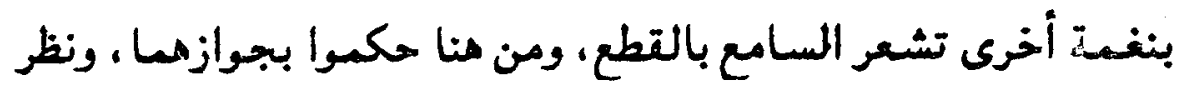

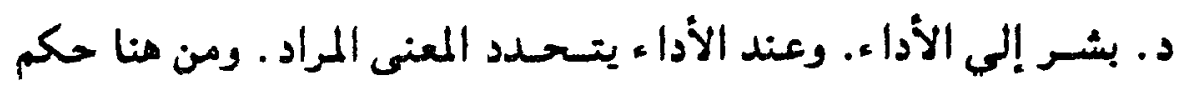
د. بشر بوجوب التطع أو وجوب الإتباع.

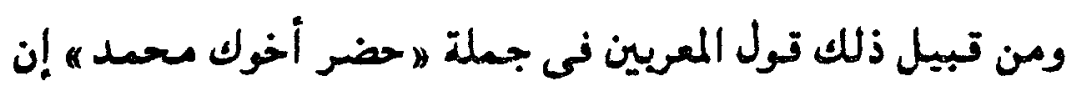

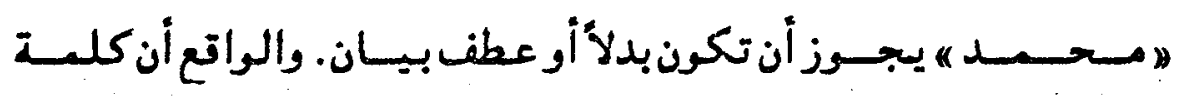

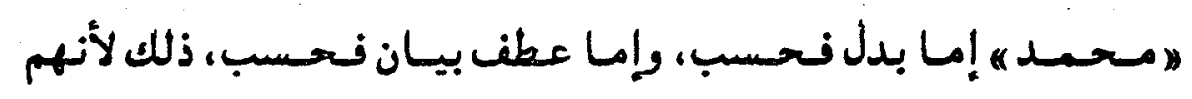
ينظرون إلى الجبعلة منفصلة عن الموقف اللغوى وسيات المات الكلام وقرائن

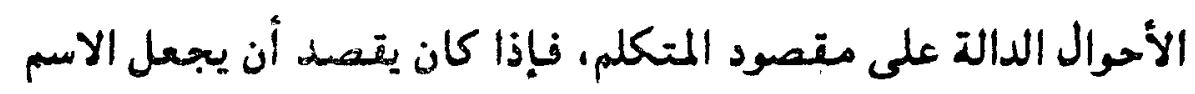

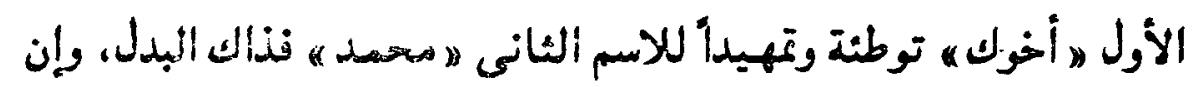

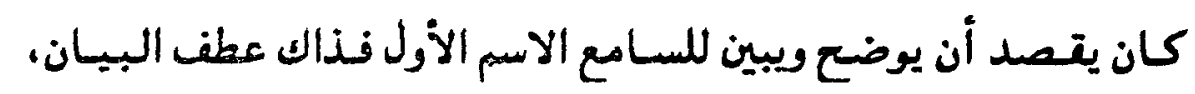

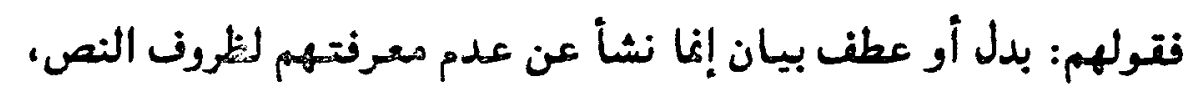

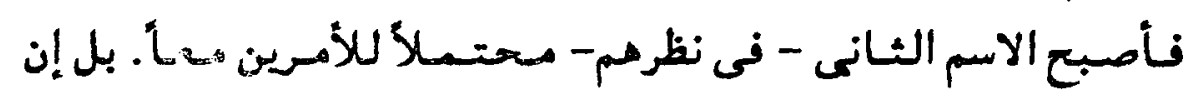


"أوه فى قولهم : لابدل أو عطف بيانه تشعرنا بإدراكهم لهذه المقيقة لأن هأو ألأحد الشيئين كما نعرن.

هل يتع التطع نه تابع غير تابع النعت؟

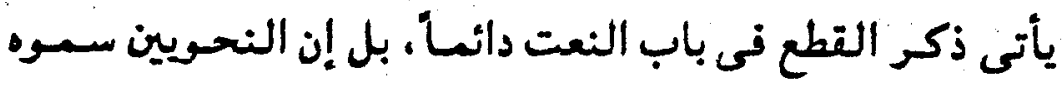

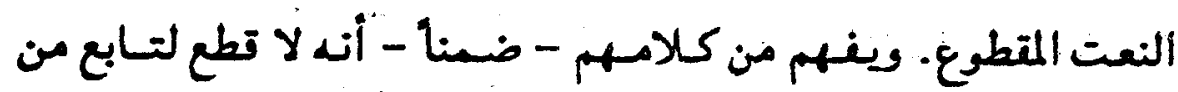

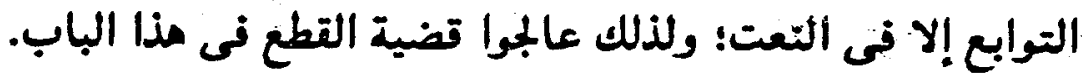
أقول: لما كان عطف البيان وظينته كوظيفة النعت فى إيضاح

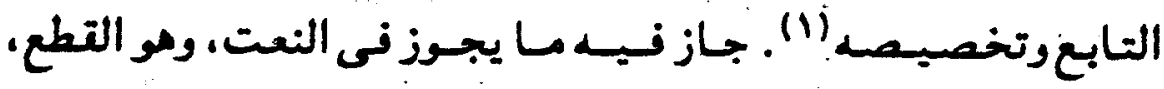
ولكن النحوين لم يوضحوا في باب النعت جواز القطع في غيره، وإنا

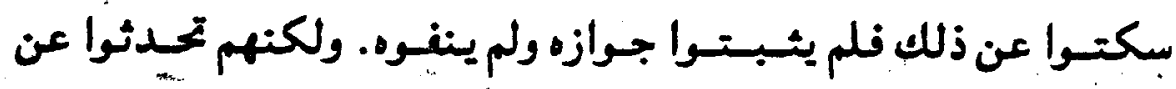

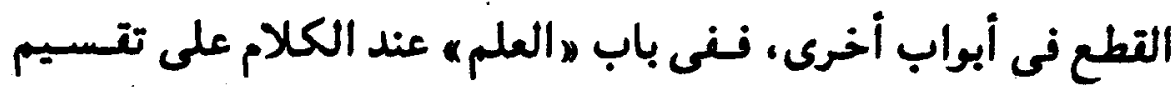

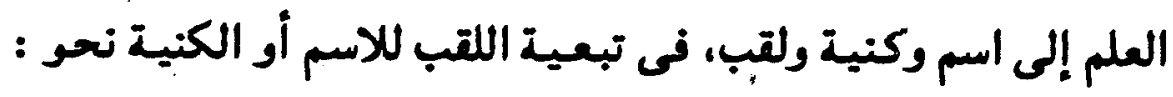

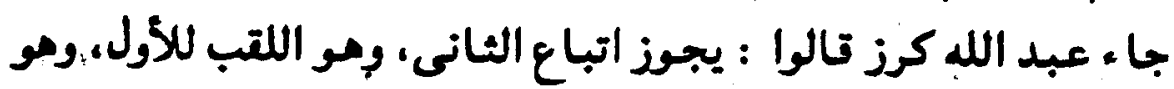

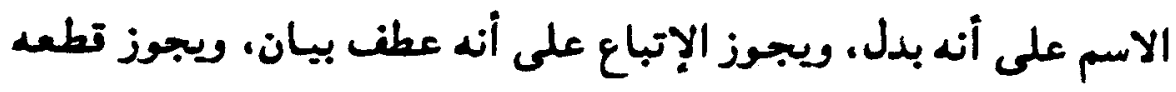

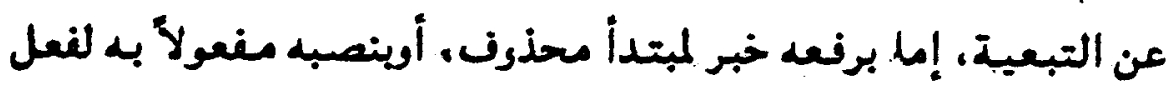
سحذون.

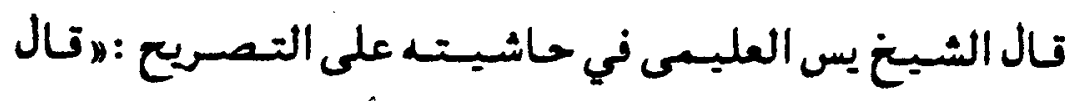

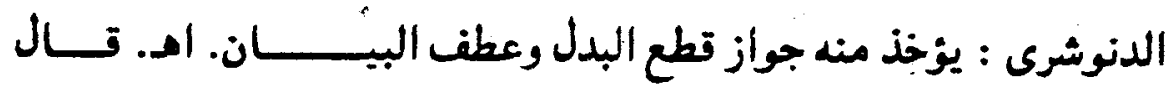

تال ابن مالل ص 110 من الألفية:

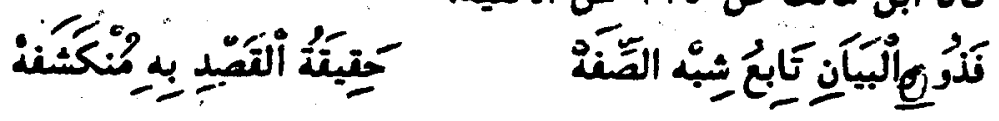


العليـمى معتبـاً: وفيـه إشعار بأن تطعهمبا غيــر منصوص عليـه فى كلامهم وليس كذلكه" (1") وقال العلامة الصبان فى حاشيته على شرح الأشبـونى معلقا

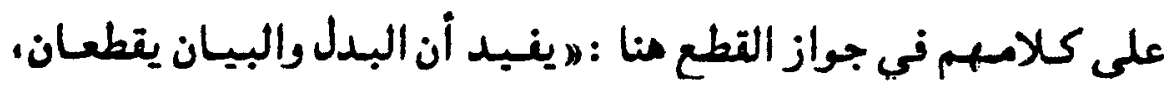

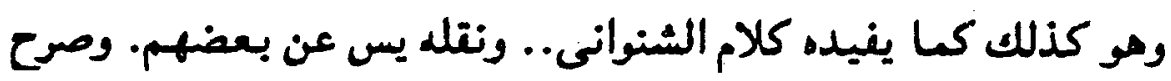

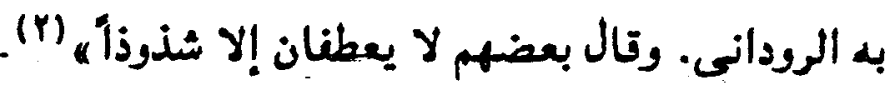

ولكن العلامـة الصبـان ذكر بعـد ذلك أن من الفـروق بين البـل

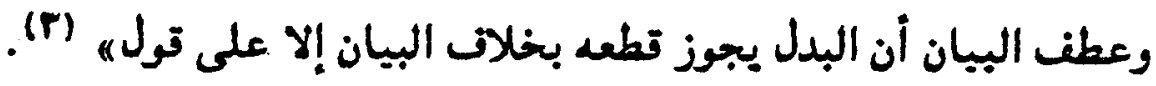

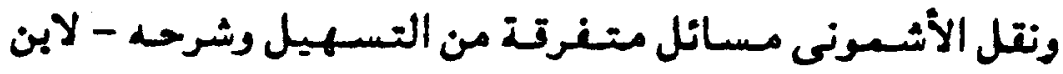

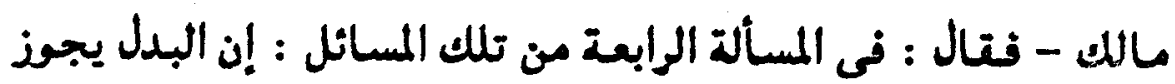

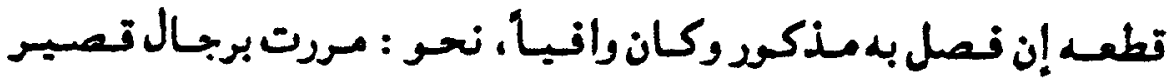

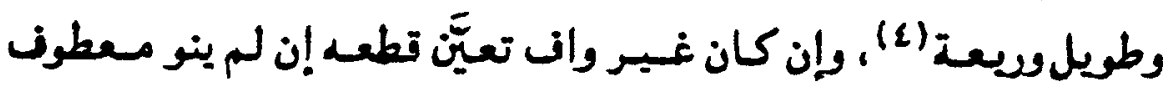

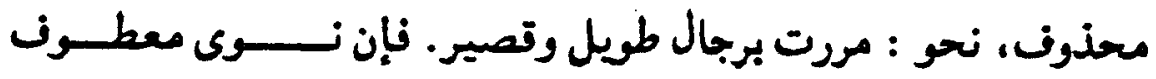

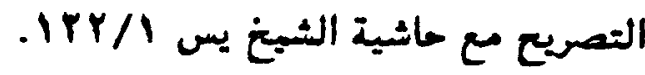

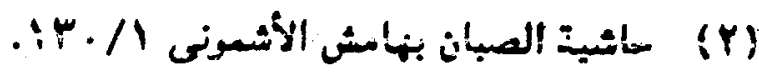
المرجع السابق آهA

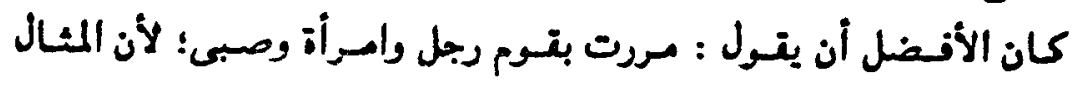

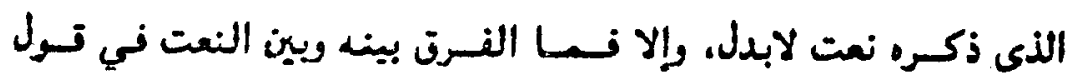

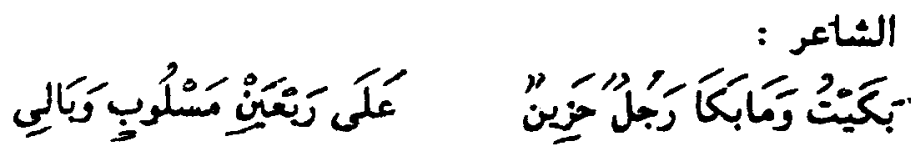

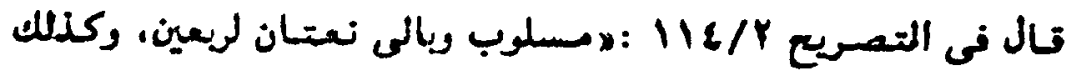

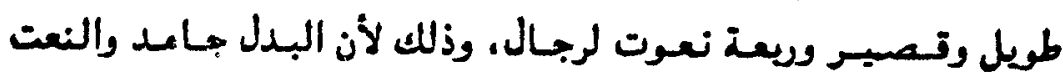




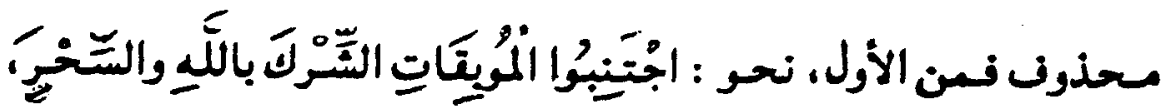

بالنصب، التقدير: واخواتهما، "(1)

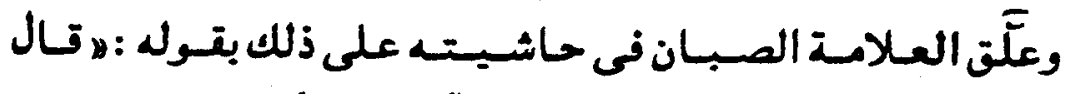

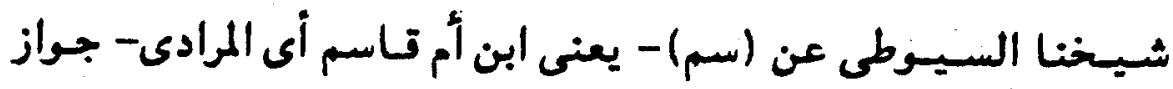

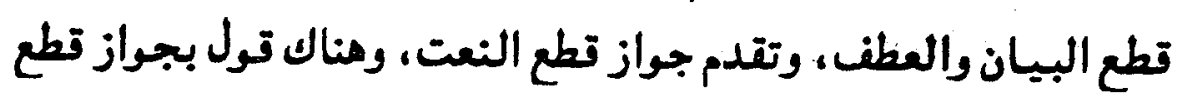
(r) التوكيد النيبان

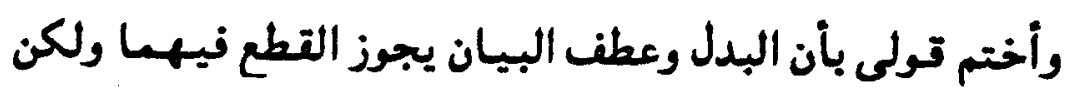

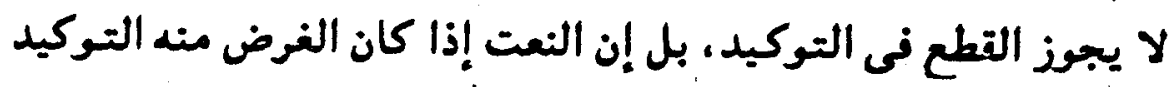

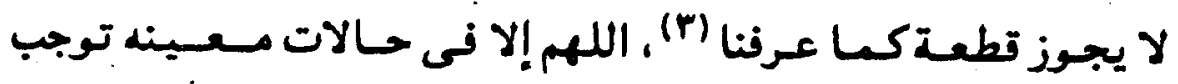

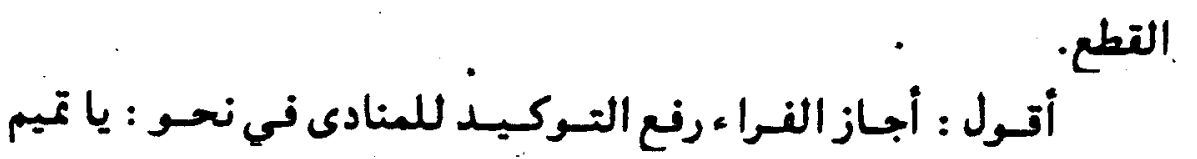

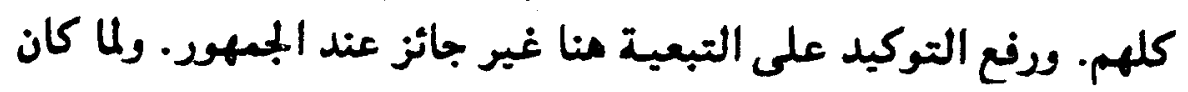

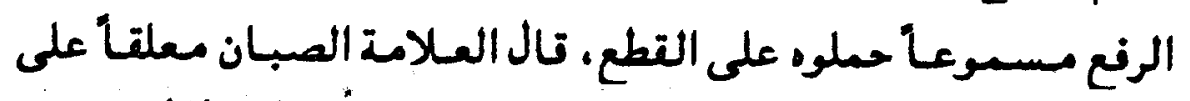

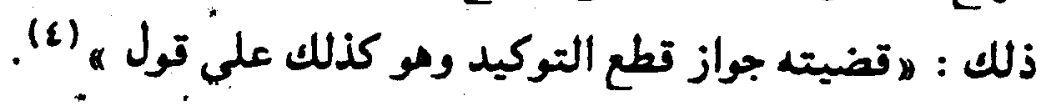

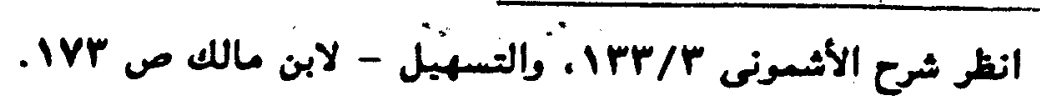

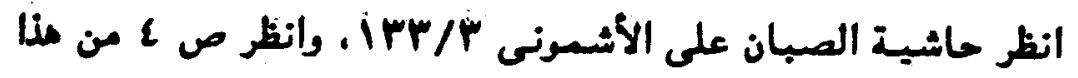
البحث.

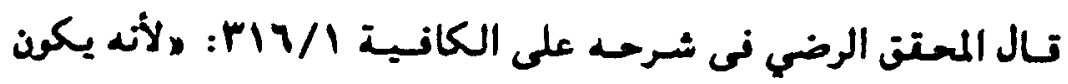

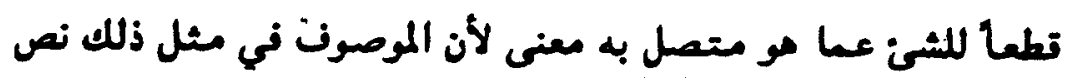

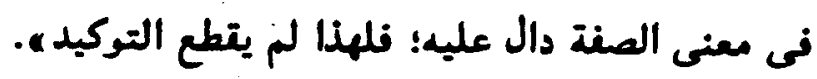

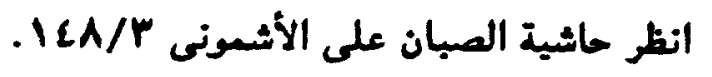




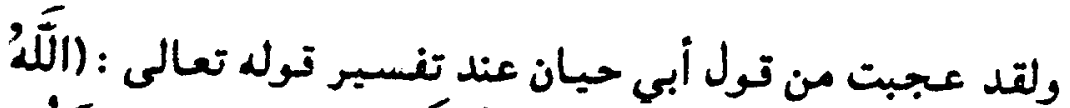

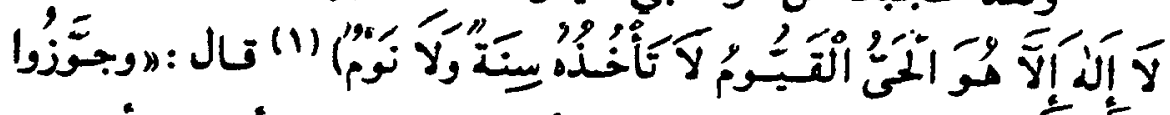

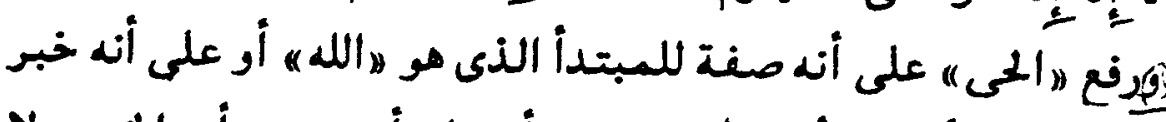

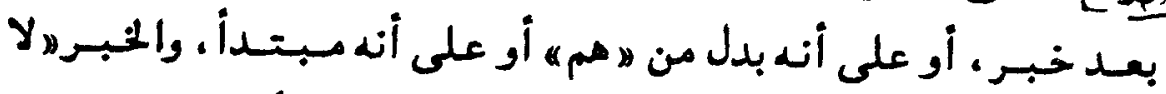

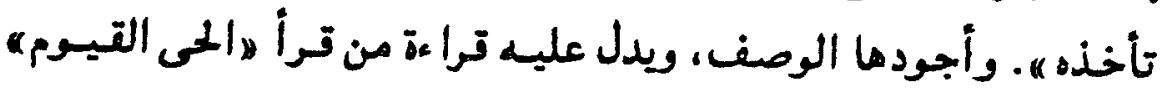

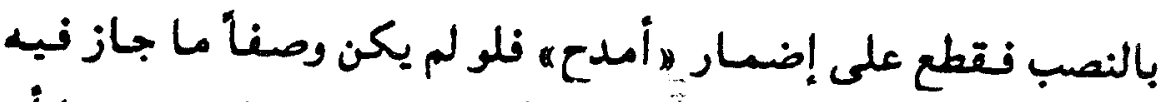

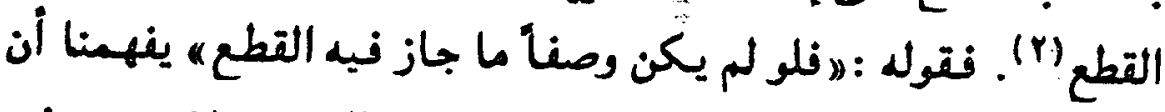

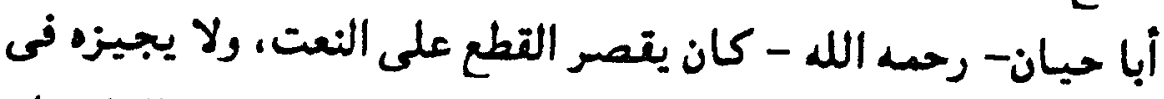
غيره، وركن القطع - كسا عرفنا وكما سنعرن في النصل الثانى إن

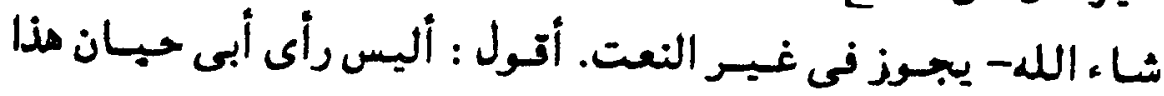

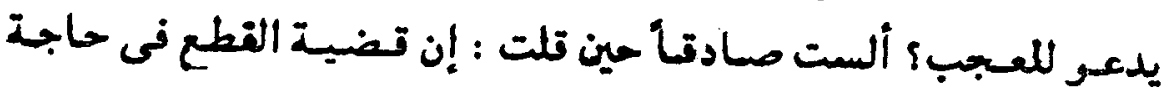

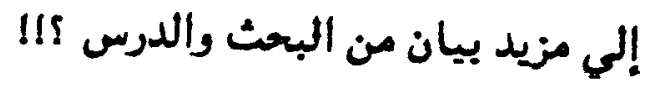

هصطالح التطك عند الكونيفين وعلاتنه بتضية النعت الهتطوع :

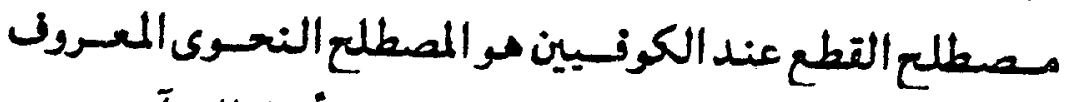
بالهال، والطبرى نى تفسيره "جامع البيان عن تأويل القرآنه يعبر

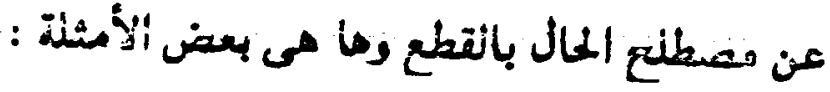

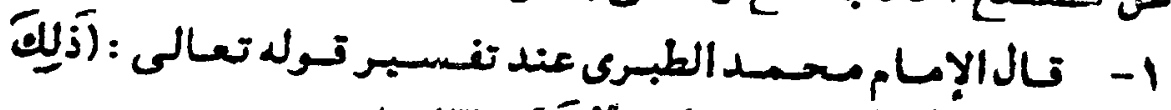

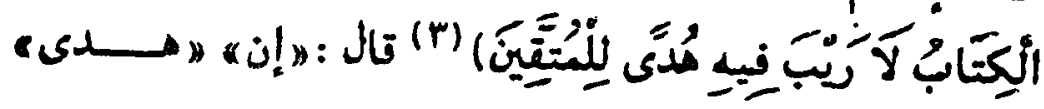

$$
\begin{aligned}
& \text { من الآية POO من سورة البترة. } \\
& \text { انظ البحر المحيط - لأهى حيان PVV/F. } \\
& \text { من الآية Y من سورة البترة . }
\end{aligned}
$$




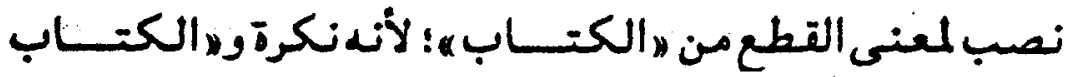

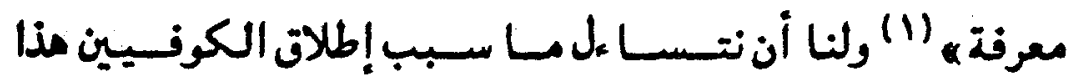

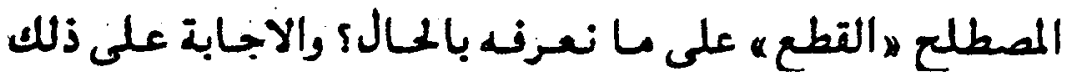

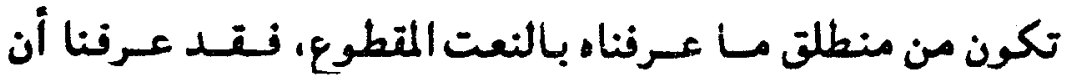

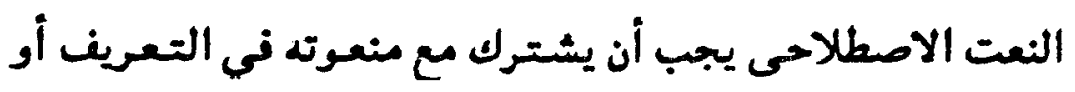

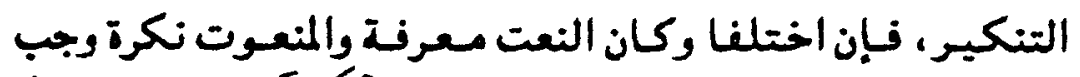

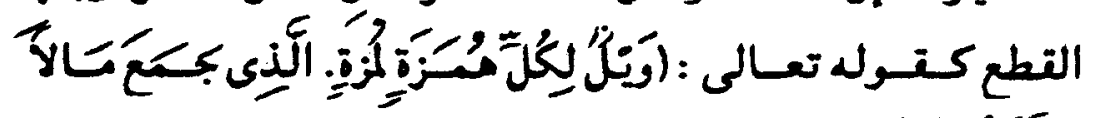

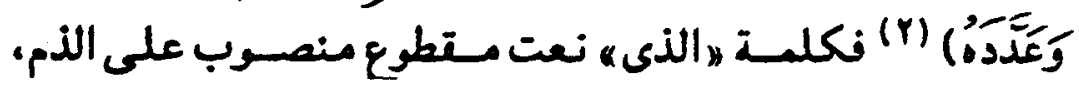

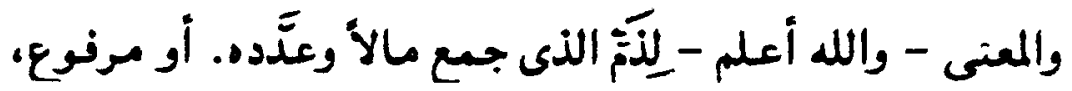

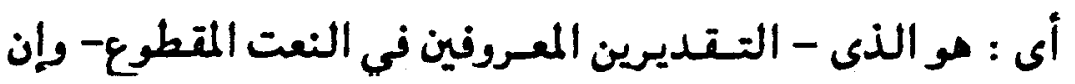

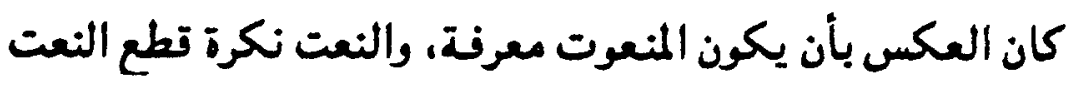

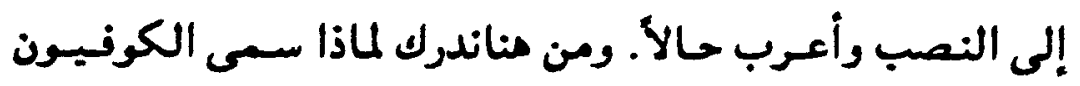

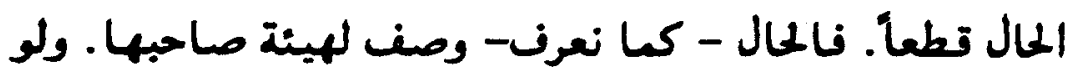

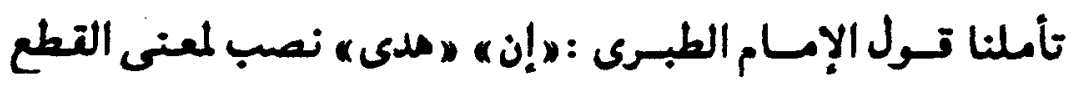

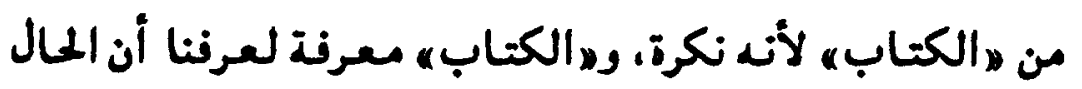

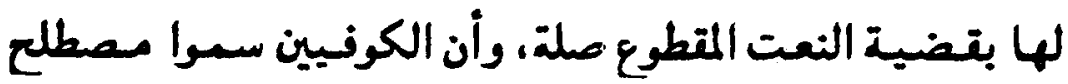

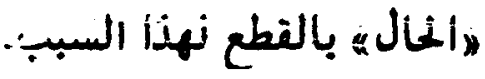

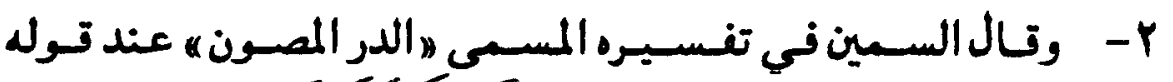

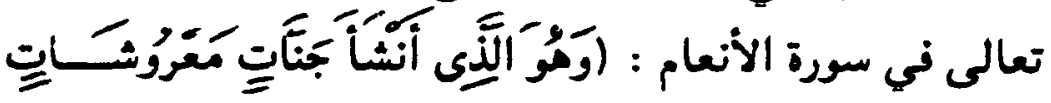

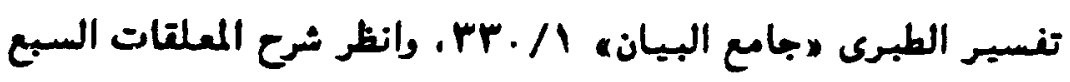

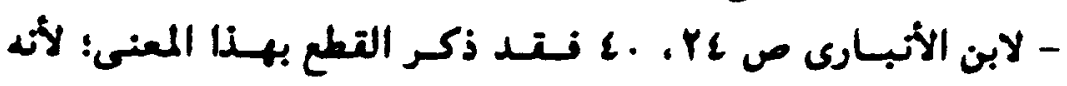
كوفى المذهب.

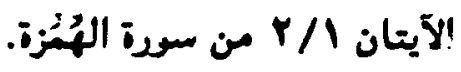




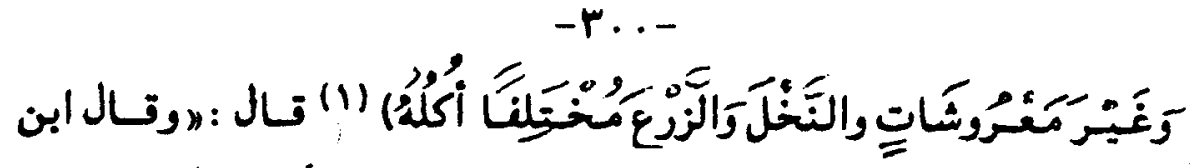

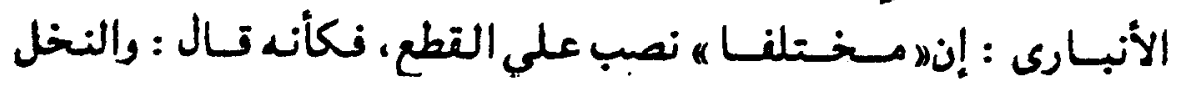

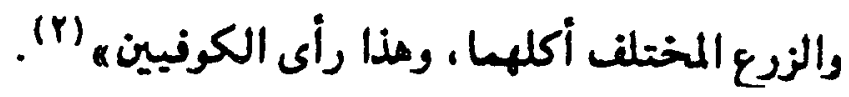

ومن منا نفهم أن كلمة „المختلف ه لما كانت معرفة نصبت على

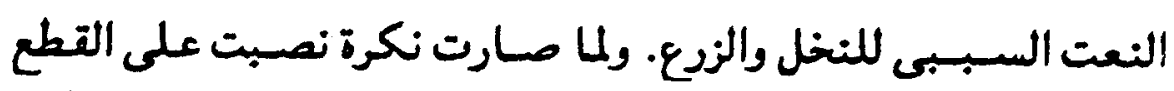

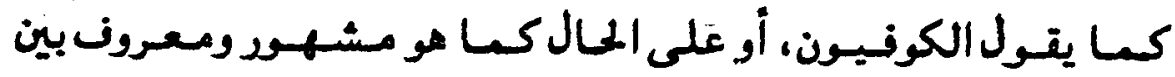
النحويين قدما ـ ومحدثين.

$$
\text { (1) (1) من الآية (1) }
$$

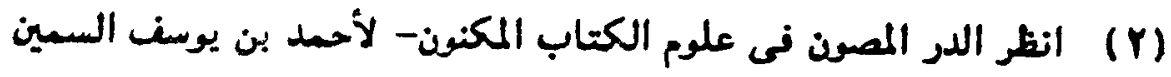

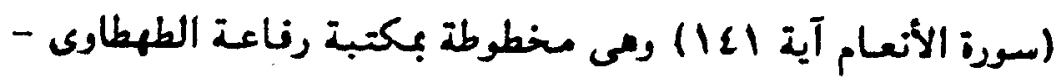
بسوهاج. 


\section{$-r \cdot 1-$

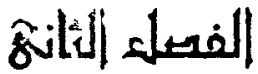

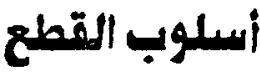

دراسلة تطبيتية على نصوص مه القرآن الكريم والشهر

(1) دراسة اسلوب التطع على نصوم هـن التر آن الكريم

ورد أسلوب القطع فى الترآن الكريم كثبـبرا، بـاء فى القراءات السبع والعشر، وجاء كثيرأ فى القراءات الثاذة.

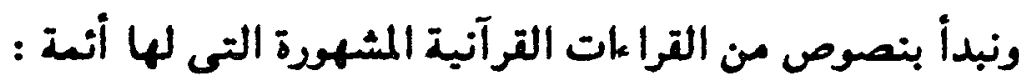

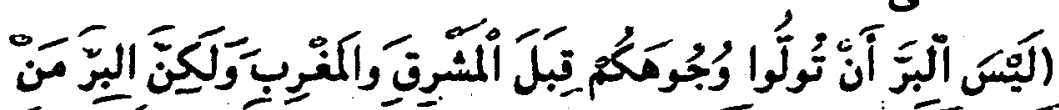

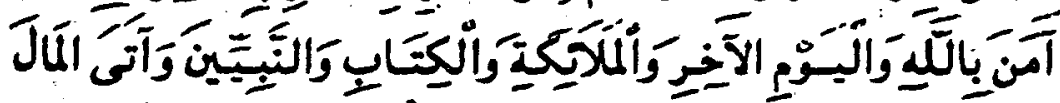

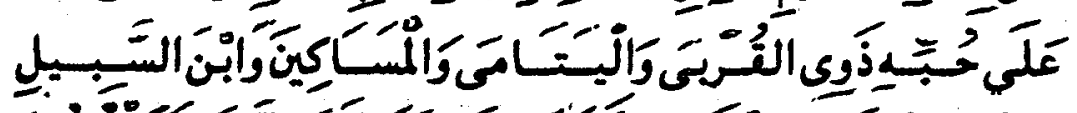

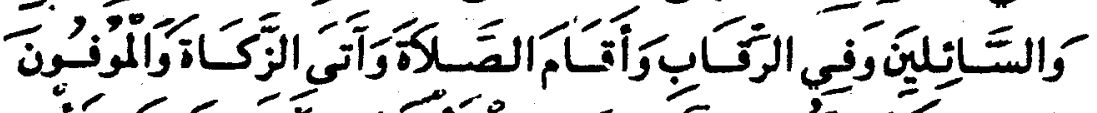

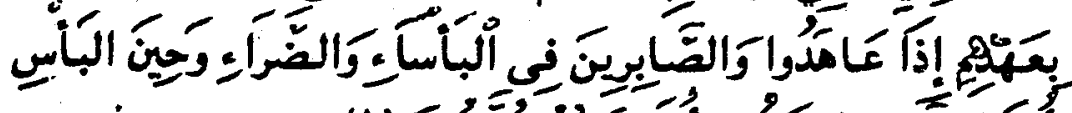

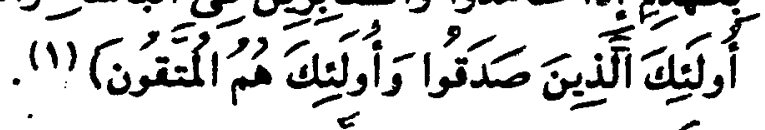

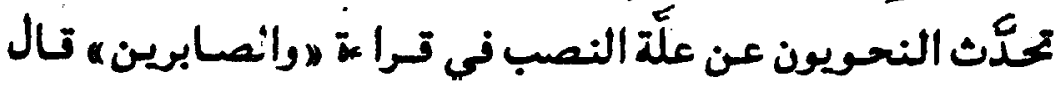

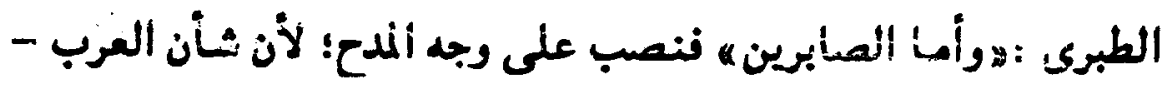

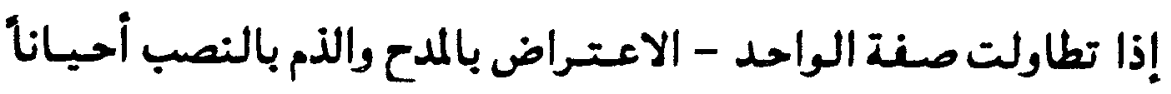

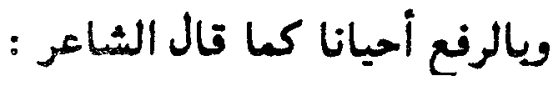

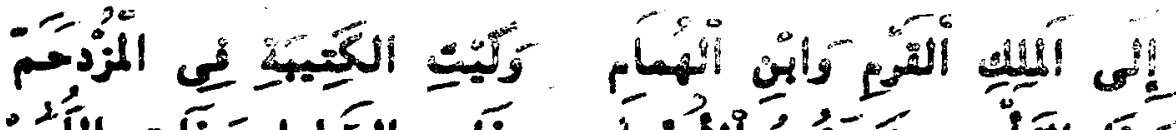

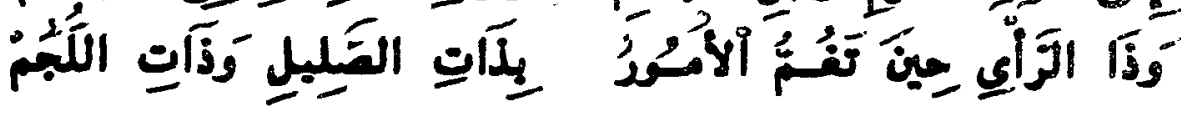


فنصب هليت الكتيبة، ولاذا الرأى ه على المدح، والاسم قبلهيا مخفوض؛ لأنه من صفة واحد، ومنه تول الآخر :

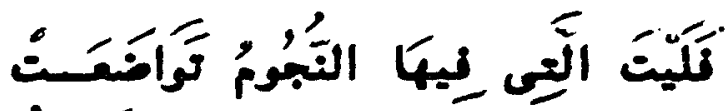

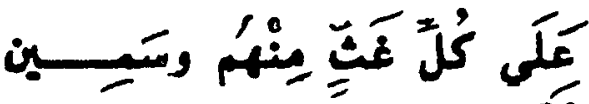

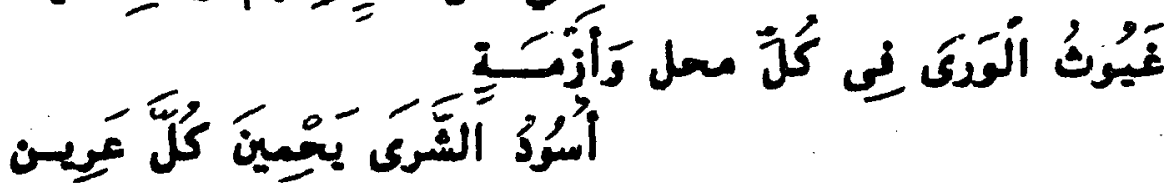

$$
\text { (1) } * \text {. } 1
$$

وعلق ابن تتيبة على قراءة النصب هذه بقوله : لاوالقراء جعيعا

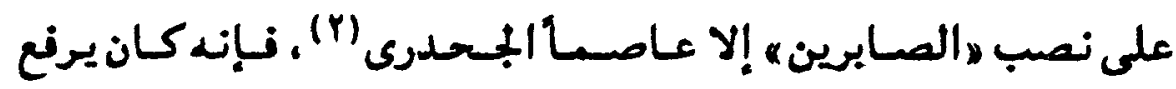

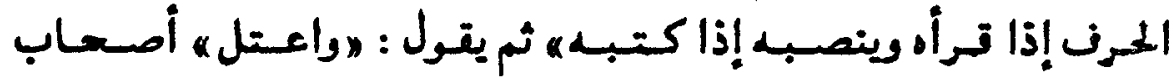

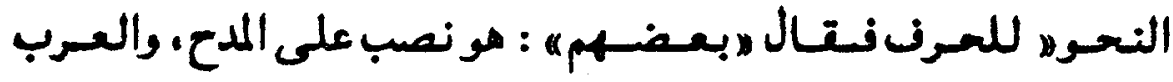

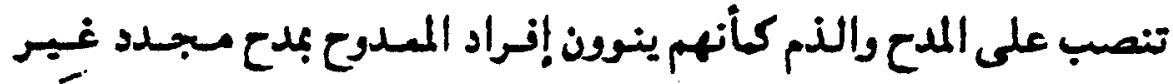

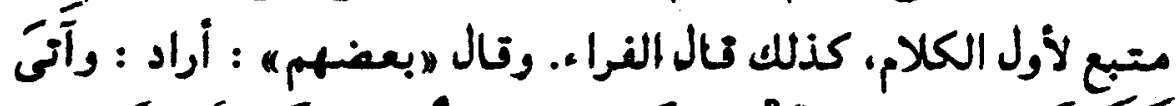

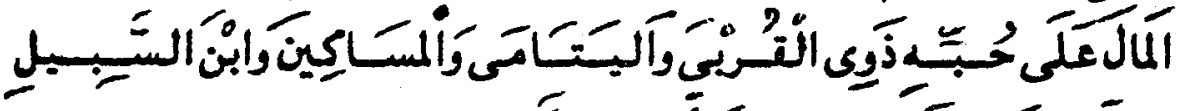

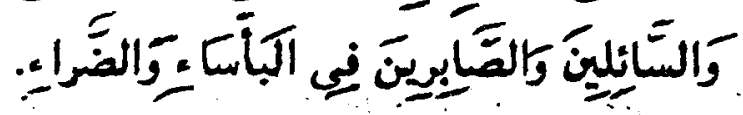

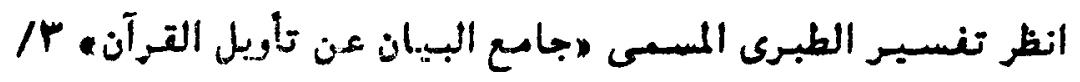

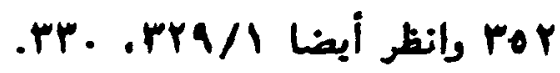

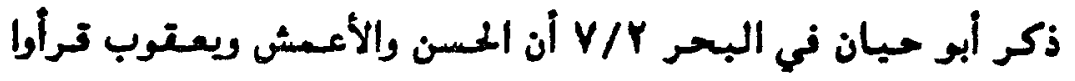

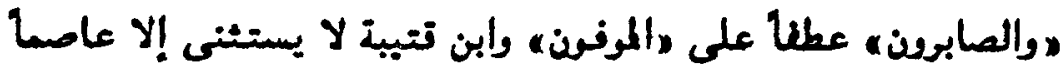
الجملدرى كما ترى، ولعل المراد انفراده بالنصب كتابة. 


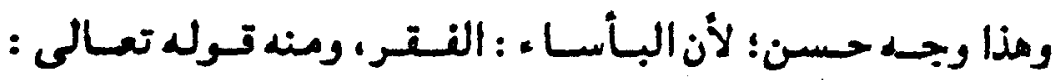

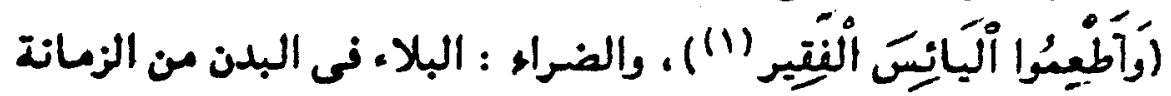

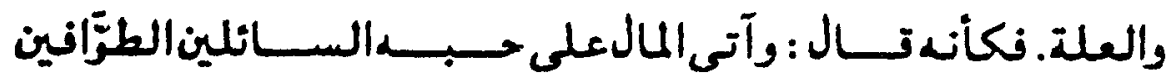

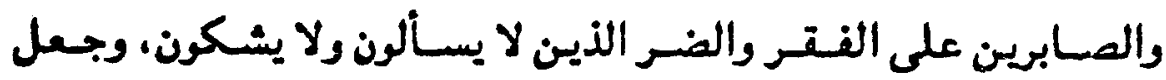

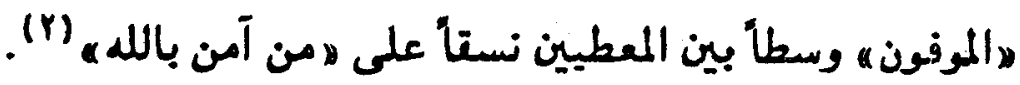

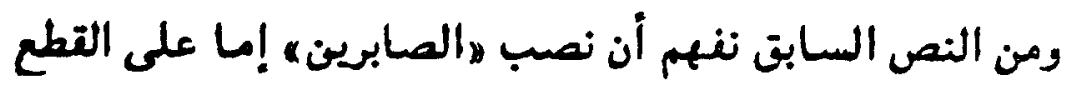

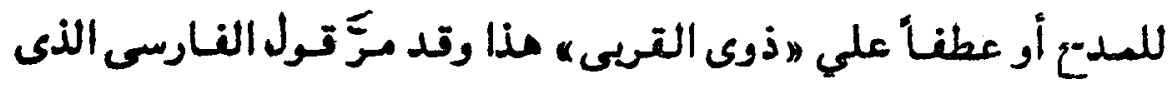

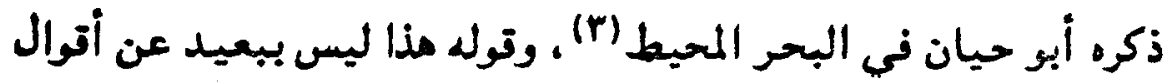

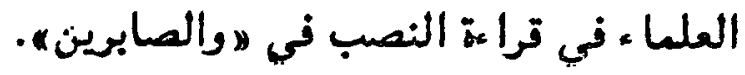

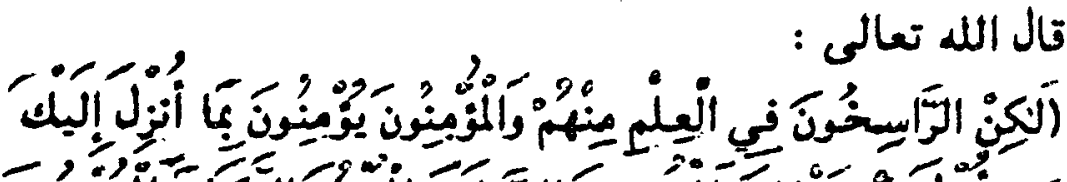

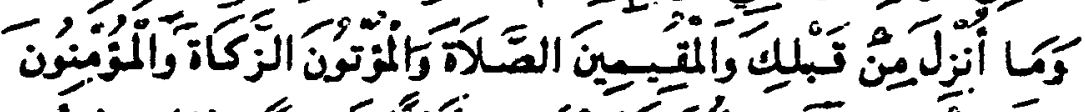

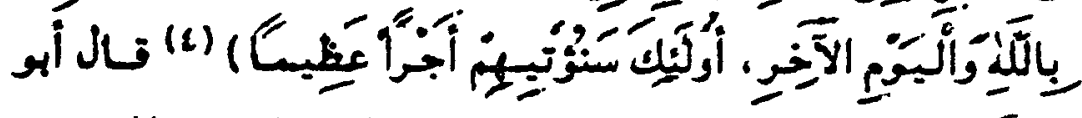

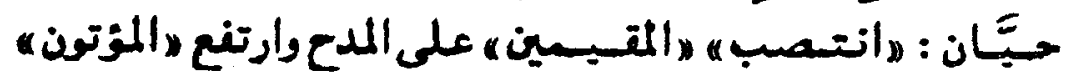

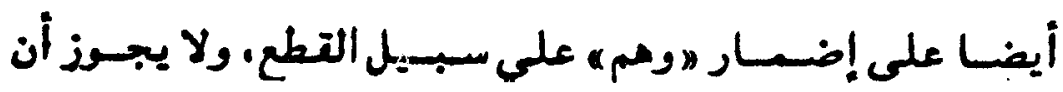

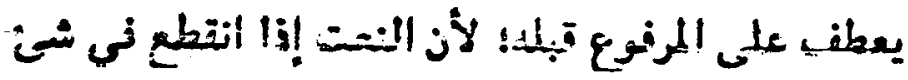

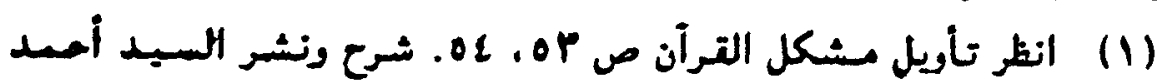

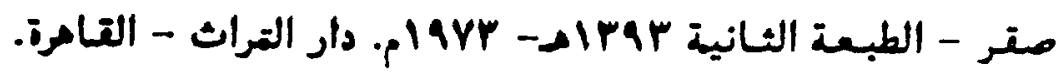

$$
\text { والآية PA من سودة الحجب. }
$$

(Y) تكون على الأول.

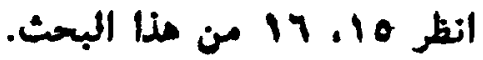




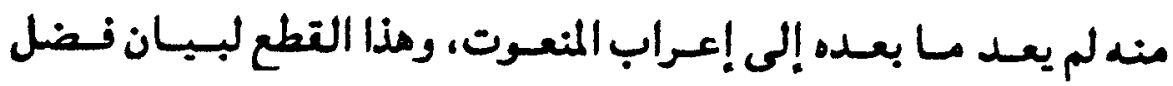
الصلاذ والزكاة نكثر الوصف بأن جعل في جمله" (1).

وقال ابن تيبة : هال بعضهم, : مو نصب على المدخ، قال ها أبو

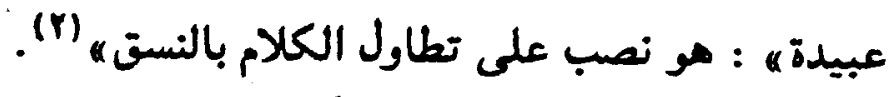

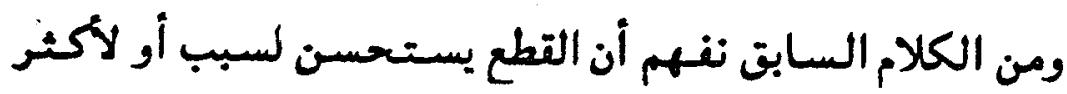

$$
\text { من الأسباب الآتية : النيابت }
$$

1- التطع لبيان نضل صنة على غيرما من الصنات.

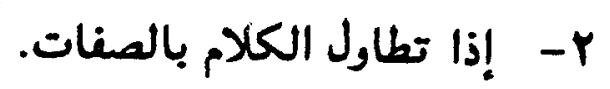

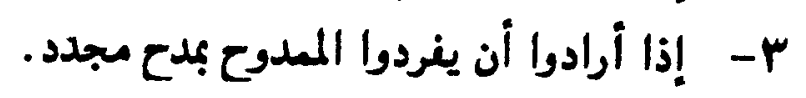

هذا وقد سبق أن تحدثت عن الأغراض البلاغية للقطع (r)

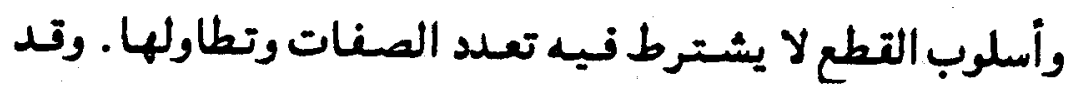

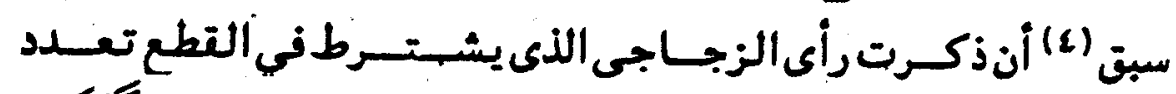

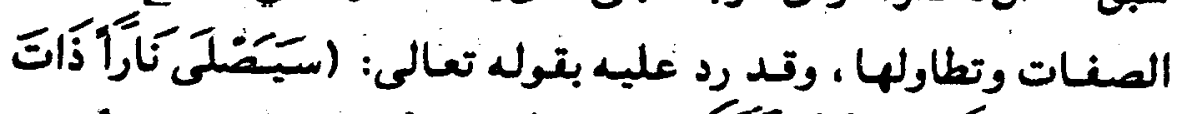

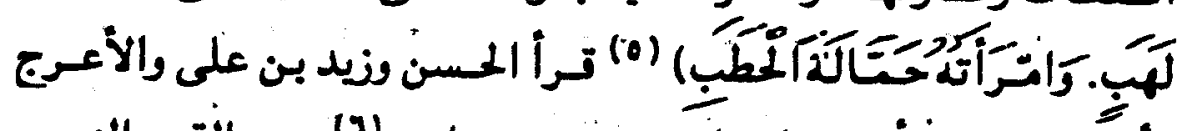

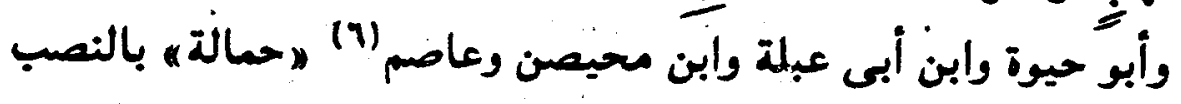

$$
\begin{aligned}
& \text { (1) (1) انظر البحر المحيط - لأبى حيان. r/ (1) }
\end{aligned}
$$

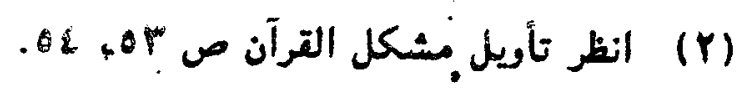

$$
\begin{aligned}
& \text { (T) }
\end{aligned}
$$

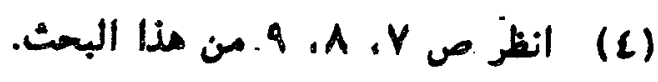

$$
\begin{aligned}
& \text { (0) }
\end{aligned}
$$

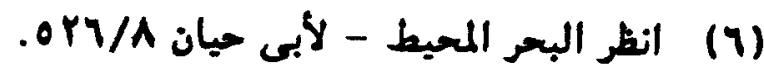




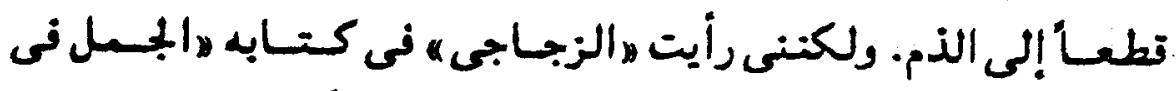

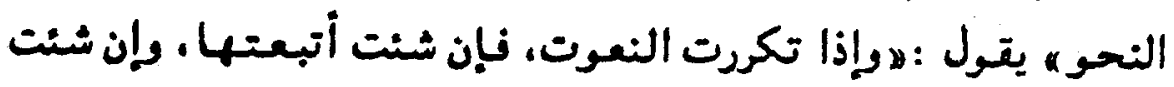

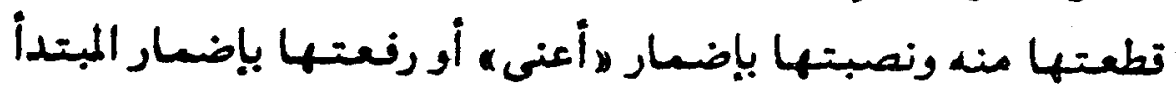

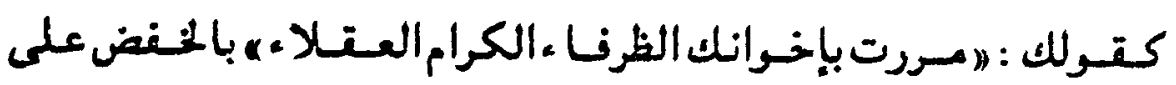

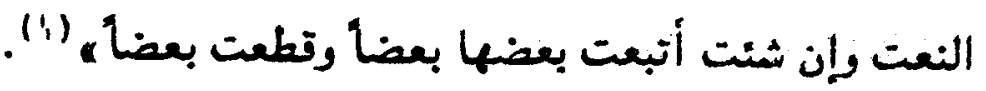

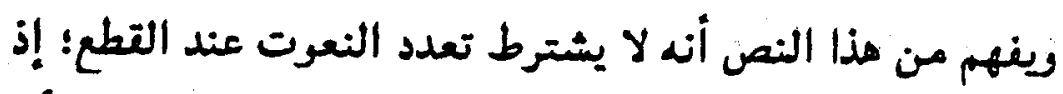

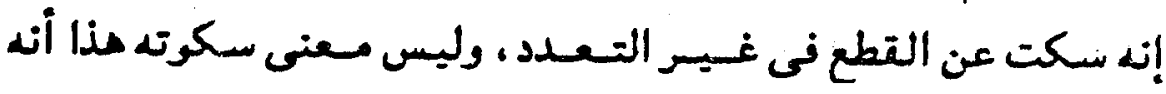

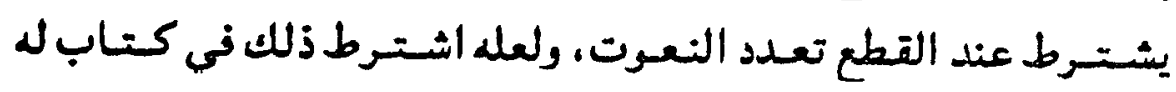

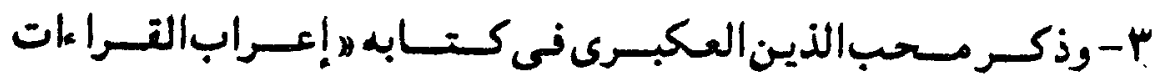

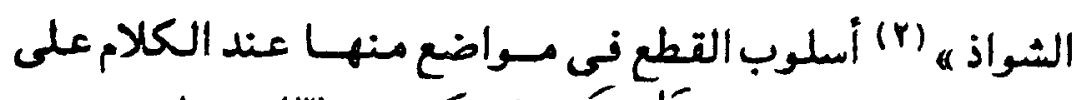

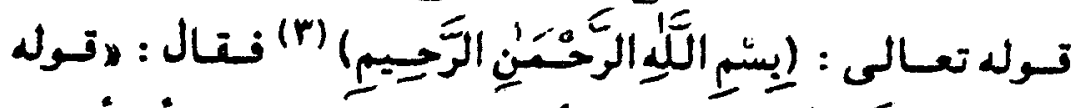

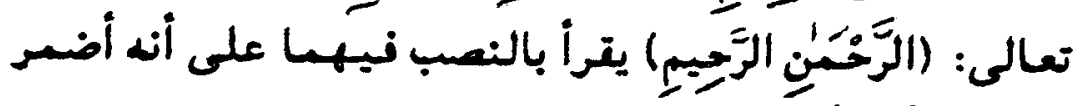

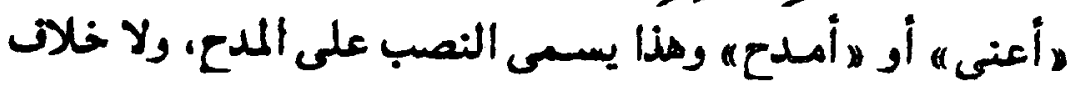

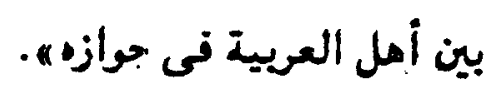

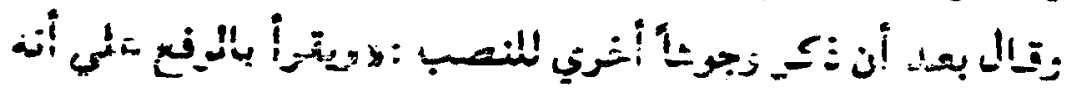

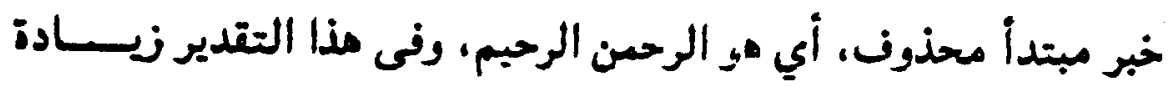

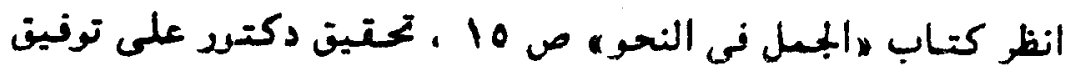

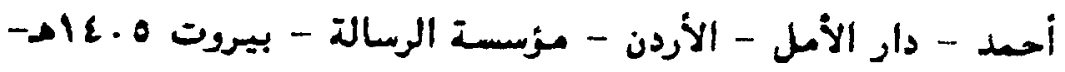
م1910

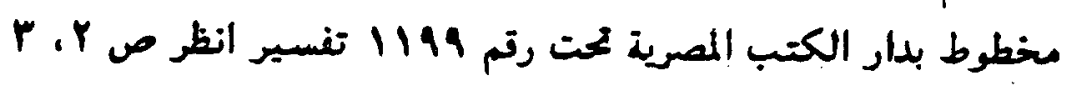
منه. 


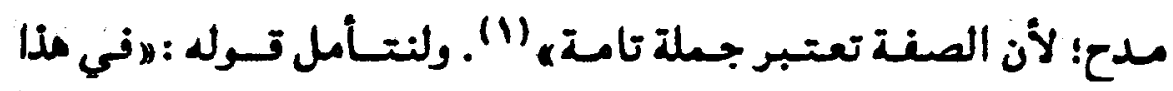

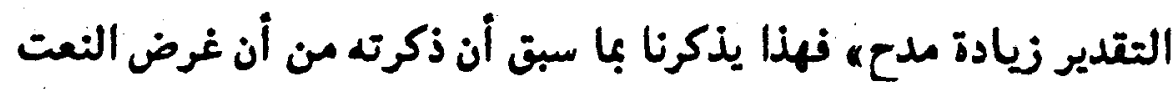
المتطوع أبلغ من غرض النعت المتبع.

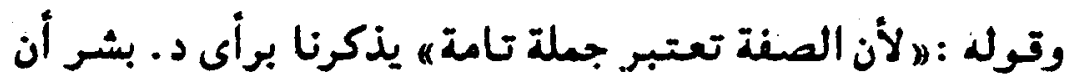

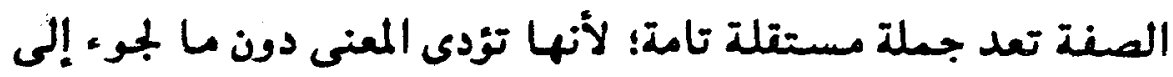

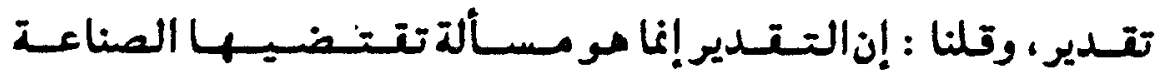
النحوية) (r)

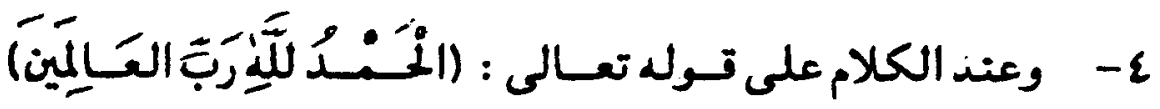

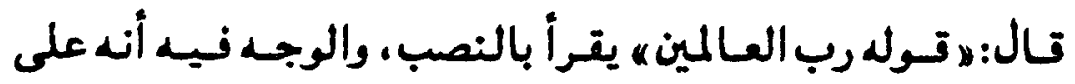

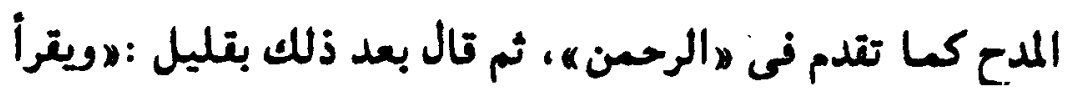

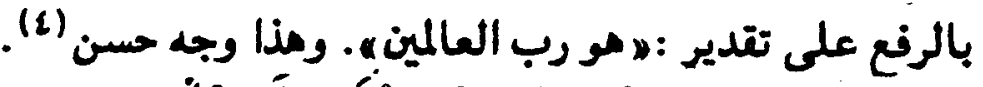

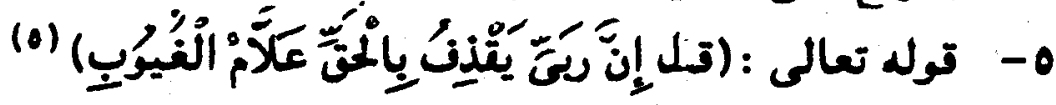

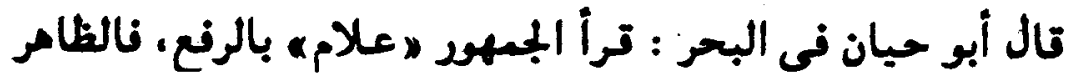

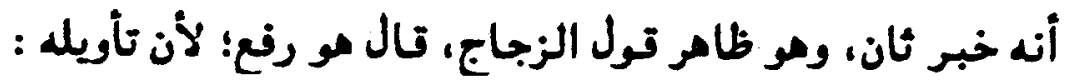

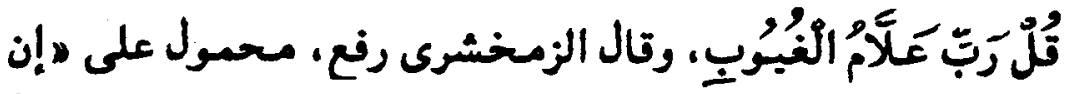

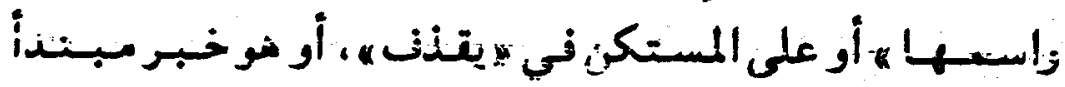
محذوف: انتهن.

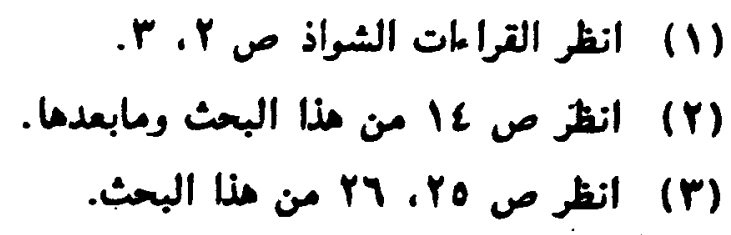

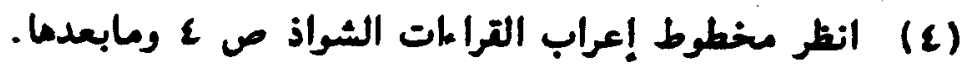

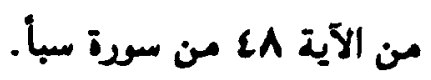


أما الحسل على محل ه إنه واسمها فهـو غير مذهب سيبويده وليس

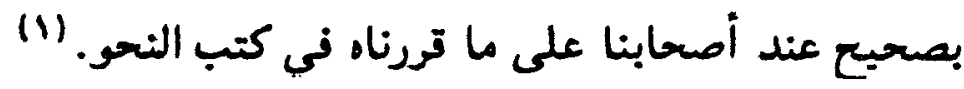

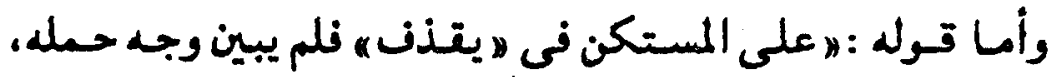

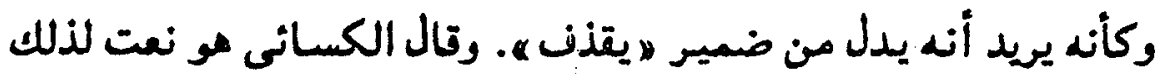

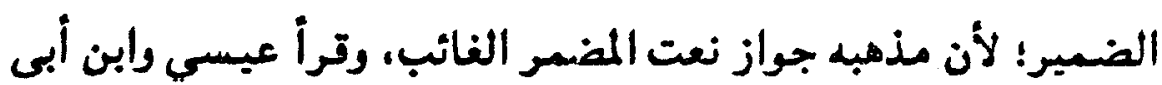

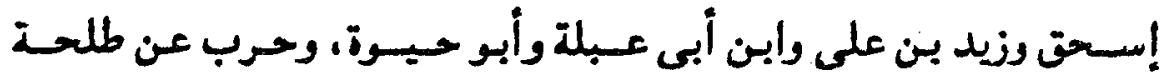

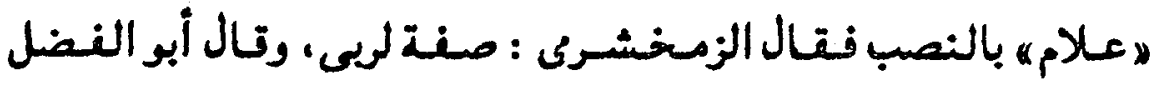

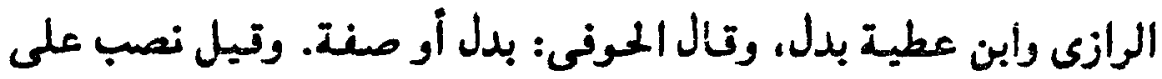

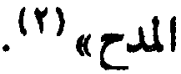

بالتأمل نى النص السابق نرى أن الزمخشرى ذكر من وجوه رنع

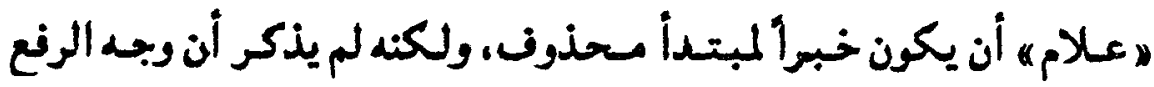

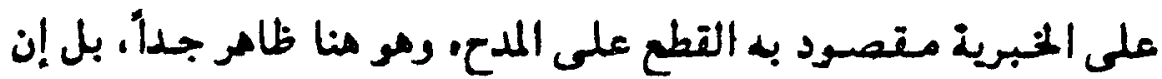

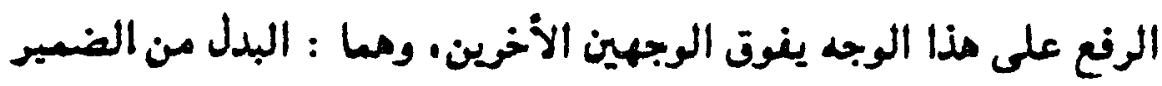

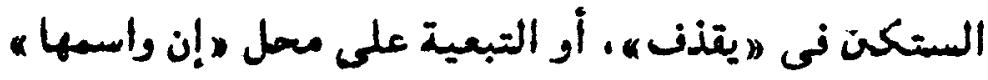

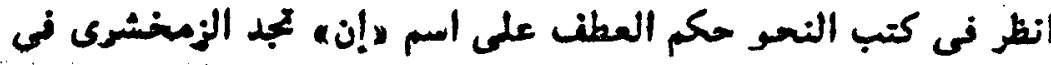

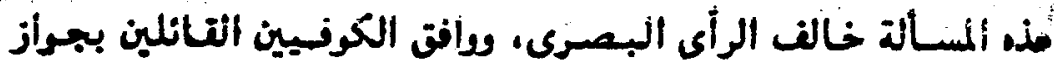

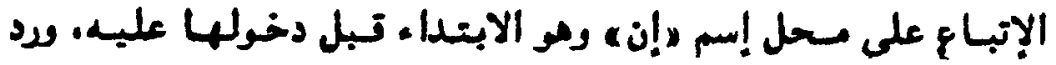

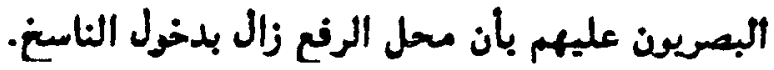

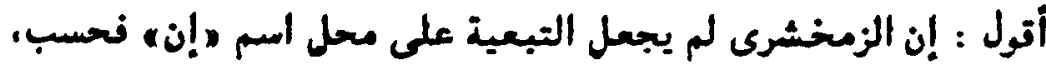

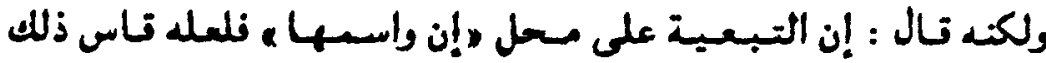

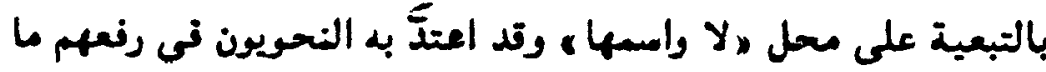

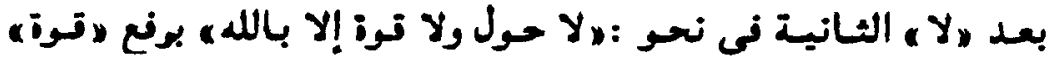

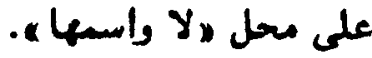

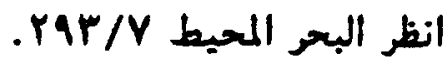




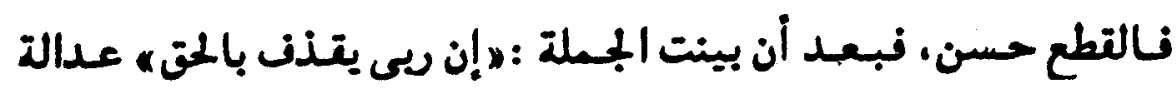

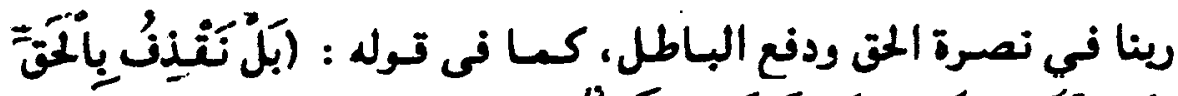

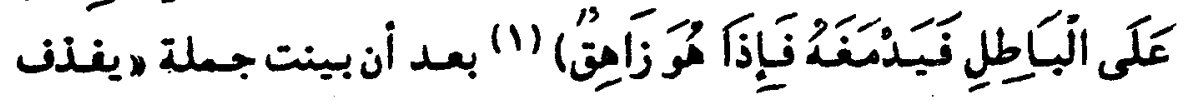

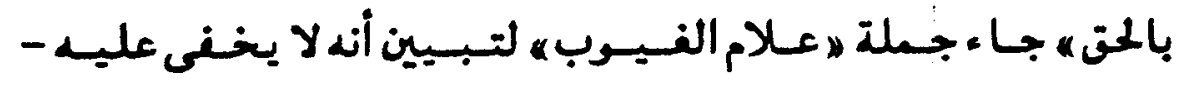

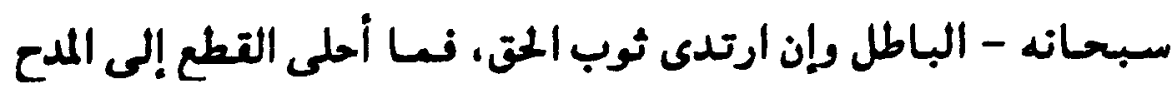

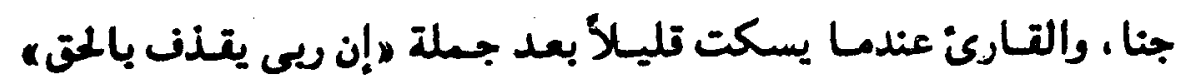

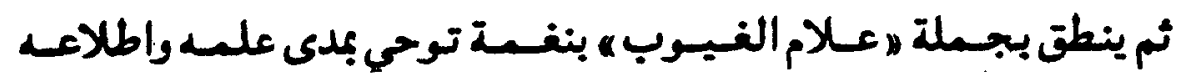

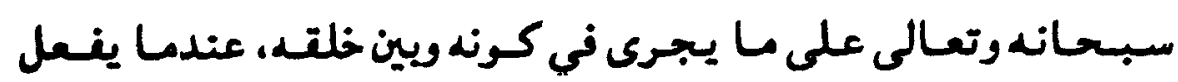
القارئ مذا يكون قد أجاد التلاوة. والله أعلم.

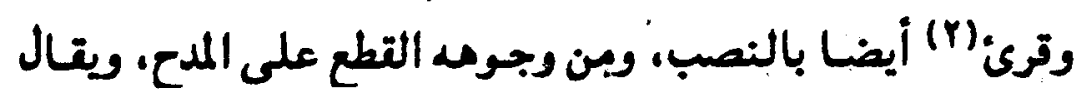
نيه ما قلناه في التطع بالرفع.

r- وراسة أسلوب التطع على نصوص من الشعر

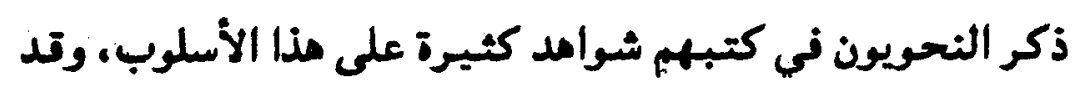

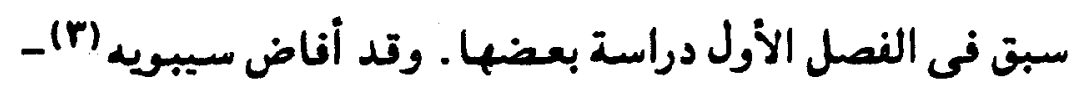

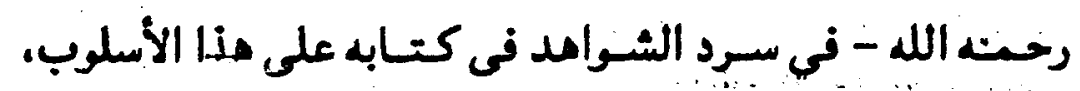

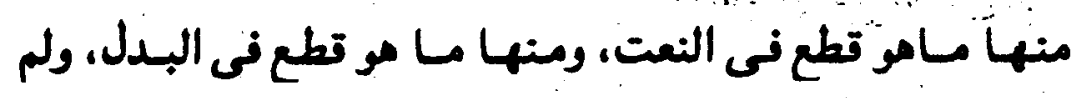
يقتصر على ذلل بل ذكر شواهد شعرية يصلج فيها التطع. فمن شواهد تطع النعت على المدح والتعظيم قول الأخطل:

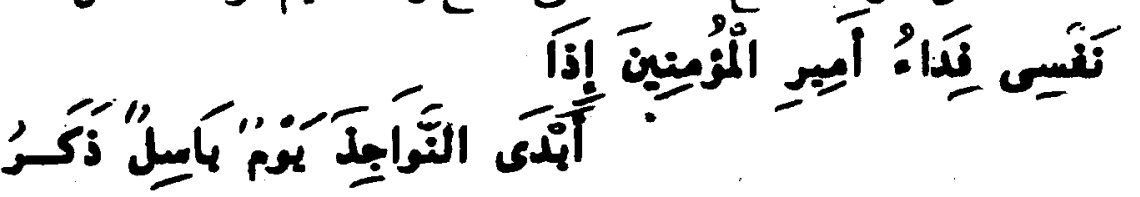

$$
\text { من الآية ال المن سورة الأنبياء. }
$$

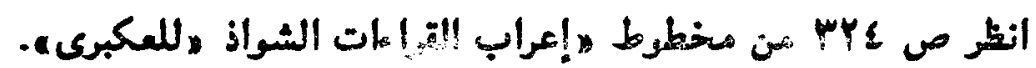




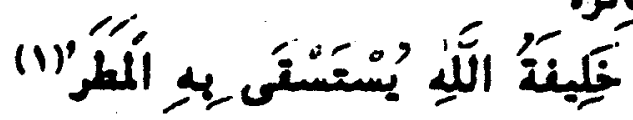

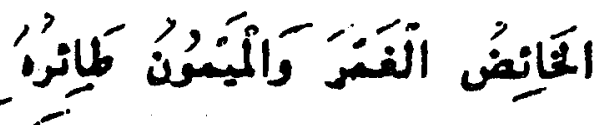

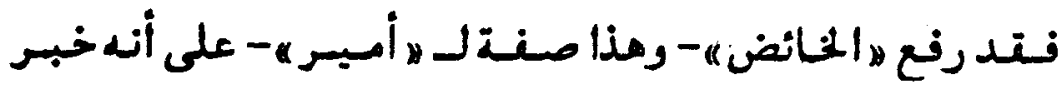

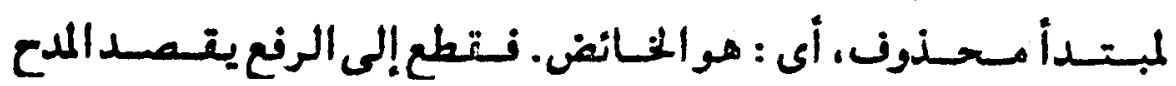

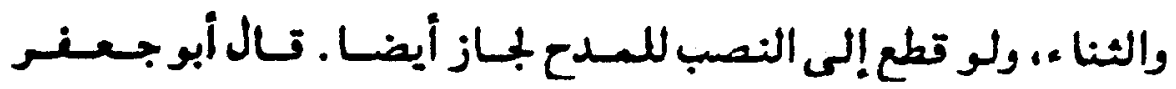

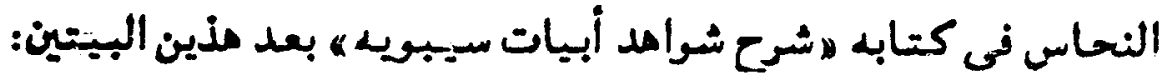

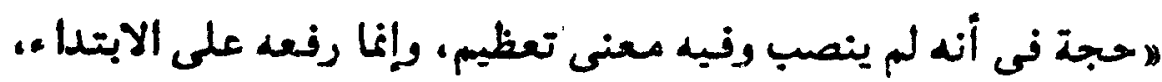

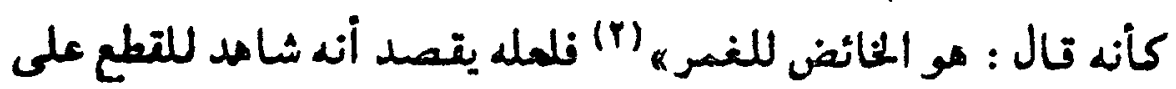

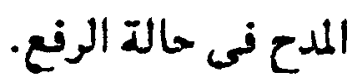

ومن شواهد تطع النعت إلى النصب على الذم تول ابن الميباط

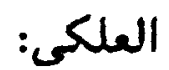

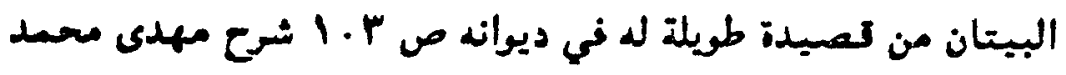

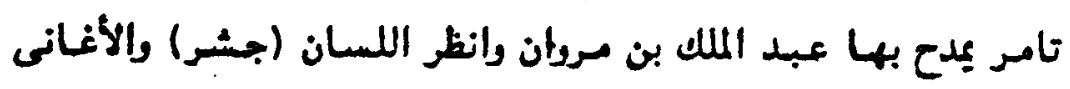

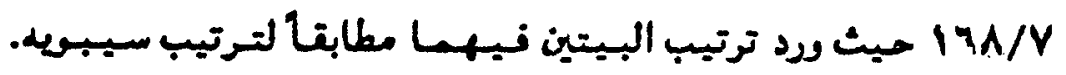

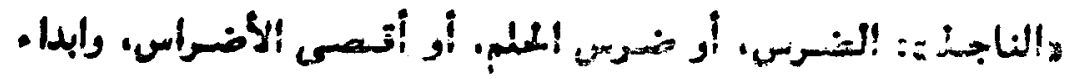

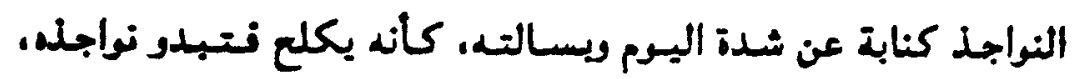

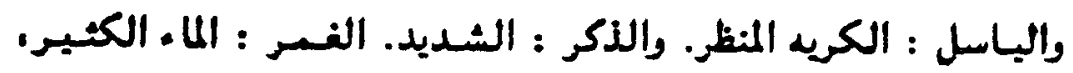

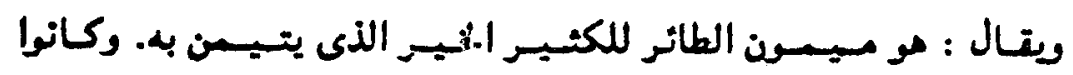
يستسقون المطر بمن بأسون فيه اليسن والخير.

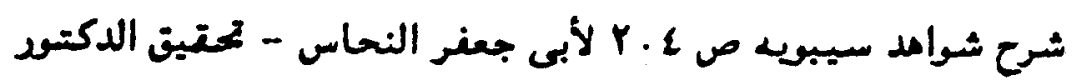

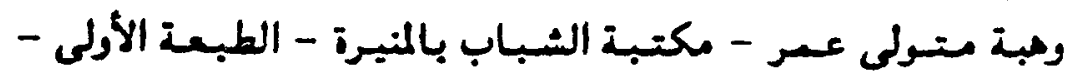

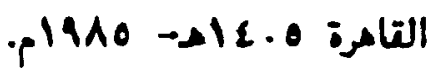




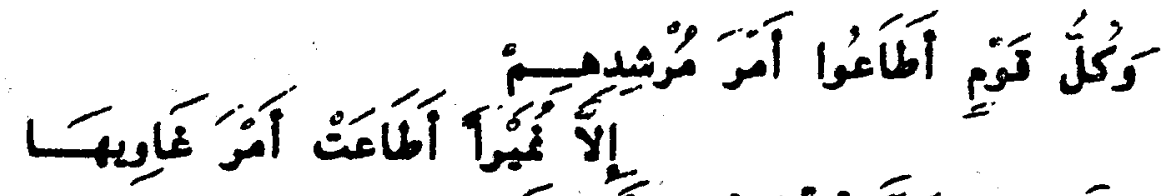

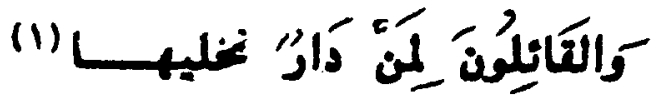

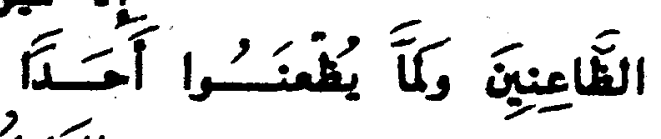

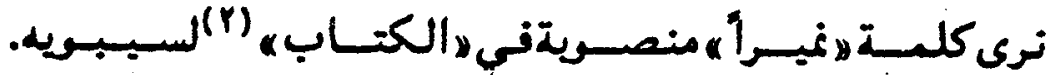

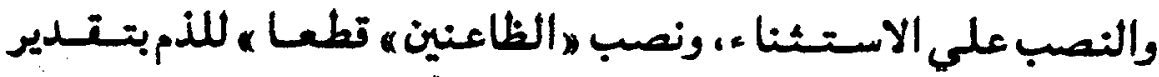

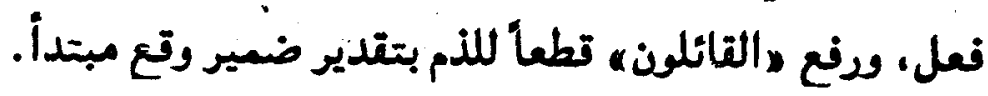

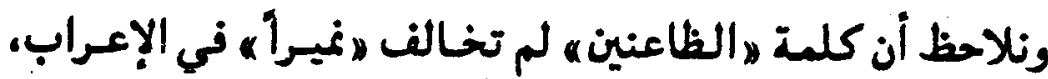

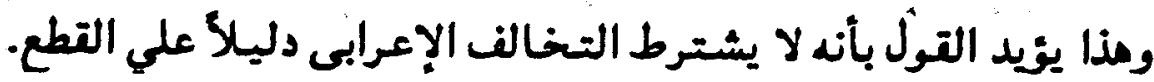

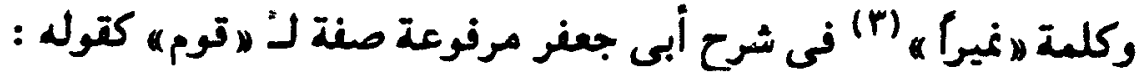

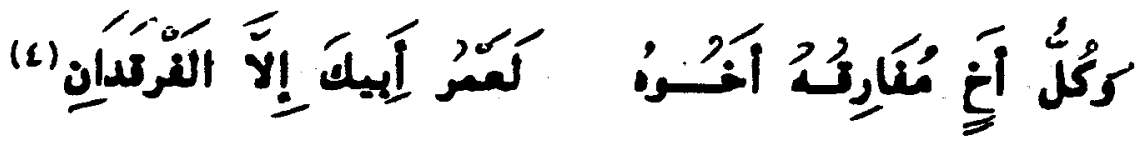

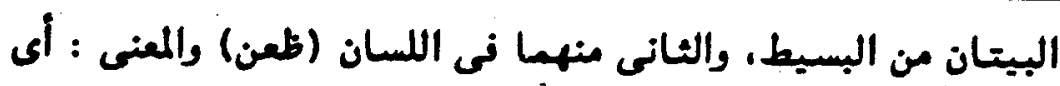

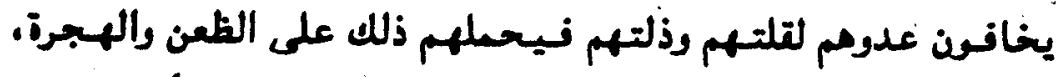

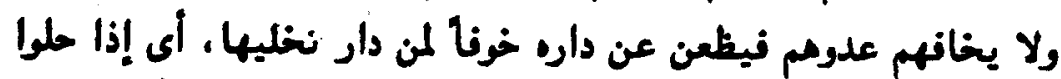

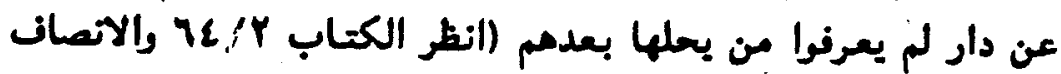

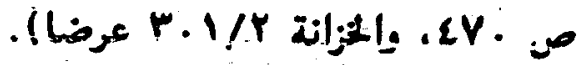

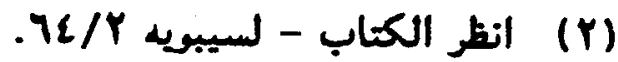

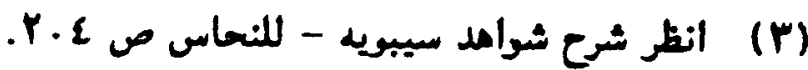

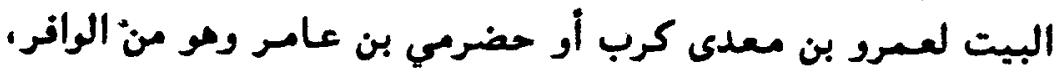

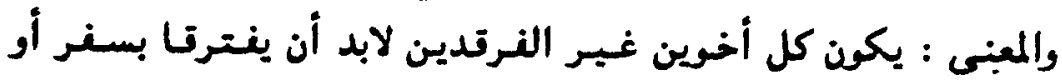

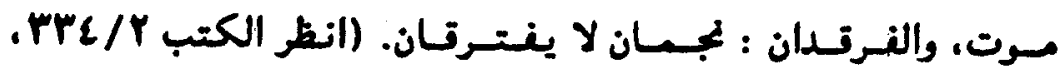

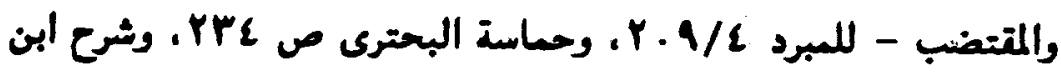

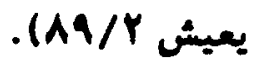


ودردت كلة „الظاعنينه بالزعب، وهالقائلينه بالنصب أيضا

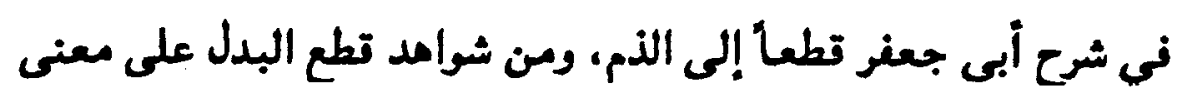
المدح قول خويلد الحزاعى:

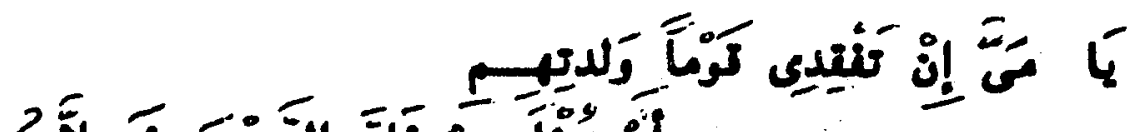

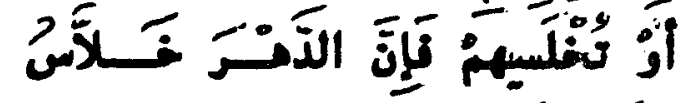

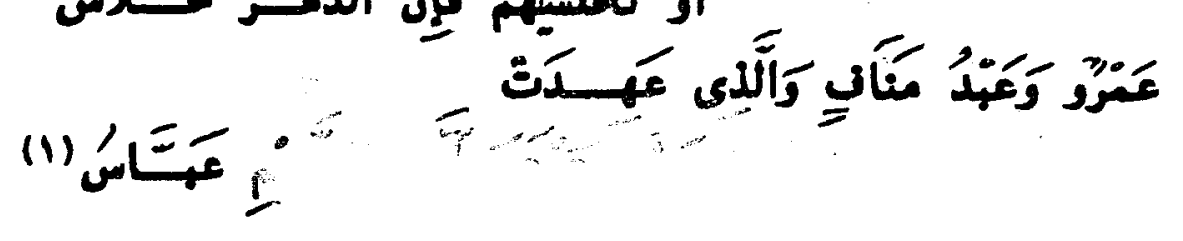

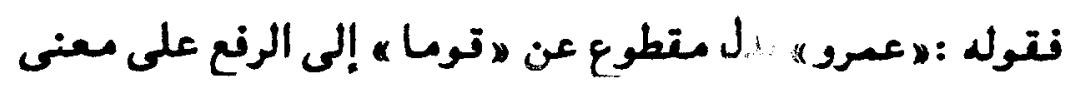

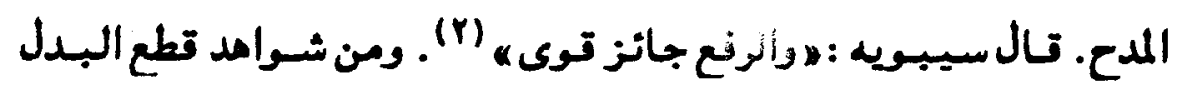
. على معنى الشتم والذم قول النابغة الذبيانى:

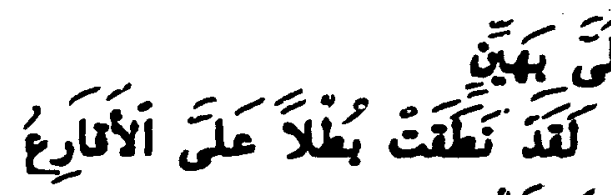

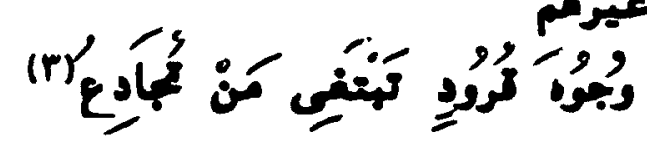

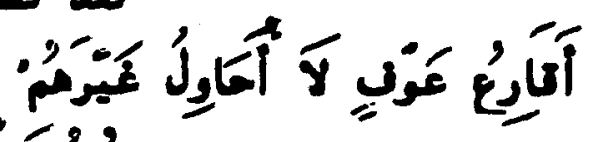

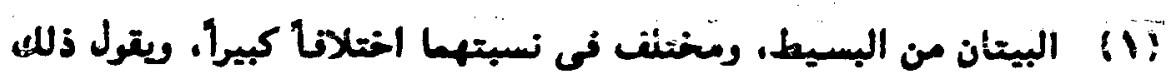

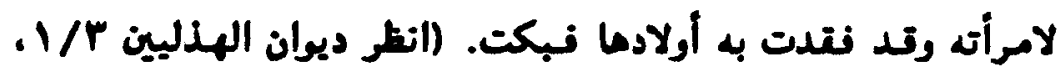

$$
\begin{aligned}
& \text { والكتاب - لسيبويد / / 110). }
\end{aligned}
$$

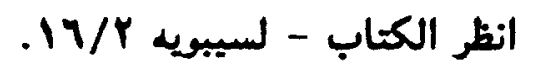

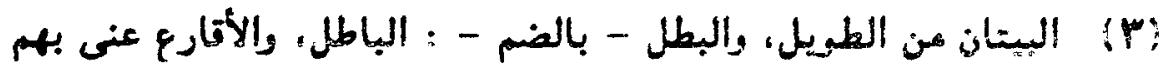

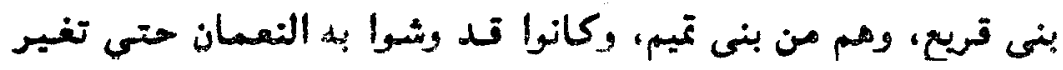

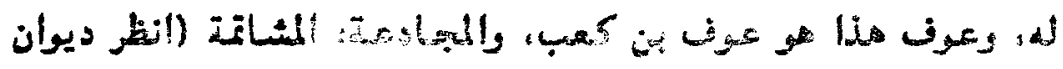

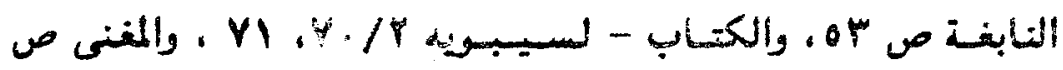


تـال شارح الشاهد أبو جعنـ : لاحجـة، لنصب الوجـوه؛ لأند لم

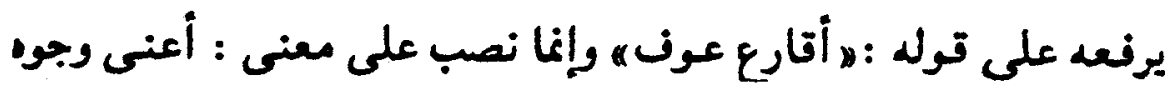
قرود.

وتال محقق ديوان النابغة محسد أبو الفضل إبراهيم: لا نصبه

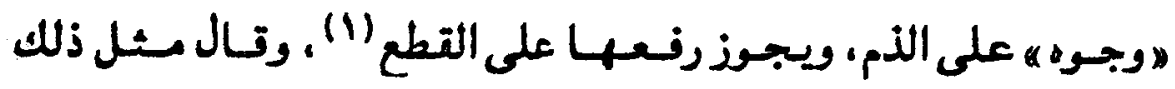

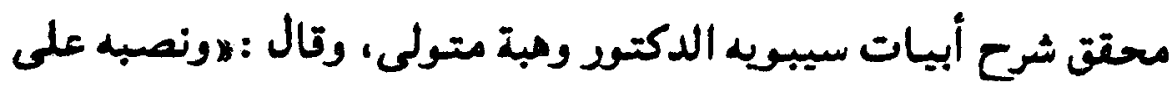

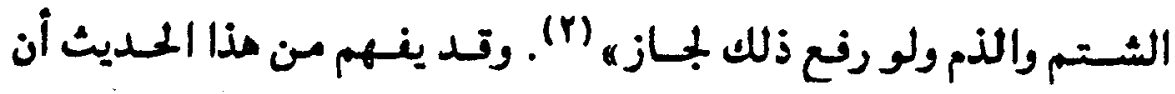
حالة النصب غير حالة القطع ولكن كلتاما تطع على الذهم.

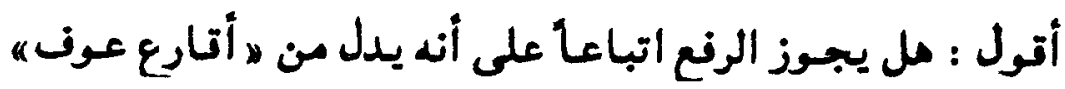

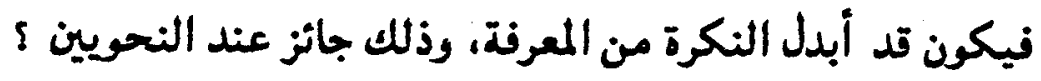

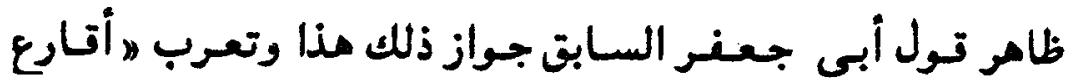

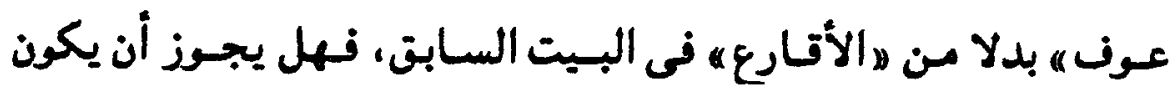

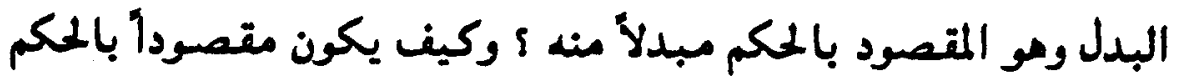

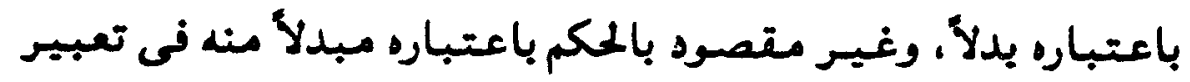
واحد؟

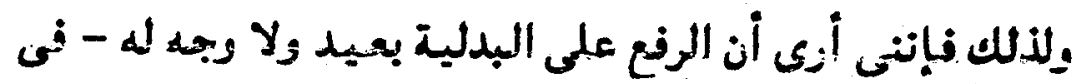

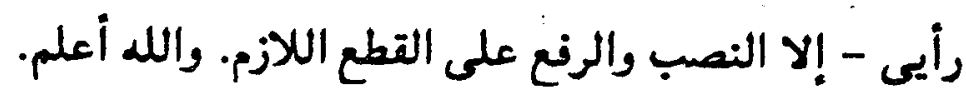

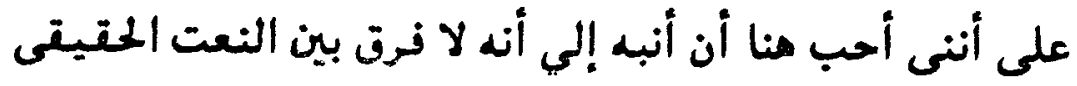

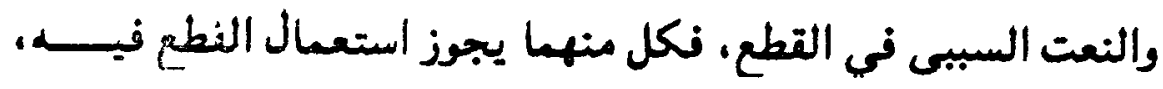

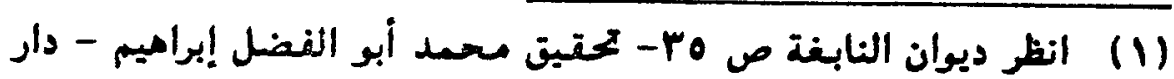
المعارف 19YV - التاهرة.

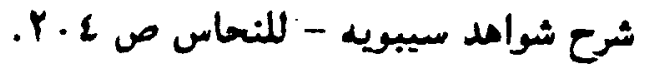




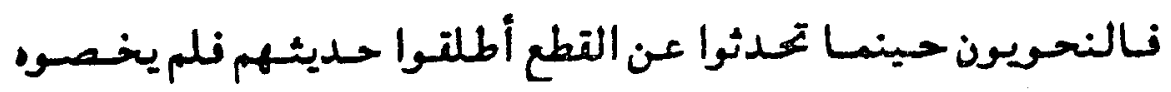

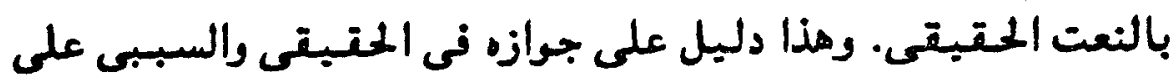
السواء.

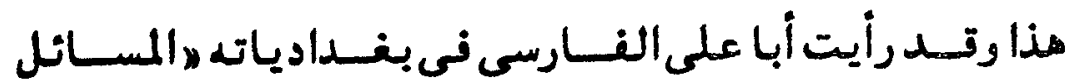

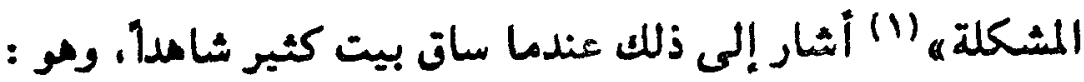

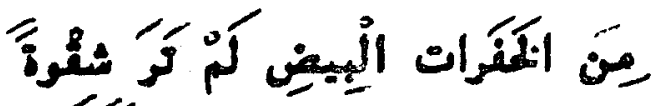

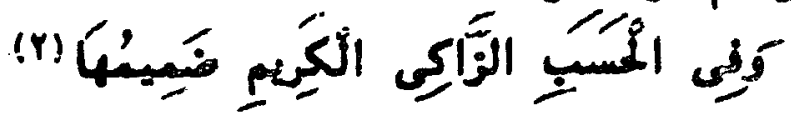

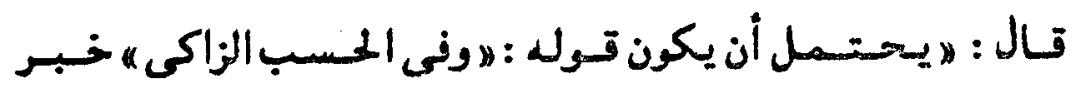

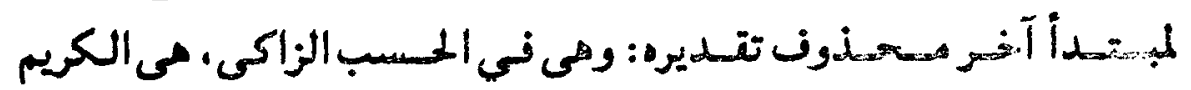

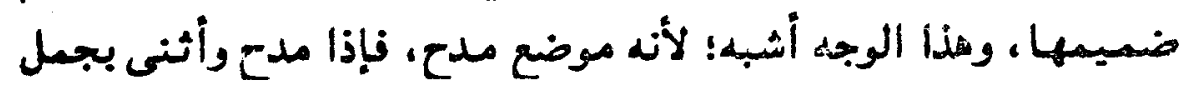

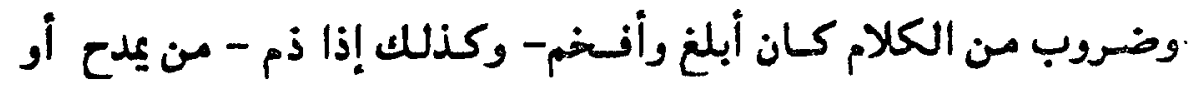

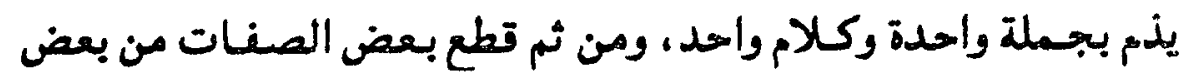

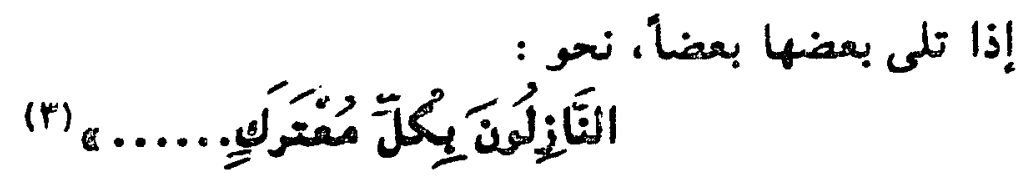

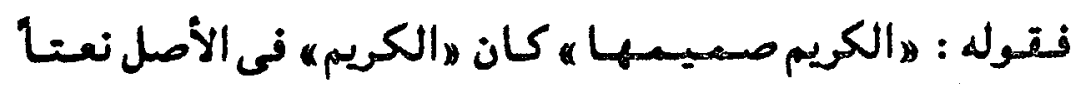

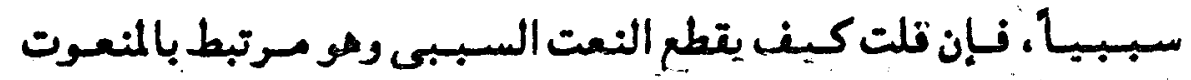
بضميره

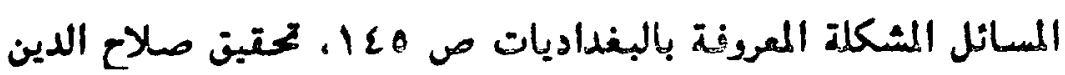

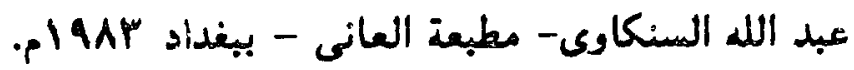

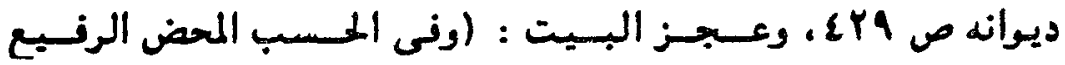

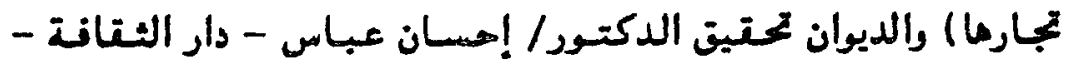




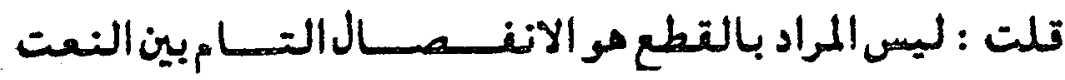

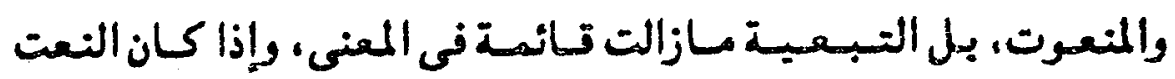

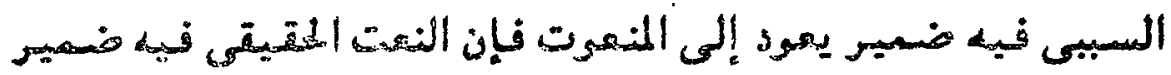

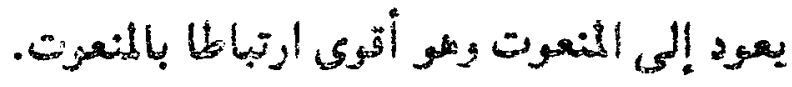

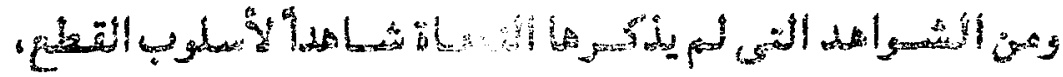
وإنا ذكرت شامداً لمسألة أخرى تول لبيد العامرى يصف حسارأ وحشياً يطلب الأتان :

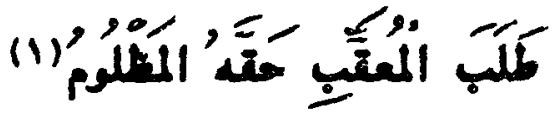

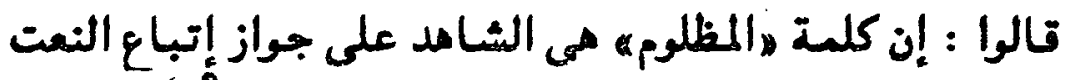

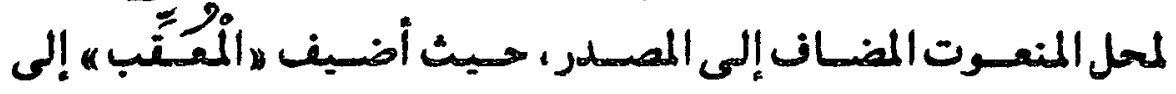

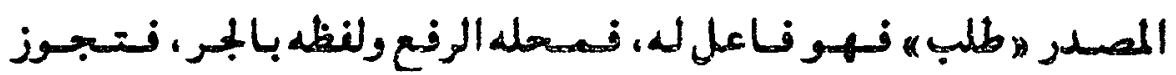

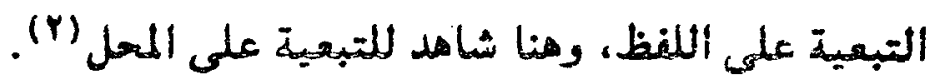

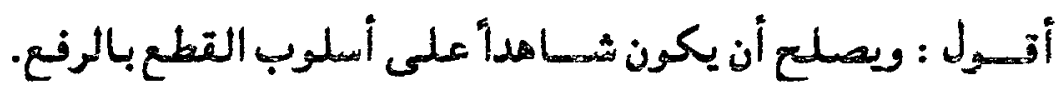

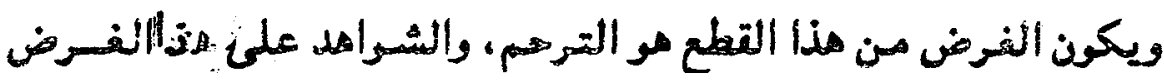

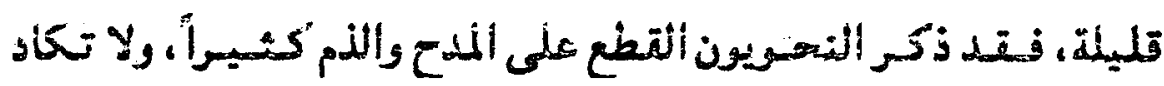
تظفر بشاهد للقطع على هالترحمه . هذا ما أرى والله أعلم.

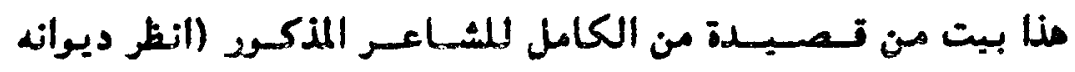

صنrá

انظر حاشية الصبان بهامش الأشسونى، وشرح شراهد العبنى بذيلها 


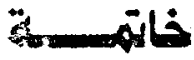

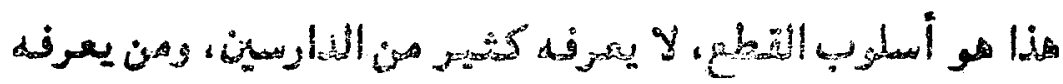

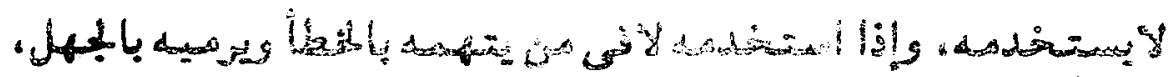

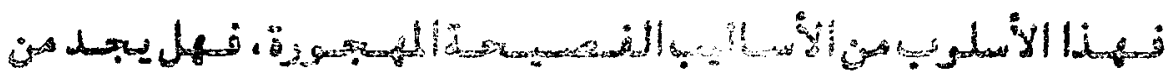

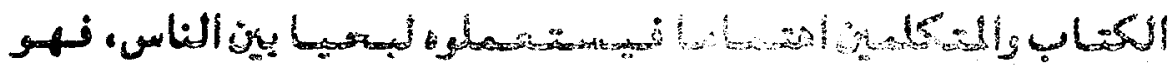
أَسلوب فرآنى، وما أكثر الأُساليب القُرآئية التى ماتت على ألسنتيا

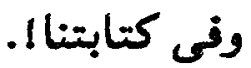

نعم، تد حدث خلاف فى جواز استخدام بعض أساليب القطع،

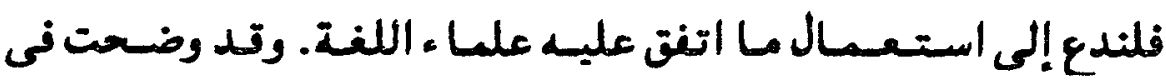

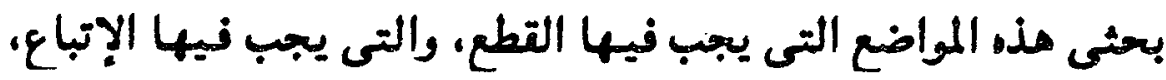

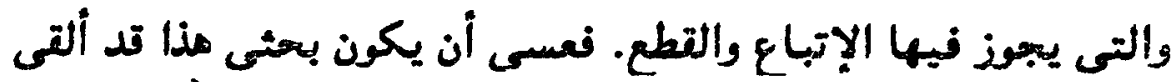

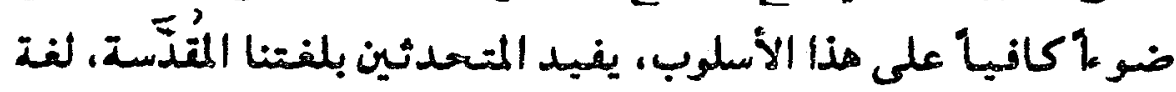

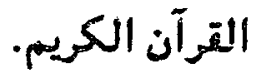

أسنأل الله الثوئب والتوفيت، نهو - عز وجل- حسبى ونمم المزفق، ونعم ألثيب.

دكتور

جمال الالين محتًّ حمَّاد شحاته 


\section{ثبت با" هم المر اجع بعد كتاب الله - تعالى}

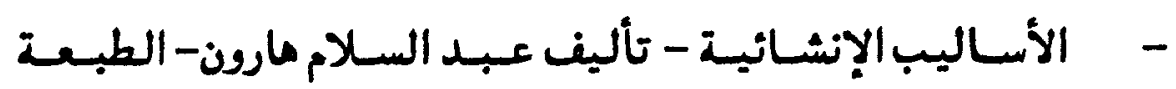

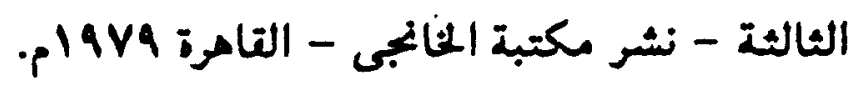

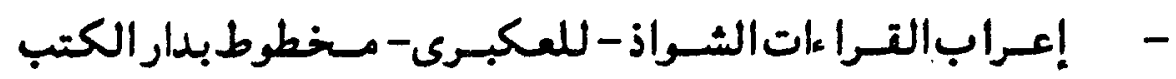

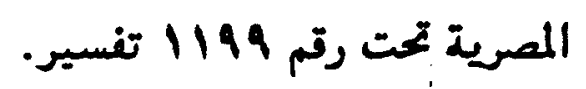

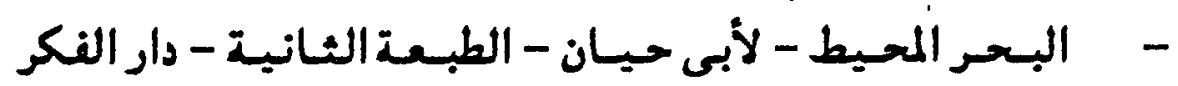

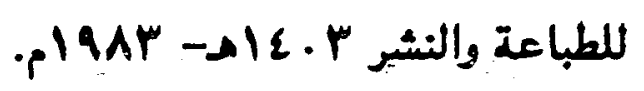

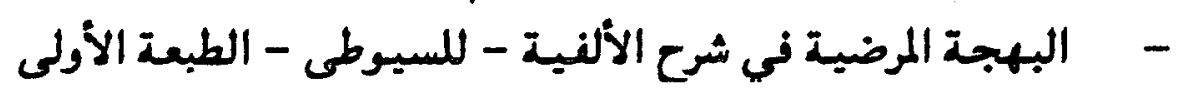
- بمطبعة المدارس- بدون تاريخ.

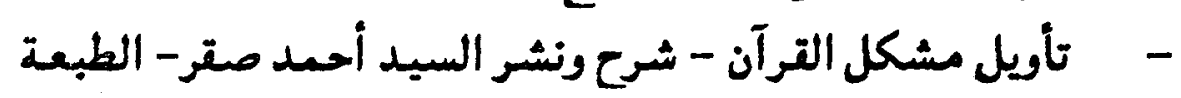

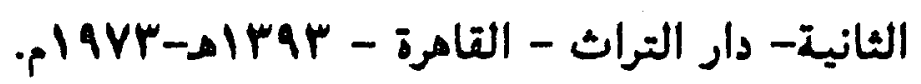

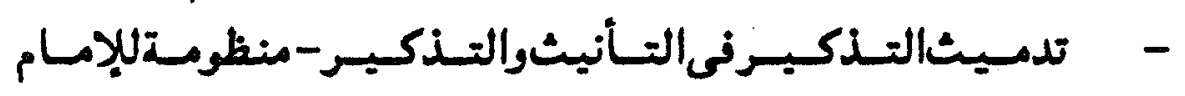
الجعبرى - شرح ويحقيق د. محسمد عامر أحمد حسن - القامرة

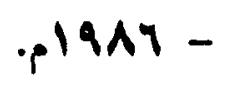

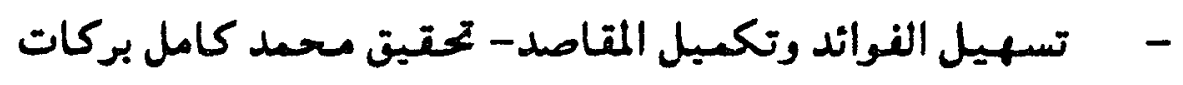

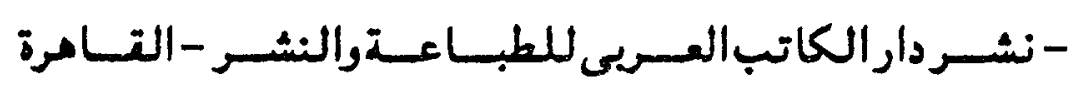

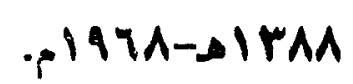

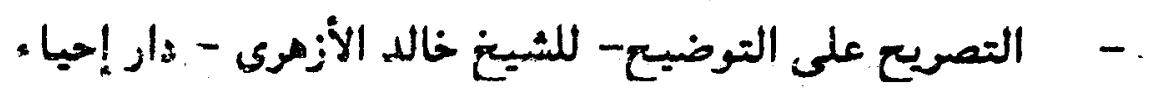
الكتب العريية عيسى البابع الحلبى وشركاه - بدون تاريخ.

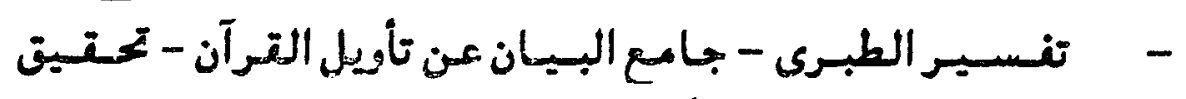

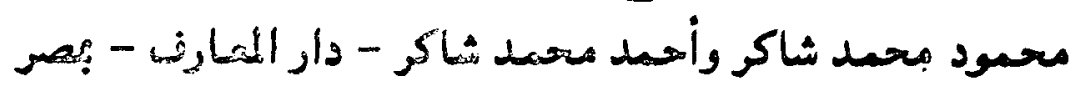
.plaVe -

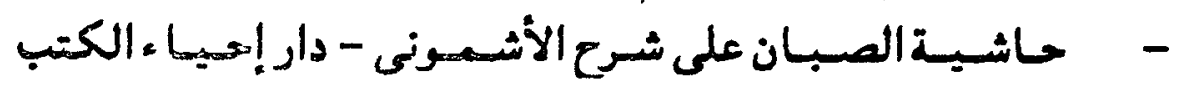
العربية - عيسى البابى الملبى - القاهرة - بلدون تاريخ. 


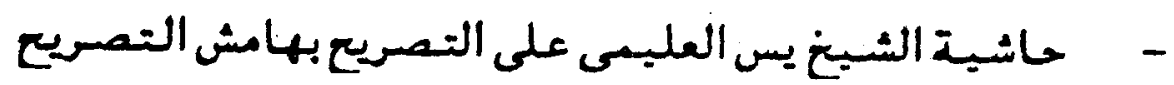

$$
\text { على التوضيح. }
$$

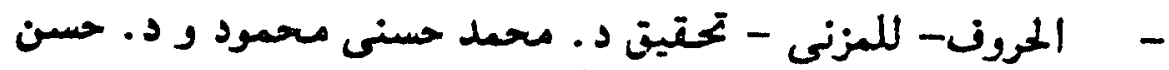

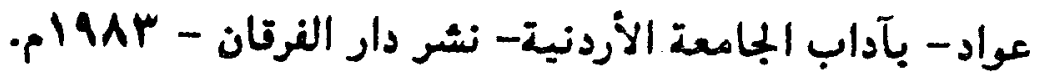

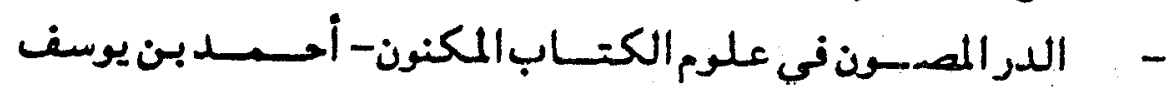
السمين- بخطوط بكتبة رفاعة الطهطاوى بسوماج.

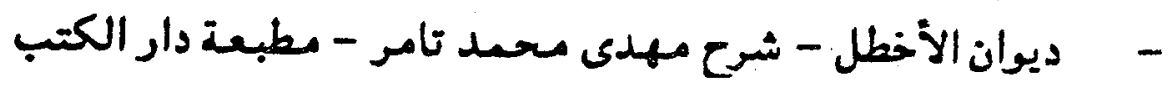

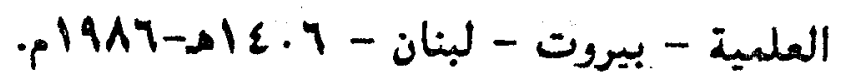
- - ميوان كثير- تحقيق د. - إحسان عباس - دار الثقانة - بيروت.

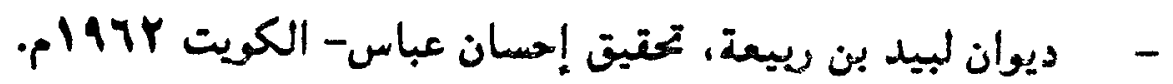

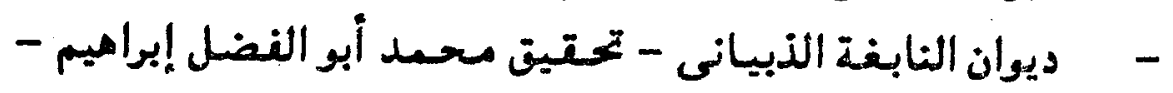

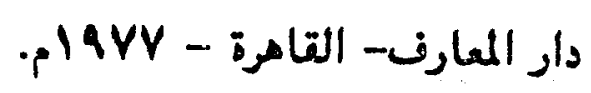

- - مشرح الأشمونى مع حاشية الصبان - دار إحياء الكتب العريسية - عيسى البابى الحلبى وشركاه - القامرة بدون تاريخ.

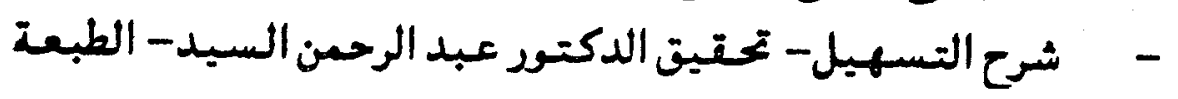

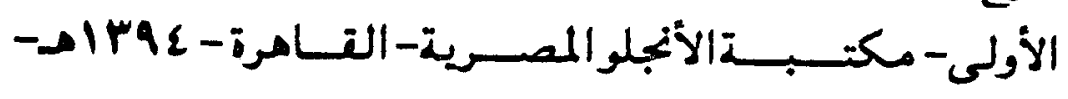

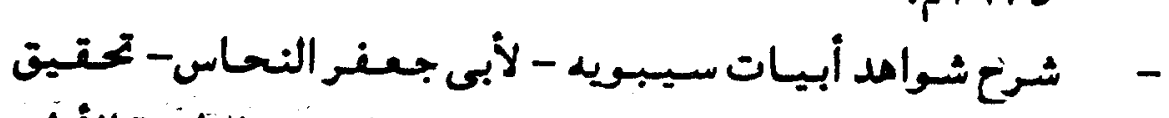

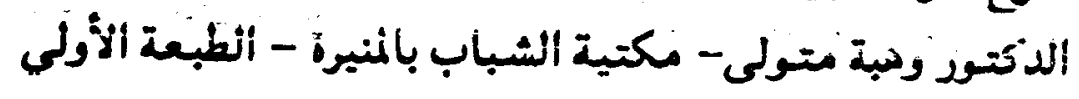

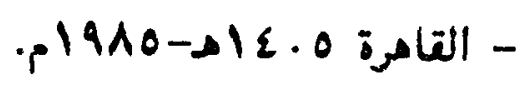

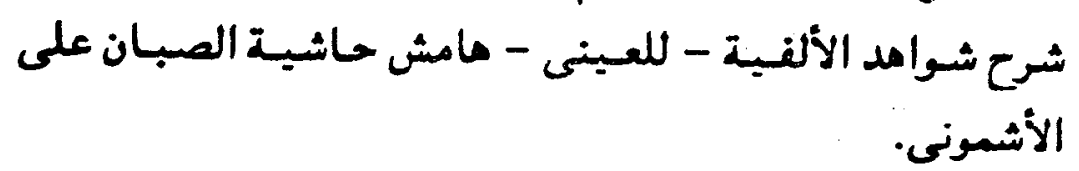

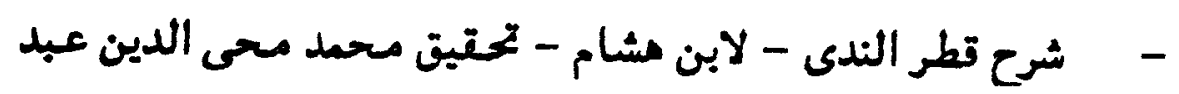


- - شرح الكافية- للرضس- دار الكتب العلمية - لبنان - الطبعة -

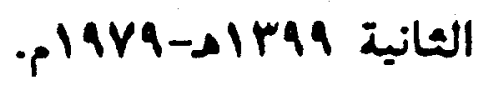

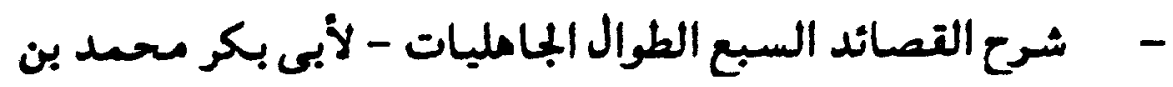

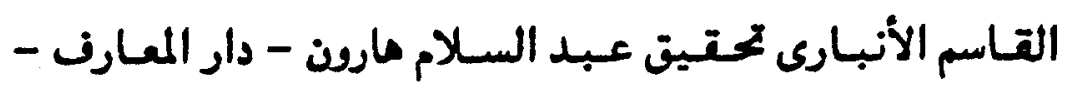

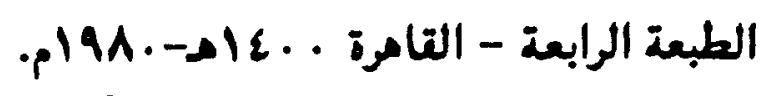

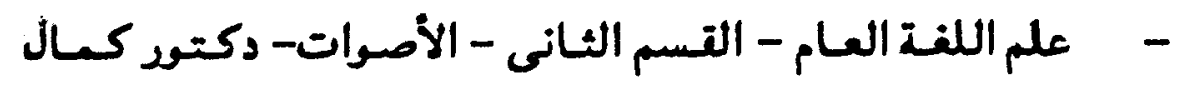

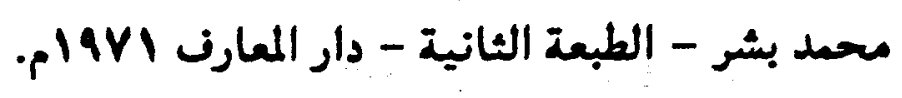

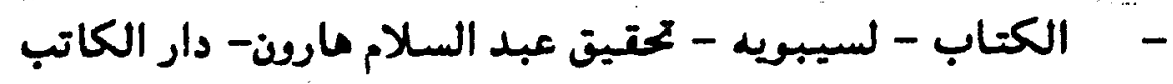

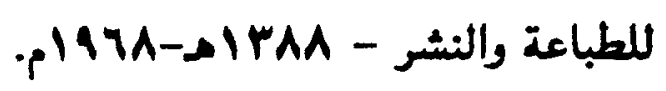

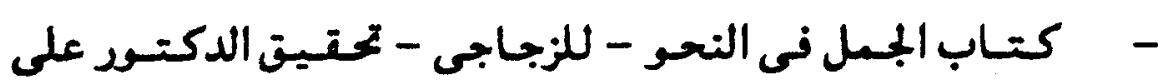

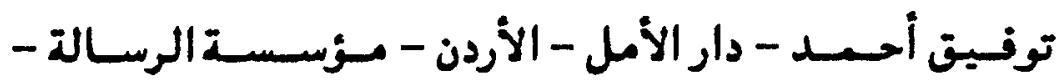

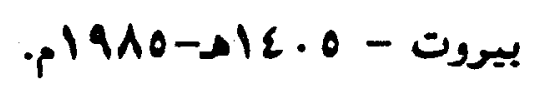

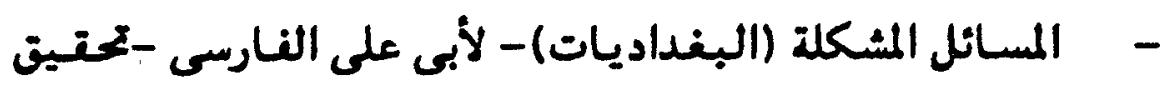

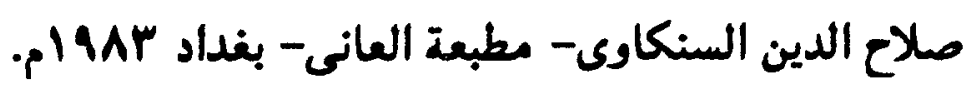

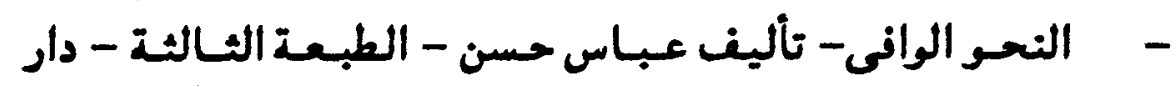

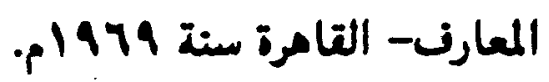

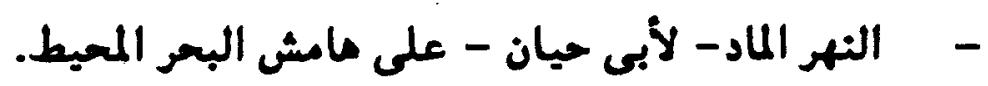

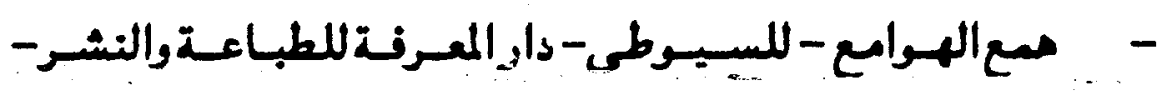
بيروت- لبنان - بدون تاريخ. 
هن الإ"هر فـ العربية المتثابهة

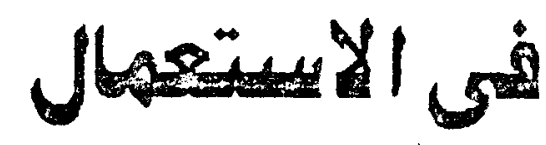

$$
\text { (i) }
$$

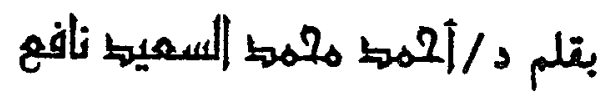

أستاذ اللفويات المساعد فى الكلية 
بسم إلله الرحمن إلرحير

الحمد لله والصـلاذ والسلام على رسول الله وعلى آله وصسبـ

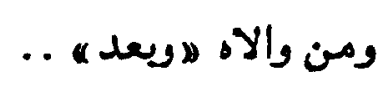

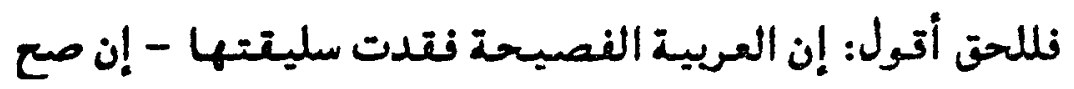

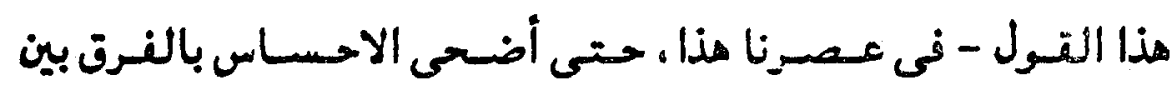

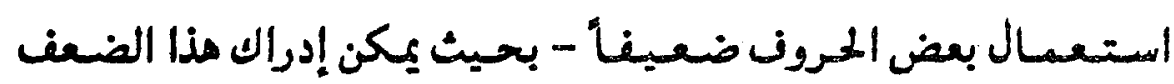
بإدراك قوة احساس المتكلم بهذا الغرق ..

من أبجل هذا وجدت أنه من الضرورى أن تعالج تضية استعمال

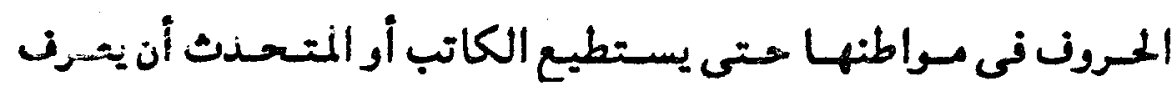

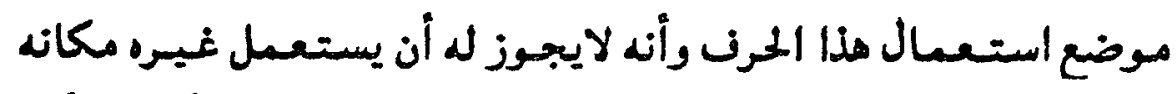

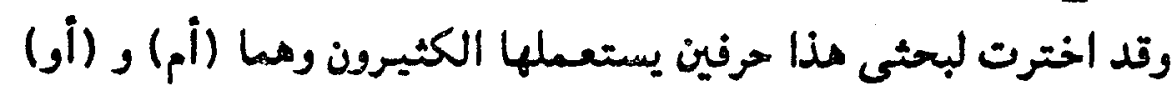

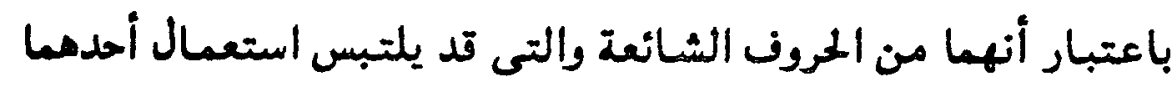

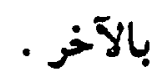

ولما كان كتـاب الله تعـالى تسمة القسم فى الأساليب الرنعية

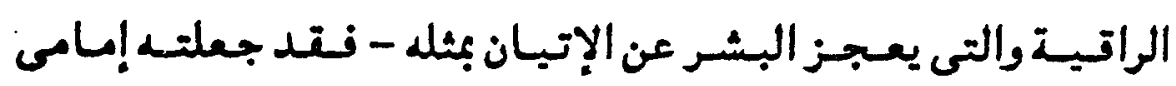

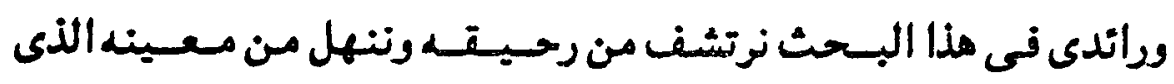

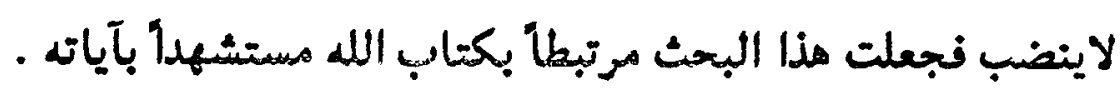

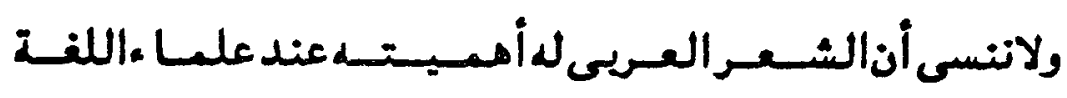

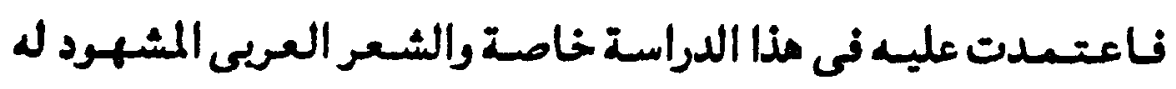

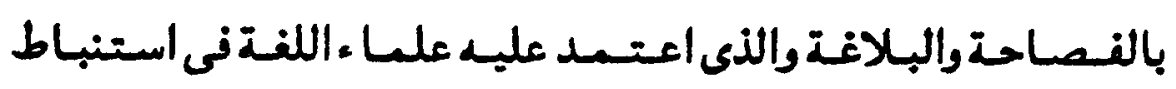
القواعد النحوية والأمكام اللغوية فنتول ويالله التوفيق . 


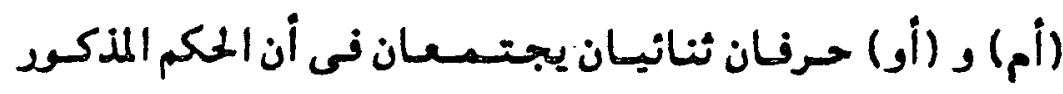

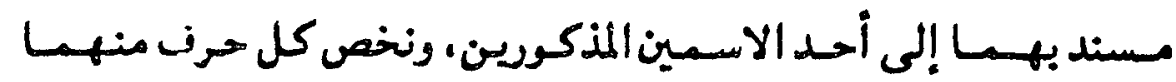

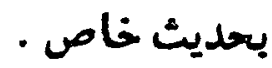

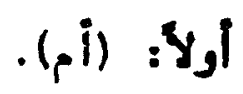

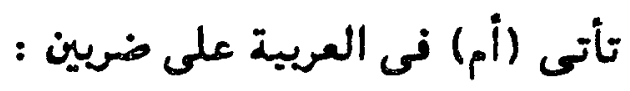

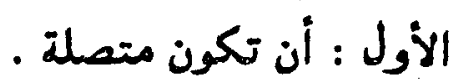

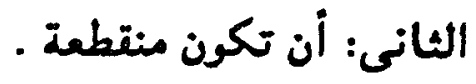

أولا: المتصلة : ومى التى: ماتبلها ومابعدما لايستغنى بأحدمها

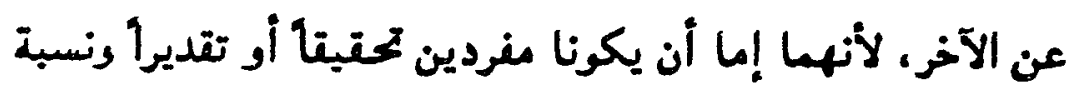

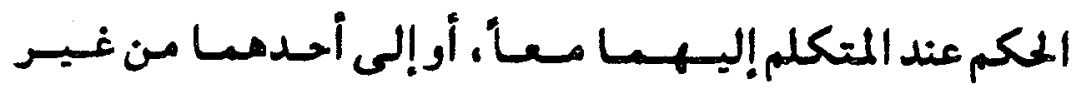
تعيسين.

وقيل: إنها سميت متصلة لاتصال مابعدها بما تبلها وكونه

$$
\text { كلاما واحدا . أنال. }
$$

\section{وأم المتصلة مده إما أن :}

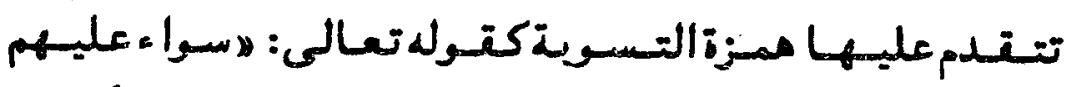

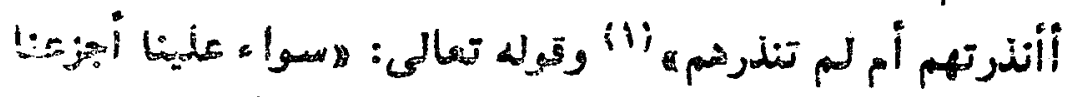

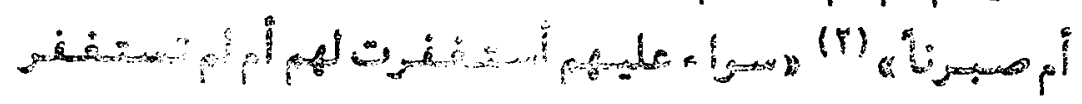

(")

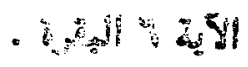

- 
وتقول : ها سواء علمي أزيد فى الدار أم عمروه لاومأبالى أزهب

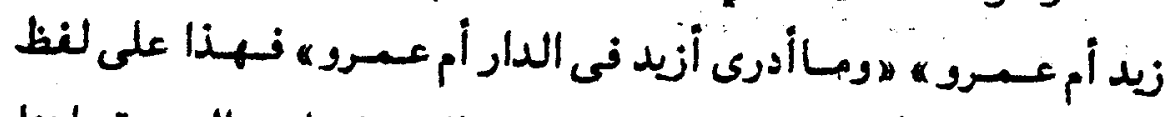

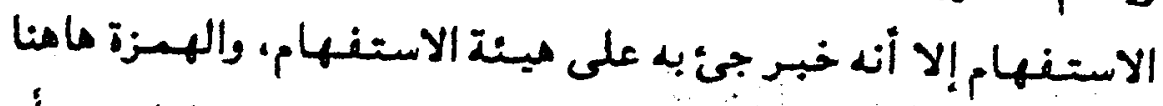

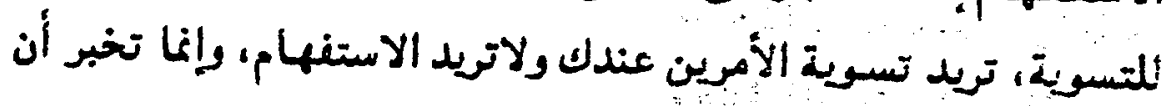

الأمرين عندك واحلد.

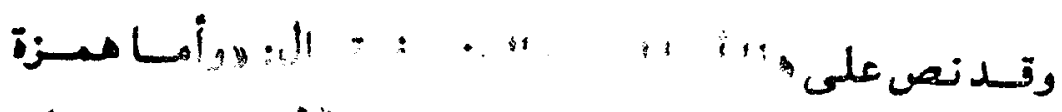

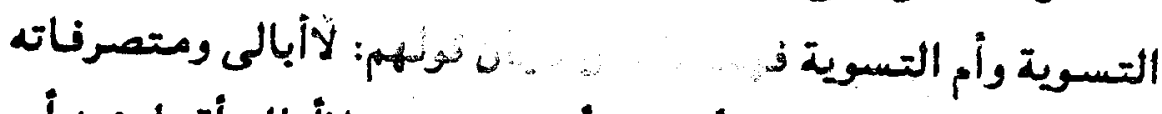

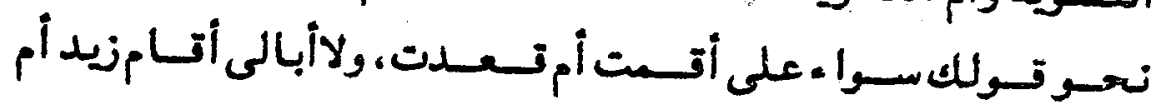
تعد ه (Y)

ومن مجىن (أم) المتصلة المتقدم عليها همزة التسوية فى الشعر

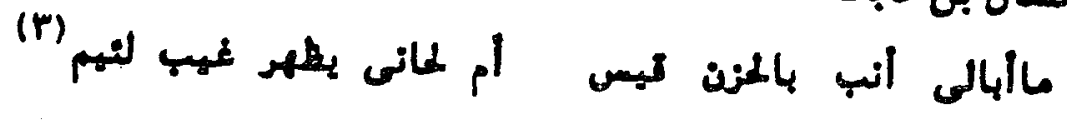

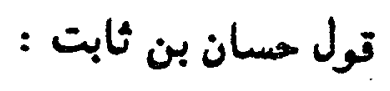


رلست أهالى بعد كتدى مالكسا

أموتى ناء أم مو الأن واتع (1)

والمراد : ماأبالى بعد فقدى مالكاً بنأي موتى ولابوقوعه . وكذا قول زمير بن أبى سلعى :

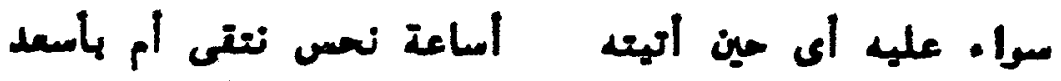

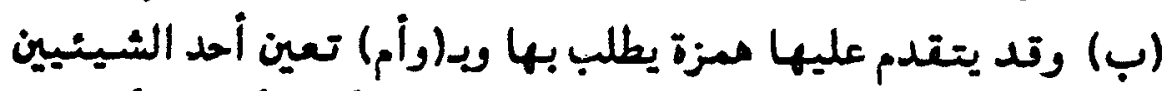

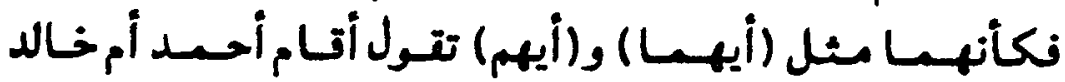

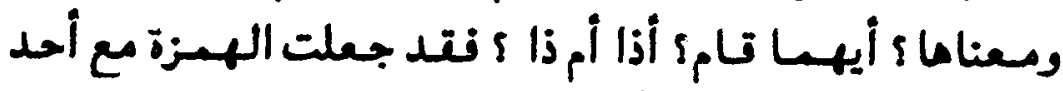

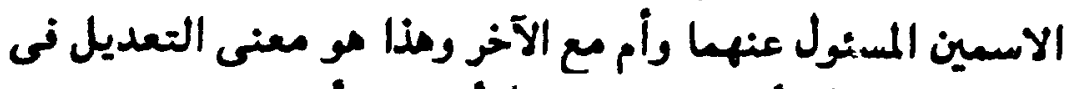

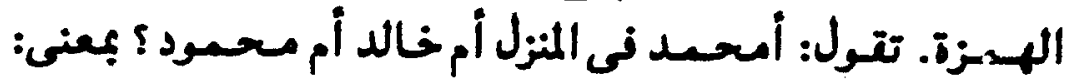

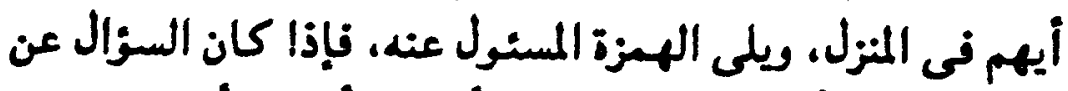

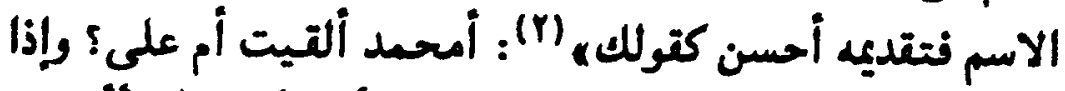

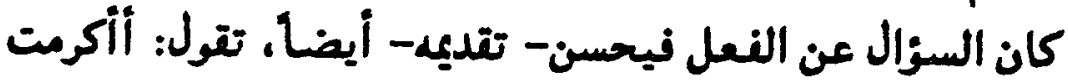
محمدا أم أمنته أ من الفعر

تال سيبـبويه : هواعلم أنك إذا أردت هذا المعنى فتتـديم الاسم

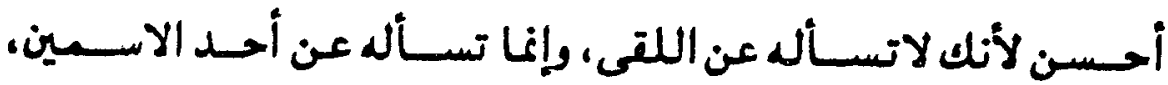

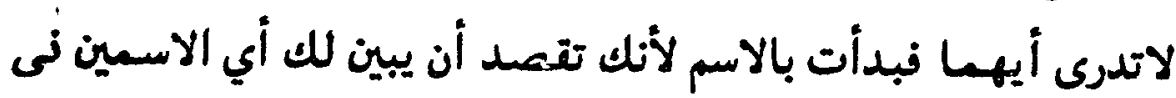
(r) مذه الحال

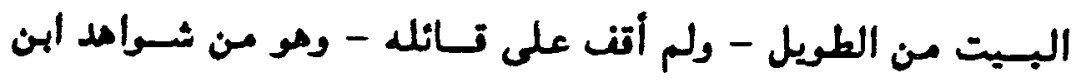

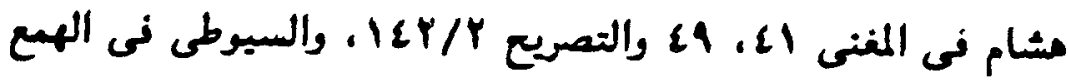

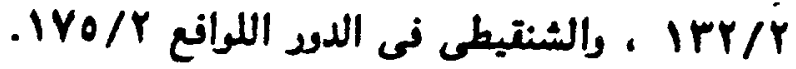

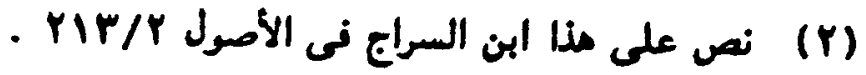

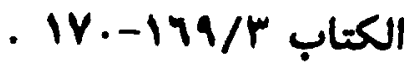


- rro-

وتقع (أم) مذه بين مغردين نحو توله تعالى: لاوإن أدرى أتريب

$$
\text { أم بعيد ماتوعدونه (1) }
$$

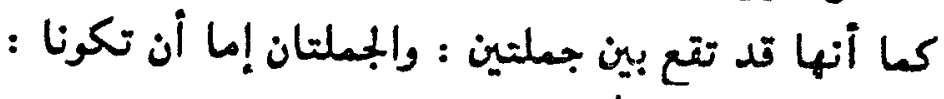

: (l)

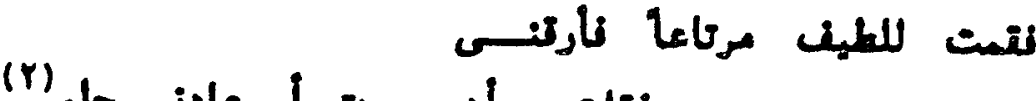

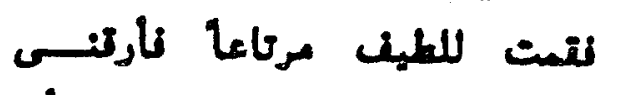

نتلت : أمى سرت أم عادنى ملم

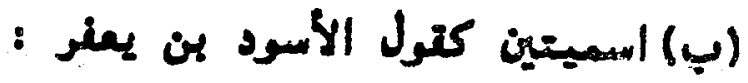

لعسرك مأدرى وإن كنت داريا

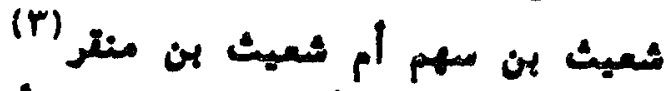

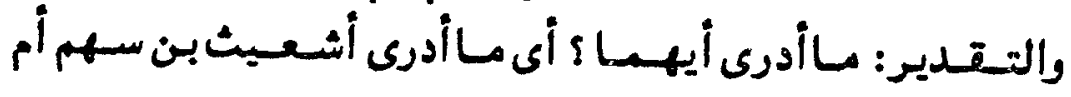

شعيث بن منتر

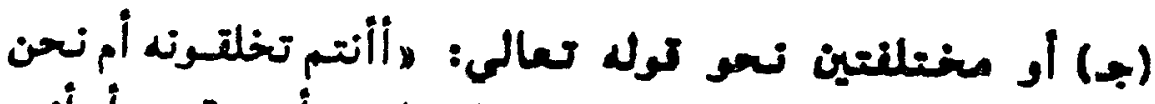

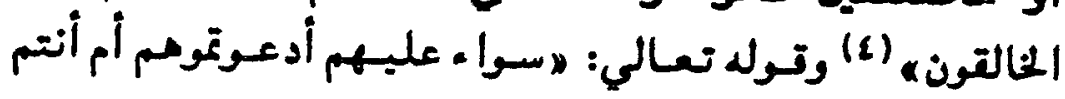

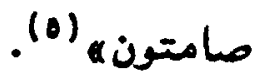

$$
\text { آية } 1.1 \text { الأتبيا . }
$$

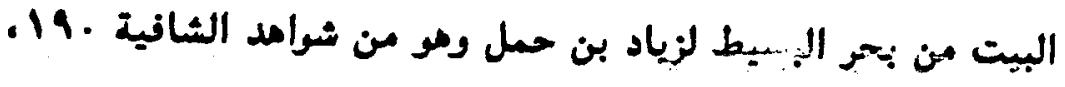

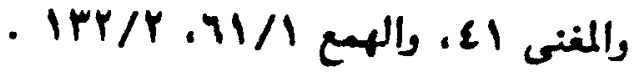

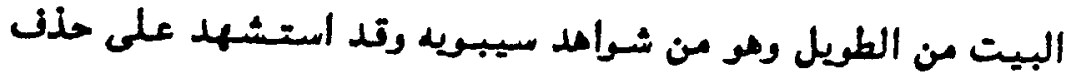

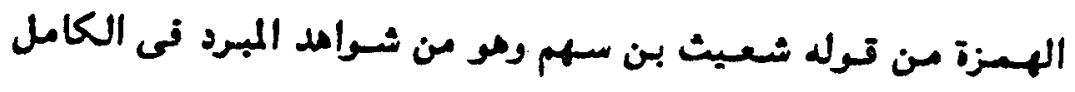

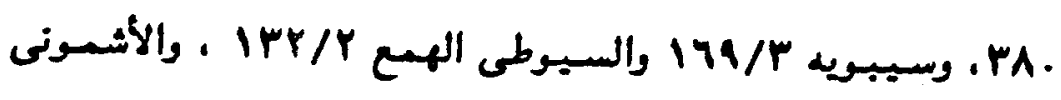

$$
\begin{aligned}
& .1 .1 / 4 \\
& \text { آية } 09 \text { من الواتعة . } \\
& \text { آية سو19 من الأعراف - }
\end{aligned}
$$


وبـاز اختـلاف الجمبلتين مع أنها متصلة لأمنهم من الالتسباس

بالمنقعة لأن التسوية لامعنى فيها للمنفصلة .

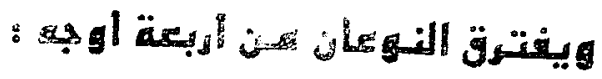

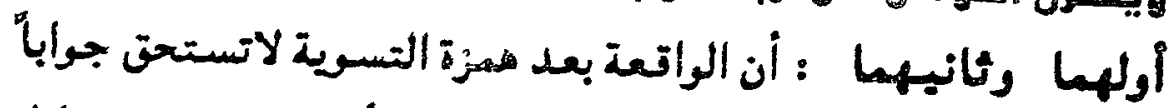

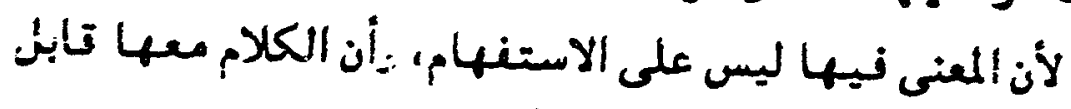

للتصديق والتكذيب لأنه خبر (1)

وليست تلك كذلك، لأن الاستنهام معها على حقيقته :

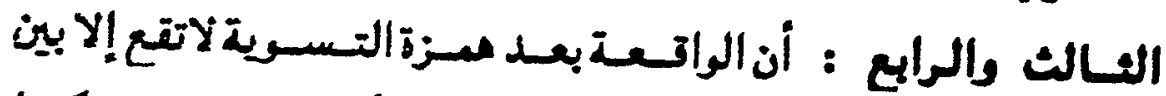
جملتين ولاتكون المبلتان معها إلا فى تأويل المغردين، وتكونا

نعليتين أو اسميتين. كما تقدم ولاتحن

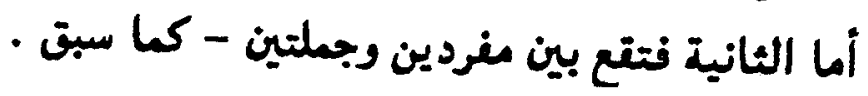

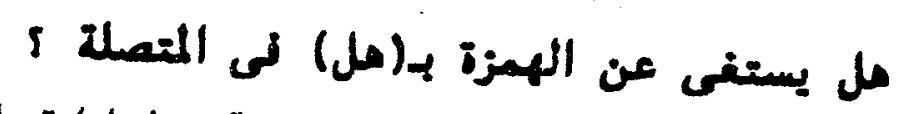

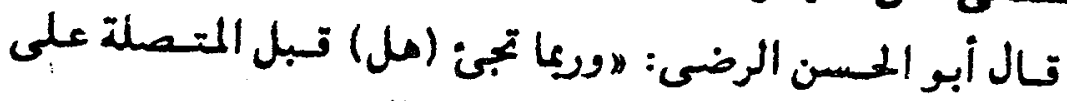

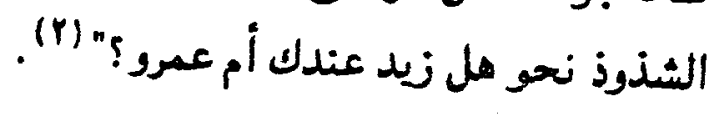

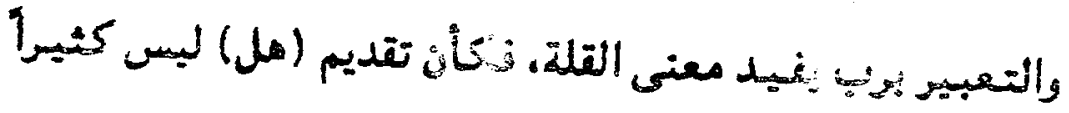

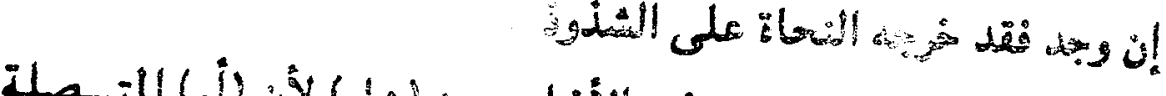

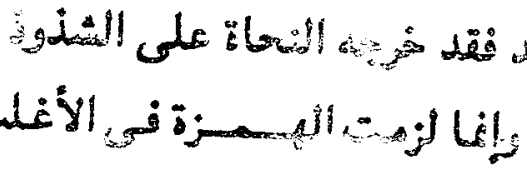

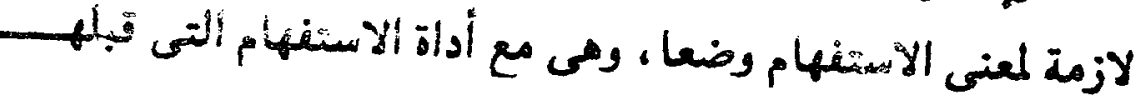

$$
\text { - (1) }
$$

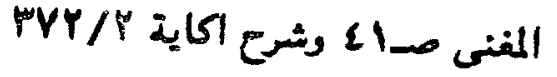




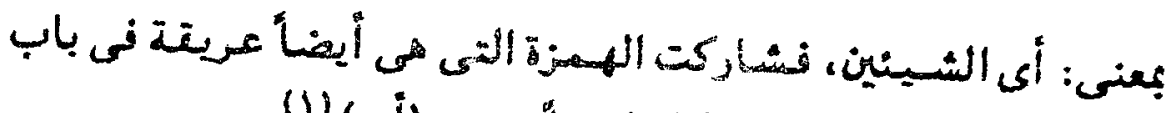

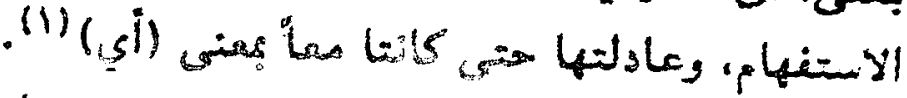

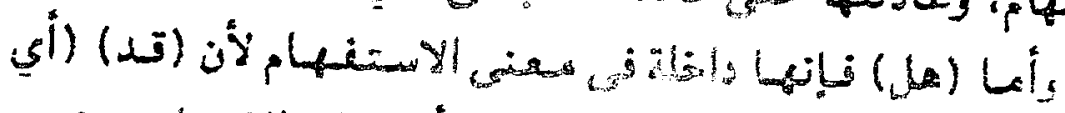

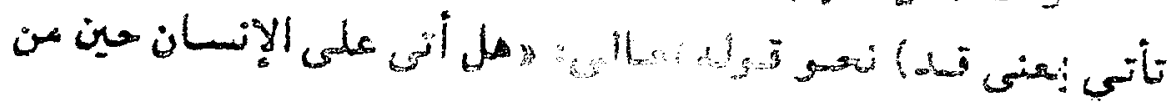
(r) "(I)

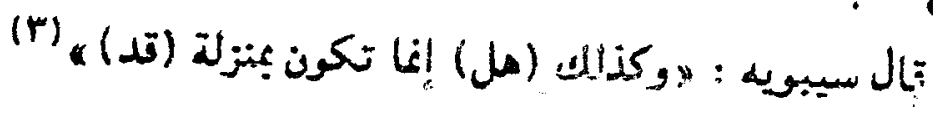

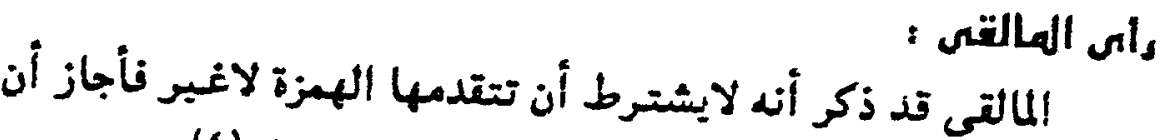

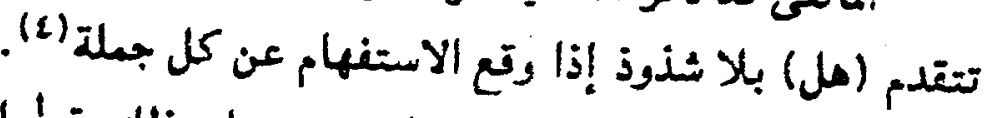

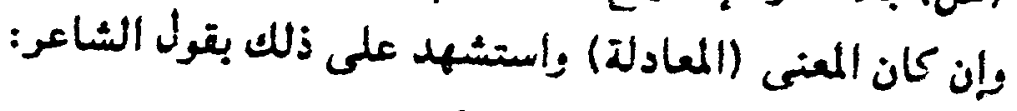

(o)

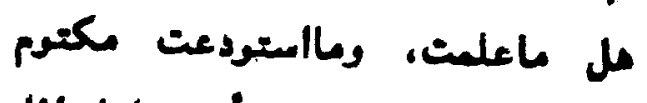
أم عهلها إذا ناقله اليوم مصروم

$$
\begin{aligned}
& \text { لأن المعنى - كسا قال المالقى - أى مذين كان ؟ }
\end{aligned}
$$

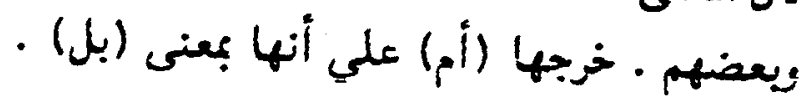

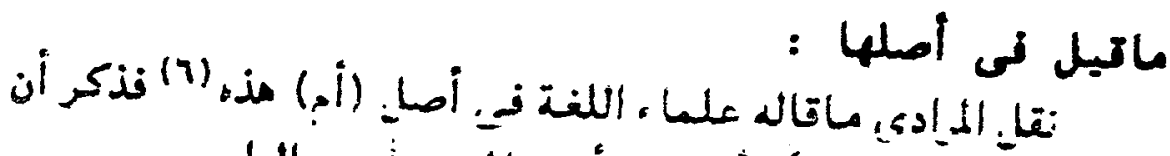

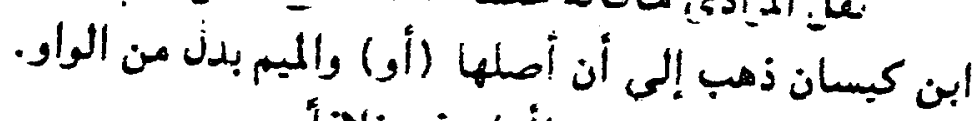
وزكر النهاس في (أم) هذه خلافياً.

-

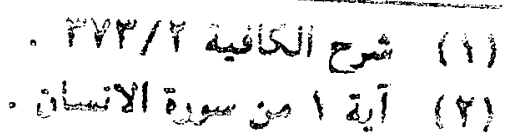
زصف المبانتى 18

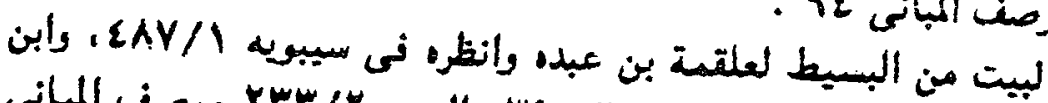

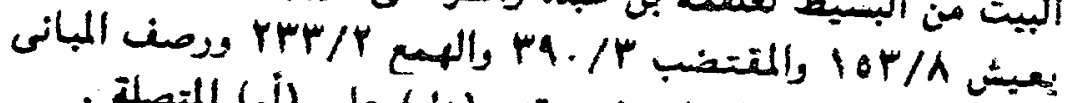

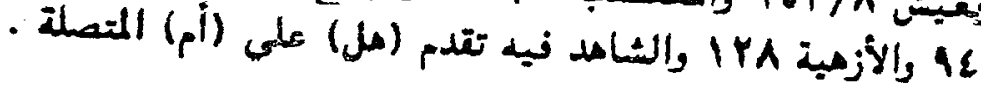


-rra-

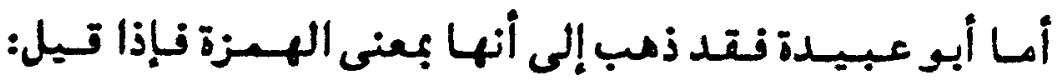

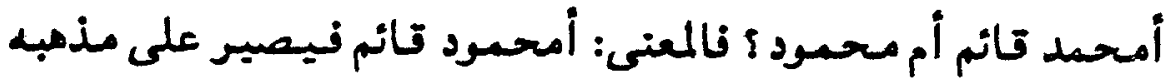

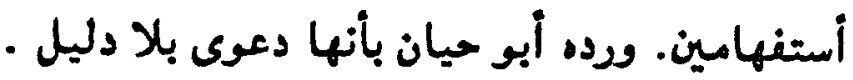

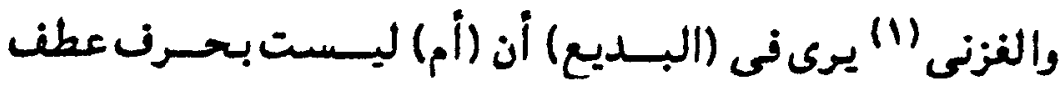

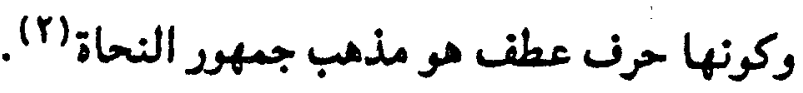

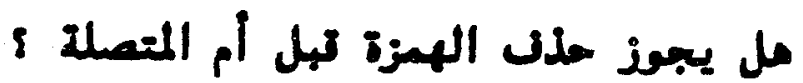

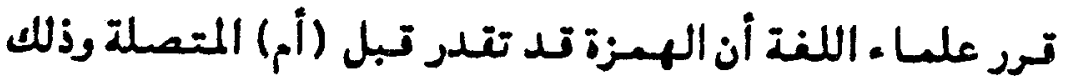
مخصوص بالشعر ومن شواهدمم على هذا تول عمر بن أبى ريبعة:

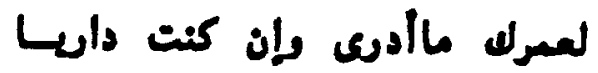
بسمع رمين الجمر أم يعسان

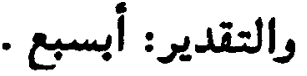

وقول الآخر :لعبرك أيسع مأدرى دإن كنت داريا معدث بن عمرو أم شعبث بن مندر

ثانياً: (ام) المنتطعة:

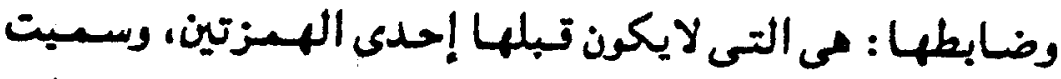

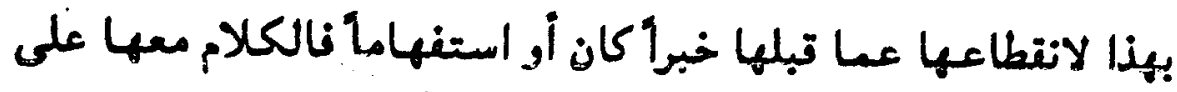

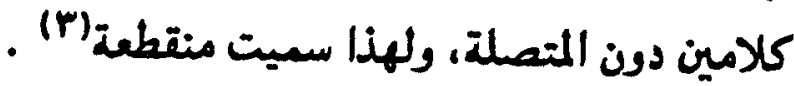

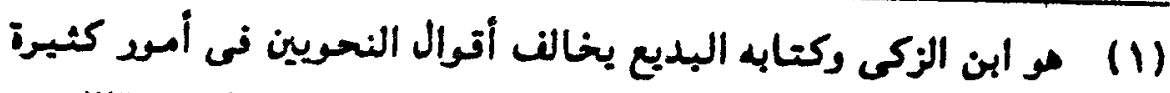

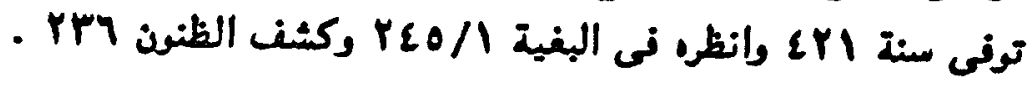

(Y)

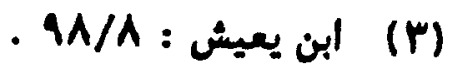


الخلاف نى هعناهل :

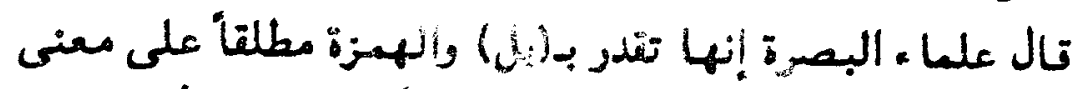

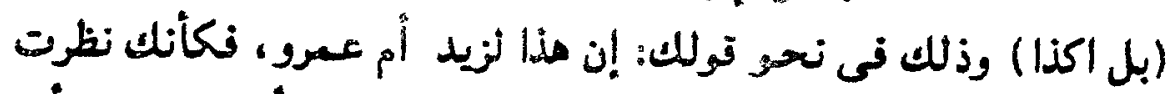

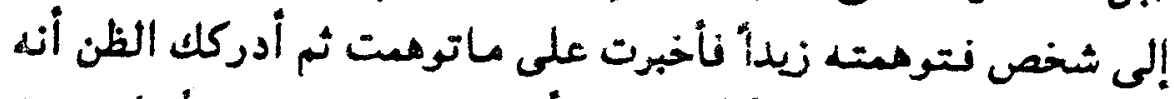

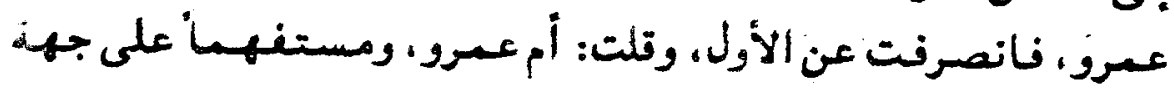

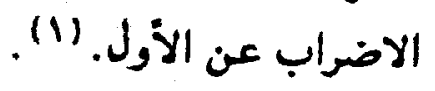

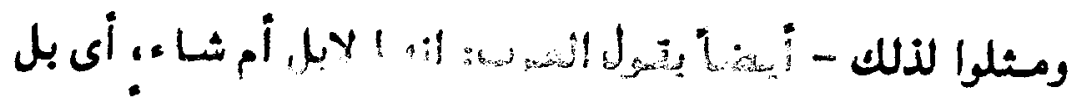

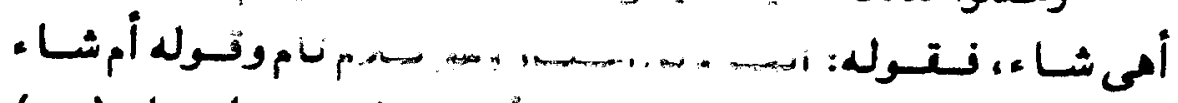

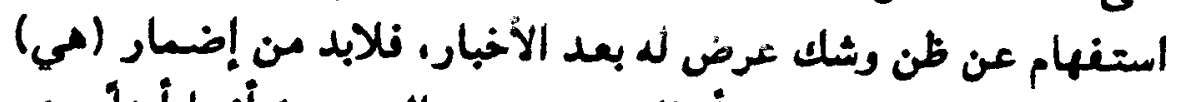

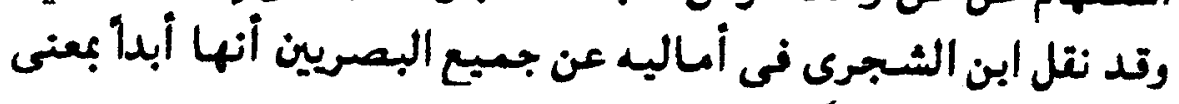

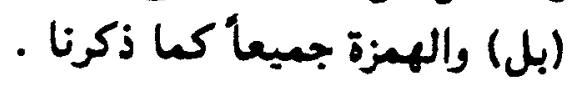

وذكر بعض النحاة أنها تقدر بـ(بل) مطلقاً .

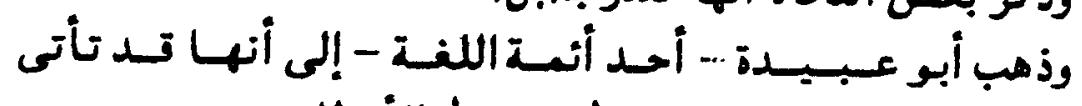
للاستفهام المجرد من الإضراب.نفال فى تول الأخطل:

علس الطلام من البعاب خبالاو(r)

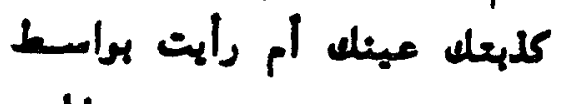

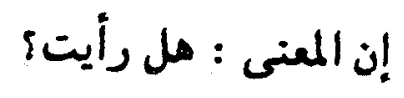

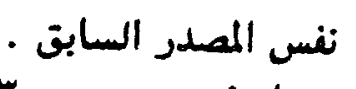

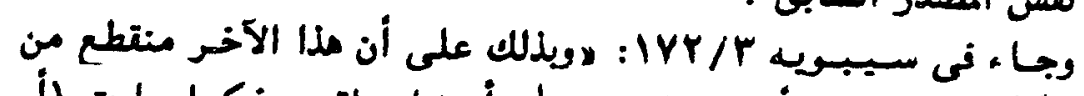

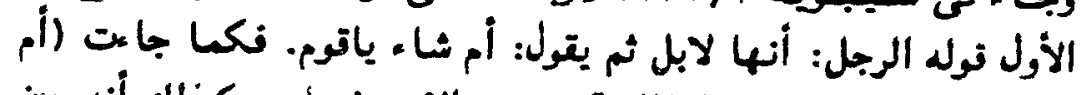

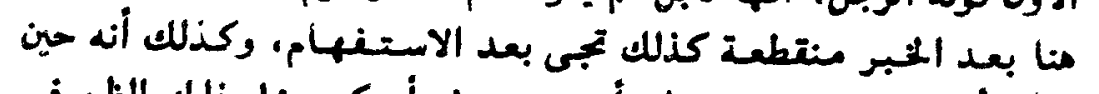

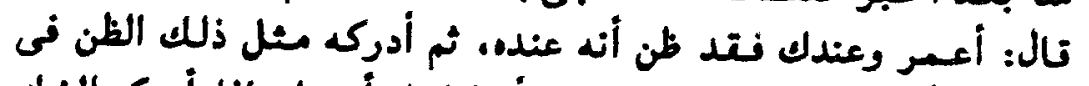

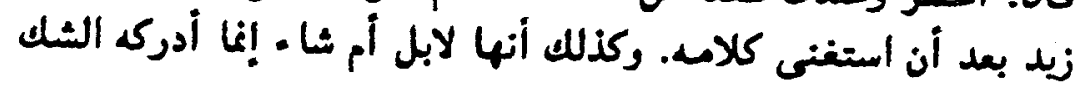

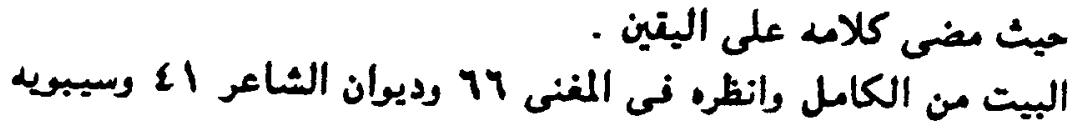

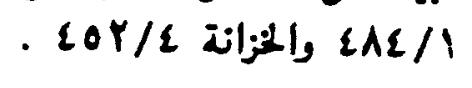


راب ابن هـالك

ذكر ابن مالل أن الاكثر أن تدل على الإضراب مع الاستفهبام

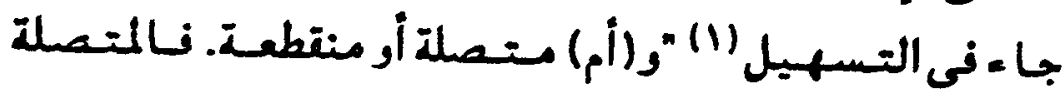
وقد تدل على الإضراب فقط : والئ

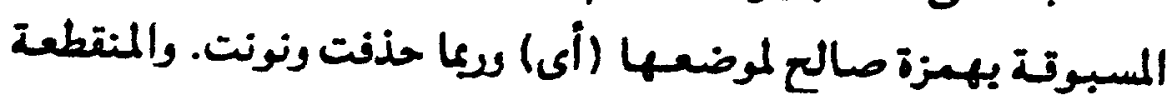

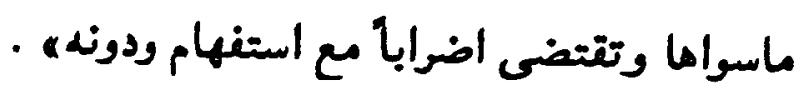

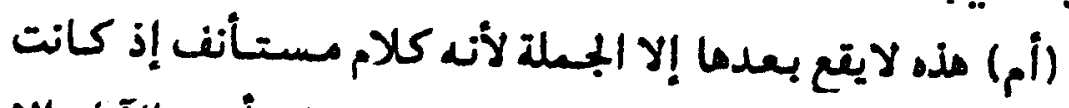
بيان وتعتيب :

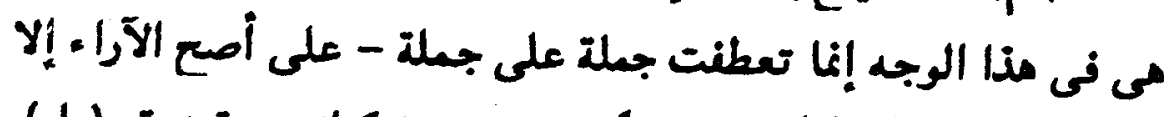

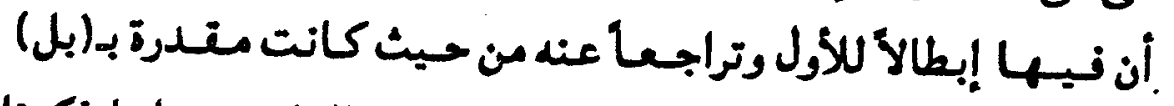

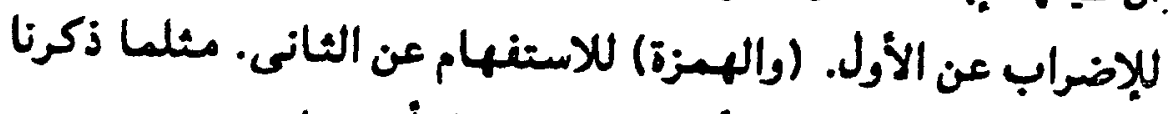

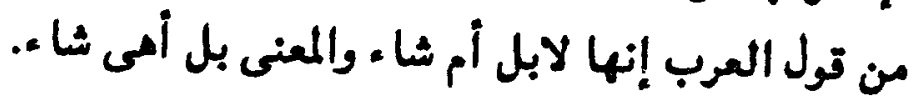

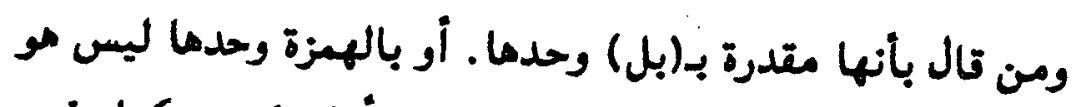

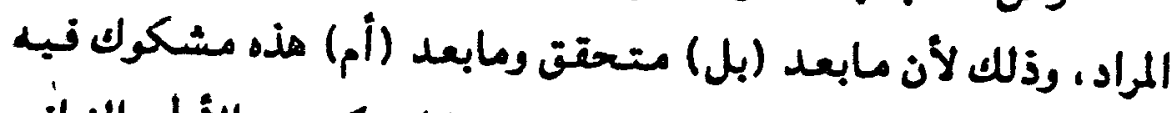

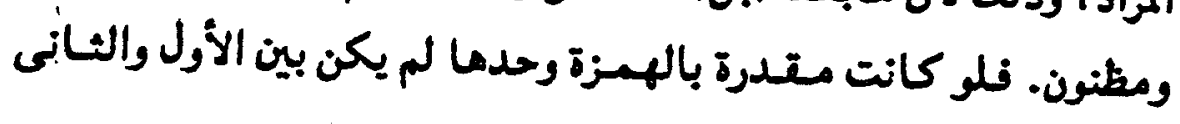
علآثة.

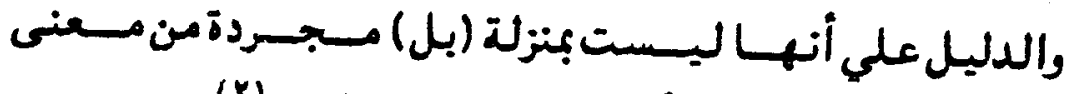
الاستغهام قول الله تعالى: هأم اتخذ ما يخلق بناته (T)". 


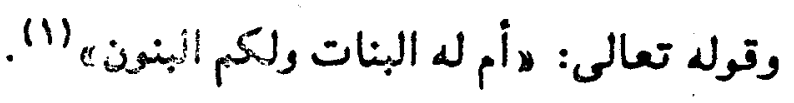

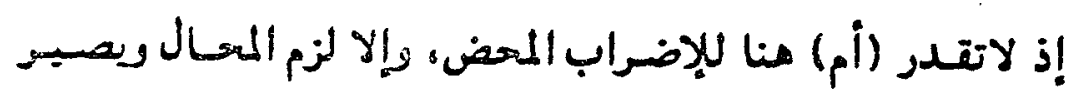

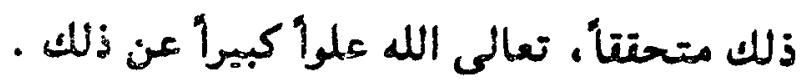
ويؤكد ذلل ماجا ، فى الكتاب من تول سيبيويه :

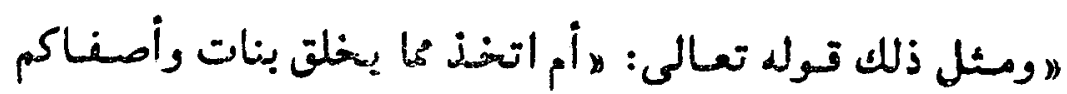

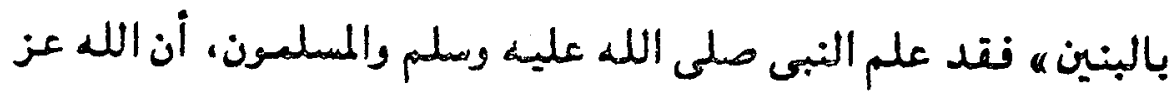

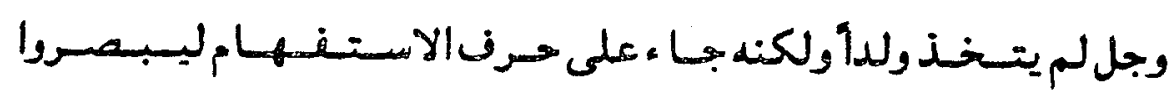

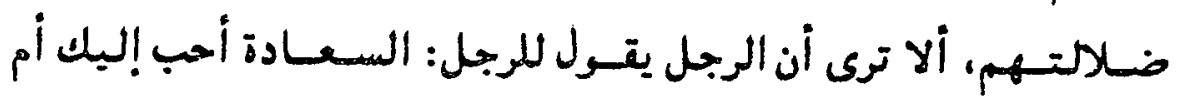

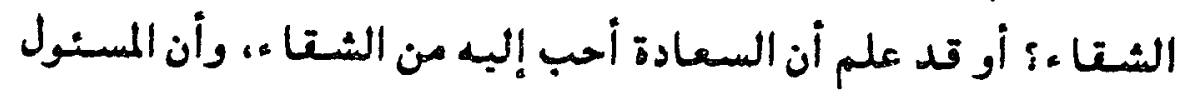

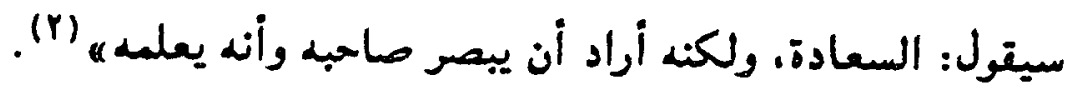

\begin{abstract}
مل (أم) المتنطعة عاطنة أ

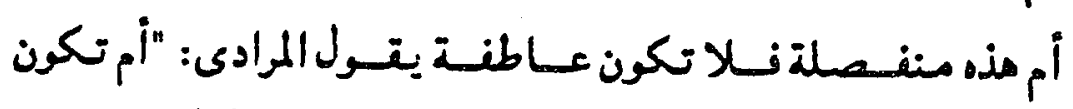
منفصلة فلا تكون عاطفة ويقع قبلها الاستنهام وغيره ه "(r). وكذلك الغنارية يقولون: إنها لست عـاطفة لافى مـفرد ولافى فيله
\end{abstract} (2) جملة أيضاً

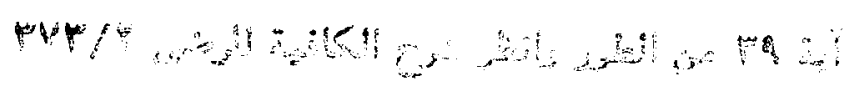

- stry you

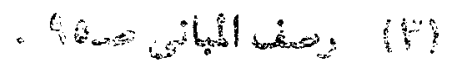

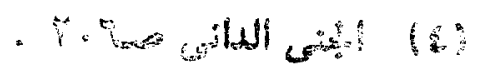




$$
\text { رابى ابن هـالك }
$$

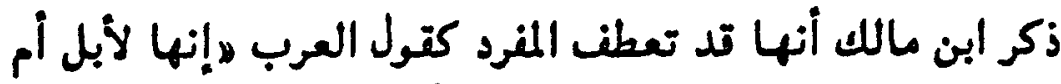

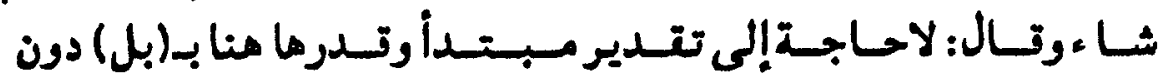

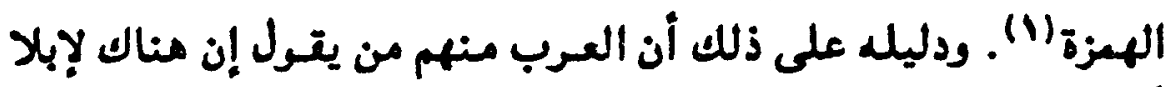

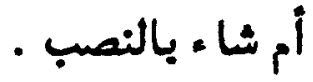

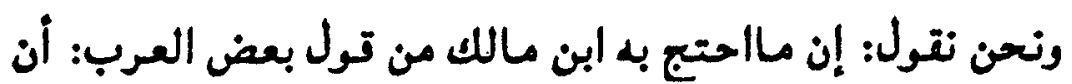

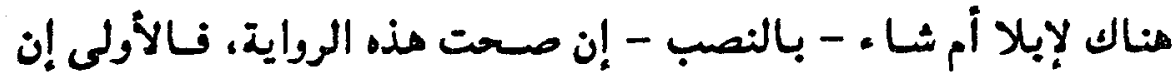

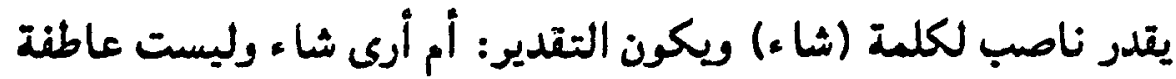
لمفرد . المتر ناصي

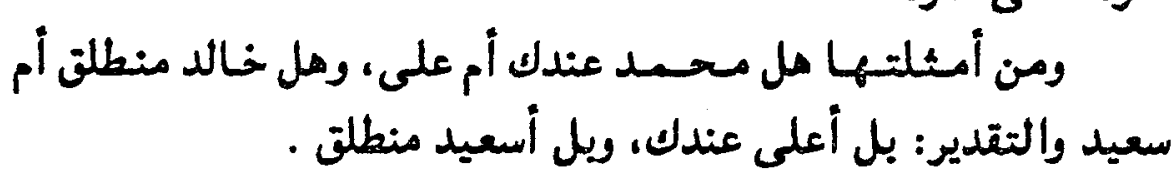

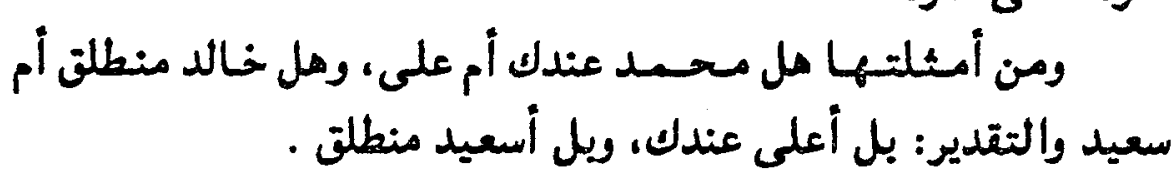

أما رأى الجمهور: فهى عاطفة تعطف جملة على جملة، وليس

$$
\text { كائ البهمور : }
$$

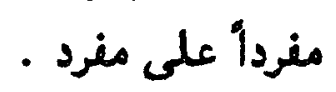

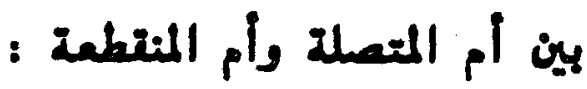

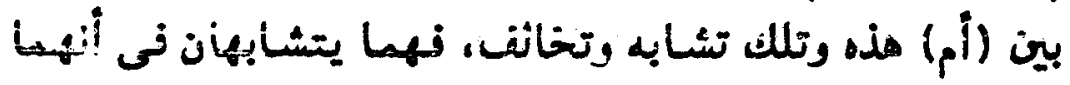

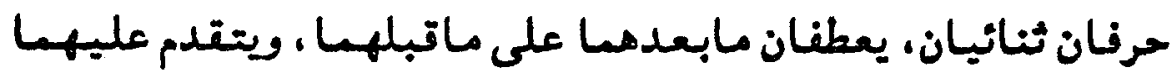

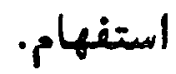
الها وبه الهخالفة بينهما فكها يآتى: أولاً: تختص المثصلة بثلاثة أشياء : 


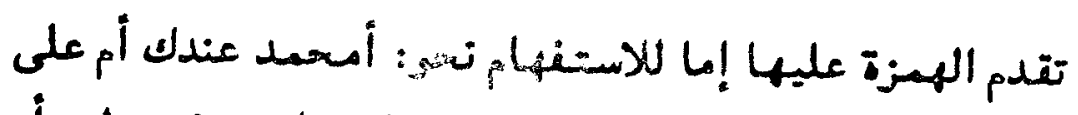

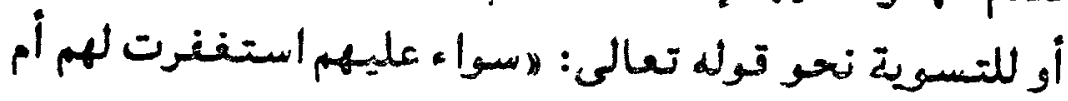

لم تستغنر لهمه .

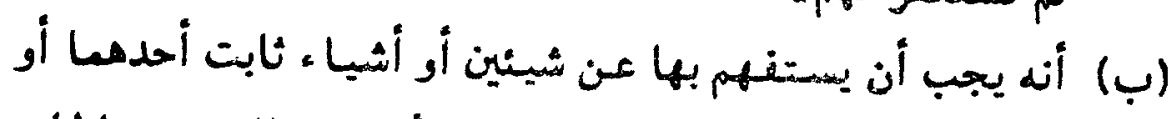

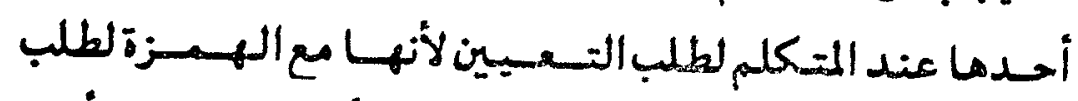

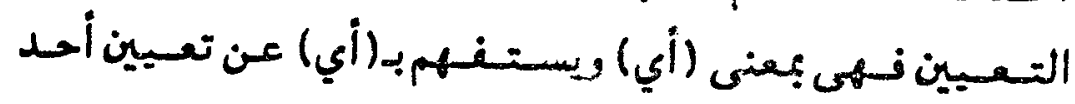

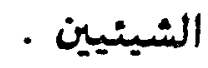

(ج) أنه يليها المفرد والجملة .

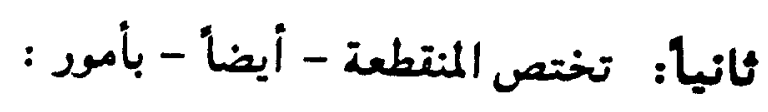

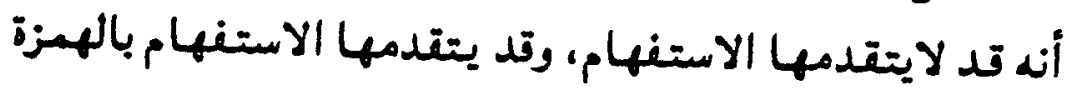

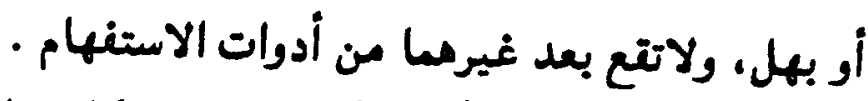

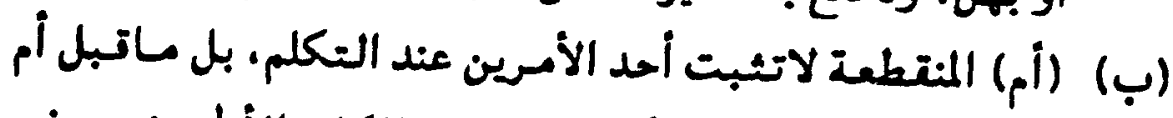

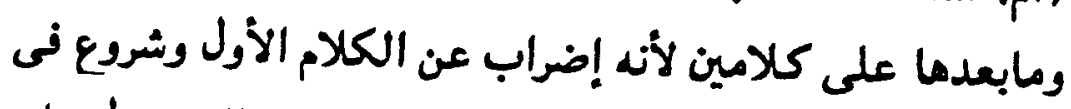

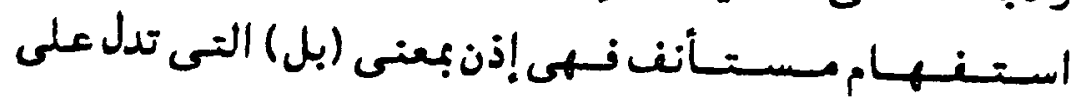

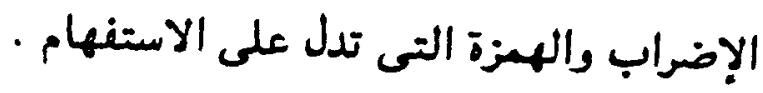

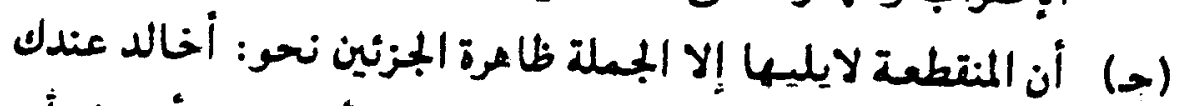

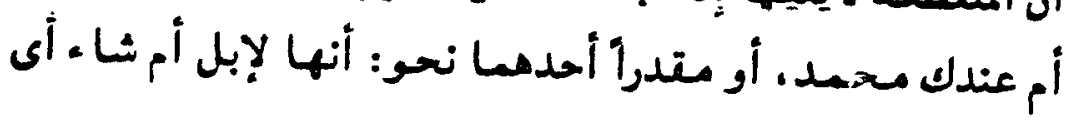
أم هى شا .. ولاتحذن هذه الجملة .

4an

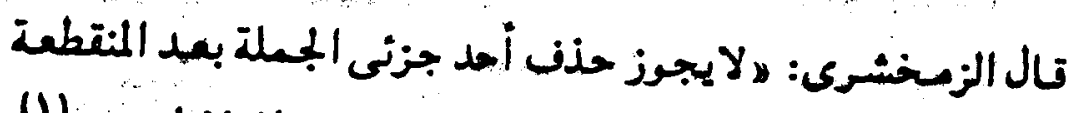
فى الاستغهام لنلا يلتبس بالمتصلة، ويجوز فى الحبر إذ لايلتبس. 
وتال ابن الناظم: لاوأم المنقطعة هى الواتعة بين جملتين ليستا

$$
\begin{aligned}
& \text { فى تقدير المفردين بل كل منهما مستتل بغائدته. }
\end{aligned}
$$

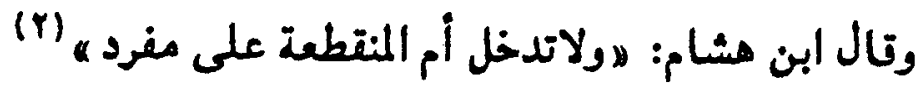

(د) يتعين فى (أم) أن تكون منقطعة إذا وتع بعدها جملة من مبتدأ

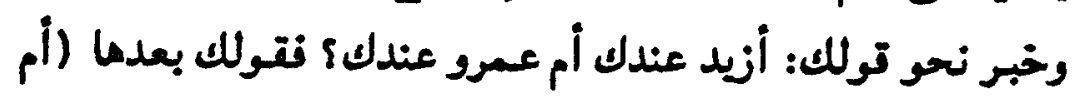
عمرو عندك) يقتضى أن تكون منفصلة .

تال سيبويه : لاوذلل قولك: أعمرو عندك أم عندك زيد، فهذا

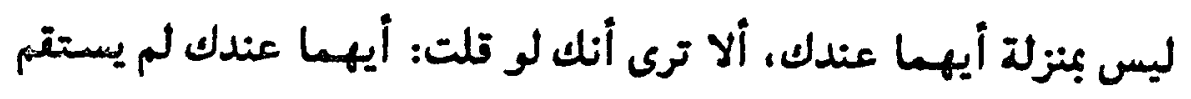

$$
\text { إلا على التكرير والتوكبد. }
$$

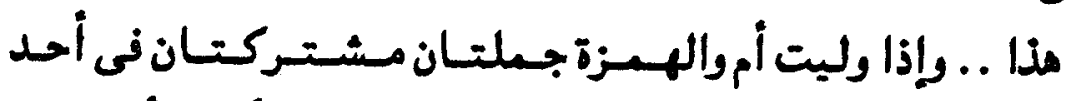

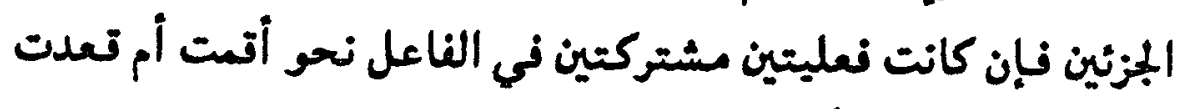

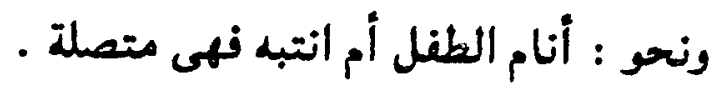

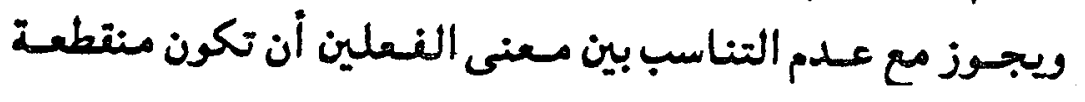

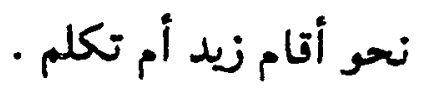

وأما إن جئت بعدها بجمليبن غيز مشـتركتين فى أحد الجزز أين

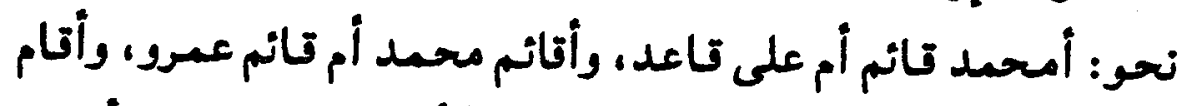

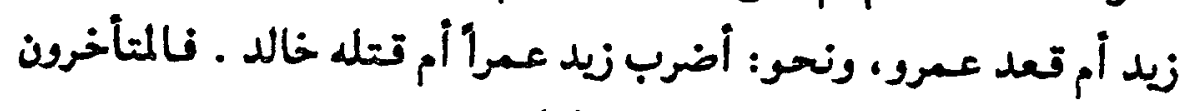

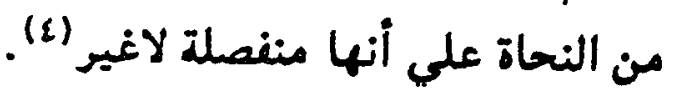

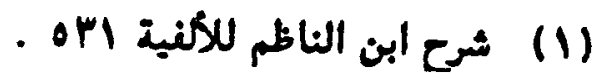

.

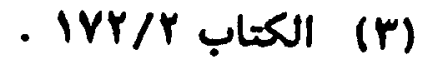

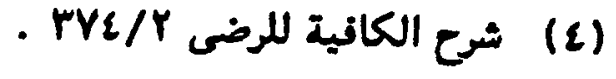




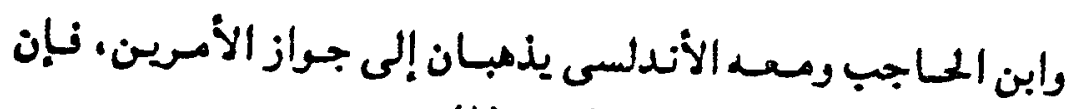

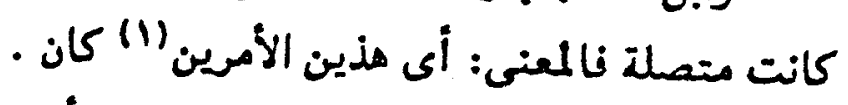

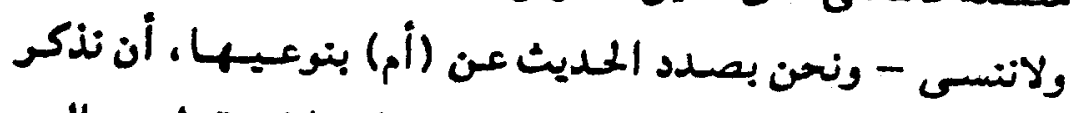

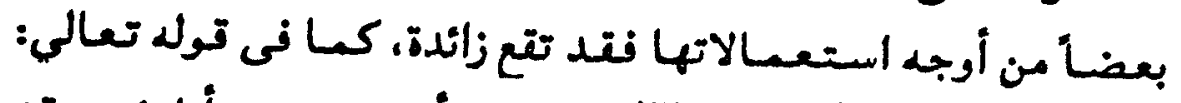

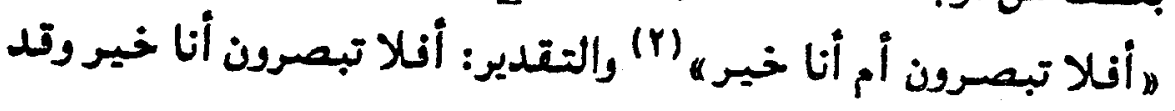
تبدو الزيادة ظاهرة فى قول الثـاعر :

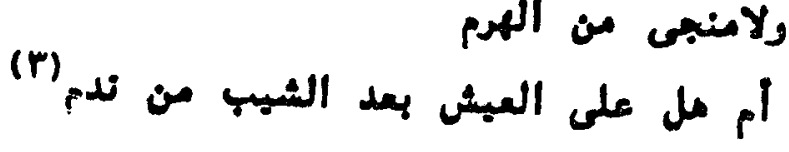

\section{عاليت شعرى ولامنجى من الهرم}

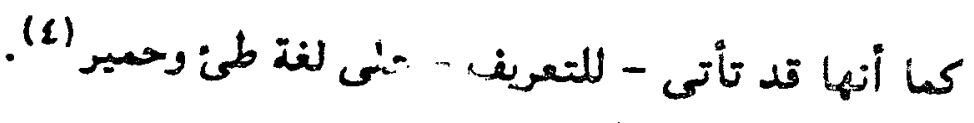

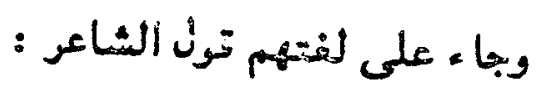

ذال خليلى وذو بواصالن لهن ترن

برمى ورائى بامسهم وامسلفي(10)

$$
\text { الزفس المصدر السابق . }
$$

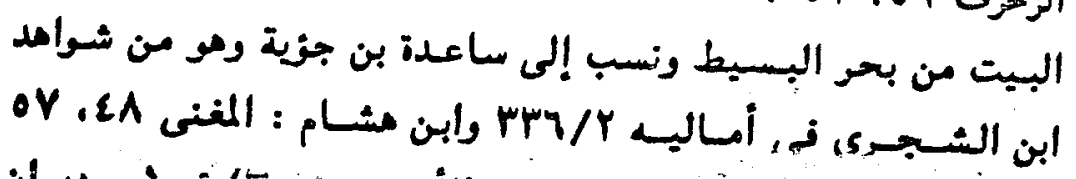

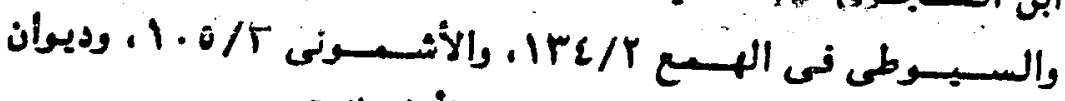

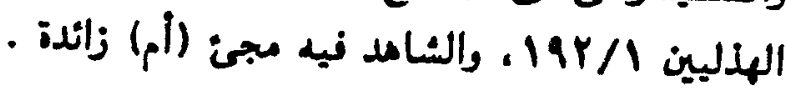

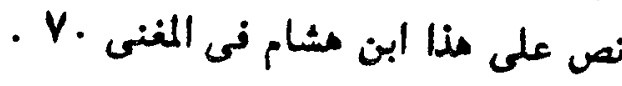

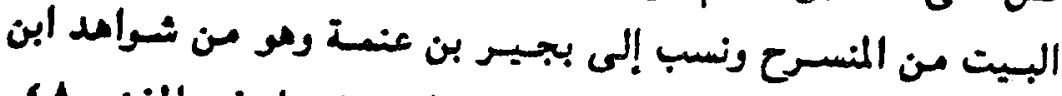

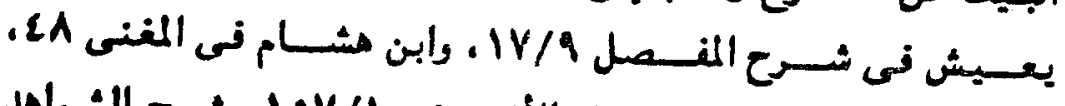

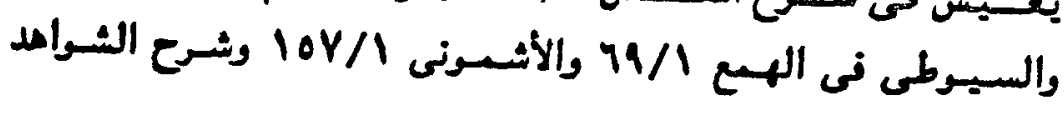

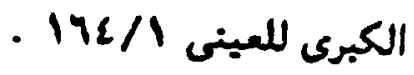




\section{-rry-}

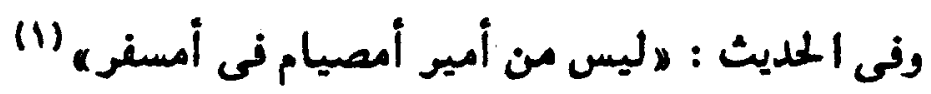

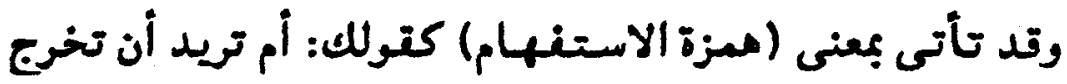

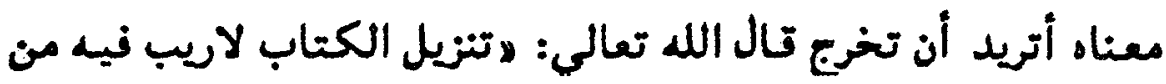

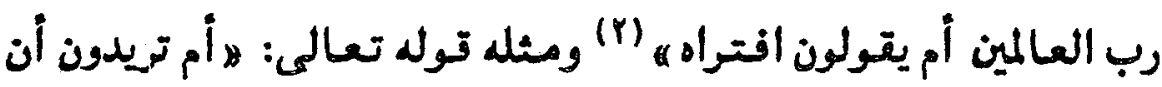

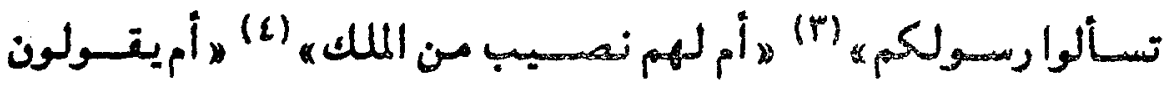

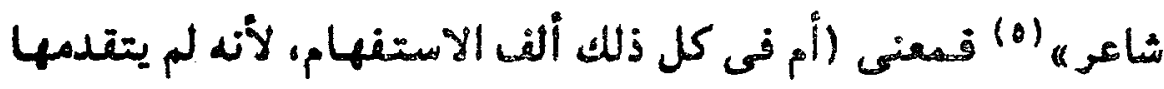

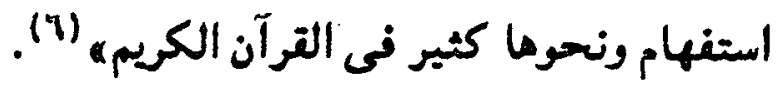

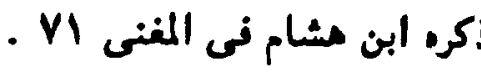

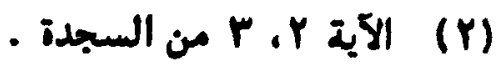

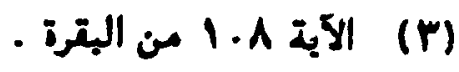

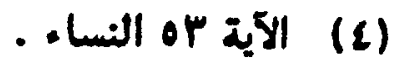

• (0)

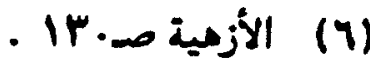




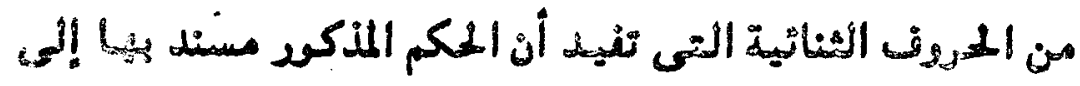

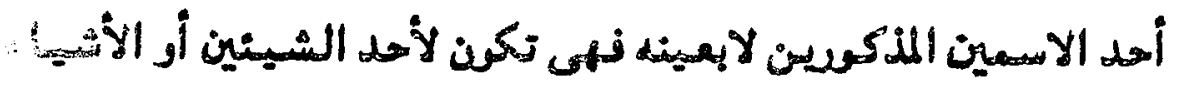

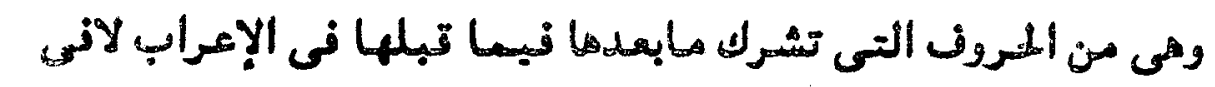

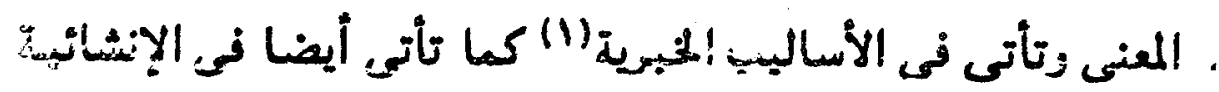
تقول فى الحببر : زيد أو عمرو نجيج، نالنعل واقع من أحدمها وتقول

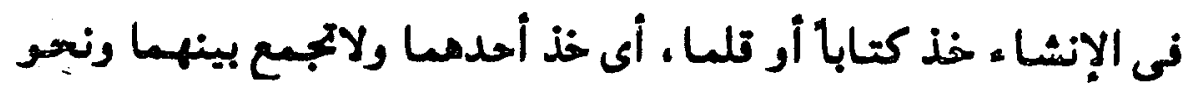

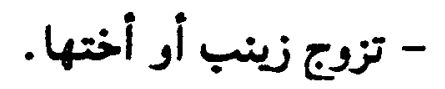

$$
\text { رالى ابن عالك : }
$$

تـال ابن مـالل، إنها تشـرك فى الإعراب والمعنى لأن مابعدها

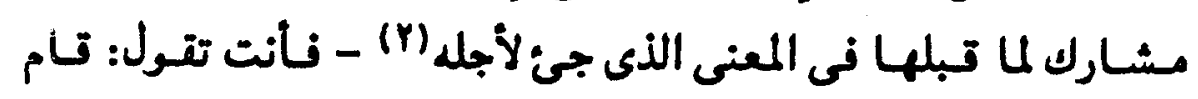
خالد أو سعيد نكل واحد منها مشكوك فى فيامه.

$$
\begin{aligned}
& \text { عبعانيماء }
\end{aligned}
$$

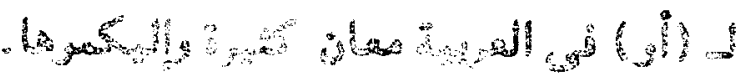

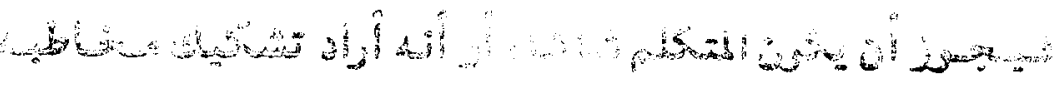

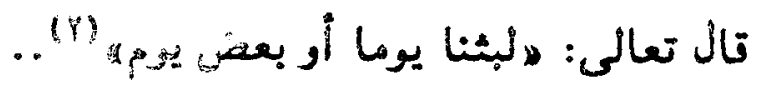

(1) ومى التى تقابل الأساليب الإنشائية أى الكلام الحبرى اللى من شأند

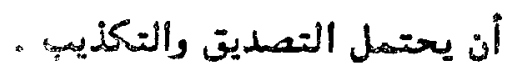$$
\text { المني الندانى ص MPV }
$$ 
والثانيد: تكون (أو) للتخبير بين أمرين، وتصد أحدها دون

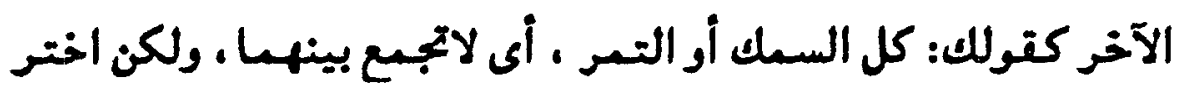
أحدها وتتول : أعطنى دينارا أو ثوياً.

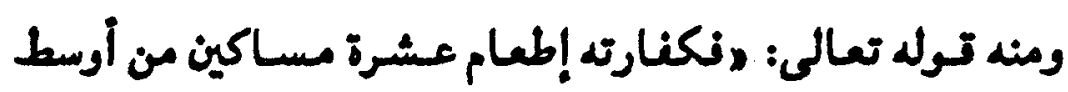

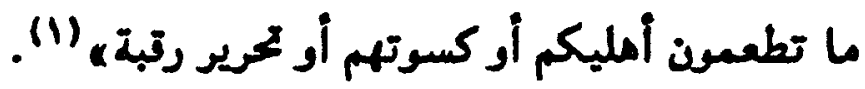

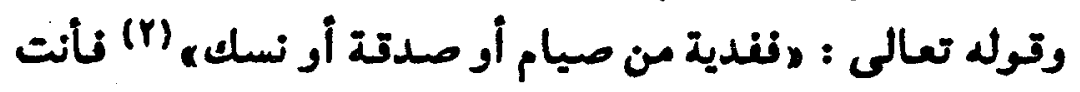

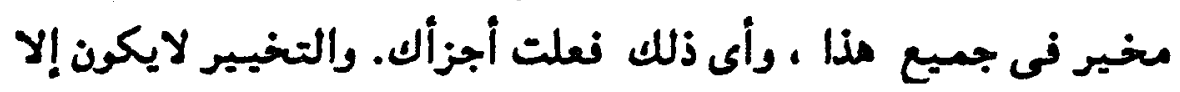
بعد طلب.

الثـالث: أن تكون (أو) للإباحسة كـــــلك: جـالس العلهـاء أو

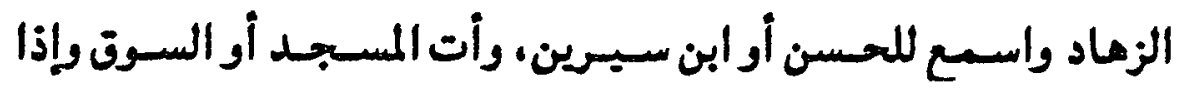

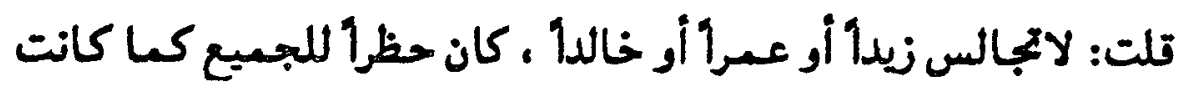

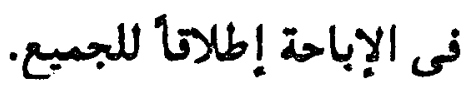

ها الغرت بين التخبير هالإباسة ؟ يغرق بينهـا بجواز الجمبع بين النعلين فى الإباحة والاتنتصار

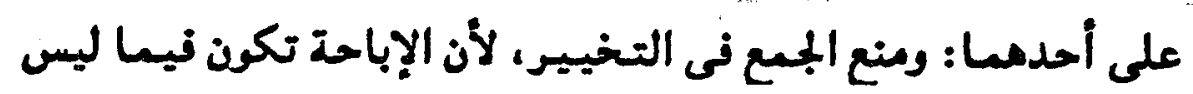

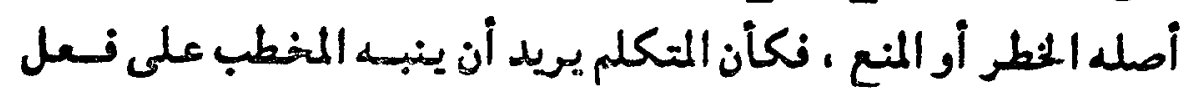
أشياء . من المباحات.

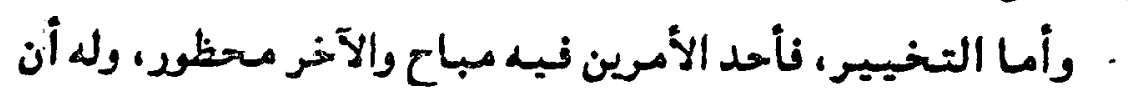

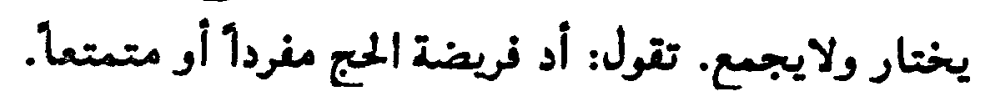


الرابع: أن تأتى لتبيين النوع كتولك، ما أكلت إلا تمرا أو زبيبا

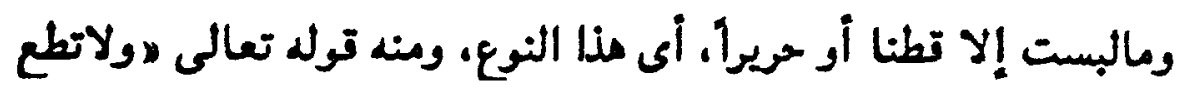

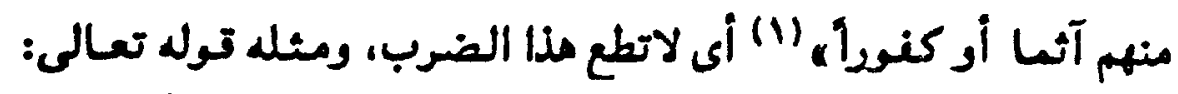

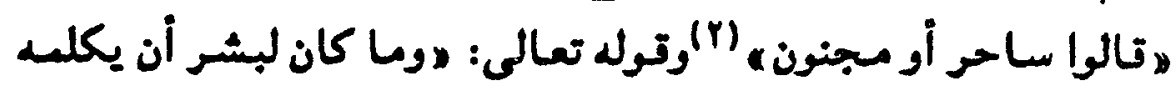

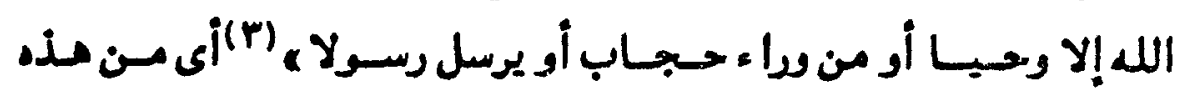
الوجوه.

النا هس : تكون (أو) بعنى واو الصطف كقوله عز وجل: ، ولا

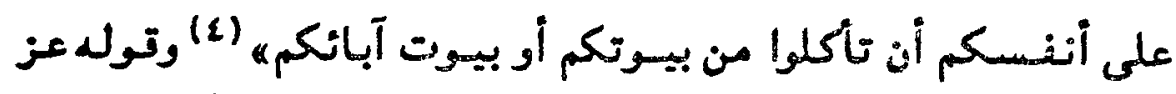

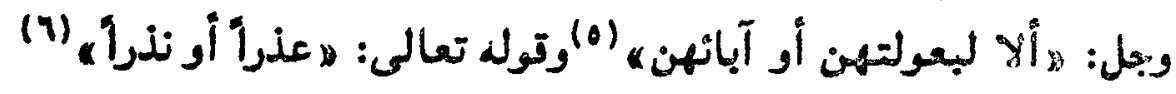

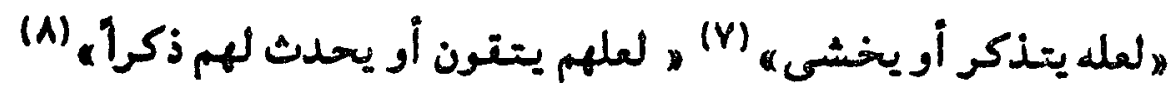

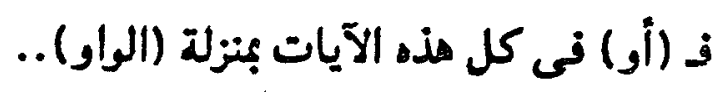

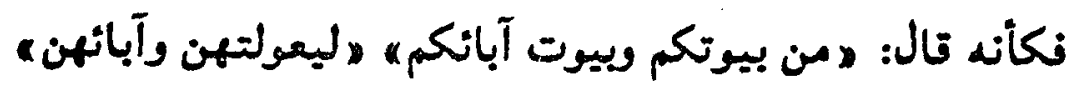

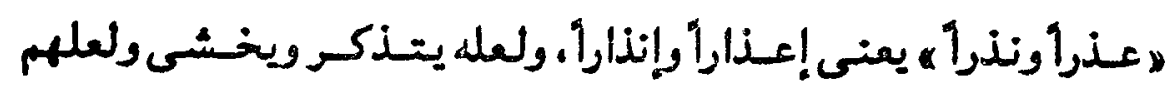
يتقون ويحدث لهم الترآن ذكرا.

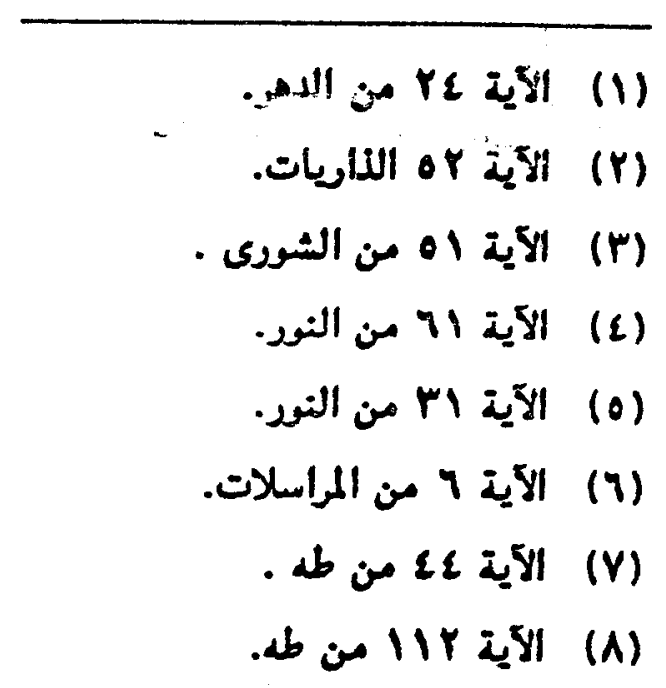


$-r i$.

ومنه قول النابغة :

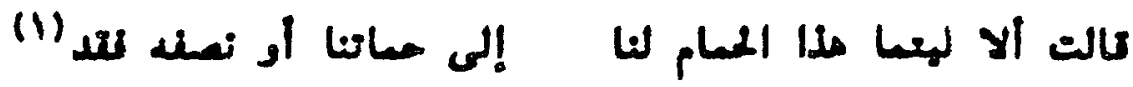
أراد : ونصند نقد ، ذ (أو) بعنى (الواو)

ولمرل تولة هن العمير:

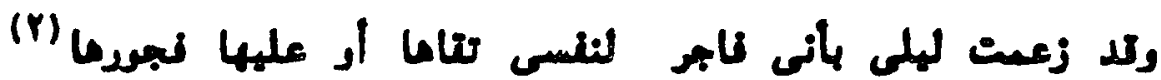
المعنى، وعليها فجورما. وقال جرير

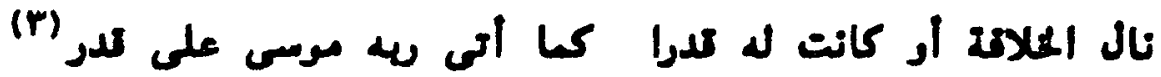
معناه: وكانت له قدرا.

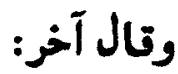

البيت من بعر البسيط رالشـاهد ذيه مبئ (أو) بعنى الواو وانطره

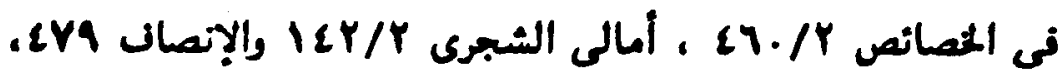

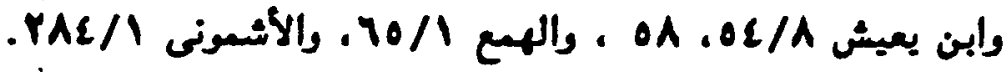

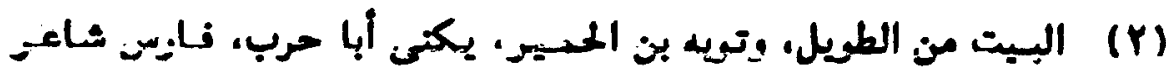
إسلامى صاحب ليلى الأخيلية، والشامد نيه استعمال (أو بعنى الواد

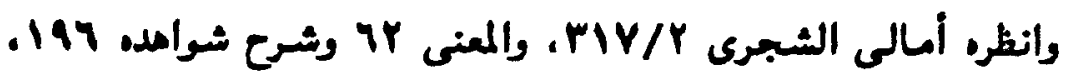

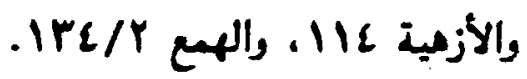

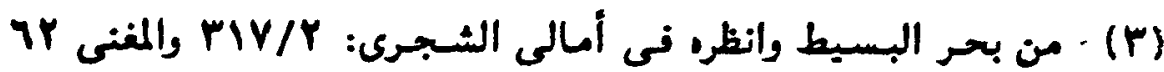

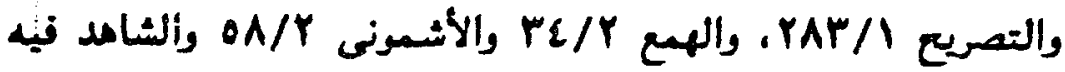

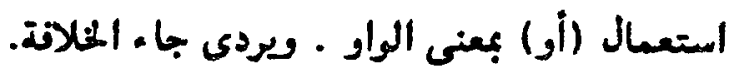




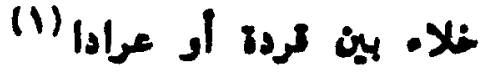

sا نسال منازل من لهن: معناه : وعرادا

ومثلد كول اين أهعر: وعراه

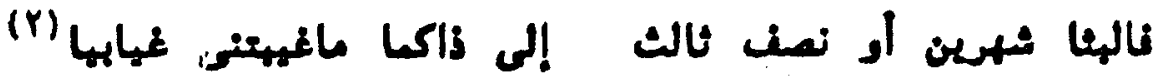
يريد: البثا شهرين ونصف ثالث، لأن لبث نصف الدالث لايكرن

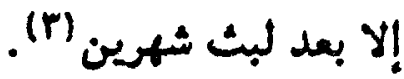

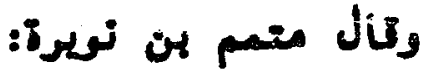

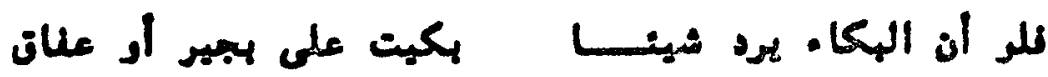

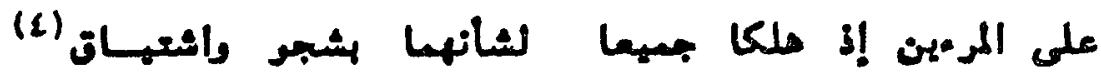
أراد الثاعر أن يقول: بكيت على بجير وعنات. ومنه قول لبيد :

تمنى الهتاى أن يعيش أبوشا

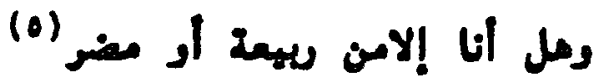

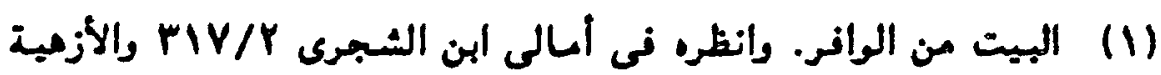

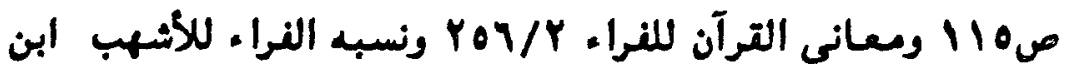
زميله والشاهد فيه كسأبقه.

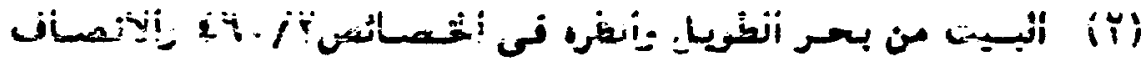
rا

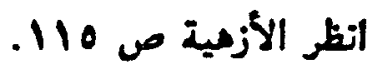

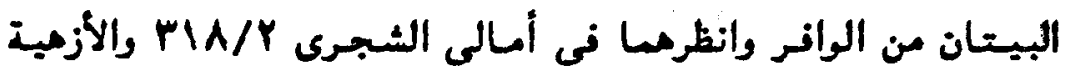

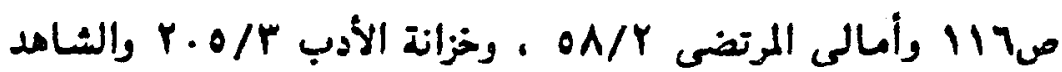
فيه كسابقة.

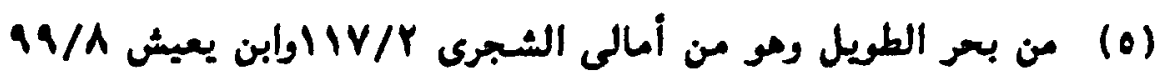

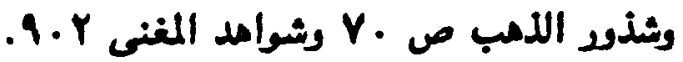


ف (أو) بعنى (واو) العطن وليس للشك، لأن الشاعر (لبيد)

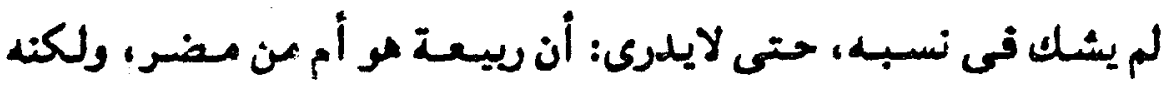

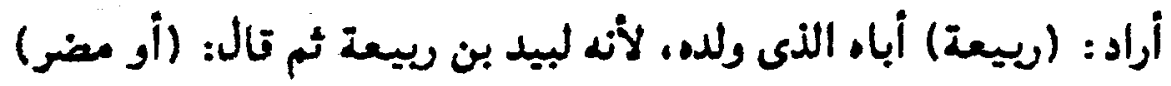

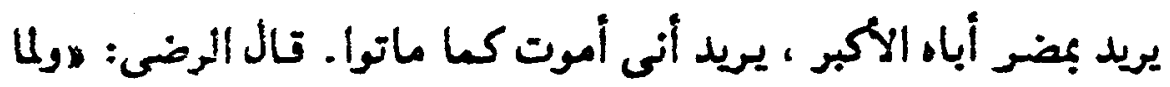

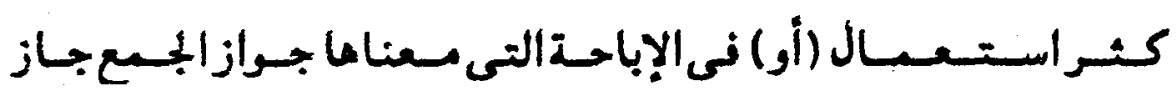

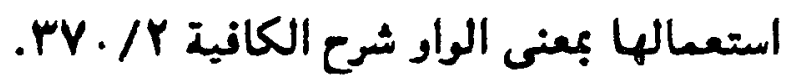

\section{وكال ابت مالل :}

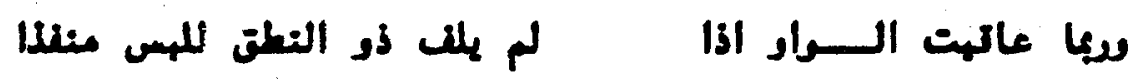

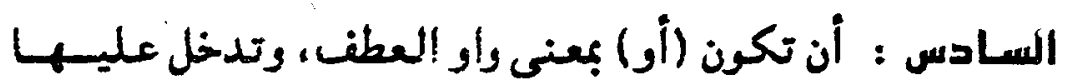

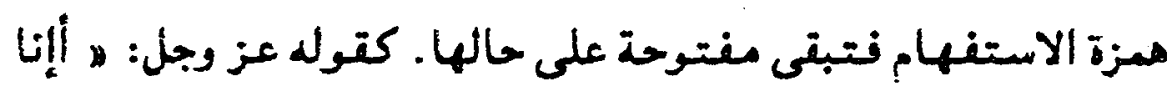

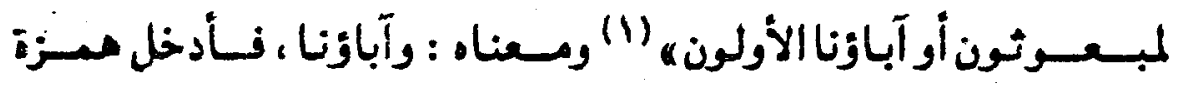

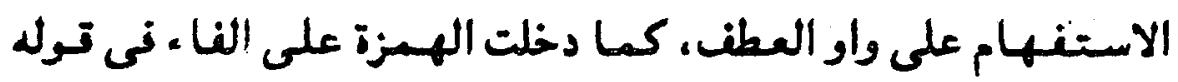

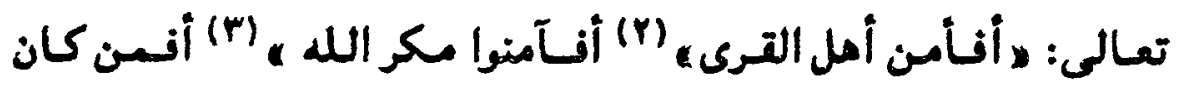

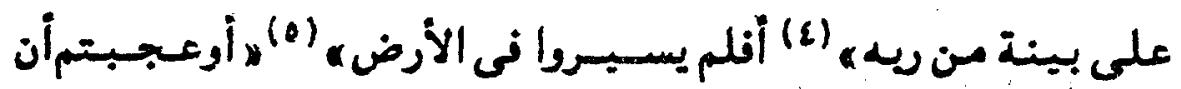

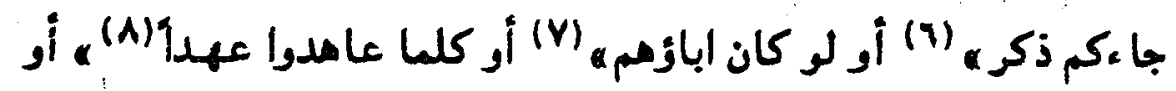

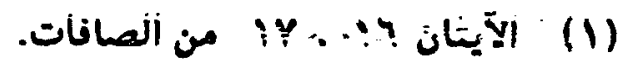

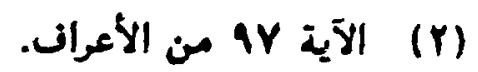
(r)

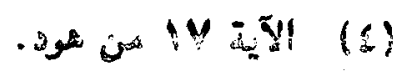

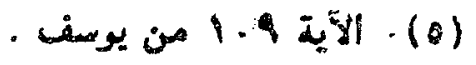

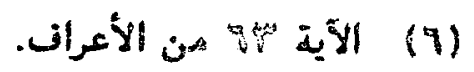

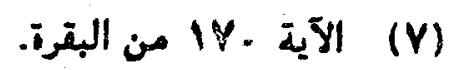
(A) 


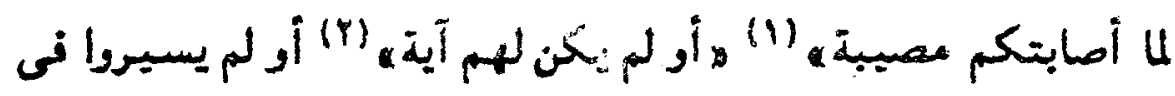

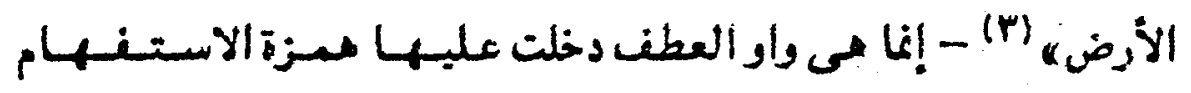
ويتيت مغتوحة.

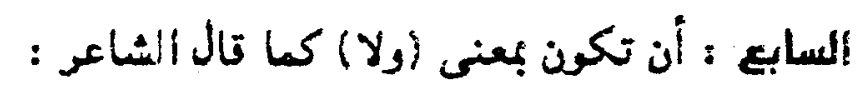
ماوبد ثكلى وجدت، ولا

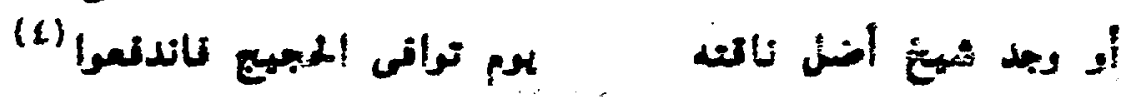

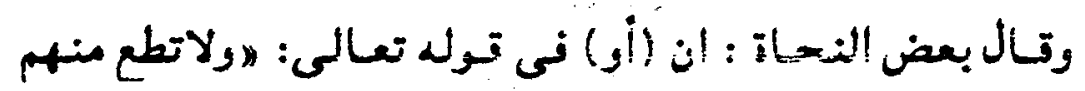

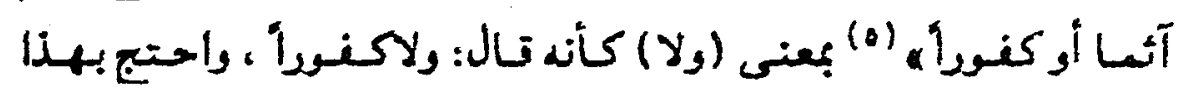

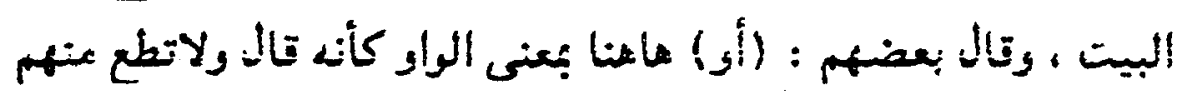
آثما وكفورا.

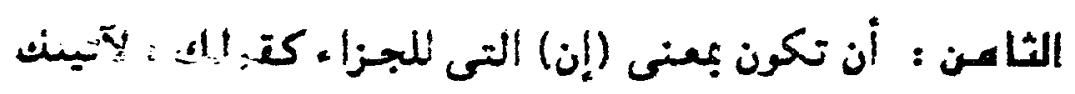

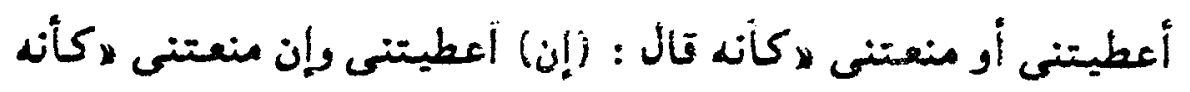

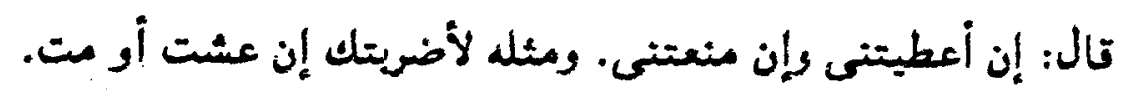

$$
\begin{aligned}
& \text { (1) } 178 \text { نمن آل عمران. }
\end{aligned}
$$

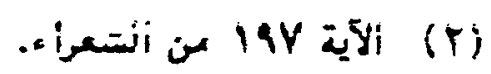

$$
\begin{aligned}
& \text { آية } 9 \text { من ألروم. }
\end{aligned}
$$

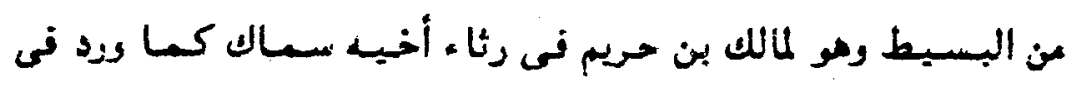

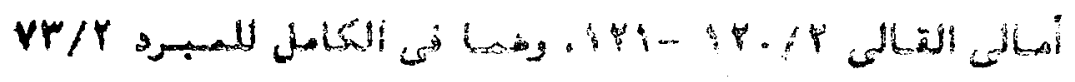

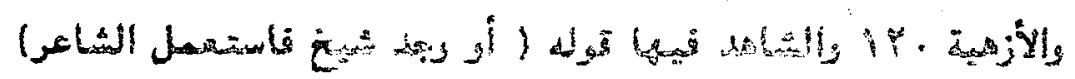

$$
\begin{aligned}
& \text { أو هنا بمعنى أ ولانا. }
\end{aligned}
$$

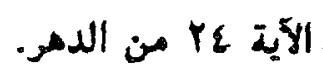




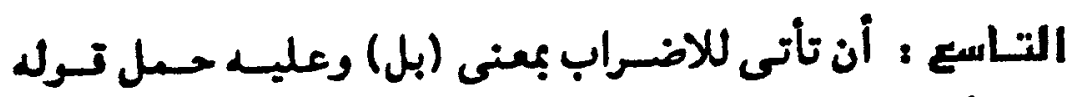

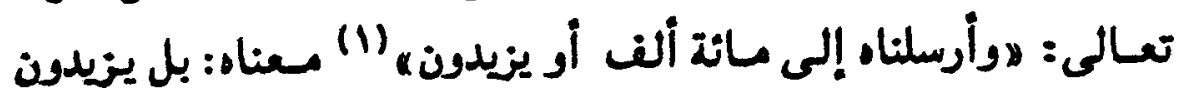

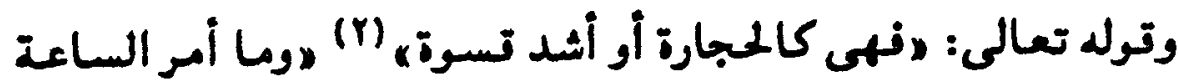

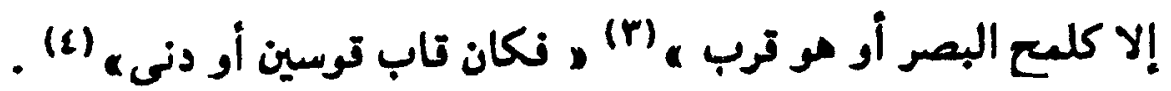

\section{ومثله كول ذى الرمة :}

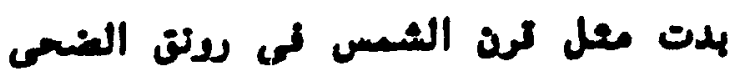

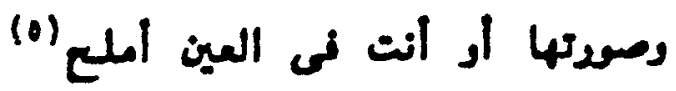

يريد : بل أنت فى العين أملح.

العاشر: تكون بعنى ^إلا أن ، كقولك: لأضرينك أو تطيعنى

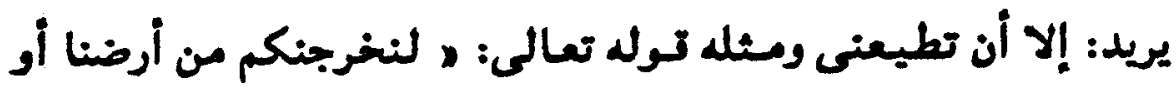

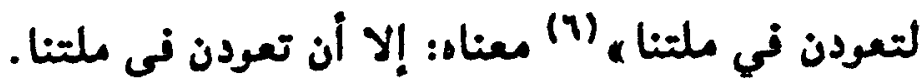

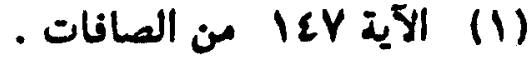

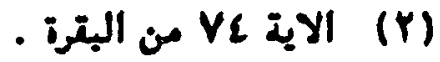

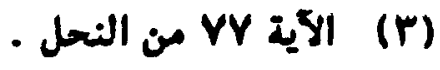

$$
\begin{aligned}
& \text { الآية } 1 \text { من النجم. }
\end{aligned}
$$

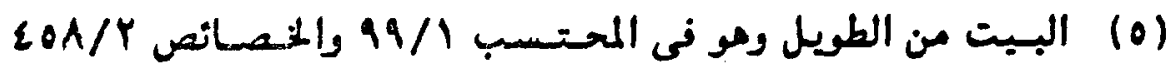

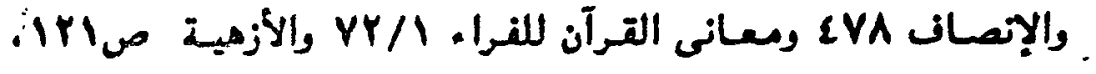

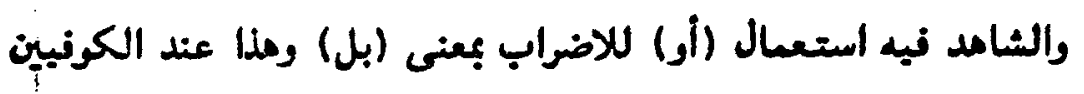
والبصرين لايستعلونها بهذا المعنى..

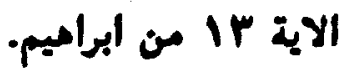


ومثله لول زياد الأعبم :

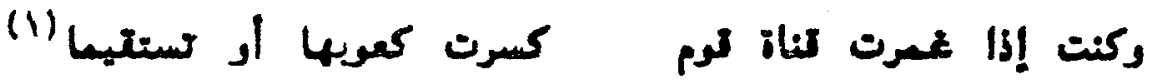
يريد : إلا أن تستقيم ......

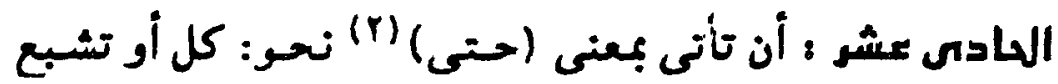

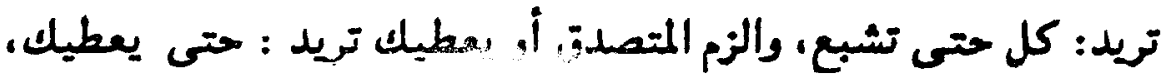

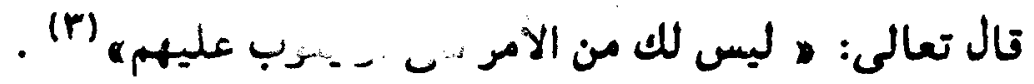

\section{ومثله كول امرين القيس :}

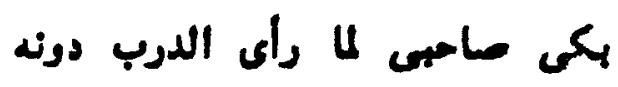

رأيكن أنا لامتان بتيصسرا

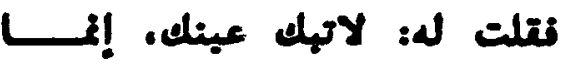

نماول ملكا أ مهرت كنعدر

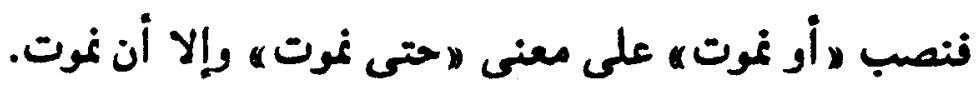

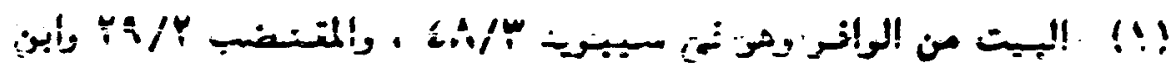

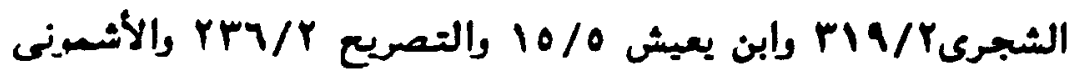

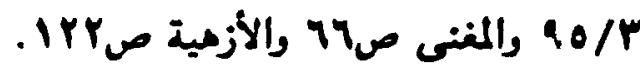

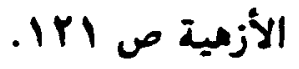

$$
\begin{aligned}
& \text { الآية الآعه آل عمران. }
\end{aligned}
$$

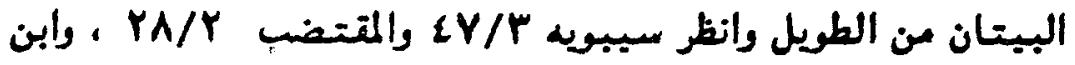

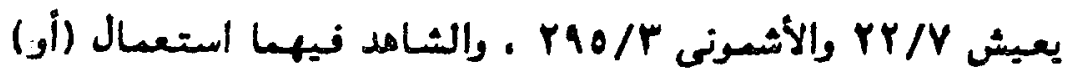

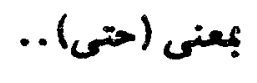




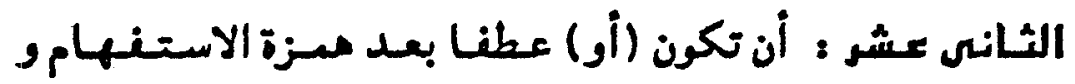

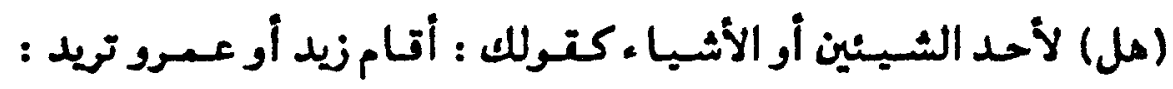

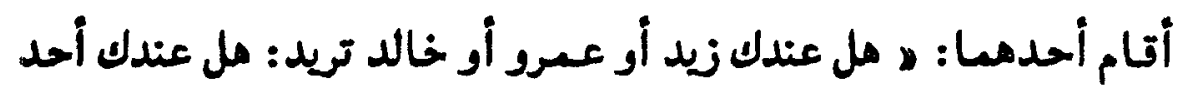

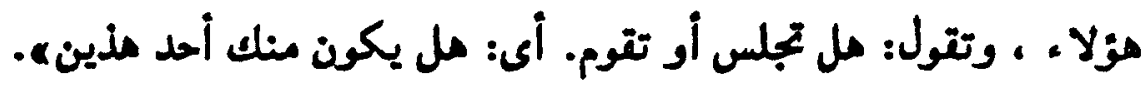

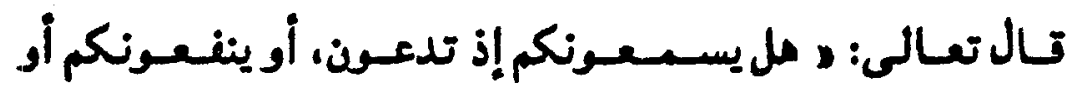

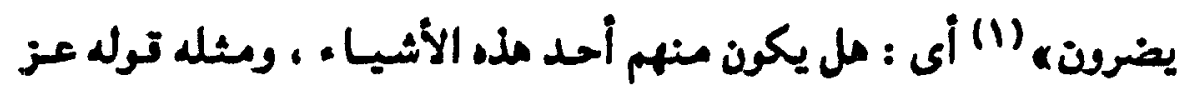

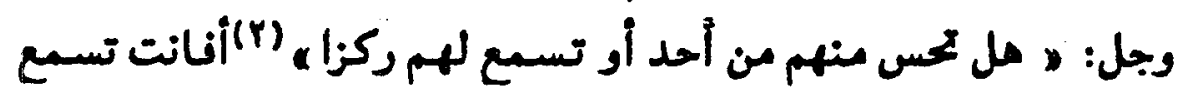

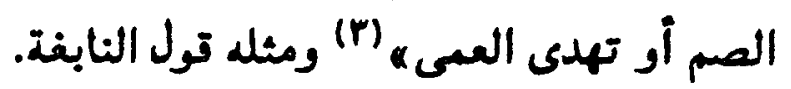

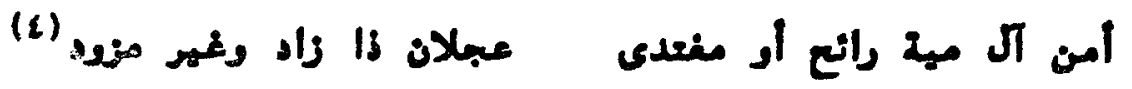
نأو هنا عاطفة :

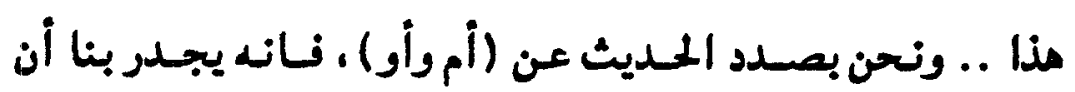
نتناول أوجه المشابهة والمخالفة بينها.

الآكل : أوجه الهشابهة بينطما:

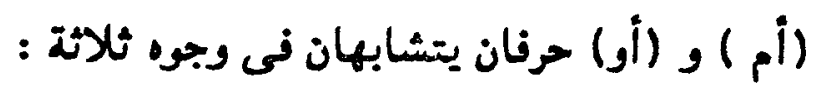

ا- الحرنبة فها حرفان ثنائيان يبدآن بالهمزة.

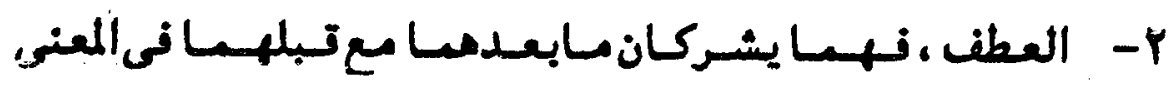
والإعراب على الأرجح.

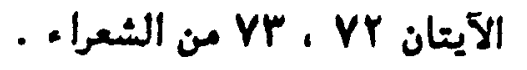

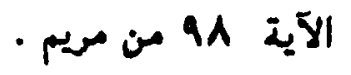

$$
\begin{aligned}
& \text { الآية • ع من الزخرن . من مينم }
\end{aligned}
$$

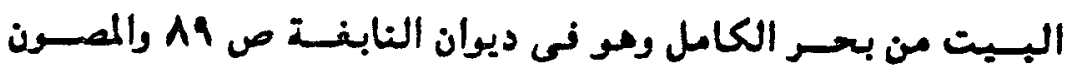

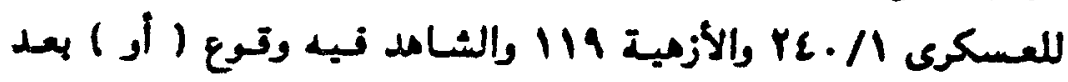

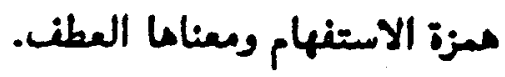


r- أنهما لأحد الشيئين أو الأشبا ، نبجتمعا فى أن الحكم المدكور

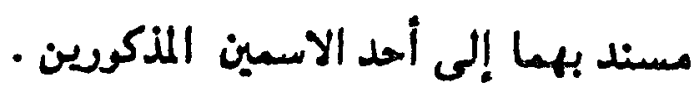

الثُانس : أوجه المغارتة بينهما :

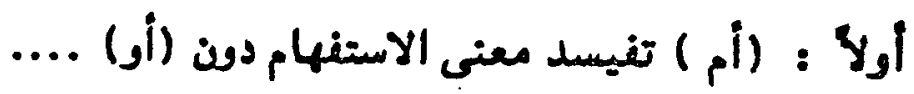

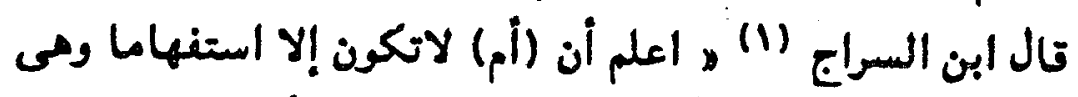

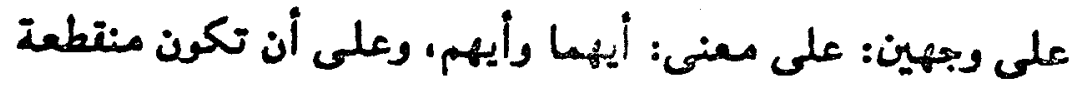
من الأوله.

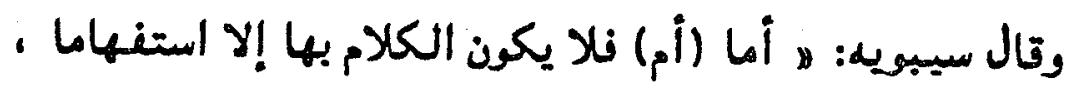

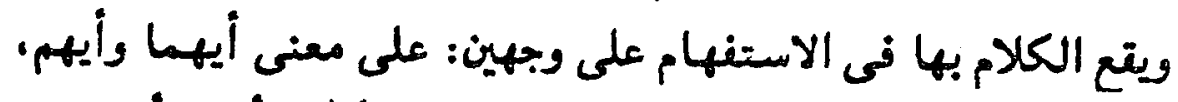

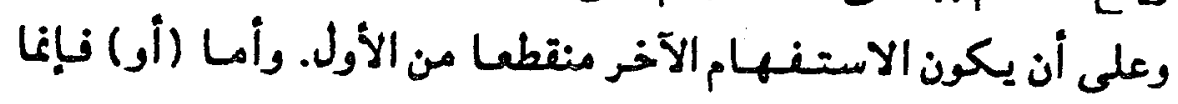

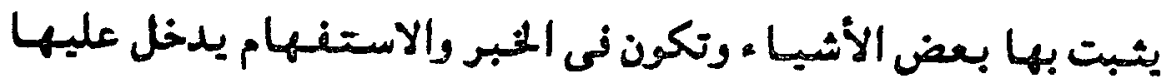

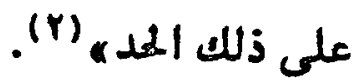

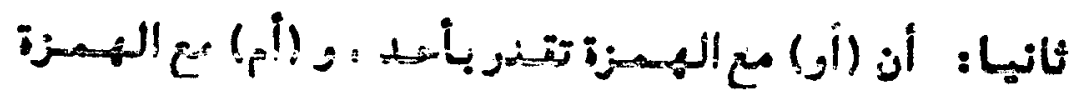

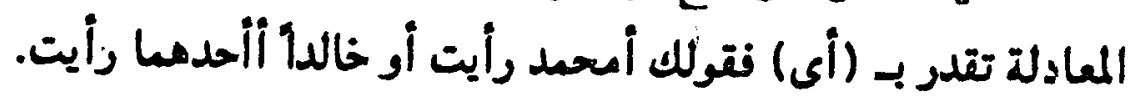
ومهنى قولك : أمحسد رأيت أم خالدا : أيهما رأيت.

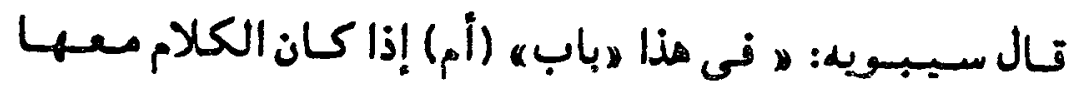
بمتزلة أبهها وأيهمه (")

الأصول rir/r

الكتاب r/179. 


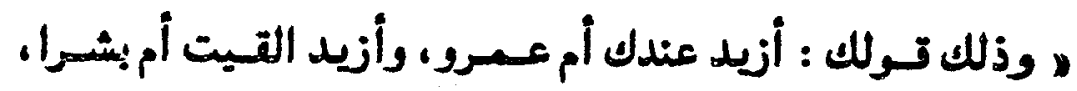

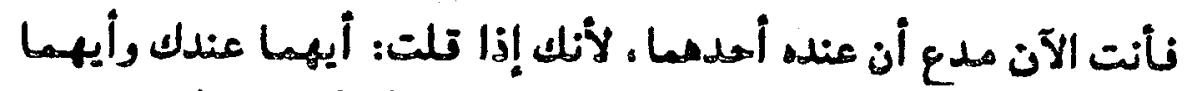

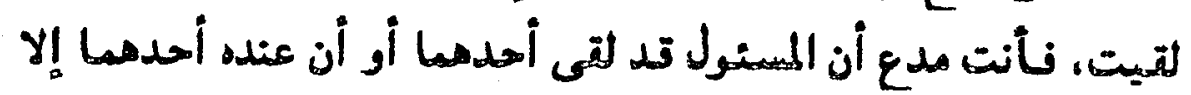

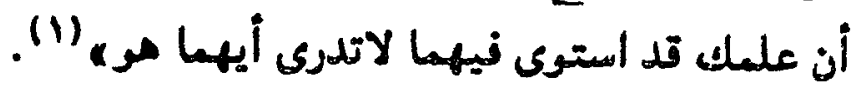

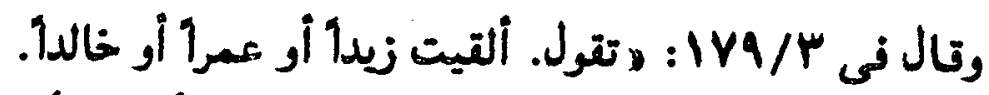

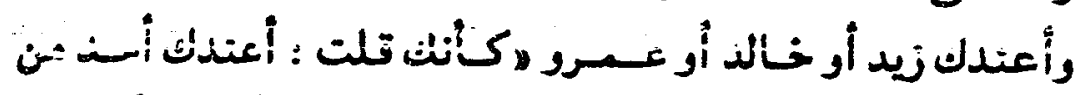

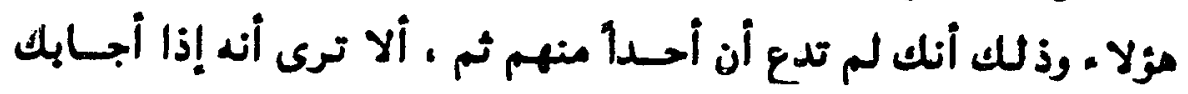

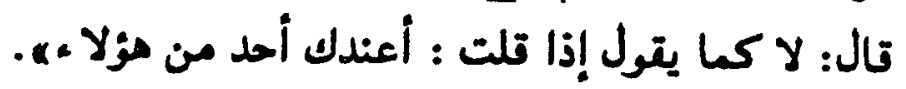

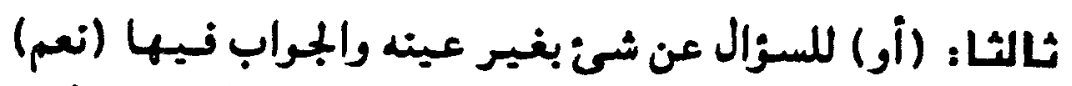

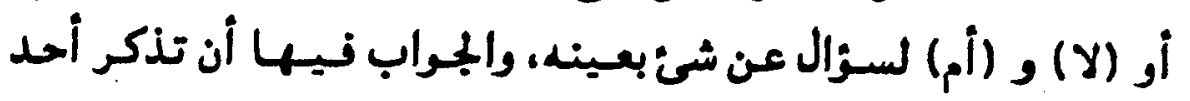
الاسمين (بالتعيين) .

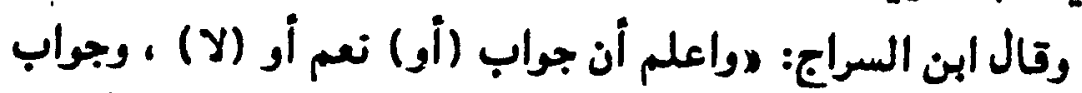

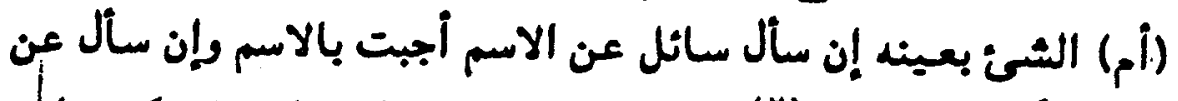

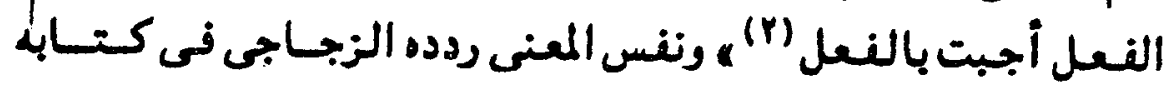
الجمل (r) الفعل اجيت

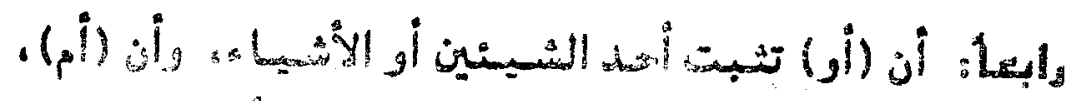

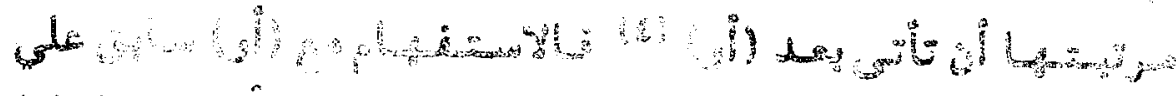
bis

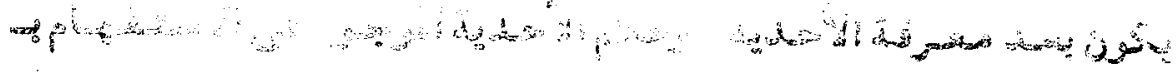
i)

1) 179/r الكتاب 179.

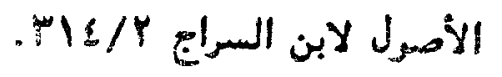

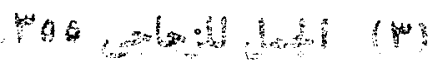




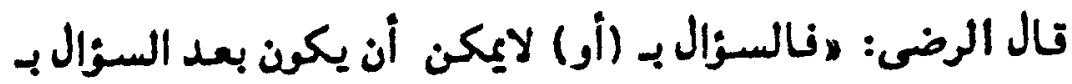

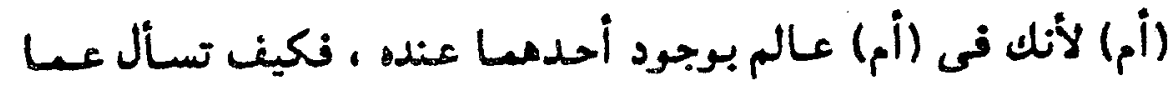

تعلمه "الك في

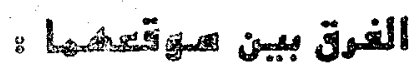

تفارق (أو) (أم ) فى الاستعمال، نتد يتعين استعمال أحد

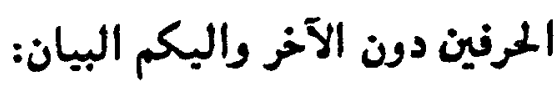

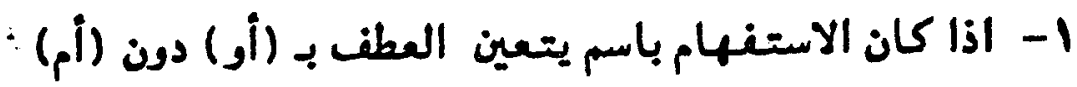

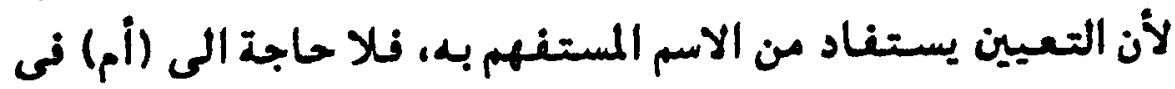

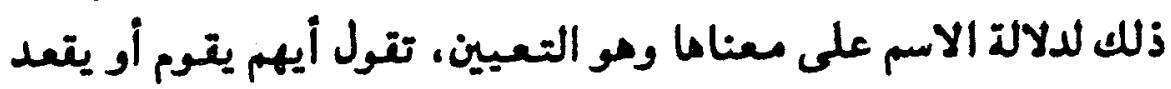
ومن قوم أو يقعد (r).

كال سيهيه: اتقول: أيهم تضرب أو تتتل (تعمل أحدهما)

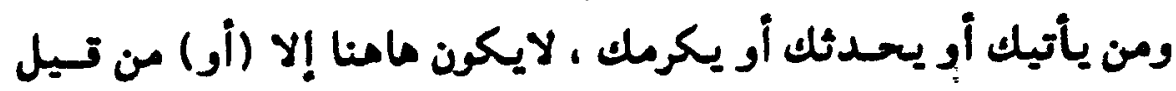

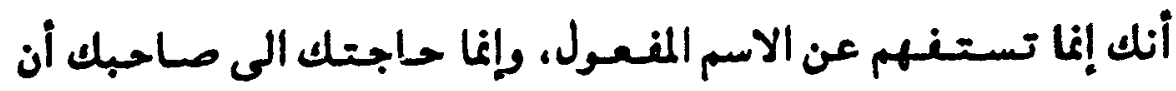
يقول: فلانه آنان

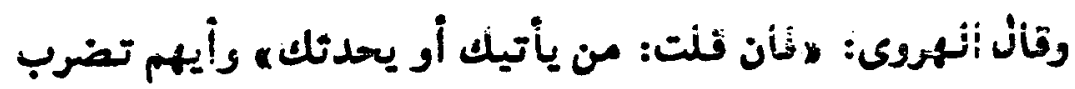

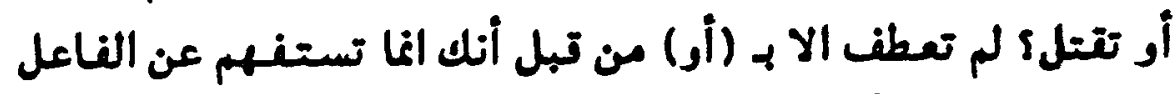

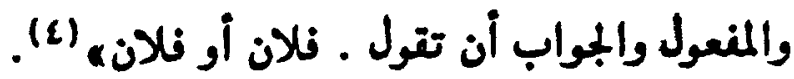

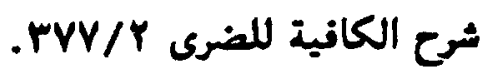

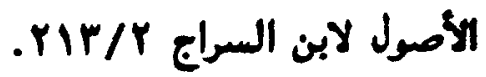

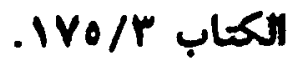




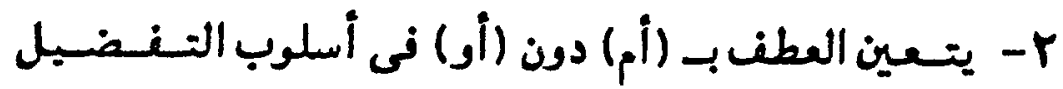

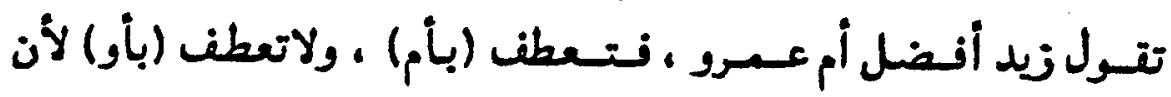

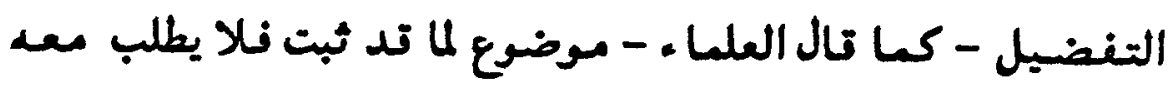

الا التعين لـ (أز) دون (أو) التى معناها الأحدية.

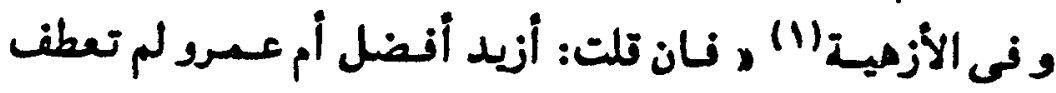

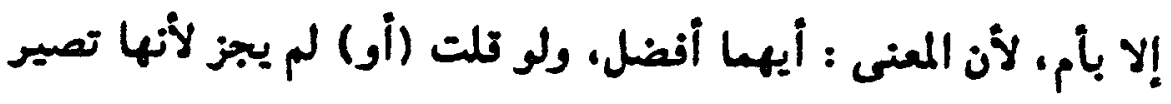

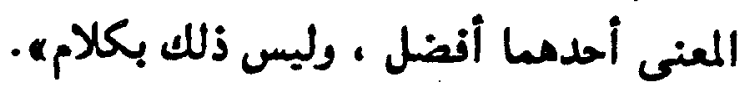

r- إذا وتعت كلمة (سواء) تبل ممزة الاستفهام يتعين العطف

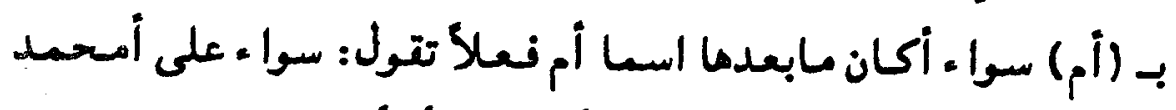

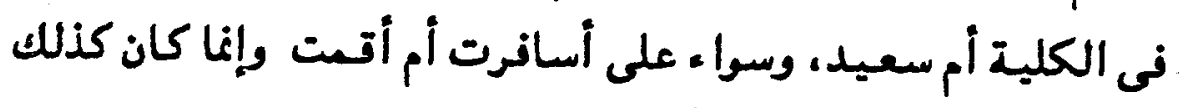

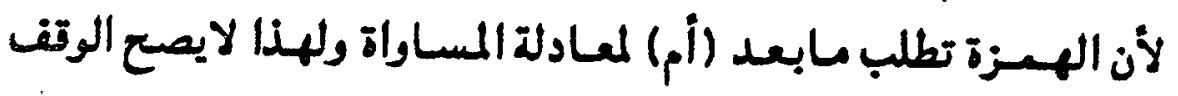

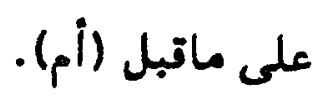

فى سيبيويد: ها وإنما لزمث (أم) هاهنا لأنك تريد معنى أيهـا

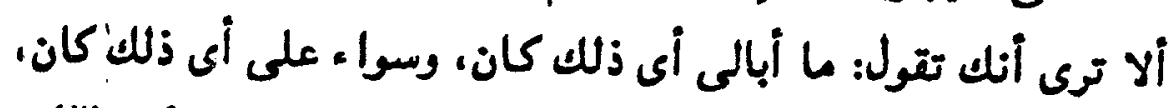

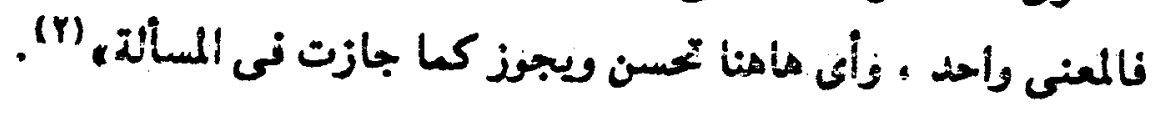

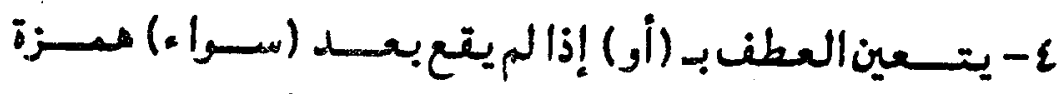
الإستغهام ووتع بعدما نعلان تتول: سواء على تحت أر تعدت.

(1) المصدر السابق ص وبال.

(r) 
تـال السـيـرافى: هو(سـواء) اذا دخلت بعدها ألف الاســـنهام

$$
\text { لزمت (أم) بعدها كقولك: سواء أتمت أم تعدت. }
$$

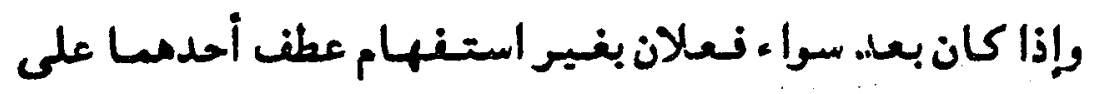

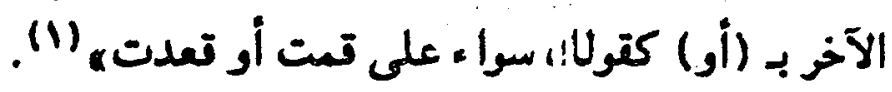

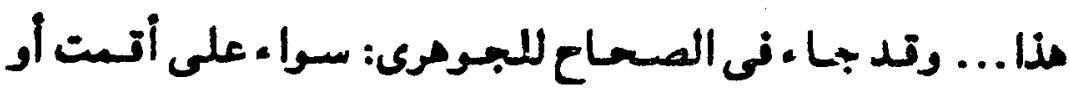
قعدت ولم يذكر غير ذلك. وأرى أنه سهو منه .

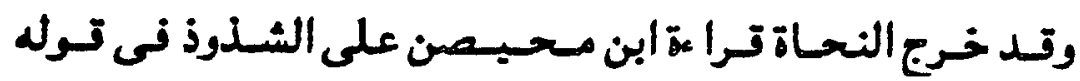

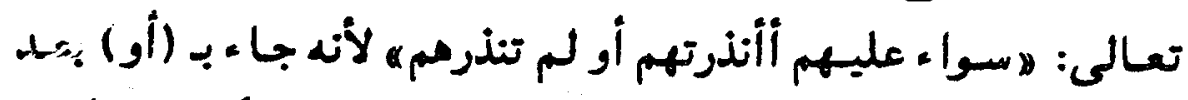

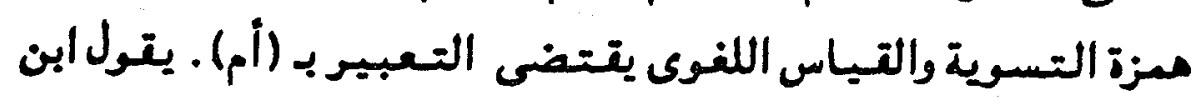

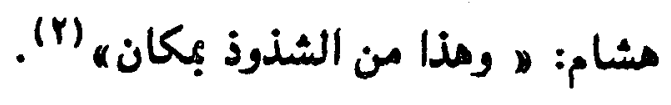

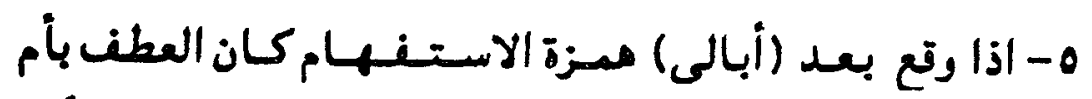

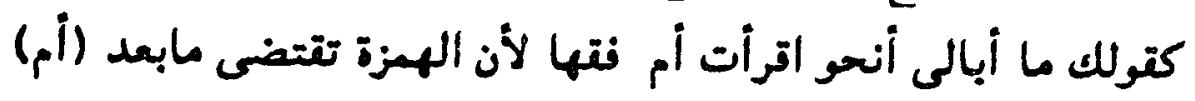

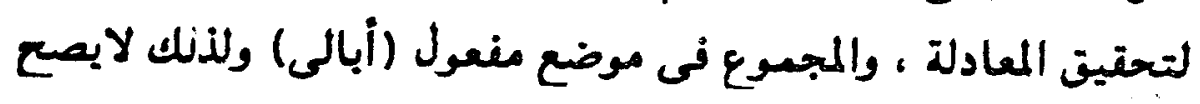

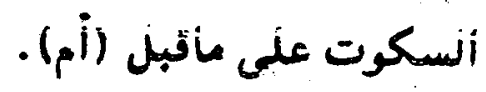

وأما اذا لم يقع بعده مـزة الاستغهام كقولك : ما أبالى ترأت

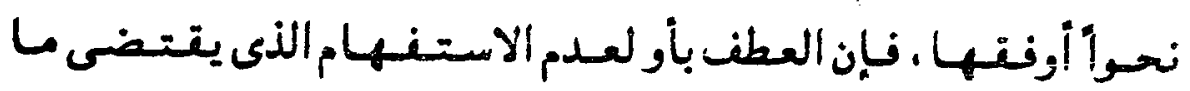
بعدها.

مغنى اللبيب rع ط الملبي.

نغس المصدر السابق ع ط ط دار النكر. 


$$
\text { -ror- }
$$

ولذلك يحسـسن السكوت على مـاتـبل (أو) تتــول. مـا أبالى

1- (أو) تثبت أحد الشيئين أو الأشياء مبهـا (وأم) تقتضى

$$
\text { ضريت زيداً. }
$$

وتطلب ايضاح ذلك المبهم.

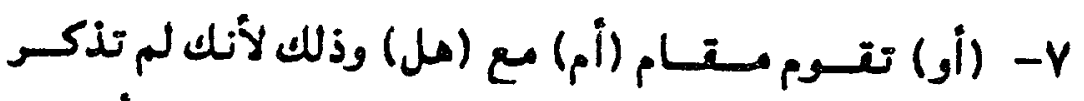

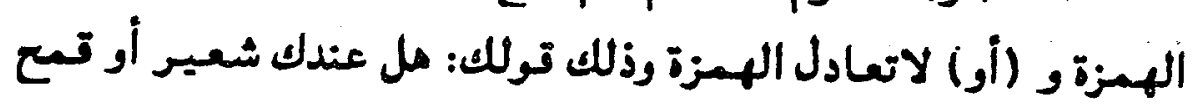

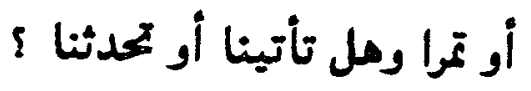

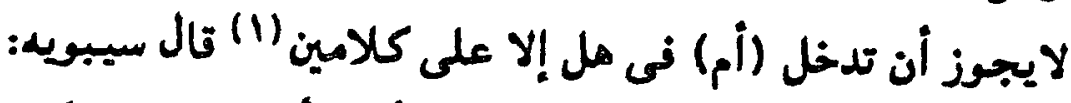

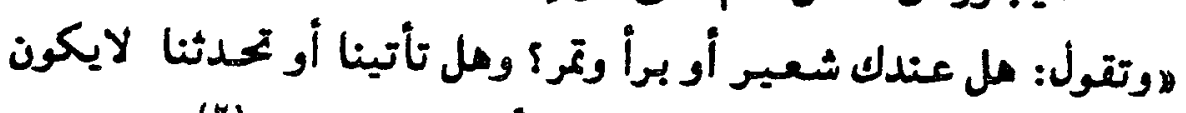

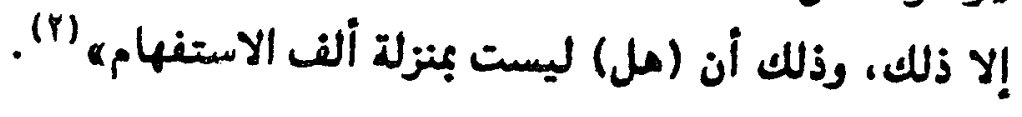

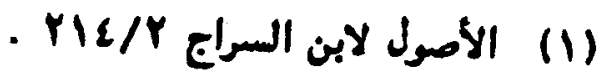

(r) 


\section{-ror_ \\ فهرس المصادر والمراجه}

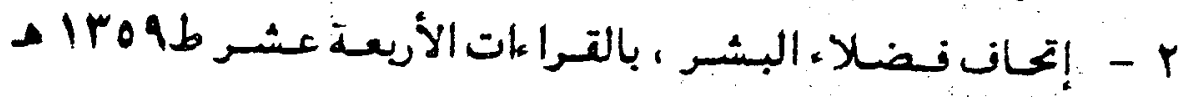

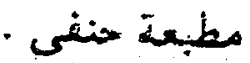

r - أخباز النحويبين البصريين، تحقيق الأستاذين: الزينى وخفاجي:

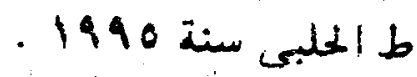

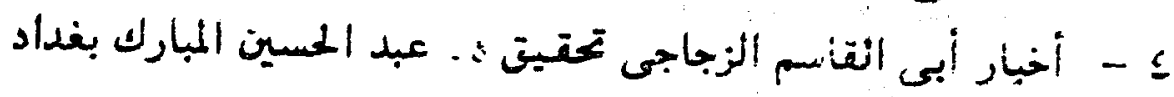

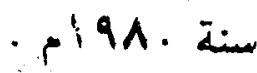
ه - أدب الكاتب لابن تتيبة- تحقيق محعد محى الدين عبد الحميد

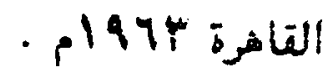

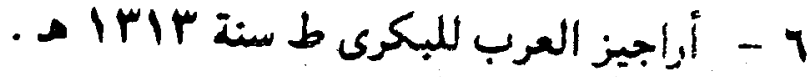

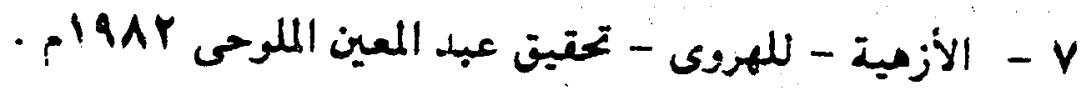

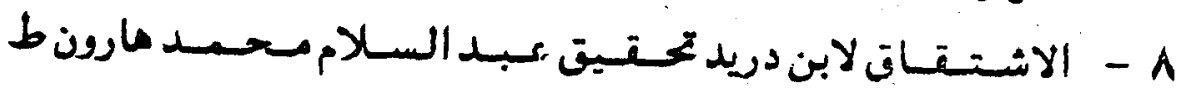
الخانجى.

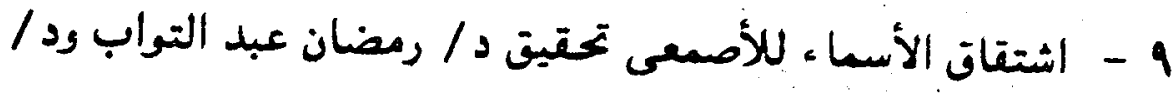

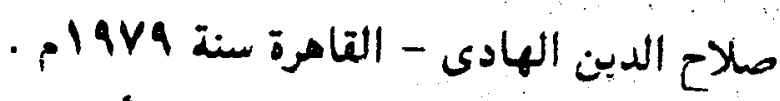

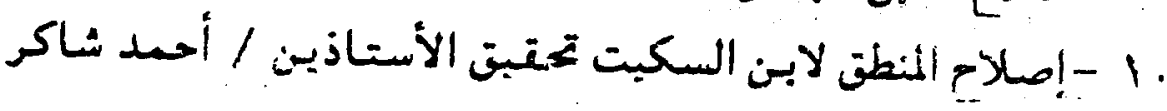

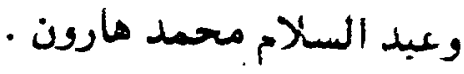
11 - الأصسعبات - اختبار الأصسعى - تحنيق/ أحمد شاكر وعبد

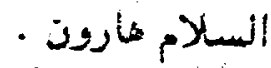

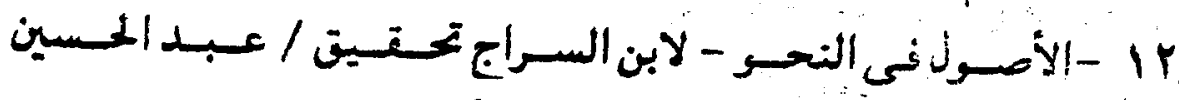

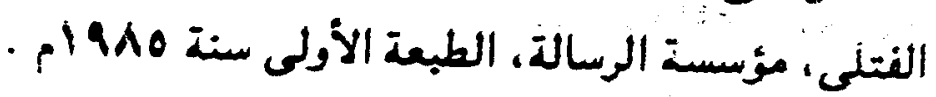
rا - إعراب ثلاثين سورة لابن خالويه - مكتبة المتينى - القاهرة. 
ع - الإفـصـاح فى شـرح أبيـات مس كلة الاعـراب للحسسن بن أسـد

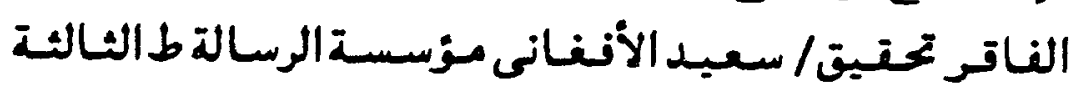

.191.

1 - الاقتضاب في شي.ح أدب الكاتب لابن السيد البطليرس تحقيق

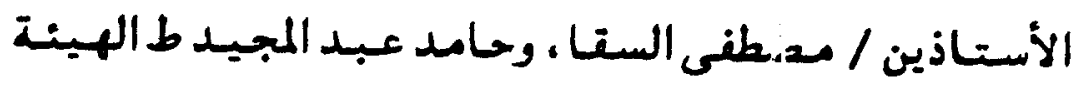
العامة للكتاب .

17 - الأمـالهى لأبسى على التـالى - منشــورات دار الآفـات الجــديد

بيروت.

IV - الأمالى الشجرية - لابن الشجرى حيدر أباد

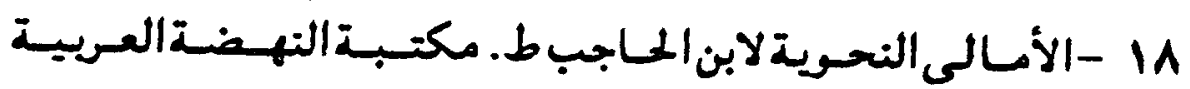
تحتيق/ مادى حسين حمودى - مادي

19 - أمالى الزجاجى تحقيق عبد السلام مارون القاهرة Irar

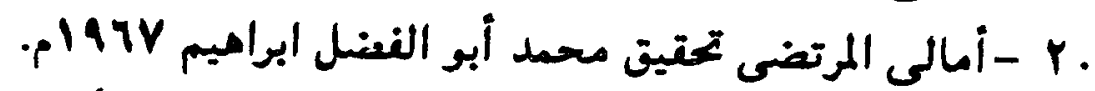

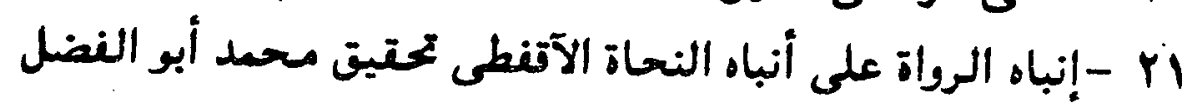

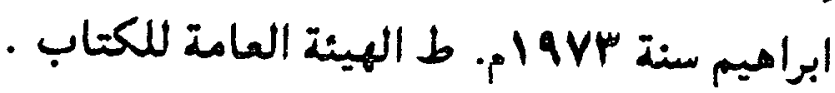

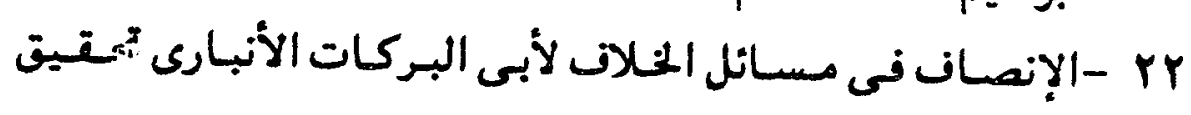

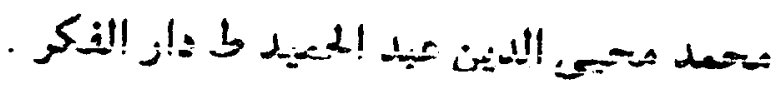

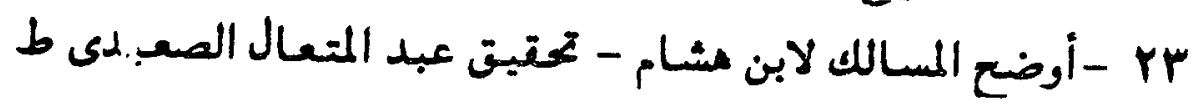

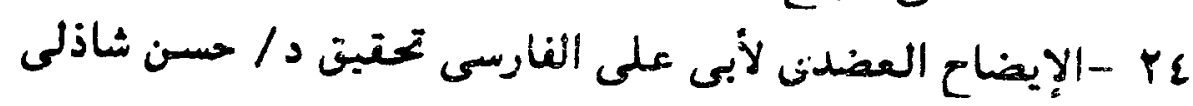
فرهود مصر

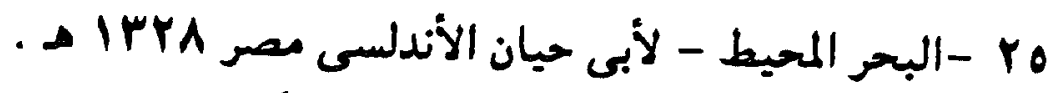

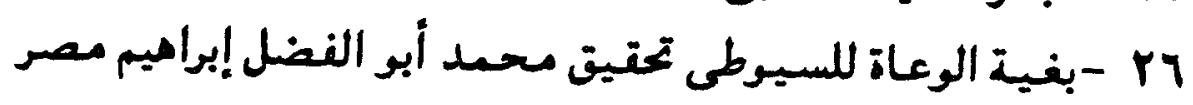




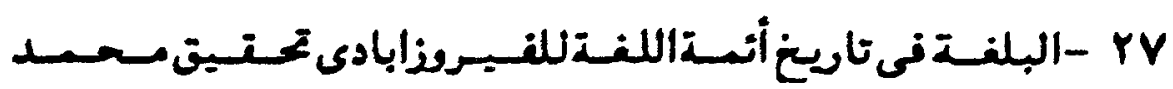

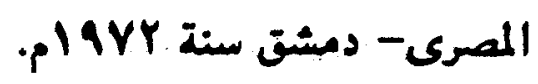

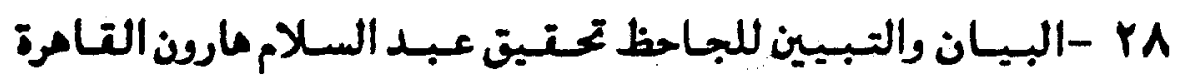
- illa

1 - تأويل مشكل الترآن - لابن تتيبة - تحتقيت السيد أحسد نصر -

• r -التبصرة فى القراعات السبع لمكى بن أبى طالب تصحيع محمد

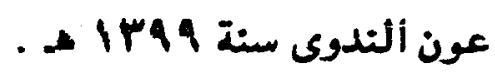

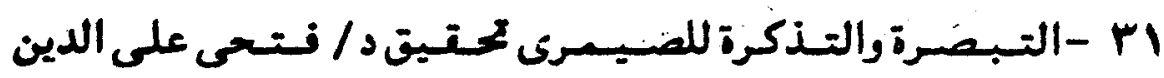

$$
\text { - مشئ }
$$

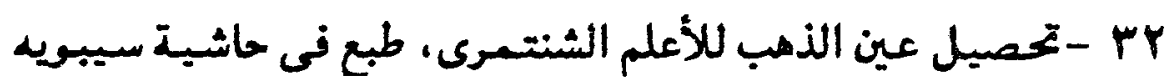

$$
\text { بولات Irir }
$$

rr - التصريف الملوكى لابن جنى تحتيق / محسد سعبد النعسانى

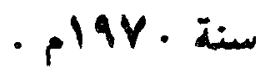

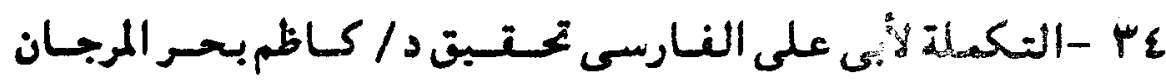

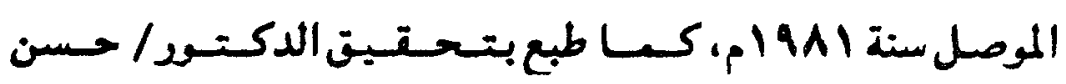

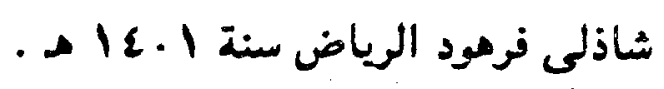

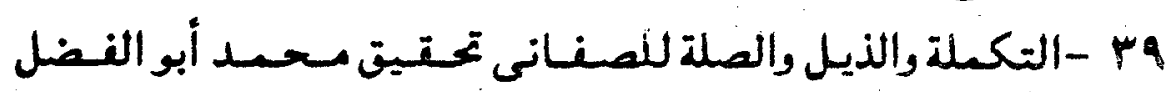

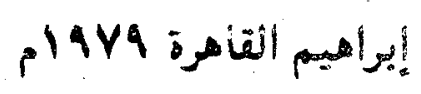

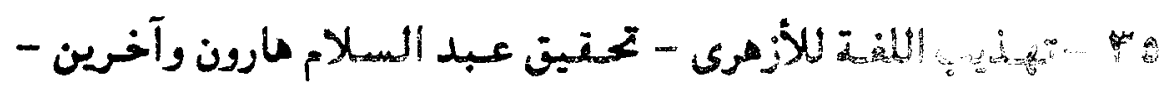

$$
\text { 1958 }
$$

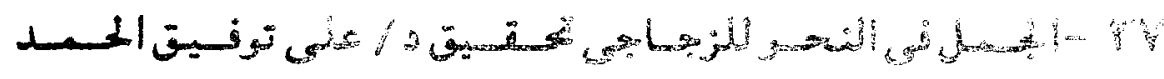

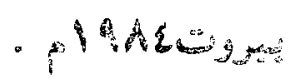




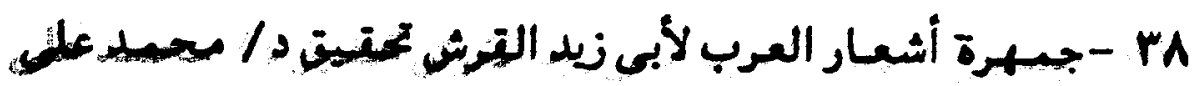

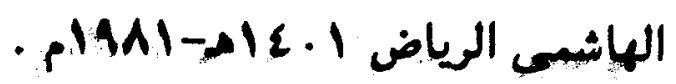

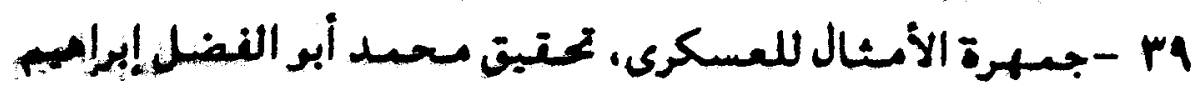

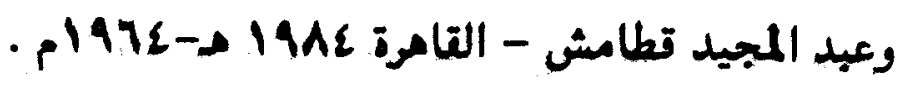

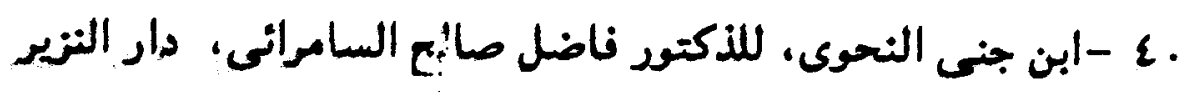

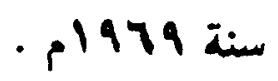

اح -الجنى الداتى فى حروف المعانى، للعرادى تحقيق د / فخر الدين

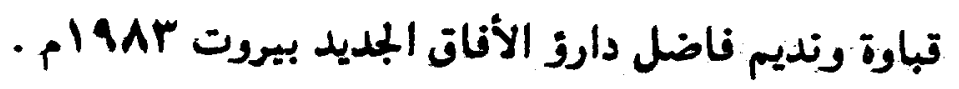

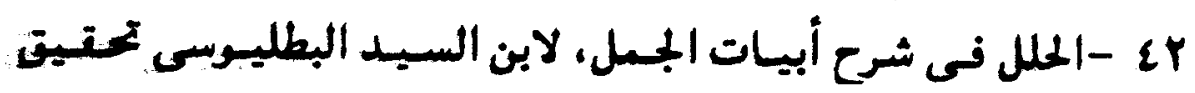

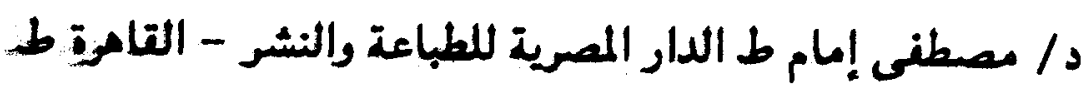

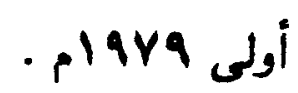

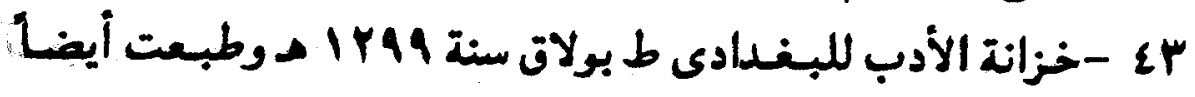

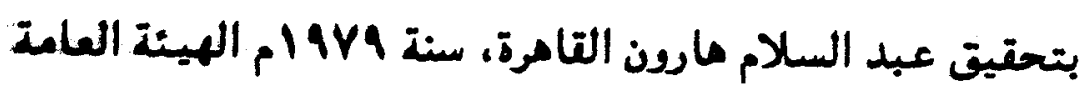

$$
\text { للككاب }
$$

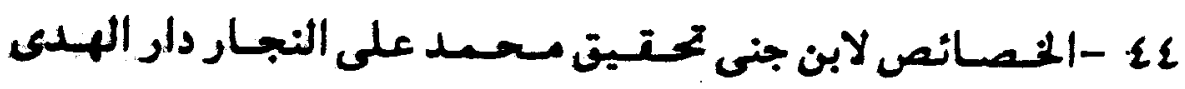
للطباعة والنشر بيروت ط الثاني لائين

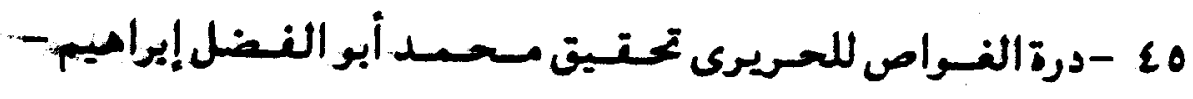

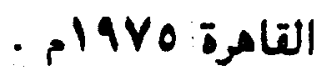

27 - الكتاب: لسببويد تحقيق عبد السلام مارون •

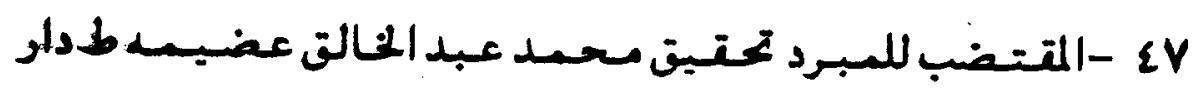




\title{
تاكملات فى التشبية القر آنى وسماته البلاغية
}

\author{
تاليف \\ الأستاذ الدكتور \\ صباح عبيد درزز \\ عميد كلية اللغة العريية بإيتاى البارود
}

$p^{1999}$ 



\section{$\operatorname{tin}$}

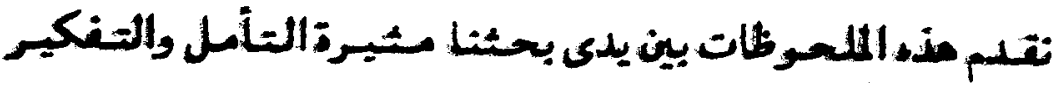

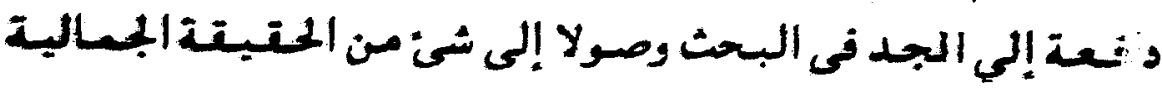

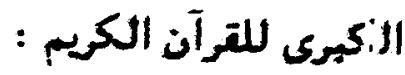

\section{تlligation aldo}

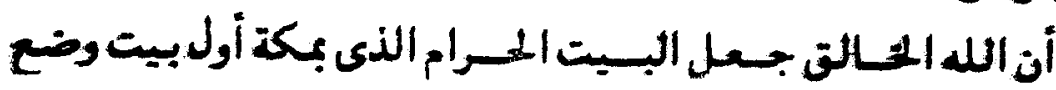

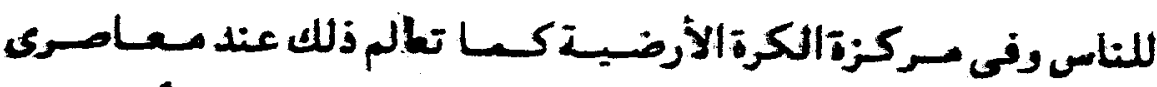

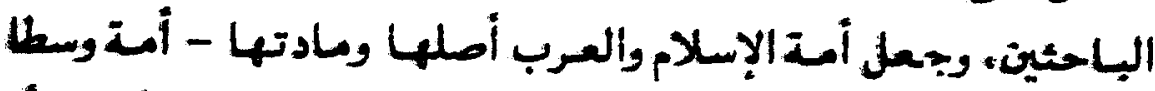

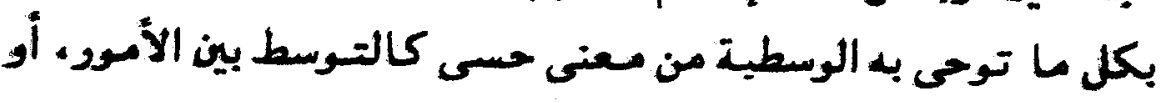
عتلى كالعدل والنفل والنغيلة، وهى وسط بين طرفينه بهنا كانت

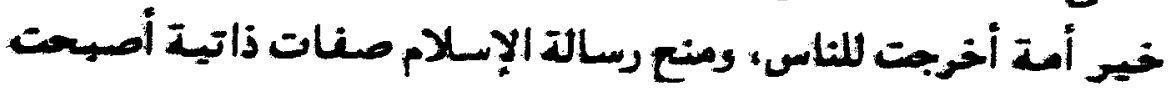

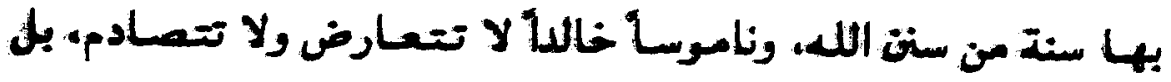

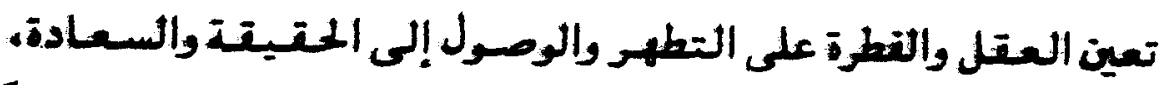

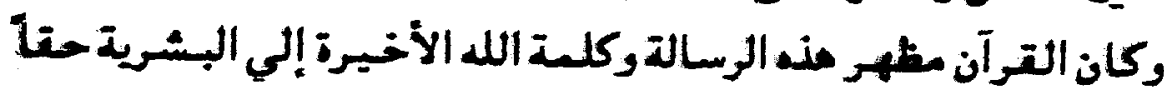

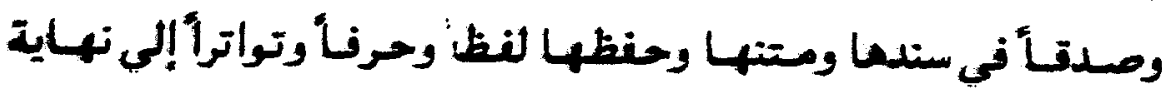

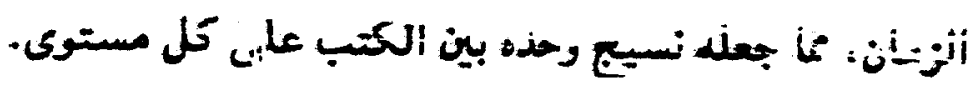

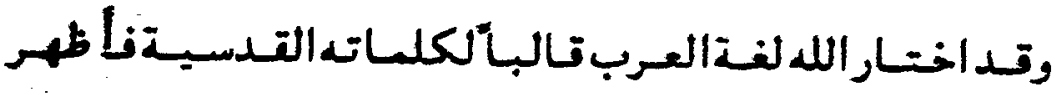

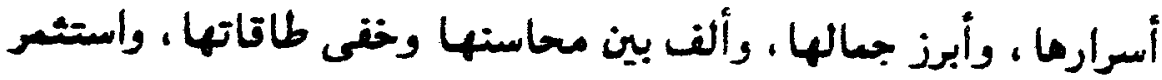

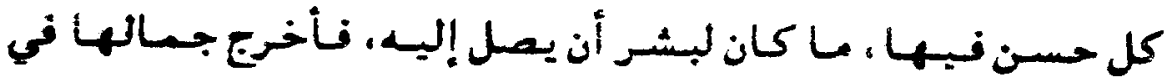

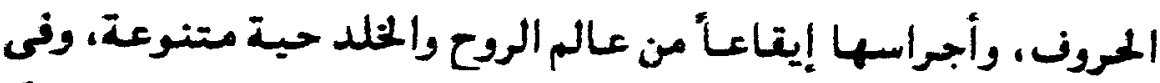

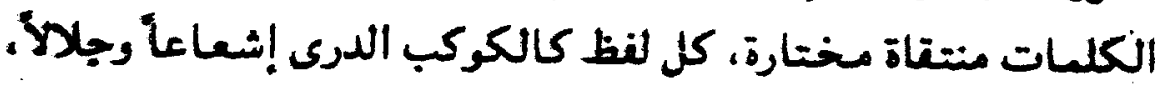
ونى أسـاليب لها ظاهر بامر ومعنى قامر بدلالات إلهـيـة وفي تلأزم 


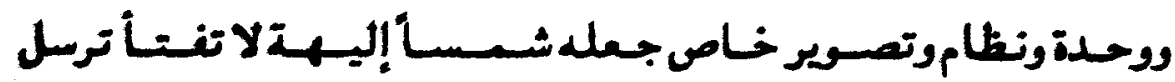
شعاعاتها للإتسان (1).

\section{وثانس هذه التغايا:}

أن الله منح العرب توة فى البيان، وبمالاً فى التعبير، وتاط

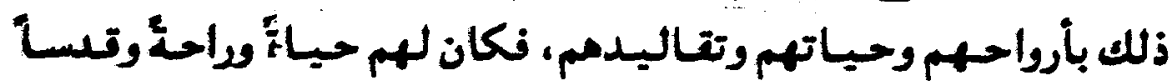

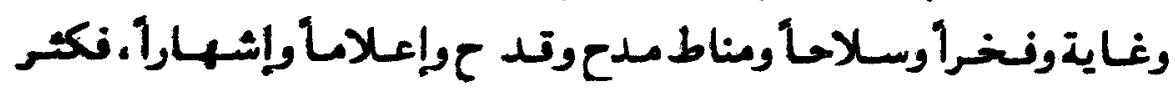

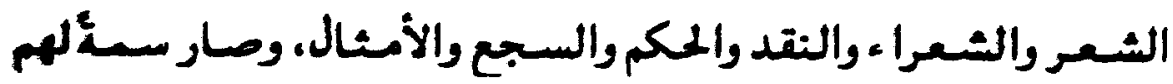

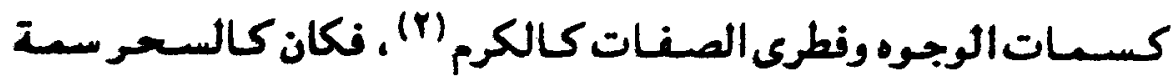

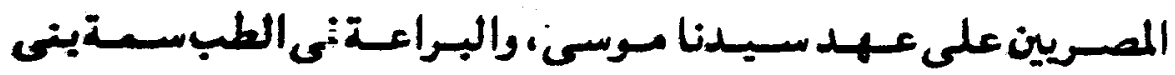

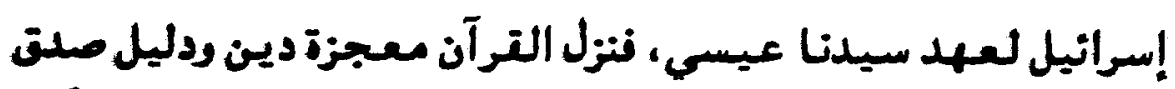
وحجة سيدنا محسد عليه الصلآ والسلام في عالم البلاغنة، وقد أخذاند

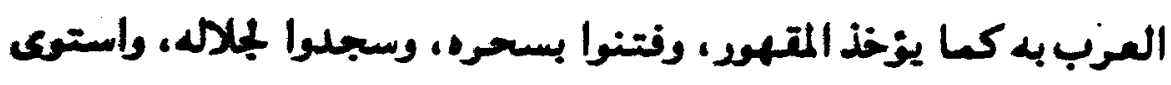

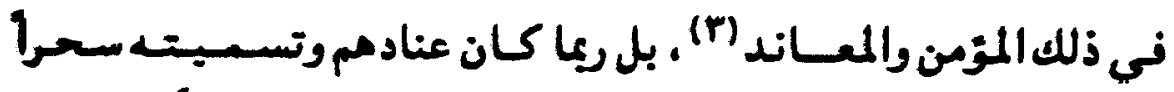

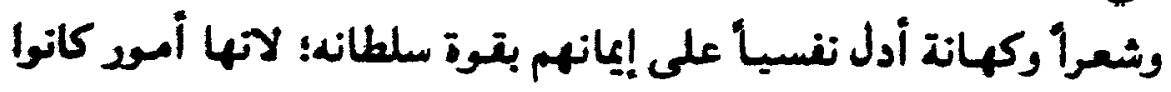

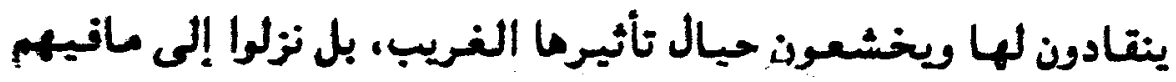

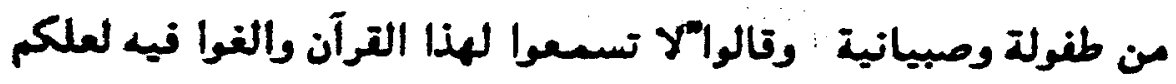

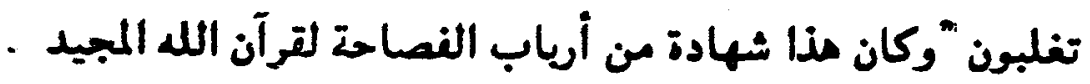

راجع : اللغة الشـاعرة- العتاد آ والتصوير الفنى فى الترآن سيد تطب الم: :المة

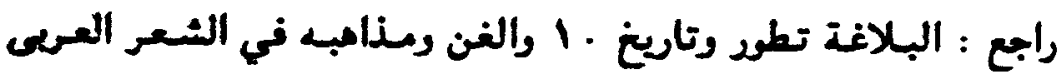

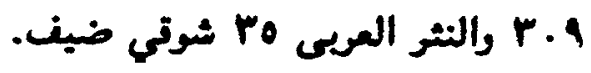

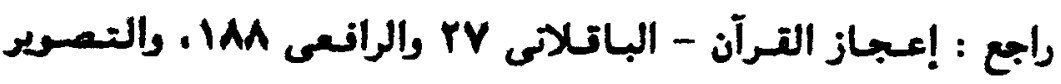


هثالثة هذه التضايبا:

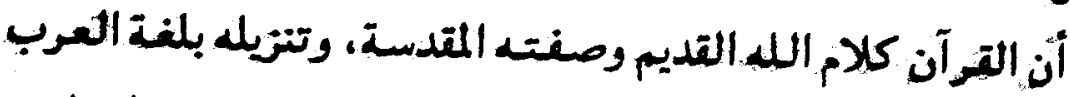

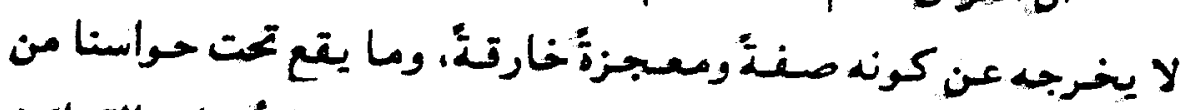

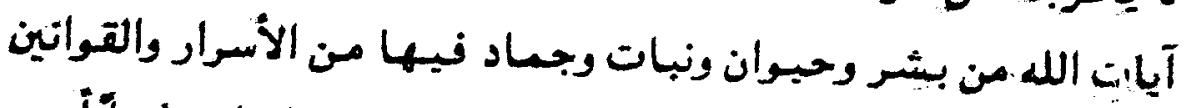

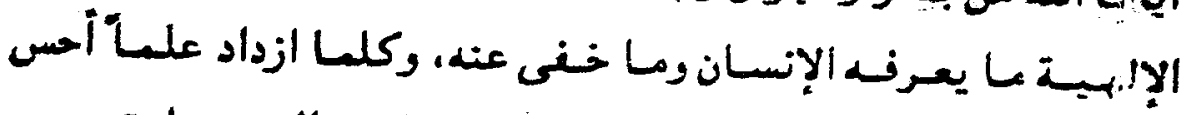

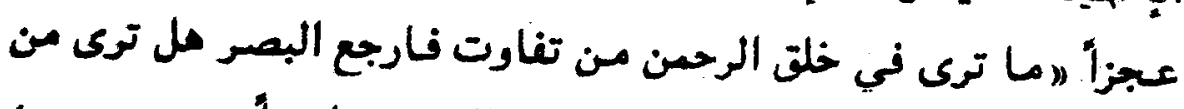

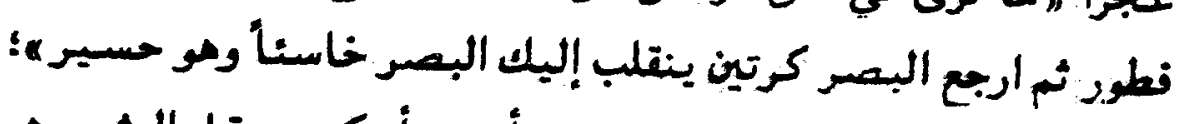

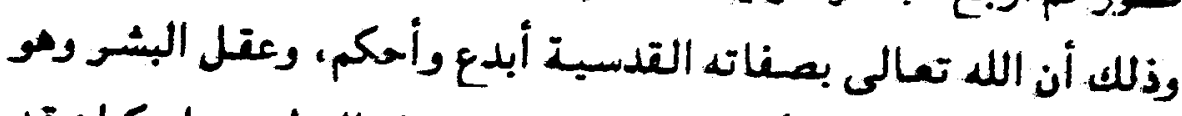

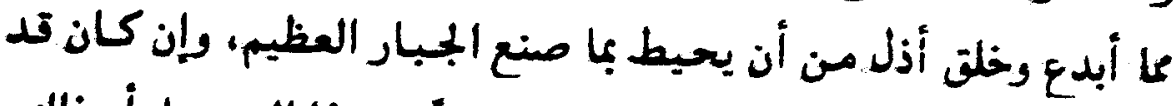

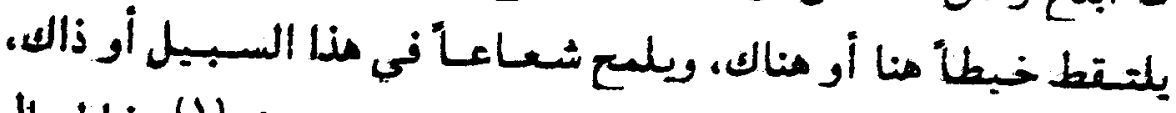

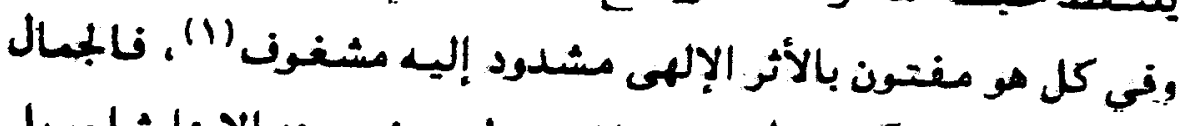

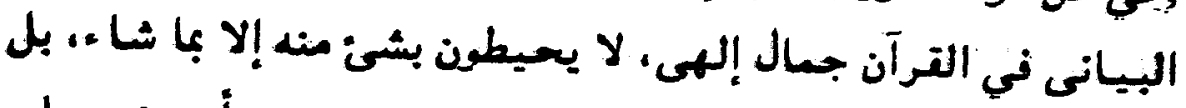

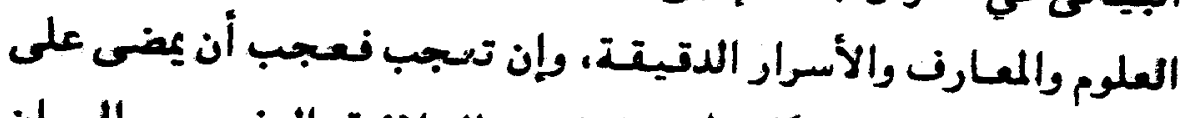

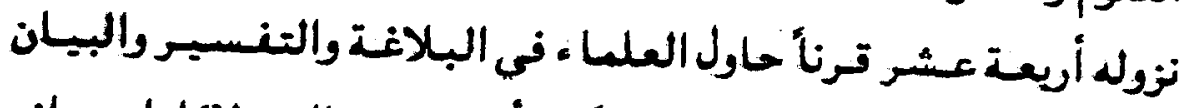

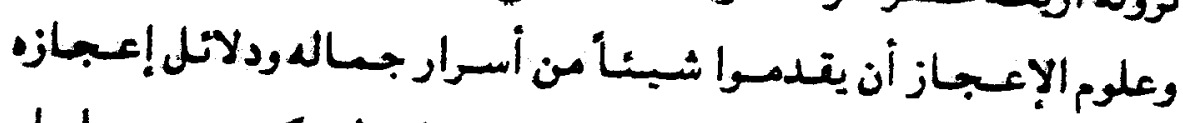

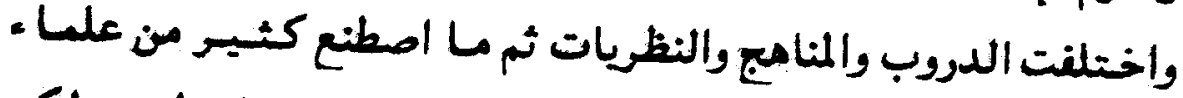

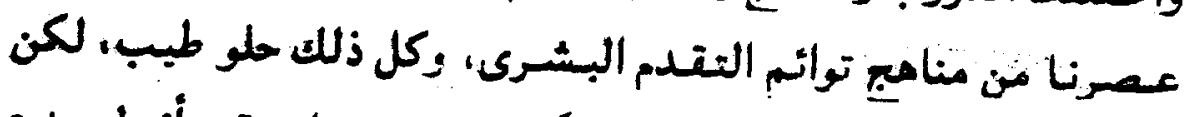

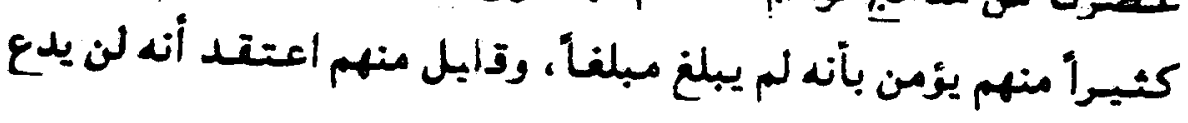

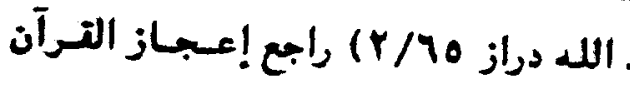

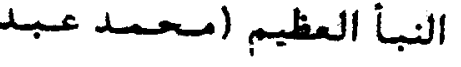

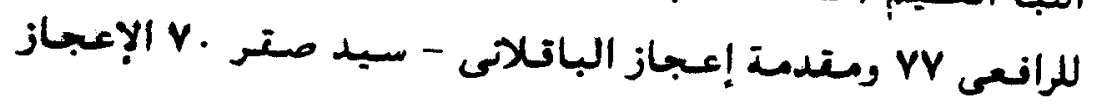
البيانى- بنت الثاطن 


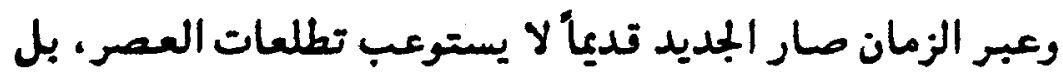

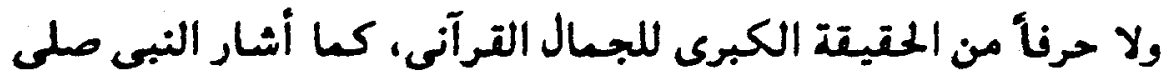

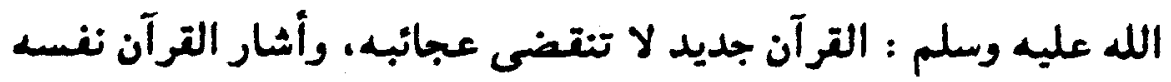

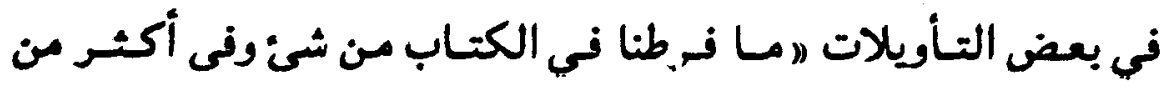

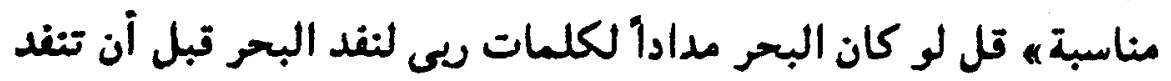
كلمات ريى ولو جئنا بثيله مدداً.

المتيتة الرابعة : أن الصورة البيانية بفهومها البلاغى في

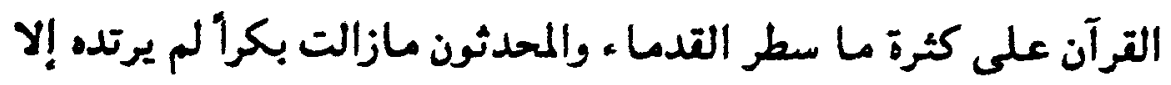

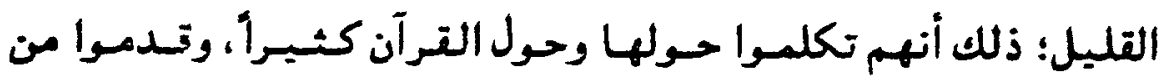

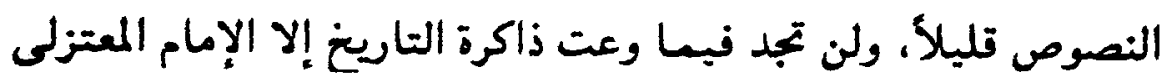

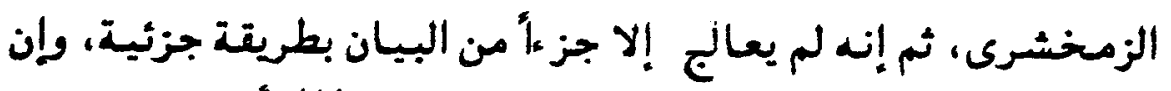

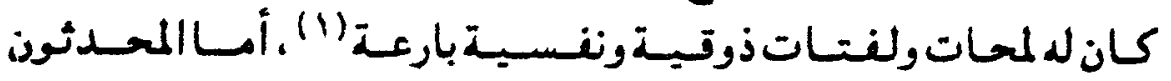

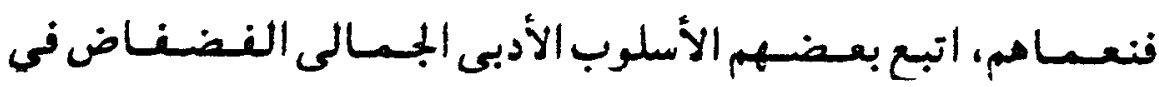

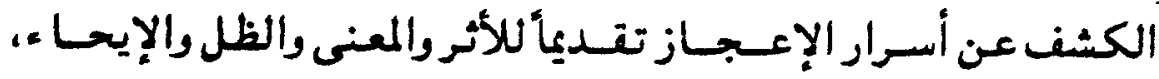

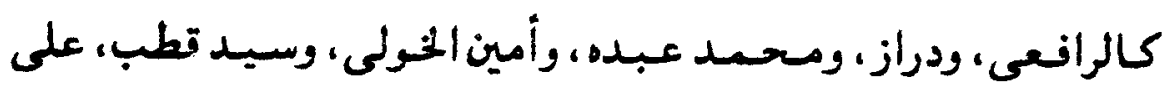

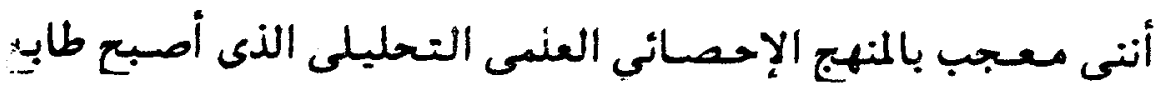

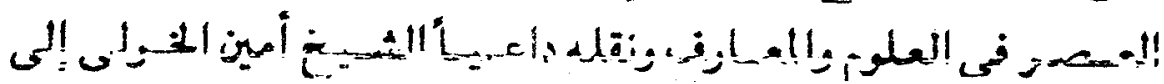

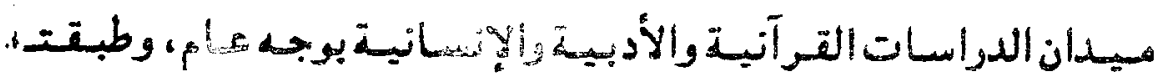

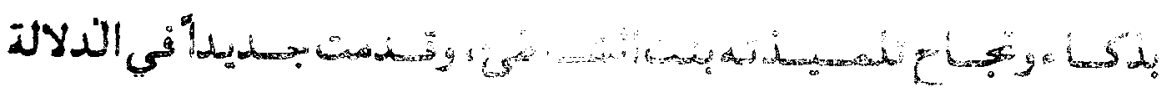

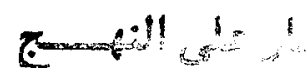

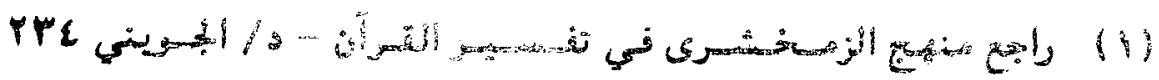
والبلاغة تغور وتاريخ rer (r) 


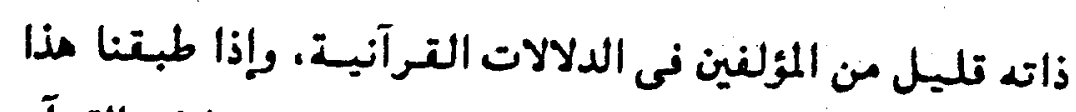

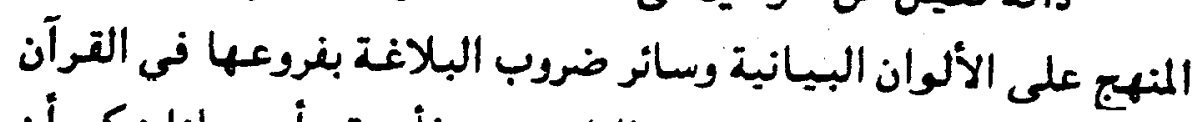

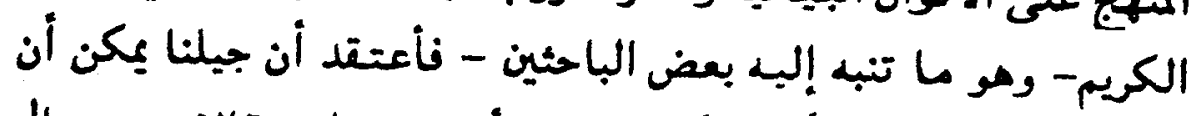

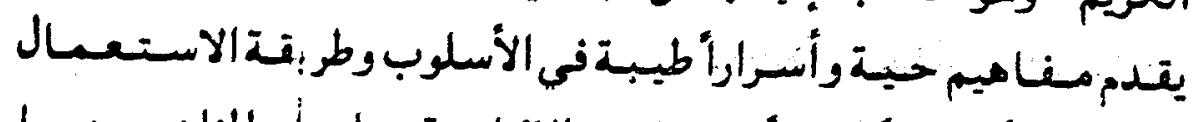

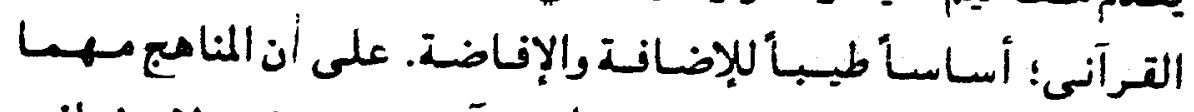

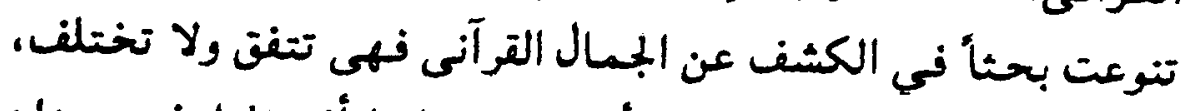

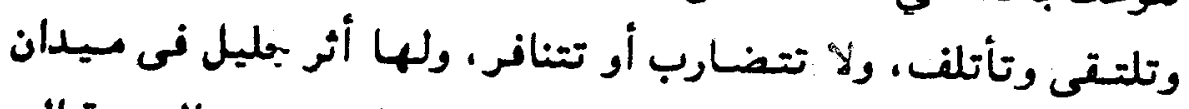

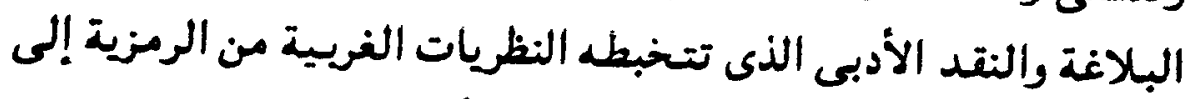

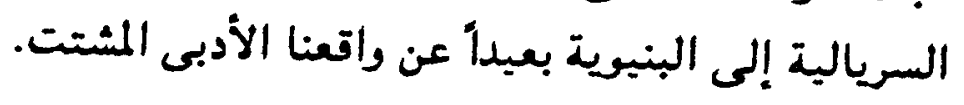

\section{الحقيقة الحامسة :}

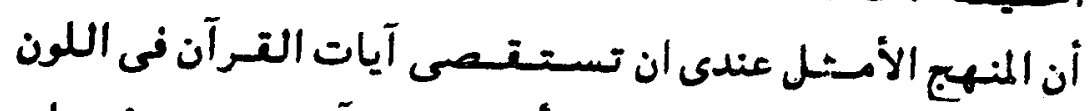

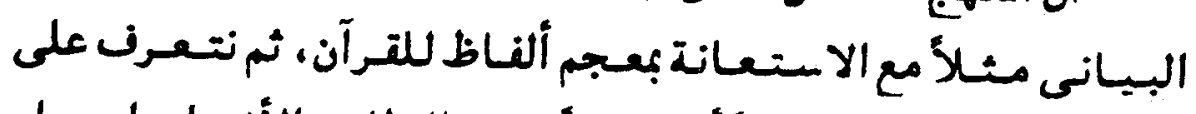

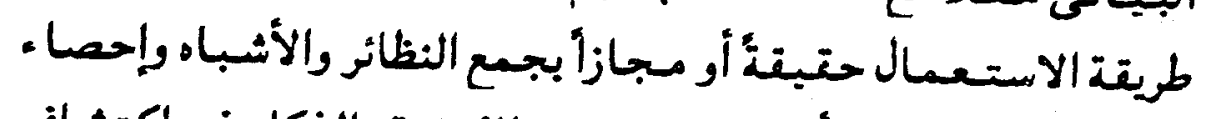

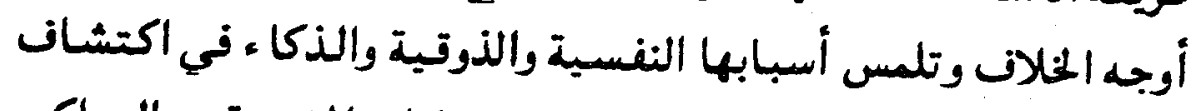

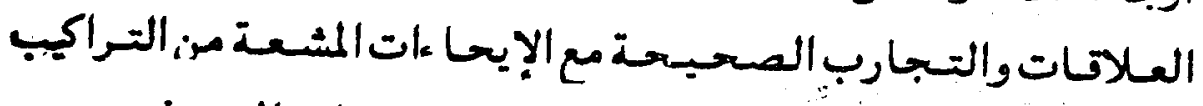

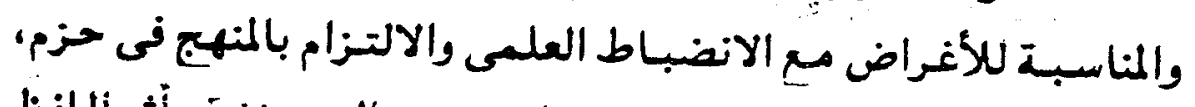

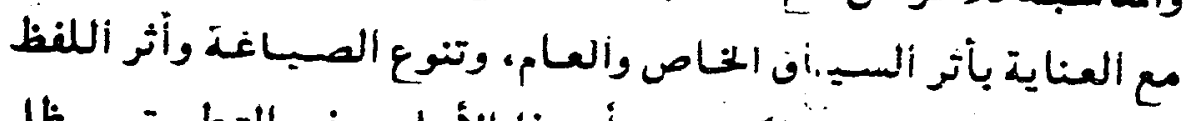

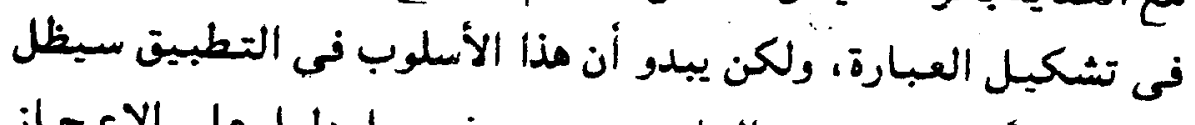

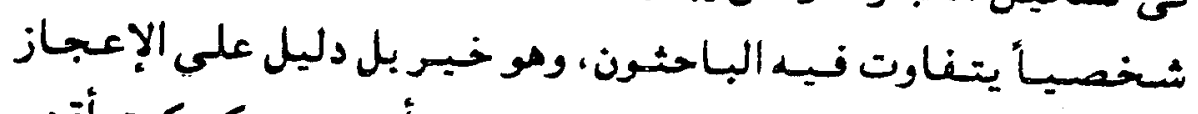

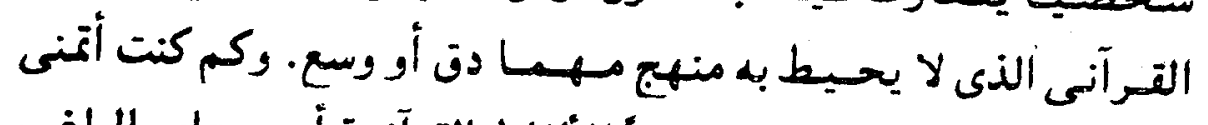

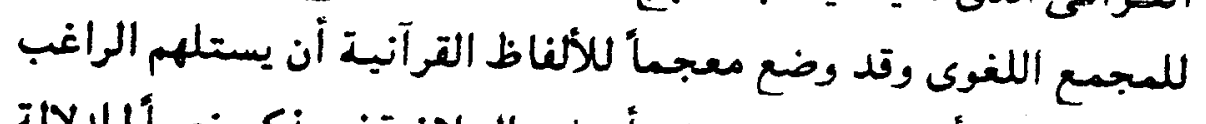

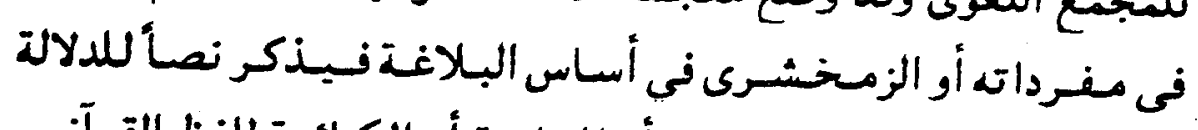

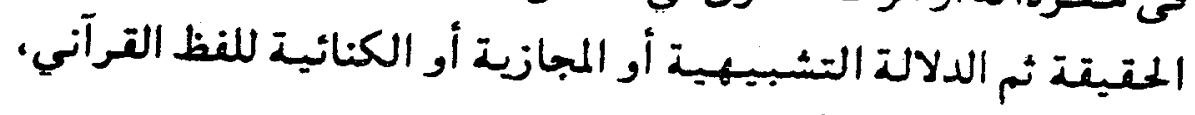
ولو قد فعل لقدم خيراً بحمد عليه. 


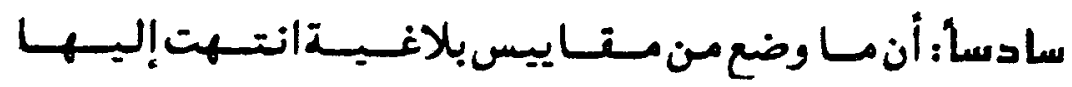

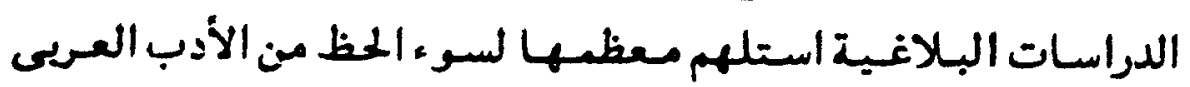

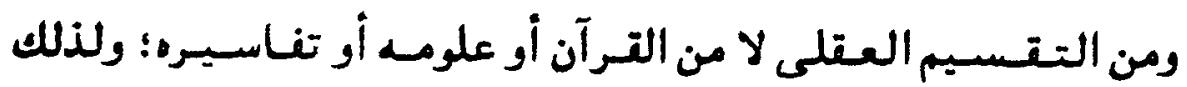

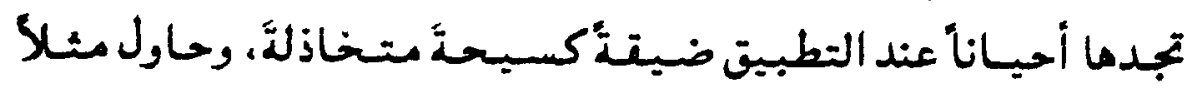

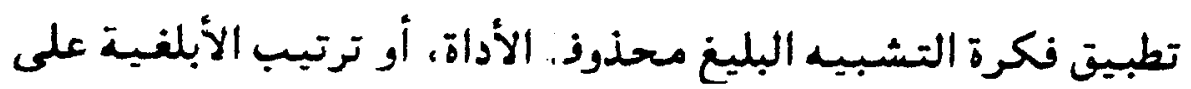

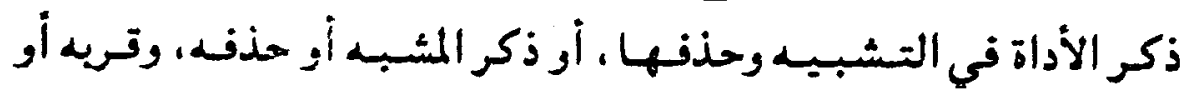

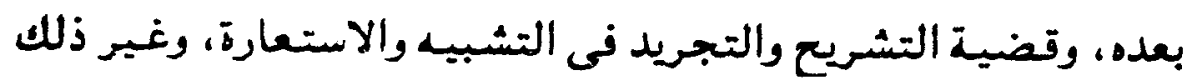

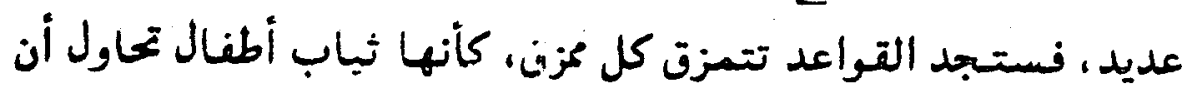

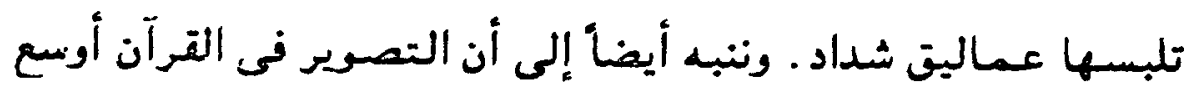

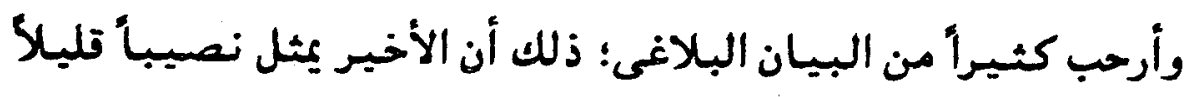

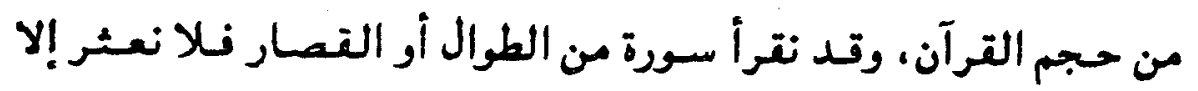

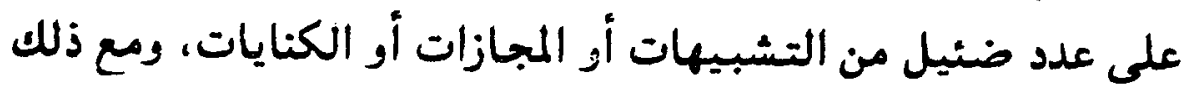

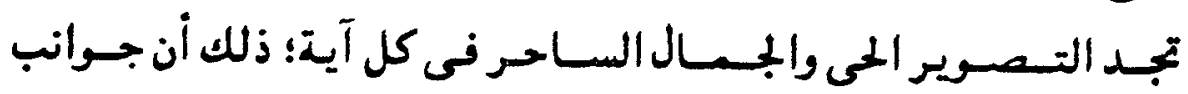

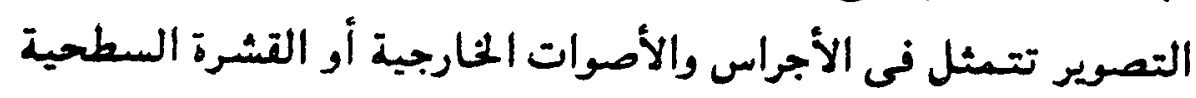

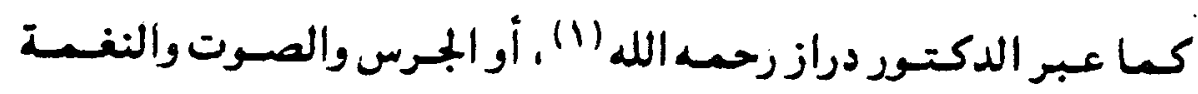

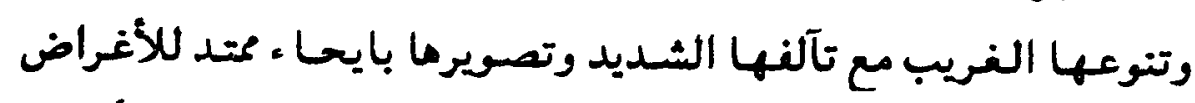

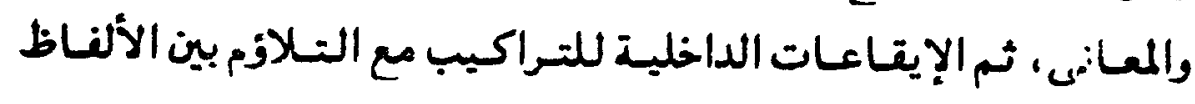

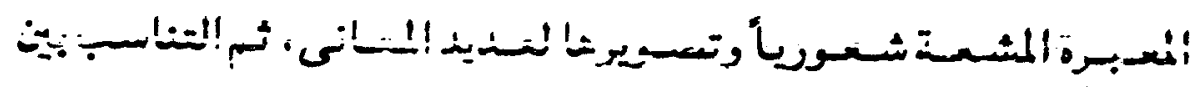

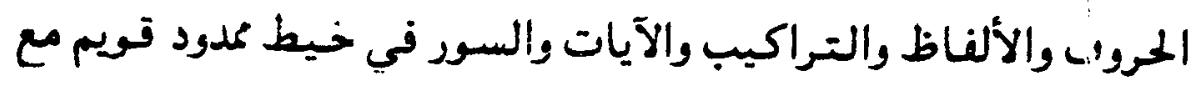

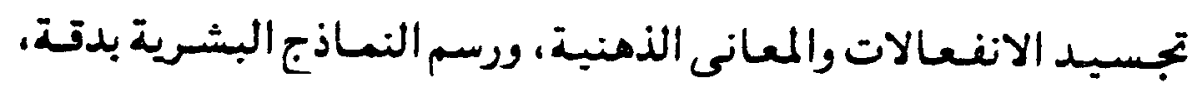

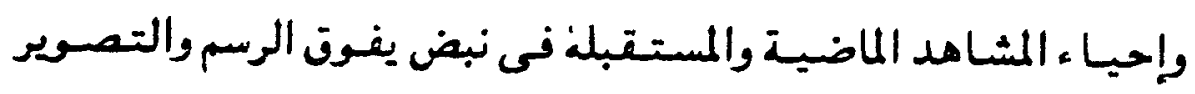

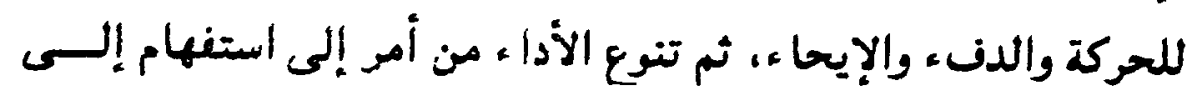


تعسجب إلى حسوار أو تقــير، ثم الريسم بالطبـات والتـتـابل فى معناه

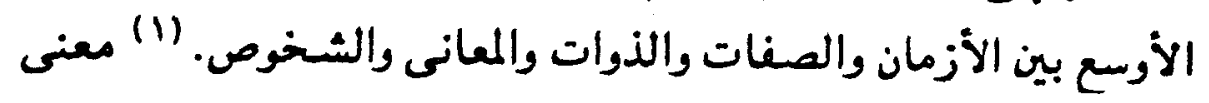

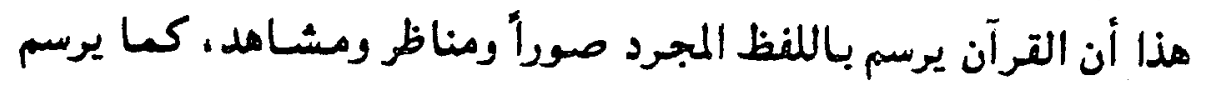

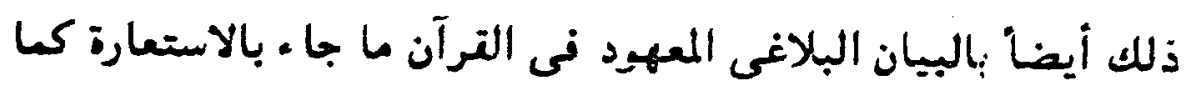

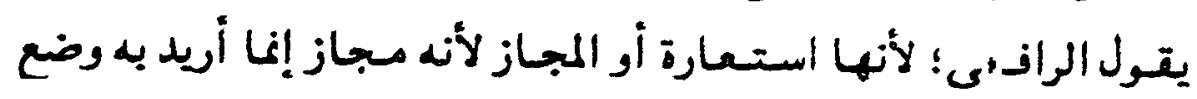

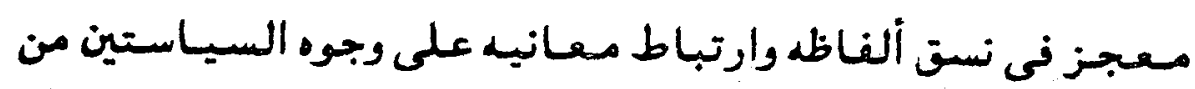

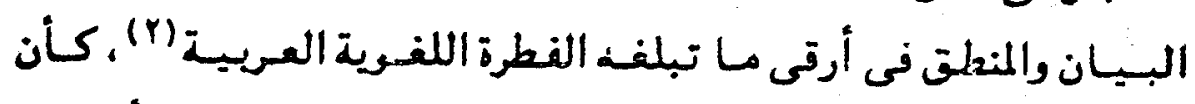

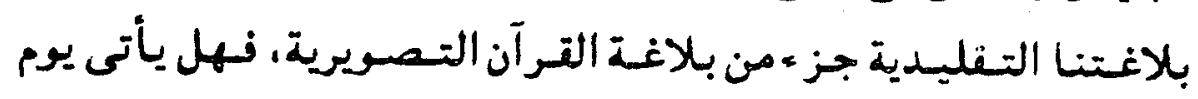

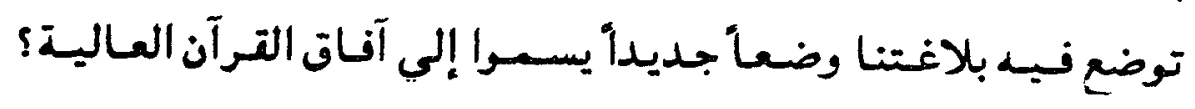

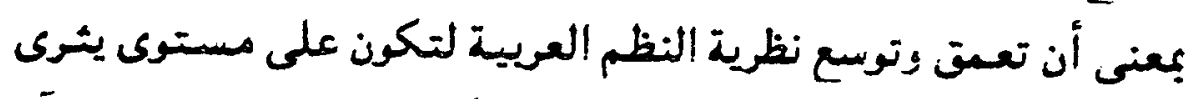

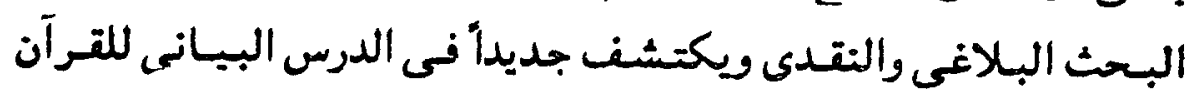
الكريم.

ومهما يكن من أمر فهذه محاولة نحاول تأصيلها فى الدرس

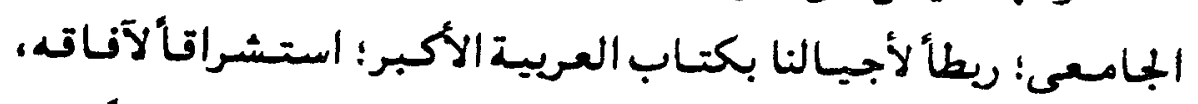

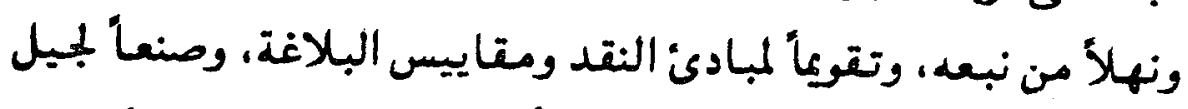

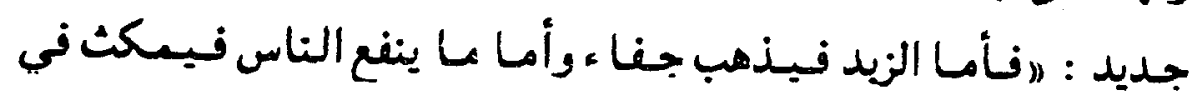

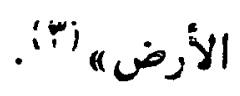

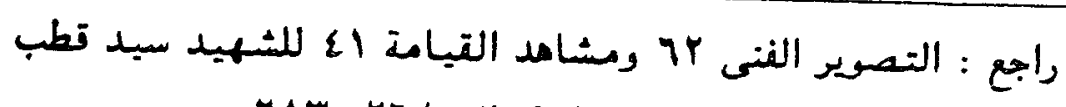

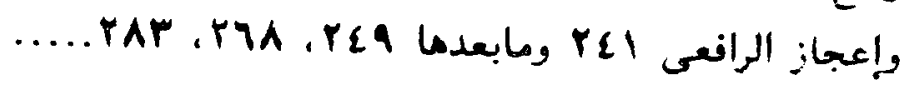

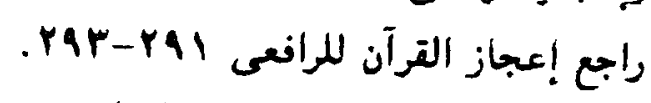

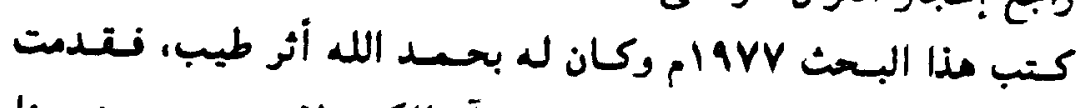

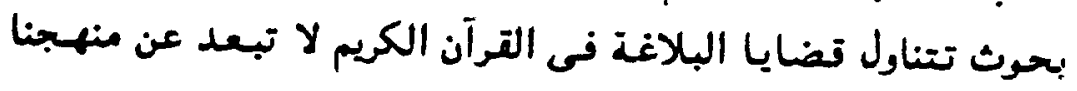
ولله المعد والمنة. 
مظا هر القهر في الدنيا

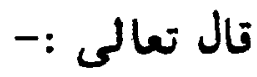

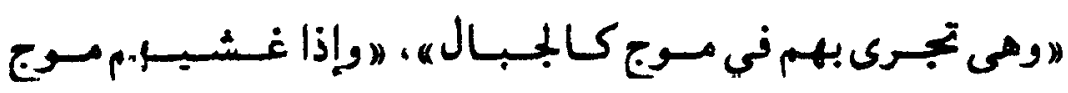

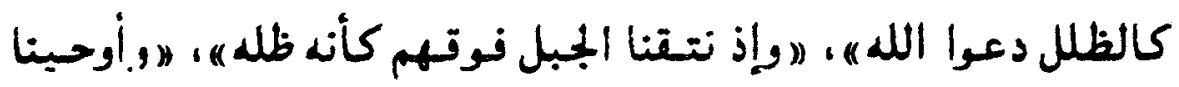

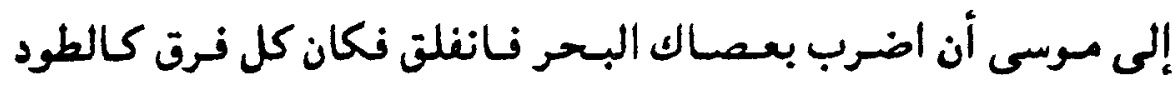

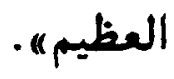

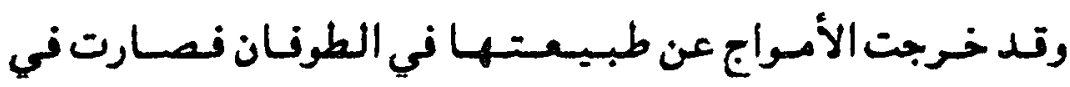

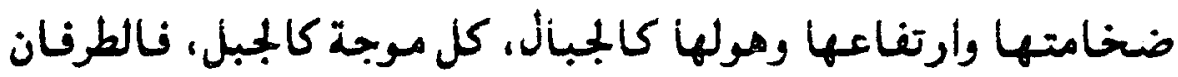

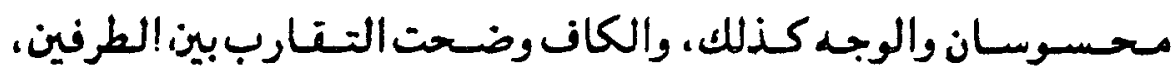

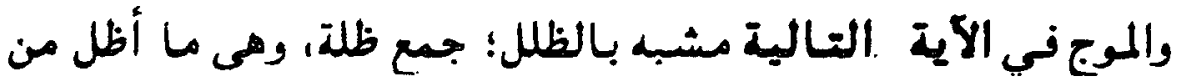

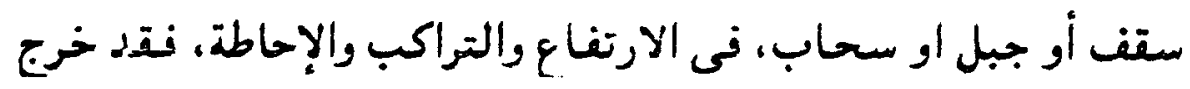

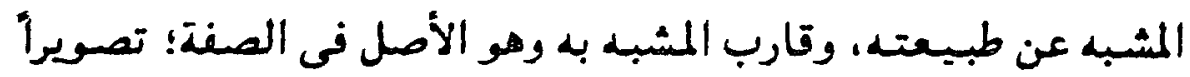

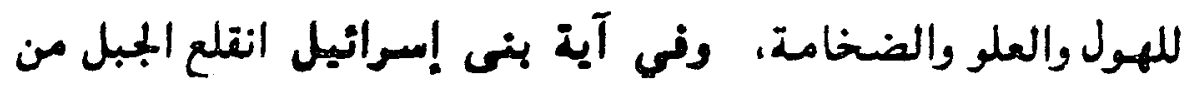

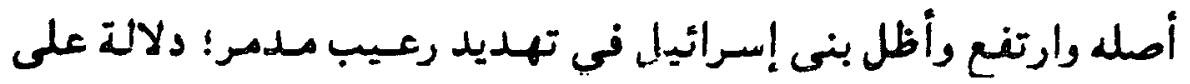

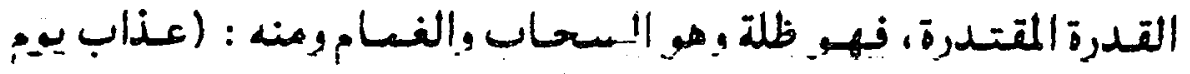

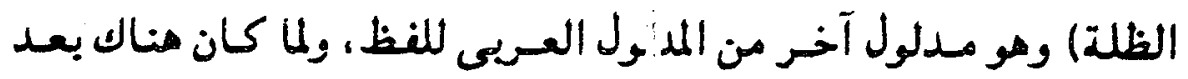

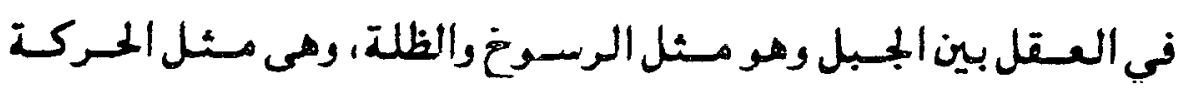

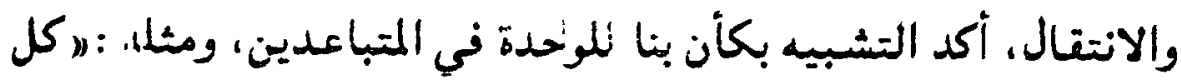

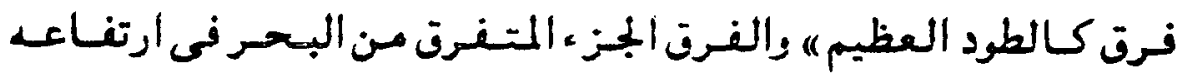

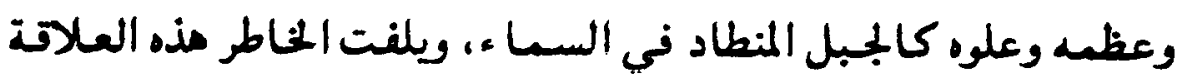

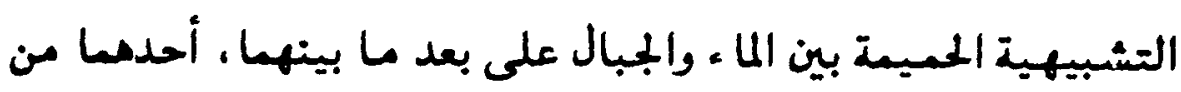

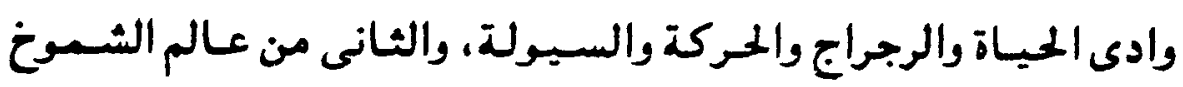




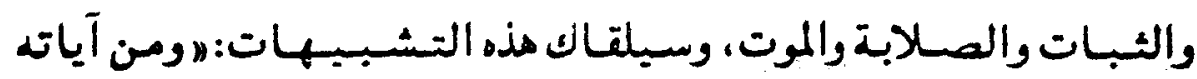

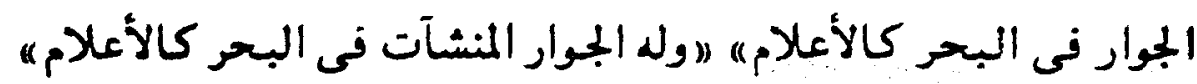

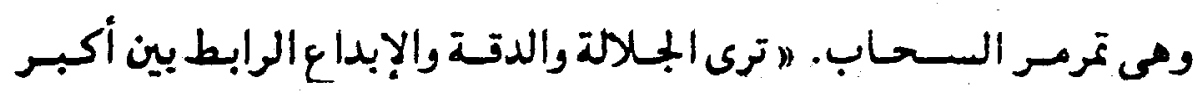

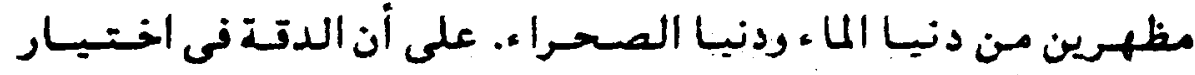

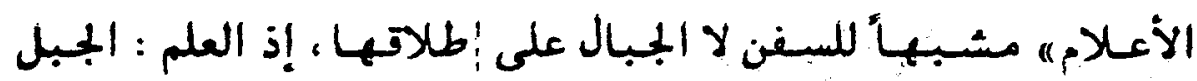

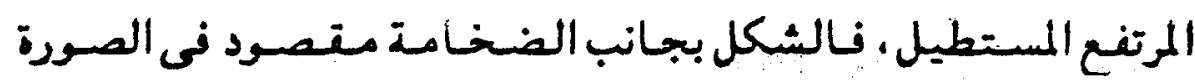

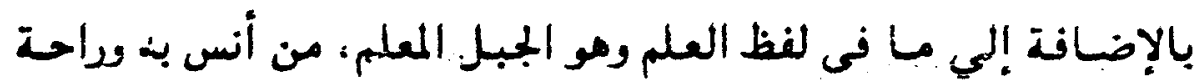

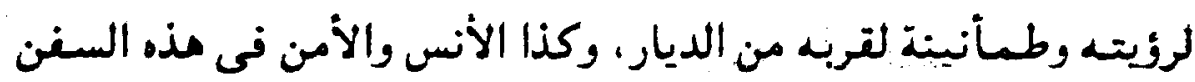
الكبيرة التى تسير بقدر الله ورحته.

\section{وقال تعالى :}

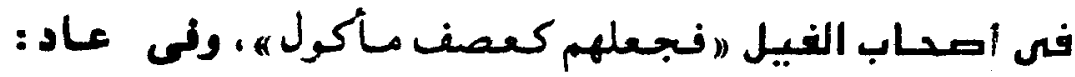

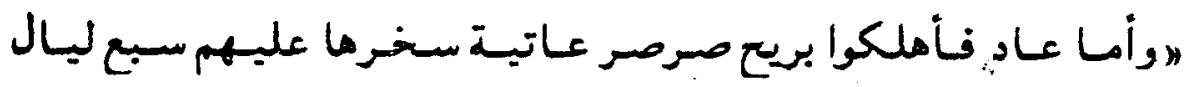

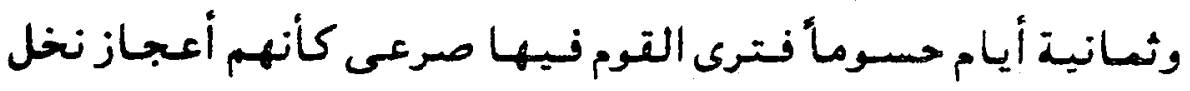
خاوية ه.

"إنا أرسلنا عليهم ريحاً صرصراً في يوم نحس مستـمر تنزع

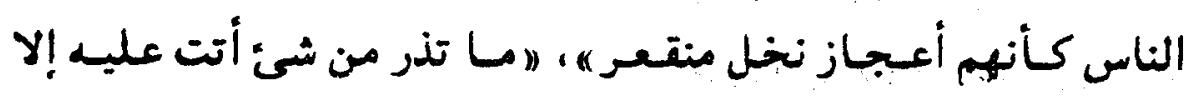

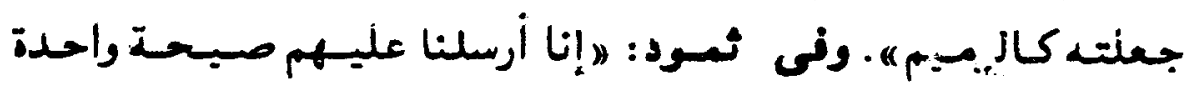

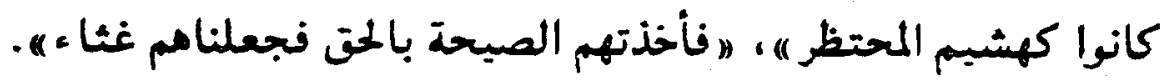

وتبال عن الهكذبيز : "فما زالت تلك دعرأهم حتى جعلناهم

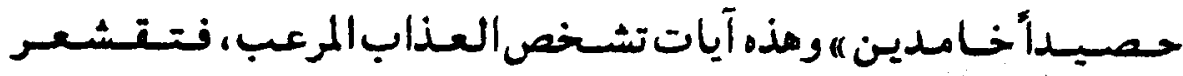

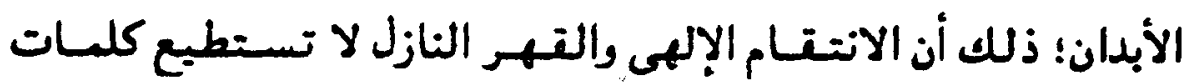

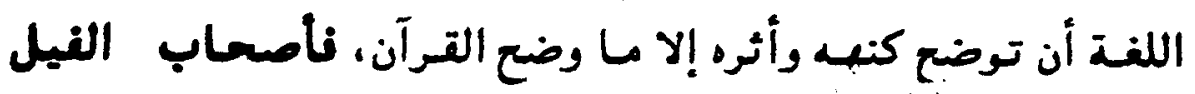




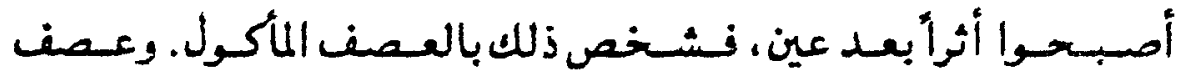
الـزرع: حطام التبن ودنـاته، لم يكتف بجعله عصناً حتى جعله

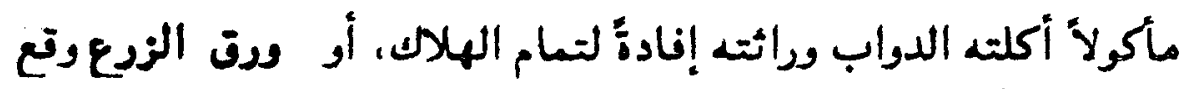

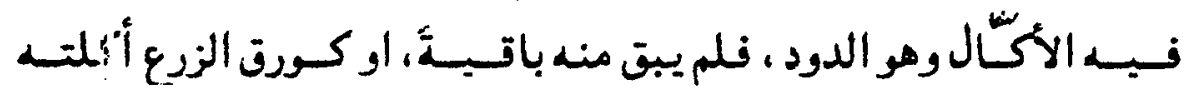

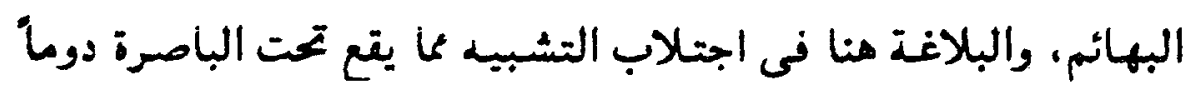

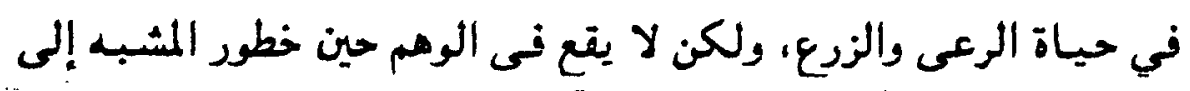

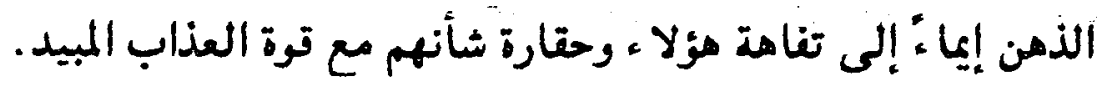

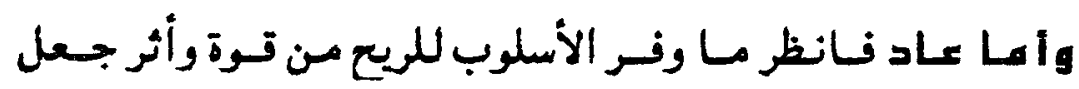

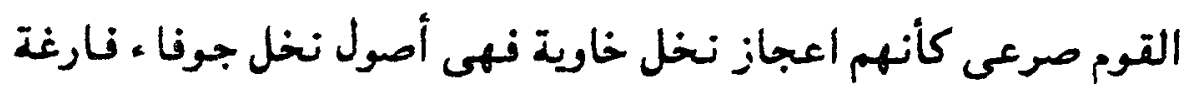

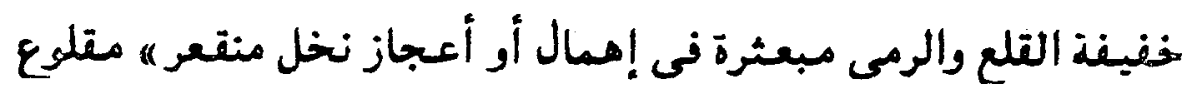

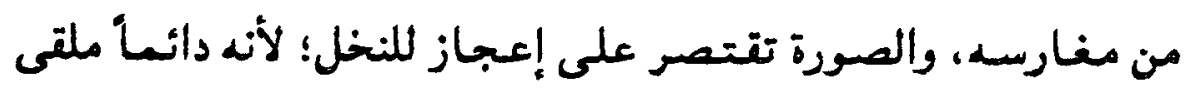

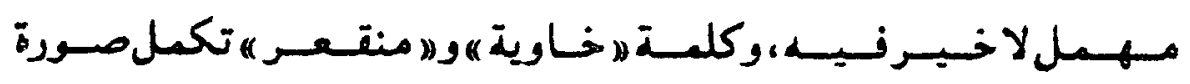

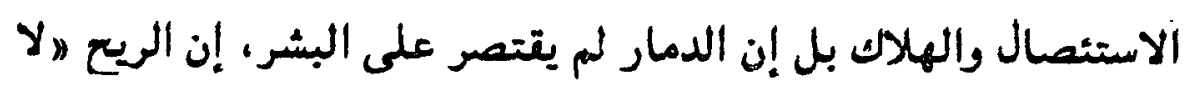

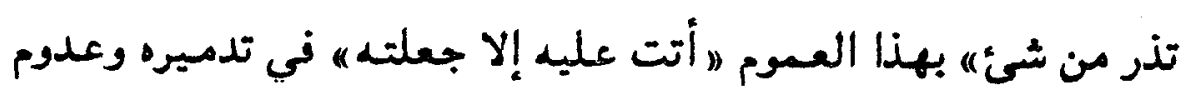

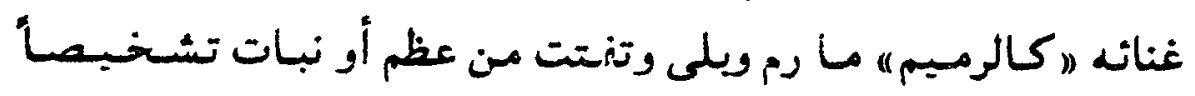

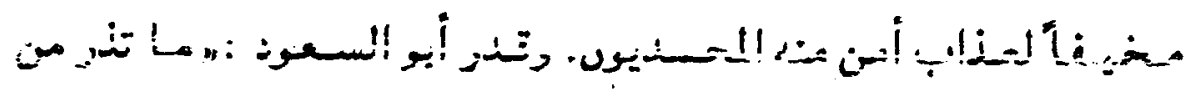

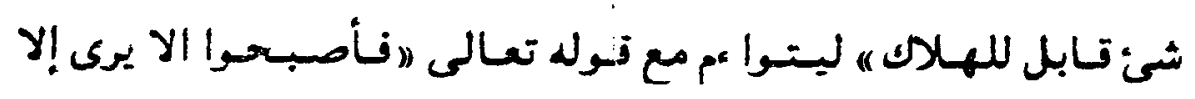

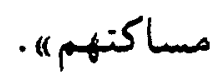

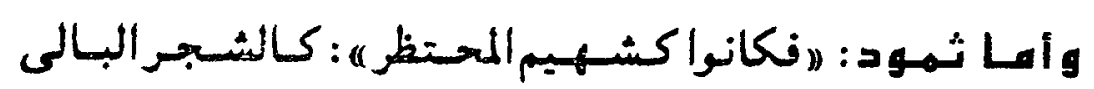

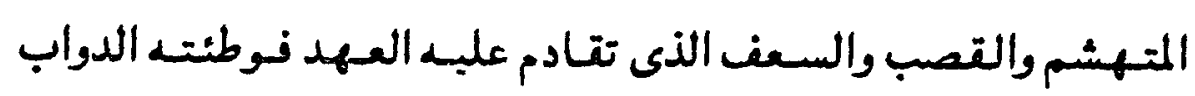

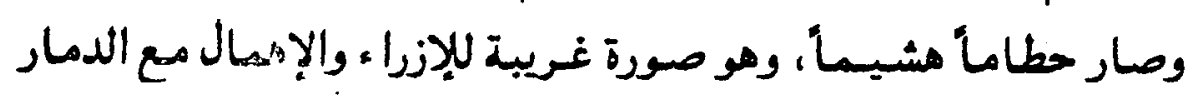


والغثنا ، ما بلى واسود من عيدان وزرق من حسيل السبل ، وقد

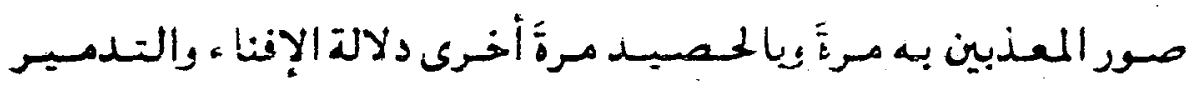

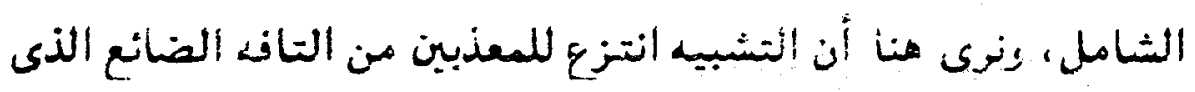

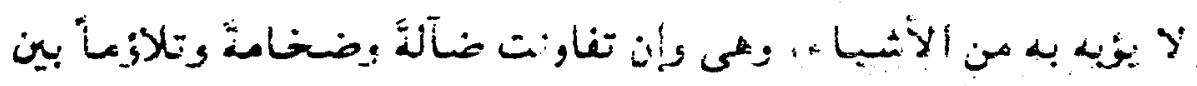

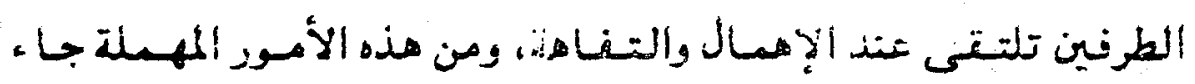

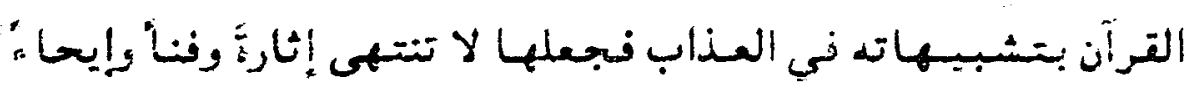
وترهيباً من إلكفر هـالعصيان.

\section{(ب) وتال تعالى : (بالى :}

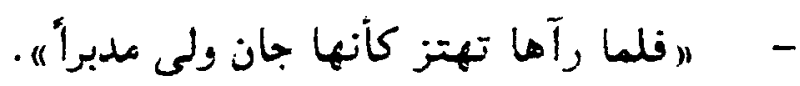

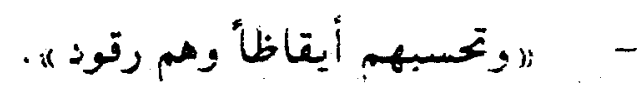

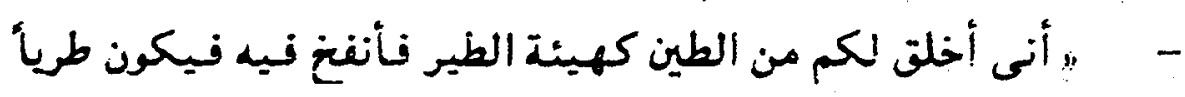

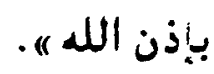
وبعجزة الله لا تتوتف عند النواميس والعقول :

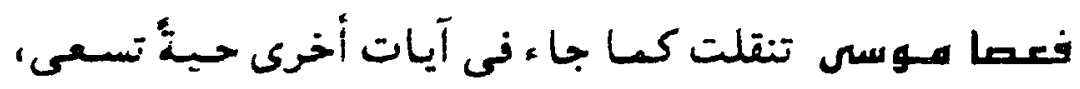

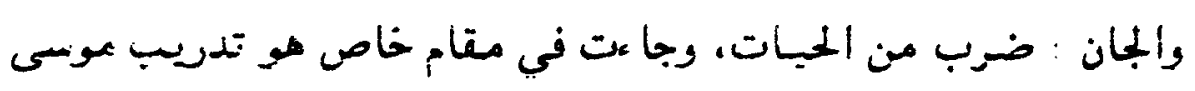

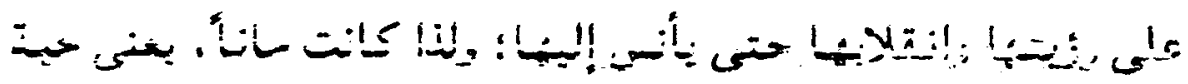

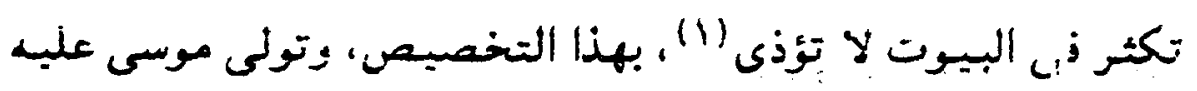

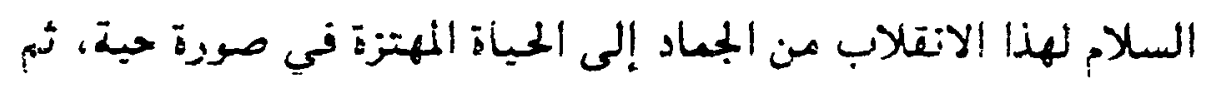

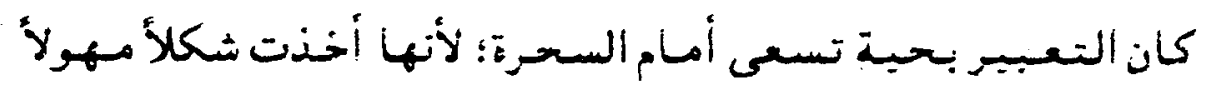

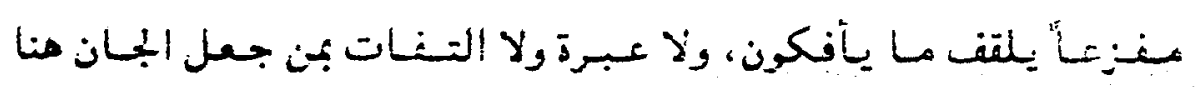
رعميأ من الجن توعسا وخبطاً دون تثبت. 


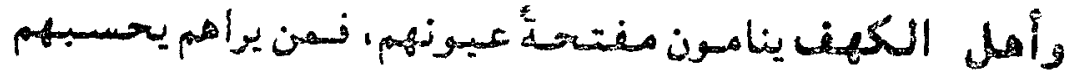

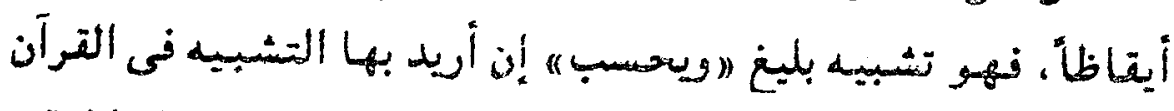

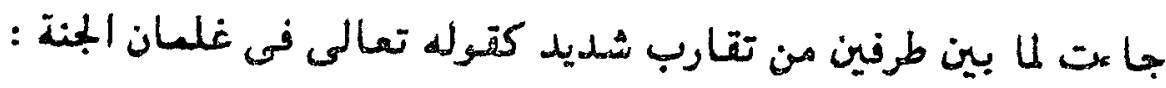
"إذا رأيتهم حسبتهم لؤلوا منثوراً " .

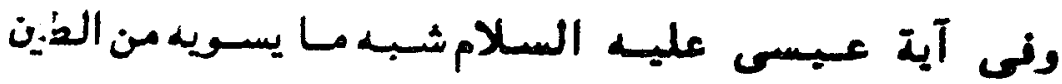
بهيئة الطير، وهى تشبيـات يكاد يتحد فيها الطرفان لقوة الإعجاز وبلوغ المشتبه درجة المشبه به ومو الأصل.

أحداث التباهة : :

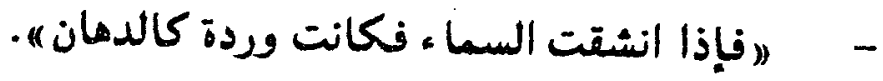

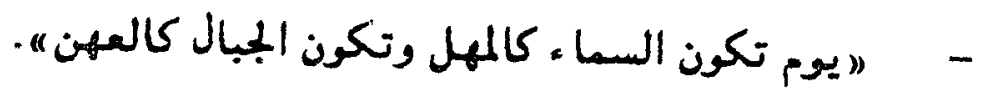

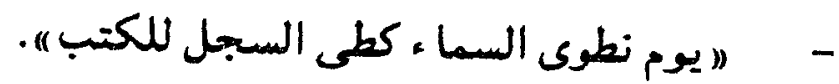

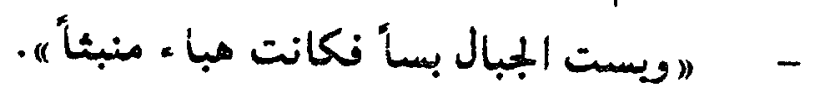

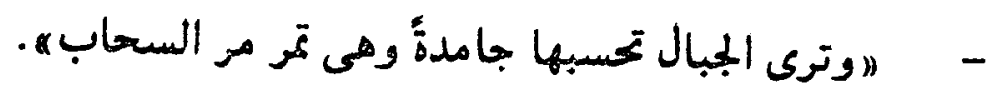

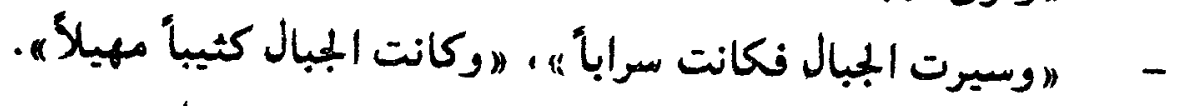

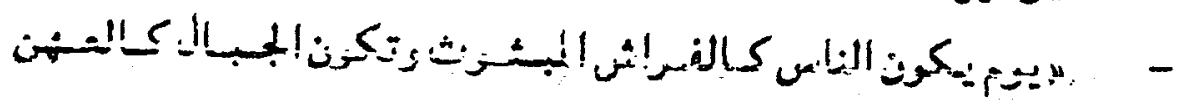

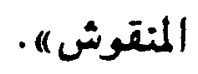

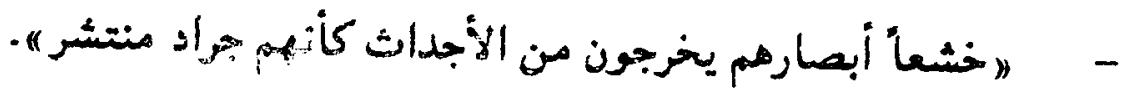

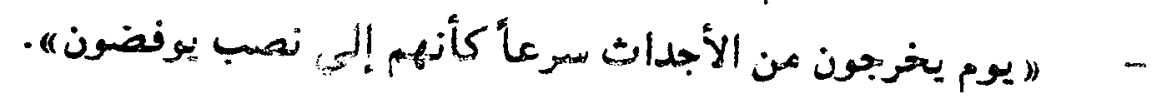

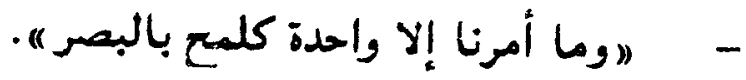

$$
\begin{aligned}
& \text { - " وما أمر الساعة إلا كلمع البصر أو هو أقربب) . }
\end{aligned}
$$

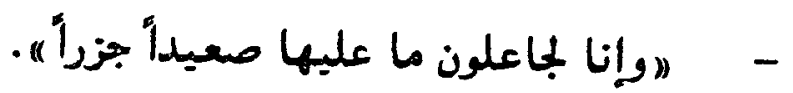


وأحداث القيامة يقدمها القر آن مصورة محسوسة حيدة متحركئ

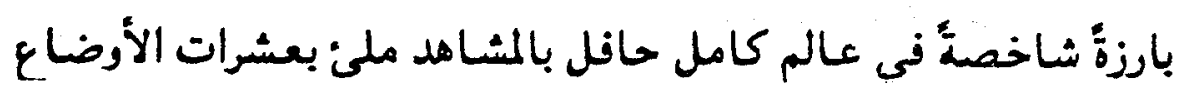

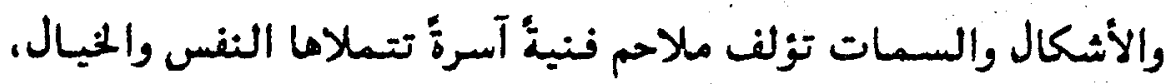

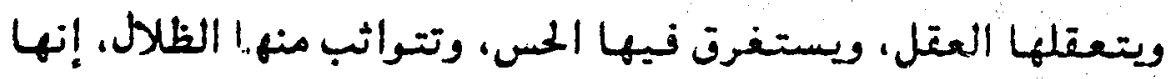

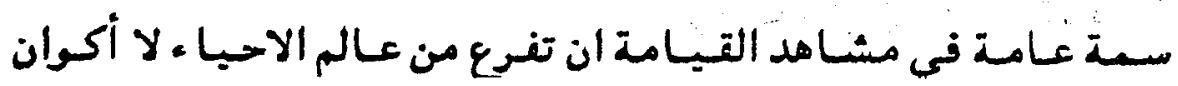

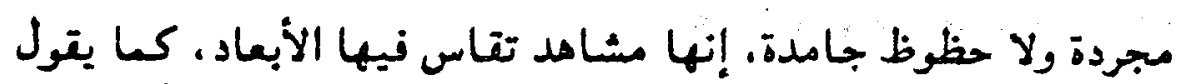

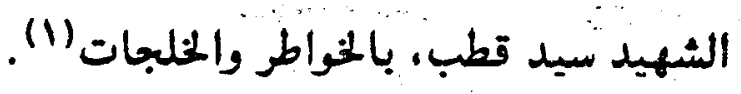

والتشبيه يدلى بدلوه فالســاء بعد الانشتاق والانغطار تتقلب

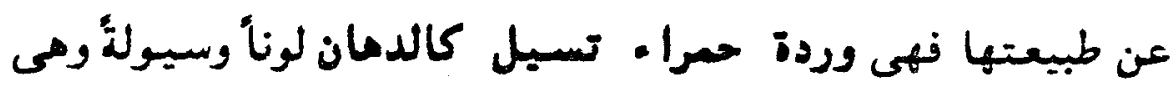

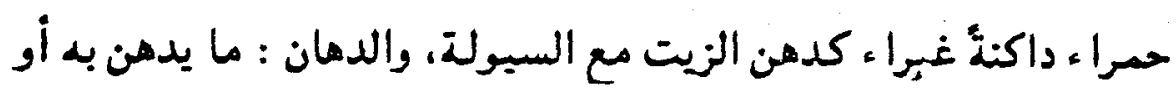

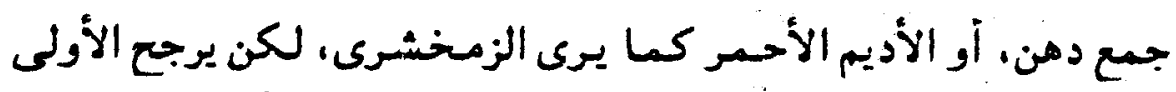

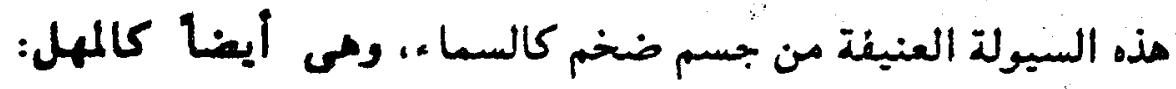

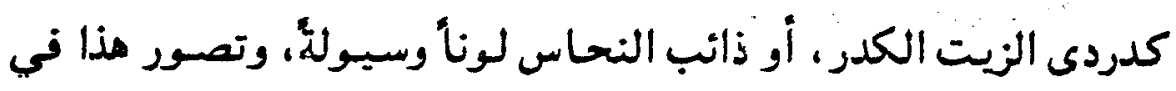
جانب السما ، أمر يكاد لا' يطيقه عقل.

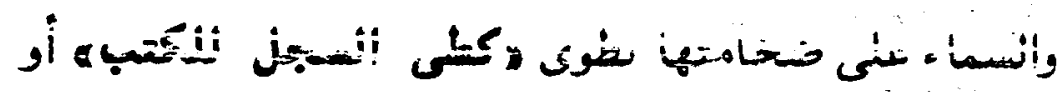

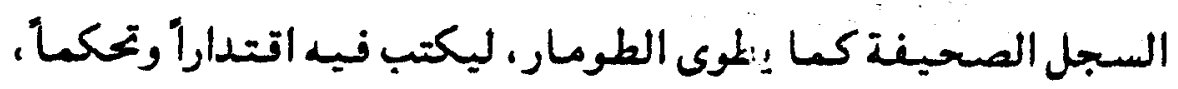

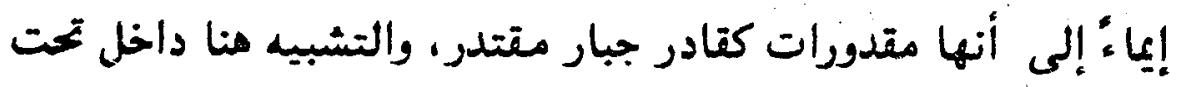

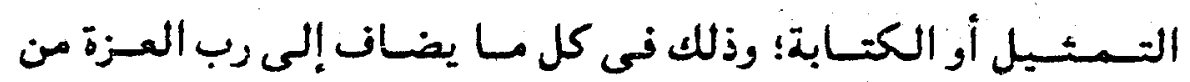

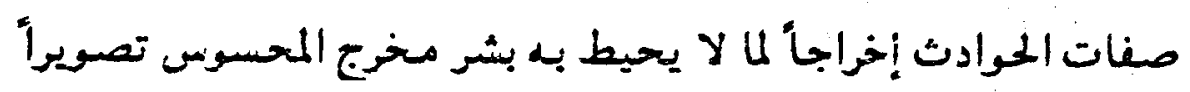
وتبليغاً. 
والجـبـال على عظمها تخرج عن طبعها وصـلابتهبا وتاسكها

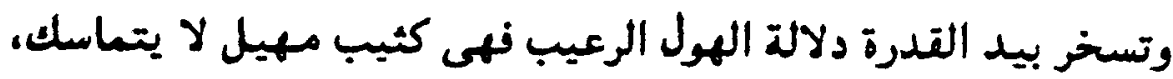

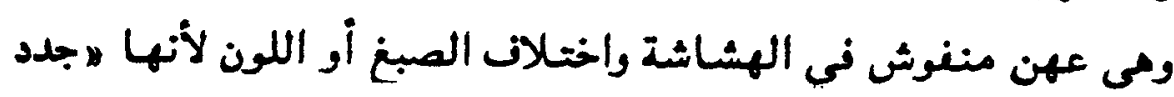

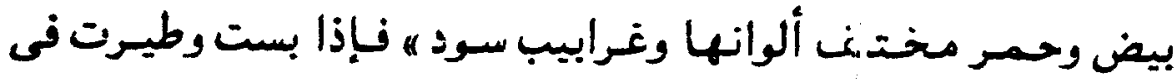

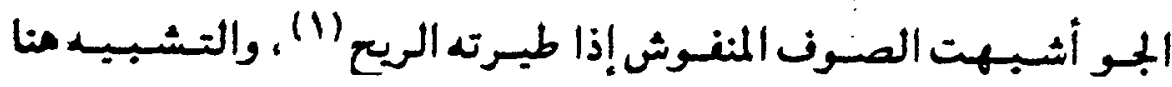

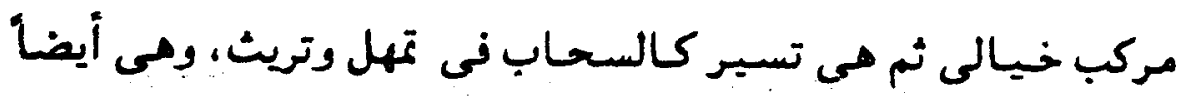

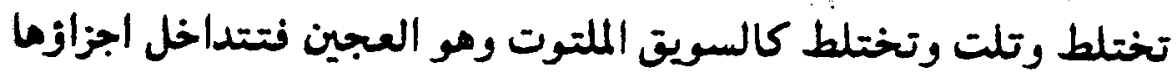

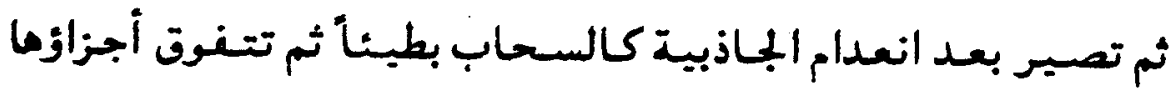

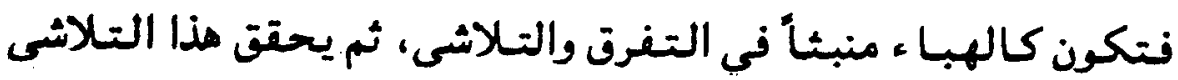

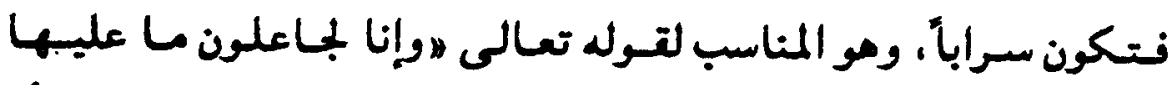

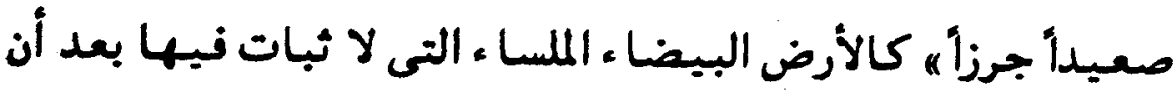

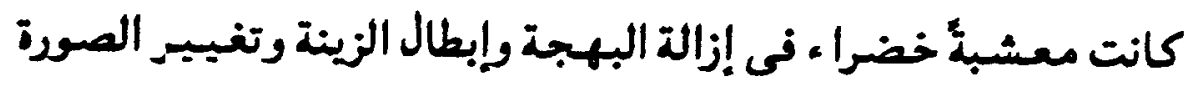

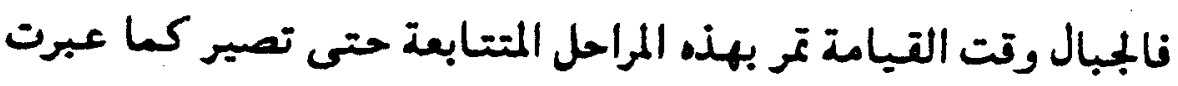

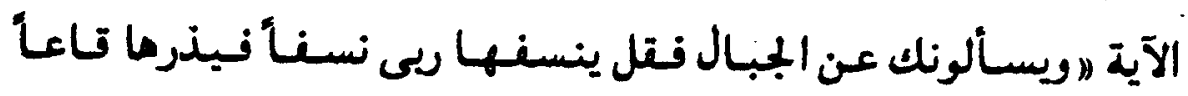

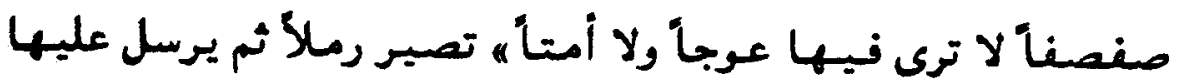

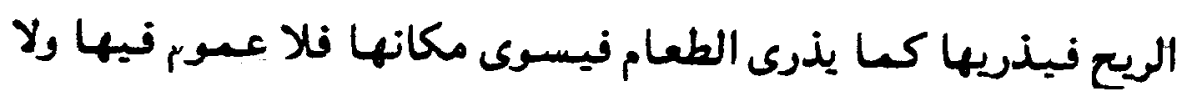
نتو. (K)

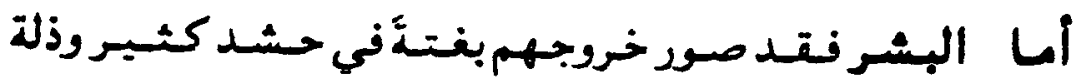

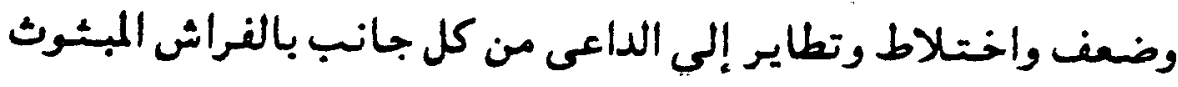

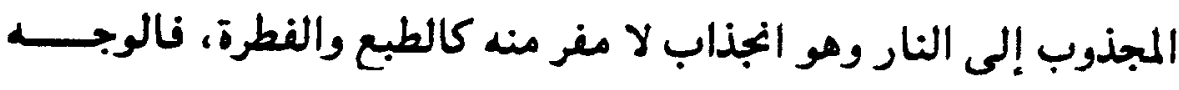

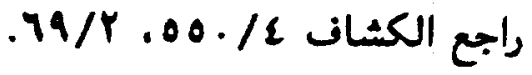

(r) 
مينـة لا تحـد ظلالها ، والعـبـيب من انتزاع الصسورة من مذا الفراش

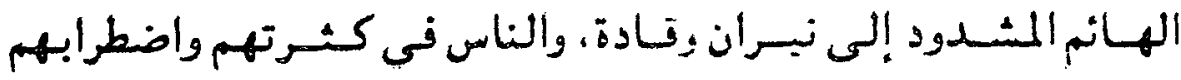

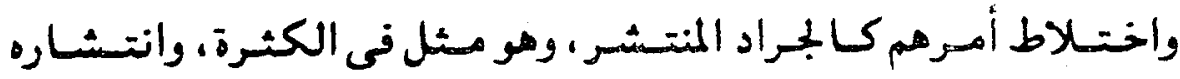

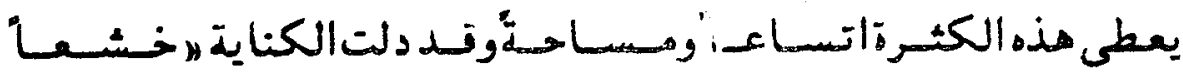

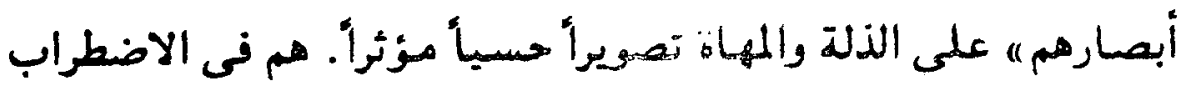

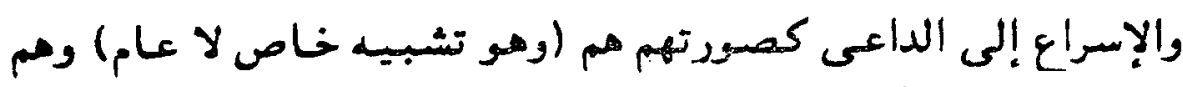

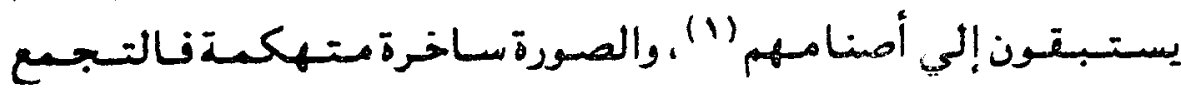

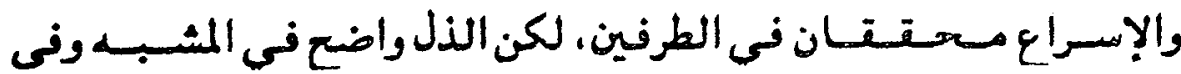

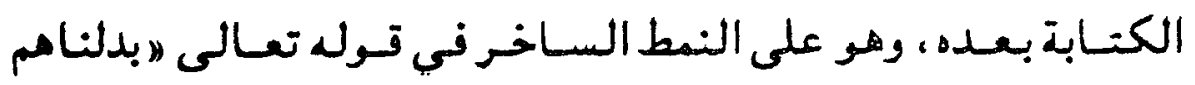

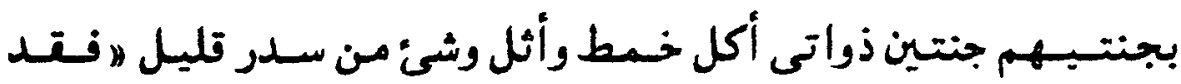

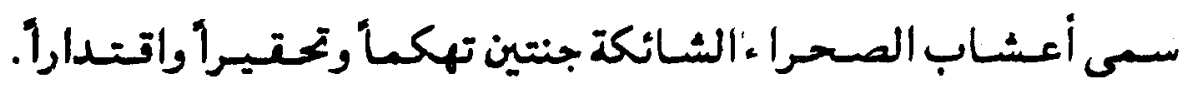

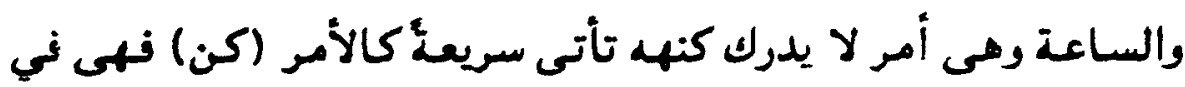

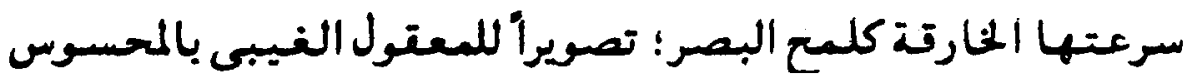

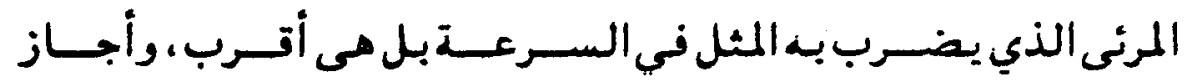

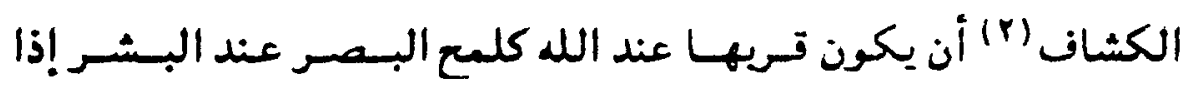

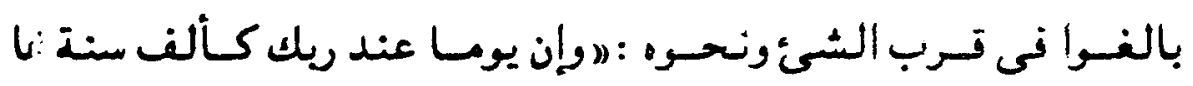

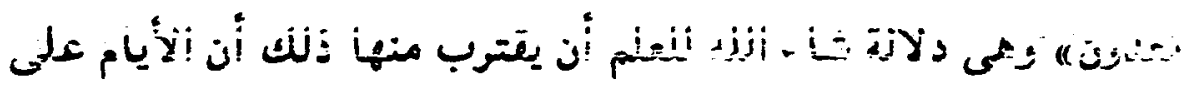

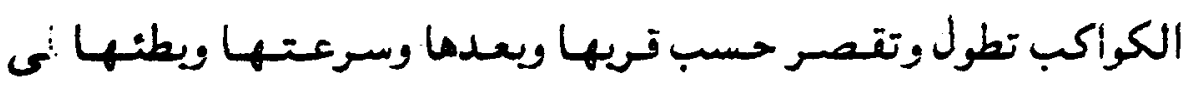

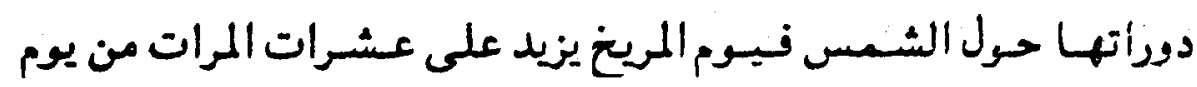

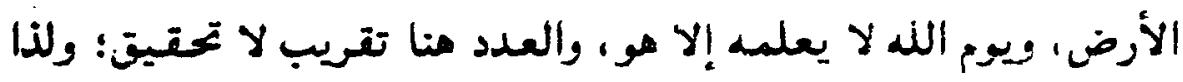
جاء على الصيغة العددية ", ألف ه التى يراد بها لها الكئرة لا التحقيق.

$$
\text { المرجع المر 2ar/2. }
$$




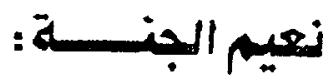

تدم التشبـيـه لمحات دالت لها أثرما البهـيج من شـغل الحسواس

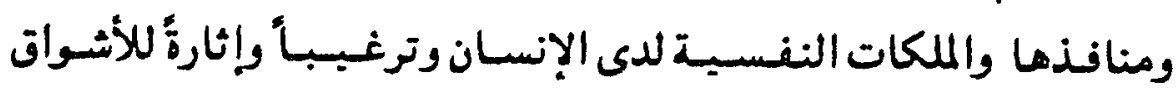
لهذه الدار التى يدندن حولها المتقون قال تعالى :

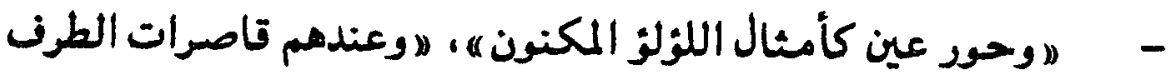

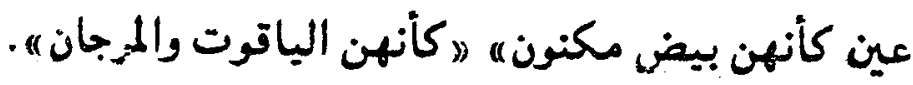

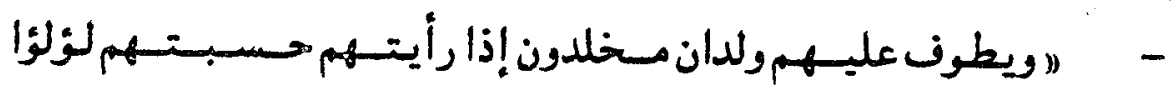
منثورا I). - يطون عليهم غلصان لهم كأنهم لؤلؤ مكنون ".

ونلحظ أن التشبيده حسى صسورت فيس المسود المين مع أنهن

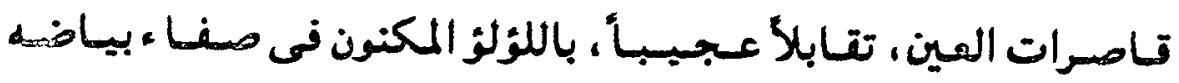

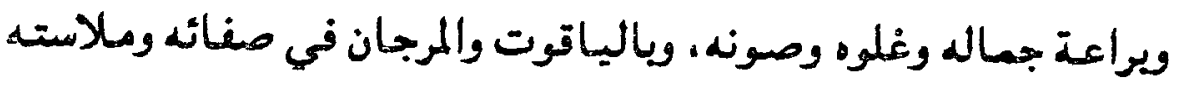

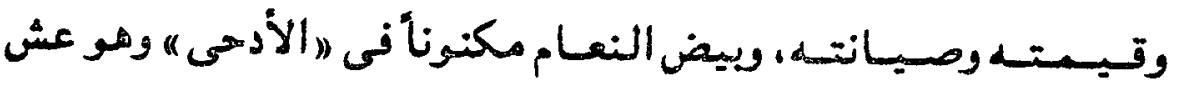

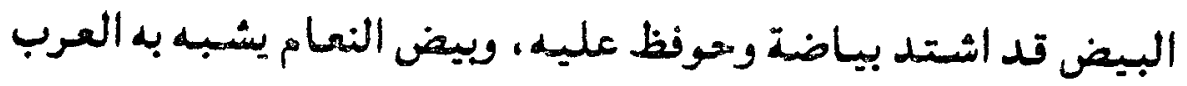

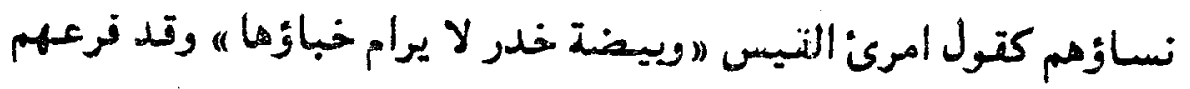

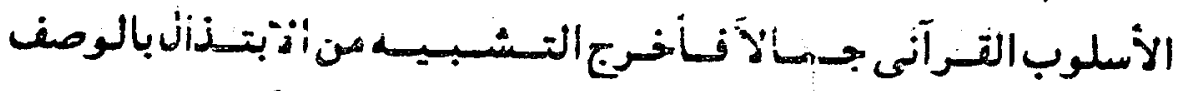

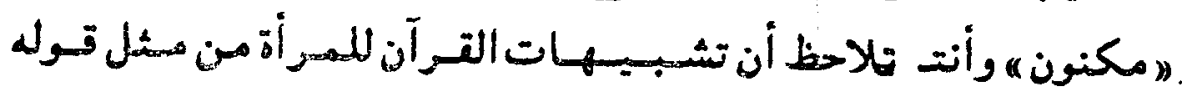

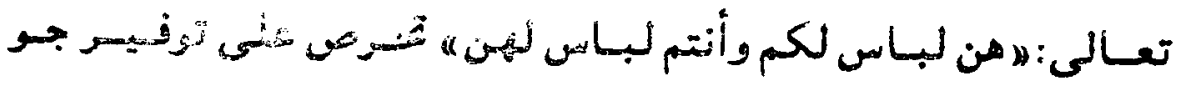

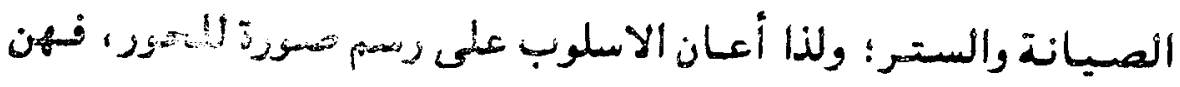

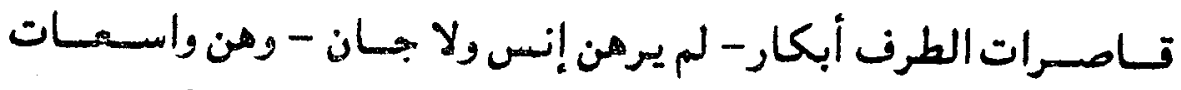

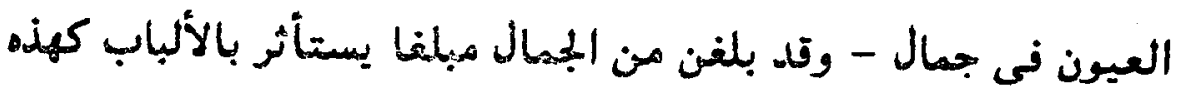

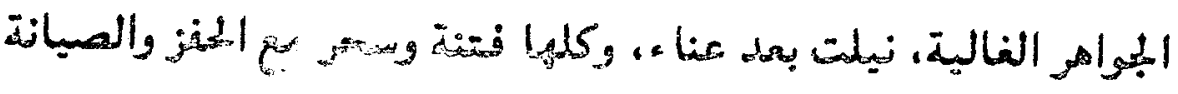


ودعوة إلى الستسر حتى في الآخرة فالحسيـات هنا لها أثرما المعنوى والأدبى والعقلى فى التكريم.

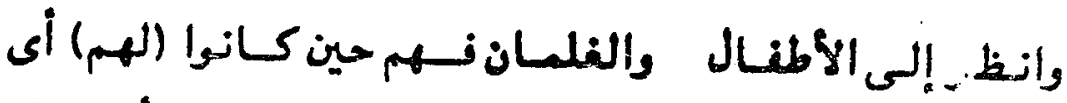

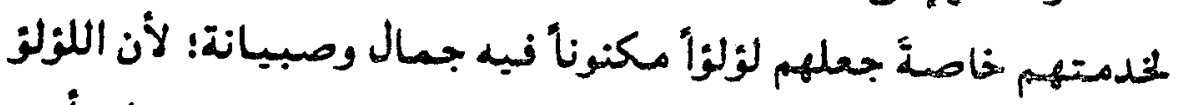

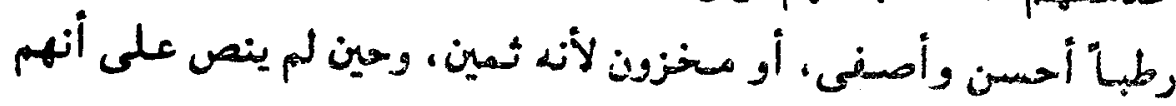

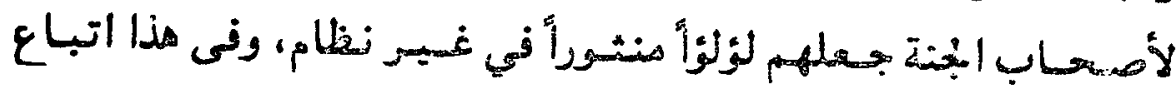

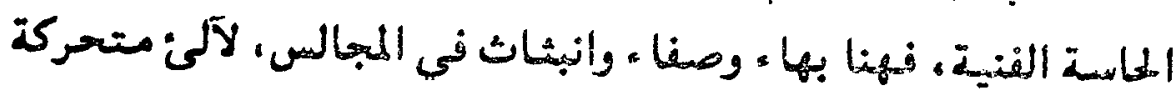

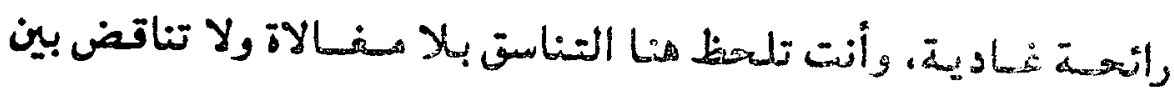
اللمون وإلحركة والمحياة والظملال المرتحة.

وتلجظظ أن الكاف دخلت علي هأمثال ه مشبهاً به بعنى ميئات

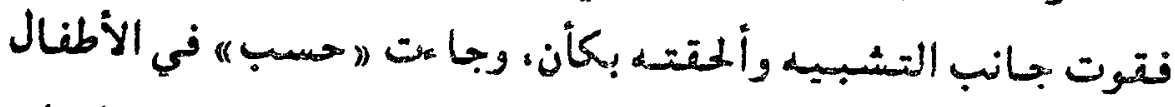

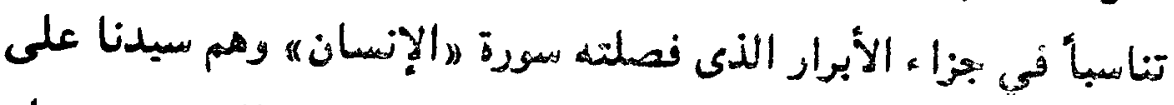

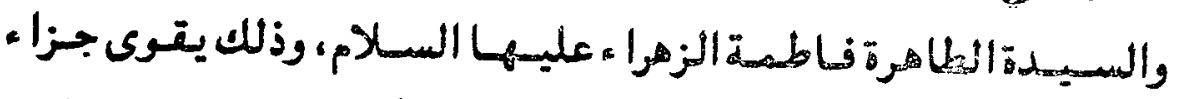

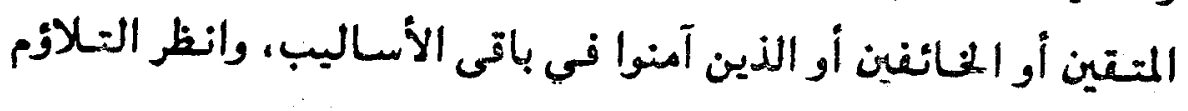

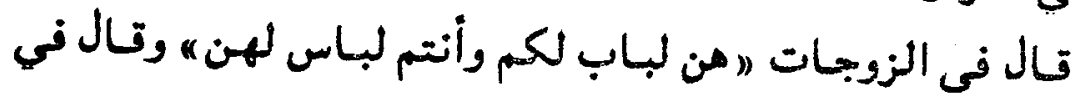

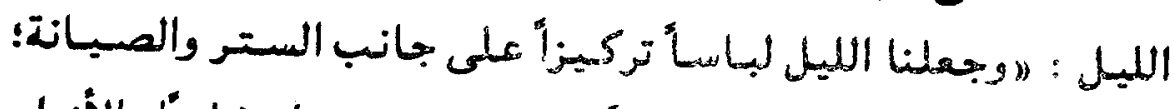

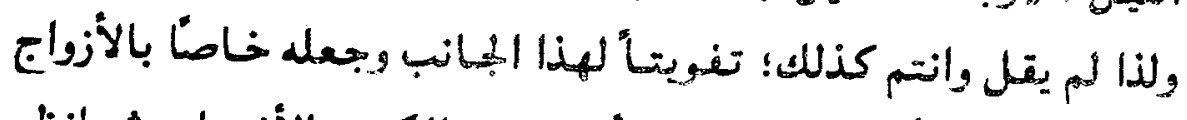

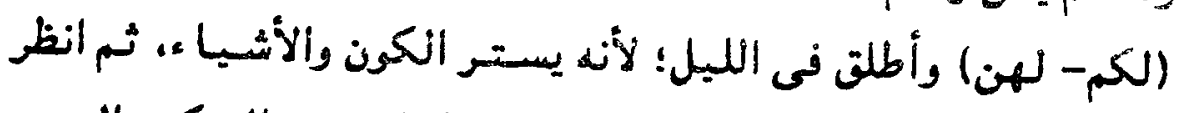

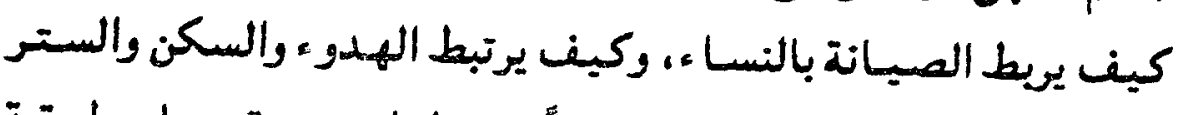

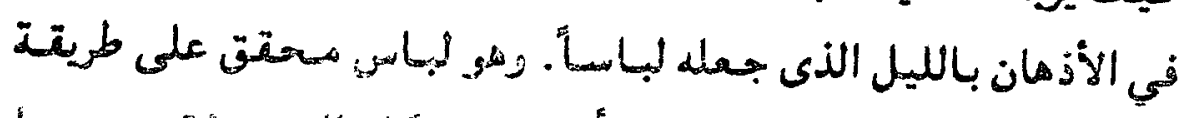

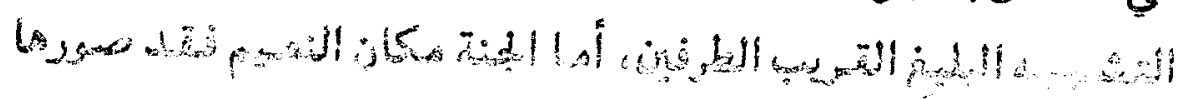


في السعــة بالســـا ، والأرض ونص على العـرض ؛ لأنه أو فى الطول

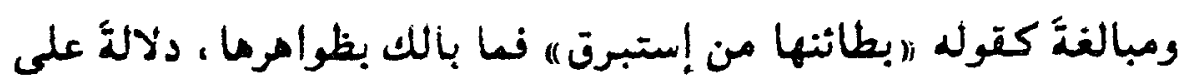

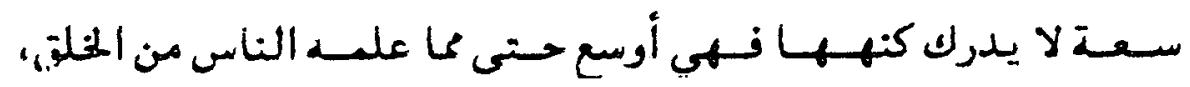
الكناية عن السعة تفرعت عن تشبيه محسوس.

مشا مد التهـذزابه:

كال سبكاند

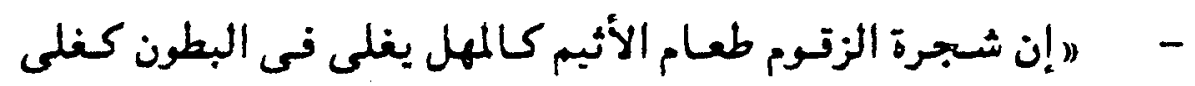

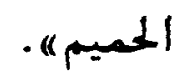

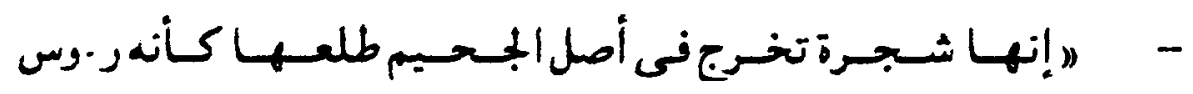

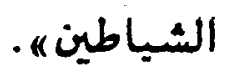

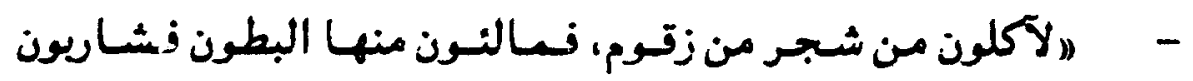

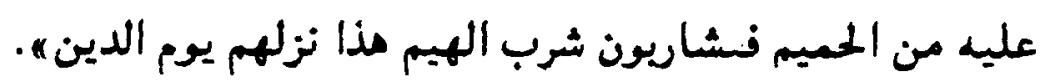

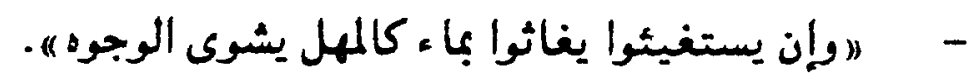

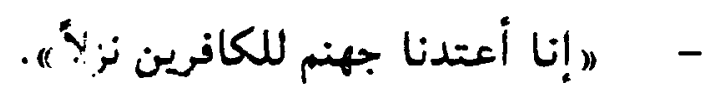

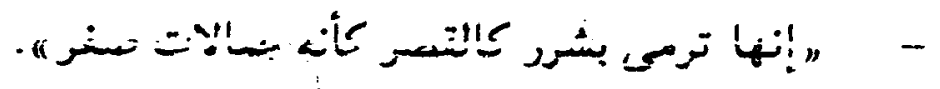

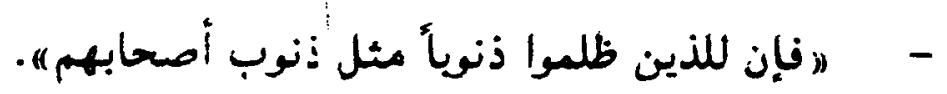

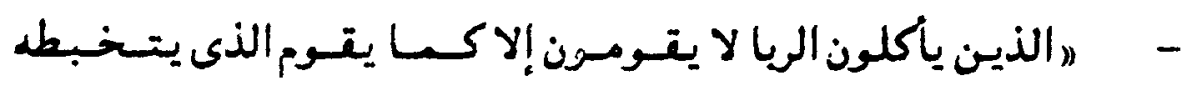

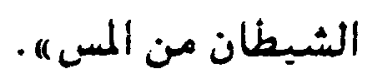

وكل ما فى الآخرة غبب مكنون له قوانينه الخاصة ولا نعلم منه

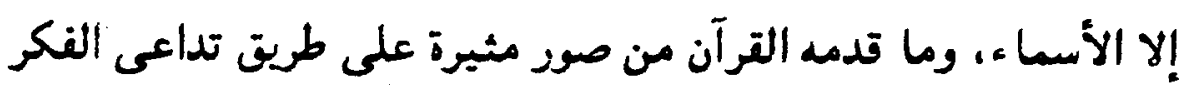

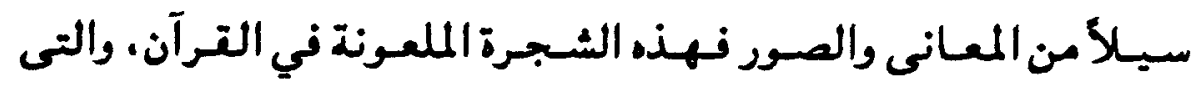


كانت فتندّ للظالمِن عالجها القرآن من ناحية طعسها وشكلها أثرما ،

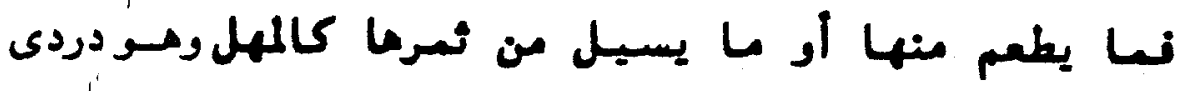

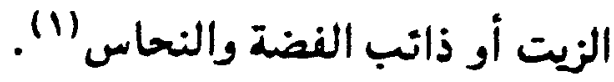

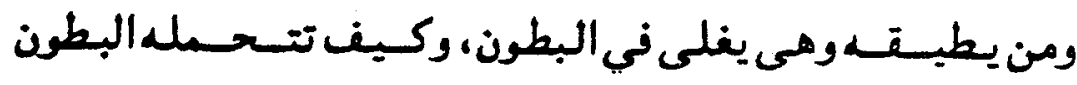

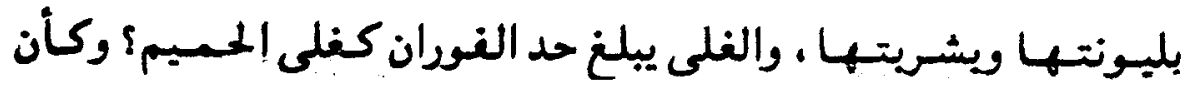

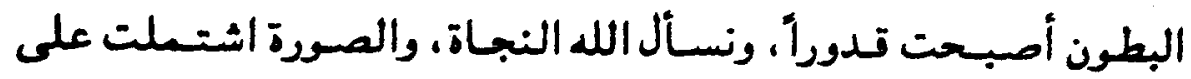

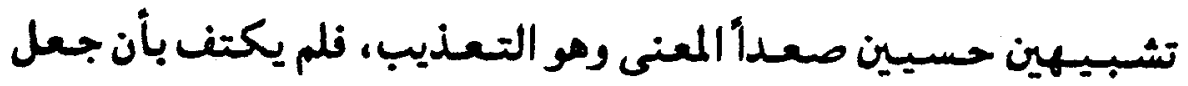

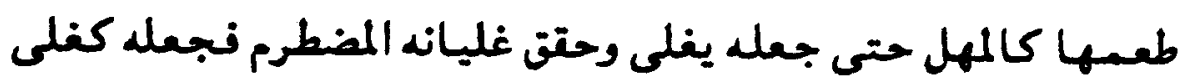
الما ـ الحلار في الداخل جيشاناً وتوقداً، ونعوذ بالله.

والصورة اشتملت على الحركة واللون والحرارة والتوقد والإثارة،

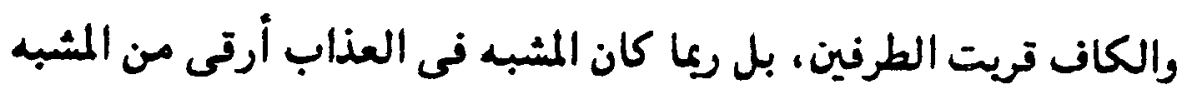

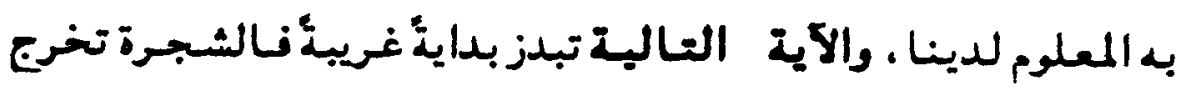

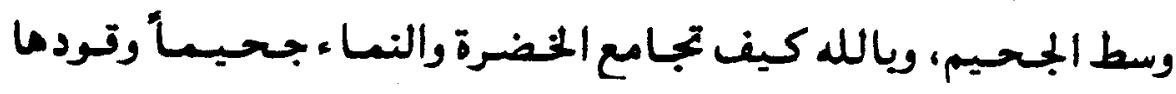

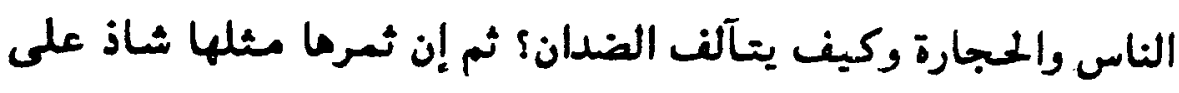

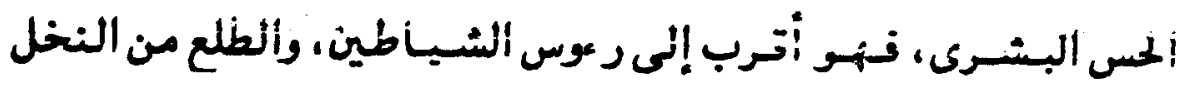

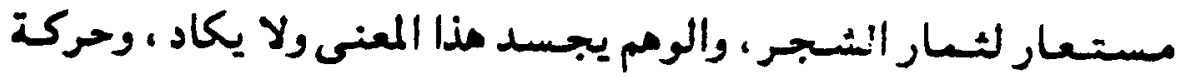

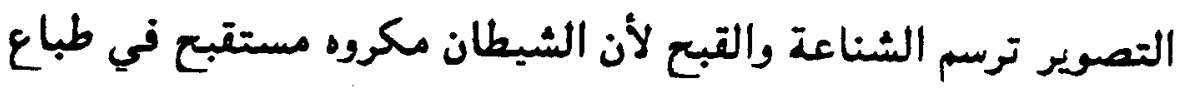

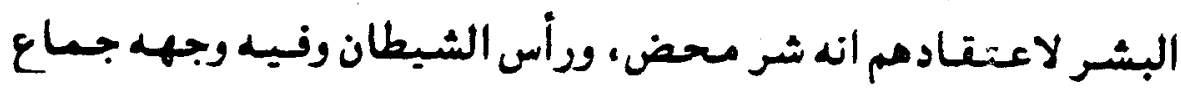

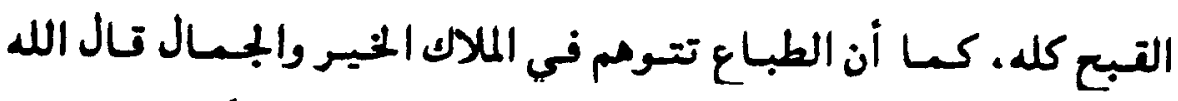

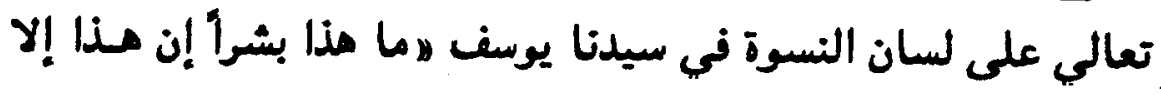




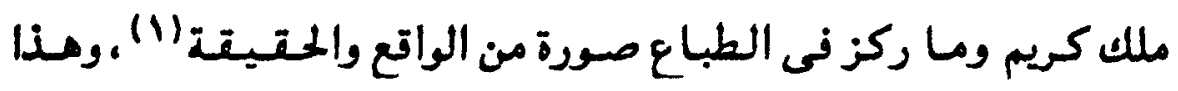

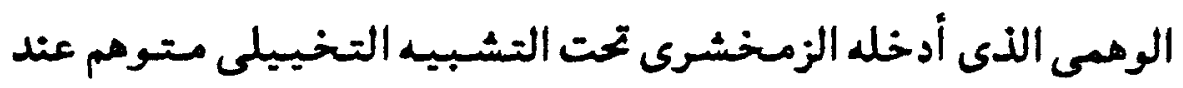

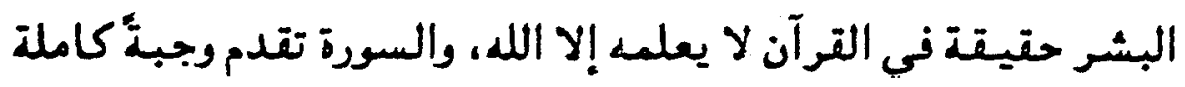

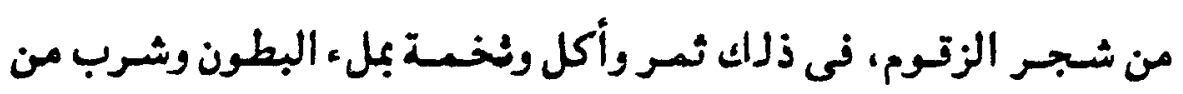

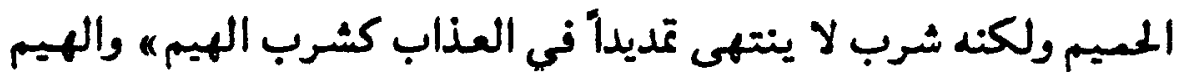

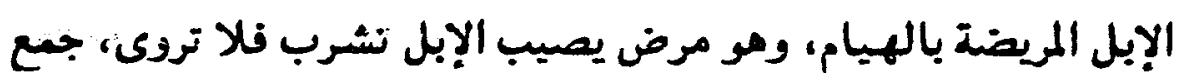

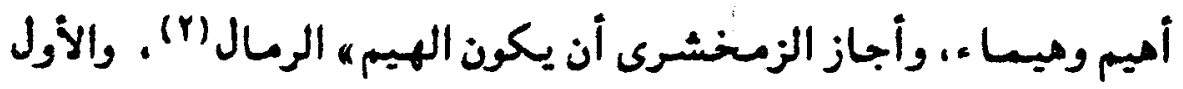

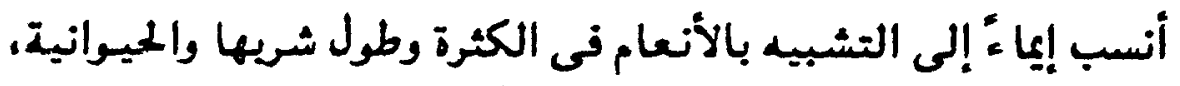

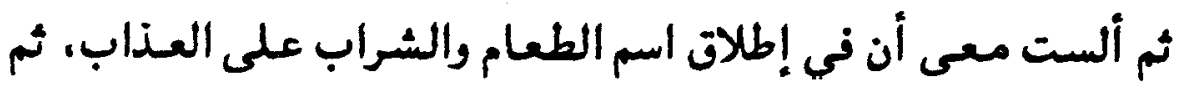

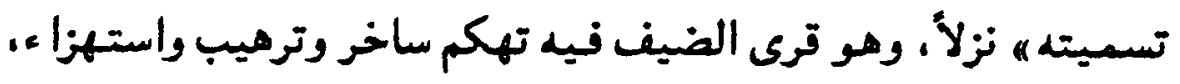

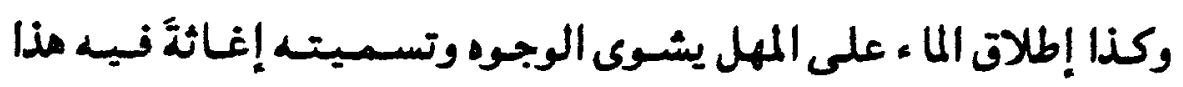

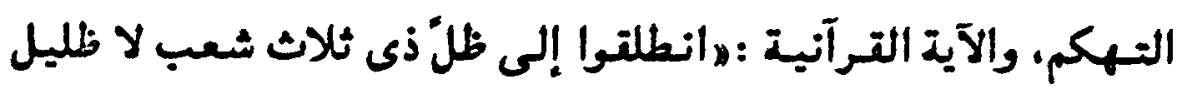

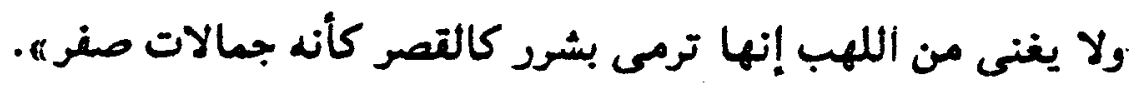

يقول الشـهـيد سيـد تطب : هانطلقوا إلى مـا كنتم به تكذبونه

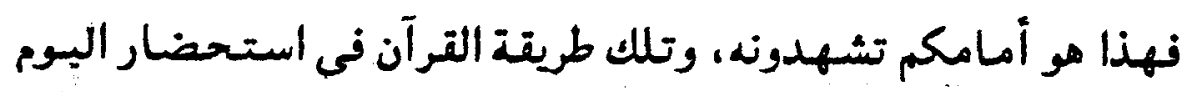

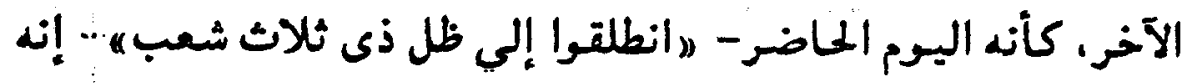

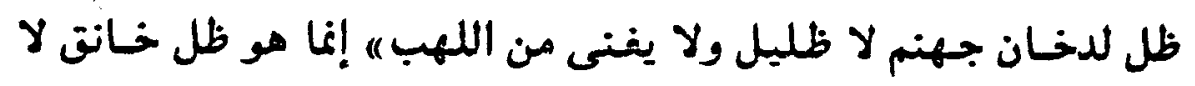

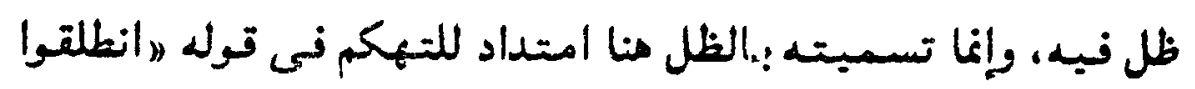

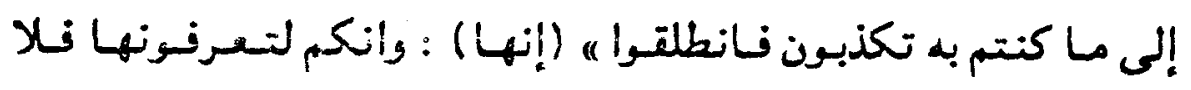

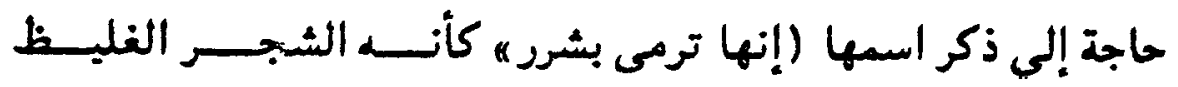




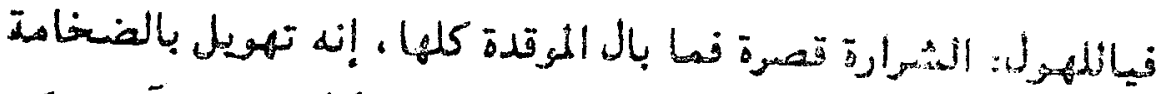

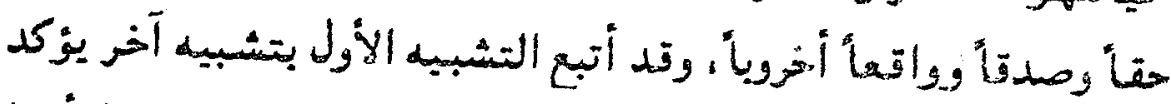

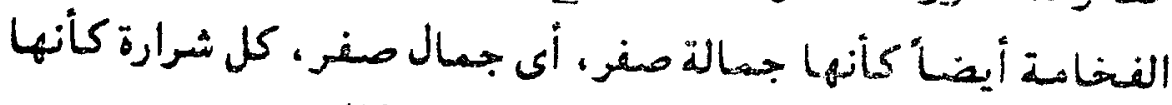

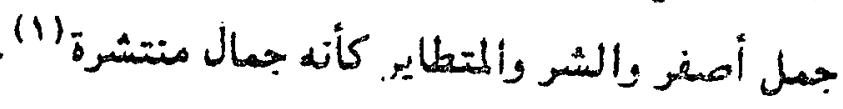

والطرفان مفرد ان حسيان والوجه كذلك، والأداة الكان، وليس

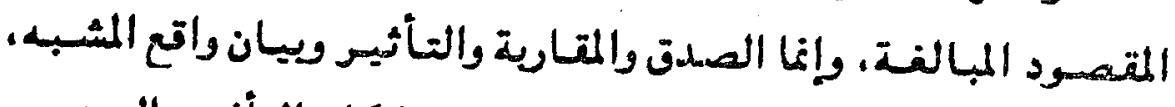

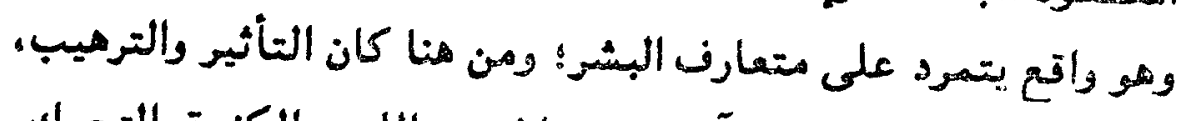

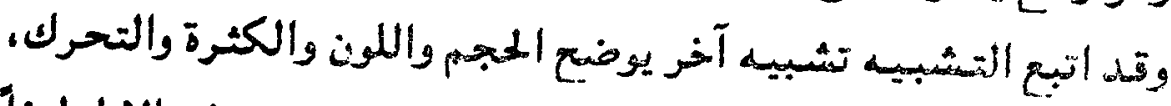

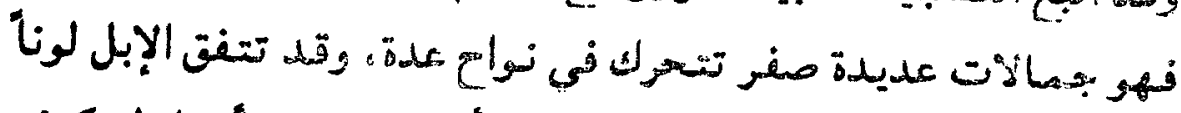

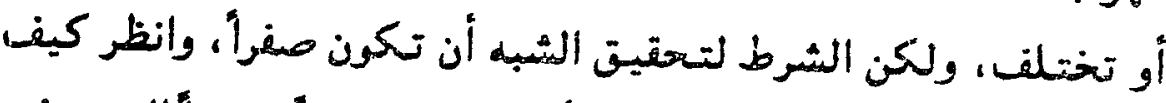

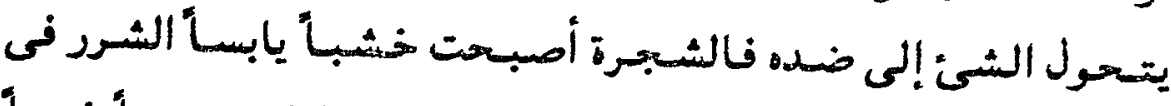

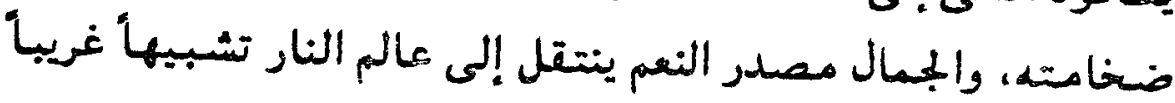

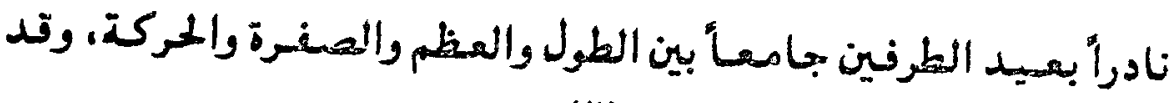
تأثر المعرى هذا التشبيه في قوله (Y):

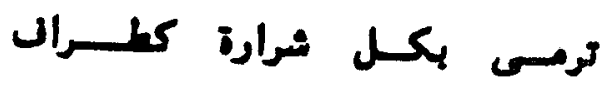

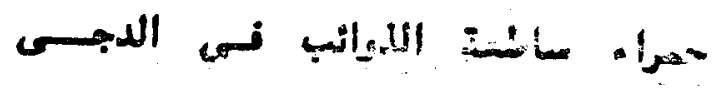

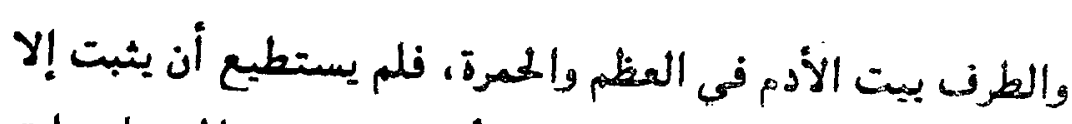

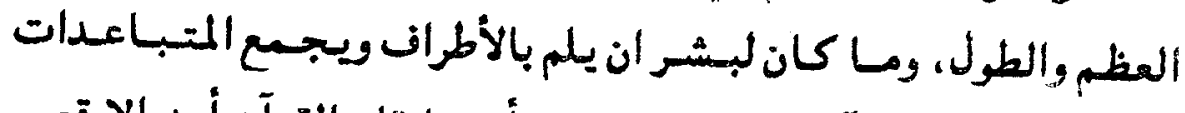

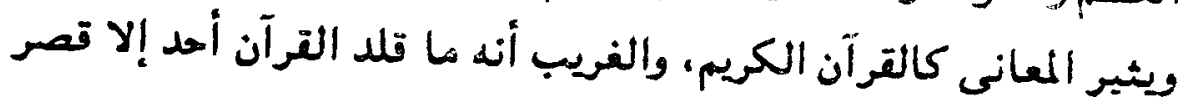




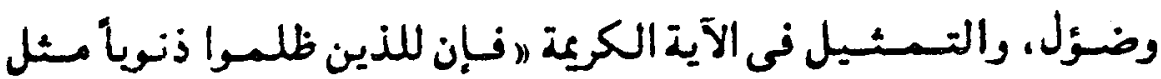

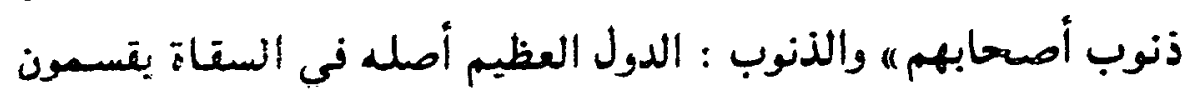

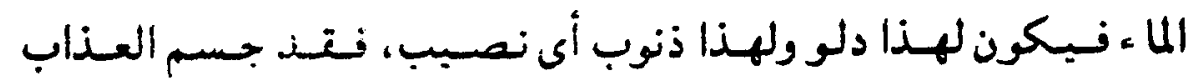

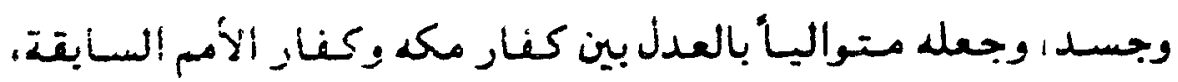

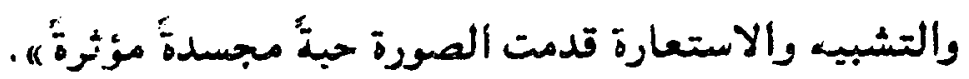

وأمـا الذين ياكلون الريا نقتد صورمم على طريق التصر

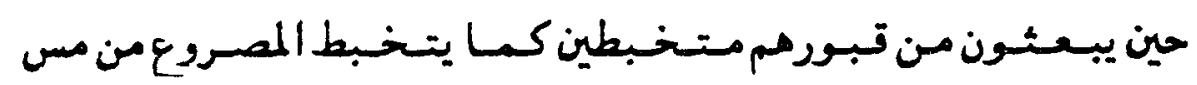

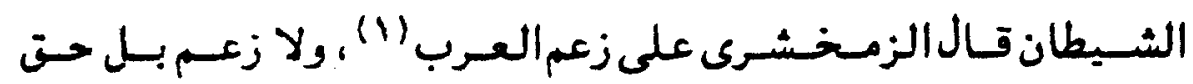

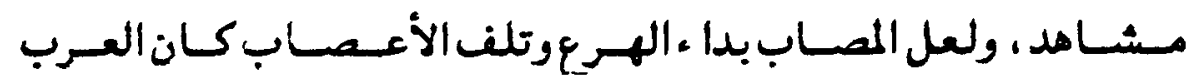

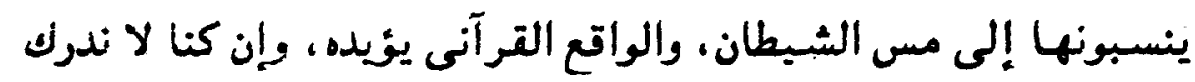

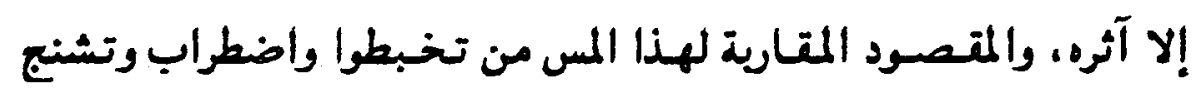

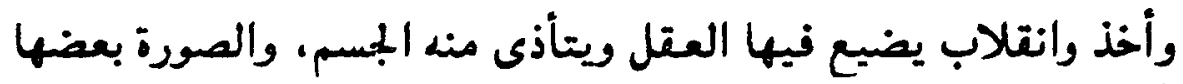

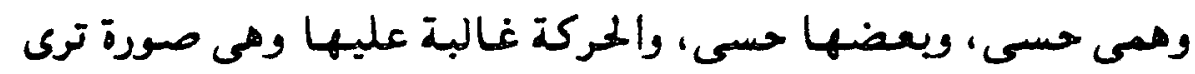
فى كل زمان ومكان، ولها وقعها فى النفس. ودئ والهركي

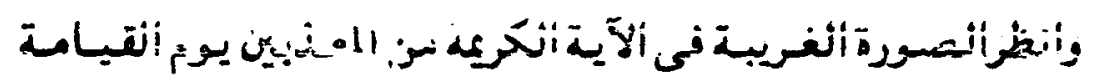

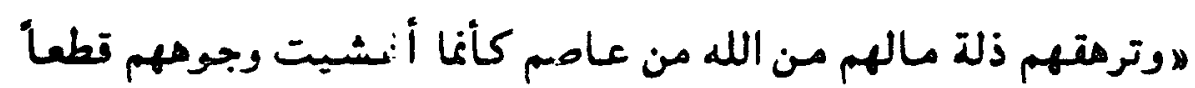
من الليل مظلماًه. .

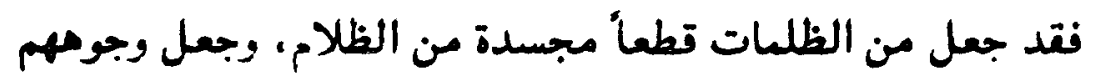

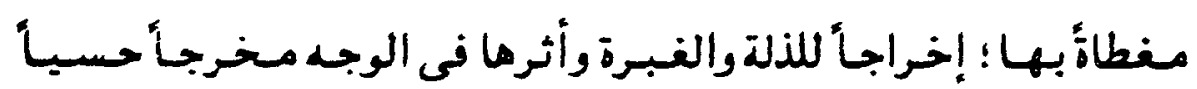
تخييلياً غريباً على سبيل التمثيل. 
مظاهمر الطبيعة فيى التشبية التر انسى :

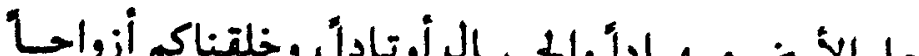
تال تعالى : -

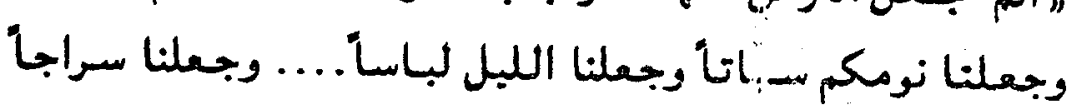
وهاجاً ،.

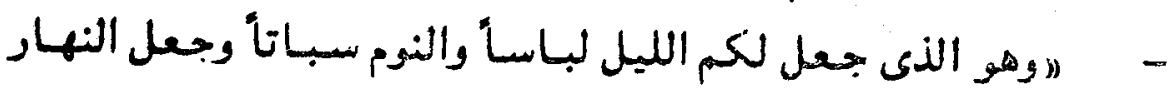

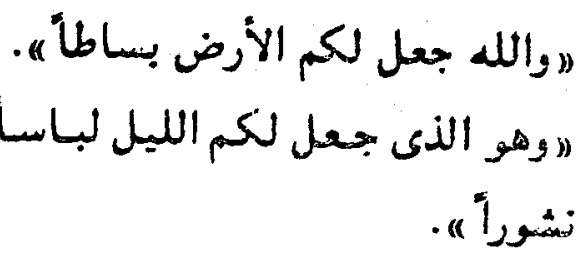

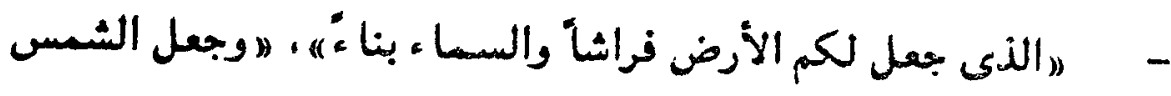
سراجاًا، بعل.

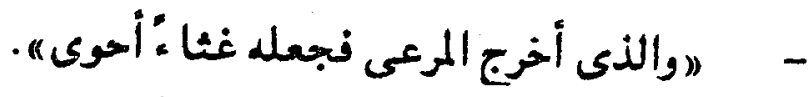

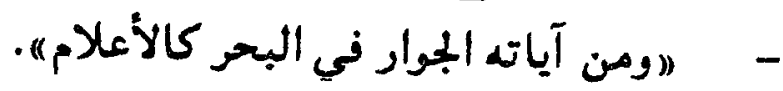

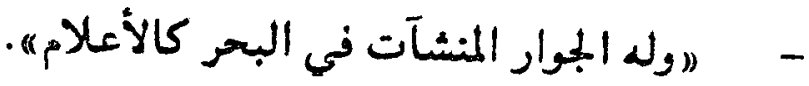

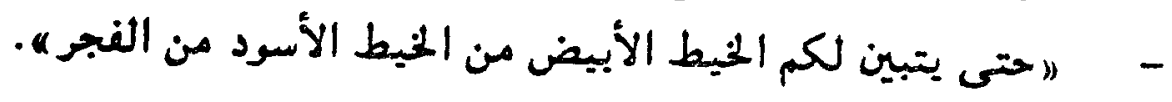

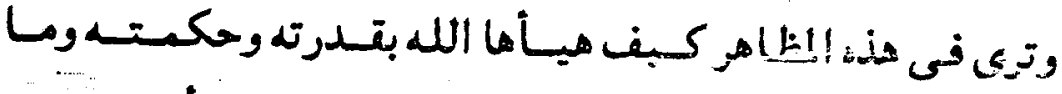

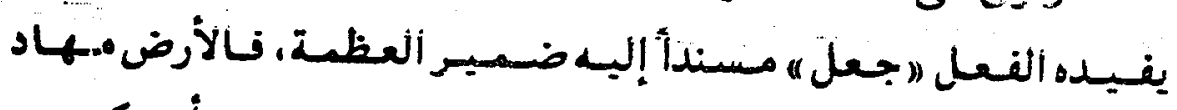

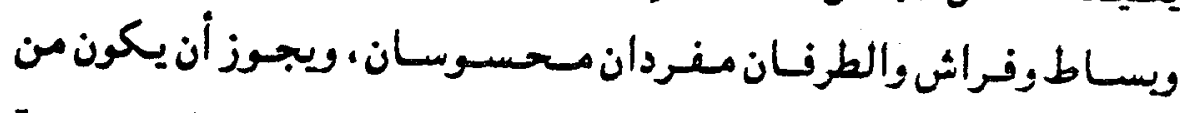

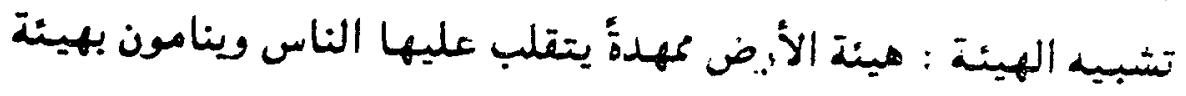

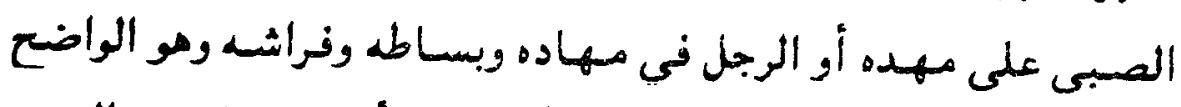

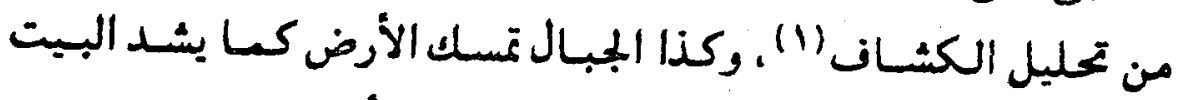

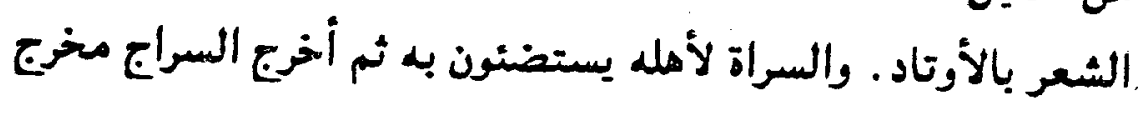




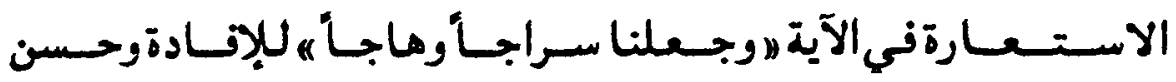

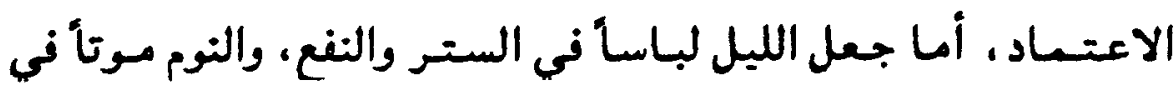
عدم الأثر، والنهار بعثأ كتابة عن اليقظة والحركت فهو تشبيـه مفرد

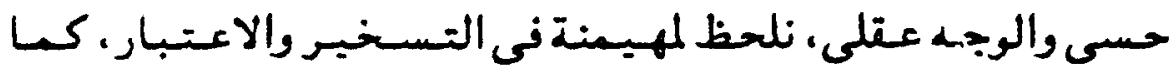
نلحظ التزا.ر حـف الأداة والوجد؛ تحتقاً في الطرفين؛ لأنها آية الليل ولا تتخلف ، كسا نجد التزام الفعل (جعل) مسنداً إنى ضسير الجلالة، ولئ

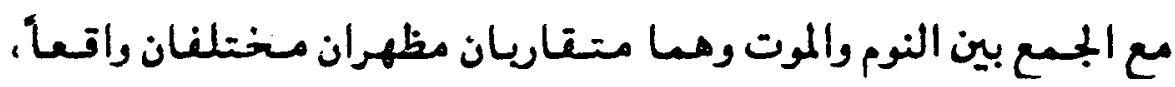
وجعل اليقظة بعثاً إياء إلى أن النشاط والمركة دليل إلهياة وأن النوم بألواتد علامة الموت، وآية الفجر "فيها إيجاز بالحذف يعنى الحيط الفيط الأبيض من الحيطيط الأسود من سواد الليل والفجر مشبها؛ سواد الليل بالخيط الأسود ويياض الفجر بالخيط الأبيض فحذف المشبد فى جانب

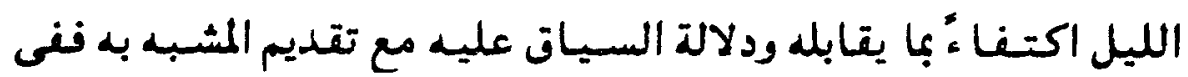

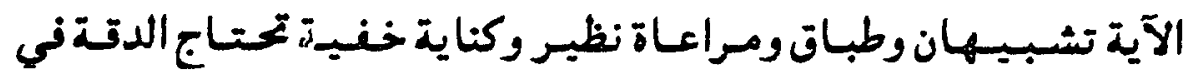

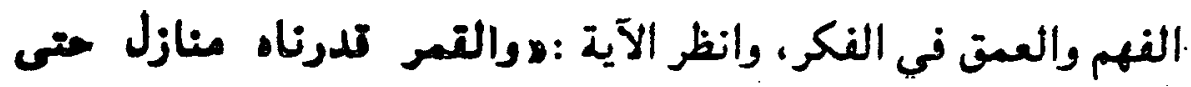
عاد كالمرجمن القديمه يلفت الذهن إلى تتبع القـمر في منازله

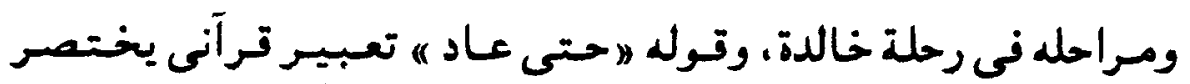

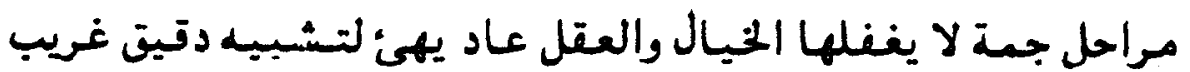
نافذ، إنه كالعرجون القديم وهو العذت ما بين شماريثنة إلي منبتة|"(1)،

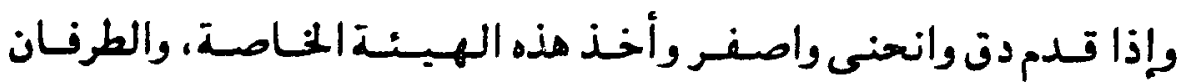

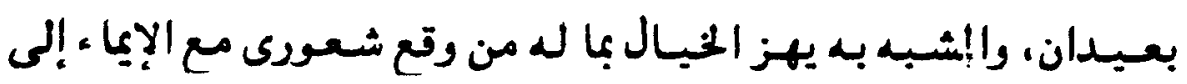
ضآلة القـر وضسياعة فى صحة السـا ـ العريضـة دليل تدرة خارقة، وقد أراد ابن الرومى أن يدخل التشبيه في حسن تعليل نقال : 


\section{-ror_}

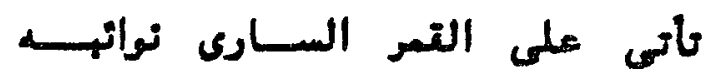

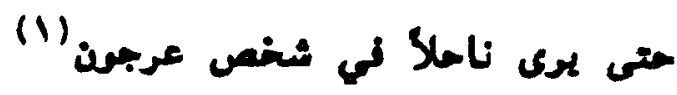

وقد أخطأه التوفيقا؛ لأن العربون لا يكون على هيئة القبر دقدً وانحناء وصفرةً إلا إذا تدم وفى القدم لفتة إلى ضآلته.

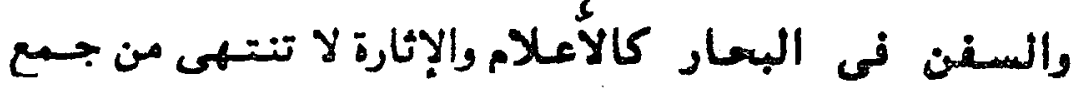

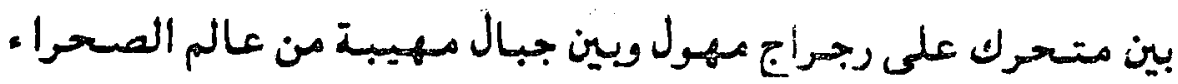

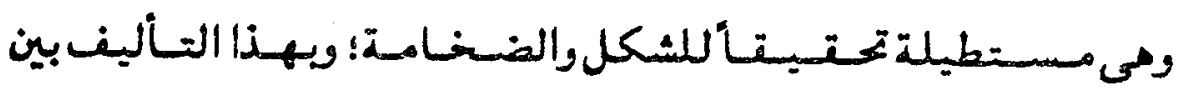
متناقضين كانت الغرابة والجمال.

التوغيب فيى بعض الغضائل :

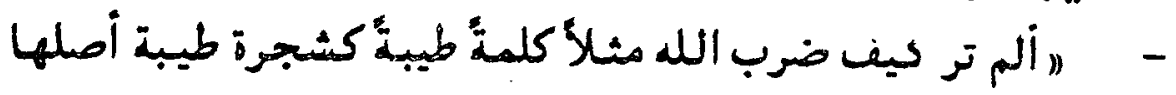

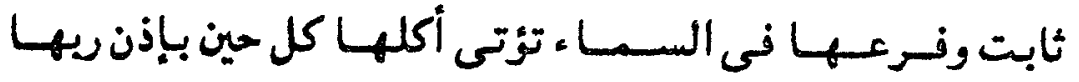

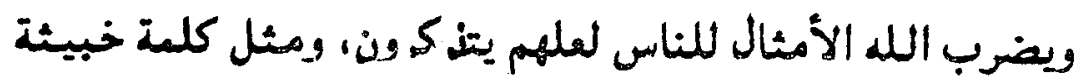

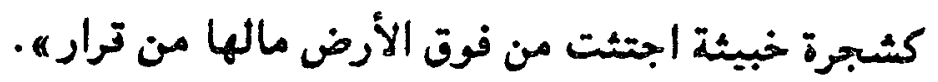

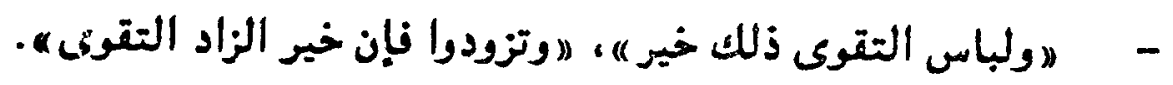

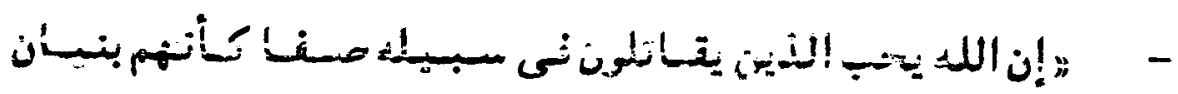
مرصوص" "

والكلمة الطيبة كلمة التوحيد، وقيل : كل كلمة معروف، وقد

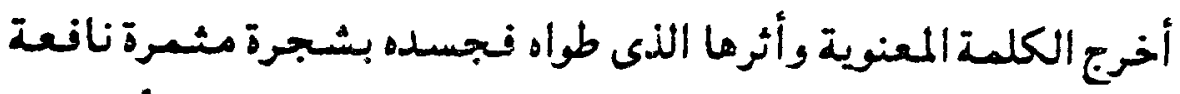

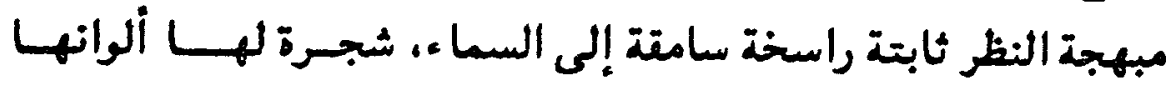


وطولها وثمرتها وناؤها وظلالها ، أحاط بها التشبيه من كل ناحية ترشيحاً للتشبيه وترغيباً في الكلمة الطيبة وتأكيداً لأثرها. والتصوير قواه تصوير مضاد للكلمة الخبيئن في شجرة شائهة

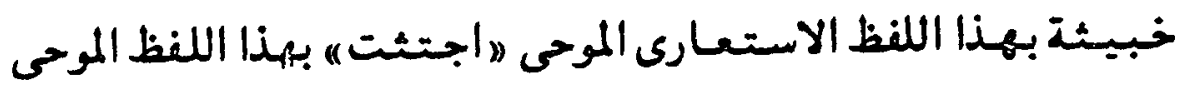

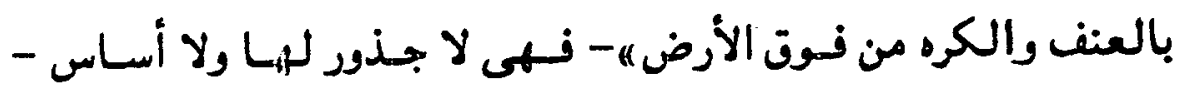

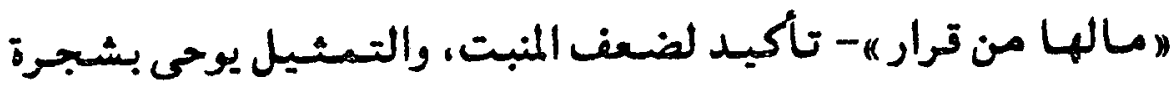

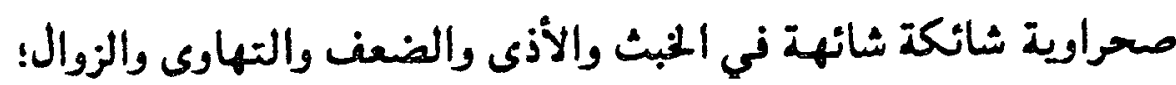
تجسيدا" معجزاً ترهيباً ويحذيراً.

أما التقوى فقد ظهرت فى معرضين على طريقة التشبيه البليغ

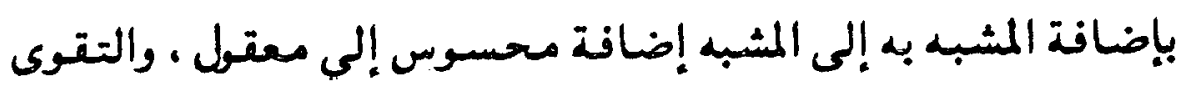

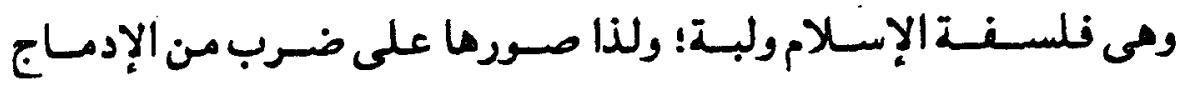

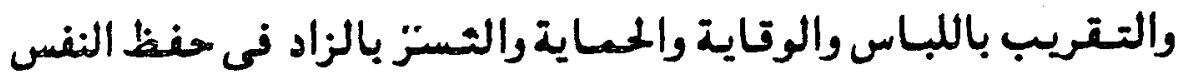

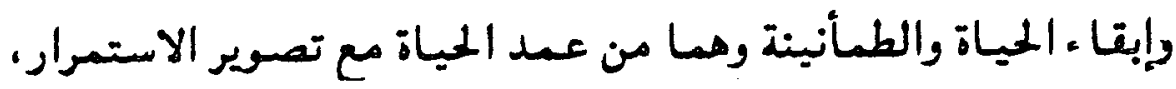

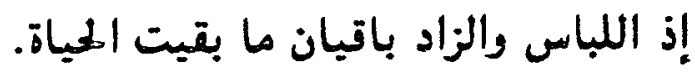

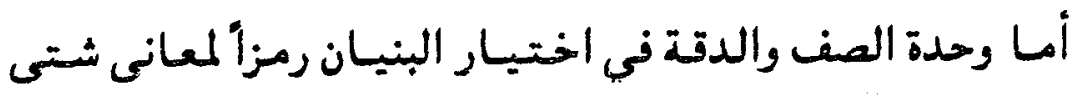

فقد سبق ولا يخفى "')

التشبيه فى النواهى : قال الله تعالى :

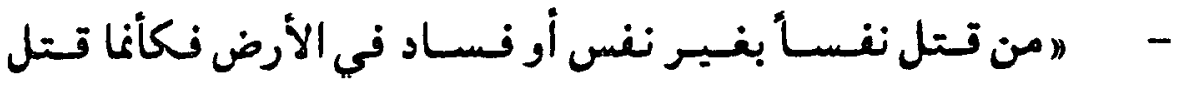

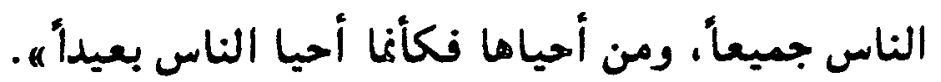




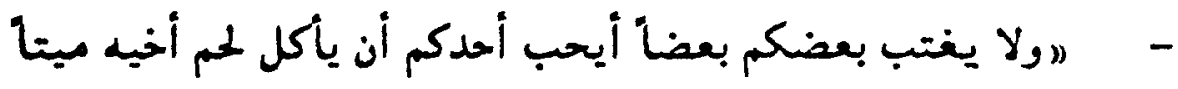
فكرهتموه ا I) .

- " " " ماغضض من صوتك إن أنكر الأمهوات لصوت الحمير ".

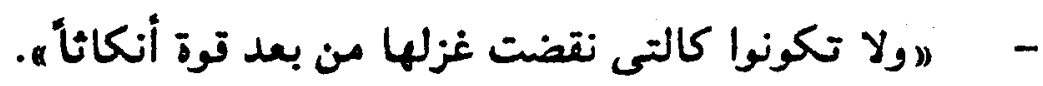

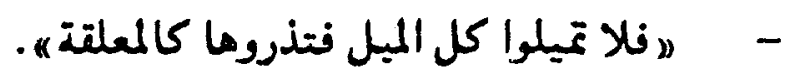

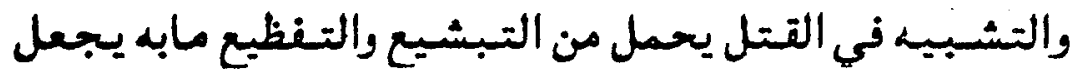

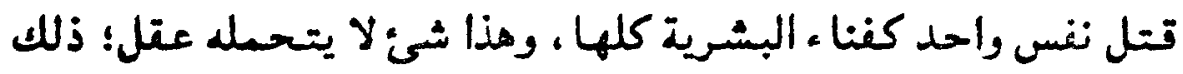

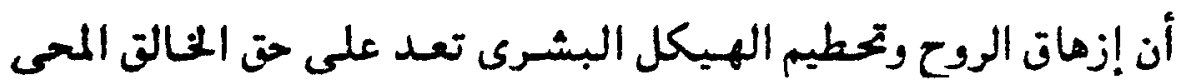

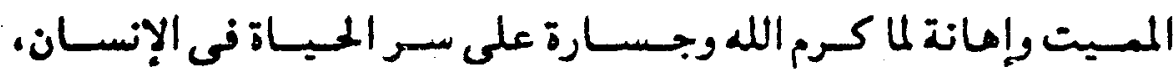

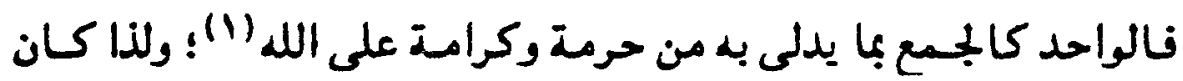

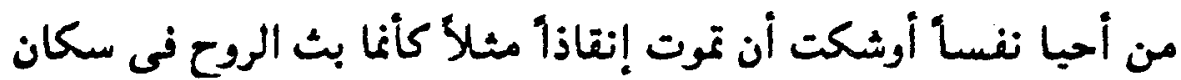
هذا الكوكب.

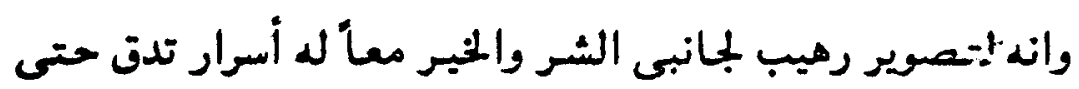

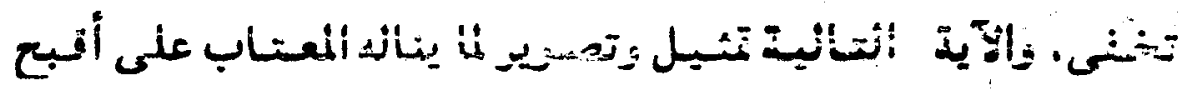

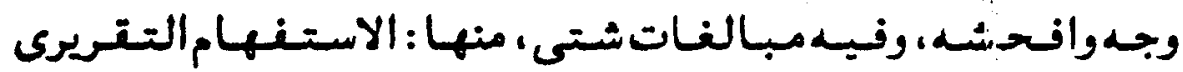

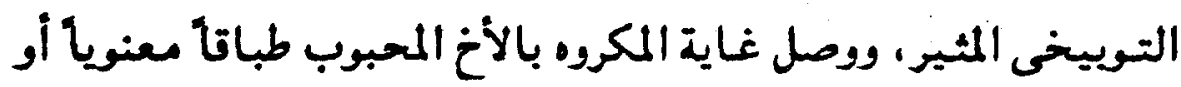

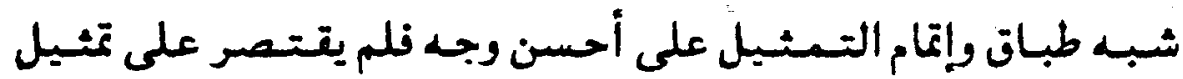

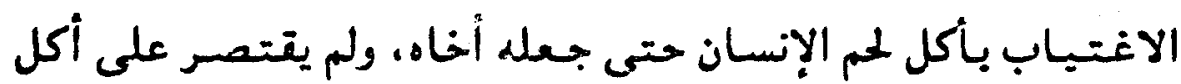

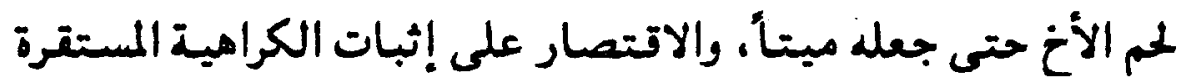

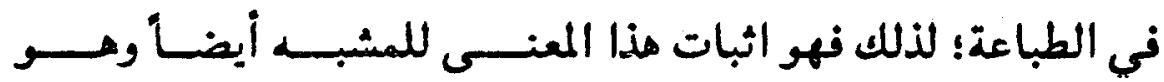


الاغتـياب، وقد جا ء التــثيل ضمنياً مركباً ينهم من السياق وما

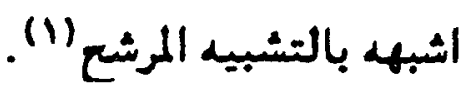

ولى الآية :دواغسضض من صسوتك إن أنكر الأصسرات

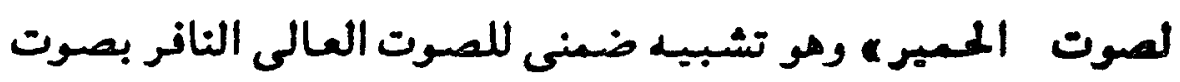

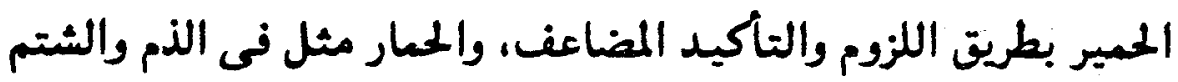

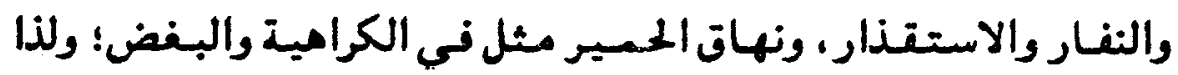

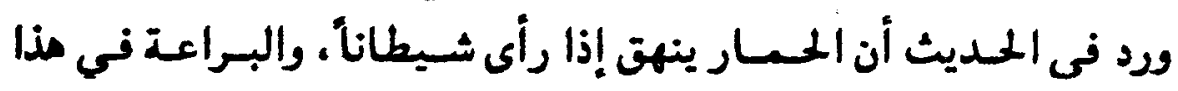

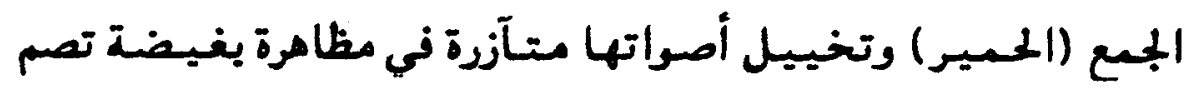

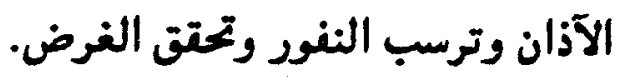

رالآية : (ولا ككونوا كالتى نتصنت عُلها من بعـد

كوi أiكاثان

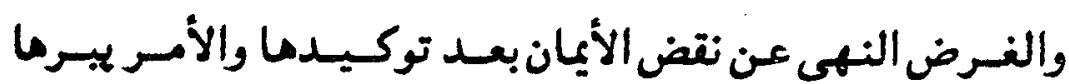

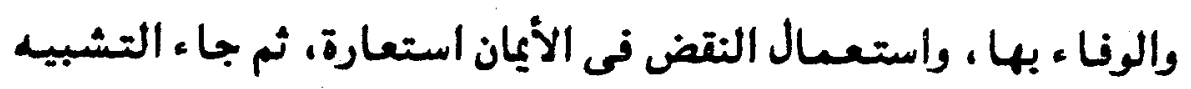

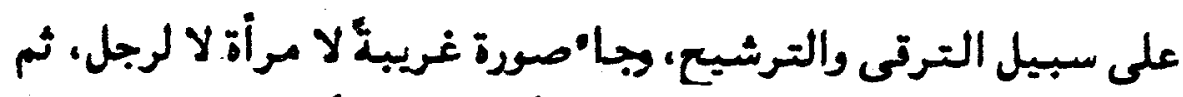

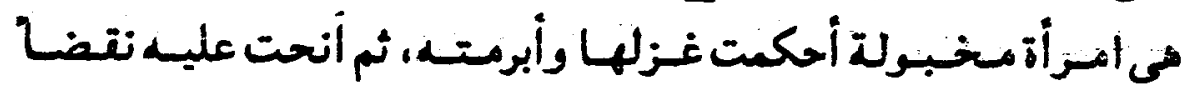

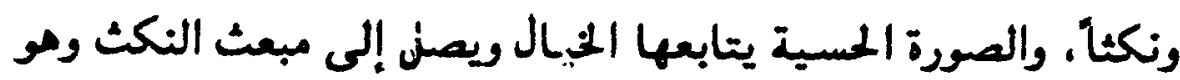
السفه والغبا • وخفة العقل، والعجب أن نسب مذا العـل العل لامرأة لم

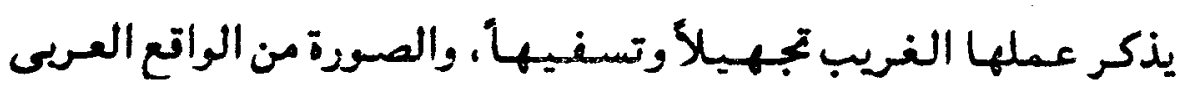

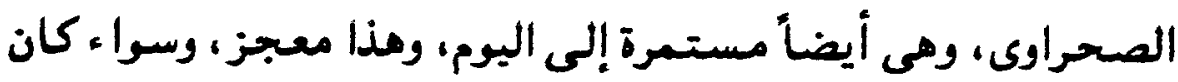

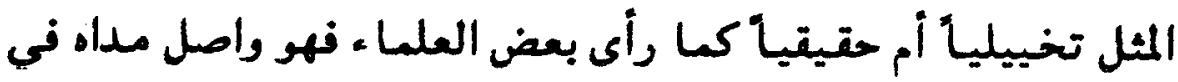

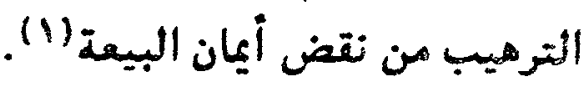




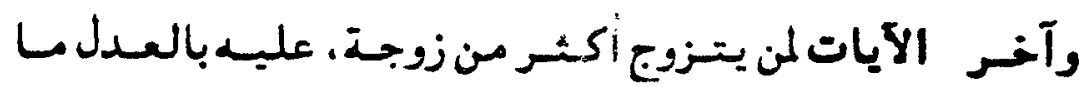

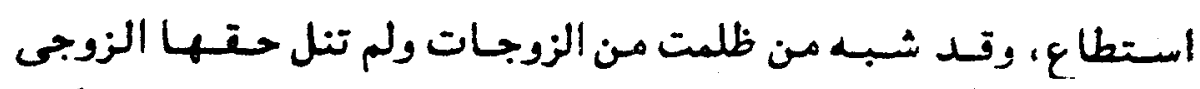

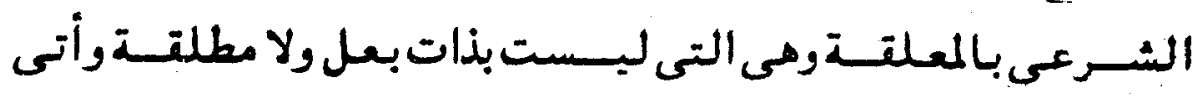

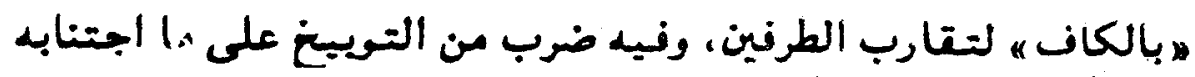

يقول القرَآن في جانب أمهاب المؤمنين عليهن السلام :

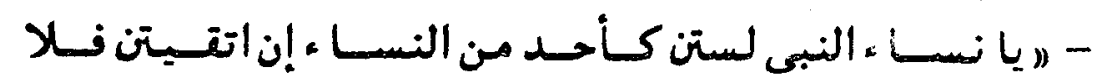

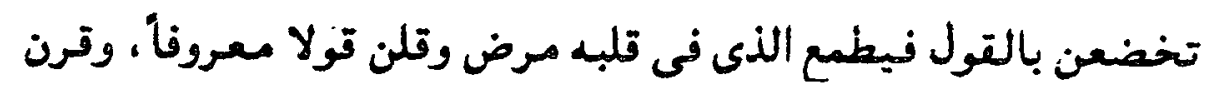

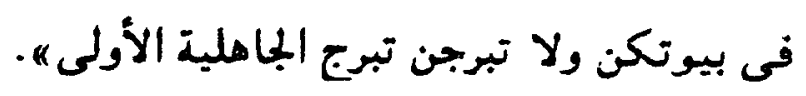

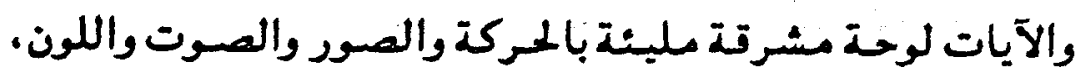

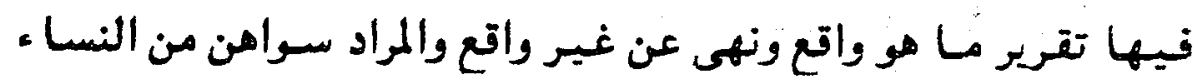

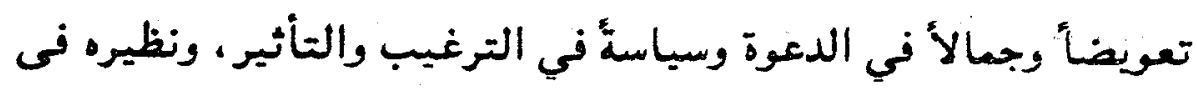

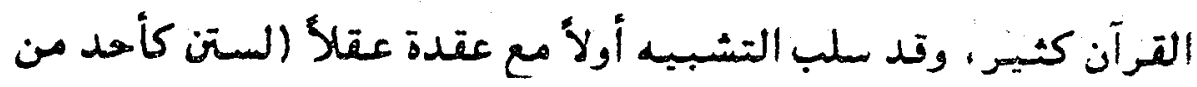

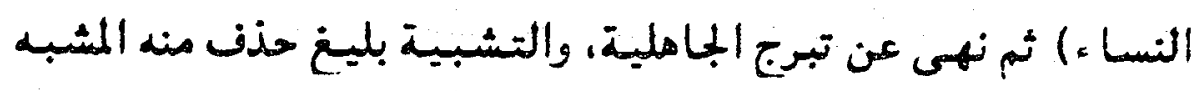

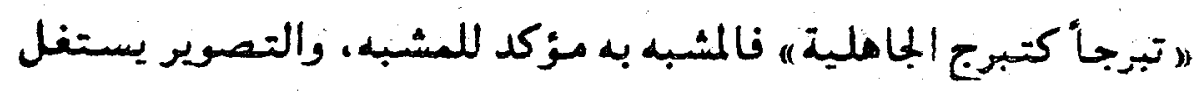

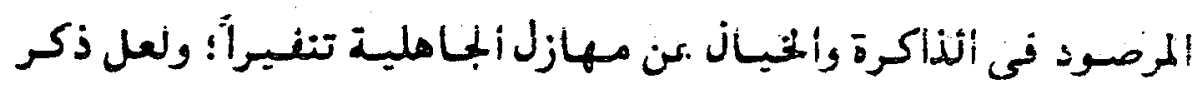

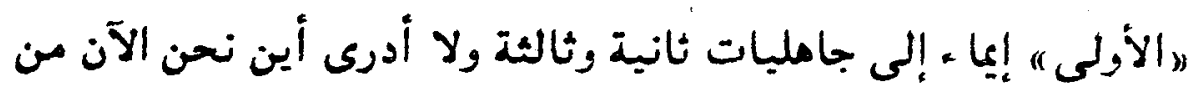

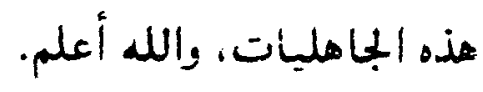

النور في التشبية الترانى : قال تعالى :

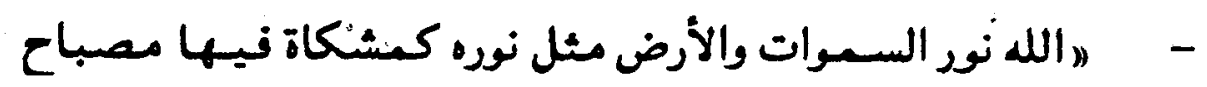
المباح فى زجاجة، الزجاجة كأنها كوكب دوى يوتد من شجرة 
مباركتة زيتونة لا شـرقيـة ولا غريـية يكاد زيتها يضئ ولو لم

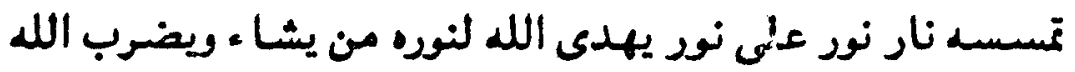

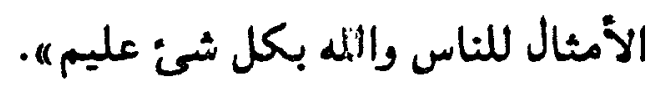

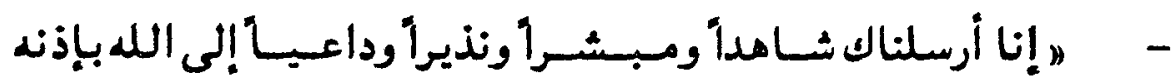
وسراجاً منيرأ): - وكذلك أوحينا إليك روحاً من أمرنا ما كنت تدرى ما الكتاب

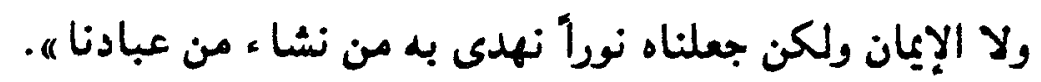

ولفظة نور ذكرت فى القرآن ثلاثة وأربعين مرة مراداً بها النود

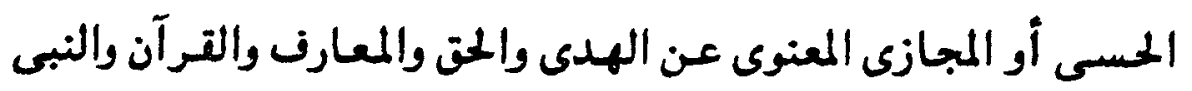

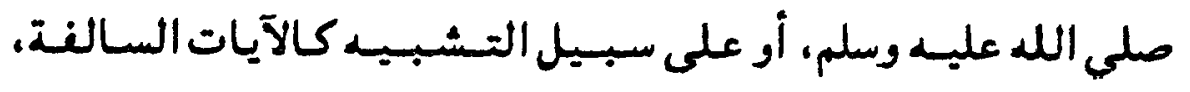

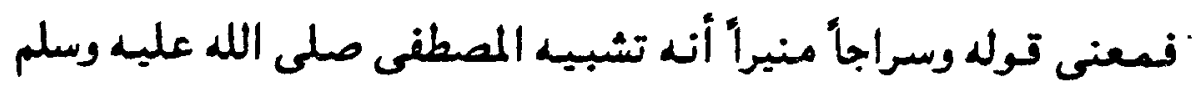
في تجليته ظلمات الشرك واهتداء ـ الضالين به أو تنوير البصائر بنور

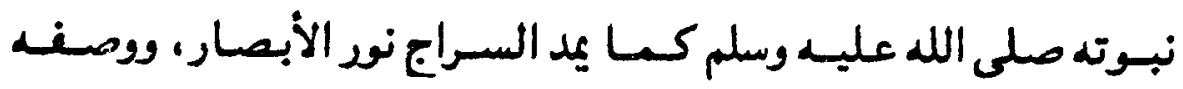

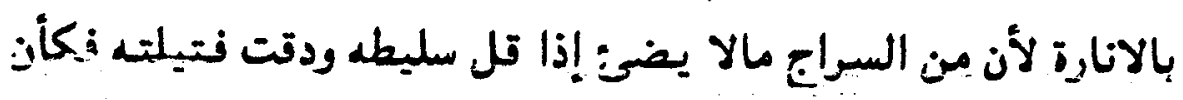

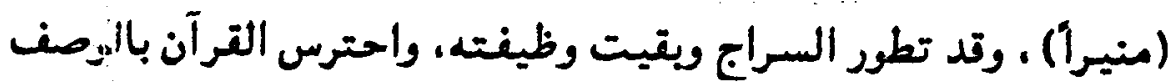
" منيرأ، نهذا الوصف ثابت يفوق ما نعرف عن السرج والمصابيح.

ولعلك تلمع أنه جـمع له الإضـاءة المـــلة في الســراجِ والإنارة

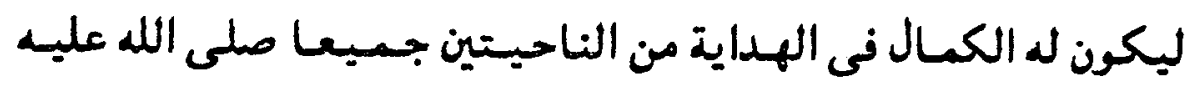

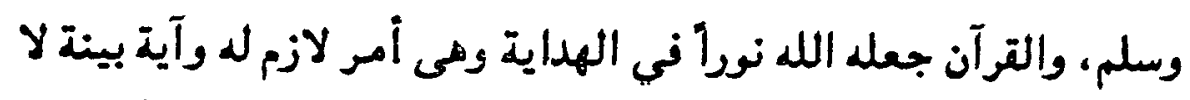

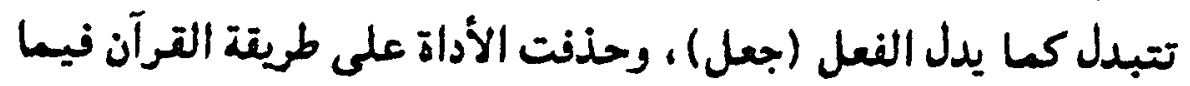
قرب طرفاه ثم تحقق الوصف في الطرفين على تقارب شديد. 
وفى آية النور : ،الله نور السموات والأرضه

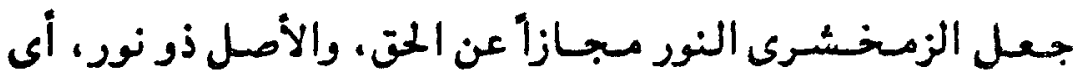

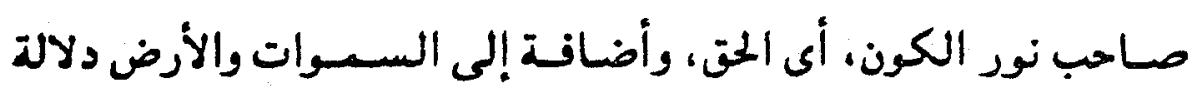

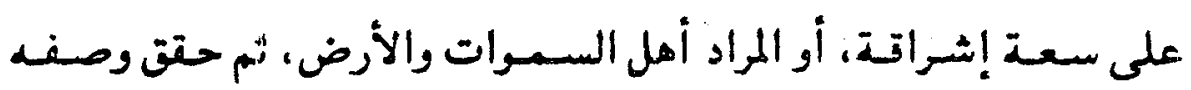

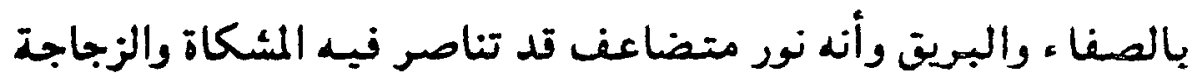
والمصباح والزيت والصيت وانه نواء

واستشف سيد قطب ظلال الأسلوب وآثاره النفسيد والأسلويية،

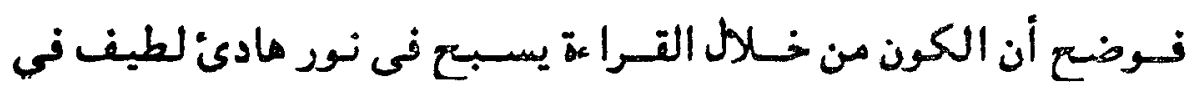

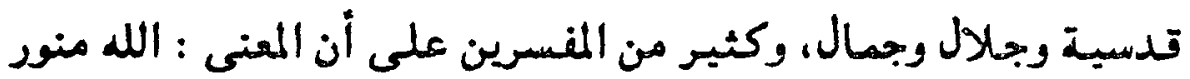

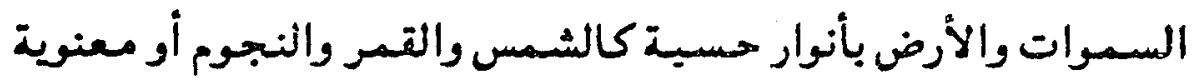

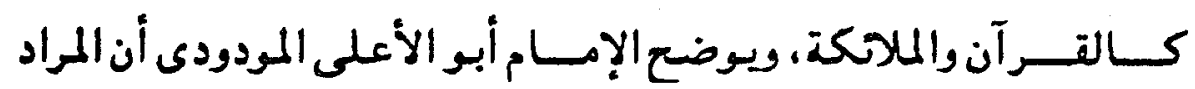

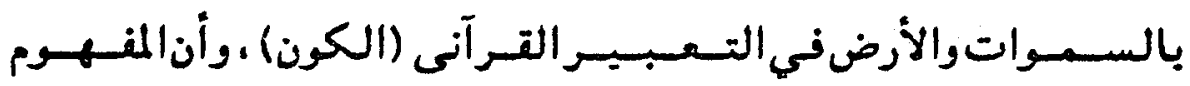

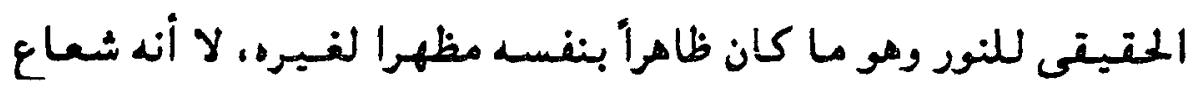

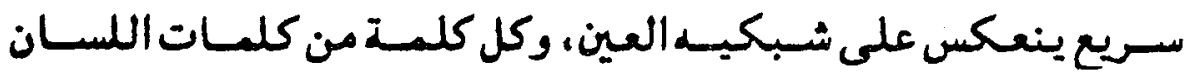

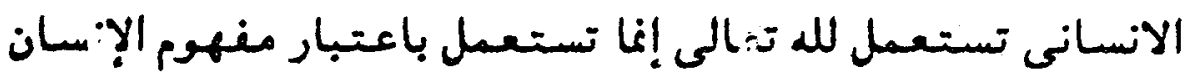

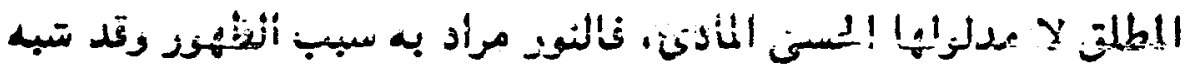

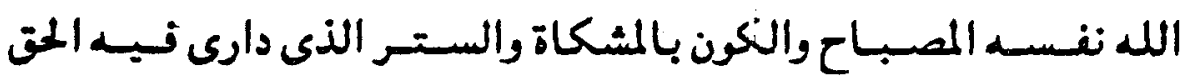

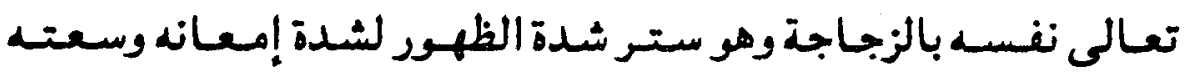

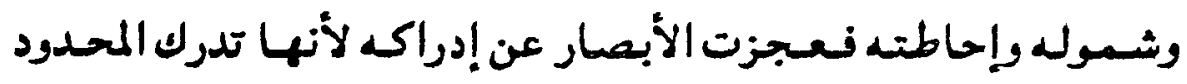

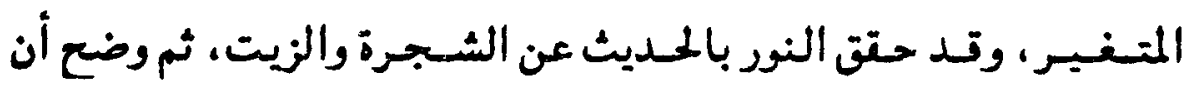
النور صفة كالعلم والقدرة، فهو مصاحبها ولكن تيل لهيل له النور لبيــان 
كسالد فيـ كما يتال للكامل فى الكرم ويعنى مذا كسا مو معلوم

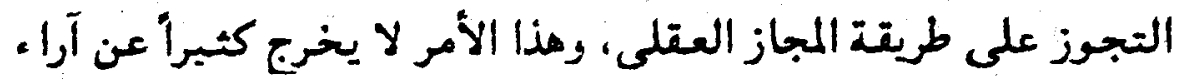

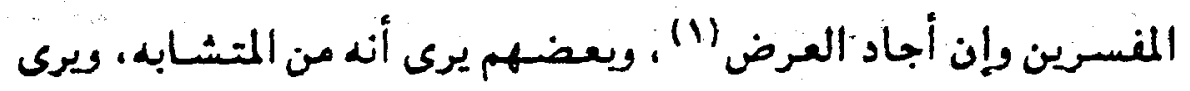

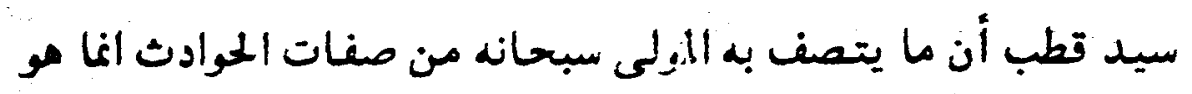

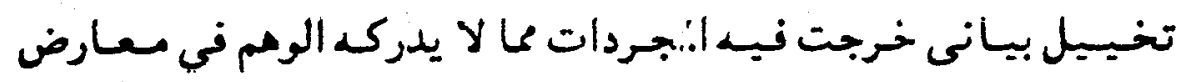

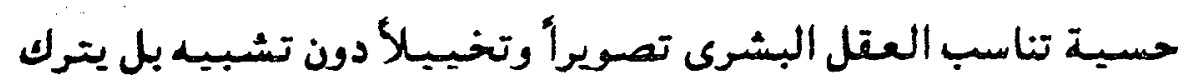

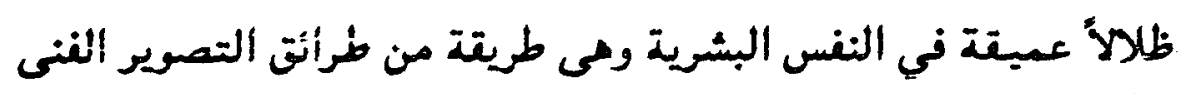

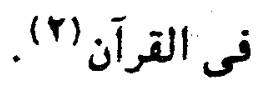

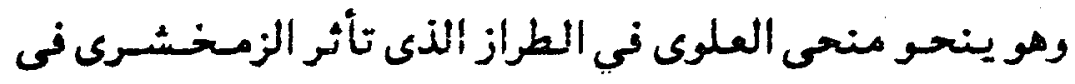

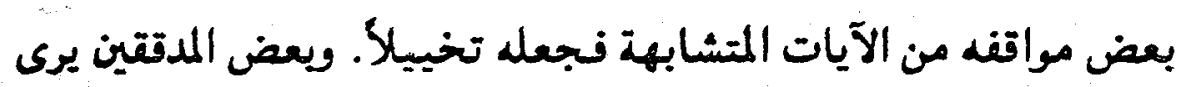

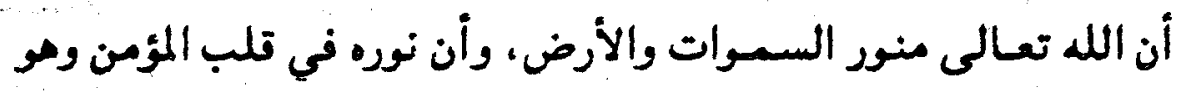

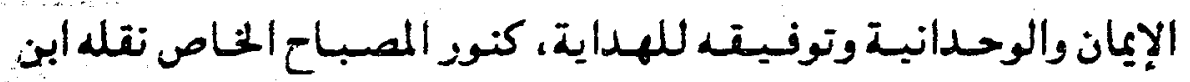
تيمية وابن القيم عن بعض الصحابة -رضى الله عنهم ورجحه، ويكل

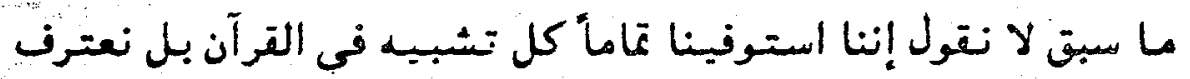

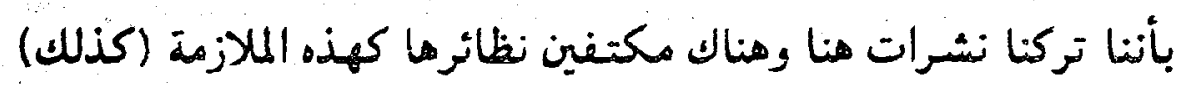

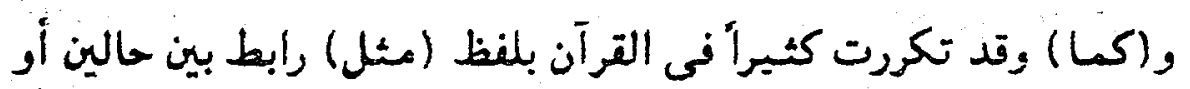

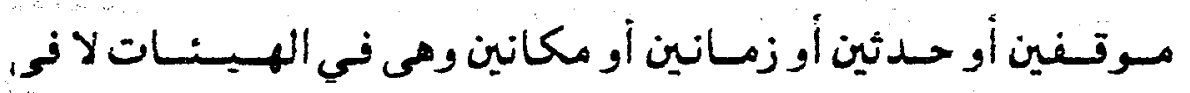

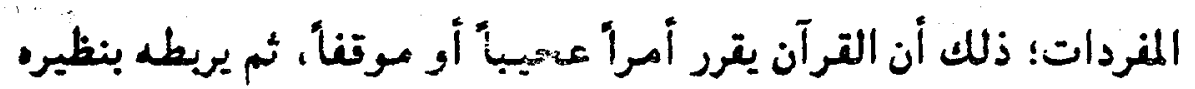

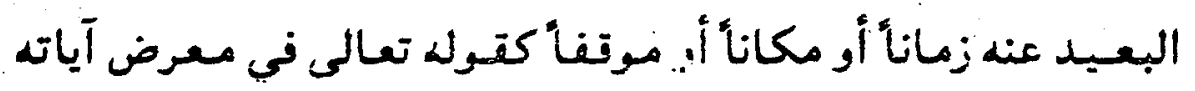
الكونية.

راجع تغسيره سوره النور 199-Y. 19. راجع التصوير الفنى لr. 


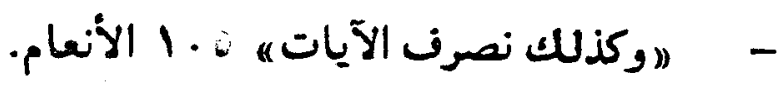

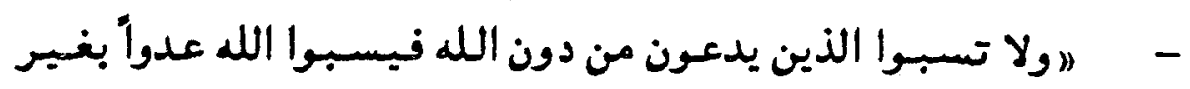
علم كذلك زينا لكل أمة عملهمه A ـ ـ الأنعام.

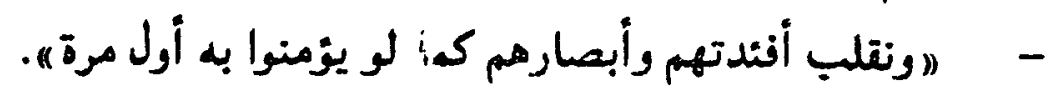

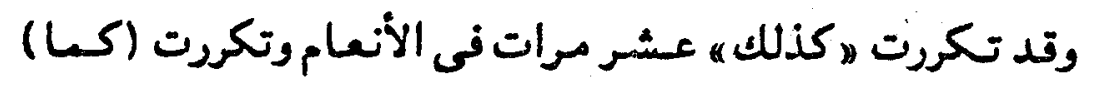

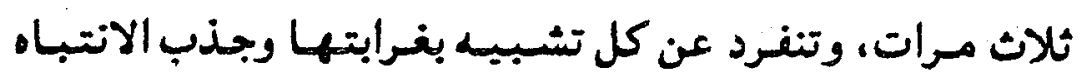
إليها وقوة مدلولها ونكتفى بالآية :

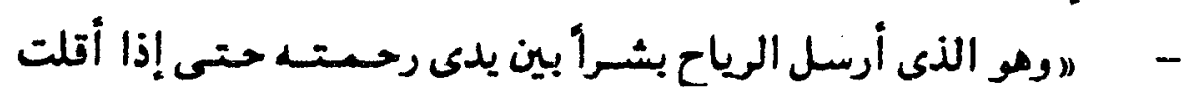

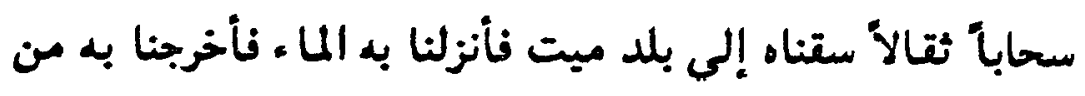

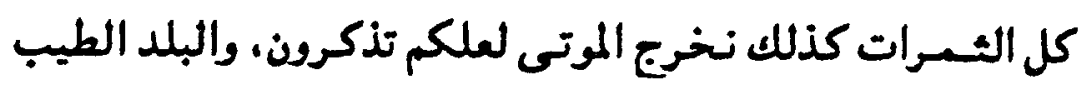

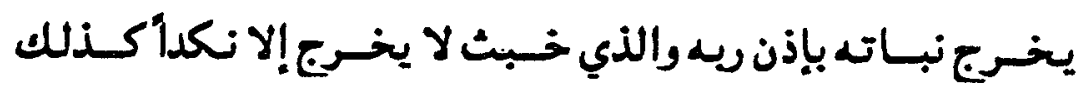

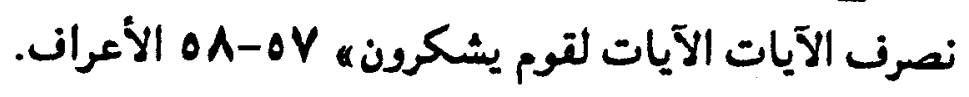

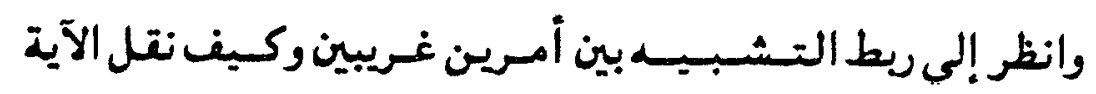

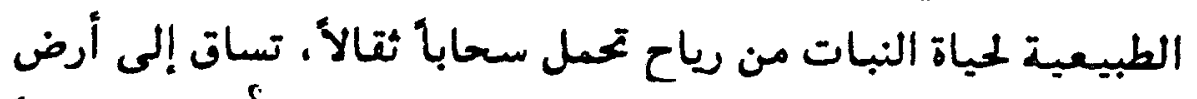

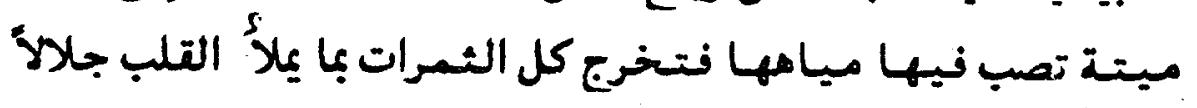

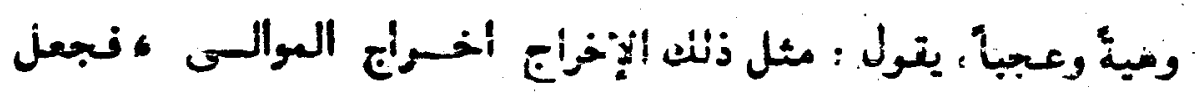

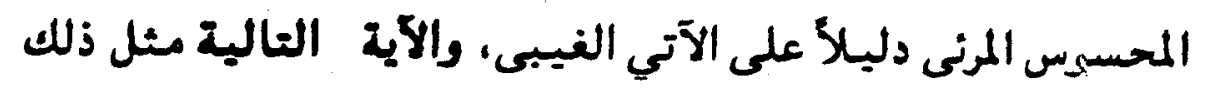

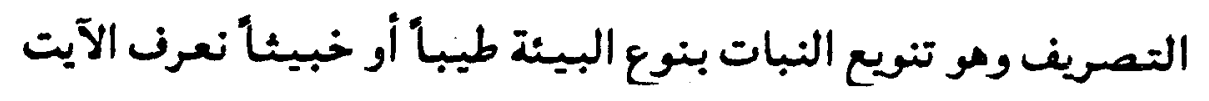

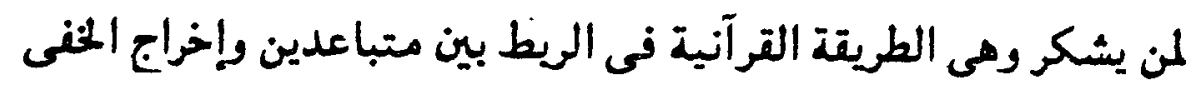

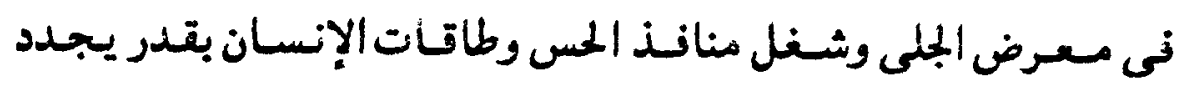

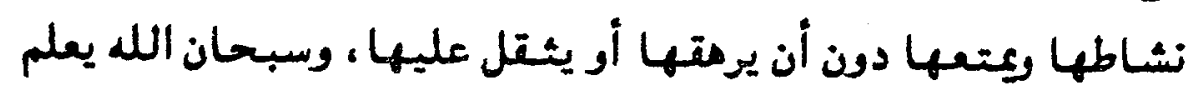


لقـد طفت بخصائص التشبـيـه من خلال البحث وأدركت كبيف

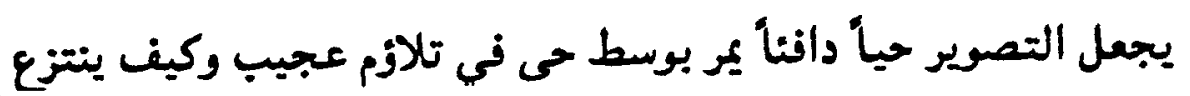

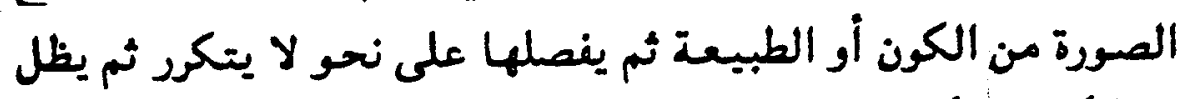

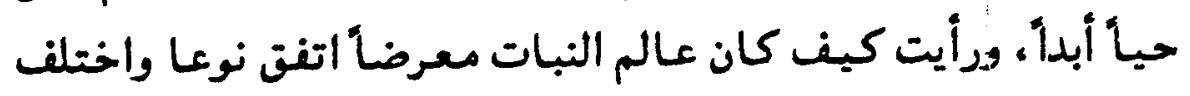

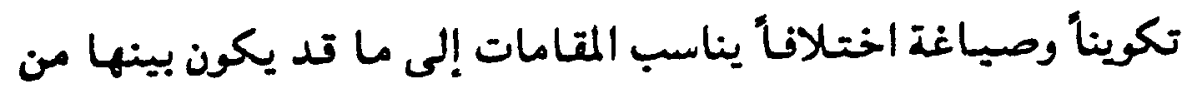

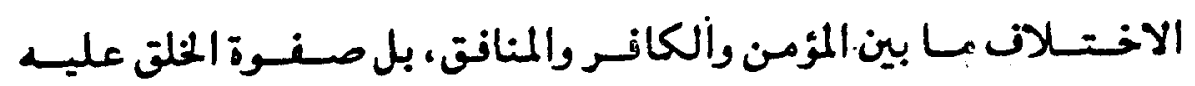

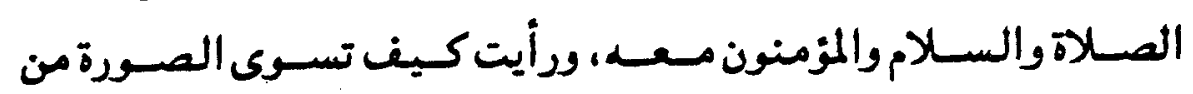

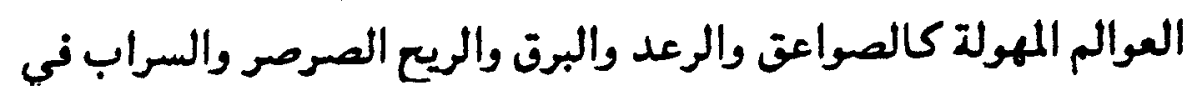

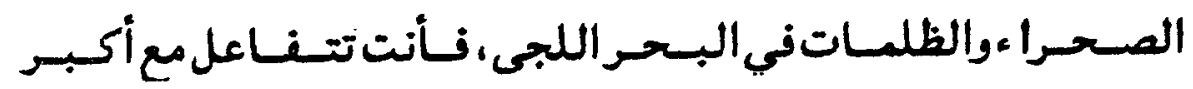
الكائنات وتنبهر فى قهرها على نحو غريب.

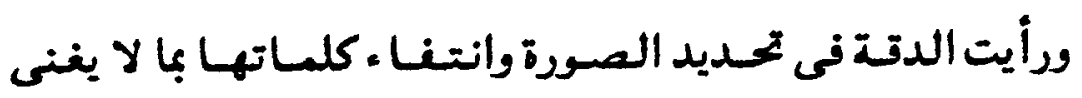

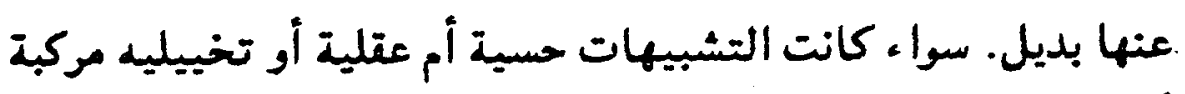

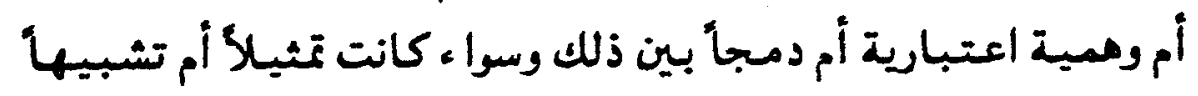

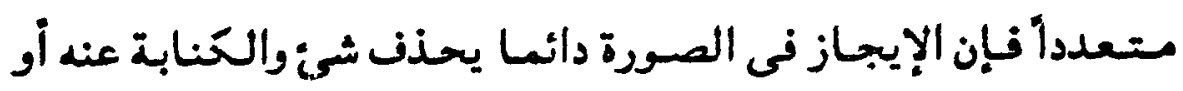

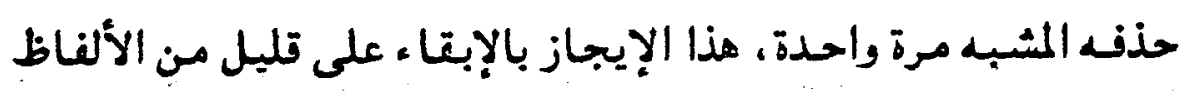

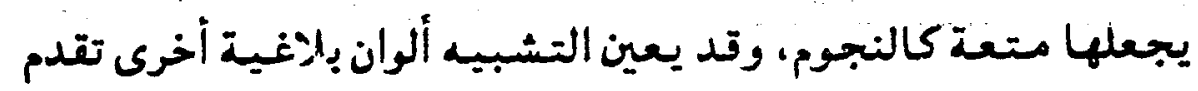

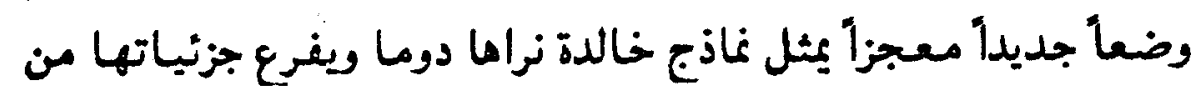

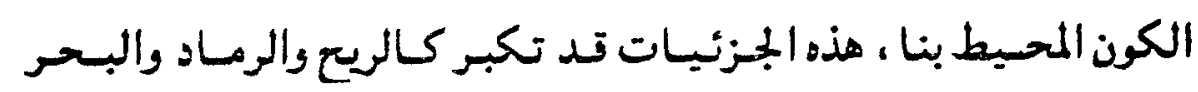

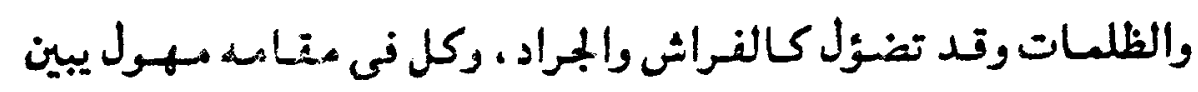

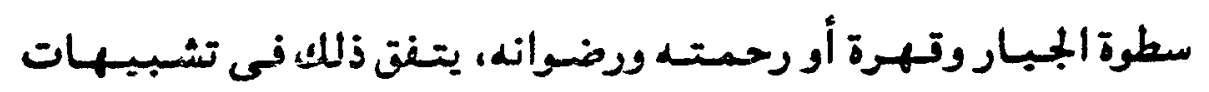

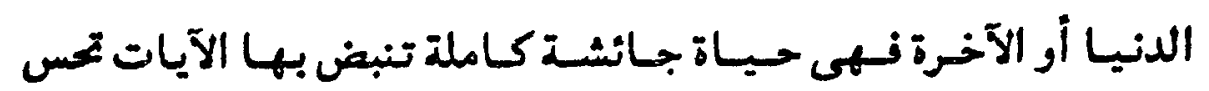

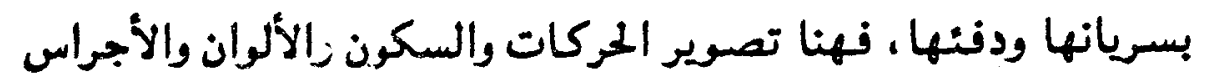
والظلال بدقة غريبة وهندسة وقوانين كقوانين ألحياة. 


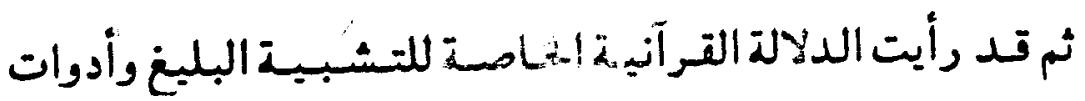

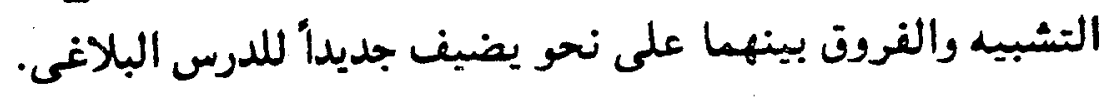

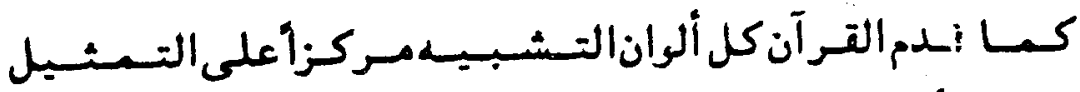
التصعى، ورأيناتناسبالتشبيهات جميعاً- على تفرتها- واتفاتها

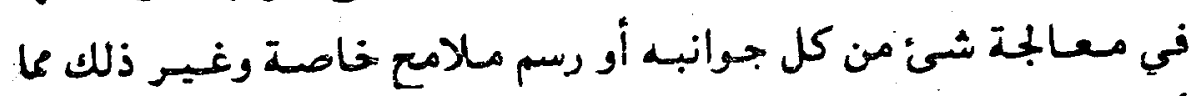

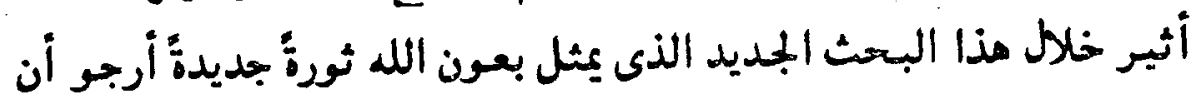

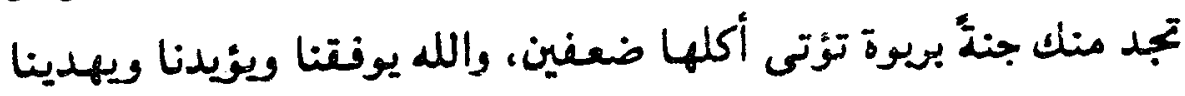

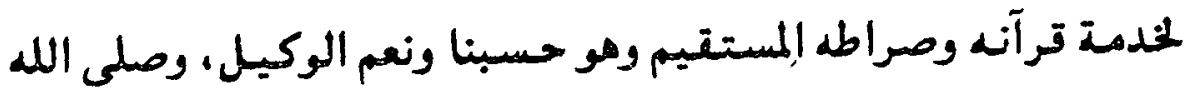
على سيدنا محمد وعلى آله وصحبه وسلم تسليماً كثيراً.

أ.د ا مباح عبيد دراز

عميد الكلية 